\title{
Reconciling privatization with human rights
}

Citation for published version (APA):

Hallo de Wolf, A. G. (2011). Reconciling privatization with human rights. [Doctoral Thesis, Maastricht University]. Intersentia. https://doi.org/10.26481/dis.20111220ah

Document status and date:

Published: 01/01/2011

DOI:

10.26481/dis.20111220ah

Document Version:

Publisher's PDF, also known as Version of record

\section{Please check the document version of this publication:}

- A submitted manuscript is the version of the article upon submission and before peer-review. There can be important differences between the submitted version and the official published version of record.

People interested in the research are advised to contact the author for the final version of the publication, or visit the DOI to the publisher's website.

- The final author version and the galley proof are versions of the publication after peer review.

- The final published version features the final layout of the paper including the volume, issue and page numbers.

Link to publication

\footnotetext{
General rights rights.

- You may freely distribute the URL identifying the publication in the public portal. please follow below link for the End User Agreement:

www.umlib.nl/taverne-license

Take down policy

If you believe that this document breaches copyright please contact us at:

repository@maastrichtuniversity.nl

providing details and we will investigate your claim.
}

Copyright and moral rights for the publications made accessible in the public portal are retained by the authors and/or other copyright owners and it is a condition of accessing publications that users recognise and abide by the legal requirements associated with these

- Users may download and print one copy of any publication from the public portal for the purpose of private study or research.

- You may not further distribute the material or use it for any profit-making activity or commercial gain

If the publication is distributed under the terms of Article $25 \mathrm{fa}$ of the Dutch Copyright Act, indicated by the "Taverne" license above, 
Reconciling Privatization with Human Rights 
Cover cartoon (C) Nick Anderson. Nick Anderson's Editorial Cartoon used with the permission of Nick Anderson, the Washington Post Writers Group and the Cartoonist Group. All rights reserved.

School of Human Rights Research Series, Volume 49

A commercial edition of this dissertation will be published by Intersentia under ISBN 978-1-78068-049-1.

The titles published in this series are listed at the end of this volume.

The publication of this book has been made possible by the financial contribution of the Nederlandse Organisatie voor Wetenschappelijk Onderzoek (NWO).

No part of this publication may be reproduced, stored in an automated data system or transmitted in any form or by any means, electronic, mechanical or photocopying, recording, or otherwise, without the prior written permission from the author/publisher. 


\title{
Reconciling Privatization with Human Rights
}

\author{
DISSERTATION \\ to obtain the degree of Doctor \\ at Maastricht University, \\ on the authority of the Rector Magnificus, \\ Prof. dr. G.P.M.F. Mols \\ in accordance with the decision of the Board of Deans, \\ to be defended in public \\ on Tuesday 20 December 2011 at 16:00 hours
}

by

Antenor Gijs Hallo de Wolf 


\section{Supervisors:}

Prof. dr. M.T. Kamminga

Prof. dr. W. Devroe, KU Leuven, Maastricht University

\section{Assessment Committee}

Prof. Th.C. van Boven (chairman)

Prof. dr. F. Coomans

Prof. dr. C. Graham, University of Leicester, United Kingdom

Prof. dr. W.J.M. van Genugten, Tilburg University 


\section{ACKNOWLEDGEMENTS}

This book has been a long time in coming. When I started the research for this book in November 2001, I was quite confident I would be able to finish it in the allotted time. Ten years later, it is finally over. In the beginning, I decided to approach the issue of privatization and human rights by using five case studies that illustrated the problems related to the topic. It did not take too long before realizing that the research would be better off by focusing on two case studies: the privatization of the water utility in Buenos Aires, Argentina, and the use of private military and security companies in Iraq (before the Blackwater incident). At that point in time the financial crisis in Argentina had just reached its zenith and casted an uncertain future on the continuity of Aguas Argentinas, the object of study of the Argentine case study. No long thereafter, the scandal at Abu Ghraib and the involvement of private military contractors was making the news and I felt I was on the right path. A number of years passed by, however, and in 2006 I switched jobs from Maastricht University to the School of Law of Bristol University. At Bristol I joined Prof. Rachel Murray and Prof. Malcolm Evans to assist in a cutting edge research project on the Optional Protocol to the Convention Against Torture (OPCAT), which had just entered into force. Needless to say, this very intensive research project made it difficult to focus on finishing the dissertation (I always maintained that it was almost done, which was true, but I just could not find the time to properly put an end to it). In the meantime, the privatization of the water utility in Argentina ended up abruptly, and a year later in 2007, everybody sank their teeth into the Blackwater incident. Suddenly my research topic was 'hot'. In 2009 I moved back to the Netherlands, this time to Groningen University. At Groningen, Prof. Marcel Brus gave me the opportunity to finally conclude the dissertation. This (overly) long book would not have been possible without the help and support of various individuals and friends. Hence, I would like to extend my heartfelt gratitude to Prof. Richard Young at Bristol University for reading an earlier version of the manuscript and for providing great feedback and commentary, as well as boosting my confidence on what I was doing. Equally, I would like to thank Professors Murray and Evans at Bristol for giving me the opportunity to work with them and for their patience. I would like to thank Mr. Kenneth Schindler at the ILO in Geneva, Prof. Koen De Feyter at Antwerp University, and Prof. Alfred Aman, Jr. at Indiana University for the help they provided me during this research. Lots of inspiration and tons of fun came from my former colleagues and $\mathrm{PhD}$ fellows at Maastricht University: Jona Israël, Carol Nighiollarnath, Eva Rieter (who also provided some comments for one of the chapters), Joakim Zander, Michał Gondek, Mariolina Eliantonio, Mieke Olaerts, and Ida Wendt. At Groningen University, Prof. Brus, dr. André de Hoogh, Ms. Marlies Hesselman, Ms. Esther Knot, and dr. Gerhard Hoogers also deserve my appreciation. In addition, a number of student assistants made this work possible: 
Bas van der Zwaan, Jan and Folkert de Vries, Ida Nylund, Niels Dekker, Amra Avdic, and Luuk de Kanter. My thanks also go to my parents, my brother Axel, my sister Marijke, and to Françoise Wijenbergh who put up with this for far too long. Finally, and not to be forgotten, my former band mates in Bristol, Martin, Jim, and Tim provided inspiration and good music. Cheers mates! Reuben: Thank you!

This dissertation would not have been possible without the financial support of the Nederlandse Organisatie voor Wetenschappelijk Onderzoek (NWO), and the original authors of the topic of this dissertation, Prof. Menno Kamminga and Prof. Wouter Devroe.

My love and gratitude go to Nathalie for her support and assistance, and love of rock 'n roll!

This manuscript was completed in August 2011, with some minor subsequent updates afterwards. 


\section{Contents}

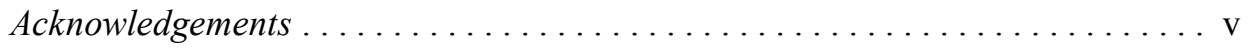

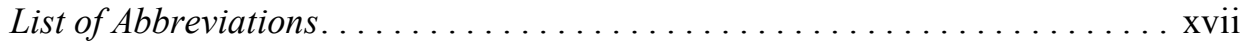

Chapter I

General Introduction. . . . . . . . . . . . . . . . . . . . . 1

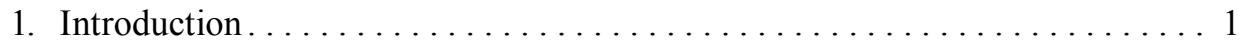

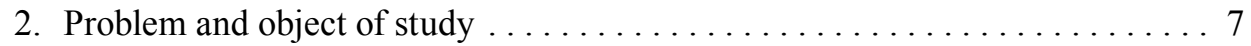

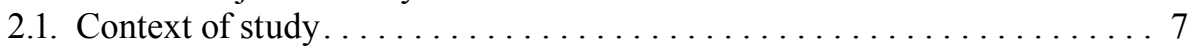

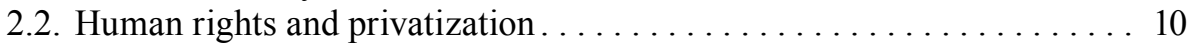

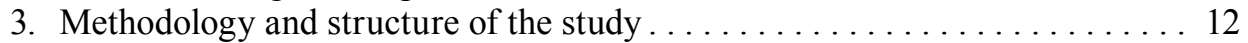

\section{Part I}

Theoretical Framework

Chapter II

Privatization in Context $\ldots \ldots \ldots \ldots \ldots \ldots \ldots \ldots \ldots \ldots \ldots \ldots$

1. Introduction. ............................. 19

2. Privatization: definition, historical context, and nature . . . . . . . . . 19

2.1. Defining privatization and its rationale ................ 19

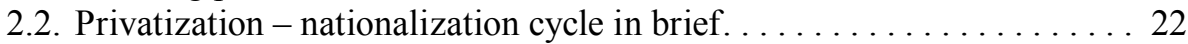

2.2.1. The privatization of 'core' or 'intrinsic' State functions . . . . . 23

2.2.2. The privatization of networks, and municipal services and

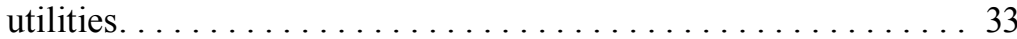

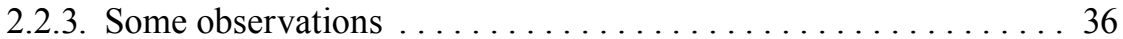

2.3. Dynamic nature and rationale . . . . . . . . . . . . . . 37

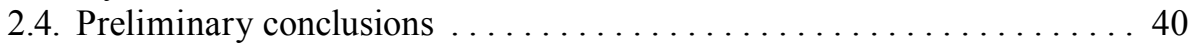

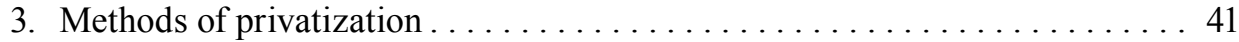

3.1. Privatization through the transfer of ownership . . . . . . . . . . . 42

3.2. Privatization through the transfer of management $\ldots \ldots \ldots \ldots \ldots \ldots 42$

3.3. Privatization through contracting out $\ldots \ldots \ldots \ldots \ldots \ldots \ldots \ldots \ldots$

3.4. Privatization through deliberate withdrawal or incapacity . . . . . . . 43

3.5. Preliminary conclusions $\ldots \ldots \ldots \ldots \ldots \ldots \ldots \ldots \ldots \ldots \ldots$

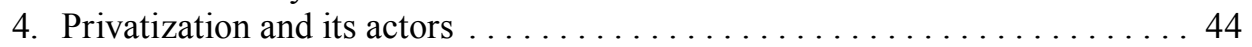

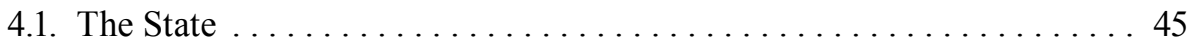

4.2. International Financial Institutions (IFIs) . . . . . . . . . . . . 47

4.3. National and Multinational Business Enterprises . . . . . . . . . . 52 
Contents

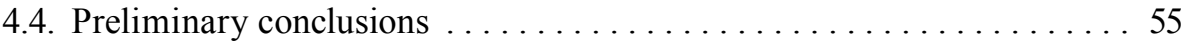

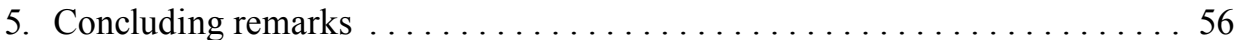

Chapter III

Issues of Doctrine . . . . . . . . . . . . . . . . . . . . . . . . . 59

1. Introduction . . . . . . . . . . . . . . . . . . . . . . . 59

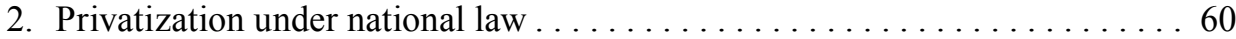

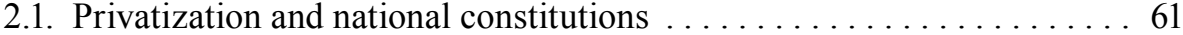

2.1.1. Substantive constraints . . . . . . . . . . . . . . . . 62

2.1.2. Procedural constraints . . . . . . . . . . . . . . 67

2.1.3. Constraints based on Constitutional/legal traditions . . . . . . . . 67

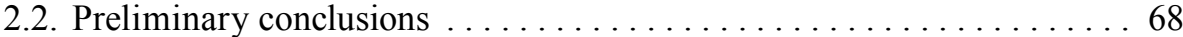

3. Privatization under general international law . . . . . . . . . . . 69

3.1. Relevant State obligations under international law . . . . . . . . . . 76

3.1.1. Obligations pertaining to International Treaty Law . . . . . . . . . 77

3.1.2. Obligations pertaining to the principle of non-intervention. . . . . 78

3.1.3. Obligations pertaining to state responsibility. . . . . . . . . 79

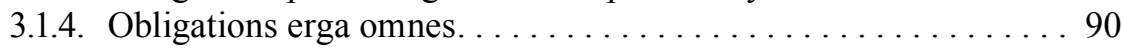

3.1.5. Some observations ..................... 91

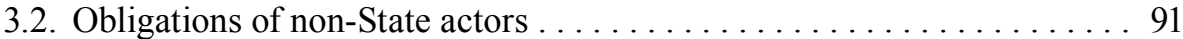

3.2.1. Obligations of international financial institutions . . . . . . . 91

3.2.1.1. Indirect human rights obligations? . . . . . . . . . . 94

3.2.1.2. Practical accountability through internal auditing . . . . . 99

3.2.2. Obligations of business enterprises . . . . . . . . . . 108

3.2.2.1. Legal obligations and regulatory efforts . . . . . . . . 112

3.2.2.2. The search for accountability. . . . . . . . . . 121

3.2.3. Some observations . . . . . . . . . . . . . . . . . . 124

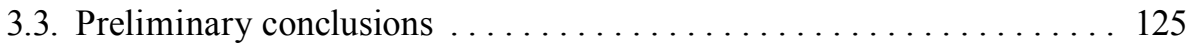

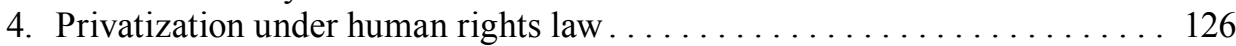

4.1. Obligations emanating from human rights treaties . . . . . . . . . 128

4.1.1. Specific human rights obligation of States: General

background ........................... 129

4.1.2. Positive and negative obligations . . . . . . . . . . . . . . 132

4.1.2.1. Negative obligations and privatization . . . . . . . 133

4.1.2.2. Positive obligations and privatization . . . . . . . 136

4.1.2.3. Positive obligations: a duty to regulate privatized

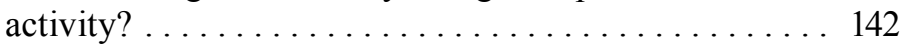

4.1.3. Obligations to respect, protect and fulfill . . . . . . . . . . 145

4.1.4. Core obligations with respect to economic social and cultural rights . . . . . . . . . . . . . . . . . . . . . . . . . 148

4.1.5. Some observations . . . . . . . . . . . . . . . . . . . 149 
4.2. Margin of appreciation and privatization $\ldots \ldots \ldots \ldots \ldots \ldots \ldots \ldots$

4.2.1. General applicability. .................. 151

4.2.1.1. Margin of appreciation, negative obligations and privatization........................ 153

4.2.1.2. Margin of appreciation, positive obligations and privatization ....................... 155

4.2.1.3. Margin of appreciation, economic, social and cultural rights, and privatization................. 157

4.2.2. Margin of appreciation, its limits, and privatization . . . . . . . 159

4.2.2.1. Margin of appreciation, economical policies, environmental nuisance and privatization. . . . . . . . 160

4.2.2.2. Margin of appreciation, non-derogable rights and due process rights . ....................... 167

4.2.2.3. Margin of appreciation and consistent practice of

States ............................. 169

4.2.3. Some observations $\ldots \ldots \ldots \ldots \ldots \ldots \ldots \ldots \ldots \ldots \ldots . \ldots \ldots$

4.3. Availability of (judicial) remedies and regulation. . . . . . . . . 172

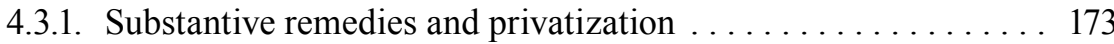

4.3.2. Procedural remedies and privatization ............. 175

4.3.2.1. Procedural remedies under human rights law . . . . . . . 177

4.3.2.2. Regulation as a procedural remedy? . . . . . . . . . 180

4.3.3. Some observations . . . . . . . . . . . . . . . . . . . . . 183

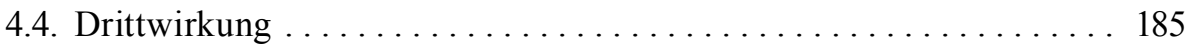

4.4.1. Current status of Drittwirkung under international human

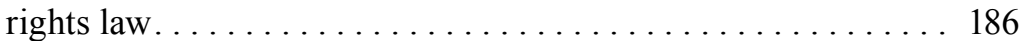

4.4.1.1. Substantive Drittwirkung . . . . . . . . . . . . 187

4.4.1.2. Procedural Drittwirkung . . . . . . . . . . . . . . . 192

4.4.2. Some observations . . . . . . . . . . . . . . . . . . . 193

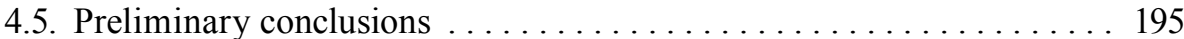

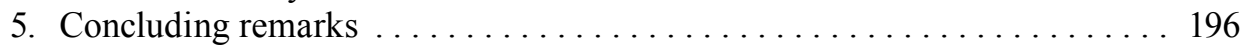

Chapter IV

Accountability for Injury Caused by Privatization . . . . . . . . . . . . . 199

1. Introduction. . . . . . . . . . . . . . . . . . . . . . . . . . . . . 199

2. State responsibility ........................... 200

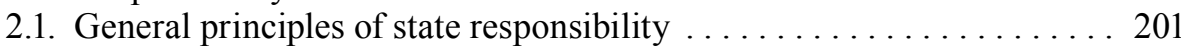

2.2. Attribution to the State for conduct of private actors . . . . . . . . . 204

2.2.1. Private actors exercising elements of governmental authority... 206

2.2.1.1. The delegated functions must contain elements of governmental authority ................ 210

2.2.1.2. The functions, tasks or services must be delegated to the entity by law . . . . . . . . . . . . . . . . . . . 221 
Contents

2.2.1.3. The private entity must act in a public or governmental

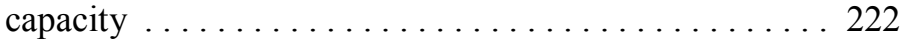

2.2.2. Private actors acting under orders of, or whose conduct is controlled by the State. . . . . . . . . . . . . . . . . . 224

2.3. Indirect state responsibility for failure to exercise due diligence . . . . 230

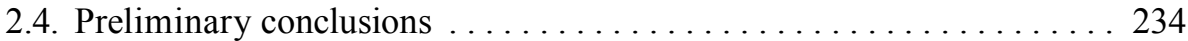

3. Responsibility of privatized actors as State actors exercising functions of

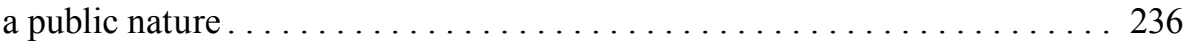

3.1. Private actors as State organs under international and regional human rights treaties . . . . . . . . . . . . . . . . . . . . . . 244

3.1.1. Private actors as State organs in the case law of UN human

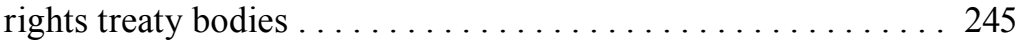

3.1.2. Private actors as State organs in the case law of the European Court of Human Rights. . . . . . . . . . . . . . . . . . . . . . . 248

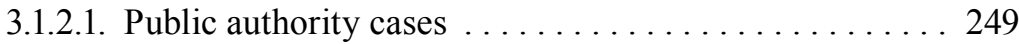

3.1.2.2. Article 34 ECHR cases .................. 252

3.1.2.3. Cases regarding responsibility for the conduct of non-State actors . . . . . . . . . . . . . . . . 254

3.1.3. Some observations . . . . . . . . . . . . . . 257

3.2. Applicability of EU law to private actors exercising functions of a public nature ............................ 258

3.2.1. EU competition law and governmental authority. . . . . . . . 258

3.2.2. Freedom to provide services and official authority . . . . . . . . 260

3.2.3. Applicability of directives to private actors . . . . . . . . . 263

3.2.4. Applicability of EU procurement law to private actors acting on behalf of the State . . . . . . . . . . . . . . . . . . 269

3.2.4.1. Contracting authorities or other bodies governed by public law . . . . . . . . . . . . . . . . . . . . 269

3.2.4.2. Other contracting entities not necessarily being public undertakings. .................... 275

3.2.5. Some observations . . . . . . . . . . . . . . . . . . . . . 277

3.3. Functions of a public nature and public authorities in the United Kingdom . . . . . . . . . . . . . . . . . . . . . . . . . . . . . . 278

3.3.1. Judicial review of private actors exercising public functions. . . 279

3.3.2. Human rights review of private actors exercising public

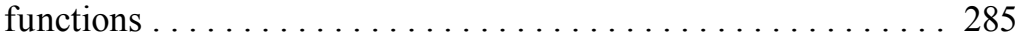

3.3.2.1. Definition of a 'public authority' under the Human Rights Act. . . . . . . . . . . . . . . . . . . 286

3.3.2.2. Interpretation of the Human Rights Act's 'public authority' by British courts . . . . . . . . . . . . . . 289

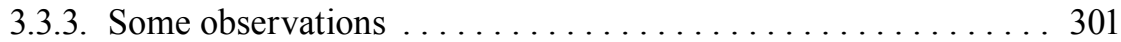


3.4. Applicability of constitutional norms to private actors in the United States . . . . . . . . . . . . . . . . . . . . . . 303

3.4.1. The state action doctrine . . . . . . . . . . . . . . 306

3.4.1.1. The 'public function' test. . . . . . . . . . . . . . 307

3.4.1.2. The "nexus' test . . . . . . . . . . . . . . . . . . . . . 314

3.4.1.3. The 'joint action' test ................. 316

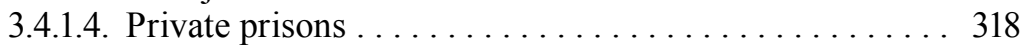

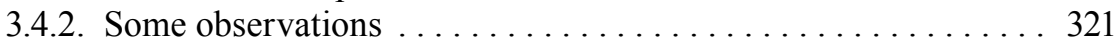

3.5. Private entities as governmental actors in Canada ............ 322

3.5.1. Formal applicability of the Canadian Charter of Rights and

Freedoms............................. 323

3.5.2. Charter applicability to non-State actors . .......... 325

3.5.2.1. Applicability to non-State actors that are considered to be 'government' ........................ 327

3.5.2.2. Applicability to non-State actors performing a 'governmental function'.................... 331

3.5.3. Some observations . ...................... 334

3.6. Applicability of public law norms in non common law countries .... 335

3.6.1. Applicability of public law norms in France to public services

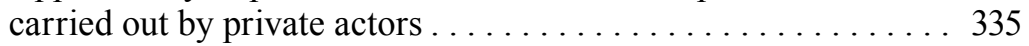

3.6.1.1. The concept of service public . . . . . . . . . 336

3.6.1.2. The concept of contrat administratif ........... 340

3.6.2. Applicability of public law norms in to privatized activities:

the case of Ecuador . . . . . . . . . . . . . . . . . . . . 342

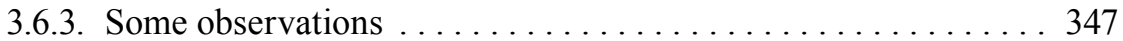

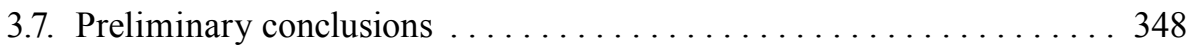

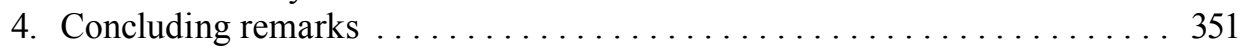

\section{Part II}

Practice and Sectorial Analysis $\ldots \ldots \ldots \ldots \ldots \ldots \ldots \ldots \ldots \ldots \ldots \ldots \ldots \ldots \ldots \ldots$

Chapter V

Privatization and the Practice of Human Rights Monitoring Mechanisms . . . . 355

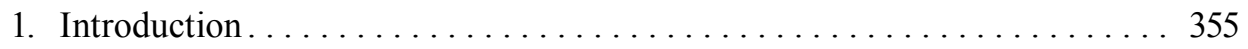

2. The UN human rights treaty bodies and privatization .......... 357

2.1. Human Rights Committee. . . . . . . . . . . . . . . . . . . . . . . 359

2.1.1. General Comments . . . . . . . . . . . . . . . . . . . . . . . . . 359

2.1.2. Case law .............................. 360

2.1.3. Examination of State reports ................ 363

2.2. Committee on Economic, Social and Cultural Rights .......... 368

2.2.1. General Comments . . . . . . . . . . . . . . . . . . . . . . 368

2.2.2. Examination of State reports . . . . . . . . . . . . 372 
2.3. Committee on the Elimination of All Forms of Racial Discrimination . 379

2.3.1. General Comments . . . . . . . . . . . . . . . . . . . . . . . . . . . . . . 379

2.3.2. Examination of State reports . . . . . . . . . . . 380

2.4. Committee on the Elimination of Discrimination Against Women . . . 382

2.4.1. General Comments . . . . . . . . . . . . . . . . . . . . . . . . . . . 382

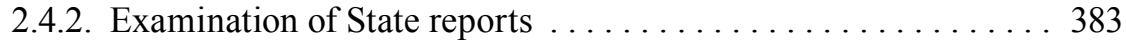

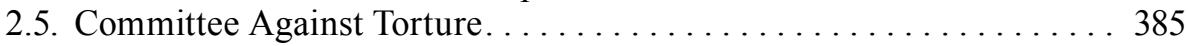

2.5.1. General Comments . . . . . . . . . . . . . . . . 385

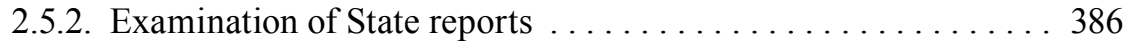

2.6. Committee on the Rights of the Child. . . . . . . . . . . . . . . . 390

2.6.1. General Comments . . . . . . . . . . . . . . . . . . . . . . 390

2.6.2. Examination of State reports . . . . . . . . . . . . . 391

2.7. Preliminary conclusions . . . . . . . . . . . . . . . . . . . . 394

3. The European human rights supervisory mechanisms and privatization. . . 395

3.1. European Court of Human Rights . . . . . . . . . . . . . . . . . . 396

3.1.1. Non-admissible or manifestly ill-founded privatization cases . . 396

3.1.2. Privatization as an issue of (indirect) concern before the

European Court of Human Rights . . . . . . . . . . . . . . . . . . . 399

3.2. European Committee on the Prevention of Torture . . . . . . . . . . . 406

3.2.1. Prison privatization in the Netherlands Antilles . . . . . . . . . . 407

3.2.2. Prison privatization in the United Kingdom. . . . . . . . . . . . . . . 409

3.2.3. Private Security services and the CPT . . . . . . . . . . . 411

3.3. European Committee for Economic and Social Rights. . . . . . . . . . . 413

3.3.1. Privatization and the right to work . . . . . . . . . . 414

3.3.2. Privatization, the right to bargain collectively and the right to strike ........................ 416

3.3.3. Privatization, health care, social security and other welfare related rights . . . . . . . . . . . . . . . . . . . . . . 419

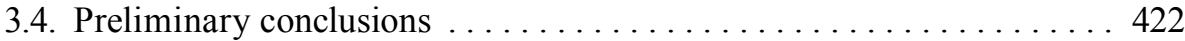

4. The International Labor Organization and privatization . . . . . . . . 423

4.1. Committee of Experts on the Application of Conventions and

Recommendations . . . . . . . . . . . . . . . . . . 423

4.1.1. Privatization and the prohibition of forced labor . . . . . . . . . 424

4.1.2. Privatization and the freedom of association . . . . . . . . . . . 429

4.1.3. Privatization and the protection of wages. . . . . . . . . . 431

4.1.4. Privatization and Social Security . . . . . . . . . . . 431

4.1.5. Privatization and the prohibition of discrimination at work. . . . 433

4.1.6. Privatization and employment injury benefits . . . . . . . . . 434

4.1.7. Privatization and employment . . . . . . . . . . . . . . 434

4.2. ILO Bodies Dealing with complaints and allegations. . . . . . . . . 438

4.2.1. The ILO Governing Body. . . . . . . . . . . . . . . . . 438

4.2.2. Committee on Freedom of Association . . . . . . . . . . . . . . . 440

4.2.2.1. Privatization, job dismissals and anti-trade union discrimination ................... 440 
4.2.2.2. Privatization measures, the suspension of collective agreements and the duty to consult ........... 445

4.2.2.3. Privatization and restrictions on the right to strike or bargain collectively . . . . . . . . . . . . . . . . 447

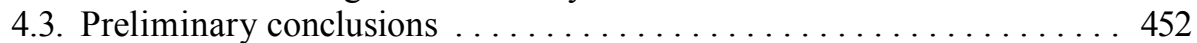

5. Concluding Remarks . .......................... 454

Chapter VI

Privatization of Security and Military Services. . . . . . . . . . . . . 457

1. Introduction............................... 457

2. Is war being privatized? The definition of privatization of military and

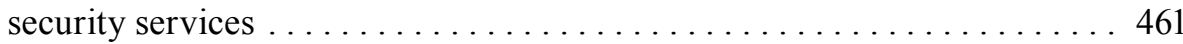

3. The mercenary issue and the status of private international security and military companies ............................ 465

3.1. Mercenaries under international law . . . . . . . . . . . . . 465

3.2. Mercenaries in historical perspective . . . . . . . . . . . . . 466

3.3. The emergence of PMSCs . . . . . . . . . . . . . . . . . 472

3.4. The legal status of PMSCs: mercenaries or legitimate businesses? . . . 474

3.4.1. Defining the mercenary . ................... 474

3.4.2. Difficulties of applying the current definition of mercenary to PMSCs. . . . . . . . . . . . . . . . . . . . . . . . . . 477

3.4.3. The legal status of PMSCs and regulatory efforts . . . . . . . 480

3.5. Preliminary conclusions ....................... 495

4. Case study: PMSCs, IHL and human rights law in Abu Ghraib prison, Iraq . . . .................................. 497

4.1. The presence of PMSCs in Iraq. . . . . . . . . . . . . . . 497

4.2. Violations of international humanitarian and human rights law in Abu Ghraib by contractors of PMSCs . . . . . . . . . . . . . . 498

4.2.1. Violations of international humanitarian law . . . . . . . . . 501

4.2.2. Violations of human rights . ................ 503

4.3. Is the U.S. responsible for the alleged violations committed by

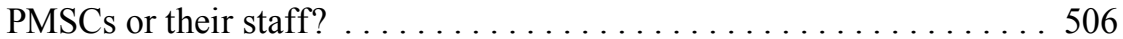

4.3.1. State responsibility under international law . . . . . . . . . 507

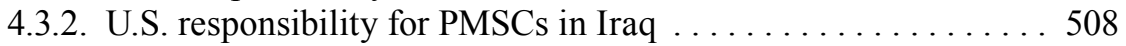

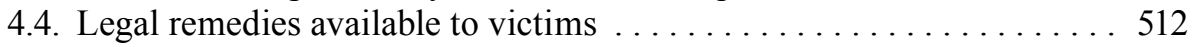

4.4.1. International procedural remedies . . . . . . . . . . . . 514

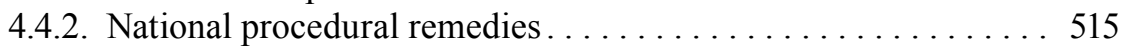

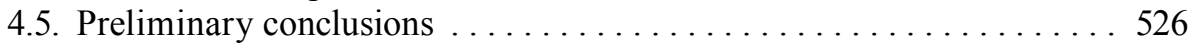

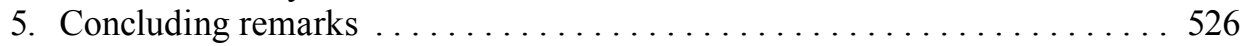


Contents

Chapter VII

Privatization of Essential Public Utilities. . . . . . . . . . . . . . . . . . . . . . . 529

1. Introduction................................ 529

2. The privatization of water utilities: definition, (historical) context, and techniques .............................. 536

2.1. Defining the privatization of water utilities............. 537

2.2. The nature of essential network and water utilities and universal

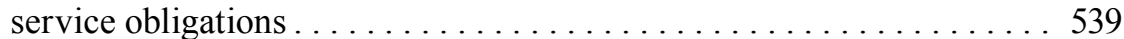

2.3. Methods and modes of the privatization of water utilities ....... 544

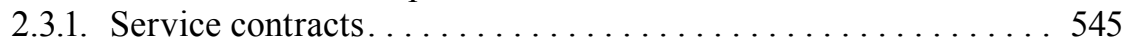

2.3.2. Management contracts ................... 546

2.3.3. Lease contracts . . . . . . . . . . . . . . . . . . . . . 546

2.3.4. Concession contracts. . . . . . . . . . . . . . . . . . . . 547

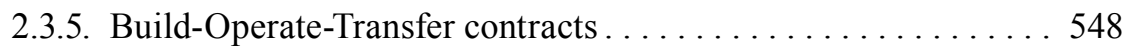

2.3.6. (Full) divestiture . . . . . . . . . . . . . . . . . . 548

2.4. Historical overview and reasons behind the privatization of water utilities ............................. 548

2.4.1. Privatization of water utilities in 'developed' countries. . . . . . 549

2.4.2. Privatization of water utilities in developing countries ...... 551

2.5. Recent developments in the privatization of water utilities ....... 557

2.6. Issues of general interest regarding privatization of water utilities

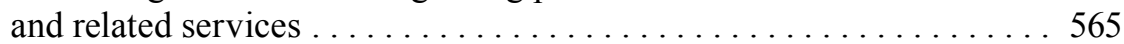

2.6.1. Private vs. public water. . . . . . . . . . . . . . 566

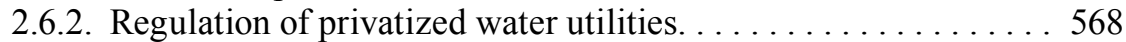

2.6.3. Privatization of water utilities and GATS . . . . . . . . . . 575

2.6.3.1. GATS: scope and application............... 577

2.6.3.2. GATS and privatization of water utilities? . . . . . . . 579

2.7. Preliminary conclusions $\ldots \ldots \ldots \ldots \ldots \ldots \ldots \ldots \ldots \ldots \ldots$

3. The privatization of water utilities and Economic, Social and Cultural

Rights. ............................... 586

3.1. The relationship between the privatization of water utilities and human rights .............................. 587

3.2. The right to water: definition and normative content . . . . . . . 593

3.2.1. Definition of the right to water ................ 593

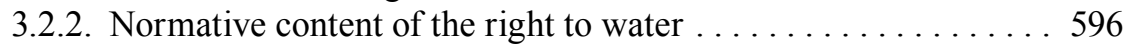

3.3. Scope of obligations under the right to water ............. 599

3.3.1. General obligations . . . . . . . . . . . . . . . . . . . 599

3.3.2. Specific obligations of the right to water ............ 601

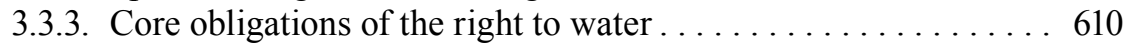

3.3.4. Violations of the right to water ................. 612

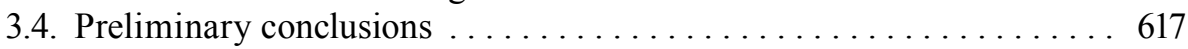


4. Case study: the privatization of water utilities in the city of Buenos Aires . 619 4.1. The privatization of essential utilities in Argentina: background. . . . 620

4.2. The Buenos Aires water concession ................... 623

4.3. Outcomes of the Buenos Aires water privatization............. 634

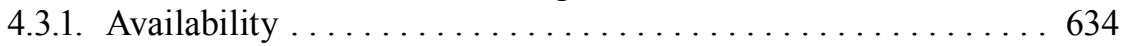

4.3.2. Quality................................. 637

4.3.3. Accessibility .........................6641

4.3.3.1. Physical accessibility . . . . . . . . . . . . . . 642

4.3.3.2. Economic accessibility: . . . . . . . . . . . . . . 646

4.3.3.3. Non-discrimination accessibility............ 650

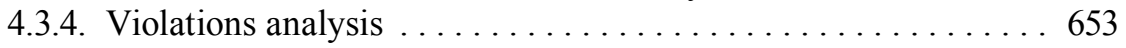

4.3.4.1. Violations of obligation to respect? ........... 654

4.3.4.2. Violations of obligation to protect? . . . . . . . . 656

4.3.4.3. Violations of obligation to fulfill? ............. 662

4.3.4.4. Violations of core obligations . . . . . . . . . . . . 664

4.3.5. Some observations ..................... 665

4.4. Accountability for the effects of the privatization of water utilities in

Buenos Aires? .............................. 666

4.5. Legal remedies available to individuals $\ldots \ldots \ldots \ldots \ldots \ldots \ldots \ldots 671$

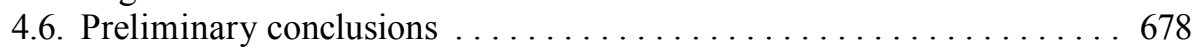

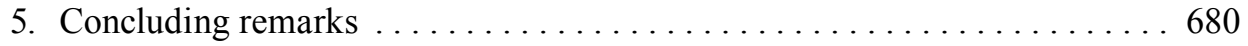

Chapter VIII

Summary and General Conclusions ...................... 683

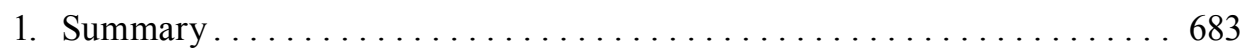

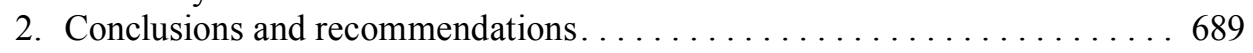

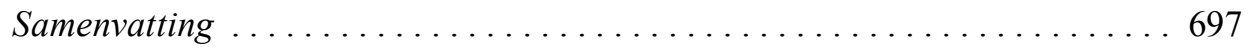

Selected Bibliography............................. 707

Table of Cases ..................................... 721

Index .............................................. 737

Curriculum Vitae ................................... 745 



\section{List of Abbreviations}

ACHR American Convention on Human Rights

ACHPR African Charter on Human and Peoples' Rights

ATCA Alien Torts Claims Act

CAT Committee Against Torture

CEACR Committee of Experts on the Application of Conventions and

Recommendations

CEDAW UN Committee on the Elimination of Discrimination Against Women

CERD UN Committee on the Elimination of All forms of Racial

Discrimination

CESCR UN Committee on Economic, Social and Cultural Rights

CPT European Committee for the Prevention of Torture

CRC UN Committee on the Rights of Children

ECHR European Convention on Human Rights

ECtHR European Court of Human Rights

ECJ European Court of Justice

ESC European Social Charter (Revised)

EU European Union

GATS General Agreement on Trade in Services

HRA Human Rights Act

HRC UN Human Rights Committee

IADB Inter-American Development Bank

ICCPR International Covenant on Civil and Political Rights

ICESCR International Covenant on Economic, Social and Cultural Rights

ICSID International Center for the Settlement of Investment Disputes

ICJ International Court of Justice

ILC International Law Commission

ILO International Labour Organization

IMF International Monetary Fund

NAFTA North American Free Trade Agreement

OPCAT Optional Protocol to the Convention Against Torture

SPT UN Subcommittee for the Prevention of Torture

OECD Organization for Economic Co-operation and Development

PMSC Private Military and Security Company

UN United Nations

UNDP United Nations Development Programme

UNCITRAL United Nations Commission on International Trade Law

VCLT Vienna Convention on the Law of Treaties

WHO World Health Organization

WTO World Trade Organization 



\section{Chapter I \\ GENERAL INTRODUCTION}

\section{INTRODUCTION}

On 5 May 2008, the New York Times reported that Mr. Boubacar Bah, a 52-year old tailor from Guinea who lived in New York and had overstayed a tourist visa, died while in solitary confinement in an immigration jail operated by a company providing security and correctional services. ${ }^{1} \mathrm{Mr} \mathrm{Bah}$ had been detained while attempting to re-enter the United States in 2006 following a brief visit to his family in his home country. He waited nine months in the Elizabeth Detention Center, an immigration jail in New Jersey managed by Correctional Corporations of America $(\mathrm{CCA}),{ }^{2}$ while he unsuccessfully reapplied for a green card. While in detention, $\mathrm{Mr}$. Bah collapsed in a restroom and injured his head. He became incoherent and agitated, and was put in solitary confinement. After a number of days his condition deteriorated and he was transferred to a hospital in Newark, where he went into a coma and died four months later on 30 May 2007. The incident was never properly investigated, and his family was only informed of his hospitalization five days after the fact. According to the New York Times news report, both the CCA's private security guards and the Public Health Service officer on duty in the Elizabeth Detention Center had neglected Mr. Bah's situation. Mr. Bah's death is one of 66 on a government list of deaths that occurred in immigration custody from January 2004 to November 2007. Many of these deaths have taken place in privately run prisons, currently the United States' fastest-growing form of incarceration. ${ }^{3}$ It would appear that no independent inquiry is mandated for these situations. The immigration officials only internally review the incidents and then report them to their inspector general who decides which ones warrant investigation. ${ }^{4}$ There is no apparent remedy open to victims or their families.

Mr. Bah's case illustrates two important aspects of the current globalization phenomenon. First, there is the issue of mass economic migration and the detention of 'illegal' aliens. Second, and more relevant to the present study, is the use of private actors to carry out tasks, functions or services that until a number of years

1 See "Few Details on Immigrants Who Died in U.S. Custody," New York Times newsreport, 5 May 2008, accessible through <www.nytimes.com/2008/05/05/nyregion/05detain.html?ref=n yregion\&pagewanted $=$ print $>$ (last visited 5 May 2008).

2 Correctional Corporations of America is one largest private companies in the world that manage and run prisons in various countries in the world. See.

3 See "Few Details on Immigrants Who Died in U.S. Custody," New York Times newsreport, 5 May 2008, accessible through <www.nytimes.com/2008/05/05/nyregion/05detain.html?ref=n yregion\&pagewanted $=$ print $>$ (last visited 5 May 2008). Ibid. 
ago had been carried out or operated by the State itself. The present globalization wave has been characterized by an immense expansion of world trade, the almost exponential growth of information and technology advances, mass migration movements, and the appearance of many non-State actors with the capacity to influence ${ }^{5}$ the national and transnational relationships between countries and peoples. Globalization has made our small world even smaller. It has also assisted in reducing the role of the State in certain ways.

The globalization of the world economy and its inevitable effects has carried tremendous consequences for the provision of tasks and services that once were carried out by the State. ${ }^{6}$ Many countries have been compelled to privatize the provision of these services. The reasons are manifold and will be explained in greater detail in another section of this study. However, whether it is due to internal political convictions, the ever-growing pressure to cut back the high costs of running a government, or the desire to improve competition and to provide efficient services for less money, the privatization of tasks and services by States can have far reaching implications for the enjoyment of human rights as well as for the human rights obligations of States. ${ }^{7}$

The privatization of state functions and services has been the subject to wide reporting in the news and media. For example, another recent New York Times report discussed the hiring of private military and security contingent led by Erik Prince, the director of a company called Xe formerly known as Blackwater, by the government of the United Arab Emirates to "[...] put together an 800-member battalion of foreign troops for the U.A.E." " According to the news report, the force was brought in not only to train the local military but also to supplement it, by conducting " [...] special operations missions inside and outside the country, defend oil pipelines and skyscrapers from terrorist attacks and put down internal revolts[.]" 9

5 See J. Matthews, "Power Shift," Foreign Affairs Vol. 76, no. 1 (1997), p. 50-66.

6 For a particularly negative view of this development see P. O'Connell, "On Reconciling Irreconcilables: Neo-liberal Globalisation and Human Rights," Human Rights Law Review Vol. 7 (2007), p. 498-501.

7 For a discussion of whether globalization advances human rights see, J.L. Dunoff, "Symposium: The Universal Declaration of Human Rights at 50 and the Challenge of Global Markets: Does Globalization Advance Human Rights?," Brooklyn J. Int'l L. Vol. 25 (1999), p. 125; R.E. HowardHassman, "The Second Great Transformation: Human Rights Leapfrogging in the Era of Globalization," Human Rights Quarterly Vol. 27 (2005), p. 1-40. For a highly critical discussion on whether (neo-liberal) globalization is compatible with human rights see the abovementioned paper by. O'Connell. O'Connell regards the current form of globalization, characterized by neoliberal tendencies, as inimical to human rights values, and argues that human rights proponents should resist it.

8 See "Secret Desert Force Set Up by Blackwater's Founder," New York Times newsreport, 14 May 2011, available through <www.nytimes.com/2011/05/15/world/middleeast/15prince. html?_r=2\&hp=\&pagewanted=all $>$ (last visited 20 May 2011). Ibid. 
General Introduction

The use of private actors to take over tasks usually carried out by governmental ones has even been the subject of theatrical entertainment. ${ }^{10}$

The phenomenon of privatization has also been brought to the attention of academic study as evidenced by the vast number of publications on the subject. The main focus of academic study on privatization has been on the political and social desirability of privatization and its economic advantages and disadvantages, although some attention has also been paid to the legal aspects of privatization. ${ }^{11}$

10 The 1987 motion picture "Robocop" provides one of the most violent examples. In the crimeridden Detroit of the future, the police service is in hands of a private company which develops the ultimate crime deterrent tool: a part man, part machine police officer. In the 2003 motion picture, "Johnny English", British comedian Rowan Atkinson playing an inept secret service agent takes on a greedy French CEO of a large multinational company played by John Malkovich, who wants to transform the United Kingdom into the largest privatized prison in the world and crown himself as king. Even more recently, John Cusack plays a contractor working for a private military and security company managed by a former Vice President of the United States and who is deployed in the first war entirely waged by a privatized army against the fictitious country of Turaqistan in 2008's "War Inc."

11 See for example, A. Walker, "The Political Economy of Privatisation," in Privatisation and the Welfare State, ed. J. Le Grand and R. Robinson, London: George Allen \& Unwin (1984), p. 19-44; E. Savas, Privatization: The Key to Better Government (Chatham, New Jersey: Chatham House, 1987); R.A. Cass, "Privatization: Politics, Law and Theory," Marq. L. Rev. Vol. 71 (1988), p. 449-523; S. Kamerman and A. Kahn, eds., Privatization and the Welfare State (Princeton: Princeton University Press, 1989); V.V. Ramanadham, "Privatisation: the UK Experience and Developing Countries," in Privatisation in Developing Countries, ed. V.V. Ramanadham, London: Routledge (1989), p. 3-63; C. Graham and T. Prosser, Privatizing Public Enterprises: Consitutions, the State, and Regulation in Comparative Pespective (Oxford: Oxford University Press, 1991); C.D. Foster, Privatization, Public Ownership and the Regulation of Natural Monopoly (Oxford: Blackwell Publishers, 1992); L.C. Bresser Pereira, "Economic Reforms and Cycles of State Intervention," World Development Vol. 21 (1993), p. 1337-1353; T. Daintith and M. Sah, "Privatisation and the Economic Neutrality of the Constitution," Public Law (1993), p. 465-487; L.S. Hyman, "Privatization: The Hows and the Whys," Public Utilities Fortnightly Vol 131 (1993), p. 18-26; A. Miller, "British Privatization: Evaluating the Results," Columbia Journal of World Business, no. Winter (1995), p. 83-98; M. Siragusa, "Privatization and EC Competition Law," Fordham Int'l L.J. Vol. 19 (1996), p. 999-1110; W. Devroe, "Privatizations and Community Law: Neutrality Versus Policy," CML Rev. Vol. 34 (1997), p. 267-306; P.B. Stephan, "Toward a Positive Theory of Privatization: Lessons From Soviet-type Economies," in Economic Dimensions in International Law: Comparative and Empirical Perspectives, ed. J.S. Bhandari and A.O. Sykes, Cambridge: Cambridge University Press (1997); D. Parker, "Privatisation in the European Union: an Overview," in Privatisation in the European Union, ed. D. Parker, London: Routledge (1998), p. 10-48; H. Feigenbaum, J. Henig, and C. Hamnett, Shrinking the State: The Political Underpinnings of Privatization (Cambridge: Cambridge University Press, 1999); S. Nestor and L. Mahboobi, "Privatisation of Public Utilities: The OECD Experience," Organisation for Economic Cooperation and Development, (1999); W. Devroe, "Privatisering en Verzelfstandiging: Een Verkenning Vanuit Nationaal en Europees Economisch Recht”, Faculty of Law, Katholieke Universiteit Leuven, Leuven, (2000); J. Freeman, "The Private Role in Public Governance," N.Y.U.L. Rev. Vol. 75 (2000), p. 543-675; and S. Nugraha, "Privatisation of State Enterprises in the $20^{\text {th }}$ Century: A Step Forward or Backwards?", Faculteit der Rechtsgeleerdheid, Rijksuniversiteit Groningen, Groningen, (2002). 
One needs only to do a simple search on the internet to find hundreds of references, handbooks, articles, manuscripts and commentaries on privatization and its economic benefits or pitfalls. And although not alone in its efforts, the World Bank has been instrumental in providing the detailed economical groundwork and theoretical framework for the privatization programs in many countries. ${ }^{12}$

However, relatively little attention has been devoted to the relationship between privatization and international law and human rights. Aside from the sporadic academic articles on the topic and despite the growing, albeit not always satisfactory, discussion of the issue at the level of international human rights organizations, arguably the first major academic publication on the issue of human rights and privatization appeared in 2005 in a book entitled "Privatisation and Human Rights in the Age of Globalisation" edited by De Feyter and Gómez Isa, to which the present author contributed a co-authored piece. ${ }^{13}$ This book was the result of a conference organized by Prof. Koen De Feyter, Prof. Fons Coomans and the present author at Maastricht University partly to facilitate the latter's doctoral research on the topic. A further stimulus for what has been increasing academic interest in this area is, no doubt, the growing (negative) attention that privatized services have garnered in the media, in particular with regard to the use of private military services in armed conflicts such as Iraq. ${ }^{14}$

12 See for example, World Bank discussion paper, Divestiture in Developing Countries, WDP11, 30 June 1987 and World Bank policy research working paper, Emerging Issues of Privatization and the Public Sector, WPS80, 30 September 1988, where the World Bank discusses issues pertaining to privatization in developing countries and strategies to be followed for successful privatizations. See also, inter alia, C. Vuylsteke, "Techniques of Privatization of State-Owned Enterprises, Vol. I Methods and Implementation,” World Bank Technical Paper WTP - 88, The International Bank for Reconstruction/World Bank, Washington D.C., (1988); D. Donaldson and D.M. Wagle, "Privatization: Principles and Practice," The World Bank and International Finance Corporation (IFC), Washington D.C., (1995); F. Sader, "Privatizing Public Enterprises and Foreign Investment in Developing Countries, 1988-1993," Foreign Investment Advisory Service, Occasional Paper 5, The World Bank, Washington D.C., (1995); P. Guislain, The Privatization Challenge: A Strategic, Legal and Institutional Analysis of International Experience (Washington D.C.: The International Bank for Reconstruction and Development/The World Bank, 1997); P. Keefer, "Contracting Out: An Opportunity of Reform and Private Sector Development in Transition Economies," ECSPF Occasional Paper No. 3, The World Bank, Washington D.C., (1998); J. Davis, R. Ossowski, and T. Richardson, "Fiscal and Macroeconomic Impacts of Privatization,” Occasional Paper No. 194, IMF, Washington D.C., (2000); P.J. Brook and S.M. Smith, "Contracting for Public Services: Output-based aid and its applications," The World Bank, Washington, (2001); F. Annuati-Neto, "Costs and Benefits of Privatization: Evidence from Brazil - Research Network Working Paper \# R-455," Inter-American Development Bank, Washington DC, (2003); N. Brune, G. Garret, and B. Kogut, "The International Monetary Fund and the Global Spread of Privatization," IMF Staff Papers Vol. 51 (2003), p. 195-219.

13 See F. Coomans and A. Hallo de Wolf, "Privatisation of Education and the Right to Education," in Privatisation and Human Rights in the Age of Globalisation, ed. K. De Feyter and F. Gómez Isa, Antwerp: Intersentia (2005), p. 229-258. See Chapter VI. 
Telling examples of the potential problems with regard to human rights and privatization can be found in the contracting out of prisons, ${ }^{15}$ and the privatization of public utilities such as water. ${ }^{16}$ Several States have taken steps to (partially) privatize prison services with the twin aims of streamlining state functioning by cutting back costly operations and providing an efficient service through the application of the free market and healthy competition. ${ }^{17}$ Private entrepreneurial companies such as the CCA described at the beginning of this section have taken over the task of the state by running prisons as a profitable business. In order to make the prison business profitable and cost effective, these companies have sometimes resorted to cutting back in the costs of certain aspects of prison life. Allegations have been made about cutting back costs related to prisoners' health services and education. ${ }^{18}$ Smaller prison cells have been built to accommodate even more prisoners in smaller prison facilities. Sometimes prisoners have been forced to share prison space with two or more prisoners. Similarly, the privatization of water services and utilities, which will be discussed in more detail in Chapter VII, has brought up questions with regard to its potential effects on certain economic, social

15 D. W. Dunham, "Note: Inmates' Rights and the Privatization of Prisons," Colum. L. Rev. 86 (1986), p. 1475-1504; A.C. Aman, "Privatisation, Prisons, Democracy and Human Rights: The Need to Extend the Province of Administrative Law," in Privatisation and Human Rights in the Age of Globalisation, ed. K. De Feyter and F. Gómez Isa, Antwerp: Intersentia (2005), p. 91-128; C. Fenwick, "Private Use of Prisoner's Labor: Paradoxes of International Human Rights Law," Human Rights Quarterly Vol. 27 (2005), p. 249-293; I.P. Robbins, "Privatisation of Corrections: A Violation of U.S. Domestical Law, International Human Rights and Good Sense," in Privatisation and Human Rights in the Age of Globalisation, ed. K. De Feyter and F. Gómez Isa, Antwerp: Intersentia (2005), p. 57-90.

16 See for example, N. Rosemann, "Das Menschenrecht auf Wasser unter den Bedingungen der Handelsliberalisierung und Privatisierung: eine Untersuchung der Privatisierung der Wasserversorgung und Abwasserentsorgung in Manila," Friedrich-Ebert-Stiftung, Division for International Cooperation, Global Trade Union Program, Bonn, (2003); M. McFarland SanchezMoreno and T. Higgins, "No Recourse: Transnational Corporations and the Protection of Economic, Social and Cultural Rights in Bolivia," Fordham Int'l L.J. Vol. 27 (2004), p. 16631805; C. Graham, "Human Rights and the Privatisation of Public Utilities and Essential Services," in Privatisation and Human Rights in the Age of Globalisation, ed. K. De Feyter and F. Gómez Isa, Antwerp: Intersentia (2005), p. 33-56; A. Kok, "Privatisation and the Right to Access to Water," in Privatisation and Human Rights in the Age of Globalisation, ed. K. De Feyter and F. Gómez Isa, Antwerp: Intersentia (2005), p. 259-287.

17 See J. E. Field, "Making Prisons Private: An Improper Delegation of a Governmental Power," Hofstra L. Rev. Vol. 15 (1987), p. 649-675; K. Beyens, S. Snacken, and C. Eliaerts, Privatisering van Gevangenissen (Brussels: VUBPRESS, 1992); J. R. Lilly and P. Knepper, "An International Perspective on the Privatisation of Corrections," The Howard Journal Vol. 31, no. 3 (1992), p. 174-191; D. C. McDonald, "Public Imprisonment By Private Means: The Re-emergence of Private Prisons and Jails in the United States, the United Kingdom and Australia," Brit. J. Criminol. Vol. 34, no. special issue (1994), p. 29-48; J.G. DiPiano, "Note: Private Prisons: Can They Work? Panopticon in the Twenty-First Century," N.E. J. on Crim. \& Civ. Con. Vol. 21 (1995), p. 171-202; P. J. Duitsman, "The Private Prison Experiment: A Private Sector Solution to Prison Overcrowding,” N.C.L. Rev. Vol. 76 (1998), p. 2209-2265.

18 I.P. Robbins, "Managed Health Care in Prisons As Cruel and Unusual Punishment," J. Crim. L. \& Crimonology Vol. 90 (1999), p. 195-237. 
and cultural rights. There are concerns that privatizing water services is improper and is detrimental to the most vulnerable sectors of society. ${ }^{19}$ People fear that privatization of water utilities will result in cherry picking, that privatized water companies will only provide these essential services in those areas where consumers who can actually pay for the services live, leaving those in poorer areas without access to the services. There are also concerns, that privatization of water utilities will drive the prices of water access up, leading to various negative consequences, such as health care and hygiene problems. These two examples, together with the one described at the beginning of this Chapter, raise questions on issues like the right to an adequate standard of living (including a right to water), ${ }^{20}$ the right to health, ${ }^{21}$ the right to humane treatment while in detention and the respect for the inherent dignity of the human person, ${ }^{22}$ and the prohibition of (psychological) torture. $^{23}$

Not everybody is convinced that privatization is detrimental to human rights. As will be discussed in Chapter II, the World Bank has actively campaigned for privatization as a means of modernizing the State, improve its financial and economic situation, provide cheaper and more efficient services, thus indirectly contributing to the realization of human rights. Although the World Bank has recently recognized that privatization is not always the ideal recipe to solve all the financial, economic, and social problems of States, and privatization is no longer forcefully prescribed upon borrowing countries, the Bank still recommends its application.

How does this all justify the topic of this study? Harding has stated with regard to one of the abovementioned examples of privatization that, "[...] private prisons are here to stay for the foreseeable future." ${ }^{24}$ Similarly, in spite of the hard criticism issued towards the privatization of other public services, and a small but perceived recent reduction in the willingness to privatize among States (in particular

19 For example, in a 2002 preliminary report on the right to drinking water supply and sanitation, Mr. El Hadji Guissé observed that "[t]he effect of untimely privatizations of water supplies in Africa in the last decade has been chiefly to create further water shortages. Water has become too expensive and the system of management by exclusion has given rise to extreme and now endemic poverty in Africa." See Sub-commission on the Promotion and Protection of Human Rights, "Relationship between the enjoyment of economic, social and cultural rights and the promotion of the realization of the right to drinking water supply and sanitation", Preliminary report submitted by Mr. El Hadji Guissé in pursuance of decision 2002/105 of the Commission on Human Rights and resolution 2001/2 of the Sub-Commission on the Promotion and Protection of Human Rights, UN Doc. E/CN.4/Sub.2/2002/10 (25 June 2002), para. 30. Article 12 International Covenant on Economic, Social and Cultural Rights, 19 December 1966. Article 10 International Covenant on Civil and Political Rights, 19 December 1966. treatment or punishment, 10 December 1984.

24 R.W. Harding, Private Prisons and Public Accountability (Open University Press, 1997) p. 17. 
developing ones), it can be argued that privatization will remain a tool frequently resorted to by States. Even if the potential human rights effects of privatization are not always as serious as many would argue, the fact that privatization is here to stay for the foreseeable future warrants an analysis of its relationship with the obligations of the State and other actors involved in the privatization process under international law in general and the international law of human rights in particular. A number of international and regional human rights monitoring mechanisms have stated that the contracting out to the private commercial sector of 'core' State activities or the delegation of its obligations to private bodies or individuals does not absolve that State of its obligations under the various human rights treaties. ${ }^{25}$ Whatever the 'core' State activities or its obligations under international law and the international law of human rights may be, it is clear that the increasing reliance of the State on private actors for their performance and the potential problems that this may bring is a topic that needs to be analyzed in more detail.

\section{Problem AND ObJeCt OF STUdY}

\subsection{Context of study}

The above-mentioned examples illustrate some of the problems that can arise with regard to human rights and privatization. But what is privatization, and does privatization actually affect the enjoyment of human rights? The first question is hard to answer. Most studies on privatization cannot agree upon an ultimate definition for the term. The opinions on what privatization really encompasses differ broadly. Although a working definition of privatization is necessary for defining the scope of this study, ${ }^{26}$ it is not the purpose of this research to come up with an all-encompassing definition for privatization. Nor will this study explore in detail all the tasks which are being privatized and why. The number of tasks and services that have been privatized is large and it is beyond the aim of this study to include them all here. These tasks range from garbage collection, to the provision of infrastructural, municipal and utilities services such as road construction, electricity and water services, from the provision of basic medical assistance and care, housing, to the coercive use of force and the administration of justice. This study will focus on a number of tasks, functions and services whose current privatization is highly controversial and which raise serious questions with regard to the place of the State in society: the State as the ultimate actor with regard to the use of coercive force in

25 See Cabal and Pasini Bertran v. Australia, Communication No. 1020/2001, UN Doc. CCPR/ C/78/D/1020/2001 (19 September 2003), para. 7.2 and Costello-Roberts v. the United Kingdom, judgment of 25 March 1993, ECtHR Series A247-C, paras. 28-30. The actual meaning of this statement and its implications for the study at hand will be discussed in more detail in Chapter IV.

26 For the definition used in the context of this study see Chapter II Section 2.1. 
military conflicts, and the State as responsible for the provision of essential services, without which, arguably, modern societies are not able to function effectively due to the externalities related to the service. ${ }^{27}$ Thus, this study will concentrate in analyzing the privatization of military and security services in times of armed conflict and the privatization of essential utilities, with particular focus on water utilities. These two sectors currently subject to privatization also provide the opportunity of studying privatization from the perspective of civil and political rights as well as from economic, social and cultural rights.

It is worth noting that international human rights monitoring bodies have to a varying degree and depth questioned the trend to transfer so called 'core' or traditional State functions to private actors. ${ }^{28}$ For example, in one of the earliest UN studies on prison privatization commissioned by the now defunct UN SubCommission on the Promotion and Protection of Human Rights, Ms. Claire Palley concluded that,

"[...] the responsibility of the State does not permit it to sub-delegate the power of giving effect to restrictions on personal liberty, including having custody of prisoners. In short, privatization of prisons by way of contracting out management (control) and custody is not in accordance with international human rights law."29

Although it can be debated whether indeed privatization of prisons is not in accordance with international human rights law, this statement serves as an example of the scepticism that the privatization of governmental functions and publicly provided services has received. This has often been coupled to the (academic) discussion related to the perceived tension between the public and private spheres, which according to some, has been further strained by the pursuit of privatization policies. ${ }^{30}$ This study will not pay full attention to the private-public distinction nor

27 According to the New Oxford American Dictionary, in economics externalities are side effects or consequences of an industrial or commercial activity that affects other parties without this being reflected in the cost of the goods or services involved. See also G. Tullock, Public Goods, Redistribution and Rent Seeking (Cheltenham: Edward Elgar Publishing Ltd., 2005) p. 7.

28 This is partially evidenced by the observations alluded to in the previous section. A deeper discussion on the practice of international and regional human rights monitoring bodies with regard to the topic of privatization is presented in Chapter V.

29 See Sub-Commission on Prevention of Discrimination and Protection of Minorities, "The possible utility, scope and structure of a special study on the issue of privatization of prisons," outline prepared by Mrs. Claire Palley pursuant to Sub-Commission decision 1992/107UN Doc. E/CN.4/Sub.2/1993/21 (25 June 1993), para. 66.

30 On the issue of the private - public discussion related to privatization and globalization see M. Aronson, "A Public Lawyer's Responses to Privatisation and Outsourcing," in The Province of Administrative Law, ed. M. Taggart, Oxford: Hart Publishing (1997), p. 40-70; P. Craig, "Public Law and Control Over Private Power," in The Province of Administrative Law, ed. M. Taggart, Oxford: Hart Publishing (1997), p. 196-216; A.C. Aman, "The Globalizing State: A FutureOriented Perspective on the Public/Private Distinction Federalism, and Democracy," Vand. J. 
will it attempt to provide a concrete answer to the question of what these 'core' or traditional State functions. ${ }^{31}$ What is important to note is that opinions differ as to what is a 'core' task, function or service of the State. In the most minimalist view, a core State function could entail the provision of public safety for society and the monopoly of the use of force to function without fear of a Hobbesian world. ${ }^{32}$ Some authors regard the core functions of a State to comprehend those functions necessary to uphold the rule of law. These include functions pertaining to the coercive use of force, the administration of justice, legislative, executive and judiciary functions. ${ }^{33}$ According to other views, 'core' State functions go beyond the provision of basic safety and entail the taking care of the individual from the cradle to the grave (the so-called welfare state). With regard to the question of what is a traditional State function, it has become clearer that several functions or tasks that are often regarded as being tasks which the State has traditionally performed, turn out to be tasks which not so long ago were carried out by private individuals or entities. ${ }^{34}$ It is for these reasons that it is not always correct to speak of traditional State functions and why branding a function, task or service as traditionally belonging to the State is not a sufficient reason for arguing against its privatization. ${ }^{35}$

This study will, however, attempt to provide some insights as to the propriety of privatizing certain tasks, functions or services vis-à-vis State's legal obligations from the perspective of international law in general, and the international law of human rights in particular. Therefore, for the purpose of this study it does not matter whether a State function, task or service has always belonged to the State or whether it belongs to the 'core' of the functions or tasks that a State must perform. What does matter, is that human rights problems can arise when the State decides to

Transnat'l L. Vol. 31 (1998), p. 769-870; G. Teubner, “After Privatization? The Many Autonomies of Private Law," Current Legal Problems Vol. 51 (1998), p. 393-424; D. Oliver, Common Values and the Public Private Divide, Law in Context (London: Butterworths, 1999);

A. Barak, "Constitutional Human Rights and Private Law," in Human Rights in Private Law, ed. D. Friedmann and D. Barak-Erez, Oxford: Hart Publishing (2001), p. 13-42; A.C. Aman, The Democracy Deficit: Taming Globalization Through Law Reform (New York: New York University Press, 2004).

31 A historical, if possibly now out-of date, account of the development of the State from ancient times until the $19^{\text {th }}$ century, as well as the different functions that have been traditionally coupled to the State can be found in Johan Kaspar Bluntschli's 1875 work entitled, Lehre vom modernen Staat (The Theory of the State), translated to English in 1895, Batoche Books, Ontario, Canada (2000).

32 See C.J. Rosky, "Force, Inc.: The Privatization of Punishment, Policing, and Military Force in Liberal States," Conn. L. Rev. Vol. 36 (2004), p. 883-886.

33 See for example D.M. Lawrence, "Private Exercise of Governmental Power," Ind. L. J. Vol. 6 (1986), p. 647-648.

34 See Section 2.2 of Chapter II for a brief overview.

35 Even so-called 'core' or traditional tasks related to the coercive use of force such as policing and military tasks have been subjected to privatization. With regard to the latter see further Chapter VI. See also Cass, "Privatization: Politics, Law and Theory," p. 499. 
transfer to private parties functions and services that have a wide impact (either positive or negative) on the population. Privatization may have particular consequences on those elements of the population, which depend on these services, are more vulnerable, and which may have little choice for seeking alternative services. This could be especially the case of services that are natural monopolies. ${ }^{36}$ Under these circumstances, it is imperative to consider whether the international law and human rights obligations of States ensuing from regional and international human rights treaties can provide any guidance or restrictions for States that decide to privatize. With this in mind, it is useful to circumscribe the object of this research in order to provide a limited context in which the problems related to human rights and privatization can be studied. For this purpose, privatization is understood to mean the deliberate transfer or delegation of tasks, activities and or services from the government that was responsible for performing them to private parties, which then are in charge of carrying them out. ${ }^{37}$

\subsection{Human rights and privatization}

At first glance, one could easily assume that privatization has no bearing on human rights. After all, it usually is an operation that mostly entails economic causes and effects. Privatization is also supposed to bring positive (economic) results and contribute to a more efficient and cheaper provision of services, although the debate as to whether this is actually true is still raging. ${ }^{38}$ However, with all the focus on the positive or negative economic returns of privatization, the human and social aspect

36 Thus, the privatization of water utilities can have an impact on the poorest sectors of society if it results in higher prices of water leading to less physical access to the service; the privatization of policing and prisons can have an impact on those who are deprived of their liberty; the privatization of social security services can have an impact on those who rely on welfare benefits; the privatization of health care can have an impact on patients; and the privatization of education can have an impact on children.

37 It should be borne in mind that sometimes the definition of privatization will also depend on the sector that is being privatized and the method that has been chosen to make feasible the transfer from the State to private parties. See also Chapter II infra for a more detailed definition of privatization as understood in this study.

38 Cass has argued that claims of greater efficiency in the provision of services by either the State or private actors is an oversimplification of the issue. He noted that there are other factors to take into account in the discussion as to whether a private means of providing a particular service or function is better or more efficient than the public one. He observes, that "[t]he dominant problem in selecting the optimal vehicles for supply of a given service ultimately is the underlying normative problem of social choice. The positive evidence indicates that government provides many services that could be provided more efficiently by private enterprise but for the desire, whether self-interested or public-spirited, to effect efficiency-reducing wealth transfers. The evidence also indicates that public decision makers are not unconcerned with efficiency. The difficulty of selecting a single, definitive goal for government action, which increases agency costs in government, also frustrates efforts to prescribe mechanisms for accomplishing the ends chosen for the polity and to deduce the social goal for any given activity from the means chosen.” Cass, "Privatization: Politics, Law and Theory," p. 491. 
of privatization in the academic world has usually been lost. ${ }^{39}$ The problem illustrated at the beginning of this Chapter shows that privatization can also have grave consequences for the enjoyment of human rights. This does not mean that privatization always has a negative impact on human rights. In fact, it is perfectly possible for privatization to enhance their enjoyment. The introduction of privatization can, if properly implemented, help to solve the problems in countries with deficient public institutions that are unable to provide essential services to the population. Nevertheless, it is necessary to pay attention to the potential pitfalls that privatization can bring for human rights. States have engaged various international obligations pertaining to the respect and fulfillment of human rights when they ratified the numerous international and regional human rights treaties. It is therefore important to investigate whether privatization of certain functions and services conflicts with these obligations and what the consequences are of these conflicts.

It is important to emphasise that this study will focus on the legal and human rights issues related to privatization rather than the political issues concerning whether to privatize or not. The study will not a priori question whether it is sensible to privatize or not certain functions, tasks or services. Rather, this study departs from the given that privatization is already taking place and asks questions related to the human rights aspects of this phenomenon. It will thus attempt to evaluate the problems connected to privatization and how these can have an impact on human rights.

This raises the following question. Under which circumstances does the privatization of State functions and services results in breaches of the human rights obligations engaged by States? Additionally, it is essential to look at the possible solutions to conflicts between human rights and privatization and the role of general international law and human rights law therein. Consequently, the central research question of this study is the question whether and if so how international law in general and human rights law in particular can be reconciled with the privatization of state functions and services?

There are several related questions to this problem, which this study will also attempt to answer. In the first place, to what extent can human rights and international law principles provide limits and guidelines to the State if it decides to privatize its functions? ${ }^{40}$ This involves identifying the circumstances and conditions under which privatization must take place if the State wants to be human rights

39 See J. Stiglitz, Globalization and Its Discontents (London: Allen Lane/The Penguin Press, 2002) p. 56.

40 It is the purpose of this study to examine the conflicts that could exist between (international) human rights obligations and privatization obligations imposed for example by international financial institutions and deemed necessary for improving the economic situation of States and try to seek how these conflicting obligations could be reconciled. 
compliant. Thus the question will be how can human rights obligations determine how a particular function or service may be privatized?

In the second place, a problem arises as to who should be held accountable for the respect of human rights during a privatization process. Should the State be held accountable for human rights abuses that took place during and after privatization? Or is the private party responsible for carrying out the privatized function or service to be held accountable for human rights abuses? This question leads to problems related to the horizontal application of human rights norms ${ }^{41}$ and how to hold the various actors involved in the privatization process accountable for human rights abuses that have taken place in the excersize of privatized tasks. In this context one can validly ask which remedies, if any, are available for individuals or groups whose (human) rights have been affected by privatization or by the carrying out of privatized functions? Can human rights issues in the context of privatization be best resolved through regulation (for example the creation of regulatory bodies) or through normal adjudication?

In the third place, there are questions related to the role of international, regional and national supervisory and monitoring mechanisms for human rights with regards to privatization. What have they to say in relation to privatization and have they developed viable and practical solutions to eventual conflicts between human rights and privatization? Is there a common approach to the problem?

\section{Methodology AND STRUCTURE OF THE STUdY}

In attempting to answer the various questions that have been brought up, the present study has used a dual analytical approach to examine the various relevant issues. It has first attempted to examine how the general rules of international law and international human rights law apply to the issue of privatization. By relying on existing principles of these two bodies of law and the practice of international and human rights adjudicating bodies in their interpretation, the present study has attempted to distill the conditions under which privatization may be contrary to these norms or when it may be deemed to be compliant with them. Due to the lack of specific human rights case law (few cases from international and regional human rights adjudicators have actually dealt with privatization as an issue of concern, and most of them only indirectly), the present study has attempted to infer by analogy the various concepts related to international and human rights law as they would

41 In this regard, some scholars speak about the 'privatization' of human rights. See A. Clapham, Human Rights in the Private Sphere (Oxford University Press, 1993). In the view of the present author the use of the term in such a way is somewhat confusing as it detracts from the central aspect of the current discussion which is the privatization of state functions as it relates to human rights. 
apply to privatization and discuss what would be the potential outcomes thereof. The case law of the UN Human Rights Committee and the European Court of Human Rights has been particularly useful in this regard. In the second place, it has adopted an inductive methodology to discover patterns and related approaches of adjudicatory bodies dealing with a similar issue. Thus, with regard to the question of accountability of States for the conduct of privatized actors for human rights abuse, the present study discusses and compares the practice of various international adjudicatory bodies including the Permanent Court of International Justice, the International Court of Justice, and various international arbitral tribunals that have dealt with the question of state responsibility for the conduct of private actors. In addition, an analysis on whether human rights norms can be directly applied to privatized actors exercising what may be regarded as services of general public interest, draws on the examination of the case law from various international, regional, and national jurisdictions in an attempt to infer general principles from those particular instances. Thus, a comparative approach was adopted to examine and evaluate this case law to see how these jurisdictions have dealt with a common issue: what is the status of private actors exercising public functions and does this have an effect on the applicability of public, constitutional or human rights norms on their activities? The national jurisdictions used in that analysis were chosen because they have been confronted with questions arising from the use of private actors in performing these functions, and because of the frequency in which the question as to the status of these private actors with respect to constitutional norms and human rights was raised. The study has attempted to apply these general observations to the two case studies discussed below.

Where possible, the study has used primary sources and documentation to enrich the analysis. These sources include national legislation, case law from various international, regional and national jurisdictions, and reports from stakeholders such as the World Bank, business enterprises, and national monitoring or regulatory institutions and agencies like Ombudsmen. The choice of the sources can be justified by their direct or indirect link to the issue of privatization. Although, the study does not claim to have used an interdisciplinary approach, it also relies on the analysis of documentation and academic research from other branches of the social sciences such as economics. Some of the research output examined comes from international financial institutions such as the World Bank, which has been extensively involved in the privatization field. In addition, non-governmental organizations and academic institutions that have looked at the social and economic effects of privatization have prepared relevant research studies and analysis, which have been useful for the present study. ${ }^{42}$ These sources have been chosen for their

42 The Public Services International Research Unit of the School of Business at Greenwich University is particularly prolific in this respect and has built an extensive archive of studies and policy papers dealing with privatization in general, but also with specific or thematic topics and case studies discussing the effects of privatization, albeit not from a human rights perspective. 
external appraisal of the issue of privatization, in particular for their outlook as to how privatization may have an impact on human rights.

In an attempt to see how the various concepts studied are reflected in practice, this study makes use of two case studies as discussed in the following paragraph. From a methodological perspective the use of these case studies has the purpose of discussing and testing some of the concepts that are discussed in the previous chapters. These two case studies were selected for analysis for three main reasons. In the first place, the use of privatization in these two cases was deemed to be controversial, giving way to a major debate as to the perceived negative impact they have had on civil and political rights, and economic, social and cultural rights respectively. Thus, the case studies will allow the examination of how the privatization of two important services (military and security, and water provision) has had practical effect on the prohibition of torture, and the right to water. In the second place, the case studies have also been selected because they have been widely documented and the ramifications of the use of privatization in their respective sectors are still being felt. ${ }^{43}$ In the third place, these two case studies have been chosen for their current impact: the use of private military and security companies is an issue that still makes the daily news, especially due to their broad deployment in the current conflict in Iraq. Similarly, the question of privatizing public utilities, in particular water utilities, is a topic that aside from being widely debated in the media, has also led to recent 'popular revolts' as witnessed by the 'water wars' that took place in Bolivia only a few years ago, and the explosion of international arbitration procedures against States that are reversing their privatization efforts under popular demand.

This study is divided into 2 parts. Part A is devoted to the examination of the contextual and theoretical framework of privatization as it relates to international law in general, and human rights in particular. Chapter II of Part A will thus provide a definition of privatization for the purposes of the present study. It will briefly discuss the nature and historical context of privatization, the general methods utilized to implement privatization, and the actors which play an important role in its design and implementation. Chapter III will then look at the relevant theoretical and doctrinal aspects of international law and human rights law as they relate to privatization. It will enumerate the relevant rules, principles and obligations flowing from international law and international human rights law that could be applicable for the purpose of answering the problems related to privatization and human rights. In Chapter IV, the issue of accountability will be discussed. It will first provide an

43 For example, the contractors and companies that have been accused of involvement in the disturbing occurrences at Abu Ghraib prison leading to horrendous abuses between 2003-2004 that, as will be argued, amounted to torture, have not yet been brought to justice, and while there is an ongoing civil law procedure against some of the contractors, the prospects of an outcome favorable to the victims of those abuses is not yet certain. 
evaluation of the concept of State responsibility as a means of ensuring that the State remains accountable for what happens if it decides to privatize certain functions or services. It will also look at the question of the accountability of the non-State actor that is actually carrying out the privatized function or service. It will attempt to suggest a paradigm that establishes a pragmatic way of holding these non-State actors accountable for abuses of human rights in the exercise of their privatized activities.

Part B of this study takes a practical approach to the topic at hand. Chapter V will analyze the practice of various international and regional human rights mechanisms with respect to privatization. A review of the way United Nations treaty monitoring bodies have dealt with the issue of privatization will be complemented with an account of the practice of the various human rights bodies working under the Council of Europe and the International Labor Organization system. They have been chosen because they have addressed the issue of privatization in relationship to the various human rights instruments under their jurisdiction quite extensively, if not always in a consistent manner. This will be followed by the examination of two case studies that look at how the privatization of two important services has had an impact on particular human rights. Thus Chapter VI will examine the privatization of military and security services and discuss the deployment of private military and security companies in the current conflict in Iraq. More specifically, it will analyze the use of private military and security contractors to perform interrogations in the now infamous Abu Ghraib prison. Chapter VII will, in turn, focus on the privatization of water utilities. Particular attention will be paid to the privatization of water services in the city of Buenos Aires, Argentina, which ran from 1993 to 2006. These case studies will look at the historical development of privatization in their respective sectors. In addition, they will discuss the role of the actors involved in the privatization of military and security services and the water utilities sector, and the content of the various international and regional human rights norms as they relate to these sectors. They will also try to apply the set of principles of international law explored in Part A to concrete problems of privatization and human rights in the two case studies.

It is necessary to observe at this point that the present study has attempted to be as thorough as possible with regard to the examination of issues that are of relevance in the context of the topic. Of course, the present study does not aim to cover all aspects of privatization as it relates to international law and international human rights law. While the two sectors that receive the most attention in this study military and security services and essential water utilities - are undoubtedly topical and important, there are other areas of pressing concern that merit further study with regard to the relationship between the privatization efforts therein and their relationship with international human rights law. Although the study by De Feyter and Gómez Isa covers a broad range of aspects and sectors with regard to the issue 
of privatization and human rights, ${ }^{44}$ there is still ample space to examine the relationship between privatization and certain other sectors such as housing, electricity, and even mundane, yet important public services such as garbage collection. In this study, however, the aim is depth rather than breadth. Restricting attention to two case studies enables exploration of perspectives that may appear obvious, but have not yet been thoroughly discussed. The issue of the accountability of private actors exercising privatized functions comes to mind. Although there have been doctrinal suggestions that human rights can apply horizontally to third party private actors, ${ }^{45}$ adjudicating bodies have yet to accept this. A less considered but probably more practical and useful approach to cover this gap is discussed in this study, thus illustrating the value of a comprehensive analysis of the practical implications of privatization. The foundations for that analysis are laid in the next chapter.

44 That study covers the privatization of prisons, social security, health care, education, and water.

45 See for example, A. Clapham, Human Rights Obligations of Non-State Actors (Oxford: Oxford University Press, 2006); C. Courtis, "The Applicability of Human Rights Between Private Parties," in Human Rights in Education, Science and Culture: Legal developments and challenges, ed. Y. Donders and V. Volodin, Paris/Aldershot: UNESCO Publishing/Ashgate (2007), p. 153-181. 


\section{Part I}

\section{Theoretical Framework}





\section{Chapter II \\ Privatization in Context}

\section{INTRODUCTION}

Before dealing with the specific issue of privatization as it relates to international law and, in particular, to human rights, it is necessary to place privatization in a broader perspective. To this end, this chapter will firstly explore the meaning of privatization, and provide a brief history of privatization, the types and methods of privatization that have been commonly applied as well as the reasons behind privatization. It will also briefly discuss the actors usually involved in the process of privatization. Special attention will also be given to elucidating the role of international financial institutions in the privatization process and exploring the national and international legal contexts that have contributed/facilitated to privatization.

\section{Privatization: Definition, historical CONTEXT, AND NATURE}

This section will provide a definition for the term privatization that is relevant for the scope of this study. Additionally, this section will provide a general overview of the methods that are usually applied to implement privatization policies. Finally, this section will briefly focus on the actors and stakeholders that either actively or passively play a role prior, during and after the privatization process.

\subsection{Defining privatization and its rationale}

Privatization can be an elusive term with various meanings. Starr has noted that privatization is a fuzzy concept evoking sharp political reactions and covering a wide range of ideas and policies. ${ }^{1}$ As with many concepts, there appears to be no officially agreed definition of privatization and commentators on the subject have different views with regard to its concrete meaning and content. ${ }^{2}$ The definition of privatization depends upon the political outlook from which it is being examined, the concrete situation and manner in which this phenomenon occurs and the

1 P. Starr, "The Meaning of Privatization," in Privatization and the Welfare State, ed. S. Kamerman and A. KahnPrinceton University Press (1989), p. 16.

2 Feigenbaum, Henig, and Hamnett, Shrinking the State: The Political Underpinnings of Privatization, p. 5. See also T. Daintith, "Legal Forms and Techniques of Privatisation," in Legal Aspects of Privatisation, XXIst Colloquy on European Law, Budapest: Council of Europe (1993), p. 50; Devroe, "Privatisering en Verzelfstandiging: Een Verkenning Vanuit Nationaal en Europees Economisch Recht", p. I-7. 
motivations behind it. ${ }^{3}$ For example, privatization could mean reducing the role of the state while at the same time enhancing that of the private sector. ${ }^{4}$ Another definition refers to the transfer of ownership of a state owned enterprise to a private actor. ${ }^{5}$ It could mean the (partial) transfer of management duties of a state owned facility from the state to a private entity that then takes over the managerial day-today activities, while the ownership of the facility remains in the hands of the state. Privatization can also be defined as a switch in the responsibility to provide certain services: the state is no longer responsible for providing a certain service, but it delegates that duty to a private entity either through action (law or concession contract) or de facto by omission. In short, the concept of privatization can be wide and deals with aspects that are related to the ownership, organization, management and operation of state assets, functions, services and tasks. ${ }^{6}$

In spite of the apparent lack of a concrete definition for privatization, the common denominator running through the privatization debate seems to be "[...] an increased reliance on private actors and market forces to take over functions or responsibilities that had in recent decades come to be regarded as properly within the governmental sphere." 7 The increased reliance on private actors can take different shapes and forms and can be full or partial. The amount of reliance on these actors also depends on the factors that have influenced the decision to privatize. These factors include political, economic, and legal aspects that help to shape the extent of privatization and the sector to which it is applied. These factors will be further discussed below. Nevertheless, it is necessary to sum up a number of reasons behind privatization in order to have a better understanding of what privatization is.

In general, privatization has been hailed as a way to counter what is perceived to be a failure of governments to provide certain services in a cost-effective and efficient way. Privatization has multiple objectives, many of which are conflicting with each other. ${ }^{8}$ These objectives include fiscal objectives such as the reduction of public spending, attracting foreign investment, improving corporate efficiency and performance, introducing competition into monopolistic markets, as well as

3 Miller and Simmons observe that there are multiple legitimate interpretations of privatization and attempt to examine privatization and its meaning through four different perspectives each providing its own political or economical view on the subject. H.T. Miller and J.R. Simmons, "The Irony of Privatization," Administration and Society Vol. 30, no. No. 5 (1998), p. 514.

4 Savas, Privatization: The Key to Better Government.

5 J.F. Robert, "Law and Privatisations: A General Presentation of Issues," in Legal Aspects of Privatisation, XXIst Colloquy on European Law, Budapest: Council of Europe (1993), p. 20.

6 See Ramanadham, "Privatisation: the UK Experience and Developing Countries," p. 4-10.

7 Feigenbaum, Henig, and Hamnett, Shrinking the State: The Political Underpinnings of Privatization, p. 1.

8 "Privatising State-Owned Enterprises: An Overview of Policies and Practices in OECD Countries," OECD, 2003, p. 8. See also Guislain, The Privatization Challenge: A Strategic, Legal and Institutional Analysis of International Experience, p. 20. 
objectives of a more political nature. The general view appears to be that privatization allows for more flexibility and efficiency for the provision of certain services than their provision by the State would allow. ${ }^{9}$

Taking into account the abovementioned common denominator running through the privatization debate and from the general aims and motives that have propelled its implementation, it is possible to come up with a definition that can be useful for the purposes of this study. In a recommendation (No. R(93) 7 of 18 October 1993) on the issue of privatization of public undertakings and services, the Committee of Ministers of the Council of Europe (CoE), through the work of the Project Group on Administrative Law, adopted a workable definition for privatization that can be used as a guideline for the current study. ${ }^{10}$ The definition found in the Appendix to Recommendation No. R(93) 7 defines privatization as follows:

"i. the total or partial transfer from public ownership or control of a public undertaking so that it ceases to be a public undertaking;

ii. the transfer to a private person of an activity previously carried on by a public undertaking or public authority, whether or not accompanied by a transfer of property $[\ldots]^{\prime \prime 11}$

The explanatory memorandum to the recommendation notes that there are situations other than those described in the definition provided by the recommendation that could also be considered to be privatization. ${ }^{12}$ It nevertheless points out that the above mentioned categories cover the main aspects of privatization as it is commonly understood and which, in the opinion of the drafters of the recommendation, give rise to the need for protection of the individual and his or her

$9 \quad$ See for example Robert, "Law and Privatisations: A General Presentation of Issues," p. 23.

10 The Committee of Ministers of the Council of Europe has approached the problem of privatization from the perspective of administrative law with the aim of examining the "[...] question of the useful and possible extent of privatisation in the light of fundamental principles of public law and of safeguards protection of the rights and interests of the users of public services." See Council of Europe, Privatisation of Public Undertakings and Activities, Recommendation No. R(93) 7 and explanatory memorandum adopted by the Committee of Ministers of the Council of Europe (18 October 1993), p. 9.

11 Council of Europe, Recommendation No. R(93) 7, p. 5. Under 'public undertaking', the recommendation means "any undertaking over which the public authorities may exercise directly or indirectly a dominant influence by virtue of their ownership of it, their financial participation therein, or the rules which govern it." Ibid., p. 6. The recommendation additionally defines a 'public authority' as an entity of public law of any kind and at any level or any private person, when exercising prerogatives of official authority. Ibid. This last definition is quite interesting as it equates private entities or persons that have been endowed with powers of a public nature, as being a public or maybe even a state actor. See for a deeper discussion on this issue Part 4 below, and Chapter IV, Section 3.

12 Council of Europe, Recommendation No. R(93) 7, Explanatory memorandum, p. 13. 
rights. ${ }^{13}$ It is suggested that the Council of Europe's definition is relevant for the purposes of the present study because it distinguishes two important aspects of what may be understood as privatization. In the first place, it covers the transfer of the actual ownership of State assets or companies to other than State actors. An example of privatization under this part of the definition is the divestment of the ownership of public utilities in the United Kingdom. ${ }^{14}$ In the second place, the definition recognizes that privatization may also entail the transfer of activities that were carried out by the State to a private actor. The management of prisons by a private corporation, the provision of security and policing services by private companies, or the concession of public utilities are examples of this aspect of privatization as understood by the definition.

A word of caution is merited with regard to this definition. Neither the definition provided by Recommendation No. R(93) 7 nor its explanatory memorandum makes it clear whether the transfer mentioned must necessarily involve (deliberate) acts of commission or may be achieved by omission, and they have nothing to say about the possible significance of this distinction. Similarly nothing is said about the possible significance of the transfer occurring through a legislative act as opposed to a contractual obligation. As we shall see later in this study, these questions and distinctions could be of great importance with respect to establishing whether a private person/entity carrying out a former public task, function or service can be deemed to be a state agent to whom international law and human rights obligations apply. Finally, it should be noted that a precise definition of privatization requires that the transfer noted above be sufficient to give the private operators or owners of a privatized entity substantive independent power. ${ }^{15}$

\subsection{Privatization - nationalization cycle in brief}

Since the end of the 1970s, privatization has gradually emerged as an important policy option for reforming the State, especially under the auspices of international financial institutions. ${ }^{16}$ This, however, does not signify that privatization is a completely new phenomenon that has only appeared in the last 30 years. To a certain

\footnotetext{
13 Ibid. Compare with Barak-Erez who makes a similar distinction between two types of privatization (privatization of government owned industries or other economic enterprises owned by the government, and privatization of social services such as education, health and others), but argues that the privatization of enterprises that do not serve the public does not necessarily rise any issues with respect to human or constitutional rights, whereas the privatization of social services may have an effect on the rights of individuals. See D. BarakErez, "Civil Rights and Privatization in Israel," Israel Yearbook on Human Rights Vol. 28 (1998), p. 205.

14 See Chapter VII.

15 Donaldson and Wagle, "Privatization: Principles and Practice," p. 13.

16 See Section 4.3 infra.
} 
extent, privatization (in the raw sense of public tasks being performed by private entities) is a recurring phenomenon that comes and goes depending on the political and economical climate that reigns at a certain point in time. This Section, does not attempt to provide an all-encompassing and detailed history of privatization. Its only purpose is to illustrate that privatization and the active participation of private actors in what are today considered to be public tasks is not of recent date and is in fact part of a cyclic and dynamic process. In fact, there are various examples of the recourse to private actors for carrying out public tasks and services throughout history. According to Freeman, "[v]irtually every service or function we now think of as 'traditionally' public, including tax collection, fire protection, welfare provision, education, and policing, has at one time or another been privately performed." 17 A historical look at the use of private actors in what may be called 'core' State functions may help to illustrate this. In addition, the cycle between private and public sector involvement in State functions is even more apparent in the various network utilities sectors.

\subsubsection{The privatization of 'core' or 'intrinsic' State functions}

'Core' State functions in the context of privatization are difficult to define. However, human rights monitoring bodies such as the UN's Human Rights Committee (HRC) have hinted at what these functions may include when commenting about the possible effects of their privatization on human rights. For example, in its Concluding Observation to the United Kingdom's fourth periodic report under the ICCPR, the HRC observed that "[...] contracting out to the private commercial sector core State activities which involve the use of force and the detention of persons weakens the protection of rights under the Covenant [on Civil and Political Rights, $A H W]$. ."18 This statement assumes that 'core' State functions are essential for guaranteeing human rights, and that these involve at least the coercive use of force and the deprivation of liberty in criminal proceedings under a mandatory order issued by a court of law. In this respect, it is worth to point out to a recent decision of the Israeli Supreme Court, sitting as the High Court of Justice, which barred governmental plans to grant a concession to a private company to manage a prison in that country. ${ }^{19}$ The High Court declared a law arranging for this privatization unconstitutional, not because there is evidence that privatized prisons violate human rights more than public prisons. ${ }^{20}$ According to the High Court of Justice, the imprisonment of convicted criminals is an exercise of the monopoly of the use of force by the State, traditionally belonging to it, and which should further

17 Freeman, "The Private Role in Public Governance," p. 552-553. (Footnote omitted).

18 Concluding Observations of the Human Rights Committee: United Kingdom of Great Britain and Northern Ireland, UN Doc. CCPR/C/79/Add.55 (27 July 1995).

19 Academic Center of Law and Business v. Minister of Finance, 19 November 2009, High Court of Justice, HJC 2605/05.

20 According to the High Court of Justice, there is no evidence of this. Ibid., para. 19. 
a public interest. ${ }^{21}$ The High Court deemed the reasons behind the privatization of prisons in Israel to be economic in nature. The law was meant to save the State money by transferring imprisonment functions to a private entity and served private economic interests, namely that of the company. According to the Court this was unconstitutional and violated the right to personal liberty as well as the human dignity of prison inmates by transforming them into the means for the private corporation to make profits. ${ }^{22}$

It is also interesting to observe that the United States, a country that has been at the forefront of privatization, has developed guidelines whose departing point is 'the public interest', and thus the nature of the function, for categorizing what it calls inherently governmental activities. ${ }^{23}$ According to an official document from the Office of Management and Budget, which resorts under the Executive Office of the President of the United States, an inherently governmental activity

"[...] is an activity that is so intimately related to the public interest as to mandate performance by government personnel." 24

However, from a historical perspective, a number of these 'core' or inherently governmental functions have previously been exercised by private actors in the past. ${ }^{25}$ Although it would be difficult to pin point when privatization actually

Ibid., paras. 21-28.

Ibid., paras. 30 and 36 .

This is required for determining whether certain activities should be delegated or contracted out to private entities.

24 See Circular No. A-76 (Revised), Office of Management and Budget, Executive Office of the President, 23 May 2003, page A-2. The inherently governmental activity is further defined as activities that "[...] require the exercise of substantial discretion in applying government authority and/or in making decisions for the government. Inherently governmental activities normally fall into two categories: the exercise of sovereign government authority or the establishment of procedures and processes related to the oversight of monetary transactions or entitlements. An inherently governmental activity involves:

(1) Binding the United States to take or not to take some action by contract, policy, regulation, authorization, order, or otherwise;

(2) Determining, protecting, and advancing economic, political, territorial, property, or other interests by military or diplomatic action, civil or criminal judicial proceedings, contract management, or otherwise;

(3) Significantly affecting the life, liberty, or property of private persons; or

(4) Exerting ultimate control over the acquisition, use, or disposition of United States property (real or personal, tangible or intangible), including establishing policies or procedures for the collection, control, or disbursement of appropriated and other federal funds."

See also Rosky, "Force, Inc.: The Privatization of Punishment, Policing, and Military Force in Liberal States," p. 803-894. and Cass who argues that "[t]here is virtually no discrete function that one can identify as historically committed to government, rather than to private parties." Cass, "Privatization: Politics, Law and Theory," p. 499. 
started, ${ }^{26}$ private actors have carried out certain functions which could be considered as 'core' or inherent to the State, even before the State assumed their responsibility. The transfer of these functions to private actors as a matter of deliberate State policy has also been around for ages. Probably one of the oldest forms of using private actors to perform what could be considered to be one of the most intrinsic functions/powers/tasks of the state (the coercive use of force) has been the hiring of mercenaries or private armies by states or other public entities. ${ }^{27}$

Other historical examples of the privatization of 'core' State functions can be found in the establishment of commercial trade companies between the $17^{\text {th }}$ and the $18^{\text {th }}$ centuries, and which were endowed by colonial States such as the United Kingdom and the then United Republic of the Netherlands with far reaching sovereign and quasi-statal powers. This is, for example, the case of the Verenigde Oostindische Compagnie (VOC: the United East India Company), which was established in 1602 through a charter granted by the Staten Generaal (the 'States General' or the governing council of the united provinces forming the United Republic of the Netherlands, later to become the Dutch Parliament). The VOC was an amalgamation of various private companies that sailed to the East Indies to gather spices and other tradable objects for trade in Europe. ${ }^{28}$ Its goal was to compete with traders from Spain and Portugal, countries with which the United Republic was at war. For this purpose, the VOC charter granted the company far reaching powers, which are usually associated with the powers normally wielded by a State. ${ }^{29}$ Thus, within its theater of operations (the East Indies), the VOC was authorized, inter alia, to sign treaties with other princedoms and potentates on behalf of the States General, build up forts, establish an army, wage war, and contract persons to keep the peace and public order. ${ }^{30}$ Similarly, the Hudson Bay Company, which obtained a concession to

26 According to Savas, the actual term 'privatization' as opposed to nationalization has only been known since 1969 when it was apparently introduced for the first time by Peter Drucker, widely regarded as the father of modern management, in his book "The Age of Discontinuity" E. Savas, "Symposium: Privatization of Prisons: Privatization and Prisons," Vand. L. Rev Vol. 40 (1987), p. 889. Bel, however has suggested that the term privatization was coined even earlier. See G. Bel, "The Coining of 'Privatization' and Germany's National Socialist Party," Journal of Economic Perspectives Vol. 20 (2006), p. 187-194.

27 See further Chapter VI infra discussing the issue of mercenaries and the use of private military and security companies with regard to human rights.

28 R. van Gelder, Het Oost-Indisch Avontuur - Duitsers in dienst van de VOC (1600-1800) (Nijmegen: Uitgeverij SUN, 1997) p. 33. See also "The Dutch East Indies Company - the first 100 years," lecture given by Dr. Thomas Crump in Gresham College on 1 March 2006, available at $<$ www.gresham.ac.uk/event.asp?PageId $=45 \&$ EventId $=454>$ (last visited on 20 January 2008).

$29 \quad$ Ibid., p. 35.

30 See Article XXXV of the VOC Charter, which states "[...] dat die van de voorsz Compagnie zullen vermogen Beoosten de kaap de Bonne Esperance, mitsgaders in ende door de engte van Magellanes, met de Princen ende Potentaten verbintenis te maken, ende contracten op den naam van de Staaten Generaal van de vereenigde Nederlanden, ofte Hooge Overheden der zelve, mitsgaders aldaar eenige fortressen ende verzekertheden te bouwen, gouverneurs, volk van 
operate and trade in what is now Canada, was granted various State-like powers through a royal charter issued by Charles II - king of the United Kingdom - in 1670. These included powers,

"[...] in case they conceive it necessary, to send either Ships of War, Men or Ammunition, unto any their Plantations, Forts, Factories, or Places of Trade aforesaid, for the Security and Defence of the same, and to choose Commanders and Officers over them, and to give them Power and Authority, by Commission under their Common Seal or otherwise, to continue or make Peace or War with any Prince or People whatsoever, that are not Christians, in any Places where the said Company shall have any Plantations, Forts or Factories, or adjacent thereunto, as shall be most for the Advantage and Benefit of the said Governor and Company, and of their Trade[...]"31

It would thus appear that until the $17^{\text {th }}$ century, it was not uncommon to grant Statelike powers to private commercial actors to further geo-political objectives. However, direct State involvement into certain areas that are now considered to be inherently governmental, generally started to take place following the Treaty of Westphalia in 1648. With the coming of age of the centralized State system, many of the powers and functions that had either been performed by local, feudal, and (in some cases) private authorities and entities, were handed over to the sovereign State. These included tasks such as the administration of justice, the enforcement of laws and the coercive use of force, as well as welfare and health care related tasks. This concentration of core tasks in the hands of the sovereign State could also be partly attributed to new political and philosophical developments such as the idea of the social contract as introduced by Hobbes, Locke and Montesquieu. One speaks in this respect, about the monopolization of the use of force. ${ }^{32}$

In spite of these developments leading to the 'statization' or nationalization of core State functions, certain important areas remained subjected to a privatization nationalization cycle. This is best illustrated with the case of the administration of prisons. Until the $19^{\text {th }}$ century, the administration of prisons was in a number of countries a private task entrusted to bailiffs who were not employees of the sovereign or feudal lord but private entrepreneurs making their living out of the business of incarceration. Beyens et. al describe the medieval English prisons system in which the so called 'gaols', while being under control of the King, were

oorlog, ende officiers van justitie, ende tot andere noodelyke diensten, tot conservatie van de plaatzen, onderhouding van goede ordening, politie, en justitie, eenzamelyk tot vordering ende nering te stellen $[\ldots . . . "$

31 See The Royal Charter For Incorporating the Hudson's Bay Company, available at The Project Gutenberg EBook of Charter and supplemental charter of the Hudson's Bay Company, www. gutenberg.org/dirs/etext04/chhds10.txt (last visited on 20 January 2008).

32 See about some conceptual aspects on this discussion Rosky, "Force, Inc.: The Privatization of Punishment, Policing, and Military Force in Liberal States," p. 891-896. 
deemed to be self-sufficient and as such did not receive any government money for their support. Instead, the jail keepers would act as 'entrepreneurs' who would run the prison and try to get a profit out of it by charging the prisoners for the 'services' provided. ${ }^{33}$ At the end of the eighteenth century, British philosopher Jeremy Bentham developed the concept of a new type of incarcerating system and played with the idea of a privately run prison. ${ }^{34}$ Besides providing a place for safe custody of criminals, Bentham envisioned three other joint purposes for the prison he had in mind: punishment, reformation and pecuniary economy. ${ }^{35}$ To accomplish the last purpose, Bentham suggested the use of forced labor, not uncommon in those days. The management of the prison would then be carried out by way of contract in order to "[...] farm out the profits, the no-profits, or if you please the losses, to him who [...] offered the best terms." 36 Bentham's propositions were, however, considered and subsequently rejected by a British parliamentary committee in 1811: increasing discontent in the public opinion towards the 'gaols' system and its abuses resulted in the gradual entrustment of the prison system in Great Britain under complete government control. ${ }^{37}$

It would appear, however, that during the nineteenth century the United States tried to apply some of Bentham's ideas regarding privately managed prisons. The main motivation for private involvement in the prison system in the nineteenth century United States was the prospect of saving money and if possible, making a profit. ${ }^{38}$ To this end, prison management, prisons or prisoners would be contracted out or leased to private entrepreneurs. ${ }^{39}$ Although some scholars would argue that the

Beyens, Snacken, and Eliaerts, Privatisering van Gevangenissen.

Bentham called his novel system of incarceration the panopticon, based on his observations of a prison his brother had designed and built in Russia during the latter part of the eighteenth century. This system encompassed the construction of a circular building in which the prisoners would be submitted to constant supervision. Bentham called this system the 'Inspection House'. Jeremy Bentham, The Panopticon Writings, ed. M. Bozovic (London: Verso, 1995) p. 33-34. See also Beyens, Snacken, and Eliaerts, Privatisering van Gevangenissen, p. 17-18; DiPiano, "Note: Private Prisons: Can They Work? Panopticon in the Twenty-First Century," p. 172.

Bentham, The Panopticon Writings, p. 50.

Ibid., p. 51.

Beyens, Snacken, and Eliaerts, Privatisering van Gevangenissen, p. 18.

J. Austin and G. Coventry, "Emerging Issues on Privatized Prisons," Bureau of Justice Assistance, National Council on Crime and Delinquency, Washington, (2001), p. 10. See also W.M. McAfee, "Symposium: Privatization of Prisons: Tennessee's Private Prison Act of 1986: An Historical Perspective With Special Attention to California's Experience," Vand. L. Rev Vol. 40 (1987), p. 853; Duitsman, "The Private Prison Experiment: A Private Sector Solution to Prison Overcrowding," p. 2215.

The contract system, involving legal agreements between prisons and entrepreneurs to use prisoners' labor inside the prison, was more popular in the American North. In the South, the lease system was the preferred method of private participation in the prison system and usually implied the use of prison inmates for labor purposes outside the prison walls. J. J. Misrahi, "Factories With Fences: An Analysis of the Prison Industry Enhancement Certification Program in Historical Perspective," Am. Crim. L. Rev. Vol. 33 (1996), p. 415-416. See also Beyens, 
convict lease system is not a form of privatization, ${ }^{40}$ this system did imply in some cases handing over complete control over prisons, prison staff and prisoners to private parties, which then had a lot of leeway for using the prisoners as cheap labor. ${ }^{41}$

According to McAfee the lease system suffered from a number of deficiencies leading to its dismissal at the end of the nineteenth century and beginning of the twentieth. ${ }^{42}$ The problems were related to the lack of public consultation and transparency of private prisons' contract bids. The monitoring on the part of the individual states over the lessee was deficient, making it difficult to assess prison conditions inside private prisons. Additionally, the frequent lack of escape clauses in lease contracts resulted in long and expensive court proceedings for the state to void the lease contracts when they wanted to regain control over the prisons. Finally, there was a lack of state control over convict labor. This made it difficult to prevent unfair competition with enterprises using regular labor and the exploitation of prisoners. Prisoners were often abused, mistreated and kept under inhumane, slavelike conditions. This led to a high mortality rate among prisoners, most of whom were black. ${ }^{43}$

A combination of public disgust at the inhumane exploitation of prisoners through the lease system and (more importantly) the threat it posed to unions and manufacturers which could not keep up with the lower production costs of cheap prison labor, led to the fall of the lease and contract systems. ${ }^{44}$ By the 1930s the lease system in the United States had been 'abolished' and prisons were placed

Snacken, and Eliaerts, Privatisering van Gevangenissen, p. 18-19; A.L. James et al., Privatizing Prisons: Rhetoric and Reality (London: Sage Publications, 1997) p. 1-4. The first state to use the lease system was Kentucky in 1825. McAfee, "Symposium: Privatization of Prisons: Tennessee's Private Prison Act of 1986: An Historical Perspective With Special Attention to California's Experience," p. 852-853.

40 According to Thomas, the convict lease system was not a form of privatization because "[...] it had little to do with the delivery of an essential public service." See C.W. Thomas, Frequently Asked Questions related to correctional privatization to be found on $<w w w . c r i m . u f l . e d u / p c p />$, last visited on 7 May 2002 (this website is no longer available as of 15 January 2008).

41 R. P. Weiss, "Private Prisons and the State," in Privatizing Criminal Justice, ed. R. Mathews, London: Sage Publications (1989), p. 29. See also Dunham, "Note: Inmates' Rights and the Privatization of Prisons," p. 1476.

42 McAfee, "Symposium: Privatization of Prisons: Tennessee's Private Prison Act of 1986: An Historical Perspective With Special Attention to California's Experience," p. 854-857, 859-863.

43 See J. Roback, "Southern Labor Law in the Jim Crow Era: Exploitative or Competitive?," $U$. Chi. L.Rev. 51 (1984), p. 1170. A number of scholars point out that the lease system in the South was a continuation of pre Civil War slavery as many of the convicts were black and were put to work in the fields where once enslaved Africans used to work. C. Weaver and W. Purcell, "The Prison Industrial Complex: A Modern Justification for African Enslavement?," How. L.J. Vol. 41 (1998), p. 249-381. See also Thomas, Frequently Asked Questions op. cit. note 17.

44 S. P. Garvey, “Freeing Prisoners' Labor," Stan. L. Rev. Vol. 50 (1998), p. 354-366. See also Field, "Making Prisons Private: An Improper Delegation of a Governmental Power," p. 652; Misrahi, 
under public authority. ${ }^{45}$ By way of legislation, individual states were entitled to prohibit products manufactured through prison labor. ${ }^{46}$ The dismissal of the lease system, however, did not mean the end of private participation in the prison system. In many countries, governments recognized the necessity of approaching private parties for the provision of essential prison services such as food, clothing and medical attention. ${ }^{47}$ The for-profit sector, however, gradually started to get more involved in the area of corrections itself. This included prison construction and the supplying of goods and services, which in 1992 were deemed to be even more profitable than the management of private prisons itself. ${ }^{48}$

In the late $1970 \mathrm{~s}$ and in the $1980 \mathrm{~s}$, the complete delegation of prison operation to private parties came once again under the spotlight. Complaints about increasing prison populations, overcrowding problems, terrible living conditions inside public remand facilities and a quest to reduce the high costs of running prisons made a number governments turn with renewed interest to the idea of privately run prisons. In 1976 the first high security prison entirely owned and managed by private hands was established in Pennsylvania. ${ }^{49}$ In 1982, the state of Florida placed a second juvenile correctional facility under private control. ${ }^{50}$ The first adult correctional institution to be wholly privately owned and managed followed shortly hereafter. The privatization process in the United States was sped up by firms like Corrections Corporation of America (CCA), Wackenhut Corrections Corporation (WCC) and

"Factories With Fences: An Analysis of the Prison Industry Enhancement Certification Program in Historical Perspective," p. 417-418.

See McDonald, "Public Imprisonment By Private Means: The Re-emergence of Private Prisons and Jails in the United States, the United Kingdom and Australia," p. 29; Duitsman, "The Private Prison Experiment: A Private Sector Solution to Prison Overcrowding," p. 2216.

46 The Hawes-Cooper Act, passed by the U.S. Congress in 1929 enabled states to ban these products. See Misrahi, "Factories With Fences: An Analysis of the Prison Industry Enhancement Certification Program in Historical Perspective," p. 419; Austin and Coventry, "Emerging Issues on Privatized Prisons," p. 11. This legislation was later reinforced by the 1935 Ashurst Sumners Act, which penalized the violation of the individual states' laws enacting the Hawes-Cooper Act. Misrahi, "Factories With Fences: An Analysis of the Prison Industry Enhancement Certification Program in Historical Perspective," p. 419.

47 Lilly and Knepper, "An International Perspective on the Privatisation of Corrections," p. 177. Also Weiss, "Private Prisons and the State," p. 27.

48 Lilly and Knepper, "An International Perspective on the Privatisation of Corrections," p. 176177.

49 The Weaversville Intensive Treatment Unit, a juvenile high security correctional institution came under management by private company called RCA Services. A. M. Durham, III, "The Future of Correctional Privatization: Lessons From the Past," in Privatizing Correctional Institutions, ed. G. Bowman, S. Hakim, and P. Seidenstat, Brunswick, NJ: Transaction Publishers (1993), p. 33; Austin and Coventry, "Emerging Issues on Privatized Prisons," p. 12.

Austin and Coventry, "Emerging Issues on Privatized Prisons," p. 12. 
Cornell Companies that saw potential financial opportunities in the private prison market in the United States and around the world..$^{51}$

According to Harding, Australia was the second (western) country to implement a private prison program when in 1990 a medium security prison was opened in Queensland. ${ }^{52}$ In the United Kingdom, the conservative Thatcher government, already busy with great scale privatization programs in other areas, viewed the privatization discussion in the United States with interest. Plans for prison privatization were considered and a Green Paper on the issue was drafted in 1988. ${ }^{53}$ But it was not until 1992 that the first privately run prison in the United Kingdom began its operations. ${ }^{54}$ Shortly after, three more private prisons became operational (most of them being medium-security facilities) ${ }^{55}$ Later, countries like South Africa, Canada and New Zealand followed suit. By 2004, over 120 private correctional facilities had been set up around the world with the largest number being located in the United States. ${ }^{56}$ By mid 2009, eight percent of the United States' one million and six hundred thousand adult prisoners were incarcerated in privately run facilities, amounting up to 127,688 inmates. ${ }^{57}$

Another example of the shift between the alternate use of private actors and governmental actors for 'core' state functions can be appreciated in the policing and security sector. Private security is one of the fastest growing industries in the world ${ }^{58} \mathrm{~A}$ glance at security arrangements in airports, shopping malls, and other semi-public spaces reveals the prevalent presence of private security guards, and is now so common that their presence is almost taken for granted. Less than twenty years ago, public security officers would have policed most of these places. But,

51 These are Wall Street listed firms turning out a solid profit, and which have become part of what is known as the 'criminal justice-industrial complex.' D. Shichor, Punishment for Profit: Private prisons/public concerns (Thousand Oaks [California]: SAGE Publications, 1995) p. 238.

52 Harding, Private Prisons and Public Accountability, p. 5.

53 Beyens, Snacken, and Eliaerts, Privatisering van Gevangenissen, p. 112.

54 Harding, Private Prisons and Public Accountability, p. 5.

55 Ibid., p. 6-7.

56 According to a 2004 research carried out by the Parliamentary Library Research Service in New South Wales Australia, the United States had the largest number of private correctional facilities with over 100 facilities. The United Kingdom housed 11 facilities, while Australia had 7. private facilities. The largest facilites were found in South Africa with 2 privately managed prisons, whereas Canada and New Zealand had 1 private facility. See L. Roth, Privatisation of Prisons, Briefing Paper No. 03/2004, NSW Parliamentary Library Research Service (2004), p. 5-6 available at <www.parliament.nsw.gov.au/prod/parlment/publications.nsf/key/ResearchBp200403> (last visited 31 August 2011).

57 See Heather C. West, Prison Inmates At Midyear 2009 - Statistical Tables, 23 June 2010, NCJ 230113, Bureau of Justice Statistics of the Office of Justice Programs, U.S. Department of Justice available at $<$ http://bjs.ojp.usdoj.gov/content/pub/pdf/pim09st.pdf $>$ (last visited 31 August 2011). A.P. Kontos, "Private' Security Guards: Privatized Force and State Responsibility Under International Human Rights Law," Non-State Actors and International Law Vol. 4 (2004), p. 199. 
like prisons, policing has not always been a State run affair. In medieval England for example, policing and law enforcement were carried out by members of the local community who carried out their tasks on a more or less voluntary basis. ${ }^{59}$ Sklansky observes that when crimes were committed, "[...] the victims themselves were responsible for catching the offenders, turning them over to the authorities, and then prosecuting the cases." 60

A more organized system of reactive law enforcement (that is involving investigation, recovery and apprehension) carried out by private actors was introduced in the $18^{\text {th }}$ century by the 'Bow Street Runners', private individuals who worked for a reward and private fees provided by London magistrate and novelist Henry Fielding. ${ }^{61}$ Sklansky notes, however, that there were increasing calls to introduce more effective, state-sponsored patrols. According to Sklansky, by the end of the $18^{\text {th }}$ and beginning of the $19^{\text {th }}$ centuries, English policing "[...] was a loosely coordinated patchwork of public and private arrangements." 62 It was only in the late 1820 s that legislation was adopted to create a tax-financed police force for London under the centralized control of the Home Office, a model that was followed by other countries. ${ }^{63}$ Slowly the publicly organized police forces started to replace the old private policing arrangements. More or less at the same time, the United States, which had a similar 'private' system as in England, started to adopt public police forces that were initially met with skepticism. ${ }^{64}$ However, by the end of the $19^{\text {th }}$ century, every major city in the United States had a uniformed police force. In rural United States, on the other hand, policing for hire was still prevalent, and sometimes private police agencies were publicly appointed as special policemen thus making it difficult to differentiate between public and private policing. In spite of this, the idea that policing was an inherently public function started to gradually take hold. ${ }^{65}$ In spite of this, private policing continued to exist, in the form of so-called Pinkerton agencies, and in the 1970s there was a resurgence of private security companies. The spectacular growth of private security companies in the United States has been attributed to the ideological shift that places more emphasis

\footnotetext{
59 See D.A. Sklansky, “The Private Police,” UCLA L. Rev. Vol. 46 (1999), p. 1195-1197.

60 Ibid., p. 1198.

61 Ibid., p. 1200-1201.

62 Ibid., p. 1202. Sklansky further observed that governmental initiatives to establish a professional police force around this time were not successful.

63 Ibid.

64 Ibid., p. 1206-1208.

65 Ibid., p. 1210. According to Sklansky, this was partially due to the "[...] heightened expectations: uniformed, publicly funded police forces had fostered the notion among urban Americans that "freedom from crime and disorder is a right, not just a privilege of the privileged." Moreover, the emergence of these new expectations coincided with the arrival of the public-private distinction at "the center of the stage in American legal and political theory." ibid. (citation omitted $A H W)$.
} 
on more private participation in society and less government, and to the failure of public law enforcement to fulfill the security requirements of society. ${ }^{66}$

In spite of an increasing trend towards privatizing certain functions involving the coercive use of force and law enforcement, there are some indications that this trend is not entirely irreversible. The foremost example can be seen in New Zealand, where after a short-lived experiment with a private prison, the government decided to 're-nationalize' it. The Auckland Central Remand Prison (ACRP) was privatized in 2000 under the conservative government of the National Party. ${ }^{67}$ However, after the Labour Party assumed power in 2000, it decided not to renew the contract with Australasian Correction Management Prisons, which managed ACRP. ${ }^{68}$ In 2004, the Labour government adopted the Corrections Act 2004, which mandated that "[n]o person may, on behalf of the Crown, enter into any contract with any person for the management, by that person instead of the Crown, of any prison."69 The contract with Australasian Correction Management Prisons expired on 12 July 2005 and the management of the ACRP reverted to the Public Prisons Service of New Zealand. Following the elections of a right wing majority government in 2008, however, the Corrections Act was amended in November 2009 to once again allow the possibility of contract management of prisons. ${ }^{70}$ Another example of 'nationalization' can be found in the replacement of private security screeners at airports in the United States. Following criticisms about the failure of private security companies to operate passenger screening stations in a number of U.S. airports in the wake of the terrorist attacks of 11 September 2001, the U.S. Congress adopted a law to federalize and put back under public control these activities. ${ }^{71}$

66 Ibid., p. 1221-1222.

67 L. Roth, "The Privatization of Prisons," Background Paper No. 3/04, NSW Parliamentary Research Office, 2004, p. 5.

68 See "Cell-by date up for private jails," New Zealand Herald, 7 March 2003 (news article available in West Law: 2003 WL 13273741).

69 See Section 198 of the Corrections Act 2004, available at <www.legislation.govt.nz $>$ as it stood until 1 November 2008.

70 See Corrections (Contract Management of Prisons) Amendment Act 2009 No 59 available at $<$ www.legislation.govt.nz/act/public/2009/0059/latest/DLM1888320.html?search=ts_act corrections + act +2004 resel $\& p=1>$ (last visited 31 August 2011). See also "Govt Moves to Privatise Prisons," TVNZ news report available at $<$ http://tvnz.co.nz/politics-news/govt-movesprivatise-prisons-2527966> (last visited 31 August 2011).

71 See J. Reaves, "Aviation Security Bill Finally Takes Off," Time Magazine news article available at $<$ www.time.com/time/nation/article/0,8599,184840,00.html $>$ (last visited on 31 Augustus 2011). See also Rosky, "Force, Inc.: The Privatization of Punishment, Policing, and Military Force in Liberal States," p. 880 and p. 934-935. 


\subsubsection{The privatization of networks, and municipal services and utilities ${ }^{72}$}

Another example of the cyclical presence of the State and private actors in what are currently regarded as important public functions can be found in the area of networks, and municipal services and utilities. The latter part of the Enlightenment, with its focus on reason, individuality and entrepreneurship, together with the gradual advent of the industrial revolution at the end of the $18^{\text {th }}$ century and its coming of age in the $19^{\text {th }}$ century, resulted in many technological inventions, advances and discoveries that encouraged private initiatives in sectors that are nowadays considered to be a matter of public policy/interest. This was the case with the arrival of inventions and new developments in the so-called network industries or utilities that are usually natural monopolies. ${ }^{73}$ Thus the production and distribution of electricity through electricity networks; ${ }^{74}$ the unveiling of network systems for the treatment and distribution of piped water and sewerage in several countries $; 7$ the introduction of gas utilities for the provision of (street) lighting and industrial and household energy $;{ }^{76}$ and the invention of the telegraph and telephone and the concomitant expansion of telecommunication networks were all private initiatives and their expansion in the public domain was the end-result of private companies' efforts to make money out of the sector.

Due to the externalities ensuing from the exploitation of (privately operated/owned) utilities, ${ }^{77}$ the ownership and management of electricity, water and telecommunications companies in most of Europe and North America gradually passed from private to public hands during the latter part of the $19^{\text {th }}$ century and the first half of the $20^{\text {th }}$ century. Nationalization of utilities and other strategic industries was regarded as necessary to guarantee their functioning for the benefit of all. In many cases government takeover of privately owned utilities was required in the aftermath of financial difficulties faced by the private companies controlling the utilities sector. ${ }^{78}$ In spite of the nationalization wave that started at the beginning of

72 A more detailed account of the privatization of network utilities, in particular of water will be presented in Chapter VII.

73 Foster, Privatization, Public Ownership and the Regulation of Natural Monopoly, p. 17.

74 Guislain, The Privatization Challenge: A Strategic, Legal and Institutional Analysis of International Experience, p. 205.

75 C.D. Jacobson and J.A. Tarr, "Ownership and Financing Infrastructure: Historical Perspectives," Policy Research Working Paper WPS 1466, The World Bank, Office of the Vice President of Economics, Washington, (1995), p. 11; Guislain, The Privatization Challenge: A Strategic, Legal and Institutional Analysis of International Experience, p. 204-205.

76 Guislain, The Privatization Challenge: A Strategic, Legal and Institutional Analysis of International Experience, p. 205.

77 For example, the operation of water utilities is closely related to public health. Similarly, the operation of electricity networks and utilities has an effect on economic development and sometimes even health.

78 Guislain, The Privatization Challenge: A Strategic, Legal and Institutional Analysis of International Experience, p. 205. 
the $20^{\text {th }}$ century $^{79}$ and reached its apex following WWII, the ownership, management and distribution of a number of utilities' services remained in private hands in countries such as the United States and France. ${ }^{80}$

In the countries where public utilities had been nationalized, the State remained in control of their ownership and the distribution of their services until the (late) 1980s when, under the inspiration of conservative governments in the United Kingdom and the United States, and under the auspices of international financial institutions, governments started to consider their privatization. To a certain extent, the shift towards privatization in developed countries was the result of ideological shifts in policy making. In the United Kingdom, for example, the Conservative Government of Margaret Thatcher, which took office in 1979, was inspired by the belief that market mechanisms worked better than state-centered mechanisms, and thus saw privatization as a natural policy. ${ }^{81}$ Privatization was a response to the perceived increase in the size of the State: the State had become too bloated and too omnipresent. It was seen as necessary to curb the growth of the State and rely more on the efficiency of markets to provide certain services. ${ }^{82}$ In addition, since the United Kingdom was going through a severe economic crisis, cutting back public spending in the nationalized industries was seen as necessary to reduce public sector borrowing. ${ }^{83}$ Although the privatization program in the United Kingdom had a modest start, ${ }^{84}$ it soon grew to become an important policy aspect of the Conservative government. The privatization movement gained momentum and following recommendations by the European Union, the liberalization and

79 C.D. Jacobson, Ties that Bind: Economic and Political Dilemmas of Urban Utility Networks, 1800-1900 (Pittsburg: University of Pittsburg Press, 2000) p. 69-73.

80 Guislain, The Privatization Challenge: A Strategic, Legal and Institutional Analysis of International Experience, p. 205.

81 C. Graham, Regulating Public Utilities: A Constitutional Approach (Oxford: Hart Publishing, 2000) p. 14..

82 For example, the Secretary of State for Industry in the UK during Margaret Thatcher's government, Sir Keith Joseph observed that "[w]e came to office convinced that the structure of the nationalised industry contributed to the national malaise... in all too many cases, particularly when the nationalised industry commanded a monopoly, those concerned did not see themselves as living under the healthy necessity of satisfying the customer in order to survive; they had no incentive to cut costs to beat competitors; they were free of risk of liquidation... Such was our diagnosis; what was our aim? our aim (was) to abate inflation and to create a prospering social market economy - that is, a mainly free enterprise economy." Quoted from Miller, "British Privatization: Evaluating the Results." See also M. Florio, "A State Without Ownerhip: The Welfare Impact of British Privatizations - 1979-1997," Working Paper n.24.2002, World Bank ref: Working Paper WP37, Dipartamento di Economia Politica e Aziendale, Università degli Studi di Milano/The World Bank, Milan, (2002), p. 2.

83 Graham, Regulating Public Utilities: A Constitutional Approach, p. 14..

84 Graham and Prosser, Privatizing Public Enterprises: Consitutions, the State, and Regulation in Comparative Pespective, p. 21. See also Graham, Regulating Public Utilities: A Constitutional Approach, p. 14.. 
privatization of various utilities, such as telecommunications, electricity and gas started to take place in the 1990s in many Western European countries.

The cycle between State intervention/nationalization and privatization is also discernable in a number of developing countries. Reliance in (foreign) private enterprise to provide certain products and services after the independence of various Latin American countries gave way to increasing State intervention and nationalization following World War II. ${ }^{85}$ The desire to boost their economic independence vis-à-vis developed countries moved developing countries to adopt policies geared towards import substitution and stimulating industrial development through nationalization and direct government intervention in the economy. ${ }^{86}$

The utilities sector in Latin America provides a good example. In the late $19^{\text {th }}$ and early $20^{\text {th }}$ centuries, public utilities in Latin America had been in the hands of private companies, some of them of foreign origin. ${ }^{87}$ However, increased government regulation in the utilities sector favoring mostly the productive sectors and lower income segments of the population, the rapid growth of urban populations following World War II requiring vast infrastructure investments, and a bleak outlook on the future of private companies in the sector due to the inevitable government take over of these industries in pursuance of the abovementioned industrial policies made private investments in the sector unattractive. ${ }^{88}$

Thus, States' pursuit of industrial development policies, together with a lack of interest of the private investors in the utilities sector helped to ease the nationalization of private companies in the sector, which remained in public hands until the early 1990s. Under the influence of conditionality policies of the IMF, World Bank, the pendulum in the utilities sector then swung towards private involvement through privatization. In particular, these international financial institutions encouraged reforms of the sector as a requirement for financial aid in the context of poverty reduction strategy programs (PSRPs), ${ }^{89}$ and so called

85 See in general A.L. Chua, "The Privatization - Nationalization Cycle: The Link Between Markets and Ethnicity in Developing Countries," Columbia Law Review Vol. 95 (1995), p. 223303. See also M. Baker, "Privatization in the Developing World: Panacea for the Economic Ills of the Third World or Prescription Overused?," New York Law Journal of International \& Comparative Law Vol. 18 (1999), p. 245-248.

86 Baker, "Privatization in the Developing World: Panacea for the Economic Ills of the Third World or Prescription Overused?," p. 245-248.

87 W. Baer and M. Birch, "Privatization and the Changing Role of the State in Latin America," New York University Journal of International Law and Politics Vol. 25 (1992), p. 8.

88 Ibid., p. 8-9.

89 D. Hall and R. de la Motte, "Dogmatic Development: Privatisation and Conditionalities in Six Countries," Public Services International Research Unit, Business School, University of Greenwich, (2004), p. 4. 
'adjustment lending. 90 Private sector participation, ${ }^{91}$ and privatization ${ }^{92}$ were among the suggested reforms. ${ }^{93}$

However, recent popular opposition to privatization in certain developing countries, in particular Bolivia and Argentina, has resulted in the reversal of a number of privatizations. ${ }^{94}$ Some governments are again taking over tasks that had previously been privatized, ${ }^{95}$ or are adopting a more cautious approach towards delegating tasks in key networks and utilities sectors to the private sector. These developments, and disappointing results of privatization efforts in a number of countries, has moved the international financial institutions to revise its stance with regard to privatization, which is apparently no longer viewed as the only way of dealing with problems in the utilities sector. ${ }^{96}$ In general, it would appear that there is a trend to move away from privatization policies in the utilities sector altogether. ${ }^{97}$

\subsubsection{Some observations}

It is evident from above that the cycles between the reliance on public or private actors for the performance or delivery of certain functions, tasks or services is linked to beliefs concerning what the role of the State should be. This cycle also suggests that speaking about core, inherent, intrinsic or traditional governmental functions does not reflect the complexity of the matter. As explained in the previous

90 "Private Sector Development Strategy - Directions for the World Bank Group," The World Bank Group, (2002), p. 24-25 and 27.

91 See in general ibid., p. 21 and 25.

92 "World Bank Assistance to Privatization in Developing Countries." Report 13273, World Bank, Operations Evaluation Department, Washington D.C., 1994. See also ibid., p. 25 and 26.

93 Hall and Motte, "Dogmatic Development: Privatisation and Conditionalities in Six Countries," p. 4.

94 In Bolivia, the privatized water utilities of the cities of Cochabamba and La Paz/El Alto were 're-nationalized' following protests in 2000 and 2007 respectively. In Argentina, the privatization contract for operating the water utility in the province of Tucumán, which had been privatized in 1995, was cancelled in 1998 and a public body took over the operations of the utility. Similarly, a public entity took over the Buenos Aires water utility in 2006 after it had operated as a privatized water utility since 1993. See further Chapter VII.

95 See for example "Chávez Moves to Nationalize Two Industries", New York Times report, 9 January 2007 available at <www.nytimes.com/2007/01/09/world/americas/09venezuela. html?pagewanted $=$ print $>$ (last visited on 9 January 2007). The report describes the proposals by President Chávez of Venezuela to nationalize privatized enterprises in the telecommunication and electricity sectors. According to the report, President Chávez is quoted to have said, "All that was privatized, let it be nationalized."

96 See further Section 4.3 infra.

97 See in general A. Estache, "PPI Partnerships versus PPI Divorces in LDCs (Or Are We Switching From PPPI to PPDI?)," World Bank Policy Research Working Paper 3470 (WP S3470), World Bank and ECARES (Université Libre de Bruxelles), (2005) and S. Kikeri and A. Fatima Kolo, "Privatization: Recent Trends and Developments," World Bank Policy Research Working Paper WPS3765, The World Bank, (2005). 
paragraphs, many of the functions which one would regard as core, inherent or traditional have been performed by private actors at one point or another. Arguments against privatization claiming that certain functions should not be privatized because they belong to the core activities of the State seem in this respect less authoritative in view of the fact many of these functions, including those involving the monopoly on the use of coercive force other than for self-defense purposes (a quintessential State function?) have not always been under the direct control of the State. However, in view of the fact that these important functions have been at a certain point transferred to the State out of public interest reasons, ${ }^{98}$ it is suggested here that discussions about the appropriateness of privatization or the accountability for its results or the actors involved in its implementation, should rather focus on the nature of the function and the purpose they serve. ${ }^{99}$

In addition, the apparent existence of a privatization-nationalization cycle, as well as the recent trend to move away from privatization ${ }^{100}$ implies that the latter is not an irreversible or inevitable process. However, a decision to reverse privatization should not be taken lightly. As explained in Chapter III, it may entail an obligation on the part of the State to compensate those private (multinational) companies affected by the decision to re-nationalize. In any event, the brief description of privatization's history presented above makes it possible to conclude that privatization is not a static concept, which clearly divides the tasks of the public and private sector. Rather, privatization is a concept with a dynamic nature.

\subsection{Dynamic nature and rationale}

Privatization is often considered to be a response to the welfare State that relied too generously on the government and public institutions for the provision of public services and tasks. ${ }^{101}$ Due to the way in which privatization as defined above attempts to modify the roles of the State and private actors in the provision of

98 F.e. by monopolizing the use of force, the State is preventing vigilantism; by taking over the management of prisons, the State wants to prevent abuse by corrupt private actors; by nationalizing essential utilities, the State wants to prevent negative externalities such the spread of infectious diseases with regard to water supply, or improve on universal coverage. For a further discussion of this approach see Chapter IV.

100 The banking crisis affecting the world economy in 2009 even led to the nationalization of once powerful and wealthy financial institutions in various pro-privatization countries like the United States and the United Kingdom. See for example, Stephen Gandel, "Nationalized Banks: Why They Might Work," TIME, 6 March 2009 available at <www.time.com/time/business/ article $/ 0,8599,1883418,00 . h t m l>$ (last visited on 15 July 2010). See also news report "U.S. not always averse to nationalization, despite its free-market image," New York Times, 13 October 2008, available at <www.nytimes.com/2008/10/13/business/worldbusiness/13iht-nationalize.4. 16915416.html $>$ (last visited on 15 July 2010).

101 Feigenbaum et al. label this the direct governmental model where public sector institutions fund and provide key services doing so in response to political incentives as opposed to market ones. 
services, it has been placed at the forefront of the public-private discussion. ${ }^{102}$ This discussion departs from the notion of two different and strictly segregated spheres: the public sphere emphasizing the role of the State, public institutions and procedures and the private sphere, involving individuals, firms, personal responsibility and markets. ${ }^{103}$ Traditionally, both spheres are considered to be mutually exclusive. Privatization is then an absolute occurrence where tasks, functions and services are transferred from the public to the private sphere leaving the public realm with no other task to do or role to play.

This strict division of tasks and spheres of operation provided by the public-private discourse, treating the provision of services as either a public or private task, easily results in the conclusion that privatization by definition leads to a reduction of the role of the State. This view however, as the brief history of privatization described above suggests, does not do justice to the dynamic nature of privatization. ${ }^{104}$ It negates the complexity of the process of privatization and the ways in which it operates. Privatization as defined above operates on different levels or dimensions along the public-private continuum. Feigenbaum et.al have distinguished four dimensions involving financing, delivery, responsibility and decision-making. ${ }^{105}$ The financing dimension relates to the way services are being financed (through public funding at the end of the public continuum or through user fees charged by private service providers at the opposite end). The delivery dimension relates to the actor involved in delivering the service or in accomplishing a task or function (public bodies or institutions vs. private entities such as firms). The responsibility dimension deals with the question who is ultimately responsible for the conditions in which the services are delivered: at the 'public' end of the continuum, the State bears responsibility and has an overall regulatory role, while at the 'private' end,

See Feigenbaum, Henig, and Hamnett, Shrinking the State: The Political Underpinnings of Privatization, p. 8. See also Section 2.1 supra on the motives behind privatization.

102 Starr, "The Meaning of Privatization," p. 16.

103 Feigenbaum, Henig, and Hamnett, Shrinking the State: The Political Underpinnings of Privatization, p. 9.

104 Ibid. Metzger also observes "[...] that privatization is poorly characterized as government withdrawal or disinvolvement from an area of activity. That description fails not only because privatization so often accompanies an expansion in government responsibilities, but more importantly because it misses privatization's core dynamic. In many instances of privatization, the overall context remains one of significant government endeavor; $[. .$.$] the government$ provides the funds, sets programmatic goals and requirements, or enacts the regulatory scheme into which private decision making is incorporated. But the government relies on private actors for actual implementation. Rather than government withdrawal, the result is a system of publicprivate collaboration, a "regime of "mixed administration"" in which both public and private actors share responsibilities." G.E. Metzger, "Privatization as Delegation," Colum. L. Rev. Vol. 103 (2003), p. 1394-1395. See also Aronson, "A Public Lawyer's Responses to Privatisation and Outsourcing," p. 52.

105 Feigenbaum, Henig, and Hamnett, Shrinking the State: The Political Underpinnings of Privatization, p. 9-10. 
companies or individuals are solely responsible for their own actions. The decisionmaking dimension involves the questions of who takes decisions affecting the public and in which way are they taken: decisions at the 'public' end of the continuum are taken by public institutions according to formalized procedures, while at the 'private' end, decisions are made by private individuals or companies. In addition to these four levels it is here suggested that it is possible to distinguish a fifth one, closely related to the decision-making and delivery dimensions. This fifth level, the management dimension, entails the day-to-day administration of providing services (not just their delivery). On the 'private' end, this would entail a complete takeover of the management of public enterprises by private parties.

This gamut of dimensions along which privatization operates denotes the relative and dynamic character of privatization. ${ }^{106}$ It also indicates that the role of the State in privatization may move on different directions along this dynamic gliding scale. Feigenbaum et al. observe that these dimensions are interrelated but at the same time sufficiently independent from each other. ${ }^{107}$ This means that while privatization can lead to a decreasing role of the State along one or more of the five levels, it does not necessarily always have to be so. For example, a decrease of the role of the State within the delivery, decision-making or management dimensions does not necessarily lead to a decrease of the financing or regulatory levels. Experience in the utilities sector in the United Kingdom, for example, shows that privatization of gas, electricity and water utilities was followed by an increase of regulatory mechanisms and regulations. ${ }^{108}$ In fact, regulation will be highly desirable in privatized industries that have the characteristics of a natural monopoly, whereby due to reasons of economies of scale only one actor is able to perform. This can be described as the 'privatization paradox', whereby the goal of privatization to reduce the role of the State, is 'negatively' supplemented by the necessity to adopt regulatory reforms to ensure that privatization works properly, thereby increasing the role of the State in an unexpected way. ${ }^{109}$ A particular outcome of this situation is what Prosser describes as 'public service law' - the corpus of legal rules that provides the means of regulating the activity of privatized bodies, in particular in the utilities sector. ${ }^{110}$ According to Prosser, this body of law is administered by new regulatory bodies established by the State, thus leading to the conclusion that privatization does not necessarily lead to a smaller role or size of the State.

\footnotetext{
106 Ibid.

107 Ibid.

108 See G. Majone, "Paradoxes of Privatization and Deregulation," Journal of European Public Policy Vol. 4 (1994), p. 62. Feigenbaum et al. speak in this respect of a compensatory shift toward a greater public sector role on other dimensions. Feigenbaum, Henig, and Hamnett, Shrinking the State: The Political Underpinnings of Privatization, p. 9.

109 See T. Prosser, "Public Service Law: Privatization's Unexpected Offspring," Law \& Contemp. Probs. No. 63 (2000), p. 72.

110 Ibid. See further the discussion in Chapter VII Section 2.2 related to the public service obligations of States when they privatize essential utilities.
} 
The dynamic nature of privatization will also be affected by the rationale for privatization. In a 2003 report, the OECD described a number of reasons driving the privatization efforts of the last two decades. According to the OECD, privatization was fueled by,

"(a) the emergence of a tight fiscal environment and the need to control government spending and debt; (b) disillusionment with the generally poor performance of stateowned enterprises; (c) technological changes in sectors such as telecommunications and electricity generation that have rendered monopoly provision of certain goods and services obsolete, and market liberalisation, particularly among the European Union members of the OECD; (d) globalisation of financial markets and the need to free up companies from the constraints of state ownership in order to effectively access these markets; (e) ideological shifts regarding the appropriate role of the state in the economy; and in the case of the former transition economies, the massive overhaul of the economic system."."11

On the basis of this evaluation by the OECD, the reasons for privatization can be classified as either ideological or pragmatic. The ideological rationale will argue in favor of privatization based on the premise that the role of the State should be kept to a minimum and only concern itself with the most basic tasks necessary for the survival of the State (national security, policing, adjudicating and legislating). The pragmatic approach will argue in favor of privatization to seek a solution to a specific problem: if a particular service is not efficiently provided or catered by a public body, privatizing it might increase the effectiveness and efficiency of the service; if the State can not longer afford to maintain certain services due to budgetary constraints, it may be better to allow private entities to do so. ${ }^{12}$

It has been noted above that privatization is a dynamic process whereby the roles of the State and the private actor involved in the privatization operation may vary and shift at various levels. These shifts will likely depend on the rationale and aims that the State pursues through privatization. Thus if the reason for privatization is based on ideological premises that prefer markets over the State, then the role of State will likely be less than if it is based on pragmatic arguments (which may be willing to accept a more involved role of the State through, for example, regulation).

\subsection{Preliminary conclusions}

Privatization entails a transfer of functions or tasks from the State to private actors. This transfer may be absolute or partial. Privatization is, however, not a recent

\footnotetext{
111 "Privatising State-Owned Enterprises - An Overview of Policies and Practices in OECD Countries," OECD, Paris, (2003), p. 8.

112 In this respect, privatization has been regarded as a cure for government's inefficiency. See Cass, "Privatization: Politics, Law and Theory," p. 451-452.
} 
phenomenon and it is possible to discern a cycle between public sector involvement and private sector involvement is various areas, some of which are sometimes considered to be 'core' state functions. The fact that one can speak of a cycle means that privatization as such is not irreversible. Privatization is also a dynamic process entailing a varying degree of involvement of private and public actors. The dynamic nature of privatization also means that it does not always necessarily lead to an absolute reduction in the size of the State and its role in society. It may imply a lesser role in the actual exercise of a function or the provision of a particular service; but it can also lead to a bigger role in another function: that of a regulator. In addition it is possible to discern a certain interplay between the dynamic nature of privatization and the rationale behind it.

Having found a definition for privatization that fits within the scope of this study, and having briefly examined its history, rationale, nature, and the ways in which the roles of public and private actors shift along the public-private continuum, it is now possible to explore the methods by which privatization policies are applied.

\section{Methods Of PRivatization}

Privatization is a complex phenomenon that involves and requires different levels of interaction between public and private actors as well as different techniques for its realization. The choice for a specific technique will depend, among other things, on the objectives of the government; the organizational form and specific characteristics of the public enterprise to be privatized as well as its legal status; the financial condition and record of performance of the public enterprise; its sector of activity; the ability to mobilize private sector resources; the degree of development of the capital market; and socio-political and legal factors. ${ }^{113}$ For example, if the objective of the State is to improve the efficiency of a state owned enterprise (SOE), it can choose to privatize that enterprise through a complete or partial divestiture and sale of assets. Alternatively, it can choose to liberalize the sector where the enterprise operates, thereby allowing it to operate in a competitive market and then privatize it by delegating its management to private entities without selling the enterprise. With regard to the status of the SOE to be privatized, the method of privatization can depend, for example, on whether shares of the enterprise are already being publicly traded. If this is the case, then privatization can be easily achieved by selling the shares that are owned by the State. ${ }^{114}$ On the other hand if the enterprise has been

113 See Vuylsteke, "Techniques of Privatization of State-Owned Enterprises, Vol. I Methods and Implementation," p. 57. See also Guislain, The Privatization Challenge: A Strategic, Legal and Institutional Analysis of International Experience, p. 23 and 26.

114 Vuylsteke, "Techniques of Privatization of State-Owned Enterprises, Vol. I Methods and Implementation," p. 54. 
established by public law, privatization through the sale of assets or shares will probably be possible only after amending the law.

According to Guislain, a number of privatization techniques "[...] have been borrowed from private commercial practices, where mergers and acquisitions are common."115 Vuylsteke distinguishes seven basic methods through which privatization can take place. ${ }^{116}$ Most of the techniques discussed by Vuylsteke involve the transfer of ownership of a SOE to private actors, although he also notes that other techniques involving the delegation of management or the contracting out of services can also be applied. For the purposes of this study, four main techniques or methods of privatization can be differentiated.

\subsection{Privatization through the transfer of ownership}

The most frequently used technique to privatize state owned industries involves the transfer of ownership of a SOE to private actors through the sale of shares of SOEs or through the overall sale of SOE's assets (liquidation). This is usually known as divestiture. ${ }^{117}$ In some cases shares are sold to the management or employees of former public enterprises. ${ }^{118}$

\subsection{Privatization through the transfer of management}

As discussed in Section 2.1 supra privatization does not necessarily involve a transfer of ownership. It can also be achieved by transferring the management of a

115 Guislain, The Privatization Challenge: A Strategic, Legal and Institutional Analysis of International Experience, p. 122.

116 These techniques include: a. public offering of shares; b. private sale of shares; $c$. new private investment in an SOE; d. sale of government or SOE assets; e. reorganization (or break-up) into component parts; d. management/employee buyout; and lease and management contract. See Vuylsteke, "Techniques of Privatization of State-Owned Enterprises, Vol. I Methods and Implementation," p. 8.

117 It must be noted that divestiture is used and defined in different ways by various authors. Berg and Shirley for example also include privatization of management under the definition of divestiture. E. Berg and M.M. Shirley, "Divestiture in Developing Countries," World Bank Discussion Papers WDP - 11, The World Bank, Washington D.C., (1990), p. 1-2. Contrast with the definition of divestiture provided by Guislain. P. Guislain, "Divestiture of State Enterprises: An Overview of the Legal Framework," World Bank Technical Paper WBTP 186, The International Bank for Reconstruction and Development/The World Bank, Washington D.C., (1992), p. 1-2. In this study, divestiture will refer only to privatization through change of ownership and will deal with privatization of management as a separate technique.

118 In a number of countries, sale of shares to the management and/or (former) employers of privatized enterprises has been categorized as a form of 'popular capitalism' whereby support for privatization was secured by giving those who otherwise would be opposed to the privatization a stake in the business. Vuylsteke, "Techniques of Privatization of State-Owned Enterprises, Vol. I Methods and Implementation,” p. 122. 
public company to private actors who then run the company or service as if it were a private entity. This happens through management contracts, leases or concessions. For example, in the water utilities sector, privatization usually takes place through a concession agreement whereby the ownership of the water network remains in the hands of the State, but the private entity takes over the day-to-day operation and business or service activities of the company or service provider. ${ }^{119}$ The main feature of privatization through delegation of management is that the private party in charge of the management, lease or concession retains full control and the authority to manage the privatized entity. ${ }^{120}$

\subsection{Privatization through contracting out}

Additionally, depending on the sector where the privatization takes place, other techniques such as contracting out can be used. Under contracting out, a State pays or compensates a private party that supplies/provides non-commercial government services such as prisons, education or health care services. ${ }^{121}$

\subsection{Privatization through deliberate withdrawal or incapacity}

Privatization can also take place without transferring the ownership of SOEs, delegating the management or contracting out. For example, SOEs can be dissolved or the State may deliberately withdraw its activities in one sector in the hope that private enterprises will fill the gap left by the former SOE. The State can also find itself unable to provide a certain service for which it is primarily responsible, and so allow private initiatives to take over. ${ }^{122}$ This inability may arise due to lack of sufficient financial resources, lack of personnel, capacity or expertise. In addition, non-State actors can move in and take over governmental functions when the State ceases to exercise them in a proper way, for example due to a civil war of internal armed conflict. This is the case of so-called failed States, and the issue was taken

119 An exception to this was the privatization of public utilities such as water, electricity and gas in the United Kingdom, which took place through the complete sale of shares and assets to private corporations. See further Chapter VII.

120 S.O. Hegstad and I. Newport, "Management Contracts: Main Features and Design Issues," World Bank Technical Paper WTP-65, The International Bank for Reconstruction and Development/The World Bank, Washington D.C., (1987), p. 7. See also H. Shaikh and M. Minovi, "Management Contracts: A Review of International Experience," CFS Discussion Paper 108, The World Bank, Washington D.C., (1995), p. 14-15.

121 Keefer, "Contracting Out: An Opportunity of Reform and Private Sector Development in Transition Economies," p. 3.

122 In El Salvador, for example, the State has not been able to provide primary education in remote areas, but has allowed private individuals and (non-governmental) groups to set up schooling initiatives. See Coomans and Hallo de Wolf, "Privatisation of Education and the Right to Education." 
for example into consideration in the case of Elmi v. Australia, in which the UN Committee Against Torture noted that

"[...] for a number of years Somalia has been without a central government, that the international community negotiates with the warring factions and that some of the factions operating in Mogadishu have set up quasi-governmental institutions and are negotiating the establishment of a common administration. It follows then that, de facto, those factions exercise certain prerogatives that are comparable to those normally exercised by legitimate governments." 123

Arguably the above-cited situation comprises a type of privatization in which nonState actors perform State related functions due to the incapacity of traditional governmental authroities to do so.

\subsection{Preliminary conclusions}

In sum, four main techniques of privatization can be identified: privatization through transfer of ownership, privatization through transfer or delegation of management, privatization through contracting out, and privatization through withdrawal or incapacity. At the same time, it should be acknowledged that certain specific sectors that have been exposed to privatization efforts will have their own particular methods of implementing privatization. ${ }^{124}$ Lastly, a combination of techniques is also possible, ${ }^{125}$ thus demonstrating once again the dynamic nature of privatization.

\section{Privatization and its actors}

Many different actors play a direct or indirect role during and after privatization processes. These are public and private actors, some of which have (limited) international legal personality. The actors that are of most relevance for the purposes of this study are: the State, international financial institutions, national and business

123 Elmi v. Australia, Communication No 120/1998, Committee Against Torture, UN Doc. CAT/ C/22/D/120/1998 (14 May 1999), para. 6.5.

124 See for example Coomans and Hallo de Wolf, "Privatisation of Education and the Right to Education," p. 243-250, with respect to the techniques used in the context of education privatization. Some of these techniques are similar to the ones generally discussed in this section, but others are sui generis for the sector of education. See also Guislain, The Privatization Challenge: A Strategic, Legal and Institutional Analysis of International Experience, p. 122. For the techniques employed in the privatization of essential utilities such as water see Chapter VII. Guislain, The Privatization Challenge: A Strategic, Legal and Institutional Analysis of International Experience, p. 123. See also Donaldson and Wagle, "Privatization: Principles and Practice," p. 13. 
enterprises, national regulatory bodies, trade unions and private consumers/users/ individuals.

\subsection{The State}

The State has a primordial role to play with regard to privatization. As a sovereign entity with international legal personality, the State has the legitimacy, and capacity to take economic and political measures or decisions that it deems necessary. ${ }^{126}$ Privatization is without doubt such a measure. The State can adopt privatization policies, enact new laws or amend existing ones to make privatization possible, and devise and apply privatization techniques necessary for its implementation. Depending on the objective to be achieved through privatization, the sector in which it will be applied and the technique chosen, the State will have different tasks to perform. The State can be the facilitator of privatization establishing the necessary legal infrastructure to help privatization policies succeed. A State may adopt new legislation in the field of competition law, property rights law, or investment law. The State can also be the contractual partner of the private entity taking over the State's functions, tasks or services through management contracts, concessions, or contracting out arrangements. It is the State or one of its subordinate organs or entities that signs the agreement or contract that transfers the ownership of SOEs or their management to private parties. Furthermore, the State may also assume a regulatory role and implement regulatory legislation to ensure that privatized industries or services live up to their contractual or legal obligations.

126 See in this respect the preamble of UN General Assembly resolution 1803 (XVII) of 14 December 1962 on the Permanent Sovereignty over Natural Resources where it was recognized that States have "the inalienable right [...] freely to dispose of their natural wealth and resources in accordance with their national interests, and on respect for the economic independence of States." Resolution 1803 was adopted by consensus. See also article 2 of chapter II of the controversial Charter of Economic Rights and Duties of States, UN Doc. GA Res. 3281(xxix), UN GAOR, 29 th Sess., Supp. No. 31 (1974) 50, which states in its first paragraph that "[e]very State has and shall freely exercise full permanent sovereignty, including possession, use and disposal, over all its wealth, natural resources and economic activities." The Charter, a controversial document adopted by the UN General Assembly without the support of a number of Western countries, deals mainly with nationalization of foreign companies (the reverse situation of privatization). Nationalization can be seen as one of the expressions of the State's freedom to exercise sovereignty, possession, use and disposal of its economic activities and organization. Since privatization also falls into the realm of the State's economic activities, it can be argued that the State is free to choose how to deal with the possession and disposal of its SOEs. Privatization, like nationalization is just a tool for these purposes. For a more in depth discussion about the legal value of these documents and the controversies they have brought see A.F. Lowenfeld, International Economic Law, ed. J.H. Jackson, International Economic Law Series (Oxford: Oxford University Press, 2002) p. 407-414. 
At the same time the State's sovereign rights to take the economic decisions it deems necessary is limited by certain rules and principles of international law. ${ }^{127}$ For example, under the rules of the law of treaties and state responsibility, States are not allowed to invoke provisions of internal/municipal law to justify nonperformance of their international obligations arising out of treaties or to preclude the international wrongfulness of national actions. ${ }^{128}$ National policies or legislation such as privatization that give rise to breaches of international legal obligations can thus not be used as justifications not to live up to these obligations.

A number of regional and international human rights treaty monitoring bodies have stressed that privatization policies (or any other type of delegation to private actors) does not relieve State parties to human rights treaties of their legal obligations arising thereof. For example, the European Court of Human Rights (ECtHR) observed in the Costello-Roberts case that a State cannot "[...] absolve itself from responsibility by delegating its obligations to private bodies or individuals." 129 Similarly, the Human Rights Committee under the individual complaint mechanism of the first Optional Protocol to the International Covenant on Civil and Political Rights (ICCPR) has concluded that, "[...] a State party is not relieved of its obligations under the Covenant when some of its functions are delegated to other autonomous organs." 130 The most explicit view of the Human Rights Committee with regard to the obligations of the State and privatization concerned a case where two Mexican prisoners were held in a privatized maximum-security prison in Australia. The two prisoners submitted a complaint before the Human Rights

127 Additionally, the behavior of a State could be limited by its membership of an international or regional organization such as the United Nations or the European Union with their own subset of rules that set certain limits to a State's sovereignty in several areas. Thus States are not allowed to use force unilaterally unless acting in self defense or with the approval of the UN Security Council (Articles 2, 43 and 51 UN Charter). Similarly, member States of the EU are not allowed to take unilateral economic measures that harm the free movement of goods, persons or services (Articles 28, 43 and 47 EC Treaty, now Articles 24, 49 and 53 Treaty on the Functioning of the European Union).

128 Art. 27 Vienna Convention on the Law of Treaties states that: "A party may not invoke the provisions of its internal law as justification for its failure to perform a treaty." Article 3 of the Articles on the Responsibility of States for International Wrongful Acts, UN Doc. A/ RES/56/83(28 January 2002) provides that: "The characterization of an act of a State as internationally wrongful is governed by international law. Such characterization is not affected by the characterization of the same act as lawful by internal law." Although the Articles on the Responsibility of States as drafted by the International Law Commission and accepted by the UN's General Assembly are not legally binding, many of its provisions are considered to be reflective of customary international law.

129 See Costello-Roberts v. the United Kingdom, judgment of 23 February 1993, ECtHR Series A247-C, para. 27.

130 B.d.B. v. The Netherlands, Communication No 273/1988, UN Doc. CCPR/C/35/D/273/1988 (2 May 1989), para. 6.5. This view was subsequently reiterated in L. et al v. Sweden. See Joint Communications No 298/1988, UN Doc. CCPR/C/40/D/298/1988 (2 May 1989) and No 299/1988, UN Doc. CCPR/C/40/D/299/1988 (2 May 1989). 
Committee on the conditions of detention within the privatized prison. In this case the Human Rights Committee confirmed the abovementioned observations and concluded that "[...] the contracting out to the private commercial sector of core State activities which involve the use of force and the detention of persons does not absolve a State party of its obligations under the Covenant and the Optional Protocol $[\ldots]^{\prime \prime 131}$

In sum, the State's role with regard to privatization is not limited to devising and implementing privatization policies. It also involves respecting international legal obligations that may be affected by national privatization measures. This means that the State cannot justify breaches of its international legal obligations by pointing to internal law and policies such as privatization, and that the privatization of State functions, tasks or services does not relieve the State from these obligations. ${ }^{132}$ These substantive legal aspects of international and human rights law as they relate to the role of the State with regard to privatization will be discussed in more detail in Chapter III.

\subsection{International Financial Institutions (IFIs)}

The International Monetary Fund (IMF) and the International Bank for Reconstruction and Development (the World Bank) were established by the Bretton Woods Agreement in 1944 to help achieve financial stability and long term economic development. ${ }^{133}$ The IMF's main objective is to render short and mediumterm assistance to countries experiencing balance of payment problems. ${ }^{134}$ The IMF provides credit to these countries through special drawing rights using stand-by agreements but only if borrowing countries agree to meet certain conditions (this practice has been branded 'conditionality'). Article V $\$ 3 b$ (i) of the IMF Articles of Agreement, codifies conditionality ${ }^{135}$ and states, inter alia, that (b) "[a] member shall be entitled to purchase the currencies of other members from the Fund in exchange for an equivalent amount of its own currency subject to the following conditions: (i) the member's use of the general resources of the Fund would be in accordance with the provisions of this Agreement and the policies adopted under them [...]" (emphasis added). Based on this article the IMF has set a number of further conditions and policies to be complied with by borrowing countries, if they

\footnotetext{
131 Cabal and Pasini Bertran v. Australia, Communication No. 1020/2001, UN Doc. CCPR/ C/78/D/1020/2001 (29 August 2003), para. 7.2. For a more detailed review of this case see Chapter IV.

132 Chapter III, Section 3 below discusses these international obligations in further detail.

133 Lowenfeld, International Economic Law, p. 502.

134 See Article I and V §3 IMF Articles of Agreement. See also Lowenfeld, ibid., p. 618.

135 Ibid., p. 545.
} 
want to become eligible for financial assistance by the IMF. Among these further conditions, privatization has received a prominent role. ${ }^{136}$

The World Bank and its related institutions, the International Development Association and the International Finance Corporation ${ }^{137}$ were established to provide long-term assistance by, inter alia, granting loans to particular/specific "useful and urgent projects." 138 Additionally, the World Bank may "in special circumstances"139 grant loans not coupled to specific projects, as in the case of adjustment lending. Adjustment lending was introduced in the early 1980s to assist countries with severe balance of payment problems with the objectives to "[...] to prevent or reverse unsustainable economic conditions that hurt the poor and to establish or restore the conditions for sustainable development that can help reduce poverty." ${ }^{40}$ From the 1980s onward, privatization became an important feature of the World Bank's adjustment lending policy in view of the concurrent ideological shift in favor of private ownership and its failed attempts at reforming public enterprises. ${ }^{141}$ This fitted well in the context of the 'Washington Consensus', a paradigmatic approach to development supported by the IMF and the World Bank and which focused on export-oriented development through rapid liberalization and privatization. ${ }^{142}$ The percentage of loans including privatization conditions

136 Davis, Ossowski, and Richardson, "Fiscal and Macroeconomic Impacts of Privatization.”; Hall and Motte, "Dogmatic Development: Privatisation and Conditionalities in Six Countries," p. 5. See also Brune, Garret, and Kogut, "The International Monetary Fund and the Global Spread of Privatization," p. 5-6, recalling further literature describing to how privatization was adopted by the IMF as a conditionality policy.

137 The World Bank group in its entirety is composed of the International Bank for Reconstruction and Development (IBRD); the International Development Association (IDA); the International Finance Corporation (IFC); the Multilateral Investment Guarantee Agency (MIGA); and the International Centre for Settlement of Investment Disputes (ICSID).

138 Article I IBRD Articles of Agreement. See also Lowenfeld, International Economic Law, p. 618 .

139 Article III $\$ 4$ (iv) Articles of Agreement IBRD. According to the World Bank's Operations Policy and Country Services division, because the articles of agreement do not define what can be understood under special circumstances, the World Bank has latitude to determine what these circumstances may be and when they are present. These circumstances have been broadly interpreted to mean circumstances that can justify a departure from the general rule and can be country-specific, related to a certain period of time, or result from a general economic situation affecting some or all borrowing countries. "From Adjustment Lending to Development Policy Lending: Update of World Bank Policy," Operations Policy and Country Services/The World Bank, Washington D.C., (2004), p. 3-4.

140 "Adjustment Lending in Retrospective," Operations Policy and Country Services/The World Bank, Washington D.C., (2001), p. 1.

141 Ibid., p. 56.

142 Hall and Motte, "Dogmatic Development: Privatisation and Conditionalities in Six Countries," p. 5. The term 'Washington Consensus' was coined in the early 1990s by economist John Williamson to denote a set of economic policies which he though most serious economists around the world agreed upon and were necessary to achieve economic reform as well as to increase welfare and efficiency. Privatization or the restructuring of public enterprises to 
increased from $8 \%$ in the mid 1980 s to around $30 \%$ in the mid 1990 s, although it would appear that the role of privatization as a pre-condition for adjustment loans has declined in recent years. ${ }^{143}$

The World Bank's policies with regard to adjustment lending were codified in its Adjustment Lending Policy Operational Directive OD 8.60 of December 1992. This Operational Directive recommended privatization in a competitive environment as the best remedy for reform of public enterprises which is "[...] often needed to (a) reduce or eliminate the large budgetary subsidies such enterprises receive, and (b) remove the allocative inefficiencies such enterprises introduce through uneconomic pricing and investment policies, excessive employment, and weak management."144 However, probably as a result of increasing disenchantment with the outcomes of various privatization projects in a number of countries, and the growing opposition to privatization endeavors in particular in those sectors that are likely to impact the poor (such as in essential services such as water and electricity utilities), the World Bank has started to revise its privatization as conditionality policy. ${ }^{145}$ As of 2004 , Operational Directive 8.60 was replaced by Operational Policy 8.60 and by Bank Practice 8.60 , which no longer prescribe privatization as a condition of credit lending. ${ }^{146}$ According to the World Bank, these new policy guidelines no longer attempt,

improve their performance was among the prescribed policies. See J. Williamson, "Democracy and the 'Washington Consensus'," World Development Vol. 21 (1993), p. 1329-1336. See also Stiglitz, Globalization and Its Discontents, p. 53.

143 "Adjustment Lending in Retrospective," p. 56.

144 World Bank, Operational Directive OD 8.60: Adjustment Lending Policy (21 December 1992), para. 31. The Operational Directive additionally recommended sector wide reforms including the privatization of public enterprises and utilities. Ibid, para. 32. The Bank's Operational Directives and policies are only binding on its officials.

145 See for example, "Adjustment Lending in Retrospective." See also World Bank "Infrastructure Action Plan", Informal Board Meeting, 8 July 2003, p.3, available at $<$ http://siteresources. worldbank.org/INTTRM/Resources/InfrastructureActionPlan.pdf $>$ (last visited 10 December 2007), and World Bank "Infrastructure development: The roles of the public and private sectors - World Bank Group's approach to supporting investments in infrastructure", November 2005, p. 3-4, available at <http://siteresources.worldbank.org/INTINFNETWORK/Resources/ Rolesupdt.pdf $>$ (last visited 10 December 2007). For an assessment of the disappointing consequences of privatization in transition countries see J. Nellis, "Time to Rethink Privatization in Transition Economies?," Discussion Paper Number 38, International Finance Corporation/ The World Bank. 456. See also S. Kikeri and J. Nellis, "An Assessment of Privatization," The World Bank Research Observer Vol. 19 (2004), p. 87-118; Kikeri and Fatima Kolo, "Privatization: Recent Trends and Developments." See further D. Hall, E. Lobina, and R. de la Motte, "Public Resistance to Privatisation in Water and Energy," Development in Practice Vol. 15 (2005), p. p. 286-301. These developments are further discussed in Chapter VII with regard to the privatization of essential utilities in the water sector.

146 See World Bank, Operational Policy OP 8.60: Adjustment Lending Policy (11 August 2004), para.13. 
"[...] to codify the specific policy areas and approaches (such as public finance, trade policy, financial sector policy, and public enterprise reforms and privatization) that were discussed as 'selected areas of policy reform in OD 8.60. Nor does it include discursive passages, such as those on interdependence and sequencing of structural adjustment and stabilization. This shift in focus reflects the recognition that there is no single blueprint for policy programs that will work in all countries, and that any country's policy program must be designed with country ownership to fit that country's specific circumstances. Where the analytic underpinnings are solid, some of these issues could serve as examples of good practice that would provide helpful guidance to staff."147

In short, the World Bank has come to understand that privatization in itself is not the wonder remedy that it once touted it to be, and that specific policies should be tailored to fit each country's particular situation. ${ }^{148}$ Of particular importance in this regard is the recognition that adjustment policies such as privatization must be designed with country ownership in mind. This entails that privatization should not be imposed from above by the IFIs, but should be discussed with and accepted by not only the borrowing governments, but also with civil society organizations and the population that is affected by them. Inclusiveness, consultation and participation of key stakeholders in decisions regarding adjustment policies like privatization have become elements of the new operational policy of the bank under OP 8.60 and BP 8.60. ${ }^{149}$ In addition, the new operational policy requires the World Bank to assess how adjustment policies such as privatization "[...] are likely to have significant and social consequences, especially on poor people and vulnerable groups." 150 If this is the case, OP 8.60 requires the World Bank to come up with suggestions as to how these consequences should be addressed before or during the implementation of the adjustment lending program.

The role of IFIs with respect to privatization is crucial. Whereas developed countries have usually applied privatization policies on their own initiative, most of the privatization endeavors in developing countries have been made under the auspices of the IMF and the World Bank as part of conditionality requirements by both institutions under the so-called 'Washington Consensus.' This has drawn criticism in particular from certain commentators in the human rights arena who are concerned that privatization policies promoted by IFIs can have a negative impact

\footnotetext{
147 "From Adjustment Lending to Development Policy Lending: Update of World Bank Policy," p. 11 (emphasis $A H W$ ).

148 See Kikeri and Nellis, "An Assessment of Privatization," p. 105. See also Nellis, "Time to Rethink Privatization in Transition Economies?"”

149 See World Bank, Operational Policy OP 8.60: Adjustment Lending Policy (11 August 2004), para. 6. See also "From Adjustment Lending to Development Policy Lending: Update of World Bank Policy," p. 30-31.

150 See World Bank, Operational Policy OP 8.60: Adjustment Lending Policy (11 August 2004), para. 10.
} 
on the enjoyment of those rights. For example, a former special rapporteur of the now defunct ${ }^{151}$ UN's Sub-Commission on the Promotion and Protection of Human Rights, Danilo Türk, examined in a series of reports the (negative) implications of the implementation of structural adjustment programs including privatization, which are promoted by these institutions, on the realization of economic, social and cultural rights. In his final report, Mr. Türk observed that "[d]espite the more recent visions of adjustment by IMF and the World Bank, these programmes still appear far too often to be inspired by economic theory rather than practical experience of the human, political, social and economic impact adjustment has had upon the more than 70 countries which have applied what is often referred to as 'bitter medicine.'."152 According to Mr. Türk, structural adjustment programs promoted by the IMF and the World Bank have common components including the decrease of government expenditure on public services, the reduction of the role of the State in the economy and the privatization of heretofore public enterprises. ${ }^{153}$ Although $\mathrm{Mr}$. Türk acknowledged that privatization and the private sector could have a positive effect on the realization of certain aspects of economic, social and cultural rights, he pointed out that there is scant evidence that reduction of government involvement has actually resulted in the alleged improvement of these rights. ${ }^{154} \mathrm{In}$ his analysis Mr. Türk observed that, "[t]he human rights impact of [structural] adjustment must be seen from a holistic viewpoint and the extensive countrywide implications of such programmes must be recognized, as well as the fact that certain social groups tend more frequently to feel the negative impacts of adjustment than others."155

Another former UN human rights expert, Mr. Fantu Cheru, has observed an interesting aspect of the IMF's and World Bank's influence on privatization policies in heavily indebted poor countries (HIPCs). In 1996, the IMF and the World Bank issued a strategy intended to alleviate the debt burden of these countries (the HIPC Initiative). ${ }^{156}$ Under this initiative, HIPCs draft Poverty Reduction Strategy Papers

151 The Sub-Commission on the Promotion and Protection of Human Rights, which was established to undertake studies and make recommendations to the UN's Commission on Human Rights ceased to exist after its fifty-eighth and final session, following the UN General Assembly's decision that the newly established Human Rights Council should assume all the mandates, mechanisms, functions and responsibilities of both the Commission and Sub-Commission. See UN General Assembly Resolution 60/251 of 15 March 2006 entitled 'Human Rights Council'. "The Realization of Economic, Social and Cultural Rights," Final report submitted by Mr. Danilo Türk, Special Rapporteur, UN Doc. E/CN.4/Sub.2/1992/16 (3 July 1992), para. 49.

153 See "Realization of economic, social and cultural rights," Second progress report prepared by Mr. Danilo Türk, Special Rapporteur, UN Doc. E/CN.4/Sub.2/1991/17 (18 July 1991), para. 85. According to Mr. Türk, the main objective of these adjustment programs is the reduction of inflation, the re-establishment of equilibrium in the balance of payments of States and the promotion of economic growth. Ibid., para 86.

156 See for more information on the HIPC Initiative: < http://go.worldbank.org/85B908KVE0> (last visited on 31 August 2011). 
(PRSPs) that are co-authored with the IFIs, and which serve as the basis for debt relief and poverty reduction loans. In his role as an independent expert on the effects of structural adjustment policies and foreign debt on the full enjoyment of all human rights, particularly economic, social and cultural rights, Mr. Cheru prepared a report for the former UN Commission on Human Rights assessing the HIPC Initiative and the PRSPs. ${ }^{157} \mathrm{Mr}$. Cheru observed that as a result of their desire to fulfill the conditions necessary for debt relief and trying to meet the lending criteria of the IMF and the World Bank, HIPCs "[...] have thus put too much emphasis on macroeconomic considerations, fiscal reform and privatization measures to placate these powerful institutions, without thinking through how such policies impact on poverty reduction and in what context." 158 In the eyes of the expert,

"[t]he decision by debtors to 'placate' the IMF is both political and financial, since eligibility for debt relief under HIPC-II is conditioned upon 'good performance' in the implementation of IMF and World Bank policies. While countries should be encouraged and supported to adopt sensible policies that make good economic and political sense, IMF-supported programmes remain stringent, inflexible and in some instances very punitive, leaving very little room for countries to manoeuvre."159

Mr. Türk's and Cheru's observations, as well as those noted in the previous paragraphs, indicate that IFIs have been instrumental in helping to shape or influence the privatization policies of developing countries. Although it appears that in recent years the IFIs have toned down the emphasis on privatization and have come to realize that there is a need to be more inclusive with regards to its implementation, privatization still remains an important aspect of their lending policies. This has, in turn, drawn criticism from those who fear that these policies can have a negative impact on vulnerable people and their human rights. This brings up the question whether IFIs have any type of human rights obligations that they must respect when they recommend or impose economic reform policies such as privatization on borrowing countries. This question will be dealt with in Chapter III.

\subsection{National and Multinational Business Enterprises}

National and business enterprises also play an important part in the privatization arena. Private corporations are being entrusted with functions, tasks and with the delivery of services that were previously carried out by the State or its formal agencies. As observed above, there is even a historical record of the participation of private corporations in what many would consider core State activities. The example

\footnotetext{
157 See The Highly Indebted Poor Countries (HIPC) Initiative: a human rights assessment of the Poverty Reduction Strategy Papers (PRSP), UN Doc. E/CN.4/2001/56 (18 January 2001).

158 Ibid., para. 25.

159 Ibid., para. 26
} 
of the VOC - which, as we saw in Section 2.2 supra, exercised what may be regarded as far-reaching State powers - is very evocative in this regard. There are various current examples of business enterprises that either directly or through local subsidiaries have become involved in taking over former State functions, tasks or services. Examples of large (multinational) companies in the prisons sector are Corrections Corporation of America (CCA), and The GEO Group (formerly Wackenhut Corrections Corporation (WCC)), an United States based company that is now part of the G4S concern (formerly known as Group 4 Securicor), the world's largest private security corporation. ${ }^{160}$ Companies such as Blackwater (American), Erinys International (British), and Aegis (British, formerly known as Sandline Inc.), provide military and security services to various countries, in particular the United States and the United Kingdom, in support of military operations in Iraq and Afghanistan. ${ }^{161}$ In the water utilities sector the leading companies are French multinationals Veolia (formerly known as Compagnie Générale des Eaux and Vivendi) and Suez (formerly known as Lyonnaise des Eaux), which have been awarded various concessions to operate the water utilities in a number of Latin American countries, in particular Argentina. ${ }^{162}$

There is some controversy regarding the international legal personality of business enterprises and whether they have rights as well as obligations. ${ }^{163}$ In general the expanding activities of business enterprises have been met with growing concern due to the actual or perceived (economical) power they appear to exert. The participation of private profit seeking actors in the provision of certain services that are considered essential or of great public interest has been regarded with suspicion and sometimes with outright animosity. ${ }^{164}$ Arguably, the disputable (or shall we say controversial) role of companies such as Shell in the so-called extractive industries in developing countries, ${ }^{165}$ or Bechtel in the privatization of water services in

160 According to G4S's website, the company operates in over 100 countries. See <www.g4s.com/ home/about.htm> (last visited 15 January 2008).

161 See Chapter VI.

162 See Chapter VII.

163 See for example Clapham, Human Rights Obligations of Non-State Actors, p. 76-80; M.N. Shaw, International Law, $6^{\text {th }}$ ed. (Cambridge Cambridge University Press, 2009) p. 249-250.

164 Among the most measured evaluations of the use of private entities for services that are of public relevance see E. Palmer, "Should Public Health Be a Private Concern? Developing a Public Service Paradigm in English Law," Oxford Journal of Legal Studies Vol. 22 (2002). A critical appraisal of the privatization of prisons can be found in Robbins, "Privatisation of Corrections: A Violation of U.S. Domestical Law, International Human Rights and Good Sense." Other critical evaluations of privatization from the NGO perspective can be found inter alia in C. Joy and P. Hardstaff, "Dirty Aid, Dirty Water - The UK Government's Push to Privatise Water and Sanitation in Poor Countries," World Development Movement, 2005.

165 See S. Skogly, "Complexities in Human Rights Protections: Actors and Rights Involved in the Ogoni Conflict in Nigeria," NQHR, Vol. 15 (1997), p. 52. 
Bolivia, ${ }^{166}$ has contributed to increase the clamour for imposing social obligations on (multinational) corporations and undertakings and increasing their accountability.

Although the issue of the human rights obligations of business enterprises will be discussed in more detail in Chapter III, Section 3.2.2, it is nevertheless appropriate to observe at this point that while not being entirely beyond the grasp of international and human rights law, business enterprises are currently and formally not subject to them. In particular, international human rights obligations are in principle binding only on States. They do not work horizontally, that is they are not directly applicable to private national or business enterprises in relationship to their conduct with other private individuals. ${ }^{167}$ The lack of horizontal applicability of human rights with regard to corporations may lead to a gap in the accountability for human rights abuses as a result of their operations. Human rights monitoring bodies have tried to fill this gap by establishing that States have positive obligations to ensure that the conduct of these actors does not result in situations that are detrimental to human rights. ${ }^{168}$ Failure to do so will lead to the legal responsibility of the State under international law. As we will see in the next chapters, these bodies have also noted that States cannot absolve themselves of their international law and human rights obligations by delegating their functions or the services they provide to other nonState actors. In addition, there are ongoing efforts to encourage the adherence of business enterprises to voluntary codes of conduct that promote 'social corporate responsibility' such as the UN's Global Compact. ${ }^{169}$ It is worth noting that several companies which have taken over a number of former public services and functions have adhered themselves to voluntary codes of conduct. Several private military and security companies, for example, have organized themselves and formed the International Peace Operations Association (IPOA), and drafted a voluntary code of conduct which encourages these companies to respect international humanitarian lawn and international human rights norms. ${ }^{170}$ Interestingly, the companies

166 See further Chapter VII. See also H.H. Abendroth, "Der 'Wasserkrieg' von Cochabamba: Zur Auseinandersetzung um die Privatisierung einer Wasserversorgung in Bolivien," Bundeskammer für Arbeiter und Angestellte, Vienna, Informationen zur Umweltpolitik Nr. 161 (2004), A. Nickson and C. Vargas, "The Limitations of Water Regulation: The Failure of the Cochabamba Concesion in Bolivia," Bulletin of Latin American Research Vol. 20 (2002), p. 128-149, and McFarland Sanchez-Moreno and Higgins, "No Recourse: Transnational Corporations and the Protection of Economic, Social and Cultural Rights in Bolivia," p. 1663-1805.

167 In the case of the present study, these would be individuals who are affected by the conduct of privatized entities like service users of privatized utilities, persons deprived of their liberty in privatized prisons, students in privatized schools, or patients under privatized health care schemes.

170 See further Chapter VI Section 3.4.3 and A. Bearpark and S. Schulz, "The Regulation of the Private Security Industry and the Future of the Market," in From Mercenaries to Market The Rise and Regulation of Private Military Companies, ed. S. Chesterman and C. Lehnardt, Oxford: 
associated to the IPAO have also adopted a standards compliance and oversight procedure to monitor compliance with the code of conduct. This mechanism, however, is not legally binding, and the highest sanction for non-compliance is expulsion from the association.

Other efforts at closing the gap are focused on progressively developing legal standards that will ultimately aim to hold corporations accountable for their human rights abuses. Thus in 2003, the now defunct UN Sub-Commission on the Promotion and Protection of Human Rights adopted the 'Norms on the Responsibilities of Transnational Corporations and Other Business Enterprises with Regard to Human Rights'. ${ }^{171}$ The norms, which are not legally binding, state that "[w]ithin their respective spheres of activity and influence, transnational corporations and other business enterprises have the obligation to promote, secure the fulfilment of, respect, ensure respect of and protect human rights recognized in international as well as national law[...]."172 This soft-law approach requires that corporations that are engaged in privatized activities in their respective 'spheres of activity' such as the running of privatized utilities and essential services, prison management, policing and security, and so on, be mindful of the human rights aspects that are related to these activities. Although the Sub-Commission's Norms represent an important advance in the quest for accountability for business enterprises, the lack of a proper enforcement mechanism that would enhance their status and practical value is still a serious obstacle for them to be effective. As we will also see in Chapter III, 3.2.2, the Norms themelves have been subjected to criticism and appear to have been relegated from discussion at the former UN Commission on Human Rights and its successor body, the Human Rights Council.. ${ }^{173}$

\subsection{Preliminary conclusions}

In the previous paragraphs, we have briefly discussed the roles of three major actors that have a major role to play in the privatization of State functions, activities or services. The State plays various important roles with regard to privatization: it devises privatization policies, enables them, and in the end is responsible for their actual application and results. In addition to the State, IFIs have also contributed to privatization by encouraging the State to adopt it as a sound policy for structural reform, and also by making it a condition for receiving structural adjustment credit.

Oxford University Press (2007), p. 239-250, for a discussion on regulation and self-regulation of the private military and security sector.

171 See Sub-Commission on the Promotion and Protection of Human Rights, Norms on the Responsibilities of Transnational Corporations and Other Business Enterprises with Regard to Human Rights, UN Doc. E/CN.4/Sub.2/2003/12/Rev.2 (2003).

172 Ibid., para. 1.

173 See J.G. Ruggie, "Business and Human Rights: The Evolving International Agenda," AJIL Vol. 101 (2007), p. 821-822. 
It would appear however, that the privatization mantra has been toned down in recent years in view of the less than successful privatization efforts in a number of countries. It is officially no longer required as a condition for receiving adjustment loans, although it remains an important policy tool of IFIs. Finalizing this trinity, business enterprises, as the practical executors of privatization policies are also key actors in the privatization debate. The lack of a formal status under international law and thus of proper accountability mechanisms for business enterprises raises concerns with regard to their role in the process of privatization. There are however, a number of efforts and developments to increase the (human rights) accountability of these actors. It is, however, not yet certain if these efforts will suffice to limit potential harmful conduct of these actors when they are entrusted with the exercise of former public functions.

\section{Concluding Remarks}

The previous sections have focused on the definition of privatization, its history and dynamic nature, as well as the reasons that have been put forward to justify its implementation. The methods of privatization that have been applied were also reviewed. It can be concluded that privatization is not a new phenomenon. It has almost always been around and States have gone through various cycles of privatization and nationalization (or in other words, expanding and shrinking the role and activities of the State). These cycles have usually depended on the reigning political, economic, and social views that determine what the role of the State is supposed to be. Contrary to what many think, the historical origin of certain functions, tasks or services that are sometimes considered to be the responsibility of the State alone, makes it difficult to conclude that there are inherently governmental functions, tasks or services that cannot be privatized. Some of these have 'private' origins, but may have at a certain point in time been transferred to the State, which then later decided to put it back in 'private' hands. In any case it can be argued that it does not matter whether functions, tasks or services are 'inherently' or 'traditionally' governmental or not. What matters is what is the practical consequence of the delegation of these activities to private entities in the light of the current international legal obligations of States.

In addition it may be concluded that, although controversial, privatization does not necessarily entail a reduction or shrinking of the State. The State maintains a certain role in the whole process of privatization. This role will vary according to the method of privatization chosen. Sometimes the State's role will be one of facilitator of the process of privatization: it will enable the legislation, sign the contracts and in general create the necessary environment to make privatization possible. After that the State may choose to remain aloof and let privatization fulfill its objectives. Most of the times, however, the State will play a greater role. Besides creating the right environment for the realization of privatization, the State will 
usually choose to establish a regulator that monitors the activities of privatized entities, or at the very least set down the rules through which privatized entities may operate. The State will provide the setting and goals, and the private entity will be responsible for their implementation, oftentimes in cooperation with the State. Whether privatization leads to a shrinkage of the State or to a mere relocation or reorganization of its activities, it must be stated that the State will nonetheless maintain a number of legal obligations at the international level, which it still is expected to live up to. This will be further discussed in the next Chapter. There are however, other actors involved in the privatization process. With regard to privatization initiatives in developing countries, International Financial Institutions have played a crucial role in helping spread the privatization message. However, it would appear that there has been some rethinking about imposing privatization as a pre-condition for receiving adjustment loans from these entities. Although privatization as a policy is still recommended, it is no longer a mandatory precondition and there appears to be the realization that the adoption of policies such as privatization requires consultation with stakeholders at the international and national level, in particular with those that will be affected directly by those policies. Finally, it is worth mentioning the role of national and business enterprises/ companies in the privatization process. These non-State actors have been involved in the actual running of privatized tasks. However, their some-what ambiguous status under international law raises concerns as to how these can be held accountable for potential abuses when they are entrusted with functions of a public nature previously exercised by the State. 



\section{CHAPTER III IsSues OF DoCTRINe}

\section{INTRODUCTION}

Although privatization is a policy that is implemented at the national level, it also has an international dimension. As noted in the previous Chapter, privatization efforts in many countries, in particular in developing ones, have been endorsed and assisted by international financial institutions. Additionally, transnational privatization efforts (that is, those privatization endeavors whereby private service providers of one country, usually multinational corporations, are contracted to take over former public services in another country) entail the potential application of various norms of public international law. This is the case, for example, of privatization efforts leading to foreign investments by private companies in developing countries and which may require the protection of these investments through bilateral or multilateral investment treaties. ${ }^{1}$ The international dimension of privatization perhaps becomes most visible in the question whether international law prohibits or limits privatization efforts by States, especially if privatization has (negative) effects on the enjoyment of international human rights.

This Chapter will mainly focus on the latter issue and will map out the relevant doctrinal issues that may be relevant for the discussion of privatization and human rights. It will examine the various legal aspects that may have an impact on the

1 For example, a number of private multinational companies have brought various claims related to the protection of their investments in privatized utilities in developing countries before the International Center for the Settlement of Investment Disputes (ICSID). This is the case of several multinational companies operating privatized utilities in Argentina. Following a financial crisis which started in 1999 and peaked in 2002, the Argentine government adopted several measures that prompted these companies to bring claims before the ICSID claiming that these measures amounted to expropriation and undue interference with investments in breach of the Bilateral Investment Treatie (BITs) between Argentina and the countries of origin of those companies. See for example, Camuzzi International S.A. v. Argentine Republic, ICSID, Decision of the Arbitral Tribunal on Objections to Jurisdiction, ICSID Case No. ARB/03/7, June 10, 2005, in which a company registered in Luxemburg and running several privatized electricity utilities in Argentina alleged a violation of the BIT between Luxemburg and Argentina. This case was settled outside of the ICSID by both parties and the proceedings before the ICSID were withdrawn in January 2007. See $<$ http://icsid.worldbank.org/ICSID/FrontServlet?requestType $=$ GenCaseDtlsRH\&actionVal=ListConcluded $>$ (last visited on 23 July 2011. See also Suez, Sociedad General de Aguas de Barcelona S.A. and Interagua Servicios Integrales de Agua S.A. v. Argentine Republic, Decision on Jurisdiction, ICSID Case No. ARB/03/17, Decision on Liability, 30 July 2010, in which a French-Spanish consortium running a privatized water utility in the province of Santa Fé alleged a violation of the BIT between Argentina and Spain. 
implementation of privatization policies. To this end, this Chapter will attempt to place privatization in the context of national law and general international law.

On the whole, it can be stated that national law provides the initial framework for the formulation and implementation of privatization policies, and will for the most part provide for the initial constraints for their actual application. These constraints are based on substantive constitutional and other national legal precepts that may hinder a State in implementing privatization policies. As we shall see, however, these constraints are not absolute. Therefore, this Chapter will also consider the various international legal obligations that States have with respect to the question whether international and human rights law prohibit or place limits on privatization.

From the perspective of international law, privatization is mainly a national phenomenon that may have effects on the international plane. It may be stated that general international law tends to be privatization neutral. This has probably to do with the fact that under general international law, the State as a sovereign entity, is allowed to determine its own economic policies. This flows from the principle of non-intervention in the internal affairs of States including economic and political ones, which is also recognized in Article $2 \S 7$ of the UN Charter. In spite of this perceived neutrality, however, international and human rights monitoring mechanisms have shown their concern with respect to privatization and the human rights obligations of States. As will be shown in Chapter $\mathrm{V}$ these monitoring mechanisms have, however, fallen short of declaring privatization to be contrary to these obligations. The apparent neutral stance towards privatization is also formally perceptible at the level of international trade law, although privatization antagonists insist that this is not so at a deeper level.

The Chapter's structure is as follows: it will first look at the national doctrinal aspects involved with privatization and the legal constraints found therein. It will then turn to examine privatization under international law and review the general international law obligations of States that are relevant for the topic of privatization. This will be followed by a brief examination of the international legal obligations of non-State actors that have a role to play in the privatization of State tasks, functions or services. The Chapter will then examine a number of specific human rights doctrinal issues relevant to the discussion at hand.

\section{Privatization Under national LAW}

The present study focuses on the international (human rights) dimensions of privatization. However, the implementation of privatization policies ensuing from political programs or economical reform policies under the auspices of international 
financial institutions occurs at the national level. Thus, the privatization programs of a State will be affected by the differing legal concepts and traditions of that State, and how these concepts and traditions perceive the role the State has to play in society. $^{2}$

Privatization may entail a major change in the legal order of a State. States that have hitherto been entrusted with certain tasks in their national constitutions will need to amend them if they decide to privatize these tasks. According to Guislain, this means that any plans to privatize sectors, industries or services must be congruent and compatible with national legal norms, general principles of law such as the rule of law, and with international norms that are binding on the national legislator. ${ }^{3}$ States that choose to privatize have to take these national legal norms into account, otherwise they risk the privatization exercise being set aside by national adjudicators for its incompatibility with the national legal framework. The national legal norms will usually deal with the legality or constitutionality of privatization, or the procedural aspects of its application (for example, they could require prior consultation with the people or parliament). Sometimes these norms will not leave any leeway for the implementation of privatization policies. In other instances, national legal norms will be indifferent with regard to privatization but will require certain procedural steps to take place prior to its application.

In the following paragraphs, a brief overview will be provided regarding the place of privatization in the national legal framework of a number of different countries. The primary focus will be on the relationship between privatization and its constitutionality in a number of legal orders.

\subsection{Privatization and national constitutions}

Depending on what is being privatized and how privatization has to take place, the particular constitutional arrangement of a State may facilitate or place obstacles that could hinder, if not prevent a government's privatization policy and its implementation. Scholars have noted that constitutional law could be considered to be an autonomous element in the privatization process. ${ }^{4}$ Graham and Prosser, identify three different types of constitutional constraints influencing the implementation of a privatization program. These are substantive constraints, procedural constraints and constraints related to the constitutional cultural tradition

2 See Graham and Prosser, Privatizing Public Enterprises: Consitutions, the State, and Regulation in Comparative Pespective, p. 37.

3 Guislain, The Privatization Challenge: A Strategic, Legal and Institutional Analysis of International Experience, p. 33.

4 Graham and Prosser, Privatizing Public Enterprises: Consitutions, the State, and Regulation in Comparative Pespective, p. 3. 
of a particular State. ${ }^{5}$ In the following paragraphs, these types of constraints will be examined together with examples from the constitutional experience of various countries.

\subsubsection{Substantive constraints}

Substantive constraints comprise those constraints that are embedded in the legally binding provisions of national constitutions and which prevent a government from taking particular actions, unless the constitution is amended. Substantive constraints in the constitution may be explicit or implicit and may deal with the permissiveness of certain type of State action or the manner and form in which the State may carry out that action. ${ }^{6}$ Explicit constraints of a substantive nature are those that are expressly written down in a particular constitutional text. ${ }^{7}$ In a number of countries, for example, national constitutions contain specific and explicit provisions pertaining to the role of the State in the performance of certain tasks and the delivery of certain services. Constitutions may also contain provisions regarding the ownership of certain assets or enterprises and sometimes provisions safeguarding certain sectors from being privatized. ${ }^{8}$ Certain sectors that are considered to be of vital or strategic importance to a country may, for example, be constitutionally barred from privatization. ${ }^{9}$ Other constitutions may reserve certain sectors to the State, but may allow the State to delegate their management or operation to the private sector through concessions. ${ }^{10}$ Explicit restrictions may also impose conditions under which privatization may take place, such as the type of legislative measure required to proceed with privatization, the requirement for the establishment of a regulatory agency, the length of a privatization contract if this takes place through contracting out or concessions, or who may take over privatized services.

$5 \quad$ Ibid., p. $3-4$

6 Daintith and Sah, "Privatisation and the Economic Neutrality of the Constitution," p. 470.

7 Daintith and Sah observe that explicit constraints are more likely to be found in codified than in uncodified constitutions, whereas implicit constraints will appear in both types of constitutions. Ibid. On implicit constraints, see further below.

8 Guislain, The Privatization Challenge: A Strategic, Legal and Institutional Analysis of International Experience, p. 246.

9 Guislain notes that this may also be the result of the concrete political setting in a country. Ibid., p. 20-21. The most extreme examples of explicit substantive constitutional constraints affected by a political background or setting are found in socialist states which exclude privatization altogether by reserving the ownership of assets or enterprises to the State. Guislain, "Divestiture of State Enterprises: An Overview of the Legal Framework," p. 33; Guislain, The Privatization Challenge: A Strategic, Legal and Institutional Analysis of International Experience, p. 34-35; and Daintith and Sah, "Privatisation and the Economic Neutrality of the Constitution," p. 473. See also further below on the discussion with regard to the third type of constitutional restraint.

10 Guislain, The Privatization Challenge: A Strategic, Legal and Institutional Analysis of International Experience, p. 246. 
An example of a substantive and explicit constitutional restraint relating to the status of public services that are in principle not amenable for privatization can be found in the French constitution. The preamble to the 1946 constitution ${ }^{11}$ states that "[t]out bien, toute entreprise, dont l'exploitation a ou acquiert les caractères d'un service public national ou d'un monopole de fait, doit devenir la propriété de la collectivite." 12 It would appear that the capacity of the French government to privatize is restricted with regard to the type of enterprises or services as well as the legal foundation for an eventual transfer of ownership to the private sector. For example, the French Conseil d'Etat declared unlawful a number of transfers of property of public sector enterprises to the private sector in the absence of a law authorizing them. ${ }^{13}$ This restriction, however, has not proven to be a major obstacle to the privatization program that the French government enacted in 1986, following a constitutional assessment of the privatization law by the French Conseil Constitutionnel. ${ }^{14}$

An example of the substantive and explicit constitutional restrictions pertaining to the role of the State in the provision of certain services can be found in the Uruguayan constitution. Although Article 52 of the Uruguayan constitution provides that the State may allow the establishment of concession agreements to provide public services, these concessions should not last indefinitely. ${ }^{15}$ Additionally, a new paragraph in Article 47 of the Uruguayan constitution was added, which provides that "[e]l servicio público de saneamiento y el servicio público de abastecimiento de agua para el consumo humano serán prestados exclusiva y directamente por personas jurídicas estatales." 16 This provision has the

11 According to the preamble of the current 1958 constitution, the preamble of the 1946 is still an integral part of the constitution.

12 All property and all enterprises that have or that may acquire the character of a public service or de facto monopoly shall become public property.

13 See Graham and Prosser, Privatizing Public Enterprises: Consitutions, the State, and Regulation in Comparative Pespective, p. 52.

14 T. Prosser, "Constitutions and Political Economy: The Privatisation of Public Enterprises in France and Britain," The Modern Law Review Vol. 53 (1990), p. 309-311. See decision of the Conseil Constitutionnel, June 25-26 1986, C.C. 207, 1986, No. 86-207 DC (visited Nov. 16, 2000) $<$ www.conseil-constitutionnel.fr/decision/1986/86207dc.htm> (last visited on 5 January 2008).

15 A similar provision in Article 134 of the Bolivian constitution states that "[l]as concesiones de servicios públicos, cuando excepcionalmente se hagan, no podrán ser otorgadas por un período mayor de cuarenta años." (the concessions for public services, when exceptionally granted, shall not last longer than forty years) (translation by the author). It should be noted that Bolivia is currently undergoing a constitutional reform, and it is not unimaginable that the current left-wing president of Bolivia, Evo Morales, who is very much against privatization, will attempt to remove this provision and introduce a prohibition of the privatization of public property and services.

16 Public services related to water sanitation and the distribution of water for human consumption shall be exclusively and directly provided by public legal entities [translation by $A H W$ ]. This amendment was introduced in 2004, when the Uruguayan people had to decide through a plebiscite whether to include the right to water in the national constitution and whether water should be directly distributed by State entities. See further Chapter VII, and D. Hall, E. Lobina, 
effect of placing the responsibility for the delivery of water related services in the hands of the State and explicitly excludes their privatization.

Other constitutions would seem to be less severe with regard to the role the State plays in the provision of certain services, allowing the State the possibility to either provide the services itself or to permit private parties to provide them. For example, the Brazilian federal constitution provides that the State is obliged to "[...] provide public utility services, either directly or by concession or permission, which will always be through public bidding."17 Similarly, although the 1991 Colombian constitution places a core responsibility for the implementation and monitoring of social security programs on the State, social security may also be provided by public or private entities in conformity with the law. ${ }^{18}$

An example of substantive constitutional constraints explicitly limiting the range of parties that may take part in the privatization is to be found in the Philippines. Article XII $\S 11$ of the Philippine constitution allows the privatization of public utilities through a franchise or any other form of authorization, but requires that these shall be granted only to "[...] to citizens of the Philippines or to corporations or associations organized under the laws of the Philippines at least sixty per centum of whose capital is owned by such citizens [..." "19 Additionally, the participation of foreign investors in the governing body of any public utility enterprise is limited to their proportionate share in its capital, and all the executive and managing officers of such corporation or association must be citizens of the Philippines. ${ }^{20}$ Moreover, this privatization may not be exclusive and may not be granted for a longer period than fifty years and is furthermore subject to amendment, alteration or repeal by the Philippine Congress when it deems that the common good so requires.

Besides the explicit substantive constitutional restraints, a State's constitution can have implicit substantive constitutional restraints that can limit the State's capacity

and R. de la Motte, "Making Water Privatization Illegal: New Laws in the Netherlands and Uruguay," Public Services International Research Unit (PSIRU), Business School, University of Greenwich, (2004), p. 2; D. Hall and E. Lobina, "Water as a Public Service," Public Services International (www.world.psi.org), (2006), p. 10.

17 Article 175 Constitution of the Federal Republic of Brazil. Additionally the State has to provide by law "I - the operating rules for the public service concession- or permission-holding companies, the special nature of their contract and of the extension thereof, as well as the conditions of forfeiture, control and termination of the concession or permission; II - the rights of the users; III - tariff policy; IV - the obligation of maintaining adequate service." Ibid.

18 See Article 48 Colombian Constitution. See also D. Schneiderman, "Constitutional Approaches to Privatization: An Inquiry Into the Magnitude of Neo-Liberal Constutionalism," Law \& Contemp. Probs. Vol. 63 (2000), p. 97.

19 The text of the Constitution of the Philippines can be found at <www.gov.ph/aboutphil/ constitution.asp $>$.

20 Article XII $\S 11$ Constitution of the Philippines. 
to implement privatization policies. ${ }^{21}$ Implicit constraints may be found in certain constitutional provisions, which although not particularly or directly related to privatization, may still impose limits on privatization depending on the way these provisions are interpreted and on the societal values imbedded in the constitution. Daintith and Sah, for example, observe that, "[v]alue-based constitutions may create a vision of society which justifies a large public sector, and thus constrain the privatisation process in the absence of any explicit provision stating the nature and extent of state participation in the economy." 22 An example can be found in the Canadian Charter of Rights and Freedoms, which is embedded in the Canadian Constitution. Although the Canadian Constitution and the Charter do not explicitly limit privatization, it has been be argued that in the case of the privatization of correctional facilities,

"[...] there seems little or no doubt that the private operators will remain subject to the constraints of the Charter in the way in which they deal with inmates or prisoners. Not only is the physical confinement of the convicted seen as part of the government's role even under the most minimalist conceptions of the role of the state, but it is also at the core of section 7 of the Charter and its protection of the right to 'life, liberty and security of the person.' [...] [I]t would be odd indeed if government, through the simple expedient of delegation or contracting out to the private sector, could avoid its central Charter responsibilities." 23

A recent ruling of the Israeli High Court of Justice deciding on the constitutionality of an amendment to the Israel Prison Ordinance aimed at allowing a private firm, ALA Management and Operations, to build and operate a privatized prison, can also be seen as an example of the application of substantive constitutional restraints on privatization. In this judgment, ${ }^{24}$ eight of the nine High Court justices argued that the privatization of prisons in Israel would be unconstitutional because "[...] the actual transfer of powers to manage a prison from the state, which acts on behalf of the public, to a private concessionaire that is a profit-making enterprise, causes a serious and grave violation of the inmates' basic human rights to personal liberty and human dignity[...]"25 The High Court's conclusion was based on the premise that the deprivation of liberty of an individual is a violation of the right to personal

21 Daintith and Sah, "Privatisation and the Economic Neutrality of the Constitution," p. 474.

22 Ibid.

23 D. Mullan and A. Ceddia, "The Impact on Public Law of Privatization, Deregulation, Outsourcing and Downsizing: A Canadian Perspective," Ind. J. Global Legal Stud. Vol. 10 (2003), p. 215-216. Mullan and Ceddia point in this respect to the case of Eldridge v. British Columbia, Supreme Court of Canada (1997), 3 S.C.R. 624, which is discussed in more detail in Chapter IV, Section 3.5.

24 Academic Center of Law \& Business, Human Rights Division v. Minister of Finance, HCJ, 2605/05, judgment of 19 November 2009.

25 Ibid., para. 19. See also the news article by Dan Izenberg, "High Court prohibits privately run prison," The Jersulaem Post, 20 November 2009, available at <www.jpost.com/servlet/Satellite? cid $=1258624598788 \&$ pagename $=J P A r t i c l e \% 2 F S h o w F u l l>($ last visited on 20 November 2009 ). 
liberty as protected by the human rights provisions of Israel's High Law. This violation can be legitimate and justifiable on public interest grounds when it is executed by the State, for example when the aim is to punish criminal behavior and to deter its occurrence. However, when the State grants a private company the power to deprive an individual of its liberty, one of the most invasive powers given to the State under the concept of the social contract as understood by Thomas Hobbes, the State undermines the legitimacy of that power. ${ }^{26}$ In the eyes of the High Court this legitimacy is undermined,

"[...] since the sanction [to deprive an individual from his liberty at the behest of a judicial sentence] is enforced by a party that is motivated first and foremost by economic considerations - considerations that are irrelevant to the realization of the purposes of the sentence, which are public purposes." 27

In other words, privatizing prisons goes against the constitutional tradition of Israel pertaining to the exercise of the monopoly of police and imprisonment in the hand of the State. Accordingly, the Court conferred greater weight to a violation of the right to personal liberty by a private corporation operating a prison as delegated by the State, than to a similar violation committed by State managed prisons. ${ }^{28}$ Furthermore, an improvement on the economic benefits to the State and efficiency in the exercise of the task through privatization, did not justify the violation of the right to personal freedom by a private entity. ${ }^{29}$

These constitutional constraints can be circumvented through amendments to the national constitution resulting in a removal or toning down of the constraint. ${ }^{30}$ Although this would require "a demanding form of democratic scrutiny" 31 and thus prove challenging, it is still feasible. This occurred for example in Portugal that amended its constitution to remove special constitutional provisions introduced in 1974 to protect nationalized enterprises after the start of the dictatorship. ${ }^{32}$ The reverse, of course, is also true. The above-mentioned example of Uruguay illustrates

26 Academic Center of Law \& Business, Human Rights Division v. Minister of Finance, paras. 22 and 23.

27 Ibid., para. 29.

28 Ibid., para. 33.

29 Ibid., para. 55. See also news report by Tomer Zarchin and Jonathan Lis, "High Court: Israeli prisons will not be privatized," Haaretz.com, 19 November 2009, available at <www.haaretz. com/hasen/spages/1129347.html> (last visited on 20 November 2009).

30 Graham and Prosser, Privatizing Public Enterprises: Consitutions, the State, and Regulation in Comparative Pespective, p. 3. Cass has suggested in this regard that in the United States, strong substantive constitutional constraints on privatization are unlikely because of a paucity of substantive constraints in the political process. Cass, "Privatization: Politics, Law and Theory," p. 480 .

31 Prosser, "Constitutions and Political Economy: The Privatisation of Public Enterprises in France and Britain," p. 311.

32 Ibid. 
that constitutional amendments can also be introduced to limit or prohibit privatization. In 2008, Ecuador underwent a constitutional reform whereby a constitutent assembly drafted a new constitution. One of the provisions of the new constitution allows for the (partial) privatization of certain 'strategic' sectors, but at the same time explicitly prohibits the privatization of water utilities. ${ }^{33}$

\subsubsection{Procedural constraints}

Procedural constraints refer to those constraints entailing a procedural supervision of policy-making and implementation. ${ }^{34}$ Thus a Government may be legally obligated to seek the views, or approval, of a legislative body before proceeding with privatization proposals. An example of such a constraint may be found in the restriction related to the legislative requirement to proceed with privatization present in Article 34 of the 1958 French constitution according to which, "[...] les nationalisations d'entreprises et les transferts de propriété d'entreprises du secteur public au secteur privé [...]" have to be determined by formal legal statutes that have to be passed by the French Parliament. This provision limits the legal instrument for an eventual transfer of ownership to the private sector to a formal legislative act to give effect to the envisaged privatization. In this way, the French Parliament is exercising some procedural control on the privatization policy. This was one of the points of contention in the 1986 decision of the French Conseil Constitutionnel on privatization. ${ }^{35}$

\subsubsection{Constraints based on Constitutional/legal traditions}

Constraints on privatization based on Constitutional or legal traditions limit the capacity of the State to transfer certain functions or tasks to non-governmental entities based on what is traditionally believed to be the role of the State and which functions and responsibilities it is supposed to exercise. An example may be found in Canada with the principle of non-delegable duty that has been derived from the common law. ${ }^{36}$ According to Mullan and Cedia this concept entails that when " $[. .$. the legislature has entrusted someone with a power to do something, and that person

33 See newspaper report of newspaper El Comercio, available at $<$ www.elcomercio.com/imprima. asp?id_noticia $=131263 \&$ medio $=E C>$ (last visited on 3 July 2008), as well as Articles 314, 316 and 318 of the new constitution, which was submitted for adoption by referendum at the end of July 2008. The text of the new constitution is available at: <www.asambleanacional.gov.ec/ documentos/constitucion_de_bolsillo.pdf > (last visited on 1 August 2011).

34 Graham and Prosser, Privatizing Public Enterprises: Consitutions, the State, and Regulation in Comparative Pespective, p. 3.

35 See note 14 supra.

36 See Mullan and Ceddia, "The Impact on Public Law of Privatization, Deregulation, Outsourcing and Downsizing: A Canadian Perspective," p. 224. A similar development has appeared in the United States under the name of the non-delegation doctrine, according to which the U.S. Congress may not delegate, to public or private actors, its constitutionally assigned lawmaking 
delegates the performance of the work to a third party, the person legislatively entrusted with the power remains legally responsible for discharging the duty of care, whether employees or independent contractors are the means for exercising the power." 37 In other words, the work to be performed by a privatized entity may be delegated, but not the duty: the delegation does not absolve the State from its duties, in particular if these are statutory. A leading case in Canada with respect to the non-delegable duty principle is the case of Lewis (Guardian ad Litem of) $v$. British Columbia. ${ }^{38}$ In this case, the Ministry of Transportation of British Columbia had contracted the services of an independent contractor to remove dangerous rocks beside a highway. However, due to the negligence of the contractor a rock fell on the highway and crushed a car, killing the driver. The question dealt by the Supreme Court was whether the Ministry of Transportation was absolved of any liability caused by the accident because it had hired an independent contractor to do the work. The Court established that there was a duty of care owed by the Ministry to the traveling public and that this duty could not be delegated to a private actor because of statutory powers and policy reasons which included the reasonable expectations of the users of the highway. ${ }^{39}$ The Court then concluded that the Ministry " $[. .$.$] cannot escape liability for negligence in maintaining and repairing$ roads by delegating that work to independent contractors." 40

Finally, it is also worth pointing out that particular constitutional traditions, may also in fact contribute to enacting privatization programs. In the United Kingdom, for example, the lack of a written constitution together with the Diceyan constitutional tradition, which focuses on the sovereignty of parliament, has permitted the British legislator to adopt one of the most far-reaching privatization programs in the late 1980 s under a conservative government which was very much in favour of reducing the size of the State. ${ }^{41}$

\subsection{Preliminary conclusions}

It has been noted above that privatization exercises sometimes find their limits at the national level with respect to the constitutional arrangement of the State. Constitutions may prohibit or curb privatization practices. Ironically, constitutional

power. It would appear, however, that in the United States the non-delegation doctrine has lost its appeal as of late and is rarely used. Freeman, "The Private Role in Public Governance," p. 580. Mullan and Ceddia, "The Impact on Public Law of Privatization, Deregulation, Outsourcing and Downsizing: A Canadian Perspective," p. 224-225.

38 Lewis (Guardian ad Litem of) v. British Columbia, Supreme Court of Canada (1997) 3 S.C.R. 1145 .

39 Ibid., paras. 21-37.

$40 \quad$ Ibid., para. 38.

41 Prosser, "Constitutions and Political Economy: The Privatisation of Public Enterprises in France and Britain," p. 309. 
limitations can be surmounted with relative ease through constitutional amendment, or by choosing a certain type or method of privatization that effectively circumvents any national legal or constitutional limitations to privatization. In sum, constitutional and other legal constraints on privatization are of relative value. Some constraints are easier to circumvent than others, and even constitutional provisions may prove ineffective in ruling out privatization entirely. The latter may nonetheless strongly influence the way privatization is implemented. ${ }^{42}$ They may, for example, limit the choices of privatization methods or mandate a residual degree of control for the State over the sectors that are to be privatized. The most effective national legal constraints on privatization may well come from judicial decisions enforcing constitutional or legal principles which curb the extent of privatization or their effects (see for example the concept of non-delegable duty in Canada). By the same token, judicial intervention may also help to facilitate the implementation of privatization policies even in spite of constitutional provisions that at first sight would seem to restrict these policies. Nevertheless, it is clear that the legality of a privatization program, notwithstanding the sector in which it takes place, can be shaped by the national outlook on the role of the State, and this in turn will depend on the legal, political and economical values that are reigning at any given point in time.

\section{Privatization under general international LaW}

There are currently no rules deriving either from international customary law or from specific international treaties that directly prescribe, endorse, or prohibit the privatization of State functions, tasks, services or companies. Until very recently, privatization had not figured in any specific treaty. One of the few (indirect) references available on privatization in an international treaty may be found in Article 10 of the 2004 United Nations Convention on Jurisdictional Immunities of States and their Property, which is not yet in force. ${ }^{43}$ Article 10 places restrictions on States' claims to immunity for commercial transactions. ${ }^{44}$ Article 10 (3) also

42 Daintith and Sah, "Privatisation and the Economic Neutrality of the Constitution," p. 472.

43 See UN General Assembly resolution UN Doc. A/RES/59/38 (2 December 2004). The Convention attempts to codify certain rules of customary international law pertaining to the jurisdictional immunities of States from suits in foreign courts. In particular, the Convention deals with issues on immunities with regard to commercial agreements between States and companies, the modalities giving effect to State immunity and the rules regarding immunity claims against proceedings before national courts.

44 This is based on the restrictive theory of sovereign or State immunity. As is well known, under the restrictive theory of immunity, States are entitled to immunity for their official or sovereign acts (acta iure imperii). For acts of a commercial nature (acta iure gestioni, e.g. those acts in which the State participates in the marketplace in the same way a private citizen or company would and thus is not exercising a sovereign activity which private individuals themselves may not exercise), however, State are not entitled to invoke immunity. With regard to State immunity in general and immunity with respect to commercial transactions of States and other natural or 
leaves open the possibility for States to maintain their immunity for the acts of a State enterprise " [...] or other entity established by a State which has an independent legal personality [...]" which a State has authorized to operate or manage property. Although this provision does not mention privatization directly, it would appear to suggest the possibility that States may delegate certain activities to other entities.

Another recent reference to privatization may be found in Article 4 of the Optional Protocol to the Convention Against Torture and other Cruel, Inhuman or Degrading Treatment or Punishment (OPCAT), which was adopted in 2002 and came into force in 2006. The OPCAT establishes a system of visits to places of detention with the aim of preventing torture or other forms of ill-treatment to persons who are deprived of their liberty. The visits are to be carried out by an international body, the Subcommittee for the Prevention of Torture, and by national monitoring bodies called national preventive mechanisms. ${ }^{45}$ According to Article $4 \S 2$ of the OPCAT, deprivation of liberty for the purposes of the Protocol means "[...] any form of detention or imprisonment or the placement of a person in a public or private custodial setting which that person is not permitted to leave at will by order of any judicial, administrative or other authority [emphasis added $A H W$ ]." By referring to private custodial settings, the OPCAT appears to acknowledge that States will make use of detention facilities operated by private companies under contract with them. ${ }^{46}$ As a consequence, this provision allows the Subcommittee and the national preventive mechanisms to visit privatized prisons or other private places of detention, thus narrowing down the possibility of States escaping scrutiny for torture and other abuses that may take place in such places.

An even more recent development is the drafting of a Draft International Convention on the Regulation, Oversight and Monitoring Of Private Military and Security Companies, ${ }^{47}$ which has been prepared by the UN's Working Group on the use of mercenaries as a means of violating human rights and impeding the exercise of the rights of peoples to self-determination. The Draft International Convention is the result of an international process that started in 2006 under the auspices of the Government of Switzerland and the International Committee of the Red Cross, which noted an increase in the demand to clarify the pertinent legal obligations of private military and security companies (PMSCs) in the light of the growing

juridical persons see D.P. Stewart, "Current Development: The UN Convention on Jurisdictional Immunities of States and their Property," A.J.I.L. Vol. 99 (2005), p. 194-211.

45 Article $4 \S 1$ and Article 2 and 3 OPCAT.

46 See also "Establishment and Designation of National Preventive Mechanisms," The Association for the Prevention of Torture, Geneva, 2006, p. 23.

47 Draft International Convention on the Regulation, Oversight and Monitoring Of Private Military and Security Companies (13 July 2009) available at the website of the Working Group on the use of mercenaries as a means of violating human rights and impeding the exercise of the rights of peoples to self-determination: <www.unwg.rapn.ru/en/main.htm> (last visited on 10 May 2010). The Draft International Convention will be discussed in more detailed in Chapter VI. 
reliance upon their services and controversies surrounding their activities. ${ }^{48}$ While the Draft International Convention acknowledges the various efforts of the private military and security sector towards self-regulation, its preamble considers these efforts to be insufficient. Thus, it aims at providing a comprehensive regime to regulate and monitor the activities of PMSCs through the adoption of rules regarding inter alia the responsibility of the state for the conduct of these companies, the use of force by them, the prohibition of illicit arms trade, the adoption of regulatory legislation and the establishment of a licensing regime for their activities, the exercise of criminal jurisdiction for any illegal acts committed by PMSCs, and by delineating these companies' obligations. ${ }^{49}$ In addition it provides for the establishment of an international committee with a mandate to monitor the activities of these companies through the use of the usual UN human rights monitoring tools like state reporting, inquiry procedure, inter-state complaints, and whenever accepted by future States Parties, the handling of individual or group petitions. ${ }^{50}$ Although it is too premature to discuss the potential impact of this Draft International Convention, the mere fact that it is being considered suggests that in spite of the controversies surrounding the privatization of military functions, international law appears to acquiesce the fact that States are going to use or need the services provided by these companies.

Beyond the above-mentioned instruments and efforts, it appears there are no other international instruments in force that have thoroughly taken privatization into consideration or deal with it as an issue of concern. ${ }^{51}$ As noted above, privatization is often a matter of national choice and policy. General international law appears to be neutral towards privatization. This generally agnostic stance towards privatization stands in stark contrast with that in relationship to privatization's antithesis, nationalization and expropriation. Nationalization and expropriation of (foreign) private property have been at the heart of various international disputes that have helped to generate a set of international legal rules designed to guide or

48 See the "Montreux Document" on the pertinent international legal obligations and good practices for States related to operations of private military and security companies during armed conflictattached to a letter dated 2 October 2008 from the Permanent Representative of Switzerland to the United Nations addressed to the Secretary-General of the United Nations, UN Doc. A/63/467-S/2008/636 (6 October 2008).

49 See Parts II, III, and V of the Draft International Convention on the Regulation, Oversight and Monitoring Of Private Military and Security Companies.

50 Ibid., Part VI.

51 Arguably, the UN's Committee on Economic, Social and Cultural Rights, which monitors the implementation of the International Covenant on Economic, Social and Cultural Rights, has referred to the privatization of water utilities with regard to the right to water which is implied to exist in the context of Article 11 IESCR. See General Comment No. 15 (2002), the Right to Water (Articles 11 and 12 of the International Covenant on Economic, Social and Cultural Rights), CESCR, UN Doc E/C.12/2002/11 (20 January 2003). See further Chapter VII. 
limit their application. ${ }^{52}$ These rules include for example the payment of 'appropriate and adequate compensation' as required by international law for the taking of foreign property in the public interest as a result of nationalization. ${ }^{53}$ Many of the cases dealt by the Iran-U.S. Claims Tribunal focused on the nationalization or expropriation of (mostly US) private property by the Iranian revolutionary government following the fall of the Shah and the occupation of the American Embassy in Teheran in 1979.54 Nationalization of private enterprises or their expropriation by the State has also been the subject of a number of (controversial) UN General Assembly resolutions such as resolution 1803 (XVII) on the "Permanent Sovereignty Over Natural Resources" 55 and the Charter of Economic Rights and Duties of States ${ }^{56}$ in which States have attempted to 'codify' the rules that may apply when nationalization and expropriation takes place. Rules regarding nationalization and expropriation of foreign property have also seaped through to the hundreds of Bilateral Investment Treaties (BITs) that have been adopted between developed and developing nations in order to protect the investments of foreign companies. ${ }^{57}$ The basic rules on the taking of private property in the public interest and eventual compensation have even found their way to the human rights arena and have been codified in Article 1 of the First Protocol to the ECHR, which

52 See for example the Factory at Chorzów (Merits), PCIJ Series A (1928) No. 17; the AngloIranian Oil Company case, ICJ Reports (1951); Texaco Overseas Petroleum Company v. Libyan Arab Republic, 53 ILR (1977) 389. See also the voluminous jurisprudence of the Iran-United States Claims Tribunal mentioned below.

53 See the Barcelona Traction Co. case, ICJ Reports (1970), p. 40 in which the International Court of Justice acknowledged the possibility of compensation for the nationalization of foreign property. See further C.F. Amerasinghe, "Issues of Compensation for the Taking of Alien Property in the Light of Recent Cases and Practice," ICLQ Vol. 41 (1992), and Section 3.1.3 infra on the obligations pertaining to the responsibility of the State under International law.

54 See for example Iran-United States Claims Tribunal, INA Corp. v. Government of the Islamic Republic of Iran, AWD 184-161-1 (13 August 1985), Malek v. Government of the Islamic Republic of Iran, AWD 534-193-3 (11 August 1992), and Khosrowshahi v. Government of the Islamic Republic of Iran, AWD 558-178-2 (30 June 1994). For a general appraisal of the work and jurisprudence of the Iran-United States Claims Tribunal see G.H. Aldrich, The Jurisprudence of the Iran-United States Claims Tribunal - An Analysis of the Decisions of the Tribunal (Oxford: Oxford University Press, 1996).

55 UN GA resolution 1803 (XVII) on Permanent Sovereignty over Natural Resources, 17 UN GAOR, Supp. (No. 17) 15, UN Doc. A/5217 (1962).

56 UN GA resolution, 3281 (XXIX) Charter of Economic Rights and Duties of States, 29 UN GAOR, Supp. (No. 31) 50, UN Doc. A/9631 (1974). See for a discussion on the controversies surrounding the Charter of Economic Rights and Duties of States, which was adopted by a majority of developing and left leaning countries and ushered the so-called New International Economic Order, see B.H. Weston, "The Charter of Economic Rights and Duties of States and the Deprivation of Foreign-Owned Wealth," A.J.I.L. Vol. 75 (1981), p. 437-475.

57 For an overview of the uses of BITs to protect foreign investment against nationalization and expropriation see R. Dolzer and M. Stevens, Bilateral Investment Treaties (The Hague: Martinus Nijhoff Publishers, 1995) p. 97-118, and A.T. Guzmán, "Why LDCs Sign Treaties that Hurt Them: Explaining the Popularity of Bilateral Investment Treaties," Virginia Journal of International Law Vol. 38 (1998), p. 639-688. 
arguably deals mainly with local property. No such attempts have been made with regard to privatization. To a certain extent this may be due to the fact that nationalization and expropriation have sometimes a 'stigma' of illegality given that they may have a direct impact on property rights and investments of foreign companies, whereas privatization is (rightly or wrongly) usually regarded as a technical economic policy for improving national efficiency and productivity. It is thus here suggested that at present there are no substantive constraints to privatization under general international law.

In the present author's view, the fact that nationalization as a political or economical policy has resulted in more specific regulation and discussion at the international level than privatization is an indication of the apparent indifference of general international law towards privatization. Even in international disputes in which conflicts arising out of defective implementation of privatization policies or the deficient operation of privatized entities would seem to be at stake, the relevance of privatization is not discussed, questioned or considered to be a part or cause of the problem. This may be illustrated by various investment disputes before international arbitration tribunals such as the World Bank's International Center for the Settlement of Investment Disputes (ICSID). As already observed at the introduction of this chapter, these disputes are mainly focused on State measures affecting the investments of foreign private conglomerates in privatized industries.

For example, the arbitration between Aguas del Aconquija S.A., a subsidiary of French water multinational Vivendi Universal (formerly Compagnie Generale Des Eaux) and the Argentine Republic was not centered around the (international) legality of, or the substantive problems surrounding, the privatization of water services in the province of Tucumán. Rather, the case focused on the legality or illegality of the unilateral termination of a privatization contract by Argentina in the light of a BIT between the latter and France in spite of the fact that Argentina blamed the privatized water company for the problems surrounding the privatized water concession. ${ }^{58}$ In another recent case against Argentina before the

58 One of the arguments presented by Argentina to unilaterally rescind the concession contract was the deficient operation of the water concession by Aguas del Aconquija. However, the political context (popular opposition to privatization and the election of an local government which was elected on a platform against privatization) also had an effect on the termination of the concession contract. See Companía de Aguas del Aconquija S.A. and Vivendi Universal (Formerly Compagnie Generale Des Eaux) v. Argentine Republic, ICSID Case No. ARB/97/3. For a good overview of the various arbitral awards in this case, see the website of the ICSID at: $<$ http://icsid.worldbank.org/ICSID/FrontServlet?requestType=CasesRH\&reqFrom=ListCases \& caseId $=\mathrm{C} 159$ \&actionVal $=$ viewCase $>$ (last visited 30 December 2008). An initial award was rendered in 2001 (Companía de Aguas del Aconquija S.A. and Vivendi Universal (Formerly Compagnie Generale Des Eaux) v. Argentine Republic, ICSID Case No. ARB/97/3, 3 July 2002, I.L.M., Vol. 40, p. 426). However, Argentina submitted a request to annul the award. See Companía de Aguas del Aconquija S.A. and Vivendi Universal (Formerly Compagnie Generale 
ICSID,${ }^{59}$ the central issue did not revolve around the privatization of the gas sector. In fact, the privatization was not even disputed as being a problem. Instead the case is focused on the unilateral alteration by Argentina of a regulatory scheme for the privatized gas sector as a result of the economic crisis of 2001-2002. A privatized gas company (a subsidiary of an American gas company, Sempra Energy International) had been precluded by Argentina from raising the gas tariffs prompting the company to allege a breach of the BIT between Argentina and France for measures that amounted to expropriation and violation of the obligation to fair and equitable treatment. ${ }^{60}$ There are other examples, including Aguas del Tunari S.A. v. Republic of Bolivia, which revolved around measures adopted by the Bolivian government and which led to the termination of the privatization of water utilities in the city of Cochabamba, Bolivia. ${ }^{61}$ Aguas del Tunari, a local offshoot of a multinational utilities consortium led by U.S. based company Bechtel, had been awarded a concession to operate the water utilities of Cochabamba. After the contract was rescinded Aguas del Tunari and Bechtel claimed that the measures adopted by the Bolivian government amounted to expropriation of property without due compensation. The case, however, was discontinued with the agreement of both parties. ${ }^{62}$ In short, these cases deal not with the substantive issues pertaining to privatization and its consequences under international law, but to issues arising out of alleged illegal termination of privatization schemes affecting foreign investments.

Given the nature of the disputes, which are mostly related to State action affecting investments made by foreign companies, it is not surprising that they are mainly focused on problems related to the applicability of the obligations ensuing from

Des Eaux) v. Argentine Republic, ICSID Case No. ARB/97/3, 3 July 2002, I.L.M., Vol. 41, p. 1135. Following a partial annulment, the procedure was resubmitted and a new award was renderd in 2007 by a new arbitral tribunal. However, at the end of 2007, Argentina submitted a second request to annul the latest award. A decision on this issue was reached in 2010, when the ad-hoc committee dealing with the application for annulment rejected the request. See Companía de Aguas del Aconquija S.A. and Vivendi Universal (Formerly Compagnie Generale Des Eaux) v. Argentine Republic, Decision on the Argentine Republic's Request for Annulment of the Award rendered on 20 August 2007, ICSID Case No. ARB/97/3, 10 August 2010. See further Chapter VII.

59 See Sempra Energy International v. Argentine Republic, ICSID Case No. ARB/02/16.

60 The case is still pending following an award rendered in favor of by the ICSID tribunal in September 2007 (Sempra Energy International v. Argentine Republic, Award, ICSID Case No. ARB/02/16, 28 September 2007), which then was subjected to the institution of an annulment procedure in January 2008 at the request of Argentina. This request for annulment was subsequently granted: See Sempra Energy International v. Argentine Republic, Decision on Annulment, ICSID Case No. ARB/02/16, 29 June 2010.

61 See Aguas del Tunari S.A. v. Republic of Bolivia, ICSID Case No. ARB/02/3; See also Biwater Gauff (Tanzania) Limited v. United Republic of Tanzania, ICSID Case No. ARB/05/22, Azurix Corp. v. Argentine Republic, ICSID Case No. ARB/01/12. See further Chapter VII. 
bilateral investment treaties (BITs) following the sudden unilateral change in a privatization contract by a State or its termination rather than the privatization itself. At the same time, it is somewhat disappointing that these tribunals have not been able or are not willing to deal with substantive issues pertaining to the legality or legal propriety or factual implementation of privatization projects lying at the heart of these disputes. Thus, in the abovementioned arbitration case dealing with the unilateral termination of a concession agreement that allowed for the privatization of water services in the province of Tucumán, the Arbitral Tribunal did "[...] not consider it necessary to come to a definitive view as to whether either party has or has not breached the Concession Agreement."63

Similarly, the legality or illegality of the privatization of military services was not questioned in an arbitration dispute between Sandline International and the government of Papua New Guinea. The government of Papua New Guinea had entered into a contract with Sandline, a (no longer functioning) private military and security company based in the UK, to provide troops and material to terminate an uprising in the island of Bougainville. Following the sudden and unilateral termination of the contract by Papua New Guinea due to the opposition of the national army to the operation, Sandline brought the case before an arbitral tribunal in Australia as stipulated in the contract. Sandline successfully claimed that Papua New Guinea's action amounted to breach of contract and requested monetary compensation. ${ }^{64}$

In sum, there are no explicit restraints on privatization under international law yet, although the possible future adoption of the Draft International Convention on the Regulation, Oversight and Monitoring Of Private Military and Security Companies may change that. States applying privatization policies are, however, subject to other international obligations that may have an (indirect) effect on how they implement

63 Compañia de Aguas del Aconquija S.A. and Vivendi Universal v. Argentine Republic, Award, ICSID Case No. ARB/97/3, 20 August 2007, para. 7.3.11. See for a similar opinion Aguas Argentinas, S.A., Suez, Sociedad General de Aguas de Barcelona, S.A. and Vivendi Universal, S.A. v. Argentine Republic, Decision on Liability, ICSID Case no. ARB/03/19, 30 July 2010, para. 246 noting that the Arbitral Tribunal in that particular does not consider itself to have jurisdiction to judge whether the termination of the water concession granted to a conern of multinational companies in order to run a privatized water utiliy is in breach of the concession contract. These cases are further discussed in Chapter VII, as well as in section 3.1.3 below.

64 See In the Matter of an International Arbitration under the UNCITRAL Rules between Sandline International Inc and the Independent State of Papua New Guinea (Interim Award) [Arbitration Tribunal] Arbitral Award of 9 October 1998 and Independent State of Papua New Guinea $v$. Sandline International Inc, [Queensland Supreme Court of Appeal, Australia] Arbitral award of 30 March 1999, International Law Reports, Vol. 117 (2000), p. 552 and p. 565. See also D. Sturzaker and C. Cawood, "The Sandline Affair: Illegality and International Law," Australian International Law Journal (1999), p. 214-223. For a deeper discussion on the legal status of private military and security companies and the privatization of military and security services see Chapter VI infra. 
these policies. As we shall see in the next Section, a number of principles of general international law impose certain obligations on States that potentially could have an impact on or restrain how privatization may be implemented. In addition, there is a nascent development under international law that imposes certain obligations on non-State actors which also take part in the privatization process.

\subsection{Relevant State obligations under international law}

As observed in the previous paragraphs, international law is in general mute with regard to privatization. States are therefore free to adopt privatization measures they deem necessary. The adoption and implementation of privatization is, in other words, a sovereign decision of the State. Although there are no specific rules limiting the extent of the State's freedom to adopt privatization policies or measures, general international law does impose some broad obligations that may somewhat limit the State's sovereignty and discretion therein. It is therefore necessary to investigate whether these broad obligations under general international law have any bearing on the State's capacity to adopt and implement privatization measures.

According to the Declaration of Principles of International Law concerning the Friendly Relations and Co-operation Among States in Accordance with the United Nations Charter, ${ }^{65}$ every State,

"[...] has the duty to fulfill in good faith the obligations assumed by it in accordance with the Charter of the United Nations[,]

[...] has the duty to fulfill in good faith its obligations under the generally recognized principles and rules of international law [and]

$[\ldots]$ has the duty to fulfill in good faith its obligations under international agreements valid under the generally recognized principles and rules of international law."

These duties were again reaffirmed in the Final Act of the Conference on Security and Cooperation in Europe, ${ }^{66}$ which also stipulated that "[i]n exercising their sovereign rights, including the right to determine their law and regulations, [States] will conform with their legal obligations under international law." 67 Accordingly, when deciding whether or not to adopt and implement national legislation and other measures with regard to privatization, States have to take into consideration the various obligations that they have incurred under international law.

Obligations emanating from general international law usually come into existence through the consent of States accepting to be bound by legal rules in the form of

\footnotetext{
65 General Aassembly Res. 2625 (XXV), UN Doc A/8028 (24 October 1970).

66 Helsinki, 1975.

67 See also I.I. Lukashuk, "New Thinking by Soviet Scholars: The Principle Pacta Sunt Servanda and the Nature of Obligation Under Interantional Law," A.J.I.L. Vol. 83 (1989), p. 514.
} 
treaties. There are however many rules and concomitant obligations under international law which do not require the consent of States for them to be equally valid between States. ${ }^{68}$ There are various sources for the legal obligations emanating from general international law. The most widely recognized sources of international law, which at the same time are also the sources of international legal obligations, can be found in Article 38 (1) of the Statute of the International Court of Justice. 69

The most relevant obligations emanating from general international law with regard to privatization are those relating to compliance with international treaties, obligations pertaining to the principle of non-intervention in the economic affairs of States, obligations ensuing from the responsibility of the State for breaches of international obligations that are attributable to that State, and the concept of obligations erga omnes. They are relevant in the sense that they may place some limitations on the otherwise unfettered freedom to adopt privatization policies.

\subsubsection{Obligations pertaining to International Treaty Law}

Treaties create binding legal obligations on those States that have accepted to be bound by them. One of the most important obligations found under international law is the requirement for States to respect the agreements made between each other through treaties. This obligation is embodied in the principle of pacta sunt servanda which entails that treaties are binding upon the parties to them and must be performed in good faith. ${ }^{70}$ With regard to privatization, the principle of pacta sunt servanda may play a significant role when States, by adopting privatization policies, run the risk of jeopardizing the performance of a treaty that already exists.

Another important principle of international treaty law imposing an obligation on States is the principle whereby States that have signed, or have expressed their consent to be bound by, a treaty, but have not yet ratified it, are under the obligation to refrain from acts that could defeat the object and purpose of a particular treaty. ${ }^{71}$ Thus, States are called upon to respect a treaty even though they are formally not yet parties to it. States that have agreed to become parties to a particular treaty may

68 See in general Shaw, International Law, p. 10 and 91.

69 Article 38 (1) of the Statute provides that " $[\mathrm{t}]$ he Court, whose function is to decide in accordance with international law such disputes as are submitted to it, shall apply: a. international conventions, whether general or particular, establishing rules expressly recognized by the contesting states; b. international custom, as evidence of a general practice accepted as law; c. the general principles of law recognized by civilized nations; d. subject to the provisions of Article 59, judicial decisions and the teachings of the most highly qualified publicists of the various nations, as subsidiary means for the determination of rules of law." See also ibid., p. 66.

70 This principle has been codified in Article 26 of the Vienna Convention on the Law of Treaties.

71 See Article 18 Vienna Convention on the Law of Treaties. 
therefore not implement privatization policies if by doing so they would run the risk of defeating the object and purpose of that treaty.

Moreover, States are not allowed to invoke national legislation as a justification for not acting according to what is established in a treaty. ${ }^{72}$ This means, for example, that States cannot argue that national legislation providing for the privatization of public utilities and municipal services prevents them from performing their treaty obligations, whatever these may be. Only under the circumstances described in Section Three of the Vienna Convention on the Law of Treaties and under the specific circumstances described in each individual treaty can a State terminate, suspend the operation of or act contrary to the obligations ensuing from treaties. ${ }^{73}$

\subsubsection{Obligations pertaining to the principle of non-intervention}

The principle of non-intervention in the internal affairs (including economic affairs) of a State is derived from the notion of State sovereignty ${ }^{74}$ and is closely related to the principle of self-determination of peoples. The process of independence and decolonization of the $19^{\text {th }}$ and $20^{\text {th }}$ centuries led to a growing desire of the newly formed countries to guard their newly found independence and sovereignty, and keep at bay and restrict the influence of their former colonizers. This desire found its embodiment in the principle of self-determination of peoples, which is considered a settled rule of international law, albeit with undetermined borders. ${ }^{75}$ The principle of self-determination was complemented with the principle of non-intervention in the internal matters of any State. The latter principle had been strongly endorsed by Latin American countries through the Calvo doctrine, which was aimed at limiting the legal and political interventions of Western countries. ${ }^{76}$ The principle of nonintervention places an obligation on other States not to meddle in the internal or external affairs of a State. This principle was reaffirmed by the International Court of Justice in the Military and Paramilitary Activities in and against Nicaragua (Nicaragua v. United States of America) case in which the Court also stated its corollary that,

"[a] prohibited intervention must accordingly be one bearing on matters in which each State is permitted, by the principle of State sovereignty, to decide freely. One of these is the choice of a political, economic, social and cultural system, and the

72 Article 27 Vienna Convention on the Law of Treaties.

73 For example in the case of a fundamental change of circumstances (rebus sic stantibus, Art. 62 Vienna Convention).

74 Shaw, International Law, p. 39, 824 and 1205.

75 Ibid., p. 39. The principle of self-determination was itself 'codified' in the Declaration on the Granting of Independence to Colonial Countries and People, General Assembly res. 1514 (XV), 15 U.N. GAOR Supp. (No. 16), p. 66, U.N. Doc. A/4684 (1961).

76 A. Cassese, International Law, $2^{\text {nd }}$ ed. (Oxford: Oxford University Press, 2005) p. 32; Shaw, International Law, p. 734. 
formulation of foreign policy. Intervention is wrongful when it uses methods of coercion in regard to such choices, which must remain free ones." 77

Although the principle of non-intervention therefore provides the State with a wide discretion to adopt or discard privatization policies in its own territory, it may also impose an obligation on States not to force other States, in particular developing ones, to adopt privatization policies. It may also prevent any State from exerting any undue pressure or influence on the government of another State that may result in the adoption of privatization policies against the will of the latter. However, except for a number of States that decry the use of privatization as a way of imposing neo-liberal economic policies on others, there are no known cases of States actually appealing to the principle of non-intervention as a way to prevent the adoption of privatization policies influenced by outside actors, derogating privatization legislation, or reducing the effects of privatization policies applied by previous governments. It is not unimaginable however, that opponents of neo-liberal economic policies who rise to power, may in the future appeal to the principle of non-intervention in an effort to do away with privatization, which in their view has been imposed by International Financial Institutions and the host States of multinational corporations that had previously assumed those privatized tasks. ${ }^{78}$

\subsubsection{Obligations pertaining to state responsibility}

The principle of state responsibility for a breach of an international obligation is one of the most fundamental principles of international law. States are expected to live up to the various obligations emanating from treaties or international customary law. If for whatever reason a State commits an internationally wrongful act against another State thus breaching an international obligation, the former can be held responsible for such an act vis-à-vis the latter. ${ }^{79}$ In respect of privatization this raises the important question whether the conduct of a privatized entity may be attributed to the State. This matter will be considered in detail in Chapter IV. It suffices here to observe that state responsibility requires a breach of an international obligation and conduct that is attributable to the State breaching such an obligation.

77 Military and Paramilitary Activities in and against Nicaragua (Nicaragua v. United States of America), ICJ Reports 1986, p. 14, para. 205.

78 The example of Evo Morales, the former coca growing farmer and political activist who became president of Bolivia in early 2006 comes to mind. See "Bolivia's Morales rejects US domination," The Financial Times, 22 January 2006. See also "Coca Farmer Wins Bolivian Election: New President to Challenge Multinationals," available at <www.corpwatch.org/article.php?id=12989> (last visited 30 January 2006).

79 Article 1 Articles on the Responsibility of States for international wrongful acts, UN Doc A/ RES/56/83 (12 December 2001). Although the Articles on the Responsibility of States as drafted by the UN International Law Commission (ILC) and as adopted for further consideration by the UN General Assembly are not formally legally binding, many of its provisions are considered to be rules of customary international law. 
A breach of an international obligation takes place when a State fails to act in conformity with what is required of it by that particular obligation, regardless of the obligation's origin or character ${ }^{80}$ Of course, the precise terms of the obligation, its interpretation and application and the particular circumstances and facts of the case will determine whether there has been a breach of that obligation. ${ }^{81}$

A State that is responsible for a breach of a legal obligation is required to make reparations. ${ }^{82}$ With regard to privatization, this may entail a duty on a contravening State to repair any damages incurred by an injured State (or its subjects) when the application of a privatization policy results in a breach of an international duty. It is thus possible that a State may be held liable for privatization, if this amounts to a breach of the property rights of individuals. This has been suggested by the European Court of Human Rights in the case of Budescu and Petrescuv. Rumania. ${ }^{83}$ In this case, Rumania had nationalized a number of apartments during the former Communist regime. Following the revolution at the end of 1989, the apartments were subsequently privatized and sold to some tenants. The original owners of the apartments claimed that Rumania had acted contrary to Article 1 Protocol 1 of the European Convention on Human Rights on the right to property. The Court agreed with this argument, and held Rumania responsible for the breach of Article 1 Protocol 1 and ordered it to pay compensation.

In addition, the obligations arising out of the concept of State responsibility also apply to the situation in which a State decides to re-nationalize a privatized company operated by a foreign company or adopts regulatory measures that have an impact on the company's investments. Here, it is possible to distinguish two types of situations. In the first place there is the case in which the decision to re-nationalize or reverse a privatization (by ending a concession contract, for example) is carried out for a legitimate purpose. Although there appears to be no general consensus, under the principles of international law regarding the treatment of alien property and State responsibility, it has been contended that a State has the right to nationalize or expropriate private property such as enterprises and assets on public grounds. ${ }^{84}$ Arguably, a situation in which the activities of privatized enterprises owned by

Article 12 Articles of the Responsibility of States and Factory at Chorzów (Juridsiction), 1927, PCIJ, Series A. No. 9, p. 21.

81 See ILC Commentary in J. Crawford, The International Law Commission's Articles on State Responsibility: Introduction, Text and Commentaries (Cambridge: Cambridge University Press, 2002) p. 125. The ILC Commentary adds to this that one has to take into account the object and purpose of the obligation as well.

83 See Budescu and Petrescu v. Rumania, ECtHR, Application No. 33912/96, judgment of 2 July 2002. See further Chapter V Section 3.1.2.

84 See for example UN GA resolution 1803 (XVII) on Permanent Sovereignty over Natural Resources, 17 UN GAOR, Supp. (No. 17) 15, UN Doc. A/5217 (1962), which states that "[n] ationalization, expropriation or requisitioning shall be based on grounds or reasons of public 
foreign companies seriously impairs the human rights of individuals or groups could provide sufficient grounds to reverse the privatization. In doing so, however, the State has an obligation to pay due, prompt and appropriate compensation. ${ }^{85}$ In such a situation the rules of State responsibility will only engage if there is a breach in the obligation to pay the compensation. ${ }^{86}$ This also applies to situations in which the State adopts legitimate regulatory measures without discrimination or which are not arbitrary. This view was adopted by a North America Free Trade Agreement (NAFTA) arbitral tribunal in the Methanex Corp vs. United States arbitration. ${ }^{87}$ In this dispute about environmental measures which allegedly affected the investments of a Canadian corporation operating in California, the arbitral tribunal constituted under Chapter 11 of the NAFTA Agreement observed that,

"[...] as a matter of general international law, a non-discriminatory regulation for a public purpose, which is enacted in accordance with due process and, which affects, inter alios, a foreign investor or investment is not deemed expropriatory and compensable unless specific commitments had been given by the regulating government to the then putative foreign investor contemplating investment that the government would refrain from such regulation." 88

In the second place, there is the situation in which the decision to re-nationalize or reverse the privatization may entail a breach of an international obligation. In such a situation the rules of State responsibility will engage. A case in point is the dispute before the ICSID between a privatized water utility operated by Azurix, a U.S. based water services company, and Argentina. ${ }^{89}$ The dispute arose out of the termination of the concession contract for the operation of the water utility in the province of

utility, security or the national interest which are recognized as overriding purely individual or private interests, both domestic and foreign."

This has been referred to as the 'Hull' formula, named after United States Secretary of State Hull who in 1938 presented a claim to the Mexican Government asking Mexico for 'prompt, adequate and effective' compensation following expropriation by the latter of property owned by U.S. citizens in Mexico. R. Dolzer, "New Foundations of the Law of Expropriation of Alien Property," A.J.I.L. Vol. 75 (1981), p. 558.

86 See Crawford, The International Law Commission's Articles on State Responsibility: Introduction, Text and Commentaries, p. 75-76.

87 Methanex Corp. v. United States, Jurisdiction and Merits, NAFTA Tribunal, Chapter 11 Arbitration, 3 August 2005.

Ibid., Part IV, Chapter D, page 4, para. 7, See also S. Leader, "Human Rights, Risks, and New Strategies for Global Investment," Journal of International Economic Law Vol. 9 (2006), p. 674.

Azurix Corp. v. Argentine Republic, ICSID Case No. ARB/01/12. This dispute should not to be confused with the concession contract involving the city of Buenos Aires, which is the subject of the case study presented in Chapter VII. It should be noted that in spite of the fact that an award on this case was rendered (Azurix Corp. v. Argentine Republic, Award, ICSID Case No. $\mathrm{ARB} / 01 / 12$, 14 July 2006), Argentina subsequently filed a request for annulment of the award as made possible by Article 52 of the ICSID Convention, on the grounds that (a) the Tribunal was not properly constituted; (b) the Tribunal manifestly exceeded its powers; (c) there had been a serious departure from a fundamental rule of procedure; and (d) that the Award failed to state 
Buenos Aires between the local government and Azurix. The province of Buenos Aires terminated the concession in 2002 following disagreements concerning the way the concession was being operated. The contract had been awarded in 1999, but the parties fell out on issues regarding changes to the water tariffs, valuation of the assets, and the actual operation of the concession. Subsequent financial problems that were allegedly caused by fines imposed on the company and further arbitrary conduct by the province moved the company to file for bankruptcy. ${ }^{90}$ This was followed by the termination of the contract on the initiative of the province, alleging that Azurix abandoned the service and did not fulfill its contractual obligations. Azurix filed a claim before an ICSID arbitration tribunal arguing that the conduct and measures adopted by the province amounted to expropriation and discrimination in breach of the U.S. - Argentina BIT, and requested compensation. ${ }^{91}$ The tribunal concluded that although there had been no expropriation of property as such, ${ }^{92}$ Azurix was nevertheless entitled to compensation for the arbitrary conduct of the province which "impaired the management, operation, maintenance, use, enjoyment, acquisition, expansion, or disposal of the investment of Azurix in Argentina" and which resulted in a breach of the standard of fair and equitable treatment, and the standard of full protection and security of the investment as required by the BIT. ${ }^{93}$

Perhaps a more dramatic case that illustrates both situations discussed in the previous paragraphs with regard to state responsibility is the one involving the termination of a water privatization concession contract in the city of Buenos Aires, Argentina, ${ }^{94}$ which is also discussed in more detail in Chapter VII. Here the discussion will focus on those aspects of the case related to state responsibility. The water utility in Buenos had been privatized in 1993 through the signing of a 30-year concession contract between the city of Buenos Aires and the claimants in the case, a consortium of Spanish, French, United Kingdom, and Argentine water companies. In the wake of the financial crisis affecting Argentina from 2001-2003, the

the reasons on which it was based. See Azurix Corp. v. Argentine Republic, Decision on the Continued Stay of Enforcement of the Award, ICSID Case No. ARB/01/12, 28 December 2007.

90 The alleged arbitrary conduct consisted inter alia of actions of the provincial authorities calling for non-payment of bills requiring, requiring Azurix not to apply a new tariff that was necessary to cover some additional investment costs, and denying the company access to documentation on the basis of which Azurix was sanctioned.

91 Azurix Corp. v. Argentine Republic, Award, paras. 43-44 and 244-245.

92 Ibid., para. 322.

93 Ibid., paras. 377, 393, and 408. Lowenfeld, International Economic Law, p. 466-468 and p. 472 pointing out to the Chorzów Factory case.

94 Aguas Argentinas, S.A., Suez, Sociedad General de Aguas de Barcelona, S.A. and Vivendi Universal, S.A. v. Argentine Republic, Decision on Liability, ICSID Case no. ARB/03/19, 30 July 2010. For a similar case and decision involving the termination of the privatized water concession in the province of Santa Fé in Argentina and which reached similar conclusions almost at the same time by the same panel of arbitrators see Suez, Sociedad General de Aguas de Barcelona S.A. and Interagua Servicios Integrales de Agua S.A. v. Argentine Republic, Decision on Libaility, ICSDI Case no. ARB/03/17, 30 July 2010. 
government of Argentina unsuccessfully attempted to renegotiate the concession contract with claimants. ${ }^{95}$ At the same time, the national Argentine government adopted a number of austerity measures in an effort to avert the effects of the crisis. ${ }^{96}$ The measures adopted resulted in an increase in the costs of the privatized company, difficulties in repayment of its debts, and loss of revenue. This situation prompted the privatized company to seek and request in accordance with the concession contract an extraordinary adjustment of the water tariffs to be collected from consumers to recoup the lost profits and to allow it to pay back the loans. However, the request was denied and further forcible attempts by Argentina to renegotiate the concession failed. The consortium then filed a claim in 2003 before the ICSID. In the midst of the proceedings before the ICSID arbitration tribunal, the government unilaterally terminated the concession in 2006, and took over the provision of water services as stipulated in the concession contract. The consortium alleged essentially that the various actions adopted by the national government amounted to a violation of the Argentina - Spain, Argentina - France and the Argentina - United Kingdom BITs' provisions on expropriation, and on providing the investments full protection and security, as well as a violation of the provisions on fair and equitable treatment found in the BITs, and sought compensation for the losses incurred. ${ }^{97}$

On the matter of the expropriation claim, the consortium argued that aforementioned measures, the Argentine government's refusal to adjust the water tariffs, and the termination of the concession contract resulted in both direct and indirect expropriation because they affected the privatized company's possession of the concession and because they deprived the consortium of the economic benefit of their investment respectively. However, the tribunal concluded that until 2006 the privatized company remained in possession of the concession and the consortium maintained control of the privatized company. ${ }^{98}$ It also concluded that the measures adopted by Argentina to cope with the financial crisis were legitimate and corresponded to the regulatory measures that states may adopt as understood in Methanex, because they did not constitute a permanent and substantial deprivation of the investments of the consortium. ${ }^{99}$ The tribunal furthermore observed that the refusal to revise the tariffs also did not result in a substantial deprivation of the investment since the privatized company "[...] remained in control of the Concession

Aguas Argentinas, S.A., Suez, Sociedad General de Aguas de Barcelona, S.A. and Vivendi Universal, S.A. v. Argentine Republic, Decision on Liability, ICSID Case no. ARB/03/19, 30 July 2010, paras. 43-52.

96 These measures included the decoupling of the Argentine Peso from the U.S. Dollar leading to a major depreciation of the former, abolishing the adjustment of public service contracts according to agreed upon indexations, and authorizing the national Executive branch to renegotiate all public service contracts. Ibid., paras. 43-44. Ibid, para. 127.

98 Ibid., para. 136.

99 Ibid., paras. 138-140. 
and its authority to manage and direct the operation of the water and sewage system was undiminished." 100 With regard to the termination of the concession contract, the arbitration tribunal observed first that neither the privatized water utility nor the consortium "[...] owned or had property rights in the physical assets of the water and sewage system of Buenos Aires."101 According to the tribunal, the privatized utility only held contractual rights to operate the concession and obtain an income from the operation, both of which were not absolute since they were contingent to various contractual conditions of the concession contract, which also "[...] granted the Argentine government the right to terminate the Concession due to the fault of the Concessionaire and to retake possession of the water and sewage system." 102 Basing itself on previous arbitral awards dealing with similar issues, ${ }^{103}$ the arbitration tribunal made a distinction between the termination of the contract by Argentina in the exercise of its sovereign powers (acta iure imperii), and termination by Argentina in its capacity as a contractual party (acta iure gestionis). According to the tribunal, the former amounts to expropriation, whereas the latter does not. ${ }^{104}$ It concluded that since the privatized water utility had been fined on various occasions for deficiencies in the operation of the services, and that it had requested itself to terminate the contract to which Argentina originally refused, the decision to terminate the contract by the Argentine government was taken,

"according to the rights it claimed under the Concession Contract and the legal framework. Indeed, Argentina's behavior in ending the Concession Contract seems not unlike the behavior of a private contracting party faced with the threatened termination of an important long-term supply contract: it quickly made other provisions for supply of the needed commodity or service and then took steps to end the deteriorated contractual relationship itself.". ${ }^{105}$

The tribunal thus concluded that no expropriation had taken place. ${ }^{106}$ It also concluded that the obligation to accord investments with full protection and security was not relevant to the case since the standard, according to the Arbitral Tribunal, entails the exercise of "[...] due diligence to protect investors and investments primarily from physical injury, and that in any case Argentina's obligations under the relevant provisions do not extend to encompass the maintenance of a stable legal and commercial environment."107

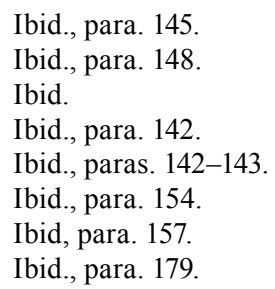


In spite of this appraisal, however, the tribunal found that Argentina had failed to accord fair and equitable treatment to the investments for most of the same actions. After defining the meaning of what fair and equitable treatment meant under the BITs at the heart of the dispute, ${ }^{108}$ the Arbitral Tribunal noted that the existence of such a treatment towards an investment depends on the legitimate and reasonable expectations that are raised by the conduct and legislation of the host State, and which influences the investors' decisions on the investment and its management. According to the Arbitral Tribunal, "[w]here a government through its actions subsequently frustrates or thwarts those legitimate expectations, arbitral tribunals have found that such host government has failed to accord the investments of that investor fair and equitable treatment." 109 The Tribunal noted that in the case of the Buenos Aires water concession, the expectations were raised by the concession contract and legal framework of the concession, from which both the State and the privatized water company could derive their conduct. The latter were held to have a reasonable expectation that, in the light of the thirty-year contractual relationship established by the concession contract, the Argentine government would be open to cooperate and work together with the investors. ${ }^{110}$ Notwithstanding Argentina's right to regulate the provision of a vital public service, its rigid refusal to revise the water tariffs during the crisis as requested by the concessionaire in accordance with what was stipulated in the concession contract and the legal framework, frustrated the expectations of investors. ${ }^{111}$ Any necessary regulatory measures to protect the poor from tariff adjustments could have been adopted, as the Arbitral Tribunal suggested, within the confines of the concession contract and regulatory framework. ${ }^{112}$ However, even when the economic crisis diminished, Argentina

“[...] enacted various measures directing the regulatory authorities not to respect important elements of the legal framework. Such actions were outside the scope of

108 The Arbitral Tribunal observed that 'fair and equitable treatment' entailed not only that host States must provide specific levels of protection to individual investors and to promote those investments, but they must also pursue goals of further economic cooperation between States in order to achieve increased economic prosperity or development. Ibid., paras. 218-219.

Ibid., paras. 222-223. The Arbitral Tribunal further observed that the expectations raised are relevant when these can be derived from the laws and regulations of a country causing investors to act in a particular way in the hope that the conduct of the State will be in accordance with the rules and environment laid down by those laws and regulations. Ibid., para. 226.

110 Ibid., para. 233.

111 Ibid., para. 232.

112 The Arbitral Tribunal noted, for example, that the concession contract allowed the adoption of flexible measures for the benefit of the poor. Thus, tariff increases could have been avoided by relieving the concessionaire from its obligation to make investments in the water network as required by the contract. Alternatively, tariff increases that would have negatively affected the poor could have been avoided through applying a social tariff or providing subsidies for the poor, while charging other consumers with higher tariffs. Ibid., para. 235. 
its legitimate right to regulate and in effect constituted an abuse of regulatory discretion." 113

In other words, by adopting a rigid position and by refusing to adhere to the rules established by the contract during and after the economic crisis, the Argentine government breached its obligation to treat the investment fairly and equitably under the BITs. In addition, Argentina's attempts to renegotiate the concession without resorting to the rules found in the concession contract were equally deemed to be a breach of the obligation to provide fair and equitable treatment, since it also frustrated the legitimate expectations of the investors. ${ }^{114}$ At the same time, the Arbitral Tribunal found that it could not judge whether the termination of the concession contract did not amount to a breach of the obligation to provide fair and equitable treatment. It also observed that the question whether the termination of the contract breached the concession contract itself was a question that could better be answered through the dispute resolution mechanism provided for in the contract itself. $^{115}$

Argentina attempted to argue, however, that even if some of the measures it adopted during and after the crisis might have breached the BITs' provisions on fair and equitable treatment, it still could not be held liable by this. Argentina's reasoning was that the measures were necessary to safeguard certain essential interests of the State as recognized under international customary law and as restated in Article 25 of the ILC's Articles on the Responsibility of States for internationally wrongful acts. ${ }^{116}$ In particular, Argentina argued that the measures were intended to safeguard the human right to water of the inhabitants of the country, and given its importance with respect to life and health, Argentina should have be granted a margin of

$113 \quad$ Ibid., para. 237.

114 Ibid., para. 243. Argentina tried to force a renegotiation through, among other things, enacting a number of laws and decrees that changed the rules of the renegotiation process and which derogated from the rules for renegotiation provided for in the regulatory and contractual framework.

115 Ibid., paras. 244-246.

116 Ibid., paras. 249-250. Article 25 is usually invoked to preclude the wrongfulness of an act, which in principle is contrary to an international obligation. However, the Article is worded in strict negative terms, presumably to prevent its abuse and as such its use is seen as exceptional: "1. Necessity may not be invoked by a State as a ground for precluding the wrongfulness of an act not in conformity with an international obligation of that State unless the act: a) Is the only way for the State to safeguard an essential interest against a grave and imminent peril; and (b) Does not seriously impair an essential interest of the State or States towards which the obligation exists, or of the international community as a whole. 2. In any case, necessity may not be invoked by a State as a ground for precluding wrongfulness if: (a) The international obligation in question excludes the possibility of invoking necessity; or (b) The State has contributed to the situation of necessity." See ILC Commentary Crawford, The International Law Commission's Articles on State Responsibility: Introduction, Text and Commentaries, p. 178-186. See also Aguas Argentinas, S.A., Suez, Sociedad General de Aguas de Barcelona, S.A. and Vivendi Universal, S.A. v. Argentine Republic, Decision on Liability, para. 258. 
discretion when adopting these measures. ${ }^{117}$ This position was also supported by NGOs that made submissions as amicus curiae in this case. ${ }^{118}$ However, the Arbitral Tribunal disagreed with this argument due to the strict conditions imposed on the necessity defense as restated in Article 25 of the ILC's Articles on State responsibility. According to the Tribunal "[t]he severity of a crisis, no matter the degree, is not sufficient to allow a plea of necessity to relieve a state of its treaty obligations." 119 In order to successfully invoke the necessity plea, Argentina had to fulfill four criteria:

a. the measures adopted by Argentina must be the only way to safeguard the essential interest (in this case the right to water);

b. the measures must not seriously impair an essential interest of the States toward which the obligations ensuing from the BITs are owed, or toward the international community as a whole;

c. the obligations enshrined in the BITs must not exclude the necessity defense; and

d. Argentina must not have contributed to the situation of necessity.

With respect to the first criteria, the Tribunal did not see Argentina's measures as the sole means of safeguarding the right to water. According to the Tribunal, the protection of the right to water as an essential interest and the respect of the obligations flowing from the BITs are not mutually exclusive. ${ }^{120}$ Thus, if Argentina had rally wanted to protect the most vulnerable sectors of society from an increase in the water tariffs as required by the Concessionaire, it could have allowed the latter to temporarily forego its investment commitments that could only be financed through higher tariffs, or it could have introduced targeted subsidies or a social tariff for the poor as allowed by the concession contract. ${ }^{121}$

Turning to the second and third criteria, the Tribunal found respectively that no essential interests of Spain, France, and the United Kingdom were at stake, and that the BITs themselves did not exclude the necessity defense. ${ }^{122}$ Nonetheless, the Tribunal was moved to observe that the argument posed by Argentina and the

117 Ibid., para. 252. One of the reasons put forward by Argentina was that "[...] water cannot be treated as an ordinary commodity[,]" and thus the margin of discretion to be granted to the country should be broader in this particular case "[...] than in cases involving other commodities and services." Ibid.

118 Ibid., para. 256. See also Aguas Argentinas, S.A. Suez, Sociedad General de Aguas de Barcelona, S.A., and Vivendi Universal S.A., v. the Argentine Republic, Order in Response to a Petition for Transparency and Participation as Amicus Curiae, ICSID Case No. ARB/03/19, 19 May 2005. Aguas Argentinas, S.A., Suez, Sociedad General de Aguas de Barcelona, S.A. and Vivendi Universal, S.A. v. Argentine Republic, Decision on Liability, para. 258.

120 Ibid., para. 260.

121 Ibid, and para. 235.

122 Ibid., paras. 261-262. 
NGOs to the effect that the existence of a human right to water should have precedence over the obligations ensuing from the BITs did not have any basis either in the BITs or international law. ${ }^{123}$ This observation poses an interesting conundrum for human rights lawyers, who in general would rather like to place human rights above all other international law obligations. However, outside of those few human rights norms that have obtained the status of jus cogens, such as the prohibition of slavery, racial discrimination, and torture, it would seem difficult to argue that human rights obligations essentially have a higher value under international law than any other norm, notwithstanding the special nature of human rights norms, and the values they seek to protect. ${ }^{124}$ The Arbitral Tribunal, thus observed that,

\begin{abstract}
"Argentina is subject to both international obligations, i.e. human rights and treaty obligation, and must respect both of them equally. Under the circumstances of these cases, Argentina's human rights obligations and its investment treaty obligations are not inconsistent, contradictory, or mutually exclusive." 125
\end{abstract}

Thus, as discussed above, Argentina could have respected both types of obligations. It is suggested that this is a solid argument in general, since from the perspective of international law, states are required to comply with their legal obligations in good faith and state responsibility, and trying to preclude international wrongfulness by relying on necessity must be exceptional and reserved for the most serious, and unexpected situations in which States do not have much choice for action. It is difficult to argue otherwise in the Argentine case given the fact that, as will be discussed in Chapter VII, the concession contract did provide for alternative ways to deal with the problem. However, it is not unthinkable that in States with less developed legal and regulatory frameworks legitimate measures aimed at protecting human rights vis-à-vis the conduct of privatized entities could be too easily waived away in order to protect investments. Whether the ICSID Tribunal's approach to necessity will entail the responsibility of a State cancelling other privatization efforts that have been enabled or facilitated through BITS in the name of human rights, will thus depend on the respective ways States have contractually arranged those efforts with foreign investors and through the regulatory terms accepted by the latter. The present author suggests that this could be an interesting avenue for further research.

Finally with respect to the fourth criteria mentioned in Article 25 of the ILC Articles, the Tribunal relied on the conclusions of another ICSID Tribunal in the

\footnotetext{
123 Ibid., para. 262.

124 For a discussion on the issue of whether human rights norms have primacy over other international legal obligations see M. Milanović, "Norm Conflict in International Law: Whither Human Rights?," Duke Journal of Comparative \& International Law Vol. 20 (2009), p. 69-131. Universal, S.A. v. Argentine Republic, Decision on Liability, para. 262.
} 
CMS Gas Transmission Company v. Argentine Republic case. ${ }^{126}$ Echoing the decision in that case, the Tribunal observed that although the country itself was not entirely responsible for some of the external factors that led to the crisis, the actions and policies of the successive Argentine Governments prior to and during the crisis, had contributed to the overall problems resulting in the financial meltdown that affected the country. ${ }^{127}$ All these deliberations led the Tribunal to concluded that Argentina is internationally responsible for the measures leading to the termination of the privatized water utility of Buenos Aires in so far it denied the claimants' investments a fair and equitable treatment. A decision on compensation for the damages for this breach was at the time of this writing yet to be rendered.

The standard for compensation may vary from case to case depending on whether there is a friendly relations or investment treaty in place between the parties to the dispute. However, the Iran - US Claims Tribunal has in a number of cases decided that the standard for compensation can also be ruled by rules of international customary law (which can also serve as an auxiliary means of filling any gaps that the abovementioned investment treaties might have). ${ }^{128}$ There is no full agreement under international law on the amount of compensation to be paid (cases refer often to appropriate compensation). Appropriate compensation has been interpreted to entail full compensation regarding the full value of the enterprise at the moment it was nationalized (based on the historical cost or replacement cost of physical assets), but under certain circumstances full compensation could also include the value based on reasonable expectation of future earnings at the time nationalization took place. ${ }^{129}$

With regard to privatization, it can thus be stated that a State may be entitled to re-nationalize or de-privatize enterprises and services on the grounds of public policy. It is submitted that a perceived negative impact on human rights by a privatization process, or human rights abuses committed by privatized entities could ground sufficient arguments to terminate or reverse a privatization process on the grounds of public necessity. However, this does not exempt States from respecting other equally important legal obligations and the affected (foreign) corporations/multinationals/investors would be entitled to prompt and adequate compensation according to international law. The liability of the State for re-nationalizing privatized bodies could also be engaged when such a measure is

126 See CMS Gas Transmission Company v. Argentine Republic, Award, ICSID Case No. ARB/01/8, 12 May 2005.

127 Aguas Argentinas, S.A., Suez, Sociedad General de Aguas de Barcelona, S.A. and Vivendi Universal, S.A. v. Argentine Republic, Decision on Liability, paras. 263-264.

128 Aldrich, The Jurisprudence of the Iran-United States Claims Tribunal - An Analysis of the Decisions of the Tribunal, p. 218.

129 Ibid., p. 247-270. See also Crawford, The International Law Commission's Articles on State Responsibility: Introduction, Text and Commentaries, p. 225-230. 
adopted in breach of obligations arising out of bilateral investment treaties between the host country and the country in which the private company operating the privatized service is registered. These breaches could be unlawful expropriation, arbitrary or discriminatory measures or treatment falling below the fair and equitable treatment expectd by the affected privatized companies. States claiming that these breaches are the result of concerns to protect human rights should be aware that international responsibility can nevertheless be engaged if the measures adopted are not proportionally necessary and exclude in an arbitrary way the protection of investments.

\subsubsection{Obligations erga omnes}

In the judgment of the Case Concerning the Barcelona Traction, Light and Power Co., Ltd., ${ }^{130}$ the International Court of Justice introduced the concept of obligations erga omnes. The Court observed that a particular set of obligations that a State has towards the international community as a whole should be distinguished from the traditional ones that govern the bi-lateral relationships between States. According to the Court,

"[b]y their very nature, the former are the concern of all States. In view of the importance of the rights involved, all States can be held to have a legal interest in their protection; they are obligations erga omnes." 131

The Court noted that these obligations can be derived from, inter alia, the principles and rules concerning the basic rights of the human person, including protection from slavery and racial discrimination. ${ }^{132}$

Although there appears to be no agreement about the specific scope of the concept, the notion of obligations owed to the international community as a whole has been widely accepted by adjudicatory bodies and legal scholars alike. ${ }^{133}$ The concept of obligations erga omnes is often invoked in an attempt to induce the cessation of internationally wrongful conduct, and theoretically could be applied to countries whose privatization actions may run contrary to these obligations.

\subsubsection{Some observations}

The broad set of international obligations examined above appears to be of limited use with regard to limiting the adoption and deployment of privatization policies.

Case Concerning the Barcelona Traction, Light and Power Co., Ltd., ICJ Reports 1970.

Ibid., para. 33.

Ibid., para. 34.

133 C.J. Tams, Enforcing Obligations Erga Omnes in International Law (Cambridge: Cambridge University Press, 2005) p. 2-3.
} 
States are bound to respect existing treaties and other primary rules of international law in so far as they may oppose privatization (which is currently not the case) or when its adoption results in the breach of another international legal obligation. The potentially more useful principle of non-intervention, has also not yet resulted in concrete situations in which privatization has been overturned.

\subsection{Obligations of non-State actors}

In the previous section, the general international obligations of traditional State actors with respect to privatization have been evaluated. The present section will be devoted to examining the international and human rights obligations (if any) of nonState actors that are involved in the privatization process. Under international law, only few recognized subjects of international law possess international legal personality and with it, concomitant rights and obligations. ${ }^{134}$ It is well known that States, as the original international actors, do posses international legal personality. The international legal personality of other actors not being States is, however, more controversial. ${ }^{135}$ It is now accepted that international organizations may, to a certain degree, possess international legal personality that is necessary for a proper discharge of their functions. ${ }^{136}$ Whether business enterprises are proper subjects of international law with legal personality and thus with legal rights and obligations is more open to debate. ${ }^{137}$ The following paragraphs will examine the international (human rights) obligations of a particular type of international organization, international financial institutions, and of business enterprises since they arguably play (or have played) an important role in the privatization debate.

\subsubsection{Obligations of international financial institutions}

In Chapter II we described the role that IFIs have played in the development and implementation of privatization policies. These policies and the role of these institutions therein have been criticized for their alleged negative impact on the human rights of individuals and groups belonging to the vulnerable sectors of society of the countries in which these policies have been implemented. ${ }^{138}$ At the

134 See Shaw, International Law, p. 196-197.

135 For an overview of the different arguments put forth with regard to whether other international actors other than states have legal international and human rights obligations see Clapham, Human Rights Obligations of Non-State Actors, p. 25-58.

136 See Reparation for Injuries Suffered in the Service of the United Nations, ICJ Reports 1949.

137 Shaw, International Law, p. 249-250. For an in depth evaluation about this discussion see Liability of Multinational Corporations Under International Law, ed. M.T. Kamminga and S. Zia-Zarifi (The Hague: Kluwer Law International, 2000); N. Jägers, Corporate Human Rights Obligations: In Search of Accountability, vol. 17, School of Human Rights Research (Antwerpen: Intersentia - Hart, 2002) p. 19.

See Chapter II, Section 4.2. 
same time, this raises the question whether these institutions can be held responsible for eventual breaches of international and human rights obligations that may be the direct consequence of privatization policies they have urged or imposed on the basis of credit conditionality under the 'Washington consensus'.

There has been a wide discussion about the human rights obligations of IFIs. ${ }^{139}$ Within, the World Bank itself, for example, former Bank president James Wolfensohn established a taskforce to examine the interplay between the World Bank and human rights. ${ }^{140}$ Between 2002 and 2004 the taskforce discussed the problems of adopting a human rights policy within the Bank, and in spite of the adoption of a report and other internal initiatives, no concrete results were achieved. ${ }^{141}$ It is not the aim of this study to examine in full depth the extent to which these institutions are bound to respect these obligations in the devising and implementation of their policies. However, it can be stated that IFIs, being international organizations, are bound by obligations ensuing from the general rules of international law. ${ }^{142}$ This can be inferred from the International Court of Justice's advisory opinion on the Interpretation of the Agreement of 25 March 1951 between the WHO and Egypt, in which the Court noted that, "[i]nternational organizations are subjects of international law and, as such, are bound by any obligations incumbent upon them under general rules of international law, under their constitutions or under international agreements to which they are parties."143

Thus, in contrast to business enterprises, international financial institutions such as the IMF and the World Bank have limited international legal personality with concomitant international rights and duties. ${ }^{144}$ However, since these international

139 See for example S.I. Skogly, The Human Rights Obligations of the World Bank and the International Monetary Fund (London: Cavendish, 2001); K. De Feyter, "The International Financial Institutions and Human Rights - Law and Practice," IDPM - UA Discussion Paper 2002-7, Insitute of Development Policy Mangement - University of Antwerp Antwerp, (2002). See also the compilation of essays devoted to the subject in W. van Genugten, P. Hunt, and S. Mathews, eds., World Bank, IMF and Human Rights - Including the Tilburg Guiding Principles on World Bank, IMF and Human Rights (Nijmegen, The Netherlands: Wolf Legal Publishers (WLP), 2003).

140 G.A. Sarfaty, "Why Culture Matters in International Institutions: the Marginality of Human Rights at the World Bank," A.J.I.L. Vol. 103 (2009), p. 660.

141 Ibid., p. 660-661.

142 Feyter, "The International Financial Institutions and Human Rights - Law and Practice," p. 8.

143 Interpretation of the Agreement of 25 March 1951 between the WHO and Egypt, Advisory Opinion, ICJ Reports 1980, p. 89-90. This is a logical outcome of the ICJ's earlier advisory opinion Reparation for injuries suffered in the service of the United Nations, Advisory Opinion, ICJ Reports 1949, p. 147, wherein the ICJ concluded that international organizations such as the UN must possess international legal personality to carry out their activities and objectives, and that as international legal subjects they can possess rights and duties under international law to the extent that these activities and goals require. Ibid., p. 179-180.

144 Feyter, "The International Financial Institutions and Human Rights - Law and Practice," p. 7; S.I. Skogly, "The Human Rights Obligations of the World Bank and the IMF," in World Bank, 
organizations were created for specific purposes ${ }^{145}$ the scope of these rights and duties is limited. Thus, IFIs are bound by those obligations ensuing from the treaties or agreements establishing them, and by other rules of (customary) international law and general principles of international law. ${ }^{146}$ However, IFIs are not formally bound by obligations ensuing from human rights treaties. This is because they are not parties to them (only States are), nor can they accede to those treaties. In addition, Article IV $\S 10$ of the World Bank's Articles of Agreement states that in providing funding for development projects, the World Bank and its officers,

"[s]hall not interfere in the political affairs of any member; nor shall they be influenced in their decisions by the political character of the member or members concerned. Only economic considerations shall be weighed impartially in order to achieve the purposes stated in Article I."147

This provision suggests that the World Bank is, strictly speaking, not obliged to take into consideration other elements such as human rights when devising reform policies including privatization, or when it lends credit for development projects that require the privatization of State owned or managed companies and services. ${ }^{148}$

IMF and Human Rights - Including the Tilburg Guiding Principles on World Bank, IMF and Human Rights, ed. W. van Genugten, P. Hunt, and S. Mathews, Nijmegen, The Netherlands: Wolf Legal Publishers (WLP) (2003), p. 46-47.

145 According to Article I of the IMF's Articles of Agreement, the objectives of the institution include providing financial assistance for solving balance of payment problems. Under the World Bank Group's Articles of Agreement, one of its main purposes is to provide finance for particular projects aimed at improving borrowing countries' development. See Article I of Articles of Agreement of the International Bank for Reconstruction and Development (IBRD), Article I of Articles of Agreement of the International Development Agency (IDA), and Article I of Articles of Agreement of the International Finance Corporation (IFC).

146 Feyter, "The International Financial Institutions and Human Rights - Law and Practice," p. 8; Skogly, "The Human Rights Obligations of the World Bank and the IMF," p. 50.

147 Article IV $\$ 10$ of the IBRD Articles of Agreement.

148 In 2006, a former general counsel of the World Bank, Roberto Dañino, presented a Legal Opinion on Human Rights and the Work of the World Bank, which concluded that the "[... ] Articles of Agreement permit, and in some cases require, the Bank to recognize the human rights dimensions of its development policies and activities since it is now evident that human rights are an intrinsic part of the Bank's mission." See Legal Opinion on Human Rights and the Work of the World Bank, 27 January 2006, Roberto Dañino, available at <www.ifiwatchnet. org/?q=en/node/335> (last visited on 31 January 2010). The Legal Opinion stops short of concluding that the World Bank has direct human rights obligations. The Legal Opinion was also meant as an internal document, and was not widely distributed among the directors of the Bank. Since the Opinion's legal status is not clear, its actual impact on the policies of the World Bank with respect to human rights is also not evident. See further Sarfaty, "Why Culture Matters in International Institutions: the Marginality of Human Rights at the World Bank," p. 663-667. 


\subsubsection{Indirect human rights obligations?}

According to Skogly and De Feyter, it is nevertheless possible to argue that IFIs are bound by human rights obligations in a number of ways. In the first place, it can be argued that there are a number of human rights or some elements thereof that can be considered to form a part of customary international law and as such bind IFIs in their dealings. ${ }^{149}$ In addition, Skogly has argued that the status of the IMF and the World Bank as specialized agencies of the United Nations and the cooperation agreements signed between the UN and these agencies places them under an obligation to observe the fundamental principles of the UN Charter including the promotion of respect for human rights. ${ }^{150}$ Skogly also observes that both institutions are composed of countries that have ratified the various human rights instruments and as such these countries should "[...] in principle not enter into international financial agreements that may jeopardize the human rights of their people."151 The UN Committee on Economic, Social and Cultural Rights, the body monitoring the implementation of the ICESCR, has thus observed in a number of general comments ${ }^{152}$ that States parties to the Covenant, which at the same time are members of IFIs, should ensure that the lending policies, credit agreements and other measures of these institutions take due account of the various rights found in the Covenant. ${ }^{153}$ This means that IFIs should not propose or accept programs and policies which may be contrary to the human rights treaties that the member States of these institutions have agreed to respect. ${ }^{154}$

Using the typology of human rights obligations that the Committee on Economical, Social and Cultural Rights and academics use (obligations to respect, protect and fulfill, see Section 4.1.3 infra), Skogly appears to induce from the previous observations that the human rights obligations that can bind IFIs are mainly

149 Feyter, "The International Financial Institutions and Human Rights - Law and Practice," p. 8; Skogly, "The Human Rights Obligations of the World Bank and the IMF," p. 51-52. See also Clapham, Human Rights Obligations of Non-State Actors, p. 150-151.

150 Skogly, "The Human Rights Obligations of the World Bank and the IMF," p. 47-48; Clapham, Human Rights Obligations of Non-State Actors, p. 150.

151 Skogly, "The Human Rights Obligations of the World Bank and the IMF," p. 48-49.

152 General comments are the authoritative interpretations of the texts of the various UN human rights treaties, and which are issued by the respective UN treaty body in charge of their monitoring.

153 See General Comment No. 13, The right to education (Art. 13 of the Covenant), UN Doc. E/C.12/1999/10 (8 December 1999), para. 56; General Comment No. 14 on right to the highest attainable standard of health, (article 12 of the International Covenant on Economic, Social and Cultural Rights), UN Doc. E/C.12/2000/4 (11 August 2000), para. 39; and General Comment No. 15 on the right to water (Articles 11 and 12 of the International Covenant on Economic, Social and Cultural Rights), UN Doc. E/C.12/2002/11 (20 January 2003), para. 36.

Skogly, "The Human Rights Obligations of the World Bank and the IMF," p. 49. 
obligations to 'respect'. 155 This entails that IFIs would be under an obligation to ensure that their policies do not violate human rights, as suggested by the Committee in some general comments pointing out the obligations of actors other than States parties to the ICESCR. Thus, the Committee has concluded with regard to the right to adequate housing that, "[i]nternational financial institutions promoting measures of structural adjustment should ensure that such measures do not compromise the enjoyment of the right to adequate housing."156

In the second place, De Feyter argues that another way of distilling human rights obligations of the IFIs is through a broad interpretation of their Articles of Agreement. The Articles of Agreement for the respective institutions do not contain any references to human rights nor state that these institutions are bound by other legal obligations beyond those found in their constituent documents. ${ }^{157}$ However, some of the objectives of the institutions or the conditions under which they must decide on lending money to borrowing countries as defined in their Articles of Agreement can be interpreted as allowing the consideration of human rights in their decision-making. For example, according to Article I of the IBRD's Articles of Agreement one of the purposes of the World Bank is to "[...] assist in the reconstruction and development of territories of members by facilitating the investment of capital for productive purposes, including the restoration of economies destroyed or disrupted by war, the reconversion of productive facilities to peacetime needs and the encouragement of the development of productive facilities and resources in less developed countries." 158 According to De Feyter, development is a multidimensional concept that includes not only macroeconomic concerns but also human rights ones as evidenced by the various efforts by several UN agencies such as UN Agendas for development, UNDP's Agendas for development, and the UN Declaration on the right to development. ${ }^{159}$ The World Bank has acknowledged the relationship between the objectives of development and the realization of human

155 Ibid., p. 54-55. In a book review essay examining Skogly’s work, Matthews criticizes this conclusion since the obligation to 'respect' as applied to IFIs, only entails that they might only "[...] persuade the IFIs to attend to human rights but it may not sufficiently deal with breaches of human rights." See S. Matthews, "Resistance is Futile - You Will Be Assimilated," Leiden Journal of International Law, Vol. 19 (2006), p. 265.

156 General Comment No. 4 on the right to adequate housing (Art. 11 (1) of the International Covenant on Economic, Social and Cultural Rights), UN Doc. E/1992/23, para. 19. See also General Comment No. 12 on the right to adequate food (Article 11 of the International Covenant on Economic, Social and Cultural Rights), UN Doc. E/C.12/1999/5 (12 May 1999), para. 41; General Comment No. 13 on the right to education, para. 60; General Comment No. 14 on right to the highest attainable standard of health, para. 64; and General Comment No. 15 on the right to water, para. 60 . Feyter, "The International Financial Institutions and Human Rights - Law and Practice,” p. 9 and 11 .

158 Article I (i) IBRD Articles of Agreement (emphasis $A H W$ ).

159 Feyter, “The International Financial Institutions and Human Rights - Law and Practice,” p. 10. 
rights. In a report that was published on the occasion of the $50^{\text {th }}$ anniversary of the Universal Declaration of Human Rights, the World Bank noted that it,

"[...] believes that creating the conditions for the attainment of human rights is a central and irreducible goal of development. By placing the dignity of every human being - especially the poorest - at the very foundation of its approach to development, the Bank helps people in every part of the world build lives of purpose and hope. And while the Bank has always taken measures to ensure that human rights are fully respected in connection with the projects it supports, it has been less forthcoming about articulating its role in promoting human rights within the countries in which it operates." 160

Although it still remains debatable whether human rights obligations can be directly read into the instruments establishing the IMF and the World Bank, both institutions have acknowledged that the respect of human rights is necessary for the deployment of their activities. ${ }^{161}$ This may encourage them to take look into the potential human rights impact of policies such as privatization.

In the third place, it has been argued that the internal operational policies of IFIs may also provide a potential source of international legal obligations including human rights ones. ${ }^{162}$ These internal policies contain guidelines to the staff of IFIs, in particular the World Bank, for assessing the viability of loans for development projects. These guidelines, which are found in the World Bank's Operational Manual, also contain safeguards that have to be taken into account by Bank staff

160 A. Gaeta and M. Vasilara, "Development and Human Rights: the Role of the World Bank," The International Bank for Reconstruction and Development/The World Bank, Washington D.C., (1998), p. 2. The report continues, "The Bank contributes directly to the fulfillment of many rights articulated in the Universal Declaration. Through its support of primary education, health care and nutrition, sanitation, housing, and the environment, the Bank has helped hundreds of millions of people attain crucial economic and social rights. In other areas, the Bank's contributions are necessarily less direct, but perhaps equally significant. By helping to fight corruption, improve transparency and accountability in governance, strengthen judicial systems, and modernize financial sectors, the Bank contributes to building environments in which people are better able to pursue a broader range of human rights." Ibid., p. 3.

161 Both De Feyter and Skogly quote from statements made by IMF and World Bank's officials stating that human rights considerations may indeed be of relevane to their activities. See Feyter, "The International Financial Institutions and Human Rights - Law and Practice," p. 11, and Skogly, The Human Rights Obligations of the World Bank and the International Monetary Fund, p. 41. Indeed, the World Bank has even published a study on the right to water, which denotes the importance the World Bank attaches to human rights as part of the development agenda. See S.M.A. Salman and S. McInerney-Lankford, The Human Right to Water: Legal and Policy Dimensions (Washington D.C.: The International Bank for Reconstruction and Development/ The World Bank, 2004).

Feyter, "The International Financial Institutions and Human Rights - Law and Practice,” p. 14. 
while preparing lending operations. ${ }^{163}$ Although these guidelines do not deal directly with human rights, a number of them could be regarded to contain indirect human rights obligations.

As already observed, in the last fifteen years, the World Bank has grown more sensitive to the potential social effects of its policies and has incoporated a number of guidelines in its Operational Manual to steer its activities when dealing with certain projects. ${ }^{164}$ Thus, Skogly draws attention to the principle that the World Bank should not finance projects that are contrary to the obligations ensuing from environmental treaties ratified by the countries in which the Bank operates. ${ }^{165}$ This principle is embodied in the newly revised Operational Policy OP 4.01: Environmental Assessment (January 1999, updated March 2007). ${ }^{166}$ It can be argued by analogy that a similar requirement applies to other guidelines dealing with social related issues. Specifically, this could apply to guidelines that have been developed with respect to the financing of projects that may have effects on the

163 These guidelines are divided into several types of documents: Operational Policies (OPs), Bank Procedures (BPs), Good Practices (GPs), Operational Directives (ODs), and Operational Memoranda (Op Memos). According to the Bank's Operational Manual available at $<\mathrm{http}: / /$ wbln0018.worldbank.org/Institutional/Manuals/OpManual.nsf/05TOCpages/The\%20World\%20 Bank\%20Operational\%20Manual?OpenDocument $>$ OPs are " [...] short, focused statements that follow from the Bank's Articles of Agreement, the general conditions, and policies approved by the Board. OPs establish the parameters for the conduct of operations; they also describe the circumstances under which exceptions to policy are admissible and spell out who authorizes exceptions. [BPs] explain how Bank staff carry out the policies set out in the OPs. They spell out the procedures and documentation required to ensure Bankwide consistency and quality. [GPs] contain advice and guidance on policy implementation, for example, the history of the issue, the sectoral context, analytical framework, best practice examples. [ODs] contain a mixture of policies, procedures, and guidance. The ODs are gradually being replaced by $\mathrm{OPs} / \mathrm{BPs} / \mathrm{GPs}$, which present policies, procedures, and guidance separately. [Op Memos] are interim instructions intended to elaborate on material in OPs/BPs or ODs. Once the instructions in OP Memos are incorporated into revisions of the pertinent OPs/BPs, the Op Memos are retired." De Feyter notes that Bank Procedures and the old Operational Directives are binding on staff, unless their wording suggests otherwise. Ibid. See Chapter II, Section 4.2.

165 See also Skogly, "The Human Rights Obligations of the World Bank and the IMF," p. 61-62.

166 According to this Operational Policy, the Bank's environmental assessment (EA), "[...] also takes into account the variations in project and country conditions; the findings of country environmental studies; national environmental action plans; the country's overall policy framework, national legislation, and institutional capabilities related to the environment and social aspects; and obligations of the country, pertaining to project activities, under relevant international environmental treaties and agreements. The Bank does not finance project activities that would contravene such country obligations, as identified during the EA." (emphasis added $A H W$ ) See Operational Policy (OP) 4.01 of January 1999 (updated March 2007) on Environmental Assesment, para. 3. 
livelihood of indigenous peoples, ${ }^{167}$ physical cultural heritage, ${ }^{168}$ and involuntary resettlement. ${ }^{169}$ In particular, the Operational Policy on indigenous peoples contains the only explicit reference to human rights available in the Bank's Operational Manual. In this Operational Policy the Bank acknowledges that in its mission to reduce poverty and aid in sustainable development it has to ensure "[...] that the development process fully respects the dignity, human rights, economies, and cultures of Indigenous Peoples." 170 Thus, it can be argued that the World Bank should take into account the human rights obligations ensuing from the human rights treaties to which borrowing countries have become a party.

A certain level of human rights protection can also be inferred from the fact that the Bank requires the borrowing states to engage in a process of free, prior and informed consultation for projects that affect indigenous peoples. ${ }^{171}$ The Bank will provide project financing only where this consultation results in broad community support for the project by the affected indigenous peoples. The projects eventually financed by the Bank must include measures to
“[...] (a) avoid potentially adverse effects on the Indigenous Peoples' communities; or (b) when avoidance is not feasible, minimize, mitigate, or compensate for such effects. Bank-financed projects are also designed to ensure that the Indigenous Peoples receive social and economic benefits that are culturally appropriate and gender and intergenerationally inclusive." 172

This could mean that when drafting or recommending privatization policies as part of a condition for financing a specific project that involves these topics, Bank staff will have to test whether their recommendations meet the requirements or fulfill the safeguards that are part of the guidelines. Arguably, a number of these safeguards could involve certain considerations related to human rights that may suffer an impact from the World Bank's projects that involve privatization, such as the right to a cultural identity, the right to health, the right to adequate housing, and the right

167 See Operational Policy (OP) 4.10 of July 2005 on Indigenous Peoples (replacing the original Operational Directive 4.20 on the same subject dated September 1991).

168 See Operational Policy (OP) 4.11 of July 2006 on Physical Cultural Resources, which are defined as "[...] movable or immovable objects, sites, structures, groups of structures, and natural features and landscapes that have archaeological, paleontological, historical, architectural, religious, aesthetic, or other cultural significance." Ibid., para. 1.

169 See Operational Policy (OP) 4.12 of December 2001 (updated in March 2007) on Involuntary Resettlement.

170 OP 4.10, para. 1. See also Feyter, "The International Financial Institutions and Human Rights Law and Practice," p. 15.

171 OP 4.10, para. 1. See also Bank Procedure (BP) 4.10 of July 2005, para. 2. A similar requirement is also present in OP 4.11 on Physical Cultural Resources, para. 11, and Bank Procedure (BP) 4.11 of July 2006, para. 7 and in OP 4.12 on Involuntary Resettlement, para. 13.

Operational Policy 4.10, para. 1. 
to water. Moreover, there is a requirement to consult those affected by these policies, which it may be argued is also an important human rights aspect. ${ }^{173}$

In sum, although strictly speaking IFIs are not formally bound by direct human rights obligations as found in the various (international) human rights treaties, there are various ways of distilling indirect human rights obligations that can and should be taken into consideration by them when devising and implementing their policies. It seems to appear that the IFIs, in particular the World Bank, are becoming more conscious of the relevance of human rights issues in their work. This development is encouraging, but it is still all too evident that human rights have yet to become an essential aspect in the work of the IFIs. As long as their constituent instruments do not reflect this, human rights considerations will remain a relevant, but not essential element in their decision making process.

\subsubsection{Practical accountability through internal auditing}

There is a practical way of putting into effect the nascent human rights conscience in the IFIs described in the previous paragraph. The Bank has created an independent three-member Inspection Panel that allows the submission of requests for inspection by private individuals aggrieved by a World Bank financed project. ${ }^{174}$ According to the Inspection Panel's Operating Procedures, its purpose is to provide people that are directly and adversely affected by a Bank-financed project,

"[...] with an independent forum through which they can request the Bank to act in accordance with its own policies and procedures. It follows that this forum is available when adversely affected people believe the Bank itself has failed, or has failed to require others, to comply with its policies and procedures, and only after

173 See for example, the UN CESCR's General Comment No. 4 on the right to adequate housing, paras. 8(a) and 12; General Comment No. 7 The right to adequate housing (Art. 11.1 of the Covenant): forced evictions, UN Doc. E/1998/22, annex IV, paras. 13 and 15; and General Comment No. 15 on the right to water, para. 56.

174 The Inspection Panel was established in 1993 through World Bank's Resolution No.93-10 of the Executive Directors establishing the Inspection Panel for the IBRD (22 September 1993) and Resolution No. 93-6 of the IDA (22 September 1993). According to Resolution No. 93-10, paragraph 13, the Inspection Panel has competence to receive a request for inspection from a party that considers " $[\mathrm{t}]$ hat its rights or interests have been or are likely to be directly affected by an action or omission of the Bank as a result of a failure of the Bank to follow its operational policies and procedures with respect to the design, appraisal and/or implementation of a project financed by the Bank (including situations where the Bank is alleged to have failed in its follow-up on the borrower's obligations under loan agreements with respect to such policies and procedures) provided in all cases that such failure has had, or threatens to have, a material adverse effect." See also Feyter, "The International Financial Institutions and Human Rights Law and Practice," p. 22. 
efforts have been made to ask Bank Management [...] itself to deal with the problem." 175

The World Bank's Inspection Panel together with the guidelines found in the Bank's Operational Manual could be seen as a practical way of ensuring indirect accountability for international law and human rights issues through an internal auditing process. It provides an important international remedy for those individuals or groups affected by projects financed by it. Although strictly speaking not a human rights tribunal, the Inspection Panel may take into consideration the social issues reflected in the Bank's operational guidelines and thus, albeit indirectly, human rights. De Feyter has observed that even though the Panel is not competent to establish violations of international law, including human rights law, nothing prevents the requesters from arguing that their human rights have been adversely affected by Bank action. ${ }^{176}$ The Panel has already handled a number of complaints that raised human rights issues and which garnered a substantive response from the Bank's management and the Inspection Panel. ${ }^{177}$ Even in cases in which human rights references are not explicit, it is still possible to read the findings of the Inspection Panel from a human rights perspective.

Indeed, in a recent case of particular interest to the present study, the Inspection Panel has been faced with a complaint related to the potential economic, social, cultural, environmental, and health effects of a water supply, sewerage and environmental management project in the city of Cartagena, Colombia. ${ }^{178}$ The project involved an expansion of the water supply and sewerage systems for Cartagena, the construction of a main wastewater conveyance system, of wastewater treatment installations, and of a submarine outfall off the coast of a town nearby that would discharge the wastewater in the ocean. The project was to be carried out

175 See Operating Procedures as adopted by the Panel, available at $<$ http://web.worldbank.org/ WBSITE/EXTERNAL/EXTINSPECTIONPANEL/0,,contentMDK:20175161 menuPK:641292 54 pagePK:64129751 piPK:64128378 theSitePK:380794,00.html> (last visited 1 May 2010). Feyter, "The International Financial Institutions and Human Rights - Law and Practice," p. 22.

177 Ibid. De Feyter has highlighted three such Panel reports: Inspection Panel, Report and recommendation on request for inspection on India: Ecodevelopment project (21 October 1998), Inspection Panel, Report and recommendation on request for inspection on Nigeria: Lagos drainage and sanitation project (6 November 1998), and Inspection Panel, Report and recommendation on request for inspection on Chad: Petroleum development and pipeline project (17 September 2000). In these instances, the complaints alleged violations of certain human rights that had taken place in the context of World Bank sponsored development projects, and these were considered "[...] in so far as they were related to Bank conduct under the relevant operational policies." ibid.

178 See Investigation Report, Colombia: Cartagena Water Supply, Sewerage and Environmental Management Project (Loan No. 4507-CO), Inspection Panel, Report No. 32034-CO, 24 June 2005. 
by the privatized water utility already serving the city of Cartagena, ACUACAR, with financial assistance from the World Bank. ${ }^{179}$

In 2004 a number of NGOs representing various groups of inhabitants living in the neighborhood of where the submarine outfall would be constructed filed a claim before the Inspection Panel alleging,

"[...] that the World Bank violated its own policies and procedures in the design, appraisal and implementation of the Colombia: Cartagena Water Supply, Sewerage and Environmental Management Project ("the Project"). The Request claimed that this violation caused and will cause harm to the communities living in areas north of the city of Cartagena and to human health and the marine environment."180

According to the complaint, the proposed submarine outfall would pollute the marine environment in the surrounding area. This would have adverse effects to the health of the people living there as well as their fishery and tourism activities, which were their primary sources of food and income. Complainants argued that in making the necessary assessments for the project, the World Bank had violated a number of its own policies and procedures. This included among others its Operational Directive on Environmental Assessment (OD 4.01), its Operational Policy on Natural Habitats (OP/BP 4.04), its Operational Policy on Water Resources Management (OP 4.07), and its Operational Directive on Indigenous Peoples (OD 4.20). With regard to the latter, it was argued that the Bank had failed to identify the affected communities of the area (composed of Afro-Colombians) as indigenous peoples and thus failed to prepare an Indigenous Peoples Development Plan (IPDP) as required by the Operational Directive to avoid and mitigate the Project's adverse impact on these communities.

The Inspection Panel approached the complaint by dividing it into four topics: environmental compliance, social compliance, economic compliance, and financial compliance. For the purposes of the present study, it is only necessary to focus on the first two topics. With regard to the claims dealing with the environmental assessment and impact on the natural habitat of the area and its inhabitants, the Panel found that even though the Project had complied with most of the requirements found in OD 4.01, including the exercise of due diligence in looking for alternative arrangements that might mitigate the effects of the Project, its potential effects on fishing in the area had not been adequately addressed during its preparation. ${ }^{181}$ In

179 ACUACAR is a private-public partnership between the municipality of Cartagena and Spanish water multinational Aguas de Barcelona. ACUACAR took over the public municipal water utility in 1995 with assistance of the World Bank through a \$ 150 million US Dollar loan (Loan 2961-CO) to finance the Colombia Water Supply and Sewerage Project.

180 See Inspection Panel, Report No. 32034-CO, p. 2.

181 See Inspection Panel, Report No. 32034-CO, p. 47. 
particular, the Panel noted that there was a lack of adequate social evaluation and mitigation proposals in relation to the impact of these effects on the local population's lives and livelihood. This specific aspect did not comply with OD 4.01.

On the issue of social compliance, the Panel stumbled upon the fact that the Bank Management had applied too strictly the criteria found in OD 4.20 to determine if an affected community can be considered as indigenous peoples. Although the group met most of the requirements found in OD 4.20 to be considered as indigenous peoples, the Bank's management nevertheless concluded that the Afro-Colombian population of the affected zone wer not indigenous peoples since they did not have an 'indigenous language' and a 'predominant primarily-oriented subsistence production'. The Panel disagreed with this strict interpretation of OD 4.20 and observed that no specialized anthropological and sociological experts were consulted in this decision contrary to what is required from the Operational Directive. ${ }^{182}$ It then noted that the policy indeed requires that all the criteria have to be met in order for the policy to be triggered. This led to the conclusion that,
"[...] in the case of the Afro-Colombians who submitted the Request, the affected community meets most of the OD's criteria, except for an 'indigenous language' and arguably a predominant 'primarily-oriented subsistence production.' The Panel finds that Afro-Colombians could reasonably have been regarded as indigenous peoples under Bank policies. But because of the absence of two of the policy criteria, the failure to do so in this specific case may not be deemed as noncompliance with the 'judgment' called for in OD 4.20, paragraph 5. If the Afro-Colombians were regarded as indigenous peoples, the provision of OD 4.20 would have applied." 183

As a consequence of the consideration that the Afro-Colombian community of the area affected were not indigenous peoples, the Bank did not undertake an Indigenous Peoples Development Plan (IPDP) or a similar document identifying impacts of the Project on these people and providing mitigation measures for risks and potential harm as required by OD 4.20. The Panel found that there had been no serious effort to come up with a complete list, schedule or financial arrangements of mitigating measures or compensation for the project's risks for the people living in the area of the proposed outfall, and that the ones which were in place were weak even though the risks were deemed to be significant. ${ }^{184}$ The Panel then concluded that "[s]ince the Afro-Colombians could reasonably have been regarded as indigenous peoples within the Indigenous Peoples policy, the Panel finds that the Bank would have been well advised to require an Indigenous Peoples Development Plan (IPDP) or a similar document identifying impacts of the Project on these people and providing mitigation measures for risks and potential harm, particularly in light of the

\footnotetext{
182 Ibid., p. 61.

183 Ibid., p. 62.

184 Ibid., p. 63.
} 
inadequacies of the Social Impact Assessment." 185 With regard to the latter the Panel observed that the Social Impact Assessment, which had been prepared in 1998, focused mostly on the positive social benefits of the project on the target population of the city of Cartagena, but failed to address in an adequate way the negative effects on the Afro-Colombian communities bearing the brunt of the risks of the sewerage outfall. In particular no adequate compensation had been considered for the negative effects. This led the panel to consider the Social Impact Assessment as unsatisfactory. ${ }^{186}$

The Bank's Management, however, contended that the Project would bring several benefits to the affected communities. Thus according to the Bank's Management, ACUACAR was going to construct piped water and sanitation services for the communities in accordance with OD 4.01, as well as ways to optimize the fishing activity of one of the affected communities. In addition a Social Impact Mitigation and Community Development Program had been developed which was going to be financed jointly with the borrower. This Program would offer, among other things, training and assistance to develop small productive activities in the affected areas. ${ }^{187}$ The Inspection Panel agreed that bringing piped water and sanitation services would be an improvement for the communities, in particular as piped water is cheaper and safer than the trucked water the communities used to receive, and commended the Project for this. ${ }^{188}$ The Panel also welcomed the initiative to provide compensation for the Afro-Colombian minorities, although it found that details about some of the compensation measures were not specific and that information about these compensatory measures had not been adequately disseminated to the villages. ${ }^{189}$ Nevertheless, the Panel noted that there appeared to be no direct relation between the benefits of the Project and the risks that people may be exposed to as a consequence of Project construction and operation. The Panel observed that

"[t]here is no graduated approach to compensate the population for - or mitigate the different risks as they materialize. For example, there are no social mitigation or compensatory measures in case of severe malfunction of the outfall that could lead to high presence of pathogens or other contaminants and/or a need to chlorinate the outfall discharge. This could affect the water quality near Punta Canoa and may affect people's health and their social and economic activities. In this sense, the proposed Social Impact Mitigation and Community Development Program seems to fall short in addressing the mitigation or compensation for harm related to potential adverse impacts of the Project as required by OD 4.01."190

\footnotetext{
185 Ibid.

186 Ibid., p. 66.

187 Ibid., p. 70-71.

188 Ibid., p. 71-72.

$189 \quad$ Ibid., p. 73.

190 Ibid.
} 
Furthermore, as the project required the connection of certain affected areas to the water and sewerage network, the Panel found that there had been no appropriate consultation with the affected communities, in particular on the issues of willingness to pay for the connection and the water tariffs. ${ }^{191}$

In response to the Panel's investigation report, the Bank's Management submitted in July 2005 its own report with recommendations, which included an Action Plan. ${ }^{192}$ According to the Bank's Management, several measures were adopted in the Action Plan to meet the Inspection Panel's recommendations. ${ }^{193}$ These included expanding the piped water, sanitation, and sewerage system by the privatized water company ACUACAR in the affected communities. The report also notes that ACUACAR has plans to complete a study on strengthening fishing activities of the population in the affected areas. Equally the company financed the establishment of a plant nursery in one of the affected towns which is to be managed cooperatively by the local community to create jobs and supply trees to be planted in the area in compliance with the conditions of the environmental license required by the Project. Management also committed itself to continue to work with ACUACAR to improve its efforts in addressing the communities' perceptions of the adverse impacts of the Project and better explain its overall benefits. ${ }^{194}$

The Inspection Panel's Annual Report for 2007 provides some follow-up information on the case. ${ }^{195}$ According to the 2007 Annual Report, the Bank's Management had submitted a progress report on the implementation of the Action Plan and observed that there has been additional consultation with the affected communities on the impact of the proposed outfall resulting in a change of its route to reduce some of its negative effects. ${ }^{196}$ ACUACAR had also been involved in helping the local fishing communities by providing training, and purchasing fishing equipment for them.

191 Ibid., p. 80. It is also worth observing that the Panel found that with regard to the economic aspects of the Project, in particular in the light of OD 4.15 on poverty reduction strategies, that there had been no proper consideration of the risks that the project entailed to the affected communities leading to non-compliance with said policy. In the eyes of the Panel, compliance "[...] would have meant giving greater and earlier attention to the risks to and concerns of these communities, whose willingness to accept the location and consequences of the outfall was key to the successful delivery of the potentially very substantial benefits intended for so many of Cartagena's other poor citizens." Ibid., p. 121.

192 See Management Report and Recommendation in Response to the Inspection Panel Investigation Report, Report No. 32034-CO, Colombia Cartagena Water Supply, Sewerage and Environmental Management Project (Loan No. 4507-CO), International Bank for Reconstruction and Development - International Development Association, 29 July 2005.

193 Ibid., p. 3. A detailed summary of the Action Plan can be found in the Management's Report, Ibid., p. 12-14 and its first Annex.

194 Ibid., p. 6.

195 See The Inspection Panel, Annual Report, July 1, 2006, to June 30, 2007, The International Bank for Reconstruction and Development/The World Bank, Washington D.C., (2007).

196 Ibid., p. 74. 
The proposed water supply system had been completed resulting in the provision of potable water for the communities.

The Panel's findings and subsequent follow-up reports in this particular case do not point directly to human rights concerns. However, it can be argued that the issues raised in the Cartagena Water Supply, Sewerage and Environmental Management Project complaint are very much related to human rights topics such as the right to health, the right to adequate housing, and in particular the right to family life as interpreted by the ECtHR with regard to environmental pollution and nuisance caused by private actors in cases such as the Lopez Ostra, Guerra, and Fadeyeva decisions discussed in Section 4.1.2 infra. These issues were handled in a practical way by the Panel. It addressed head on the main concerns of those affected by the activities of a privatized entity working in a World Bank financed project. In particular attention was paid to the potential effects of the Project on the livelihood, and health of affected communities as well as the presence or lack of consultation and appropriate compensatory measures for those affected. Arguably, its approach is similar to the ones favored by human rights monitoring bodies.

There are some caveats, however, to the use of the Inspection Panel. In the first place, the findings of the Inspection Panel are recommendatory in nature, so there are no actual means of enforcing the Panel's findings. In the second place, the procedure of the Panel itself does not provide for compensation to those negatively affected by the Bank's sponsored projects held to be not in conformity with the Bank's policies. ${ }^{197}$ Nevertheless, the Inspection Panel's procedure provides an important way of addressing the negative impact of the Bank's sponsored privatization projects. ${ }^{198}$ By holding the Bank accountable upon its own standards

197 Feyter, “The International Financial Institutions and Human Rights - Law and Practice,” p. 23.

198 Another, albeit failed, example of the potential use of the Inspection Panel to address the negative impact of privatization related projects can be found in the Panel's investigation of the Manila Second Sewerage Project. See Report and Recommendation on Request for Inspection, Philippines: Manila Second Sewerage Project (MSSP) (Loan No. 4019-PH), Inspection Panel, 25 November 2003. This request revolved around the potential effects to the environment of a World Bank sponsored project similar to the Cartagena one: the project proposed the expansion of a sewerage disposal and outfall facility by two privatized water companies serving Manila. The water services carried out by the original municipal water company of Manila had been privatized under the auspices of the World Bank in the early 1990's and delegated to two companies, Manila Water Company Inc. (MWCI) and Manyilad Water Services Inc. (MWSI) which operated in two different concession areas. The request for investigation alleged violation of, inter alia, Operational Directive OD 4.01 on Environmental Assessment because of the expected environmental impact of the project and Operational Policy and Bank Policy OP/BP 17.50 on Disclosure of Information because of the lack of consultation with the stakeholders and those affected by the project. In spite of generally agreeing with requesters, the Panel concluded that it could not investigate the matter because requesters had not fulfilled all the eligibility criteria to further consider the request. In particular requesters had failed to bring the subject matter to the Bank's Management attention and that Management had failed to respond 
through an internal audit, which can be started by individuals affected by the Bank's policies and activities, the Panel procedure exemplifies a practical way of dealing with issues of privatization as it affects human rights albeit indirectly.

Finally, another example of an internal auditing mechanism within international financial institutions is the Compliance Advisor/Ombudsman (CAO) available for projects funded by the International Financial Corporation and the Multilateral Investment Guarantee Agency (MIGA), the private sector lending bodies of the World Bank Group. The CAO was established in 1999 and its mandate is to address complaints presented by groups of individuals affected by IFC and MIGA projects, and to "enhance the social and environmental outcomes of IFC/MIGA projects."199 In this capacity the CAO was involved in assessing a complaint filed by local NGOs related to the privatized water utility in the city of Guayaquil, Ecuador, which had received MIGA funding in 2001.200 The International Project Water Services Guayaquil ("Interagua"), a company which was headed by Bechtel until 2008 was granted a 30 year concession in 1999 to operate the water and wastewater facilities of Guayaquil. Interagua received financial support through an \$18 million US Dollar MIGA guarantee in 2001 at the beginning of the concession. The concession was supposed to improve and expand the operation of the water utility and its quality, in particular in the poorest areas of the city. ${ }^{201}$ However, complaints started to arise with respect to the non-fulfillment of Interagua's obligations under the concession contract. The complaints filed in 2008 before the CAO argued that Interagua's operations had caused a range of social and environmental problems that affected the poorer communities of Guayaquil. ${ }^{202}$ The social complaints included:

"[...] repeated cuts of residential water without any additional supply regulations for water service; water cuts in residences of elderly and low-income people owing to their inability to pay; lack of service extension to specific neighborhoods, especially

adequately demonstrating that it had followed or had taken steps to follow the Bank's policies and procedures as required by rules governing the Panels procedures. See Report and Recommendation on Request for Inspection, Philippines: Manila Second Sewerage Project (MSSP), p. 12-14.

199 See CAO Operational Guidelines, p. 4 available at $<$ www.cao-ombudsman.org/about/whoweare/ documents/EnglishCAOGuidelines06.08.07Web.pdf> (last visited 20 July 2011).

200 See Ombudsman Assessment Report, Complaint Regarding MIGA's Involvement in International Water Services Project - Interagua, December 2008, Office of the Compliance Advisor/ Ombudsman International Finance Corporation/Multilateral Investment Guarantee Agency, p. 1, available at $<w w w . c a o-o m b u d s m a n . o r g /$ cases/document-links/links-84.aspx $>$ (last visited 20 July 2011).

201 Ibid., p. 3.

202 Ibid. 
low income residents; non-compliance of contractual obligations for the refurbishing and expansion of services." 203

The complainants further alleged that the privatization project did not comply with a number of norms imposed by MIGA on financed projects with respect to social, environmental and pollution prevention requirements. In addition, the complaints mechanism established by Interagua was not well known and ineffective to address the consumers' grievances with respect to the utility's operation. ${ }^{204}$ Finally, the complainants argued that "[...] access to water is a fundamental human right, and that no one should ever be denied the right to water for basic living needs because of an inability to pay." 205

The CAO's assessment started with visits to Ecuador and discussions with the parties to the dispute in an attempt to clarify the standing issues, facilitate communication between the parties, and assist them to find opportunities to solve the problem. This resulted in the drafting of a number of agreements in which a number of proposals were laid down to gradually solve the issues at hand through consultation and dialogue between the parties. The discussions involved issues such as debt forgiveness of consumers who had incurred debts vis-à-vis de concessionaire due to arrears in the payment of water bills, and ideas towards preventing disconnection of poor households from the water mains due to inability to pay. ${ }^{206}$ As a result, in November 2008 it was initially agreed to await the constitutional reform process Ecuador was going through at the time of the dispute to see if that would solve some of the problems of the dispute given the new constitution's stance towards the right to water and privatization of utilities. Interagua and the NGOs also agreed that the company would reconnect water service to those users that paid one of the outstanding water bills. Interagua would further suspend some of the debts and endeavor not to cut services as long as the outstanding water bills and future bills were paid, and to provide flexible payment agreements to certain category of users. Furthermore, it was agreed that Interagua would review 3500 outstanding complaints from the users represented by the NGOs together with the latter and seek solutions to them. ${ }^{207}$

203 Ibid. It is worth observing that the complaints were filed at a time in which Ecuador was undergoing a constitutional reform that led later in 2008 to the adoption of a new Constitution, which prohibited the privatization of water. See further Section 2.1.3 supra.

204 Ombudsman Assessment Report, Complaint Regarding MIGA's Involvement in International Water Services Project, p. 3 and 4.

205 Ibid., p. 4.

206 See Ombudsman Conclusion Report, Interagua Case Conclusion Report - January 2011, p. 2, available at <www.cao-ombudsman.org/cases/document-links/links-84.aspx $>$ (last visited 20 July 2011).

207 Ombudsman Assessment Report, Complaint Regarding MIGA's Involvement in International Water Services Project, p. 5. 
Further meetings between the $\mathrm{CAO}$ and the parties to the dispute led to subsequent agreements refining the initial 2008 agreement, resulting in a final agreement "[...] indicating steps that had been accomplished and issues that they would continue to work on." 208 One of the most interesting outcomes of this dialogue was the establishment of an Ombudsman Office within Interagua itself, which would deal in a more transparent way with complaints from users of the service. ${ }^{209}$ Although it was later reported that this Ombudsman Office was not sufficiently robust, lacked independence, and its was also not sufficiently publicized in order to allow it to work effectively, ${ }^{210}$ it was nonetheless regarded as an important mechanism to increase the transparency of the company's operations and the participation of users in issues affecting them. ${ }^{211}$ The Ombudsman's Conclusion Report notes that not all the problems were solved entirely, but that major inroads were done and both stakeholders continued the ongoing dialogue surmount the remaining issues. Arguably, and as observed by the report itself, the conflict resolution approach established through the participation of the $\mathrm{CAO}$, including active participation of stakeholders, is a model that could be followed in similar situations involving privatization of essential services. It also helps to maintain some sort of accountability of the financial institutions by granting them a central role in the mediation process of disputes between individuals or groups and private parties that have benefitted from financial assistance from those institutions.

\subsubsection{Obligations of business enterprises}

The position of business enterprises and multinational companies under international law, and the impact of their activities have not gone unnoticed since the Barcelona Traction case. ${ }^{212}$ Their increasing influence in the international arena and growing (economic) power has prompted a broad debate about whether business enterprises should possess international legal obligations and be held accountable for their international wrongful acts. The academic literature on this subject, in particular with regard to the human rights obligations and accountability of business enterprises, is vast. ${ }^{213}$ There are ongoing efforts at the international level to examine

\footnotetext{
208 Ombudsman Conclusion Report, Interagua Case Conclusion Report, p. 4.

209 Ibid.

210 Ibid., p. 6.

211 Ibid., p. 7.

212 Barcelona Traction, Light and Power Company Limited (Belgium v. Spain), ICJ Reports 1970.

213 See among others van Hoof, G.J.H, "International Human Rights Obligations for Companies and Domestic Courts: An Unlikely Combination?," in The Role of the Nation-State in the $21^{\text {st }}$ Century: Human Rights, International Organisations and Foreign Policy, Essays in Hounour of Peter Baehr, ed. M. Castermans-Holleman, van Hoof, G.J.H, and J. Smith, The Hague: Kluwer Law International (1998), p. 47-59; D. Weissbrodt, "Non-State Entities and Human Rights within the Context of the Nation-State in the $21^{\text {st }}$ Century," in The Role of the Nation-State in the $21^{\text {st }}$ Century: Human Rights, International Organisations and Foreign Policy, Essays in Hounour of Peter Baehr, ed. M. Castermans-Holleman, van Hoof, G.J.H, and J. Smith, The
} 
Issues of Doctrine

ways to "[...] provide more effective protection to individuals and communities against corporate-related human rights harm."214

Currently there is no general rule of international law stating that companies are responsible for their internationally wrongful acts. ${ }^{215}$ This is not to say that business enterprises are completely devoid of international legal obligations. Kamminga, for example, observes that some provisions found in a few multilateral treaties directly

Hague: Kluwer Law International (1998), p. 175-195; M.T. Kamminga, "Holding Multinational Corporations Accountable for Human Rights Abuses: A Challenge for the EC," in The EU and Human Rights, ed. P. Alston, Oxford: Oxford University Press (1999), p. 553-626; Liability of Multinational Corporations Under International Law; P.T. Muchlinski, "Human Rights and Multinationals: Is There a Problem?," International Affairs Vol. 71 (2001), p. 123-152; S.R Ratner, "Corporations and Human Rights: A Theory of Legal Responsibility," Yale Law Journal Vol. 111 (2001), p. 443-545; Jägers, Corporate Human Rights Obligations: In Search of Accountability; J.J. Paust, "Human Rights Responsibilities of Private Corporations," Vand. J. Transnat'l L. Vol. 35 (2002), p. 801-825; P.T. Muchlinski, "Human Rights, Social Responsibility and the regulation of international business: The development of international standards by intergovernmental organisations," Non-State Actors and International Law Vol. 3 (2003), p. p. 123-152; D. Weissbrodt and M. Kruger, "Norms on the Responsibilities of Transnational Corporations and Other Business Enterprises with Regard to Human Rights," A.J.I.L. Vol. 97 (2003); S. Deva, "UN's Human Rights Norms for Transnational Corporations and Other Business Enterprises: An Imperfect Step in the Right Direction?," ILSA Journal of International \& Comparative Law Vol. 10 (2004), p. 493-523; M.T. Kamminga, "Corporate Obligations Under International Law," in Report of the Seventy First Conference, Berlin: International Law Association (2004), p. 422; U. Baxi, "Market Fundamentalisms: Business Ethics at the Altar of Human Rights," Human Rights Law Review Vol. 5 (2005), p. 1-26; R.G. Steinhardt, "Corporate Responsibility and the International Law of Human Rights," in Non-State Actors and Human Rights, ed. P. Alston, Oxford: Oxford University Press (2005), p. 177-226; Clapham, Human Rights Obligations of Non-State Actors, p. 195-270; and D. Kinley and R. Chambers, "The UN Human Rights Norms for Corporations: The Private Implications of Public International Law," Human Rights Law Review Vol. 6 (2006), p. 447-497.

214 "Protect, Respect and Remedy: a Framework for Business and Human Rights," Report of the Special Representative of the Secretary-General on the issue of human rights and transnational corporations and other business enterprises, John Ruggie, UN Doc. A/HRC/8/5 (7 April 2008), para. 1. The mandate of the Special Representative of the Secretary-General on the issue of human rights and transnational corporations was established in 2005 through resolution 2005/69 of the UN's former Commission on Human Rights with a mandate "(a) To identify and clarify standards of corporate responsibility and accountability for transnational corporations and other business enterprises with regard to human rights; (b) To elaborate on the role of States in effectively regulating and adjudicating the role of transnational corporations and other business enterprises with regard to human rights, including through international cooperation; (c) To research and clarify the implications for transnational corporations and other business enterprises of concepts such as "complicity" and "sphere of influence"; (d) To develop materials and methodologies for undertaking human rights impact assessments of the activities of transnational corporations and other business enterprises; (e) To compile a compendium of best practices of States and transnational corporations and other business enterprises[...]" See UN Commission on Human Rights resolution 2005/69 of 20 April 2005, para. 1.

Kamminga, “Corporate Obligations Under International Law,” p. 423. 
impose obligations on companies. ${ }^{216}$ However, it would appear that under current international law, business enterprises have more rights than duties. This is evident with regard to a number of principles ensuing from bilateral (and multilateral) investment treaties and which are usually derived from the rules pertaining to the treatment of foreigners under the rules of the international responsibility of States. ${ }^{217}$ These rules usually require host States to respect foreign investment, avoid discriminatory practices against it, ${ }^{218}$ prevent expropriation of the assets of foreign companies without compensation, and thus by extension respect and protect the interests of business enterprises operating in those host States. Bilateral investment treaties have even gone so far as to establish particular dispute settlement remedies for companies, which feel negatively affected in their investments by governmental action amounting to breaches of the requirements described above, by allowing them to present claims before (ad-hoc) arbitration tribunals such as the ICSID, sometimes even bypassing the local court system. ${ }^{219}$

The presence of business enterprises in developing countries can be quite beneficial for the local economy. They help to increase foreign investment capital and contribute to improving employment opportunities. They also produce goods and provide services that may otherwise not have been offered, and they can also transfer new technologies that may be beneficial for society. Arguably, business enterprises have an important role to play in the development of the economies of poor countries. ${ }^{220}$ However, while acknowledging that business enterprises can positively contribute to the development of a country's economy and also that it is necessary for States to respect their rights against arbitrary governmental decisions

216 These are Article III of the 1969 Convention on Civil Liability for Oil Pollution Damage, which provides that "[...] the owner of a ship at the time of an incident, or where the incident consists of a series of occurrences at the time of the first such occurrence, shall be liable for any pollution damage caused by oil which has escaped or been discharged from the ship as a result of the incident [...]"; and Article $137 \S 1$ of the 1982 Convention on the Law of the Sea, which states that "[n]o State shall claim or exercise sovereignty or sovereign rights over any part of the Area or its resources, nor shall any State or natural or juridical person appropriate any part thereof. No such claim or exercise of sovereignty or sovereign rights nor such appropriation shall be recognized." ibid., p. 424.

217 For an overview of the increasing reliance on Bilateral Investment Treaties to regulate the legal relationship between international companies and host States see H. Mann, "International Investment Agreements, Business and Human Rights: Key Issues and Opportunities," International Institute for Sustainable Development/OECD Global Forum on International Investment, (2008).

218 This includes protecting against discrimination in favor of domestic investors, otherwise known as national treatment (that is provide foreign investors with treatment no less favorable than that which a domestic investor would receive), and protection against discrimination between foreign investors, also known as most favored nation treatment of foreign investors. See also ibid., p. 3-4. Ibid., p. $4-5$.

220 The Special Representative on human rights and transnational corporations also acknowledges this important role. See UN Doc. A/HRC/8/5 (7 April 2008), para. 2. 
affecting their investment, ${ }^{221}$ it is also unquestionable that they should not be allowed to do as they please. Experience in various (developing) countries with no strong regulatory capabilities but willing to attract foreign corporations to extract and commercialize their valuable natural resources, shows that the activity of business enterprises can also be harmful. ${ }^{222}$ As the next section will discuss, these experiences have in turn prompted extensive efforts to seek a concrete set of guidelines that may govern the conduct of their activities at the international level. This task, however, has proven complicated and thorny in spite of the initiatives taken by various actors at the international level. This is especially true with regard to whether business enterprises have human rights obligations and thus whether they have to take into consideration their potential impact on human rights when they are engaged in their primary activities, which are mainly of a commercial nature.

In addition to the issue of corporate obligations under international law and international human rights law, the question whether business enterprises can be held accountable for human rights abuses has been very much debated. ${ }^{223}$ Although there appears to be a general consensus that business enterprises should be held accountable for human rights abuses, it has not yet resulted in the adoption of hard international legal rules aimed at achieving this. This, however, does not entail a complete absence of attempts to hold mulitnational corporations accountable through law. In the United States for example, there is a growing practice of suing business enterprises under the Alien Torts Claims Act (ATCA), a 200-year old law that allows victims of human rights abuses to bring claims before a United States court in civil law cases. ${ }^{224}$

The question of the international legal obligations, and, more importantly, of the accountability for human rights abuses, of business enterprises is of importance to the present study. Although most of the privatization efforts of States will result in delegating former public functions, tasks or services to local private entities (usually business enterprises), business enterprises will also take over some of these activities. In some situations, it will not be the multinational company itself that has

221 Indeed, a calm national environment in which the rule of law and the respect of private property are held in high regard will help to attract foreign investment and companies, and bring the benefits described in the previous paragraph.

222 This has been the case of the presence of Shell in Nigeria and Unocal in Myanmar/Burma. See for example S. Skogly, "Complexities in Human Rights Protections: Actors and Rights Involved in the Ogoni Conflict in Nigeria," NQHR, Vol. 15 (1997), p. 52; Paust, "Human Rights Responsibilities of Private Corporations," p. 805.

223 See for example Kamminga, "Holding Multinational Corporations Accountable for Human Rights Abuses: A Challenge for the EC," and Jägers, Corporate Human Rights Obligations: In Search of Accountability; Steinhardt, "Corporate Responsibility and the International Law of Human Rights."

224 See further below for a brief discussion of the use of ATCA vis-à-vis multinational corporations. 
been entrusted with these functions or tasks, but a local concessionary or subsidiary. ${ }^{225}$ In any case, the scope of this study makes it necessary to briefly examine what are the international and human rights obligations, if any, of multinational corporate actors that engage in privatized activities. It is not the intention of the present author to go into all aspects of the discussion with regard to the international legal and human rights obligations of business enterprises as this has already been done in extenso by others. ${ }^{226}$ In the following paragraphs only a brief recapitulation of the most relevant issues at stake (legal obligations, regulatory efforts for corporate conduct, and the accountability of business enterprises for human rights abuses) will be presented with their relevance for the subject of this study.

\subsubsection{Legal obligations and regulatory efforts}

Assuming that business enterprises have limited legal personality under international law, 227 it can be argued that they can also have certain international obligations, albeit of a limited nature. As Kamminga has pointed out, and as briefly noted in the previous section, a number of international treaties place certain obligations on business enterprises operating in the field covered by those treaties. However, all international human rights treaties at present only address the State and none mention anything about the conduct of business enterprises. ${ }^{228}$ According to John Ruggie, the UN Special Representative of the Secretary-General on the issue of human rights and transnational corporations,

"[t]he root cause of the business and human rights predicament today lies in the governance gaps created by globalization - between the scope and impact of economic forces and actors, and the capacity of societies to manage their adverse consequences. These governance gaps provide the permissive environment for wrongful acts by companies of all kinds without adequate sanctioning or reparation.

225 For example, the privatized water utilities in Bolivia (Aguas del Tunari, which operated the failed Cochabamba water concession, and Aguas del Illimani, which operated the now rescinded water concession in the city of El Alto near La Paz) and in Argentina, (Aguas del Aconquija, Aguas Argentinas, ) were subsidiaries of a myriad of multinational water consortia including Suez, Vivendi, Aguas de Barcelona, and Bechtel.

226 See footnote 213. A good overview of the academic literature on the subject may be found in Jägers, Corporate Human Rights Obligations: In Search of Accountability. Furthermore, broad information about the efforts to consolidate the human rights obligations of multinational corporations, recent examples of good and bad practice of multinational corporate activity and evaluations thereof, may be found at $<w w w$.business-humanrights.org $>$.

227 As already stated in Chapter II, Section 4.3 the question whether multinational corporations have legal personality under international law is one which is still being debated.

228 It is worthy of note that the African Charter on Human and Peoples' Rights does include a set of duties that individuals have towards their family, society, the State and other legally recognized communities and the international community. See Articles 27-29 of the African Charter. 
Issues of Doctrine

How to narrow and ultimately bridge the gaps in relation to human rights is our fundamental challenge."229

Attempts to narrow these gaps have been conducted by trying to identify the legal and human rights obligations of business enterprises in the sphere in which they operate by other means. Jägers, for example, argues that in spite of the lack of direct references to business enterprises in human rights treaties, it is still possible to derive from a number of rights a set of obligations based on the tripartite obligations to respect, protect, and fulfill. ${ }^{230}$ In addition, Jägers argues that there is an additional obligation that should cover some situations which the tripartite set of obligations do not address: a duty not to cooperate and would apply to corporations operating in States that are engaged in serious human rights violations. ${ }^{231}$ This duty would require corporations to withdraw their operations from those States or adopting the necessary measures to ensure it does not unintentionally take part in human rights violations.

Other efforts have focused in establishing obligations through the adoption of 'soft law' regulatory initiatives under the banner of Corporate Social Responsibility (CSR). ${ }^{232}$ In general, it is possible to distinguish between general initiatives envisaged by international or regional organizations, self-regulation initiatives originating from the corporate world itself, and initiatives emanating from civil society together with several companies. The United Nations' Global Compact, ${ }^{233}$ the International Labor Organization's (ILO) Tripartite Declaration of Principles Concerning Multinational Enterprises and Social Policy, ${ }^{234}$ the Organization for Economic Co-operation and Development's (OECD) Declaration on International

229 UN Doc. A/HRC/8/5 (7 April 2008), para. 3.

230 Jägers, Corporate Human Rights Obligations: In Search of Accountability, p. 79-92. For a discussion on the content of the tripartite obligations to respect, protect, and fulfill see Section 4.1.3 infra.

231 Ibid., p. 92.

232 For an overview of the development of CSR in general see R. Jenkins, "Globalization, Corporate Social Responsibility and poverty," International Affairs Vol. 81 (2005), p. 525-540.

233 The Global Compact is an initiative of the UN's Secretary General launched in 2000. The Compact contains a set of principles in the areas of human rights, labor standards and the environment designed to promote responsible corporate behavior. The Secretary General encouraged business corporations to join the compact to help promote the principles. In the meantime, more than one thousand corporations have joined the initiative. Business corporations may voluntarily join the initiative. The principles are not legally binding and there is no monitoring or enforcement mechanism to control whether corporations live up to them. See $<$ www.unglobalcompact.org $>$ for more information on the Global Compact.

234 See ILO Tripartite Declaration of Principles Concerning Multinational Enterprises and Social Policy (1977), available at $<$ www.ilo.org/empent/Publications/WCMS 094386/lang--en/index. $\mathrm{htm}>$. The Tripartite Declaration provides a number of offer guidelines to multinational corporations, governments, and employers' and workers' organizations in a number of fields including employment, training, conditions of work and life, and industrial relations. According to the Tripartite Declaration, their aim "[...] is to encourage the positive contribution which 
Investment and Multinational Enterprises and the OECD's Guidelines for Multinational Enterprises, ${ }^{235}$ and the European Union's European Framework for Corporate Social Responsibility ${ }^{236}$ are examples of the first. The Levi Strauss \& Co. Global Sourcing and Operating Guidelines and Reebok's Human Rights Program are examples of corporate initiatives for self-regulation in the apparel industry. ${ }^{237}$ We already observed in Chapter II that several companies that operate in certain sectors that have been subjected to privatization have adopted voluntary codes of conduct. ${ }^{238}$ Thus several private military and security companies have formed the International Peace Operations Association (IPOA), and drafted a voluntary code of conduct that encourages them to "[...] follow all rules of international humanitarian law and human rights law that are applicable as well as all relevant international protocols and conventions[...]"239 A similar effort has been endeavored by a group of British private military and security companies, which in 2006 established the British Association of Private Security Companies (BAPSC)

multinational enterprises can make to economic and social progress and to minimize and resolve the difficulties to which their various operations may give rise [...]" They were revised in 2006.

235 See OECD Declaration on International Investment and Multinational Enterprises (1976), available at <www.oecd.org/document/53/0,3343,en_2649_34887_1933109_119672_1_1_1,00. $\mathrm{html}$. The OECD Declaration is mainly a policy commitment by the OECD's member states (as well as a small number of non-member states which have affiliated themselves to the initiative) to recommend and encourage multinational enterprises to adopt practices that can contribute to economic and social progress and minimize and resolve difficulties that may arise from their operations. The Declaration consists of a number of elements, the most relevant of which for the current discussion are the Guidelines for Multinational Enterprises. The Guidelines contain a set of voluntary recommendations addressed to multinational corporations in the areas of, inter alia, business ethics, including employment and industrial relations, human rights, environment, and combating bribery. Member governments of the OECD have committed to promote them among multinational enterprises operating in or from their territories. Under the Guidelines, participant States have to set up National Contact Points (NCPs) which are tasked at monitoring national implementation of the Guidelines. These NCPs are expected to handle enquiries, discuss matters related to the Guidelines, and provide assistance in solving problems related to these matters. According to a decision of the OECD Council establishing the NCPs, the latter should provide a forum to resolve these problems through non-judicial means such as offering good services, mediation or conciliation. See OECD Guidelines and appended OECD Council decision in OECD Guidelines for Multinational Enterprises, Recommendations for Responsible Business Conduct in a Global Context, OECD Ministerial Meeting, 25 May 2011, p. 69-70, available at $<$ www.oecd.org/dataoecd/43/29/48004323.pdf $>$. For an example of an intervention of an NCP in an actual problem involving a multinational corporation see J.L. Cernic, Global Witness v. Afrimex Ltd.: Decision Applying OECD Guidelines on Corporate Responsibility for Human Rights, ASIL Insights, Vol. 13, 23 January 2009 available at <www.asil.org/ insights090123.cfm $>$ (last visited 20 July 2011). See European Framework for Corporate Social Responsibility, Green Paper (2001).

237 See <www.levistrauss.com/library/levi-strauss-co-global-sourcing-and-operating-guidelines-0 and www.reebok.com/Static/global/initiatives/rights/home.html> respectively (last visited on 10 May 2010).

238 See Chapter II, Section 4.3.

239 See the preamble of the International Peace Operations Association Code of Conduct Version 11, available at $<\mathrm{http}$ ://ipoaworld.org/eng/codeofconduct.html $>$ (last visited 10 May 2010). 
and have drafted a code of practice. ${ }^{240}$ Finally, the Voluntary Principles on Security and Human Rights is an example of initiatives from civil society and business enterprises with a particular emphasis on the use of security arrangements of companies mainly in the extractive industries. ${ }^{241}$ Currently, there are attempts to make these Voluntary Principles relevant to the activities of private security companies providing security arrangements for companies, in particular in the extractive sector. ${ }^{242}$ At the time of this writing, seven governments and seventeen companies from the oil and mining sectors were participating under the Voluntary Principles. ${ }^{243}$ Under these principles, Governments are acknowledged to have the primary responsibility to promote and protect human rights. Participating companies, on the other hand, have to recognize the importance of acting in a way that respects local law and international law standards. To this end companies relying on security arrangements by either public or private security forces have to conduct an assessment of the human rights risks that are associated with security in their operations. They are also expected to engage with public and private security actors. This includes carrying out screenings of private security companies, organize trainings for them where necessary, and develop some form of reporting and investigating allegations of human rights abuses by the actors providing security. However, although the Voluntary Principles provide a set of guidelines for private security providers, ${ }^{244}$ there are no clear indications as to how successful the suggested engagement with private security companies has been, ${ }^{245}$ and it would appear that given the list of participants, no private security companies are actively taking part or are allowed to participate in this initiative.

240 Bearpark and Schulz, "The Regulation of the Private Security Industry and the Future of the Market," p. 247.

241 See <www.voluntaryprinciples.org/> (last visited on 12 August 2010).

242 See Report of the Special Representative of the Secretary-General on the issue of human rights and transnational corporations and other business enterprises, John Ruggie, Business and human rights: mapping international standards of responsibility and accountability for corporate acts, UN Doc. A/HRC/4/35 (19 February 2007), paras. 59-60.

243 See $<w w w . v o l u n t a r y p r i n c i p l e s . o r g / p a r t i c i p a n t s />$ (last visited on 12 August 2010).

244 See $<$ www.voluntaryprinciples.org/principles/private_security $>$ (last visited on 12 August 2010).

245 A summary report on the activities carried out by the participants of the Voluntary Principles provide examples of promotion of the principles in various countries, and how companies in the extractive sector are carrying out screenings of private security companies and including Voluntary Principles considerations in the contracts with private security companies. See Summary Report of the Voluntary Principles Implementation Efforts 2009, Voluntary Principles on Security and Human Rights, available at $<$ www.voluntaryprinciples.org/files/Vps_Summary_ Report_March_10_2010_.pdf $>$ (last visited on 12 August 2010). However, the report does not include any actual effectiveness assessment or overview of achievements or challenges, aside from a brief list of lessons learned and recommendations. 
Many corporations have urged for self-regulation as the most efficient and business friendly way to deal with the (human rights) problems created by their conduct. ${ }^{246}$ It has been argued, however, that these voluntary efforts may not be sufficient and calls have been made to design legal or semi-legal binding standards against which the conduct of business enterprises can be measured. ${ }^{247}$ Another, if seemingly ineffective effort to provide a set of rules/guidelines geared towards establishing obligations for corporate behavior has been the drafting of the "Norms on the Responsibilities of Transnational Corporations and Other Business Enterprises with Regard to Human Rights' by the UN Sub-Commission on the Promotion and Protection of Human Rights (the Norms). ${ }^{248}$ Hailed as "[...] the first nonvoluntary initiative accepted at the international level[,]"249 the Norms recognized that States have the primary responsibility in the promotion, protection and respect of human rights. However, States were also to ensure that business enterprises respect human rights. On the other hand the Norms stated that these corporations have an obligation to promote, secure the fulfilment of, respect, ensure respect of and protect human rights (including those of indigenous peoples and other vulnerable groups, within their respective spheres of activity and influence. ${ }^{250}$

The Sub Commission's Norms are not a legally binding 251 and were subject to criticism. Thus it was argued that they still "[...] fall short of what is required for evolving an effective international regulatory regime of corporate human rights responsibility." ${ }^{252}$ After a cold reception by the business community, the former UN Human Rights Commission put them on hold at its $61^{\text {st }}$ Session in 2005, when it

246 See S. Joseph, "An Overview of the Human Rights Accountability of Multinational Enterprises," in Liability of Multinational Corporations Under International Law, ed. M.T. Kamminga and S. Zia-Zarifi, The Hague: Kluwer Law International (2000), p. 82.

247 See M.T. Kamminga and S. Zia-Zarifi, "Introduction," ibid.), p. 9-10, and C. Avery, "Business and Human Rights in a Time of Chane," in Liability of Multinational Corporations Under International Law, ed. M.T. Kamminga and S. Zia-Zarifi, The Hague: Kluwer Law International (2000), p. 57-58. See also "Beyond Voluntarism: Human Rights and the Developming International Legal Obligations of Companies," International Council on Human Rights Policy, 2002, Versoix, Switzerland.

248 See 'Norms on the Responsibilities of Transnational Corporations and Other Business Enterprises with Regard to Human Rights,' Sub-Commission on the Promotion and Protection of Human Rights, UN Doc. E/CN.4/Sub.2/2003/12/Rev.2 (26 August 2003).

249 Weissbrodt and Kruger, "Norms on the Responsibilities of Transnational Corporations and Other Business Enterprises with Regard to Human Rights," p. 903.

250 Norms on the Responsibilities of Transnational Corporations and Other Business Enterprises with Regard to Human Rights,' Ibid., para. 1.

251 Indeed, the former UN Commission on Human Rights affirmed in its decision 2004/116 on Responsibilities of transnational corporations and related business enterprises with regard to human rights of 20 April 2004 that the Norms, being a draft proposal, did not have any legal standing.

252 Deva, "UN's Human Rights Norms for Transnational Corporations and Other Business Enterprises: An Imperfect Step in the Right Direction?," p. 495. See also D.F. Vagts, "The UN Norms for Transnational Corporations," Leiden Journal of International Law Vol. 16 (2003), 
requested the UN High Commissioner on Human Rights to appoint a Special Representative on human rights and transnational corporations. ${ }^{253}$ In his interim report for 2006, the UN Special Representative, argued that the Norms' "[...] exaggerated legal claims and conceptual ambiguities created confusion and doubt even among many mainstream international lawyers and other impartial observers." 254 According to Ruggie, there are two issues of concern regarding the Norms. In the first place, the Norms' claims of their nonvoluntary nature are problematic because they attempt to assert that State based human rights instruments are binding on corporations, even though this assertion has little authoritative basis in internatioal law. ${ }^{255}$ The values proposed by the Norms are mere legal aspirations, de lege ferenda. In the second place, the Norms attempt to allocate and differentiate human rights responsibilities between States and corporations. Thus according to Ruggie, the Norms "[...] articulate no actual principle for differentiating human rights responsibilities based on the respective social roles performed by States and corporations." 256 Ruggie is particularly concerned that a lack of differentiation in the allocation of these responsibilities under the Norms could result in a situation in which corporations would end up excersising these responsibilities when States are unable or unwilling to act, ${ }^{257}$ something that in the context of the present study would be akin to privatizing the role of the State with regard to human rights promotion, securement and fulfillment. To him this would be particularly troublesome because business enterprises are not democratic institutions. In the words of the Special Representative, making companies,

"[...] co-equal duty bearers for the broad spectrum of human rights - and for 'the obligation to promote, secure the fulfilment of, respect, ensure respect and protect' those rights, as the General Obligations of the Norms put it - may undermine efforts to build indigenous social capacity and to make Governments more responsible to their own citizenry." 258

p. 795-802; Ruggie, "Business and Human Rights: The Evolving International Agenda,” p. 819840.

253 See Report of the United Nations High Commissioner on Human Rights on the responsibilities of transnational corporations and related business enterprises with regard to human rights, UN Doc. E/CN.4/2005/91 (15 February 2005), and UN Commission on Human Rights Resolution 2005/69 of 20 April 2005. See also Kinley and Chambers, "The UN Human Rights Norms for Corporations: The Private Implications of Public International Law," p. 449.

See Interim report of the Special Representative of the Secretary-General on the issue of human rights and transnational corporations and other business enterprises, UN Doc. E/CN.4/2006/97 (22 February 2006), para. 59.

255 Ibid., paras. 59-65.

256 Ibid, para. 66. The Special Representative then goes on to observe that "[...] in several instances, and with no justification, the Norms end up imposing higher obligations on corporations than on States by including as standards binding on corporations instruments that not all States have ratified or have ratified conditionally and even some for which States have adopted no international instrument at all." Ibid.

Ibid. 
Ruggie concludes that the Norms' flaws obscure the discussions and cooperation between business, civil society, governments, and international organizations with respect to human rights. Ruggie's concerns, are in general directed mainly towards efforts to make business enterprises responsible for a list of human rights and towards efforts to accord them the same range of responsibilities as States in the areas where these companies have influence. He believes this is not the most approapriate way to approach the issue since the operations of MNCs can affect virtually all internationally recognized rights, ${ }^{259}$ and argues that,

"[...] any limited list will almost certainly miss one or more rights that may turn out to be significant in a particular instance, thereby providing misleading guidance. At the same time, as economic actors, companies have unique responsibilities. If those responsibilities are entangled with State obligations, it makes it difficult if not impossible to tell who is responsible for what in practice."260

In an attempt to tackle these concerns, Ruggie has proposed a new paradigm to deal with the issue of MNCs and human rights by addressing the specific responsibilities of companies in relation to all rights they may impact. In his 2008 report, Ruggie suggested a framework based upon three premises. Firstly, States have a duty to protect against human rights abuses by third parties. Secondly, (multinational) corporations have a duty to respect human rights. Finally, the victims of human rights abuses need more effective access to remedies. This framework to 'protect, respect, and remedy' calls for human rights treaty bodies to "[...] play an important role in making recommendations to States on implementing their obligations to protect rights vis-à-vis corporate activities." $261 \mathrm{He}$ also calls for revision and update of the OECD Guidelines for Multinational Enterprises, which according to him need to provide greater detail to keep pace with the voluntary codes of practice that many companies have established.

Expanding on his proposed framework, and after wide consultation with various stakeholders including States, multinational companies and non-governmental organizations, Ruggie drafted the 'Guiding Principles on Business and Human Rights' which were formally presented in his report to the UN Human Rights Council in March 2011. ${ }^{262}$ The Guiding Principles contain further refinements to the protect, respect, and remedies elements developed by Ruggie. According to

259 See Protect, Respect and Remedy: a Framework for Business and Human Rights, Report of the Special Representative of the Secretary-General on the issue of human rights and transnational corporations and other business enterprises, John Ruggie, UN Doc. A/HRC/8/5 (7 April 2008), para. 6. Ibid.

261 Ibid, para. 43.

262 See Report of the Special Representative of the Secretary-General on the issue of human rights and transnational corporations and other business enterprises, John Ruggie, Guiding Principles on Business and Human Rights: Implementing the United Nations "Protect, Respect and 
Ruggie's report the Guidelines are not intended to introduce new legal obligations for MNCs. ${ }^{263}$ Rather they aim at elaborating existing standards to clarify the obligations of States with respect to the conduct of these companies and encourage the latter to take human rights into consideration in their activities. In clarifying the State's obligation to protect, the Guidelines require States to enforce laws aimed at or requiring companies to respect human rights, and encourage or require business enterprises to communicate how they address the impact of their activities on human rights. ${ }^{264}$ Of particular interest for the present study, Principle 5 requires States to

"[...] exercise adequate oversight in order to meet their international human rights obligations when they contract with, or legislate for, business enterprises to provide services that may impact upon the enjoyment of human rights."265

In the commentary to this Principle, Ruggie observes that States which privatize "[...] the delivery of services that may impact upon the enjoyment of human rights[,]" do not abdicate their international human rights obligations, ${ }^{266}$ thus echoing what other international and regional human rights bodies have already observed with respect to privatization (See further Chapter IV and V).

With regard to the respect element, the Guiding Principles stipulate that business enterprises should avoid infringing on the human rights of others and address adverse human rights impacts of their activities. ${ }^{267}$ The commentary to this Principle refers to a responsibility of business enterprises to respect human rights, instead of a proper legal obligation. According to Ruggie's commentary this responsibility entails a global standard applying to enterprises operating everywhere and exists independently from the States" "[...] abilities and/or willingness to fulfil their own human rights obligations, and does not diminish those obligations." 268 From the wording of the Principles and their commentary it would appear that currently this is the furthest international human rights law can be taken in terms of attempting to apply human rights obligations directly to private actors. Given the state-centered nature of international law, this realistic approach is probably the

Remedy" Framework, Human Rights Council UN Doc. A/HRC/17/31 (21 March 2011) (hereinafter referred to as the 'Guiding Principles').

Ibid., para. 14: "The Guidelines Principles' normative contribution lies not in the creation of new international law obligations but in elaborating the implications of existing standards and practices for States and businesses; integrating them within a single, logically coherent and comprehensive template; and identifying where the current regime falls short and how it should be improved."

See Principle 3, ibid., p. 8.

Ibid., p. 10.

Ibid.

Principle 11, ibid., p.13.

Ibid. 
closest MNCs can be asked to comply with human rights. In terms of what human rights should be respected by business enterprises, the Principles note that the International Bill of Human Rights and the principles concerning fundamental rights set out in the International Labour Organization's Declaration on Fundamental Principles and Rights at Work are the minimal standards applicable. ${ }^{269}$

Since the Principles do not impose legal obligations on MNCs, what is then expected then from them under this initiative? In the first place, business enterprises are expected to adopt policies and processes to underline their commitment to respect human rights. This includes having operational policies and procedures that are not only known throughout the enterprise, but also to the outside public. ${ }^{270}$ In addition, the Principles require business enterprises to establish due diligence processes "[...] identify, prevent, mitigate and account for how they address their impacts on human rights[,]" and processes that help to the redress any adverse human rights impacts business enterprises directly cause through their conduct or to which they contribute. ${ }^{271}$ Business enterprises are thus be expected to draft human rights impact assessments to guide their activities as part of their human rights due diligence, ${ }^{272}$ and engage in risk assessments. ${ }^{273}$

In terms of the remedy aspect of the approach outlined by Ruggie, States have a duty to set up effective judicial and non-judicial remedies, although the Principles allow for the possibility of non-State based non-judicial remedies. With respect to the judicial remedies, States are under an obligation to ensure their " [...] impartiality, integrity and ability to accord due process." ${ }^{274}$ Furthermore, they should be accessible. According to the commentary, non-judicial remedies complement and supplement judicial remedies and should meet a number of requirements to make them effective. These include legitimacy, accessibility, predictability, transparency, and compatibility with human rights. ${ }^{275}$ In addition these mechanisms should be geared towards dialogue and engagement with stakeholders. ${ }^{276}$

In contrast to the Sub-Commission's Norms, the Guiding Principles have enjoyed broader acceptance from States and MNCs. ${ }^{277}$ This led to their adoption by

\footnotetext{
269 Principle 12, ibid.

270 Principle 15, ibid., p. 15.

271 Ibid.

272 See Principle 17, ibid., p. 16.

273 See Principle 18, ibid., p. 17.

274 See Principle 26 and respective commentary, ibid., p. 23.

275 See Principle 31, ibid., p. 26.

276 See further Section 4.3 below on remedies and privatization.

277 See J.H. Knox, The Human Rights Council Endorses "Guiding Principles" for Corporations, ASIL Insights, Vol. 15, 1 August 2011, available at <www.asil.org/insights110801.cfm> (last visited on 8 August 2011).
} 
consensus in the Human Rights Council on 16 June 2011,278 which has been regarded as opening "[...] a new chapter in the continuing effort to bring human rights law to bear on corporations." 279 Given their freshness, however, it is too early to pass any judgment on whether the Guiding Principles will be successful in enhancing MNCs compliance with human rights norms. In any case, it is possible to state that they will contribute to the growing efforts to bring business enterprises to account for eventual conduct contrary to human rights.

In sum, there have been various attempts to clarify the content of the legal obligations of business enterprises with regard to human rights. In practice, however, the efforts to take practical steps to apply these obligations in real life have not enjoyed much success. These obligations are still regarded as de lege ferenda, and as such do not have more than moral value. This does not take away the fact that existing initiatives such as codes of practice and Ruggie's suggested approach attempt to 'pierce the corporate veil' for human rights abuses are making further inroads.

\subsubsection{The search for accountability}

As observed above, the issue of corporate accountability for violations of international law and in particular human rights abuses is a much-discussed issue. In a number of cases against German companies during the Nuremberg war crimes tribunals held that the directors of these companies could be held accountable for committing war crimes. ${ }^{280}$ Although in the I.G. Farben Trial the case was focused in trying twenty-two officials of the I.G. Farben company and the latter was not indicted, it was alleged that the officials had acted " $[\ldots]$ 'through the instrumentality of Farben and otherwise'[...]"281 Thus, the US Military Tribunal in Nuremberg held with respect to the company, the Tribunal held that

"[i]t is appropriate here to mention that the corporate defendant, Farben, is not before the bar of this Tribunal and cannot be subjected to criminal penalties in these proceedings. We have used the term "Farben" as descriptive of the instrumentality of cohesion in the name of which the enumerated acts of spoliation were committed. But corporations act through individuals and, under the conception of personal individual guilt to which previous reference has been made, the prosecution, to

278 See Human rights and transnational corporations and other business enterprises, Human Rights Council resolution, UN Doc. A/HRC/RES/17/4 (6 July 2011).

279 Knox, The Human Rights Council Endorses "Guiding Principles” for Corporations.

280 See further A. Clapham, "The Question of Jurisdiction Under International Criminal Law Over Legal Persons: Lessons from the Rome Conference on an International Criminal Court," in Liability of Multinational Corporations Under International Law, ed. M.T. Kamminga and S. Zia-Zarifi, The Hague: Kluwer Law International (2000), p. 166-171.

281 The I.G. Farben Trial, Case No. 57, US Military Tribunal, Nuremberg, 14 August 1947 - 29 July 1948, Law Reports of Trials of War Criminals, Vol. X, p. 1. 
discharge the burden imposed upon it in this case, must establish by competent proof beyond a reasonable doubt that an individual defendant was either a participant in the illegal act or that, being aware thereof, he authorized or approved it. Responsibility does not automatically attach to an act proved to be criminal merely by virtue of a defendant's membership in the Vorstand. Conversely, one may not utilize the corporate structure to achieve an immunity from criminal responsibility for illegal acts which he directs, counsels, aids, orders, or abets." 282

In other words, the criminal responsibility of the company officials flowed from their activities in the corporation, which served as the 'instrument' to carry out certain war crimes. According to Clapham, although I.G. Farben itself was not indicted and held accountable, by finding that the officials of the company were members of an industrial organization that was connected with the commission of a war crime, the Tribunal appears to have implied that the company itself had committed the war crime. ${ }^{283}$

Aside from the foregoing, at the international level there have been no official initiatives to properly subject business enterprises to account for their activities, in particular with regard to human rights abuses. In some jurisdictions, national legislation has made it possible to file civil legal actions against business enterprises for violations of international norms. This is the case of the United States Alien Tort Claims Act (ATCA). ATCA is a 200-year old statute that allows individuals to bring civil claims before a United States court "[...] for a tort only, committed in violation of the law of nations or a treaty of the United States." 284 Under ATCA various

282 The Farben Case, Trials of War Criminals Before the Nuernberg Military Tribunals Under Control Council Law No. 10, Nuernberg October 1946 - April 1949, Vol. VIII, p. 1153.

283 Clapham, "The Question of Jurisdiction Under International Criminal Law Over Legal Persons: Lessons from the Rome Conference on an International Criminal Court," p. 170.

284 See 28 U.S.C. $\$ 1350$ (1982). The first case to have used the ATCA as a way of enforcing international human rights through litigation in the U.S. was the seminal case of Filártiga $v$. Peña Irala, 630 F. 2d 876 (2d Cir., 1980). For a general discussion of the use of the ATCA in the U.S. see A. Bianchi, "International Law and US Courts: the Myth of Lohengrin Revisited," EJIL Vol. 15 (2004), p. 777-779. Particular attention with regard to ATCA as applied to the conduct of multinational corporations can be found in B. Stephens, "Corporate Accountability: International Human Rights Litigation Against Corporations in US Courts," in Liability of Multinational Corporations Under International Law, ed. M.T. Kamminga and S. Zia-Zarifi, The Hague: Kluwer Law International (2000), p. 209-229; M. Swan, "International Human Rights Tort Claims and Experience of the United States Courts: An Introduction to the US Case Law, Key Statutes and Doctrine," in Torture as Tort, ed. C. Scott, Oxford: Hart Publishing (2001), p. 65-107; J. Terry, "Taking Filártiga on the Road: Why Courts Outside the United States Should Accept Jurisdiction Over Actions Involving Torture Committed Abroad," in Torture as Tort, ed. C. Scott, Oxford: Hart Publishing (2001), p. 109-133; P.I. Blumberg, "Asserting Human Rights Against Multinational Corporations Under United States Law: Conceptual and Procedural Problems," The American Journal of Comparative Law Vol. 50 (2002), p. 493-529; Paust, "Human Rights Responsibilities of Private Corporations," p. 802-809; J.M. Chanin, "The Regulatory Grass Is Greener': A Comparative Analysis of the Alien Tort Claims Act and the 
business enterprises have been sued before U.S. district courts for tortious behavior amounting to alleged breaches of international environmental law and international human rights treaties. ${ }^{285}$ The results so far have been mixed. Only a few cases against multinationals have actually been successful, and in many occasions the U.S. courts have turned the cases down sometimes declaring that they have no jurisdiction over the case on the grounds of forum non-conveniens, ${ }^{286}$ and sometimes concluding that the alleged conduct did not amount to a breach of the law of nations. In addition, many of the cases have concerned corporate complicity with State actors for aiding and abetting the latter in governmental violations of international law norms, ${ }^{287}$ and not direct liability of the corporations themselves. Nevertheless, the use of ATCA to attempt to hold corporations accountable for human rights abuses is regarded by the author of the present study as a positive step towards a more fully developed concept of international corporate accountability. In fact, in one of the earlier ATCA cases against corporations, the district court deciding the case observed that "[n]o logical reason exists for allowing private individuals and corporations to escape liability for universally condemned violations of international law merely because they were not acting under color of law." 288

This positive outlook on the potential applicability of international law norms on corporations under the ATCA was recently disputed by the US Court of Appeals of the Second Circuit in a case against Royal Dutch Petroleum. ${ }^{289}$ The case involved a claim by Nigerian citizens that "[...] Dutch, British, and Nigerian corporations engaged in oil exploration and production aided and abetted the Nigerian government in committing violations of the law of nations." 290 According to the judge presiding the case, the main legal issue in the case was whether the jurisdiction

European Union's Green Paper on Corporate Social Responsibility," Ind. J. Global Legal Stud. Vol. 12 (2005), p. 745-778; and Clapham, Human Rights Obligations of Non-State Actors, p. 252-263 and 443-447.

285 See for example, Iwanowa v. Ford Motor Co., 67 F. Supp. 2d 424 (D.N.J. 1999), Wiwa v. Royal Dutch Petroleum Co., 226 F.3d 88, 103 (2d Cir. 2000), Doe I v. Unocal, 395 F.3d 932, 949 (9th Cir. 2002), Aguinda v. Texaco, Inc., 303 F.3d 470 (2d Cir. 2002), Flores v. S. Peru Copper, 343 F.3d 140, 156 (2d Cir. 2003), and more recently, Vietnam Association for Victims of Agent Orange/Dioxin v. Dow Chemical Co., US Federal.ca2 Federal Circuits, Second Circuit (February 22, 2008), Docket number: 05-1953 (available through <http://vlex.com/vid/35895336>, last visited on 20 May 2008).

286 Blumberg, "Asserting Human Rights Against Multinational Corporations Under United States Law: Conceptual and Procedural Problems," p. 501-505.

287 Clapham, Human Rights Obligations of Non-State Actors, p. 254.

288 Iwanowa v. Ford Motor Co., 67 F. Supp. 2d 424 (D.N.J. 1999), p. 445. See also T. Garmon, "Domesticating International Corporate Responsibility: Holding Private Military Firms Accountable Under the Alient Tort Claims Act," Tulane Journal of International and Comparative Law Spring 2003 (2003), p. 342-343.

289 See Kiobel v. Royal Dutch Petroleum, No. 06-4800-cv, 06-4876-cv, 2010 WL 3611392 (2d Cir. September. 17, 2010).

290 Ibid., p. 5. 
granted by ATCA extends to civil actions brought against corporations under international law?291 Following a brief outline of international jurisprudence starting from the Nuremberg war crimes trials, the majority of judges in the Court of Appeals observed that

"[l]ooking to international law, we find a jurisprudence, first set forth in Nuremberg and repeated by every international tribunal of which we are aware, that offenses against the law of nations (i.e., customary international law) for violations of human rights can be charged against States and against individual men and women but not against juridical persons such as corporations. As a result, although international law has sometimes extended the scope of liability for a violation of a given norm to individuals, it has never extended the scope of liability to a corporation." 292

In the light of this observation, the majority contended that since corporations have not yet been subject to any form of liability under the customary international law of human rights, the ATCA consequently did not confer jurisdiction over suits against companies. ${ }^{293}$ To a certain degree this judgment effectively kills the possibility of using the ATCA to hold companies accountable for human rights abuses, although according to one commentator, it does not preclude the possibility of bringing individuals working for companies before justice. ${ }^{294}$

\subsubsection{Some observations}

IFI's while not formally bound by human rights treaty obligations, can nevertheless be called to pay attention to them in an indirect way. By pointing at their internal obligations, some of which can be read from a human rights perspective, and by using an available remedy in the form of the World Bank's Inspection Panel, it is possible to draw the attention of these institutions to the potential negative effects of their policies, including privatization, on the rights of those groups affected by them. Similarly, the adoption of the UN Sub-commission's Norms is an encouraging first step in this direction in the field of human rights. However, with regard to privatization, it is clear that currently these actors are not subject to specific and direct legal obligations that may help control their activities in this field.

Similarly, business enterprises have only very limited direct international legal obligations, in particular with respect to human rights. There are ongoing efforts to address this. Thus, various companies have adopted voluntary codes of practice that

\footnotetext{
291 Ibid

292 Ibid., p. 9 (emphasis in the original).

293 Ibid., p. 10.
}

294 See Chimène I. Keitner, "Kiobel v. Royal Dutch Petroleum: Another Round in the Fight Over Corporate Liability Under the Alien Tort Statute," ASIL Insight September 30, 2010 Volume 14, Issue 30 available at <www.asil.org/files/insight100930pdf.pdf $>$ (last visited on 5 October 2010). 
are aimed at self-regulating their activities with the aim of making their operations human rights compliant. International initiatives that suggest guiding principles for corporations have also been adopted by various international such as the OECD and the ILO. Clearly, there is no lack of initiatives to provide guidelines to the conduct of business enterprises. This, however, may also lead to fragmented and disjointed approaches that may provide concurring and potentially incoherent views on how multinational companies should behave under international law.

In spite of its flaws, the UN Sub-Commission's Norms for multinational corporations are also a step in the right direction (albeit a limited one) in establishing the accountability of these actors for the eventual harmful effects of their activities. There are also calls to improve access to remedies in order to increase the awareness of multinational actors of their human rights responsibilities. National efforts to allow victims of human rights abuses resulting from direct or indirect corporate behavior to sue these corporate actors for torts are also very promising. However, this is still short of holding business enterprises fully accountable for conduct incompatible with human rights. This, coupled together with the issue of limited horizontal applicability (or Drittwirkung, see further Section 4.4 infra) of human rights obligations to private entities could be a grave obstacle in protecting human rights against corporate abuses in a privatized setting.

\subsection{Preliminary conclusions}

The implementation of privatization policies is a matter of political, economical or practical consideration that is left to the exclusive domain of the State. States are sovereign entities that have, as suggested above, a considerable margin of discretion for choosing the (economic) policies they deem necessary. ${ }^{295}$ The notion of the sovereign autonomy to organize its internal economic arrangements anyway it likes is a concept that is accepted by general international law. In other words, under general international law there appears to be no general substantive constraints limiting the State's prerogative to design and implement privatization policies. Nevertheless, it is possible to discern certain constraints to this freedom arising out of a number of international law fields and principles such as international treaty law, the principle of non intervention, as well as those obligations that ensue from State responsibility for the actions performed by the State itself, its agents and under certain circumstances private actors (in this case actors performing privatized tasks, functions or services).

295 As we will later see in Section 4.2 infra, the State's margin of discretion (or appreciation) will have some bearing on whether human rights law can have any impact in constraining the State's sovereign power to implement privatization policies. 
In addition to the legal international obligations pertaining to States that may be of relevance for the issue of privatization, this section has briefly examined the international legal obligations of actors that are actively involved with privatization. In spite of ongoing developments under international law, the legal obligations of non-State actors such as international financial institutions and multinational companies have not yet been clearly defined. It is apparent that in the light of the far reaching influence these actors have in the international arena, concrete steps have to be taken to adopt legally enforceable rules that subject them to a similar regime as States, albeit in their respective spheres of influence. Self-regulatory efforts do appear to help to limit or otherwise curb the reach of their power. But it is probably too early to conclude that these actors can be held directly accountable under international law for abuses which are the result of efforts to promote privatization policies, in the case of IFIs, or which are the result of direct activity by (multinational) corporations operating privatized tasks or services.

As we will see further below, however, States may be held indirectly responsible for human rights abuses perpetrated by third parties (or privatized entities in the context of this study). This follows from the States' legal obligations to ensure the proper enjoyment of human rights in their jurisdiction, as well as the concomitant positive obligations that flow from human rights treaties (see Section 4.1.2 infra). However, it is here suggested that this may not always be a satisfactory solution as this only shifts the responsibility to the State from those who should really be held accountable - the corporate actors actually responsible for impropriate human rights behavior. ${ }^{296}$ There is a need to move towards such an approach. In the context of privatization, it is suggested that business enterprises (or their concessionaires) that are exercising functions of a public nature on behalf of the State, and with the State's legislative acquiescence, should be considered State actors sui generis for only those privatized functions and thus subject to the same human rights obligations as State actors in the strict sense of the word. This proposition will be further elaborated in Chapter IV.

\section{Privatization under human Rights laW}

Similar to the situation under international law, there are no specific legal rules or obligations under (international) human rights law dealing specifically with privatization or explicitly prohibiting it. ${ }^{297}$ It is not that the phenomenon of

\footnotetext{
296 See also A. Nolan, "Adressing Economic and Social Rights Violations by non-State Actors through the Role of the State: A Comparison of Regional Approaches to the 'Obligation to Protect'," Human Rights Law Review Vol. 9 (2009), p. 230.

297 Again, this contrasts with the attention that, at least in the context of the European Convention on Human Rights, nationalization has received. Article 1 of Protocol 1 to the European Convention deals with the right to property and any interference with this right (as in the form of nationalization) is subjected to a number of rules. According to the ECtHR "[t]he first rule,
} 
privatization has been neglected from the perspective of human rights. On the contrary, as will be discussed in Chapter $\mathrm{V}$ the various international and regional human rights monitoring mechanisms have paid considerable attention to the issue of privatization. However, maybe due to the lack of a proper legal basis dealing with privatization as such, the human rights approach of these bodies towards privatization has usually been carried out on an ad-hoc, fragmentary basis, with limited reliance on existing human rights principles and concepts. ${ }^{298}$ This is gradually starting to change. Thus, the European Court of Human Rights, while recognizing the State's power to adopt a policy like privatization, has at the same time acknowledged the existence of an implicit substantive constraint to what can be considered privatization when it observed in a recent decision that,

"[t]he [European] Convention [on Human Rights] does not exclude the transfer of competences under an international agreement to a body operating under private law provided that Convention rights continue to be secured [...]. The responsibility of the respondent State thus continues even after such a transfer." 299

The present author would like to emphasize that it is not his intention to suggest that human rights treaties should include direct references to privatization. However, due to the apparent concern that privatization may curtail or affect human rights in one way or another, it would be helpful to approach the issue through a more systematic use of existing human rights concepts than has been done hitherto. By analyzing particular aspects of these concepts in a way that by analogy may also be

which is of a general nature, enounces the principle of peaceful enjoyment of property; it is set out in the first sentence of the first paragraph [of Article 1 of Protocol 1. The second rule covers deprivation of possessions and subjects it to certain conditions; it appears in the second sentence of the same paragraph. The third rule recognises that the States are entitled, amongst other things, to control the use of property in accordance with the general interest, by enforcing such laws as they deem necessary for the purpose; it is contained in the second paragraph." See Case of Sporrong and Lönnroth v. Sweden, judgment of 23 September 1982, ECtHR, Series A-52, para. 61. See also Case of Lithgow and Others v. the UK, judgment of 8 July 1986, ECtHR Series A-102, para. 106. The latter case, in particular, dealt with nationalization of commercial industries in the United Kingdom.

298 In all fairness, privatization has not been a central issue of discussion in the practice of the human rights monitoring mechanisms. In addition, some mechanisms such as the UN Committee on Economic, Social and Cultural Rights have started to approach the topic more carefully. This is evident in General Comment No. 15 on the right to water, in which the Committee attempts to deal with the issue of privatization of water services using its established methodology of applying its typology of legal obligations of a particular rights, albeit in a limited way. See UN Doc. E/C.12/2002/11 (20 January 2003) op. cit. footnote 51. See further Chapter V.

299 See, Woś v. Poland, Decision on Admissibility of 1 March 2005, ECtHR Reports of Judgments and Decisions 2005-IV, para. 72. This is the ultimate result of the Court's earlier case law, which held that the State cannot absolve itself from responsibility under the ECHR by delegating its obligations to private bodies or individuals. See Costello-Roberts v. the United Kingdom, judgment of 25 March 1993, ECtHR Series A no. 247-C, para. 27 (also discussed in Section 4.4.1 infra and in Chapter IV, Section 3.1.2. 
applied to privatization, it is hoped that this approach will provide a theoretical context that is useful for international, regional, and national human rights adjudicators and practitioners confronted with the issue of privatization.

Thus we now turn to a number of specific human rights obligations and concepts that may be helpful in dealing with the issue of privatization and human rights, and therefore identify eventual implicit constraints with regard to the State's power to apply privatization policies. These specific obligations include positive and negative obligations, the obligations to respect, protect and fulfill, and the concept of core obligations of economic, social and cultural rights. Other relevant human rights concepts that will play an important role with regard to privatization are the doctrine of the margin of appreciation with regard to the State's latitude to adopt and implement particular economic policies such as privatization; the issue of the availability of legal remedies and its relationship with regulation as a means of controlling the effects of privatization; the issue of the horizontal application of human rights norms between private individuals (Drittwirkung), in this case between individuals and the private entity carrying out privatized functions, tasks and services of a public nature; and finally the concept of the violations approach as a means of monitoring the implementation of economic, social and cultural rights with regard to potential human rights abuses as a result of privatization. The set of specific obligations emanating from human rights law and the other aforementioned concepts will be discussed in the following paragraphs.

\subsection{Obligations emanating from human rights treaties}

International (and regional) human rights treaties impose on States a number of obligations, which in general are more specific than those described in Section 3.1 supra. On the one hand there are general human rights obligations, which are also derived from general international law obligations. The signing and ratification of international human rights treaties, for example, bind States parties to them upon their entering into force and establishes a duty on States to perform the provisions of those treaties in good faith. ${ }^{300}$ Since the Barcelona Traction case, obligations erga omnes have also been closely related to human rights obligations.

On the other hand, international and regional human rights treaties logically impose obligations upon States that are related to the nature and purpose of these treaties, namely the protection of the human dignity of the individual. These (human rights) obligations may vary according to the specific content of the individual rights present in each treaty and to the particular circumstances upon which the different rights are put into practice. By becoming parties to international and regional human rights treaties States agree to circumscribe their conduct in such a way that

300 Pacta sunt servanda. See Article 26 Vienna Convention on the Law of Treaties. 
makes the enjoyment of the rights enshrined in those human rights instruments a reality for each individual within their jurisdiction. Additionally, States agree to take the necessary measures that allow their subjects to enjoy those rights as well and to actively work to maintain the standards imposed by the rights. These two basic obligations are embodied for example in Article 2 (1) ICCPR which states, that

"[e]ach State Party to the present Covenant undertakes to respect and to ensure to all individuals within its territory and subject to its jurisdiction the rights recognized in the present Covenant, without distinction of any kind, such as race, colour, sex, language, religion, political or other opinion, national or social origin, property, birth or other status." [emphasis added $A H W$ ]

Relevant to the topic of this study, the Human Rights Committee has concluded in its General Comment No. 31 on the Nature of the General Legal Obligation Imposed on States Parties to the Covenant, that "[t]here may be circumstances in which a failure to ensure Covenant rights as required by article 2 would give rise to violations by States Parties of those rights, as a result of States Parties' permitting or failing to take appropriate measures or to exercise due diligence to prevent, punish, investigate or redress the harm caused by such acts by private persons or entities." 301 To a certain extent, these obligations ("to respect and to ensure) could be considered as a departing point for the various types of obligations that will be discussed below in connection to privatization.

\subsubsection{Specific human rights obligation of States: General background}

During the framing of the main international human rights treaties - the International Covenant on Civil and Political Rights (ICCPR) and the International Covenant on Economic Social and Cultural Rights (ICESCR) - the common perception among States and scholars was that the former imposed a set of obligations that only required the State to refrain from acting in such a way that negatively affected the enjoyment of the rights enshrined in that instrument. ${ }^{302}$ In other words, the obligations ensuing from civil and political rights were of a negative nature. Their implementation did not seemingly require further legislative action and/or the allocation of budgetary resources and would therefore not be

301 General Comment No. 31 on the Nature of the General Legal Obligation Imposed on States Parties to the Covenant, UN Doc CCPR/C/21/Rev.1/Add.13 (26 May 2004), para. 8. See also Section 4.4.1.1 infra.

302 See van Hoof, G.J.H, "The Legal Nature of Economic, Social and Cultural Rights: a Rebuttal of Some Traditional Views," in The Right to Food, ed. P. Alston and K. Tomasevski, Utrecht: Stichting Studie- en Informatiecentrum Mensenreechten (SIM)/Martinus Nijhoff Publishers (1984), p. 102-105. See also M. Sepúlveda, The Nature of the Obligations under the International Covenant on Economic, Social and Cultural Rights, vol. 18, School of Human Rights Research (Antwerpen: Intersentia - Hart, 2003) p. 118-122. 
costly. They would only require abstention from harmful conduct. On the other hand, States claimed that the ICESCR only prescribed a progressive development of economic, social and cultural rights and did not impose any immediate obligations on States. ${ }^{303}$ These rights were regarded as a set of vaguely worded aspirations requiring positive actions by the State including budgetary allocations in the long term and were therefore intended to be guidelines for lawmaking bodies. ${ }^{304}$ Unfortunately, this stance resulted in a dichotomy that favored the rapid development of the content of the obligations of States ensuing from civil and political rights, and prevented a similar development in the field of economic, social and cultural rights. ${ }^{305}$ Additionally, this dichotomy negatively affected the latter's justiciability. Courts were required to act with restraint in dealing with economic, social and cultural rights, with their observance at the international level a matter for monitoring through general reporting obligations as specified in, for example, the ICESCR. ${ }^{306}$

In the last twenty years, however, it has been firmly established that this dichotomy is based on false presumptions. ${ }^{307}$ Accordingly, the 1993 Vienna Declaration and

303 Article $2 \S 1$ of the ICESCR states that, "Each State Party to the present Covenant undertakes to take steps, individually and through international assistance and co-operation, especially economic and technical, to the maximum of its available resources, with a view to achieving progressively the full realization of the rights recognized in the present Covenant by all appropriate means, including particularly the adoption of legislative measures."

304 See I.E. Koch, "The Justiciability of Indivisible Rights," Nordic Journal of International Law Vol. 72 (2003), p. 3-39.

305 In her dissertation on the nature of the obligations under the ESCR, Sepúlveda noted that this dichotomy was also exacerbated by the initial lack of a monitoring mechanism that ensured that States complied with their obligations under the ESCR. The Committee on Economic Social and Cultural Rights was only established by the UN's Economic and Social Council in 1987. In comparison, the Human Rights Committee, the body entrusted with monitoring the implementation of the ICCPR started its monitoring activities in 1977 thereby taking a lead in the interpretation of the various provisions of that treaty through the drafting of general comments clarifying the content and applicability of the treaty's rights and through the concrete application of the treaty's norms in individual cases submitted to the Committee under Art. 1 of the Optional Protocol that established the individual complaint mechanism. See Sepúlveda, The Nature of the Obligations under the International Covenant on Economic, Social and Cultural Rights, p. 132-133.

306 Koch, "The Justiciability of Indivisible Rights," p. 6.

307 For a thorough analysis as to why this dichotomy is indeed misleading see Sepúlveda, The Nature of the Obligations under the International Covenant on Economic, Social and Cultural Rights, p. 122-156. See also Hoof, "The Legal Nature of Economic, Social and Cultural Rights: a Rebuttal of Some Traditional Views," p. 97-110. It is also worth mentioning that among legal scholars, there is a growing consensus regarding the indivisibility and interdependence of the rights enshrined in both the ICCPR and the ICESCR. This consensus is reflected in the so-called Limburg Principles on the Implementation of the International Covenant on Economic, Social and Cultural Rights, a non-binding yet influential set of principles adopted by a group of experts in international law in 1986 and which is aimed at providing useable and valuable guidelines for the interpretation of the obligations found in the ICESCR. For a brief analysis of the impact of 
Program of Action proclaimed by the Vienna World Conference on Human Rights rightly noted that both sets of rights are indivisible interrelated and interdependent. ${ }^{308}$ Since these sets of rights are bound in such a tight relationship it can then be argued that the obligations arising out of the ICCPR and ICESCR are similar in nature and only differ in relationship to the material content of each right and their concrete application in specific circumstances. As we will see below, international and regional human rights monitoring bodies have confirmed this by regularly holding that civil and political rights on the one hand, and economic, social and cultural rights on the other, similarly carry both positive and negative obligations.

Academic debate has further given content to the nature of the obligations ensuing from both civil and political rights and from economic, social and cultural rights. These are the so-called obligations to respect, protect and fulfill. The debate surrounding the nature of these obligations has been picked up by a number of treaty bodies in their efforts to further develop the content of the obligations ensuing from economic, social and cultural rights. Moreover, in an attempt to seek additional elements that might help in determining when a State has fallen short of fulfilling these obligations, the concept of minimum core obligations has been developed.

The question at hand is how these obligations are related to the issue of privatization and human rights and do they provide any guidance for States that are privatizing functions, tasks and services of a governmental or public nature? Do these obligations limit the State's ability to privatize? In the following paragraphs, the relevant obligations ensuing from human rights treaties and their relationship to privatization will be further explained. Firstly, the concept of negative and positive obligations will be examined. This will be followed by a description of the obligations to respect, protect and fulfill. Finally, the concept of core minimum obligations will be reviewed in light of the privatization of state functions, tasks and services of a governmental or public nature.

the Limburg Principles in the practice of the CESCR, other UN human rights bodies and the academic literature see D.L. Martin, "The Limburg Principles Turn Ten: An Impact Assesment," in The Maastricht Guidelines on Violations of Economic, Social and Cultural Rights: Proceedings of the Workshop of Experts organised by the International Commission of Jurists (Geneva, Switzerland), the Urban Morgan Institute on Human Rights (Cincinnati, USA) and the Maastricht Centre for Human Rights of Maastricht University, SIM Special, No. 20, ed. T.C. Boven van, C. Flinterman, and I. Westendorp, Utrecht: SIM (1998), p. 191-205.

See Vienna Declaration and Program of Action proclaimed by the Vienna World Conference on Human Rights, UN Doc. A/Conf.157/23 (25 June 1993), Section 1, para. 5, which states that "[a] 11 human rights are universal, indivisible and interdependent and interrelated. The international community must treat human rights globally in a fair and equal manner, on the same footing, and with the same emphasis[...].” 


\subsubsection{Positive and negative obligations}

As noted above, civil and political rights as protected by human rights treaties such as the ICCPR, the European Convention on Human Rights (ECHR), and the American Convention for Human Rights were initially perceived to solely impose obligations of a negative nature upon States. States were thus expected to refrain/ abstain from interfering in the free exercise of these rights. ${ }^{309}$ Economic, social and cultural rights as guaranteed in the ICESCR and the European Social Charter (ESC), on the other hand, were deemed to impose positive obligations of a programmatic nature only, leaving States with a certain margin of discretion to progressively take measures to ensure these rights.

It could be argued that this traditionalist view of the nature of the obligations imposed by both sets of rights clashes with the wording of Article 2(1) ICCPR (quoted above). Nowak, for example, has observed that Article 2(1) ICCPR imposing a duty on the State to 'respect and ensure' the rights enshrined therein to all the individuals within their territory, can be taken to mean that the ICCPR contains rights of a negative and positive character. ${ }^{310}$ The traditionalist view was in any case upset by the recognition of the European Court of Human Rights (ECtHR) that sometimes the observance of civil and political rights also required the adoption of positive measures. Since the Marckx judgment, ${ }^{311}$ the European Court has consistently held that States not only have negative obligations in the sense that States should refrain from conduct that could hurt the enjoyment of the rights guaranteed by the Convention, but also have positive obligations to guarantee these rights. Equally, the UN Human Rights Committee, and the Inter-American

309 R. Lawson, "Positieve Verplichtingen Onder het EVRM: Opkomst en Ondergang van de 'FairBalance'-Test Deel I," NJCM Bulletin Vol. 20 (1995), p. 562; van Dijk, P., “'Positive Obligations' Implied in the European Convention on Human Rights: Are the States Still the 'Masters' of the Convention?," in The Role of the Nation-State in the 21 ${ }^{\text {st }}$ Century: Human Rights, International Organisations and Foreign Policy, Essays in Hounour of Peter Baehr, ed. M. CastermansHolleman, van Hoof, G.J.H, and J. Smith, The Hague: Kluwer Law International (1998), p. 17; Sepúlveda, The Nature of the Obligations under the International Covenant on Economic, Social and Cultural Rights, p. 120-124. M. Nowak, U.N. Covenant on Civil and Political Rights: CCPR Commentary (Kehl: N.P. Engel, 1993) p. 36-37.

311 Marckx v. Belgium, judgment of 13 June 1979, ECtHR, Series A-31. In this judgment dealing with the right to respect for family life (Art. 8 ECHR) the European Court observed that, "[...] the object of the Article [Article $8 E C H R, A H W$ ] is 'essentially' that of protecting the individual against arbitrary interference by the public authorities [...] Nevertheless it does not merely compel the State to abstain from such interference: in addition to this primarily negative undertaking, there may be positive obligations inherent in an effective 'respect' for family life. This means, amongst other things, that when the State determines in its domestic legal system the régime applicable to certain family ties such as those between an unmarried mother and her child, it must act in a manner calculated to allow those concerned to lead a normal family life." Marckx v. Belgium, para. 31, cursive added. 
Commission and Court of Human Rights have asserted that the rights enshrined in their respective treaties carry both types of obligations. In the Velásquez Rodríguez ${ }^{312}$ case, the Inter-American Court of Human Rights reaffirmed this when it concluded that the general obligation to ensure the exercise of the rights enshrined in ACHR found in Article 1(1) of said convention ${ }^{313}$

"[...] implies the duty of States Parties to organize the governmental apparatus and, in general, all the structures through which public power is exercised, so that they are capable of juridically ensuring the free and full enjoyment of human rights. As a consequence of this obligation, the States must prevent, investigate and punish any violation of the rights recognized by the Convention and, moreover, if possible attempt to restore the right violated and provide compensation as warranted for damages resulting from the violation."314

With regard to the obligations ensuing from economic, social and cultural rights, the UN Committee on Economic, Social and Cultural Rights has in turn also observed that the rights protected in the ICESCR carry both negative and positive obligations. 315

Additionally, and of particular interest for the subject matter of this study, the various human rights monitoring bodies have on various occasions closely linked the State's positive obligations with the State's responsibility for acts performed by private parties that violate human rights. ${ }^{316}$

\subsubsection{Negative obligations and privatization}

The concept of negative obligations can play a role in analyzing whether the privatization of state functions, tasks and services of a governmental or public

312 Velásquez Rodríguez Case, Merits, judgment of 29 July 1988, IACtHR, Series C No. 4.

313 Article 1(1) ACHR reads "The States Parties to this Convention undertake to respect the rights and freedoms recognized herein and to ensure to all persons subject to their jurisdiction the free and full exercise of those rights and freedoms, without any discrimination for reasons of race, color, sex, language, religion, political or other opinion, national or social origin, economic status, birth, or any other social condition." Emphasis added $A H W$. Velásquez Rodríguez Case, para. 166.

315 See in general Sepúlveda, The Nature of the Obligations under the International Covenant on Economic, Social and Cultural Rights, p. 124-126. Additionally, the CESCR has been keen to point out at the various negative and positive duties of States in the context of the obligations to respect, protect and fulfill, which will be discussed further below. Examples can be found in ICESCR General Comment No. 12 on the right to adequate food (Art. 11) paras. 15 and 37, ICESCR General Comment No. 13 on the right to education (Art. 13) para. 47, ICESCR General Comment No. 14 on the right to the highest attainable standard of health (Art. 12) paras. 33-34, and ICESCR General Comment No. 15 on the right to water (Art. 11 and 12) para. 21. The obligations to respect, protect and fulfill are further discussed below. 
nature is compatible with human rights. This analysis may take place on two, closely related, levels. In the first place, the concept of negative obligations may be used proactively to require the State to abstain from conduct that is detrimental to the enjoyment of a right. This entails obliging the State to abstain from actively pursuing privatization efforts or from enacting privatization legislation that is incompatible with human rights. This is however not so straightforward. Determining a priori whether privatization will have a negative impact on the enjoyment of human rights, and thus move the State to abstain from enabling such a policy may be rather difficult. The use of human rights impact assessment tools and mechanisms to examine whether particular privatization measures can cause harm to human rights might be useful in this respect. ${ }^{317}$ The State would first have to take into consideration these impact assessment studies to determine whether and how privatization would harm human rights. Arguably, this proactive approach falls more within the context of States' positive obligations than the negative ones and will be dealt with in the next section.

In the second place, the concept of negative obligations could be used reactively to oblige States to put an end to ongoing privatization measures if their execution interferes with the enjoyment of human rights. In other words, this aspect of negative obligations would require States to single out, modify, or discontinue detrimental privatization efforts. This involves actively monitoring the immediate and longer-term effects of deployed privatization policies. It can also involve abrogating or modifying privatization legislation that enables privatized entities to cause harm to individuals in disregard of their human rights. An example of the latter may be found in the case of Young, James and Webster $v$. the UK ${ }^{318}$ where it became apparent that national legislation had allowed a private entity to violate Article 11 ECHR on the freedom of association. Admittedly, these types of situations may require the adoption of positive obligations as examined in the following sub-section. However, it can also be argued that the State has a negative

317 Human Rights Impact Assessment (HRIA) is a new development in the field of human rights whereby the potential direct or indirect impact of policies in various fields on human rights is 'measured' in order to systematically determine whether these policies take human rights sufficiently in to account. HRIA uses an eight-step approach to analyze the potential impact of intended policies on human rights. These steps are: 1. Assessment of the Actual Human Rights Situation, 2. Political Contextual Analysis; 3. Development of a View of the Desired Situation; 4. Selection of Essential Questions; 5. Formulation of Policy Options and Activities; 6. Decision on Policy and Activities; 7. Monitoring; and 8. Evaluation. For an overview of HRIA developments, a more detailed description of these steps, and the use of toolsets as well as examples see <www.humanrightsimpact.org/home/ $>$ (last visited 19 July 2008). See also B.A. Andreassen and H.O. Sano, "What's the Goal? What's the Purpose? Observations on Human Rights Impact Assessment," In: Research Notes (2004), Norwegian Centre for Human Rights, Oslo, p. 1-24.

318 Young, James and Webster v. the United Kingdom, judgment of 13 August 1981, ECtHR Series A-44. 
obligation to end a situation it created (i.e. allowing the interference with a right by a private party).

In reality, there are no actual examples of the application of negative obligations on these two levels (refraining from adopting privatization measures that may be incompatible with human rights, and ending an ongoing privatization effort that has actually had a negative impact on human rights). An examination of the practice of human rights treaty monitoring bodies in the field of civil and political rights as well as economic, social and cultural rights does not reveal any cases or situations in which States have been urged to refrain from adopting privatization measures or from reversing privatization legislation because of their incompatibility with human rights. ${ }^{319}$ Neither are there cases of States being asked to immediately cease with the implementation of ongoing privatization efforts. At the most, States have been asked to consider the effects of privatization measures on the most disadvantaged sectors of society, ensure that the rights of those affected by privatization are respected, and implement monitoring and safety net programs to ameliorate any negative effects. ${ }^{320}$

A strict application of States' negative obligations with respect to human rights is not without its own problems. For example, requiring States to abruptly stop or radically modify far-reaching and complex economic programs that have been already implemented may not always be practically feasible. It would presume the ability of a State to implement fall back or contingency measures that would allow it to take over the privatized measures in order to ensure the continuity of the service. It is doubtful, for example, that developing countries, which have been urged to privatize various sectors or services mainly because they were themselves not able to effectively or efficiently provide these services, would be in a position to resume these activities if due to their negative obligations they were pressed to roll back their privatization. The failed privatization of water services in Cochabamba, Bolivia in 2000 is an example of such a situation.

Following the privatization of water services in Cochabamba, water prices rose to levels that prevented the more economically vulnerable groups from enjoying the services. ${ }^{321}$ Massive anti-privatization demonstrations and riots ensued, the 'guerra

319 For further examination of the practice of human rights bodies with respect to privatization see Chapter V.

320 See Chapter V Sections 2.1.3, 2.2.2, 2.3.2, 2.4.2, 2.5.1, and 2.6.2 on the recommendations issued by the various $\mathrm{UN}$ treaty bodies with regard to privatization policies.

321 See inter alia K. Bayliss, "Privatization and Poverty: The Distributional Impact of Utility Privatization," Annals of Public and Cooperative Economics 73 (2002), p. 615; Nickson and Vargas, "The Limitations of Water Regulation: The Failure of the Cochabamba Concesion in Bolivia," p. 137-142; McFarland Sanchez-Moreno and Higgins, "No Recourse: Transnational Corporations and the Protection of Economic, Social and Cultural Rights in Bolivia," p. 17611765. 
del agua' (water war), and demands were made to put an end to the privatization program. The local government caved in to public pressure and rescinded the privatization program with the company Aguas del Tunari, a subsidiary of the Dutch-American consortium Bechtel almost a year after it was put into effect. The local public water company that took over the service has, however, not been able to provide a good service, let alone improve on the work of Aguas del Tunari. ${ }^{322}$

Moreover, abruptly stopping privatization measures involving the activities of business enterprises falling under the umbrella of BITs could, as we have already seen in Section 3.1.3 supra, also result in costly financial claims against the State for potentially affecting investments incurred by these corporations. For example, in response to the cancellation of the water privatization program in Cochabamba and the rescission of the contract with Aguas del Tunari, the latter filed a claim before the ICSID for compensation of damages incurred by the cancellation under the Bolivian - Dutch BIT. ${ }^{323}$ Argentina's decisions to either roll back privatization efforts or to adopt measures impacting the activities of privatized industries in the face of the financial crisis that affected the country between 1999 and 2002 have led to a myriad of claims before the ICSID amounting to hundreds of millions of dollars. ${ }^{324}$ States must be thus prepared to deal with the potential (financial) consequences if they decide to track back on their privatization efforts. We will now see if the concept of positive obligations is more effective in limiting the negative effects of privatization on human rights.

\subsubsection{Positive obligations and privatization}

Positive obligations may be more helpful in limiting the negative impact of privatization on human rights. On the other hand, determining the scope and content of positive obligations arising out of both civil and political rights and economic, social and cultural rights is potentially more problematic. Van Dijk has observed

322 See among other reports "Who Will Bring Water to the Bolivian Poor?" New York Times, 15 December 2005, describing the problems encountered by the national water company in Cochabamba, SEMAPA, which retook over the water service following the dismissal of Aguas del Tunari.

323 Although the mother company of Aguas del Tunari is the American multinational Bechtel, the former had been registered in the Netherlands. The claim, however, has been recently withdrawn, following a mutual agreement between Bolivia and Aguas del Tunari/Bechtel. See Chapter VII.

324 See for example the various claims involving privatized water utilities such as Compañia de Aguas del Aconquija, and Compagnie Générale des Eaux v. the Argentine Republic, ICSID Case No. ARB/97/3; Azurix Corporation v. the Argentine Republic, ICSID Case No. ARB/01/12; Aguas Argentinas, S.A., Suez, Sociedad General de Aguas de Barcelona, S.A. and Vivendi Universal, S.A. v. Argentine Republic, ICSID Case no. ARB/03/19; and Aguas Provinciales de Santa Fe S.A., Suez, Sociedad General de Aguas de Barcelona S.A. and InterAguas Servicios Integrales del Agua S.A. (Claimants) and The Argentine Republic (Respondent), ICSID Case No. ARB/03/17. See further Chapter VII. 
that the most obvious way of determining the scope and content of positive obligations would be to ascertain those measures that are necessary to make the enjoyment of the right or freedom concerned effective. ${ }^{325}$ Even van Dijk recognizes that this is not sufficient as there are no clear-cut criteria that might help to establish when effectiveness is achieved; ${ }^{326}$ in particular as there may be a broad scale between minimum effectiveness and maximum effectiveness. In addition, there may be several alternatives for making the enjoyment of a certain right effective. ${ }^{327}$ The answer that the European Court has provided for this conundrum is pragmatic: in determining which positive obligations a State has to take into account in a particular circumstance in which a right or freedom might be at stake, the State has a certain margin of appreciation. ${ }^{328}$

Notwithstanding the conceptual problems in determining the scope and content of positive obligations, the ECtHR has taken the position that the underlying principles applicable to both negative and positive obligations are comparable. In López Ostra v. Spain $^{329}$ the ECtHR held that,

"Whether the question is analysed in terms of a positive duty on the State - to take reasonable and appropriate measures to secure the applicant's rights under paragraph 1 of Article 8, as the applicant wishes in her case, or in terms of an 'interference by a public authority' to be justified in accordance with paragraph 2 (art. 8-2), the applicable principles are broadly similar. In both contexts regard must be had to the fair balance that has to be struck between the competing interests of the individual and of the community as a whole, and in any case the State enjoys a certain margin of appreciation. Furthermore, even in relation to the positive obligations flowing from the first paragraph of Article 8 (art. 8-1), in striking the required balance the aims mentioned in the second paragraph (art. 8-2) may be of a certain relevance." 330

Van Dijk, "'Positive Obligations' Implied in the European Convention on Human Rights: Are the States Still the 'Masters' of the Convention?," p. 22.

Ibid. Van Dijk notes in this regard, that what is effective will naturally depend on the right involved and the particular circumstances of the case and situation in the country concerned. Ibid.

Van Dijk observed that the Court's position in this issue is also fairly realistic, especially in light of the fact that the concept of positive obligations are not expressly mentioned in the ECHR. For further discussion on the margin of appreciation see Section 4.2 infra.

López Ostra v. Spain, judgment of 9 December 1994, ECtHR Series A303-C. The case dealt with the question whether Spain was responsible for the nuisance caused by a polluting third party on one of the neighboring families and thus could be held accountable for a violation of the right to family life (Article 8 ECHR). Article 8 ECHR states that "1. Everyone has the right to respect for his private and family life, his home and his correspondence. 2 . There shall be no interference by a public authority with the exercise of this right except such as is in accordance with the law and is necessary in a democratic society in the interests of national security, public safety or the economic well-being of the country, for the prevention of disorder or crime, for the protection of health or morals, or for the protection of the rights and freedoms of others."

López Ostra v. Spain, para. 51. 
In other words, whether the obligations on the side of the State requires negative or positive measures, States have to balance competing interests in the particular case and in doing so they enjoy a certain margin of appreciation. In addition, this balancing can be subject to specific limitation clauses included in human rights treaties such as the requirement of legality and necessity. In the context of the ECHR this would naturally include an examination involving the principle of proportionality to find out whether the lack of negative or positive measures can be justified.

Having in mind the scope and content of positive obligations, it is now possible to place them in the context of privatization. A positive obligations approach to privatization can be divided into a substantive and procedural approach. A substantive application of the concept of positive obligations with regard to the issue of privatization involves a positive duty on the State to take the necessary measures to prevent human rights abuses from private actors performing former State functions, tasks or services. The ECtHR has embraced this type of positive obligation in the $X$ and $Y v$. The Netherlands judgment ${ }^{331}$ in which the Court concluded that,

"[...] although the object of Article 8 is essentially that of protecting the individual against arbitrary interference by the public authorities, it does not merely compel the State to abstain from such interference: in addition to this primarily negative undertaking, there may be positive obligations inherent in an effective respect for private or family life. These obligations may involve the adoption of measures designed to secure respect for private life even in the sphere of the relations of individuals between themselves." 332

In other words, although the rights of the ECHR can be directly invoked only against the State, the latter has a positive obligation to take particular measures to prevent private actors from violating the rights of other individuals. The ECtHR has confirmed this conclusion in various other judgments involving the conduct of private actors, albeit with regard to Article $8 \mathrm{ECHR}$ on the right to a private life. ${ }^{333}$

$331 X$ and $Y v$. The Netherlands, judgment of 26 March 1985, ECtHR Series A. The case also involved a violation of Art. 8 ECHR in a situation that originally concerned private actors inter se.

332 Ibid., para. 23.

333 See among others, López Ostra v. Spain, Guerra and Others v. Italy, judgment of 19 February 1998, ECtHR Reports 1998-I, Calvelli and Ciglio v. Italy, judgment of 17 January 2002, ECtHR, Reports 2002-I, and Hatton and Others v. The United Kingdom, Grand Chamber judgment of 8 July 2003, ECtHR, Reports 2003-VIII. It is interesting to note that in a number of occasions involving the responsibility of the State for the conduct of private actors, the Court has not expressly referred to positive obligations, but has concluded that the State has an "[...] obligation under Article 1 [ECHR $A H W]$ to secure those rights and freedoms in its domestic law to everyone within its jurisdiction." See Young, James and Webster v. the United Kingdom, judgment of 13 August 1981, ECtHR, Series A-44 and Costello-Roberts v. the United Kingdom, 
These cases usually involve the State's failure to act and adopt protective measures to ensure the rights of individuals vis-à-vis the conduct of other private entities. They also include cases where States tolerate harmful conduct by private parties without making genuine efforts to end the situation. ${ }^{334}$

In particular, the above-mentioned case of López Ostra v. Spain paved the way for holding States responsible for the harmful conduct of private companies whenever the former fall short of their positive obligations of preventing such conduct. In this case Spanish local authorities failed to issue a proper license for a waste treatment plant to operate. The plant's operations caused severe environmental and health harm to individuals residing in the vicinity of the plant. In addition, the local authorities did not take adequate measures to regulate the plant's activities, and allowed the operations to continue without intervening. The little measures the local authorities had taken to protect the individuals proved to be insufficient. The Court observed that in determining Spain's positive obligations, "[...] it need only establish whether the national authorities took the measures necessary for protecting the applicant's right to respect for her home and for her private and family life under Article 8." ${ }^{335}$ Having found that the local authorities had not only failed to take steps to protect the rights of the individuals affected by the plant's operation, but also had resisted local judicial decisions to that effect, the Court had no trouble in concluding that Spain had failed to fulfill its positive obligations under Article 8 ECHR.

The UN Human Rights Committee and the Inter-American Court of Human Rights have also contributed to the development of the concept of positive obligations with respect to the conduct of private individuals. Summarizing its views developed throughout its case law, the Human Rights Committee observed in its General

judgment of 25 March 1993, ECtHR, Series A-247-C. Lawson observes that in the light of the facts of the latter case and its similarity with the abovementioned case law on positive obligations and the State's responsibility for the conduct of private actors, this conclusion would at first glance appear to be a fluke. R. Lawson, "Positieve Verplichtingen Onder het EVRM: Opkomst en Ondergang van de 'Fair-Balance'-Test Deel II," NJCM Bulletin Vol. 20 (1995), p. 734-739. Lawson believes that this conclusion appears to be a limited application of the positive obligations doctrine. Van Dijk notes, however, that for all practical purposes, the Court's conclusion with regard to the State's obligation to secure the rights guaranteed under the ECHR to everyone within its jurisdiction amounts to the application of the positive obligations doctrine. Van Dijk, "'Positive Obligations' Implied in the European Convention on Human Rights: Are the States Still the 'Masters' of the Convention?," p. 19. It is not difficult to see why: in order to secure the rights guaranteed under the ECHR as required by Article 1 ECHR, the State will have to take both negative and positive measures.

334 See, for example, Moreno Gómez v. Spain, judgment of 16 November 2004, ECtHR, Reports of Judgments and Decisions 2004-X, para. 61-62. See also Fadeyeva v. Russia, judgment of 9 June 2005, ECtHR, Reports of Judgments and Decisions 2005-IV, para. 89 (discussed in the next Section).

335 López Ostra v. Spain, para. 55. 
Comment No. 31 on the General Legal Obligations Imposed on States Parties to the $\mathrm{ICCPR}^{336}$ that,

"[...] the positive obligations on States Parties to ensure Covenant rights will only be fully discharged if individuals are protected by the State, not just against violations of Covenant rights by its agents, but also against acts committed by private persons or entities that would impair the enjoyment of Covenant rights in so far as they are amenable to application between private persons or entities. There may be circumstances in which a failure to ensure Covenant rights as required by article 2 would give rise to violations by States Parties of those rights, as a result of States Parties' permitting or failing to take appropriate measures or to exercise due diligence to prevent, punish, investigate or redress the harm caused by such acts by private persons or entities." 337

Similarly, in the case of Velásquez Rodríguez the Inter-American Court held that, "[a]n illegal act which violates human rights and which is initially not directly
imputable to a State (for example, because it is the act of a private person or because
the person responsible has not been identified) can lead to international responsibility
of the State, not because of the act itself, but because of the lack of due diligence to
prevent the violation or to respond to it as required by the Convention. [...] The State
has a legal duty to take reasonable steps to prevent human rights violations and to
use the means at its disposal to carry out a serious investigation of violations
committed within its jurisdiction, to identify those responsible, to impose the
appropriate punishment and to ensure the victim adequate compensation." 338

Therefore, States are not only required to adopt measures of protection against the conduct of privatized entities, but also to carry out investigations into abuses by these entities. Equally important, States are obliged to provide means of redress (either compensatory or judicial) for the victims of abuse by private actors exercising privatized tasks.

In addition to the substantive aspect obliging the State to protect individuals from the harmful conduct of privatized entities, positive obligations also have a procedural aspect. They may, for example, require that the decision-making process leading to measures of interference (such as privatization if their deployment results in interfering with the rights of individuals) be fair and afford due respect to the

336 See General Comment No. 31 on the General Obligations Imposed on States Parties to the Covenant, UN Doc. CCPR/C/21/Rev.1/Add.13 (26 May 2004).

337 Ibid., para. 8.

338 Velásquez Rodriguez, paras. 172-174. See for a similar conclusion with regard to the conduct of a private health care body in Brazil, Case of Ximenes-Lopes v. Brazil, Judgment of July 4, 2006 (Merits, Reparations and Costs), IACtHR, Series C No. 149, para. 85. 
interests of the individuals affected. ${ }^{339}$ In the case of Hatton and Others $v$. the $U K,{ }^{340}$ the European Court of Human Rights held in this respect that it is "[...] necessary to consider all the procedural aspects, including the type of policy or decision involved, the extent to which the views of individuals were taken into account throughout the decision-making process, and the procedural safeguards available."341

The use of a human rights impact assessment study that investigates and evaluates the potential human rights effects of privatization legislation would very likely fit under this positive requirement. As observed in the previous sub-section, it could be used to prevent or modify the adoption of privatization legislation that is contrary to the State's human rights obligations. It also would require the use of consultation and approaching stakeholders, including those who are to be directly affected by the privatization policies to gather their views and listen to alternatives. ${ }^{342}$ The use of such a preventive tool has been suggested in the case law of the European Court of Human Rights. For example, in a case involving the issuing of a permit to operate a gold mine with toxic materials affecting the health and environment of people living around the mine, Taşkin and Others v. Turkey, the Court held that,

"[w]here a State must determine complex issues of environmental and economic policy, the decision-making process must firstly involve appropriate investigations and studies in order to allow them to predict and evaluate in advance the effects of those activities which might damage the environment and infringe individuals' rights and to enable them to strike a fair balance between the various conflicting interests at stake." 343

In addition, the Court emphasized that the conclusions to such studies and other relevant information that would enable members of the public to assess any danger to which they could be exposed should be publicly accessible. ${ }^{344}$

The procedural aspect of the State's positive obligations also includes allowing the individuals concerned to "[...] appeal to the courts against any decision, act or

339 See for example the case of Tasskin and Others v. Turkey, judgment of 10 November 2004, ECtHR Reports of Judgments and Decisions 2004-X, para. 118.

340 Hatton and Others v. the UK, Grand Chamber judgment of 8 July 2003, ECtHR Reports 2003VIII. The case dealt with noise hinder caused by night flights in and around the privatized airport of Heathrow near London. This case is discussed in more detail in Section 4.2.2.1 infra.

341 Ibid., para. 104. See also Taşkin and Others v. Turkey, para. 118.

342 Compare in this regard the emphasis the World Bank's Inspection Panel has placed on consultation with local stakeholders when the World Bank has plans to provide credit for development projects that can have severe impact on the local population. See Section 3.2.1.2 supra.

343 Taşkin and Others v. Turkey, para. 119.

344 See also in this respect the Case of Öneryildiz v. Turkey, Grand Chamber judgment of 30 November 2004, ECtHR, Reports of Judgments and Decisions 2004-XII, paras. 89-91. 
omission where they consider that their interests or their comments have not been given sufficient weight in the decision-making process." ${ }^{445}$ Another way for a State to discharge itself of the procedural aspect of its positive obligations in an effective way would be through the adoption of regulatory measures and oversight bodies that are accessible to persons who are affected by the activities of privatized bodies. Since the issue of regulation as a positive obligation is important with regard to privatization, it will be discussed in more detail in the following section.

\subsubsection{Positive obligations: a duty to regulate privatized activity?}

Privatization efforts have often resulted in the adoption of regulatory measures aiming to control or curb the behavior of privatized entities so that it conforms to socially desirable norms. As already observed, this has led to a 'privatization paradox', ${ }^{346}$ Because regulation can take various forms and operate on different levels, it is difficult to define. Baldwin and Cave observe that regulation can be defined in three different ways. ${ }^{347}$ Regulation may be specific set of commands whereby a set of binding rules are promulgated and applied by a particular body created for this purpose. Regulation can also be defined as the deliberate influence of the State to control or influence industrial or social behavior. Finally, regulation can also be defined in a more broad way as all forms or mechanisms of social control and influence. These mechanisms may be of legislative origin, but they can also originate from other sources (for example self-regulation or market regulation). In addition, regulation is not always restrictive or meant to prevent undesirable behavior. Regulation may also be used to enable or facilitate a desired conduct or result. $^{348}$

According to Baldwin and Cave, many of the rationales for regulation can be described as instances of 'market failure,'349 that is situations in which "[m]arket imperfections make it impossible for market forces to achieve an efficient allocation of resources." 350 Since regulation serves various purposes, such as compensating for market failure, and may take various forms, it is necessary to make a general distinction of the reasons why regulation may be required. For the purposes of this study, it will suffice to follow Foster's approach of distinguishing between economic regulation and social regulation. ${ }^{351}$ Economic regulation deals with the regulation of monopoly and competition. Its objectives are the promotion of competition and

See Chapter II, Section 2.3.

347 R. Baldwin and M. Cave, Understanding Regulation: Theory, Strategy and Practice (Oxford: Oxford University Press, 1999) p. 2. 
the control of the natural monopoly in order to enhance economic efficiency. Social regulation, on the other hand, is concerned with the promotion of social objectives. Foster provides some examples of objectives that may be served by social regulation, including achieving fairness between various interest groups, income redistribution, and the provision of a service deemed important by Government. With regard to privatization, the existence of a natural monopoly whereby only one actor is in the position to provide a particular essential service that has been privatized, such as water utilities, can be regarded as a market failure requiring both economic and social regulation. ${ }^{352}$ In the light of the current study, it is precisely this type of regulation that may be of interest with regard to the concept of positive obligations.

Although human rights law does not expressly provide for an obligation to regulate the conduct of privatized entities, it can be inferred from the concept of positive obligations. As we have seen, under this concept (and the obligation to protect as described in the next section), States have a duty to protect individuals from human rights incompatible conduct of private actors, and to prevent any harm carried out by these actors. States are under an obligation to adopt the necessary measures to protect persons affected by privatization and to offer redress for any negative consequences that are the result of delegating State tasks and services to private actors.

In many instances compliance with positive obligations will require the adoption of regulatory measures that help protect the rights of individuals against any harmful effects of privatization or its actors. Some examples may be drawn from the practice of a number of human rights monitoring bodies. Although these bodies have not extensively addressed regulation as a means to ensure the guarantee of human rights, they have on occasion recommended the adoption of regulatory measures to control or influence the conduct of private actors. For example, in the case of Fadeyeva v. Russia, ${ }^{353}$ the ECtHR emphasized regulation as a means of discharging the State's positive obligations. In this case, a woman living in the neighborhood of a privatized steel plant complained that there had been a violation of Article 8 ECHR due to Russia's failure to protect her private life and home from severe environmental nuisance caused by the plant's industrial activities. Following the trend set in López Ostra, the European Court held that,

"[...] the State's responsibility in environmental cases may arise from a failure to regulate private industry. Accordingly, the applicant's complaints fall to be analysed in terms of a positive duty on the State to take reasonable and appropriate measures to secure the applicant's rights under Article $8 \S 1$ of the Convention. In these circumstances the Court's first task is to assess whether the State could reasonably

352 See further Chapter VII.

353 Fadeyeva v. Russia, judgment of 9 June 2005, ECtHR, Reports of Judgments and Decisions 2005-IV. 
be expected to act so as to prevent or put an end to the alleged infringement of the applicant's rights." 354

In another case, Storck v. Germany, ${ }^{355}$ the ECtHR addressed the issue of regulation over private psychiatric institutions performing similar functions as public ones. The Court observed that with regard to persons who are deprived of their liberty for psychiatric treatment, [...] the State is under an obligation to secure to its citizens their right to physical integrity under Article 8 of the Convention. ${ }^{356}$ After following its observation in the case of Costello-Roberts v. United Kingdom ${ }^{357}$ that the State cannot completely absolve itself of its responsibility by delegating its obligations in this sphere to private bodies or individuals, the Court found that the State remained under a duty to exercise supervision and control over private psychiatric institutions. ${ }^{358}$ This could include requiring private bodies to obtain the necessary licenses to operate as well as having other types of competent and regular supervisory control in place. ${ }^{359}$ But it could also include judicial supervision over the decisions of private bodies, or in the case of private psychiatric bodies, the introduction of visiting bodies "[...] created to inspect psychiatric institutions, to check whether the rights of patients were being respected and to give patients the opportunity to raise complaints." 360 Failure to do so would amount to a breach of the State's "[...] existing positive obligation to protect the applicant against interferences with her liberty by private persons." 361

The Inter-American Court of Human Rights has also addressed the issue of regulation with respect to the activities of a private mental health care body in Brazil, which participated in the public health scheme set up by the State. ${ }^{362}$ In the Case of Ximenes-Lopes v. Brazil, the Inter-American Court considered in the context of positive obligations that,

"States must regulate and supervise all activities related to the health care given to the individuals under the jurisdiction thereof, as a special duty to protect life and

354 Ibid., para. 89. See also Ledyayeva, Dobrokhotova, Zolotareva and Romashina v. Russia, judgment of 26 October 2006, ECtHR, Applications Nos. 53157/99, 53247/99, 53695/00 and 56850/00 (not yet published), confirming Fadeyeva.

355 Storck v. Germany, Judgment of 16 June 2005, ECtHR Reports of Judgments and Decisions 2005-V.

356 Ibid., para. 103.

357 Costello-Roberts v. the United Kingdom, para. 27.

358 Storck v. Germany, para. 103.

359 Ibid., para. 106.

360 Ibid., para. 107.

361 Ibid., para. 108.

362 Case of Ximenes-Lopes v. Brazil, footnote 338 supra. Under the Brazilian Constitution, public bodies or private institutions may provide health care services. In the case of services rendered by private bodies, the services are private and paid by the patients themselves, but the State keeps its power to supervise them. Ibid., para. 94. 
personal integrity, regardless of the public or private nature of the entity giving such health care." 363

According to the Court, failure to regulate such activities gives raise to international responsibility. ${ }^{364}$ Among the regulatory measures that the State should enact in such a situation are the establishment of proper mechanisms to carry out inspections at psychiatric institutions, submitting, investigating, and solving complaints, as well as taking the appropriate disciplinary or judicial actions regarding cases of professional misconduct or the violation of the patient's rights. ${ }^{365}$

Other human rights monitoring bodies have also indicated the importance of regulation. For example, the UN Committee on Economic, Social and Cultural Rights made a recommendation to Azerbaijan that it should regulate the oil industry more effectively, particularly with respect to its potential adverse effects on the environment. ${ }^{366}$ With regard to the use of private military and security companies (PMSCs) in conflict situations, the UN Working Group on the use of mercenaries as a means of violating human rights and impeding the exercise of the right of people to self-determination, has suggested that States using, exporting or importing these companies, should adopt legislation and set up regulatory mechanisms to control and monitor their activities. ${ }^{367}$ Such regulatory efforts should include a system of registering and licensing which would authorize these companies to operate and allow them to be sanctioned when the norms are not respected, thus guarding against these companies impeding or violating human rights in the countries in which they operate.

\subsubsection{Obligations to respect, protect and fulfill}

It has been argued that merely establishing two sets of obligations for States (both positive and negative) is a simplification of the nature of both civil and political

363 Ibid., para. 89.

364 Ibid., para. 90.

365 Ibid., para. 99. It is worth noting that as, a source of inspiration, the Court pointed out in this regard to the measures States should adopt under the Principles for the Protection of Persons with Mental Illness and the Improvement of Mental Health Care, UN General Assembly Resolution 46/119.46, UN Doc. A/46/49 (1991), principle 22.

366 See Concluding Observations on State Report by Azerbaijan, UN Doc. CESCR E/1998/22 (5 December 1997), para. 345.

367 See the Report of the UN Working Group on the use of mercenaries as a means of violating human rights and impeding the exercise of the right of people to self-determination, UN Doc. A/HRC/7/7 (9 January 2008), p. 26. As discussed in Chapter VI, the Working Group on the use of mercenaries took over the mandate of the Special Rapporteur of the Commission on Human Rights on use of mercenaries as a means of impeding the exercise of the right of peoples to selfdetermination in 2005. 
rights and economic, social and cultural rights. ${ }^{368}$ Since the 1980 's a more exact delineation of States' obligations has been developed. Shue, for example, introduced three types of obligations that applied equally to civil and political and economic, social and cultural rights. ${ }^{369} \mathrm{He}$ suggested that every basic right had three kinds of duties: duties to avoid depriving, duties to protect from deprivation and duties to aid the deprived. Eide further developed this typology in a report on the right to food for the UN's Sub-Commission for the Promotion and Protection of Human Rights. $^{370}$ In this report, Eide made a distinction between three levels of State obligations: to respect, to protect, and to fulfill. There appears to be some debate as to whether this tripartite typology is the most appropriate since other commentators have made further distinctions within the three main types of obligations and have added a few new ones. ${ }^{371}$ The tripartite typology developed by Eide has, nevertheless, been embraced by the CESCR when it was formally introduced in General Comment No. 12 on the right to food in $1999 .{ }^{372}$ This typology has been subsequently used in all the General Comments drafted ever since.

The obligation to respect requires States and all its organs and agents, to refrain from interfering directly or indirectly with the enjoyment of the rights of individuals. The obligation to protect requires States and all its organs and agents to take measures that are necessary to prevent third parties from interfering with any of the rights of individuals. Finally, the obligation to fulfill requires States to ensure the adoption of appropriate legislative, administrative, budgetary, judicial, promotional, and other measures towards the full realization of the rights guaranteed in human rights instruments.

Although the obligations to respect, protect and fulfill have primarily been used or referred to by the CESCR in its efforts to further define the content and scope of States parties' obligations under the ICESCR, it has been noted that these three levels of obligations also apply to civil and political rights. ${ }^{373}$ To a certain extent

368 Sepúlveda, The Nature of the Obligations under the International Covenant on Economic, Social and Cultural Rights, p. 137.

369 H. Shue, Basic Rights: Subsistence, Affluence and U.S. Foreign Policy (Princeton: Princeton University Press, 1980) p. 52. See also Sepúlveda, The Nature of the Obligations under the International Covenant on Economic, Social and Cultural Rights, p. 158.

370 See Report on the right to adequate food as a human right submitted by A. Eide, UN Doc. E/ CN.4/Sub.2/1987/23 (7 July 1987) paras. 66-69. See also Sepúlveda, The Nature of the Obligations under the International Covenant on Economic, Social and Cultural Rights, p. 161, and Koch, "The Justiciability of Indivisible Rights," p. 9.

371 For a description and analysis of the various types of observations, which essentially are quite similar with some subtle differences see Sepúlveda, The Nature of the Obligations under the International Covenant on Economic, Social and Cultural Rights, p. 158-169.

372 Ibid., p. 196.

373 The Maastricht Guidelines on Violations of Economic, Social and Cultural Rights emphasize for example that the tripartite set of obligations are applicable to both civil and political rights and economic, social and cultural rights. "The Maastricht Guidelines on Violations of Economic, 
this tripartite typology can be seen as a type of refinement of the negative and positive obligations as described above. Arguably, the obligation to respect is similar to the concept of negative obligations. Moreover, the obligation to protect could be regarded as a derivative of the concept of positive obligations as developed by the ECtHR and the Inter-American bodies. The particular aspects of these two types of obligations with respect to privatization as discussed in the previous sections are thus similarly applicable.

Under the obligation to fulfill, however, it is possible to observe that the State is expected to go the extra mile in guaranteeing that rights are actually realized. With this obligation, the State is expected to lay down the conditions and guarantees under which specific rights are fulfilled and fully enjoyed by individuals. Thus if privatization policies in certain sectors such as electricity and water are carried out, the State must facilitate the circumstances under which the rights that could be affected by these policies are effectively respected and fully enjoyed by individuals subject to the consequences of these policies. Here, a link to the concept of universal service obligations may be discerned. The concept of universal service obligations, which will be discussed in more detail in Chapter VII, entails that States have an obligation to make certain services available to all end-users in their territory, independently of geographical location, and, in the light of specific national conditions, at an affordable price. ${ }^{374}$ The concept has been developed in particular in the field of network utilities ${ }^{375}$ such as telecommunications, electricity, and water.

Social and Cultural Rights: Proceedings of the Workshop of Experts organised by the International Commission of Jurists (Geneva, Switzerland), the Urban Morgan Institute on Human Rights (Cincinnati, USA) and the Maastricht Centre for Human Rights of Maastricht University," in The Maastricht Guidelines on Violations of Economic, Social and Cultural Rights: Proceedings of the Workshop of Experts organised by the International Commission of Jurists (Geneva, Switzerland), the Urban Morgan Institute on Human Rights (Cincinnati, USA) and the Maastricht Centre for Human Rights of Maastricht University, SIM Special, No. 20, ed. T.C. Boven van, C. Flinterman, and I. Westendorp, Utrecht: SIM (1997). Additionally, it should be noted that the Committee for the Elimination of All Forms of Discrimination Against Women has made some references to these obligations in a number of General Comments. See, for example, CEDAW General Comment No. 24 on women and the right to health (Art. 12 CEDAW), paras. 7 and 13 and CEDAW General Comment No. 25 on temporary special measures (Art. $4 \S 1$ CEDAW), para. 4.

374 This definition is borrowed for the sake of illustration from the one used by the EU under its Universal Service Directive. See Article 3(1) of Directive of the European Parliament and of the Council on universal service and users' rights relating to electronic communications networks and services (Universal Service Directive), PE-CONS 3673/01, 4 February 2002. For a discussion of the content of universal service obligations in various sectors within the EU see also Devroe, "Privatisering en Verzelfstandiging: Een Verkenning Vanuit Nationaal en Europees Economisch Recht", p. IV-44 and further. See further Chapter VII, Section 2.6.4.

375 See in general T. Prosser, "Marketisation, Public Service and Universal Service," in Adapting legal Cultures, ed. D. Nelken and J. Feest, Oxford: Hart Publishing (2001), p. 223-239, and M. Young, "The Future of Universal Service. Does it Have One?," International Journal of Law and Information Technology Vol. 13 (2006), p. 188-205. 
From the nature of the universal service obligations (providing universal access to important services which are economically and physically accessible to all), it may be inferred that the concept of universal service obligations is closely related to the obligation to fulfill and may impose on States a duty to guarantee that certain services that have been privatized remain accessible to all at the most affordable price.

\title{
4.1.4. Core obligations with respect to economic social and cultural rights
}

In an effort to provide additional guidance in determining when a State is not fulfilling its obligations under the ICESCR, and in clarifying the normative content of the Covenant, academics and the CESCR have elaborated the concept of minimum core obligations. ${ }^{376}$ In General Comment No. 3 (1990), the Committee confirmed that States parties have an obligation to ensure the satisfaction of minimum essential levels of each of the rights guaranteed by the Covenant. In the words of the Committee,

\begin{abstract}
"[...] a minimum core obligation to ensure the satisfaction of, at the very least, minimum essential levels of each of the rights is incumbent upon every State party. Thus, for example, a State party in which any significant number of individuals is deprived of essential foodstuffs, of essential primary health care, of basic shelter and housing, or of the most basic forms of education is, prima facie, failing to discharge its obligations under the Covenant. If the Covenant were to be read in such a way as not to establish such a minimum core obligation, it would be largely deprived of its raison d'être." 377
\end{abstract}

The concept of minimum core obligations denotes the essential elements without which a right loses its substantive significance as a human right. ${ }^{378}$ The State has the duty to, at the very least, do its utmost to implement the minimum levels of the rights guaranteed in the ICESCR. In the event that the State does not even meet these minimum obligations, the burden of proof lies on the State to demonstrate its inability to comply with them. ${ }^{379}$

With regard to privatization and economic, social and cultural rights, it can be argued that a State that is unable to provide directly for basic and essential services in the sectors of health care, water utilities, housing, or education, is also failing to

376 See A.R. Chapman and S. Russel, "Introduction,” in Core Obligations: Building a Framework for Economic, Social and Cultural Rights, ed. A.R. Chapman and S. Russel, Antwerp: Intersentia (2002), p. 8, and Sepúlveda, The Nature of the Obligations under the International Covenant on Economic, Social and Cultural Rights, p. 369.

377 ICESCR General Comment No. 3 on the nature of States parties obligations (Art. 2, par.1), para. 10.

378 Chapman and Russel, "Introduction," p. 9.

379 Ibid., p. 10. 
comply with its minimum core obligations under the ICESCR if, through the privatization of these services, the privatized service providers are unable to provide or deny persons of:

- essential primary health care and access to health facilities, goods and services on a non-discriminatory basis, especially for vulnerable or marginalized groups; 380

- minimal access to the minimum essential amount of water, that is sufficient and safe for personal and domestic uses to prevent disease as well as access to water and water facilities and services on a non-discriminatory basis, especially for disadvantaged or marginalized groups; ${ }^{381}$ and

- primary education $^{382}$ respectively.

\subsubsection{Some observations}

Generally speaking, the application of negative obligations (or obligation to respect) on States that are privatizing may be of limited help. In theory, the concept may be of help in preventing States from adopting privatization legislation that is a priori in contravention of human rights. In practical terms, however, the State's margin of appreciation is likely to play a role in diminishing the scope of these types of obligations. Similarly, negative obligations may sometimes argue in favour of States having to repeal privatization measures that have been found to have a negative impact on human rights. However, the predicted economical and legal repercussions of abruptly putting an end to privatization measures may be severe and this may help a State resist this argument, not least through a similar invocation of the margin of appreciation doctrine.

The positive obligations (or obligation to protect) of a State ensuing from international human rights treaties may nonetheless impose some limits on the way privatization policies may be applied. In particular a substantive approach to positive obligations may require States to pro-actively adopt the necessary measures to ensure that privatized actors do not infringe human rights, and to protect or mitigate the effects of privatization on individuals. A procedural approach to a State's positive obligations in terms of privatization would require it to consult those affected by privatization measures before adopting them. Such an approach would

380 See General Comment No. 14 on the right to the highest attainable standard of health (Article 12 of the International Covenant on Economic, Social and Cultural Rights, UN Doc. E/C.12/2000/4 (11 August 2000), para. 43.

381 See General Comment No. 15 on the right to water (Arts. 11 and 12 of the International Covenant on Economic, Social and Cultural Rights), UN Doc. E/C.12/2002/11 (20 January 2003), para. 37.

382 See General Comment No. 13 on the right to education (Article 13 of the International Covenant on Economic, Social and Cultural Rights), UN Doc. E/C.12/1999/10 (8 December 1999), para. 57. 
also require a State to prevent any potential harm caused by privatization itself by developing and applying a human rights impact assessment study on privatization, allowing individuals to access the outcomes of such an assessment, and by providing them with judicial avenues for seeking redress. The regulation of privatized entities by independent monitoring bodies, which, as we will see in Section 4.3.2.2 infra, have been put in place in a number of countries that have adopted privatization policies, would probably also serve to satisfy a State's positive obligations. In addition to these type of obligations it must be noted that the obligation to fulfill may impose on States a duty to guarantee that certain services that have been privatized remain accessible to all at the most affordable price, thus imposing what are otherwise known as universal service obligations. ${ }^{383}$

In terms of economic, social and cultural rights the concept of minimum core obligations establishes a threshold below which States are deemed not to be fulfilling their legal obligations under the IESCR. States are primarily and directly responsible if they fail to meet this minimum threshold. They are of course also responsible if due to their decision to privatize certain sectors which are closely linked to activities that have an impact on certain economic, social and cultural rights, such as the privatization of housing, health care, primary education, or essential utilities like water, this threshold is also not met.

\subsection{Margin of appreciation and privatization}

Under international human rights law, the term 'margin of appreciation' refers to the discretion ascribed to States through which they can evaluate factual situations when applying the provisions enumerated in the various international and regional human rights treaties. ${ }^{384}$ In evaluating these factual situations States enjoy some latitude in determining how to balance the rights and freedoms of individuals with respect to other policies they may want to implement and which may potentially interfere with those rights. The doctrine of the margin of appreciation is not only an international phenomenon, but has been influenced by the legal practice in the administrative law of various countries. ${ }^{385}$ It limits the reach of (international) adjudicators by showing deference to the judgments of governments or authorities, which are considered to be in a better position to assess local conditions, national cultural factors, and the necessity of specific measures in particular situations. ${ }^{386}$ In

\footnotetext{
383 See Chapter VII, Section 2.6.4.

384 Y. Arai-Takahashi, The Margin of Appreciation Doctrine and the Principle of Proportionality in the Jurisprudence of the ECHR (Antwerp: Intersentia, 2002) p. 2. Arai-Takahashi has compiled an exhaustive bibliography on the subject of the margin of appreciation for further reference. For the purposes of this study only the most relevant authorities will be referred to. Ibid., p. 2-3.

386 R. Lawson and H.G. Schermers, Leading Cases of the European Court of Human Rights, $2^{\text {nd }}$ ed. (Nijmegen: Ars Aequi Libri, 1999) p. xxviii.
} 
other words, it is concerned with the intensity and scope of review of (international) adjudicators. ${ }^{387}$ With a wide margin of appreciation, international adjudicators will review this conduct less intensely and defer more to national authorities than with a narrower margin. In addition, the margin of appreciation doctrine serves to maintain a balance between the sovereignty of States and their obligations towards the various human rights treaties and supervisory bodies. ${ }^{388}$

With regard to human rights review of State conduct and the privatization of functions, tasks and services previously exercised by governmental entities, the doctrine of the margin of appreciation could play an important role. Although it would appear that there is not yet any specific case law involving privatization and the margin of appreciation, this section will attempt to apply the concepts related to the margin of appreciation in the light of privatization to see what would be the results. Thus it is suggested that international adjudicators could rely on the doctrine to determine whether States have latitude to apply particular privatization measures that may go against the States' human rights obligations. In doing so, they could conclude that States enjoy a wide margin of appreciation to justify certain limitations on human rights in areas where national (economic) interests are at stake and where privatization is used to serve those interests. Moreover, in cases involving privatization and where the State is expected to adopt positive measures to protect the rights of individuals against private/privatized entities, the State will probably be granted a wide margin of appreciation in determining which measures to adopt. It is important to note, however, that the width (or the limits) of this margin with respect to privatization measures (and any concomitant positive measures) will depend on various factors, some of which will be discussed below. In any case, the application of the margin of appreciation doctrine in the context of privatization has consequences for the intensity of review of the conduct of privatizing States.

\subsubsection{General applicability}

The doctrine of the margin of appreciation has been mainly applied in the context of regional human rights systems, and then especially with regard to civil and political rights. Under the ECHR, the doctrine has acquired great importance ever since the ECtHR's decision on the Handyside ${ }^{389}$ case. Although Handyside was not the first case to use the notion of the margin of appreciation under the ECHR, it did

387 R.St.J. Macdonald, "The Margin of Appreciation," in The European System for the Protection of Human Rights, ed. R.St.J. Macdonald and et al. (eds.)Kluwer Academic Publishers (1993), p. 84.

388 Ibid., p. 123; Arai-Takahashi, The Margin of Appreciation Doctrine and the Principle of Proportionality in the Jurisprudence of the ECHR, p. 3-4.

389 Case of Handyside v. The United Kingdom, judgment of 7 December 1976, ECtHR, Series A no. 24. 
help to establish the main concepts involved in reviewing the notion. ${ }^{390}$ The InterAmerican system of human rights protection has also adopted the doctrine inspired by its European counterpart. ${ }^{391}$ International human rights monitoring mechanisms such as the Human Rights Committee overseeing the implementation of the ICCPR have also acknowledged the discretion States have with regard to limiting human rights, albeit in a limited way. ${ }^{392}$

In general, it may be stated that the question whether a State enjoys a wide margin of appreciation under the case law of the ECtHR is raised in cases in which difficult social or technical issues are at stake. These can relate to topics in the field of sexual relations $^{393}$ or topics related to economic and urban policies. ${ }^{394}$ The margin of appreciation has been usually invoked with regard to the States' 'negative obligations' in the context of the application of limitations or derogations to rights as allowed by human rights treaties. However, the concept has also been used with respect to States' 'positive obligations'. It has also acquired some recognition in the sphere of economic, social and cultural rights, as we will see below.

390 Macdonald, "The Margin of Appreciation," p. 84; Arai-Takahashi, The Margin of Appreciation Doctrine and the Principle of Proportionality in the Jurisprudence of the ECHR, p. 7.

391 See for example the Advisory Opinion of the Inter-American Court of Human Rights, The Legal Status and Human Rights of the Child, Inter-Am.CtHR, Advisory Opinion OC-17/2002 (28 August 2002), Ser A, No. 17, para. 3. See also J. M. Pasqualucci, The Practice and Procedure of the Inter-American Court of Human Rights (Cambridge Cambridge University Press, 2003) p. 51.

392 M.G. Schmidt, "The Complementarity of the Convenant and the European Convention on Human Rights - Recent Developments," in The International Covenant on Civil and Political Rights and the United Kingdom Law, ed. D. Harris and S. Joseph, Oxford: Clarendon Press (1995), p. 657. Schmidt speculates that overtly embracing the doctrine could be regarded as an obstacle for the effective protection and applicability of the universal norms found in the ICCPR. This could happen due to the diversity of cultural situations of the more than 150 States parties to the Covenant, which could be used as an excuse to argue that they should be allowed to implement the rights in the way that is most appropriate to their situation, thus making it easier to justify serious human rights violations. In addition, other UN committees such as the Committee on the Elimination of Racial Discrimination (CERD) have also made strict/limited references to the concept of the margin of appreciation. See for example the Concluding Observations of the CERD to Australia's $13^{\text {th }}$ and $14^{\text {th }}$ periodic reports under the United Nations International Convention on the Elimination of All Forms of Racial Discrimination, where the CERD stressed that "[...] the use by the State party of a margin of appreciation in order to strike a balance between existing interests is limited by its obligations under the Convention." See Concluding Observations of the Committee on Australia, UN Doc. CERD/C/AUS/CO/14 (14 March 2005), para. 16.

393 See Rees v. the UK, judgment of 17 October 1986, ECtHR Series A-106.

394 See for example Powell and Rayner v. the UK, judgment of 21 February 1990, ECtHR Series A-172 (further to be discussed below), para. 44 and Hatton and Others v. the UK, Grand Chamber judgment of 8 July 2003, ECtHR Reports 2003-VIII, paras. 100-101. See also the Case of Öneryildiz v. Turkey, judgment of 30 November 2004, ECtHR, Reports of Judgments and Decisions 2004-XII, para. 107. 


\subsubsection{Margin of appreciation, negative obligations and privatization}

The margin of appreciation is used to strike a "[...] balance between national views of human rights and the uniform application of [...]"395 human rights conventions. Under the ECHR, the margin of appreciation is often invoked with respect to States' negative obligations not to interfere with the rights in the context of the limitation clauses that are present in the second paragraph of Articles 8-11 ECHR and in Article 1 of Protocol No. 1 to the ECHR on the right to property. ${ }^{396}$ These limitation clauses allow interferences under three conditions. Firstly, the interference must be prescribed by law. ${ }^{397}$ Secondly, they must be necessary in a democratic society. Finally, they must be geared towards protecting certain (public) interests (also known as legitimate aims). These interests include national security, public safety or the economic well-being of the country, the prevention of disorder or crime, the protection of health or morals, and the protection of the rights and freedoms of others. 398

Let us examine the potential application of the first and third requirements (the limitation must be prescribed by law, and must be geared towards protecting public interests or legitimate aims) to privatization. Under the first requirement, a privatization measure that (potentially) interferes with the enjoyment of a right will only be legitimate from a human rights perspective if it is adopted by law. It is however safe to assume that privatization endeavors of States will easily comply with this standard since in most countries, general as well as specific privatization legislation has been adopted. With regard to the third standard, privatization would be relatively easy to reconcile with some of the interests or aims mentioned in the limitation clauses of human rights treaties. For example, privatization could be seen as a measure aimed at safeguarding the economic-well being of a nation by reducing

395 Arai-Takahashi, The Margin of Appreciation Doctrine and the Principle of Proportionality in the Jurisprudence of the ECHR, p. 3.

396 Articles 8-11 ECHR refer to personal freedom rights including the right to a private and family life (Article 8 ECHR), the freedom of thought, conscience and religion (Article 9 ECHR), the freedom of expression (Article 10 ECHR) and the freedom of assembly and association (Article 11 ECHR). See also Macdonald, "The Margin of Appreciation," p. 83; Arai-Takahashi, The Margin of Appreciation Doctrine and the Principle of Proportionality in the Jurisprudence of the ECHR, p. 9. In addition, the margin of appreciation is also invoked in the context of Article 14 ECHR on the prohibition of discrimination (which may only be used together with another right) and Article 15 ECHR on the derogation of rights in times of emergency.

397 The case law of the ECtHR has made it clear that this requires that the legal norm in question be accessible to all citizens, and formulated in such a way that its content and scope is reasonably foreseeable to all. See among other authorities, Sunday Times v. UK, judgment of 26 April 1979, ECtHR, Series A no. 30.

398 Article 10 ECHR also includes the protection of the reputation or rights of others, preventing the disclosure of information received in confidence, and maintaining the authority and impartiality of the judiciary. 
excessive government expenditures. It is therefore suggested that privatization as an interference will be easily justified under these two standards.

The use of the margin of appreciation, however, has usually been concerned with the second requirement, 'necessary in a democratic society'. ${ }^{399}$ This necessity requirement was further developed in the already mentioned Handyside case ${ }^{400}$ in which the State attempting to justify an interference with a right was required to show that the measure satisfied a 'pressing social need'. 401 The ECtHR held that States have a margin of appreciation in assessing the existence of a pressing social need. ${ }^{402}$ The Court, emphasized, however, that this margin is not unlimited: the Court reserved to itself the right of giving the final opinion on whether a particular measure limiting a right was reconcilable with the Convention's rights. ${ }^{403}$ Thus the Court held that it had to examine whether that measure was proportional to the aim pursued. In the second place, it observed that it was not the Court's task to take the place of the competent national courts, but rather to review under the Convention's rights the decisions they delivered in exercise of their power of appreciation. ${ }^{404}$ In doing so, the Court noted that it must decide on the basis of the different information available to it whether the reasons provided by the State to justify the interfering measures were 'relevant and sufficient'. ${ }^{405}$ The latter criterion also involves a proportionality test. ${ }^{406}$ In sum, the margin of appreciation aspect of the necessity test allows national authorities to make an initial assessment of the 'necessity' for an interference including both the legislative framework and the particular measure of implementation. ${ }^{407}$ Human rights adjudicators have, however, a task to investigate whether the interference and the measures implementing it are compatible with the rights (i.e. proportional).

In the situation in which a privatization measure adopted by law is seen as an interference with the enjoyment of a particular right, the question focuses on whether it is 'necessary in a democratic society'. A State endeavoring to privatize must therefore evaluate whether a 'pressing social need' is present to justify

399 See for example Groppera Radio v. Switzerland, judgment of 28 March 1990, ECtHR, Series A. no. 173 , para. 72 .

400 See footnote 389 supra.

$401 \quad$ Handyside, para. 48.

402 Ibid., para. 48.

403 Ibid., para. 49. The Court then added that "[t]he domestic margin of appreciation thus goes hand in hand with a European supervision. Such supervision concerns both the aim of the measure challenged and its 'necessity'; it covers not only the basic legislation but also the decision applying it, even one given by an independent court." Ibid.

404 Ibid., para. 50.

405 Ibid.

406 See also Arai-Takahashi, The Margin of Appreciation Doctrine and the Principle of Proportionality in the Jurisprudence of the ECHR, p. 87.

407 See also Buckley v. the United Kingdom, judgment of 26 August 1996, ECtHR, Reports 1996-IV, para. 74. 
privatization. This pressing social need will usually consist of requirements for economic expediency (such as the need to reduce government expenditure or the national debt) or the perceived efficiency gains that privatization allegedly could bring. In addition, a State will have to demonstrate that the privatization measure is relevant and sufficient to achieve the goal required by the pressing social need. This requires the State to strike a balance between the means used and the aim pursued. Thus, the State will have to demonstrate that there were no other suitable and less intrusive alternatives to privatization as the appropriate means of achieving its goals. It is however suggested that, without engaging into complex economical and political investigation and assessment, it will be difficult for an international human rights adjudicator to evaluate the reasonableness of the State's justification for privatization and will thus easily accept this justification. Human rights adjudicators are in this respect not adequately equipped to perform complex economical and political assessments of national policy (and it is of course open to question whether it would be appropriate for them to do so).

\subsubsection{Margin of appreciation, positive obligations and privatization}

We have already observed in Section 4.1.2 supra that (international) human rights law has developed the concept of positive obligations whereby States have a duty not only to refrain from interfering with human rights, but also a duty to take the necessary measures to ensure an effective protection of those rights. The margin of appreciation is not only applied with respect to the States' negative obligations not to interfere with a right, but is also often invoked with respect to the States' positive obligations. ${ }^{408}$ With regard to privatization, the margin of appreciation in the context of positive obligations could play a role in cases in which the human rights abuse is caused by a private entity. In such a situation, the State will be required to adopt measures to prevent harmful conduct by third parties or mitigate the harm created by them. In adopting these precautionary measures, States will have a certain margin of appreciation.

In Rees v. the U.K, ${ }^{409}$ the ECtHR already hinted at the possible link between positive obligations and the margin of appreciation when it concluded that, " $[. .$.$] in$ determining whether or not a positive obligation exists, regard must be had to the

408 Later cases in the ECHR jurisprudence have clarified that the margin of appreciation can be applied in a similar way to situations involving negative and positive obligations. In Powell and Rayner $v$. the UK, the ECtHR held that whether cases are examined from the perspective of negative or positive obligations, "[...] in both contexts regard must be had to the fair balance that has to be struck between the competing interests of the individual and of the community as a whole; and in both contexts the State enjoys a certain margin of appreciation in determining the steps to be taken to ensure compliance with the Convention." Ibid., para. 41.

In other words, the margin of appreciation and the concomitant principle of proportionality apply in similar ways to both negative and positive obligations.

Rees v. the U.K., judgment of 17 October 1986, ECtHR Series A-106. 
fair balance that has to be struck between the general interest of the community and the interests of the individual [...] ${ }^{\prime 410}$ In subsequent case law, the Strasbourg organs shed more light on the subject. In the Johnston v. Ireland case, ${ }^{411}$ for example, the ECtHR observed that States will enjoy a wide margin of appreciation in cases involving positive obligations whereby the underlying practice of States to adopt positive measures for the enjoyment of a particular right varies considerably from case to case. ${ }^{412}$

The rationale for this wide margin of appreciation with regard to positive obligations appears to be that States have to make a complex assessment of the particular national circumstances in order to adopt specific positive measures. In such a situation, the ECtHR may feel that it would be improper for it to dictate which measures States should adopt, especially if they involve the allocation of (financial) resources. ${ }^{413}$ Some international human rights bodies may therefore decide to defer to the State authorities, which are possibly in a better position to adopt the measures. This contrasts, however, with the position adopted by the Inter-American Commission and Inter-American Court of Human Rights. Both sometimes go to great lengths to prescribe specific positive measures to States especially in the case of interim measures designed to protect vulnerable groups or individuals that run the risk of suffering irreparable harm. ${ }^{414}$ Under such circumstances, the margin of appreciation of States will be necessarily narrower. However, this could be more the exception than the rule given the proclivity of some human rights adjudicators to err on the side of the State when weighty national interests such as the economy or national security are at play in the context of the margin of appreciation (see for example the case of Hatton and Others v. the UK discussed further below).

The relationship between positive obligations and the margin of appreciation also has consequences for the issue of privatization and human rights. Since the adoption of privatization policies also requires a complex assessment of the economical and political circumstances of a given country, positive measures deployed to fulfill the State's positive obligations will be subject to less scrutiny by international adjudicators since these measures could require eventual modification of the already implemented privatization policies in order to ensure the respect of their human rights obligations. States would thus have to see how these positive measures fit in the general context of their privatization programs and what their consequences are

\footnotetext{
$410 \quad$ Ibid., para. 37.

411 Johnston and others v. Ireland, judgment of 18 December 1986, ECtHR Series A-112.

412 Ibid., para. 55.

413 Arai-Takahashi, The Margin of Appreciation Doctrine and the Principle of Proportionality in the Jurisprudence of the ECHR, p. 85.

414 See V. Gómez, "Inter-American Commission on Human Rights and the Inter-American Court of Human Rights: New Rules and Recent Cases," Human Rights Law Review Vol. 1 (2001), p. $123-$ 124.
} 
for their implementation. Arguably, the State is in a better position to do so than an international adjudicator. This is appreciable in the case of Fadeyeva v. Russia. ${ }^{415}$ The case involved the conduct of a privatized steel company whose polluting activities caused grave environmental and health problems to complainants to the detriment of the right to respect for private life (Article $8 \mathrm{ECHR}$ ). This required the adoption of positive measures on the side of the State to tackle the problem. The Court held that,

"[...] where the State is required to take positive measures, the choice of means is in principle a matter that falls within the Contracting States' margin of appreciation. There are different avenues to ensure "respect for private life", and even if the State has failed to apply one particular measure provided by domestic law, it may still fulfil its positive duty by other means." 416

However, as we will see below positive obligations with regard to the conduct of private entities, as is the case when privatization has been adopted (and as illustrated by Fadeyeva v. Russia), may well lead to a more narrow margin of appreciation.

\subsubsection{Margin of appreciation, economic, social and cultural rights, and privatization}

Although the doctrine of the margin of appreciation is mainly known for its application with respect to civil and political rights, in the sphere of economic, social and cultural rights there has been recognition of the concept. This is appreciable in Guideline 8 of the Maastricht Guidelines on Violations of Economic, Social and Cultural Rights, which states that

"[a]s in the case of civil and political rights, States enjoy a margin of discretion in selecting the means for implementing their respective obligations." ${ }^{17}$

As we previously observed, the development of economic, social and cultural rights has been lagging due to the impression that these sets of rights are merely

415 Fadeyeva v. Russia, judgment of 9 June 2005, ECtHR, Reports of Judgments and Decisions 2005-IV.

416 Ibid., para. 96.

417 Note the use of margin of discretion instead of margin of appreciation. In the Commentary to the Guidelines, Dankwa, Flinterman, and Leckie, observe that the term discretion is used instead of appreciation in order to, "[...] distinguish it from the application of the latter term under, inter alia, the ECHR, although all human rights allow some degree of leeway, whether they are civil, cultural, economic, political or social in nature." E.V.O. Dankwa, C. Flinterman, and S. Leckie, "Commentary on the Maastricht Guidelines on Violations of Economic, Social and Cultural Rights," in The Maastricht Guidelines on Violations of Economic, Social and Cultural Rights, SIM Special No. 20, ed. T.C. Boven van, C. Flinterman, and I. Westendorp, Utrecht: Netherlands Institute for Human Rights (1998), p. 21-22. 
programmatic in nature. This impression has been reinforced by Article 2(1) ICESCR that places an emphasis on achieving progressively the full realization of the rights recognized in the Covenant. Many States appear to interpret this provision as allowing them a lot of leeway in the choice of measures they ought to adopt to realize these rights and in the speed of their implementation. In their commentary to the Maastricht Guidelines, Dankwa et al observe that the margin of discretion/ appreciation accorded to States in the framework of economic, social and cultural rights does not remove "[...] the duty of States to ensure the enjoyment of 'universal minimum standards' regarding these rights." ${ }^{\prime 418}$ Moreover, Guideline 8 states that

\begin{abstract}
"[t]he fact that the full realization of most economic, social and cultural rights can only be achieved progressively, which in fact also applies to most civil and political rights, does not alter the nature of the legal obligation of States which requires that certain steps be taken immediately and others as soon as possible. Therefore, the burden is on the State to demonstrate that it is making measurable progress toward the full realization of the rights in question. The State cannot use the "progressive realization" provisions in article 2 of the Covenant as a pretext for non-compliance. Nor can the State justify derogations or limitations of rights recognized in the Covenant because of different social, religious and cultural backgrounds."
\end{abstract}

This means that as a rule States will not be allowed to rely on the margin of appreciation with respect to economic, social and cultural rights if this stands in a way of effectively realizing these rights. The UN Committee on Economic, Social and Cultural Rights has confirmed this in the General Comments on the rights to food, healthcare and water. ${ }^{419}$ For example, with regard to Article 12 IECSCR on the right to adequate health care, the Committee has observed that although every State has a margin of discretion in assessing which measures are most suitable to meet its specific circumstances, the Covenant, "[...] clearly imposes a duty on each State to take whatever steps are necessary to ensure that everyone has access to health facilities, goods and services so that they can enjoy, as soon as possible, the highest attainable standard of physical and mental health." 420

Furthermore, the concept of the core minimum obligation as adopted by the UN Committee on Economic, Social and Cultural Rights in General Comment No. 3 on the nature of States parties' obligations to the ICESCR, ${ }^{421}$ may also help to clarify

\footnotetext{
418 Ibid., p. 22.

419 See General Comment No. 12 on the right to adequate food (Art. 12 ICESCR), UN Doc. E/C.12/1999/5 (12 May 1999), para. 21; General Comment No. 14 on right to the highest attainable standard of health, UN Doc. E/C.12/2000/4 (11 August 2000), para. 53; and General Comment No. 15 on the right to water (Art. 11 and 12 ICESCR), UN Doc. E/C.12/2002/11 (20 January 2003), para. 45.

420 General Comment No. 14, para. 53.

421 General Comment No. 3 on the nature of States parties' obligations (art. 2, para. 1 ICESCR), UN Doc. HRI/GEN/1/Rev.7 (12 May 2004), p. 17, para. 10.
} 
how far the margin of discretion may be with respect to economic, social and cultural rights. Since it is similar to the 'very essence' notion adopted by the ECtHR with regard to certain rights (see further below), it stands to reason that the core minimum concept will be applied in a fashion akin to the former. This means that the realization and enjoyment of economic, social and cultural rights may not be made illusory by resorting to certain measures such as privatization under the pretext of a wide margin of discretion. These measures (and their concomitant consequences) must be equally foreseeable for everybody, allow for a real and effective enjoyment of the right at stake, and be proportional to the aim sought. The minimum core obligation entails that for guaranteeing a real and effective enjoyment of that particular right States will have to "[...] ensure the satisfaction of, at the very least, minimum essential levels of [...]"422 of the right involved.

At the same time, the UN Committee acknowledges that any assessment regarding whether a State has discharged its minimum core obligation must also take account of resource constraints applying within the country concerned. Thus a State's margin of discretion remains susceptible to national measures that have a broad effect on national (budgetary) resources. Privatization could fall under such a measure, since it is often adopted in order to cut back governmental expenditures. ${ }^{423}$ The Committee, however, has attempted to limit this side effect by observing that States must be able to demonstrate that every effort has been made to use all resources that are at its disposition in an effort to satisfy, as a matter of priority, those minimum obligations. 424

\subsubsection{Margin of appreciation, its limits, and privatization}

The assessment of whether a State has overstepped its margin of appreciation involves a number of factors, some of which have already been discussed in the previous paragraphs. Since the margin of appreciation is concerned with the intensity of review (or scope of review) of State conduct, it is dependent on the context of each case. ${ }^{425}$ The width of the margin of appreciation will differ depending on the type of right at stake, the different claims in respect of the same right by applicants in different situations, and on the different justifications that States may advance to defend any limitation of those rights. This means that the limits of the margin of appreciation with regard to certain policies such as privatization will always be fluid. After all, as we have seen in Chapter II, the rationale behind privatizations may vary, as may the methods used for privatization.

422 Ibid.

423 On the other hand, privatization may also generate financial surpluses to the State through the sell of State owned corporations, which then could be used to help satisfy the minimum core obligations of economic, social and cultural rights.

425 Macdonald, "The Margin of Appreciation," p. 84-85. 
Nevertheless, the State will always be required to seek a fair balance between the competing interests. In the case of privatization, the competing interests will usually be on the one hand general economic expediency and the necessity to improve service provision and efficiency, and the interests of individuals potentially affected by privatization measures on the other.

The Strasbourg case law offers interesting examples demonstrating the fluidity of the limits to the margin of appreciation of States with regard to economic and social policies. Some of these examples involve the conduct of private (and sometimes privatized) entities, for which the State indirectly bears responsibility. In the following paragraphs, the limits of the margin of appreciation with respect to economical policies, environmental issues, non-derogable rights and the differing practice of States will be briefly discussed. An attempt will be made to draw parallels with the present discussion and to discuss how the factors affecting the margin of appreciation in those cases may be applied to privatization.

\subsubsection{Margin of appreciation, economical policies, environmental nuisance and privatization}

The ECtHR has on a number of occasions observed that a State's margin of appreciation can be wide with respect to the implementation of general policies of national or public interest. For example, in James and Others v. the $U K,{ }^{426}$ a case involving the taking of private property effectuated by the State in contravention of the right to property as guaranteed in Article 1 of Protocol 1 to the ECHR, the Court found it natural that the margin of appreciation "[...] available to the legislature in implementing social and economic policies should be a wide one [...]". 427 The rationale was that national authorities are better placed than an international court to assess what is in the 'public interest'. 428 Thus, in Lithgow $v$. the $U K^{429}$ the Court held with respect to a nationalization program in the UK that,

426 James and Others v. the UK, judgment of 21 February 1986, ECtHR Series A-98.

427 Ibid., para. 46.

428 Article 1 of Protocol No. 1 to the ECHR protecting the right to property, allows the deprivation of this right by the State in the public interest. In general, the ECtHR has held that the margin of appreciation with regard to expropriation of property in the public interest is necessarily wide. According to Ruiz Fabri, the Court "[...] has recognized that it is for national authorities to make the initial assessment of the existence of a problem of public concern warranting measures that result in a deprivation of property." See H. Ruiz Fabri, "The Approach Taken by the European Court of Human Rights to the Assessment of Compensation for 'Regulatory Expropriations' of the Property of Foreign Investors," N.Y.U. Envtl. L.J. Vol. 11 (2002), p. 158, and Arai-Takahashi, The Margin of Appreciation Doctrine and the Principle of Proportionality in the Jurisprudence of the ECHR, p. 151-156.

429 Case of Lithgow and Others v. the UK, judgment of 8 July 1986, ECtHR Series A-102. 
"[a] decision to enact nationalisation legislation will commonly involve consideration of various issues on which opinions within a democratic society may reasonably differ widely. Because of their direct knowledge of their society and its needs and resources, the national authorities are in principle better placed than the international judge to appreciate what measures are appropriate in this area and consequently the margin of appreciation available to them should be a wide one." 430

The present author believes that there is no reason to think that privatization would elicit a different conclusion. Privatization, being a general economic policy such as nationalization albeit in the complete opposite direction, is also a policy that will undoubtedly spark different opinions in a society. Its adoption and eventual implementation will sometimes depend on economic expediency and requirements, and on the political support required to adopt it. As long as the goals justifying privatization are regarded to be legitimate, for example because they serve the 'public interest', the State's wide margin of appreciation can be justified. Thus, the ECtHR has held with regard to socio-economic legislation that it did not consider the political considerations that may have influenced the legislative process of such legislation (as it is bound to reflect the political attitudes to a greater or lesser degree) to preclude the objectives pursued by the legislation from being legitimate. ${ }^{431}$ It is therefore submitted that privatization would very likely be regarded as a national policy for which a State should be accorded a wide margin of appreciation.

However, the wide margin of appreciation for economical and social policies may have certain limits. International human rights adjudicators such as the European Court of Human Rights have not hesitated to make it clear, as per the Handyside case, that they will reserve the right to examine whether the State has overstepped its margin of appreciation. Thus in the case of Sporrong and Lönnroth, the ECtHR observed that in complex societal matters, in which the State should enjoy a wide margin of appreciation, the Court is still bound to examine whether a fair balance has been struck between the demands of the general interest of the community and the requirements of the protection of individuals' fundamental rights. ${ }^{432}$ According to the Court this fair balance is upset when an individual bears an excessive burden and the possibilities of any form of redress is limited. ${ }^{433}$ In James and Others, the ECtHR noted that while the margin of appreciation is wide for measures that pursue a legitimate aim in the 'public interest', there "[...]must also be a reasonable relationship of proportionality between the means employed and the aim sought to be realized." "434 In Broniowski v. Poland, the Court again acknowledged the

\footnotetext{
430 Ibid., para. 122.

431 James and Others $v$. the UK, para. 48

432 Case of Sporrong and Lönnroth v. Sweden, judgment of 23 September 1982, ECtHR, Series A-52, para. 69.

433 Ibid., para. 73.

434 James and Other $v$. the UK, para. 50, referring to the aforementioned case of Sporrong and Lönnroth.
} 
importance of according considerable discretion to national authorities in the light of a "[...] wide-reaching but controversial legislative scheme with significant economic impact for the country as a whole [...]"435 However, the Court added that this considerable margin is not unlimited, and "[...] the exercise of the State's discretion, even in the context of the most complex reform of the State, cannot entail consequences at variance with Convention standards." ${ }^{\text {"436 }}$

In cases involving the adoption of economical and technical measures (indirectly) resulting in environmental nuisance caused by private entities to the detriment of the enjoyment of Article 8 ECHR, the Strasbourg Court has gradually developed a test to assess the limits of the States' margin of appreciation in adopting these measures. In Powell and Rayner v. the UK, the ECtHR was faced with the question whether aircraft noise produced by air traffic in and around Heathrow airport (which during the course of the case had been privatized) resulted in a violation of the right to respect for a person's private life and home. Claimants doubted the effectiveness of the measures adopted by the public authorities to reduce noise exposure, and maintained that the noise levels allowed by the public authorities were not acceptable. The UK admitted that there was an interference with the rights of applicants, but argued that it had taken the necessary measures to abate the noise nuisance to those living in the neighborhood of the airport. In addition, it pointed out at the economic importance of the airport. After having agreed with the economic significance of Heathrow airport, and having briefly examined the regulatory measures adopted by the UK to mitigate the noise problems, the Court held that,

"[i]t is certainly not for the Commission or the Court to substitute for the assessment of the national authorities any other assessment of what might be the best policy in this difficult social and technical sphere. This is an area where the Contracting States are to be recognised as enjoying a wide margin of appreciation." 437

In a somewhat brief assessment, the Court found that the UK had not exceeded this margin in forming a judgment as to the proper scope of the noise abatement measures adopted, and that it had not upset the fair balance required by Article 8 ECHR. ${ }^{438}$ It would appear then that in the eyes of the Court the proportionality requirement was easily met without too much investigation.

\footnotetext{
435 Broniowski v. Poland, judgment of 22 June 2004, ECtHR, Reports of Judgments and Decisions 2004-V, para. 182.

436 Ibid.

437 Powell and Rayner v. the UK, para. 44. As already observed the Court treated this subject as being equally applicable to both negative and positive obligations.

438 Powell and Rayner $v$. the UK, para. 45.
} 
In later cases involving environmental nuisance, the Court intensified the proportionality requirement in circumstances in which States had allowed private entities to cause environmental nuisance to the detriment of individuals' rights. The Court placed more emphasis on the balancing of interests and the procedural aspects of national decision-making that preceded the alleged conduct. For example in the case of López Ostra v. Spain, ${ }^{439}$ in which local authorities had failed to regulate the operation of a waste treatment plant which caused severe environmental and health harm to individuals residing in the vicinity, the Court held that in view of Spain's positive obligations and,

"[...] despite the margin of appreciation left to the respondent State, the Court considers that the State did not succeed in striking a fair balance between the interest of the town's economic well-being - that of having a waste-treatment plant - and the applicant's effective enjoyment of her right to respect for her home and her private and family life." 440

In sum, the Court's early case law with regard to environmental harm caused by private entities and the State's margin of appreciation enables the following assessment. States have a wide margin of appreciation with regard to economic or social policies that allow private entities to run operations that carry significant economical benefits to the region or country in general, even if the latter infringe on the rights of individuals. However, a fair balance has to be struck between the economic or social interests, and the interests of the individuals affected, whereby the State's adoption of positive measures or lack thereof can reduce its margin of appreciation. When national procedural aspects are not complied with, then it can be argued that the State has not struck a fair balance between the competing interests leading to a violation of the right at stake.

In applying these concepts to the issue of privatization, the following can be stated. As previously observed, the adoption and implementation of privatization policies (which are of an economic and political nature) will inherently lead to a wide margin of appreciation for the State. This wide margin of appreciation implies that national authorities are in the better position to assess whether privatization is necessary for the advancement of national economic interests. It includes an assessment of the national authorities of the necessity to interfere in the enjoyment of a right through the adoption of privatization policies, and of the choice of methods of privatization used to interfere with a right. The State's wide margin of

439 López Ostra v. Spain, judgment of 21 February 1990, ECtHR Series A-172.

440 Ibid., para. 58. Similarly, in Guerra v. Italy, the Court, without even having expressly observed whether Italy had a margin of appreciation, held that the State had failed to adopt positive measures to adequately and timely inform the inhabitants of a village of the environmental harm caused by a neighboring private fertilizer factory. See Guerra and Others $v$. Italy, judgment of 19 February 1998, ECtHR Reports 1998-I, paras. 58 and 60. 
appreciation with regard to privatization will depend on how well reasoned the balancing of competing interests (individual versus the national economical interests that privatization is supposed to serve) has been, and on whether national procedural requirements have been appropriately followed. However, when privatization leads to harmful conduct by private entities the margin of appreciation will be reduced, particularly in instances where the State has failed to follow its own procedural rules and this is causally related to the harm caused. If the State then fails to promptly adopt adequate positive measures to limit the harm caused by the privatized entities or the measures chosen are not sufficient to alleviate the consequences of the harmful conduct, then States will see their margin of appreciation considerably reduced. This could be the case, for example, even when adequate regulatory procedures have been put in place to control the conduct of private actors that have taken over functions or tasks previously performed by the public authorities, but the State failed to follow them. ${ }^{441}$

Further guidance on the limits of a State's margin of appreciation with regard to economical policies and environmental nuisance caused by the conduct of private actors may be found in the Hatton and Others v. the UK (Grand Chamber) judgment. ${ }^{42}$ The case revolved around a similar problem as the one in Powell and Rayner: noise nuisance caused by flights in and out of (privatized) Heathrow airport, although this time the noise complained of was caused by night flights. In 2001 the third section of the ECtHR observed that, "[...] in the particularly sensitive field of environmental protection, mere reference to the economic well-being of the country is not sufficient to outweigh the rights of others." ${ }^{243}$ In the eyes of the third section, the UK had not adopted the required measures to mitigate the nuisance as required by the UK's positive obligations. In particular, the third section was of the opinion that the UK should have minimized as far as possible interference with Article 8, by trying to find alternative solutions and by generally seeking to pursue its (economical) aims in the least harmful way vis-à-vis human rights. It then found a violation of Article 8 concluding that the UK had not struck the required balance between the country's economic well-being and the applicants' effective enjoyment of their right to respect for their homes and their private and family lives. ${ }^{444}$

Unsatisfied by this outcome, the UK referred the case to the Court's Grand Chamber, which overturned the third section's judgment and concluded that the UK

441 See Fadeyeva v. Russia, para. 132-134, in which the Court concluded that "[...] despite the wide margin of appreciation left to the respondent State, it has failed to strike a fair balance between the interests of the community and the applicant's effective enjoyment of her right to respect for her home and her private life."

Hatton and Others v. the UK, Grand Chamber judgment of 8 July 2003, ECtHR Reports 2003VIII.

443 Hatton v. the UK (Third Section), judgment of 2 October 2001, ECtHR, Application Number 36022/97, para. 97.

444 Ibid., para. 107. 
had not overstepped its margin of appreciation. In its findings regarding the UK's margin of appreciation, the Grand Chamber firstly observed that,

"[i]n matters of general policy, on which opinions within a democratic society may reasonably differ widely, the role of the domestic policy-maker should be given special weight." 445

The Grand Chamber then noted that Article 8 ECHR could be relevant in environmental cases whether the pollution is directly caused by the State or whether State responsibility arises from the failure to regulate private industry properly. ${ }^{446}$ Following a recapitulation of the principles adopted by the ECtHR in Powell and Rayner v. the UK and López Ostra v. Spain, ${ }^{447}$ the Grand Chamber observed that there are two aspects to the inquiry that may be carried out to assess whether the national measure (or conduct) complained of complies with the Convention's rights (in these types of cases, usually Article 8 ECHR). ${ }^{448}$ The first aspect involves an investigation of the substantive merits of the national authorities' decision to ensure its compatibility with the right at stake. The second aspect involves an examination of the decision making process to test whether due weight was accorded to the interests of the individual (procedural aspect).

With respect to the substantive aspect, the Grand Chamber asked whether the interfering measures were compatible with the right at stake. ${ }^{449}$ The Grand Chamber first confirmed what it had previously held in Powell and Rayner and Buckley v. the $U K$, noting that in areas involving social, technical, or environmental issues, States are to be accorded a wide margin of appreciation. ${ }^{450}$ However, citing Buckley, the Grand Chamber observed that the scope of this margin will be determined by several factors including the nature of the Convention right at issue, its importance for the individual and the nature of the activities concerned. To emphasize this point the Grand Chamber cited previous case law and observed that, "[...] where

445 Hatton v. the UK (Grand Chamber), para. 97.

446 Ibid., para. 98.

447 Ibid.: "Whether the case is analysed in terms of a positive duty on the State to take reasonable and appropriate measures to secure the applicants' rights under paragraph 1 of Article 8 or in terms of an interference by a public authority to be justified in accordance with paragraph 2 , the applicable principles are broadly similar. In both contexts regard must be had to the fair balance that has to be struck between the competing interests of the individual and of the community as a whole; and in both contexts the State enjoys a certain margin of appreciation in determining the steps to be taken to ensure compliance with the Convention. Furthermore, even in relation to the positive obligations flowing from the first paragraph of Article 8, in striking the required balance the aims mentioned in the second paragraph may be of a certain relevance."

448 Ibid., para. 99. The Court has subsequently applied this two-tiered inquiry in the case of Taşkın and Others v. Turkey, judgment of 10 November 2004, ECtHR Reports of Judgments and Decisions 2004-X, paras. 11-125.

449 Hatton and Others v. the UK (Grand Chamber), para. 99.

450 Ibid., para. 100-101. 
government policy [...] interferes with a particularly intimate aspect of an individual's private life, the margin of appreciation left to the State will be reduced in scope." 451

Again, the necessity of the measure that entails a wide margin of appreciation (i.e. the 'economic' necessity for privatization or the necessity to adopt regulatory measures vis-à-vis privatized entities) will have to be balanced against the interests of individuals. Proportionality will play an important role. This means that the inquiry with regard to privatization will have to marginally examine how far privatization is necessary for the State and whether its application affects the rights of individuals too deeply. It will also have to look at whether the individuals' concerns have been totally disregarded, and whether measures have been adopted to mitigate any adverse effects directly caused by privatization policies or by the conduct of privatized entities. ${ }^{452}$

With respect to the procedural aspect, the Court has observed that the decisionmaking process leading to measures of interference must be fair and should afford due respect to the interests of the individual as safeguarded by the right at stake. ${ }^{453}$ In cases involving environmental issues this means considering "[...] all the procedural aspects, including the type of policy or decision involved, the extent to which the views of individuals (including the applicants) were taken into account throughout the decision-making procedure, and the procedural safeguards available." 454 According to the Grand Chamber in Hatton, governmental decisionmaking processes concerning complex issues of environmental and economic policy must therefore involve appropriate investigations and studies that allows the State to strike a fair balance between the various conflicting interests at stake. ${ }^{455}$

The procedural considerations with regard to privatization will therefore require appropriate studies that make an impact assessment of the effects of privatization not only on an economical level, but also on a human rights level. ${ }^{456}$ In addition, it will require appropriate consultation with all involved. Moreover, all impact assessments and studies with regard to the reasons for privatization, the methods to be applied, and the expected effects/results will have to be made available to those persons affected. ${ }^{457}$ This may also include providing information to citizens on the

\footnotetext{
451 Ibid., para. 102. See also Dudgeon v. the UK, judgment of 22 October 1981, ECtHR Series A-45, para. 52.

452 Hatton and Others $v$. the UK (Grand Chamber), paras. 125-127.

453 Taşkin and Others v. Turkey, para. 118.

454 Ibid., para. 104.

455 Hatton and Others $v$. the UK, para. 128.

456 With respect to impact assessments and human rights see S. Walker, The Future of Human Rights Impact Assessments of Trade Agreements (Antwerp: Intersentia, 2009). Ibid.
} 
potential harmful conduct of privatized entities as determined in Guerra. ${ }^{458}$ It will also require that those affected be allowed to make representations and put forward their views or present complaints against the privatization plans (or the harmful conduct of private entities involved in the exercise of privatized tasks). This means providing proper avenues and procedures for consultation and guaranteeing eventual access to the courts for challenging the privatization measures, especially if they believe that the decision-making process did not take due consideration of their interests. ${ }^{459}$

In sum, the limits to a State's margin of appreciation adopting and implementing privatization policies will involve a two-step inquiry. In the first place the privatization measures will be checked for compatibility with the right they could impact. Although at this stage the margin of appreciation for privatization will be wide, it may be reduced if the measures affect the right too deeply and the State does not adopt mitigating measures. Secondly, the decision-making procedure that led to privatization will also be examined. At this stage, the margin of appreciation will be reduced if a State fails to involve those affected by privatization in the debate that leads to the adoption of the policy and if it does not allow them to intervene or act against what they may consider harmful to their interests.

\subsubsection{Margin of appreciation, non-derogable rights and due process rights}

In the previous paragraphs, it was asserted that the nature of the right can play a role in determining the margin of appreciation. This is appreciable with respect to non-derogable rights. The various human rights treaties encompass a wide variety of rights ranging from the right to life to the right to adequate health care. However, several human rights treaties consider a number of those rights to be non-derogable. Under the ECHR, for example, the right to life (Article 2), the prohibition of slavery, the prohibition of torture, and the prohibition of retroactivity in criminal law are considered as non-derogable. According to Arai-Takahashi, the European Court has refrained from even considering that States may have any margin of appreciation in dealing with these rights. ${ }^{460}$ The importance of these rights is so great and their nature so intimately bound with the essence of the minimum respect a State must show towards human dignity that any consideration of allowing a margin of appreciation in their application would undermine the whole concept of human rights.

458 See Guerra v. Italy, paras. 58 and 60. See also Arai-Takahashi, The Margin of Appreciation Doctrine and the Principle of Proportionality in the Jurisprudence of the ECHR, p. 219.

459 Guerra v. Italy, para. 60. See also Taşkin and Others v. Turkey, para. 119.

460 Arai-Takahashi, The Margin of Appreciation Doctrine and the Principle of Proportionality in the Jurisprudence of the ECHR, p. 226. 
It stands to reason that privatization measures or the conduct of privatized entities that affect in any way the enjoyment of non-derogable rights would not be subject to the margin of appreciation. This is very much the case with the prohibition of torture or any other ill treatment, which may come into play with regard to the privatization of prisons or the privatization of military and security services. As we will see in Chapter VI, it is likely that States which have privatized military and security services will be confronted with issues involving torture and other forms of intolerable abuse. It is submitted that States should not be allowed to invoke a margin of appreciation in such a situation, not even when it claims that privatization of this sector is necessary to pursue important public interests such as the fight against terrorism.

Under the ECHR, the margin of appreciation is also invoked with respect to 'due process' rights such as the right to liberty and security of the person (Article 5 ECHR), and the right to access to court and a fair trial (Article 6 ECHR). The Court has held that these rights are not absolute and contain implied limitations. ${ }^{461} \mathrm{With}$ respect to these rights (and other rights not having express reference to limitation clauses), the assessment of whether a State has gone beyond what is allowed by its margin of appreciation will involve a number of criteria similar to the ones described above. This means investigating whether a legitimate goal is being pursued by a limitation imposed by the State. It also requires the State to seek proportionality between the goal or aim to be achieved and the means employed to restrict the right. ${ }^{462}$ In addition, the Strasbourg jurisprudence has made it clear that States relying on their margin of appreciation to impose a limitation on a right have to take care not to restrict the right in such a way that its 'very essence' is impaired. ${ }^{463}$ This requirement entails that the exercise of rights must be real and effective and that States have to be careful not to make their enjoyment non-existent or so reduced as to be of no practical value. ${ }^{464}$ Although it would appear that the Strasbourg case law initially did not always manifest what the 'very essence' of a particular right might be, it did suggest that it would increase its standard of review if it considered that

461 See Golder v. UK, judgment of 21 February 1975, ECtHR, Series A-18, paras. 37-38.

462 See f.e., Ashingdane v. UK, judgment of 28 May 1985, ECtHR, Series A-93, para. 57, and Lithgow and others $v$. the UK, judgment of 8 July 1986, ECtHR, Series A-102, para 194. See also Lawson and Schermers, Leading Cases of the European Court of Human Rights, p. 25-26, and Arai-Takahashi, The Margin of Appreciation Doctrine and the Principle of Proportionality in the Jurisprudence of the ECHR, p. 35.

463 See, among others, Winterwerp v. The Netherlands, judgment of 24 October 1979, ECtHR, Series A-33, para. 60, and Rees v. UK, judgment of 17 October 1986, ECtHR, Series A-106, para. 50. The Court also refers to 'very substance' of a rights. See Young, James and Webster v. the UK, judgment of 13 August 1981, ECtHR, Series A-44, paras. 55-56. See also Arai-Takahashi, The Margin of Appreciation Doctrine and the Principle of Proportionality in the Jurisprudence of the ECHR, p. 36-42.

464 Young, James and Webster v. UK, para. 55. Compare this 'very essence' requirement with the 'minimum core content' approach advocated in the context of economic, social and cultural rights. See Section 4.1.4 supra. 
the hard core of that right was impaired. ${ }^{465}$ In latter years, the Court has attempted to flesh out the 'very essence' notion. For example, with regard to Article 6 ECHR, the Court adopted three further requirements: a. the foreseeability test whereby States have to make sure that the access to courts and their procedural rules are made sufficiently clear and offer sufficient safeguards; b. the effectiveness principle, whereby States must make the enjoyment of the right to a fair trial real and effective and not merely theoretical; and c. the proportionality principle, whereby procedural rules restricting the access to courts may not be made so harsh that the right to access a court is made illusory. ${ }^{466}$ In sum, States are expected not to render the exercise of a particular right meaningless and ineffective by claiming that they have a certain margin of appreciation. Furthermore, the measures adopted under the margin of appreciation have to respect the hard core of the right and be proportional to the aim sought.

Thus, the exercise of a right must not be made illusory by an appeal to a wide margin of appreciation in the name of privatization. Privatization policies will have to respect the 'very essence' or minimum core content of a right. From this we can conclude that the proportionality condition will always play an important role.

\subsubsection{Margin of appreciation and consistent practice of States}

In matters where there is little consensus between signatories to the ECHR, the European Court of Human Rights has accorded States a wide margin of appreciation, thus limiting the scope of review of human rights adjudicating bodies. ${ }^{467}$ This was the case in Abdulaziz v. the $U K^{468}$ in which the ECtHR held that with regard to positive obligations under the banner of Article 8 ECHR on the right to family life, States enjoyed a wide margin of appreciation due to the fact that the practice of States with respect to the admission of aliens for the purpose of family reunification varied considerably. ${ }^{469}$ Similarly, in the already mentioned case of Rees $v$. the UK, the Court concluded that due to differing practice of States regarding the recognition of the status of transsexuals,

"[...] there is at present little common ground between the Contracting States in this area and that, generally speaking, the law appears to be in a transitional stage. Accordingly, this is an area in which the Contracting Parties enjoy a wide margin of appreciation.," 470

\footnotetext{
465 Arai-Takahashi, The Margin of Appreciation Doctrine and the Principle of Proportionality in the Jurisprudence of the ECHR, p. 38-39.

466 Ibid., p. 39-40.

467 Ibid., p. 84.

468 Abdulaziz v. the UK, judgment of 28 May 1985, ECtHR, Series A-94.

469 Ibid., para. 67.

$470 \quad$ Rees v. the UK, para. 37.
} 
With respect to privatization the following is suggested. At first sight, it would appear that there is little consensus about the desirability or necessity to apply privatization measures among States. Not all States have adopted privatization measures. Those States that have adopted these measures have done so under different circumstances and have chosen different methods to realize them. However, it would be fair to assume that among groups of States, such as those members of the Organization for Economic Cooperation and Development (OECD), that actively pursue privatization policies a consensus has grown with regard to the application of these policies, the circumstances under which they are to be applied, and the adequate methods of privatization for particular cases, to the extent that detailed recommendations are issued on how to apply privatization policies. It would thus be reasonable to accept that an assessment of the margin of appreciation for those States could result in finding that there is common ground with regards to the necessity and applicability of privatization, and as such the margin of appreciation would be less wide than with other economical or social policies.

\subsubsection{Some observations}

As already noted, there is no case law dealing with privatization and the margin of appreciation as the central issue of concern. Nevertheless, this Section has attempted to apply the existing concepts related to the margin of appreciation to privatization in an effort to evaluate the potential results. Within the context of the current study, the margin of appreciation doctrine may well play an important role in determining whether privatization measures are compatible (or not) with human rights obligations. Although the examples used in this section stem from the case law of the ECHR, it is suggested that they may be of assistance in determining how far States are allowed to go in adopting general economic policy measures under other jurisdictions.

In general, it can be stated that with regard to devising, deploying, and applying policies of a general economic, social, or technical nature, States will be allowed a wide margin of appreciation. This is due to the fact that striking a balance between individual interests and the public interest in general is a delicate issue for international adjudicators confronted with issues that are strongly influenced by national political choices. Thus, the review of State conduct involving privatization, pre-eminently an economical policy at heart sometimes borne out of deeply debated political choices, could very likely result in granting the State a wide margin of appreciation. This is evident, for example, in the case law of the ECtHR such as Powell and Rainer and Hatton (Grand Chamber), in which the Court accorded the State a wide margin of appreciation in respect of measures involving a privatized entity and aspects of general economic interest for a country. 
This proposition, however, can be somewhat qualified by pointing out that (international) human rights adjudicators will also take into account the nature (or importance) of the right at stake. ${ }^{471}$ Thus, the margin of appreciation for nonderogable personal freedom rights such as, the right to life, the prohibition of illinhumane or degrading treatment or the right to a due process will be narrow. It is therefore suggested that in cases involving the privatization of prisons, police services, military services and other services involving the coercive use of force by the State and law enforcement, as well as the possible privatization of the judiciary, ${ }^{472}$ States will have a narrow margin of appreciation. In contrast, the margin of appreciation for rights that allow derogations (right to family life and home) or which envisage progressive realization such as economic, social and cultural rights (right to adequate healthcare, adequate standard of living including water and housing, social security and education) may be wider. Thus cases related to the privatization of activities that potentially have great economical and budgetary impact such as the privatization of airports, housing, social security, health care, or utilities will probably be subjected to a wide margin of appreciation. With regard to privatization measures affecting the 'core content' of economic, social and cultural rights, however, the margin of appreciation could be narrower, since deciding otherwise would render the realization of these rights meaningless or ineffective. ${ }^{473}$

The margin of appreciation's width in respect of privatization will also depend on the additional measures States have taken to ameliorate any possible negative impact from privatization. These measures may include procedural ones such as consultation and involvement with those closely affected by privatization measures as suggested by the ECtHR in Hatton, as well as providing them with adequate and prompt compensation or restitution or instituting adequate (legal) remedies where those affected could seek help or redress or a review of the decision that affected them. These measures may also be of a more substantive nature including providing assistance in securing a minimal enjoyment of the rights affected by offering alternatives to a service, and providing properly targeted subsidies to those not in

471 See for example Macdonald who observes that "[...] the importance of the right concerned may limit the margin of appreciation regarding any particular derogation." Macdonald, "The Margin of Appreciation," p. 90.

472 See, for example, D.M. Kahan, "Privatizing Criminal Law: Strategies for Private Norm Enforcement in the Inner City," UCLA L. Rev. Vol. 46 (1999), p. 1859-1872, in which different strategies to privatizing criminal law by enhancing the participation of local communities in law enforcement are reviewed.

473 This would also apply to civil and political rights when the 'very essence' of the right is at stake by privatization measures. For further discussion on the 'very essence' doctrine as it relates to the margin of appreciation (within the context of the right to fair trial see Arai-Takahashi, The Margin of Appreciation Doctrine and the Principle of Proportionality in the Jurisprudence of the ECHR, p. 36-37. 
the position to easily afford a service as recommended by the UN Committee on Economic Social and Cultural Rights. ${ }^{474}$

\subsection{Availability of (judicial) remedies and regulation}

International and regional human rights treaties impose on States an obligation to provide effective remedies for human rights violations. ${ }^{475}$ Under international human rights law, the concept of remedies has a twofold meaning. On the one hand, it has a substantive meaning encompassing a right to a remedy, which may be understood as the availability of redress for harm caused by human rights violations. ${ }^{476}$ On the other hand, the concept of remedies comprises a procedural meaning that relates to the availability of procedures through which this redress or relief may be obtained. ${ }^{477}$ The latter may be termed as procedural or judicial remedies.

The issue of remedies is highly relevant to the central theme of this study. From the substantive perspective, States are obliged to provide effective redress for the eventual negative effects privatization may have directly on individuals, or, indirectly, for the harmful conduct of privatized entities. As we will see this redress may take various forms such as monetary compensation, or cessation of wrongdoing. From the procedural perspective, States have an obligation to provide adequate avenues for seeking redress in the light of privatization measures or the activities of those entities entrusted with privatized functions, tasks or services. These avenues may include access to regular courts (criminal, civil, or administrative), although as we will see, it may also include other mechanisms that allow individuals to seek a resolution for the problems that privatization may cause.

In the following paragraphs attention will be paid to the substantive aspect of remedies under international human rights law with regard to privatization. However, the emphasis will be placed on the procedural aspect and its link with regulation. In Section 4.1.2.3 supra we discussed the issue of regulation from the perspective of positive obligations. One important aspect of regulation is the establishment of a regulatory agency (the regulator) that monitors the activities of private entities entrusted with privatized tasks. Some regard the role of the regulator as essential to ensure that privatization functions properly. This section will therefore discuss whether regulation and regulatory mechanisms monitoring the

\footnotetext{
474 See for example General Comment No. 15 on the right to water, para. 13.

475 See for example Article 2 (3) ICCPR, Article 13 ECHR, Article 25 ACHR, and Article 7 African Convention on Human and Peoples' Rights.

476 D. Shelton, Remedies in International Human Rights Law (Oxford: Oxford University Press, 1999) p. 4.

477 Ibid.
} 
conduct of privatized entities can be regarded as judicial remedies in the procedural sense of the concept.

\subsubsection{Substantive remedies and privatization}

Victims of human rights abuses have the right to an adequate redress caused by the violation of their rights. Remedies and redress in this context must be understood as the measures that are to be adopted as a response to an actual or threatened violation of human rights and which are meant to provide relief to the victim. ${ }^{478}$ Shelton notes that substantive remedies are necessary to convert law into actual results, act as deterrents to behavior that may cause harm to the enjoyment of human rights and restore the moral balance when wrongs are committed. ${ }^{479}$ In sum, they are meant to restore "[...] the situation 'as if' the wrongdoer had not violated the rights of the victim." $" 480$

Although international human rights norms reflect this approach, the actual content of substantive remedies has been filled in by human rights monitoring mechanisms. For example, Article 8 of the Universal Declaration of Human Rights provides that,

"[e]veryone has the right to an effective remedy by the competent national tribunals for acts violating the fundamental rights granted him by the constitution or by law."

This provision was further codified in Article 2(3)(a) ICCPR, which guarantees to persons whose rights or freedoms have been violated an effective remedy notwithstanding whether the violation was committed by persons acting in an official capacity. The ICCPR, however, does not expressly mention what the actual content of the remedy may be. The Human Rights Committee has addressed this (apparent) lapse in its General Comment No. 31 on the nature of the general legal obligations imposed on States parties to the ICCPR. According to the Committee Article 2(3) ICCPR requires, inter alia, "[...] that States Parties make reparation to individuals whose Covenant rights have been violated." 481 This is reinforced by the fact that Article 9 ICCPR on the right to liberty and security of the person and Article 14 ICCPR on the right to a fair and public trial provide a right to compensation for those individuals that have been subject to unlawful detention (Article 9(5) ICCPR) or to a miscarriage of justice (Article 14(6) ICCPR). The Human Rights Committee further observes that reparation as understood by the term remedy in Article 2(3) ICCPR may take the shape of restitution, rehabilitation and measures of satisfaction, such as public apologies, public memorials, guarantees

\footnotetext{
478 Ibid.

479 Ibid., p. 54.

480 Ibid., p. 55.

481 See General Comment No. 31 on the Nature of the General Legal Obligation Imposed on States Parties to the Covenant, UN Doc. CCPR/C/21/Rev.1/Add.13 (26 May 2004), para. 16.
} 
of non-repetition and changes in relevant laws and practices, as well as bringing to justice the perpetrators of human rights violations. ${ }^{482}$

Similarly, the Inter-American Court of Human Rights concluded in the Velásquez Rodriguez case that the obligation to ensure the rights of the American Convention on Human Rights (as expressed in Article 1(1) ACHR) requires States to "[...] prevent, investigate and punish any violation of the rights recognized by the Convention and, moreover, if possible attempt to restore the right violated and provide compensation as warranted for damages resulting from the violation." ${ }^{, 43}$

In contrast to the treaties covering civil and political rights, the treaties that deal with economic, social and cultural rights, the ICESCR and the (revised) ESH do not contain any express references to the availability of remedies (both substantive and procedural). However, the UN Committee on Economic, Social and Cultural Rights has acknowledged the importance of substantive remedies in General Comment No. 12 on the right to adequate food (Article 11 ICESCR), ${ }^{484}$ in General Comment No. 14 on the right to the highest attainable standard of health (Article 12 ICESCR), 485 and in General Comment No. 15 on the right to water (Articles 11 and 12 ICESCR) ${ }^{486}$ According to the Committee, all victims of violations of the right to adequate food, the right to the highest attainable standard of health, or the right to water, "[...] are entitled to adequate reparation, which may take the form of restitution, compensation, satisfaction or guarantees of non-repetition."

Substantive remedies in the context of privatization will of course entail offering those individuals who have been subjected to harm or abuses by privatized entities effective redress for that conduct. Although the remedies usually applied in the context of human rights violations will generally apply to human rights abuses as a result of privatization (compensation, declaratory judgments, public apologies and assurances of non-repetition), other types of substantive remedies may be more pertinent depending on the type of privatization and particular circumstances of the case. Thus, with regard to the privatization of public utilities such as water, some practical effective substantive remedies can be thought of. For example, if a violation of the right to water as embodied in Article 11 ICESCR (in so far as it is

\footnotetext{
482 Ibid.

483 Velásquez Rodríguez Case, Merits, judgment of 29 July 1988, IACtHR, Series C No. 4, para. 166.

484 See General Comment No. 12 on the right to adequate food (Article 11 of the International Convention on Economic, Social and Cultural Rights, UN Doc. E/C.12/1999/5 (12 May 1999), para. 32.

485 See General Comment No. 14 on the right to the highest attainable standard of health, para. 59.

486 See General Comment No. 15 on the right to water, para. 55.
} 
justiciable $)^{487}$ results from the cutting off of the service, the appropriate substantive remedy could be the restoration of the service.

In other cases, providing an effective substantive remedy will not entail restoring the situation so that it recreates the one prior to the violation. If a privatized water utility fails to expand the water distribution network as required under the concession contract, compensation for the lack of service will only alleviate part of the problem. A more practical substantive remedy would be to impose an obligation on the privatized water utility to increase its efforts to rapidly spread the water network and connections to those areas or individuals affected.

\subsubsection{Procedural remedies and privatization}

In addition to substantive remedies, international human rights law also requires States to adopt procedural remedies, which guarantee, inter alia, a right of effective access to a fair hearing. ${ }^{488}$ For example, under Article 2(3) ICCPR,

"[e]ach State Party to the present Covenant undertakes: (a) To ensure that any person whose rights or freedoms as herein recognized are violated shall have an effective remedy, notwithstanding that the violation has been committed by persons acting in an official capacity; (b) To ensure that any person claiming such a remedy shall have his right thereto determined by competent judicial, administrative or legislative authorities, or by any other competent authority provided for by the legal system of the State, and to develop the possibilities of judicial remedy; (c) To ensure that the competent authorities shall enforce such remedies when granted."

Having an effective avenue for seeking redress for the harmful effects of privatization or for challenging the decision of a private entity in charge of privatized functions or services is of great importance under the privatization discussion. Depending on the function, task or service being privatized, those individuals making use of the services provided by a particular privatized sector (or are subjected to it in some other way) can have different ways of seeking redress for any harm caused to them. In some of these cases the obvious avenue for seeking redress will be a national judicial or adjudicatory body capable of determining the rights or obligations of individuals, or any criminal charge against them. This essential right of access to court is guaranteed in Article 14 ICCPR. ${ }^{489}$

487 For a more in depth discussion on the right to water with regard to privatization and its possible justiciability, see Chapter VII Section 3.2.

488 Shelton, Remedies in International Human Rights Law, p. 14.

489 Article 14 ICCPR guarantees that, “[...][i]n the determination of any criminal charge against him, or of his rights and obligations in a suit at law, everyone shall be entitled to a fair and public hearing by a competent, independent and impartial tribunal established by law.[...]" See also Article 6(1) ECHR, Article 8(1) ACHR and Article 7(1) ACHPR. 
In other situations finding a proper procedural remedy could be more complex. For example, the users of privatized water and sewerage services will in all likelihood have signed service contracts with the privatized utility providing the services. They pay the privatized utilities for having access to the mains and for the amount of water consumed. Complaints against the quality of the service provided, against the water bill, or for (unfair) disconnection from the water mains will first probably have to be directed to the privatized utility. If for whatever reason the problem cannot be sorted out between the service user and the privatized utility, complaints may have to be submitted before the monitoring or regulatory body entrusted with overseeing the compliance with the concession contract between the privatized water utility and the State. If the outcome of this procedure is not satisfactory individuals could seek recourse to a court of law for judicial review of the decision by the regulatory body. But it may also be possible to directly challenge the decision of the privatized utility for non-compliance with human rights. ${ }^{490}$

For other privatized functions, the situation may be less clear. Students of a privatized school will probably have to first present their grievances to the school board, and then to a (governmental) school monitoring body if one exists. In the case of a privatized social welfare benefit system, the recipients of the benefit will probably have to turn to the private entity in charge of paying the benefits. Inmates in a privatized correctional facility do not have a contractual relationship with the company running the facility. The contractual relationship will usually be between the State and the private prison company. In countries with privatized prisons, inmates may turn to a correctional control, monitoring mechanism or inspectorate if they believe that their prisoner privileges are unfairly reduced, or if the disciplinary measures adopted against them are unduly harsh. ${ }^{491}$ However, to where can individuals turn when they have been detained by a private security service, which has been entrusted with coercive powers for seizing and detaining persons? Much will depend on how a State has chosen to privatize these different sectors and also on the regulatory and monitoring arrangements they might have adopted. ${ }^{492}$

In the light of these seemingly complex possibilities, which of course, are not entirely exclusive to privatization, it is necessary to determine how procedural remedies may be regarded as effective and in conformity with human rights standards. It is also necessary to examine whether regulation and a regulatory agency entrusted with monitoring the (economic) activities of privatized entities may be regarded as effective procedural remedies.

490 On this issue see Chapter IV Section 3 which argues that under specific circumstances, privatized entities could be regarded as special State entities, whose conduct or decisions are amenable to human rights review.

491 See next Section.

492 On the issue of regulation as a positive obligation under human rights see Section 4.1.2.3 supra. 


\subsubsection{Procedural remedies under human rights law}

The availability of procedural remedies under human rights is of great importance as a means to protect individuals against violations of these rights. ${ }^{493}$ What do the procedural remedies as understood by Article 2(3) ICCPR or Article 13 ECHR encompass? The UN Human Rights Committee has observed in its General Comment No. 31 that "Article 2, paragraph 3, requires that in addition to effective protection of Covenant rights States parties must ensure that individuals also have accessible and effective remedies to vindicate those rights." 494 However, it is necessary to note that both Article 2(3) ICCPR and 13 ECHR have an accessory character. That means that this provision can be violated in conjunction with some other right guaranteed by the Covenant. A person who argues that a substantive right of the Covenant has been violated in their respect has a right to an effective remedy under Article 2(3) ICCPR. ${ }^{495}$ The same is true with regard to Article 13 ECHR that contains a similar (if less extensive) provision. ${ }^{496}$ This, however, does not mean that an effective remedy must be available only if a substantive right has been violated. An individual who claims that his rights under a particular convention have been violated is entitled to an 'effective remedy before a national authority' where this claim may be decided and, if appropriate, granted redress. ${ }^{497}$ Thus, individuals claiming that their rights have been affected by privatization or by the conduct of a private actor in charge of a privatized activity, should have access to a body or procedure that allows them to present their grievances against privatization or challenge the decisions of that private actor.

What types of national authorities or bodies fulfill the requirements of a procedural remedy? Although the text of Article 2(3)(b) ICCPR appears to give priority to 'judicial' remedies in the sense of national adjudicatory bodies, ${ }^{498}$ non-judicial avenues such as administrative bodies may also serve as effective remedies. According to Nowak, Article 2(3) ICCPR does not require a court or any other organ with quasi-judicial independence. ${ }^{499}$ In General Comment No. 31, the Human Rights Committee noted that

493

494

See also Nowak, U.N. Covenant on Civil and Political Rights: CCPR Commentary p. 57. General Comment No. 31, para. 15.

See Nowak, U.N. Covenant on Civil and Political Rights: CCPR Commentary p. 34-35.

Article 13 ECHR states that "[e]veryone whose rights and freedoms as set forth in this Convention are violated shall have an effective remedy before a national authority notwithstanding that the violation has been committed by persons acting in an official capacity." See van Dijk, P. and van Hoof, G.J.H, Theory and Practice of the European Convention on Human Rights, $3^{\text {rd }}$ ed. (The Hague: Kluwer Law International/SIM, 1998) p. 697.

See with respect to Article 13 ECHR, Klass and Others v. Germany, judgment of 6 September 1978, ECtHR Series A-28, para. 67, and Silver and Others v. UK, judgment of 25 March 1983, ECtHR Series A-61, para. 113. See also ibid., p. 698.

See Nowak, U.N. Covenant on Civil and Political Rights: CCPR Commentary p. 58.

Ibid., p. 60. 
"[...] the enjoyment of the rights recognized under the Covenant can be effectively assured by the judiciary in many different ways, including direct applicability of the Covenant, application of comparable constitutional or other provisions of law, or the interpretive effect of the Covenant in the application of national law. Administrative mechanisms are particularly required to give effect to the general obligation to investigate allegations of violations promptly, thoroughly and effectively through independent and impartial bodies. National human rights institutions, endowed with appropriate powers, can contribute to this end. A failure by a State party to investigate allegations of violations could in and of itself give rise to a separate breach of the Covenant." 500

The European Court of Human Rights has adopted a similar approach. In the case of Golder v. the $U K^{501}$ the Court concluded that an effective remedy before a national authority within the meaning of Article 13 ECHR "[... need] not be a 'tribunal' or 'court' within the meaning of Articles $6 \S 1$ and $5 \$ 1 . " 502$ This was reaffirmed in the case of Klass and others $v$. Germany, ${ }^{503}$ in which the Court held that an effective remedy, "[...] may not necessarily in all instances be a judicial authority in the strict sense." 504

In addition, the European Court has established that although one single remedy may not suffice to fulfill the requirements of Article 13 ECHR, other remedies available to a particular situation may help to make up for the shortcomings of the first one. ${ }^{505}$ This implies, however, that States also enjoy a certain margin of appreciation in determining what types of bodies and procedures will be available. 506

In spite of this margin of appreciation, any procedural remedy available in a privatization situation must also be effective. The effectiveness requirement entails that those bodies that are meant to fulfill the role procedural remedies must be able to secure and enforce the protection of the substance of the rights at stake in the domestic legal order, and provide appropriate relief. ${ }^{507}$ To be effective a procedural remedy must not only provide repressive measures, but also take preventive ones. ${ }^{508}$ Thus in the case of Herrera Rubio v. Colombia, the Human Rights Committee held

500 UN Human Rights Committee, General Comment No. 31, para. 15.

501 Golder v. the UK, judgment of 21 February 1975, ECtHR Series A no. 18.

502 Golder, para. 33.

503 Klass and others v. Germany, judgment of 6 September 1978, ECtHR Series A no. 28.

504 Ibid., para. 67. See also Silver and Others v. the UK, para. 113.

505 See $X v . U K$, judgment of 5 November 1981, ECtHR Series A no. 46, para. 60, and Silver and Others $v$. the UK, para. 113.

506 See for example Vilvarajah and Others v. the UK, judgment of 30 October 1991, ECtHR Series A-94, para. 122.

507 See van Dijk and Hoof, Theory and Practice of the European Convention on Human Rights, p. 706.

508 See Nowak, U.N. Covenant on Civil and Political Rights: CCPR Commentary p. 61-62. 
that States parties to the ICCPR should take specific and effective measures to prevent the violations of individual's rights and establish effective facilities and procedures to investigate thoroughly, by an appropriate impartial body, cases of human rights abuses. ${ }^{509}$ This fits, of course, with the State's positive obligations, which, as we have seen, imposes an obligation to protect the rights of individuals. Establishing procedural remedies that help in preventing harmful conduct by privatized entities would arguably be in line with the State's positive obligations and its new role under privatization. Finally, to be effective, a body offering a procedural remedy in the case of privatization should also have the competence to make a decision on the merits of a complaint, ${ }^{510}$ and provide a legally binding decision regarding complaints against privatized bodies. ${ }^{511}$ However, since the entity acting as a procedural remedy may not necessarily be a judicial body in the strict sense of the word, "[...] the powers and procedural guarantees an authority possesses are relevant in determining whether the remedy before it is effective." 512

To sum up, human rights law appears not to specifically require a judicial or adjudicatory body to fulfill the role of a procedural remedy in a privatization situation. Nevertheless, such a body should have sufficient powers and procedural guarantees that allows it to properly investigate allegations of violations of rights which are the result of privatization or of the conduct of the privatized actor. It should, therefore, be able to adopt binding decisions against privatized entities. In addition, such a procedural remedy must be able to act pro-actively to prevent any harmful conduct by privatized entities. Finally, the aggregate of remedies available to individuals suffering harm as a result of privatization will be determinative in assessing whether these remedies are effective. The State's margin of appreciation in this regard will mean that it may choose whatever type of procedure or body it deems to be sufficient to deal with privatization complaints. In the following subparagraph, it will be suggested that the adoption of regulatory measures and the establishment of proper regulatory bodies could be an adequate way of providing an effective procedural remedy under privatization.

509 Herrera Rubio v. Colombia (161/1983), Human Rights Committee, UN Doc. CCPR/ C/31/D/161/1983 (2 November 1987), para. 10.3. This observation was made in the context of violations of human rights as a result of ill-treatment and disappearances, but it also has bearing in the present context.

510 See Vilvarajah and Others $v$, the UK, para. 122. See also van Dijk and Hoof, Theory and Practice of the European Convention on Human Rights, p. 706-707.

511 See for example Leander v. Sweden, judgment of 25 February 1987, ECtHR Series A-116, para. 82.

512 Klass and Others v. Germany, para. 67. 


\subsubsection{Regulation ${ }^{513}$ as a procedural remedy?}

One of the aims of privatization is shrinking the State: to roll back the size of the State and make way for private actors. These actors would then take over the State's role in certain areas where it is estimated that they can perform the State's tasks more efficiently and more cost effectively through the workings of the market. In addition some governments intended the market to reduce government involvement in dispute resolution between its privatized industries and services, and consumers or service users. Prosser observed, for example, that in the United Kingdom the extensive privatization of public utilities was, "[...] intended to replace hierarchical administrative controls with a marketplace in which resort to the courts on public law matters would be unnecessary." 514

Privatization, however, has sometimes resulted in outcomes that contradict some of its goals, namely a reduction in the size of the State and deregulation of activities. As observed in Chapter II countries that have applied privatization policies in certain sectors have often also established some sort of regulatory mechanism together with a concomitant regulatory agency to monitor the performance of the private entities carrying out privatized tasks. This may be described as the 'privatization paradox' and is particularly true in the area of essential utilities that involve a natural monopoly, where independent regulators have been set up to ensure economic efficiency, prevent abuse of the monopolists position (economic regulation), as well as promoting social objectives, like safety, environmental protection, guarantee universal services, and protect consumer interests. ${ }^{515}$ Arguably, certain sectors that amount to natural monopolies, provide essential services, and that have been privatized should be subject to supervision and control by a regulator to prevent abuse and ensure compliance with privatization-enabling law and contracts. In addition, regulators can serve as points of access to consumers who have complaints about the delivery of these essential services, and as the protectors of the interests of particular types of consumers, including vulnerable groups. In England and Wales, for example, privatized water utilities are regulated by the Water Services Regulation Authority (Ofwat), the economic regulator of the water and sewerage industry, the Drinking Water Inspectorate, responsible for setting standards for the quality of drinking water, and the Consumer Council For Water, which represents customers of the water services and deals with complaints from consumers. ${ }^{516}$ In particular, Ofwat's main role under Section 2 of the Water

513 For a discussion on regulation from the perspective of positive obligations see Section 4.1.2.3 supra.

514 Prosser, "Public Service Law: Privatization's Unexpected Offspring," p. 63.

515 Foster, Privatization, Public Ownership and the Regulation of Natural Monopoly, p. 186 and 292.

516 Water utilities in England and Wales were privatized in 1989 through the Water Act 1989 (c. 15), which was later consolidated by the Water Industry Act 1991 (c. 56). Under these Acts, regulation 
Industry Act 1991 and Section 39 of the Water Act 2003 amending the former is to, inter alia, protect and seek value to consumers by setting limits to water tariffs the private water utilities may charge, protecting the standards of service companies provide, and encouraging the private water utilities to be more efficient. More notably, under Sections 39 and 43 of the Water Act 2003, both Ofwat and the Consumer Council for Water are expected to have regard to the particular interests of, among others, individuals who are disabled or chronically sick, individuals of pensionable age, individuals with low incomes, and individuals residing in rural areas.

In addition, it may also be valid to require the regulation of sectors involving the privatization of coercive functions such as privatized prisons, private security, and private military companies, in order to prevent any abuses by the entities carrying out these tasks. In fact, under the Optional Protocol to the UN Convention Against Torture and other Cruel, Inhuman or Degrading Treatment or Punishment (OPCAT), this may have already happened with regards to places of detention. The OPCAT establishes a new international human rights monitoring body, the Subcommittee on Prevention of Torture (SPT). ${ }^{517}$ State parties to the OPCAT are also required to establish, designate or maintain one or more independent visiting bodies for the prevention of torture, also called national preventive mechanisms (NPMs). ${ }^{518}$ Both the SPT and the NPMs have a mandate to visit places of detention in a proactive basis with the aim of preventing torture or other types of ill-treatment. Under Article 4 of the OPCAT State parties have to allow these preventive visits to any place under their jurisdiction and control where persons are deprived of their liberty. This includes explicitly 'public or private custodial settings', 519 arguably including privatized prisons. Several countries have already inspecting and visiting bodies that carry out visits to privatized prisons. In the United Kingdom for example, HM Inspectorate of Prisons carries out frequent visits to privatized prisons and immigration removal centers managed by private security companies. ${ }^{520}$ There is

was taken care for by the Director General of Water Services. The latter was replaced by the Water Services Regulation Authority in 2003 through the Water Act 2003 (c. 37), which also established the Consumer Council for Water.

518 See Article 3 OPCAT.

519 See Article 4 (1) and (2) OPCAT.

520 Under section 5A of the 1952 Prison Act (c.52) the Inspectorate of Prisons is authorized to inspect and report on prisons in England and Wales and report its findings. By virtue of section 84 para. 1 of the Criminal Justice Act 1991, which authorizes the UK Secretary of State to enter "[...] into a contract with another person for the running by him of any prison [...]", contracted out prisons shall be run subject to the 1952 Prison Act. According to the website of HM Prison Service, the Inspectorate of Prisons inspects private prisons in the same way as public sector prisons. See <www.hmprisonservice.gov.uk/prisoninformation/privateprison/> (last visited 20 June 2008, no longer available, but accessible through the national archive at: $<$ http:// webarchive.nationalarchives.gov.uk/20110204170815/www.justice.gov.uk/inspectorates/hmiprisons/>). For an example of an inspection to a privatized prison see the 2006 report of the visit 
also a UK Prison Ombudsman, who carries out investigations motu propio, and allows inmates in privatized prisons to submit complaints. ${ }^{521}$

In sum, although privatization was initially deployed to roll back the size of the State, it has also unintentionally resulted in establishing procedures and institutions that, to a certain extent, have counterbalanced the diminishing size of the State. ${ }^{522}$ In other words, privatization probably has not always led to the shrinking State as initially envisioned. ${ }^{523}$ The consequence of this privatization paradox is a shift in the activities and role of the State. The State is no longer the major producer of goods and provider of services. It has transferred the exercise of these tasks to private entities. But in so doing, the State has had to strengthen its monitoring role through the use of regulation of private activities. It has transformed itself from the producer to the regulator. ${ }^{524}$

From the perspective of human rights, this shift means that the emphasis of States' obligations under human rights treaties will be placed more on their positive obligations rather than the negative ones. ${ }^{525}$ In the words of the tri-partite set of obligations endorsed by the UN Committee on Economic, Social and Cultural Rights this would mean that although its obligations to respect and fulfill remain important, the privatizing State will have to focus more on its obligations to protect.

to Peterborough prison, the newest privatized prison in England and Wales, run by Kalyx (formerly UK Detention Services, a company that manages prisons and immigration removal centers in the United Kingdom): Report on an announced inspection of HMP/YOI Peterborough (Men), 9-13 October 2006, by HM Chief Inspector of Prisons, available at <www.justice.gov.uk/ downloads/publications/inspectorate-reports/hmipris/peterboroughmen-rps.pdf $>$ (last visited on 31 August 2011).

521 Under the Prisons and Probation Ombudsman's terms of reference, the Ombudsman can investigate "[...] all decisions relating to individual prisoners taken by Prison Service staff, people acting as agents of the Prison Service, other people working in prisons and members of the Board of Visitors [...]" The Ombudsman's terms of reference thus include contracted out prisons, contracted out services and the actions of people working in prisons but not employed by the Prison Service. See the website of the Prisons and Probation Ombudsman at <www.ppo. gov.uk/terms-of-reference.html > (last visited 31 August 2011).

522 In Prosser's opinion, privatization has engendered an unexpected offspring, public service law, which has come accompanied with new institutional arrangements (regulators). Prosser, "Public Service Law: Privatization's Unexpected Offspring," p. 63-82. For example, in the United Kingdom these regulators are not formally part of the public administration. However, they do operate in special public and administrative law arrangements. Their decisions are also subject to judicial review.

523 For a similar perspective on this phenomenon see also J. Freeman, "Extending Public Law Norms Through Privatization," Harvard Law Review Vol. 116 (2003), p. 1285-1352. Freeman argues that privatization can also be seen as a mechanism to expand the reach of government into realms that were traditionally thought to be private.

524 See also A. Petretto, "The Liberalization and Privatization of Public Utilities and the Protection of Users' Rights: The Perspective of Economic Theory," in Public Service and Citizenship in European Law, ed. M. Freedland and S. Sciarra, Oxford: Clarendon Press (1998), p. 99.

Although admittedly, the State's negative obligations remain very important. 
This entails providing effective procedural remedies to help ensure that privatized entities behave in a human rights friendly way vis-à-vis the users of privatized services or $v i s-\grave{a}$-vis those individuals that are subjected to privatized conduct. It will also require that States undertake measures to prevent abuses by privatized entities in a proactive manner.

Due to the nature of some of the services being privatized, regulatory bodies such as the ones described above, could embody the type of procedural remedies envisaged here. The use of these bodies as procedural remedies, however, raises the question as to their effectiveness. Although it is beyond the scope of the present study to go into further detail with regard to the question of effectiveness, it is suggested that regulatory bodies of privatized sectors could be deemed sufficiently effective and credible as procedural remedies if they conform to a minimum set of benchmarks. Taking inspiration from the suggestions of the UN Special Representative of the Secretary General on the issue of human rights and transnational corporations and other business enterprises, the following aspects should be taken into consideration in respect of regulatory bodies supervising the activities of privatized entities: legitimacy, transparency, accessibility and equitability, predictability, and compatibility with international human rights standards. ${ }^{526}$ Legitimacy and transparency would require regulatory bodies to be independent and open, and to provide a clear, fair and impartial process to manage complaints against privatized entities. They should guarantee transparent processes and outcomes, which arguably should include binding sanctions against privatized bodies if necessary. In terms of accessibility, regulatory bodies should ideally be open to anyone who may wish to approach them, in particular consumers of services provided by privatized entities, or those directly affected by their actions. They should also do away any barriers (financial, spatial, or legal) that may prevent access to them. In addition, information, advice, and expertise should be equally accessible to all parties involved. With regard to predictability, the procedures, outcomes such as eventual sanctions, and the monitoring of the implementation of these outcomes have to be predictable. This is particularly important if the process involves a complaint against a privatized actor. Finally, regulatory bodies should be aware of international human rights, and their procedures should be human rights compatible.

\subsubsection{Some observations}

There are two types of remedies available, substantive and procedural remedies. In the context of privatization, substantive remedies will have to offer an effective redress for persons that have been abused by privatized conduct. These substantive remedies will usually amount to compensation, declaratory judgments, public

\footnotetext{
526 See UN Doc. A/HRC/8/5 (7 April 2008), op. cit note 214 supra, para. 92.
} 
apologies and assurances of non-repetition. Other types of substantive remedies may, however, be more relevant and will depend on the type of privatization and particular circumstances of the case. For example, persons who have lost access to an essential service that has been privatized, such as water or electricity, could be entitled to the restoration of the service together with eventual compensation. ${ }^{527}$ Procedural remedies with regard to privatization entail providing a venue where those affected by privatization can seek redress. These will usually include courts of law, in which persons whose rights have been abused by privatized entities can attempt to seek redress. It is suggested that regulation and monitoring by independent bodies can also fulfill the role of procedural remedies as required by human rights law. In many cases regulation and regulatory mechanisms or agencies can be the most effective way of ensuring that these entities comply with the privatization arrangements or contracts. In addition, these regulatory mechanisms and agencies will also be the first bodies besides the privatized entities to which individuals will turn whenever they cannot resolve their problems with the privatized entities themselves, and when they want to challenge their decisions. Thus, the establishment of regulation and regulatory bodies that monitor the conduct of privatized entities, together with additional procedural remedies such as national judicial institutions that review both the decisions of the privatized entities and the regulators, could be an important method for States to ensure that these entities also respect human rights. It is therefore submitted that proper regulation and an independent and impartial regulatory mechanism may fulfill the role of an adequate (procedural) remedy as required by the various regional and international human rights treaties in situations of privatization.

In sum, regulation and regulators may be regarded as procedural/judicial remedies that may provide an effective means of redress for those whose rights have been aggrieved by privatized entities. To be effective, these bodies should be independent and impartial, and should be able to proactively and preventively act and adopt measures to guide and if necessary constrain the activities of privatized entities. Regulators should be open and offer direct access to individuals for purposes of consultation and provision of information. Ideally, they should also investigate the conduct of privatized entities, where possible on the basis of complaints, and they should have the power to impose binding sanctions on privatized entities when necessary. The necessity to adopt these types of procedural remedies entails that privatization does not necessarily lead to 'shrinking' the State. What it does lead to is a reassessment of the State's role. prohibited from entirely cutting the provision of water to individuals even in the case of nonpayment of the service. This will be discussed in more detail in Chapter VII. 


\subsection{Drittwirkung}

Can a prisoner bring a human rights claim before a national (or international) tribunal for the abuse when the guards of a privatized correctional facility mistreat or abuse him or her inside the facility? Can the user/consumer of a privatized water utility bring a claim for violation of his or her right to water against the private actor that is in charge of the utility for having increased the price of water consumed? These questions ${ }^{528}$ are very important with regard to the issue of privatization and human rights. The answer, of course, depends on the applicability of human rights norms between private individuals inter se.

Traditionally, human rights have been regarded as claims that an individual has against the State for the latter's conduct. ${ }^{529}$ This traditional view departs from the premise that human rights (or basic constitutional or fundamental rights) are guarantees necessary to limit the power of the State vis-à-vis the individual. ${ }^{530}$ According to Hunt, this traditional approach is based on a "[...] rigid distinction between the public and the private sphere and presupposes that the purpose of fundamental rights protection is to preserve the integrity of the private sphere against coercive intrusion by the state." 531 The traditional notion has tended to fuel the view that only States are capable of violating basic rights and that only States should be held accountable for these violations. In other words, human rights only apply in the vertical relation between the individual and the State. The State only has a duty to abstain from interfering with the enjoyment of these rights.

On the other hand, it has been acknowledged that private entities can and do engage in egregious violations of the rights of other private actors. ${ }^{532}$ The question has thus been raised whether human rights obligations, either rooted in international and regional human rights treaties, or national constitutional provisions, also apply to

528 Admittedly, the latter question is more hypothetical than the former one. Presently, economic, social and cultural rights, such as the right to water are not regarded as justiciable before a court of law, in contrast to civil and political rights, which usually may be directly relied upon.

529 See among others, W.N. Nelson, "Human Rights and Human Obligations," in Human Rights, ed. J.R. Pennock and J.W. Chapman, New York: New York City Press (1981), p. 281; Clapham, Human Rights in the Private Sphere, p 91-93; Barak, "Constitutional Human Rights and Private Law," p. 16-17; Jägers, Corporate Human Rights Obligations: In Search of Accountability, p. 36; J.M. Smits, "Constitutionalisering van het Vermogensrecht," in Preadviezen Uitgebracht voor de Nederlandse Vereniging voo Rechtsvergelijking, Deventer: Kluwer (2003), p. 14; Clapham, Human Rights Obligations of Non-State Actors, p. 25. For arguments as to why the perceived lack of horizontal effect of human rights treaties, in terms of their content, is exaggerated and wrong see Courtis, "The Applicability of Human Rights Between Private Parties," p. 153-181.

Barak, "Constitutional Human Rights and Private Law," p. 13. See also Smits, "Constitutionalisering van het Vermogensrecht," p. 14.

531 M. Hunt, “The 'Horizontal Effect' of the Human Rights Act," Public Law (1998), p. 424.

532 See Jägers, Corporate Human Rights Obligations: In Search of Accountability, p. 36; Clapham, Human Rights Obligations of Non-State Actors, p. 3. 
the relationships between private actors. Moreover, there has been a debate as to the obligations of the State with regard to human rights abuses perpetrated by private actors against other private individuals. This debate has ended in the recognition of the doctrine of positive obligations and obligations to protect as discussed in Section 4.1.2 and 4.1.3 supra. According to this doctrine, the State has a positive duty to take the necessary measures to protect individuals against human rights abuses that are the result of the conduct of private actors.

The question of the horizontal application of human rights between private actors (or, as Clapham calls it, the effect of human rights in the private sphere) ${ }^{533}$ with regard to privatization is clear. In an age where the implementation/execution of tasks, functions and services that were previously considered to be domain of the State are delegated or transferred to private parties, the question whether human rights and the respective obligations ensuing from them are applicable between the entities carrying out privatized tasks on the one hand and private individuals that are subject to the decisions and conduct of the former on the other is of utmost relevance. ${ }^{534}$ If human rights are indeed applicable between private individuals at all levels, then it can be observed that privatized actors may be held directly accountable for their conduct. Individuals who are victims of human rights abuses as a result of privatized conduct could employ an effective remedy. If, however, the concept of Drittwirkung is not applicable, then it is necessary to seek alternative avenues to ensure that private actors exercising privatized functions do not escape accountability for any conduct that is detrimental to the rights of those individuals or groups that are covered by privatization (i.e. prisoners inside privatized prisons, patients of privatized hospitals, or consumers of privatized utilities). In the following paragraphs, the status of Drittwirkung (literally, third party effect), or horizontal application of human rights standards, under international human rights law will be examined.

\subsubsection{Current status of Drittwirkung under international human rights law}

The development of Drittwirkung with regard to (international) human rights has been discussed in great detail by numerous scholars including Alkema, ${ }^{535}$ Verhey, ${ }^{536}$

\footnotetext{
533 Clapham, Human Rights in the Private Sphere, p. 1.

534 See also ibid., p. 348.

535 E.A. Alkema, "The Third-party Applicability or 'Drittwirkung' of the European Convention on Human Rights," in Protecting Human Rights: The European Dimension, ed. F. Matscher, H. Petzold, and G.J. Wiarda, Cologne: Carl Heymanns Verlag (1990), p. 33-45 (discussing Drittwirkung in the context of the ECHR).

536 L.F.M. Verhey, Horizontale Werking van Grondrechten, in het Bijzonder van het Recht op Privacy (Zwolle: W.E.J. Tjeenk Willink, 1992) (discussing Drittwirkung in the context of the right to privacy).
} 
Clapham, ${ }^{537}$ Jägers, ${ }^{538}$ Barak, ${ }^{539}$ and Smits. ${ }^{540}$ This sub-section will therefore focus on the current status of the concept under (international) human rights law as it relates to privatization. The concept of Drittwirkung, deals with the protection of human rights when private individuals or bodies are the perpetrators of human rights abuses. ${ }^{541}$ At the risk of simplifying the issue, it can be stated that Drittwirkung may be raised at two different levels. ${ }^{542}$ Firstly, at a substantive level, it relates to the applicability of these norms in the legal relationship between private entities. Secondly, at a procedural level, it deals with the question whether individuals, who claim to be victims of human rights abuses at the hand of private actors, may enforce these rights by, for example, bringing a claim against those perpetrators before an adjudicatory body. In the following paragraphs, a brief assessment of Drittwirkung at these two levels will be made taking into consideration the practice of international human rights monitoring bodies. ${ }^{543}$ Where necessary a link will be made to the issue of privatization.

\subsubsection{Substantive Drittwirkung}

With regard to privatization, substantive Drittwirkung entails that (international) human rights norms are directly applicable in the relationships between privatized actors and those who are affected by the conduct of the former (consumers of

537 In general, A. Clapham, "The 'Drittwirkung' of the Convention," in The European System for the Protection of Human Rights, ed. R.St.J. Macdonald, The Netherlands: Kluwer Academic Publishers (1993), p. 163-206, and Clapham, Human Rights in the Private Sphere.

538 Jägers, Corporate Human Rights Obligations: In Search of Accountability, p. 36-44 (discussing the issue of Drittwirkung in the context of the human rights obligations of multinational corporations).

539 Barak, "Constitutional Human Rights and Private Law," (discussing Drittwirkung in the context of the relationship between human rights and private law).

540 Smits, "Constitutionalisering van het Vermogensrecht," (discussing Drittwirkung in the context of the relationship between human rights and private law).

541 Clapham, Human Rights in the Private Sphere, p. 89.

542 See also van Dijk and Hoof, Theory and Practice of the European Convention on Human Rights, p. 23.

543 In the interests of brevity, the issue of the horizontal effect of human or fundamental rights norms at the national level will not be further discussed. For detailed accounts as to whether human rights norms work horizontally in a number of national jurisdictions (a discussion which has been entitled the constitutionalization of private law) see further Hunt, "The "Horizontal Effect' of the Human Rights Act," p. 423-443; I. Leigh, "Horizontal Rights, the Human Rights Act and Privacy: Lessons from the Commonwealth," ICLQ Vol. 48 (1999), p. 57-87; Barak, "Constitutional Human Rights and Private Law," p. 13-42; C. Starck, "Human Rights and Private Law in German Constitutional Development and in the Jurisdiction of the Federal Constitutional Court," in Human Rights and Private Law, ed. D. Friedmann and D. Barak-Erez, Oxford: Hart Publishing (2001), p. 97-112; J.M. Smits, "Private Law and Fundamental Rights: a Sceptical View," in Constitutionalisation of Private Law, ed. T. Barkhuysen and S. Lindenbergh, Leiden/Boston: (2006), p. 9-22. Hunt, for example, describes how human rights do have direct horizontal effect in Ireland, while in Canada and in South Africa, an indirect horizontal effect is discernible. See Hunt, “The 'Horizontal Effect' of the Human Rights Act," p. 428-434. 
privatized water utilities, prisoners incarcerated in privatized prisons, students attending privatized schools, patients receiving treatment in privatized health care facilities, or welfare recipients receiving welfare benefits from privatized social security arrangements). In other words, substantive Drittwirkung would allow those individuals affected by the conduct of privatized entities to invoke human rights standards against the latter.

International and regional human rights instruments currently do not contain any provision that explicitly states that the rights enshrined therein are also applicable to the legal relationship between private individuals. This may appear to support the view that human rights, at least at the international level, are rights that can only be invoked against the State. As the Human Rights Committee has noted in its General Comment No. 31, the obligations to 'ensure' and 'respect' the rights guaranteed in the ICCPR as provided by its Article 2(1)

"[...] are binding on States [Parties] and do not, as such, have direct horizontal effect as a matter of international law. The Covenant cannot be viewed as a substitute for domestic criminal or civil law." 544

Thus in essence, human rights norms appear not to apply horizontally to private actors entrusted with privatized tasks. This follows from the fact that these norms contain obligations that are binding only on States.

In spite of the apparent lack of explicit substantive Drittwirkung, human rights obligations that are in principle geared towards the State are not entirely devoid of any horizontal effect. For example, the preambles of the ICCPR and the ICESCR provide that individual has "[...] duties to other individuals and to the community to which he belongs $[\ldots]$ " and has "[...] a responsibility to strive for the promotion and observance of the rights recognized [...]" in both Covenants. ${ }^{545}$ The preparatory works of the ICCPR suggest also that some level of horizontal effect was not entirely ruled out, at least with regard to some of its provisions. ${ }^{546}$ Thus a complete lack of horizontal effect of the Covenants' rights should not be taken for granted. In addition, even though the Human Rights Committee has acknowledged the

544 See General Comment No. 31 on the Nature of the General Legal Obligation Imposed on States Parties to the Covenant, UN Doc CCPR/C/21/Rev.1/Add.13 (26 May 2004), para. 8.

545 See also Alkema, "The Third-party Applicability or 'Drittwirkung' of the European Convention on Human Rights," p. 36; Clapham, Human Rights in the Private Sphere, p. 97.

546 Clapham, Human Rights in the Private Sphere, p. 97. However, it must be borne in mind that the preparatory works of international treaties may only serve as supplementary means of interpreting a treaty as stipulated by Article 31 (1) of the Vienna Convention on the Law of the Treaties. This means that the preparatory works may only serve as guidelines for interpretation when the context and object and purpose of a particular treaty provision can not be easily determined without reference to them or if the provision bears more than one meaning. 
provisions of the ICCPR do not have direct horizontal effect, it has ascertained in its case law and in the same General Comment No. 31 that,

"[...] the positive obligations on States Parties to ensure Covenant rights will only be fully discharged if individuals are protected by the State, not just against violations of Covenant rights by its agents, but also against acts committed by private persons or entities that would impair the enjoyment of Covenant rights in so far as they are amenable to application between private persons or entities. There may be circumstances in which a failure to ensure Covenant rights as required by article 2 would give rise to violations by States Parties of those rights, as a result of States Parties' permitting or failing to take appropriate measures or to exercise due diligence to prevent, punish, investigate or redress the harm caused by such acts by private persons or entities." 547

The provisions in other international conventions such as Article 2 (1)(d) CERD, 548 also reinforce the view that States have a positive duty to adopt national legislation that prohibits human rights abuses such as discrimination by private parties, thus establishing a certain, indirect, horizontal effect at the national level.

The case law of the European Court of Human Rights reveals a similar position. The ECHR does not contain any explicit provision that the rights guaranteed therein are horizontally applicable in the relationship between individuals. However, in a number of cases in which the conduct of private entities had a harmful effect on the rights of individuals, the ECtHR has taken two related paths to accord some sort of horizontal effect to particular provisions of the ECHR. First, the Court has concluded that, under Article 1 of the Convention, States are under an obligation to secure everyone within their jurisdiction the rights guaranteed in the ECHR. Thus in the case of Young, James and Webster ${ }^{549}$ the Court held that when a violation of one of the rights guaranteed in the Convention is the result of non-observance of the obligation ensuing from Article 1 " [...] in the enactment of domestic legislation, the responsibility of the State for that violation is engaged." 550 This means that States have to make sure that national legislation regulating the conduct of private individuals inter se does not permit or condone conduct contrary to the rights of the Convention. Similarly, in the case of Costello-Roberts v. the United Kingdom, ${ }^{551}$ dealing with corporal punishment carried out at a private school on a child, the Court reaffirmed that "[...] the responsibility of a State is engaged if a violation of one of the rights and freedoms defined in the Convention is the result of non-

\footnotetext{
547 General Comment No. 31, para. 8.

548 Article 2(1)(d) CERD requires States “[...] to bring to an end, by all appropriate means, including legislation as required by circumstances, racial discrimination by any persons, group or organization."

549 See Young, James and Webster, judgment of 13 August 1981, ECtHR Series A-44.

550 Ibid., para. 49.

551 Costello-Roberts v. the United Kingdom, judgment of 25 March 1993, ECtHR Series A247-C.
} 
observance by that State of its obligation under Article 1 (art. 1) to secure those rights and freedoms in its domestic law to everyone within its jurisdiction." 552 In practical terms, this means that the State has to adopt the necessary legislation to ensure that the ECHR's rights are respected by private individuals (or private schools as in Costello Roberts). Commenting on this case, Lawson and Schermers observe that properly securing the rights and freedoms of the ECHR endows the Convention with 'partial' or 'indirect' horizontal effect between individuals: the legal relationship is between between individuals, but the liability for violations under this relationship and an eventual legal action is against the State. ${ }^{553}$ In addition, the ECtHR reinforced the notion of indirect Drittwirkung, by observing that "[...] the State cannot absolve itself from responsibility by delegating its obligations to private bodies or individuals." 554 It will be argued in Chapter IV, Section 3 that this observation may have an additional connotation, namely that under certain circumstances, private entities excercising governmental functions could be considered as a State actors, albeit in a very limited fashion, and thus directly responsible for human rights abuses.

In the second place the ECtHR has held that with respect to Article 8 ECHR on the right to a family life and respect of privacy, States have positive obligations inherent in an effective respect of this right that may "[...] involve the adoption of measures designed to secure the respect for private life even in the sphere of the relations of individuals between themselves." 555 These positive obligations regarding the adoption of measures securing the respect of rights in the sphere of the relations between individuals themselves, however, are also accompanied with a wide discretion on the side of the State in the choice of means to be used. ${ }^{556}$

In addition to this case law, some scholars point out that a number of rights enshrined in the ECHR may, due to their nature and character, lend themselves to a substantive horizontal application. Since these rights may be considered to be fundamental, they argue that it is difficult to appreciate why they should only deserve protection in relation to public authorities, but not in relation to private parties. ${ }^{557}$

Explicit substantive Drittwirkung is also absent in the other regional human rights instruments. However, this has not prevented their respective treaty monitoring

\footnotetext{
552 Ibid., para. 26.

553 Lawson and Schermers, Leading Cases of the European Court of Human Rights, p. 490-491.

554 Costello-Roberts $v$. the United Kingdom, para. 27.

555 See $X \& Y v$. the Netherlands, judgment of 26 March 1985, ECtHR Series A-91, para.23.

556 See "Artze für das Leben” v. Austria, judgment of 21 June 1988, ECtHR Series A-139, paras. 32 and 34.

557 Van Dijk and Hoof, Theory and Practice of the European Convention on Human Rights, p. 24-25.
} 
bodies from adopting a similar approach to the Human Rights Committee and the ECtHR with regard to the legal relationship between individuals in the context of human rights. The African Commission on Human and Peoples' Rights, for example, has held that States have a positive duty "[...] to protect their citizens, not only through appropriate legislation and effective enforcement but also by protecting them from damaging acts that may be perpetrated by private parties." 558 Equally, The Inter-American Court of Human Rights has concluded in the Velásquez Rodriguez case and subsequent case law that the obligation to 'ensure' as found in Article 1 (1) ACHR entails that the State bears the burden of adopting measures to protect individuals against the conduct of other private actors. ${ }^{559}$ Other cases have reaffirmed this. In a case dealing with a request for provisional measures asking the government of Colombia to adopt the necessary measures to protect the life and personal integrity of the inhabitants of the community of San José de Apartadó against acts of violence committed by Colombian armed forces and paramilitary groups, ${ }^{560}$ the Inter-American Court observed that a State party to the ACHR has a general obligation to effectively protect the rights of all the persons residing under its jurisdiction. According to the Inter-American Court this general obligation was not only applicable vis-à-vis the power of the State, but was also applicable to "[...] actuaciones de terceros particulares, inclusive grupos armados irregulares de cualquier naturaleza [acts of private individuals, including irregular armed groups of whichever nature, $A H W]$." 561 This observation was further strengthened in an advisory opinion on the Juridical Condition and Rights of the Undocumented Migrants. ${ }^{562}$ Although the advisory opinion was limited to determining the obligations of State parties to the ACHR with regard to the rights of migrant workers, the Court observed that

"[i]n an employment relationship regulated by private law, the obligation to respect human rights between individuals should be taken into consideration. That is, the positive obligation of the State to ensure the effectiveness of the protected human rights gives rise to effects in relation to third parties (erga omnes). This obligation has been developed in legal writings, and particularly by the Drittwirkung theory, according to which fundamental rights must be respected by both the public

See The Social and Economic Rights Action Center for Economic and Social Rights v. Nigeria, African Commission on Human and Peoples' Rights, Comm. No. 155/96 (2001), para. 56. See also Commission Nationale des Droits de l'Homme et des Libertes v. Chad, African Commission on Human and Peoples' Rights, Comm. No. 74/92 (1995), para. 22.

559 See Velásquez Rodríguez case, paras. 172-174. See also Case of the "Gómez-Paquiyauri Brothers" v. Peru, Judgment of 8 July 2004, IACtHR, Series C No. 110, para 91, Case of Tibi v. Ecuador, Judgment of 7 September 2004, IACtHR, Series C No. 114, para. 108, and Case of Ximenes-Lopes v. Brazil, footnote 338, para. 85.

560 Matter of the Peace Community of San José de Apartadó regarding Colombia, provisional measures, Order of 17 November 2004, IACtHR.

561 Ibid., para 13 (footnotes omitted).

562 Juridical Condition and Rights of the Undocumented Migrants, Advisory Opinion OC-18 of 17 September 2003, IACtHR, Series A No. 18 (2003). 
authorities and by individuals with regard to other individuals. [...] [T]he obligation to respect and ensure human rights, which normally has effects on the relations between the State and the individuals subject to its jurisdiction, also has effects on relations between individuals." 563

The case law of international and regional human rights monitoring bodies thus reveals that various human rights norms entail a certain protection against harmful conduct between private parties. States should therefore ensure that such protection is realized at the national level. Failing to do so, may lead to State responsibility for not securing at the national level the rights enshrined in these conventions.

To summarize, the rights guaranteed in the various international and regional human rights instruments do not explicitly have direct Drittwirkung. Thus, at the international level, these obligations cannot be invoked against private actors exercising privatized functions, tasks or services. However, various international and regional human rights monitoring bodies have held that States are obliged to ensure that the national legal system takes consideration of the relationships between private individuals in a way that the rights of those individuals are respected. This amounts to what may be termed as mittelbare Drittwirkung ${ }^{564}$ or indirect horizontal effect. The result is that although the legal relationship is between private individuals, the liability attaches to the State. ${ }^{565}$ Thus States engaging in privatization exercises have an obligation to ensure that their national legislation regarding privatization does not permit private entities to act contrary to the rights of individuals that are in direct relationship to them. In addition, privatizing States have, as we have previously examined, a positive obligation to protect individuals against human rights abuses by privatized actors and may be held internationally responsible for not adopting the necessary measures required to achieve this protection.

\subsubsection{Procedural Drittwirkung}

Substantive horizontal application is only part of the story. For Drittwirkung to have practical meaning to victims of human rights abuses at the hands of other private entities or individuals, it has to be legally enforceable. At the international level, however, procedural Drittwirkung is currently not possible through established individual complaints procedures before international or regional human rights monitoring mechanisms. These mechanisms allow complaints only against the State,

563 Ibid., paras. 140 and 146.

564 Clapham, "The 'Drittwirkung' of the Convention."; Dijk and Hoof, Theory and Practice of the European Convention on Human Rights, p. 23; Jägers, Corporate Human Rights Obligations: In Search of Accountability, p. 38.

565 See also Lawson and Schermers, Leading Cases of the European Court of Human Rights, p. 491. (commenting on the case of Costello-Roberts v. the UK). 
not against other private individuals who may be the actual perpetrators of the conduct complained of. Thus, under Article 1 of the $1^{\text {st }}$ Optional Protocol to the ICCPR, the Human Rights Committee may only consider communications from individuals " [...] who claim to be victims of a violation by that State Party of any of the rights set fort in the Covenant." Similarly, even though the CERD opens the possibility for the horizontal application of the prohibition of discrimination on various grounds, ${ }^{566}$ only individual communications of individuals within the jurisdiction of a State Party " [...] claiming to be victims of a violation by that State Party of any of the rights set forth[... ]"567 in the CERD may be submitted even though the actual discriminatory act may have been carried out by a private actor. At the regional level, the situation is the same. For example, Article 34 ECHR stipulates that the ECtHR may receive individual applications from individuals "[...] claiming to be a victim of a violation by one of the High Contracting Parties". Article 44 of the ACHR recognizes the rights of individuals to lodge petitions with the Inter-American Commission of Human Rights "[...] containing denunciations of complaints of violation of this Convention by a State Party." Bringing a complaint against another private individual or entity will result in its dismissal for incompatibility ratione personae.

National and international jurisprudence, however, has developed a way to circumscribe this procedural limitation through the adoption of the doctrine of mittelbare Drittwirkung, or indirect horizontal effect, as discussed in the previous paragraph. Although individuals cannot for reasons ratione personae bring a complaint against another private individual or entity for violation of human rights before a national, regional or international human rights adjudicating body, they may attempt to implicate the State for not ensuring the protection of the individual's human rights in its national legislation against abuses by other private individuals, or for not adopting the necessary positive measures to prevent such abuses. ${ }^{568}$

\subsubsection{Some observations}

In the context of the present study the horizontal effect of human rights presents a dilemma for individuals or groups that have been negatively affected by the

566 For example, the right to security of the person against violence or bodily harm "whether inflicted by government officials or by any individual, group or institution" (Art. 5(b) CERD), or the right to housing and education (Art 5(e) CERD), or even "the right to access to any place or service intended for use by the general public such as transport, hotels, restaurants, cafés, theatres and parks" (Art. 5(f) CERD).

567 See Art. 14 CERD. See also Art. 2 of the 1999 Optional Protocol to the CEDAW allowing for individual complaints to be submitted by individuals: "Communications may be submitted by or on behalf of individuals or groups of individuals under the jurisdiction of a State Party, claiming to be victims of a violation of any rights set forth in the Convention by that State Party." Emphasis added, $A H W$.

568 See for example the above mentioned request for provisional measures in the Matter of the Peace Community of San José de Apartadó regarding Colombia of the IACtHR. 
activities of privatized entities. On the one hand substantive and procedural Drittwirkung allow the victims of harm caused by these entities to hold the government to account if it does not adopt the necessary measures for protecting the victim's rights against this harmful behavior. As it now stands, procedural Drittwirkung would allow the victims to bring to account privatized entities through private law, although it would not always be possible to do so under the banner of human rights due to the traditional barriers preventing a real application of human rights between private individuals.

The lack of real horizontal effect at the international level reveals a stark contrast between the private and public sphere. Scholars have argued that it is difficult to differentiate between them. For example, Smits does not agree that human rights should directly apply to horizontal relations unless they deal with human dignity because they would otherwise place a heavy burden in the autonomous relationships between private individuals. ${ }^{569}$ The present author suggests that in the light of the current status of international human rights law, the horizontal application of these norms is indeed not always appropriate to private relationships inter se. Similarly, a proper direct Drittwirkung at the national level will not always be feasible due to national legal traditions and conservative case law that refuses to acknowledge the effect of the new relationships between individuals and privatized actors: the latter having assumed a position that was formerly in hands of the State for which human rights obligations would have applied directly. In some cases refusing to acknowledge a horizontal effect could result in the indirect international responsibility of the State for failing to adopt the necessary measures to guarantee that individuals are protected against the conduct of other private actors (or in our case privatized ones). The question is whether this indirect horizontal effect is always satisfactory. Although it has served well in providing a remedy for victims of abuses at the hand of private actors, it eschews taking the bull by the horns. At best it is a patchwork remedy that seeks to shift the blame for the abuse to the State. At worst it can be regarded as an artificial solution that avoids placing the blame where it really belongs.

In the light of the tendency to privatize State functions or services, a new paradigm is necessary to deal with the lack of Drittwirkung as a result of which the authors of human rights abuses escape their accountability. In the opinion of the present author, when a private actor is carrying out former state functions or at least functions that have a public purpose and have overall effects on both the public and private sphere, and this private actor is acting on behalf of the state or under its supervision and through a legally (by law) delegated faculty, then the private actor ceases to be wholly private and enters the public realm. By entering this realm the private actor has to face a more direct application of human rights obligations and 
their decisions should be open to judicial review. This would be not so much a form of pure horizontal application of human rights obligations or an indirect horizontal application, but rather a special genus of the vertical application, where the private actor has temporarily become under the privatization/delegation mandate a special form of public actor. This is also closely related to the concept of (international) State responsibility for the conduct of certain private actors when they are performing (public) functions in the name of the State. The main difference with the (indirect) horizontal application would be that the privatized actors temporarily ceases to be a private actor and becomes a public one which is then directly accountable for any human rights abuse it performs in the context of its privatized functions. This particular applicability of human rights obligations to private actors exercising functions, tasks or services of a public nature will be discussed in more detail in Chapter IV Section 3.

\subsection{Preliminary conclusions}

Reflecting the situation under general international law, human rights law does not impose any kind of substantive constraints to privatization. On the contrary, human rights law appears to give States sufficient freedom to adopt and implement privatization policies. However, a number of legal obligations ensuing from human rights law may be considered as imposing procedural constraints that may to a certain extent limit the State's margin of appreciation regarding privatization. These constraints are enrooted in the obligations to respect, protect and fulfill human rights as developed in the last twenty-five years, as well as the obligation to adopt effective (judicial) remedies for the victims of human rights abuses that result from privatization. This may be referred to as the human rights approach towards privatization whereby a number of human rights obligations limit the purview of the State's wide-ranging liberty to adopt the economic policies it deems right.

This human rights approach towards privatization is based on a number of premises. On the first place, human rights obligations including positive obligations and obligations to ensure, respect, protect and fulfill compel the State to refrain from taking any measure in the sphere of privatization that would result in a violation of specific human rights. This may require also proper consultation with individuals who may be affected by privatization policies, in particular those located in the most vulnerable sectors of society, and the implementation of a human rights assessment of those policies. Secondly, they oblige the State to take the necessary measures to prevent the violation of rights by private actors carrying out privatized tasks. This entails, for example, establishing proper regulatory measures and agencies that monitor the effects of privatization on individuals (be it consumers of particular privatized services or those directly under the control of privatized service providers, for example, prisoners in privatized prisons). Thirdly, some human rights obligations (i.e. the obligation to fulfill) require the State to create the 
conditions under which privatization policies in particular sectors, if carried out, can guarantee that specific rights are met and fully enjoyed by individuals subject to the consequences of these policies. This may impose on States a duty to guarantee that certain services that have been privatized remain accessible to all at the most affordable price (universal service obligations).

However, the doctrine of the margin of appreciation will allow the State some leeway with regard to policies of an economical nature, such as privatization, in particular if general public or national interests are served through them. Nevertheless in the devising and implementation of these policies, States are still expected to give proper considerations to the effects of these policies on individuals, and maintain a fair balance between the objective to be achieved and the rights affected. Again, proper consultation beforehand will be necessary and the effective substantive and procedural remedies to ameliorate any harm caused by privatization policies will need to be put in place.

\section{Concluding Remarks}

This chapter has looked at various doctrinal aspects of national, international, and human rights law as they relate to privatization. Under national law, it was observed that certain limitations may curb the State's discretion to adopt privatization measures. These constraints can be of a constitutional nature, either explicit or implicit and may imply substantive or procedural limits. Although the presence of constitutional or legal constraints at the national level may restrict the adoption of privatization measures, it is by no means an absolute guarantee that these measures will not be adopted. Although some countries have prohibited certain types of privatization through constitutional amendments (f.e. the privatization of essential water utilities in Uruguay), it does not follow that other sectors will not be subjected to privatization, or that the constitution may be amended in the future to allow privatization. Whether any particular sector is privatized or not and to what extent, will depend on the political will of national governments and the degree to which their legal order allows privatization. In comparison, under international law, there are currently no concrete limits on the State restraining its capacity to privatize public functions. This flows from the freedom accorded to States under international law to adopt sovereign decisions involving economic policies without foreign interference. At the most, recent initiatives under international law such as the OPCAT deal mainly with monitoring of sectors that have already been subjected to privatization, such as prisons and the deprivation of liberty by private actors on behalf of the State. Nevertheless, the various obligations under international law may impose indirect implicit limitations constraining the States' freedom to adopt privatization policies including those obligations relating to international treaty law, the principle of non-intervention, and those arising under the law of state 
responsibility. Some of these obligations have been further refined under international human rights law.

Due to the State centered nature of international law, however, these obligations do not apply to other actors playing important roles in the privatization process, namely International Financial Institutions and multinational companies. In spite of the fact that IFIs are not formally bound by direct human rights obligations as found in the various (international) human rights treaties, there appears to be a growing consciousness in their midst about being more mindful of the impact of their lending policies requiring privatization on human rights. This is taking place through the use of internal procedural guidelines prescribing the World Bank to be mindful of human rights, and through internal auditing in the form of the Bank's Inspection Panel. Nonetheless, as long as the constituent instruments of IFIs do not oblige them to respect human rights, human rights considerations will remain a relevant, but not essential element in their decision making process. Similarly, business enterprises do not have direct human rights obligations. This has not prevented efforts to bring multinational companies to account for human rights abuses through soft law instruments adopted by several international organizations like the OECD, and the ILO, or through self-regulation. This however does not mean that business enterprises exercising privatized functions can be easily brought to account for human rights abuses. In this regard, the State is still, under current international law, considered the primary entity that has to ensure that the effects of privatization are not contrary to human rights. Thus the concept of positive obligations requires from States the adoption of measures to protect individuals against the conduct of privatized actors. Similarly, States will also have to ensure that effective remedies, both substantive and procedural are in place to enable individuals who have been subjected to abuse by privatized entities to seek redress. Regulatory rules and bodies through which privatized entities and their conduct are monitored are examples of both positive measures and procedural remedies that are required from States, although their effectiveness needs to be guaranteed through legitimacy, transparency, accessibility and equitability, predictability, and compatibility with international human rights standards. This is necessary since human rights do not work horizontally meaning that privatized entities cannot be held directly accountable for human rights abuses. Although the lack of direct horizontal effect of human rights is mitigated by the indirect horizontal effect of human rights and positive obligations, States maintain through the concept of the margin of appreciation the sovereign right to adopt privatization policies. Human rights obligations do not prohibit privatization as such and may only impose the conditions under which privatization should take place. Of course, the main issue then is what happens when privatization of public functions, tasks or services takes place and human rights are impinged? This leads to the issue of accountability for human rights abuses which are the result of privatization or the conduct of privatized actors, and which will be discussed in the next chapter. 



\section{Chapter IV Accountability for InJury Caused by Privatization}

\section{INTRODUCTION}

In the previous chapter we have explored the general issues of doctrine that are related to privatization. An important conclusion from that chapter was that at the international level, there is no direct legal obligation that may restrain the States' discretion to design and implement privatization policies. There is no legal rule of international (customary) law that prohibits or limits privatization outright. As a matter of fact, international law leaves a great deal of discretion to States with regards to their economic policies. It may even be cautiously stated that some more specific branches of international law such as international economic law including the law of international financial institutions and WTO law - do seem to set the right conditions for privatization policies (although with regard to WTO law, it is fair to state that no WTO rule prescribes privatization or imposes legal obligations on States to privatize). With regard to human rights obligations, it can be stated that they are in principle neutral towards the economic policies of States, leaving them with a certain margin of appreciation. It can thus be stated that States are in principle free to adopt privatization policies if they deem them necessary.

However, in the privatization debate concerns have been expressed around the issue of accountability: what happens if privatization goes wrong? Who is ultimately responsible for the negative effects (if any) on human rights of privatization? Another, often heard concern is the fear that the State may be avoiding its international legal obligations by delegating important functions, tasks or services to private actors. These questions and concerns are relevant to the extent that States are the actors that devise privatization policies and have a major role in implementing them, while private actors (usually business enterprises) are the ones that actually bear the day-to-day task of exercising the functions, tasks or services delegated to them as a consequence of these policies. Thus the main questions to be dealt with in this Chapter are: to what extent is the State accountable for the outcomes of privatization, and can the private entities actually carrying out these tasks be held accountable and to what extent? These questions become very relevant when we realize that, as we have already seen in Chapter III Section 4.4 supra, human rights obligations are in principle not directly applicable in disputes between private entities (at least not at the international level).

The issue of accountability with regard to privatization will be explored in this chapter. To this end, Section 2 of this chapter will first focus on the general issue of international state responsibility and the different ways in which the State can 
assume the responsibility for the conduct of privatized entities. The relevance of state responsibility in relationship to privatization resides in the issue of accountability for the conduct of private actors carrying out functions, tasks or services that had previously been performed by the State itself. The general question that comes to mind is whether the conduct of these private actors is attributable to the State under international law, and whether the State bears international responsibility for this conduct. In an attempt to answer this question, the relevant articles of the International Law Commission's Articles on the Responsibility of States for international wrongful acts will be discussed. In particular the attribution to the State for conduct of private actors exercising elements of governmental authority will be analyzed by dissecting the content of the different elements composing this ground of attribution at the hand of various decisions of adjudicatory bodies that have had to decide on whether the acts of private entities could be attributed to the State. It is worth observing that most of these decisions, which are few in number, are of relative recent date and have been mainly issued by arbitral tribunals in investment or trade disputes.

Since it is not currently possible to directly apply international legal obligations (including human rights obligations) to private entities, this chapter will subsequently focus on a possible alternative, which is closely related to the issue of state responsibility. Section 3 will argue that a potential solution to the shortcomings of traditional direct and indirect state responsibility is to consider private entities that are exercising functions, tasks or services of a public/governmental nature to be a special type of State/governmental actor to which in a very narrow way, human rights obligations may also be applied. This notion is one that is familiar in international and national legal systems, but which has yet to be fully explored in the context of privatization and human rights. A comparative overview of various legal jurisdictions may serve to show how legal norms of a public nature that are in principle only applicable to State or public actors, may nevertheless be applied to private actors that have been entrusted with the exercise of privatized functions, tasks or services. The ultimate goal of this exercise is to draw some inspiration and lessons from the practice of a number of legal systems with regard to the question how these private actors may be held accountable for eventual human rights abuses in the performance of these privatized activities. Such lessons may later serve as an inspiration for international, regional and national human rights adjudicators confronted with privatization issues. It is suggested that such an approach may be of help to these bodies in applying human rights obligations in concrete privatization situations.

\section{State RESPONSIbiLITy}

According to well-established principles of international (customary) law, the responsibility of a State is engaged through acts of commission or omission that 
entail a breach of an international obligation of the State and which are attributable to it under international law. ${ }^{1}$ The question that must be considered in the context of the present study is whether the conduct of privatized entities that is incompatible with international legal norms such as human rights obligations can be attributed to the State. It is an important question since States are in principle only internationally responsible for their own breaches of international law obligations and for the conduct of their agents/institutions in the exercise of an official function. ${ }^{2}$ With privatization, however, a State can delegate or transfer certain functions, tasks and services of a governmental or public nature to private entities. These actors are generally ruled by principles of (national) civil law, civil liability and/or criminal law and criminal liability, and generally cannot be considered to be State actors. ${ }^{3}$ State responsibility for the behavior of private actors as such is not evident, although under general international law the conduct of these actors can, as we will see below, sometimes be attributed to the State. In other instances, the State will be held internationally responsible for not having exercised due diligence in respect of the conduct of private actors. In the following paragraphs, the concepts related to State responsibility (general principles, the issue of attribution to the State for conduct of a private actor, and the responsibility of the state for lack of due diligence) will be reviewed.

\subsection{General principles of state responsibility}

International law can be divided into two types of rules. The first set of rules are the so-called 'primary' rules that determine the content and duration of specific obligations of States arising out of specific treaties or rules on international customary law. ${ }^{4}$ An example would be a specific provision in a human rights treaty protecting a particular right. The rules of state responsibility belong to the so-called

1 See also Articles 1 and 2 Articles on the Responsibility of States for international wrongful acts, UN Doc A/RES/56/83 (12 December 2001). Although the Articles on the Responsibility of States as drafted by the UN International Law Commission and as adopted for further consideration by the UN General Assembly are not legally binding, many of its provisions are considered to be rules of customary international law.

2 Article 4 Articles on the Responsibility of States for international wrongful acts, UN Doc A/ RES/56/83 (12 December 2001).

3 For a discussion as to whether private actors carrying out privatized functions, tasks and services can be regarded as State actors, see Section 3 infra.

4 Crawford, The International Law Commission's Articles on State Responsibility: Introduction, Text and Commentaries, p. 16. See further R. Lawson, "Out of Control. State Responsibility and Human Rights: Will the ILC's Definition of the 'Act of State' Meet the Challenges of the $21^{\text {st }}$ Century?," in The Role of the Nation-State in the 21st Century: Human Rights, International Organisations and Foreign Policy, Essays in Hounour of Peter Baehr, ed. M. CastermansHolleman, van Hoof, G.J.H, and J. Smith, The Hague: Kluwer International Law (1998), p. 93. 
'secondary' rules of international law, which indicate the legal consequences of a breach of the primary rules. ${ }^{5}$

The most basic principle underlying the rules of State responsibility has been codified in Article 1 of the International Law Commission's (ILC) Articles on the Responsibility of States for international wrongful acts. ${ }^{6}$ According to this principle, every internationally wrongful act of a State entails the international responsibility of that State. Article 2 of the ILC Articles on the Responsibility of the State identifies the two main elements that determine what an international wrongful act is: an international wrongful act consists of actions or omissions or a combination of both that a. can be attributed to a State, and b. which lead to a breach of an international obligation. The nature of the international obligation breached is not relevant. In the case of the Gabcikovo-Nagymaros Project, the ICJ observed that it is well established that "[...] when a State has committed an internationally wrongful act, its international responsibility is likely to be involved whatever the nature of the obligation it has failed to respect." This means that the secondary rules of international law pertaining to state responsibility are also applicable to violations of international obligations arising out of human rights treaties, although their concrete applicability to human rights may sometimes be regarded as problematic. ${ }^{8}$ International human rights monitoring mechanisms have on various occasions applied the rules on state responsibility to cases of human rights violations

5 Crawford, The International Law Commission's Articles on State Responsibility: Introduction, Text and Commentaries, p. 16. Also Lawson, "Out of Control. State Responsibility and Human Rights: Will the ILC's Definition of the 'Act of State' Meet the Challenges of the $21^{\text {st }}$ Century?," p. 93.

6 Articles on the Responsibility of States for international wrongful acts, UN Doc A/RES/56/83 (12 December 2001).

7 Gabčikovo-Nagymaros Project (Hungary v. Slovakia)(Merits), ICJ Reports 1997, para. 47.

$8 \quad$ For a general overview of the applicability of the principles of state responsibility concerning human rights see M.T. Kamminga, Inter-State Accountability for Violations of Human Rights (Philadelphia: University of Pennsylvania Press, 1992); S. Farrior, "State Responsibility for Human Rights Abuses by Non-State Actors," American Society of International Law Proceedings Vol. 92 (1998); Lawson, "Out of Control. State Responsibility and Human Rights: Will the ILC's Definition of the 'Act of State' Meet the Challenges of the $21^{\text {st }}$ Century?." See also Danwood Mzikenge Chirwa, "The Doctrine of State Responsibility as a Potential Means of Holding Private Actors Accountable for Human Rights," Melbourne Journal of International Law Vol. 5 (2004), p. 9. Clapham has in the past argued that the application of the rules of state responsibility to human rights cases may not be appropriate. See Clapham, "The 'Drittwirkung' of the Convention," p. 170. Evans has recently illustrated that the rules of state responsibility, although in principle applicable to human rights obligations, have in practice been used by international human rights bodies in different terms than those which are traditionally related to state responsibility. See M.D. Evans, "State Responsibility and the European Convention on Human Rights: Role and Realm," in Issues of State Responsibility Before International Judicial Institutions, ed. M. Fitzmaurice and D. Sarooshi, Oxford: Hart Publishing (2004). 
brought before them, albeit in an implicit way. ${ }^{9}$ The International Court of Justice has moreover observed in an obiter dictum in the Barcelona Traction case, that breaches of obligations emanating from human rights treaties gives rise to the establishment of a legal relationship between the wrongdoing State and the international community as a whole in view of the importance the latter attaches to the protection of human rights. ${ }^{10}$

The effecting of a wrongful act gives rise to the establishment of a legal relationship between the wrongdoing-State and the injured State to the effect that the wrongdoing-State will have to make some sort of amends towards the injured State. ${ }^{11}$ This has been established by the Permanent Court of International Justice in the case of Factory at Chorzów (Jurisdiction), in which it stated that "[i]t is a principle of international law that a breach of an engagement involves an obligation to make reparation in adequate form." 12 This duty to make reparation may take the form of inter alia compensation. ${ }^{13}$

As indicated by Article 2 of the ILC Articles on the Responsibility of the State, the breach of an international legal obligation must be attributable to the State in order to engage its responsibility. It is a well-established principle of international law that only the conduct of State organs or agents are attributable to the State. ${ }^{14}$ The ICJ confirmed this in its advisory opinion on the Difference Relating to Immunity

9 For an extensive overview of the case law of the Human Rights Committee, which has employed the principles of state responsibility to various concrete situations under the individual complaints procedure of the First Optional Protocol to the ICCPR, see D. McGoldrick, "State Responsibility and the International Covenant on Civil and Political Rights," in Issues of State Resposibility Before International Judicial Institutions, ed. M. Fitzmaurice and D. Sarooshi, Oxford: Hart Publishing (2004), p. 161-200. See also Lawson, "Out of Control. State Responsibility and Human Rights: Will the ILC's Definition of the 'Act of State' Meet the Challenges of the $21^{\text {st }}$ Century?," p. 115, and Chirwa, "The Doctrine of State Responsibility as a Potential Means of Holding Private Actors Accountable for Human Rights," p. 9-10.

10 The ICJ speaks of obligations erga omnes. See Case Concerning the Barcelona Traction, Light and Power Co. Ltd., ICJ Reports, 1970, paras. 33-34.

11 This could include cessation of the wrongful conduct and eventual reparations for damage incurred by the affected State. See further Articles 28-33 of the Articles on the Responsibility of States.

12 Factory at Chorzów (Juridsiction), 1927, PCIJ, Series A. No. 9, p. 21.

13 See Gabčikovo-Nagymaros Project (Hungary v. Slovakia)(Merits), para. 152. See also Legal Consequences of the Construction of a Wall in the Occupied Palestinian Territory, Advisory Opinion, ICJ Reports 2004, paras. 152-153, and more recently Case Concerning the Application of the Convention on the Prevention and Punishment of the Crime of Genocide (Bosnia and Herzegovina v. Serbia and Montenegro), ICJ, judgment of 26 February 2007, para. 460. See also Article 36 of ILC Articles on the Responsibility of States.

14 See ILC Yearbook 1975 Vol. II, United Nations, New York, 1976, p. 71, para 3; I. Brownlie, System of the Law of Nations: State Responsibility (Part I) (Oxford: Oxford University Press, 1983) p. 159; and Crawford, The International Law Commission's Articles on State Responsibility: Introduction, Text and Commentaries, p. 91 and 94. 
From Legal Process of a Special Rapporteur of the Commission on Human Rights. ${ }^{15}$ The Court observed, "[...] the conduct of any organ of a State must be regarded as an act of that State." 16 It further noted that this rule, which is now codified in Article 4 of the ILC's Articles, is of a customary character.

In any event, the general rule of attribution entails that the conduct of private actors is as such not attributable to the State. However, it has been recognized that under certain conditions the State could become responsible for the harm caused by private actors in breach of an international obligation. ${ }^{17}$ In the following paragraphs, attention will be paid to the circumstances under which attribution to the State for the conduct of private entities is possible and how this relates to privatization.

\subsection{Attribution to the State for conduct of private actors}

From the wording of the ILC's Articles on state responsibility it is apparent that for a particular conduct to be considered internationally wrongful it must be attributable to the State. What constitutes an act of a State that can be attributed to it for the purposes of State responsibility? Article 4 of the ILC's Articles sheds some light to this question. The first paragraph of Article 4 states that, "the conduct of any State organ shall be considered an act of that State under international law."18 Interestingly, in the Case Concerning the Application of the Convention on the Prevention and Punishment of the Crime of Genocide (Bosnia and Herzegovina $v$.

15 Difference Relating to Immunity From Legal Process of a Special Rapporteur of the Commission on Human Rights, ICJ Reports, 1999.

16 Ibid., para. 62.

17 ILC Yearbook 1975 Vol. II, United Nations, New York, 1976, p. 76, paras 19-21. See also Brownlie, System of the Law of Nations: State Responsibility (Part I), p. 159.

18 Art. $4 \$ 1$ notes that this conduct can come from organs exercising legislative, executive, judicial or any other functions, whatever their position in the internal organizational or territorial order of the State. Brownlie provides an overview of all the possible actors that have been regarded as State organs or agents including heads of state, members of government, diplomatic agents, the executive branch of government and the administration, the legislative branch, the judiciary, armed forces, and federal units, provinces and other internal divisions. Ibid., p. 138-144. In the ILC Commentary, Crawford observes that "[...] there is no category of organs specially designated for the commission of internationally wrongful acts, and virtually any State organ may be the author of such an act." Crawford, The International Law Commission's Articles on State Responsibility: Introduction, Text and Commentaries, p. 95. Additionally, Art $4 \S 2$ points out that an organ of the State includes any person or entity which has the status in accordance with the internal law of the State. This provision, however, should not be interpreted to mean that at the international level internal law will ultimately dictate what is considered to be an organ of the State. Sometimes internal law will not be conclusive for determining the status of an actor and as such other (international) criteria could be applied as well. See Brownlie, System of the Law of Nations: State Responsibility (Part I), p. 135-136; Crawford, The International Law Commission's Articles on State Responsibility: Introduction, Text and Commentaries, p. 98. 
Serbia and Montenegro), ${ }^{19}$ the ICJ examined the question whether other entities could be equated with State organs under Article 4 when they do not have that status under internal law. Taking a cue from its views expressed in the case of the Military and Paramilitary Activities in and against Nicaragua (Nicaragua v. United States of America),${ }^{20}$ the Court observed that such entities could only be equated with State organs, "[...] provided that in fact the persons, groups or entities act in 'complete dependence' on the State, of which they are ultimately merely the instrument." 21 According to the Court, however, equating such entities with the State must be exceptional since it requires proof of a particularly great degree of State control over them. ${ }^{22}$ The Bosnia and Herzegovina v. Serbia and Montenegro illustrates that it is indeed difficult to prove that entities, such as the Army of the Republika Srpska and a Paramilitary Group called the 'Scorpions' operating in the territory of Bosnia and Herzegovina, and which allegedly committed atrocities in Srebenica, can be equated with organs of the State (in this case the Army of Serbia and Montenegro). In that case, the Court concluded that the Army of the Republika Srpska, in spite of having close ties with the Federal Republic of Yugoslavia, still maintained "[...] some qualified, but real, margin of independence." 23 It was also further unable, on the basis of the information available to it, to conclude that the 'Scorpions' could be equated to the Army of Serbia and Montenegro. ${ }^{24}$

Thus, the general rule is that only the conduct of organs of government, or of other agents of the State that have acted under the direction, control or instigation of the governmental organs can be attributed to the State. ${ }^{25}$ In terms of the context of the present study, this would mean on initial consideration that the State would not be responsible for the conduct of privatized entities, since they are technically not organs of the State or 'traditional' State agents as understood by the international law of state responsibility. ${ }^{26}$

Notwithstanding the general rule of attribution, breaches of international obligations as a result of conduct by private actors can under certain circumstances be attributed

19 See note 13.

20 See Military and Paramilitary Activities in and against Nicaragua (Nicaragua v. United States of America), Merits, Judgment, I.C.J. Reports 1986.

21 Case Concerning the Application of the Convention on the Prevention and Punishment of the Crime of Genocide (Bosnia and Herzegovina v. Serbia and Montenegro), para. 392.

22 Ibid., para. 393.

23 Ibid., para. 394.

24 Ibid., para. 395.

25 See in general Brownlie, System of the Law of Nations: State Responsibility (Part I), p. 133 and further, and Crawford, The International Law Commission's Articles on State Responsibility: Introduction, Text and Commentaries, p. 91. Responsibility also ensues in the case where State organs or agents are acting ultra vires. See Art. 7 of the ILC Articles on the Responsibility of States. See also Kamminga, Inter-State Accountability for Violations of Human Rights, p. 139. However, it can be argued that under certain circumstances, private actors can be viewed as a type of State organ sui generis. See Section 3 infra. 
to the State. Brownlie has described a number these circumstances including the admission of responsibility by the state itself for the private conduct, the approval and adoption of harmful acts as in the case of United States Diplomatic and Consular Staff in Tehran, ${ }^{27}$ and the acts of officials outside their official competence. $^{28}$ The ILC has recognized these instances in Articles 7 and 11 of the ILC Articles. However, the most relevant types of attribution for the conduct of private actors in respect of the present are when private actors have been empowered to 'exercise elements of governmental authority' (Article 5 ILC Articles on state responsibility), or when the conduct of these private actors is in fact directed or controlled by the State (Article 8 ILC Articles on state responsibility). ${ }^{29}$

\subsubsection{Private actors exercising elements of governmental authority ${ }^{30}$}

Acts performed by non-State entities while exercising elements of governmental authority or other public tasks that have been delegated to them by law can be considered an act of the State and thus attributable to the latter. ${ }^{31}$ Article 5 of the ILC's Articles on Responsibility of the State states that,

"[t]he conduct of a person or entity which is not an organ of the state under article 4 but which is empowered by the law of that State to exercise elements of the governmental authority shall be considered an act of the State under international law, provided the person or entity is acting in that capacity in the particular instance."

The drafting history of Article 5 reveals that States and the ILC had anticipated the growing importance of non-State actors or para-statals to which the exercise of governmental functions had been delegated. In the Replies made by Governments to the Preparatory Committee for the 1930 Conference for the Codification of International Law, the government of Germany brought up the issue of delegation of state functions to private entities and its relationship with state responsibility. Commenting on a discussion point about acts or omissions of bodies exercising

United States Diplomatic and Consular Staff in Tehran, ICJ Reports 1980, p. 3 at p. 29-30. Brownlie, System of the Law of Nations: State Responsibility (Part I), p. 160-162.

Arguably, Article 9 on the conduct carried out in the absence or default of the official authorities, and Article 11 on the conduct acknowledged and adopted by a State as its own, are also relevant. However, they will not be fully considered here as the general principles applicable to Articles 5 and 8 are broadly similar to those applicable to Articles 9 and 11 .

Section 3 infra will deal in more detail from a comparative perspective with similar issues.

See also Brownlie, System of the Law of Nations: State Responsibility (Part I), p. 159-166; G. Sperduti, "Responsibility of States for Activities of Private Law Persons," in Encyclopedia of International Law, ed. R. Bernhardt, Amsterdam: Max Planck Institute for Comparative Public Law and International Law - North Holland (1987), p. 373-375; Crawford, The International Law Commission's Articles on State Responsibility: Introduction, Text and Commentaries, p. 100; and Clapham, Human Rights Obligations of Non-State Actors, p. 241-244. 
public functions, the German government observed that the principles governing the responsibility of the State are also

"[...] applicable when the State, as an exceptional measure, invests private organizations with public powers and duties or authorities [sic] them to exercise sovereign rights, as in the case of private railway companies permitted to maintain a police force." 32

This observation by the German government back in 1930 was not further considered with respect to the issue of state responsibility until the late 1960s and 1970 s. Article 5 as it stands now, was originally based on two separate articles drafted by the ILC's second Special Rapporteur on state responsibility, Roberto Ago. The predecessors to Article 5 as drafted by Ago were Article 7 and 8. ${ }^{33}$ Ago took into consideration the possibility that non-State entities, including private ones, could be endowed with public functions, thus making the State responsible for their conduct. ${ }^{34} \mathrm{Mr}$. Ago acknowledged that there might be situations or circumstances in which State authorities are not in the position to properly perform their functions or provide services prompting the State to entrust private natural or legal persons with the provision of a service or the performance of a specific task. ${ }^{35}$ Since according to Ago the State often assumes responsibility at the internal level for the acts of private natural or legal persons commissioned to provide a particular public service, it would seem that, a fortiori, at the international level, the State should bear responsibility for the acts of these types of actors where they relate to functions, tasks or missions delegated to them, and which result in the breach of an

32 See League of Nations Conference for the Codifications of International Law [1930], Volume Two, Edited by Shabtai Rosenne, 1975, Oceana Publications, Inc., Dobs Ferry, New York, Bases of Discussion III (Responsibility of States for Damage done in their Territory to the Person or Property of Foreigners), Point VI, p. 512.

33 The then Article 7 on the attribution to the State, as a subject of International law, of the acts of organs of public institutions separate from the State, read " The conduct of a person or group of persons having, under the internal legal order of a State, the status of an organ of a public corporation or other autonomous public institution or of a territorial public entity (municipality, province, region, canton, member state of a federal State, autonomous administration of a dependent territory, etc.) and acting in that capacity in the case in question, is also considered to be an act of the State in international law." Old Article 8 on the attribution to the State, as subject of International law, of acts of private persons in fact performing public functions or in fact acting on behalf of the State, read: "The conduct of a person or group of persons who, under the internal legal order of a State, do not formally possess the status of organs of that State or of a public institutions separate from the State, but in fact perform public functions or in fact act on behalf of the State, is also considered to be an act of the State in international law." See ILC Yearbook 1971, vol. II, Part One, United Nations, New York, 1971, p. 253-267.

35 Ibid., p. 263. Ago gives as examples the provision of "[...] public transport, postal communications or some other public service; non-official associations or groups of private persons may be used as auxiliaries in official health units, the police or the armed forces; drivers of private vehicles may be used to carry troops to the front, etc." Ibid. (Footnote omitted). 
international obligation of the State. ${ }^{36}$ In Ago's opinion, the underlying criterion in international law to determine whether the State can be held responsible for the conduct of private actors carrying out delegated functions should be the "[...] public character of the function or mission in the performance of which the act or omission contrary to international law was committed, rather than the formal link between the State organization and the person whose conduct is in question." 37

After Ago's initial considerations on the matter, the ILC redrafted Articles 7 and $8 .^{38}$ This redrafting discarded the use of 'private actors' in both articles to describe the type of actors involved and scrapped the use of public functions of old Article 8 as a determinant of the types of activities that may lead to State responsibility. Instead, Article 7 focused on territorial entities (section 1), and on 'an organ or entity which is not a part of the formal structure of the State' (section 2) ${ }^{39}$ Article $7 \S 2$ also introduced the notion of 'exercising elements of governmental authority' as the determining factor for leading to state responsibility. ${ }^{40}$ The rationale behind this choice of words, was according to the ILC, that since it is difficult to figure out whether these bodies can be classified as public or private, or whether or not they are owned by the State or subject to its control, and since these criteria appear not to be decisive for the purposes of attribution or non-attribution to the State with regard to the conduct of its own organs, it was better to let the attribution depend on the feature these entities have in common: "[...] namely that they are empowered, if only exceptionally and to a limited extent, to exercise specified functions which are akin to those normally exercised by organs of the State." 41

Article 8, on the other hand, was left for cases in which non-State actors acted on behalf of the state or in the absence of official authorities. ${ }^{42}$ Both Articles 7 and 8

Ibid., p. 264.

Ibid.

See ILC Yearbook 1974, vol. I, United Nations, New York, 1975, p. 152.

The use of the term entity was deemed by the ILC to be the most appropriate since it was a more neutral term, which was easiest to translate into various languages, and was also wide enough to encompass various bodies such as "[...] public corporations, semi-public entities, public agencies of various kinds and even, in special cases, private companies." ILC Yearbook1974, vol. II, part 1, United Nations, New York, 1975, p. 282-283.

40 Article 7 (2) came then to read: "The conduct of an organ of an entity which is not a part of the formal structure of the State or of a territorial governmental entity, but which is empowered by the internal law of that State to exercise elements of the governmental authority, shall also be considered as an act of the State under international law, provided that organ was acting in that capacity in the case in question."

$41 \quad$ ILC Yearbook1974, vol. II, part 1, United Nations, New York, 1975, p. 282.

42 See ILC Yearbook 1974, vol. I, United Nations, New York, 1975, p. 153. See also Yeager v. Islamic Republic of Iran, Case No. 10199 (1987) 17 Iran-U.S.C.T.R., ILR Vol. 82 (1990), p.193194. 
as adopted on the first reading of the Draft Articles were later again redrafted and split to what eventually became current Articles 4, 5, 8 and 9.43

The relative importance of the topic touched by current Article 5 ILC became apparent, when the ILC observed in its report to the General Assembly in 1974 that the delegation of governmental powers to entities other than the State was a phenomenon of recent development, which nevertheless had already been foreseen by some states as early as $1930 .{ }^{44}$ Its importance may also be implicitly read in the fact that following all the redrafts described in the previous paragraph, it was accorded its own individual provision in the final Articles on State Responsibility submitted by the ILC. ${ }^{45}$ In addition, the apparent relevance of Article 5 has not gone unnoticed by a number of international tribunals, which have made passing reference to this provision. ${ }^{46}$ One tribunal has even claimed that its content reflects international customary law. ${ }^{47}$

What does Article 5 encompass in its current form? In his commentary to the ILC's Articles on State Responsibility, the last ILC Special Rapporteur on the issue, Crawford, notes that the 'entity' mentioned in Article 5 may include private companies, provided they have been empowered by a law of the State to exercise functions of a public character normally exercised by State organs and their conduct relates to the exercise of the public authority that empowered them. ${ }^{48}$ The ILC Commentary observes that Article 5 is intended,

"[...] to take into account of the increasingly common phenomenon of para-statal entities, which exercise elements of governmental authority in place of State organs, as well as situations where former State corporations have been privatized but retain certain public or regulatory functions." 49

According to the ILC, an example of such an empowerment of a private entity could be the contracting out of private security firms to act as prison guards. ${ }^{50}$ The ILC

See ILC Yearbook 1998, vol. I, United Nations, New York, 2000, p. 289.

ILC Yearbook1974, vol. II, part 1, United Nations, New York, 1975, p. 281

See ILC Yearbook 1998, vol. I, United Nations, New York, 2000, p. 289.

See Dispute Concerning Access to Information Under Article 9 of the OSPAR Convention (Ireland v. The United Kingdom), Permanent Court of Arbitration, (2 July 2003), para. 145; EnCana Corporation v. Republic of Ecuador, LCIA Case No. UN3481, UNCITRAL (Canada/ Ecuador BIT), London Court of International Arbitration (3 February 2006), para. 154; Jan de Nul N.V. and Dredging International N.V. v. Arab Republic of Egypt, Decision on Jurisdiction, ICSID Case No. ARB/04/13 (Belgo-Luxembourg/Egypt BIT), 16 June 2006, para. 89.

Noble Ventures, Inc. v. Romania, Award, ICSID Case No. ARB/01/11 (US/Romania BIT), 12 October 2005, para. 70.

Crawford, The International Law Commission's Articles on State Responsibility: Introduction, Text and Commentaries, p. 100.

Ibid.

Ibid. 
considers that in such capacity private security companies "[...] may exercise public powers such as powers of detention and discipline pursuant to a judicial sentence or to prison regulations." ${ }^{51}$ Additionally, the commentary observes that it does not matter whether the national legal context classifies a particular entity as either public or private. The internal classification is not decisive for the purpose of attribution. What counts is that these entities have been empowered to exercise specified elements of governmental authority, albeit for a limited period of time or in a specific context. ${ }^{52}$

In order to regard the conduct of private entities carrying out privatized functions, tasks and services as an act of the State, Article 5 requires three conditions:

1. The functions, tasks and services delegated to these private entities must be of a public nature: they must contain elements of governmental authority.

2. The functions, tasks or services must be delegated to the entity by law.

3. The private entity performing functions, tasks and services of a governmental or public nature that were privatized must be acting in that capacity.

These conditions will be examined below in further detail.

\subsubsection{The delegated functions must contain elements of governmental authority}

Apparently, the special nature of the functions, tasks and services performed is essential in determining whether they contain elements of governmental authority ${ }^{53}$ In the final commentary submitted by Crawford on the Articles on the Responsibility of the State, the nature of the activity is briefly discussed. The commentary observes that in order for the conduct of a private entity to be regarded as an act of the State for the purposes of international responsibility, the conduct "[...] must accordingly concern governmental activity and not other private or commercial activity in which the entity may engage." 54 The commentary exemplifies this by noting that the conduct of a railway company, which has been endowed with certain police powers, will be regarded as an act of the State, while other activities such as the sale of tickets or the purchase of rolling-stock will not be regarded as such..$^{55}$ Another example provided by the ILC commentary is the above

\footnotetext{
51 Ibid.

52 Ibid

53 ILC Yearbook 1974 Volume II (part 1), United Nations, New York, 1975, p. 282, para. 18. See also Lawson, "Out of Control. State Responsibility and Human Rights: Will the ILC's Definition of the 'Act of State' Meet the Challenges of the $21^{\text {st }}$ Century?," p. 95, who comments, en passant, that this seemingly important requirement is not well-defined.

54 Crawford, The International Law Commission's Articles on State Responsibility: Introduction, Text and Commentaries, p. 101 (emphasis added, $A H W$ ). Ibid.
} 
noted case of private security guards or private prison companies: their conduct could be attributable to the State when public powers related to the detention of prisoners pursuant to a prison sentence or the application of disciplinary sanctions such as denial of prisoners' privileges have been delegated to them by law. ${ }^{56} \mathrm{~A}$ similar situation can be observed with respect to the 'Komitehs' or 'Revolutionary Guides', which had emerged from neighborhood committees following the Islamic revolution in Iran in the 1970s, and which performed certain security functions with the acquiescence of the Ayatollah regime. According to the Iran-US Claims Tribunal the acts of these 'Komitehs' (arresting individuals and confiscating property) made it possible to conclude that they "[...] at least exercised elements of governmental authority in the absence of official authorities, in operations in which the new Government must have had knowledge and to which it did not specifically object." 57

These examples, however, do not provide sufficient indications regarding the scope of what is considered to be the exercise of elements of governmental authority especially with regard to privatization, which the commentary acknowledges to cover. It would be easy to conclude that police powers or powers related to the administration of justice contain elements of governmental authority. After all, these functions or tasks are often considered to be typically governmental. ${ }^{58}$ In a trade dispute involving export subsidies of dairy products between Canada, the United States and New Zealand, the Appellate Body of the WTO's Dispute Settlement Unit observed that functions of a governmental character are functions necessary to 'regulate', 'restrain', 'supervise' or 'control' the conduct of private citizens. ${ }^{59}$ In short, 'typical' governmental functions are those that have police or regulatory elements.

56 Ibid., p. 100.

57 Yeager v. Islamic Republic of Iran, p. 193-194 (footnote omitted). Although the Tribunal refers specifically to former Article 8 (b) of the ILC Draft Articles on Responsibility of the State, which indeed dealt with another situation of exercise of elements of governmental authority (namely in the absence of official authorities), the interpretation of the concept is similar. This however, does not mean that the government has always been involved with these functions. See supra Chapter II.

59 See Canada - Measures Affecting the Importation of Milk and the Exportation of Dairy Products, Report of the Appellate Body, WT/DS103/AB/R (13 October 1999), para. 97. It is worth noting that the original ad-hoc panel that had been instituted to resolve this dispute had to examine whether Canadian provincial milk marketing boards, composed of local milk producers and endowed with certain regulatory powers, could be regarded as governmental agencies. To this end the panel made a passing reference to the old Article $7 \S 2$ of the Draft Articles on State Responsibility, which is now Article 5. See Canada-Measures Affecting the Importation of Milk and the Exportation of Dairy Products, Report of the Panel, WT/DS103/R and WT/DS113/R (17 May 1999), para. 7.77, footnote 427. The Appellate Body upheld the findings of the panel in this regard, although went further to define what it understood to be governmental functions. 
But what about other functions tasks and services that also are being privatized, and which arguably contain commercial, economic and private elements? These include services that are provided in some kind of market with payment at point of use. The provision of potable water to consumers, for example, is in essence a commercial activity: a water utility, whether it is publicly or privately owned, will usually require payment of a water bill for continued delivery of its services and charge consumers for the water consumed (either according to fixed rates or according to how much water households have actually consumed based on metered readings). Some, however, have argued that the provision of water is a traditional or essential government task that should not be privatized. ${ }^{60}$ It can also be argued that the provision of clean water involves a certain public or general interest due to the public health and potential human rights issues involved ${ }^{61}$ The ICSID Arbitration Tribunal in the international investment dispute between Aguas Argentinas, S.A., Suez, Sociedad General de Aguas de Barcelona, S.A., and Vivendi Universal S.A., and Argentina ${ }^{62}$ acknowledged this. Discussing the appropriateness of the participation of a number of NGOs as amicus curiae in the proceedings of this dispute involving the privatization of water and sewage services in the city of Buenos Aires, the Tribunal observed that

\begin{abstract}
"The factor that gives this case particular public interest is that the investment dispute centers around the water distribution and sewage systems of a large metropolitan area, the city of Buenos Aires and surrounding municipalities. Those systems provide basic public services to millions of people and as a result may raise a variety of complex public and international law questions, including human rights considerations. Any decision rendered in this case, whether in favor of the Claimants or the Respondent, has the potential to affect the operation of those systems and thereby the public they serve." 63
\end{abstract}

Similarly, the provision of health care or even education can also contain certain commercial elements, especially if they are provided by private entities. However, public health and education can be considered to concern the whole of society since they serve public interests, and under human rights law involve negative and positive legal obligations on the side of the State. ${ }^{64}$ The Inter-American Court of

60 For a deeper discussion on the privatization of essential utilities, in particular water utilities, see Chapter VII infra.

61 See on this discussion Chapter VII.

62 Aguas Argentinas, S.A. Suez, Sociedad General de Aguas de Barcelona, S.A., and Vivendi Universal S.A., v. the Argentine Republic, Order in Response to a Petition for Transparency and Participation as Amicus Curiae, ICSID Case No. ARB/03/19, 19 May 2005.

63 Aguas Argentinas, S.A. Suez, Sociedad General de Aguas de Barcelona, S.A., and Vivendi Universal S.A., v. the Argentine Republic, Order in Response to a Petition for Transparency and Participation as Amicus Curiae, para. 19.

64 See for example CESCR General Comment No. 14, the right to the highest attainable standard of health (Article 12), UN Doc. E/C.12/2000/4 (11 August 2000), and CESCR General Comment No. 13, the Right to Education (Article 13), UN Doc. E/C.12/1999/10 (8 December 1999). With 
Human Rights has acknowledged this in the case of Case of Ximenes-Lopes $v$. Brazil $^{65}$ involving the provision of health care services by private actors within the context of a public health system in Brazil. In this case, the Court observed that a private health institution engaged by the State to render mental health services under the coverage of public health legislation operated as a public health institution on behalf of the State. ${ }^{66}$ Pointing out to Article 5 of the Articles on Responsibility of the State, the Court concluded that Brazil was internationally responsible for the conduct of the staff of that private health institution since the latter "[...] exercised the state authority in rendering public health services under" the Brazilian public health legislation. ${ }^{67}$ The Inter-American Court also noted that under the Brazilian constitution health care was a right to everyone and a duty of the State, and that the constitution and implementing legislation allowed also the private provision of health care as supplementary agents of the public health system. According to the Court, under this system,

"[...] private institutions may also render services for the public health system, in which case health care will be financed by the State and will be of a public nature. [...] Rendering public services implies the protection of public interests, which is one of the objectives of the State. Though the States may delegate the rendering of such services, through the so-called outsourcing, they continue being responsible for providing such public services and for protecting the public interest concerned." 68

These observations led the Inter-American Court to consider that this places the State under a positive obligation to regulate and supervise at all times the rendering of health services by both public and private entities. ${ }^{69}$

In sum, the provision of services such as water, health care, and education are examples of services of a public nature and which may also be called 'services of general interest' because of the particular public interests they serve. ${ }^{70}$ Arguably, 'typical' police and regulatory functions may also fall under this term.

regard to the right to education and privatization see further Coomans and Hallo de Wolf, "Privatisation of Education and the Right to Education."

Case of Ximenes-Lopes v. Brazil, Merits, Reparations and Costs, judgment of 4 July 2006, IACtHR, Series C No. 149.

66 Ibid., paras. 86, 87 and 100.

67 Ibid., para. 100.

68 Ibid., paras. 92 and 96.

69 Ibid, para. 99. Among the positive measures that could be adopted in this particular case were the creation of proper mechanisms to carry out inspections at psychiatric institutions, submiting, investigating, and solving complaints and taking the appropriate disciplinary or judicial actions regarding cases of professional misconduct or the violation of the patients rights. See also Chapter III, Section 4.1.2.3 on the issue of regulation with regard to this case.

70 This is an umbrella term, which is increasingly being used under EU law, and which is used to describe services that are affected with a public interest, but contain economic elements. See C. Scott, "Services of General Interest in EC Law: Matching Values to Regulatory Technique in 
The current reality in which private actors are providing the same services of general interest simultaneously with or instead of state actors, and for arguably commercial purposes (policing vs. private policing, military services vs. private military services, public health vs. private health, public water vs. privatized water), raises some important questions. Which functions, tasks or services are inherently governmental, or are intrinsic and belong to the core tasks of the State and thus contain elements of governmental authority? Do functions, tasks or services that were formerly performed by the State change in nature once they are privatized? Do they turn commercial? In other words, and borrowing the language used in discussing state immunity, when are we speaking of acta jure imperii (governmental acts presumably embodying elements of governmental authority) and when of acta jure gestiones (commercial acts) with respect to the conduct of private entities carrying out privatized tasks? ${ }^{71}$ Do the latter not contain any elements of governmental authority, and does it always preclude attribution to the State and thus state responsibility? During the latter discussions on Article 5 (which at that point was Article 7 \$2) of the then called Draft Articles on the State Responsibility, the ILC considered whether the term 'governmental authority' could be replaced by 'functions'. It was argued that this "[...] could lead readers to believe that the draft articles concerned acta jure gestiones, which was not self-evident and should in any case be made clear in the commentary." 72 This observation could be interpreted both ways: either excluding commercial acts of the State that have been delegated to private actors or acknowledging that under certain circumstances these seemingly commercial acts may also lead to state responsibility if it contain elements of governmental authority.

It is suggested here that limiting state responsibility to conduct that concerns governmental activity or functions in a narrow sense, including policing, military actions, incarceration or taxation (or as suggested by the Appellate Body's report in Canada-Measures Affecting the Importation of Milk and the Exportation of Dairy

the Public and Privatised Sectors," European Law Journal Vol. 6 (2000), p. 312-313. For further discussion about the relevance of services of general interest and privatization in the context of this study see Chapter VII.

71 It should be noted that in the context of state immunity, acta jure imperii are usually amenable to state immunity, while acta jure gestiones are not. The ICJ has observed, however, that a minister of foreign affairs that is still in office will still enjoy state immunity for acts that are carried out in both an official or private capacity. See Case Concerning the Arrest Warrant of 11 April 2000 (Democratic Republic of the Congo v. Belgium), ICJ Reports 2002, para. 54. The Court added however, that once the minister is no longer in office, the immunity is no longer applicable for those acts carried out in a private capacity. Ibid., para. 61. Various scholars have criticized this confusing and unfortunate approach. See among others A. Cassese, "When May Senior State Officials Be Tried for International Crimes? Some Comments on the Congo v. Belgium Case," EJIL Vol. 13 (2002), p. 866-870.

72 Report of the International Law Commission on the work of its fiftieth session, 20 April 12 June and 27 July - 14 August 1998, UN Doc. A/53/10, p. 83, para. 392. 
Products ${ }^{73}$ regulatory, restraining, supervisory or control functions) and excluding certain commercial acts, as the ILC's commentary appears to suggest, would not be in line with one of the aims of state responsibility, which is to prevent States from escaping their legal obligations under international law for harm that has been committed or allowed by the State either by its actions or omissions. Higgins and Chinkin have observed that it would seem illogical or possibly contradictory to not apply state responsibility to commercial acts that constitute international wrongs, since already in the field of state immunity States do not enjoy immunity for certain commercial acts. ${ }^{74}$ Similarly, van Harten has argued that the distinction between public acts and commercial acts in the field of international commercial arbitration and investment treaty arbitration has become blurred to the point that disputes in investment treaty arbitration, which has its origins in seemingly commercial acts, can be regarded as dealing with public law issues. ${ }^{75}$ The International Center for Settlement in Investment Disputes has similarly held in Noble Ventures, Inc. v. Romania $^{76}$ that

"[h]owever, in the context of responsibility, it is difficult to see why commercial acts, so called acta iure gestionis, should by definition not be attributable while governmental acts, so called acta iure imperii, should be attributable. The ILC-Draft does not maintain or support such a distinction. Apart from the fact that there is no reason why one should not regard commercial acts as being in principle also attributable, it is difficult to define whether a particular act is governmental. There is a widespread consensus in international law, as in particular expressed in the discussions in the ILC regarding attribution, that there is no common understanding in international law of what constitutes a governmental or public act." 77

What is the relevance of all this? Arbitral tribunals have observed that Article 5 means "[...] a State will not necessarily escape responsibility for wrongful acts or omissions by hiding behind a private corporate veil." ${ }^{\prime 7}$ Similarly, human rights monitoring bodies have also concluded that States cannot escape their international responsibilities under human rights treaties' obligations by delegating their obligations to private entities. ${ }^{79}$ Clearly, allowing States to escape their legal

73 See footnote 59.

74 R. Higgins, Problems and Process: International Law and How We Use It (Oxford: Oxford University Press, 1994) p. 152-153; Shaw, International Law, p. 718; and C. Chinkin, "A Critique of the Public/Private Dimension," EJIL Vol. 10 (1999), p. 392.

75 G. van Harten, "The Public - Private Distinction in the International Arbitration of the Individual Claims Against the State," ICLQ Vol. 56 (2007), p. 371-393.

76 Noble Ventures, Inc. v. Romania, ICSID Case No. ARB/01/11 (US/Romania BIT), see footnote 47.

77 Ibid., para. 82.

78 Maffezini v. Kindgom of Spain, decision on objections to jurisdiction, ICSID Case No. ARB/97/7, 25 January 2000, para. 78 (footnotes omitted).

79 The ECtHR concluded in Costello Roberts v. UK that "[...] the State cannot absolve itself from responsibility by delegating its obligations to private bodies or individuals." See Costello 
responsibility by privatizing tasks and delegating them to private entities that are essentially doing the same thing the State officially did would also not be in line with these developments and those in other areas of international law including international criminal law, ${ }^{80}$ and international economic law, ${ }^{81}$ or with one of the original intentions of the ILC with regard to Article $5{ }^{82}$

Roberts v. UK, ECtHR judgment of 25 March 1993, Series A-247-C, para. 27. The Human Rights Committee has concluded (in similar words) that "[...] the contracting out to the private commercial sector of core State activities which involve the use of force and the detention of persons does not absolve a State party of its obligations under the Covenant [...]" See Cabal and Pasini Bertran v. Australia, Communication No. 1020/2001, UN Doc. CCPR/C/78/D/1020/2001 (19 September 2003), para. 7.2. For further discussion of these cases see Section 3 infra. Prosecutor v. Dusko Tadic, ICTFY, Appeals Chamber, 15 July 1999, Case IT-94-1, para. 117: "The rationale behind this rule is to prevent States from escaping international responsibility by having private individuals carry out tasks that may not or should not be performed by State officials, or by claiming that individuals actually participating in governmental authority are not classified as State organs under national legislation and therefore do not engage State responsibility." It must be noted that this argument referred mainly to the application of Article 8 ILC (to be discussed below), but the gist is nevertheless applicable as well to Article 5.

81 Under certain circumstances, the conduct of private entities related to the regulation of commercial activities can lead to the responsibility of the State. See Japan-Measures Affecting Consumer Photographic Film and Paper, Report of the Panel, WT/DS44/R (31 March 1998), paras. 10.321-10.328, and Canada - Measures Affecting the Importation of Milk and the Exportation of Dairy Products, Report of the Appellate Body, WT/DS103/AB/R (13 October 1999), paras. 93-102. In particular, the ad-hoc Panel in Japan - Measures Affecting Consumer Photographic Film and Paper explicitly observed that actions taken by a number of private entities grouped together in an association (the Retailers Council) could be attributed to the government of Japan due to their approval by the latter and their being sanctioned in a public law. According to the panel, concluding otherwise "[...] would create a risk that WTO obligations could be evaded through a Member's delegation of quasi-governmental authority to private bodies." Ibid., para. 10.328. A similar assessment on whether particular bodies could be regarded as 'public bodies' that provided goods or services that constitute subsidies and which may be subjected to countervailing measures under the WTO's Agreement on Subsidies and Countervailing Measures (SCM Agreement) was made by the WTO's Appellate Body in United States - Definitive Anti-Dumping and Countervailing Duties on Certain Products from China. See United States - Definitive Anti-Dumping and Countervailing Duties on Certain Products from China, Report of the Appellate Body, WT/DS379/AB/R (11 March 2011). One of the issues at hand revolved around the scope of Article 1.1 of the SCM Agreement which stipulates that inter alia that a subsidy shall be deemed to exist if there is "[...] a financial contribution by a government or any public body within the territory of a Member (referred to in this Agreement as 'government"'. The initial ad-hoc panel had interpreted the term 'public body' to mean any entity controlled by the government. This meant that Chinese State Owned Enterprises and State Owned Commercial Banks were considered as 'public bodies' as stipulated in Article 1.1. The Appellate Body, however, disagreed and looked, among other things, at Article 5 of the ILC Articles for reference. Ibid., para. 309-310. The Appellate Body concluded that "[a] public body within the meaning of Article 1.1 (a)(1) of the SCM Agreement must be an entity that possesses, exercises or is vested with governmental authority." Ibid., para. 317. 
It is thus necessary to briefly consider a number of criteria that might be helpful in discerning functions, tasks or services containing elements of governmental authority with regard to privatization. The ILC commentary avoids, to a certain extent, providing an answer to this conundrum. The commentary limits itself to observing that Article 5 ILC Articles on Responsibility of the States does not attempt to identify the scope of "governmental authority" for the purpose of attribution of the conduct of a private entity to the State:

"Beyond a certain limit, what is regarded as 'governmental' depends on the particular society, its history and traditions. Of particular importance will be not just the content of the powers, but the way they are conferred on an entity, the purposes for which they are to be exercised and the extent to which the entity is accountable to government for their exercise. These are essentially questions of the application of a general standard to varied circumstances." 83

These observations, however, can serve as a departing point for identifying certain criteria that may be of use when attempting to distinguish conduct that can be considered 'governmental' as required by Article 5 ILC.

In the first place, the ILC commentary suggests that a particular society's history and traditions can define whether certain tasks, functions or services can be considered 'governmental'. ${ }^{84}$ This requires looking whether and for how long the legal historical context of a particular State has regarded a certain function, task or service to be within the purview of that State. However, as suggested in Chapter II, various functions, tasks or services that were considered traditionally or historically governmental have not always been such. For example, in the United States until the end of the $19^{\text {th }}$ century and in the United Kingdom until the mid $19^{\text {th }}$ century, prisons were not always in the hand of the State proper, but were sometimes managed by private entities. ${ }^{85}$ Similarly, proper standing armies controlled by the

83 Crawford, The International Law Commission's Articles on State Responsibility: Introduction, Text and Commentaries, p. 101. It is worth pointing out that Article 2 of the Draft International Convention on the Regulation, Oversight and Monitoring of Private Military and Security Companies (see Chapter VI) defines 'Fundamental State functions' as "[...] functions that a State cannot outsource or delegate to non-State actors. Among such functions, consistent with the principle of State monopoly on the use of force, are waging war and/or combat operations, taking prisoners, law-making, espionage, intelligence and police powers, especially the powers of arrest or detention, including the interrogation of detainees."

84 Crawford, p.101.

85 See Austin and Coventry, "Emerging Issues on Privatized Prisons," p. 10. See also McAfee, "Symposium: Privatization of Prisons: Tennessee's Private Prison Act of 1986: An Historical Perspective With Special Attention to California's Experience," p. 853; Beyens, Snacken, and Eliaerts, Privatisering van Gevangenissen, p. 18-19; Misrahi, "Factories With Fences: An Analysis of the Prison Industry Enhancement Certification Program in Historical Perspective," p. 415-416; Duitsman, "The Private Prison Experiment: A Private Sector Solution to Prison Overcrowding," p. 2215. 
State only came into fashion in the $18^{\text {th }}$ and $19^{\text {th }}$ century: many States relied heavily on the use of private armies, mercenaries or condottieri. ${ }^{86}$ Consider also the provision of running water and sewerage or electricity. In various countries such as England and France, these were originally private activities in the hands of companies. Only during the $20^{\text {th }}$ century would these gradually pass into the hands of the States, only to be 're-privatized' later, as was the case with English water and electricity services. ${ }^{87}$ Ironically, one of the last contentious cases before the Permanent Court of International Justice, The Electricity Company of Sofia and Bulgaria ${ }^{88}$ dealing with state responsibility following the expropriation of foreign property in a country, involved a Belgian private electricity company, which had been nationalized without compensation by Bulgaria during World War I. In short, applying a historical approach alone would not always be practical and could even lead to conclude that many tasks are not easily identifiable as historically or traditionally governmental and thus not falling under the scope of Article 5 ILC Articles. A historical approach could, nevertheless, be helpful in establishing when certain services became 'governmental' and why.

Identifying the content of the functions, tasks or services is, according to the ILC commentary, another criterion that could be used, albeit not in a conclusive way. ${ }^{89}$ Here the nature of the function, tasks or services being privatized can be important. Functions or services that pursue an aim which is in the general interest of the state or of society could be regarded as being governmental. Thus it could be argued that the provision of essential services, the absence of which has repercussions for the proper functioning of the State, its organs, or society as a whole, can be considered under certain circumstances to be 'governmental'. In the case of Le Compte, Van Leuven \& De Meyere v. Belgium, for example, the European Court of Human Rights concluded that the Belgian Ordre des medicines, by virtue of furthering an aim in the public interest (in that particular situation, the protection of public health), had been invested with a number of prerogatives that allowed it to employ processes of a public authority..$^{90}$ It is interesting to observe that the United States, a country that has been at the forefront of privatization, has developed guidelines whose departing point is 'the public interest' for categorizing what it calls inherently governmental activities and commercial activities. This is required for determining whether certain activities should be delegated or contracted out to private entities.

86 See further Chapter VI.

87 In various companies, such as France, many of the water or electricity companies providing services to cities have always remained private. See further Chapter VII.

88 The Electricity Company of Sofia and Bulgaria (Preliminary Objection), Permanent Court of International Justice (4 April 1939), Judgments, Orders and Advisory Opinions, Series A/B, Fascicule No. 77.

89 Crawford, The International Law Commission's Articles on State Responsibility: Introduction, Text and Commentaries, p. 101.

90 See Le Compte, Van Leuven and De Meyere v. Belgium, judgment of 23 June 1981, ECtHR, Series A-43, para. 64. 
According to an official document from the Office of Management and Budget, which resorts under the Executive Office of the President of the United States, an inherently governmental activity

"[...] is an activity that is so intimately related to the public interest as to mandate performance by government personnel." 91

According to the ILC commentary, another way of determining whether certain powers may be regarded as governmental depends on how these have been conferred to an entity. This suggests that governmental powers and prerogatives must be endowed to a 'governmental' entity in a formal way. Such an endowment usually happens through a constitution or through a parliamentary act that sets down the powers for the State or the areas of action in which it is allowed to adopt decisions. Some constitutions may only reserve the more 'traditional' coercive powers to the central (or federal) government, while others like the Brazilian one list a large number of areas and activities that fall within the ambit of the government. ${ }^{92}$ Thus if a certain power or activity falls within the formal realm of a government through a constitution or a formal law and this is delegated to a private actor, that power/ activity will probably still be considered as governmental. This delegation of power may require a law through which the empowerment of governmental activity takes place or any other official statement that sanctions the private actor's conduct in that

91 See Circular No. A-76 (Revised), Office of Management and Budget, Executive Office of the President, 23 May 2003, page A-2. The inherently governmental activity is further defined as activities that "[...] require the exercise of substantial discretion in applying government authority and/or in making decisions for the government. Inherently governmental activities normally fall into two categories: the exercise of sovereign government authority or the establishment of procedures and processes related to the oversight of monetary transactions or entitlements. An inherently governmental activity involves:

(1) Binding the United States to take or not to take some action by contract, policy, regulation, authorization, order, or otherwise;

(2) Determining, protecting, and advancing economic, political, territorial, property, or other interests by military or diplomatic action, civil or criminal judicial proceedings, contract management, or otherwise;

(3) Significantly affecting the life, liberty, or property of private persons; or

(4) Exerting ultimate control over the acquisition, use, or disposition of United States property (real or personal, tangible or intangible), including establishing policies or procedures for the collection, control, or disbursement of appropriated and other federal funds."

According to this document, these inherently governmental activities should not be contracted out, while commercial ones may be delegated to private contractors.

92 Article 175 of the Brazilian constitution states for example that "It is incumbent upon the Government, as set forth by law, to provide public utility services, either directly or by concession or permission, which will always be through public bidding. Sole paragraph - The law shall provide for: I. the operating rules for the public service concession- or permissionholding companies, the special nature of their contract and of the extension thereof, as well as the conditions of forfeiture, control and termination of the concession or permission; II. the rights of the users; III. tariff policy; IV. the obligation of maintaining adequate service." 
realm. ${ }^{93}$ It presupposes the existence of some sort of formal link between the State and the non-State entity. This requirement will be dealt with in the next sub-section as it is related to the second condition required by Article 5 to regard private conduct as an act of the State.

The ILC also observes that the purposes for which functions, tasks or services are to be exercised may play a role in determining whether particular functions imply governmental authority. This criterion is closely related to the one observed above regarding the nature of the function, and entails that certain functions are necessary for furthering state or public interests. An example of this criterion can be found in American practice related to the contracting out of military services, which attempts to differentiate between military services that are amenable to privatization and those that are not. ${ }^{94}$ According to a US Army regulation on the contracting out of military services, inherently governmental functions related to military services are those that are

“[...] necessary for the sustainment of combat operations, that are performed under combat conditions or in otherwise uncontrolled situations, and that require direct control by the military command structure and military training for their proper execution [...] This includes functions performed exclusively by military (active and reserve) who are trained for combat and the use of deadly force, where performance by a contractor or civilian would violate their non-combatant status under the Geneva Conventions or represent an inappropriate risk to military operations. " 95

The regulation further adds that a key criterion in identifying an inherently governmental military function with regard to its purpose is "[...] whether the proper execution of the function under combat conditions has to be ensured, or safeguarded, through strict military command and extensive military training." 96 Services that are contracted out to further these purposes arguably entail the exercise of governmental authority. It must be noted, however, that the sole purpose of furthering a public policy or objective by itself may not be sufficient to assert whether a function itself is of a governmental character. ${ }^{97}$

93 This is similar to Article 11 of the ILC's Articles on conduct acknowledged and adopted by the State as its own.

94 For a more in-depth discussion of this criterion with regard to the privatization of military and security services see Chapter VI.

95 Army Regulation 715-9, "Contractors Accompanying the Force”, p. 21.

96 Ibid.

97 See in this regard Korea - Measures Trade in Commercial Vessels, Report of the Panel, WT/ DS273/R (7 March 2005), para. 7.55. 
Finally, the ILC commentary suggests that the extent to which a private entity is accountable to the government can play a role in determining its character. ${ }^{98} \mathrm{An}$ example of accountability would be the regulatory regime imposed to control the activities of the privatized entity. Many privatized sectors are regulated, sometimes by virtue of their natural monopoly characteristics or the nature of the service that has been privatized (essential public services such as water, electricity or gas). It could be argued that a regulatory regime, whereby a regulator established by public law exercises strict control over a privatized sector of vital national importance to ensure that the service provider complies with its legal and contractual obligations under the privatization scheme, could help to establish the public importance of a certain function, task or service and hence its 'governmental' character.

Other criteria that are not mentioned in the ILC commentaries, but which could also be important to determine whether certain functions are 'governmental' are whether the activities of the privatized entity are partially or fully funded by the State, ${ }^{99}$ or whether the State has maintained an option to take over the tasks in case of non compliance with the contractual obligations or sudden inability of the privatized entity to perform its duties. This could be the case, for example, if a law characterizes a certain task as being one of public/general interest and nevertheless allows the task to become privatized, but retains the possibility for the State to take back the task in case the privatized entity fails in its duties to carry out the task in a proper way.

These criteria are, of course, not exhaustive and their application will have to be considered on a case-by-case basis due to the difficulty inherent in the task of discerning what actually belongs to the proper activities of the State and what does not. 100

\subsubsection{The functions, tasks or services must be delegated to the entity by law}

Neither the ILC's Articles nor the commentary make it clear whether the requirement of delegation to the entity by law necessitates a formal legislative act approved or sanctioned by the national legislature, or whether it also covers lower ranking rules. It may be presumed that an international adjudicatory body would reason that a broad interpretation of the term covering all rulemaking acts would be

98 Crawford, The International Law Commission's Articles on State Responsibility: Introduction, Text and Commentaries, p. 101.

99 Under United States Supreme Court case law, this criterion has been regarded as important, but not as determinant for concluding that a particular activity is public or governmental. See for example Blum v. Yaretsky, 457 U.S. 991 (1982), p. 1011. See also further Section 3.4.1.1 infra.

100 That in effect is a highly political question which would be difficult if not impossible to resolve solely on the basis of legal concepts or rules, the latter of course also being susceptible to change according to the political climate of the moment. 
valid in the same way international and regional human rights monitoring bodies have concluded. ${ }^{101}$ The issue is relevant since in many instances, privatization operations do not take place through the application of a formal legislative act, but also through governmental decisions taken by the executive or lower administrative or regional bodies. A narrow interpretation of this requirement, only embodying formal legislation, would easily enable the State to escape responsibility by allowing other rule makers than the formal legislator to enact rules allowing for privatization. However, given the fact that the actions of all State organs, whatever their place in the legal hierarchy of the State are also attributable to the State, this should not be a real difficulty. A bigger problem could be that privatization in some instances does not take place through the enactment of a law (in the broad sense of the term), but through a contractual agreement between the government and the private entity. ${ }^{102}$ In such a case, it is not altogether clear whether Article 5 would be relevant, and the attribution of the entity's conduct to the State would have to be examined through other means, for example by examining whether the State had control over the private entity (see further infra). It would be reasonable to assume in this regard, that in so far as the link between the State and the private entity is formal and can be traced back to an official public policy or regulation that can be understood as law in a substantive manner, an activity that has been privatized through a contract may also entail the exercise of governmental authority provided it fulfills the other requirements of Article 5.

According to the ILC commentary, another point for consideration is that the law endowing the private actor with governmental powers must specifically authorize the conduct involving the exercise of governmental authority. ${ }^{103}$ Legislation that permits an activity as part of the general regulation of the affairs of the community would, as noted by the ILC commentary, not fall under Article 5. However, specific regulatory measures that allow for privatization, or regulate the conduct of privatized entities may qualify for the purposes of Article 5. ${ }^{104}$

\subsubsection{The private entity must act in a public or governmental capacity}

In order to be attributable to the State, the conduct of the entity exercising elements of governmental authority must act in a governmental capacity. This entails that the

101 See f.e. at the European level Sunday Times v. UK, judgment of 26 April 1979, ECtHR, Series A-30.

102 See Chapter II for a deeper analysis on the methods through which privatization takes place.

103 See Crawford, The International Law Commission's Articles on State Responsibility: Introduction, Text and Commentaries, p. 102.

104 See for example Bartold v. Germany, judgment of 25 March 1985, ECtHR, Series A-90, para. 46, in which the European Court of Human Rights asserted that the term 'law' also includes regulatory measures taken by professional regulatory bodies under independent rule-making powers delegated to them by parliament. 
entity must be acting pursuant to such authority and that its actions are recognized as having a governmental or public character. For example, if the entity in question is carrying out purely commercial activities that are not necessary for the furtherance of its governmental mandate, this may result in that particular conduct not being attributable to the State. Admittedly, this approach may also be problematic in so far as the activities carried out by a privatized body seem to be commercial in nature, but are also necessary to further a public interest. An ad-hoc WTO panel has observed in this regard that

"[...] it is not clear to us that an entity will cease to act in an official capacity simply because it intervenes in the market on commercial principles if that intervention is ultimately governed by that entity's obligation to pursue a public policy objective. For example, a police officer patrolling a football match as part of his/her police work does not cease to act in an official capacity simply because the home football club is required to pay a market rate for that service." 105

Likewise, during the discussion of the Articles on their second reading, the UK had similar reservations with old Article $7 \S 2$ (current Article 5) regarding the question of how far the conduct of a private entity may be attributable to the State if it acts outside (or even ultra vires) of the field for which it had been empowered to exercise elements of governmental authority. It was not clear to the UK what would happen if some entities empowered with certain governmental powers exercised them in another context or capacity:

"For example, a State may empower a private security firm to act as railway police. A railway policeman in uniform may arrest a suspected criminal (whose crime has nothing to do with the railway) in a place near to, but not a part of a railway station. As a matter of the State's internal law, the powers of the railway police may not extend to that place. Is that an example of an article 7, paragraph 2, organ exceeding its competence (in which case the conduct is attributable to the State - article 10)? Or is it an example of an article 7, paragraph 2, organ not acting in the capacity of a railway policeman, but rather in the capacity of an ordinary citizen (in which case the conduct is not attributable to the State: - article 7, paragraph 2, article 11)?"106

It is suggested that this criterion (i.e. acting in a public or governmental capacity) should be applied in a broad way since on many occasions it will not be very clear if certain functions are exercised in a particular capacity or not, unless there is no reasonable doubt that the privatized entity is acting ultra vires or for entirely different purposes than foreseen by the delegating body.

105 Korea-Measures Trade in Commercial Vessels, para. 7.48.

106 See State Responsibility: Comments and Observations Received by Governments, International Law Commission, UN Doc. A/CN.4/488 (25 March 1998), p. 43. 


\subsubsection{Private actors acting under orders of, or whose conduct is controlled by the State}

So far we have examined situations that fall under Article 5 of the ILC Articles on the Responsibility of States, which is only applicable to entities that are empowered by law to exercise elements of governmental authority. However, as the ILC Commentary observes, Article 5 is not applicable when an entity acts under the direction or control of the State. ${ }^{107}$ Furthermore, Article 5 covers situations in which the exercise of authority involves an independent discretion or power to act. In such a situation there is no need to show that the conduct was in fact carried out under the control of the State.

Outside of the situation envisaged by Article 5, the conduct of private entities can also be attributed to the State whenever this conduct has been authorized by the State or when the private entity is acting under the State's instructions/orders or under its direct control, supervision or direction. 108 This situation has been acknowledged by the ILC in Article 8 of the Articles on the Responsibility of the State, which states that

" $[t]$ he conduct of a person or group of persons shall be considered an act of a State under international law if the person or group of persons is in fact acting on the instructions of, or under the direction or control of, that State in carrying out the conduct."

The history of Article 8 reveals that the situations envisaged by Article 8 involved private actors acting as de facto organs of the State acting under its instructions or control. ${ }^{109}$ The requirements are disjunctive so it is only necessary to prove one of them. ${ }^{110}$ According to the ILC Commentary, the attribution to the State for conduct authorized by it is widely accepted in international jurisprudence. ${ }^{111}$ It does not matter whether private individuals carry out the conduct, or whether the conduct itself involves a governmental activity. ${ }^{12}$ What matters is that the conduct was the result of orders issued by the State or that the State controlled such conduct. The classic example of the former may be found in the Stephens case, ${ }^{113}$ while the Zafiro

\footnotetext{
107 Crawford, The International Law Commission's Articles on State Responsibility: Introduction, Text and Commentaries, p. 101.

108 See also ibid., p. 110-112.

109 ILC Yearbook1971, vol. II, part 1, United Nations, New York, 1971, p. 264. See also Prosecutor v. Dusko Tadic, ICTFY, Appeals Chamber, 15 July 1999, Case IT-94-1, para. 114.

110 Crawford, The International Law Commission's Articles on State Responsibility: Introduction, Text and Commentaries, p. 113.

111 Ibid., p. 110, citing various arbitral decisions.

112 Ibid., p. 110.

113 Charles S. Stephens and Bowman Stephens (U.S.A.) v. United Mexican States, Mexico/U.S.A. (General Claims Commission, 15 July 1927, R.I.A.A., Vol. IV, p. 265-268.
} 
case is an example of the latter. ${ }^{114}$ In Stephens, Mexico was held responsible for the conduct of irregular auxiliaries working for the Mexican army when they killed a U.S. citizen during a routine inspection stop. The auxiliaries had been acting under an army ordinance, which obligated civilians who are halted by sentries to answer and stop, and were additionally supervised by a sergeant. The arbitral tribunal had no problem in concluding that the auxiliaries did not act according to the instructions, and since they were in the presence and under the order of a superior, concluded that, given the circumstances, the auxiliaries could be considered or assimilated as soldiers, thus leading to the responsibility of Mexico. ${ }^{115}$ The Zaphiro case involved the conduct of rioting sailors working on a private merchant ship that had been hired by the United States Navy to provision American troops during the Spanish-American war. The riotous conduct of the sailors was attributed to the United States on the grounds that the Navy officers in charge of the private ship and the crew had allowed the latter to go ashore uncontrolled leading to the incident. ${ }^{116}$ Thus the failure to exercise proper control in the particular circumstances of the case led to the responsibility of the United States.

One of the most debated issues with regard to the principle detailed in Article 8 is the question of the amount of control necessary in order to attribute the conduct of private actors to the State. The International Court of Justice has concluded in the case of the Military and Paramilitary Activities in and against Nicaragua that direct control over their activities entails 'effective control'. 117 When it was called to determine whether the United States could be held accountable for the conduct of contra rebels whom the United States actively assisted (by providing financial and military support) in Nicaragua, the ICJ observed that there was "[...] no clear evidence of the United States having actually exercised such a degree of control in all fields such as to justify treating the contras as acting on its behalf." 118 It then concluded that,

"[f]or this conduct to give rise to legal responsibility of the United States, it would in principle have to be proved that that State had effective control of the military or paramilitary operations in the course of which the alleged violations were committed." 119

The threshold established by the ICJ to determine the attribution of private conduct to the State with 'effective control' is quite high. According to the ICJ, the amount

114 D. Earnshaw and Others (Great Britain) v. United States (Zafiro case), Arbitral Tribunal Great Britain - United States, 30 November 1925, R.I.A.A., Vol, VI, p. 160-165.

115 Stephens case, p. 267.

116 Zafiro case, p. 164.

117 See Military and Paramilitary Activities in and against Nicaragua (Nicaragua v. United States of America), para. 115.

118 Ibid., para. 109.

119 Ibid., para. 115. 
of control effected by a State over non-State entities has to go beyond a situation of dependence or financial or material support. ${ }^{120}$ Aside from demonstrating the financial and material assistance, it would have to be proved that the State directed or enforced the perpetration of each of the acts that could lead to attribution. ${ }^{121}$

This approach has been criticized since it makes it quite difficult to attribute the conduct of private actors whose acts are substantially shaped or facilitated by the State to that State under Article 8. ${ }^{122}$ In the Tadic case the International Criminal Tribunal for the Former Yugoslavia took issue with the ICJ approach and attempted to soften the requirement of 'effective control'.123 The Appeals Chamber of the Yugoslavia Tribunal, in deciding whether a State can be held responsible for violations of international law perpetrated by armed groups acting on its behalf, first observed that "[...] States are not allowed on the one hand to act de facto through individuals and on the other to disassociate themselves from such conduct when these individuals breach international law." 124 It then concluded that

"[...] international rules do not always require the same degree of control over armed groups or private individuals for the purpose of determining whether an individual not having the status of a State official under internal legislation can be regarded as a de facto organ of the State. The extent of the requisite State control varies. Where the question at issue is whether a single private individual or a group that is not militarily organised has acted as a de facto State organ when performing a specific act, it is necessary to ascertain whether specific instructions concerning the commission of that particular act had been issued by that State to the individual or group in question; alternatively, it must be established whether the unlawful act had been publicly endorsed or approved ex post facto by the State at issue. By contrast, control by a State over subordinate armed forces or militias or paramilitary units may be of an overall character (and must comprise more than the mere provision of financial assistance or military equipment or training). This requirement, however, does not go so far as to include the issuing of specific orders by the State, or its direction of each individual operation." 125

Thus with respect to acts of private actors, the Appeals Chamber's requirement of control entails issuing specific instructions with regard to each particular (harmful) act or in the alternative, a public endorsement or approval after the fact (as concluded in the United States Diplomatic and Consular Staff in Tehran case). However, with regard to acts of quasi- or para- statal actors, the degree of control required is one of

\footnotetext{
120 Ibid.

121 Ibid.

122 See for example Chirwa, "The Doctrine of State Responsibility as a Potential Means of Holding Private Actors Accountable for Human Rights," p. 7.

123 Prosecutor v. Dusko Tadic, para. 115.

124 Ibid., para. 117.

125 Ibid., para. 137.
} 
'overall control' going beyond financial or material assistance but not requiring issuing specific orders for each particular act.

The Tadic approach to the issue of overall control has in turn been criticized by the ICJ in the recent Case Concerning the Application of the Convention on the Prevention and Punishment of the Crime of Genocide (Bosnia and Herzegovinav. Serbia and Montenegro). ${ }^{126}$ In this case, the ICJ dealt with the question whether the massacres at Srebrenica in 1995 perpetrated by a group of Bosnian Serb paramilitary militias, which did not have the status of organs of Serbia and Montenegro, could be attributed to the latter on the basis of direction or control. After analyzing Article 8 in the context of the Nicaragua case, it reconfirmed its conclusions with respect to the issue of control. ${ }^{127}$ The ICJ then went on to argue why the 'overall control' test used by the Appeals Chamber of the Yugoslavia Tribunal was unpersuasive. It first observed that it was not bound by the Appeals Chamber's views on issues of general international law, which according to the ICJ did not lie within the specific purview of its jurisdiction. ${ }^{128}$ It then observed that the 'overall control' test had the major drawback of

\begin{abstract}
"broadening the scope of State responsibility well beyond the fundamental principle governing the law of international responsibility: a State is responsible only for its own conduct, that is to say the conduct of persons acting, on whatever basis, on its behalf $[\ldots][\mathrm{T}]$ he 'overall control' test is unsuitable, for it stretches too far, almost to breaking point, the connection which must exist between the conduct of a State's organs and its international responsibility."129
\end{abstract}

It is regrettable that the ICJ has chosen to adhere to its very strict and limited interpretation of the amount of control required to attribute the conduct of private/ privatized actors to the State under Article 8. This limited approach seemingly goes against the ICJ's opinion that

"[...] it is appropriate to look beyond legal status alone, in order to grasp the reality of the relationship between the person taking action, and the State to which he is so closely attached as to appear to be nothing more than its agent: any other solution would allow States to escape their international responsibility by choosing to act

\footnotetext{
126 See note 13.

127 "It must however be shown that this 'effective control' was exercised, or that the State's instructions were given, in respect of each operation in which the alleged violations occurred, not generally in respect of the overall actions taken by the persons or groups of persons having committed the violations." Ibid., para. 400.

129 Ibid., para. 406.
} 
through persons or entities whose supposed independence would be purely fictitious." 130

Admittedly this quote is related to Article 4 ILC, but arguably the same principle applies to Article 8 ILC. Nevertheless, we must not forget that both the ICJ's 'effective control' and the Appeals Chamber's 'overall control' depart from the same assumption: that the State must direct or control, and not merely support or encourage the conduct of the private actor. ${ }^{131}$

With regard to privatized entities, which for whatever reason cannot be regarded as exercising elements of governmental authority as prescribed by Article 5 ILC, Article 8 would be a type of catch-all provision if it is demonstrated that they acted under the instructions of the State, or if it can be established that their conduct was controlled by the State. This situation could be encountered in cases where the legal link between the State and the privatized entity is tenuous (privatization through contract without a concrete legal mandate to privatize). Admittedly, these situations could be less common as most privatizations have a legal origin.

The ILC commentary observes that the cases involving Article 8 will usually involve States commissioning private actors as 'auxiliaries' or 'volunteers' to supplement their own action, or persons employed to carry out certain assignments abroad. ${ }^{132}$ A case in point is the use by the United States Army of private military contractors working for private military and security companies as 'auxiliaries' to supplement its own forces charged with the duty of interrogating prisoners in the infamous Abu-Ghraib prison in Iraq. ${ }^{133}$ It would appear that a number of these contractors took part in conduct that may amount to torture and ill treatment of a number of Iraqi prisoners. Although it could be argued that these contractors were exercising elements of governmental authority since the function they carried out is arguably a military function and the contracting out took place under the auspices of military regulations, it is also possible to conclude that their conduct was

130 Ibid., para. 392. Admittedly this observation was done in the context of attribution on the basis of Article 4 of the ILC's Articles on Responsibility of the State, but the principle is the same.

131 D. Jinks, "State Responsibility for the Acts of Private Armed Groups," Chicago Journal of International Law Vol. 4 (2003), p. 89.

132 Crawford, The International Law Commission's Articles on State Responsibility: Introduction, Text and Commentaries, p. 110. See also ILC Yearbook1971, vol. II, part 1, United Nations, New York, 1971, p. 264.

133 See further Chapter VI for a more detailed discussion of this case study. See also in general, A. Hallo de Wolf, "Wordt oorlog geprivatiseerd? Het inzetten van particuliere militaire bedrijven in Irak in het licht van internationaal recht en de rechten van de mens (Is War Being Privatised? The deployment of private military companies in Iraq under international and human rights law)," Nederlands Juristen Blad Vol. 79 (2004), p. 1687-1695, and A. Hallo de Wolf, "Modern Condottieri in Iraq: Privatizing War from the Perspective of International and Human Rights Law," Ind. J. Global Legal Stud. Vol. 13 (2006), p. 315-356. 
attributable to the U.S. under Article 8. It is possible to argue that the contractors were under the direct control of the U.S. Army, which not only issued the instructions to the contractors about their interrogations, but also provided the setting for the interrogations themselves (which also took place in the presence of military personnel and with their acquiescence), and in some instances acted collusively with them. In addition, the U.S. Army was in charge of their contracts with the ability to terminate them if necessary. According to its own regulations, the U.S. Army even had a contract officer, who served as a liaison to the contractors and who was responsible for supervising their activities. ${ }^{134}$ In sum, the U.S. Army had what may be termed 'effective control' over the conduct of the contractors.

In addition, the ILC commentary observes that Article 8 could be engaged by the conduct of companies that are state owned and controlled. ${ }^{135}$ In the Barcelona Traction case, the ICJ acknowledged the independent existence of corporations at the national level. ${ }^{136}$ However, it also recognized that there may be a need under international law to 'lift the corporate veil' to prevent fraud or the evasion of international legal obligations. ${ }^{137}$ It follows that the State may also be held responsible for the corporations that it owns or controls. ${ }^{138}$ The Iran - United States Claims Tribunal has examined in a number of cases the issue of control related to state owned companies. ${ }^{139}$ While the conduct of corporations that are (partially) owned by the State may also be attributed to the latter on the basis of Article 5 if they exercise elements of governmental authority), in cases in which this is not clear enough, Article 8 could provide a way out, in particular with regard to state owned corporations that have been only partially privatized. This can be the case of the so-called 'golden share' constructions in which a state maintains a decisive amount of shares in a privatized corporation in order to exert some form of control over it. 140

134 See Army Regulation 715-9 "Contractors Accompanying the Force", p. 14.

135 Crawford, The International Law Commission's Articles on State Responsibility: Introduction, Text and Commentaries, p. 111.

136 Barcelona Traction, para. 56.

137 Ibid., para. 58. See also Crawford, The International Law Commission's Articles on State Responsibility: Introduction, Text and Commentaries, p. 112. See further Chapter III, Section 3.2.2 for a brief discussion on the legal personality of (multinational) corporations under international law and their relationship with human rights.

138 Chirwa, "The Doctrine of State Responsibility as a Potential Means of Holding Private Actors Accountable for Human Rights," p. 7-8.

139 See for example Flexi-Van Leasing, Inc. v. Iran, Case no. 36, (1986) 12 Iran-U.S.C.T.R., p. 349351, Foremost Theran, Inc. v. Iran, Case no. 37, (1986) 10 Iran-U.S.C.T.R., p. 240-242. Although not dealing with the conduct of a corporation, but with a semi-private entity accused of expropriating the property of an American hotel in Iran under the control of the latter, see also Hyatt International Corporation v. Iran, Case No. 134, (1985) 9 Iran-U.S.C.T.R., p. 88-96.

140 With regard to 'golden share' constructions see Guislain, "Divestiture of State Enterprises: An Overview of the Legal Framework," p. 56-58; Hyman, "Privatization: The Hows and the Whys," p. 21; Siragusa, "Privatization and EC Competition Law," p. 1026. It is, however, important to 


\subsection{Indirect state responsibility for failure to exercise due diligence}

Until now, we have examined state responsibility for the conduct of private entities that can be attributed directly to the State either because these were exercising elements of governmental authority, or because they were following instructions from, or acting under orders or control of the State. Additionally, States incur responsibility under international law if they fail to take the necessary measures to either prevent the harm or stop the continuation of the aggravating conduct of private entities when these entities engage in activities that result in harm through the violation of international standards. In other words, the failure of the State to take reasonable care or act with due diligence gives way to the indirect responsibility of the State. This is also clear from the formulation of Article 2 ILC Articles on the Responsibility of States which states that actions or omissions attributable to the State and leading to a breach of an international obligation gives way to an international wrongful act. ${ }^{141}$

Under the principle of due diligence, the act of the private actor is not considered to be an act of the State, either in itself or because of the participation or complicity of organs of the State. ${ }^{142}$ It is rather the inaction on the part of the State that triggers its responsibility. In other words, the State does not incur responsibility for the conduct of the private actors itself, but for its lack of due diligence to ensure that the conduct did not take place. The principle has been used mainly with regard to the injuries suffered by aliens and their property in a particular State, especially as a result of mob violence, riots or insurrections. ${ }^{143}$ An example may be found in the

note that the European Court of Justice has ruled in a number of cases that 'golden share' constructions are incompatible with the free movement of capital enshrined in Article 56 EC, unless it can be demonstrated that the need of a golden share is justified on grounds of overriding requirements of the general interest. See the judgments of 4 June 2002, Case C-367/98, Commission v. Portugal [2002] ECR I-4731; Case C-483/99, Commission v. France [2002] ECR I-4781; and Case C-503/99 Commission v. Belgium [2002] ECR I-4809, in particular para. 45. See also more recently, Case C-463/00, Commission v. Spain [2003] ECR I-4581, judgment of 13 May 2003.

141 See also the ILC Commentary on Article 2. Crawford, The International Law Commission's Articles on State Responsibility: Introduction, Text and Commentaries, p. 82. See ILC Yearbook 1972 Volume II (part 1), United Nations, New York, 1975, p. 97.

One of the earliest examples can be found in the Alabama case (Great Britain v. The United States of America), in which an arbitral tribunal concluded that "[...] the government of Her Britannic Majesty cannot justify itself for a failure in due diligence on the plea of insufficiency of the legal means of action which it possessed." See J. B. Moore, History and Digest of the International Arbitrations to which the United States has been a Party (Washington, U.S. Government Printing Office, 1898), vol. I, p. 656. For other examples of arbitral awards and situations in which the conduct of private groups (in particular with regards to mob violence and riots) was not attributed as such to the State, but the latter was nevertheless held responsible due to the lack of diligence, see the commentary to the proposed, but never adopted Article 11 on the conduct of private individuals. ILC Yearbook 1972 Volume II (part 1), United Nations, New York, 1975, p. 95-126. Old Article $11 \S 1$ as submitted in the first reading by Special Rapporteur 
case of British Property in Spanish Morocco. ${ }^{144}$ In this case, Spain was held responsible for the wrongful acts that were the results of uprisings and banditry. Arbitrator Max Huber noted that although the State may not be directly responsible for the acts committed by non-State actors, it could nevertheless be,

“[...] responsable de ce que les autorités font ou ne font pas, pour parer, dans la mesure possible, aux suites. La responsabilité pour l'action ou l'inaction de la puissance publique est tout autre chose que la responsabilité pour des actes imputables à des personnes échappant à l'influence des autorités ou leur étant ouvertement hostiles. [...] un État ne pourra pas exiger qu'un autre État, lésé dans les intérêts de ses ressortissants, reste indifférent si des possibilités de secours sont, sans raison plausible, manifestement négligées, ou si les autorités, averties en temps utile, ne prennent aucune mesure de prévention, ou si, encore, la protection n'est pas accordée dans des conditions égales aux ressortissants de toutes les nations."145

Other international arbitral and adjudicatory tribunals have also embraced these notions and concluded that the duty of reasonable care or due diligence imposes an obligation on the State to pro-actively and diligently prevent, investigate and punish harmful actions by private individuals or entities which, if committed by the State, would trigger its responsibility. ${ }^{146}$ In the case of the United States Diplomatic and Consular Staff in Tehran, the ICJ concluded that, although the conduct of private individuals who had assailed the American embassy in Tehran could not be imputed to Iran itself, it could nevertheless be held responsible since it had, "[...] failed altogether to take any 'appropriate steps' to protect the premises, staff and archives of the United States' mission against attack by the militants, and to take any steps either to prevent this attack or to stop it before it reached its completion."147

Human rights monitoring bodies have also adopted the due diligence approach with regard to conduct of private actors that is contrary to human rights. In the oftenquoted case of Velásquez Rodríguez, the Inter-American Court of Human Rights stated that,

"[a]n illegal act which violates human rights and which is initially not directly imputable to a State (for example, because it is the act of a private person or because the person responsible has not been identified) can lead to international responsibility

Ago read: "The conduct of a private individual or group of individuals, acting in that capacity, is not considered to be an act of the State in international law." For the reasons why old Article was not adopted see First Report on State responsibility, by Mr. James Crawford, ILC, Fiftieth Session, UN Doc. A/CN.4/490/Add.5 (22 July 1998), para. 244-148. 
of the State, not because of the act itself, but because of the lack of due diligence to prevent the violation or to respond to it as required by the Convention."148

The Inter-American Court then added that the State must

"[...] take reasonable steps to prevent human rights violations and to use the means at its disposal to carry out a serious investigation of violations committed within its jurisdiction, to identify those responsible, to impose the appropriate punishment and to ensure the victim adequate compensation." 149

This observation is interesting because aside from placing an obligation on the State to adopt reasonable preventive measures, the due diligence test expects the State to investigate abuses by private actors in a serious and effective manner. ${ }^{150}$ In addition, the due diligence test obliges the State to adopt measures for the adequate compensation of the victims of abuses by private actors. Failure by the State to redress damage incurred by victims of these actions will also result in the responsibility of the State. The Inter-American Court also noted that the duediligence duty to investigate the violations should be undertaken in a serious and effective manner.

The African Commission on Human and Peoples' Rights has directly cited from the Velásquez Rodríguez case. In its decision on Social and Economic Rights Action Centre and the Centre for Economic and Social Rights v. Nigeria, the African Commission examined alleged violations to the right to freely dispose of wealth and natural resources, the right to health, the right to food and housing, and the right to a satisfactory environment as protected by the African Charter on Human and Peoples' Rights. ${ }^{151}$ The case revolved around the activities of national and international oil companies operating in the Ogoni region in Nigeria. These activities allegedly resulted in grave environmental damage contaminating water, soil and earth and causing various types of health problems to the Ogoni people. Directly referring to the Velásquez Rodríguez case, the African Commission observed that

"[g]overnments have a duty to protect their citizens, not only through appropriate legislation and effective enforcement but also by protecting them from damaging acts that may be perpetrated by private parties (reference ommitted). This duty calls

\footnotetext{
148 Velásquez Rodríguez, Merits, judgment of 29 July 1988, IACtHR, Series C No. 4, para. 172.

149 Ibid., para. 174.

150 Ibid. See also para. 177, in which the Court notes that the lack of a serious investigation means that the State is aiding the private perpetrators, thereby making the State responsible on the international plane.

151 Social and Economic Rights Action Centre and the Centre for Economic and Social Rights v. Nigeria, Communication No. 155/96, African Commission on Human and Peoples' Rights (2001).
} 
for positive action on part of governments in fulfilling their obligation under human rights instruments." 152

Noteworthy of the human rights case law with regard to due diligence is that it appears that this test has morphed into the concept of positive obligations which are also enshrined in the various international and regional human rights treaties ${ }^{153}$ and which have been refined to encompass obligations to respect, protect and fulfill. ${ }^{154}$ In particular, the obligation to protect requires the State to adopt adequate measures to prevent harmful conduct contrary to human rights by non-State actors. This is arguably the same goal of the due diligence obligation to prevent harmful conduct. $^{155}$

The obligation to prevent a violation of an international legal norm, which may be found within the context of the due diligence obligation, was recently given a new impulse in the Bosnian Genocide Case. In this case the ICJ examined whether Serbia and Montenegro could be held responsible for the failure to prevent and punish genocide as required by the Genocide Convention. After observing that the Genocide Convention was not the only international instrument that provides for an obligation on the States parties to take certain steps to prevent the acts it seeks to prohibit, ${ }^{156}$ the ICJ noted that

“[...] responsibility is [...] incurred if the State manifestly failed to take all measures to prevent genocide which were within its power, and which might have contributed to preventing the genocide. In this area the notion of "due diligence", which calls for an assessment in concreto, is of critical importance."157

The Court was quick to qualify its position, explaining that with the Bosnian Genocide Case it was not seeking to

\footnotetext{
$152 \quad$ Ibid., para. 57.

153 Article $2 \S 1$ of the ICCPR states that State Parties have an obligation to "[...] to respect and to ensure to all individuals within its territory and subject to its jurisdiction the rights [...]" recognized in the Covenant. Similarly, the ECHR states in Article 1 that the State Parties to the Convention "[...] shall ecure to everyone within their jurisdiction the rights and freedoms[...]" defined therein.

154 For a more detailed discussion on the nature of these obligations, see Chapter III, Section 4.1 supra.

155 See Jägers, Corporate Human Rights Obligations: In Search of Accountability, p. 146-147, and Chirwa, "The Doctrine of State Responsibility as a Potential Means of Holding Private Actors Accountable for Human Rights," p. 17. For a slightly different view on the issue, see Lawson, "Out of Control. State Responsibility and Human Rights: Will the ILC's Definition of the 'Act of State' Meet the Challenges of the $21^{\text {st }}$ Century?," p. 106-108.

156 Bosnian Genocide Case, para. 429. The Convention against Torture and Other Cruel, Inhuman or Degrading Treatment or Punishment (Article 2) was among the conventions referred to by the ICJ.

157 Bosnian Genocide Case, p. 430.
} 
Chapter IV

“[...] establish a general jurisprudence applicable to all cases where a treaty instrument, or other binding legal norm, includes an obligation for States to prevent certain acts. Still less does the decision of the Court purport to find whether, apart from the texts applicable to specific fields, there is a general obligation on States to prevent the commission by other persons or entities of acts contrary to certain norms of general international law." 158

Although the ICJ denotes that its observations are in particular relevant in the context of the Genocide convention, it is nevertheless possible to argue a fortiori that, where other treaties, and in particular human rights conventions, include an obligation to prevent (as a part of the general positive obligations or obligations to protect), States are bound to adopt reasonable measures that prevent privatized entities from engaging in conduct that is contrary to the human rights obligations of States. Failure to act with 'due diligence' in this respect will evidently engage the responsibility of the State vis-à-vis the conduct of privatized entities.

\subsection{Preliminary conclusions}

In the previous paragraphs, the responsibility of the state for the conduct of privatized actors has been reviewed. As a general rule, the State is not responsible for the acts of private actors. However, under special circumstances, such acts may be attributed to the State, in particular if they involve the exercise of governmental authority by private actors, or if they were carried out under the instructions or 'effective' control of the State. Additionally, it has been discussed that the responsibility of the State may be engaged if it does not adopt measures that would have prevented the wrongful conduct of privatized entities. These concepts equally apply to breaches of obligations emanating from human rights treaties, although it has been argued that the general rules of state responsibility may not always properly fit in the context of human rights. ${ }^{159}$ It may thus appear that international law, and in particular the law of state responsibility takes due consideration of the consequences of privatization or in any case of the use of private actors by the State to perform certain tasks or functions on its behalf. These principles appear to form a tight system that prevents States from evading their international obligations by delegating the exercise of functions, tasks and services of a public nature to private actors.

By asserting the types of attribution discussed above, one is in fact determining that the privatized entities are acting as de facto organs of the State, even if their

\footnotetext{
158 Ibid., para. 429.

159 A more comprehensive analysis about the applicability of the principles of state responsibility to human rights can be found in Evans, "State Responsibility and the European Convention on Human Rights: Role and Realm," and McGoldrick, "State Responsibility and the International Covenant on Civil and Political Rights."
} 
status de jure is not such. In other words, the issue here is equating privatized entities by means of international law (i.e. the rules of state responsibility) with State organs when they do not have such status under internal law. The ICJ has observed, however, that equating the status of private entities with that of State organs, must be exceptional. ${ }^{160}$ This observation leads to the question whether attribution of the conduct of private actors to the State or the due diligence test are an ideal means for dealing with abuses perpetrated by privatized entities. The addressee of the principles of state responsibility as developed by customary law and as reflected in the ILC Articles, remains the State: the State as the entity answerable for the conduct of private actors. This results from the fact that States are still considered the main legal entities under international law, whereas other non-State actors such as business enterprises still do not have a formal status or are still not formally or fully bound by certain international obligations such as those stemming from human rights treaties. This is currently the position under international law and human rights law with regard to international responsibility for breaches of international obligations. State responsibility entails the responsibility of the State vis-à-vis other States, and in taking up a claim under the principles of diplomatic protection for the wrongful conduct of a privatized entity, a State will be seeking an international remedy on its own behalf, not on behalf of the individuals that are victims of the wrongful conduct. ${ }^{161}$

Arguably this traditional approach may not always be the best solution for victims of private/privatized conduct. ${ }^{162}$ As Evans has observed, this situation will baffle the common person who has suffered abuse at the hands of privatized entities, for under current international law, it is the State which is exclusively responsible for that conduct (if the criteria discussed in the previous paragraphs are met), and not the actual perpetrator. To a certain extent this is a cumbersome fiction, and may even be regarded as a farce: it is the private actors who should be brought to account for their actions.

The State should remain internationally responsible in the traditional sense since it enabled the private actors through privatization to commit abuses. However, it is also necessary for these actors, which are factually responsible for the abuses, to share the burden and be held responsible for their actions as well. One could speak in this regard of a concept of shared responsibility, whereby the State and private actors should respectively and proportionally be held internationally responsible for their conduct. It is submitted, that holding only the State internationally responsible (be it on the basis of attribution for private conduct or through the lack of due diligence) is not satisfactory for those who were actually subjected to the conduct of

\footnotetext{
160 Bosnian Genocide Case, para. 393.

161 See Shaw, International Law, p. 809-810.

162 And as examined in Chapter III Section 4.4 it also has an impact on the concept of the horizontal application of human rights norms.
} 
private/privatized actors. Admittedly, for the victims it may not matter in the end exactly who is held responsible as long as an effective solution in terms of remedies, reparations, or just satisfaction is achieved on their behalf. However, for the sake of legal and moral clarity it is important to allocate the international responsibility where it actually should be placed: on the shoulders of the actual perpetrator be it the State or, in the context of the present study, the privatized actor.

In this regard, it may be necessary to try to give a more fulfilling meaning to the claim which international adjudicators make when they maintain that the State should not be allowed to shirk its international obligations by delegating state functions. In the context of privatization, a possible way of achieving this idea of shared responsibility could be by equating privatized actors to actual state actors when exercising their privatized tasks (and not utilizing a legal fiction like the attribution concept or due diligence). This approach will be discussed in the following section.

\section{Responsibility of PRIVATIZEd aCtORS as State aCtORS EXERCISING FUNCTIONS OF A PUBLIC NATURE}

In the previous section it was observed that under the principles of state responsibility the conduct of private actors cannot be attributed to the State. The general rule is that only the conduct (including actions of commission or omission) of the organs of the State or its agents ${ }^{163}$ is attributable to the State and may lead to international responsibility. However, it was also noted that conduct of private actors exercising elements of governmental authority can, under certain circumstances, be attributed to the State. States are equally responsible for the conduct of private entities that they have acquiesced in or which they condoned, or whenever States facilitate private conduct that amounts to a breach of the international legal obligations of States by failing to take appropriate steps to prevent this conduct.

We have also observed in Chapter III that under (international) human rights law the concept of Drittwirkung or direct horizontal application (or third party application) of human rights is not widely accepted. Additionally, at the international level non-State/private actors bear only limited legal responsibility for gross human rights violations and for the "[...] most serious crimes of concern to the international community as a whole." 164 Business enterprises, for example, are currently not

163 That is, "[...] others who have acted under the direction, instigation or control of those organs [...]" according to the ILC Commentary. See Crawford, The International Law Commission's Articles on State Responsibility: Introduction, Text and Commentaries, p. 91.

164 See Article 5 of the Statute of the International Criminal Court, which allows individuals to be prosecuted for the crime of genocide, crimes against humanity, war crimes and in the future crime of aggression. 
legally bound by (international) human rights norms and obligations in the same way as States are, although - as has been noted - efforts are underway to change this. ${ }^{165}$ States, however, do have a duty to ensure or secure to all the individuals in their territory the rights guaranteed in the various human rights treaties/instruments that they have ratified and in this respect they must ensure their respect "even in the sphere of relations of individuals between themselves."166

This analysis also applies to relations between individuals and private entities (be they business enterprises or others) that have been entrusted with performing former State functions, tasks or services. Only indirect horizontal application of human rights obligations is possible in the sense that the State bears the (international) responsibility for human rights abuses perpetrated by private actors. It has been accepted in this regard, that States have positive obligations - including obligations to protect and sometimes to fulfill - to ensure the respect of human rights obligations by these private actors. Moreover, human rights monitoring mechanisms have confirmed that States cannot absolve themselves from their (international) legal obligations by delegating certain functions to private actors. The Human Rights Committee has concluded on a number of occasions that a State "[...] is not relieved of its obligations under the Covenant when some of its functions are delegated to other autonomous organs." 167 The treaty monitoring bodies have not further explained what this observation actually means, However, it is suggested that it may be understood as imposing on the State the ultimate responsibility for the acts of private entities. Together with the notion of positive obligations, and in the light of the lack of direct horizontal applicability of human rights norms, this approach should offer sufficient protection against the (potentially harmful) conduct of private entities carrying out privatized functions, tasks or services. In the end, the State is under a legal obligation to take the necessary steps to prevent human rights abuses by private actors, and eventually punish them for their actions. The State should also modify national legislation to enhance the protection of individuals vis-à-vis private actors and provide effective legal remedies to allow victims to seek redress against harmful action by these actors (including any necessary reparation or satisfaction). Moreover, even though human rights will usually not apply horizontally, individuals that have suffered harm due to the conduct of private/ privatized actors can try to seek redress through civil law actions such as tort

\footnotetext{
165 See Chapter III Section 3.2.2.

166 For example, Case of $X \& Y$ v. the Netherlands, judgment of 26 March 1985 ECtHR, Series A-91.

167 B.d.B. v. The Netherlands (273/88), UN Doc. CCPR/C/35/D/273/1988 (2 May 1989), para. 6.5, Lindgren et al v. Sweden (298-299/88), UN Doc. CCPR/C/40/D/298/1988 (2 May 1989), and more recently Cabal and Pasini Bertran v. Australia (1020/2001), UN Doc. CCPR/C/78/D/1020/2001 (29 August 2003), para. 7.2. See also Costello-Roberts v. UK, ECtHR judgment of 25 March 1993, Series A-247-C, para. 27.
} 
claims. ${ }^{168}$ In short, it would appear at first sight that any harm caused by the conduct of private actors carrying out privatized functions, tasks or services can be addressed both through State responsibility for conduct of these actors and/or through seeking redress against these actors in civil courts.

However, this latter outcome may not always be satisfactory. The privatization of State functions, tasks and services of a governmental or public nature may create a gap in the protection of human rights of those individuals whose (legal) situation is directly affected or influenced by privatization. This can be the case in situations when service users/consumers are not directly in a contractual relationship with the privatized service provider. Usually, privatized service providers will have a direct contractual relationship with the governmental authority that has contracted out the service and service users will not take part in this relationship and thus have no influence as to the decisions that may affect them. This was the case, for example, in the United Kingdom where a group of elderly residents of a publicly funded care home that was managed by a private organization were faced with a decision to close the home and place the residents elsewhere. The elderly residents were not in a contractual relationship with the private organization managing the care home, and therefore could not influence the private entity's decision. ${ }^{169}$ This is also the case of detainees in centers of detention or prisons that are managed by private security companies. Here only a civil action for tortious conduct may be available for prisoners. Civil litigation can, however, be time consuming and costly for those who may be particularly affected by privatization policies (or, to put this in human rights parlance: the most vulnerable sectors of society meaning inter alia, the poor, the elderly, children, persons with disabilities, minority groups, persons subjected to various kinds of detention).

States may also argue that since they are not carrying out the particular activity, they should not be held responsible for the conduct of private entities. Of course, this argument could be precluded by arguing that under international human rights law the State has positive obligations (to protect, respect and fulfill). However, even positive obligations have their limitations. For example, under the doctrine of positive obligations, the margin of appreciation of States to take measures that may limit or constrain human rights can be considerably greater than in the situation

168 See for example the U.S. Supreme Court decision, Richardson v. McKnight, 521 U.S. 399, 401, 412 (1997), where the Court decided that private security guards of a privatized prison did not enjoy qualified immunity from tort actions as opposed to guards from public prisons who had qualified immunity and could thus not be prosecuted for alleged misconduct against prisoners. In this respect, it can be argued that sometimes privatization may come with certain benefits for victims of human rights abuses and that to a certain degree the rights of individuals may be better protected under privatized conditions. See Aman, "Privatisation, Prisons, Democracy and Human Rights: The Need to Extend the Province of Administrative Law," p. 114.

169 See Heather \& Ors, $R$ (on the application of) $v$ Leonard Cheshire Foundation \& Anor [2001] EWHC Admin 429, which will be discussed further below. 
where the State or its entities are directly responsible for human rights abuses. In the latter situation the margin of appreciation is much more narrow. The same can be said for the indirect responsibility of States for the conduct of private actors. This leaves us with a potential gap with regards to the accountability for the conduct of non-State actors carrying out privatized functions, tasks or services that may be felt on a practical level vis-à-vis individuals who are affected in their human rights by that conduct: there is the danger that the State that has chosen to privatize will argue that it is not responsible for the decisions or conduct of privatized actors, since it no longer exercises those activities, while the latter could argue that they are not responsible since they are just private actors and the State is the one which should be held accountable.

There are other complications. It has been pointed out that international and regional human rights treaties currently do not have horizontal effect. The State is the addressee of the obligations enshrined in these treaties and only the State is answerable for complaints regarding breaches of its legal obligations. At the national level, individuals who have been victims of human rights abuses will usually only be able to complain about this conduct against the State, unless the State has made specific provisions for a horizontal application of these rights. After exhaustion of domestic remedies, individuals may submit an individual complaint before a treaty monitoring mechanism whenever obligatorily provided for by the specific treaty as in the case of the ECHR, or when the State has voluntarily accepted this complaint mechanism through the ratification of, for example, an additional protocol. This complaint, however, must be directed against the State, since it is the State that bears the responsibility of ensuring/securing the rights found in the various human rights treaties. Complaints directed against private individuals or companies will be declared inadmissible.

With these problems in mind, it must be considered whether a complaint against a privatized entity/service provider for conduct leading to a breach of human rights obligations could be successful by arguing that this entity is in fact an organ of the State (as a governmental or public authority), and thus that (most of) its decisions may be amenable to human rights review. ${ }^{170}$ This approach, which is similar to the one adopted under Article 5 of the ILC Articles on Responsibility of the State as discussed in the previous Section, is potentially more effective in providing a direct means of challenging the conduct and decisions of privatized actors, which would otherwise not be susceptible for challenge under (international) human rights law. It would also be more satisfactory, because it would lay the accountability directly

170 See also Alkema, who argues that there is little need for third party applicability/Drittwirkung of human rights norms if the offending party - in spite of appearances - has acted in an official capacity. Alkema, "The Third-party Applicability or 'Drittwirkung' of the European Convention on Human Rights," p. 39. 
where it should be, the privatized actor, whose conduct results in abuses. ${ }^{171}$ At the same time, this proposition is potentially more complex than simply arguing that the State has failed to live up to its obligations by not taking the necessary measures to control the conduct of private entities. The potential benefits of providing direct access for human rights review may, however, outweigh this negative aspect.

In view of the fact that the State has delegated certain functions, tasks and services of a governmental/public nature to private actors, it is suggested that under particular circumstances these private actors may become a sui generis type of State actor and can accordingly be held directly responsible/accountable for conduct or actions that amount to violations of human rights. The central question of this section therefore is: under what conditions can privatized actors/service providers be regarded as emanations/continuations of the State for the purpose of directly and vertically applying human rights norms in order to enhance the human rights protection of those individuals or service users dependent on the activities of these privatized entities, and thus fill any gap that the privatization of functions, tasks or services may have created? ${ }^{172}$

A number of, mainly common law, legal systems support the proposition that private actors under certain circumstances may (temporarily) become State actors or authorities so that constitutional or public law rules and human rights obligations usually reserved for State actors can be applied to them in view of the nature of the functions, tasks and services they are performing. Additional inspiration for this proposition may be drawn from the practice of the European Union, where the ECJ has accepted that EU directives, which are devoid of horizontal application, may on occasion be directly applied against a private entity when this entity is regarded as an 'emanation of the State.' 173 From the practice in the various jurisdictions, the following concept may be derived. Instrumental in filling the perceived/potential gap in accountability observed above is the concept that the State should not be allowed to absolve itself or avoid or circumvent its legal obligations under international human rights treaties by privatizing functions, tasks or services and thus delegating them to private entities. This means not just that the State is ultimately responsible for the effects of privatization on the human rights of those affected by that policy. In addition, this concept means that on a practical level, non-State actors may sometimes be held accountable on the grounds that they are State actors sui generis when they exercise these privatized activities.

\footnotetext{
171 Herein would also reside the difference between the suggested approach with that envisaged by Article 5: the suggested approach is not about traditional attribution to the State of the conduct of a non-State actor in a conflict between States, but about designating a private actor as a quasistate actor in a conflict between two private parties. Privatization,” Syracuse Law Review Vol. 45 (1995), p. 1172. 
Before embarking on this exploratory journey a number of clarifications and caveats are pertinent. First, in identifying the factors that play a role in determining whether a privatized entity can be regarded as a State organ for the purpose of applying human rights obligations, it is necessary to ascertain the nature of functions, tasks and services that the entity performs. However, it is not this study's aim to exhaustively define what a governmental/public function task or service is. It has been argued that certain public functions, tasks or services are not necessarily public. Oliver has observed that it is important to distinguish between the different concepts that may be involved. ${ }^{174}$ These concepts include duty, power, function, activity and act, to which the present author would add tasks and services. Oliver rightly noted that,

"[a] function can be of a public or private nature, and it can be performed as part of a duty or under a power. Acts or activities done in the course of performing a function of a public nature may or may not be public."175

It may be useful to add that, as previously observed in Chapter II, many of the functions, tasks and services that are commonly regarded as inherently or traditionally governmental or public have in the past been carried out by private actors before the emergence of the 'welfare state'. It is thus wrong in the present author's opinion to simply conclude that in order to designate a certain function, task or service as inherently governmental or public, it must have been performed by a State organ at a certain point in time. This does not mean that the fact that the State took over some task or services should not be taken into account. However, solely relying on historical or institutional aspects to determine whether an entity or function is governmental/public is not sufficient. It will therefore be argued that a functional approach (e.g. looking at the nature of the function, task or service that is being discharged and the effect of the exercise of these activities for the public at large) together with certain institutional considerations provide a basis for determining whether a privatized body carrying out functions, tasks or services formerly carried out by a State body can in turn be considered as a State body sui generis. One can accept that a complete catalogue of (inherent or traditional) governmental functions, tasks, and services is perhaps impossible to draft. It is nonetheless arguable that the activities of private entities that carry out certain functions, tasks, and services for which the government had assumed the ultimate legal responsibility for their realization, and for which their proper realization has externalities which in law and in fact affect the public interest and the public at large, and which may hinder or impair the rights guaranteed under international human rights instruments, should be amenable to direct human rights review. This

174 D. Oliver, "Functions of A Public Nature Under the Human Rights Act," Public Law (2004), p. 335.

175 Ibid. 
should be possible irrespective of who is in charge of their exercise or how these tasks or services are realized. ${ }^{176}$

Secondly, this study also wants to avoid getting involved in the public/private sphere debate, which arguably has played a major role in the privatization process. ${ }^{177}$ This section does not purport to provide a specific solution to the perceived divide between these two spheres. ${ }^{178}$ Above all, it does not argue that the best way to solve the public/private debate is to introduce public law norms into all aspects of the private sphere and engage in "compensatory political justice."179 The approach proposed above should not be viewed as a way of extending public law views in a general way over the private domain. Rather the analysis relates to a grey area where the boundaries of the public and the private spheres overlap - in which privatization takes place. It is suggested that it is only here where it may be warranted to apply human rights norms to private entities that are carrying out functions, tasks and services of a public nature under close control or cooperation with the State (and are thus, for the purposes of human rights, State actors sui

176 This approach is similar to the one found in the concept of 'services of general interest' that has been used at the EU level. Under the concept of 'services of general interest' a number of services can be classed as being of general interest and subject to specific public service obligations. See further Chapter VII Section 2.2 for a brief discussion of this topic.

177 See in general Teubner, "After Privatization? The Many Autonomies of Private Law."

178 For a general discussion of the public/private debate and how the perceived divide may be overcome see, for example, Clapham, Human Rights in the Private Sphere; Chinkin, "A Critique of the Public/Private Dimension," p. 387-395; Oliver, Common Values and the Public Private Divide; A. Grear, "Theorising the Rainbow? The Puzzle of the Public-Private Divide," Res Publica Vol. 9 (2003), p. 169-194. A brief historical overview of the public/private distinction can be found in J.H. Merryman, "The Public Law - Private Law Distinction in European and American Law," Journal of Public Law Vol. 17 (1968), p. 3-18, and M.J. Horwitz, "The History of the Public/Private Distinction," U.Pa.L.Rev. Vol. 130 (1982), p. 1423-1428. In particular, Merryman explains why the public/private debate is largely a European debate, while it is (or was) not taken as seriously in the United States. Merryman, "The Public Law - Private Law Distinction in European and American Law," p. 4-5. Hunt also provides some appealing arguments as to why the public/private debate is not particularly helpful with regard to the applicability of human rights. He argues that there is no firm distinction between the public and the private spheres, "[...] because the very presence of law introduces a public element: private relations are in part constituted by both statute and common law, and the state lurks behind both." M. Hunt, "Human Rights Review and the Public-Private Distinction," in Litigating Rights: Perspectives From Domestic and International Law, ed. G. Huscroft and P. Rishworth, Oxford: Hart Publishing (2002), p. 84.

179 Teubner, "After Privatization? The Many Autonomies of Private Law," p. 394. For another critical view of imposing public law values on the private sphere which would "[...] roll forward the frontiers of the state and roll back the frontiers of civil society [...]" see D. Oliver, "The Frontiers of the State: Public Authorities and Public Functions Under the Human Rights Act," Public Law (2000), p. 477. The reverse - private law values taking over public law values (and not always in a negative way) - is of course also possible. See Freeman, "The Private Role in Public Governance," p. 548-549. 
generis).$^{180}$ This is in line with the approach adopted by the human rights monitoring bodies, which have concluded that States cannot absolve themselves of their human rights obligations by delegating functions of a public nature to private bodies. ${ }^{181}$ This section is therefore only meant as a tentative way of providing an answer to the specific problem of the privatization of certain State functions, tasks and services of a governmental or public nature with respect to human rights.

In the following paragraphs, the practice of various legal systems regarding the application of public law norms and/or human rights norms to private entities will be reviewed for the purpose of examining under which circumstances, privatized actors/service providers can be considered as State organs/governmental authorities sui generis and thus be held directly (vertically) accountable for any conduct contrary to human rights obligations in the performance of privatized activities. It must be stressed that this exercise is only meant to gather guidelines that may direct the future reasoning of bodies burdened with examining cases pertaining to human rights abuses by (private) actors carrying out privatized functions, tasks or services. It is by no means meant as an exhaustive examination of the various jurisdictions being examined and it should be noted that the chosen examples do not always deal with examples of privatization as understood in this study. Rather they are meant as illustrative of the developments of the various jurisdictions with regard to a similar problem: to what extent can public law, constitutional or human rights norms be applied to non-State actors when their activities are closely related to those of the

180 For a similar approach see A.S. Butler, "Is This a Public Law Case?," Victoria University of Wellington Law Review Vol. 38 (2000), available at <www.austlii.edu.au/au/journals/ VUWLRev/2000/2038.html $>$. It can additionally be argued that even if by extending human rights review to the activity of private entities carrying out privatized functions, tasks and services of a public nature we are unduly extending the applicability of human rights norms into the private realm, this would be nothing out of the ordinary. Currently, national adjudicatory bodies/courts are under the obligation to abide by human rights norms while adjudicating disputes even if these are in the private law domain. This means, for example, that a national adjudicatory body, which as an entity of the State is bound to respect human rights norms itself when exercising its adjudicatory duties, will be under the obligation to give effect to human rights norms in its decisions. See Clapham, "The 'Drittwirkung' of the Convention," p. 197-200; Butler, "Is This a Public Law Case?." Barak calls this the judiciary model for the applicability of constitutional human rights in the sphere of private law. Barak, "Constitutional Human Rights and Private Law," p. 27-28. Barak cites some examples of the U.S. Supreme Court, in particular the highly criticized case of Shelley v. Kraemer (1948) 334 US 1 where the Supreme Court concluded that a lower court enforcing a clearly (racially) discriminatory contract between private parties, violated the state's duty not to discriminate under the Constitution as amended by Equal Protection Clause of the Fourteenth Amendment. Ibid., p. 26. Barak, however, remains somewhat skeptical about the proper use of this method. Ibid., p. 27-28.

181 See for example Costello-Roberts v. the United Kingdom, judgment of 23 February 1993, ECtHR Series A247-C, para. 27; Cabal and Pasini Bertran v. Australia, Communication No. 1020/2001, UN Doc. CCPR/C/78/D/1020/2001 (19 September 2003). These cases will be discussed below in more detail. See also Alkema, "The Third-party Applicability or 'Drittwirkung' of the European Convention on Human Rights," p. 34. 
State. To begin with, the practice of international and regional human rights monitoring bodies with regard to what are governmental authorities for the purpose of applying the respective human rights obligations ensuing from the various treaties will be examined. This will be followed by a review of the practice in the EU and the applicability of EU norms originally meant for public entities to private ones. The practice in a number of common-law countries with extensive experience in privatization and delegation to private entities will then be appraised. These include the United Kingdom with regard to the application of judicial review and, since the adoption of the Human Rights Act in 1998, human rights review to nonState actors exercising public functions, the United States and its 'state action' doctrine, and Canada, which has had its fair share of experience with the application of constitutional rights to non-State actors carrying out what may be considered 'public' activities. Finally, a brief overview of a number of civil-law/non-commonlaw countries will be presented. Following this, some reflective comments on this exercise will be given.

\subsection{Private actors as State organs under international and regional human rights treaties}

As indicated earlier in Chapter III, human rights monitoring mechanisms have recognized that human rights norms ensuing from the various regional and international human rights treaties may have a certain effect in the sphere of the relations between private individuals themselves. Moreover, States are duty bound to secure and ensure these rights. This does not mean, however, that private individuals may complain of human rights abuses by other private individuals before national or international human rights monitoring bodies. The latter will dismiss applications directed against private parties as not admissible rationae personae. At the most, individuals are allowed to submit an individual complaint against States that have failed in their (positive) obligations to secure these rights at the national level in this sphere of relations between individuals. ${ }^{182}$ This flows from the provisions of these treaties, which state that these individual complaints can only be filed against States. ${ }^{183}$ It is therefore reasonable to conclude that individual

182 For example by allowing or enabling private individuals to act in harmful ways such as in the cases of Young, James and Webster v. the UK, $X$ and $Y v$. the Netherlands and López Ostra v. Spain.

183 Art. 34 ECHR stipulates for example that the ECtHR may receive individual applications of individuals "[...] claiming to be a victim of a violation by one of the High Contracting Parties". Art. 44 of the ACHR recognizes the rights of individuals to lodge petitions with the InterAmerican Commission of Human Rights "[...] containing denunciations of complaints of violation of this Convention by a State Party." Under Art. 1 of the $1^{\text {st }}$ Optional Protocol to the ICCPR State Parties recognize the competence of the Human Rights Committee to receive communications from individuals "[...] who claim to be victims of a violation by that State Party of any of the rights set fort in the Covenant." Additionally, even though the CERD opens the possibility for the horizontal application of the prohibition of discrimination on various 
complaints against the conduct of private companies carrying out privatized functions, tasks or services leading to human rights abuses will not succeed unless it can be shown that the State has failed to secure or ensure the rights guaranteed in the treaties by facilitating the activities of these companies, by failing to take positive measures to prevent these abuses, or in so far as economic, social and cultural rights are justiciable, by failing to ensure the minimum core obligations. ${ }^{184}$ Alternatively, a complaint may succeed if it is claimed that these private entities are State actors, which as organs of the State are equally bound by the treaties' provisions as States normally are under the law of State responsibility. In this section we briefly consider whether under the case law of human rights monitoring bodies private actors have been considered as organs of the State for the purpose of applying the provisions of various human rights treaties.

\subsubsection{Private actors as State organs in the case law of UN human rights treaty bodies}

The Human Rights Committee has never dealt with the question of whether a particular private actor could be regarded as a public or State authority for the purpose of directly applying the ICCPR's norms. As will be shown in Chapter V infra, to date neither the Human Rights Committee nor other international and

grounds in the enjoyment of, for example, the right to security of the person against violence or bodily harm "whether inflicted by government officials or by any individual, group or institution" (Art. 5(b) CERD), or the right to housing and education (Art 5(e) CERD), or even "the right to access to any place or service intended for use by the general public such as transport, hotels, restaurants, cafés, theatres and parks" (Art. 5(f) CERD), only individual communications of individuals within the jurisdiction of a State Party "[...] claiming to be victims of $a$ violation by that State Party of any of the rights set forth[...]" in the CERD may be submitted even though the actual discriminatory act may have been carried out by a private actor. See also Art. 2 of the 1999 Optional Protocol to the CEDAW allowing for individual complaints to be submitted by individuals: "Communications may be submitted by or on behalf of individuals or groups of individuals under the jurisdiction of a State Party, claiming to be victims of a violation of any rights set forth in the Convention by that State Party." Emphasis added, $A H W$.

184 Although the latter possibility is currently not possible at the international level due to the lack of an individual complaint mechanism to deal with alleged breaches of the ICESCR, it should not be excluded that present day human rights adjudicators could be faced with complaints in which they may be willing to express themselves on the issue. In any case, this argument could also be used in the future when an individual complaint mechanism for these type of rights becomes a reality. Indeed this may be the case in the near future as an Optional Protocol to the ICESCR, which provides for such a complaint mechanism has been recently adopted by the UN's General Assembly after years of discussion. See Report of the Human Rights Council containing a draft Optional Protocol to the International Covenant on Economic, Social and Cultural Rights, to be transmitted to the General Assembly for consideration in the plenary meeting of 10 December 2008, UN Doc. A/63/434 (28 November 2008). See also General Assembly resolution UN Doc. A/RES/63/117 (10 December 2008) adopting the Optional Protocol to the International Covenant on Economic, Social and Cultural Rights. 
regional human rights monitoring mechanisms that are allowed to receive individual complaints from individuals claiming to have been victims of a human rights abuse have been directly confronted with a complaint centring on privatization or the conduct of a private actor carrying out privatized functions, tasks or services. ${ }^{185}$ The closest it has come yet to such a complaint was in the already mentioned case of Cabal and Pasini Bertran v. Australia, a complaint submitted before the Human Rights Committee under the First Optional Protocol to the ICCPR. ${ }^{186}$ The case involved two Mexican detainees awaiting their deportation to Mexico. They had been transferred to Port Phillip Prison, a privatized prison operated by Group 4 Correction Services (Group 4) in the state of Victoria. The detainees complained of, inter alia, violations of Articles 7 and $10 \S 1$ ICCPR. ${ }^{187}$ They alleged that during their detention at Port Phillip Prison they had been subjected to cruel and inhuman treatment (including excessive shackling and frequent cavity searches) and that they were detained together in a triangular cell the size of a telephone booth. The cell had only one chair on which, due to the lack of space, only one person at a time could sit. ${ }^{188}$ In deciding whether there was a violation of Articles 7 and $10 \S 1$ ICCPR, the Human Rights Committee did not directly apply the ICCPR's obligations ensuing from these provisions to the company running the privatized prison, although a close reading of some of the Committee's observations in this case suggests it almost did so. ${ }^{189}$ Before deciding on the admissibility of the case, the Committee took a somewhat unusual step and chose in an obiter dictum fashion to “[...] consider whether the State party's obligations under the Covenant apply to privately-run facilities, as is the case in this communication, as well as State-run facilities." 190 The Committee decided to consider whether the communication concerned a State party to the Covenant within the meaning of Article 1 of the Optional Protocol. ${ }^{191}$ This observation led the Committee to reiterate an opinion it

185 See further Chapter $\mathrm{V}$ for an in-depth review of the practice of human rights treaty bodies with respect to privatization. It suffices here to observe that privatization has in particular been brought up on various occasions during the consideration of State reports by UN treaty bodies and in a number of General Comments. Under the Council of Europe mechanisms, privatization has received some attention from the Committee for the Prevention of Torture and has only sporadically shown up as a side-issue before the ECtHR and the European Committee for Economic and Social Rights. Privatization has also come up as an issue of indirect concern in some complaints filed before ILO complaints mechanisms.

186 See Cabal and Pasini Bertran v. Australia, Communication No. 1020/2001, UN Doc. CCPR/ C/78/D/1020/2001 (19 September 2003).

187 Art. 7 ICCPR reads: "No one shall be subjected to torture or to cruel, inhuman or degrading treatment or punishment." Art. 10 para. 1 states that "[a]ll persons deprived of their liberty shall be treated with humanity and with respect for the inherent dignity fo the human person." Cabal and Pasini Bertran v. Australia, paras. 2.9-2.10 and 8.2-8.3.

189 The Committee concluded that although there had been no violation of Art. 7 ICCPR, the conditions of detention resulting from the use of the 'cage' were in violation of Art. 10 para. 1 ICCPR. Cabal and Pasini Bertran v. Australia, para. 8.3-9. 
had previously formulated in other cases, e.g. that a State party "[...] is not relieved of its obligations when some of its functions are delegated to other autonomous organs." 192 The Committee then went to add that it

\begin{abstract}
"[...] considers that the contracting out to the private commercial sector of core State activities which involve the use of force and the detention of persons does not absolve a State party of its obligations under the Covenant, notably under articles 7 and 10 which are invoked in the instant communication. Consequently, the Committee finds that the State party is accountable under the Covenant and the Optional Protocol of the treatment of inmates in the Port Philip Prison facility run by Group 4."193
\end{abstract}

While the Committee fell short of directly applying the obligations ensuing from Articles 7 and 10 ICCPR to the privatized prison (even though it gave the impression of attempting to do so in its preliminary observations by stating that it had to verify whether the communication concerned a State party in the first place), it did conclude that in the event of the privatization of core State activities that involve the use of force and the deprivation of liberty the State always remains accountable for the treatment of prisoners in a privatized prison. It is, however, somewhat unfortunate that the Committee did not attempt to further define what core State activities are other than those involving the use of force and detention of persons. Of course, this was probably not to be expected due to the nature of the complaint. In any case, the position of the Human Rights Committee may appear to indicate that the nature of certain activities could be relevant in determining whether a complaint is directed against a State party. If the Committee had found otherwise, it probably would have considered the case non-admissible.

Unlike the Human Rights Committee, the Committee Against Torture has been faced more often with the question whether the CAT, or more precisely, the definition of torture, could be applied directly to the conduct of private entities. According to the definition of torture provided by Article 1 CAT, acts or treatment amounting to torture must be "inflicted by or at the instigation of or with the consent or acquiescence of a public official or other person acting in an official capacity." At first sight, this provision implies that private acts of cruelty fall outside the scope of Article 1 CAT. On the other hand, cruel and harsh treatment that is carried out by private actors with the acquiescence or consent of public officials for extracting information may well be regarded as torture as understood by the Convention. The Committee Against Torture has nevertheless concluded in a number of cases involving Article 3 CAT (on the prohibition of non-refoulement) in conjunction with Article 1 CAT, that fear or risk of torture by non-State entities in States to which

\footnotetext{
192 Ibid., citing the Committee's previous views on similar issues (B.d.B. v. The Netherlands (273/88), UN Doc. CCPR/C/35/D/273/1988 (2 May 1989), para. 6.5, Lindgren et al v. Sweden (298-299/88), UN Doc. CCPR/C/40/D/298/1988 (2 May 1989), para 10.4. 
applicants will be expelled, fell outside the scope of Article 3 CAT. ${ }^{194}$ The Committee has, however, sometimes concluded that Articles 1 and 3 CAT could be applicable to non-State or governmental entities that, due to the falling apart of a State, have occupied and exercise quasi-governmental authority over the territory to which a complainant would be returned. This was the case in Somalia where at a certain point non-governmental entities had set up quasi-governmental institutions and were negotiating the establishment of a common administration whereby these were exercising de facto certain prerogatives that were comparable to those exercised by legitimate governments. ${ }^{195}$ The defining factor in determining whether Articles 1 and 3 CAT may be applied to private entities thus appears to be that private entities must exercise certain prerogatives that are reminiscent of quasigovernmental authority similar to that required by Article 5 of the ILC's Articles on the Responsibility of the State. ${ }^{196}$ What these prerogatives are, however, has not been fully addressed by the Committee, although the existence of quasigovernmental institutions and administrative activities may provide some indication as to the nature of these actors.

\subsubsection{Private actors as State organs in the case law of the European Court of Human Rights}

The European Court of Human Rights and the old European Commission on Human Rights have not yet been faced with actual cases of privatization, ${ }^{197}$ nor have they decided whether private entities carrying out privatized functions may be regarded as an emanation of the State or public authority to which the Convention's rights may be applicable. Until now, the Commission and the Court's case law has focused on breaches of the Convention by formal public authorities such as ministries, municipalities, the police, the judiciary and the armed forces of Member States. ${ }^{198}$

194 See for example G. R. B. v. Sweden (83/1997), CAT, UN Doc. CAT/C/20/D/83/1997 (19 June 1998), para. 6.5; and V.X.N. and H. N. v. Sweden (130 and 131/1999), CAT, UN Doc. CAT/C/24/D/130 \& 131/1999 (2 September 2000), para. 13.8. Of course, if the non-State entity is committing acts of torture with the consent of the State or its acquiescence then the application may be declared admissible. See M.P.S. v. Australia (138/1999), CAT, UN Doc.

CAT/C/28/D/138/1999 (22 January 2003), para. 7.4, which confirms the non-applicability of CAT to acts of non-State entities, but leaves the possibility open for the latter proposition. See also Hajrizi Dzemajl et al. v. Serbia and Montenegro (161/2000), CAT, UN Doc. CAT/C/29/D/161/2000 (2 December 2002), para. 9.2.

195 See Elmi v. Australia (120/1998),CAT, UN Doc. CAT/C/22/D/120/1998 (14 May 1999), para. 6.5. See also S.S. v. The Netherlands (191/2001), CAT, UN Doc. CAT/C/30/D/191/2001 (19 May 2003), para. 6.4.

196 See section 2.2 supra.

197 See further Chapter V.

198 See also written response to question by a member of the House of Lords regarding the definition of public authority under the ECHR during the parliamentary debates accompanying the adoption of the Human Rights Act in the UK in 1997, where on behalf of the UK government, Lord Williams of Mostyn observed that "[t]he jurisprudence of the convention institutions 
However, in a small number of these cases the Commission and the Court have been confronted with applications wherein the issue of the Convention's applicability on seemingly non - state actors was raised. These can be divided into cases related to the question of whether a particular entity is a public authority, cases dealing with Article 34 ECHR, and cases where the State bears responsibility for acts of private entities. Although not examples of privatization, these cases could nonetheless provide some guidance for the discussion at hand.

\subsubsection{Public authority cases}

Articles 8 and 10 ECHR are geared towards protecting individuals from interferences by a 'public authority'. 199 The case law of the ECtHR and the former European Commission of Human Rights has not really provided a definition of the term 'public authority'. There have been only a few cases where some reference was made to it in view of the question whether a particular body whose conduct resulted in a possible violation of these rights could be considered a 'public authority' for the purposes of Articles 8 and 10 ECHR. In a case against the United Kingdom (UK), in which an individual complained that information concerning her personal background was used by the BBC and the Security Service to her detriment and in contravention of Article 8 ECHR, the Commission decided not to look into the question regarding the status of the $\mathrm{BBC}$ and whether its conduct led to responsibility of the UK under the ECHR. ${ }^{200}$ The applicant had argued that the BBC was a public authority as understood under Article 8 ECHR since the UK Government had charged it with the performance of public service broadcasting functions. Her complaint was directed against the BBC in its capacity as a public authority and not as a private employer performing exclusively private functions. The UK on the other hand argued that "[...] in any event, the acts of the BBC do not engage the responsibility of the United Kingdom since it is not a department of Government." In the eyes of the Commission, however, it was not necessary to consider this question since the complaint was manifestly ill-founded on other grounds.

contains no statement of general principle as to what constitutes a public authority for the purpose of Article 8. Bodies which the convention institutions have treated as public authorities for the purposes of Article 8 in cases against the United Kingdom, include the Secretary of State for the Home Department, the Security Service, the police, prison authorities and local authorities." See Lords Hansard, Written Answers, 25 November 1997, Column WA111.

199 The second paragraph of Art. 8 ECHR on the right to a private and family life reads "There shall be no interference by a public authority with the exercise of this right except such as is in accordance with the law and is necessary in a democratic society in the interests of national security, public safety or the economic well-being of the country, for the prevention of disorder or crime, for the protection of health or morals, or for the protection of the rights and freedoms of others." The second sentence of Art. 10 (1) on the freedom of expression reads "This right shall include freedom to hold opinions and to receive and impart information and ideas without interference by public authority and regardless of frontiers." Emphasis added, $A H W$.

200 See Hilton v. UK, Application No. 12015/86, decision by the European Commission of Human Rights, 6 July 1988. 
Although not strictly a case involving the question of a public authority, Van der Mussele v. Belgium ${ }^{201}$ can nevertheless be regarded as an attempt by the European Court to classify a particular body as an emanation or part of a Member State in order to hold the latter responsible for the conduct of the former. In this case the Court had to examine whether an order from the Belgian Bar Association obliging a lawyer to provide his legal services free of charge to indigent clients in criminal cases amounted to a violation of Article 4 ECHR (on the prohibition of slavery and forced labor). The Belgian Government denied any responsibility claiming that it did not prescribe how the Bar Association had to deal with the appointment of lawyers for indigent clients. The Court disagreed observing that Article $6 \S 3$ of the Convention lays an obligation on the member states to provide free legal assistance in criminal cases to clients who are not able to afford it. ${ }^{202}$ This obligation had been incorporated in the Belgian criminal procedure legislation, which in turn mandated the Bar Association to make the necessary arrangements for procuring free legal assistance in criminal cases. The Court observed that the Belgian Bar Associations had no discretion in the matter (they were compelled by law to oblige lawyers to provide their services free of charge). This led the Court to conclude that relying on the Bar Associations to make provisions for the legal assistance of indigent persons "[...] cannot relieve the Belgian State of the responsibilities it would have incurred under the Convention had it chosen to operate the system itself." 203 Additionally, the Court stated that the Bar Associations were bodies associated with the exercise of judicial power, carrying out an important task and the legislation governing their activities states their objectives, establishes their institutional organs, and endows them with legal personality in public law. ${ }^{204}$ These considerations led the Court to establish the responsibility of Belgium for the conduct of these bodies.

In a similar case to Van der Mussele, the Court concluded that the Barcelona Bar Council was a 'public authority' as understood by Article 10 ECHR. In Casado Coca v. Spain ${ }^{205}$ the Barcelona Bar Council imposed a disciplinary sanction on a lawyer for having published a notice about his practice in a local newsletter. National regulations with regard to the National Bar Council, which had been drafted by members of the Bar themselves and ratified by the Government through a royal decree, prohibited the advertising of lawyers' services in the media without previous permission from the Council. The lawyer argued that the imposition of the sanctions breached the freedom of expression and the freedom to impart information guaranteed by Article 10 ECHR. During the proceedings before the Court, the Spanish government argued inter alia that if there had been an interference with Article 10, it did not come from a 'public authority' within the meaning of Article

Van der Mussele v. Belgium, judgment of 23 November, 1983, ECtHR Series A-70.

Ibid., para. 29.

Ibid.

Ibid.

Casado Coca v. Spain, judgment of 26 February 1994, ECtHR, Series A285-A. 
$10 \S 1 .^{206}$ The Court, however, did not agree with this argument. It first noted that the Spanish law regulating the activities of professional associations stated that they were public-law corporations. ${ }^{207}$ It then observed that they served " $[. .$.$] the public$ interest through the furtherance of free, adequate legal assistance combined with public supervision of the practice of the profession and of compliance with professional ethics." 208 Finally, the decision to impose the disciplinary sanction was adopted in accordance with the provisions of the Bar Council's regulations and was upheld by various Spanish courts including the Constitutional Court. ${ }^{209}$ According to the European Court, these factors made it possible to reasonably conclude that there was interference by a 'public authority' in the applicant's freedom to impart information. ${ }^{210}$

From Van der Mussele and Casado Coca it may be concluded that the applicability of the Convention to the conduct of a particular body, and the eventual responsibility of the State for such a conduct is closely connected to the function performed by that body, ${ }^{211}$ although its institutional place in the governmental system and its status may also play a role. Thus the factors that both cases distinguish for determining whether a particular body is a 'public authority' for the purpose of directly applying the Convention are: performing a function in the public interest (in the particular cases of Van der Mussele and Cansado Coca regulating a profession), having a public law status, and the possibility of reviewing or challenging the bodies' decisions in courts. ${ }^{212}$ In addition it is important to emphasize the Court's stance in Van der Mussele that the State is not relieved of its obligations by letting other bodies do things that would incur the State's responsibility if the State had done them itself. This point was later used again in the case of Costello-Roberts v. the UK (see Section 3.1.2.3 infra). It is hereby preliminarily suggested that this does not only mean that the State is ultimately responsible for the conduct of non-State bodies, but that under certain circumstances these bodies could be considered as special state actors or 'public authorities' thus bearing responsibility for conduct that is not compatible with the human rights obligations ensuing from the Convention.

Ibid., para. 38 .

Ibid., para. 39. See also Le Compte, Van Leuven and De Meyere v. Belgium, judgment of 27 May 1981, ECtHR, Series A-43, para. 64\} for a similar reasoning involving a medical professional association.

Casado Coca, para. 39 (emphasis added $A H W$ ). With regard to this point, the Court pointed at the case of Van der Mussele.

Ibid.

Ibid.

See also Lawson and Schermers, Leading Cases of the European Court of Human Rights, p. 142 .

See also J. Coppel, The Human Rights Act 1998: Enforcing the European Convention in the Domestic Courts (Chichester: John Wiley \& Sons, 1999) p. 146. 


\subsubsection{Article 34 ECHR cases}

The Strasbourg bodies have also ruled whether certain bodies are governmental organizations for the purposes of determining whether applications submitted by them were admissible. In a number of cases brought before the Court, States have tried to argue that a number of complaints should be declared non-admissible because the bodies submitting the complaint were in fact governmental organizations that under Article 34 ECHR (former Article 25 ECHR prior to the revisions introduced by Protocol No. 11 in 1998) are not allowed to submit complaints. ${ }^{213}$ In the case of the Holy Monasteries v. Greece, ${ }^{214}$ the Commission and the Court had to determine whether the monasteries were in fact governmental organizations within the meaning of former Article $25 \mathrm{ECHR}$ for the purposes of deciding whether the complaint submitted by the monasteries was admissible. The Greek Government considered that due to the special place accorded to the Greek Orthodox Church in Greece as confirmed by the Greek constitution, the Church and its monasteries were governmental organizations, and as such not in the position to submit the complaint. In its admissibility decision, the European Commission of Human Rights observed that

"[...] a corporation pursuing social, educational or cultural aims does not by the mere fact that such aims are also pursued by the State become a governmental organisation. Moreover, the private or public law nature of a corporation, although an important indication, is not decisive for the determination of the governmental or nongovernmental character of an organisation under the Convention. As the Commission has previously held, governmental organisations which are precluded from exercising the right of individual petition under Article 25 (Art. 25) of the Convention are those which normally exercise public functions." 215

The Commission then noted that since the monasteries were religious institutions for those people living in them who were pursuing an ascetic way of life and monastic principles, the holy rules of asceticism and the tradition of the Orthodox Church of Christ, their activities could not "[...] be regarded as public functions since they are not related either to the exercise of public power or to State controlled activities in the field of public services." 216

213 Art. 34 ECHR and former Art. 25 ECHR only allow for the submission of individual complaints by any person, non-governmental organization or group of individuals claiming to be the victim of a violation by one of the Member States.

214 Holy Monasteries v. Greece, decision of 5 June 1990, European Commission of Human Rights, Applications No. 13092/87 and 13984/88; and Holy Monasteries v. Greece, judgment of 9 December 1994, ECtHR, Series A301-A. The case involved the alleged transfer of real property owned by a number of Greek Orthodox monasteries to the Greek Government contrary to Art. 1 of Protocol No. 1 to the ECHR (on the right to property).

215 Holy Monasteries v. Greece, European Commission of Human Rights.

216 Ibid. (emphasis added, $A H W$ ). 
The Court agreed with the Commission's observations and concluded that the monasteries did not exercise governmental powers on the basis that their objectives as described in the Charter of the Greek Church (essentially ecclesiastical and spiritual objectives as well as cultural and social ones) are,

[...] not such as to enable them to be classed with governmental organisations established for public-administration purposes. From the classification as public-law entities it may be inferred only that the legislature - on account of the special links between the monasteries and the State - wished to afford them the same legal protection vis-à-vis third parties as was accorded to other public-law entities." 217

In addition to this, the Court found that monasteries are under the supervision of the local archbishop and not under the direct supervision of the State. According to the Court, this made them entities distinct from the State and completely independent from it. ${ }^{218}$

In Ayuntamiento de Mula v. Spain, ${ }^{219}$ a local municipality complained that it had not had a fair hearing before the Spanish Supreme Court regarding a dispute regarding property rights. In deciding whether the application was admissible the ECtHR held that,

"[...] under the settled case-law of the Convention institutions, local-government organisations are public-law bodies which perform official duties assigned to them by the Constitution and by substantive law. They are therefore quite clearly governmental organisations [...] In that connection, the Court reiterates that in international law the expression 'governmental organisations' cannot be held to refer only to the Government or the central organs of the State. When powers are distributed along decentralised lines, it refers to any national authority which exercises public functions." 220

The Court accordingly held that the application by the municipality of Mula was not admissible. This view has been confirmed in a number of occasions. ${ }^{221}$

Holy Monasteries v. Greece, ECtHR, para. 49.

Ibid.

Ayuntamiento de Mula v. Spain, judgment of 1 February 2001, ECtHR, Reports of Judgments and Decisions 2000-I,.

Ibid. (emphasis added, $A H W$ ). The Court referred in this instance to a decision of the then existing European Commission for Human Rights which settled this issue. See Rothenthurm Commune v. Switzerland, application no. 13252/87, Commission decision of 14 December 1988, Decisions and Reports, (DR) 59, p. 251.

Most recently, the Court reiterated "[...] that under the international law the term "State organisation" is not limited only to organs of the central Government. In cases where State power is decentralised it extends to any national authority which exercises public functions." See Gerasimova v. Russia, application no. 24669/02, admissibility of 16 September 2004, ECtHR (First Section). 
Thus, it would appear that the Court may be willing to apply the Convention to nonState bodies under two circumstances: (a) when these bodies exercise public powers or State controlled activities in the field of public services (Holy Monasteries); (b) when they perform official duties conferred on them by a Constitution and by substantive law. However, the Court, or for that matter the Commission when it still functioned, has not yet provided further indication as to what may be understood to be the exercise of public powers, or activities in the field of public services. With regard to the former, the ECtHR has recently suggested that certain powers delegated to private entities pertaining to the execution of court judgments could fall under Article 34: in Sychev v. Ukraine, the Court did not find it necessary to embark on a discussion of whether a private law commission was or was not in itself a State authority for the purposes of Article $34 \S 1$ ECHR. It did state, however, that "[i]t suffices to note that the body in question exercised certain State powers at least as regards the execution of court judgments." 222 With regard to activities in the field of public services, it may be assumed that the Court means those services of general interest as understood in France and under EU law. ${ }^{223}$

\subsubsection{Cases regarding responsibility for the conduct of non-State actors}

Finally the issue of the applicability of the Convention to entities that are not traditional state actors has been dealt with by the Court in cases where the State was required to take the responsibility for the conduct of certain bodies that are not obviously state actors in the strict sense of the word. This can be appreciated in the case of Young, James and Webster v. the United Kingdom, ${ }^{224}$ and Costello-Roberts $v$. the $U K .^{225}$ In the former case the European Court was called to decide whether a closed shop agreement between trade unions and British Rail resulting in the dismissal of a number of employees who had refused to join the unions was contrary to Article 11 ECHR on the freedom of association. The UK had accepted the existence of closed shop agreements through legislation. In examining whether the alleged treatment of the employees could be attributed to the UK, the Court did not find it necessary to examine whether British Rail was a public body under control of the State (which it actually was at that point in time, British Rail being privatized some years later). ${ }^{226}$ Rather, the Court concluded that the responsibility of the State for the conduct of British Rail ensued from the enactment of domestic legislation that made the dismissals lawful. By giving its blessing to the dismissals through legislation, the UK did not live up to the obligation enshrined in Article 1 ECHR

\footnotetext{
222 Sychev v. Ukraine, Judgment of 11 October 2005, ECtHR, Application No. 4773/02 (not yet reported), paras. 54 .

223 See Section 3.6.1 infra.

224 Young, James and Webster v. the United Kingdom, judgment of 13 August 1981, ECtHR Series A-44.

225 Costello-Roberts v. the United Kingdom, judgment of 25 March 1993, ECtHR Series A-247-C.

226 Young, James and Webster, para. 49.
} 
which states that each contracting State "[...] shall ensure to everyone within [its] jurisdiction the rights and freedoms defined in [the] Convention." 227 In other words, the conduct of non-State entities made possible by the State through legislation will lead to the State's responsibility. As observed in Chapter III, Section 4.4.1, this conclusion entails that the rights of the ECHR can have an indirect horizontal effect.

This conclusion was reiterated in the case of Costello-Roberts. The case revolved around the application of disciplinary measures amounting to corporal punishment by the headmaster of a private school on a child. Dealing with the question of responsibility of the Government of the United Kingdom for the conduct of the private school, it observed that it had consistently held that States have to secure the rights and freedoms of the ECHR in domestic legislation. ${ }^{228}$ Failure to do so engages the responsibility of the State thus reaffirming the 'indirect' Drittwirkung of the Convention. However, the Court then went to discuss the State's obligation to secure children their right to education under Article 2 of Protocol No. 1 to the ECtHR and under Article 28 UN Convention on the Rights of the Child, and the functions relating to this right including the administration of schools and disciplinary measures. The Court noted that these functions and disciplinary measures fall under the right to education, and then pointing to its conclusion in Van der Mussele v. Belgium (see above), it added that "[...] the State cannot absolve itself from responsibility by delegating its obligations to private bodies or individuals." ${ }^{229}$ Although the ECtHR did not give further content to this statement, it can be suggested that the Court was trying to give more fundament to the 'indirect' applicability of the Convention to acts carried out by private entities that exercise a particular public or governmental function (in casu provide education, and administer discipline as required by the right to education). Not only does this statement mean that the State is indirectly responsible for private conduct, but it could also be interpreted in another way. It could also mean that States cannot absolve themselves from the responsibilities to secure the right to education, arguably a function of general and public interest, by delegating it to private entities it is possible to induce that the nature of these functions could play a role in determining whether these private themselves can also be held directly accountable.

The approach adopted in Costello-Roberts was confirmed and further clarified in a number of recent cases. ${ }^{230}$ In Woś v. Poland the ECtHR cited both Van der Mussele

\footnotetext{
227 Ibid.

228 Costello-Roberts v. United Kingdom, para. 26. See Chapter III, Section 4.4.1.1.

229 Costello-Roberts v. United Kingdom, para. 27. See also Van der Mussele v. Belgium, judgment of 23 November 1983, Series A -70, paras. 28-30.

230 Woś v. Poland, Decision on Admissibility of 1 March 2005, ECtHR Reports of Judgments and Decisions 2005-IV, paras. 60 and 73, Buzescu v. Romania, Judgment of 24 May 2005, ECtHR,
} 
and Costello-Roberts, with regard to the fact whether State responsibility was engaged by the actions of a private body established by an international agreement between Poland and Germany to deal with compensation claims from victims of Nazi prosecution in World War II. In this case, the private entity, the Polish-German Reconciliation Foundation had partly declined to grant compensation to the applicant, who had been subjected to forced labor during the War. Although there was the possibility to appeal the decision within the Foundation itself, any negative decision after that was not amenable for judicial review, which led to a complaint of lack of access to court under Article $6 \S 1$ ECHR. In determining the question of responsibility for the acts of the Foundation, the Court, citing above-mentioned case law, stated that the "[...] State cannot absolve itself from responsibility ratione personae by delegating its obligations to private bodies or individuals." 231 The ECtHR then noted that the delegation of its powers to other bodies, private or public, is not decisive in itself to incur the responsibility of the State. As a matter of fact, the Court commented that the ECHR does not exclude the transfer of powers or competences to other bodies operating under private law. ${ }^{232}$ What matters is the manner in which they affect the ECHR's rights when these powers are exercised, and in any event the State remains responsible even after the particular functions have been transferred to other bodies. A similar conclusion was reached in the case of Sychev v. Ukraine, in which the State had established a private law commission that exercised certain State powers at least as regards the execution of court judgments. For the court it did not matter who exercised the powers, but the manner in which that occurred: "In the Court's view, the exercise of State powers which affects Convention rights and freedoms raises an issue of State responsibility regardless of the form in which these powers happen to be exercised, be it for instance by a body whose activities are regulated by private law." 233

Another case that gave more meaning to the Costello-Roberts approach was Buzescu $v$. Romania. In this case, the question was put forward whether a decision by the Romanian Union of Lawyers to annul the registration of a lawyer at the local bar association was an interference with Article 1 of Protocol 1 to the ECHR and would lead to the responsibility of Romania. The Government argued that the State could not be held liable as the case involved a dispute between two private parties. The Court thought different, however. Reiterating the Costello-Roberts criteria, the Court went on to examine what type of body the Romanian Union of Lawyers was.

Application No. 61302/00, para. 78, Storck v. Germany, Judgment of 16 Juni 2005, ECtHR Reports of Judgments and Decisions 2005-V, para. 103 (see Chapter III, Section 4.1.2.3), and Sychev v. Ukraine, Judgment of 11 October 2005, ECtHR, Application No. 4773/02 (not yet reported), paras. 53-55. 
It first remarked that the Union had been established by law and invested with administrative as well as rule-making prerogatives. ${ }^{234}$ It then observed that the Union pursued an aim of general interest in relation to the legal profession since it exercised some form of public control over the registration of lawyers to the bar. In addition, its decisions were subject to the jurisiction of administrative notes. Finally the Court took note of the fact that domestic case law classified the Union as a public authority that performs administrative acts and fulfils a public service role. ${ }^{235}$ This functional analysis allowed the ECtHR to conclude that the responsibility of Romania was engaged as a result of the administrative decisions of the Union, which resulted in the complaint.

\subsubsection{Some observations}

The international and regional human rights monitoring bodies have in some occasions been confronted with questions regarding the direct applicability of human rights norms to the conduct of non-State actors that were performing activities or functions of a governmental or public nature. These monitoring bodies have yet to conclude that these norms should be directly applied to the activities of these actors. The limited practice of the Human Rights Committee and the Committee Against Torture, and the ECtHR on this field does not enable us to conclude that human rights norms, under certain circumstances could be applied to private bodies carrying out functions, tasks or services that have been privatized because they could then be regarded as special types of governmental actors. The case law studied here, however, has been keen to emphasize that States remain responsible for abuses committed by private actors in the exercise of public functions delegated to them. It would appear that some of the human rights monitoring bodies have adopted a functional approach to classify the types of powers being delegated to private actors. Thus the nature of the tasks exercised by private actors (exercising the use of force, running prisons, exercising State-like or administrative prerogatives, managing quasi-governmental institutions in the absence of a proper State authority, administer functions related to the right to education, paying compensation to victims of human rights a buses as a result of an international agreement between two countries, or performing an activity that fulfills a public service role) appear to have played a role in determining the extent of the involvement of these bodies. Nevertheless, the ECtHR has concluded that in the end, what matters is not the transfer of the functions to private actors, but the manner in which they are exercised, in particular if they affect the rights of others.

234 Buzescu v. Romania, para. 78.

235 Ibid. 


\subsection{Applicability of EU law to private actors exercising functions of a public nature}

The question whether certain norms of EU law that are strictly speaking addressed to EU Member States and their organs can nevertheless, under certain circumstances, be applied to private entities exercising functions of a public nature, has been raised a number of times in the case law of the ECJ. This question has been raised in three different contexts. First, it has been of general importance in deciding whether some derogations of primary EU law, 236 which in theory are only applicable to bodies exercising governmental authority, were in fact applicable to a particular body (either private, public or semi-public). This question has also been of relevance in deciding whether directives, which as a general rule of EU law are only enforceable against Member States and its organs and then only under specific circumstances, could be invoked against a private entity entrusted with certain tasks that had been formerly discharged by the State or its organs. Finally, the question has arisen as to whether EU norms on public procurement can be applied to private entities charged with the exercise of public functions. In general, the ECJ has approached this dilemma from a functional perspective, whereby the nature of the function, rather than the institutional arrangements, was decisive in differentiating between bodies exercising governmental authority (which sometimes may include private entities) and bodies undertaking mainly economic or commercial activities (which sometimes may include 'public' entities sensu strictu).

\subsubsection{EU competition law and governmental authority}

EU competition law is geared towards curbing the conduct of undertakings, either public or private, that threaten to distort competition within the internal market by concluding dubious agreements between undertakings, by abusing their dominant position, or by receiving financial aid from the State. Thus, under EU competition law, the question is not whether this law is applicable to the conduct of private undertakings, which it is. Rather, and reversing the approach used thus far in this (and in the rest of this) chapter, the question is under which circumstances are (private) undertakings exempt from the applicability of competition law because the State has entrusted them with the exercise of certain (former) public activities. In other words, are private entities that carry out activities of a public nature subject to competition law?

The ECJ has concluded in a number of cases that activities that are connected with the exercise of official authority do not fall within the scope of competition law.

236 In particular those rules pertaining to EC competition law regarding the abuse of dominant position (Art. $82 \mathrm{EC}$ ) and the applicability of competition rules on undertakings entrusted with the operation of services of general economic interest (Art. $86 \mathrm{EC}$ ) and the freedom to provide services (art. $49 \mathrm{EC}$ together with art. $45 \mathrm{EC}$ ). 
This would include activities performed by private bodies entrusted to them by the State. In coming to this conclusion, the ECJ has held that it is necessary to consider the nature of the activities carried out to determine whether Articles 82 and $86 \mathrm{EC}$ are applicable. ${ }^{237}$ For the purposes of applying Articles 82 and $86 \mathrm{EC}$, it is thus first necessary to differentiate between a situation in which a particular body acts in the exercise of official authority and a situation in which it carries out economic activities of an industrial or commercial nature by offering goods or services on the market. ${ }^{238}$ If that particular body turns out to be a body exercising official authority, then both articles will be inapplicable. In order to make this differentiation the ECJ observed that, "[...] it is of no importance that the State is acting directly through a body forming part of the State administration or by way of a body on which it has conferred special or exclusive rights." ${ }^{239}$ According to the Court, however, it is necessary to consider "[...] the nature of the activities carried on by the public undertaking or body on which the State has conferred special or exclusive rights." 240

Of particular interest for the subject of this study is the ECJ's determination that tasks, which are performed in the public interest by a private entity, may be considered as acts in the exercise of official authority. ${ }^{241}$ The precise definition of what amounts to tasks performed in the public interest will, however, depend on the specific aspects of each individual situation, leading thus to a case by case approach by the Court. According to the Court's case law the following tasks may be regarded as being performed in the public interest: surveillance and control tasks whereby entities, regardless of whether they are governmental in the strict sense of the word or private, are endowed with rights and powers of coercion which derogate from ordinary law and which affect the users of the entity's services. ${ }^{242}$ On the other hand, the ECJ considers activities of a commercial nature that are performed by

237 Following the coming into force of the Treaty on the Functioning of the European Union (TFEU), Articles 82 and 86 EC have been renumbered to Articles 102 and 106 TFEU.

238 See A. Winterstein, "Nailing the Jellyfish: Social Security and Competition Law," ECLR (1999), p. 324.

239 ECJ, Case 118/85 Commission v Italy [1987] ECR 2599, paras. 7 and 8. See also ECJ, Case C-343/95 Diego Cali \& Figli Srl v Servizi ecologici porto di Genova SpA (SEPG) [1997] ECR I-01547, paras. 16-18.

240 Ibid. See also ECJ, Case C-364/92 SAT Fluggesellschaft mbH v Eurocontrol [1994], ECR I-00043, para. 19.

241 See Diego Cali \& Figli Srl v Servizi ecologici porto di Genova SpA, para. 22. Compare to the approach under Article 5 of the ILCs Articles on the Responsibility of States, Section 2.2 supra.

242 See SAT Fluggesellschaft $m b H v$ Eurocontrol, para. 24. These tasks may include more specifically, tasks in the public interest aimed at contributing to the maintenance and improvement of air navigation safety (Case C-364/92, para. 27) and tasks in the public interest which forms part of the essential functions of the State as regards protection of the environment in maritime areas (Case C-343/95, para. 22). With regard to the latter, the Court concluded that "[s]uch surveillance is connected by its nature, its aim and the rules to which it is subject with the exercise of powers relating to the protection of the environment which are typically those of 
governmental entities sensu strictu or which have been entrusted to private ones by the State not to be acts in the exercise of official authority. ${ }^{243}$

It can therefore be concluded that with regard to activities, which may or may not be covered by EU law with respect to market integration such as those on EU competition law, the ECJ uses a rather narrow view of what activities may belong to the public realm excluding those activities that have some commercial elements, even when carried out by public organs sensu strictu. It is worth pointing out, however, that in the eyes of the ECJ it does not matter whether a particular activity is performed by a public or private entity for that activity to be branded public. It is the nature of the activity that is decisive in determining whether particular rules of primary EU law apply to those entities and not the entities' specific status (public or private).

\subsubsection{Freedom to provide services and official authority}

The Court has followed a similar approach in determining whether a particular entity comes within the scope of the provisions dealing with the freedom to provide services (Article 49 EC/Artilce 56 TFEU) and its general exception. ${ }^{244}$ Article 49 EC prohibits restrictions on the freedom to provide services within the Community. However, according to Article 45 EC (Article 51 TFEU) the prohibition, "[...] shall not apply, so far as any given Member State is concerned, to activities which in that State are connected, even occasionally, with the exercise of official authority." It is not altogether clear whether the provisions regarding the freedom to provide services (Articles 49-55 EC, now Articles 56-62 TFEU) have horizontal effect. ${ }^{245}$ These provisions are in any case directed towards the State and have vertical direct effect meaning that individuals who want to exercise this freedom within the EU may rely on them in a court of law. ${ }^{246}$ In light of the direct vertical applicability of

a public authority. It is not of an economic nature justifying the application of the Treaty rules on competition." Ibid., para. 23.

243 See for a similar approach Section 3.2.4 infra regarding the applicability of EU procurement law to private entities.

244 Article $45 \mathrm{EC}$, which by way of Article $55 \mathrm{EC}$ equally applies to the provisions regarding services. Both provisions have now been renumbered into Article 51 TFEU and Article 62 TFEU.

245 For a more general discussion with regard to whether or not the fundamental freedom provisions of EC law (free movement of persons, goods, services and the freedom of establishment) have horizontal effect see S. van den Bogaert, "Horizontality: The Court Attacks?," in The Law of the Single European Market, ed. C. Barnard and J. Scott, Oxofrd: Hart Publishing (2002), p. 123 152.

246 ECJ, Case 33/74 Van Binsbergen v. Bestuur van de Bedrijfsvereniging voor de Metaalnijverheid (1974) ECR 1299. See also P. Craig and G. De Búrca, EU Law: Text, Cases, and Materials (Oxford: Oxford University Press, 2003) p. 802-803. 
Article $49 \mathrm{EC}$, the question has been raised whether the official authority exception also applies to private entities carrying out 'public' functions, tasks or services.

In a number of cases related to Article 45, the ECJ has adopted a rather limited approach to decide whether a particular entity exercises official authority and thus is amenable to the exception. In one of the first cases dealing with the exception, Reyners v. Belgium, ${ }^{247}$ the Court did not attempt to provide a definition of 'official authority', but limited itself to observe that the term "[...] is limited to those activities which, taken on their own, constitute a direct and specific connexion [sic?] with the exercise of official authority." 248 In Reyners, the Court found no such connection. $^{249}$ The Court also limited the application of the exception of Article 45 in a case involving private schools, ${ }^{250}$ and traffic accident experts, ${ }^{251}$ the latter on the ground that,

“[...] experts' reports regarding traffic accidents are not binding on the courts. They leave the discretion of the judicial authority and the free exercise of judicial power intact." 252

247 ECJ, Case 2/74, Reyners v. Belgium (1974) ECR 631. The case revolved around the question whether the activities of a Belgian avocat could be connected with the exercise of official authority and thus excempted from the application of Articles 49-55.

248 Ibid., para. 45.

249 In the end the Court noted that the exception was not applicable to the profession of avocat because "[...] within the framework of an independent profession, the activities connected with the exercise of official authority are separable from the professional activity in question taken as a whole. [...] The most typical activities of the profession of avocat, in particular, such as consultation and legal assistance and also representation and the defence of parties in court, even when the intervention or assistance of the avocat is compulsory or is a legal monopoly, cannot be considered as connected with the exercise of official authority. The exercise of these activities leaves the discretion of judicial authority and the free exercise of judicial power intact." Ibid., paras 47 and 52-53. See also M. Krajewski, "Public Services and Trade Liberalization: Mapping the Legal Framework," Journal of International Economic Law Vol. 6 (2003), p. 363364.

250 ECJ, Case C-147/86, Commission of the European Communities v Hellenic Republic (1988) ECR 1637. According to the Court private schools could not be considered to exercise activities connected to official authority because, "[a]lthough it is for each member state to determine the role of, and the responsibilities attaching to, official authority with regard to instruction, it cannot be accepted that the mere fact that a private individual sets up a school [...] or a vocational training school, or gives private lessons at home, is connected with the exercise of official authority within the meaning of Article 55 [now Article $45 A H W$ ] of the treaty. Those private activities remain subject to supervision by the official authorities which have at their disposal appropriate means for ensuring, in any event, the protection of the interests entrusted to them, without there being any need to restrict freedom of establishment for that purpose." Ibid., paras 9-10.

251 ECJ, Case C-306/89, Commission of the European Communities v Hellenic Republic (1991) ECR I-05863.

252 Ibid., para. 7. 
In a case involving the activities of an internal insurance auditor working at an Insurance Inspectorate the ECJ gave more indications as to what elements may be relevant in determining whether a particular person or entity exercises public authority. ${ }^{253}$ According to the Court, it is first necessary to consider the nature of the duties carried out by the particular entity. ${ }^{254}$ Even though the nature of the insurance auditor's activities did not amount to an exercise of official authority, the Court noted that the Inspectorate itself exercised such an authority. ${ }^{255}$ According to the Court this was because the Inspectorate was a body governed by public law, with legal personality and subject to the authority of the Ministry of Economic Affairs. In addition the Inspectorate had the task of supervising the application of the law and had the power to make regulations, thus allowing it to determine the obligations that must be impose on insurance undertakings. Summarizing, the Court noted that the Inspectorate had a supervisory function that serves to protect insured parties and the public interest allowing it to intervene directly in the management of insurance undertakings by imposing preventive and positive measures.

Later, however, the Court concluded in a number of cases that private security guards were not regarded as exercising official authority. Citing the findings of Advocate General Alber, the Court observed in Commission of the European Communities $v$ Kingdom of Spain ${ }^{256}$ that the activities of private security guards, carrying out surveillance and protection tasks, were based on contractual relations. ${ }^{257}$ However the exercise of this activity did not mean that

"[...] security undertakings and security staff are vested with powers of constraint. Merely making a contribution to the maintenance of public security, which any individual may be called upon to do, does not constitute exercise of official authority. Furthermore [...] the Spanish legislation makes a clear distinction between tasks entrusted to security undertakings and security staff and those reserved for the public security forces. Where in very specific situations the former are called upon to assist the latter, the functions they perform are only auxiliary functions. It follows that private security undertakings and private security staff are not directly and specifically involved in the exercise of official authority and that the exception

253 ECJ, Case C-42/92, Adrianus Thijssen v Controledienst voor de verzekeringen (1993) ECR I-04047.

254 Ibid., para 9.

255 Ibid., para. 10-11. In essence the insurance auditor was deemed to carry only auxiliary and preparatory functions vis- $\grave{a}-v i s$ the Insurance Inspectorate "[...] which itself is the body which exercises official authority by taking the final decision." Ibid., para. 22. I-06717.

257 Ibid., para. 36. 
provided for in the first paragraph of Article 55 combined, where appropriate, with Article 66 of the Treaty does not apply in this case." 258

In general it can be stated that the ECJ has narrowly interpreted what activities connected with the exercise of official authority entail. Of course, one of the reasons for the limited interpretation of the term 'exercise of official authority' and the frequent refusal to apply it to private bodies could be explained in the context of the necessity to prevent a circumvention of the freedom of establishment to provide services or its limitation due to the application of restrictive and discriminatory rules restricting the scope of Article $49 \mathrm{EC}$ to the detriment of other service providers from other EU countries. ${ }^{259}$ However, the Court appears to have acknowledged that a functional test is necessary to determine whether a body can be regarded as acting with official authority and thus be amenable to the exception of Article $45 \mathrm{EC}$. Among the elements that can play a role in this determination are whether a particular body acts solely on a contractual basis, whether it has decision making powers and the possibility to enact binding decisions, whether the body serves the public interest or whether it performs auxiliary or ancillary functions without any coercive power, or whether its activities are governed by public law.

\subsubsection{Applicability of directives to private actors}

Article 249 EC (now Article 288 TFEU) specifies the different types of legislation possible under EU law, regulations, directives and decisions. According to this provision, regulations are binding in their entirety and are directly applicable in the EU's Member States. The latter statement has been interpreted by the ECJ to mean that individuals may derive rights from regulations that can be enforced "in their own name before national courts." 260 This means that regulations have direct vertical, and sometimes even horizontal effect. Directives, however, are addressed towards the Member States and are only "binding, as to the result to be achieved [...], but shall leave to the national authorities the choice of form and methods." 261

258 Ibid., paras. 37-39. Similar conclusions were reached in ECJ, Case C-355/98, Commission of the European Communities v Kingdom of Belgium (2000) ECR I-01221, para. 26 were the ECJ observed that "[t]he activities of security firms, security systems firms and internal security services are not normally directly and specifically connected with the exercise of official authority, and the Belgian Government has not adduced any evidence to permit the contrary to be established." See also ECJ, Case C-283/99, Commission of the European Communities $v$ Italian Republic (2001) ECR I-04363, paras. 20-21.

259 In ECJ, Case 147/86, Commission of the European Communities v Hellenic Republic. para 6, for example, the Court stated that "[...] since it derogates from the fundamental rule of freedom of establishment, Article 55[now Article 45 EC] of the treaty must be interpreted in a manner which limits its scope to what is strictly necessary in order to safeguard the interests which it allows the member states to protect."

260 Craig and De Búrca, EU Law: Text, Cases, and Materials, p. 113 and p. 202.

261 Art. 249 EC (Art. 288 TFEU). 
Directives are typically used to harmonize the differing national legislation of EU Member States concerning the different sectors that they address. ${ }^{262}$ They leave Member States with a certain margin of discretion to adopt the necessary measures required to implement the content of the directives. The ECJ has held that under certain circumstances directives may have (in)direct effect. Individuals may sometimes rely on them, although they can only be invoked vertically against a Member State and then only when the directive has not, or not timely or incorrectly been implemented at the national level. ${ }^{263}$

In Marshall $v$. Southhampton, ${ }^{264}$ the ECJ categorically refused to apply a directive to a relationship between private individuals. The ECJ observed that "[...] the binding nature of a directive, which constitutes the basis for the possibility of relying on the directive before a national court, exists only in relation to "each Member State to which it is addressed' [...]," and concluded that a directive "[...] may not of itself impose obligations on an individual and that a provision of a directive may not be relied upon as such against such a person." ${ }^{265}$ The ECJ's principled refusal to horizontally apply directives is partly based on the fact that the EC Treaty has made a specific distinction between the different legislative acts in the EC Treaty (regulations, directives and decisions) that are meant for different purposes. This distinction is still present in the TFEU. Granting a directive horizontal effect whereby individuals may directly rely on them makes directives no different from regulations. ${ }^{266}$ However the Court's main reason to deny a horizontal application of directives is a very textual interpretation of Article 249 EC, according to which directives are only addressed to States and these are the ones who have to give effect to the directive. ${ }^{267}$ As a result private parties cannot directly invoke a directive against another private entity: they may only invoke it

262 Craig and De Búrca, EU Law: Text, Cases, and Materials, p. 202.

263 This (in)direct effect works in various ways. The ECJ has held that national courts must first try to interpret national legislation in the light of directive. See ECJ, Case 14/83 Von Colson and Kamman v. Land Nordrhein-Westfalen [1974] ECR 1891 and ECJ, Case C-106/89 Marleasing SA v. La Comercial Internacional de Alimentación SA [1990] ECR I-4135. If this is not possible, it must then be examined whether the directive's contents are sufficiently clear and precise and whether they concede individuals concrete rights that they may claim without further action from the State. See ECJ, case C-If the State has failed to take measures to properly implement the directive, an individual may claim a compensation for any damages which are the direct result thereof. See ECJ, joint Cases C-6 \& 9/90 Francovich and Bonifaci v. Italy [1991] ECR I-5357.

ECJ, case C-152/84, Marshall v. Southhampton and South-West Hampshire Area Health Authority [1986] ECR 723. Ibid, para. 48.

Conclusion of Advocate General Slynn in Marshall v. Southhampton. Ibid Craig and De Búrca, EU Law: Text, Cases, and Materials, p. 207-208. Craig and De Búrca are, however, not so convinced of the Court's reasoning due to the fact that regulations are also directed towards the Member States, but has nevertheless accorded horizontal direct effect to these legislative measures. Ibid., p. 208. 
against the State and then only when the State has failed to implement a directive in national law correctly and at the proper time, and then only in so far as these directives contain provisions that are unconditional and sufficiently precise. Thus, like at the international level, the reach of the vertical application of a directive depends in part on the scope of the concept of 'State'.

The ECJ has, however, expanded the vertical direct effect of directives by allowing for a broader interpretation of what may be understood under the concept of the State. ${ }^{268}$ A first step in this direction was taken in the case of Johnston $v$ Chief Constable of the Royal Ulster Constabulary. ${ }^{269}$ The Court examined whether the Chief Constable was a public authority bound by the principle of equal treatment for men and women as guaranteed in Council Directive No. 76/207/EEC, even though the Chief Constable was involved in that particular case as an employer. The UK government argued that the Chief Constable was constitutionally independent of the State and only involved as an employer; therefore the directive could not be applied to him. The ECJ, however, found that notwithstanding the constitutional relationship of the Chief Constable with the State, "[...] such a public authority, charged by the State with the maintenance of public order and safety, does not act as a private individual. It may not take advantage of the failure of the State, of which it is an emanation, to comply with community law."270 Admittedly, a Chief Constable has more of a semblance with public authorities sensu stricto because of its policing powers, it is nevertheless noteworthy that a public law rule (in this a EU directive) may sometimes apply to the private or even commercial activities of particular entities.

The ECJ went a step further in the case of Foster v. British Gas. ${ }^{271}$ In that case the Court made an exception to its refusal to directly apply directives to relationships between private parties. In Foster the Court recognized three particular conditions that may lead to the conclusion that a particular private body may be subject to a directive in its dealings with other private entities. The case dealt with forced employment termination of a number of female employees of British Gas, a gas utility which at the time of the events had not been yet privatized. ${ }^{272}$ The employees complained before an industrial tribunal that British Gas discriminated against them on the ground of sex since it required them to retire at the age of 60 whereas male employees retired at age 65. The employees invoked Council Directive 76/207/ EEC, which guarantees equality of treatment for men and women in relation to working conditions. The industrial tribunal and the Court of Appeal, however,

\footnotetext{
268 Ibid.

269 ECJ Case C-222/84, Johnston v Chief Constable of the Royal Ulster Constabulary, [1986] ECR 1651.

270 Ibid., para. 56.

271 ECJ Case C-188/89, Foster v. British Gas Plc, [1991] ECR I-3313.

272 British Gas was privatized in 1986 under the UK Gas Act 1986.
} 
concluded that complainants could not directly rely upon the directive because British Gas was not a state authority. The complainants filed an appeal before the House of Lords, which referred the question to the ECJ whether British Gas was a body against which the Directive was directly enforceable.

In answering the question whether in this instance the directive could be applied to the relationship between entities that are at first glance private, the Court followed Advocate General Van Gerven's proposal ${ }^{273}$ and held that,

"[...] a body, whatever its legal form, which has been made responsible, pursuant to measures adopted by the State, for providing a public service under the control of the State and has for the purpose special powers beyond those which result from the normal rules applicable in relations between individuals is included among the bodies against which the provisions of a Directive capable of having direct effect may be relied upon." 274

Craig and da Burca observe that in spite of this ruling, the Court has not really made it clear what kind of control over a body the State must have in order for it to be regarded as part of the State. ${ }^{275}$ What Foster does, is merely indicate that a body that has been made responsible for providing a public service under the control of

273 In its opinion, Advocate General van Gerven proposed to answer the question as follows: "Individuals may rely on an unconditional and sufficiently precise provision such as article 5(1) of Directive (76/207/E.E.C.) against a person or body, in this case a public undertaking, in respect of which the state (understood as any body endowed with public authority, regardless of its relationship with other public bodies or the nature of the duties entrusted to it) has assumed responsibilities which put it in a position to influence decisively the conduct of that person or body in any manner whatsoever (other than by means of general legislation) with regard to the matter in respect of which the relevant provision of a Directive imposes an obligation which the member state has failed to implement in national law."

274 Foster v. British Gas Plc, para. 20. The House of Lords then held the same in the original proceedings. See.

275 The House of Lords, however, in the main proceedings following the referral to the ECJ, did attempt to give further content to the test developed by the Court of Justice in Foster. Thus the Lords observed through the leading opinion of Lord Tempelman, that legislation enabled British Gas to provide a public service namely to develop and maintain an efficient, coordinated and economical system of gas supply in the UK and to satisfy, so far as it is economical to do so, all reasonable demands for gas in the country. The Lords also stated that British Gas provided the gas supply under control of the State: thus according to the Lords the company was not independent; its members were appointed by the State; it was responsible to the minister acting on behalf of the State, and was subject to directions by the relevant Secretary of State. Finally, the Lords noted that British Gas had been conferred 'special powers beyond those which result from the normal rules applicable in relations between individuals' since legislation stated that no person other than British Gas itself was allowed to supply gas to any premises except with its consent and in accordance with such conditions as may be attached to that consent. See Foster $v$. British Gas Plc, House of Lords, [1991] IRLR 268 HL. 
the State falls within the Community's definition of a public body. ${ }^{276}$ It is nevertheless clear that the ECJ chose a functional approach in this matter. The institutional form of a particular body is not relevant to decide whether it can be regarded as a public body. What is relevant is whether the State has endorsed it with special powers (public powers).

Arguably, with regard to a privatized body, the issue of special powers and State control will be of importance in determining whether such a particular directive could be directly applied to such a body. In this regard, it is of interest to note that in the United Kingdom the Foster test has been applied to a specific case of a privatized water utility. In Griffin \& others $v$ South West Water Services Ltd, ${ }^{277}$ the High Court had to decide whether a directive that related to collective redundancies ${ }^{278}$ was directly enforceable against a privatized water utility. The High Court applied the Foster test to South West Water and first observed that it fulfilled the first condition of the test, namely that it provided a public service. The legislation which had privatized water utilities in England, the Water Act 1991, enabled the company to provide a public service since it had to develop and maintain an efficient and economical system of water supply within its area, and to provide supplies of water to premises in that area and for making such supplies available to persons who demand them as well as having to maintain, improve and extend the water mains and other pipes. ${ }^{279}$ With regard to the third condition of the test, that the particular body exercises 'special powers beyond those which result from the normal rules applicable in relations between individuals', the High Court noted that this condition was also fulfilled since legislation conferred upon the water company a number of exclusive powers in its area of operation. ${ }^{280}$ With regard to the second

276 Craig and De Búrca, EU Law: Text, Cases, and Materials, p. 210-211. See also ECJ Case C-343/98 Collino and Chiappero, [2000] ECR I-6659, paragraph 23; ECJ Case C-53/04 Cristiano Marrosu, Gianluca Sardino v. Azienda Ospedaliera Ospedale San Martino di Genova e Cliniche Universitarie Convenzionate, [2006] ECR I-7213, para. 29; and ECJ Case C-180/04 Andrea Vassallo v. Azienda Ospedaliera Ospedale San Martino di Genova e Cliniche Universitarie Convenzionate, [2006] ECR I-7251, para. 26, in which the Court reiterated Foster without further explanation.

277 Griffin \& others $v$ South West Water Services Ltd, High Court, Chancery Division, [1995] IRLR 15.

278 Council Directive 75/129/EEC of 17 February 1975 on the approximation of the laws of the Member States relating to collective redundancies, OJ L 48, 22.2.1975, p. 29-30 (no longer in force).

279 See Griffin. According to the High Court, the public service as indicated by the Water Act 1991 also included "[...] a duty to provide a water main to provide sufficient water supplies for domestic purposes [...], a duty to make a connection between the main and a building for the purpose of providing a water supply to that building for domestic purposes [...], a duty to ensure a supply of water sufficient for domestic purposes and to maintain the connection between the main and the service pipe by which the water supply is provided [...], and a duty to provide a public sewer for the drainage for domestic purposes of premises in localities in its area." Ibid.

280 These powers included "[...] the power to impose temporary hosepipe bans [...], the power compulsorily to declare that sewers within the area of the sewerage undertaker and any sewage 
condition, that the provision of this service takes place under control of the State, the High Court finally observed that this condition was also fulfilled. In its analysis of this condition, the Court observed that it was necessary to appreciate several points that had been made clear in Foster:

"1. The question is not whether the body in question is under the control of the State but whether the public service in question is under the control of the State.

2. The legal form of the body is irrelevant.

3. The fact that the body is a commercial concern is also irrelevant.

4. It is also irrelevant that the body does not carry out any of the traditional functions of the State and is not an agent of the State.

5. It is irrelevant too that the State does not possess day-to-day control over the activities of the body."281

The Court went then to illustrate in extenso why the private water company was under State control. Among the considerations that the High Court took into account to conclude in the affirmative was the fact that the State appointed the water undertaker to exercise its activities in a particular region. It was also important that the State had also wide powers of control over the manner in which as a water and sewerage undertaker South West Water's functions were to be carried out. The legislation also made the State responsible to ensure that the interests of consumers and customers of the water services provided by the company are protected. Finally the Court noted that the State had "[...] extended powers to ensure that a company holding an appointment as a water or sewerage undertaker complies with the conditions of its appointment." 282 This led the High Court to conclude that the privatized water utility fulfilled all three conditions of the Foster test, and was thus a State authority against which EC directives are capable of direct enforcement.

More recent caselaw from the ECJ has confirmed Foster, while attempting to apply its conditions to concrete situations. Thus in the case of Rieser Internationale Transporte GmbH and Autobahnen- und Schnellstraßen-Finanzierungs-AG (Asfinag), the Court concluded that the provisions of a directive could be relied against a legal person governed by private law where the State has entrusted to that

disposal works which are so situated or which serve the whole or any part of that area are to be vested in the undertaker [...], power to alter the drainage system of premises within an area [...], power, with the approval of the Secretary of State, compulsorily to purchase land [...], the power to make by-laws with respect to any waterway owned or managed by it and with respect to any land held or managed with the waterway [...], the power to lay pipes in streets and other land [...] divers powers to enter land for various purposes [...] and, until 31 March 2000, power, as a water undertaker, to charge for its services by reference to the rateable value of a property rather than by reference to the consumption of water by the person concerned." Griffin. 
legal person a public-interest service (in casu levying tolls for the use of public road networks) and where it has direct or indirect control of that legal person. ${ }^{283}$

It would thus appear that under certain conditions, privatized bodies fulfilling a public service could be regarded as a State authority for the purposes of directly applying a directive. Again, as is the case in EU law, this may happen only in so far as such a directive contains provisions that are unconditional and sufficiently precise.

\subsubsection{Applicability of EU procurement law to private actors acting on behalf of the State}

The rules governing EU procurement law have been developed to ensure that the EU's Member States act in a transparent, non-discriminatory way when they intend to tender contracts for public works or the provision of services. These contracting partners are usually private enterprises offering the goods, services or capacity required by the tender in the competitive bid thereof. EU procurement law usually applies to the governmental authorities of the Member States. This raises the question as to which entities should be considered governmental for the purpose of applying all or some of its rules. In general, EU procurement law makes a distinction between two types of bodies that may be amenable to its rules: contracting authorities, or other bodies governed by public law, and other contracting entities not necessarily being public undertakings.

\subsubsection{Contracting authorities or other bodies governed by public law}

In principle the rules governing EU procurement law apply to all governmental authorities that are entrusted with closing the procurement contracts with the contracting partners bidding for the tender. These governmental authorities are referred to as contracting authorities. According to the two public procurement directives currently in force ${ }^{284}$ they are defined as

283 ECJ Case C-157/02, Rieser Internationale Transporte GmbH and Autobahnen- und Schnellstraßen-Finanzierungs-AG (Asfinag), [2004] ECR I-01477, paras. 24-28.

284 Directive 2004/17/EC of 31 March 2004 coordinating the procurement procedures of entities operating in the water, energy, transport and postal services sectors, and Directive 2004/18/EC of 31 March 2004 on the coordination of procedures for the award of public works contracts, public supply contracts and public service contracts. These directives replaced Council Directive 93/37/EEC of 14 June 1993 concerning the coordination of procedures for the award of public works contracts and Council Directive 93/38/EEC of 14 June 1993 coordinating the procurement procedures of entities operating in the water, energy, transport and telecommunications sectors. 
"State, regional or local authorities, bodies governed by public law, associations formed by one or several such authorities or one or several of such bodies governed by public law." 285

The directives further define bodies governed by public law as:

" $[\ldots]$ any body:

- established for the specific purpose of meeting needs in the general interest, not having an industrial or commercial character,

- having legal personality and

- financed, for the most part, by the State, regional or local authorities, or other bodies governed by public law; or subject to management supervision by those bodies; or having an administrative, managerial or supervisory board, more than half of whose members are appointed by the State, regional or local authorities, or by other bodies governed by public law[...]"286

A body that fulfills all three criteria may thus be considered a body governed by public law. The question has been raised whether former public entities that have been privatized may still be regarded as contracting authorities, as public undertakings, or as 'bodies governed by public law' as understood by the directives for the applicability of the rules of EU procurement law. ${ }^{287}$ A positive answer to this question would entail that this category of entities are fully subjected to all the rules governing EU procurement law.

The ECJ has paid attention to the question of what is actually meant by contracting authorities and other bodies governed by public law as understood in the directives. In particular, the Court has attempted to clarify with regard to the first criterion of Article 2 (1)(a) of Directive 2004/17/EC and Article 1(9) of Directive 2004/18/EC (and their respective predecessors) what may be understood by bodies "[...] established for the specific purpose of meeting needs in the general interest, not having an industrial or commercial character [...]"

The issue was first dealt with in the case of Gebr. Beentjes v. The Netherlands. 288 In this case the Court was asked to answer whether Directive 71/305/EEC (the predecessor of Directive 2004/18/EC) applied to the award of public works contracts by a local committee that had no legal personality, but whose functions and composition were governed by legislation, whose members are appointed by a provincial authority, and whose decisions were monitored by the State for

285 See Article 2 (1)(a) of Directive 2004/17/EC and Article 1(9) of Directive 2004/18/EC.

286 Ibid. In addition, Article 1(9) of Article 1(9) of Directive 2004/18/EC observes that States may provide a list of entities that fulfill the criteria referred to in (a), (b), and (c). The same definitions had been laid down in the Directives 93/37/EEC and 93/38/EEC. 
observance. The old directive stipulated that the State, regional or local authorities and the legal persons governed by public law specified in an annex to the directive were to be regarded as 'authorities awarding contracts'. In other words, the inquiry revolved around the question whether this committee could be considered as a contracting authority or as a body governed by public law. The Court held that for the purposes of the directive,

"[...] the term 'the State' must be interpreted in functional terms. The aim of the directive, which is to ensure the effective attainment of freedom of establishment and freedom to provide services in respect of public works contracts, would be jeopardized if the provisions of the directive were to be held to be inapplicable solely because a public works contract is awarded by a body which, although it was set up to carry out tasks entrusted to it by legislation, is not formally a part of the State administration. Consequently, a body such as that in question here, whose composition and functions are laid down by legislation and which depends on the authorities for the appointment of its members, the observance of the obligations arising out of its measures and the financing of the public works contracts which it is its task to award, must be regarded as falling within the notion of the State for the purpose of the abovementioned provision, even though it is not part of the State administration in formal terms." 289

From this conclusion, it would appear that the Court accepts that it is necessary to take a functional approach when determining if a particular actor can be regarded as being part of the 'State' in the context of EU public procurement law. As we will see in the next paragraphs, the Court has acknowledged this approach in later public procurement case law, although it has added a new twist to it based on the changes made to the procurement directives.

This functional approach appears to be linked to a particular concern of the Court. In the abovementioned citation, the Court is concerned that States could try to avoid their legal obligations under EU law with respect to the freedom of establishment and to provide services by entrusting certain tasks to actors that are not formally a part of the State. Member States could then claim that these actors are not bound by these rules because they are private and thus circumvent EU law. In the Court's opinion, it is thus necessary to apply a functional approach to these situations.

In Mannesmann Anlagenbau Austria AG and Others v Strohal Rotationsdruck GesmbH (Mannesmann) ${ }^{290}$ the Court was requested to answer the question whether a printer that had been entrusted with printing passports and other official administrative documents in Austria could be regarded as a body governed by public law within the meaning of the Directive. At issue was the requirement of

289 Ibid., paras. 11-12.

290 ECJ Case C-44/96, Mannesmann Anlagenbau Austria AG and Others v Strohal Rotationsdruck GesmbH (1998) ECR I-73. 
meeting needs of general interest, not having an industrial or commercial character in order to be considered a body governed by public law. Defendants in the main proceedings and Austria had argued that the entity was not a body governed by public law since meeting needs in the general interest (printing official administrative documents) constituted only a small portion of the body's activities. According to them, it mainly carried out commercial activities (printing and distributing books and other printed matter). The Court observed that the printer had been entrusted by legislation to meet needs of a general interest because the documents produced by the body

"[...] are closely linked to public order and the institutional operation of the State and require guaranteed supply and production conditions which ensure that standards of confidentiality and security are observed.".291

Furthermore, since the printer had been established by legislation to meet those needs in the general interest, it was immaterial for the definition that it was free to carry out other (commercial) activities. ${ }^{292}$ Similarly, the fact that the printer's official activities only constituted a small portion of its overall activities was also irrelevant, provided that it continued to attend to those needs of general interest. The Court concluded that the fact that "the body must have been established for the 'specific' purpose of meeting needs in the general interest, not having an industrial or commercial character, does not mean that it should be entrusted only with meeting such needs." 293 In addition, the Court found that the definition did not exclude the possibility that the commercial activities of a particular body may also be of such a nature that they also meet needs of a general interest. ${ }^{294}$

With Mannesmann, the Court has added an interesting twist to the functional approach. It appears that it is not relevant whether a particular entity exercising a function, which is essentially of a non-commercial nature, also carries out commercial activities to be considered a public body in the context of the directive. It is also not relevant that those activities of a non-commercial nature meeting a general interest comprise a small percentage of the total activities of that entity (while the rest of activities are commercial in nature). What matters is that the activity or function in question must meet a need in the general interest in order for that entity to be regarded as a body ruled by public law. Of course, the Court did not explain what meeting a need in the general interest would precisely mean in abstracto. It did, however, go on to reason what this would entail in the particular

\footnotetext{
291 Ibid., paras. 21-24.

292 Ibid., para. 25.

293 Ibid., para. 26.

294 Ibid., para. 30-33.
} 
situation of Mannesmann, thus suggesting that it would rather decide on a case by case basis what meeting a need in the general interest might mean. ${ }^{295}$

The Court's opinion on this matter was reaffirmed in the case of Gemeente Arnhem and another v. BFI Holding $B V(B F I) .{ }^{296}$ The case revolved around the award of a contract for the recollection and treatment of household and industrial waste under Directive 92/50/EEC relating to the coordination of procedures for the award of public service contracts, which also included the definition of a body governed by public law. In $B F I$ the ECJ was requested to clarify the relationship between the terms 'needs in the general interest' and 'not having an industrial or commercial character'. ${ }^{297}$ The Court first observed that the term 'needs in the general interest' actually establishes a subcategory of needs that are not of an industrial or commercial character. ${ }^{298}$ The Court then addressed the issue of whether the term 'needs in the general interest, not having an industrial or commercial character' excludes needs that can also be met by private undertakings. The respondent in the main proceedings had argued that the possibility of a body governed by public law must be ruled out if certain activities are being performed on a competitive basis because private undertakings are allowed to carry out the same activities as public bodies. In the particular case of BFI the respondent observed that more than half the municipalities in the Netherlands had entrusted the collection of waste to private economic operators. They reasoned that the collection of waste was thus a commercial market governed by competition between undertakings. Therefore the entities active in it did not constitute bodies governed by public law within the meaning of the directive. The Court was not willing to follow this line of reasoning. It first noted that the directive refers only to the needs that an entity must meet and does not say whether or not those needs may also be met by private undertakings. ${ }^{299}$

295 See also the conclusions of Advocate General Alber in the case of Adolf Truley GmbH $v$. Bestattung Wien GmbH (ECJ Case C-373/00, Adolf Truley GmbH v. Bestattung Wien GmbH (2002) ECR 2003 I-01931), were he concluded that "[t]he term needs in the general interest should be interpreted in accordance with Community law. Only when this abstract legal concept is applied to a practical set of circumstances do the legal and factual situation of the body concerned and, in this context, national law become relevant[,]" at para. 116. ECJ Case C-360/96, Gemeente Arnhem and another v. BFI Holding BV (1999) All ER (EC), p. 709.

297 More specifically, the Court was asked to explain whether the latter expression limits the term 'needs in the general interest' to those which are not of an industrial or commercial character or whether it means that all needs in the general interest are not industrial or commercial in character.

298 Ibid., para. 34. The Court further reasoned that "[i]f the Community legislature had considered that all needs in the general interest were not of an industrial or commercial character it would not have said so because, in that context, the second component of the definition would serve no purpose."

Ibid., para. 40 . 
According to the Court, the fact that there is a competive market does not rule out the possibility of public law entities being active in it. ${ }^{300}$ The Court then stated that

[...] since it is hard to imagine any activities that could not in any circumstances be carried on by private undertakings, the requirement that there should be no private undertakings capable of meeting the needs for which the body in question was set up would be liable to render meaningless the term 'body governed by public law' used in [the directive]."301

On the other hand, the ECJ recognized that the presence of strong competition in a particular market could be indicative of the absence of a 'need in the general interest, not having an industrial or commercial character'. ${ }^{302}$ Nevertheless the Court attempted to differentiate these needs from needs in the general interest that do have an industrial or commercial character. It did so by highlighting a list of bodies governed by public law contained in an Annex to Directive 93/37 to which Directive $92 / 50$ referred $^{303}$ and then observing that,

"[a]n analysis of that list shows that in general the needs in question are ones which, for reasons associated with the general interest, the state itself chooses to provide or over which it wishes to retain a decisive influence.

In this case it is undeniable that the removal and treatment of household refuse may be regarded as constituting a need in the general interest. Since the degree of satisfaction of that need considered necessary for reasons of public health and environmental protection cannot be achieved by using disposal services wholly or partly available to private individuals from private economic operators, that activity is one of those which the state may require to be carried out by public authorities or over which it wishes to retain a decisive influence." 304

$300 \quad$ Ibid., para. 43.

301 Ibid., para. 44. As an aside this observation could be of importance in the privatization debate. What the Court is essentially stating here is that there are hardly any activities that cannot be carried out by private actors. This would include, of course, also activities or functions that fulfill a need in the general interest, not having an industrial or commercial character. In general this means that in the eyes of the Court, (most of) these activities could be privatized, but since they appear to be of such an importance public law rules such as EU procurement law would apply to the bodies entrusted with these activities.

302 Ibid., para. 49.

303 This non-exhaustive list contains a description of bodies throughout the Member States that meet a need in the general interest, not having an industrial or commercial character. Among them are some private law bodies performing non-profit activities such as hospitals. The list was updated for Directive 2004/18/EC. A similar list has been drafted for Directive 2004/17/EC on the procurement procedures of entities operating in the water, energy, transport and postal services sectors. The list included in the Annex to this directive includes the private undertakings which have taken over the provision of gas, electricity and water in the United Kingdom since their privatization in the early 1990s.

$B F I$, paras. 51-53. 
The Court then concluded that the term 'needs in the general interest, not having an industrial or commercial character' does not exclude needs which are or can be satisfied by private undertakings as well.

Of relevance for the present discussion is that the definition of a 'body governed by public law' depends on what activities such a body performs. When these activities meet a need of general interest that in itself is not (fully) commercial in nature, then such a body could be subjected to EU procurement law. What a need of general interest actually is, depends on the circumstances of the case. Nevertheless, an indication can be inferred from activities that a State chooses to provide itself, or over which the State wishes to retain a decisive influence or control in case these activities have been delegated to other (private) entities.

\subsubsection{Other contracting entities not necessarily being public undertakings}

The applicability of the rules of EU procurement law depends on whether a particular body can be labeled a contracting authority, public undertaking, or as a body governed by public law. However, States may delegate the provision of services to private entities through the granting of exclusive rights through the use of concession contracts. Therefore the EU lawmaker has extended, albeit on a limited basis, the reach of EU procurement law to these entities.

Article 2(2)(a) of Directive 2004/17/EC on the procurement procedures of entities operating in the water, energy, transport and postal services sectors not only applies to standard contracting authorities but also to public undertakings that are involved in the provision of, inter alia, water, electricity, gas, transportation and postal services. More importantly, Article 2(2)(b) of the Directive, however, also opens the possibility of applying EU procurement rules to other (private) entities that are not strictly speaking former State actors (such as contracting authorities and/or public undertakings). According to this provision the Directive also applies to other contracting entities,

"[...] which, when they are not contracting authorities or public undertakings, have as one of their activities any of the activities referred to in Articles 3 to 7 [e.g. in the sectors of water, electricity, gas, transportation and postal services, $A H W]$, or any combination thereof and operate on the basis of special or exclusive rights granted by a competent authority of a Member State."

Private entities that have been entrusted with the activities mentioned above on the basis of exclusive rights granted by a Member State, and in addition are involved in procurement procedures as contracting entities are also subject to the rules of EU procurement law. This is the case with private entities that through concession contracts have been contracted to take over certain activities or services from the 
State. Manunza calls this category of bodies subject to EU procurement law private entities $a b$ initio. ${ }^{305}$ She also observes that these entities may be fully or partially subject to these rules in contrast to former public entities that have been privatized. ${ }^{306}$

Directive 2004/18/EC on the coordination of procedures for the award of public works contracts, public supply contracts and public service contracts also takes into account the possibility that Member States may delegate or grant exclusive rights to non-State entities to carry out public service activities. Thus according to Article 3 of Directive 2004/18/EC, when a contracting authority (e.g. a public entity sensu stricto)

“[...] grants special or exclusive rights to carry out a public service activity to an entity other than such a contracting authority, the act by which that right is granted shall provide that, in respect of the supply contracts which it awards to third parties as part of its activities, the entity concerned must comply with the principle of nondiscrimination on the basis of nationality."

This means that such non-State entities are only partially subjected to Directive 2004/18/EC with respect to supply contracts. They are only required to comply with the principle of non-discrimination and not required to comply with the tendering rules of the directive as such. This was confirmed by the ECJ in the case of Unitron Scandinavia A/S and 3-S A/S, Danske Svineproducenters Serviceselskab $v$. Ministeriet for Fødevarer, Landbrug og Fiskeri. The Court held that with respect to non-State entities entrusted with a public service, "[...] the body in question must comply with the principle of non-discrimination on grounds of nationality." 307 The Court then added that

"[a] systematic interpretation of that provision therefore shows that the contracting authority is not required to demand that the body in question comply with the tendering procedures laid down by Directive 93/36 [which was later incorporated in Directive 2004/18/EC].

Manunza, EG-aanbestedingsrechtelijke Problemen, p. 64.

Ibid., p. 64-65. For the sake of completeness, it should be noted that the Directive does not apply to the awarding of concessions that have as objective allowing other bodies carry out those activities. According to Article 18 of the Directive, the rules of the directive do not apply to works and service concessions which are awarded by contracting entities carrying out one or more of the activities referred to in Articles 3 to 7 of the Directive, where those concessions are awarded for carrying out those activities. These contracting entities (whether public law bodies or private bodies operating under a concession), are however subjected to the remaining rules of EC law with respect to the free movement of goods and services and the freedom of establishment. See ibid., p. 138-147.

ECJ Case C-275/98, Unitron Scandinavia A/S and 3-S A/S, Danske Svineproducenters Serviceselskab v. Ministeriet for Fødevarer, Landbrug og Fiskeri, (1999) ECR I-08291, para. 29. See also Manunza, p. 136-137. 
It should be noted, however, that the principle of non-discrimination on grounds of nationality cannot be interpreted restrictively. It implies, in particular, an obligation of transparency in order to enable the contracting authority to satisfy itself that it has been complied with. ${ }^{308}$

In other words, although the directives rules are not in toto applicable to non-State entities with regard to public supply contracts, the applicability of the EU-wide principle of non-discrimination on the grounds of nationality requires these entities to act in a transparent way in order to allow the public authorities to control whether these entities have complied with the principle. This entails, of course a duty of care on the side of Member States.

A duty of care is also present in Article 8 of Directive 2004/18/EC. This provision is intended for public contracts that are subsidized by Member States. According to Article 8 Member States are obliged to take the necessary measures to ensure that non-State entities receiving subsidies from Member States for executing public contracts comply themselves with the rules of the directive.

In sum, although non-State entities that have been entrusted with the provision of certain public services are not expected to comply with all the rules of EU procurement law, they are subject to the general regime of EU/EC law such as the provisions regarding the freedom of establishment, the freedom to provide services and the principle of non-discrimination on the basis of nationality. In addition Member States are expected, under certain circumstances, to see that non-State entities carrying out these services abide by the general rules of procurement law.

\subsubsection{Some observations}

As illustrated by the previous paragraphs, the various fields of EU law have been confronted with the issue of applicability to private entities of norms meant for proper Member States authorities. Under the evolving case law, it has become accepted that private entities may be equated to public ones for the purpose of applying certain rules of EU law. In interpreting the rules of EU law, the ECJ has adopted a functional approach for determining whether private entities can indeed be equated with public ones. Among the considerations that can be relevant for this analysis are whether the private entities are involved in activities or functions related to the exercise of official authority, or whether such entities are entrusted with the provision of public services or activities that fulfill needs in the general interest and which are not of a commercial or industrial character. 
With respect to privatization and the amenability of private entities to public law norms such as human rights, it is suggested that human rights monitoring mechanisms could follow a similar approach as used under EU procurement law. This would mean that privatized entities could be directly held responsible for their conduct if their activities meet a certain general interest such as the provision of water, public safety, the maintenance of law and order, or national security, whenever these interests are closely linked to human rights obligations. Public entities serving a general interest are expected to respect the obligations linked to the way that interest needs to be served. Thus, the general interest to secure society from criminals by enclosing them in prisons is closely related to human rights obligations pertaining to human conditions of persons in places of detention and the prohibition of torture. Services related to these interests may be (and are being) provided by private entities. However, it is arguable that due to the nature of the interests involved and the externalities that are bound to them (such as public health as related to the provision of clean water or public safety with regard to prisons), the State will be moved to provide such services in the absence of private activity or will wish to retain some control or supervision over them through regulation or licensing systems. This argues in favour of rendering private entitities providing such services directly amenable to human rights law.

\subsection{Functions of a public nature and public authorities in the United Kingdom}

The potential applicability of public law norms to private entities performing public functions has been debated in the United Kingdom since the beginning of the 1980s. Various industries and services were privatized and private entities were entrusted with various functions, tasks or services formerly performed by nationalized industries or public bodies. ${ }^{309}$ This was the case inter-alia in the sectors of gas and electricity, ${ }^{310}$ water, ${ }^{311}$ education, ${ }^{312}$ and prisons. ${ }^{313}$ In light of these privatization efforts, the question was raised whether the conduct of certain private entities carrying out these activities entrusted to them by public authorities was amenable

309

310

311

312

p. 248

313 The privatization of prisons was allowed through sections 84-89 of the Criminal Justice Act 1991. 
to judicial review, which in principle is only applicable to public law bodies. ${ }^{314}$ The British courts have gradually but reluctantly accepted that this may indeed be the case. Influential in this respect was the decision of the British Court of Appeal in $R$. v. Panel on Take-Overs and Mergers, ex p. Datafin (hereinafter Datafin) in which it was recognized that in deciding whether a particular body is amenable for judicial review it is necessary to take into account the nature of the functions performed by that body rather than only examining the formal source of its powers. ${ }^{315}$ Following the adoption of the Human Rights Act (HRA), which incorporated the ECHR into UK law in 1998, a similar question was formulated: are the provisions of the ECHR operating through the HRA applicable to private bodies entrusted with public tasks, in light of the lack of direct horizontal application of the ECHR? Early case law following the adoption of the HRA has cautiously confirmed that it is possible to apply the Convention's rights to private entities carrying out functions, tasks or services of a public nature, although it would appear that the UK courts are not willing to interpret the circumstances under which this could happen in a broad way. The developments in UK law with respect to the amenability of judicial review and the applicability of the ECHR through the HRA to the conduct of private bodies, will be examined below.

\subsubsection{Judicial review of private actors exercising public functions}

Judicial review of administrative action has grown in importance as one of the methods for holding individuals and bodies performing public functions in the UK accountable for their conduct. ${ }^{316}$ The lack of a separate administrative or constitutional court system in the UK has not prevented its courts from duly controlling the State's activities, and the instrument of judicial review has greatly helped to shape administrative law in spite of the apparent judicial restraint these courts have exercised from time to time. ${ }^{317}$ The process of judicial review, whereby a court exercises its supervisory jurisdiction over the decisions of bodies or persons who are charged with the performance of public acts and functions, is concerned with reviewing the decision making process of a particular decision taken by these bodies. ${ }^{318}$ It is meant to control administrative action and is thus in principle only applicable to public law bodies.

314 See also D. Pannick, "What is a Public Authority for the Purposes of Judicial Review?," in Current Legal Problems: New Directions in Judicial Review, ed. J.L. Jowell and D. Oliver, London: Stevens \& Sons (1988), p. 24.

315 R. v. Panel on Take-Overs and Mergers, ex p. Datafin plc [1987] Q.B. 815, to be discussed in more detail below. See also S Fredman and G.S. Morris, "The Price of Exclusivity: Public and Private Re-Examined," Public Law (1994), p. 72. Administrative Action (London: Sweet \& Maxwell, 1995) paras. 1-001-001-003 and 001-033.

318 M. Supperstone and J. Goudie, Judicial Review (London: Butterworths, 1992) p. 24. 
The decision of the House of Lords in O'Reilly v. Mackman ${ }^{319}$ in 1983 forced judges to differentiate between public law applications and private law actions. ${ }^{320} \mathrm{Up}$ to the mid 1980s the dominant method of courts to decide whether activities were subject to public law and thus amenable to judicial review was by considering the source of the power being exercised. ${ }^{321}$ Judicial review could only be exercised in respect of a body whose functions derive from statute. Where the source of power was statutory, the constitutional justification for allowing for judicial review was the ultra vires doctrine. In contrast, a body deriving its powers from a (contractual) agreement between parties was not subject to judicial review. It has nevertheless not been easy to differentiate between bodies that are subject to judicial review, usually public bodies, and others which are not, in spite of various attempts to analyze the possible criteria that may help to distinguish a 'public body' from others. ${ }^{322}$

The decision of the Court of Appeal in Datafin has helped, however, to shed more light on the issue of applicability of judicial review to other bodies than public authorities strictly speaking. ${ }^{323}$ Datafin involved a negative decision of the Panel on Take-overs and Mergers to impose sanctions to a number of financial bodies following allegations of misconduct. The Panel is a financial regulatory body with no legal personality, no statutory underpinnings or prerogatives and no contractual relationship with the financial market or with those dealing with that market. The members of the Panel are chosen by several financial and industrial associations and committees. The panel's main activities concern the interpretation and enforcement of the City Code on Take-overs and Mergers.

The company seeking the sanctions, Datafin, sought leave at a lower court to apply for judicial review of the Panel's decision, but its application was dismissed. At the Court of Appeal, the question came up whether "[...] the historic supervisory jurisdiction of the Queen's courts extends to such a body discharging such functions, including some which are quasi-judicial in their nature, as part of such a system[,]"324 in view of the fact that the Government was depending more and more on non-governmental institutions to perform regulatory activities to the extent that they were being incorporated in the Government's regulatory network.

O’Reilly v. Mackman, [1982] 3 All ER 1124, [1983] 2 AC 237, [1982] 3 WLR 1096, HL.

Supperstone and Goudie, Judicial Review, p. 17. See also de Smith, Woolf, and Jowell, de Smith, Woolf \& Jowell: Judicial Review of Administrative Action, para. 3-012, and Graham, "Human Rights and the Privatisation of Public Utilities and Essential Services," p. 44.

Pannick, "What is a Public Authority for the Purposes of Judicial Review?," p. 27; Supperstone and Goudie, Judicial Review, p. 27; Woolf, Jowell, and Le Sueur, de Smith, Woolf \& Jowell's Principles of Judicial Review, para. 3-012.

Pannick, "What is a Public Authority for the Purposes of Judicial Review?," p. 24 and 29.

See also ibid., p. 32.

Datafin. 
The Panel argued that jurisdiction to exercise judicial review only extended to bodies whose power derived from legislation or the exercise of prerogative. Datafin, on the other hand, contended that this view was too narrow and that besides looking at the source of a body's power it is also necessary to see whether the body "[...] operates as an integral part of a system which has a public law character, is supported by public law in that public law sanctions are applied if its edicts are ignored and performs what might be described as public law functions." 325 The Court unanimously agreed with the arguments put forth by Datafin. The Court noted that the panel was without doubt performing an important public duty. They then reasoned that as long as there is a possibility, however remote, that the Panel might abuse its broad powers, then it would be wrong not to subject the Panel's decisions to judicial review. ${ }^{326}$ Accordingly, the Court noted that the source of the power was not the sole test to be turned to. Although it admitted that the source of the power could often be decisive in determining whether that body is subject to judicial review, the Court observed that between the extremes where the source of power is a statute, or where the source of power is contractual,

"[...] there is an area in which it is helpful to look not just at the source of the power but at the nature of the power. If the body in question is exercising public law functions, or if the exercise of its functions have public law consequences, then that may, as counsel for the applicants submitted, be sufficient to bring the body within the reach of judicial review." 327

Accordingly, when non-State actors (a) have either through statute or through implication a public duty to exercise particular (public) functions, and when (b) these functions have public law consequences, then Courts may subject these bodies to judicial review. Thus the nature of the function is relevant in determining whether judicial review and thus the public law norms may be applied to non-State actors.

The question of what public functions are remains difficult to answer, and it is not always clear what criteria may be relevant in this respect. ${ }^{328}$ One of the judges in Datafin, Sir John Donaldson M.R., suggested that "[p]ossibly the only essential elements are what can be described as a public element, which can take many different forms, and the exclusion from the jurisdiction of bodies whose sole source of power is a consensual submission to its jurisdiction." 329 However, he noted that although in law reports it is possible to find enumerations of factors that may help

\footnotetext{
325 Ibid.

326 Ibid.

327 Ibid. See also $R v$ Servite Houses and another ex parte Goldsmith and another, High Court, Queen's Bench Division, Case No. CO/3652/99, [2001] LGR 55.

328 See also de Smith, Woolf, and Jowell, de Smith, Woolf \& Jowell: Judicial Review of Administrative Action, para. 3-027.

329 Datafin.
} 
in this regard, "[...] it is a fatal error to regard the presence of all those factors as essential or as being exclusive of other factors." 330

Subsequent case law has struggled to come up with criteria that may satisfy the functional test of Datafin. These efforts have resulted in an overlapping patchwork of factors that could play a role in determining whether a particular function is a 'public' function for the purpose of subjecting a non-State actor performing it to judicial review. According to De Smith, Woolf and Jowell the most outstanding factors are: ${ }^{331}$

a. A 'but for' test: whether, but for the existence of a non-statutory body, the Government would itself have carried out the function. ${ }^{332}$ In this case, the assumption is made that if there were no non-State actor carrying out a particular function, the State would have a duty to assume it, apparently because of the (public/ national) importance of the function itself. The importance of a function (in the sense of public or governmental interest) could serve as an indication of whether the function is public or not in order to justify public intervention in the absence of a non-State actor carrying it out. Examples are the management of a prison, the provision of essential utilities such as water and electricity or the provision of compulsory primary education. Arguably, it would be very likely that the Government would step in if the private bodies carrying out those activities became unable to fulfill them (see further below). In more recent case law, however, it would appear that this test has somewhat been diluted. ${ }^{333}$

b. Whether the Government has acquiesced or encouraged the activities of the nonState actor, has submitted the actor to governmental regulation, or has itself helped

330 Ibid. See also de Smith, Woolf, and Jowell, de Smith, Woolf \& Jowell: Judicial Review of Administrative Action, para. 3-027.

331 Ibid., para. 3-027, p. 170-172. De Smith, Woolf and Jowell warn that these factors should be weighed and balanced in the context of each specific case and overly reliance on just one of them should be avoided. Ibid., para. 3-028. Datafin and the factors developed in subsequent case law have helped to change the face of judicial review in so far as it has become more acceptable to submit the activities and decisions of certain private bodies to judicial review.

332 See $R \quad v$ Chief Rabbi of the United Hebrew Congregations of Great Britain and the Commonwealth ex parte Wachman, Queen's Bench Division (Crown Office List) [1993] 2 All E.R. 249; $R$ v Disciplinary Committee of the Jockey Club, ex parte Aga Khan, Court of Appeal, Civil Division [1993], 2 All ER 853; and more recently $R v$ Servite Houses. On the practical application of this test and a review of reservations expressed toward it see M. Hunt, "Constitutionalism and the Contractualisation of Government in the United Kingdom," in The Province of Administrative Law, ed. M. Taggart, Oxford: Hart Publishing (1997), p. 30-31.

333 In Donoghue v. Poplar Housing and Regeneration Community Association Ltd, [2001] EWCA Civ 595 (which will be further discussed in the next section), it was observed for example, that the fact that a body performs an activity that otherwise a public body would be under a duty to perform does not mean that such performance was necessarily a public function. See Donoghue v. Poplar Housing, para. 59. 
to establish the actor and its activities under its authority. ${ }^{334}$ This test entails a close relationship between the Government and the non-State actor that may manifest itself in different ways. This could be the case when the activities of the non-State bodies are closely enmeshed with those of the delegating State body, ${ }^{335}$ when they receive governmental funding to carry out a specific governmental policy that is statutorily mandated, ${ }^{336}$ or there is a substantial degree of Government supervision through regulatory agencies. ${ }^{337}$

c. Whether the non-State actor exercises monopolistic powers. ${ }^{338}$ It is worth noting, however, that the mere fact that a monopoly power is enjoyed does not entail $a$ priori the existence of a 'public function.' 339 The exercise of monopolistic powers in the private sphere, for example, does not mean that judicial review is available. The seriousness of the impact of a decision on those affected, ${ }^{340}$ the number of people affected by the non-State actor's action or its importance in national life, would appear not to be decisively relevant to conclude that a particular non-State actor is exercising a 'public function'.

d. Whether those affected by the conduct or decision of the non-State actor have consensually accepted to be bound by the latter's decisions. ${ }^{341}$ In fact, this factor entails the lack of an alternative: if an individual has no other choice but to be subjected to the decisions of a particular body, this could suggest the exercise of a public function. If the source of power is a consensual submission through a contract between private parties, judicial review will not be available. However, it is suggested that even in such a situation, it may well be the case that one of the parties enters into such an agreement due to the lack of choice. ${ }^{342}$ For example, since

See Datafin, Aga Khan, and Donoghue v. Poplar Housing, para. 65.

Or, as put in Aga Khan, when these activities have been woven into a system of governmental control.

See $R v$ Cobham Hall School Ex Parte S, High Court, Queen's Bench Division [1998] ELR 389, in which a private school receiving governmental funding to carry out a specific governmental policy related to providing special assisted space for pupils was held to be subject to judicial review in respect of a particular decision related to that policy.

Donoghue v. Poplar Housing, para. 65, with the caveat that "[...] the fact that the acts are supervised by a public regulatory body does not necessarily indicate that they are of a public nature." In the United Kingdom various regulators are in charge of supervising the activities of the privatized public utilities. Thus the Office for Water Services (OFWAT), regulates the activities of privatized water utilities, and the Office for Gas and Electricity Markets (OFGEM), regulates the activities of privatized gas and electricity utilities.

See Datafin and Aga Khan.

De Smith, Woolf, and Jowell, de Smith, Woolf \& Jowell: Judicial Review of Administrative Action, para. 3.027, p. 170-171.

See R. v. Chief Rabbi.

Datafin, and R. v. Chief Rabbi.

See also Hunt, "Constitutionalism and the Contractualisation of Government in the United Kingdom,” p. 32. 
potable water delivery and sewerage disposal are natural monopolies, a consumer has no choice but to accept a contractual service with the service provider. In such a situation, although the source of power (a contract for the delivery of water related services) appears to be consensual, thus eliminating the possibility of judicial review, it is in fact the opposite, and as such should not automatically mean that judicial review is not possible.

With respect to the topic of this study, De Smith, Woolf and Jowell point out that some activities of a private body

"[...] may be governed by the standards of public law when its decisions are subject to duties conferred by statute, or when, by virtue of the function it is performing or possibly its dominant position in the market, it is under an implied duty to act in the public interest." 343

This 'public' or 'governmental interest' aspect could be particularly important in differentiating purely commercial activities that do not have an effect on the public at large and thus are not susceptible to judicial review from those activities that, though also commercial, do have such an effect and are consequently subject to judicial review. The 'public interest' element has been referred to in at least one case in which it was held that while private actors

"[...] may be motivated by considerations of commercial profit (in the same way as private companies may carry out functions in relation to prisons or hospitals or housing) the impact [of some of their decisions adversely affecting the rights of individuals with respect to what may be called an important activity] remain broader matters of public concern and interest and have an impact upon and affect the public interest." 344

A concrete example would be the case of privatized water utilities in the United Kingdom, which by virtue of the fact that their activities constitute a natural monopoly in an important sector, and the fact that they have been given a statutory duty to provide their service through the Water Industry Act of $1999,{ }^{345}$ can take

343 De Smith, Woolf, and Jowell, de Smith, Woolf \& Jowell: Judicial Review of Administrative Action, para. 3-031. Emphasis added, $A H W$.

344 Wylie, Re An Application for Judicial Review, High Court of Justice in Northern Ireland Queen's Bench Division, NIQB 2 (19 January 2005), para. 21 (available through <www.bailii.org/nie/ cases $/ \mathrm{NIHC} / \mathrm{QB} />$ ). See with regard to the conduct of state-owned enterprises and decisions affecting the 'public interest' the decision of the Judiciay Committee of the Privy Council in Mercury Energy Ltd $v$ Electricity Corporation of New Zealand Ltd, (1994) 2 NZLR 385. In this case the Privy Council concluded that state-owned enterprises carrying out businesses in the interests of the public and which make decisions in the 'public interest' affecting the rights and liabilities of private individuals without affording them any redress, are subject to judicial review.

345 See Prosser, “Public Service Law: Privatization’s Unexpected Offspring,” p. 70. 
decisions that may be of public concern. Again, the fact that an activity may affect the 'public interest' in itself does not necessarily entail the conclusion that it is a 'public function'. To sum up, the nature of the function is a general factor to be taken into account when reviewing the applicability of public norms to privatized actors.

The approach to judicial review following Datafin, has helped shape the discussion under the Human Rights Act of what a 'public authority' is for the purpose of applying the Act. As we will see in the following section, the question as to whether a non-State body could be submitted to human rights review under the Human Rights Act for exercising 'public functions' and thus be considered as a 'public authority' is very similar to the question of submission to judicial review.

\subsubsection{Human rights review of private actors exercising public functions}

In 1998 the ECHR was incorporated in the United Kingdom through the adoption of the Human Rights Act (HRA) giving further effect to the rights and freedoms guaranteed under the Convention. ${ }^{346}$ The HRA entered into force in October 2000. As a result, persons affected by the actions or decisions of officials exercising a 'public function' in breach of the ECHR's rights may now file a complaint before a domestic court requesting judicial review of these actions. ${ }^{347}$

The HRA, like the ECHR, does not provide for direct horizontal application of the rights guaranteed by the Convention. ${ }^{348}$ An indirect horizontal application would nevertheless still be possible. ${ }^{349}$ Public authorities including the national courts

346 Until 1998 the United Kingdom, lacking a written constitution, did not have a bill of rights that could guarantee its citizens protection from human rights abuses by the State, its organs or agents, or other actors. Although the UK had ratified the ECHR and the ICCPR, individuals who claimed to be a victim of human rights abuses in the UK could not directly rely on the conventions' rights in the domestic courts since the latter did not have the power to enforce them. Woolf, Jowell, and Le Sueur, de Smith, Woolf \& Jowell's Principles of Judicial Review, para. 1-015. These victims could nevertheless seek redress under the individual complaints mechanism established under the ECHR or the ICCPR after having exhausted the national local remedies.

Ibid., para. 1-017.

348 See in general Hunt, "The 'Horizontal Effect' of the Human Rights Act." Coppel, The Human Rights Act 1998: Enforcing the European Convention in the Domestic Courts, p. 18, and Hunt, "Human Rights Review and the Public-Private Distinction," p. 73-88.

349 See the document prepared by the UK Government explaining the purpose of the HRA, White Paper, Rights Brought Home: The Human Rights Bill, Cmnd. 3782 (24 October 1997), hereinafter referred to as the White Paper, as well as the parliamentary debates surrounding the Act's adoption which suggest that direct horizontal effect was not intended for the HRA. During the parliamentary debates in the House of Lords, there was some discussion regarding an amendment to provide full horizontal effect to the Act. This amendment was however rejected. See Human Rights Bill [H.L.] House of Lords (Lords Hansard debate), vol. 583, columns 795- 
have to give effect to the rights and freedoms in the relations between private individuals, and a public authority may be found liable for a violation of a Convention right by a private body where the former indirectly contributed through its actions to the violation. Thus at the moment, under the HRA it is not possible to directly enforce the rights of the ECHR in legal disputes between private individuals, unless it is argued that the UK Government failed with respect to its positive obligations to protect individuals against violation of their Convention rights by these private actors. This is made more clear by Section 6(1) of the HRA which makes it "[...] unlawful for a public authority to act in a way which is incompatible with a Convention right." (emphasis added $A H W$ ). In addition, under Section 7(1)(a) (potential) victims of an act in violation of Section 6(1) may only "[...] bring proceedings against the authority under this Act in the appropriate court or tribunal [...]"350 The applicability of the HRA and thus also of the ECHR in the United Kingdom on private bodies exercising privatized tasks, therefore depends on whether they can be considered as a 'public authority'.

\subsubsection{Definition of a 'public authority' under the Human Rights Act}

According to the UK Government's White Paper on the HRA, the Act is first of all intended to prohibit 'public authorities' such as '[...] central government (including executive agencies); local government; the police; immigration officers; prisons; courts and tribunals themselves," or others exercising similar executive powers to act in a way which is incompatible with the Convention's rights. ${ }^{351}$ The HRA extends the scope of human rights review to other 'public authorities'. According to Section 6(3) HRA 'public authorities' also include (a) courts and tribunals, and more important for the purposes of the present study, (b) "any person certain of whose functions are functions of a public nature, but does not include either House of Parliament or a person exercising functions in connection with proceedings in Parliament." In practical terms, the HRA therefore differentiates between two types of 'public authorities':

809 (24 November 1997). See also Hunt, "The 'Horizontal Effect' of the Human Rights Act," p. 439; Coppel, The Human Rights Act 1998: Enforcing the European Convention in the Domestic Courts, p. 26.

350 Emphasis added $A H W$. However, Section 7(1)(b) adds that these persons may rely on the Convention right or rights concerned in any legal proceedings. Although this provision appears to accept a horizontal effect, it is only intended to mean that courts and their judicial decisions must be consistent with the Convention in normal court proceedings between private parties. This means that the Convention may be invoked in procedures between private parties only where a failure of a court to apply the Convention would result in a breach of the Convention rights for which the UK would be answerable in a proceeding before the ECtHR. Coppel, The Human Rights Act 1998: Enforcing the European Convention in the Domestic Courts, p. 26-27. See White Paper, para. 2.2. 
a. Those 'public authorities' that have been labeled as 'pure' public authorities and are in fact already directly covered by the Strasbourg case law (see Section 3.1.2 supra). These are authorities wielding governmental power such as the central and local governments, the police and the courts. ${ }^{352}$ All the activities of these bodies are covered by the Act ${ }^{353}$ including those that would normally be considered private (such as those in relation with the employment of staff). ${ }^{354}$

b. The second type of 'public authorities' are 'hybrid' or 'functional' public authorities. ${ }^{355}$ 'Functional' public authorities include private actors which exercise functions of a public nature. The White Paper explicitly observes that the activities of "[...] companies responsible for areas of activity which were previously within the public sector, such as the privatised utilities[,]" may also be challenged under the act to the extent that they are exercising public functions. ${ }^{356}$ Thus, although their 'public' acts will be subject to review for compatibility with the ECHR, their 'private' acts will not. ${ }^{357}$

The White Paper recognizes that the HRA's definition of what constitutes a 'public authority' is drafted in wide terms. ${ }^{358}$ The definition of Section 6(3)(b) led to some debate as to its real scope during the parliamentary discussions leading to the adoption of the HRA. In the House of Lords, for example, it was apparent that there was some concern that Section 6(3)(b) would be too broadly interpreted thus potentially covering non-public activities. ${ }^{359}$ In the House of Commons a proposal to draft a list of public authorities to be included in the Act and thus eliminate any uncertainty was discussed although in the end dismissed. ${ }^{360}$ The then Home Secretary, Jack Straw, observed that if a list of public authorities in the Act were to

352 See "The Meaning of Public Authority under the Human Rights Act," House of Lords, House of Commons, Joint Committee on Human Rights, Seventh Report of Session 2003-2004, HL Paper 39, HC 382 (hereinafter, the Public Authority Report 2004), p. 5. Carss-Frisk speaks of 'standard' public authorities. See M. Carss-Frisk, "Public Authorities: The Developing Defenition," European Human Rights Law Review (2002), p. 319.

353 See Public Authority Report 2004, p. 5.

354 See Public Authority Report 2004, p. 6. See also Coppel, The Human Rights Act 1998: Enforcing the European Convention in the Domestic Courts, p. 24; Carss-Frisk, "Public Authorities: The Developing Defenition," p. 319.

355 Carss-Frisk, "Public Authorities: The Developing Defenition," p. 319-320. The Joint Committee on Human Rights' Public Authority Report 2004 comments that the term 'hybrid' public authority is unhelpful because it focuses on the intrinsic nature of these bodies instead of the nature of their functions for the purposes of applying the HRA.

356 White Paper, para. 2.2.

357 See Section 6(5) HRA which reads: In relation to a particular act, a person is not a public authority by virtue only of subsection (3)(b) if the nature of the act is private.

358 White Paper, para. 2.2.

359 Human Rights Bill [H.L.] House of Lords (Lords Hansard debate), vol. 583, columns 794-803 (24 November 1997). This concern was brought up during a debate on a number of amendments regarding the applicability of the Convention to certain commercial activities and the Church of England.

360 See HC Deb. vol. 314, cols. 408-433 (17 June 1998). 
be drafted, it would quickly go out of date in the light of the quick privatization of various public bodies. ${ }^{361}$

In any case the wide-ranging definition of 'public authority' was justified as necessary to create a "[...] correspondingly wide liability [to] provide as much protection as possible for the rights of individuals against the misuse of power by the state within the framework of a Bill which preserves parliamentary sovereignty." 362 Moreover, it would seem that the addition of Section 6(5), which states that acts of a private nature are not covered by the Act in the case of 'hybrid' public authorities, was sufficient enough to limit the scope of application of Section 6(3)(b).

In sum, Section 6(3) HRA combines an institutional test ('pure' public authorities) with a functional test ('functional' or 'hybrid' public authorities) to determine whether a particular body can be subjected to the Act and thus to the Convention. Section 6(3)(b) HRA is a purely functional provision which pays attention to the nature of the function rather than looking at the source of power or the actual nature of the body or institution carrying out the function. The main objective of this provision is to secure the rights enshrined in the ECHR. The debates in the Parliament indicate that Section 6(3)(b) was inspired by the approach taken by the Court of Appeal in Datafin. On the other hand, it has been argued that blindly applying the same approach used in judicial review cases is missing the point of the Section 6(3)(b): amenability to judicial review is grounded in procedural concerns, whereas Section 6(3)(b) is about identifying the reach of substantive obligations under the HRA. ${ }^{363}$ As was acknowledged in the White Paper, the wide scope of this provision makes it suitable to cover those activities of privatized bodies that are deemed to be of a public nature and thus to investigate whether these activities (including both acts or omissions) conform to the Convention's rights.

361 Ibid., column 433. A similar debate had been held earlier in the House of Lords where it was stated that "[t]he disadvantage of a list is [...] that it would be easy to regard it as exhaustive or to suggest that any non-listed body could be a public authority only if it was sufficiently analogous in its essential characteristics to a body that had qualified in the list." See Human Rights Bill [H.L.] House of Lords (Lords Hansard debate), vol. 583, column 796 (24 November 1997).

362 Human Rights Bill [H.L.] House of Lords (Lords Hansard debate), vol. 583, columns 808 (24 November 1997).

363 R. Costigan, "Determining 'Functions of a Public Nature' under the Human Rights Act 1998: A New Approach," European Public Law Vol. 12 (2006), p. 578. According to Costigan, the use of a judicial review type of approach in Section 6(3)(b) cases has led to a narrow interpretation of the latter, limiting its practical use and going against the original intentions of the HRA, which is to extend the protection of the ECHR to those who are at the mercy of 'functional' public authorities. This will be discussed in the next sub-section. 


\subsubsection{Interpretation of the Human Rights Act's 'public authority' by British courts}

Since the HRA's entry into force, Section 6(3)(b) HRA has been invoked in a number of cases involving the conduct of non public bodies, some of which were exercising activities that had been delegated to them following privatization. An evaluation of case law surrounding Section 6(3)(b) HRA by the British Parliament's Joint Committee on Human Rights concluded that courts have been reluctant to apply Section 6(3)(b) HRA as intended by Parliament. ${ }^{364}$ Courts, apparently, have rather opted for a mixed approach where institutional aspects such as the source of power (contractual or statutory) also play a role in determining whether a particular body is a public authority exercising functions of a public nature in a similar way to the approach adopted in the case law following Datafin.

The first case that dealt with the application of Section 6(3)(b) was Donoghue v. Poplar Housing and Regeneration Community Association Ltd. ${ }^{365}$ In Poplar a tenant was faced with eviction from a social housing complex managed by Poplar Housing, a so-called registered social landlord. These are private organizations that have been entrusted with the management of social housing stock that had previously been in the hands of the local authorities. The transfer of management in the housing stock to private entities such as RSLs had been carried out in the context of a legislative framework that aimed at increasing social housing stock by allowing local housing authorities to cooperate with private entities. The tenant in Poplar argued that her eviction would be contrary to Article 8 ECHR on the right to respect to privacy, family life and home.

The question that was thus brought up was whether Poplar Housing was a public body or performing public functions within the meaning of Section 6(3)(b) HRA. The Court of Appeal agreed that the definition of public authority under Section 6 HRA, and of what is a public function should be generously interpreted. However, it observed that, "[t]he fact that a body performs an activity which otherwise a public body would be under a duty to perform, cannot mean that such performance is necessarily a public function." ${ }^{366}$ According to the Court of Appeal, Section 6 should not be interpreted to mean that the performance by a private actor of services

364 See Public Authority Report 2004, p. 6. See also ibid., p. 579. This concern was reiterated in a more recent report by the Joint Committee on Human Rights. See "The Meaning of Public Authority under the Human Rights Act," House of Lords, House of Commons, Joint Committee on Human Rights, Ninth Report of Session 2006-2007, HL Paper 77, HC 410 (hereinafter, the Public Authority Report 2007), p. 7. Donoghue v. Poplar Housing and Regeneration Community Association Ltd, [2001] EWCA Civ 595.

366 Ibid., para. 58. It also observed that a public body can use the services of a private body in order to perform its public duties. 
that had been carried out by a public body does not inevitably make the nature of these services public. Such an interpretation would be too broad and entail that private bodies temporarily carrying out acts of a private nature that have been entrusted to them by public bodies would also be covered by the HRA. ${ }^{367}$ The Court refused to accept this and stated that

\begin{abstract}
"Section 6(3) means that hybrid bodies, who have functions of a public and private nature are public authorities, but not in relation to acts which are of a private nature. The renting out of accommodation can certainly be of a private nature. The fact that through the act of renting by a private body a public authority may be fulfilling its public duty, does not automatically change into a public act what would otherwise be a private act [...] The purpose of Section 6(3)(b) is to deal with hybrid bodies which have both public and private functions. It is not to make a body, which does not have responsibilities to the public, a public body merely because it performs acts on behalf of a public body which would constitute public functions were such acts to be performed by the public body itself. An act can remain of a private nature even though it is performed because another body is under a public duty to ensure that that act is performed" 368
\end{abstract}

In sum, Poplar's conclusions appear to point out that in order for a private body to be considered a public authority within the meaning of Section 6(3)(b), three elements have to be present in the function carried out: (a) statutory authority for the service or activity being performed; (b) a public authority in the strict sense of the word must have a fair amount of control over the function exercised by the private actor; and (c) the acts of the private body must be closely enmeshed in the activities of a public body, or as the Court of Appeal put it: "the more closely the acts that could be of a private nature are enmeshed in the activities of a public body

367 As an example of extending the reach of the HRA too broadly, the court observed that a small hotel providing bed and breakfast accommodation as a temporary measure, at the request of a housing authority that is under a duty to provide that accommodation, the small hotel would be performing public functions and required to comply with the HRA. The Court stated that this could not be the intention of the HRA. Ibid.

368 Ibid., para. 58-59. It is worth observing that following this statement, the Court of Appeal made a reference to the Costello-Roberts v. UK case (see Section 3.1.2 supra) commenting that "[...] if a local authority, in order to fulfil its duties, sent a child to a private school, the fact that it did this would not mean that the private school was performing public functions. The school would not be a hybrid body. It would remain a private body. The local authority would, however, not escape its duties by delegating the performance to the private school. If there were a breach of the Convention, then the responsibility would be that of the local authority and not that of the school." Ibid., para. 60. Costigan has criticized this reference observing that the purpose of Section 6 is to actually make private bodies answerable themselves when they discharge public duties whereas the Costello-Roberts approach entails that the State itself is answerable for the conduct of the private school on the grounds of the positive obligations doctrine. Costigan, "Determining 'Functions of a Public Nature' under the Human Rights Act 1998: A New Approach," p. 582. 
the more likely they are to be public," and thus amenable to human rights review under the HRA.

Following Poplar, other British (administrative) courts have kept to the rather strict interpretation of Section 6(3)(b). In $R$ (on the application of Heather and others) $v$. The Leonard Cheshire Foundation and another, ${ }^{369}$ the Civil Division of the Court of Appeals concluded that private bodies providing or running public services under contractual arrangements with public bodies could not be regarded as 'public authorities' within the meaning of Section 6(3)(b) HRA. The case concerned the closing of a home for disabled people and relocation of some of the home's residents. Under statutory authority, local authorities in the United Kingdom have the possibility of providing residential accommodation to disabled persons who are in need of care and attention which would otherwise not be available to them. Once a disabled person's need of care and attention have been established, local authorities have a duty to make arrangements to provide for care placements in homes that have to be registered and conform with national legislation. Many local authorities choose to fulfill this duty by relying on private entities to provide the arrangements instead of themselves.

In Leonard Cheshire, local authorities had placed (and funded) a number of disabled persons in a care home managed by the Leonard Cheshire Foundation, a private charity organization that provides care and support services for the disabled. The Leonard Cheshire Foundation decided to close the home to open smaller communitybased homes and relocate the residents to these new places of residence. A number of residents sought to overturn this decision by way of judicial review arguing that in relation to them, the Leonard Cheshire Foundation was a public authority exercising functions of a public nature within the meaning of Section 6(3)(b) HRA, and was thus bound to respect the ECHR. They argued that the Foundation's decision to close the home was contrary to Article 8 ECHR.

The residents claimed that the Foundation's functions were of a public nature because: a. the State provided the funding for the placement; $b$. the State regulated the registration requirements of bodies providing care homes as required by national legislation; $\mathrm{c}$. if the private provider were not undertaking the function of managing the home, this would, under the statutory scheme, have to be undertaken by a State authority; $d$. if the functions were undertaken by the local authorities they would be themselves held accountable by public law standards for the same conduct exhibited by the Foundation; e. finally, they argued that a gap in public law protection would

369 Heather and others $v$ The Leonard Cheshire Foundation and another, Court of Appeal (Civil Division) [2002] EWCA Civ 366. See also K. Markus, "Leonard Cheshire Foundation: What is a Public Function?," European Human Rights Law Review (2003), p. 92. 
arise for persons in the same position as claimants if the same public law standards would not apply to the Foundation.

The court of first instance dealing with the case did not accept these arguments. ${ }^{370}$ It concluded that even though the legislature had permitted local authorities to provide mandatory services either themselves or by contracting with third parties, this did not of itself make the third parties public authorities or mean that they exercised public functions. In the words of the court, "[t]he third parties are simply contractors to the local authorities." 371 The Court of Appeal did not show much sympathy for these arguments either. The Court agreed that a local authority providing itself the accommodation for disabled persons, or making arrangements with the Foundation to provide for the accommodations, are both public functions. $^{372}$ However, it observed that a body like the Leonard Cheshire Foundation providing accommodation to those whom the authority owes a duty under national legislation is not performing a public function. Important in reaching this conclusion was the reasoning, also found in Poplar, that if it were found that the Foundation was performing a public function, then any lodging house or hotel providing accommodation for someone in relation to whom a local authority had a public duty to provide or secure the provision of accommodation, would become a public body. 373

Although this argument seems reasonable, it is possible to take issue with it. The Court seems to ignore the fact that determining whether a particular body is a 'functional' authority will remain a case-by-case exercise. It is necessary to make a distinction between the individual acts of the body and its functions. The former can be indeed private and as such will fall outside the scope of the review. However if those acts are performed in a wider context, for example when they are necessary

370 See Heather and others v. The Leonard Cheshire Foundation and another, Queen's Bench Division (Administrative Court), [2001] EWHC Admin 429, in which the presiding judge, following an extensive review of the case law pertaining to the applicability of judicial review to private entities in the wake of Datafin and Poplar, held: a. that public funding was not of itself indicative that a body exercises public functions notwithstanding whether the funding came from statute or contract; $b$. that State regulation if anything, points against the body regulated being a public authority (in this regard the judge mentioned that privatization had led to increasing regulation of private bodies, and that the regulator, not the regulated, were the actual public bodies); c. that the fact that the government would step in to provide a service if it was not provided by a private body was not sufficient in itself to conclude that a private body exercised public functions, as demonstrated in Aga Khan (see the previous sub-section); d. that it was a logical fallacy that if public authorities' activities are governed by public law that all bodies carrying on some of those activities are also subject to public law (the judge maintained that "[i]t is only if the activity itself involves a public function that public law applies."). Ibid., para. 48. Ibid., para. 49.

372 Leonard Cheshire Foundation (Court of Appeals), para. 15.

373 Ibid., para. 18. See also Oliver, "Functions of A Public Nature Under the Human Rights Act," p. 332-333. 
to fulfill a particular public interest, then it is possible to speak of a pubic function. The Court's argument ignores the fact that Section 6 provides a two-step approach to answering the question whether a particular body is a 'functional' authority and thus requires looking at the nature of the act. ${ }^{374}$

The Court of Appeal then held that whether a particular body could be regarded as a public authority under Section 6(3)(b) HRA depended firstly on the extent to which the activity performed by the body was publicly funded, although this is not by itself determinative of whether the function was public or private. ${ }^{375}$ Secondly, it also depended on whether the body was "[...] standing in the shoes of a public authority." ${ }^{376}$ For the Court this meant that legislation must allow the body to exercise statutory powers. In the eyes of the Court, the Foundation did not satisfactorily meet these criteria.

Although one can agree with the courts' arguments that the fact that activities of public authorities' are governed by public law does not necessarily mean that all bodies performing some of those activities are also subject to public law, it is still hard to fathom why this would exclude the functions described in Poplar and Leonard Cheshire (providing social housing in furtherance of public policy and providing care and support for disabled people at the request and cost of local public authorities, respectively) from being of a public nature. In Poplar the Court observed that the purpose of Section 6(3)(b) is not to transform a body, which does not have responsibilities to the public, into a public body just because it performs acts on behalf of a public body that would constitute public functions were such acts to be performed by the public body itself. It is debatable, however, that the nature of a function would change merely because the function has been transferred from a public body to a private one. If a function were of a public nature when carried out by a public actor, why would its nature cease to be public when it is delegated to a private actor? ${ }^{377}$ In the case of Leonard Cheshire, the function of placing an obligation on public authorities to provide for placement for persons with disabilities in a care home has been instituted by national legislation and is thus 'public'. It would follow that the delegation of the same function to a private body (as allowed by the same legislation) would not change its nature. Arguably, the Court chose an institutional approach to answer the question rather than the prescribed functional one. ${ }^{378}$ This approach served as a stepping stone for one of

\footnotetext{
374 See Costigan, "Determining 'Functions of a Public Nature' under the Human Rights Act 1998: A New Approach," p. 582.

375 Leonard Cheshire Foundation (Court of Appeals), para. 35.

376 Ibid.

377 See also P. Craig, "Contracting Out, The Human Rights Act and the Scope of Judicial Review," Law Quarterly Review Vol. 118 (2002), p. 558, and Costigan, "Determining 'Functions of a Public Nature' under the Human Rights Act 1998: A New Approach," p. 581.

See also Public Authority Report 2004, p. 15.
} 
the most recent cases handled by the House of Lords (YL v. Birmingham City Council and others, see further below).

A number of cases following Poplar and Leonard Cheshire, appear to take a more relaxed approach. In Aston Cantlow and Wilmcote with Billesley Parochial Church Council v. Wallbank and another ${ }^{379}$ the House of Lords was confronted with the question whether a parochial church council could be considered a public authority as understood by Section 6(3)(b) HRA. A parochial church council had intervened to make some repairs to the chancel of a church, which the owner (a lay rector of the Church of England) had neglected to carry out. ${ }^{380}$ The parochial church council then attempted to recover the costs for the repair from the lay rector. The lay rector claimed that it was illegal for a parochial church council to enforce a lay rector's obligation to meet the cost of chancel repairs and since the parochial church council was a public authority under Section 6(3)(b) HRA, its actions would be contrary to Article 1 of Protocol 1 to the ECHR on the right to property.

The House of Lords first laid out the definition of 'public authority' as understood in Section 6(1) HRA and observed that the classification of bodies such as local authorities, the police and the armed forces as 'core' public authorities depended on factors such as "[...] the possession of special powers, democratic accountability, public funding in whole or in part, an obligation to act only in the public interest, and a statutory constitution." 381 It also observed that 'core' public authorities did not enjoy rights under the ECHR (as made clear by Article 34 of the ECHR, see Section 3.3.2 supra). The Lords then noted that in a modern State, governmental functions extended far beyond those related to the maintenance of law and order, and that the manner in which many of these functions are discharged vary considerably. ${ }^{382}$ For example, States may choose to allow non-governmental bodies to discharge certain functions in the interests of efficiency and economy as in privatization. The Lords then commented that this type of situation is embraced by Section 6(3)(b) with the exception of those acts that are of a 'private' nature (as stated by Section 6(5) HRA). ${ }^{383}$ Thus, 'hybrid' bodies are not entirely disabled from having rights under the ECHR since they are only public authorities with respect to the functions of a public nature.

\footnotetext{
379 Aston Cantlow and Wilmcote with Billesley Parochial Church Council v. Wallbank and another, House of Lords, [2003] UKHL 37.

380 In the United Kingdom, the clergy of the Church of England is allowed to 'own' a local church and its land, as well as receive a percentage of the donations made to the church in exchange for maintaining and eventually repairing the property. Ibid., para. 7. See in also in general Oliver, "The Frontiers of the State: Public Authorities and Public Functions Under the Human Rights Act," p. 276.

383 Ibid.
} 
In identifying these 'hybrid' bodies and the public functions they perform, the House of Lords noted that,

"[c]learly there is no single test of universal application. There cannot be, given the diverse nature of governmental functions and the variety of means by which these functions are discharged today. Factors to be taken into account include the extent to which in carrying out the relevant function the body is publicly funded, or is exercising statutory powers, or is taking the place of central government or local authorities, or is providing a public service." 384

In essence these factors are similar to those already suggested by Poplar and Leonard Cheshire. Having stated the potential factors for identifying bodies exercising functions of a public nature, the Lords concluded that the parochial church council performed functions concerned with pastoral and administrative matters within the parish and did not perform functions of a public nature. It would appear that in Aston Cantalow the House of Lords attempted to encourage a more generous interpretation of public functions when compared to previous cases. ${ }^{385}$ The Lords also noted that the case law on judicial review may provide further assistance as to what does or does not constitute a function of a public nature under Section 6 of the HRA. ${ }^{386}$ The Lords did not, however, further elaborate on the issue of when a private body can be said to be 'taking the place of central government or local authorities', or what should be understood by 'providing a public service. ${ }^{387}$ The latter is somewhat unfortunate in the light of the position taken by the European Court of Justice and later by the House of Lords itself in Foster and by the High Court in Griffin (both cases are described in more detail above in Section 3.2.3).

Case law from lower courts has followed the lead set by Aston Cantalow and has been more receptive of the functional test under Section 6(3)(b) HRA. ${ }^{388}$ Thus, in $R$ v. Partnerships in Care Limited ${ }^{389}$ the Administrative Court held that a private psychiatric hospital was a public authority because it had a statutory duty to provide adequate professional staff and adequate treatment facilities, it was allowed to exercise detention powers on patients, and because there was a public interest in the hospital's care and treatment of its patients that could allow them to be released from that detention. ${ }^{390}$ Similarly, the Court of Appeal in Hampshire County Council

\footnotetext{
384 Ibid., para. 12.

385 Oliver, "Functions of A Public Nature Under the Human Rights Act," p. 333.

386 See Aston Cantlow, para. 52.

387 See also Oliver, "Functions of A Public Nature Under the Human Rights Act," p. 334.

388 Costigan, "Determining 'Functions of a Public Nature' under the Human Rights Act 1998: A New Approach,” p. 580.

$389 R$ (on the application of A) v. Partnerships in Care Limited, Queen's Bench Division (Administrative Court) [2002] EWHC 529 (Admin).

390

Ibid., para. 24.
} 
v. Graham Beer ${ }^{391}$ applied a functional test when to the question whether a private company with a monopoly in the operation of farmers' markets was a public authority under Section 6(3)(b). The Court of Appeal first referred to the case law on judicial review and the growing reliance of a functional test therein as an inspiration for the application of Section 6(3)(b). It then observed that the company had been set up by Hampshire County Council using statutory powers, and that it was performing the same functions (running the farmers' markets) that had been previously performed by the Council, including decisions that affected the rights of access to the markets. ${ }^{392}$

In Marcic $v$ Thames Water Utilities Ltd, a case dealing with a complaint against a privatized water utility (Thames Water) for, inter alia, breaching the HRA and ECHR's rights, the question whether Thames Water was a public authority within the meaning of Section 6 was not put in doubt by the courts that handled the case. The original complaint alleged that Thames Water had failed to take appropriate measures to prevent the damage caused to a private residence due to recurring flooding. The flooding and resulting nuisance was the consequence of overcharged sewers that could not cope with excess rainwater thus discharging surface and foul water on the property of complainant. It was claimed that the failure to act on the part of Thames Water resulted, inter alia, in a breach of the Human Rights Act due to violation of Article $8 \mathrm{ECHR}$ (on the right to privacy and family life) and Article 1 of the First Protocol to the ECHR on the right to property.

The first court to deal with the case, the Queen's Bench Division of the High Court held that Thames Water was in breach of Section 6(1) HRA and thus was liable for breaching Article 8 ECHR, and Article 1 of the First Protocol to the Convention. ${ }^{393}$ Following a recitation of 6(1) and 6(3)(b) HRA, the High Court went on to examine the specifics regarding the violation of Article 8 ECHR and Article 1 of the First Protocol. ${ }^{394}$ There was no further examination of whether Thames Water was a 'public authority' within the meaning of Section 6(3)(b). On appeal, Thames challenged the lower court's finding that its conduct contravened the HRA. The Court of Appeal (Civil Division) left the High Court's findings essentially untouched. ${ }^{395}$ The House of Lords, however, overturned the decision, not because

391 Hampshire County Council v. Graham Beer (T/A Hammer Trout Farm), Court of Appeal (Civil Division), [2003] EWCA Civ 1056.

392 Ibid., paras. 36 and 37.

393 See Marcic v Thames Water Utilities Ltd [2001] 3 All ER 698.

394 In reaching its decision the High Court drew parallels with Marcic's situation and the failure to act on the side of Thames Water, and those of the Strasbourg cases of López Ostra v. Spain and Guerra v. Italy (see Section 3.1.2 supra), while at the same time carrying out a balancing and margin of appreciation test along the lines of Hatton v. the UK (see Section 4.2.1 supra). Ibid., paras. 60-108.

395 Marcic v Thames Water Utilities Ltd [2002] EWCA Civ 64, paras. 106-111. See also Graham, "Human Rights and the Privatisation of Public Utilities and Essential Services," p. 43-44. 
Thames Water was not a 'public authority' under Section 6(3)(b), but because the claim under the HRA was not well founded. ${ }^{396}$ It would appear that the courts involved in this case assumed by default that Thames Water as a privatized water and sewerage undertaker fell within the definition of a 'public authority' as already indicated by the UK Government's White Paper on the HRA. 397

In spite of this case law, more recent judgments from the Court of Appeal and the House of Lords dealing once again with privately operated care homes providing care and accommodation for the elderly, have declined to apply a functional approach. Thus in Johnson and others v. London Borough of Havering ${ }^{398}$ the Court of Appeal was not convinced that private care homes were a 'public authority' under the HRA. In this case, the Court was faced with two related appeals. With regard to the first appeal, claimant argued that the London Borough of Havering's decision to close some public care homes and transfer others to the private sector would diminish her rights under Article 8 ECHR since Havering is a public authority and the private care homes are not. The Court concluded that this privatization did not breach any Convention rights as the actual public entities carrying out the decision still remained responsible for the conduct of the private care homes. ${ }^{399}$ This position is interesting since it follows the ECtHR's views that in principle privatization is allowed as long as it does not breach the rights enshrined in the ECHR, and that in any event the State remains primarily responsible. 400

The second appeal dealt with a removal from a care home and whether the care home could be considered a public authority since it was exercising the same tasks as publicly managed ones. Following a lot of interventions by third parties

396 Marcic v Thames Water Utilities Ltd [2003] UKHL 66 (04 December 2003), para 46. In the opinion of Lord Nicholls of Birkenhead, Lord Hoffman, and Lord Hope of Craighead, the High Court and the Court of Appeal had failed to take into account the statutory context created by the Water Industry Act of 1991, which also authorized the privatization of water and sewerage services. According to the Lords, the Water Industry Act provided the proper context to deal with this case. The complainant had neglected to present his case before the Director General of the Office for Water Services (OFWAT), the regulatory agency overseeing the activities and statutory duties of privatized water and sewerage utilities. The Lords held that this statutory context provides an adequate remedy in which the complainant could have submitted its (human rights based) complaint and seek the compliance of Thames Water with the duties that are laid on private water/sewerage undertakers under the Water Industry Act. In the opinion of the Lords this statutory scheme strikes a reasonable balance between the general interests of society and the interests of the individual as required by Hatton $v$. the UK, and is thus compatible with the complainant's Convention Rights, Ibid., paras. 40-43, 46, 49 and 71, 80-84 and 87.

It could be, however, argued that the courts in Marcic were also influenced by the fact that under the British Water Industry Act of 1991, privatized utilities are under a statutory duty to fulfill its service obligations to operate and repair the water and sewerage networks, and deal with nuisance caused these operations. Johnson and others v. London Borough of Havering [2007] EWCA Civ 26.

Ibid., paras. 21-25.

400 See Woś v. Poland, Section 3.1.2.3 supra. 
contending that private care homes are a 'public authority' under Section 6(3)(b), the Court nevertheless followed the narrow interpretation of Section 6 set by Poplar and Cheshire with regard to care homes. The Court argued that it is difficult to find in the Strasbourg case law "[...] any direct parallel to a private body becoming a public authority, therefore a body for which the state is directly responsible in the ECtHR, because it performs some public functions." 401 According to the Court, the reason behind this situation is that the consequence of applying Section 6(3)(b) to a care home would be that the whole jurisprudence of the ECHR and the whole of its articles would apply to that part of a care home's activities which is considered to be part of its activities as a public authority. For the Court of Appeal, this would be acceptable with respect of activities carried out by private entities that touch absolute obligations found in articles such as Article 3 ECHR (prohibition of torture). However, with regards to private activities touching qualified obligations like those found in Article 8 ECHR, this would go too far. Article 8 \$2 provides that public authorities may interfere with the exercise of the right to a private and family life when it is in accordance with the law and is necessary in a democratic society in the interests of national security, public safety or the economic well-being of the country, for the prevention of disorder or crime, for the protection of health and morals, or the protection of the rights and freedoms of others. In the eyes of the Court of Appeal these are standards that can only be applied to bodies that "[...] actually have power and responsibility to do something about national security or the protection of morals." 402 Thus it concluded that the question of whether a private body can be held to be a public authority will depend on the article of the Convention which the victim of an abuse claims to assert against the body. ${ }^{403}$

In the most recent decision issued by the House of Lords with regard to Section 6(3) (b), YL v Birmingham City Council \& Ors., ${ }^{404}$ the reach of Section 6(3)(b) has been further limited. The case revolved around a privately run care home for the elderly, which issued a notice to terminate the right of a resident to remain in the care home. The resident complained that the decision to terminate her accommodation was incompatible with Article 8 ECHR and was therefore unlawful under Section 6(1) HRA. The question was thus whether the private company in providing care and accommodation for the resident was exercising a public function for the purposes of Section 6(3)(b). In a three to two decision, the Lords concluded that the company did not fulfill the conditions to be considered a public authority. The majority

\footnotetext{
401 Ibid., para. 73.

402 Ibid., para. 74

403 Ibid,, para. 76. The Cour of Appeal then added, that "[i]f it is seriously asserted that the body has indulged in conduct contrary to article 3 , then to be able to make that assertion directly against the body will be the obvious course. But if the article in issue is article 8 , with all the difficulties indicated above, the question of whether it is necessary and justified to treat the body as a public authority for the purposes of article 8 will be much more difficult to answer." Ibid. 
considered that the company managing the care home was under a contractual duty, not a statutory duty to provide care. ${ }^{405}$ According to one of the Lords, the statutory duty to provide accommodation by a public authority did not provide for the delegation of those activities to other actors, unlike, for example, the delegation of functions to private companies managing a privatized prison. If that were the case, then the acts or omissions of a person that has been delegated certain functions through statutory means would be considered to be done or omitted to be done as it were the public authority itself.4 ${ }^{406}$ In addition to this, the majority also argued that the fact that an actual public authority would be responsible for performing the activity if nobody else would is relevant but not sufficient to conclude that a private actor doing the same thing is exercising a public function.

The majority of the Lords also discussed a number of additional factors that may indicate whether a function is of a public nature or not, but which on their own, according to the majority, are not decisive. In particular, the majority observed that the presence of regulation for certain functions does not entail that they are public in nature ${ }^{407}$ Moreover, the fact that a function may fulfill a public interest plays a role in determining whether a function is public or not, but is not to be accorded too much importance. ${ }^{408}$ The protection of vulnerable persons also does not mean that a function can be regarded as public. ${ }^{409}$

In applying these concepts to the case at hand, the majority of the Lords established that contracting out the provision of accommodation by Birmingham City Council to fulfill its statutory duties did not amount to the delegation of a public function: the actual provision of the care and accommodation was a contractual obligation governed by private law, whereas the decision to contract out was a decision based on a public function. ${ }^{410}$ Then it noted that the payment by Birmingham City Council to the private actor for the provision of the accommodation did not render such a

405 Ibid., paras. 31, 104 and 106. The statutory duty to arrange for the provision of accommodation by a public authority did not provide for the delegation of those activities to other actors, unlike, for example, the delegation of functions to private companies managing a privatized prison. Ibid., para. 104.

406 Ibid. This is the gist of section 70 of the Deregulation and Contracting Out Act 1994, under which the Secretary of State is entitled to specify statutory functions which may be discharged by a person other than the authority primarily responsible for them. Ibid., paras. 116 and 134 .

408 Ibid., para. 135. Contrast with the position adopted by the Inter-American Court of Human Rights in the case of Case of Ximenes-Lopes v. Brazil. See Section 2.2.1.1 supra. In that case, the Inter-American Court did put an emphasis on the public interest as a determinant factor to conclude whether private actors providing mental health care services and which were operating under a public health care scheme could be regarded to exercise elements of governmental authority.

409 YL v. Birmingham City Council \& Ors, para. 136.

$410 \quad$ Ibid., para. 141. 
provision as a function of a public nature. ${ }^{411}$ Finally, the fact that the City Council itself could have provided the accommodation itself is indicative, but not determinant on its own to consider the activity as being of a public nature. ${ }^{412}$ The majority of the Lords did agree, however, that "[t]here is undoubted force in the point that, if a person would have Convention rights if a service was provided by a core public authority, she should not lose them merely because the service is contracted-out by that authority to a private company."${ }^{\prime 413}$ Nonetheless, the problem arising from the facts of the case was that the public authority was not under a statutory duty to provide care and accommodation itself, just to arrange or pay for it. 414

In addition to these factors, one of the Lords speaking for the majority focused on wider policy considerations, some of which are worthy of noting here. In the first place, he observed that the case at hand would not be susceptible to judicial review in the United Kingdom nor would Applicant be able to submit a complaint before the Strasbourg Court against the private care home, although it would be able to do so against the City Council. ${ }^{415}$ In the second place, he noted that certain powers which may be regarded public in some States, may not be considered as such in others. Thus the provision care and accommodation in a care home would not be considered to be a 'governmental' function in the United Kingdom. ${ }^{416}$ In the third place, the private care home had not been endowed with special coercive statutory powers over the residents of the care home. ${ }^{417}$

Arguably $Y L v$ Birmingham City Council \& Ors. has set the bar very high with regard to particular services and functions which do not belong to 'core' State or governmental functions such as those related to the coercive use of force, and the adjudication of disputes, and the recollection of taxes. Before a private entity, which is carrying out certain contracted out functions, can be considered a "public authority' it must fulfill a long list of criteria. This makes it almost impossible in all but the most obvious cases (prisons, for example) for private actors to fall under Section 6(3)(b) of the Human Rights Act. This will be particularly true of private actors that carry out activities, which may be considered public, but also have a high commercial component. It is telling in this regard that the Lords consider that the provision of health or education services in a private school or private hospital is

\footnotetext{
411 Ibid., para. 142.

412 Ibid., para. 144.

413 Ibid., para. 146. In this respect, the Lords mentioned that the appellant in the case continued to enjoy her rights under the ECHR vis-à-vis the City Council.

$414 \quad$ YL v. Birmingham City Council \& Ors, para. 147.

415 Ibid., para. 161.

416 Ibid., para. 162.

417 Ibid., para. 166.
} 
not a function of a public nature, ${ }^{418}$ even if this serves a larger public interest in which arguably the State has a high stake.

One of the general concerns of the Lords is the fact that a decision to contract out certain services is a matter of policy and should better be left to the legislature. The legislator may deem it more efficient or convenient to contract out these services in order to "to avoid some of the legal constraints and disadvantages which apply to local authorities but not to private operators." $" 119$ A decision to apply Section 6(1) of the Human Rights Act in such situations would be contrary to this policy, something that the Lords are not relishing to do. One can, however, argue that it is precisely the legislature, which is worried about the narrow interpretation of the "public authority' provision. Thus, as observed at the beginning of this sub-section, the Houses of Parliament's Joint Committee on Human Rights has evaluated this case law in two reports dating from 2004 and 2007 and come to the conclusion that the narrow interpretation of 'public authority' was a worrisome development that increased rather than decreased the gap in protection of human rights intended by the HRA. ${ }^{420}$

\subsubsection{Some observations}

The developments in the UK with regard to the expansion of judicial review and the applicability of the HRA to the actions of private actors exercising public functions are of great importance to the discussion of this study, in particular because of the apparent realization that the privatization of various services and functions in that country has reshaped the landscape with regards to how private entities exercising these activities need to be held accountable in respect of the UK's human rights obligations. By adopting in the HRA a 'functional' approach in determining whether non-State actors exercising functions of a public nature can be held accountable for their activities in detriment of individuals' rights, the United Kingdom is one of the few countries that provide a practical way of holding these actors accountable. Although it would appear that British courts are somewhat reluctant to let go of previous conceptions with regard to the applicability of public law norms usually reserved to 'traditional' governmental entities, it is nonetheless an encouraging development that may help inspire other jurisdictions confronted with privatization.

$418 \quad$ Ibid., para. 164.

419 Ibid., para. 152.

420 See Public Authority Report 2004 and 2007 op.cit footnotes 352 and 364 supra. The Joint Committee, however, declined to discuss both Johnson and YL v. Birmingham City Council in its 2007 report since those cases were at that time bound to be handled by the House of Lords. See Public Authority Report p. 10. 
Of course, the UK's approach is not without problems. It has not always been apparent to the British courts how to apply the 'public authority' requirement with regard to private actors exercising 'public' functions. The UK's approach towards defining a 'public authority' is somewhat different than the one used in Strasbourg. While the latter has chosen a path where some official or statutory connection is required before a particular body may be considered a 'public authority' (as in Cansado Coca and Holy Monasteries see section 3.1.2 supra), the UK chose a functional approach where the nature of the function is more relevant. In actual practice however, and under the influence of the case law pertaining to judicial review, British courts faced with the question of what a 'public authority' is for the purposes of the HRA, have been rather cautious in solely applying the functional test. They still appear to require some statutory connection before conceding that the HRA may apply to a particular non-State body. This has been criticized as being contrary to the spirit of the HRA, which is to increase the protection of the ECHR by covering those activities that have sufficient public elements in them. ${ }^{421}$ As observed, not all courts have had a problem in applying the functional approach. In the particular case of privatized water and sewerage utilities, it would appear that it is a given that they are 'functional' public authorities within the meaning of Section 6(3)(b) HRA. This means, that in principle their 'public' activities may be subject to human rights review.

In addition it must be observed that until now, the case law under the HRA has barely scratched the surface with regard to the question as to what a function of a public nature actually is. The furthest the case law has come in determining what a public function entails is close governmental control of the activity in particular. During the parliamentary debates leading to the HRA, it was accepted that a public function in any case does not entail a function that is available to the public such as the activities of newspapers or supermarkets. Although some courts have concluded that the fact that activities which are or have been carried out by public authorities sensu stricto does not, in and of its own, transform their nature to a public one, the alternative presented by some of these courts fails to convince the present author. Whether private acts that are more closely enmeshed in the activities of a public body are more likely to be considered sufficiently public is also conjectural and in a sense contradictory to what the courts have concluded: these functions will usually include those that have been performed by public authorities under statutory duties. Looking at the nature of the activity or function in particular requires examining its context and aim. If the aim of such an activity is to achieve social goals that would otherwise not be attained by sole private action (social housing, social security, and universal services for water) without strict governmental supervision, and if these

421 A particular concern is that the current approach by UK courts may leave vulnerable service users, such as residents in care homes, without access to an effective remedy. See Public Authority Report 2007, p. 81. See in general Costigan, "Determining "Functions of a Public Nature' under the Human Rights Act 1998: A New Approach,” p. 601. 
goals are embedded in statutory obligations, then it would follow that this activity is 'public' This observation is even more valid when those that are affected by the exercise of this activity do not have choice and must rely on a particular body for its realization.

It would be fair to acknowledge that British jurisprudence on the issue of applying Section 6(3)(b) HRA to concrete private actors exercising 'public' functions is still in its infancy, even though it has allowed itself to be influenced by the more 'mature' experience of judicial review applicability. In addition it must be observed that until now, the case law under the HRA has been hesitant to go too far in accepting a broader interpretation of what a public function entails. Parliament, however, is of the opinion that a narrow interpretation of public function goes against the spirit of the HRA, which would certainly cover a broader range of privatized activities.

\subsection{Applicability of constitutional norms to private actors in the United States}

Ever since the adoption of the 1866/1870 Civil Rights Act and the introduction of new constitutional amendments in the aftermath of the American Civil War, the U.S. Supreme Court has ruled that constitutional and other federal civil rights provisions apply in principle only to federal and state governmental actors. ${ }^{422}$ The prohibition of a denial of federal constitutional rights under the Fifth Amendment and the due process of law clause of the Fourteenth Amendment, for example, do not apply to private parties. ${ }^{423}$ The activities of private actors are therefore not subject in principle to scrutiny under these constitutional provisions unless their conduct breaches another law such as the Civil Rights Act of 1964, which prohibits discrimination on the grounds of race, color, or national origin. ${ }^{424}$

This distinction between 'state action' and 'private action,' to use the American terminology, was first established by the Supreme Court in 1879, when it ruled that

422 Barak-Erez, "A State Action Doctrine for an Age of Privatization," p. 1171.

423 Robbins, "Privatisation of Corrections: A Violation of U.S. Domestical Law, International Human Rights and Good Sense," p. 63. The Fifth Amendment of the United States Constitution provides that "[n]o person shall be held to answer for a capital, or otherwise infamous crime, unless on presentment or indictment of a Grand Jury, except in cases arising in the land or naval forces, or in the Militia, when in actual service in time of War or public danger; nor shall any person be subject for the same offense to be twice put in jeopardy of life or limb; nor shall be compelled in any criminal case to be a witness against himself, nor be deprived of life, liberty, or property, without due process of law; nor shall private property be taken for public use, without just compensation." The Fourteenth Amendments states "[n]o State shall make or enforce any law which shall abridge the privileges or immunities of citizens of the United States; nor shall any State deprive any person of life, liberty, or property, without due process of law; nor deny to any person within its jurisdiction the equal protection of the laws."

Barak-Erez, "A State Action Doctrine for an Age of Privatization," p. 1171. 
"[...] the provisions of the Fourteenth Amendment [...] all have reference to state action exclusively, and not to any action of private individuals." ${ }^{\prime 25}$ This was shortly reaffirmed thereafter when the Court concluded that the constitutional Bill of Rights and the Reconstruction Amendments later introduced were intended to shield against the unique danger of government power abusing basic rights: "Individual invasion of individual rights is not the subject- matter of the amendment." ${ }^{926}$ The Court's position on this issue became known as the 'state action' doctrine. This effectively restricted a horizontal application of constitutional rights to protect individuals from harmful conduct amounting to constitutional violations by private entities and limited court actions seeking redress for these violations to suits against federal or state actors. The latter limitation is noticeable in 42 U.S.C. $\$ 1983$ which provides that "[A]ny person who, under color of any law, statute, ordinance, regulation, custom, or usage of any State, shall subject, or cause to be subjected, any person [...] to the deprivation of any rights, privileges, or immunities secured by the Constitution of the United States, shall, any such law, statute, ordinance, regulation, custom, or usage of the State to the contrary notwithstanding, be liable to the party injured in any action at law, suit in equity, or other proper proceeding for redress [...]" In order to successfully rely on 42 U.S.C. $\$ 1983$, one must prove that a particular actor is acting 'under color of law,' which is similar to proving that a particular conduct amounts to "state action. ${ }^{427}$ Indeed, the Supreme Court has recognized that the concepts of 'state action' and 'under color of law' are related. Thus the Court held that

"[i]f the challenged conduct of respondents constitutes state action as delimited by our prior decisions, then that conduct was also action under color of state law and will support a suit under 1983." 428

In sum, establishing 'state action' under the Fourteenth Amendment is a prerequisite for suing a private actor under 42 U.S.C. $\$ 1983,{ }^{429}$ although not all conduct that satisfies the under-color-of-state-law requirement would satisfy the Fourteenth Amendment requirement of state action. ${ }^{430}$ This would be the case if action under color of law were interpreted as meaning that the individual merely acted 'with the knowledge of and pursuant to [a] statute'. ${ }^{431}$

\footnotetext{
425 Virginia v. Rives, 100 U.S. 313, (1879), p. 318; see also United States v. Cruikshank, 92 U.S. 542, (1875), p. 554-555.

426 Civil Rights Cases, 109 U.S. 3 (1883), p. 11. See also Barak-Erez, "A State Action Doctrine for an Age of Privatization," p. 1171.

427 See Sklansky, "The Private Police," p. 1247.

428 Lugar v. Edmondson Oil Co., 457 U.S. 922 (1982), p. 935.

429 D.S. Spurlock, "Liability of State Officials and Prison Corporations for Excessive Use of Force Against Inmates of Private Prisons," Vand. L. Rev Vol. 40 (1987), p. 985.

430 Lugar v. Edmondson Oil Co., 457 U.S. 922 (1982), p. 935, footnote 18.

431 Ibid., citing Adickes v. S. H. Kress \& Co., 398 U.S. (1970), p. 162, n. 23. See also K.M. Blum and K.R. Urbonya, "Section 1983 Litigation," Federal Judicial Center, (1998), p. 5.
} 
The growing tendency to delegate or transfer tasks that were previously carried out by federal agencies or state officials to private entities, and the growing concern for this development especially with regard to the privatization of prisons in the United States, has led various scholars to discuss in which ways and to what extent the 'state action' doctrine plays a role in securing the rights of those affected by the conduct of these entities. ${ }^{432}$ The only possibility to apply constitutional rights to a private actor, and thus by extension to those carrying out privatized functions, tasks or services in the US, would be by establishing that this actor is performing a 'state action.' Likewise, seeking financial redress for harmful conduct from such an actor would require establishing that it acted 'under color of law.'

The Supreme Court itself has not remained indifferent to the transfer of State/ federal functions to private entities and has conceded in various cases that under certain circumstances, private parties carrying out these functions may be considered to perform 'state action.' In fact, the Supreme Court has left open the possibility to decide in the future on "[...] the extent, if any, to which a city or State might be free to delegate to private parties the performance of such functions and thereby avoid the strictures of the Fourteenth Amendment."433 This opinion notwithstanding, it would appear that the Court has gradually made it more difficult for the actions of private entities to be considered as 'state action.' Moreover, the lack of consistency, to use one of the judge's own words, ${ }^{434}$ in the Court's 'state action' case law means that clearly establishing what 'state action' is in relation to a private actor's conduct may not always be straightforward. The Supreme Court's decisions on 'state action' may, however, provide some inspiration to the question of the direct vertical applicability of human rights obligations to privatized actors. In the following paragraphs, some of the most relevant cases decided by the Supreme Court on the issue of 'state action' with respect to the conduct of private actors for the purpose of applying constitutional norms will be reviewed.

432 See with regard to privatization in the United States in general, Cass, "Privatization: Politics, Law and Theory." and more recently with specific regard to state action Barak-Erez, "A State Action Doctrine for an Age of Privatization."; Freeman, "The Private Role in Public Governance." With specific regard to the privatization of prisons in the United States and state action S.L. Kay, "Privatization of Prisons: The Implications of Prison Privatization on the Conduct of Prisoner Litigations under @ 42 U.S.C. Section 1983," Vand. L. Rev Vol. 40 (1987), p. 867-888; I.P. Robbins, "Privatization of Prisons: An Analysis of the State Action Requirement of the Fourteenth Amendment and 42 U.S.C. Section 1983," Conn. L. Rev. Vol. 20 (1988), p. 835864; and Robbins, "Privatisation of Corrections: A Violation of U.S. Domestical Law, International Human Rights and Good Sense." On the privatization of policing and state action see Sklansky, "The Private Police."

433 Flagg Bros. Inc. v. Brooks, 436 U.S. 149 (1978), p. 163-164.

434 Justice Scalia has admitted as much in observing that "[i]t is fair to say that "our cases deciding when private action might be deemed that of the state have not been a model of consistency.", See Michael A. Lebron, v. National Railroad Passenger Corporation, 513 U.S. 374 (1995), p. 378 (Justice Scalia quoting from Edmonson v. Leesville Concrete Co., 500 U.S. 614 (1991)). Freeman speaks of lack of conceptual clarity. Freeman, "The Private Role in Public Governance," p. 576. See also Metzger, "Privatization as Delegation," p. 1412. 


\subsubsection{The state action doctrine}

Generally, the 'state action' question arises in two types of situation. ${ }^{435}$ The first type of situation involves the activity of the federal or state government that on its own does not violate constitutional provisions, such as the Fourteenth Amendment, but that enables a private actor to operate in a way that would violate these provisions if the federal or state government were to act in the same way. McCoy observes that in this type of situation, "[...] the aid or encouragement of the federal or state government becomes a violation of the constitutional provisions because of the questionable nature of the private activity aided." 436 The second type of situation relates to activities carried out by a private actor in partnership with the government, activities carried out on behalf of the government in pursuit of some federal/state goal, or activities that are voluntarily carried out in place of the state in performance of certain federal or state functions. According to McCoy, these activities involve private actors "[...] performing state activities with, as agents for, or in place of the state[,]" and as such may be considered as 'state action' and would give way to constitutional liability as if they were the actions of formal state agencies. ${ }^{437}$ It is the latter situation that is the most relevant for the purposes of this study.

In general, the Supreme Court has stated that to constitute state action, "[...] the deprivation [of a right, $A H W$ ] must be caused by the exercise of some right or privilege created by the State [...] or by a person for whom the State is responsible," and "the party charged with the deprivation must be a person who may fairly be said to be a state actor." 438 The Court has developed a number of tests in different contexts to ascertain whether a private party exercising certain functions, tasks or services can be converted into a state actor under the 'state action' theory. These include the 'public function' test, the 'nexus' test, and the 'joint action' test. ${ }^{439}$ These tests are also used to discern if a private actor is acting under the color of law and seek to assert whether there is a sufficient link between the private actor and

435 T.R. McCoy, "Current State Action Theories, the Jackson Nexus Requirement, and Employee Discharges by Semi-Public and State-Aided Institutions," Vand. L. Rev Vol. 31 (1978), p. 791.

436 Ibid.

437 Ibid.

$438 \quad$ Lugar v. Edmondson Oil Co., 457 U.S. 922 (1982), p. 937.

439 The Supreme Court has summed up all these types of tests it may use to "justify the characterization of [a private] party as a "state actor" in Lugar v. Edmondson Oil Co., p. 939. See also Spurlock, "Liability of State Officials and Prison Corporations for Excessive Use of Force Against Inmates of Private Prisons," p. 987-989; Barak-Erez, "A State Action Doctrine for an Age of Privatization," p. 1173-1183; Sklansky, "The Private Police," p. 1247-1265; Freeman, "The Private Role in Public Governance," p. 576; F.R. Kemerer, "Legal Issues Involving Educational Privatization and Accountability," Occasional Paper No. 6, The National Center for the Study of Privatization in Education, Teachers College, Columbia University, (2000), p. 13; Robbins, "Privatisation of Corrections: A Violation of U.S. Domestical Law, International Human Rights and Good Sense," p. 64. For a human rights perspective see Clapham, Human Rights Obligations of Non-State Actors, p. 486-499. 
the State. ${ }^{440}$ It is important to observe that the use of these tests to find out whether 'state action' is present in a particular case is not mutually exclusive. The Supreme Court has clarified that if the findings in one case do not reveal 'state action' by applying one of the tests, this does not mean that 'state action' might not be present under another test. ${ }^{441}$ Finally, it would appear that the common thread among a number of these tests is determining whether an action can "fairly be attributed to the State." 442

\subsubsection{The 'public function' test}

The 'public function' test first appeared in Marsh v. Alabama 443 in which the Supreme Court was called on to decide whether a State could impose criminal punishment on a woman who attempted to distribute religious literature on the premises of a companyowned town contrary to the wishes of the town's management. The state of Alabama claimed that since the town was privately owned, the First Amendment (free speech) and the Fourteenth Amendment did not apply. In spite of the fact that a private company owned and managed the town, the Court maintained that,

"[o]wnership does not always mean absolute dominion. The more an owner, for his advantage, opens up his property for use by the public in general, the more do his rights become circumscribed by the statutory and constitutional rights of those who use it." $" 44$

The Court then compared the function of the town with those of bridges, ferries, turnpikes and railroads that may also be owned by private actors: "Since these facilities are built and operated primarily to benefit the public and since their operation is essentially a public function, it is subject to state regulation." 445 The Court saw no difference between allowing a corporation to operate a highway and allowing it to use its property as a town since the operation of both facilities boil down to a public function. ${ }^{446}$ The Supreme Court, however, did not define at this

440 Blum and Urbonya, "Section 1983 Litigation," p. 7.

441 See Brentwood Academy v. Tennessee Secondary School Athletic Association, 531 U.S. 288 (2001), p. 303.

442 See the dissenting opinion of Justice Thomas joined by Chief Justice Rhenquist and Justices Scalia and Kennedy in Brentwood Academy, p. 306. See also Blum v. Yaretsky, 457 U.S. 991 (1982), p. 1004.

443 Marsh v. Alabama, 326 U.S. 501 (1946).

444 Ibid., p. 506.

445 Ibid. Emphasis added. See also Terry v. Adams, 345 U.S. 461 (1953), p. 468-470, where a private whites-only association was in charge of organizing primary elections for the Democratic party in Texas and discriminated against people of color by denying them the possibility of casting their votes. In Terry, the Court concluded that holding elections that produced "the uncontested choice of public officials" was a public function even if these were conducted by a private organization.

446 See also Sklansky, “The Private Police,” p. 1254. 
time what a 'public function' could be, although it would appear that from the context of this case as evidenced by the quotes noted above, benefiting the public at large could play an important role in clarifying the scope and nature of this term. ${ }^{447}$ What was important however, was that the public had an interest in the functioning of the community in such a manner that the right to free speech remains available, and since the town in question did not function differently from any other town (with a community shopping center which was freely accessible and open to the people in the area and those passing through), the managers appointed by the corporation could not curtail the freedom of speech. ${ }^{448}$

The Supreme Court has confirmed Marsh on several occasions although it has endeavored to limit the extent of the 'public function test' by adding a number of requirements that made it more difficult, if not impossible, to conclude that there was 'state action." ${ }^{449}$ In the case of Evans v. Newton, ${ }^{450}$ the Court observed that,

447 See also Evans v. Newton, 382 U.S. 296 (1966), discussed in more detail below.

448 Marsh v. Alabama, p. 507-508.

449 In addition, the Court has declined to apply the Marsh reasoning to shopping centers. Although the Court initially applied the Marsh reasoning in Amalgamated Food Employees Union $v$. Logan Valley Plaza Inc, 391 U.S. 308 (1968) (where a shopping center owner had prohibited protesters from picketing on the shopping center's sidewalk) it later revised its views in Lloyd Corp. v. Tanner, 407 U.S. 551 (1972) and Hudgens v. NLRB, 424 U.S. 507 (1976). In these cases, also involving protesters who had been prohibited from demonstrating at shopping centers, the Court clarified the extension of the Marsh decision by holding that in that particular case, the private enterprise that owned the city had assumed "[...] all of the attributes of a state-created municipality and the exercise by that enterprise of semi-official municipal functions as a delegate of the State." Lloyd Corp. v. Tanner, p. 569. This was not the case in the privately-owned shopping centers in Hudgens and Logan Valley where in addition the protesters had alternatives to convey their message in public areas near or by the shopping centers. See also McCoy, "Current State Action Theories, the Jackson Nexus Requirement, and Employee Discharges by Semi-Public and State-Aided Institutions," p. 798-800; Spurlock, "Liability of State Officials and Prison Corporations for Excessive Use of Force Against Inmates of Private Prisons," p. 986987. In the context of the ECHR, compare with Appleby and Others v. The United Kingdom, judgment of 5 May 2003, ECtHR Reports of Judgments and Decisions 2003-VI, where the ECtHR was confronted with a similar situation to Logan Valley, Lloyd Corp. and Hudgens. In Appleby the ECtHR observed that "[w]hile it is true that demographic, social, economic and technological developments are changing the ways in which people move around and come into contact with each other, the Court is not persuaded that this requires the automatic creation of rights of entry to private property, or even, necessarily, to all publicly owned property (government offices and ministries, for instance). Where, however, the bar on access to property has the effect of preventing any effective exercise of freedom of expression or it can be said that the essence of the right has been destroyed, the Court would not exclude that a positive obligation could arise for the State to protect the enjoyment of the Convention rights by regulating property rights. A corporate town where the entire municipality is controlled by a private body might be an example." Ibid., para. 47 (reference to Marsh v. Alabama omitted, $A H W$ ). In a similar fashion to the U.S. Supreme Court's cases observed above, the ECtHR concluded that in the particular situation of Appleby, the protesters had adequate alternatives to exercise their freedom of expression and that the property rights of the shopping center's owner did not effectively prevented them from communicating their views to their fellow citizens. Ibid., para. 48. 
"[...] when private individuals or groups are endowed by the State with powers or functions governmental in nature, they become agencies or instrumentalities of the State and subject to its constitutional limitations." 451 The Court, however, stressed in this case that "[t]he range of governmental activities is broad and varied, and the fact that government has engaged in a particular activity does not necessarily mean that an individual entrepreneur or manager of the same kind of undertaking suffers the same constitutional inhibitions." 452 This was probably a caveat that the Court deemed necessary to emphasize in order to prevent extensive application of the Marsh decision. Nevertheless, the Evans Court did manage to point out two elements that may help decide whether a particular activity or service is governmental. These elements relate to the entity formerly performing a particular activity or service, and the nature of the activity. When a particular service has been subject to municipal (or governmental control) in the past, and when it has a long tradition of serving the community, and the service is open to all members of the public without exclusion (the latter meaning that there is no selective element in allowing who may benefit from the activity) then this activity involves a public function. ${ }^{453}$ In such a circumstance the Constitutional limitations may apply to private actors since the character and purpose of the services or activities they carry out are predominantly municipal.

In later cases, the Court went on to further limit the scope of the Marsh decision. ${ }^{454}$ In Jackson v. Metropolitan Edison Co. ${ }^{455}$ the Court had to decide whether the disconnection of the electric service by a privately owned electric utility for non payment of electric bills amounted to a deprivation of property in violation of the Fourteenth Amendment's guarantee of due process of law. The petitioner argued that she could not be deprived of her entitlement to utility service as guaranteed by state legislation without adequate notice and a hearing before an impartial body: until these are completed, her service must continue. The petitioner presented a number of arguments in favor of 'state action'. With regard to the 'public function' test, petitioner argued that since the utility provided an essential public service

$451 \quad$ Ibid., p. 299.

452 Ibid., p. 300.

453 Ibid., p. 301-302. However, the Court later diminished the importance of this element by concluding that the performance of a function that serves the public by a private actor does not render the acts of this actor public. See Rendell-Baker v. Kohn, 457 U.S. 830 (1982), p. 842. In this case, the Court did nevertheless clarify in a footnote that there was no "[...] evidence that the State has attempted to avoid its constitutional duties by a sham arrangement which attempts to disguise provision of public services as acts of private parties." Ibid., footnote seven. This last point was emphasized by Justice Marshall who dissented in Rendell-Baker and noted that ' $[\mathrm{t}] \mathrm{he}$ State should not be permitted to avoid constitutional requirements simply by delegating its statutory duty to a private entity. In my view, such a delegation does not convert the performance of the duty from public to private action when the duty is specific and the private institution's decisionmaking authority is significantly curtailed." Ibid., p. 849. 
required to be supplied on a reasonably continuous basis by state legislation, and hence performed a 'public function', the conduct of the utility could be regarded as 'state action.' This would have subjected the utility to the obligations of the Fourteenth Amendment. While the Court acknowledged that 'state action' could be present in the exercise by a private entity of "[...] powers traditionally exclusively reserved to the State", 456 the majority observed that the delegations of powers to private entities must entail powers that are "[...] traditionally associated with sovereignty [...]"457 before it could be regarded as a public function. The Court noted that while the state statute imposed "[...] an obligation to furnish service on regulated utilities, it imposes no such obligation on the State." 458 Thus the Court concluded that the provision of electricity was not a 'public function' because state legislation did not oblige the state to engage in such an activity. ${ }^{459}$

In the case law following Jackson, the Supreme Court further circumscribed the 'public function' test by focusing on the exclusivity of the powers being delegated to private actors. In Flagg Bros. Inc. v. Brooks, ${ }^{460}$ the Court had to decide whether 'state action' was present in a dispute between two private actors. The case involved the sale proposal of goods stored in a warehouse for non-payment of the storage fee. The law of the state of New York authorized such a sale without requiring prior recourse to a court. The owner of the goods to be sold by the warehouse sued the latter under 42 U.S.C. $\$ 1983$ and claimed, inter alia, that the state legislation had delegated a number of exclusive prerogatives of the government, namely the sovereign monopoly power over binding conflict resolution, and a function traditionally performed by a sheriff (the execution of a lien). According to the owner of the goods, these delegations gave way to 'state action' and thus violated the Fourteenth Amendment's due process and equal protection clause because it deprived the owner of his property without due process of law. Justice Rhenquist,

456 Ibid., p. 352, citing previous case law including Marsh v. Alabama and Evans v. Newton (emphasis added, $A H W$ ).

457 Ibid., p. 353. The decision was written by Justice Rehnquist who wrote for the majority, while three of the nine Justices dissented. Ibid.

459 In addition, the Court also declined to accept that businesses entrusted with supplying of utility services such as electricity were state actors under the doctrine of businesses "affected with the public interest." Under this doctrine, certain businesses performing important social and economical functions, such as inns and common carriers, were not allowed to discriminate among potential customers on any basis. Businesses affected with a public interest were deemed analogous to state actors. Ibid. See also J.M. Beerman, "Administrative-Law-Like Obligations on Private[ized] Entities," UCLA L. Rev. Vol. 49 (2002), p. 1729-1730. The Supreme Court has questioned the usability of this doctrine and it abandoned it in the case of Nebbia v. New York, 291 U.S. 502 (1934). In this case the Court concluded that the phrase "affected with the/a public interest" only means "[...] that an industry, for adequate reason, is subject to control for the public good[,]" and as such unsatisfactory to test the constitutionality of legislation aimed at business practices or the setting of prices. Ibid., p. 536. 
writing for the majority of the Court, observed however, that "[w]hile many functions have been traditionally performed by governments, very few have been 'exclusively reserved to the State."'461 The Court then pointed out two previous examples from its case law highlighting the exclusivity aspect of 'public function': holding elections which in practice produce "the uncontested choice of public officials" as in Terry, ${ }^{462}$ and the performance of all the necessary municipal functions of a town as in Marsh. ${ }^{463}$ Since there were alternative remedies available under state law to resolve the dispute of the proposed sale of goods the Court concluded that "[...] the settlement of disputes between debtors and creditors is not traditionally an exclusive public function." 464 Finally, the majority of the Court in Flagg Bros. decided to express no view "[...] as to the extent, if any, to which a city or State might be free to delegate to private parties the performance of such functions and thereby avoid the strictures of the Fourteenth Amendment," although it did not exclude the possibility of deciding this issue in some future case. ${ }^{465}$ This observation makes it possible to discern that throughout its 'public function' case law, the Court has been concerned with the possibility that the State may opt to avoid its constitutional obligations through such a delegation and that this may be a valid concern as supported by its observations in the earlier cases of Terry $v$. Adams, ${ }^{466}$ and Rendell-Baker v. Kohn, ${ }^{467}$ and in the latter case of West v. Atkins. ${ }^{468}$ Indeed in that case the Supreme Court gave its opinion as to what are the State's obligations if it decides to contract out certain public functions to private parties.

West $v$. Atkins involved the question of whether a private physician (Dr. Atkins) who was under contract with a state to provide medical services to inmates at a stateprison hospital on a part-time basis acted 'under the color of state law' within the meaning of 42 U.S.C. $\$ 1983$. After observing that the fulfillment of the 'state action' requirement in the case of an infringement of constitutional rights also constituted action 'under color of state law', ${ }^{469}$ the Court observed that

461 Ibid., p. 158.

462 See note 445 supra.

463 Flagg Bros., p. 158-159.

464 Ibid., p. 161. Here the Court compared Flagg Bros. with Terry and Marsh noting that "[c]reditors and debtors have had available to them historically a far wider number of choices than has one who would be an elected public official, or a member of Jehovah's Witnesses who wished to distribute literature in Chickasaw, Ala., at the time Marsh was decided." Ibid. Ibid., p. 163-164.

466 In Terry v. Adams (see note 445 supra) the Court concluded that "[i]t violates the Fifteenth Amendment for a state, by such circumvention [e.g. allowing a private whites-only association to organize primary elections and discriminate against people of color by denying them the possibility of casting their votes], to permit within its borders the use of any device that produces an equivalent of the prohibited election." Terry, p. 469.

See footnote 453 supra.

468 West v. Atkins, 487 U.S. 42 (1988).

469 See note 427 supra. 
"[c]ontracting out prison medical care does not relieve the State of its constitutional duty to provide adequate medical treatment to those in its custody, and it does not deprive the State's prisoners of the means to vindicate their Eighth Amendment rights. The State bore an affirmative obligation to provide adequate medical care to West; the State delegated that function to respondent Atkins; and respondent voluntarily assumed that obligation by contract." ${ }^{\text {Th }}$

The Court then observed that it was the nature of the physician's function (delivering health care in a correctional setting which is under the responsibility of the state and for which the state has a statutory duty to provide health care) that determined the conclusion that Dr. Atkins could be regarded as acting 'under color of law' and hence be regarded as a 'state actor'. ${ }^{471}$

Nonetheless, the Court has more often than not declined to apply the "public function' test to various situations such as privately run nursing homes, ${ }^{472}$ the United States Olympic Committee's refusal to allow the use of the word Olympic by an association wanting to organize a sport event called the Gay Olympic Games, ${ }^{473}$ and a private insurer's decision to withhold payment for disputed medical treatment as allowed by state law, ${ }^{474}$ because the private actors involved in those cases did not perform a function that has been traditionally the State's exclusive prerogative. One of the few recent instances in which the court agreed with 'state action' arguments based on the 'public function test' can be found in Edmondson v. Leesville Concrete Co ${ }^{475}$ Here in a six to three decision the Supreme Court concluded that the selection of potential jury members in civil law cases by private parties amounted to 'state action.' According to the Court, the selection of, or decision to challenge prospective jury members is a traditional governmental function because the jury is a "quintessential governmental body, having no attributes of a private actor." 476 Referencing to, inter alia, Terry, the Court observed that,

$470 \quad$ Ibid., p. 56 (footnote omitted).

471 Ibid., p. 57.

472 Blum v. Yaretsky, 457 U.S. 991 (1982), p. 1011.

473 San Francisco Arts \& Athletics v. United States Olympic Committee, 483 U.S. 522 (1987), p. 555 .

474 American Manufacturers Mutual Insurance Co. et al. v. Sullivan et al., 526 U.S. 40 (1999), p. 55-56.

475 Edmonson v. Leesville Concrete Co., 500 U.S. 614 (1991).

476 Ibid., p. 624. The case revolved around peremptory challenges issued by a private company in a civil law suit to remove black persons from a prospective jury in detriment of the opposing party in the dispute who happened to be black. These peremptory challenges were authorized by statute. The opposing party claimed that the exclusion of black members from the jury through these challenges was contrary to the equal protection cause of the Thirteenth Amendment because racial discrimination in jury selection casts doubt on the integrity of the judicial process and the fairness of the court proceedings. 
"[i]f a government confers on a private body the power to choose the government's employees or officials, the private body will be bound by the constitutional mandate of race-neutrality. [...] The fact that the government delegates some portion of this power to private litigants does not change the governmental character of the power exercised." 477

This observation is important in so far as it may allow us to conclude that a "state action' argument based on the 'public function' test is aimed at showing that a private actor has substituted or displaced the State in the performance of a 'public function'. In the course of doing so, the private actor has turned into a particular type of state actor even though the State proper is not directly involved in the conduct of the private actor. ${ }^{478}$

From these cases it may be concluded that according to the Supreme Court, a 'public function' must be one that exclusively imposes a duty on the State to perform a traditional (sovereign) function or task, or to obligatorily provide a particular public service as mandated through legislation. If a statute imposing such a duty on the State is not present, then functions, tasks or services that are delegated/privatized to private entities do not amount to a public function that could entail 'state action' turning these entities into state actors liable for constitutional violations. Even if such legislation is present, the Court has, on at least one occasion, decided that the function delegated to a private entity was not traditionally a 'public function.' ${ }^{479}$ It also appears that an element of exclusivity is important, as in the availability of remedies to solve a dispute between two private parties, one of which is exercising a function that could be deemed 'public' and which is exclusively reserved to the State. Thus a private actor that has been delegated a function which was traditionally the exclusive prerogative of the State could be regarded as a state actor if it meets these criteria. It is suggested that these limitations render the 'public function' test

\footnotetext{
477 Ibid., p. 625-626.

478 Compare with the 'nexus' test that will be discussed in section 3.4.1.2 infra where the involvement of the State is seen as a pre-requirement before concluding that there has been 'state action'. See also McCoy, "Current State Action Theories, the Jackson Nexus Requirement, and Employee Discharges by Semi-Public and State-Aided Institutions," p. 815, in which he observes that by definition, in a 'public function' test there is no actual state involvement.

479 See Rendell-Baker v. Kohn, p. 842. Additionally, the Court considered it necessary to observe that

"[...] there are a number of state and municipal functions not covered by our election cases or governed by the reasoning of Marsh which have been administered with a greater degree of exclusivity by States and municipalities than has the function of so-called 'dispute resolution.' Among these are such functions as education, fire and police protection, and tax collection. We express no view as to the extent, if any, to which a city or State might be free to delegate to private parties the performance of such functions and thereby avoid the strictures of the Fourteenth Amendment. The mere recitation of these possible permutations and combinations of factual situations suffices to caution us that their resolution should abide the necessity of deciding them." Flagg Bros., p. 163-164.
} 
meaningless. By placing the emphasis on the element of 'exclusivity', the Court severely narrows the number of 'public' functions that may be amenable for 'state action' under the public function test to the point that very few functions will qualify. These include functions that the modern State has assumed and in which it performs a very important role, even though traditionally it has not always exercised them because they were carried out by private entities in the past (for example water provision, electricity, housing, health care and social security). Taken literally, and in the light of the observations made in Chapter II supra, namely that even those functions that are regarded as traditionally or historically belonging to the State (such as prisons, or the provision of national security, and policing), the Court's approach would also mean that, strictly speaking, these functions would not fall under the 'public function' test. All this notwithstanding, the Court would appear to have some concerns as to the possibility of the State avoiding its Constitutional obligations by delegating or transferring the exercise of certain functions to private entities, which, depending on how public a function is, or how involved the State was in a particular activity, will warrant transforming a private actor into a public one.

\subsubsection{The 'nexus' test}

Under the 'nexus' test, 'state action' is found whenever a close relationship between the private activity in question and the government is such that it is difficult to separate the private actor performing the activity from the government. The 'nexus' test was introduced in Jackson. ${ }^{480}$ Besides examining the 'public function' test in this case, the Supreme Court also had to give an opinion as to whether the fact that the privately owned utility company was subject to extensive state regulation in many aspects of its business also resulted in 'state action' for the purpose of applying constitutional provisions to the private utility. The Court observed first that the mere fact that a business is subject to regulation, even if the latter is extensive and detailed, does not by itself turn the business' conduct into that of the State for the purposes of applying constitutional norms. ${ }^{481}$ Although the Court did acknowledge that a heavily regulated utility with a governmentally protected monopoly could be more readily be found to be a 'state actor', it concluded that "[...] the inquiry must be whether there is a sufficiently close nexus between the State and the challenged action of the regulated entity so that the action of the latter may be fairly treated as that of the State itself." 482 The key element of this doctrine

\footnotetext{
480 See Jackson v. Metropolitan Edison Co., note 455 supra.

481 Ibid., p. 350.

482 Ibid., p. 351. The Court added that the involvement of the State may not be obvious and that a detailed enquiry may be necessary to determine if the test is met. In the particular situation of Jackson the Court concluded that the monopoly status of the private utility was not sufficient to establish on its own the required nexus: there was insufficient relationship between the challenged actions of the private utility and its monopoly status.
} 
is the amount and type of involvement of the State in a specific private activity that is required in order to strengthen the relationship between the State and the private actor and thus conclude that there is a sufficiently close 'nexus'. ${ }^{483}$

Besides situations where regulatory involvement of a monopoly may be required to prove the 'nexus', the Supreme Court has identified few other situations that may result in 'state action'. These are when one can discern a 'symbiotic' relationship between the private actor and the State. Thus in Burton v. Wilmington Parking Auth., the Court held that a private restaurant operating in a publicly owned building dedicated to public uses was a state actor when it refused to allow service to African-Americans. ${ }^{484}$ However, the presence of state regulation or the provision of state funding to private actors do not provide a sufficient nexus. ${ }^{485}$ The Supreme Court has also adopted the position that in order for a nexus to exist, the State has to be sufficiently involved. ${ }^{486}$ Only then can the harm causing conduct of a private entity to be treated as 'state action' (and thus amenable for Constitutional rights review). State involvement may occur if the State creates the legal framework governing the conduct, if it delegates its authority to the private actor, or if it knowingly accepts the benefits derived from unconstitutional behavior. ${ }^{487}$

Finally, another way of establishing a close nexus would be if there is a close connection or a pervasive entwinement that "[...]will support a conclusion that an ostensibly private organization ought to be charged with a public character and judged by constitutional standards[...]"488 Thus, in Brentwood Academy v. Tennessee Secondary School Athletic Association the decision of a not-for-profit athletic association, which regulates interscholastic sport among Tennessee public and private high schools, to penalize a school for breaching a set of student eligibility rules was found to be 'state action'.

483 See also McCoy, "Current State Action Theories, the Jackson Nexus Requirement, and Employee Discharges by Semi-Public and State-Aided Institutions," p. 814-815.

484 Burton v. Wilmington Parking Auth., 365 U.S. 715 (1961), p. 723-724. See also Blum and Urbonya, "Section 1983 Litigation," p. 8.

485 See Blum v. Yaretsky, p. 1004, in which the decisions of physicians and administrators of a privately owned and operated nursing home to transfer Medicaid patients did not amount to state action, and Rendell-Baker v. Kohn, p. 840-843, in which the decisions of privately owned and operated school to discharge a member of staff also did not amount to state action.

486 NCAA v. Tarkanian, 488 U.S. 179 (1988), p. 192.

487 NCAA v. Tarkanian citing North Georgia Finishing, Inc. v. Di-Chem, Inc., 419 U.S. 601 (1975), West v. Atkins, 487 U.S. 42 (1988) and Burton v. Wilmington Parking Authority, 365 U.S. 715, 722 (1961) respectively.

488 Brentwood Academy v. Tennessee Secondary School Athletic Association, op cit. note 441 supra, p. 302 . 


\subsubsection{The 'joint action' test}

Another way of determining state action or action under color of law is through the 'joint action' test. This test entails collaboration between the private and State actors or complicity in a particular action. Collaboration can take place through the endowment of 'public powers' to private actors or through the acquiescent presence or participation of actual State actors in the action. Thus, in Williams $v$. United States $^{489}$ a private detective working for a private firm as a special police officer to investigate a theft and who had subjected a person to force and violence in order to obtain a confession in breach of the Due Process clause of the U.S. Constitution, was deemed to be acting under the color of law. ${ }^{490}$ There were a number of factors leading to this conclusion. In the first place, the private detective had been issued a special police officer's card by the City of Miami, and had taken an oath and qualified as a special police officer. ${ }^{491}$ The Supreme Court noted that it was the policy of the City of Miami to vest private guards and detectives with policemen's powers. ${ }^{492}$ In the second place, a regular police officer had been detailed to attend the investigation and took part in the beatings leading to the confession. ${ }^{493}$ These two factors lead the Court to conclude that the private detective acted under authority of Florida law; and the manner of his conduct of the interrogations made it clear that he was asserting the authority granted to him and not acting in the role of a private person. ${ }^{494}$ A similar conclusion was reached in Griffin v. Maryland ${ }^{495}$ in which the conduct of a private amusement park employee with deputy sheriff authority was regarded as state action. In this case, the Court concluded that

"[i]f an individual is possessed of state authority and purports to act under that authority, his action is state action. It is irrelevant that he might have taken the same action had he acted in a purely private capacity or that the particular action which he took was not authorized by state law." 496

Likewise, the Supreme Court held in the already cited case of Lugar v. Edmondson Oil Co. ${ }^{497}$ that a private individual acts under color of law "[...] because he has acted together with or has obtained significant aid from state officials[...]"498

\footnotetext{
489 Williams v. United States, 341 U.S. 97 (1951).

490 It must be noted that this case involved the violation of the criminal law equivalent of 42 U.S.C. $\S 1983,18$ U.S.C. $\$ 242$, which has the same color of law requirement.

491 Williams v. United States, p. 98.

492 Ibid., p. 99.

493 Ibid., p. 99-100.

494 Ibid.

495 Griffin v. Maryland, 378 U.S. 130 (1964).

496 Ibid., p. 135. For further discussion of Griffin see Sklansky, “The Private Police,” p. 1236-1239.

497 See footnote 428.

498 Lugar v. Edmondson Oil Co., p. 937.
} 
The element of conspiracy can be found in Adickes v. Kress \& Co. ${ }^{499}$ The case involved the refusal of an employee in a store (Kress \& Co.) to serve a white woman (Adickes) because she was in the company of colored people. A policeman had previously entered the store and observed the situation. After Adickes left the store, the policeman arrested her on the grounds of vagrancy. The Supreme Court observed that a private entity could be held to have acted 'under color of law' and thus be responsible for a violation of the Fourteenth Amendment if it can be proved that

"[...] a Kress employee, in the course of employment, and a Hattiesburg policeman somehow reached an understanding to deny Miss Adickes service in the Kress store, or to cause her subsequent arrest because she was a white person in the company of Negroes. [...] The involvement of a state official in such a conspiracy plainly provides the state action essential to show a direct violation of petitioner's Fourteenth Amendment equal protection rights, whether or not the actions of the police were officially authorized, or lawful[...]"500

Finally, it is worth noting that in the context of applying the Alien Tort Claims Act (ATCA $)^{501}$ to determine whether a corporation was liable for violations of international law, a lower court applied the 'joint action' in a case against Netherlands and United Kingdom oil multinational Royal Dutch/Shell (Shell). ${ }^{502}$ Faced with claims that Shell was liable for violations of international law including crimes against humanity, torture and cruel, inhuman, or degrading treatment, arbitrary arrest and detention, and violations of the rights to life, liberty, and security of person committed while operating in Nigeria, the U.S. District Court for the Southern District of New York observed that for the ATCA to be applicable it was necessary to demonstrate that defendant was a government actor or that he was acting under 'color of law'. ${ }^{503}$ The District Court noted that in order to determine whether a private actor acts under color of law in the context of a claim under ATCA it must look to the standards developed under 42 U.S.C. $\$ 1983 .{ }^{504}$ According to the District Court, ascertaining that a private actor was acting under 'color of law' required finding that the actors was a 'willful participant' in joint action with the

499 Adickes v. Kress \& Co., 398 U.S. 144 (1970).

Ibid., p. 152. The Supreme Court cited United States v. Price, 383 U.S. 787 (1966), p. 794, in which it held that "Private persons, jointly engaged with state officials in the prohibited action, are acting 'under color' of law for purposes of the statute [\$1983]. To act 'under color' of law does not require that the accused be an officer of the State. It is enough that he is a willful participant in joint activity with the State or its agents[...]."

501 See Chapter III Section 3.2.2 for a brief discussion on this Act as it applies to the activities of multinational corporations.

502 Wiwa v. Royal Dutch Petroleum, United States District Court for the Southern District of New York, 22 February 2002, 2002 U.S. Dist. LEXIS 3293.

503 Ibid., p. 9.

$504 \quad$ Ibid., p. 40. 
State or its agents in the deprivation of the rights involved. ${ }^{505}$ In the Court's eyes, the plaintiffs in the case had provided adequate evidence to establish a 'substantial degree of cooperative action' between Shell and Nigerian officials and thus acted under color of law in the commission of acts that allegedly violated international law. ${ }^{506}$

\subsubsection{Private prisons}

Finally, it is necessary to discuss a decision in which a 'quintessential' 'public function' was involved, but in which the majority of the Court did not think this was a deciding factor in making a distinction between a public and a private actor for the purposes of applying immunity against liability under 42 U.S.C. $\$ 1983$ for certain activities. ${ }^{507}$ Thus, in Richardson et al. v. McKnicght, ${ }^{508}$ the Court held that prison guards working in a privatized prison were not were not entitled to the qualified immunity that prison officials working for state prisons enjoy. According to the Court's case law, this qualified immunity was necessary for " $[\ldots]$ protecting 'government's ability to perform its traditional functions' by providing immunity where 'necessary to preserve' the ability of government officials 'to serve the public good or to ensure that talented candidates were not deterred by the threat of damages suits from entering public service." 509 Other reasons for immunity included protecting the public from unwarranted timidity on the part of public officials and thus allow them to perform their tasks without fear or distraction from their governmental duties. Looking at the historical use of privatized prisons in the United States ${ }^{510}$ the majority of the Court noted that throughout this history, privatized prison operators have not needed immunity. Although the privatized prison's guards had argued that they performed a similar work to their public prisons' counterparts, and thus should enjoy a similar immunity, a majority of the Court observed that,

"[...] it never has held that the mere performance of a governmental function could make the difference between unlimited $\$ 1983$ liability and qualified immunity, [...] especially for a private person who performs a job without government supervision

Ibid., p. 40-41.

Ibid., p. 41. See also Garmon, "Domesticating International Corporate Responsibility: Holding Private Military Firms Accountable Under the Alient Tort Claims Act," p. 350.

In previous case law, the Supreme Court had decided that state prison officials, including both supervisory and subordinate officers, are entitled to qualified immunity in a suit brought under 42 U.S.C. $\$ 1983$. This immunity was granted unless they knew or reasonably should have known that the action they took would violate a prisoner's federal constitutional rights, or if they took the action with the 'malicious intention' to cause a deprivation of constitutional rights or other injury to the prisoner. See Procunier v. Navarette, 434 U.S. 555 (1978).

Richardson et al. v. McKnight, 521 U.S. 399 (1997).

Ibid., p. 408.

See also Chapter II, Section 3.2.2. 
or direction. Indeed a purely functional approach bristles with difficulty, particularly since, in many areas, government and private industry may engage in fundamentally similar activities, ranging from electricity production, to waste disposal, to even mail delivery." 511

The Court's majority observed that guards working in privatized prisons do not need qualified immunity from suit for three reasons. In the first place, there is no need for immunity because unwarranted timidity will probably be not present when a private company is subjected to competitive market pressures when it operates a prison. ${ }^{512}$ According to the Court's majority, these competitive pressures mean not only that a company whose guards are too aggressive will face damages that raise costs, thereby threatening its replacement, but also that a company whose guards are too timid will face threats of replacement by other private companies with records that demonstrate their ability to do both a safer and a more effective job. Since a private prison company's contract expires after a certain number of years, its performance is disciplined not only by the prospect of a review by the state to extend or not to extend the contract, but also by pressure of competing companies who could take its place. ${ }^{513}$ In the second place, privatization ensures that those working for privatized prisons are not deterred to work for them since the private companies will be insured against claims from damages suits. ${ }^{514}$ The majority in the Court noted that such insurance increases the likelihood of employee indemnification and to that extent reduces the employment discouraging fear of unwarranted liability that potential private prison workers face. Because privatization law also frees the private prison company from many civil service law restraints, it allows the company, unlike a governmental actor, to offset any increased employee liability risk with higher pay or extra benefits. There is thus no need for applying immunity as the guards' employer, like other private companies, requires insurance against these types of situations, and therefore does not need to operate like a typical governmental actor. ${ }^{515}$ In the third place, the majority was not persuaded that the threat of distracting workers from their duties by lawsuits would be enough by itself to justify providing immunity. ${ }^{516}$ This was due to the fact there was a "[...] a continual and conceded need for deterring constitutional violations and our sense that the [privatized] firm's tasks are not enormously different in respect to their importance from various other publicly important tasks carried out by private firms." 517 Here the majority considered that even in normal circumstances, qualified immunity did not mean that lawsuit distractions are entirely eliminated. These reasons led the majority to conclude that the private

\footnotetext{
511 Ibid., p. 408-409.

512 Ibid., p. 409.

513 Ibid. p. 410.

514 Ibid.

515 Ibid., p. 410-411.

516 Ibid., p. 411-412.

517 Ibid., p. 412.
} 
prison company and its employees did not require immunity. Nonetheless, the majority observed that this conclusion did not answer the question whether the employees of the privatized prison had acted 'under color of law', and more interestingly that they had analyzed the issue of immunity in a narrow context,

"[...] in which a private firm, systematically organized to assume a major lengthy administrative task (managing an institution) with limited direct supervision by the government, undertakes that task for profit and potentially in competition with other firms. The case does not involve a private individual briefly associated with a government body, serving as an adjunct to government in an essential governmental activity, or acting under close official supervision." 518

The dissenting judges, led by Justice Scalia, disagreed with the majority's conclusions. Relying on a functional approach he observed that it did not make sense to deny immunity to private prison officers who "[...] who perform the same duties as state-employed correctional officials, who exercise the most palpable form of state police power, and who may be sued for acting "under color of state law." 519 Justice Scalia noted that private individuals have regularly been accorded immunity when they perform a governmental function that qualifies, and maintained that the market pressure reasons provided by the majority to withhold the immunity were flawed as the decision to replace one private prison for another one which has failed to act effectively is a governmental decision and not a market choice. ${ }^{520}$

This decision is worthy of note due to the fact that the Court errs on the side of status and not function with regard to the legal question of the case (are officers of a privatized prison entitled to immunity from legal suits?). The effect of the decision appears to be that that the rights of prisoners are better safeguarded under privatized prisons because officers working there cannot claim immunity for the actions. However, as already observed immunity of public prison officials is only applicable unless they knew or reasonably should have known that the action they took would violate a prisoner's federal constitutional rights, or if they took the action with the intent to cause a deprivation of constitutional rights to the prisoner. ${ }^{521}$ Richardson v. McKnight shows the complexity of the issue at hand. Whether a private actor exercising a governmental or public function will be regarded as public will depend on the issue being discussed. Thus, although the Court appears to be willing to regard privatized prisons as private actors and not as public ones as far as immunity is concerned, this only relates to the financial liability of private prison officials. However, in terms of actual responsibility for the violation of constitutional rights (did the private actor violate constitutional rights while exercising a governmental 
function) the Court still seems to be willing to prevent label private prison officials as public actors 'under color of law'.

\subsubsection{Some observations}

Under the 'state action' doctrine, the Supreme Court has not fully relied on a functional approach (i.e., trying to identify the nature of a function, task or service) to determine whether a particular private entity can be regarded as a state actor for the purpose of applying Constitutional rights. In fact, the Court has (repeatedly) eschewed deciding on the nature of certain functions in order to distinguish if certain activity is 'state action', ${ }^{522}$ and has gone to great lengths to diminish the scope and applicability of the 'public function' test albeit without totally discarding it. The Supreme Court has, rather, taken the position that in order for the harm causing conduct of a private entity to be treated as 'state action' and thus amenable for Constitutional rights review, the State has to be sufficiently involved. ${ }^{523}$ State involvement may occur if the State creates the legal framework governing the conduct, if it delegates its authority to the private actor, or if it knowingly accepts the benefits derived from unconstitutional behavior. ${ }^{524}$

Although the 'state action' doctrine appears to offer ways of treating the conduct of private actors as being that of the State, and thus converting them into temporary state actors liable for constitutional violations, the practical application of the doctrine is not without problems. Freeland has observed, for example, that in an era in which privatization and contracting out have led to a situation where the difference between public and private conduct is becoming more difficult to distinguish, the application of the 'state action' doctrine, with its emphasis on

522 See for example, Jackson v. Metropolitan Edison Co., 419 U.S. 345 (1974) where the Supreme Court, relying on previous case law (inter alia, Nebbia v. New York, 291 U.S. 502 (1934)) declined to investigate whether a particular function is a 'public function' because it is 'affected with the public interest' and thus 'state action' by arguing that '[d]octors, optometrists, lawyers, Metropolitan, and Nebbia's upstate New York grocery selling a quart of milk are all in regulated businesses, providing arguably essential goods and services, 'affected with a public interest.' We do not believe that such a status converts their every action, absent more, into that of the State." See also Evans v. Newton, 382 U.S. 296, 300 (1966) where the Court concluded that " $[\mathrm{t}]$ he range of governmental activities is broad and varied, and the fact that government has engaged in a particular activity does not necessarily mean that an individual entrepreneur or manager of the same kind of undertaking suffers the same constitutional inhibitions. While a State may not segregate public schools so as to exclude one or more religious groups, those sects may maintain their own parochial educational systems."

523 NCAA v. Tarkanian, p. 192.

524 NCAA v. Tarkanian citing North Georgia Finishing, Inc. v. Di-Chem, Inc., 419 U.S. 601 (1975), West v. Atkins, 487 U.S. 42 (1988) and Burton v. Wilmington Parking Authority, 365 U.S. 715, 722 (1961) respectively. 
strictly demarcating this difference proves to be difficult and unrealistic. ${ }^{525}$ This results in an all or nothing approach: "What falls on the public side suffers every constitutional constraint, while what falls on the private side operates unfettered." 526 Thus, according to Freeland, the 'state action' doctrine is

"[...] a crude instrument for protecting individuals from the threat of irrational, arbitrary, or unfair action, and it is irrelevant to achieving the goals of sound public policy and accountability. This approach cannot tailor procedural protections to the specific threats posed by a particular regulatory regime in which both public and private decision makers play a significant role." 527

Other commentators have observed that due to the restricted way the 'state action' doctrine is applied, its practical application will be limited. Metzger, for example, claims that the doctrine is not suited to ensure constitutional accountability for the privatization of governmental functions, because it ignores "[...] the way that privatization gives private actors control over government programs and resources, focusing instead on identifying government involvement in specific private acts." 528 This makes the doctrine inadequate for identifying and thereby controlling private exercises of government power. ${ }^{529}$ As observed above, the question of determining whether a private actor is a public one remains complex under the Supreme Court's approach. This approach is sometimes ambivalent. Nonetheless, with respect to situations entailing the use of coercive power, ${ }^{530}$ the Court's 'state action' doctrine appears to be willing to accept that private actors can be regarded as public ones, if the question at hand deals with responsibility for constitutional violations.

\subsection{Private entities as governmental actors in Canada}

Case law in other common law countries shows that there is a growing awareness about the possible applicability of public law norms to private entities carrying out certain governmental functions, tasks or services. A few examples from Canada show a cautious willingness to examine whether the Canadian Charter of Rights and Freedoms, an integral part of the Canadian constitution normally applicable to formal public entities only, may also apply to private actors when these are exercising public functions, tasks or services. These examples are by no means

\footnotetext{
525 Freeman, "The Private Role in Public Governance,” p. 579-580. Moreover, Freeland observes that as a mechanism for disciplining private actors, the doctrine proves inept. Ibid.

526 Ibid., p. 580.

527 Ibid.

528 Metzger, "Privatization as Delegation," p. 1411.

529 Ibid., p. 1421.

530 See for further discussion on the element of coercion as a helping to establish whether a private actor can be regarded as a public one Cass, "Privatization: Politics, Law and Theory," p. 503504.
} 
definitive evidence that public law or constitutional norms have to be applied to these situations. Nevertheless they do portray some readiness to look beyond the typical public/private divide constraints in the face of the growing disposition of States to transfer some of their activities to private parties in the search for improving their effectiveness, efficiency and costs.

\subsubsection{Formal applicability of the Canadian Charter of Rights and Freedoms}

The Canadian Charter of Rights and Freedoms was enacted in $1982^{531}$ to, inter alia, promote "[...] the better recognition and preservation of the fundamental rights and freedoms of contemporary liberal democracy." 532 The Charter provides the national courts with the possibility of reviewing national legislation for its compatibility with constitutionally guaranteed rights and freedoms. ${ }^{533}$ According to Section 32(1) of the Charter, the rights guaranteed therein apply,

"a) to the Parliament and government of Canada in respect of all matters within the authority of Parliament including all matters relating to the Yukon Territory and Northwest Territories; and

b) to the legislature and government of each province in respect of all matters within the authority of the legislature of each province."

Textually, the Charter appears only to apply to governmental or State organs strictly speaking. Although the Supreme Court of Canada has on several occasions confirmed the Charter's lack of horizontal applicability, ${ }^{534}$ it has been asked in a number of cases to decide whether the Charter rights were nevertheless applicable to private entities that had some connection with the government or were carrying out 'public' or 'governmental' tasks/functions. In R.W.D.S.U. v. Dolphin Delivery Ltd. ${ }^{535}$ the Court confirmed that the Charter was not applicable to disputes between private parties. The Court, however, left open the possibility that, if there was sufficient connection between an action of the government and one of the private parties to the dispute, the Charter would apply if this private party relied on this action to cause an infringement of the Charter rights of another. The case involved

531 F. Iacobucci, "Symposium: 20 Years Under the Charter- The Charter: Twenty Years Later," Windsor Y.B. Access Just. Vol. 21 (2002), p. 4.

532 Ibid. (footnote omitted).

533 Ibid., p. 5.

534 The lack of proper horizontal applicability of the Charter has been criticized on the grounds that Section 52 of the Constitution as amended in 1982 grants the Constitution and the Charter primacy over any other Canadian law that is inconsistent with them, rendering such a law as having no force or effect. This supremacy clause would therefore render private law statutes governing the relationships between private individuals inapplicable in so far they are inconsistent with the Constitution or the Charter. See P.W. Hogg, Constitutional Law of Canada (Scarborough, Ontario: Carswell, 1992) p. 848-850.

535 R.W.D.S.U. v. Dolphin Delivery Ltd., Supreme Court of Canada (1986), 2 S.C.R. 573. 
a local union that during a labor dispute wanted to picket in the grounds of a courier company. The company requested and was granted an injunction against the picketing. Before the Supreme Court of Canada, the question was raised whether picketing in a labor dispute fell under Section 2(b) of the Charter on the freedom of expression, whether the Charter applied to the common law and whether the Charter applied in private litigation. ${ }^{536}$ After giving a positive answer with regard to the first two questions, ${ }^{537}$ the Court affirmed that the Charter,

"[...] like most written constitutions, was set up to regulate the relationship between the individual and the Government. It was intended to restrain government action and to protect the individual. It was not intended in the absence of some governmental action to be applied in private litigation." 538

The Court pointed out that under Section 32(1) of the Charter, it applied to the legislative, executive and administrative branches of government "[...] whether or not their action is invoked in public or private litigation." 539 The Court, however, conceded in an obiter dictum that the Charter could apply to private litigation to the extent that an action in private litigation "[...] relies on statutory authority which constitutes or results in an infringement of a guaranteed right or freedom[...]" The Court did note that "[a] more direct and a more precisely-defined connection between the element of government action and the claim advanced must be present before the Charter applies," ${ }^{541}$ and also admitted that the element of governmental intervention necessary to make the Charter applicable in an otherwise private action could be difficult to define. The Court, however, was receptive to the idea of applying the Charter in a dispute involving private parties when one of these parties was acting on the authority of a statute. ${ }^{542}$ The Court illustrated this by providing a

536 The precise question as considered by the Court was "[...] does the Charter apply to private litigation divorced completely from any connection with Government?” Ibid., p. 593.

537 The Court did qualify the applicability of the Charter with regard to the common law: the Charter only applies to the common law when the latter is the basis of some governmental act that leads to the infringement of the Charter's rights. Ibid., p. 599.

538 Ibid. In support of this assertion, Justice McIntyre who wrote the majority opinion of the case, cited numerous (Canadian) academic and jurisprudential authorities that allowed him to conclude that the Charter is not applicable in private litigation. See also Hogg, Constitutional Law of Canada, p. 845.

539 Ibid., p. 598-599. The Court stated that the word 'government' as used in Section 32 referred "[...] not to government in its generic sense - meaning the whole of the governmental apparatus of the state - but to a branch of government. The word 'government', following as it does the words 'Parliament' and 'Legislature', must then, it would seem, refer to the executive or administrative branch of government." Ibid.

540 Ibid., p. 599. The Court also observed that the Charter could apply to an action in a public or private litigation arising out of a common law dispute only if common law was the basis of "some governmental action which, it is alleged, infringes a guaranteed right or freedom." Ibid.

541 Ibid., p. 601.

542 Ibid., p. 602, citing previous case law by the Court of Appeal of Ontario (Re Blainey and Ontario Hockey Association (1986), 26 D.L.R. (4 $\left.{ }^{\text {th }}\right) 728,54$ O.R. (2d) 513) with approval. 
number of examples supplied by academics where the Charter could apply, such as a private person exercising the power of arrest that is granted to any one under the Canadian Criminal Code, or an action of a commercial corporation that was an agent of the government by virtue of reference to Section 32. The Court then cursorily observed that,

“[w]here [...] exercise of, or reliance upon, governmental action is present and where one private party invokes or relies upon it to produce an infringement of the Charter rights of another, the Charter will be applicable. Where, however, private party 'A' sues private party ' $\mathrm{B}$ ' relying on the common law and where no act of government is relied upon to support the action, the Charter will not apply." 543

The rationale behind this seems to be that since the Charter will apply to (delegated) legislation, orders, regulations, or by-laws produced by government as identified in Section 32, private action relying on such legislative or regulatory acts to infringe a Charter right will also be covered by the Charter. The Court did not, however, further elaborate on this aspect of the case.

\subsubsection{Charter applicability to non-State actors}

Following Dolphin Delivery, the Supreme Court refined its view on the (vertical) applicability issue in a number of subsequent cases, the most important of which is Eldridge v. British Columbia. ${ }^{544}$ Eldridge is the current epitome in Canadian jurisprudence regarding the applicability of constitutional norms to non-State entities exercising what the Court called 'government action'. In an obiter dictum in Eldridge, the Canadian Supreme Court summed up and further clarified the reasons and the grounds on which the Charter may apply to private actors. The Court observed that it is possible that the legislature may empower (private) bodies that are officially not subjected to the Charter to wield certain powers. Thus, while legislation authorizing the creation of private corporations may be subject to the Charter, the corporations themselves are, in principle, not subject to it. However, Justice La Forest, writing for an unanimous Court, remarked that "[w]hen it is alleged that an action of one of these bodies, and not the legislation that regulates them, violates the Charter, it must be established that the entity, in performing that particular action, is part of 'government' within the meaning of [Section] 32 of the Charter." 545 Relying on previous case law, the Court noted that

\footnotetext{
543 Ibid., p. 602-603.

544 Eldridge v. British Columbia (Attorney General), Supreme Court of Canada (1997), 3 S.C.R. 624. The other cases are McKinney v. University of Guelph, Supreme Court of Canada (1990) 3 S.C.R. 229 and Stoffman v. Vancouver General Hospital, Supreme Court of Canada (1990) 3 S.C.R. 483.

545 Eldridge, p. 655.
} 
"[...] when an entity is determined to be part of the fabric of government, the Charter will apply to all its activities, including those that might in other circumstances be thought of as 'private'. The rationale for this principle is obvious: governments should not be permitted to evade their Charter responsibilities by implementing policy through the vehicle of private arrangements." 546

It then reaffirmed that the Charter applies to all governmental activities, including those that are private, commercial, contractual and non-public in nature. ${ }^{547}$ Then the Court acknowledged once again that the Charter may also apply to nongovernmental entities under certain circumstances. It noted that a "[...] private entity may be subject to the Charter in respect of certain inherently governmental actions." ${ }^{548}$ Although the Court declined to elucidate the factors that may help to find that an activity engaged by a private actor may be 'inherently governmental', it did offer a central principle rationalizing the Charter's application to private actors: 549

"[T]he Charter applies to private entities in so far as they act in furtherance of a specific governmental program or policy. In these circumstances, while it is a private actor that actually implements the program, it is government that retains responsibility for it. The rationale for this principle is readily apparent. Just as governments are not permitted to escape Charter scrutiny by entering into commercial contracts or other 'private' arrangements, they should not be allowed to evade their constitutional responsibilities by delegating the implementation of their policies and programs to private entities." 550

546 Ibid., p. 658 .

547 Ibid. See also Lavigne v. Ontario Public Service Employees Union, Supreme Court of Canada (1991), 2 S.C.R. 211, p. 314, and Douglas/Kwantlen Faculty Assn. v. Douglas College, Supreme Court of Canada (1990), 3 S.C.R. 570, p. 585. In Lavigne, the Court observed that, "[i]n today's world it is unrealistic to think of the relationship between those who govern and those who are governed solely in terms of the traditional law maker and law subject model. We no longer expect government to be simply a law maker in the traditional sense; we expect government to stimulate and preserve the community's economic and social welfare. In such circumstances, government activities which are in form 'commercial' or 'private' transactions are in reality expressions of government policy, be it the support of a particular region or industry, or the enhancement of Canada's overall international competitiveness. In this context, one has to ask: why should our concern that government conform to the principles set out in the Charter not extend to these aspects of its contemporary mandate? To say that the Charter is only concerned with government as law maker is to interpret our Constitution in light of an understanding of government that was long outdated even before the Charter was enacted." Lavigne, p. 314. Eldridge, p. 659.

549 The Court had already mentioned in McKinney, that "[i]t would be strange if the legislature and the government could evade their Charter responsibility by appointing a person to carry out the purposes of [a] statute." McKinney, p. 265.

550 Eldridge, p. 660 (emphasis added $A H W$ ). The Court added that this rationale applied to any entity charged with performing a governmental activity, even if that entity operates in other respects as a private actor." 
On the basis of McKinney and Stoffman, the Court emphasized two important aspects related to this principle. In the first place, the mere fact that a private entity performs ' $[. .$.$] what may loosely be termed a 'public function', or the fact that a$ particular activity may be described as 'public' in nature, will not be sufficient to bring it within the purview of 'government' for the purposes of [Section] 32 of the Charter." 551 This is, however, different when the private entity is implementing a specific governmental policy. Furthermore, it is necessary to determine the precise manner in which the Charter can be applied to a private entity performing a governmental function in furtherance of a governmental policy. To this end, the Supreme Court distinguished two different (but related) grounds on which the Charter could be found applicable to entities that at first sight do not appear to be part of the government strictly speaking:552 (a) When an entity whose actions have given rise to the alleged Charter breach can itself be considered as 'government' for the purposes of Section 32. (b) When the nature of the act at issue is truly 'governmental'. The development of these grounds will be discussed in the following paragraphs.

\subsubsection{Applicability to non-State actors that are considered to be 'government'}

The first ground for applying the Charter to private actors in a vertical way is when they can be considered as 'government' for the purposes of Section 32. Although the Court in Dolphin Delivery had originally conceived that the Charter applied only to the legislative, executive and administrative branches of government (either in public or in private actions), it later gradually expanded the scope of what could be understood by 'government'. In Slaight Communications Inc. v. Davidson, ${ }^{553}$ the next case to follow Dolphin Delivery to deal with this issue, the Court decided that the Charter applied to an adjudicator appointed by statute. The case involved an employee who had been dismissed from his employment without just cause. On the basis of Canadian labor statutes dealing with labor related disputes, an arbitrator was appointed to deal with the case. After having found that the dismissal had been unlawful, the arbitrator issued an order requiring the employer to respond to requests for references concerning the dismissed employee in certain circumscribed ways. The employer objected to the order claiming that it infringed his freedom of expression guaranteed by Section 2(b) of the Charter. A unanimous (but differently

\footnotetext{
$551 \quad$ Eldridge, p. 660.

552 Ibid., p. 661. See also D. Gibson, "Monitoring Arbitrary Government Authority: Charter Scrutiny of Legislative, Executive, and Judicial Privilege," Saskatchewan Law Review Vol. 61 (1998), p. 319; K. Wilkins, "But We Need the Eggs: The Royal Commission, the Charter of Rights and the Inherent Right of Aboriginal Self-government," Univ. of Toronto L.J. Vol. 49 (1999), p. 59-61.

553 Slaight Communications Inc. v. Davidson, Supreme Court of Canada (1989) 1 S.C.R. 1038 (available at <http://scc.lexum.umontreal.ca/en/1989/1989scr1-1038/1989scr1-1038.html>).
} 
composed) Court concluded through Justice Lamer that the Charter applied to the adjudicator observing that,

"[t]he fact that the Charter applies to the order made by the adjudicator in the case at bar is not, in my opinion, open to question. The adjudicator is a statutory creature: he is appointed pursuant to a legislative provision and derives all his powers from the statute." 554

With this conclusion, the Court extended the purview of the Charter's applicability beyond that of the 'government' in the strict sense of the word as originally conceived in Dolphin Delivery. It is therefore not necessary for an entity to be part of 'government' in the traditional sense in order to be subject to the Charter. ${ }^{555}$

This question was again raised in McKinney v. University of Guelph, ${ }^{556}$ in which the Court was asked to decide whether Section 15 of the Charter (on the prohibition of discrimination) applied to a university's policy of mandatory retirement for staff that had reached the age of $65 . .^{557}$ Following a review of the reasons why the Charter did not apply to non-governmental or private entities, the Court, relying on Dolphin Delivery, emphasized that the Charter only applied to those entities that fell under the definition of 'government' as understood in Section 32. Writing for the majority of the Court, Justice La Forest, took it then upon himself to elucidate whether universities were part of government as had been argued by the appellants. La Forest concluded that universities were not part of government on various grounds. Firstly, he observed that "[...] the mere fact that an entity is a creature of statute [as the universities in casu were] and has been given the legal attributes of a natural person is in no way sufficient to make its actions subject to the Charter." 558 Only where a statute authorizes a person to exercise discretion in the course of performing a governmental objective, would the Charter be applicable. Secondly, the fact that universities were statutory bodies performing a public service and that

554 Ibid. (emphasis in original).

555 See also Lavigne v. O.P.S.E.U., Supreme Court of Canada (1991) 2 S.C.R. 211 (available at $<$ http://scc.lexum.umontreal.ca/en/1991/1991scr2-211/1991scr2-211.html >). In another case involving the applicability of the Charter to a post-secundary college (Douglas/Kwantlen Faculty Assn. v. Douglas College, Supreme Court of Canada (1990) 3 S.C.R. 570), the Court again concluded that an entity that has been established by statute to implement government policy is subject to the Charter. Douglas College, p. 584-585.

556 McKinney v. University of Guelph, Supreme Court of Canada (1990) 3 S.C.R. 229.

557 Applicants, a group of university professors and other university staff, had argued that the university's policy for mandatory retirement at the age of 65 was discriminatory.

558 McKinney, p. 265-266. The Court added that "[s]uch an entity may be established to facilitate the performance of tasks that those seeking incorporation wish to undertake and to control, not to facilitate the performance of tasks assigned to government. It would significantly undermine the obvious purpose of s. 32 to confine the application of the Charter to legislative and government action to apply it to private corporations, and it would fly in the face of the justifications for so confining the Charter to which I have already referred." Ibid., p. 266. 
some of their decisions were also subject to judicial review did not in itself make them part of the government within the meaning of Section 32 of the Charter. ${ }^{559}$ For the Court, it was not enough that Canadian universities were public bodies. The universities were established to be autonomous bodies that had the power to negotiate collective contracts with their staff and include within them provisions for mandatory retirement. These actions were not taken under statutory compulsion or following or implementing any governmental policy with respect to the mandatory retirement, thus excluding the application of the Charter. ${ }^{560}$ Finally, the Court stated that receiving government funding to accomplish policy objectives governments seek to promote is also not sufficient to establish that an entity is part of the government. ${ }^{561}$ On the basis of these grounds, the Court's majority concluded that the Charter could not be applied to these universities. ${ }^{562}$

In the later case of Eldridge, the Court reiterated its stance with regard to the applicability of the Charter to non-State entities that may be considered as 'government'. In Eldridge a group of deaf patients complained that they received lesser quality medical services than hearing patients and thus were discriminated against in violation of Section 15 of the Charter due to the absence of sign language interpreters at a number of hospitals. ${ }^{563}$ According to the Court the case entailed whether, and in what manner, the Charter applied to the decision not to provide these services as part of the publicly funded scheme for the provision of medical care. ${ }^{564}$ The Court noted that since all legislation is subject to the Charter, no statute can authorize any entity or person to violate it. ${ }^{565}$ La Forest's rationale was that while the legislation may remain valid under the Charter, the latter can be

559 Ibid., p. 268.

560 Ibid., p. 269.

561 Ibid., p. 272.

562 The Court, did, however engage in a theoretical examination of the question whether the policy of the universities violated Section 15 departing from the assumption that the Charter did apply to them. The Court concluded that if the policy would emanate from a governmental body pur sang, it would be in breach of Section 15. See McKinney, p. 279.

563 Canada did not have an official policy to provide sign language interpreters at hospitals. State and private hospitals receiving governmental money to fund the provision of medical services did not finance specific assistive measure for the hearing impaired. A Medical Services Commission, a nine-member panel composed of representatives from the government, the British Columbia Medical Association and health care consumers, with the discretionary power to decide what constitutes a benefit under the Medicare Protection Act, also did not make any arrangements to provide translation services for the hearing impaired. Patients who were deaf or had hearing impairments relied on the services of a private not for profit institute, which due to lack of funding, was unable to further provide for sign language interpreters. The complaint alleged that the provincial Medical Services Plan (established under a national Medicare Protection Act) failed to provide sign language interpreters as an insured benefit and thus violated Section 15 of the Canadian Charter on Rights and Freedoms. Eldridge, p. 639. Ibid., p. 643.

565 Ibid., p. 644. See also Gibson, "Monitoring Arbitrary Government Authority: Charter Scrutiny of Legislative, Executive, and Judicial Privilege," p. 318. 
infringed by the actions of bodies to which the decision making under that legislation has been delegated. ${ }^{566}$ The Court concluded that it was not the health care legislation that breached the Charter. This legislation, however, did leave the Medical Services Commission and individual hospitals considerable discretion regarding decisions on where to spend the money they received from the governmental health care scheme. They could decide themselves which health care services were necessary to finance. The legislation itself did not preclude or forbid hospitals from providing sign language interpreters. ${ }^{567}$ With this in mind, the Court turned to examine whether the entities that had been delegated the discretion to decide the kind of health care services provided (hospitals and the Medical Services Commission) could be subjected to the Charter.

Citing McKinney, the Court stated that non-State entities could be subjected to the Charter if their activities in some way could be attributed to the government. This could be the case if the government sufficiently partakes in these activities or is so involved in their decision-making as to make them an act of government. ${ }^{568}$ This implies an element of control on the part of the government in the activities of nonState actors that could render them directly liable under the Charter: the greater the governmental control in their activities, the more they would be considered to be part of the government and thus subject to the Charter. The Court observed that the Charter may apply when an entity whose actions have given rise to the alleged Charter breach can, either by its very nature or in virtue of the degree of governmental control exercised over it, itself be considered as 'government' for the purposes of Section 32. The Court noted that in such cases, "[...] all of the activities of the entity will be subject to the Charter, regardless of whether the activity in which it is engaged could, if performed by a non-governmental actor, correctly be described as 'private'. 569

In sum, one of the grounds adopted by the Supreme Court of Canada to apply the Charter to private parties performing certain functions is whether these private parties can be considered 'government'. The Court opted in Dolphin Delivery, McKinney and Eldridge for a restrictive interpretation of what a government is, and what government or state action encompasses for the purpose of applying the Canadian Charter on Rights and Freedoms. The performance of a public function, task or service appears not to be sufficient to consider a private entity carrying out

\footnotetext{
566 Eldridge, p. 644.

567 Ibid., p. $652-654$

568 Eldridge, p. 659.

569 Eldridge, p. 661. In other words, private entities may be considered 'government' when these entities are endowed with powers that 'inherently governmental in nature' or when their activities are closely controlled by the government in the strict sense of the word. See also Wilkins, "But We Need the Eggs: The Royal Commission, the Charter of Rights and the Inherent Right of Aboriginal Self-government," p. 60.
} 
such an activity to be 'government' and hence be susceptible to the Charter (see section 3.5.2.2 infra). More weight is given to whether the government in the strict sense of the word is sufficiently involved in these activities and to the amount of control exercised by the government proper over these activities. Private entities whose day-to-day activities or operations are subject to a large amount of control by the government in the strict sense of the word, and which act under statutory authority, or which are creatures of statutes themselves, may fall within the Charter's reach, if the activity which leads to the claim of possible Charter violation is specifically regulated by statute or carried out in conjunction with the State. ${ }^{570}$

\subsubsection{Applicability to non-State actors performing a 'governmental function'}

Alternatively, the Court has gradually come to accept the Charter may apply to private entities whenever these are exercising or performing 'governmental functions'. In McKinney, the Court hastily rejected applying the Charter solely on the basis of a 'functional' approach. The fact that universities perform an important public service is not sufficient on its own to conclude that they are governmental entities. ${ }^{571}$ The Court remarked in this respect that a 'public purpose' test is inadequate for determining whether a particular entity formed part of the government or not: "Many institutions in our society perform functions that are undeniably of an important public nature, but are undoubtedly not part of the government." ${ }^{572}$ According to the Court's majority universities do not perform a

570 See also Stoffman v. Vancouver General Hospital, Supreme Court of Canada (1990) 3 S.C.R. 483, p. 513-514. In addition see Hogg, Constitutional Law of Canada, p. 849.

571 McKinney, p 269.

572 Ibid. This stands in stark contrast with the UK's approach under the HRA that, as we have seen, accepts a functional approach (e.g. what is the nature of the function) in Section 6(3)(b) HRA as one of factors to be considered in determining whether a particular body falls under the Act. See section 3.3.2 supra. The majority's conclusions in McKinney were also criticized by one of the dissenting justices (Justice Wilson) who observed that relying on a limited concept of state intervention and what the government is to determine whether an entity is a governmental actor or not is not the correct approach, especially in view of the different roles that governments presently assume and their predilection for entrusting other non-governmental entities in performing these roles. In her view, "[...] the Charter should not be circumvented by the simple expedient of creating a separate entity and having it perform the role. We must, in my opinion, examine the nature of the relationship between that entity and government in order to decide whether when it acts it truly is 'government' which is acting. We must [...] identify those criteria which are relevant to that determination so that they may be applied in a principled way." Ibid., p. 357. According to Justice Wilson, the following questions should be asked about entities that are not self-evidently part of the legislative, executive or administrative branches of government in order to determine if they are subject to the Charter: (1) does the legislative, executive or administrative branch of government exercise general control over the entity in question?; (2) does the entity perform a traditional government function or a function which in more modern times is recognized as a responsibility of the state?; (3) is the entity one that acts pursuant to statutory authority specifically granted to it to enable it to further an objective that government seeks to promote in the broader public interest? Justice Wilson remarked that each of these tests 
quintessentially governmental function such as municipalities, which have the power to enact coercive laws binding upon the public in general and for which offenders may be punished. ${ }^{573}$ Although the Court conceded that the Charter is not limited to entities which discharge functions that are inherently governmental in nature, its applicability to non-State entities by virtue of the functions they perform, would depend on more than in showing that the entities' activities or services "[...] are subject to the legislative jurisdiction of either the federal or provincial governments." ${ }^{\circ 74}$

In Stoffman v. Vancouver General Hospital the Court was faced with a similar situation to the one in McKinney, this time involving the mandatory retirement of physicians of a Vancouver hospital. ${ }^{575}$ The Court had to decide whether the Charter applied to a hospital that was not governmentally owned or managed (although the government had the statutory power of appointing the majority of the hospital's board of trustees) and which through the application of an internal regulation, was discriminating against a group of physicians by reasons of age. Justice La Forest, writing once more for the majority, followed the already established path in Dolphin Delivery and McKinney: La Forest first explored whether the hospital regulation could be seen as an emanation of delegated legislation to which the Charter would apply. After observing that the regulation mandating the retirement of hospital personnel at the age of 65 was not an offshoot of local or national legislation, but merely a rule of internal management, and that no other statute required the adoption of the retirement policy, La Forest concluded that "[...] neither Regulation 5.04 or its administration can properly be said to be acts of the executive branch of government." $576 \mathrm{He}$ then went on to explore whether the hospital was part of the administrative branch of the government as required in Dolphin Delivery. La Forest first noted that the fact that the hospital carried out an important public service is not determinative for concluding that the Charter applied to the hospital. ${ }^{577} \mathrm{He}$

identifies aspects of government in its contemporary context. "An affirmative answer to one or more of these questions would, to my mind, be a strong indicator that one is dealing with an entity that forms part of government. I hasten to add, however, that an affirmative answer can never be more than an indicator.” Ibid., p. 370.

Ibid., 270.

Ibid., p. 270-271.

The judgment in Stoffman was rendered at the same time as McKinney. In Stoffman, the hospital had enacted an internal regulation that obliged the medical personnel of the hospital to retire when they reached the age of 65 . A number of physicians who were not employed by the hospital itself but who treated individual patients at the hospital were not allowed to work anymore at the hospital when they became 65. These physicians claimed a violation of Section 15 of the Charter.

Stoffman, p. 511.

"This question cannot be answered by simply pointing out that the provision of health care and hospital services is an important part of the legislative mandate of provincial governments, and that the [hospital] was incorporated for the express purpose of providing such care and services. If that was by itself sufficient to bring the hospital and all other bodies and individuals concerned 
then maintained that the hospital operated autonomously from the government and that government involvement in the hospital's decision-making was minimal. 578 The majority of the Court concluded that the lack of proper governmental intrusion in the day-to-day activities of the hospital, in particular with regard to the hospital's retirement policy, meant that it could not be regarded as part of the administrative branch of the government within the meaning of Section 32 of the Charter. ${ }^{579}$ Having concluded that the hospital was not 'government', the Court rather cursorily explored whether the Charter applied on other grounds. With no significant supporting arguments La Forest concluded that there could be no question that the hospital was subjected to the Charter on the ground that it performs a governmental function since "[...] the provision of a public service, even if it is one as important as health care, is not the kind of function which qualifies as a governmental function under [Section] 32." ${ }^{580}$ In sum, the Supreme Court of Canada opted in McKinney and Stoffman for a restrictive interpretation of what a governmental function encompasses for the purpose of applying the Canadian Charter on Rights and Freedoms. In doing so, the Court seemingly discarded a 'functional' approach: the nature of the function, task or service exercised appeared not to be particularly relevant in establishing whether the Charter applied to a non-governmental actor.

The Supreme Court's stance with regard to the question of applicability of the Charter's rights under Section 32 to private actors exercising governmental functions was slightly modified a number of years later in Eldridge v. British Columbia. ${ }^{581}$ The Court once more confirmed that the Charter's rights can only be engaged to the extent that an alleged violation thereof represents or embodies action of the State (in its legislative, executive or administrative manifestation). However, La Forest, acknowledged that the nature of the action being performed by a private entity may matter in determining whether the Charter is applicable to private actors. When the nature of the act at issue is truly 'governmental', the Charter could cover the conduct of these actors. Thus, instead of looking at the nature of the entity whose activity is impugned, it is necessary to look at the nature of the act. According to the Court,

"[i]n such cases, [...] one must scrutinize the quality of the act at issue, rather than the quality of the actor. If the act is truly 'governmental' in nature - for example, the

with the provision of health care or hospital services within the reach of the Charter, a wide range of institutions and organizations commonly regarded as part of the private sector, from air-lines, railways, and banks, to trade unions, symphonies and other cultural organizations, would also come under the Charter. For each of these entities, along with many others, are concerned with the provision of a service which is an important part of the legislative mandate of one or the other level of government." Ibid., p. 511.

Ibid., p. 512-513.

579 Ibid., p. 516.

580 Ibid.

581 See note 544 supra. 
implementation of a specific statutory scheme or a government program - the entity performing it will be subject to review under the Charter only in respect of that act, and not its other, private activities." 582

As we have seen, the Court had concluded that hospitals were private entities in Stoffman because their activities in that case were not for the furtherance of governmental policies (e.g. it was not instigated by the government, nor did they reflect governmental policy with regard to the particular activity). In Eldridge, however, the Court decided that the same hospitals were governmental entities as understood by Section 32 of the Charter since in this particular case, they had been delegated the statutory authority to decide which services should receive funding from the money made available to them through the national health care legislation. In the eyes of the Court this was an act of a 'governmental' nature because it was meant to implement a specific government policy in providing health care services under that legislation. ${ }^{583}$ In the words of the Court, "in providing medically necessary services, hospitals carry out a specific governmental objective."584

\subsubsection{Some observations}

The underlying concern in Canada as in the other jurisdictions appears to be that delegating these functions or activities to private actors may somehow excuse the State from fulfilling its Constitutional obligations. The method that has been introduced to prevent this from occurring is by regarding non-State actors to be part of the State under two related circumstances: when non-State actors are to be considered as 'government', and when they perform a 'governmental function'. This approach towards the applicability of Constitutional or public norms to the conduct of private actors involved in the exercise of public functions, tasks or services is reminiscent of the British and American approaches, although some differences may be detected. For example, in the UK bodies may be subjected to judicial review on two different grounds: when a body derives its power from public law statutes,

582 Eldridge, p. 661-662.

583 See also G.W. Anderson, "Social Democracy and the Limits of Rights Constitutionalism," The Canadian Journal of Law \& Jurisprudence Vol. 17 (2004), p. 44.

584 Eldridge, p. 664. The Court concluded that "[u]nlike Stoffman, then, in the present case there is a 'direct and... precisely-defined connection' between a specific government policy and the hospital's impugned conduct. The alleged discrimination - the failure to provide sign language interpretation - is intimately connected to the medical service delivery system instituted by the legislation. The provision of these services is not simply a matter of internal hospital management; it is an expression of government policy. Thus, while hospitals may be autonomous in their day-to-day operations, they act as agents for the government in providing the specific medical services set out in the Act. The Legislature, upon defining its objective as guaranteeing access to a range of medical services, cannot evade its obligations under s. 15(1) of the Charter to provide those services without discrimination by appointing hospitals to carry out that objective. In so far as they do so, hospitals must conform with the Charter." Ibid., p. 665 (emphasis added, $A H W$ ). 
and when the function they perform is sufficiently public. Similarly, the applicability of the Human Rights Act depends on whether a non-State actor can be labeled as a 'public authority'. In such a case, the statutory underpinnings of the body or the nature of the function it performs will also play a role. In Canada, susceptibility for judicial review does not mean that a non-State actor is also subject to Constitutional norms. Furthermore, a statutory source from which a particular body derives its power is not sufficient to conclude that such an actor is 'government'. There must be, in addition, a close enmeshment of the Government in the strict sense of the word with the activities of the non-State actor before the latter can be regarded as 'government'. Another difference between the Canadian and the UK approach can be observed with regard to how they tackle the question of applicability based on the nature of the function exercised. The Canadian approach requires not only a 'public' function, but also more specifically a 'governmental' one. This means that before a function performed by a non-State actor can be regarded as 'governmental', there must be a statutory compulsion to implement a governmental policy. In any case, the nature of the function remains an important element in determining whether the Canadian Constitutional rights can be applied to these actors. This contrasts of course with the U.S. Supreme Court's approach, which in the course of the years has made this functional approach (e.g. looking at the nature of the function) less relevant, focusing instead more on the degree of involvement of the State in the activities of the private actor before concluding whether 'state action' was applicable in a particular case.

\subsection{Applicability of public law norms in non common law countries}

In a number of non common law jurisdictions that have witnessed large scale privatizations, the conduct of private actors has been subjected to public or constitutional norms under special circumstances. This has been the case in France where the conduct of private actors may sometimes be subjected to review by administrative courts. The French courts then apply public law norms to the particular case when these actors perform a 'service public' or are parties to so-called contrats administratifs. Similarly, in some developing countries it is sometimes possible to apply public law norms to the conduct of a private actor entrusted with the exercise of a public service. This is the case in Ecuador where, through the use of the 'amparo' procedure, individuals may request national courts to grant an injunction against private actors entrusted with a public service if the latter's conduct threatens the individuals' constitutional rights.

\subsubsection{Applicability of public law norms in France to public services carried out by private actors}

The applicability of French public law norms to private actors has been raised in the context of administrative law. The concepts of service public and contract 
administratif have been of great importance with respect to whether French administrative courts and the French Conseil d'Etat have jurisdiction over certain activities and decisions of public authorities. ${ }^{585}$ Under French law, French administrative courts have the exclusive jurisdiction to examine the decisions taken "[...] dans l'exercice des prérogatives de puissance publique, par les autorités exerçant le pouvoir exécutif, leurs agents, les collectivités territoriales de la République ou les organismes publics placés sous leur autorité ou leur contrôle."586 Central in this context has been the search for a criterion to distinguish the acts of administrative bodies in order to establish the jurisdiction of administrative courts over certain activities. Among the criteria used until the late $19^{\text {th }}$ Century by French courts was the concept of the 'act of public authority' (acte de la puissance publique). ${ }^{587}$ In 1873 the Tribunal des Conflits, the French court charged with determining whether disputes have to be decided by civil or administrative courts, decided that injuries arising out of activities of a service public should be dealt with by administrative courts. ${ }^{588}$ The service public criterion has been used ever since to distinguish between the acts of administrative bodies. It has also been applied to cases where private entities are entrusted with the performance of such a service.

\subsubsection{The concept of service public}

The concept of service public has been defined as any activity of a public authority aimed at satisfying a public need. ${ }^{589}$ This definition contains two elements that must be present if a particular activity is to be regarded as a service public: a. the activity

585 See in general L.N. Brown and J.S. Bell, French Administrative Law (Oxford: Clarendon Press, 1998) p. 126-130 and p. 141-143.

$586[\ldots]$ in exercise of prerogatives of public power by authorities exercising executive power, their agents, the local authorities of the Republic or the bodies placed under their authority or control. Decision by the French Conseil Constitutionnel, CC decision no. 86-224 DC (23 January 1987), para. 15, quoted in ibid., p. 128.

587 Ibid., p. 129. Y. Gaudemet, Traité de Droit Administratif-Tome 1: Droit Administratif Général, $16^{\text {th }}$ ed. (Paris: L.G.D.J., 2001) p. 387.

588 “Considérant que la responsabilité, qui peut incomber à l'Etat, pour les dommages causés aux particuliers par le fait des personnes qu'il emploie dans le service public, ne peut être régie par les principes qui sont établis dans le Code civil, pour les rapports de particulier à particulier; Que cette responsabilité n'est ni générale, ni absolue; qu'elle a ses règles spéciales qui varient suivant les besoins du service et la nécessité de concilier les droits de l'Etat avec les droits privés; Que, dès lors, aux termes des lois ci-dessus visées, l'autorité administrative est seule compétente pour en connaître." Decision by the Tribunal des Conflits, Blanco, TC 8 February 1873. See also Brown and Bell, French Administrative Law, p. 129.

589 In French, 'une activité d'intérêt général'. See ibid., p. 130. citing Rolland's definition found in "Précis de Droit Administratif," $10^{\text {th }}$ edn., Paris (1951). See also J. Rivero and J. Waline, Droit Administratif, 19 ${ }^{\text {th }}$ ed. (Paris: Editions Dalloz, 2002) p. 160-163 and 450-451. Rivero and Waline note that through a service public, "[...] l'autorite publique prend directement en charge ou délègue sous son contrôle, la satisfaction d'un besoin d'intérêt general, en assurant soit à la collectivité, soit aux particuliers individuellement, les prestations ou avantages correspondants." ibid., p. 433. 
in question must be carried out by a public authority, and b. a public need must be satisfied through the exercise of such an activity.

Brown and Bell observe that the first element requiring a public authority to carry out a particular activity has been extended in the last decades to the vanishing point. ${ }^{590}$ The existence of a service public does not necessarily depend on whether it is actually provided by a public body sensu stricto. According to Brown and Bell, transferring the provision of a service public to the private sector does not necessarily mean that this activity is no longer a service public, "but rather that it has become an ordinary profit-making activity." 591 In any case, it appears that the provision of a service public that does not entail a function directly related or connected to the national sovereignty including, national defense, police and the judiciary, may be delegated to private actors. ${ }^{592}$ Thus the Conseil d'Etat has concluded that local private law societies in France providing and administering social insurance benefits, a service which itself was created by statute or through a decision of a formal public authority, fell within the competence of the administrative courts since they were providing a service public. ${ }^{593}$ Accordingly, Brown and Bell observe that it is necessary to distinguish between a particular body's role as the creator or director of the service public and its role as provider of the service. ${ }^{594}$ In other cases, French Courts have confirmed this position and apparently narrowed it down by concluding that private bodies fulfilling "une mission de service public" and that exercise a "prérogative de puissance publique" that has been conferred on them by legislative means are also subject to the administrative jurisdiction. ${ }^{595}$

590 Brown and Bell, French Administrative Law, p. 131.

591 Ibid., p. 131.

592 Rivero and Waline, Droit Administratif, p. 434. A number of laws adopted in the early 1990s in response to the harmonization intitiatives at the European Union level on the subjects of public contracts, public procurement, and services have formalized the possibility of delegating the provision of a service public to private actors and introduced the concept of delegation des service public. See Loi du 2 février 1992 sur l'administration territoriale de la République and Loi du 29 janvier 1993 sur la prevention de la corruption (known as the law 'Sapin'). See also Brown and Bell, French Administrative Law, p. 205-206; Gaudemet, Traité de Droit Administratif - Tome 1: Droit Administratif Général, p. 667; Rivero and Waline, Droit Administratif, p. 470. The concept of delegation des service public is closely related to the one on contrats administratifs, which will be discussed in more detail below.

593 CE 13 May 1938, Caisse Primaire 'Aide et Protection'.

594 Brown and Bell, French Administrative Law, p. 131. See also Gaudemet, Traité de Droit Administratif-Tome 1: Droit Administratif Général, p. 403-404.

595 See CE 22 November 1974, Federation des Industries Françaises d'Articles de Sport, where the Conseil d'Etat held that a private sport body was subject to judicial control by an administrative judge. See Brown and Bell, French Administrative Law, p. 131-132; Rivero and Waline, Droit Administratif, p.165-166. In a case involving a private psychiatric institution, the Tribunal des Conflicts held that this institution, although providing a service public, was nevertheless subject to the normal jurisdiction because it did not exercise any "prérogative de puissance publique" in that particular situation. See TC 22 April 1980, Mme Girinon. See also ibid., p. 166. 
The second element of the definition of service public, the satisfaction of a public need, entails that a particular activity must serve or fulfill a public interest. ${ }^{596}$ Rivero and Waline have observed that this element is very broad. ${ }^{597}$ It includes at one end of the spectrum activities that relate to typical 'sovereign' functions such as defense, policing, justice, and public finances. At the other end of the spectrum the satisfaction of a public need may include providing services that are for the benefit of the public such as public utilities.

Under French administrative law, this public need may be defined by statute, but it can also be identified by a decision of a formal public authority. ${ }^{598}$ Although it has not been brought up in any known case, it is not unimaginable that the identification of a public need could also be derived from Constitutional norms or even from regional or international legal norms such as EU law, and human rights treaties such as the International Covenant on Economic, Social and Cultural Rights. Since a public need entails serving a public interest which may be defined by a statute, identifying a particular public interest could be eased by looking not only at national statutes but also at international legal norms imposing public law obligations on States.

On top of these two main elements, authors have identified other elements that may also play a role in determining whether certain activities may be considered as a service public. According to Lachaume, Boiteau and Pauliat, a service public is "[...] une activité d'intérêt général assumée par une personne publique, ou, sous son contrôle, par une personne privée et qui est soumise, à des degrés variables suivant les cas, à un régime exorbitant du droit privé (emphasis added $A H W$ ). ${ }^{" 599}$ Brown and Bell, for example, observe that the public authority carrying out the service must have recourse to methods and prerogatives which would be excluded in the relations between private parties ("des prérogatives exorbitantes du droit commun"). ${ }^{600}$ The operation of a particular service as a monopoly, or its financing through compulsory contributions from those who benefit from the service are provided as examples. This element is very similar to the one employed by the ECJ in the Foster v. British Gas case (see Section 6.2.3 supra).

596 Compare with the definition of a body governed by public law under EU public procurement law. See Section 3.2.4 supra.

597 Rivero and Waline, Droit Administratif, p. 452.

598 Brown and Bell, French Administrative Law, p. 130.

599 "An activity of general interest exercised by a public body, or under its control, by a private body and that is subdued, depending on the particular case, to an exceptional regime of private law." (translation by the author). J-F. Lachaume, C. Boiteau, and H. Pauliat, Grands Services Publics, $2^{\text {nd }}$ ed. (Armand Colin, 2000) p. 12. See also F. Mellerray, "La Notion Judiciaire de Service Public," AJDA (2003), p. 117, observing that the definition of a service public as developed by the administrative courts in France has also been adopted by civil and criminal law courts. 
The applicability of administrative law to activities entailing a service public, however has been somewhat diluted with the increasing engagement of the State in commercial activities following World War I. ${ }^{601}$ In the wake of the nationalization of many industries and the growing involvement of the State in economic activities, the Tribunal des Conflits recognized that the concept of service public had to be adapted to reflect the new realities. Hence in the case of Bac d'Eloka ${ }^{602}$ the Tribunal des Conflits held that there are certain activities in which public bodies (or private ones to which such an activity had been delegated) engage under the same or comparable conditions as those of a private enterprise and pursue the same objectives as a private entrepreneur. These services were denominated service public à caractère industriel et commercial and fell under the jurisdiction of ordinary courts. ${ }^{603}$ This goes to show that the service public criterion is not watertight for determining whether administrative law is applicable or not to a particular situation. ${ }^{604}$

In sum, the concept of service public may be helpful in determining whether public law norms may be applied to bodies carrying out such a service. Bodies exercising such a service may be subject to administrative law. Although it is usually applied to public authorities sensu stricto, it is also accepted that it can be equally applied to private bodies entrusted with the provision of a service public, in particular when they exercise a power of public authority. The concept of service public, however, is not always easy to apply, and some privatized services may not always be regarded as such, but rather as services publics à caractère industriel et commercial. Such a characterization would mean that public law norms are in principle not applicable to the bodies performing them (be them public or private) and that French administrative courts do not have jurisdiction.

This limitation notwithstanding, it is of interest to note that in France the nature of the activity or function appears to play a role in determining whether a particular body will be amenable to public law norms. A particular function may be considered of a public nature when it satisfies or realizes a public need, thus making it possible to apply public law norms to private or public bodies exercising such a function.

601 Ibid., p. 133; Rivero and Waline, Droit Administratif, p. 162.

602 TC 22 January 1921, Societé Commericale de l'Ouest Africain (Le Bac d'Eloka).

603 Brown and Bell, French Administrative Law, p. 133; Gaudemet, Traité de Droit AdministratifTome 1: Droit Administratif Général, p. 405; Rivero and Waline, Droit Administratif, p. 163.

604 Both Brown and Bell, and Rivero and Waline observe that in later case law the Tribunal des Conflits as well as the Conseil d'Etat issued contradictory judgments pertaining to the question whether social services (service public social) were services publics or services publics à caractère industriel et commercial, thus putting some doubt regarding the actual extent of the latter. It would appear that when in doubt, French administrative courts will accept the jurisdiction of cases involving a service public social even if it has some commercial characteristics. This has led to a shift towards a broader idea of service public. Brown and Bell, French Administrative Law, p. 133; Rivero and Waline, Droit Administratif, p. 163. 
This approach is comparable to the one adopted under EU public procurement law. The nature of the body carrying out such a function appears to be less relevant. Rivero and Waline, for example, observe that the State may decide to satisfy certain public needs but delegate the job of doing so to a private body. ${ }^{605}$ In fact, through the adoption of the 'loi Sapin' (see footnote 592 supra), the French government has made this possible.

Since it is possible to determine a public need through legislation, it is suggested that to answer the question of what constitutes a public need, some guidance may be found in the legal obligations imposed on States by (international) human rights treaties, and which have been transposed in national legislation. If a particular treaty imposes an obligation to guarantee the realization of easily accessible (physically and economically) adequate healthcare to the population without discrimination, and these obligations have been enacted in national laws, the bodies (public or private) entrusted with such a duty may be considered to carry out an activity satisfying a public need.

\subsubsection{The concept of contrat administratif}

As we have seen in the previous section, activities of a private, industrial, or commercial character in principle do not fall under the jurisdiction of French administrative courts. This is comparable to the position adopted under EU procurement law and confirmed by the European Court of Justice (see Section 3.2.4 supra). These activities also include contracts signed between public authorities and private entities, which in general will be dealt with by civil law courts. Exceptions to this general rule are contracts of a public or administrative character (contrats administratifs). Contrats administratifs are contracts entered by administrative/ public bodies with private actors. These contracts relate to a public service and reserve exceptional powers to the administration (i.e. contain clauses exorbitantes $d u$ droit commun) ${ }^{606}$ Issues pertaining to contrats administratifs are justiciable by French administrative courts. ${ }^{607}$

In general, the mere fact that a public authority is part of a contract does not make it a contrat administratif. ${ }^{608}$ The presence of a public authority in a contract, is however one of the three elements that may help to discern between civil law contracts and contrats administratifs. ${ }^{609} \mathrm{~A}$ second element is the requirement of closely involving a private entity in meeting a public need. This is the case of

605 Rivero and Waline, Droit Administratif, p. 450.

606 Brown and Bell, French Administrative Law, p. 202.

607 Ibid., p. 141; Rivero and Waline, Droit Administratif, p. 110-111.

608 Brown and Bell, French Administrative Law, p. 141.

609 Ibid. See also Gaudemet, Traité de Droit Administratif - Tome 1: Droit Administratif Général, p. 675 . 
concession contracts, which will be briefly dealt with below. The final element is the presence of clauses exhorbitants, that is, contract clauses that are different in their nature than those that would be included in a normal civil law contract. ${ }^{610}$ In other words, clauses which impose particular obligations on the private party to the contract, or grant certain rights to the public party, and which would normally not be acceptable or possible in a normal civil law contract. ${ }^{611}$ Examples include imposing penalties upon the contractor, or allowing the public authority to vary the terms of the contract during the course of its performance.

There are two main types of contrats administratifs: contracts entailing la concession de service public (concession contracts, sometimes also called l'affermage) and contracts entailing le marché public (these contracts include contracts for public works, maintenance and services, in similar fashion to those covered by the notion of EU competition law). ${ }^{612}$ Because of their relevance to the topic of privatization, only the first type of contrats administratifs will be dealt with in the following paragraphs.

Through a concession contract a public authority grants or delegates the operation of a public service to a private body (the concessionaire) for a specified period of time. ${ }^{613}$ The concessionaire is allowed to charge the end users/consumers a tariff for the provision of the service, and is responsible for running the service within a (legal) framework established by the public authority. In France, concession contracts have been extensively employed for the operation of motorways, public transportation, and public utilities services such as electricity, gas, and water.

The legal regime applicable to the private entities carrying out a public service through a concession contract depends on the particular activity of the entity. According to a judgment of the Conseil d'Etat, private law is applicable to the entity's internal organization, its labor relationship with its employees, and its contracts (with consumers, for example). ${ }^{614}$ However, the private entity can be subjected to administrative law with regard to its activities that are necessary for the fulfillment of the public service, as well as its decisions taken in respect thereof. ${ }^{615}$

In addition, the concessionaire in charge of a public service has a number of public law obligations, which would otherwise also be applicable to a public law entity

610 Brown and Bell, French Administrative Law, p. 142.

611 Ibid; Gaudemet, Traité de Droit Administratif-Tome 1: Droit Administratif Général, p. 681.

612 Brown and Bell, French Administrative Law, p. 204.

613 Ibid; Rivero and Waline, Droit Administratif, p. 475.

614 See CE, 3 March 1969, Societé Interlait.

615 See Rivero and Waline, Droit Administratif, p. 477. 
discharging the same service. ${ }^{616}$ These obligations relate to a main obligation to ensure the proper functioning of the public service. In the first place, the concessionaire has an obligation to ensure the continuity of the service. Thus with regard to the concessionaire's employees' right to strike, the concessionaire is subjected to the same rules applicable to public bodies proper. In the second place, the concessionaire has a duty to act in a non-discriminatory way towards end users/ consumers. Although price discrimination is allowed, private entities must treat the service's users equally. In the third place, the concessionaire is under an obligation to modify the terms of service or its operational methods according to any changes deemed necessary by the delegating authority in pursuance of the general interest.

It is, however, necessary to point out that these obligations, and other administrative law obligations ensuing from contrats administratifs in general, and concession contracts in particular, are in principle applicable between the public authority and the private body party to the contract. End users/consumers maintain merely a contractual link with concessionaires to which private law is applicable.

In sum, through the use of contrats administratifs such as concession contracts for public utilities, it is possible to subject the conduct of private actors that are parties to such a contract for the exercise of a public service to public law norms. However, the applicability of public law norms to the parties of a contract administratif is limited to those actually involved in the contract. Third parties, for example the consumers of the public service provided by the private actor under a concession contract, may not directly be in the position to invoke public law norms vis-à-vis the private actor.

\subsubsection{Applicability of public law norms in to privatized activities: the case of Ecuador}

All of the examples noted above until now are from developed countries' jurisdictions. However, various developing countries have also engaged in privatization exercises that have profoundly affected the way certain services are delivered and on the way public law norms are applied to them. This is appreciable in Ecuador where prior to the 1990s most of the key industries such as oil and essential utilities (including water, electricity, telecommunications and the postal service) were in the hands of the State. Under the influence of the IMF and the World Bank, Ecuador committed itself to apply privatization policies in several sectors. ${ }^{617}$ Although privatization efforts started in 1993 with the adoption of a

616 Ibid., p. 459-460 and p. 479.

617 In 1999 Ecuador signed an agreement with the International Finance Corporation (a member of the World Bank Group which promotes sustainable private sector investment in developing countries) in which the country solicited the advisory services of the financial institution for the restructuring and privatizing state-owned enterprises, including power generation and 
Law on the Modernization of the State, privatization did not take place on the grand scale envisioned by the international financial institutions, ${ }^{618}$ mainly due to the pervasive opposition of certain political groups in the national parliament in spite of the facts that privatization as a governmental policy had been accepted in Ecuador's 1998 Constitution. However, further opposition to privatization was taken to a new high under the constitutional reform process which took place in the country between 2007 and 2008. As observed in Chapter III, Section 2.1, the new Ecuadorian Constitution adopted in September of 2008 has prohibited certain forms of privatization.

However, privatization was deemed important enough to take it into account in the constitutional reform process that took place in the country in 1997-1998. A new Constitution was enacted following a national referendum in 1998. The 1998 Constitution included several amendments, which took into consideration the possibility of privatization. Whereas the previous Constitution ${ }^{619}$ provided that the State had exclusive control of the provision of public services and certain economic activities, Article 249 of the 1998 Constitution allowed the State to delegate these activities (including the provision of drinking water, sanitation, electricity, telecommunications, portal services, and road infrastructure) to mixed or private companies. ${ }^{620}$ This delegation may take place through concessions or through the sale of assets. In addition, Article 249 stipulated in language which is very similar to the one used by the UN Committee on Economic, Social and Cultural Rights,

distribution, telecommunications, hydrocarbons, airports, postal services and the water and sanitation sector. See press release dated 6 May 1999 of the International Finance Corporation (IFC) available at www.ifc.org/ifcext/LAC.nsf/Content/SelectedPR?OpenDocument\&UNID=5 B69EC1D9DB46E148525697D00731D18 (last visited on 25 September 2005).

See Servicios Públicos: Privatización, Regulación y Protección al Usuario en Bolivia, Ecuador $y$ Venezuela, ed. Comisión Andina de Juristas (Lima: CAJ, 2001) p. 50-51. A table with the number of actual privatizations that occurred in Ecuador in the 1990s can be found at $<w w w$. ipanet.net/documents/WorldBank/databases/plink/soceco/1lecuador.htm $>$ (last visited on 31 August 2011). See also a Washington Times Report at <www.internationalreports.net/ theamericas/ecuador/2001/ecuadoriansare.html $>$ (last visited on 25 September 2005, no longer available).

619 The text of the previous (1996) Constitution is available at $<\mathrm{http} / / /$ pdba.georgetown.edu/ constitutions/ecuador/ecuador.html $>$ (last visited on 31 August 2011).

620 Article 249 originally read: "Será responsabilidad del Estado la provisión de servicios públicos de agua potable y de riego, saneamiento, fuerza eléctrica, telecomunicaciones, vialidad, facilidades portuarias y otros de naturaleza similar. Podrá prestarlos directamen te o por delegación a empresas mixtas o privadas, mediante concesión, asociación, capitalización, traspaso de la propiedad accionaria o cualquier otra forma contractual, de acuerdo con la ley. Las condiciones contractuales acordadas no podrán modificarse unilateralmente por leyes u otras disposiciones. El Estado garantizará que los servicios públicos, prestados bajo su control y regulación, respondan a principios de eficiencia, responsabilidad, universalidad, accesibilidad, continuidad y calidad; y velará para que sus precios o tarifas sean equitativos." See also Servicios Públicos: Privatización, Regulación y Protección al Usuario en Bolivia, Ecuador y Venezuela, p. 63. 
that the State is bound to guarantee the quality, universal availability, continuity and accessibility of these services, as well as guard that their tariffs or prices be affordable to all. ${ }^{621}$

In addition to Article 249, which appeared to make privatization possible, the 1998 constitutional reform also introduced some amendments to the provision on 'amparo constitucional' that are of importance to the current discussion. As is well known, amparo constitucional (also known as 'remisión') is a procedural remedy whereby individuals who are (potential) victims of a violation of constitutional rights may submit through a direct and simple procedure a request before a court of law to stop or prevent the violation. ${ }^{622}$ Amparo is a fairly accessible legal remedy and is widely used to protect individuals against State abuse.

Under the pre-1998 Constitution a request for amparo could only be submitted against an "illegitimate act of authority of a public administrative body in violation of any constitutional right and which may cause immediate and irreparable harm." 623 Article 95 of the 1998 Constitution ${ }^{624}$ made it possible to submit a request for amparo against illegal acts of a public body. Article 95, however, spoke in terms of a 'public authority' instead of a 'public administrative body' and it made it clear that not only actions, but also omissions may lead to such a request. It may be stated that this probably extended the range of public bodies against which amparo was possible. Furthermore, Article 95 of the 1998 Constitution spoke of a "[...] violation, or potential violation of any right enshrined in the Constitution or in a valid international treaty $[\ldots]$ "625 thus expanding the scope of the norms against which the conduct of the public authority may be tested.

However, the most important amendment for the purposes of the current discussion brought by Article 95, is that the amparo procedure is also possible against acts or omissions carried out by "individuals that provide public services or that act through

621 See Chapter VII. See also ibid.

622 As it is well known, 'amparo constitucional' (also known as 'remisión') is a procedural remedy whereby individuals who are (potential) victims of a violation of constitutional rights may submit through a direct and simple procedure a request to a court of law to stop or prevent the violation. The 'amparo procedure' is typically found in Spain and various Latin American countries.

623 See Article 31 of 1996 Constitution (author's translation).

624 Article 95 originally reads "Cualquier persona, por sus propios derechos o como representante legitimado de una colectividad, podrá proponer una acción de amparo ante el órgano de la Función Judicial designado por la ley. Mediante esta acción, que se tramitará en forma preferente y sumaria, se requerirá la adopción de medidas urgentes destinadas a cesar, evitar la comisión o remediar inmediatamente las consecuencias de un acto u omisión ilegítimos de una autoridad pública, que viole o pueda violar cualquier derecho consagrado en la Constitución o en un tratado o convenio internacional vigente, y que, de modo inminente, amenace con causar un daño grave."

625 See Article 95 (author's translation). 
the delegation or concession of a public authority." 626 Ecuador's former Constitutional Tribunal (Tribunal Constitucional) ${ }^{627}$ has reaffirmed this in various amparo procedures in which this specific paragraph of Article 95 was cited (although not always applied). ${ }^{628}$ This amendment made it possible to challenge the conduct of privatized service providers that have taken over certain tasks previously exercised by proper public authorities and whose conduct is in breach of the constitutional rights enshrined in the Ecuadorian Constitution or those in international human rights treaties ratified by Ecuador. It is interesting to note that Article 95's approach appears to be functional as well: it appears not to matter what type of body is responsible for delivering what has been termed 'public services'. Rather, the function of delivering these services is relevant in determining whether amparo, and by extension the constitutional norms, is applicable to a particular body. This has been made clear in a number of cases before the Constitutional Tribunal.

In practice, the Constitutional Tribunal has been faced with few cases against privatized entities. In a number of these cases, it has acknowledged the functional approach, although it would appear that the Tribunal is strict in determining what types of activities or conduct relate to 'public services', and what types of complaints fall under the amparo procedure. For example, in a complaint related to the refusal on the part of a privatized water utility (Interagua) in the city of Guayaquil to change the consumption tariff charged, the Tribunal refused to grant amparo to the complainant. ${ }^{629}$ The complainant alleged that the water tariff he had to pay was too

626 Article 95, last paragraph (author's translation). The Spanish original reads "También podrá interponerse la acción si el acto o la omisión hubieren sido realizados por personas que presten servicios públicos o actúen por delegación o concesión de una autoridad pública." In addition, Article 95 makes it possible to file an amparo procedure against private individuals whose conduct affects a community or collective interest or a 'difuse' right, thus providing for a limited horizontal applicability of constitutional norms. The new 2008 Constitution, does not change in essence the content of 'amparo' but adds in its new Article 89 that it can be used against private entities under a number of circumstances: when the private entity has caused a violation which leads to a serious damage, when it is supplying public services in an improper way, or when it acts under delegation or concession.

627 The Constitutional Tribunal was replaced by a Constitutional Court by the 2008 Constitution, and the members of the former Tribunal have taken seat in the new Court.

628 See for example Tribunal Constitucional, Resolución No. 0640-04-RA (2 March 2005), para. 3, Tribunal Constitucional, Resolución No. 0604-2004-RA (11 March 2005), para. 2, observing that amparo is also possible in the case of acts of private entities providing public services ("También procede el amparo constitucional ante actos de particulares que prestan servicios públicos.”), and Tribunal Constitucional, Resolución No. 0748-2004-RA (18 March 2005), para. 3.

629 See Tribunal Constitucional, Resolución No. 335-2002-RA (25 October 2002). In 2001 Interagua S.A., a private water utilities company (which in turn is a subsidiary of International Water Services B.V., a Dutch consortium in the hands of the American multinational Bechtel) took over the water and sewerage services of Guayaquil from the public utility ECAPAG under the auspices of the Inter American Development Bank. See in general J. Díaz, "La participación del 
high on the grounds that it had been wrongly calculated and that Interagua had not done anything to solve the problem. He further claimed that this conduct violated Article 23 (7) and (15) of the Constitution on right to access to public and private services and the right to submit a complaint before an authority and receive a prompt response, and requested reparation for damages incurred. Although the Tribunal (implicitly) acknowledged that it had jurisdiction to hear a complaint against a body such as Interagua, it held that the amparo procedure was not suited, inter alia, to deal with complaints requesting reparation for damages since there are other legal remedies that may deal with this, and that the case did not involve immediate harm. ${ }^{630}$

In a case against a privatized electric utility, the Tribunal again acknowledged that the amparo procedure can be used against a privatized entity in charge of providing a public service. ${ }^{631}$ The Tribunal reasoned that the provision of electricity was a public service and that this service had been entrusted to the company through a concession, which finds its origin in a public law. ${ }^{632}$ The Tribunal, however, refused to handle the amparo request on the grounds that the complaint itself (a labor dispute) did not refer itself to a violation of any relevant constitutional norm. In addition, the nature of the conduct complained about was contractual and not suitable for the amparo procedure, and did not result in any grave or immediate harm or illegality. ${ }^{633}$

From the previous examples, it is possible to discern a limitation to the types of acts that may fall under public services, which are in turn amenable for review under the amparo procedure. It appears that the Tribunal is not willing to accept complaints that are at their core of a commercial nature. This is made still more apparent in the following case, which again involved privatized water utility Interagua. In this request for amparo, complainants alleged that Interagua had illegally suspended the water service following the failure of complainants to pay a high water bill. ${ }^{634}$ The high water bill had been the result of arrears in the payments of the regular water bill. Complainants claimed a violation of Article 23 (20) (on the right to an adequate standard of living including access to drinking water and sewerage and other basic services) and Article 35 (10) (which prohibits the suspension of basic services by the State and thus by extension the suspension of these services by the public or private bodies which have been entrusted with their provision) of the Constitution. They further requested the reactivation of the water service and annulment of the water

sector privado en los servicios de agua y saneamiento en Guayaquil, Ecuador," Inter American Development Bank, Washington D.C., (2003).

630 Resolución No. 335-2002-RA, para. 4.

631 Tribunal Constitucional, Resolución No. 826-2004-RA (2 December 2004), para 5.

632 Ibid. The law in particular was the "Ley del Régimen del Sector Eléctrico."

633 Ibid., para. 6.

634 See Tribunal Constitucional, Resolución No. 0801-2004-RA (10 March 2005). 
bill, which according to complainants had been incorrectly calculated. The Constitutional Tribunal once again reaffirmed that Interagua's conduct could be reviewed through an amparo petition. However, it held that a complaint dealing with the actual provision of a public service could be better dealt with through other more appropriate legal remedies, which are provided for by the National Consumer Law. ${ }^{635}$ The Tribunal's reasoning is that amparo is not suited to review acts related to the calculation of the price of water tariffs and bills or the annulment of high water bills. In the present author's view, this approach negates the object and purpose of amparo, which is to deal with actions that may cause immediate harm. In this case, complainants were seeking not only a solution to the price of the water tariff and bill, but they were also seeking to reactivate the suspension of an essential service.

In sum, the Ecuadorian experience denotes a functional approach whereby the nature of the function is relevant for accepting the applicability of constitutional (and international) rights. Although the conduct of private bodies exercising public tasks (e.g. providing public services) is ab initio amenable to an amparo procedure whereby that conduct is tested against constitutional norms, in practice, the Constitutional Tribunal does not accept complaints that are related to the commercial aspects of these public services.

\subsubsection{Some observations}

The experience of other non-common law jurisdictions where privatization has taken place in one way or the other, provides compelling examples about the applicability of public or constitutional norms to private bodies engaged in privatized activities. The examples discussed in this section show that private bodies entrusted with carrying out public services (however these may be defined) can be subjected to these norms. However, when the activities or services of these bodies are of a purely commercial nature, public law norms will not apply. It is therefore necessary to ascertain the nature of the function/service being performed. In France, this would depend on whether the service meets a public need of general interest.

In addition, private bodies that are parties to administrative contracts, such as concessions for the performance/delivery of a public service such as utilities, may also be subjected to these norms. In principle, third parties fall outside the scope of such a contract unless national legislation or the concession contract provides otherwise. An example of the latter may be found in Ecuador, where the national constitution makes it possible for consumers of a particular public service that has been entrusted to a private entity through a concession to request an injunction for 
an amparo procedure against that entity. This in turn makes it possible to examine whether the entity's conduct is compatible with constitutional norms. The privatization of water utilities in the city of Guayaquil, Ecuador, provides a concrete example from a developing country of a national court deeming it possible to apply Constitutional norms to the conduct of a private body in charge of running the service.

\subsection{Preliminary conclusions}

The differing approaches and legal traditions in most of the legal systems examined in the previous paragraphs makes it, of course, difficult to arrive at a general allencompassing conclusion with regard to the specific elements that must be present to conclude that human rights obligations may be directly imposed on actors carrying out privatized functions, tasks or services. There is no single common way of determining this. It is, however, possible to observe in a number of jurisdictions, national and international, a general common denominator: the judicial stance that States/governments are not allowed to evade their constitutional or (international) human rights obligations by simply delegating, transferring or otherwise privatizing functions, tasks or services to private actors. The concrete meaning of this imperative can, to a certain degree, be appreciated in the growing tendency - albeit a slow and careful one - in a number of jurisdictions to apply certain public law or constitutional norms to private actors exercising functions, tasks or services of a public nature. Additionally, there are also a number of small common elements present in many of the jurisdictions examined above that may make such application possible. Although it would appear that throughout all the jurisdictions examined no single criterion is exclusively decisive in determining whether public law or constitutional norms may apply to the conduct of these actors, and that such a determination will be mainly fact-bound, certain principles of general application may be distinguished. Of central importance, but by no means totally determinant, the nature of the function, task or service can help to determine whether a certain private actor carrying out privatized tasks may be regarded as a state actor sui generis. In determining the public nature of these functions, tasks or services it is important to consider the interests that these are trying to serve or respect. Sometimes the nature of these functions, tasks or services may involve what can be considered typical functions of 'imperium' whereby the use of coercive force derived from statutory permission to exercise this type of force will make it possible to distinguish the tasks as being public in nature. ${ }^{636}$ The nature of other functions,

636 Policing, prison management and military and security services. For an interesting discussion regarding the propriety of privatizing policing, prison management and military and security services see Rosky, "Force, Inc.: The Privatization of Punishment, Policing, and Military Force in Liberal States," in which the author argues that privatizing policing and prison management should not be that problematic since the core sovereignty of the State would not be much at stake if these functions/services would fail due to privatization. On the other hand, a failure in the 
however, may have a mix of public and commercial elements (e.g. the provision of water, electricity, housing or health care). It is suggested that the fact that some functions, tasks or services serve a certain public goal, but at the same time have a particular commercial or economical character, does not deprive them of having a sufficiently public nature for human rights to be applicable to the actors that exercise them. This is especially the case when the public interests they serve are considered to be of great importance to society as a whole due to the externalities that are closely related to them, and which would usually require State intervention to satisfy. With regard to these functions or services, it is further suggested that these can only be considered sufficiently public if their realization a) directly, in fact and in law affects one or more of a number of public interests, such as the maintenance of national security, public order and safety, the maintenance of public health and the prevention of infectious diseases and other health hazards, the respect of human rights (including property rights), especially those which are non-derogable; b) conveys quantifiable effects and externalities ${ }^{637}$ on the public at large; and, c) is the result of legal obligations ensuing from, for example, international human rights treaties, or national constitutions or other high level national legislation. ${ }^{638}$

Even though certain functions may be considered public in the sense that they have direct effects on the public at large, it will probably be necessary to establish a link with formal or statutory obligations on the side of the State that dictate the latter's ultimate responsibility for the way these functions are exercised in the carrying out of policy objectives. A finding that a particular private actor is a state actor sui generis because it is carrying out tasks that have public connotations in that they have relevant effects on the public at large and for which the State is regarded as ultimately responsible for their execution (through regulation for example), can be thus reinforced with a statutory basis that demonstrates that the State has delegated these tasks to that actor.

A major obstacle in determining whether a particular private actor can be regarded as a State entity sui generis is the extent to which that actor should be regarded as a State entity. This obstacle relates to concerns with regards to extending the public

privatization of military services or a revolt of these services against the State could be disastrous for the State's general wellbeing because of their immense coercive power in comparison to that of the police and prisons.

637 Does the poor execution of laying down water piping and affordable connections lead to health and hygiene concerns or the outbreak of infectious diseases such as cholera? Does the failing realization of a reasonable housing program lead to an increase in the number of homeless people? (See f.e. the Grootboom case in South Africa (Grootboom and Others v Government of the Republic of South Africa and Others - Constitutional Court Order [2000] ZACC 14).

638 For instance, Art. 11 of the ICESCR places an obligation on the States that have ratified the Covenant to realize the right to an adequate standard of living (including the right to water, see Chapter VII infra). Other national constitutions provide similar obligations or state that the State is responsible in guaranteeing the national health of its inhabitants. 
sphere too far to the detriment of the private sphere. Clearly a privatized water utility cannot be held directly accountable for human rights impairing conduct when such conduct falls outside of the scope of its 'public' related activities. But where are the boundaries? Which activities of a privatized entity carrying out certain functions, tasks or services are amenable for human rights review? This question is not easily answerable and has made, for example, the U.S. Supreme Court somewhat reticent to apply its 'state action' doctrine.

To answer this question it has to be acknowledged that not all the activities of a privatized entity will be subject to human rights review. To do so would be to unduly extend the reach of human rights law to an area in which it currently has not gained acceptance by most of the States, notwithstanding the fact that human rights bodies have maintained that human rights obligations might have effects on the relations between private individuals. Only those privatized functions, tasks or services that are sufficiently linked to the realization of public goals and interests, and for which the State has assumed the legal obligation and thus the ultimate responsibility to fulfill can be amenable to such a review. Therefore, there must be a concrete link between the privatized activity in question, the realization of a public goal or purpose, and the enjoyment of a particular human right. It is hereby submitted that those activities that a) are directly related to the realization of nationally recognized public goals (realization of public sanitation and health, protection of public safety, realization of fair dispute settlement remedies, provision of (primary) education) through national legislation, b) for which the State at the regional or international level has assumed legal obligations to guarantee through the ratification of human rights instruments, and c) which have direct or indirect public effects or externalities (that is, by legally and in fact affecting a group in society in such a way that hinders or impedes its economic, social or political development, risks its safety or life, and harms its human dignity), even if they have mainly commercial elements necessary to realize them, ${ }^{639}$ are amenable for human rights review if they are carried out by a privatized entity in the same way a formal public actor would perform them. Several additional factors that may help to determine whether private actors can be held accountable when exercising privatized public functions entail statutory obligtions to provide a particular service or function, previous exercise of those functions by the State, existence of compulsory regulation watching over public interests, and whether the State would be held accountable while performing the same task.

639 For example activities such as signing contracts with new water customers or closing the water connection for non payment of services. 


\section{Concluding Remarks}

In terms of general international law, the State will always be held responsible for any wrongful acts of privatized entities exercising elements of governmental authority. That much is certain, and some commentators acknowledge this too. ${ }^{640}$ This is a very pragmatic approach. Since States still are the primary subjects of international law, it stands to reason that they should be held ultimately accountable for breaches of international legal obligations that have been committed with their acquiescence, under their supervision, or because of the delgation of governmental authority. From the perspective of the end users or 'beneficiaries' of privatized functions, tasks or services, this traditional approach towards accountability may not be entirely satisfactory. With regard to abuses of human rights by privatized entities, this is accentuated by the lack of proper horizontal effect of these rights under current international law (lex lata) preventing the actual 'perpetrators' of these abuses to be held directly accountable. Hence, a new paradigm for accountability for these types of actors is justifiable (lex ferenda). Can the actions of privatized service providers/actors carrying out former State functions or tasks, or providing certain essential services formerly provided by the State, be considered as 'State actions' that are amenable to human rights review? Some international human rights monitoring bodies already appear to agree with this. In its General Comment No. 2 on the implementation of Article 2 of the Convention Against Torture by States parties, for example, the UN Committee Against Torture recently observed that

"[...] where detention centres are privately owned or run, the Committee considers that personnel are acting in an official capacity on account of their responsibility for carrying out the State function without derogation of the obligation of State officials to monitor and take all effective measures to prevent torture and ill-treatment."’641

It can be argued that privatized service providers under certain circumstances can be regarded to have donned a public capacity that makes them susceptible to judicial review/human rights review for their actions. At first glance, the U.S. Supreme Court appears to have taken this approach to a certain extent, although it has been claimed that no quantitative or qualitative criteria have emerged to ascertain the dividing line between state action amenable to judicial review and private action that is not subject to it. ${ }^{642}$ Clapham has noted, in the context of the application of the U.S. state action doctrine, that attempting to classify the actions of private actors as state action is deceptive, dangerous and inconsistent, essentially because it avoids making subjective judgments on the importance of the right involved and because it

\footnotetext{
640 See for example Clapham, Human Rights Obligations of Non-State Actors, p. 242-243.

641 UN Committee Against Torture, General Comment No. 2, Implementation of Article 2 by States parties, (24 January 2008) UN Doc. CAT/C/GC/2.

642 Clapham, Human Rights in the Private Sphere, p. 163.
} 
reinforces the dichotomy between the public and the private sphere. ${ }^{643} \mathrm{~A}$ fortiori this reasoning would also apply to an attempt to classify privatized service providers as being state actors, with the implication that their conduct would be amenable to human rights review. It is suggested that Clapham's fear in this regard is not fully warranted. Firstly, such a categorization (branding private actors carrying out privatized tasks and services as state entities sui generis) does not mean that human rights cannot be (in the future) applied horizontally. ${ }^{644}$ The above noted proposition is an attempt to reconcile a special situation (the delegation of public tasks, functions and provision of public essential services to private entities) that transforms the playing field: we are not talking here about mere private entities, but about entities that have been provided with public powers and public responsibilities that are considered essential for the proper functioning of society. It is the view of the present author that this special situation merits a new paradigm for the application of human rights obligations to these entities. Mere horizontal application would probably not suffice because a) most states would not recognize this and b) it would make it difficult to practically employ it (this is the classical argument that in particular private lawyers bring up about the difficulty of balancing clashes of private rights). If we recognize that, in a privatization situation, we are dealing with quasi-state entities, wielding some sort of governmental power or influence (or at the very least having the possibility of influencing the rights of individuals in a similar way in which pure state entities would do if they were in a similar position), then it would follow that the conduct of these entities must be reviewed against the same obligations governing the conduct of the State. In the second place, categorizing these entities as State entities sui generis does not entail avoiding a judgment on the importance of the right involved. On the contrary, it makes it possible to consider the actual applicability of specific rights to extraordinary situations in which the State as we knew it does not play its usual role anymore, but where individuals and groups still expect the fulfillment of certain tasks, functions and the provision of essential services of the same or better quality and with due respect of their rights.

643 Ibid. Thus probably entailing that such and attempt would mean that private action is not susceptible to an examination as to its compatibility with human rights obligations and thus negating the potential horizontal effect of human rights between private actors.

644 Although as it has been noted, the ideal application if drittwirkung in practice is far from becoming a reality, in spite of the acknowledgment at the treaty body level in the various general comments and at the academic level that human rights are applicable between private actors. 


\section{PART II}

\section{Practice and Sectorial Analysis}





\section{Chapter V \\ Privatization and the Practice of Human Rights Monitoring Mechanisms}

\section{INTRODUCTION}

In Chapter III we observed that general international law and human rights law does not prescribe or prohibit privatization. They are in principle neutral towards the internal economic and political arrangements of States. We have also seen that in spite of the apparent broad freedom of States to apply any economic policy they may deem necessary, including privatization, a number of general international law and human rights obligations may limit the latitude of States in this respect. It is now time to appreciate how international and regional human rights monitoring mechanisms have handled the question of privatization in practice.

The International Bill of Human Rights ${ }^{1}$ and the other human rights treaties that subsequently followed it (the International Convention on the Elimination of all Forms of Racial Discrimination, the Convention on the Elimination of All Forms of Discrimination against Women, the Convention against Torture and Other Cruel, Inhuman or Degrading Treatment or Punishment and the Convention on the Rights of the Child) do not make any references to privatization. The popularity of privatization as a policy of economic and structural reform to roll back the role of the State in the last 20 years has, however, not gone unnoticed by the international and regional human rights supervisory bodies. The UN, European and the ILO supervisory systems have all dealt with privatization in one way or another. ${ }^{2}$

1 The International Bill of Human Rights is comprised of the Universal Declaration of Human Rights, the International Covenant on Civil and Political Rights and the International Covenant of Economic, Social and Cultural Rights.

2 It is interesting to observe that privatization has not been brought up as a major issue of concern in the African Human Rights System, or in the Inter-American one. With regard to the former, about the only actual direct reference to privatization can be encountered in a resolution of the African Commission on Human and Peoples' Rights on Economic, Social and Cultural Rights in Africa, adopted during the Commission's 36 $6^{\text {th }}$ Ordinary Session on 7 December 2004 in Dakar, Senegal. The resolution adopts the Declaration of the Pretoria Seminar on Economic, Social and Cultural Rights in Africa, adopted on 17 September 2004, in Pretoria, South Africa which exhorts the Member States of the African Union to adopt measures to realize these rights and circumvent a number of impediments to their realization, one of which is the privatization of essential services. The text of the resolution together with the attached declaration can be found at <www.achpr.org/english/_info/index_ECOSOC_en.htm $>$ (last visited on 31 August 2011). In the Inter-American system, the Inter-American Court on Human Rights has been confronted only once with a case related to the 'privatization' of land in the Case of the Mayagna (Sumo) Awas Tingni Community v. Nicaragua, Inter-American Court of Human Rights, Judgment of 31 August 2001. In this case, the Court had to decide, inter alia, whether selling communal indigenous lands by the government of Nicaragua to a number of corporations 
However, although the supervisory bodies of these systems have shown some concern regarding privatization policies, which in their eyes could affect the rights guaranteed by their respective human rights instruments, they have fallen short of condemning privatization or stating that it is completely incompatible with the human rights obligations ensuing from the various human rights treaties they monitor. In the following paragraphs the practice of the various bodies that are responsible for monitoring the implementation of a number of international and regional human rights instruments will be examined with regard to privatization. The UN human rights system will be analyzed first, although a caveat is in place: this part of the study will focus solely on the practice of the UN treaty bodies (Human Rights Committee, Committee on Economic, Social and Cultural Rights, etc.). Although the Charter based bodies such as the Special Rapporteurs, Working Groups and the now defunct Sub-committee for the Promotion and Protection of Human Rights have also frequently discussed the issue of privatization in their various activities and reports, their practice is somewhat unwieldy and inconsistent.

interested in exploiting the land for timber (this was referred to as privatization) could amount to a violation of the right to property of the indigenous community. The Inter-American Commission on Human Rights has dealt with a petition related to privatization on only a single occasion. In a recent case, a group of retired workers and pensioners alleged before the Commission that Venezuela was responsible for violating the rights to judicial protection, private property, and the progressive development of social security as established in Articles 21, 25, and 26 of the American Convention on Human Rights and Articles XVI and XVIII of the American Declaration of the Rights and Duties of Man following the partial privatization of VIASA, the national aviation company, in 1992. The petitioners alleged that under the privatization deal, the State had agreed with the buyers of the company that all the workers would lose their status as government employees, and that they would therefore also lose the benefits of the retirement plan established for them. Following privatization the company paid its pension obligations until 1997 when it unilaterally stopped the payment of these benefits. The Inter-American Commission has, however, ruled on this case (affirmatively) only with regards to its admissibility, and has yet to decide on the merits. See Jesús Manuel Naranjo Cárdenas Et Al. Pensioners Of The Venezuelan Aviation Company - Viasa v. Venezuela, Inter-American Commission on Human Rights, Report N ${ }^{\circ}$ 69/04, Petition 667/01, Admissibility, 15 October 2004. Another example of what may amount to privatization in the health care sector through by allowing private health institutions to participate in a public health scheme can be found in the case of Case of Ximenes-Lopes v. Brazil, Merits, Reparations and Costs, Judgment of 4 July 2006, IACtHR, Series C No. 149, discussed in Chapter IV, Section 2.2.1.1 In terms of country situation reports which the Inter-American Commission prepares annually, the most prominent reference to privatization was the alleged effect of the privatization of state-owned sugar mills on the living conditions of people living in so-called bateyes (the sugar mill camps for workers on sugar cane plantations) in the Dominican Republic. It was claimed that as a result of the privatization of the sugar mills, a number of bateyes were in a situation of extreme poverty. Thus "[...] ]one-third of their residents had no access to school education at any level; half the population of those bateyes did not have electricity; and seven out of ten homes lacked sanitation services or any form of human waste disposal." See Annual Report of the Inter-American Commission on Human Rights, 2001, Chapter V, paras. 83-84 The Inter-American Commission recommended the improvement of living conditions in the bateyes to include the provision of basic supplies such as drinking water, electricity, medical services, and educational programs. Ibid., para. 129. 
In general, the attitude of various Special Rapporteurs towards privatization policies has been negative. ${ }^{3}$ Various reports have included very broad allegations on the perceived negative impact of privatization on human rights. Although these effects may be true, the sweeping manner in which many of the Charter based bodies have come to that conclusion renders them in the eyes of the present author less authoritative than the more moderate approach generally adopted by the treaty bodies. Arguably, Claire Palley carried out the most thorough study of a Charter based body with regard to privatization with the preparation of a study on the privatization of prisons for the now defunct Sub-committee for the Promotion and Protection of Human Rights in 1993. ${ }^{4}$ This study, however, never received a proper follow-up within the Sub-commission with the exception of a brief discussion on the issue in the Sub-commission's working group on the administration of justice in 2002. ${ }^{5}$ Other chapters in the present study address some of the reports by Charter based bodies. ${ }^{6}$ Since some of these reports are discussed elsewhere, the present author has chosen to focus this chapter on the work of the UN treaty bodies, although some highlights of the Charter based bodies will be briefly discussed. This will be followed by an examination of the work of the various bodies established under the Council of Europe (European Court of Human Rights, the European Committee for the Prevention of Torture and the European Committee for Economic and Social Rights). Finally, the practice of arguably one of the most underrated universal human rights systems, the ILO, will also be discussed. Interestingly enough, the practice of the various ILO monitoring bodies has been the most consistent on the issue of privatization, possibly because of their limited focus on labor rights.

\section{The UN hUMAN RIGHTS TREATY BODIES AND PRIVATIZATION}

UN human rights treaty bodies have relatively often considered privatization and its probable effects on human rights. The issue of privatization has been brought up a number of times under a number of General Comments in which the monitoring

3 See for example Report of the Special Rapporteur on the Right to Education, UN Doc. E/ CN.4/2000/6 (1 February 2000), para. 33; Report of the Special Rapporteur on adequate housing as a component of the right to an adequate standard of living, UN Doc. E/CN.4/2001/51 (25 January 2001), paras. 30, 58 and 59; Report of the Special Rapporteur on the right to food, Addendum, mission to Niger, UN Doc. E/CN.4/2002/58/Add.1 (23 January 2002), paras. 35, 50 and 64 .

4 See "The possible utility, scope and structure of a special study on the issue of privatization of prisons," outline prepared by Mrs. Claire Palley pursuant to Sub-Commission decision 1992/107, UN Doc. E/CN.4/Sub.2/1993/21 (25 June 1993).

5 See UN Doc. E/CN.4/Sub.2/2002/7 (15 August 2002).

6 For example, Chapter VI on the privatization of military and security services refers to a number of reports of the Special Rapporteur on Mercenaries and its successor, the Working Group on Mercenaries. Chapter VII refers to several reports issued by the Sub-committee on the promotion and protection of human rights with regard to the right to water. 
bodies lay down their interpretation of the rules of the various human rights treaties they have to monitor. ${ }^{7}$ It has also surfaced sporadically in the case law of the treaty bodies, in particular of the ICCPR, although it was not the main issue at hand. This contrasts with the examination of the periodic reports which States are obliged to submit under all human rights treaties, ${ }^{8}$ in which the treaty bodies have addressed privatization on various occasions. All the treaty-monitoring bodies have appended comments or recommendations in their concluding observations related to privatization of State functions and services to a varying degree. Privatization was usually raised by the supervisory bodies themselves in the list of issues provided to States prior to the final submission of the report. Sometimes, however, the issue of privatization was spontaneously brought up upon information provided by NGOs. In the concluding observations to a myriad of State reports, the committees have expressed either their concern about privatization with respect to human rights or requested additional information on the subject. In fact, the bulk of the UN committees' focus on privatization has been addressed through their concluding observations. In the following paragraphs, the General Comments, case law (where applicable) and State reports of the respective treaty bodies that have dealt with privatization will be examined. ${ }^{9}$

7 Although these General Comments and recommendations, which contain analysis and views with regard to the rights and duties enshrined in the treaties, are not binding, they are regarded as providing authoritative guidelines for the interpretation of the treaties. They provide, therefore, useful insights that can be valuable for assessing whether State parties comply with their treaty obligations. See Final Report on the Impact of Findings of the United Nations Human Rights Treaty Bodies, Committee on International Human Rights Law and Practice, International Law Association, Berlin Conference (2004), p. 5, 20-25, and 43.

8 See for example, Art. 40 ICCPR. In these periodic reports State give an account of the measures they have taken to implement their treaty obligations and of the progress achieved in securing the enjoyment of the rights in their respective territories. In their concluding observations to these reports treaty-monitoring bodies assess the human rights situation in the countries under review and present specific comments and subjects of concern. The observations conclude with a number of recommendations and requests for States to take into consideration for their next reports.

$9 \quad$ For this analysis more than 200 summary records related to the examination of state reports and dealing with privatization were reviewed. Due to the defective and uneven nature of the UN's approach to producing and archiving summary records, it is possible that not all the relevant summary records were detected. It must be also noted that the summary records do not always faithfully reflect the discussions which actually took place and should therefore be considered with care. For the sake of succinctness, only the consideration of reports that could be considered as representative of the attitude of the treaty bodies towards privatization will be presented. Finally, the summary records for the examination of State reports by the CEDAW are not currently available and were therefore not examined. 


\subsection{Human Rights Committee}

\subsubsection{General Comments}

The general comments of the Human Rights Committee do not deal explicitly with privatization of State functions, tasks or services. Nevertheless, a number of the general comments issued by the HRC could be relevant in the case of a State party to the ICCPR deciding to privatize a number of services such as penitentiary and security or policing services. The most relevant general comments within the framework of prison privatization and the privatization of security and policing services would be general comments twenty and twenty-one concerning the prohibition of torture and cruel treatment or punishment and the human treatment of persons deprived of their liberty respectively. General comment twenty addresses the interpretation and implementation of Article 7 ICCPR which deals with the prohibition of torture and cruel treatment or punishment. ${ }^{10}$ The HRC reaffirms in this general comment the non-derogable nature of Article 7 and comments that no justification or extenuating circumstances may be invoked to excuse a violation of Article 7 for any reasons. This includes reasons based on orders issued by superior officers or public authorities. ${ }^{11}$ Moreover, in the Committee's views, the prohibition includes corporal punishment, excessive chastisement ordered as punishment for a crime or as an educative or disciplinary measure, prolonged solitary confinement of prisoners and scientific experimentation without the free consent of the person concerned. ${ }^{12}$ In addition, the HRC expects the State parties to train enforcement personnel, police officers and other persons involved in the custody or treatment of any individual subjected to any form of arrest, detention or imprisonment. States should also take measures to monitor and guarantee the effective protection of individuals who are subjected to arrest or imprisonment. They should also provide effective remedies to victims of maltreatment as well as punishing those responsible for the violation whether committed by public officials, other persons acting on behalf of the State or by private persons. ${ }^{13}$

General comment twenty-one provides an analysis of the right to humane treatment of persons deprived of liberty (Article 10 ICCPR). The HRC considers this right as complementary to the prohibition of torture of Article 7 ICCPR for persons who are in a vulnerable position because of their status as persons deprived of liberty (they are basically at the mercy of the State) ${ }^{14}$ According to the Committee, article 10 ensures that persons deprived of their liberty, "are not subjected to any hardship or

\footnotetext{
10 CCPR General Comment 20 (10 March 1992).

11 Ibid., para. 3.

12 Ibid., paras. 5, 6 and 7.

13 Ibid., paras 11, 13 and 14.

14 CCPR General comment No. 21 (10 April 1992), para. 3.
} 
constraint that does not result from the deprivation of liberty." 15 In other words, States must guarantee the prisoners' dignity and treat them with humanity as well as ensuring that they enjoy other rights taking into account the restrictions inherent to imprisonment. To this end, States should report the extent to which they are applying a number of international standards related to the treatment of prisoners. ${ }^{16}$ Additionally, State parties should report on the application of monitoring and supervisory mechanisms to ensure that these standards are complied with in penitentiary establishments. They should also report on whether penitentiary personnel are trained according to these principles and on the legal remedies available to prisoners in case the rules are ignored and their rights violated. ${ }^{17}$

From the perspective of the subject of the present study, these two general comments would seem to apply to private companies that are managing privatized prisons and to private security companies that have taken over policing tasks and services. In both situations the companies should take into consideration the ban on torture and the right to a humane deprivation of liberty and apply the various international principles regarding the protection of prisoners and the codes of conduct applicable to law enforcement officials. According to these general comments, however, the State would have the ultimate responsibility of ensuring that the rights enshrined in Articles 7 and 10 ICCPR are respected by the private companies to which the State has delegated its tasks.

\subsubsection{Case law}

Under several international human rights treaties, individuals claiming to be a victim of a violation of the rights enshrined in those particular treaties may submit individual complaints to the treaty body monitoring its application. This is the case with, for example, the HRC, which under Article 3 of the First Optional Protocol to the ICCPR has the competence to examine those complaints submitted by State parties that became parties to the Optional Protocol. ${ }^{18}$ These complaints must meet a number of admissibility criteria before the treaty body examines them. The conclusions of the treaty bodies on individual cases are usually packed in the form

15 Ibid

16 These standards include United Nations' rules such as the Standard Minimum Rules for the Treatment of Prisoners (1957), the Body of Principles for the Protection of All Persons under Any Form of Detention or Imprisonment (1988), the Code of Conduct for Law Enforcement Officials (1978) and the Principles of Medical Ethics relevant to the Role of Health Personnel, particularly Physicians, in the Protection of Prisoners and Detainees against Torture and Other Cruel, Inhuman or Degrading Treatment or Punishment (1982). Ibid., para. 5.

17 Ibid., paras. 6 and 7.

18 Other individual complaint mechanisms are available under the Convention on the Elimination of All Forms of Racial Discrimination, the Convention Against Torture and the Convention Against All Forms of Discrimination Against Women. These complaint mechanisms are also optional and only available if State parties agree to accept them. 
of 'views' that formally do not have binding force/status. These views, however, are considered to be authoritative and are more often than not respected and complied with by State parties. ${ }^{19}$

Privatization as a central issue of concern with respect to human rights has not been a topic dealt with in individual complaints to treaty monitoring mechanisms. In fact, only the HRC has dealt with a limited number of individual complaints in which privatization was a side issue. This is not surprising. Human rights problems arising from privatization will probably occur in horizontal relations (that is between privatized service providers and victims) rather than in vertical relations (between the State and the victims). The different treaty monitoring mechanisms, however, have until now refused to deal with individual complaints directed against private parties. ${ }^{20}$ Nevertheless, as observed in Chapter III, a number of treaty monitoring bodies has provided an indirect way to address this issue. Under certain circumstances, States can be held accountable for human rights violations committed by private parties.

The HRC has only twice considered individual complaints that were directly related to privatization. In the first case, Somers v. Hungary, ${ }^{21}$ the problem revolved around the privatization of former State-owned property and housing accommodations (in this case an apartment) which had been previously been confiscated from its former owners by the Communist government in the years after WWII. ${ }^{22}$ The central question was whether the privatization of former Stateowned property was being applied in a discriminatory way. After the fall of the Berlin wall and the democratization of Hungary, the Hungarian government started to privatize State-owned property including residential property. Former owners of nationalized or confiscated property were given vouchers which could be used to their full value for buying State property being 'privatized' as a means of compensation for the nationalization. Vouchers redeemed on the open market because of lack of interest in the property, however, would receive less than the nominal value of the vouchers. The tenants currently living in the property were

19 See Final Report on the Impact of Findings of the United Nations Human Rights Treaty Bodies, op.cit note 7, p. 5, 13-20, and 43-44.

20 See for example, Communication No. 949/2000, CCPR/C/70/D/949/2000 (9 November 2000) were the HRC concluded that allegations directed against private parties are inadmissible ratione personae under article 1 of the Optional Protocol to the ICCPR.

21 Somers v. Hungary (566/1993), UN Doc. CCPR/C/57/D/566/1993 (29 July 1996).

22 Two similar cases dealing with allegations of discrimination of former Czech citizens who had been stripped of their Czech nationality and property have summarily been dealt by the HRC and deemed not admissible. In those cases only a vague mention of privatization of former Stateowned property was made. However, since they were declared inadmissible, the Committee was not able to make any observations on this sort of privatization. See Malik v. Czech Republic (669/1995), UN Doc. CCPR/C/64/D/669/1995 (3 November 1998) and Scholsser v. Czech Republic (670/1995), UN Doc. CCPR/C/64/D/670/1995 (3 November 1998) respectively. 
given preference and had a 'buy first option.' The State justified this measure by pointing to the rights of tenants who have contributed to the maintenance of the property through improvements of their own. Former owners were given the possibility to purchase the residential property with the vouchers if the current tenants did not make use of their 'buy first option.' However, if the current tenants used their 'buy first option' former owners would not be able to regain the property and were left with the choice of either selling their vouchers on the open market (and thus receiving less than nominal value for their vouchers) or buying other property. The complainant (a man acting on behalf of his mother, who together with his father had enjoyed the ownership of an apartment prior to its confiscation) was faced with such a situation and received less than full compensation for the loss of author's property. The complaint maintained that the privatization legislation was applied in his case in a discriminatory manner and thus constituted a breach of Article 26 ICCPR (right to equality before the law and to equal protection of the law). The HRC concluded, however, that the criteria for the privatization of former State-owned property were objective. ${ }^{23}$ The exclusionary measure of the State providing preference to current tenants when buying State-owned property was not unreasonable. In this context, the HRC reasoned that the rights of current tenants, especially those living for a long period of time in the residential property, are deserving of protection. Furthermore, it concluded that Article 26 would present no problem if the former owners were compensated on equal and non-discriminatory terms. According to the HRC this had been the case. ${ }^{24}$

The second case in which privatization was briefly discussed, Cabal \& Bertran $v$. Australia ${ }^{25}$ concerned two persons awaiting deportation from Australia to Mexico who had been detained in a privately operated maximum security prison. This case is more interesting because neither complainants nor the State party had raised any arguments against or for privatization itself. The HRC raised the issue of privatization ex officio. In fact, arguably this is the first case in which an international human rights monitoring mechanism with adjudicatory powers has brought up a specific point on privatization as an integral part of a human rights violation complaint, albeit not as a substantive issue of the complaint. The complainants claimed that they were held in detention together with convicted criminals whereas they should have been segregated from them and that Australia had failed to treat them separately in a manner appropriate to their status of unconvicted persons as required by Article 10 (2)(a) ICCPR. They also alleged that both had been placed in a very small holding cell in which only one person could sit at a time in breach of Article 10 (1) ICCPR and that physical and cavity searches carried out on them amounted to degrading treatment contrary to Article 7 ICCPR.

Ibid, para. 9.8.

Ibid, para 9.6 and 9.8 .

Cabal \& Bertran v. Australia (1020/2001), UN Doc. CCPR/C/78/D/1020/2001 (19 September

2003). This case is also discussed in Chapter IV, Section 3.1.1. 
The complainants, however, did not allege that these abuses were the result of the privatization of prisons in Australia. Nevertheless, before dealing with the admissibility of the complaint and its merits, the HRC decided to consider whether Australia's obligations under the ICCPR applied to privatized detention facilities as well as in State-run facilities. The HRC wanted to establish whether the violations complained of concerned a State party to the ICCPR as understood under Article 1 of the First Optional Protocol of the ICCPR, which creates the possibility of filing individual complaints ${ }^{26}$ since the alleged conduct had taken place in a privatized prison. After recalling its jurisprudence in which the HRC had indicated that a State party "is not relieved of its obligations under the Covenant when some of its functions are delegated to other autonomous organs," 27 the Committee concluded that

"[...] the contracting out to the private commercial sector of core State activities which involve the use of force and the detention of persons does not absolve a State party of its obligations under the Covenant, notably under articles 7 and 10 which are invoked in the instant communication. Consequently, the Committee finds that the State party is accountable under the Covenant and the Optional Protocol of the treatment of inmates in the Port Philip Prison facility run by Group 4."28

In other words, since the State party is responsible for ensuring that human rights treaty provisions are observed within its territory, it can be held accountable for not taking the necessary measures to prevent human rights violations perpetrated by private individuals, companies or organizations implementing public policy vis-àvis other individuals. As already discussed in Chapter IV, Section 3.1.1, it follows from this case that the State could be held accountable for human rights violations committed by privatized companies or private enterprises that have taken over the provision of former state functions and services. Following this observation and after considering the complaint's admissibility, the Committee dismissed the allegations regarding Article 10 (2) and Article 7 ICCPR and concluded on the merits that placing both complainants in very a small holding cell where only one person could sit at a time had been a breach of Article 10 (1) ICCPR.

\subsubsection{Examination of State reports}

The HRC has addressed the issue of privatization on a couple of occasions while drafting a list of issues for the examination of several State reports. In the list of issues prepared for the United Kingdom's fourth periodic report the HRC requested

26 Ibid., para. 7.2 As explained above in footnote 20, individual complaints are only allowed against State parties and not against private actors. A textual reading of Article 1 of the First Optional Protocol to the ICCPR makes this clear.

27 See Chapter IV, Section 3.1.1 for further discussion on this issue.

28 Cabal \& Bertran v. Australia, para 7.2. 
further information relating to prisons that had been contracted out to the private sector and asked whether these prisons were under permanent control of the State and how the rights of prisoners were guaranteed therein. ${ }^{29}$ The HRC also asked the United Kingdom to describe the role of private security firms in the expulsion process of refused asylum seekers or illegal aliens in the context of Article 13 ICCPR (rights of aliens). ${ }^{30}$ With regard to New Zealand's third periodic report, the HRC drafted a list of issues concerning the compatibility of the introduction of private contracting of prison management with the provisions of the ICCPR in the context of article 10 (humane treatment of prisoners). ${ }^{31}$ For New Zealand's fourth periodic report, the HRC followed up its inquiries regarding the contracting out of prison and custodial services. On this occasion the HRC was interested in knowing what measures had been taken to ensure that private companies contracted to provide prisoner escort and custodial services complied with the United Nations Standard Minimum Rules for the Treatment of Prisoners in the context of Article 10 ICCPR. It also wanted to know if remedies were available to prisoners alleging violations of their rights by private guards for establishing civil and criminal liability. ${ }^{32}$ It would appear that these are the few instances in which the HRC has explicitly requested information regarding any form of privatization processes in a list of issues. Furthermore, in the case of the United Kingdom, no significant follow up discussion was raised by the members of the HRC after the questions had been dutifully answered by the United Kingdom other than showing general concerns for the tendency to contract out core State functions to the private sector (see further below).

In a number of discussions with State representatives while examining the State's report, the Human Rights Committee has raised the topic of privatization of state functions and services. Occasionally, the issue was addressed in specific terms of the rights protected in the ICCPR such as the rights for human treatment of prisoners (Art. 10 ICCPR). For example, during the consideration of New Zealand's third periodic report, HRC member Evatt expanded on the list of issues submitted to the State party and asked "[...] whether prisoners had recourse to a prison ombudsman and appropriate remedies if their rights were violated in the private prisons." 33 She also inquired whether the rights of prisoners held in private prisons were different than the rights of other prisoners. Finally, she wanted to know whether mechanisms existed that ensured the respect of minimum standards by private prisons. ${ }^{34}$ The

29 List of Issues United Kingdom, quoted in UN Doc. CCPR/C/SR.1433 (8 September 1995), para 51.

30 List of Issues United Kingdom, quoted in UN Doc. CCPR/C/SR.1434 (27 July 1995), para. 48.

31 List of Issues New Zealand, quoted in UN Doc. CCPR/C/SR.1394 (7 April 1995), para. 19.

32 List of Issues New Zealand, UN Doc. CCPR/C/74/L/NZL (18 October 2001), para. 11.

33 Summary record of the $1394^{\text {th }}$ meeting: New Zealand, UN Doc. CCPR/C/SR.1394 (7 April 1995).

34 Ibid. Presumably, Evatt referred to the United Nations Standard Rules for the Treatment of Prisoners, which is also mentioned in the list of issues for New Zealand. 
State party's answer, however, limited itself to responding to the relevant question on the list of issues relating to the compatibility of the introduction of private prisons with the provisions of the ICCPR and maintaining that prisons had to ensure that all prisoners know the proper methods of making complaints. ${ }^{35}$ The issue was not further mentioned in the concluding observations of the HRC with regard to New Zealand's third report. ${ }^{36}$ During the consideration of New Zealand's fourth periodic report, the HRC returned to the issue as a matter of follow up as demonstrated by its list of issues. ${ }^{37}$ While examining the report, a member of the HRC asked whether there was a mechanism to monitor the protection of human rights in privatized prisons. ${ }^{38}$ New Zealand's representative pointed out that the Department of Correction monitored the private companies involved "[...] to ensure that they met all human rights standards." 39 It would appear that this answer did not satisfy the HRC, which through its chairperson commented that, "[...] the privatization of prisons was likely to encourage infringements of prisoners' rights, as private companies might not be subject to the discipline of human rights or might not be accountable in the same way as public authorities. ${ }^{.40}$ Accordingly, the HRC maintained a number of concerns regarding the privatization of prisons and escort services that were later addressed in the concluding observations to the United Kingdom's fourth periodic report (see below). The issue of private prisons also came up during the simultaneous consideration of Australia's third and fourth periodic report. Committee member Amor was for example interested to know what was the legal regime for privatized prisons in Australia. He then asked the State representatives whether Australia had taken all "[...] les compétences nécessaires pour assurer que les disposition du Pacte soient respectées à l'intérieur de ces établissements." ${ }^{41}$

35 UN Doc. CCPR/C/SR.1394 (7 April 1995).

36 UN Doc. CCPR/C/79/Add.47 (3 October 1995).

37 New Zealand's fourth periodic report contained a specific section on the contracting out of prison services in the context of Article 10 ICCPR. In this section, New Zealand mentioned that the creation of a new private prison had been awarded to an Australian company and that another private company had won an award for managing prisoner escort and custodial services. In this respect, New Zealand maintained that both these services are required to comply with New Zealand's Bill of Rights Act and the United Nations Standard Minimum Rules for the Treatment of Prisoners as if the institution and employees were part of the public Department of Corrections. See UN Doc. CCPR/C/NZL/2001/14 (14 May 2001), para. 137.

38 Summary record of the $2015^{\text {th }}$ meeting: New Zealand, UN Doc. CCPR/C/SR.2015 (25 November 2005), para. 40 (the original summary record of the meeting indicates that the meeting took place on 9 July 2002).

39 Summary record of the first part (public) of the $2016^{\text {th }}$ meeting: New Zealand UN Doc. CCPR/C/ SR.2016 (15 July 2002), para. 35.

40 Ibid., para. 56.

41 Summary record of the $1857^{\text {th }}$ meeting: Australia, UN Doc. CCPR/C/SR.1857 (4 October 2000), para. 55. The issue of privatized prisons had not been addressed in the list of issues for Australia, and Australia itself had only mentioned the topic in a brief way in its fourth periodic report. See UN Doc. CCPR/C/AUS/98/4 (4 August 1999), para. 78. Furthermore, there was no direct answer 
In other instances, members of the Human Rights Committee have made comments of a somewhat more general nature in order to express their concerns regarding privatization. For example, while discussing the fourth periodic report of the United Kingdom and Northern Ireland, a member of the committee stated that,

"[i]n recent years there had been a tendency, not only in the United Kingdom, to contract out core State functions to the private sector. He felt that the State was renouncing part of its legitimacy when, in particular, it contracted out functions involving the use of force in the public interest." ${ }^{32}$

Interestingly, this individual view of a member of the Committee was further adopted in the concluding observations for the United Kingdom's fourth periodic report (see further below).

The HRC has dealt with the topic of privatization in few of its concluding observations and then usually in a passing way. The HRC's concluding observations for the United Kingdom's and New Zealand's respective fourth periodic reports are an exception to this. ${ }^{43}$ In the case of the United Kingdom's concluding observations on its fourth periodic report, the HRC for example noted that, with regard to the UK's policy of prison privatization and use of private security firms in the expulsion process of illegal aliens it was,

"[...] concerned that the practice of the State party in contracting out to the private commercial sector core State activities which involve the use of force and the detention of persons weakens the protection of rights under the Covenant. The Committee stresses that the State party remains responsible in all circumstances for adherence to all articles of the Covenant." 44

It further recommended the United Kingdom to "[...] ensure that all those who are involved in the detention of prisoners be made fully aware of the international obligations on the State party concerning the treatment of detainees, including the

to this question and the Committee did not make any remarks in this regard in the concluding observations to these reports.

42 Summary record of the $1434^{\text {th }}$ meeting: United Kingdom and Northern Ireland, UN Doc. CCPR/C/SR.1434 (27 July 1995), para. 6. It should be noted that during this meeting an implicit reference was also made to possible conflicts between privatization and the rights of aliens (protected by Article 13 ICCPR), when the legal basis was requested for the right to use force by private security firms (in the context of exercising force against rejected asylum seekers and illegal aliens). Ibid., para. 71.

43 UN Docs. CCPR/C/79/Add.55 (27 July 1995) and CCPR/CO/75/NZL (26 July 2002) respectively. It has already been mentioned that in spite of being dealt with in the list of issues for New Zealand's third periodic report and during its examination, the issue of prison privatization was not dealt with in the concluding observations to that report. 
United Nations Standard Minimum Rules for the Treatment of Prisoners." 45 This would seem to include privatized prisons as well.

In the case of New Zealand, the HRC expressed its concerns that the management of a prison and prison escort services had been contracted to private parties. Although it welcomed New Zealand's assertion that the management of prisons will return to the public sector after the expiry of the contract with the government in July 2005, and that contractors for these services are expected to respect human rights norms including the United Nations Minimum Standards for the Treatment of Prisoners,

"[the Committee] nevertheless remains concerned whether the practice of privatization in an area concerning important rights of protection of persons deprived of their liberty by the State in practice meets effectively the obligations of the State party under the Covenant and its own accountability for any violations. The Committee further notes that there does not appear to be any effective day to day monitoring mechanisms to ensure that prisoners are treated with humanity and with respect for the inherent dignity of the human person and further benefit from treatment, the essential aim of which is directed to their reformation and social rehabilitation." 46

The Committee finally concluded that New Zealand should ensure that all persons who are incarcerated, and therefore by implication also those imprisoned in privatized prisons, should not be deprived of their rights as guaranteed under Article 10 ICCPR.

The HRC has also gone into the issue of the so-called 'privatization' of land. ${ }^{47}$ In its concluding observation on the fifth periodic report of Sweden, the HRC noted its concern for the lack of influence of the Sami Parliament in the decision-making process on issues "affecting the traditional lands and economic activities of the indigenous Sami people, such as [...] the privatization of land (arts. 1, 25 and 27 of the Covenant)." 48 The HRC then recommended the State party to take the necessary steps to increase the involvement of the Sami people in such issues.

45 Ibid. The use of private vigilantes and private police was also briefly brought up in the concluding observations to a report by Guatemala. See UN Doc. CCPR/C/79/Add.63 (3 April 1996), para 20.

46 UN Doc. CCPR/CO/75/NZL (7 August 2002), para. 13.

47 The HRC, or any other treaty body for that matter, has not explained what it understands by this term. The privatization of land seems to entail the change in ownership of communal or Stateowned land to private parties and falls therefore outside the scope of the issue of privatization as understood in this research project (the transfer of tasks and services performed by the State to private parties). It does show however that the term privatization is usually used in a broad 
Other concluding observations of the HRC are of a more general character. The issue of private security companies was, for example, briefly addressed in the concluding observations to Lesotho's initial report. ${ }^{49}$ Land privatization was rapidly dealt with also in the concluding observations on Estonia's initial report, where the Committee noted that the right to participate in such a privatization had been granted only to Estonian citizens. ${ }^{50}$

More recently, the HRC has examined the deployment of private military and security contractors by the United States in the conflicts in Afghanistan and Iraq. Thus, while examining the United States' third periodic report it expressed its concerns about the use of certain interrogation techniques by 'private contractors' working for the U.S. Armed Forces and intelligence agencies. ${ }^{51}$ It noted that the United States should conduct prompt and independent investigations into all allegations concerning suspicious deaths, torture or other ill-treatment inflicted by its personnel as well as contract employees, in detention facilities in Guantanamo Bay, Afghanistan, Iraq and other overseas locations, and prosecute and punish those responsible. ${ }^{52}$ The Committee then stated that the United States should also adopt all necessary measures to prevent the recurrence of those actions, in particular by providing adequate training and clear guidance to contract employees, about their obligations and responsibilities, in line with articles 7 and 10 of the Covenant. ${ }^{53}$

\subsection{Committee on Economic, Social and Cultural Rights}

\subsubsection{General Comments}

The issue of privatization has been dealt with relatively frequently by the CESCR, in particular in its most recent general comments. Although it would appear that privatization was first directly addressed in its fifth general comment, ${ }^{54}$ it can be argued that the concerns by the Committee with regard to privatization policies as a particular element of structural adjustment programs advocated by IFIs stem from General Comment No. 2 on international technical assistance measures. ${ }^{55}$ In this general comment, the Committee noted with concern the potential impact of

49 The Committee mentioned that it was concerned that no action had been taken to prosecute law enforcement officers and members of a private security agency responsible for a number of killings in that country in 1995 and then recommended Lesotho to take the necessary action against those responsible. See UN Doc. CCPR/C/79 Add.106 (8 April 1999), para. 19.

50 UN Doc. CCPR/C/79/Add.59 (9 November 1995), para. 13.

51 UN Doc. CCPR/C/USA/CO/3/Rev.1 (18 December 2006), para. 13.

52 Ibid., para. 14.

53 Ibid.

54 General comment No. 5 (9 December 1994), Persons with disabilities, contained in UN Doc. $\mathrm{E} / 1995 / 22$.

55 General Comment No. 2, International technical assistance measures (Art. 22), CESCR issued on 2 February 1990 and available in UN Doc. E/1990/23. 
adjustment programs on the implementation and realization of economic, social, and cultural rights. Although it did not say so, it would be possible to deduce that the CESCR was referring to programs, which had been devised and recommended by international financial institutions such as the IMF and the World Bank (structural adjustment measures). Privatization of State companies and services, is one of the measures recommended by these bodies. ${ }^{56}$

Nevertheless, the first direct reference to privatization appeared with relation to the effects of privatization on the rights of persons with disabilities in the CESCR's fifth general comment. The Committee firstly highlighted a report of the UN Secretary General regarding the rights of persons with disabilities wherein concerns were expressed that developments such as privatization had had a negative impact in the provision of programs and services to persons with disabilities. ${ }^{57}$ The CESCR then went on to underline certain aspects of States' obligations taking into account the increasing commitment of States to market-based policies. According to the Committee, there is the need to,

\begin{abstract}
"[e]nsure that not only the public sphere, but also the private sphere, are, within appropriate limits, subject to regulation to ensure the equitable treatment of persons with disabilities. In a context in which arrangements for the provision of public services are increasingly being privatized and in which the free market is being relied on to an ever greater extent, it is essential that private employers, private suppliers of goods and services, and other non-public entities be subject to both nondiscrimination and equality norms in relation to persons with disabilities. In circumstances where such protection does not extend beyond the public domain, the ability of persons with disabilities to participate in the mainstream of community activities and to realize their full potential as active members of society will be severely and often arbitrarily constrained." 58
\end{abstract}

The Committee furthermore stressed that the operation of the free market will not always work in a satisfactory way for persons with disabilities. In such circumstances it is a duty for the State to intervene and take appropriate measures to ameliorate, complement, compensate, and even override the effects produced by market forces. The Committee was also keen to point out that States could rely on private, voluntary groups to assist persons with disabilities in various ways. This however, does not absolve Governments from their duty to ensure full compliance with their obligations under the Covenant, according to the CESCR. ${ }^{59}$ Even though this

\footnotetext{
56 See further Chapter II.

57 General Comment No. 5, para. 10.

58 Ibid., para. 11. The Committee was quick to point out that legislative measures as such will not always be the most effective means to eliminate discrimination towards persons with disabilities in the private sphere. However the State could help to raise the awareness in society about persons with disabilities and their rights. Ibid., para. 12.
} 
observation applies to private, voluntary groups, it is possible that the Committee's view could be extended to privatized service providers entrusted with providing services to persons with disabilities.

With regard to the right to adequate housing as a component of the right to an adequate standard of living (Article 11 ICESCR) the CESCR drafted a general comment on forced evictions. ${ }^{60}$ The Committee paid particular attention to the obligations of States requiring them to take appropriate measures such as the adoption of legislation to provide effective protection against forced evictions (including the description of the strict circumstances under which evictions may take place). The CESCR observed that this legislation must also apply,

"[t]o all agents acting under the authority of the State or who are accountable to it. Moreover, in view of the increasing trend in some States towards the Government greatly reducing its responsibilities in the housing sector, States parties must ensure that legislative and other measures are adequate to prevent and, if appropriate, punish forced evictions carried out, without appropriate safeguards, by private persons or bodies." ${ }^{16}$

This passage would imply that whenever a State chooses to privatize the housing sector, it should take into account the rights of tenants and that privatized housing companies could be held accountable for carrying out undue forced evictions.

Privatization and the recourse to private entities in the sector of health care has been a concern of the Committee as well. In its fourteenth general comment relating to the right to the highest attainable standard of health (Article 12.1 International Covenant on Economic, Social and Cultural Rights), the CESCR depicted the obligations of State parties to the covenant. A number of these obligations also cover the provision of health related services by private parties. According to the CESCR the right to the highest attainable standard of health contains a number of interrelated and essential elements, the application of which depends on the conditions prevailing in a particular State party: availability, accessibility, acceptability and quality. With regard to the element of accessibility, the CESCR is of the opinion that health facilities, goods and services have to be accessible to everyone without discrimination. ${ }^{62}$ Accessibility has in turn four dimensions, of which affordability (or economic accessibility) has some bearing on the issue of privatization. This dimension entails that health facilities, goods and services must

60 General Comment No. 7, The right to adequate housing (Art.11.1 of the International Covenant on Economic, Social and Cultural Rights): forced evictions CESCR (20 May 1997).

61 Ibid., para 9.

62 General Comment No. 14, The right to the highest attainable standard of health, (Art. 12 of the International Covenant on Economic, Social and Cultural Rights), CESCR UN Doc. E/C.12/2000/4 (11 August 2000), para. 12 (b). 
be affordable to all, including socially disadvantaged groups. It should not matter whether these facilities, goods and services are provided privately or publicly. ${ }^{63}$ Although the Committee does not expressly say so, this would imply that health care services that have been privatized should offers their services at an affordable cost to all.

In the context of the legal obligations ensuing from the covenant in general and the right to the highest attainable standard of health in particular (obligations to protect, fulfill and respect), ${ }^{64}$ the Committee was more specific. According to the CESCR the obligations to protect, "include, inter alia, the duties of States to [...] ensure that privatization of the health sector does not constitute a threat to the availability, accessibility, acceptability and quality of health facilities, goods and services." 65

In 2003, the CESCR issued its General Comment No. 15 on the right to water.66 Although this particular right is not expressly mentioned in the ICESCR, the Committee has taken the position that this right is an essential element of the right to an adequate standard of living and the right to health as found in Articles 11 and 12 of the ICESCR, and as such also guaranteed by the Convention. The Committee addressed the issue of privatization in the water utilities sector with regard to the right to water. In general it discussed th role of the State and that of the private sector with regard to the availability, accessibility and affordability of water. This general comment will be discussed in further detail in Chapter VII.

The issue of privatization has also appeared with regard to non-discrimination in the sphere of economic, social and cultural rights as protected by the Convention. The CESCR noted in its General Comment No. 16 on the CESCR ${ }^{67}$ that

"States parties have an obligation to monitor and regulate the conduct of non-State actors to ensure that they do not violate the equal right of men and women to enjoy economic, social and cultural rights. This obligation applies, for example, in cases where public services have been partially or fully privatized." 68

63 Ibid

64 The obligation to respect requires States to refrain from interfering directly or indirectly with the enjoyment of a right. The obligation to protect requires the State to take measures to prevent third parties from interfering with the guarantees of a certain right. Finally, the obligation to fulfill demands that States adopt the necessary measures (legislative, financial, administrative, or judicial among others) for the full realization of the right involved. See Chapter III 4.1.3.

65 General Comment No. 14, para. 35.

66 General Comment No. 15, The right to water (arts. 11 and 12 of the International Covenant on Economic, Social and Cultural Rights), CESCR UN Doc. E/C.12/2002/11 (20 January 2003).

67 General Comment No. 16, The equal right of men and women to the enjoyment of all economic, social and cultural rights (art. 3 of the International Covenant on Economic, Social and Cultural Rights), CESCR UN Doc E/C.12/2005/4 (11 August 2005). 
Finally, in its most recent general comment related to the right to work as guaranteed in Article 6 of the ICESCR, ${ }^{69}$ the Committee made once again a reference between the various obligations ensuing from a particular right and privatization. In particular, the Committee noted that the obligation to protect the right to work included "[...] duties of States parties to adopt legislation or to take other measures ensuring equal access to work and training and to ensure that privatization measures do not undermine workers' rights (emphasis $A H W$ )." ${ }^{.70}$

\subsubsection{Examination of State reports}

Probably more than any other treaty body, the CESCR has paid considerable attention to the privatization issue while considering and discussing State reports. ${ }^{71}$ This is in the first place apparent in the list of issues that the CESCR has forwarded to at least ten states to facilitate their discussion during the actual examination of the State report. ${ }^{72}$ These lists have contained questions related to the privatization of services formerly provided by States and their effect on human rights such as the right to an adequate standard of living, the right to social security, the right to work and the right to health as illustrated by the following examples:

- Canada: the CESCR asked the government of Canada about the implications of a suggested privatization of social assistance in terms of State responsibility for guaranteeing the rights in Article 11 ICESCR (right to an adequate standard of living) ${ }^{73}$

- Bulgaria: the CESCR wanted to know about the impact of the privatization of the real estate market on the rights of tenants such as safeguards against expulsion, rent levels and security of lease in the context of Article 11 ICESCR (right to an adequate standard of living including housing). ${ }^{74}$

- Armenia: the CESCR inquired about how the privatization of the agriculture sector was being applied in the context of the right to an adequate standard of living (Article 11 ICESCR). ${ }^{75}$

- Argentina: the CESCR requested information on the impact of the privatization of pension schemes on those groups that are not able to create sufficient capital

69 General Comment No. 18, The right to work (art. 6 of the International Covenant on Economic, Social and Cultural Rights), CESCR UN Doc E/C.12/GC/18 (6 February 2006).

70 Ibid., para. 25.

71 An examination of more than 400 treaty body documents including summary records of the examination of State reports reveals that the CESCR has addressed the question of privatization more often than any other treaty body, followed by the CRC, the ICCPR, the CEDAW, CAT and CERD.

72 The countries involved were Algeria, Egypt, Czech Republic, Finland, Mexico, Australia, Argentina, Canada, Bulgaria and Armenia.

73 List of Issues Canada, UN Doc. E/C.12/Q/CAN/1 (10 June 1998), para. 34.

74 List of Issues Bulgaria, UN Doc. E/C.12/Q/BUL/1 (19 June 1998), para. 33.

75 List of Issues Armenia, UN Doc. E/C.12/Q/ARM/1 (11 December 1998), para. 36. 
for a satisfactory pension such as the unemployed, underemployed and lowincome workers in the context of the right to social security (Article 9 ICESCR). ${ }^{76}$

- Mexico: the CESCR requested information on how the federal social security system worked and how its privatization has affected the, "most vulnerable group of society," in the context of the right to social security (Article 9 ICESCR) ${ }^{77}$

- Egypt: the CESCR requested further information on the government's current privatization program which apparently resulted in numerous cases of forced early retirement, arbitrary dismissal and unemployment in the context of the right to work (Article 6 ICESCR). ${ }^{78}$

- Australia: the CESCR requested information on the impact of the privatization of health services, "on the delivery of specialist services, particularly for vulnerable groups including women and indigenous Australians," in the context of the right to health (Article 12 ICESCR) ${ }^{79}$

- Finland: the CESCR inquired about the effects of privatization and globalization in the protection of the employed against dismissal (right to work, Article 6 ICESCR). ${ }^{80}$

- Algeria: the CESCR asked the Algerian government what is the path to the privatization of social security in the context of the right to social security (Article 9 ICESCR). ${ }^{81}$

- Czech Republic: the CESCR wanted to know the rate of unemployment and its relationship with privatization policies again in the context of the right to work (Article 6 ICESCR). ${ }^{82}$

- Kenya: in the light of a recent water legislation and the privatization of water services in the country, the CESCR requested more detailed information on the measures taken to ensure affordable access to adequate water and sanitation and to reduce waiting times for collecting water, in particular in rural areas and in informal settlements in a some cities. ${ }^{83}$

In addition, during the actual examination of the State reports, individual members of the CESCR have frequently stated their concerns regarding the negative impact of privatization on the enjoyment of several rights protected by the ICESCR. During the consideration of the initial report submitted by Benin, for example, committee member Textier expressed concern,

\footnotetext{
76 List of Issues Argentina, UN Doc. E/C.12/Q/ARG/1 (17 December 1998), para. 26.

77 List of Issues Mexico, UN Doc. E/C.12/Q/MEX/1 (30 December 1998), para. 27.

78 List of Issues Egypt, UN Doc. E/C.12/Q/EGY/1 (21 May 1999), para. 13.

79 List of Issues Australia, UN Doc. E/C.12/Q/AUSTRAL/1 (23 May 2000), para. 29.

80 List of Issues Finland, UN Doc. E/C.12/Q/FIN/2 (21 September 2000), para. 16.

81 List of Issues Algeria, UN Doc. E/C.12/Q/ALG/1 (18 May 2001), para. 14.

82 List of Issues Czech Republic, UN Doc. E/C.12/Q/CZE/1 (18 May 2001), para. 13.

83 List of Issues Kenya, UN Doc. E/C.12/KEN/Q/1 (12 December 2007), para. 33.
} 
"[...] that the privatization of the electricity and water companies would have an adverse effect on the country's poor, many of whom already found it difficult to gain access to those services. He asked how the government planned to ensure that the cost of water and electricity would not increase." 84

The government of Benin responded by stating that privatization had been urged by states providing Benin with development aid and that it would adopt measures to ensure that the cost of those services being privatized would not be prohibitive. ${ }^{85}$ In reply to the reaction of Benin's representative, another committee member, $\mathrm{Mr}$. Riedel, stated that privatization was not necessarily "an adverse factor in the provision of basic services, especially when public financing was not available." 86 However, Mr. Riedel maintained that the State still had "the responsibility to ensure that such services were accessible and that the economic, social and cultural rights of the population, in particular of marginalized groups, were respected by private companies" when privatization took place. ${ }^{87}$ During this debate, committee member Kolosov added that the social consequences of privatization "were unforeseeable and out of control." 88 The general concerns regarding the privatization of water and electricity services were later reflected in the concluding observations to Benin's report. ${ }^{89}$ Similarly, during the consideration of Paraguay's initial report to the CESCR, a member of the committee claimed that privatization was viewed as a threat to the enjoyment of economic, social and cultural rights. ${ }^{90}$ He then asked the delegation of Paraguay whether privatized undertakings providing essential services would be answerable in the event of failure to observe the rights contained in the ICESCR and the Paraguayan constitution. ${ }^{91}$

It appears that mixed feelings exist with regard to privatization within the CESCR. While some committee members consider privatization as a threat to the enjoyment of the rights enshrined in the ICESCR, others are milder in their appreciation of the phenomenon as long as States take into account their treaty obligations and ensure the rights guaranteed in those treaties. ${ }^{92}$ This can be illustrated by the views of

84 Summary record of the first part (public) of the $10^{\text {th }}$ meeting: Benin, UN Doc. E/C.12/2002/ SR.10 (14 May 2002), para. 14. Although it was not explicitly mentioned, it can be assumed that these concerns are related to Article 11 ICESCR (right to an adequate standard of living). Ibid., para. 15 .

Ibid., para. 18.

Ibid.

Ibid., para 21.

UN Doc. E/C.12/1/Add.78 (17 May 2002), para. 22.

Comment of Mr. Rattray, Summary record of the $1^{\text {st }}$ meeting: Paraguay, UN Doc. E/C.12/1996/ SR.1 (23 May 1996), para 33.

Ibid. Paraguay's answer to this question was that privatization remained a sensitive issue in that country and that "in the case of the privatization of companies that supplied essential public services such services as water and telecommunications, the State could exercise control in the interests of the consumers, namely, its citizens." Ibid., para. 38.

F.e. see comment Committee member Riedel supra. 
one committee member during the consideration of Algeria's second periodic report to the CESCR. During the first session of the report's examination, one committee member stated that "privatization was a healthy phenomenon, but such measures must be implemented with due consideration for Algeria's international treaty obligations." 93 The Algerian government acknowledged that privatization of the public sector had brought about some problems (in this case job losses, which according to the government had been dealt with through a social safety net program). However, the Algerian government maintained that the privatization program had not been in contravention of the Covenant's provisions. ${ }^{94}$

The CESCR's concluding observations on State reports also reflect the interest and concern that the Committee has shown in the subject of privatization. Generally speaking, the Committee has been worried about privatization of public services and has noted, on at least one occasion, that privatization could be seen as a factor impeding the implementation of the Covenant. ${ }^{95}$ In another instance, the Committee has concluded that the high levels of poverty in one country have been exacerbated by, among other things, the privatization policies carried out by the State. ${ }^{96}$ Main subjects of concern for the CESCR have been the effects of privatization on labor related rights (Articles 6, 7 and 8 ICESCR), social security (Article 9 ICESCR), the right to an adequate standard of living (including the right to water and housing. Article 11 ICESCR), and the right to health (Article 12 ICESCR). In general, however, the Committee has only made general statements regarding perceived threats to the Convention's rights by privatization without providing any specific evidence or explanation as to how this might occur.

With regard to privatization and labor related rights, the Committee has concluded on a number of occasions that the privatization of public enterprises has led to rising levels of unemployment in certain countries. ${ }^{97}$ The Committee, however, did not

93 Summary record of the second part of the $65^{\text {th }}$ meeting: Algeria, E/C.12/2001/SR.65 (20 November 2001), para. 12.

94 Ibid., para. 21. It is interesting to note that the question regarding the privatization of social security which had been put forward in the list of issues as exemplified above did not come back during the Committee's consideration of the report. It also did not appear in the Committee's concluding observations to Algeria's second periodic report, which did address another privatization issue: the privatization of health care services which was brought up during the second session of the report's examination (Summary record of the $66^{\text {th }}$ meeting: Algeria, E/C.12/2001/SR.66 (28 February 2001).

95 See for example Committee on Economic, Social and Cultural Rights, Report on the Fourteenth and Fifteenth Sessions, UN Doc. CESCR E/1997/22 (1 January 1997), para. 99, where the Committee noted that, "[t]he decentralization and privatization of some social services, persistent large-scale unemployment and budget cuts affect the whole population, and especially the most vulnerable groups."

96 See Concluding observations, Ukraine, UN Doc. CESCR E/2002/22 (2001), para. 490.

97 See Concluding observations, Ukraine, UN Doc. CESCR E/1996/22, para. 258; Benin, UN Doc. E/C.12/1/Add.78 (17 May 2002), para. 14. See similar concerns with regard to Panama, UN Doc. CESCR E/1992/23, para. 119 and UN Doc. CESCR E/1993/22, para. 197. 
substantiate these conclusions with any factual material. The Committee has also expressed its concern regarding a potential infringement on the acquired rights of civil servants that would allegedly be caused by the privatization of public services in one country. ${ }^{98}$ Again, the Committee did not document how it thought this would happen, or what the State should do to prevent it. With regard to labor in privatized prisons, the Committee has noted that State parties should "[...] ensure that labour in private prisons is voluntarily undertaken and is properly remunerated." 99

The Committee's views on the right to social security can be illustrated with the concluding observations on Argentina's second periodic report. The CESCR was worried about,

“[...] the extension of the Government's privatization of the pension programme. The basic payment system, to which all are entitled, is gradually being replaced by a new capitalization scheme whose return depends on the pensioner's contributions. This calls in question the prospects for those who are unable to capitalize adequate pensions, including lower-paid workers, and unemployed and underemployed persons." 100

The Committee then concluded that, "[i]n relation to the stabilization programmes, the Committee, while acknowledging the great success achieved through privatization and decentralization at the macroeconomic level, observes that such measures are not being adequately monitored and thus are leading to the violation of economic, social and cultural rights." 101 This concern about Argentina's pension privatization program was reiterated in the examination of that country's third periodic report and the CESCR repeated its concern at "[t]he extent of the Government's privatization of the pension programme, in particular article 16 of Law 24,463 which allows the Government to reduce, and eventually even not to pay pensions by invoking economic constraints."102

98 Concluding observations Switzerland, UN Doc. CESCR E/1999/22, para. 351.

99 See concluding observations to Australia's third periodic report, UN Doc. E/C.12/1/Add.50 (11 September 2000,) para. 30.

100 UN Doc. E/C.12/1994/14 (19 December 1994), para. 13. Similar concerns were expressed towards Mexico's plan to privatize the social security system which, "[m]ay exclude from certain benefits those not in a position to contribute to an individual pension account, such as the unemployed, underemployed, lower-paid workers and those employed in the informal sector." See concluding observations to Mexico's third periodic report, UN Doc. E/C.12/1/Add.41 (8 December 1999), para. 24.

101 UN Doc. E/C.12/1994/14 (19 December 1994), para. 22.

102 UN Doc. E/C.12/1/Add.38 (8 December 1999), para. 18. It is at this point interesting to note that according to a news analysis the privatization of Argentina's pension system (carried out at the urging of the IMF) might have partly contributed to the Argentine economic crisis in 2001 and 2002 leading to alarming social problems in that country. See. L. Rohter, "Giving Argentina the Cinderella Treatment," Week in Review, The New York Times, 11 August 2002, <www.nytimes. com/2002/08/11/weekinreview/11ROHT.html>, last visited on 31 August 2011. 
With regard to the right to an adequate standard of living (Article 11), the CESCR expressed its serious concern with regard to "[...] the extent that structural adjustment measures and the privatization of State property have had negative consequences for the enjoyment of the economic, social and cultural rights of the Nicaraguan people, and more specifically for the standard of living of the most vulnerable sectors." 103 To address this problem, the Committee recommended that the State should provide adequate safety nets for the vulnerable sectors of society in order to avoid a deterioration of the enjoyment of the rights protected in the Covenant. The Committee has also been worried about the privatization of electricity and water services that could affect the right to an adequate standard of living and the right to water enshrined therein. ${ }^{104}$ The CESCR has expressed its concerns at the increase in the costs of these services that could be caused by their privatization and the disparities on the standard of living between rural and urban areas that it would bring, ${ }^{105}$ and has encouraged States to take effective measures to improve the access to these services and maintain accessible costs for them. ${ }^{106} \mathrm{It}$ would appear, however, that in countries where public provision of basic services such as water is not sufficiently developed enough to achieve a higher standard of living, the CESCR would accept its privatization. In its concluding observations regarding Nepal the Committee noted that "[p]rojects involving privatization of water supply should provide for continued, assured and affordable access to water by local communities, indigenous people, and the most disadvantaged and marginalized groups of society."107

Concerning the effect of privatization on the right to adequate housing, the CESCR has noted that the policy of privatization with regard to housing programs "[...] entail[s] certain risks for the social protection of all the sectors of the population."108 More specifically the Committee has been concerned that the complete privatization of housing may increase the number of homeless people in urban areas, ${ }^{109}$ while the inadequacy of the social safety nets during a privatization program has "[...] negatively affected the enjoyment of economic, social and cultural rights, in particular by the most disadvantaged and marginalized groups." 110 The CESCR,

UN Doc. E/C.12/1993/14 (4 January 1994), para. 6.

On this issue see further Chapter VII below.

105 See concluding observations to Benin's initial report, UN Doc. E/C.12/1/Add.78 (17 May 2002), para. 22.

106 Ibid., para 41.

107 UN Doc. CESCR E/2002/22 (2001) 83, para. 576.

108 Concluding observations, Italy, UN Doc. E/1993/22 (1992) 42, para. 190.

109 Concluding observations, Solomon Islands, UN Doc. CESCR E/2000/22 (1999) 40, para. 203. Similar concerns were expressed during the examination of the Czech Republic's initial report where it noted that the privatization of some public housing stocks paired to an acute housing shortage in the Czech Republic resulted in a sharp rise in rents, forced evictions and homelessness. See UN Doc. E/C.12/1/Add.76 (5 June 2002), para 19. 
however, did not shed any light as to how this has occurred. The Committee, nevertheless, strongly recommended to the State party, "[...] to integrate the provisions of the Covenant into its privatisation programs and provide for social safety nets in carrying them out," as well as taking measures to address the housing shortage and forced evictions. ${ }^{11}$

On the subject of the privatization and the right to health (Article 12 ICESCR), the CESCR has been keen to emphasize that privatization of health care services could have negative effects on vulnerable sectors of society. For example, the CESCR invited Algeria to provide information on the privatization of the health system in that country and on the measures that it should take to address the negative impact of these measures. ${ }^{12}$ Similarly, the Committee has recommended States to "[...] carefully review the probable effects of its plans to privatize portions of the national health-care system on the most disadvantaged and marginalized sectors of society, including, in particular, the unemployed and underemployed, the homeless and those living in poverty." 113 The Committee's views with regard to privatization in the health care sector are best represented in its observation that "[w]hile there is no reason why the private sector should not be fully involved in the provision of health services, it is emphasized that such an approach does not in any way relieve the Government of its Covenant-based obligation to use all available means to promote adequate access to health-care services, particularly for the poorer segments of the population." 114 In the concluding observations to Bulgaria's third periodic report, the Committee was on the other hand glad to observe that "[...] despite the privatization of health services, medicines will continue to be distributed free of charge to the disadvantaged groups of society, and that mental health services will remain public." 115

Of a more general nature are the CESCR's concerns regarding the way in which economic adjustment, austerity and privatization programs had been implemented and their adverse effects for economic social and cultural rights in El Salvador. ${ }^{116}$

111 Ibid., paras. 27 and 38.

112 Concluding observations to Algeria's second periodic report, UN Doc. E/C.12/1/Add.71 (30 November 2001), para. 36. For more brief observations on the privatization of health care see the concluding observations for Sweden's fourth periodic report, UN Doc. E//C.12/1/Add.70 (30 November 2001), para. 40; and concluding observations for Italy's third periodic report, UN Doc. E/2001/22 (2001), para. 137.

113 Concluding observations to Croatia's initial periodic report, UN Doc. E/C.12/1/Add.73 (30 November 2001), para. 34 .

114 Concluding observations to the Philippines' initial periodic report, UN Doc. E/C.12/1995/7 (7 June 1995), para. 20. See for a similar statement the concluding observations to Chile's second periodic report, UN Doc. E/1988/14, para. 198.

115 See UN Doc. CESCR E/2000/22, para. 218.

116 See concluding observations for El Salvador's initial periodic report. UN Doc. E/C.12/1/Add.4 (28 May 1996), para. 16. 
Additionally, the Committee's comments concerning Israel's initial report have made it clear that the CESCR still views the State as the central actor which has to take responsibility for the respect of human rights in its territory even though it might have divested itself of some tasks or functions. During the concluding observations on this report, the Committee remarked that the State of Israel had a decisive influence on the policies of a number of private institutions concerned with land confiscation and distribution. This influence led the Committee to conclude that Israel remained responsible for the activities of these institutions despite the fact that they were chartered under private law and noted that, "[a] State party cannot divest itself of its obligations under the Covenant by privatizing governmental functions." 117

The broad concerns of the CESCR regarding privatization are very obvious and the perceived threats with respect to the rights guaranteed in the ICESCR should be duly noted. However, the CESCR's way of dealing with privatization leaves something to be desired. In none of the concluding observations summarized above, did the Committee note how privatization actually affected the rights concerned. It limited itself to observing that privatization may have (or has had) some type of negative effect upon the enjoyment of a right without properly evidencing these conclusions with data, or specific cases. The effect of these observations on the conduct of States parties may therefore be doubted.

\subsection{Committee on the Elimination of All Forms of Racial Discrimination}

\subsubsection{General Comments}

There are no direct references to privatization by the CERD in its general recommendations (the CERD's own version of general comments). However, one general recommendation contains a reference to the conduct of private actors, which can be interpreted also to include privatized actors as well. General recommendation $\mathrm{XX}$ is directed at elucidating the obligations of States to guarantee in a nondiscriminatory way the enjoyment of the rights and freedoms enshrined in article 5 of the International Convention on the Elimination of All forms of Racial Discrimination. ${ }^{118}$ In this context, the CERD notes that, "[t]o the extent that private

117 UN Doc. E/C.12/1/Add.27 (4 December 1998), para. 11. The build-up to this conclusion was the confiscation of Palestinian land. The Committee concluded that, "[t]he large-scale and systematic confiscation of Palestinian land and property by the State and the transfer of that property to these agencies constitute an institutionalized form of discrimination because these agencies by definition would deny the use of these properties to non-Jews. Thus, these practices constitute a breach of Israel's obligations under the Covenant." Ibid.

118 These rights and freedoms include civil, political, social and cultural rights such as the right to security of the person and protection against violence or bodily harm (whether inflicted by government officials or by any other group or institution), the right to equal treatment before 
institutions influence the exercise of rights or the availability of opportunities, the State Party must ensure that the result has neither the purpose nor the effect of creating or perpetuating racial discrimination."119 This entails that the State has to control whether private entities carrying out privatized services such as housing or education abide by the prohibition of racial discrimination in those sectors.

\subsubsection{Examination of State reports}

During the examination of several State reports, the CERD has devoted some attention to the issue of privatization and how it might affect the rights enshrined in the International Convention on the Elimination of All Forms of Racial Discrimination. In a number of meetings, the Committee raised questions related to the effects of privatization in general and the 'privatization' of (agricultural) land in particular on ethnic minorities/groups or foreigners. ${ }^{120}$ However, the most eloquent observations on privatization and its effects on discrimination and the right not to be discriminated against were made by former Committee member van Boven while discussing Latvia's second and third periodic report. During this discussion, he observed that in relation to the obligations ensuing from Article 2 of the Convention,

"la política de privatización de los servicios públicos importantes que actualmente se aplica en Letonia entraña aspectos inquietantes en el plano de la lucha contra la discriminación racial. Señala a la atención de la delegación que el hecho de transferir algunas responsabilidades al sector privado no exime a un Estado Parte de la obligación de prohibir y combatir la discriminación racial, en particular en los sectores de la educación, la salud, el empleo, los servicios públicos y la vivienda, de conformidad con las disposiciones del artículo 2 de la Convención que prohíbe la discriminación racial por grupos o asociaciones." 121

tribunals and all other organs administering justice, the right to housing and the rights to education, medical care and social security. See CERD General recommendation XX (15 March 1996).

119 Ibid., para. 5.

120 See for example the summary records of the meetings dealing with the consideration of the reports from Peru (UN Doc. CERD/C/SR.1083 (13 March 1995), para. 50), Tanzania (UN Doc. CERD/C/SR.1112 (15 August 1995), para. 11), Armenia (UN Doc. CERD/C/SR.1262 (17 March 1998), paras. 51 and 59), and UN Doc. CERD/C/SR.1263 (6 April 1998), paras. 22 and 33), Kyrgyzstan (UN Doc. CERD/C/SR.1354 (25 janvier 2000), paras. 26 and 30), Sweden (UN Doc. CERD/C/SR.1417 (9 October 2000), paras. 20 and 31), and Republic of Moldova (UN Doc. CERD/C/SR.1505 (15 March 2002)). In Sweden's and Moldova's case, the comments related to the 'privatization' of land merited their inclusion in the concluding observations for that country's report (see further below).

121 The current Latvian privatization policy regarding public services has disconcerting aspects with respect to the struggle against racial discrimination. The fact that public tasks are being transferred to the private sector does not absolve a State party of its obligation to prohibit and fight racial discrimination, particularly in the areas of education, health, employment, public services and housing as stipulated in article 2 of the Convention which prohibits racial 
Adding to this observation he asked whether the Latvian government had issued laws that guaranteed that the private sector would abide by the Covenant's relevant provisions. The Latvian delegation, however, did not respond to this comment and the Committee failed to follow up the issue in the concluding observations to the report. ${ }^{122}$

The CERD's main focus regarding privatization in other concluding observations has been mainly geared towards the effects of privatization programs on the rights of ethnic groups. ${ }^{123}$ Particularly, the CERD has been wary that the 'privatization' of land might encroach on the rights of ethnic groups or minorities which dwelt on those lands or used to work in them. For example, in its concluding observations on Sweden's thirteenth and fourteenth periodic reports, the Committee was concerned,

"[o]ver the issue of land rights of the Sami people, in particular hunting and fishing rights which are threatened by, inter alia, the privatization of traditional Sami lands. The Committee recommends that the Government introduce legislation recognizing traditional Sami land rights and reflecting the centrality of reindeer husbandry to the way of life of Sweden's indigenous people."124

Likewise, the Committee pointed to reports that showed that the privatization of land held by collective farms of the Soviet era had led to landlessness among persons belonging to some minorities in Moldova. The Committee requested information to be provided for the next periodic report on measures that the State should take to address the economic condition of landless ethnic minorities. ${ }^{125}$ In a more general observation regarding the privatization of State property, the CERD noted in its conclusions for Nicaragua's combined fifth to ninth periodic reports that, "[t]he realization of economic and social rights is a matter of continuous concern, in particular as the so-called structural adjustment measures and the privatization of State property have had negative consequences on the enjoyment of the economic, social and cultural rights of the Nicaraguan people, especially on its most vulnerable sectors and among them the indigenous communities." ${ }^{.26}$ In spite

discrimination by groups or organizations (translation by $A H W$ ). Summary record of the $1348^{\text {th }}$ meeting, UN Doc. CERD/C/SR.1348 (10 December 1999), para. 44.

The privatization of media (broadcasting or printed), has also received some attention by the CERD, although the Committee has limited itself to requesting additional information regarding such privatization. It has provided no further clue as to the relevance of the privatization of this sector with regard to issues of racial discrimination, although one could guess that the Committee was interested in knowing whether privatization of the media helped to increase the plurality of news and the participation of cultural or racial minorities therein. See Concluding observations Portugal, UN Doc. A/46/18 (1991), para. 119 and Sudan, UN Doc. A/49/18 (1994), para. 454. 
of this statement, the CERD did not provide further evidence as to how privatization effected these negative outcomes.

\subsection{Committee on the Elimination of Discrimination Against Women}

\subsubsection{General Comments}

In a comparable way to that of the CESCR, the CEDAW has also approached the matter of privatization and its effects to the right to health (article 12 of the Covenant on the Elimination of Discrimination Against Women) from the perspective of the obligations to protect, fulfill and respect this right. In its $24^{\text {th }}$ General recommendation related to women and health the Committee pointed out that States have the obligation to respect the right to health by reporting on how public and private health-care providers meet their duties to respect women's rights to have access to health care. ${ }^{127}$ Although not expressly mentioned, privatized health-care providers might presumably be included as well. The obligation to protect the right to health for women requires, according to the Committee, States to take action to prevent and impose sanctions for violations of rights by private persons and organizations. ${ }^{128}$ Finally, with regard to the obligation to fulfill, the Committee is,
"[c]oncerned about the evidence that States are relinquishing these obligations [to ensure women's access to health care] as they transfer State health functions to private agencies. States and parties cannot absolve themselves of responsibility in these areas by delegating or transferring these powers to private sector agencies. State parties should therefore report on what they have been done to organize governmental processes and all structures through which public power is exercised to promote and protect women's health. They should include information on positive measures taken to curb violations of women's rights by third parties and to protect their health and the measures they have taken to ensure the provision of such services." 129

In conclusion, the CEDAW recommended State parties to monitor the provision of health services to women by public, non-governmental and private organizations, to ensure equal access and quality of care. ${ }^{130}$ It would thus appear that from the perspective of the CEDAW, privatization should not lead to States absolving themselves from responsibilities in the health care sector, and States have to adopt pro-active measures to prevent private entities carrying out tasks in a manner contrary to the Women's Convention.

\footnotetext{
127 General recommendation No. 24, Women and Health, CEDAW, General recommendation No. 24 (5 February 1999), para. 14. 


\subsubsection{Examination of State reports}

The CEDAW has also made numerous comments on privatization in respect of the States' duties to implement and respect the rights guaranteed by the Convention on the Elimination of All Forms of Discrimination Against Women. Major points of concern in the approach of the CEDAW towards the impact of privatization on the rights of women are its potential effects on the economic and labor position of women and their right to health. However, like the Committee on Economic, Social and Cultural Rights, the CEDAW has usually failed to provide a detailed analysis of the actual effects of privatization on women's rights and/or any data or evidence to back up assertions that privatization has a negative impact on the enjoyment of women's rights.

In the concluding observations on the Philippines' third and fourth periodic reports, the CEDAW noted that one of the factors affecting the implementation of the Convention on the Elimination of Discrimination Against Women is the trend towards privatization that may have serious implications for the economic position of women. ${ }^{131}$ The Committee, however, did not specify the ways in which privatization affected the rights and economic position or women, nor did it make any further recommendations in this regard. With respect to the labor position of women, the CEDAW failed to respond to a comment by the Romanian delegation during the examination of Romania's initial and combined second and third reports that the privatization of certain State enterprises had caused increased unemployment among women. ${ }^{132}$ Later on, however, the Committee did point out in its concluding observations on the Russian Federation's third and fourth periodic reports that, "[t]he high rate of unemployment among Russian women was primarily due to the rapid restructuring and privatization of industries employing a large proportion of female labour." 133 However, the Committee did not back up this contention with any supporting evidence. Additionally, it expressed its concern over the consequences of the transformation from a Marxist society to a market economy, which included a deregulated and privatized property sector, on the difficulties the Russian Federation experienced in achieving the goals of the Convention. ${ }^{134}$

Health care related problems were signaled by the Committee in its concluding observations to Armenia, Canada, Cameroon, Georgia, Spain and Mongolia. The amount of detail on the concerns and the recommendations has, however, varied

\footnotetext{
131 UN Doc. A/52/38/Rev.1, paras. 275-305 (12 August 1997), para. 283. See similar considerations in the concluding observations with regard to the Czech Republic (UN Doc. A/53/38/Rev.1 part I (1998) 16, para. 95) and Uganda (UN Doc. CEDAW/C/ 2002/EXC/CRP.3/Add.3/Rev 1 (2002), para. 37). 
from case to case. In the case of Armenia, the CEDAW expressed deep concern at the government's plans to privatize health services and emphasized the adverse effects for women and other vulnerable groups of such privatization. ${ }^{135}$ The Committee did not make clear, however, what these adverse effects were and how and why they would take place. Nevertheless, the Committee recommended to Armenia to ensure that it fulfils its social responsibilities and obligations under international human rights law while planning and implementing the privatization policies and programs so that they would not deprive women of the enjoyment of their human rights in the area of health. ${ }^{136}$ While discussing Canada's report, the CEDAW pointed out that the trend towards the privatization of health care programs, could seriously affect the accessibility and quality of services available to Canadian women, especially the most vulnerable and disadvantaged, but made no further recommendations on the issue. ${ }^{137}$ Cameroon's problems according to the Committee, were that the implementation of structural adjustment program, and the privatization of especially the health and education sectors, pose serious challenges to the full implementation of the Convention. ${ }^{138}$ Specific evidence supporting this claim or a recommendation to address the problem was, however, not provided. Similarly, the Committee observed in its concluding observations on Georgia's first periodic report that " $[t]$ he privatization of health care has negatively affected women by restricting their access to the necessary medical services and reducing jobs for women as nurses and doctors," but failed to back this up or make any specific recommendations other than recommending "[t]he creation of insurance plans that sufficiently cover women patients in hospitals and in ambulatory medical care."139 Spain was recommended to include in its next report detailed information on the provision of health services and health insurance to women. The Committee was especially interested in the potential and actual impact on women of any steps considered or taken towards privatization of the health sector. ${ }^{140}$ Finally, the Committee's concluding observations on Mongolia's combined third and fourth periodic reports denoted deep concern at the negative impact of privatization on women's access to adequate health care and education. The Committee did not expand on the nature of the negative impact of privatization on these services. It did, however, recommend to Mongolia to ensure that these services were not

135 UN Doc. A/52/38/Rev.1 part II (1997) 78, paras. 60 and 67.

136 Ibid., para. 67.

137 UN Doc. A/52/38/Rev.1, paras. 306-343 (12 August 1997), para. 329. Once again, however, the Committee did not make clear how this would happen.

138 UN Doc. A/55/38, paras. 30-66 (26 June 2000), para. 44.

139 UN Doc. A/54/38, paras. 70-116 (1 July 1999), paras. 111 and 112. Admittedly, in this concluding observation, the Committee did note that the privatization had differentially resulted in an increase in women's unemployment. To counteract these effects, the Committee recommended "the implementation of comprehensive measures aimed at the improvement of women's economic status through training and retraining, as well as the introduction of quotas for women in the governmental job creation schemes." See paras. 105 and 106. 
reduced and that the areas of health and education should not suffer as a result of privatization. ${ }^{141}$

The conclusions and recommendations for New Zealand's third and fourth periodic reports were also rather explicit. The Committee expressed its "[...] concern that the ongoing privatization of social services and the introduction of fee-based systems in areas such as health reduces women's, especially poor and Maori women's, access thereto."142 It further recommended the Government to "closely monitor the impact of privatization on social services, especially in health, so as to ensure equal access to quality health care for all women."143

Finally, the CEDAW has shown its concern at the privatization of pre-school education. In its concluding observation to Uganda's report, it considered such privatization to be an impediment to early education for children, particularly for those in the rural areas. ${ }^{144}$ Once more, there was no data to back this up and no further explanations as to how this occurred.

\subsection{Committee Against Torture}

\subsubsection{General Comments}

In its second General Commenton the implementation of Article 2 of the Convention Against Torture and other Cruel, Inhuman or Degrading Treatment or Punishment, the Committee Against Torture (CAT) discussed the status of private contractors exercising certain public functions such as managing detention centers. After clarifying that the Convention Against Torture imposes obligations on States parties but not on private individuals, it noted htat States can be internationally responsible for "[...] for the acts and omissions of their officials and others, including agents, private contractors, and others acting in official capacity or acting on behalf of the State, in conjunction with the State, under its direction or control, or otherwise under colour of law." 145 According to the CAT, the obligation to prevent torture and other cruel, inhuman or degrading treatment flowing from Article $2 \S 1$ and $16 \S 1$ requires States parties to "[...] adopt effective measures to prevent such authorities or others acting in an official capacity or under colour of law, from consenting to or acquiescing in any acts of torture."146 Failing to adopt preventive measures would result in a violation of the obligations under the Convention Against Torture.

\footnotetext{
141 UN Doc. A/56/38, paras. 234-278 (2 February 2001), paras. 267-268.

142 UN Doc. A/53/38/Rev.1, paras. 243-291 (9 July 1998), para. 275.

143 Idem., para. 276.

144 UN Doc. A/50/38 (1995) 61 at para. 334.

145 General Comment No. 2, Implementation of Article 2 by States Parties, CAT, UN Doc. CAT/C/ CG/2 (24 January 2008), para. 15.

146 Ibid., para. 17.
} 
Interestingly, the CAT illustrated this by referring to the use of privately owned or run detention centers. The CAT considered that personnel working in such centers are "[...] acting in an official capacity on account of their responsibility for carrying out the State function without derogation of the obligation of State officials to monitor and take all effective measures to prevent torture and ill-treatment." 147 Finally, the CAT observed that States bear the responsibility for authorities or others acting in official capacity or under colour of law if the latter fail to exercise due diligence to prevent torture or other types of ill treatment. ${ }^{148}$

\subsubsection{Examination of State reports}

The CAT has mainly devoted attention to the issue of privatized prisons and private security. This can be appreciated in the list of issues it has forwarded to several countries in anticipation of the examination of their State reports. For example, the Committee Against Torture has shown concern about the use of privately managed detention facilities for immigrants in Australia. In preparation for Australia's third periodic report, the Committee noted that immigration detention facilities had been contracted out in that country since $1998 . .^{149}$ The Committee asked the Australian government whether staff employed by the private contractors running these facilities are trained on the obligations under the Convention Against Torture and other international human rights instruments. ${ }^{150}$ It also wanted to know whether the Australian Immigration Detention Standards, which apply to these facilities make specific reference to the Convention and human rights law. ${ }^{151}$ In addition, the Committee wanted to know how compliance with human rights norms within the immigration detention centers was being monitored. Similarly, questions about the use of private security contractors operating at checkpoints along the security barrier that separates Israel from the occupied Palestinian territories, and whether Israel bears any responsibility for allegations of ill-treatment by these contractors were presented in the list of issues for Israel's fourth periodic report. ${ }^{152}$ Interestingly, the Committee wanted to know whether these contractors received any training regarding the prohibition of torture.

The Committee Against Torture has also addressed the issue of privatization of military services and their deployment in Iraq by the United States on the list of issues to be considered during the examination of this country's second periodic report. ${ }^{153}$ The questions related to the use of private contractors in respect of the

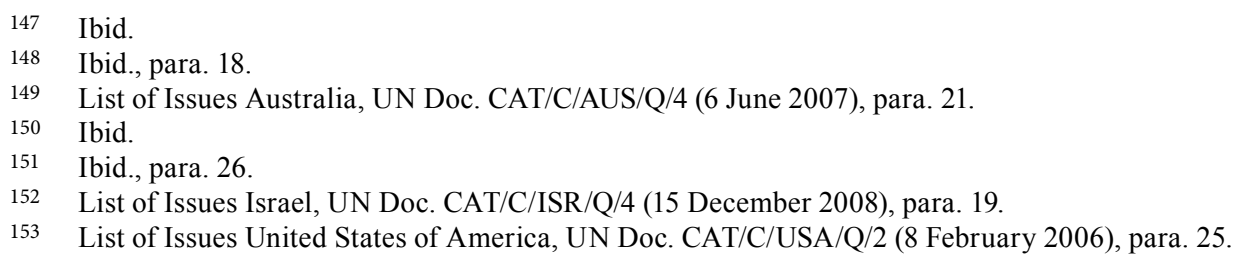


operation of detention facilities and the interrogation of detainees, as well as their training (or lack thereof) in particular in human rights.

While considering the United States' initial report ${ }^{154}$ under Article 19 of the Convention Against Torture and Other Cruel, Inhuman or Degrading Treatment or Punishment, Committee, for example, Committee member Henriques Gaspar requested additional information about the privatization of the prison system in the United States. ${ }^{155} \mathrm{He}$ thought that, "[...] it was hard to see how the State party could exercise full supervisory authority, as required by articles 11 and 12 of the Convention [respectively dealing with the States' obligations to keep under review interrogation rules, instructions and procedures, and their obligation to ensure a prompt and impartial investigation if there are reasonable grounds to believe that an act of torture or ill-treatment has been committed, $A H W]$, over extremely powerful private companies, whose aim was, by definition, to make money." 156 In response to this inquiry, the representative of the United States replied that prisons operated by private companies were subject to scrutiny under the United States Constitution. The State representative added that "[...] a corporation operating a prison facility under a contract with the State was subject to the same liabilities under federal law as a public facility." 157 During this session another member of the Committee asked whether the authorities could be held responsible for the conduct of private companies entrusted with running prisons and whether the United States believed that it was no longer responsible for the actions of private companies running prisons. ${ }^{158}$ To this last question, the United States representative responded that establishing private prison arrangements through a contract did not exempt those responsible for operating the prison from the rule of law. ${ }^{159}$ In spite of the attention it had received, the question of privatized prisons was not addressed in the concluding observations of the Committee related to the United States' report. ${ }^{160}$

154 UN Doc. CAT/C/28/Add.5 (9 February 2000).

155 See summary record of the $424^{\text {th }}$ meeting, UN Doc. CAT/C/SR.424 (9 February 2001), para. 34. The Untied States had brought up the subject in a number of passages of the report.

156 Ibid.

157 UN Doc. CAT/C/SR.427 (19 May 2000), para. 37.

158 Ibid., para. 47.

159 Ibid., para. 54.

160 This is somewhat strange, taking into consideration that almost simultaneously to the examination of the United States' report, the examination of the Netherlands' third periodic report had also addressed the issue of the possible privatization of a prison in Aruba/Netherlands Antilles and the Committee took up the point (albeit in a brief way) in its concluding observations. See the summary records of the Committee related to the Netherlands' third periodic report (UN Doc. CAT/C/SR.426 (13 February 2001), paras. 18, 26 and 27, wherein the Chairman of the Committee stated that even if prisons were privatized, the State party would continue to fulfill all its obligations under the provisions of the Convention Against Torture; UN Doc. CAT/C/SR.429 (19 May 2000), paras. 35 and 40; UN Doc. CAT/C/SR.433 (23 May 2000), para. $6(\mathrm{~g})$ ) and the respective concluding observations (UN Doc. A/55/44, paras.181-188 (16 May 2000), para 186(g)). 
Following the well-publicized use of private military and security companies by the United States Armed Forces in the invasion and subsequent occupation of Afghanistan and Iraq since 2001 and 2003 respectively, and the problems surrounding Abu Ghraib prison, ${ }^{161}$ the CAT submitted several questions on the use of contractors from these companies for discussion as part of the examination of the United State's second periodic report. Curiously, during the actual discussion the question related to the use of private military and security contractors in Iraq was mainly carried out by the representatives of the United States, who observed on various occasions that the United States government did not tolerate or condone under any circumstances unlawful practices by its personnel or employees, including contractors. ${ }^{162}$ In the concluding observations, the CAT welcomed the United States officials' statement that all government agencies, "[...] including its contractors, were prohibited from engaging in torture at all times and in all places, and that all United States officials from all government agencies, including its contractors, wherever they may be, are prohibited from engaging in cruel, inhuman or degrading treatment or punishment, in accordance with the obligations under the Convention."163 The Committee, however, was concerned about the reported acts of torture committed by the U.S. military or civilian personnel in both Afghanistan and Iraq, and the lenient outcomes of the investigations and prosecutions of those cases. ${ }^{164}$ The Committee then recommended that the United States should promptly, thoroughly, and impartially investigate any responsibility of senior military and civilian officials authorizing, acquiescing or consenting, in any way, to acts of torture committed by their subordinates. ${ }^{165}$ In addition it recommended that the United States should "[...] eradicate all forms of torture and ill-treatment of detainees by its military or civilian personnel, in any territory under its jurisdiction, and should promptly and thoroughly investigate such acts, prosecute all those responsible for such acts, and ensure they are appropriately punished, in accordance with the seriousness of the crime". ${ }^{166}$ Although the CAT strangely did not mention the contractors of private military and security companies as such, one can presume that these are covered by the use of the word 'civilians'.

\footnotetext{
161 See further Chapter VII.

162 See summary record of the 703 $3^{\text {rd }}$ meeting, UN Doc. CAT/C/SR.703 (12 May 2006), para. 25. Additionally, the U.S. representatives observed that contract interrogators were also bound by statutory duties which provide that persons in the custody or under the effective control of the Department of Defense, or in detention in a Department of Defense facility should not be subjected to treatment or technique of interrogation not authorized by the U.S. Army Field Manual or Intelligence Investigation. Ibid., para. 31. They also mentioned that the contractors had also been trained in the 'law of war' and were required to comply with regulations and standards concerning the humane treatment of detainees. Ibid., paras. 44-45. UN Doc. CAT/C/USA/CO/2 (25 July 2006), para. 6.

Ibid., para. 26.

Ibid., para 20.

Ibid., para. 26.
} 
While examining the United Kingdom's second periodic report, CAT committee members submitted a number of questions relating to the use of private security companies to carry out the deportation of illegal aliens and to privatized prisons. In the light of the use of private security companies for the escort of illegal aliens during deportation procedures, and since private security companies could potentially use force in their activities, the Committee was curious about the methods used by these companies, the training these companies received, how they were monitored, and how they were selected. ${ }^{167}$ Additionally, on the use of private security agencies one of the Committee members was especially keen to point out that,

"[...] the traditional role of the State was to safeguard public order. She asked why the Government felt it was unable to defend public order itself through its own agents, what the reasons for such privatization were and which safeguards applied to such agencies. Which legal and practical means ensured that the transfer of public authority to private parties did not endanger the primary responsibility of the State to guarantee the freedoms of its citizens?"168

The United Kingdom's representatives did not answer this question, although they explained that the Joy Gardner incident led to a review of the expulsion procedures. ${ }^{169}$

The Committee touched upon the subject of privatized prisons during its examination of the Netherlands' third periodic report. In the concluding observations on this report, the Committee briefly noted with satisfaction the assurances of the Netherlands Government that despite the privatization of prisons in the Netherlands Antilles, the State's obligations under the Convention Against Torture and Other Cruel, Inhuman or Degrading Treatment still continued to apply. ${ }^{170}$ No further observations or recommendations were made. In the case of the United Kingdom's

167 UN Doc. CAT/C/SR.234 (22 November 1995), paras. 58 and 65.

168 Ibid., para. 70.

169 Although the summary records do not reveal any questions related to privatized prisons, an issue addressed by the United Kingdom in its periodic report, the representatives went on to explain the system of privatized prisons which were regulated by 1991 legislation concerning criminal justice. The representatives were eager to assure that privatized prisons provided penitentiary services of high quality and that the private companies running them were required to comply with high quality norms. Additionally, privatized prisons in the UK are subject to financial sanctions in case of non-compliance with these norms. According to the UK, two members of the public penitentiary services are detached to each privatized prison to verify the correct execution of the contracts and to monitor other disciplinary aspects. Additionally the chief inspector of prisons and an independent monitoring committee pay frequent visits to these establishments. See UN Doc. CAT/C/SR.235 (27 November 1995), para. 14. The CAT did not delve further into this issue, although the use of private security guards came back in the concluding observations to the United Kingdom's report. See further below supra. 
second periodic report (which had partially dealt with the use of private security companies mainly for the deportation of illegal aliens), the CAT recommended the State party to review, "[...] the policies favouring private policing with a view to properly regulating that activity." 171

\subsection{Committee on the Rights of the Child}

\subsubsection{General Comments}

Following a meeting in which the CRC held a discussion with various stakeholders (NGOs, academics and other institutions) on the issue of the private sector as service provider and its role in implementing the rights of the child, ${ }^{172}$ the CRC devoted to privatization a specific section of its General Comment on general measures of implementation for the Convention on the Rights of the Child. ${ }^{173}$ According to the CRC, "[t] he process of privatization of services can have a serious impact on the recognition and realization of children's rights." 174 After observing that the Convention on the Rights of the Child imposes legal obligations on States to ensure that non-State service providers operate in accordance with its provisions, thus creating indirect obligations on such actors, the Committee emphasized that delegating or enabling private actors to provide services does not "[...] in any way

171 UN Doc. A/51/44, paras. 58-65 (9 July 1996), para. 65(h).

172 See The Private Sector as Service Provider and its Role in Implementing Child Rights, Day of Discussion held by the CRC on 20 September 2002, in Committee on the Rights of the Child, Report on the Thirty-First Session (Geneva, 16 September 2002 - 4 October 2002), UN Doc. CRC/C/121 (11 December 2002), paras. 630-653. The day of discussion focused on the role and legal obligations of States and private actors in the provision of various services in the health, education, and water sectors. At the end the Committee issued a number of recommendations including the adoption by States of appropriate legislative measures and establishment of a permanent monitoring mechanism aimed at ensuring that non-State service providers respect the relevant principles and provisions of the Convention and which is accessible to those who benefit from the services, in particular children as well as an appropriate judicial recourse, that can ensure the implementation of their rights and provide them with effective remedies in case of violations. In addition the Committee recommended "[...] that State parties provide a supportive and protective environment which enables non-State actors - whether non-profit or for-profit - providing services to children to do so in full compliance with the Convention [...]; that State parties, when considering contracting out services to a non-State provider - either forprofit or non-profit, or international or local - undertake a comprehensive and transparent assessment of the political, financial and economic implications and the possible limitation on the rights of beneficiaries in general, and children in particular. In particular, such assessments should determine the manner in which the availability, accessibility, acceptability and quality of the services will be affected." Ibid., para. 653. The Committee also recommended non-State actors to carry out the services they provide in accordance with international human rights standards and adopt codes of conduct. Rights of the Child, CRC UN Doc. CRC/GC/2003/5 (3 October 2003). Ibid., para. 42. 
lessen the State's obligation to ensure for all children within its jurisdiction the full recognition and realization of all rights in the Convention [...]"175 In particular it commented that all actions concerning children, whether carried out by public or private actors, shall take into consideration the best interests of the child as established by Article $3 \S 1$ of the Convention. The Committee then proposed that to ensure compliance with and respect of the Child Rights' Convention by all State and non-State service providers, a permanent monitoring mechanism should be established, in particular in the area of health. ${ }^{176}$ It can thus be seen that CRC's main concerns with regard to privatization appear to be related to the issue of accountability and the availability of a remedy or regulatory/monitoring mechanism.

\subsubsection{Examination of State reports}

Together with the ECSCR, the CRC has demonstrated interest in the issue of privatization throughout its consideration of State reports. Concern for the privatization of educational services and of health care services as well as their negative impact on the rights of children has been at the core of the CRC's attitude towards privatization. Even though the CRC has currently submitted only one question regarding privatization in a list of issues, it has frequently addressed the subject during the actual examination of several State reports.

For the preparation of the first periodic report of the Republic of Macedonia, the $\mathrm{CRC}$ asked whether a health privatization program had begun. Furthermore, it requested information about the impact of the program on access by children and families to health facilities in the context of Article 24 CRC (right to health). ${ }^{177}$ During the examination of the reports the CRC has frequently asked questions pertaining to the privatization of the education system in a number of countries in relation to the right to education and access to free primary education. ${ }^{178}$ While considering the second periodic report of Nicaragua, a member of the CRC mentioned that she had been informed about plans to privatize certain schools. She wondered, "[...] whether privatization might not further accentuate the disparities between urban and rural areas and be to the detriment of the schools which remained in the public education system." 179 The State representative replied by stating that a proposed autonomy plan for schools was not aimed at privatizing them. ${ }^{180}$ During the consideration of Argentina's initial report to the CRC,

\footnotetext{
175 Ibid., para. 44.

176 Ibid.

177 List of Issues Republic of Macedonia, UN Doc. CRC/C/Q/MAC/1 (17 September 1999), para. 16.

178 Article 28 Convention on the Rights of the Child.

179 See summary record of the 550 th meeting, UN Doc. CRC/C/SR.550 (13 January 2000), para. 24.

180 Ibid., para. 30.
} 
committee member Kolosov asked if the process to privatize schools in Argentina was in line with the obligation of all the organs of the State to ensure the best interests of the child as stipulated in Article 3 of the Convention on the Rights of the Child. ${ }^{181}$ The State representative responded that Argentina was not applying a privatization policy at the expense of education and that there were no privatization plans that could endanger the children's right of access to education. ${ }^{182}$ Kolosov then stated that he was referring to information provided by an NGO noting that the Argentine government had plans to privatize the public education system. The debate ended when the Argentine delegate replied that the public education system could not be privatized and that private and public schools had always existed together in Argentina. ${ }^{183}$

The $\mathrm{CRC}$ has shown considerable interest in the privatization of health care services with regard to the right to health (Article 28 of the Convention on the Rights of the Child). In a question addressed to the delegation of the Republic of Macedonia during the examination of its initial report, a member of the Committee inquired about the privatization of health care services for children. ${ }^{184}$ There was, however, no direct answer to this question other than a mention that Macedonia had drafted a law which allowed the establishment of private health clinics. ${ }^{185}$ Apparently, this answer seemed to suffice, as the issue was not taken into further consideration in the concluding observations to this report. ${ }^{186}$

The topic was raised again while considering Armenia's initial report to the CRC. The Committee asked whether the privatization of health care services was being considered in light of the economic problems that affected the free health care services provided by the public health system. ${ }^{187}$ Armenia's reply mentioned that the aim of privatization of health services was to keep a number of free hospitals available in the public health system for those who could not afford to pay, while privatizing the rest. The reason behind this move was that Armenia could no longer afford free hospital care for all. ${ }^{188}$ However, the actual concluding observations

\footnotetext{
181 See summary record of the $178^{\text {th }}$ meeting, UN Doc. CRC/C/SR.178 (14 October 1994), para. 26.

182 Ibid., paras. 32 and 33.

183 Ibid., paras. 38 and 39.

184 See summary record of the 598 ${ }^{\text {th }}$ meeting, UN Doc. CRC/C/SR.598 (22 February 2000), para. 26. In its list of issues for Macedonia's initial report, the CRC had already asked whether a plan existed to privatize health services and what the impact would be on the children's right to health. See further above.

185 Ibid., para. 29.

186 UN Doc. CRC/C/15/Add.118 (23 February 2000).

187 UN Doc. CRC/C/SR.604 (9 March 2000). Armenia's initial report mentioned that a start had been made on the development of a private sector in health care and the privatization of medical institutions and had claimed that the impact on medical services for children was minimal. See UN Doc. CRC/C/28/Add. 9 (30 July 1997), para. 112. UN Doc. CRC/C/SR.604 (9 March 2000), para. 41.
} 
show that the Committee did not respond to Armenia's claims, which stated that privatization of health care system would have a minimal impact on medical services for children and the issue was given no further attention in the concluding observations to this report. ${ }^{189}$ Thus, in spite of this interest on the effects of privatization on the right to health of children, the Committee has apparently not always reacted to information on privatization of health care systems. This is also apparent in the comments made by Suriname in its initial report that it had plans to privatize hospitals as one of the measures necessary to stop the rapid deterioration of health care in Suriname. ${ }^{190}$ This remark apparently did not lead to any commentary or question on the side of the Committee and there was no follow up in the concluding observations. ${ }^{191}$

Nevertheless, the CRC has frequently noted concern for the effects of privatization of several services on the rights of children in its concluding observations. Particularly, the CRC has paid attention to potential adverse effects of privatization on the rights to education and health. For example, with regard to the right to education (Article $12 \mathrm{CRC}$ ) and children, the CRC recommended the United Kingdom to evaluate the impact of privatization of schools on the right of children to education. ${ }^{192}$ In the concluding observations on Bahrain's initial report, the CRC was concerned "[...] about the increasing trends towards the privatization of these sectors [health and education, $A H W$ ] and the potentially negative consequences this may have on the enjoyment of economic, social and cultural rights by all children in Bahrain." ${ }^{193}$ The Committee, however did not further observe what are these potential negative effects of privatization, or how they actually take place.

The Committee's general concern with privatization and the rights of children is also apparent with respect to the privatization program being implemented in Romania after the fall of dictator Caucescu and the country's struggle towards modernization:

"The Committee is worried about the effect on children of the difficult economic situation prevailing in the country. In this connection, the Committee is particularly concerned as to whether there are adequate measures to protect children from being the victims of economic reform, in the light of articles 3 and 4 of the Convention.

\footnotetext{
189 UN Doc. CRC/C/15/Add.119 (24 February 2000).

190 UN Doc. CRC/C/28/Add.11 (23 September 1998 ), para. 92.

191 The summary records of the $635^{\text {th }}$ and $636^{\text {th }}$ meetings with Suriname, UN Docs. CRC/C/SR.635 and 636 (06 June 2000), make no mention of the subject. See also concluding observation to the initial report of Suriname UN Doc. CRC/C/15/Add.130 (28 June 2000).

193 See concluding observations to Bahrain's initial report, UN Doc. CRC/C/114 (2002), para. 464.
} 
The rights and basic needs of all children in the country should be taken into account also during the process of decentralization and privatization." 194

To this end, the Committee recommended Romania to regularly monitor the impact on children of the structural adjustment programs being implemented and to take adequate measures to protect children. ${ }^{195}$

As a more general note, the CRC observed in its concluding observations on Finland's initial report that among other structural and financial policies, privatization had, "[u]ndoubtedly affected Finnish children, particularly the most vulnerable groups." "196 Although the Committee did not present any evidence to support this assertion, it expressed apprehension regarding the trend towards privatization and wondered whether appropriate measures had been taken to protect children. The CRC was more specifically worried about the absence of an integrated monitoring mechanism that would supervise the effectiveness of privatized services such as health, education and social care for the most vulnerable groups of society including single parents, poor families and disabled, refugee and minority children. ${ }^{197}$ To this effect, the CRC recommended Finland the establishment of an integrated monitoring mechanism that would ensure that all children benefit to the same extent from basic social services. ${ }^{198}$

\subsection{Preliminary conclusions}

The UN's human rights treaty body system has actively examined privatization from the perspective of international human rights. This attitude is an exception to the one found in general international law, which has been rather indifferent towards privatization as a topic of interest. ${ }^{199}$ The UN's human rights treaty bodies approach has in general acknowledged privatization as a measure that States may adopt, but which may sometimes have negative effects on the enjoyment of human rights. However, it is not always clear on which basis some of the treaty bodies come to the conclusion that privatization may have detrimental consequences for human

194 UN Doc. CRC/C/15/Add.16 (7 February 1994), para. 7. Croatia was awarded similar concerns by the CRC. In the concluding observations to Croatia's initial report, the Committee was concerned that privatization of "some social services" might affect the most vulnerable groups of children and was worried that the government might not had taken appropriate measures to protect children as required by Article 4 of the Convention on the Rights of Children. See UN Doc. CRC/C/15/Add.52 (13 February 1996), para. 14.

195 Ibid., para. 12.

196 UN Doc. CRC/C/15/Add.53 (13 February 1996), para. 9.

197 Ibid., paras. 11 and 12.

198 Ibid., para. 23. Similar concerns regarding the privatization of social services and its possible impact on the most vulnerable groups of children were expressed in the concluding observations of Croatia, UN Doc. CRC/C/50 (1996) 31, para. 195.

See Chapter III. 
rights, or under which particular conditions this may happen. In any event, it appears that the discussion of the issue of privatization has not been really systematic, with mainly broad (and arguably not well supported) concerns that privatization can have a negative impact on human rights, as a basis for their perspective on the topic. It would appear that only the CRC has devoted some specific attention to the topic of privatization as an independent issue of concern, albeit in a limited way. In this regard it is suggested that the treaty bodies should attempt to adopt a more systematic approach towards the issue, and try to compile concrete evidence of the negative (or positive) effects of privatization.

Having said that, it is possible to state that the approach of the treaty bodies towards privatization policies is cautious and focused on preventing the State from escaping its obligations by delegating the performance of tasks, functions or services (mainly in the area of the coercive use of force, health care, housing and essential services such as water) to private actors. In addition, they also focus their attention on the obligations to respect, protect and fulfill as guidelines to make sure that privatized actors act within the limits of human rights obligations meant for States. Moreover, the treaty bodies emphasize the necessity to provide remedies for those affected by privatization measures, and to ameliorate the negative effects of privatization on the most vulnerable sectors of society. Finally, and also very importantly, the treaty bodies have stated that there is a need for some sort of monitoring or regulation for the activities of privatized entities as well as guaranteeing the access to essential services that are being privatized. These approaches are consistent with what the treaty bodies usually require from the State, although it can be argued that they may not always be suitable for ensuring the accountability of privatized actors.

\section{The EUROPEAN HUMAN RIGHTS SUPERVISORY MECHANISMS AND PRIVATIZATION}

Under the aegis of the Council of Europe, its member States have adopted a number of important human rights instruments that have helped to shape national legislation and practice into conformity with human rights standards. The European Convention on Human Rights, the European Social Charter and the European Convention for the Prevention of Torture, and Inhuman or Degrading Treatment or Punishment have been responsible for successfully maintaining respect for human rights in Europe. Although these conventions do not contain any provisions with respect to privatization as such, their monitoring mechanisms have been occasionally confronted with cases and situations in which the privatization of State provided services played a role. To assess whether the views of these monitoring mechanisms have had anything relevant to contribute with regards to the object of this study, the following paragraphs will be devoted to examining their monitoring activities in respect of privatization. Being the oldest monitoring mechanism and 
having the ability to receive individual complaints as well as issuing binding judgments, the jurisprudence of the European Court of Human Rights in this area will be firstly examined. It will be followed with an assessment of the monitoring activities of the European Committee on the Prevention of Torture in respect of privatization. Finally, the practice of the European Committee for Economic and Social Rights will be reviewed.

\subsection{European Court of Human Rights}

The European Court of Human Rights, the main human rights monitoring mechanism established by the Council of Europe has been confronted on a limited number of occasions with questions (partially) related to privatization. Some of these cases have dealt with the right to property as guaranteed in Article 1 the First Protocol to the European Convention. These cases have usually revolved around the expropriation of property or the nationalization of companies and their subsequent privatization. ${ }^{200}$ The old Commission and the Court have usually declared these cases inadmissible. The Court has rarely been confronted with the issue of compatibility of national privatization legislation with the Convention. Moreover, the Court has not yet issued a judgment in which the privatization of a State performed task or service has been directly challenged on the basis that it is incompatible with the rights guaranteed by the ECHR. A number of cases brought before the Court, however, have dealt with the responsibility of the State for actions performed by private parties (sometimes in the context of privatization) deemed to be incompatible with the European Convention. Although privatization has not yet been a central issue before the Court, these judgments could nevertheless be indicative of the responsibility of a State if it engages in a privatization process and which results in human rights abuses by privatized service providers.

\subsubsection{Non-admissible or manifestly ill-founded privatization cases}

Numerous complaints dealing with the right to property after nationalization and subsequent privatization of that property have been presented before the old European Commission for Human Rights and the Court. In many of these cases the Commission and the Court were not in a position to deal with the question at hand since the cases did not surmount the admissibility thresholds. In the case of Portugália v. Portugal, for example, the Commission could not further investigate a case involving problems with privatization of a nationalized enterprise on its

200 Although not strictly a form of privatization as understood in this study (see similar remarks regarding privatization of former State property such as land above in Section 2.1.2) the so-called privatization of nationalized or expropriated private property as dealt with by the (old) Commission and the Court, could give a general indication as to these body's views with respect to the transfer of State powers and functions to private parties and its effect on human rights. 
merits. $^{201}$ From the facts it appeared that the applicants' complaint was inadmissible, as they had not availed themselves of all the effective remedies to pursue their complaint. Similarly, the Commission ruled in a case involving the nationalization and subsequent privatization of property in Slovenia that the application was inadmissible due to non-exhaustion of local remedies. ${ }^{202}$ In yet another application dealing with a decision to privatize a State owned company under conditions that were financially unfavorable to the complainant, ${ }^{203}$ the Commission concluded that the complaint was manifestly ill founded. In the eyes of the Commission, the government had taken, within its margin of appreciation in the field of economic and social policies, due consideration of the general interests of the community vis-a-vis the particular interest of applicant in pursuing a legitimate goal when it chose to limit the applicant's right. ${ }^{204}$ In a case against the Czech Republic, the Court decided without further examination that an application that partially challenged the compatibility of a privatization act with Article 1 of Protocol No. 1 was manifestly ill founded. ${ }^{205}$ The Court has also declared an application inadmissible on grounds that the complaint (violation of Article 1 of Protocol No. 1 by Latvia in a case of nationalization and subsequent privatization of property) was incompatible ratione materiae with the provisions of the Convention. ${ }^{206}$ Latvia had entered into the regime of the European Convention with a number of reservations related to the temporary inapplicability of article 1 of the

201 See Application No. 20272/92, decision of 7 April 1995. Applicants who owned shares in a brewery that had been nationalized in 1975, had not received proper compensation for the nationalization. When the government decided to privatize part of the company, applicants were not able to bid for the privatization since the privatization law did not allow parties with entitlements to compensation claims that had not yet been paid to take part in the bidding. Applicants alleged an unjustified violation of the right to property (Article 1 of Protocol No. 1) since they had not received proper compensation following the nationalization of the brewery. They claimed that in view of the privatization, the State had not properly balanced their individual rights against the general interest.

See Application No. 27337/95, decision of 21 January 1997. Applicant complained that the proceedings under a national privatization act was a violation of article 1 of Protocol No. 1 and Articles 13 and 14 of the Convention. Applicant attempted to receive restitution in kind under a Denationalization Act and a Privatization Act for a property that had previously belonged to applicant's family and which had been nationalized between 1958 and 1961. Under both the Denationalization and Privatization Acts, applicant was not entitled to restitution in kind but to compensation. Applicant had initiated proceedings before the Slovenian Constitutional Court challenging the constitutionality and legality of both acts, but it appeared that the proceedings were still pending.

203 See Application No. 38181/97 of 1 July 1998. In this case complainant alleged that a decision to privatize a State owned company interfered with a judicial proceeding that he had started to question the privatization process, and therefore violated his right to an fair trial and access to a legal remedy (Articles 6 and 13 of the Convention).

204 "En effet, le Gouvernement a considéré que l'intérêt général commandait d'effectuer la privatisation du groupe Quimigal en bloc, sans procéder à des appels d'offres séparés pour chacune des sociétés du groupe.” Ibid.

205 See Application No. 33091/96, decision of 23 March 1999.

206 See Application No. 57381/00, decision of 23 October 2001. 
First Protocol to a number of nationalization and privatization laws. The Court was, therefore, not in the position to judge on the issue.

In another case dealing with the privatization of apartment flats on the basis of privatization legislation in Lithuania, the Court dismissed the application because it considered the complaint, claiming a violation of Article 1 of Protocol No. 1, also to be manifestly ill founded. ${ }^{207}$ In this case the applicant, a clerical organization that had previously owned the flats before they were confiscated and nationalized by the Soviet Union in 1940, had complained at the local level that the privatization of the flats was erroneous since the nationalization had been illegal. Applicant argued that it was entitled to the restitution of the property of the flats. After the privatization had been revoked by a decision of the local authorities, the tenants of the flats and beneficiaries of the privatization started judicial proceedings seeking, with success, annulment of this decision on the grounds that the restitution to the applicant had been illegal. The applicant submitted to the European Court, among other things, that the annulment of the decision to revoke the privatization of the apartment flats infringed her right to a peaceful enjoyment of her properties. In the admissibility phase the Court quickly examined the nature of the complaint and went on to examine whether the measure complained of amounted to a violation of Article 1 of Protocol No. 1. During this examination the Court concluded that the interference in applicant's rights had been lawful, namely based on domestic provisions (including a privatization act) that were sufficiently accessible, precise and foreseeable. Furthermore, the interference pursued a legitimate aim (the protection of tenants who after privatization were now owners of the apartment flats) and also achieved a fair balance between the demands of the general interest of the community and the requirements of the protection of complainant's individual rights. In this respect, the Court commented that the legal proceedings that quashed the restitution decision, "[...] resolved the apparent inconsistency of the concurrent decisions of the local authorities on privatisation and restitution while adequately protecting the interests of the individuals who had lawfully purchased flats in the building." ${ }^{208}$ Moreover, the Court noted that the interference with the applicant's right did not prevent her from receiving adequate compensation for the property loss under applicable domestic legislation. This led the Court to decide that there had been no violation of Article 1 of Protocol No. 1 and that therefore the complaint should be rejected as manifestly ill founded under Article $35 \S 4$ of the Convention.

In a case against Slovakia, an applicant complained that he had been unable to challenge the privatization of a formerly owned State company denying him the possibility to claim a debt it had with the company, thus breaching his right to an

207 See Application No. 44548/98, decision of 5 December 2002.

208 Ibid. 
effective legal remedy (Article 13 of the Convention). ${ }^{209}$ The Court found both of this claims inadmissible since they had been submitted out of time on the basis of Article $35 \S 1$ and 4 of the Convention. ${ }^{210}$

\subsubsection{Privatization as an issue of (indirect) concern before the European Court of Human Rights}

As noted above, the European Court of Human Rights has not yet decided on the merits of a case in which privatization of a public service, function or enterprise was the central issue of dispute. Nevertheless, a number of cases in which the action of a privatized service provider or the privatization of State owned property indirectly resulted in alleged violations of the ECtHR, has been filed before the Court. This was the case of Powell and Rayner v. the United Kingdom ${ }^{211}$ where noise emanating from Heathrow airport (a privatized service provider) gave rise to a complaint alleging violation of the right to family life (Article 8 ECHR). Interestingly enough, the United Kingdom maintained in its submissions that Heathrow was not owned controlled or operated by the State (since it had been privatized) and as such could not be held responsible for the complaints before the Court. Moreover, the United Kingdom argued that any responsibility of the United Kingdom could only be distilled from eventual positive obligations, but that in this case there was no ground for establishing a failure on the side of the State to secure the rights of applicants under Article 8 of the Convention. The Court partially agreed and observed in this regard that,
"[w]hether the present case can be analysed in terms of a positive duty on the State to take reasonable and appropriate measures to secure the applicants' rights under paragraph 1 of Article 8 or in terms of an 'interference by a public authority' to be justified in accordance with paragraph 2, the applicable principles are broadly similar. In both contexts regard must be had to the fair balance that has to be struck between the competing interests of the individual and of the community as a whole; and in both contexts the State enjoys a certain margin of appreciation in determining the steps to be taken to ensure compliance with the Convention."212

Subsequently, the Court examined whether the United Kingdom had indeed struck a fair balance between in this case applicants' rights under Article 8 and the competing (economic) interests of the community, namely the operation of an important privatized international airport. Concurring with the United Kingdom's submission, the Court concluded that neither the United Kingdom's policy approach

\footnotetext{
209 See Case of Vozár v. Slovakia, judgment of 14 November 2006, ECtHR, Application No. 54826/00, para. 37 and 50 (not yet published).

210 Ibid., para. 51.

211 See Powell and Rayner v. the United Kingdom, judgment of 24 January 1990, ECtHR, Series A-172.

212 Ibid., para. 41.
} 
to the problem nor the regulatory measures adopted by the State led to a violation of Article $8 .^{213}$ Some sort of follow-up to this case, also involving the privatized airport of Heathrow, was considered in the Hatton and Others v. the UK (Grand Chamber) judgment. ${ }^{214}$ Once again nuisance caused by the air traffic of the privatized airport in violation of Article 8 was at the heart of the dispute. The question posed was whether the nuisance is directly caused by the State or whether State responsibility arises from the failure to regulate private (privatized) industry properly. ${ }^{215}$ In this case the Court's Grand Chamber concluded that the State had a wide margin of appreciation with respect to areas involving social, technical, or environmental issues. ${ }^{216}$

Similar issues of pollution and nuisance caused by entities that have been privatized were dealt in a number of recent cases against Russia (Fadeyeva v. Russia, ${ }^{217}$ and Ledyayeva, Dobrokhotova, Zolotareva and Romashina v. Russia ${ }^{218}$ ). In both cases, it was established that pollution, caused by the industrial emissions of a privatized steel company seriously affected the applicants' private life and enjoyment of their homes. Taking a similar approach as the one used in the López Ostra ${ }^{219}$ and Hatton cases, the ECtHR examined whether the State failed to adopt positive measures to regulate the activities of a private entity in violation of Article 8 ECHR. In Fadeyeva the European Court observed that the plant had originally been owned by the State, but that "[f]ollowing the plant's privatisation in 1993, the State continued to exercise control over the plant's industrial activities through the imposition of operating conditions on the plant's owner and supervision of their implementation." ${ }^{220}$ It further observed that the plant was responsible for a large percentage of the pollution in the city in which complainants lived, and that the environmental situation had lasted for a long time and was well known by the State. In spite of this, however, the latter failed to adopt any "[...] effective measures which would take into account the interests of the local population, affected by the pollution, and which would be capable of reducing the industrial pollution to acceptable levels." 221 It then concluded that Russia had violated Article 8 due to this failure, and in spite of a wide margin of appreciation at Russia's disposal.

\footnotetext{
213 Ibid., para. 45.

214 Hatton and Others $v$. the UK, Grand Chamber judgment of 8 July 2003, ECtHR, Reports 2003VIII. For a more detailed discussion of this case see Chapter III Section 4.2.

215 Ibid., para. 98.

216 Ibid., para. 100-101.

217 Fadeyeva v. Russia, judgment of 9 June 2005, ECtHR, Reports 2005-IV.

218 Ledyayeva, Dobrokhotova, Zolotareva and Romashina v. Russia, judgment of 26 October 2006, ECtHR, Applications Nos. 53157/99, 53247/99, 53695/00 and 56850/00 (not yet published). See López Ostra v. Spain, judgment of 21 February 1990, ECtHR, Series A-172. This case is described in more detail in Chapter III.

220 Fadeyeva v. Russia., para. 90.

221 Ibid., para. 133.
} 
Another indirect reference to privatization can be found in VGT Verein Gegen Tierfabrieken $v$. Switzerland.222 In this case, the Swiss Radio and Television Company and the Commercial Television Company which was responsible for airing commercials for the former, refused to air a shocking commercial submitted by applicant, an association geared towards animal protection. The commercial was intended as a reaction to advertisements of the meat industry and the television company's refusal to broadcast the commercial was grounded on its estimations that the commercial was of a "clear political content". According to the company, broadcasting of the commercial would breach Swiss law on television and radio broadcasting which did not permit political advertising. The applicant submitted a complaint before a number of administrative organs. These organs concluded, inter alia, that although the television company, a former State monopoly, was the sole institution providing information in respect of home news it, "[...] acted in matters of advertising as a private entity and did not fulfil a duty of public law when it broadcasted commercials," 223 and therefore could not be ordered to broadcast the association's advertising. On appeal before the Swiss Federal Court, the complaint was again dismissed although it was noted that while the Television company no longer enjoy a monopoly and was subjected to increasing foreign competition, "[...] this did not alter the fact that, according to the applicable law, the Swiss Radio and Television Company continued to act in the area of programmes within the framework of public law duties transferred upon it." 224 The Federal Court also confirmed the Swiss law's ban on political advertising. Before the European Court the applicant submitted first of all that, "[...] the State is not permitted to delegate functions to private persons in such a way that fundamental rights are undermined by the resulting 'privatization'." 225 Moreover, the applicant complained that Swiss law governing the activities of both the Swiss Radio and Television Company and the Commercial Television Company had violated applicant's rights under the Convention because it did not ensure respect for its right to freedom of expression (Article 10 ECHR). According to the applicant, the separation of private and public law did not take sufficient account of the fact that freedom of expression on social issues also could be exercised through paid commercial advertisements. For its part, Switzerland submitted that the refusal by both companies to air the commercial did not lead to any responsibility on the part of the Swiss authorities. It maintained that the case was in essence a dispute of a horizontal nature (between two private parties in which one party was enjoying contractual freedom, i.e., it was free to refuse the airing of the commercial) and as such Article 10 of the Convention was not applicable. The State further argued that even if Article 10 was applicable, it could

\footnotetext{
222 VGT Verein Gegen Tierfabriken v. Switzerland, judgment of 28 June 2001, ECtHR, Reports 2001-VI.

223 See VGT Verein Gegen Tierfabriken v. Switzerland, judgment of 28 June 2001, ECtHR, Reports 2001-VI, para. 17.

224 Ibid., para. 19.

225 Ibid., para. 38.
} 
only be held accountable in respect of its positive obligations under that article. ${ }^{226}$ The Court recognized that in addition to the negative obligation to abstain from interfering in the enjoyment of the Convention's rights, there may be positive obligations inherent to those rights by which the responsibility of the State could be engaged if the State does not take steps to enact domestic legislation to secure those rights. ${ }^{227}$ The Court found that Swiss law prohibiting political advertising made lawful the treatment of which applicant complained and thus prohibited political speech by applicant. The Court then concluded that the State may incur responsibility for any breach of Article $10 .{ }^{228}$ After determining that the interference complained of by applicant was prescribed by law as required by Article 10 (2), the Court examined whether the interference was necessary in a democratic society. The Court noted that the prohibition of the applicants' advertising did not serve a pressing social need and it was not proportional to the aim pursued mainly because the Swiss Radio and TV Company was the only broadcaster that could be received throughout Switzerland and there were no real alternatives for the applicant to relay its message to a broad public. The Court therefore concluded that the measure was not necessary in a democratic society and that Article 10 had been breached. Additionally, after noting that the Court's task is to determine whether the Contracting States have achieved the results called for by the Convention, it observed that the State has various possibilities to organize the broadcasting of commercials and that,

"[...] the Swiss authorities have entrusted the responsibility in respect of national programmes to one sole private company. It is not the Court's task to indicate which means a State should utilise in order to perform its obligations under the Convention." 229

This conclusion, which incorporated a reference to the Cubber v. Belgium case, ${ }^{230}$ could entail that at least in the Verein Gegen Tierfabriken case the Court is not opposed to the delegation of public tasks or services (in this case the privatization of public television and the broadcasting of commercials) to private parties. It would appear that a State is free to outsource this service to private parties as long as the State guarantees the respect of human rights through its positive obligations (f.e. enacting proper legislation). ${ }^{231}$ It also implies that if a State has delegated tasks to a

Ibid., paras. 40-43. With regard to positive obligations and privatization see Chapter III Section 4.1.2.

At the same time, the Court reaffirmed its previous opinion that it is not desirable or necessary to delve on the question whether the Convention's rights also apply to relations between private individuals. Ibid., paras. 45-46.

Ibid., para. 47.

Ibid., para. 78.

See Cubber v. Belgium, judgment of 26 October 1984, ECtHR, Series A-86, para. 35.

Compare with the Court's judgment in Costello-Roberts $v$. the United Kingdom, judgment of 25 March 1993, ECtHR Series A247-C. This case is further discussed in Chapter IV. 
private service provider, the State must ensure that there are enough alternatives for the enjoyment of fundamental rights. In the Verein Gegen Tierfabriken case, the applicant was not in the position to express its opinion because of Swiss law and it did not have an effective means of presenting its opinion since the reception of alternative broadcasters was limited and the core audience for the message of applicant could only be reached through the privatized television company. The Swiss law made no provisions to redress the vacuum in this situation.

The privatization of State owned property has also led to a number of disputes before the Court. In Krcmár v. the Czech Republic, ${ }^{232}$ applicants started an action of restitution of property before the Czech authorities to stop the privatization of a margarine producing company that had previously been privately owned before it had been nationalized in the late 1940's and for which applicant's claimed to be the legal successors of the former owners. The restitution action was pursuant to a national Restitution Act and a Privatization Act that allowed claims to be filed to redress the consequences of infringements of property and other rights that had occurred between 1948 and 1989. The applicants' claims were, however, dismissed, even after appealing to the highest judicial body in the Czech Republic, on the grounds that the Restitution Act and the Privatization Act did not apply to the applicant's case, apparently because the nationalization took place before the date for which both Acts allowed a restitution action to be filed. ${ }^{233}$ The Constitutional Court based its findings on documentation that had not been shown to the parties during the proceedings. This prompted the applicants to launch a complaint before the European Court claiming that they did not have a fair hearing (Article 6 ECHR) due to the failure of the Constitutional Court to share the documents used for its decision with the applicants. The European Court ruled in favor of the applicants, but due to the nature of the complaint was not able to deal with the issue of privatization. A similar case was filed against Rumania in Budescu and Petrescuv. Rumania. ${ }^{234}$ In this case applicants complained, inter alia, about a violation of their right to property (Article 1 of the First Protocol to the ECHR). According to the applicants, Rumania had erroneously nationalized their housing unit during the Caucescu regime. Following the revolution in late 1989, the new government privatized the housing unit by selling it to the tenants living in the building without properly compensating the applicants. The Court agreed with this argument, and held Rumania responsible for the breach of Article 1 of Protocol No. 1 and ordered

232 See Krcmár v. the Czech Republic, judgment of 3 March 2000, ECtHR, Application No. 35376/97 (not published).

233 The nationalization decision had taken place in 1945/1946, while the decisive date to become eligible for restitution in the Restitution Act was 25 February 1948. Although the Constitutional Court and the lower courts disagreed on the precise grounds of dismissal, they all concluded that the applicants were not entitled to restitution.

234 Budescu and Petrescu v. Rumania, judgment of 2 July 2002, ECtHR, Application No. 33912/96. 
it to pay compensation. ${ }^{235}$ This case sheds some light on how the privatization of State property might impact the right to property of individuals if the privatization does not take duly into account previous property claims by private parties. In such a situation, the State can be held responsible for illegally disposing of private property without due compensation. ${ }^{236}$ Another example is the case of Popnikolov v. Bulgaria, in which complainant alleged that he had been denied the possibility of purchasing property that had been privatized. ${ }^{237}$ The Court noted that the case did "[...] not concern restitution of formerly nationalised property but the right to privatise leased State properties under preferential conditions once the person satisfies certain criteria and requirements for the said entitlement." 238 According to the Court, the government failed to comply with a national court ruling, which acknowledged the sale of the property to complainant. The Court concluded that the privatization procedure set up by the Government had been misused to prevent applicant from buying the privatized property. This led the Court to conclude that Bulgaria had breached Article 6 ECHR, and had also interfered with the applicant's right to peaceful enjoyment of his possessions as stipulated in Article 1 of Protocol No. 1.239

The Court has also dealt with a case in which faulty implementation of a privatization policy that was not at the center of the dispute nevertheless resulted in a claim for violations of a number of rights of the ECHR. Thus, in another case involving the privatization of State housing, Kukalo v. Russia, ${ }^{240}$ the complainants were entitled to buy a State owned apartment, which had been privatized as a result of a housing privatization act in Russia. The actual entitlement to the privatized apartment occurred through a number of judicial decisions. However, there was an extensive delay in the pronouncement of the courts' decisions and in their actual implementation and enforcement by the State. As a result, complainants alleged a violation of Article $6 \S 1 \mathrm{ECHR}$ on the right to have a claim related to one's civil rights and obligations brought before a court or tribunal, and a violation of Article 1 of Protocol No. 1 on the right to the peaceful enjoyment of one's possessions. The Court concluded that there had been a partial violation of both rights: the failure of

235 Ibid., para. 47-48.

236 See for a similar, more recent case: Moldovahidromaş v. Moldova, judgment of 27 February 2007, ECtHR, Application No. 30475/03 (not yet published), and Hutten-Czapska v. Poland, Grand Chamber judgment of 28 April 2008, ECtHR, Application No. 35014/97 (not yet published).

237 Popnikolov v. Bulgaria, judgment of 25 March 2010, ECtHR Application no. 30388/02 (not yet published).

238 Ibid., para. 37.

239 Ibid., paras. 29-30 and 43-45. A similar conclusion was reached in the Case Of Ipteh Sa and Others v. Moldova, judgment of 24 November 2009, ECtHR, Application No. 35367/08 (not yet reported).

240 Kukalo v. Russia, judgment of 3 November 2005, ECtHR, Application No. 63995/00 (not yet published). 
the Russian authorities to ensure the long awaited judgments which sanctioned the privatization of the apartment as well as some financial support for the benefit of claimants deprived the provisions of Article $6 \S 1$ a useful effect, as well interfering with the peaceful enjoyment of the possessions (the apartment and the financial contributions that were necessary for buying the apartment). ${ }^{241}$ Russia was then required to pay compensation for non-pecuniary damages. Although the privatization legislation was not at the core of the dispute, the Court's conclusions suggest that the State could also be held liable for not properly implementing privatization legislation if this leads to a breach of one of the Convention's rights. In general, the entrance of the Russian Federation and other former Soviet Union and Eastern European countries to the Council of Europe system resulted in a surge of cases dealing indirectly with privatization of former state property. These cases have been often the result of the mass privatization schemes that many of these countries adopted since 1989.

Other relevant case law that has touched the issue of privatization, not as an immediate issue of concern, but as a circumstance that may lead to State responsibility for the conduct of private actors exercising governmental or public functions, is the one spurred by the case of Costello-Roberts v. the United Kingdom, which has already been discussed in Chapeter IV. In essence this case law has held that the State cannot absolve itself of responsibility rationae personae by delegating its obligations to private bodies or individuals. ${ }^{242}$ One case standing out from this string of case law is the ECtHR's decision on admissibility in Woś v. Poland. ${ }^{243} \mathrm{In}$ this case, which dealt with compensation to a victim of forced labor during World War II by a private body set up as a result of an agreement between Poland and Germany, the Court observed that

"[...] the exercise of State powers which affects Convention rights and freedoms raises an issue of State responsibility regardless of the form in which these powers happen to be exercised, be it for instance by a body whose activities are regulated by private law. The Convention does not exclude the transfer of competences under an international agreement to a body operating under private law provided that Convention rights continue to be secured [...]. The responsibility of the respondent State thus continues even after such a transfer." 244

$241 \quad$ Ibid., paras. 54 and 64.

242 See Costello-Roberts v. the United Kingdom, para. 27, Woś v. Poland, Decision on Admissibility of 1 March 2005, ECtHR Reports of Judgments and Decisions 2005-IV, paras. 60 and 73, Buzescu v. Romania, judgment of 24 May 2005, ECtHR, Application No. 61302/00, para. 78, Storck v. Germany, judgment of 16 Juni 2005, ECtHR Reports of Judgments and Decisions 2005-V, para. 103, and Sychev v. Ukraine, Judgment of 11 October 2005, ECtHR, Application No. 4773/02 (not yet reported), paras. 53-55.

Woś v. Poland. Decision on Admissibility of 1 March 2005, ECtHR Reports of Judgments and Decisions 2005-IV.

Ibid., para. 72. 
The Court acknowledges that States may delegate functions to private entities, although it must continue to secure the rights of the ECHR. In essence, this arguably extraordinary observation means that as far as the Court is concerned, the State is free to privatize state functions. However, the Court also commonsensically acknowledges that this freedom can be constrained by the State's legal obligations under the Convention in particular when the functions being privatized have an impact on certain rights guaranteed therein. In addition, the State will continue to be responsible for the conduct of these entities.

\subsection{European Committee on the Prevention of Torture}

In an effort to improve the prevention of violations, the Council of Europe drafted in 1987 the European Convention for the Prevention of Torture, and Inhuman or Degrading Treatment or Punishment. This Convention was inspired by Article 3 of the European Convention on Human Rights, which provides that no one shall be subjected to torture or to inhuman or degrading treatment of punishment. The Convention for the Prevention of Torture has established a non-judicial preventive mechanism to primarily protect persons deprived of their liberty and ensure a more effective monitoring of Article 3 ECHR.

The Convention instituted a European Committee for the Prevention of Torture and Inhuman or Degrading Treatment or Punishment (CPT). This Committee is composed of independent experts from various countries including lawyers, doctors and specialists in prison or police matters. According to article 1 of the European Convention for the Prevention of Torture, the CPT is mandated to "[e]xamine the treatment of persons deprived of their liberty with a view of strengthening, if necessary, the protection of such persons from torture and from inhuman or degrading treatment or punishment." To carry out this task, the CPT may perform visits to places of detention of the countries that have ratified the Convention. ${ }^{245}$ The places of detention the Committee may visit include prisons, police stations, juvenile detention centers, detention centers for immigration detainees and psychiatric hospitals. During the visit the CPT investigates the conditions of detention and treatment of detainees and eventually recommends improvements to States. The visits take place on a periodical basis, although the CPT is entitled to carry out ad-hoc visits. The findings and recommendations of the Committee are drawn up in a report that is presented to the State party involved. The report is confidential, although the Committee may publicly publish the reports after the party requests it (Article 11 of the Convention) or whenever the Committee is of the

245 See Article 7 of the Convention, which enables the Committee to organize the visits to places of detention when it deems necessary. Article 2 of the Convention places an obligation on State parties to allow the Committee to visit any place within their jurisdiction where persons are deprived of their liberty by a public authority. 
opinion that the State party fails to cooperate or refuses to improve the situation in light of the Committee's recommendations (Article 10 §).

The CPT's involvement with privatization has currently been limited to the privatization of prisons in two State parties: the Netherlands Antilles and the United Kingdom. Additionally, the CPT has paid some attention to the use of private security guards in places of detention in various countries and their use as escort services in immigration cases. These cases will be analyzed in the following paragraphs.

\subsubsection{Prison privatization in the Netherlands Antilles}

Pursuant to Article 7 of the European Convention for the Prevention of Torture and following an invitation from the government of the Netherlands, the Committee visited the Netherlands Antilles on 25 - 29 January 1999. The CPT's visit was concretely a follow-up visit to two previous visits to the Netherlands Antilles in 1994 and 1997. During the 1994 visit the CPT had inspected the Koraal Specht Prison located in Curaçao and had concluded that the conditions of detention on that prison amounted to inhuman and degrading treatment. ${ }^{246}$ In 1997, the Committee had concluded that, in spite of a number of measures taken by the Netherlands, the conditions of detention in Koraal Specht remained appalling. After the CPT had threatened to publicize its findings, the government of the Netherlands agreed to the CPT making a third visit with the purpose of reviewing further action taken to act upon the CPT's previous recommendations. While evaluating the areas in which the conditions of detention in Koraal Specht Prison could be improved, the Netherlands authorities raised the possibility of privatizing the prison as a means of addressing the problems. The CPT, however, stressed,

"that the advantages of such an option may only be transient. It is true that the immediate capital costs can be defrayed over a longer time period and responsibility for certain aspects transferred to someone else. However, the outcome of such an enterprise will very much depend on the initial agreements entered into - which must ensure, inter alia, that the State remains in a position to discharge all its obligations vis-à-vis the persons it deprives of liberty - and on the existence of an appropriate ongoing monitoring process." 247

246 See Report to the Government of the Netherlands on the visit to the Netherlands Antilles carried out by the European Committee for the Prevention of Torture and Inhuman or Degrading Treatment or Punishment (CPT) from 25 to 29 January 1999, CPT/Inf (2000) 9 (25 May 2000), Strasbourg, para. 3 .

Ibid, para. 32 . 
However, in its recommendations and proposed measures for further action, 248 the CPT did not come back to the issue of the possibility of privatizing Koraal Specht Prison. It would not be until 2002 that the CPT approached this topic again, albeit in a different manner.

Having examined the recommendations made by the CPT in its 1999 report and after considering that the necessary resources and know-how to adopt the CPT's measures were unavailable in the Netherlands Antilles, the Ministry of Justice of the Netherlands Antilles took the decision to invite private companies for a bid to rebuild and manage Koraal Specht Prison with the possibility of full prison privatization. 249 Wackenhut Corrections Corporation (WCC), an American company in the sector of prison privatization and one of the market leaders in its field, won the bid and was contracted to lead the renovation and construction of Koraal Specht Prison (which then became known as Bon Futuro Prison). From 1 October 2000 to 30 September 2001, WCC led the (re) construction of Bon Futuro Prison and held senior management as well as training positions. ${ }^{250}$ After handing over the management of Bon Futuro back to the Ministry of Justice of the Netherlands Antilles, three senior Wackenhut representatives remained behind as consultants to the Ministry until 28 February 2002.

In February 2002, the Committee paid a fourth visit to the Netherlands Antilles in the context of a general visit to the Netherlands with the purpose of examining the conditions of detention in the territory of that country. During this visit, the CPT once more inspected Koraal Specht/Bon Futuro Prison. ${ }^{251}$ According to the CPT, the visit took place just after the last representatives of WCC were leaving. In the report, the CPT did not mention whether it had been inappropriate to delegate the management of Bon Futuro Prison to WCC as one would have expected in the light

248 The recommended measures included measures against overcrowding and ill-treatment of prisoners, clarification about the Prison Director's position, measures related to personnel on issues such as absenteeism, training, organizational structure and recruitment, the introduction of a classification and allocation system for prisoners, the fulfillment of prisoners' basic needs, and the health care situation.

249 See Report to the Authorities of the Kingdom of the Netherlands on the visits carried out to the Kingdom in Europe and to the Netherlands Antilles by the European Committee for the Prevention of Torture and Inhuman or Degrading Treatment or Punishment (CPT), CPT/Inf (2002) 30 (15 November 2002), Strasbourg, para. 27. The privatization of Koraal Specht Prison by the Ministry of Justice of the Netherlands Antilles led to a parliamentary debate in the Netherlands' lower house of the Parliament, in which the propriety of prison privatization was discussed. See Tweede Kamer, Interpellatie-Van Oven, gericht tot staatssecretaris van Binnelandse Zaken en Koninkrijksrelaties, over Koraal Specht, TK 5, 29 September 1999, p. 5-268-5-281, and Toekomstige samenwerking met de Nederlandse Antillen en Aruba, Verslag van een Algemeen Overleg, Tweede Kamer der Staten Generaal, vergaderjaar 1999 2000, 26 605, nr. 1.

250 See Report, CPT/Inf (2002) 30 (15 November 2002), para. 27.

251 Ibid., para. 3. 
of the concerns expressed in the previous report. The Committee, however, after emphasizing that the State owes a duty of care to the prisoners in its charge, did recommend the Netherlands Antilles authorities to appoint a prison governor who would further implement, "[...] the policies and plans already developed during the Wackenhut Corrections Corporation management period[...]"252 It also observed that a proper system of classification and allocation of prisoners (which the CPT considers to be a pre-requisite for the organization of a meaningful regime) had been developed by WCC, although Bon Futuro Prison had not yet applied it. ${ }^{253}$ The CPT urged the Netherlands Antilles government to put the classification system into use without delay. The CPT also recommended that WCC's training manuals and health care forms should be translated into the languages of the Netherlands Antilles ${ }^{254}$ and to implement WCC's recommendation to appoint additional nursing staff to improve health care within the prison. ${ }^{255}$ That WCC's involvement was regarded as positive by the Committee is inferrable through its endorsement of the programs initiated by WCC in Bon Futuro Prison. WCC's withdrawal from the project, however, appears to have caused some concerns. The Committee warned that although the current management team of Bon Futuro Prison was trying to do its best to implement parts of the project that had been started by WCC, the initial coherence had been lost. In this regard, the CPT recommended the appointment of an experienced prison director who could, "[...] redress the situation in the establishment, which appears to have started to drift again." 256 In general terms, however, and even though the CPT did not explicitly state so, it would appear that prison privatization can have a positive effect in improving conditions of detention in prisons and thus (indirectly) helping to prevent situations which amount to inhuman or degrading treatment.

\subsubsection{Prison privatization in the United Kingdom}

Although prison privatization is more common in the United Kingdom, the CPT has only provided a limited amount of information with regards to private prisons in that country with the exception of detention centers for immigrants (see the following section). In a visit to the United Kingdom in 1997, for example, the Committee made only a passing reference to the construction of four prisons in partnership with the private sector in the UK. ${ }^{257}$ After another visit in 2001, the Committee provided a more thorough account with regards to the conditions of

\footnotetext{
252 Ibid., para. 32.

253 Ibid., para. 41.

254 Ibid., paras. 50 and 56.

255 Ibid., para. 54.

256 Ibid., para. 51.

257 See Report to the United Kingdom Government on the visit to the United Kingdom and the Isle of Man carried out by the European Committee for the Prevention of Torture and Inhuman or Degrading Treatment or Punishment (CPT) from 8 to 17 September 1997, CPT/Inf (2000) 1 (13 January 2000), Strasbourg, para. 74.
} 
detention in a number of privately managed prisons and the responsibility of the UK. ${ }^{258}$ During this visit, the CPT examined a number of privately managed court detention facilities in London at the Central Criminal Court (Old Bailey), Highbury Corner Magistrates Court and Thames Magistrates Court. The staff of the private company running these detention centers is in charge of the custody of inmates and security arrangements with the exception of high security prisoners. ${ }^{259}$ According to the CPT, its delegation did not receive any allegations of ill treatment of detainees by staff members and all prisoners who were interviewed mentioned that they were correctly treated. ${ }^{260}$ There were, however, some complaints related to the cleanliness of some cells and the sanitary facilities, which the CPT recommended should be improved. ${ }^{261}$ Additionally, the Committee observed that Old Bailey detention center did not keep accurate records of the use of force against prisoners by staff members (apparently these were kept at the headquarters of the private company running the facility) and recommended that this situation should be reviewed. ${ }^{262}$ Other complaints related to the transport of prisoners to these detention centers, a task that had also been entrusted to the private company managing the centers. The complaints were related to the long duration of the transport and the small space in which prisoners had to sit in the transportation vehicles. $^{263}$

The Committee also visited a number of prison establishments. One of the facilities visited was Parch Prison, a so-called DCMF prison (a prison which has been privately designed, constructed, managed and financed) in Wales, holding mostly sentenced prisoners. Again, the CPT did not receive any allegations of ill treatment of prisoners by the staff. ${ }^{264}$ The CPT also found the conditions of detention in Parch Prison to be acceptable (in comparison to other publicly run prisons) and was pleased with the recreational and working environments present in that prison although there was room for improvement. ${ }^{265}$ The Committee had no negative comments with regard to the availability and quality of health care in Parch Prison and was generally pleased with it. A visit to a children detention facility, which

258 Report to the Government of the United Kingdom on the visit to the United Kingdom carried out by the European Committee for the Prevention of Torture and Inhuman or Degrading Treatment or Punishment (CPT) from 4 to 16 February 2001 CPT/Inf (2002) 6 (18 April 2002) Strasbourg. 
according to the Committee is under the ultimate responsibility of the Home Office but is operated by a private sector contractor, did not generate any worthwhile complaints from the Committee. ${ }^{266}$

With respect to the monitoring of privatized prisons, the CPT noted that the UK had already in place a number of specific monitoring mechanisms, including a Board of Visitors, a Chief Inspector of Prisons and a Prisons Ombudsman, which also monitored private prisons. ${ }^{267}$ Additionally the UK had deployed Home Office 'controllers' inside private prisons to ensure that private companies managing those prisons live up to the terms of their contracts. These controllers were also in charge of conducting disciplinary hearings, awarding sanctions to prisoners and investigating allegations against staff, therefore avoiding a potential problem of leaving these sensitive tasks to the private prison staff. ${ }^{268}$ In spite of these seemingly effective monitoring mechanisms, the CPT nevertheless wished to, "[...] underline the importance of ongoing monitoring systems of privately managed prisons, capable of ensuring that the State remains in a position to discharge all its obligations vis-à-vis persons deprived of their liberty." ${ }^{269}$ The CPT reiterated this wish in its general recommendations to the UK.

\subsubsection{Private Security services and the CPT}

In a number of reports on visits to places of detention in various countries, the CPT has paid some attention to the use of private security companies particularly for custody or escort purposes in cases of administrative detention of foreign nationals. During a visit to the United Kingdom in 1994, the Committee noted that a private security company, Group 4 Securitas, supervised a number of places of detention where foreign nationals were held due to immigration problems. ${ }^{270}$ The CPT requested additional information from the United Kingdom on the means of

266 The Committee found no allegations of ill treatment, the conditions of detention did not raise cause for concern and the health care facilities were also adequate. The Committee only recommended that personnel working in this detention facility should eliminate the use of uniforms. Ibid., paras. 101, 102, 103-109, 111 and 114.

267 Ibid., para. 84. Some of these bodies have been recently appointed as components of the National Preventive Mechanism of the United Kingdom under the Optional Protocol to the UN Convention Against Torture (OPCAT), which establishes a universal and national system of visits to places of detention, partially based on the CPT experience. See list of bodies to be designated as part of the NPM, prepared by the Ministry of Justice, 31 March 2009, available at $<$ www.publications.parliament.uk/pa/ld200809/ldhansrd/text/90331-wms0002.htm> (last visited on 23 July 2009). The bodies established under OPCAT have the possibility of visiting private places of detention such as privatized prisons under Article 4 OPCAT. See further Chapter III Section 3.

Ibid., para. 85 .

269 Ibid.

270 See Report to the United Kingdom Government on the visit to the United Kingdom carried out by the European Committee for the Prevention of Torture and Inhuman for Degrading Treatment 
restraint that escort groups employed by private companies are authorized to use. ${ }^{271}$ Additionally the CPT wanted to receive copies of any relevant instructions issued by the UK's Enforcement Directorate of the Immigration and Nationality Department and/or the private companies concerned.

It is worthwhile mentioning that although the UK had sub-contracted the management of a detention center for foreigners, Campsfield House, to Group 4 Security, immigration officers were also deployed with the purpose of ensuring that the company fulfilled the terms of the contract. ${ }^{272}$ This does not mean, however, that the conditions of detainment were thus fully guaranteed. For example, the CPT was concerned that, with regard to the medical services in the same place of detention,

"[...] at the time of the visit, the terms of the contract between the Immigration Service and Group 4 Securitas (the private company to which the management of Campsfield House had been sub-contracted) were not being observed in full. In particular, although the contract provided for the presence of a general practitioner between $9 \mathrm{am}$ and $5 \mathrm{pm}$, Monday to Friday, the doctor only held surgeries for between two to three hours per day."273

The Committee then recommended that steps should be taken to ensure that the terms of the contract are respected.

During a visit to the Netherlands in 1997, the CPT noted the use of personnel from a private security company, PreNed, in departure center ('vertrek centrum') Ter Appel. At this center, foreigners who are compelled to leave the country after their asylum applications have been refused await their departure. ${ }^{274}$ The Committee did not receive any allegations of ill-treatment in the departure center, but it did note that there appeared to exist a certain tension between the residents of the center. This compelled the CPT to remind the government of the Netherlands that the training and selection of staff members for these centers should be careful and should take into consideration the cultural differences of the detainees. The CPT found that the staff at Ter Appel complied with these requirements, but noted that it had received allegations that personnel of PreNed had a tendency to make racist remarks about the residents of the center. After observing that this attitude did not

or Punishment (CPT) from 15 to 31 May 1994, CPT/Inf (96) 11 (5 March 1996), Strasbourg, para.170.

271 Ibid., para. 173.

272 Ibid., para. 200.

273 Ibid., para. 378.

274 See Report to the Government of the Netherlands on the visit to the Netherlands Antilles carried out by the European Committee for the Prevention of Torture and Inhuman or Degrading Treatment or Punishment (CPT) from 17 to 27 November 1997, CPT/Inf (98) 15 (29 September 1998), Strasbourg, para. 81. 
help to improve the tense situation in the center, the CPT invited the government of the Netherlands to examine this issue and take the appropriate measures. ${ }^{275}$

Similar comments were made by the CPT following a visit to an aliens detention center in Norway in 1999. The Committee was impressed by the personal qualities of the employees of a private security company that staffed a particular detention center in that country. The Committee was however disconcerted to learn that the private security personnel had not received specialized training for their tasks. ${ }^{276}$ This prompted the CPT to emphasize the importance of carefully selected, well trained and adequately supervised personnel for security tasks. The training should include also familiarization with the different cultures of the detainees and good knowledge of languages spoken in the detention center. The CPT recommended that such training should be introduced for all staff working in centers for immigration detainees in Norway. ${ }^{277}$

It would appear from the CPT's reports that the CPT has acquiesced the use of private security personnel in tasks involving the use of force by not complaining about their deployment. With the apparent exception of one case, the CPT has not received allegations of ill treatment by private security personnel in the discharge of their duties. The Committee, however, notes that all security personnel, including those operating in the private sector, must comply to the same standards. Moreover, the CPT seems to accept that the contractual obligations between private security companies and the State play an important role in the monitoring of the conduct of private security personnel by stating that States should take the necessary steps to ensure the respect of the terms of contract. It is necessary to note that, from the point of view of human rights protection and compliance with Article 3 ECHR, the CPT should endeavor to review the terms of the contracts between private security companies and the States in order to ascertain whether these contracts live up to human rights standards, allow for an effective legal remedy or access to an independent judiciary body and eventually also regulate the accountability question.

\subsection{European Committee for Economic and Social Rights}

In 1961, the Council of Europe adopted the European Social Charter (ESC), which guarantees a number of economic and social rights including employment related rights, the right to education, the right to social security and health related rights. In

\footnotetext{
275 Ibid., para. 86.

276 Report to the Norwegian Government on the visit to Norway carried out by the European Committee for the Prevention of Torture and Inhuman or Degrading Treatment or Punishment (CPT) from 13 to 23 September 1999, CPT/Inf (2000) 15 (9 October 2000), Strasbourg, para. 33. Ibid.
} 
1988, an additional protocol was opened for signature, aimed at extending the protection of the ESC by including additional workers' rights and introducing some non-discrimination provisions and rights for elderly people. In light of the changing views with regard to economic and social rights, the ESC was revised in $1996 .{ }^{278}$

The supervision of the European Social Charter has been entrusted to the European Committee of Social Rights. The function of the European Committee is to decide on the conformity with the European Social Charter of the law and practice of the States parties to the Charter. The ESC allows for a standard state reporting mechanism whereby States present periodical information with regard to their implementation of the rights enshrined in the Charter. Additionally, under the Additional Protocol of 1995 a collective complaint mechanism is provided for, through which non-governmental groups such as trade unions and/or NGOs can submit complaints related to violations of the ESC rights. The revised ESC is submitted to the same supervisory mechanism established through the original Charter and the subsequent Protocols of 1991 and 1995.

Under the State reporting mechanism, the European Committee of Social Rights has dealt occasionally with the question of privatization or delegation of state services or functions to private parties. While examining State reports the Committee has made a number of observations in relationship to worker related rights and rights pertaining to the access to social security systems and privatization. The privatization of state provided services or functions has not yet been dealt with under the collective complaint mechanism. In the following paragraphs, the Committee's views with regard to privatization and the right to work, the right to collectively bargain and to strike and the right to social security and other welfare related rights within the framework of the State reporting mechanism will be further examined.

\subsubsection{Privatization and the right to work}

Article 1, paragraph 1 of the ESC (revised) deals with the right to work in general and the States' responsibility to achieve and maintain a high level of employment with a view to attaining full employment in particular. The Committee's main concerns with respect to privatization and the right to work and the obligation to maintain a high level of employment were focused on the general impact which privatization could have on employment. For instance, in the conclusion to Turkey's periodical report over the period 1992-1993, the Committee noted,

278 This revision incorporated a number of new rights and amendments to the ESC including, inter alia, the right to protection against poverty and social exclusion, the right to housing, the right to protection in cases of termination of employment and the right to equal treatment and opportunities for workers with family responsibilities. The revised charter entered into force on July 1999. 
“[...] that a restructuring programme for loss-making state-run enterprises was being carried out. It also took note of a privatisation programme aimed at streamlining the public sector. The Committee wished to be informed of any social protection measures accompanying these programmes and especially of the possibilities for the retraining and placement of workers having lost their jobs as a consequence of the implementation of the programmes." 279

Having received information from Turkey that a program had been devised to provide new employment opportunities for workers made redundant as a result of privatization, the Committee requested additional information on the results of that program in a follow up conclusion on that country's report over the period 19941996. ${ }^{280}$ Similar information reported by Turkey over the period 1997-1998 regarding a program aimed at minimizing the negative social implications of rapid privatization, prompted the Committee to request more information on the restructuring process, the outcome of programs put in place and their impact on the general employment situation. ${ }^{281}$

The Committee has also paid attention to the prohibition of forced or compulsory labor (Article 1 paragraph 2 ESC). Although the Committee has not directly taken privatization into consideration with regard to this prohibition, the Committee's views on the article could be relevant in the future when assessing the deployment of prisoners from privatized prisons to work for private enterprises. This could be relevant, for example, in the United Kingdom where currently a number of private prisons are operational. The Committee has taken the stance that the employment of prisoners for private enterprises can be contrary to the obligations of article 1 paragraph 2. For example, while reviewing German legislation on the subject of prison labor, the Committee took the view, "that the [German] practice of employing prisoners for private enterprises, without the prisoners' consent and in conditions so far removed from those normally associated with a private employment relationship, is not consistent with the Charter prohibition on forced labour."282

279 Turkey 01/01/1992-31/12/1993 Conclusion, ESCR, Conclusions XIII-3, Article 1 Para 1, Section 258/454 (1996), p. 230-231.

280 Turkey 01/01/1994-31/12/1996 Conclusion, ESCR, Conclusions XIV-1, Article 1 Para 1, Section 478/525 (1998), p. 757-759. The Committee has similarly asked Malta to provide further information about measures that may be labor saving, including a privatization program intended to increase productivity in the public sector. See Malta, ESCR Conclusions XVIII-1, vol. 2 (2006), Article 1, pag. 506.

281 Turkey 01/01/1997-31/12/1998 Conclusion, ECSR Conclusions XV-1 vol. 2, Article 1 Para 1, Section 155/204, (2000), p. 587-589.

282 Chapter 7 - Conclusions concerning Articles 1, 5, 6, 12, 13, 16 and 19 of the Charter in respect of Germany, ECSR Conclusions XV1-1 vol. 1 (2002). The Committee was however not unanimous in reaching this conclusion. Committee members Evju and Birk appended a dissenting opinion on the Committee's and noted that, "[...] as regards the assessment of work by prisoners within state prisons, I find the normative standard on which the conclusion is based - this being a novel standard in the context of Article $1 \S 2$ - too peremptory and also too sweeping 
With regard to Article 1 paragraph 3 of the ESC relating to the State's undertaking to establish and maintain free employment services for all workers, the privatization of these services has been addressed once by the Committee during the examination of Italy's periodic report over the period 1997-1998. Noting Italy's privatization of employment agencies, the Committee requested information, inter alia, on the market share of the private employment agencies and the number of placements made by the public and private employment services. ${ }^{283}$ During the examination of Italy's follow up report to these conclusions, the Committee did not further engage on any comment of the privatization of the employment agencies. ${ }^{284}$

\subsubsection{Privatization, the right to bargain collectively and the right to strike}

Article 6 of the ESC guarantees the right of workers to bargain collectively. To this end, State parties to the Charter undertake to promote, "[...] where necessary and appropriate, machinery for voluntary negotiations between employers or employers' organisations and workers' organisations, with a view to the regulation of terms and conditions of employment by means of collective agreements[...]"285 Additionally, to ensure the proper implementation of this right, Article $6 \S 4$ affirms that State parties have to undertake the right of workers and employers to "collective action in cases of conflicts of interest, including the right to strike, subject to obligations that might arise out of collective agreements previously entered into."

In the context of the right to bargain collectively and the right to strike, the Committee has dealt with situations involving restrictions of those rights with regard to former civil servants now being employed by the privatized entities providing certain services. The departing point for the Committee is that both rights can be restricted with regard to civil servants, but only within certain limits. ${ }^{286}$

in its implications, resting on assumptions in which I cannot fully share. [...] I add that my reservations on the latter point above apply similarly to the general statement on "prisoners' work for private undertakings" contained in the Committee's examination under Article $1 \S 2$ for the United Kingdom, in which a conclusion is however not drawn on this particular point." Idem. It should be also noted that the Committee has requested each reporting State as of these Conclusions, to provide in the future information regarding the use of prison labor for private enterprises.

Italy 01/01/1997 13/12/1998 Conclusion, ECSR Conclusions XV-1 vol. 2, Article 1 Para 3, Section 4/204, (2000), pag. 357-358.

284 European Social Charter (Revised), ECSR Conclusions 2002 (France, Italy, Romania, Slovenia, Sweden), Provisional edition (2002). The Committee did, however, note that Italy had not yet provided the requested information on the market share of these services and the number of placements made by private and public employment agencies. Commenting that on the basis of the lack of information it unable to assess how the right to employment services was guaranteed by Italy, the Committee decided to defer its conclusions on this paragraph.

286 Thus the Committee has concluded that the right of civil servants to bargain collectively could be restricted only if these are involved in the drafting of the restrictions that apply to them. With 
However, the question has been raised whether privatization and a change of status of certain civil servants working in privatized service providers still warranted a restriction of both rights.

While considering Germany's report over the period 1995-1996, the European Committee on Social Rights noted that civil servants in that country were excluded from the right to bargain collectively. The Committee also noted that it had received information from a German trade union stating that, after the German postal and railway enterprises (Deutsche Post and Deutsche Bundesbahn respectively) had been privatized, the employees of these enterprises were still being denied the right to bargain collectively even though they apparently no longer had civil servant status. The Committee requested additional information on the matter and provisionally concluded that German practice complied with the obligations of Article $6 \$ 2 .{ }^{287}$ Similarly, the European Committee observed that the employees of the German postal and railways enterprises were also denied the right to collective action as protected in Article $6 \S 4$ of the Charter, even though they no longer fell under the civil servant status after the privatization of their respective companies. ${ }^{288}$ Once again the Committee requested additional information on this issue.

In the subsequent report to the Committee, Germany clarified the situation. During the privatization process, employees of the postal and railways services were given the voluntary choice of either maintaining their civil servant status after privatization or enter into a new employment relationship with the companies after which they could enjoy the right to collective bargaining. ${ }^{289}$ In its conclusions, the Committee insisted that the next German report should clarify how the wages and terms of work of workers who did retain the status of civil servants in privatized companies are set and whether they can take part in collective bargaining in other ways. The Committee then decided to defer its conclusion after recalling that although the right to collective bargaining can be limited for civil servants, some participation in determining their terms and conditions of work must be allowed. ${ }^{290}$ With respect

regard to the right to strike of civil servants, the Committee has concluded that this right may be restricted only in respect of certain categories of civil servants such as members of the police or armed forces, judges or senior civil servants. However, a blanket restriction on this right for civil servants as a whole was deemed incompatible with the ESC. See Germany 01/01/199531/12/1996 Conclusion, ESCR Conclusions XIV-1, Article 6 Para 2, Section 169/525 (1998), p. 298-300, and Germany 01/01/1995 31/12/1996 Conclusion, ESCR Conclusions XIV-1, Article 6 Para 4, Section 171/525 (1998), p. 301-302.

287 Germany 01/01/1995-31/12/1996 Conclusion, ESCR Conclusions XIV-1, Article 6 Para 2, Section 169/525 (1998), p. 298-300.

288 Germany 01/01/1995-31/12/1996 Conclusion, ESCR Conclusions XIV-1, Article 6 Para 4, Section 171/525 (1998), p. 301-302.

289 Germany 01/01/1997-31/12/1998 Conclusion, ESCR Second Addendum to Conclusions XV-1, Article 6 Para 2 Section 8/31 (2001), p. 24-25.

Ibid. 
to the right to collective action and strike, the Committee concluded that, "[...] the situation in Germany is not in conformity with Article 6 para. 4 of the Charter as all strikes not aimed at achieving a collective agreement and not called or endorsed by a trade union are prohibited and as employees in the privatised railway and postal services who have retained the status of civil servants are denied the right to strike." 291

When the issue resurfaced again in 2004 with regard to the right to bargain collectively, Germany noted that "[...] as was the case before privatisation, postal and rail workers continue to perform duties in the public interest, which justifies the retention of their civil service status[,]"292 thus justifying a restriction of this right. In addition employees had been given a choice to change their status following privatization. The Committee did not agree with this and considered that

"[...] abolishing the right to collective bargaining can only be justified in the case of officials who exercise public authority. Although it takes account of national definitions of what constitute duties in the public interest, it reserves the right to decide for itself whether the undertakings or employees concerned directly exercise public authority. In doing so it takes account of the nature of those undertakings' or employees' duties and responsibilities. In this case, it cannot reach such a conclusion. In response to the argument that those concerned were able to choose their status, it considers that offering such a choice cannot justify the total removal of the right to bargain collectively." 293

The Committee thus concluded that the situation in Germany with regard to postal and railway employees of their respective privatized companies was not in conformity with Article $6 \S 2$ ESC since they do not exercise public authority but are nevertheless restricted in their right to bargain collectively. The Committee reached a similar conclusion with regard to the right to strike since civil servants employed in the privatized postal and rail services who are not exercising public authority were also totally denied the right to strike. ${ }^{294}$ It should be noted that in this particular situation, the privatization of the postal and railways services on its own did not directly affect the rights of workers. However, the way privatization was approached, i.e. maintaining a strict prohibition of carrying out collective action and limiting the way in which employees could bargain collectively for those who chose to maintain a civil servant status after privatization, led to a violation of the rights involved. The issue is still being discussed between Germany and the ESCR. ${ }^{295}$

291 Germany 01/01/1997-31/12/1998 Conclusion, ESCR Second Addendum to Conclusions XV-1, Article 6 Para 4, Section 10/31 (2001), p. 27-30.

292 Germany, ESCR Conclusions XVII-1 (2004), p. 203.

293 Ibid.

294 Ibid., p. 206.

295 See Germany, ESCR Conclusions XVIII-1 (2006), p. 302-304. 
On a related issue, the Committee has also expressed its views with regard to the obligation to consult with the social partners in the light of privatization and the right to work. For example, while examining Romania's report over the period 1999-2000, the Committee considered that, "[...] in view of the current economic and employment situation in Romania, in particular the privatisation and restructuring of state enterprises, effective implementation of Article $6 \S 1$ of the Revised Charter entails ongoing consultation on a tri-partite or bi-partite basis at national level."296 It would appear thus that consultation is of utmost importance, and States parties to the ESC have an obligation to inform and enter into dialogue with workers and other relevant actors whose rights may be affected by privatization measures.

\subsubsection{Privatization, health care, social security and other welfare related rights}

Other rights that have led to Committee observations (indirectly) related to privatization in its conclusions to State reports have been the right of employed women to protection of maternity (Article $8 \mathrm{ESC}$ ), the right to protection of health (Article 11), and the right to social security (Article 12 ESC). While examining the Netherlands report over the period 1993-1994, the European Committee requested detailed information from the State party on the privatization of sickness insurance, which according to a Dutch union would negatively affect maternity benefits in breach of Article 8, $\S 1$ and $2 .{ }^{297}$ In the follow up report, the Netherlands replied that the privatization of sickness insurance will not affect maternity benefits. The Committee apparently accepted the government's response because it made no further observations about the privatization of sickness insurance. ${ }^{298}$ On the other hand, the Committee has also recently shown some interest in the privatization of health systems with regard to the right to health. Thus it has recently asked about the consequences of the privatization in the health sector in Cyprus, Croatia and Latvia. ${ }^{299}$

With regard to Article $12 \S 1$ ESC on establishing or maintaining a system of social security, the Committee examined in 2004 the Netherlands' new funding scheme of its public sickness insurance and wished to obtain a more complete picture "[...] notably of the safeguards that have been implemented or are under consideration

296 Romania 01/01/1999-31/12/2000 Conclusion, ESCR Conclusions, Article 6 Para 1, Section 94/202 (2002), p. 131-132.

297 Netherlands 01/01/1993-31/12/1994 Conclusion, ECSR Conclusions XIII-4, Article 8 Para 1-2, Section 30/512 (1996), p. 86-87.

298 Netherlands 01/01/1993-31/12/1998 Conclusion, ECSR Conclusions XV-2 Volume 2, Article 8 Para 1-2 Section 12/168 (2001), p. 346-347. The Committee nevertheless concluded that the Netherlands was in breach of Article 8 paragraph 1 on other grounds than the privatization of sickness insurance.

299 Cyprus, ESCR Conclusions 2005 Volume 1, p. 86. Croatia, ESCR Conclusions XVIII-1 Volume 1 (2006), p. 160; and Latvia, ESCR Conclusions XVIII-2 Volume 1 (2007), p. 304. 
with a view to mitigating any negative effects of the privatized funding system." 300 In the follow-up report the Netherlands provided the requested information noting that the new system did not lead to a disruption in the relationship between the employee and the employer with regard to recruitment on the basis of health risks. It also noted that claims for disablement benefits decreased and that the under the new system about $50 \%$ of the Dutch workforce was covered. ${ }^{301}$ This reply, however, did not entirely satisfy the Committee. After recalling that social security systems have to be collectively funded by employers, employees, and the State for them to be in conformity with Article $12 \S 1$, it observed that "[ ...] notwithstanding the information provided on the functioning of the system, the Committee considers the situation not to be in conformity with the Charter because the report does not show that the right to sickness and invalidity benefits is effectively secured as a social security right under the new system.",302

During the examination of Italy's periodic report over the period 1993-1994 on compliance with Article $12 \S 3$, which encourages the State to raise progressively the system of social security to a higher level, the European Committee took notice of the privatization of certain agencies providing basic retirement pensions for specific categories. The Committee did not go further into this observation but decided, partly in light of the above mentioned privatization, to defer its assessment on the compliance by Italy with this provision pending the submission of additional information by the State party. ${ }^{303}$

Worthy of notice are the Committee's observations regarding Article 14 on the right to benefit from social welfare services and on Article 4 of the 1988 Additional Protocol to the ESC on the right of elderly persons to social protection. For example, the Committee has concluded that in the event of subcontracting the operational responsibility for the care of elderly people to private service providers, the State/ municipal authority still has, "[...] overall responsibility for service provision, as regards both keeping track of individuals' situations and supervising services provided by private firms." 304 Additionally, the Committee has been of the opinion that local authorities must ensure that private service providers operate at the same level as municipal services. ${ }^{305}$ Although not dealing directly with the privatization of social welfare services, the Committee has paid attention to the monitoring and supervising duties of States vis-à-vis private welfare services and the quality and

\footnotetext{
300 Netherlands, ECSR, Conclusions XVII-1 Volume 2 (2004), p. 322.

301 Netherlands, ECSR, Conclusions XVIII-1 Volume 2 (2006), p. 554.

302 Ibid.

303 Italy 01/01/1993 31/12/1994 Conclusion, ECSR Conclusions XIII-4, Article12 Para 3, Section 126/512 (1996), p. 151-153.

304 Sweden 01/01/1996-31/12/1998 Conclusion, ESCR Conclusions XV-2 Volume 2, Article 4AP, Section 151/168 (2001), p. 578-582.

305 Finland 01/01/1996-31/12/1998 Conclusion, ESCR Conclusions XV-2 volume 1, Article 4AP, Section 83/173 (2001), p. 182-185.
} 
effective access to social services. These views could be applicable to circumstances under which public social security services and providers undergo privatization. For example, based on information provided by Finland related to an increase in the number of private social service establishments, the Committee asked whether the use of private service providers had any effect on the access of all categories of the population to social services. The Committee also requested more detailed information on the rules governing the quality and the supervision of the quality of these private services. ${ }^{306}$ It has also asked to be informed on how the quality of services to the elderly and the disabled is supervised in relation to the private providers hired by municipalities. ${ }^{307}$

Finally, it should be mentioned that the Committee has dealt with only one case dealing indirectly with privatization of housing under its collective complaints mandate. In the case of Fédération européenne des Associations nationales travaillant avec les Sans-abri (FEANTSA) v. Slovenia ${ }^{308}$ the European Committee had to decide whether Slovenia had failed to ensure the right to housing as protected in Articles 16 and 31 Revised European Charter and the prohibition of discrimination found in Article $\mathrm{E}$ of the same instrument of tenants living in flats that had been nationalized under the communist regime and subsequently privatized in 1991. The main issue revolved around the fact that the flat's tenants were not able to benefit from the privatization and were thus discriminated against by not giving them the opportunity to buy the flats, many of which had been restored to the former owners of the pre-nationalization period. This posed a problem given the fact that the (new) landlords that had bought the flats through privatization could impose new rules on occupancy and increase the rents to the detriment of the tenants. The complaining organization claimed that this affected the security of tenure of those tenants and placed them in a precarious situation that prevented them from effectively exercising their right to housing. ${ }^{309}$ The Committee did not went further into the issue of

This entails an obligation to ensure that the operating principles, staff and facilities of private service providers and the manner in which these services are provided are up to par with their municipal counterparts.

Finland 01/01/1994 31/12/1995 Conclusion, ECSR Conclusions XIII-5, Article 14 Para 2, Section 47/177 (1997), pag. 102-103. Luxembourg received a similar request for information regarding the monitoring of social services provided by private providers. See Luxembourg 01/01/1996 31/12/1998 Conclusion, ECSR Addendum to Conclusions XV-2, Article 14 Para 1, Section 55/168 (2001), p. 89-90.

307 Sweden 01/01/1993 31/12/1998 Conclusion, ECSR Conclusions XV-2 Volume 2, Article 14 Para 1, Section 143/168 (2001), p. 564-565.

308 Fédération européenne des Associations nationales travaillant avec les Sans-abri (FEANTSA) v. Slovenia, decision on the merits of 8 September 2009, European Committee of Social Rights, Complaint No. 53/2008. 
privatization as such, and following an arguably thinly motivated assessment concluded that there had been a violation of the abovementioned Articles. ${ }^{310}$

\subsection{Preliminary conclusions}

The practice of the ECtHR reveals that privatization has usually not been a direct issue of concern. Nonetheless, its case law reveals that, given the State's margin of appreciation, the Court is willing to accept the privatization of public functions in so far the State guarantees that human rights will be respected. In this respect, the State will have to exercise its positive obligations of the State to protect the rights of individuals against the actions of privatized entities through the adoption of effective measures to that end. In any event, the Court is of the opinion that States remain responsible even after privatization for conduct the conduct of privatized actors. The CPT and the ECESR have dealt with the subject of privatization in a more considerable way. This is particularly true of the CPT, which has examined situations involving the use of private actors to take over certain public functions involving the deprivation of liberty. Thus, it paid attention to the privatization of a prison in the Netherlands Antilles and made visits to a number of privatized prisons in England and Wales. In this context, it commented on the necessity of constantly monitoring privately managed places of detention. The CPT also devoted some attention to the use of private security guards particularly in the context of the detention of aliens and failed refugees awaiting their return to their country of origin. The ECESCR has examined privatization from the perspective of its possible effects on labor related rights and social security rights. Although the ECESCR has refrained from declaring that privatization on its own violated any particular right, it has found on a couple of occasions that the implementation of a privatization policy in a particular context was flawed, thus leading to what amounted to violations of the rights to collective action and to bargain collectively and of the right to a system of social security. In addition it has observed that consultation including an obligation to inform and enter into dialogue with the relevant stakeholders whose rights may be affected by privatization measures are important. Finally, the Committee has noted that the State still has the overall responsibility for the provision of services that have been privatized and which have an impact on certain rights found in the ESC. This includes monitoring these services and ensuring that private providers operate at the same level as public ones.

310 In particular, the Committee concluded that the State had deprived the tenants "[...] not only of this right, but also of the opportunity to purchase the flat they live in, or another one, on advantageous terms, and of the opportunity to remain in the flat, or move to and occupy another flat, in return for a reasonable rent.” Ibid., para. 72 . 


\section{The InTERnational Labor Organization ANd PRIVATIZation}

Since its inception in 1919, the International Labor Organization (ILO) has had a pivotal role in establishing standards in the field of labor and workers' related rights. The unique structure of the ILO with its tri-partite composition has helped in the drafting of numerous conventions and recommendations on a wide range of subjects affecting the rights of workers. To ensure compliance with ratified ILO conventions two main supervisory mechanisms have been created within the framework of the ILO. ${ }^{311}$ The first mechanism entails the periodic reporting by Member States of the conventions that they have ratified. The Committee of Experts on the Application of Conventions and Recommendations (CEACR) is entrusted with the actual supervision of this mechanism. The International Labor Conference Committee on the Application of Conventions and Recommendations (ILCCR) then considers a report of the CEACR's observations. The second mechanism involves the investigation of allegations concerning the States' failure to guarantee the effective observance of conventions ratified by those States. ${ }^{312}$ The Governing Body of the ILO and the Committee on Freedom of Association supervises this mechanism.

Until now, 185 conventions have been drafted within the context of the ILO on various labor rights issues. Additionally, the General Conference of the ILO has issued more than 190 recommendations. None of these conventions or recommendations make any reference to the privatization of State tasks or services. The bodies entrusted with the actual supervision of the two main supervisory mechanisms have, however, on numerous occasions faced questions related to the effect of privatization on the enjoyment of a number of the conventions drafted in the framework of the ILO. The opinions provided by these bodies on the issue of privatization give a number of noteworthy insights regarding the effects of privatization on labor rights and the duties and obligations of States in this respect.

\subsection{Committee of Experts on the Application of Conventions and Recommendations}

Article 22 of the ILO Constitution imposes the obligation on State parties to report on the implementation of the provisions of an ILO convention in their national legislation. In 1926 the CEACR was established by the International Labor Conference to make an objective and technical examination of reports submitted by State parties. ${ }^{313}$ During the examination of State reports for various ILO

\footnotetext{
311 K. Samson and K. Schindler, "The Standard-Setting and Supervisory System of the International Labour Organisation," in An Introduction to the International Protection of Human Rights- A Textbook, ed. R. Hanski and M. Suksi (1999), p. 196. Ibid.

313 Ibid., pag. 198.
} 
conventions, the Committee of Experts has been confronted with different aspects and effects of privatization in the implementation of those conventions. The CEACR's dealings with privatization have appeared in the examination of reports under Convention No. 29 on the prohibition of forced labor, Convention No. 87 on the Freedom of Association, Convention No. 95 on the Protection of Wages, Convention No. 102 on the Minimum Standards of Social Security, Convention No. 111 on the Prohibition of Discrimination on Employment and Occupation, Convention No. 121 on Employment Injury Benefits and Convention No. 122 on Employment Policy. The Experts Committee's views with respect to privatization under these conventions will be described in the following paragraphs.

\subsubsection{Privatization and the prohibition of forced labor}

The ILO has set a number of standards in the field of forced prison labor. In Convention No. 29 on the prohibition of forced labor, the ILO has prescribed the circumstances under which persons who are deprived of their liberty are allowed to work. The CEACR has accordingly examined reports of countries where the privatization of prisons has taken place and where the implementation of the prohibition of forced labor could face problems. In this context, the CEACR has emphasized that the State has the obligation to prohibit the use of prisoners in privatized prisons for labor purposes without the prisoner's approval. This obligation is derived from Article 2, paragraph 2 (c) of Convention No. 29. ${ }^{314}$ Under Article 2, paragraph 2 (c), prison labor as a consequence of the conviction is permissible under two conditions: such labor must be carried out under supervision and control of a public authority and prisoners must not be hired to private companies or individuals. In 2002, the CEACR formulated a general observation concerning Convention No. 29 and the privatization of prisons and prison labor. The general observation was based on the Committee's interpretation of the relevant articles of the Convention, the drafting history of those articles and the practice of States which had implemented privatized prison programs. Until now, the Committee has reviewed the practice of the United Kingdom, Australia, and most recently New Zealand with regard to privatized prisons. After examining the Committee's observations with regard to the reports of these States, a short review of general observation on Convention No. 29 will be presented.

314 Art. 2, of Convention No. 29 provides in its first paragraph the definition of forced labor. According to paragraph 1, forced labor entails "[...] all work or service which is exacted from any person under the menace of any penalty and for which the said person has not offered himself voluntarily." Paragraph 2 (c) provides an exemption to this definition and states that "[...]for the purposes of this Convention, the term forced or compulsory labor shall not include $[\ldots]$ any work or service exacted from any person as a consequence of a conviction in a court of law, provided that the said work or service is carried out under the supervision and control of a public authority and that the said person is not hired to or placed at the disposal of private individuals, companies or associations [...]" (emphasis added). 
During the examination of the United Kingdom's report on the implementation of Convention No. 29 in 1993, the CEACR noted that the Government had submitted information regarding the privatization of Wolds prison which became operational in 1992. According to the government's information, convicted prisoners were required to work. In light of this information the Committee requested additional information including the number of prisons being contracted out and the number of prisoners concerned as well as information regarding the wages being paid to working prisoners. ${ }^{315}$ After considering the United Kingdom's report in 1994 and the trade union's concern about the privatization of prisons in the country, ${ }^{316}$ the Committee recalled that Article 2, paragraph 2(c), of Convention No. 29 explicitly prohibited placing prisoners at the disposal of private individuals, companies or associations even if they are required to work as part of their conviction. ${ }^{317}$ This prohibition also covers allowing prisoners to be hired to private undertakings executing public works, and is not limited to work outside the prisons but also to workshops operating inside prisons notwithstanding the circumstance that the work is supervised by a public authority. The CEACR emphasized that this prohibition covered a fortiori all work organized by privatized prisons. According to the CEACR, if prisoners are to work for private undertakings, "only work performed in conditions of a free employment relationship can be held to be compatible with the prohibition of the Convention; this necessarily requires the formal consent of the person concerned and, in the light of the circumstances of that consent, guarantees and safeguards in respect of wages and social security that are such as to justify the relationship being regarded as a free one." 318 Finally, the Committee hoped that the government would provide additional information regarding the measures that had been taken or were envisaged to guarantee respect for Convention No. 29.

In 1998, the CEACR once more reviewed a (belated) report submitted by the United Kingdom which again raised concerns related to forced labor and the privatization of prisons. After recalling its previous observations on the issue of prison labor and the prohibition of hiring prison labor to private parties without consent of the

315 CEACR: Individual Observation concerning Convention No. 29, Forced Labor, 1930, United Kingdom (ratification: 1931) Published: 1993.

316 In its report for 1994, the United Kingdom noted that Blackenhurst Prison had also been privatized and that convicted and sentenced prisoners were also required to work. The United Kingdom also provided information regarding the payment methods for prisoners. In reaction to this report, a trade union TUC noted that the privatization of prisons in the United Kingdom infringed the prohibition of forced labor as defined in Convention No. 29. In the first place, the trade union believed that the functions of the monitoring authority did not amount to supervision and control under a public authority as required in Article 2, paragraph 2 (c). Secondly, the wages paid to prisoners were substandard and the profits ensuing from such labor were not being used to improve the facilities of prisoners in private prisons, but rather to cut the costs of running the prison and increasing the profit. See CEACR: Individual Observation concerning Convention No. 29, Forced Labor, 1930, United Kingdom (ratification: 1931) Published: 1994.

Ibid.

Ibid. 
prisoners involved, the Committee of Experts reviewed the practice and national legislation in the United Kingdom. Noting that the applicable provisions on prison rules made compulsory prison labor possible and that these provisions applied to both public and privatized prisons, the Committee concluded that in spite of the effective public supervision system for privatized prisons available in the United Kingdom, the State is not exempted from fulfilling the separate condition of Article 2 paragraph 2 (c): namely that prisoners are not to be hired or placed at the disposal of private individuals, companies or associations. ${ }^{319}$ In the eyes of the Committee, the contract between the State and the companies managing privatized prisons is in contradiction with the requirements of Convention No. 29, in so far as compulsory labor is used by the private contractor (the company running the privatized prison) or a subcontractor (a third company that hires prison labor from privatized prisons). Additionally, the compulsory nature of prison labor for convicted prisoners is not removed by the fact that, as the United Kingdom pointed out, prisoners are in the position to voluntarily participate in enhanced wages schemes. The Committee indicated that in order to achieve compliance with the Convention, the United Kingdom would either have to repeal the provisions allowing for the contracting out of prisons or to allow prisoners to freely engage in a contractual obligation to work. ${ }^{320}$ This would also include the regulation of minimal guarantees and safeguards of a labor relation with respect to the level of wages and social security. Moreover, the Committee noted that in light of the system of privileges for prisoners which are granted only if prisoners conform to specified standards of behavior and performance in their work, the system of privatized prisons in the United Kingdom would appear,

"[...] to make it difficult to create the conditions of an employment relationship based upon freely given consent. [...] [E]ven if the director of a contracted-out prison, appointed by the private contractor, had no more right to compel a prisoner to work, he or she and the company behind him or her would still have an interest in having the prisoner's labour at their disposal. The Committee recalls that, as mentioned above, the "menace of a penalty" referred to in Article 2(1) of the Convention might take the form of a loss of rights or privileges. Since the director running the prison on behalf of a private contractor also has legal custody of the prisoner, it would appear both indispensable and very difficult to ensure that the prisoner's willingness or not to work for the private contractor or its subcontractor had no bearing whatsoever on his conditions of imprisonment and expectation of remission of sentence or early release." 321

In view of these conclusions, the Committee of Experts hoped the United Kingdom would take the necessary measures to ensure that prisoners performing work for

319 See CEACR: Individual Observation concerning Convention No. 29, Forced Labor, 1930, United Kingdom (ratification: 1931) Published: 1998, para. 27.

320 Ibid., para. 29.

321 Ibid., para. 30. 
private companies would do so on basis of a free consent employment relationship without any constraints that would flow from their condition as convicted prisoners. Additionally, prisoners engaging in an employment relationship should do so under similar guarantees and conditions as normal workers. ${ }^{322}$ Finally, the Committee requested additional information on the situation regarding privatized prisons and the contracts between the State and these prisons.

In 2000 the Committee published its follow-up report for the United Kingdom and noted with regret that the State party had not implemented its previous recommendations regarding the employment of prisoners under conditions of free consent with regard to contracted-out prisons. ${ }^{323}$ After recalling once again its observations concerning the conditions for prison labor the CEACR observed that, according to a trade union, prisoners serving a sentence in a number of privatized prisons, were being paid sub-standard wages. The Committee wished then to receive the UK's Government reaction to those allegations and hoped that measures would be taken to organize the work in privatized prisons in a manner compatible with Convention No. 29. ${ }^{324}$ In 2002, the Committee once more touched upon the subject of privatized prisons in the UK and repeated that the exceptions to compulsory labor provided in Article 2, paragraph 2 (c) do not, "[...] extend to privatized prisons and prison workshops - even under public supervision and control." 325 The United Kingdom indicated that all prisoners, including those who are in a privatized prison remain under the ultimate supervision of the State, notwithstanding the kind of work they may be involved in. ${ }^{326}$ Additionally, the UK noted that prisoners were not being hired to private companies nor were they placed at their disposal and that private companies were not allowed to use prisoners for whatever they wished. Prisoners in privatized prisons performed specific work that was comparable with the work done by prisoners in public prisons and was monitored under the same conditions by a public authority. ${ }^{327}$ The UK argued,

322 Ibid., para. 31.

323 See CEACR: Individual Observation concerning Convention No. 29, Forced Labor, 1930, United Kingdom (ratification: 1931) Published: 2000, para. 6. The United Kingdom for its part argued that the existing arrangements for the prison labor in all prisons in that country (including privatized prisons) did not fall under the prohibition of Art. 2, paragraph 2 (c). Additionally, it emphasized that the contracts between the Prison Service (the State institutions responsible for monitoring prisons) and private prison contractors did not concern the provision of prisoners to work and that there was no contractual obligation to provide a labor force to private sector contractors. The United Kingdom noted that private prison contractors are simply obliged to provide facilities so that prisoners may work as part of the prison's rehabilitative programs and in accordance with national prison rules. Ibid., para. 9.

324 Ib id., para. 14.

325 See CEACR: Individual Observation concerning Convention No. 29, Forced Labor, 1930, United Kingdom (ratification: 1931) Published: 2002, para. 3.

326 Ibid., para. 11.

327 Ibid. At this remark the CEACR recalled that it had already established that, “[...] even where prisoners remain at all times under the supervision and control of a public authority, this does 
moreover, that Convention No. 29 did not require that conditions approximating a free employment relationship were necessary to ensure the consent of prisoners to work. The Committee, however, pointed out that this argument should not divert attention that in the United Kingdom, prisoners apparently were not even formally asked for their consent to work. ${ }^{328}$ In a follow-up individual observation from 2004 on the same issue, the CEACR reiterated its position "[...] that, with regard to contracted-out prisons and prison industries, the necessary measures will at last be taken to ensure that any work by prisoners for private companies be performed under the conditions of a freely consented upon employment relationship and that the Government will soon be in a position to indicate steps taken to this end." 329

In 1999, the CEACR reviewed Australia's report on Convention No. 29 and provided similar comments to those of the United Kingdom's report after noting that privatized prisons had made their appearance in that country. ${ }^{330}$ During the consideration of Australia's report, Australian trade union members complained that work in private prisons was not supervised by a public authority and that prisoners were required to work for a private company at rates which were far below those for freely employed workers. For its part, the Government member of Australia replied that prison labor in public and private prisons was carried out under the supervision and control of a public authority and that prisoners remained in the custody of the State, which retained overall responsibility. ${ }^{331}$ Additionally, Australia argued that it is not appropriate to compare the pay rates for prisoners working to the pay rates of people who have engaged on the same type of work freely. After recalling the conditions under which prison labor is tolerable under the Convention and after repeating its view that the same rules apply to labor inside privatized prisons, the CEACR noted its concern that the remunerations paid to working prisoners was ten times lower than the minimum wage. 332 It also observed that the low wages did not encourage prisoners to be productive, notwithstanding the Australian argument that prisoners acquired new skills through their work. Reflecting on the trade union's comments that prisoners' labor in privatized prisons was not supervised by a public authority, the Committee observed that the practice of supervision and control by a public authority in Australia would have to be examined carefully since the Convention did not allow a full delegation of supervision or control to a private business. The Committee's follow-up discussion

not in itself dispense the Government from fulfilling the other condition in Article 2(2)(c), namely that the person is not hired to or placed at the disposal of private individuals, companies or associations.” Ibid., para. 12. 
on Australia's report which was published in 2002, reviewed the practice of Australia with regard to the operation of privatized prisons in a number of territories, the wages paid to prisoners, the fact that prison labor in a number of privatized prisons was compulsory and the lack of social security benefits for prisoners working in several privatized prisons. ${ }^{333}$ These points led the Committee to conclude that apparently, Australia has not met the conditions imposed by Convention No. 29 and hoped that the State member would take measures to observe the Convention and report on them.

More recently, the CEACR has also briefly considered the privatization of prisons in New Zealand with regard to the issue of prison labor in privatized prisons. After having examined New Zealand's report for 2005-2006, the CEACR noted with interest, "[...] the statement by the Government in its report that the Auckland Central Remand Prison (ACRP), which had been administered by Australasian Correction Management, a private concern, was to revert back to government control by July 2005." 334 It also noted that the management of the prison had been reverted to the Public Prisons Service on 12 July 2005, and that the legislation dealing with correctional institutions had been amended on 1 June 2005 providing that "[n]o person may, on behalf of the Crown, enter into any contract with any person for the management, by that person instead of the Crown, of any prison."”335

\subsubsection{Privatization and the freedom of association}

Convention No. 87 guarantees the right of workers to engage in collective bargaining and to strike. With respect to this freedom and privatization, the CEACR has dealt with a number of reports entailing the restriction to strike imposed on workers employed in privatized postal and railway services in Germany. As has been noted above, ${ }^{336}$ this restriction is based on the grounds that workers who retained their civil servant status even after the privatization fall under the same rules applying to 'normal' civil servants in Germany. Commenting on Germany's report in 1995, the Committee noted that although the right to strike may indeed be subject to certain

333 See CEACR: Individual Observation concerning Convention No. 29, Forced Labour, 1930 Australia (ratification: 1932) Published: 2002. At a certain point, the Committee observed that a code of practice for correctional industry business development had been adopted but its focus was more on market access and industry impact and made no references to prisoner's rights, wages or conditions of work.

334 See CEACR: Individual Direct Request concerning Forced Labour Convention, 1930 (No. 29) New Zealand (ratification: 1938) Submitted: 2007, Forced Labour Document No. (ilolex): 092007NZL029, para 5.

335 See Section 198 of the Corrections Act 2004, available at <www.legislation.govt.nz $>$. As noted in Chapter II, Section 2.2.1. Section 198 was once again amended to allow prison privatization in 2009.

336 See Section 3.3 supra on the European Committee on Economic and Social Rights and privatization. 
restrictions for employees in the public service, "[...] the prohibition of the right to strike should not be imposed on public servants who do not exercise authority in the name of the State." 337 The Committee then requested Germany to take the necessary measures to ensure that public servants not exercising authority in the name of the State (in this case those working for privatized companies or services) are not denied of the rights enshrined in articles 3 and 10 of Convention No. 87. In 1997, the CEACR published its follow up considerations with relationship to a new German progress report that confirmed the government's commitment to privatize a number of public services. It also confirmed that workers in certain privatized services retained their status of civil servants with the concomitant restrictions related to the right to strike. ${ }^{338}$ Once again, the Committee reiterated its previously noted opinion: public servants who are not exercising authority in the name of the State such as railway workers, postal workers or teachers, should not be denied the right to strike. ${ }^{339}$ In the view of the Committee this prohibition constitutes a considerable restriction of the potential activities of trade unions, and could be contrary to Article 8, paragraph 2 of Convention No. 87. In 2003, the Committee published its observations on Germany's follow-up report but did not add anything new to the abovementioned remarks other than requesting the German government to provide information regarding the public servants covered by privatization measures in order to assess the impact of the restriction on the right to strike. ${ }^{340}$

The CEACR has also used Convention No. 87 to observe that governments should consult those affected by privatization measures. While examining Burkina Faso's report in 2006 with regard to the freedom of association and the protection of the right to organize, the Committee received information from the International Confederation of Free Trade Unions (ICFTU) alleging repressive measures, reprisals and intimidation against trade union members in the context of the privatization of public enterprises that, according to the ICFTU, had been undertaken without consulting the local trade unions. The Committee recalled that,

"[...] that restructuring in the public sector, particularly in relation to a privatization policy, inevitably has important consequences in the social field and in relation to trade unions and that it is important for the social partners, and particularly trade union organizations, to be consulted, at least on the social reach and form of the

\footnotetext{
337 CEACR: Individual Observation concerning Convention No. 87, Freedom of Association and Protection of the Right to Organise, 1948, Germany (ratification: 1957) Published: 1995, para. 3.

338 CEACR: Individual Observation concerning Convention No. 87, Freedom of Association and Protection of the Right to Organise, 1948 Germany (ratification: 1957) Published: 1997. Ibid.

340 CEACR: Individual Observation concerning Convention No. 87, Freedom of Association and Protection of the Right to Organise, 1948 Germany (ratification: 1957) Published: 2003.
} 
measures decided upon by the authorities. The Committee requests the Government to take the necessary measures to ensure that these principles are respected." 341

Thus, with regard to privatization and the freedom of association the CEACR is of the opinion that States engaging in privatization endeavors have a duty to consult with those directly affected by privatization measures.

\subsubsection{Privatization and the protection of wages}

In a few instances, the CEACR has indirectly pondered about the effects of privatization on the wages of workers. For example, dring the examination of a report of the Ukraine on the implementation of Convention No. 95 related to the protection of wages, ${ }^{342}$ the State party noted that there were problems related to wage arrears. The Ukraine mentioned that the arrears in the payment of workers' wages were due to the country's difficult economic situation. This in turn had been caused by, among other things, radical structural transformations and the privatization of state property. ${ }^{343}$ Although the Committee did not go on to discuss the causes of the wage arrears noted by the Ukraine, it did urge the government to take the necessary measures for ensuring the effective payment of wages and the settlement of wage arrears. ${ }^{344}$ Equally, the Committee urged the government to take effective measures for enforcing sanctions and redressing injury caused by wage arrears.

\subsubsection{Privatization and Social Security}

The ILO has a number of social security related conventions wherein workers' rights to social security benefits such as health care are guaranteed. In this context, concerns have been expressed with regard to the privatization of social security benefits and its effects on wokers' rights. While discussing Spain's reports to the Committee of Experts, a trade union made an observation related to what it perceived to be the privatization of social security arrangements entailing the payment of benefits to workers in case of a temporary incapacity to work following a number of amendments in Spain's social security legislation. The amendments required the employer to take over the States' role in paying the benefits for at least the first fifteen days of incapacity. According to the trade union, these amendments

341 CEACR: Individual Observation concerning Freedom of Association and Protection of the Right to Organise Convention, 1948 (No. 87) Burkina Faso (ratification: 1960) Published: 2007, document No. (ilolex): 062007BFA087.

342 The Convention deals mainly with the rights of workers related to their remuneration. It specifically states in Article 12 that wages ought to be paid regularly.

343 CEACR: Individual Observation concerning Convention No. 95, Protection of Wages, 1949 Ukraine (ratification: 1961) Published: 2001.

344 Ibid. 
amounted to a privatization of social security schemes that in its eyes departed from the spirit of Convention No. 102 that deals with the minimum standards of social security. ${ }^{345}$ According to Spain, the amendments did not affect the level of protection for workers and contrary to what the trade union thought, did not change the public nature and character of the benefits and did not alter the predominant role and the obligation of the public authorities to supervise the system. ${ }^{346}$ In its observations to Spain's report and the trade union's concerns about the alleged privatization of incapacity benefits, the Committee concurred with the government and noted that the amendments did not appear to be contrary to Convention No. 102. The Committee stated, however, that in cases in which the payment of benefits has been partially transferred to private hands, "[...] the Government shall continue to assume general responsibility concerning the due provision of sickness benefits and must take all measures required for this purpose, in conformity with Article 71, paragraph 3, of the Convention." ${ }^{477}$ In response to further allegations by the trade union member concerning the privatization of social security arrangements related to long term incapacity benefits and health care, and in light of Spain's claim that new legislation was being adopted to combine some benefits but certainly not to privatize them, the Committee hoped that Spain would take into account the Convention's relevant provisions and requested the State party to submit the text of the legislation once it has been adopted. ${ }^{348}$

In 2003, the CEACR published its individual observations on a report presented by the Netherlands with regard to Convention No. 102. In that report, the government of the Netherlands described the country's privatization of the Sickness Benefits Act ('Ziektewet') and similar reforms to Disablement Benefits Act (WAO). ${ }^{349}$ In

345 CEACR: Individual Observation concerning Convention No. 102, Social Security (Minimum Standards), 1952, Spain (ratification: 1988) Published: 1996, para. 1.

346 Ibid.

347 Ibid. Art. 71, paragraph 3 of Convention No. 102 states that States accept the "general responsibility for the due provision of the benefits provided in compliance with this Convention, and shall take all measures required for this purpose $[\ldots] . "$

348 CEACR: Individual Observation concerning Convention No. 102, Spain, op.cit. note 345, para. 2. In light of renewed observations made by the Spanish trade union at a later State report examination that the health system was constantly at risk of being privatized, the CEACR requested Spain to send its comments on this information. See CEACR: Individual Observation concerning Convention No. 102, Social Security (Minimum Standards), 1952 Spain (ratification: 1988) Published: 2001, para. 1.

349 See CEACR: Individual Observation concerning Convention No. 102, Social Security (Minimum Standards), 1952 Netherlands (ratification: 1962) Published: 2003. Under this scheme a large portion of the implementation of paying sickness benefits has been privatized and the State is no longer solely responsible for it. Employers can decide whether to bear the risk of paying wages to sick employees themselves or reinsure the risk with private insurance companies. Additional reforms have also partially transferred the responsibility of implementing disablement benefit payments to the private sector. The State is only responsible for basic sickness benefits in cases in which market driven reforms do not produce the desired effect. The reforms are intended to shift the responsibility of taking care of sickness and disability payments 
light of these reforms the Committee wished to receive additional information regarding "[...] the regulatory and supervisory measures taken by the State in compliance with Articles 71(3) and 72(2) of the Convention to ensure the financial viability and proper functioning of the private insurance companies providing sickness and disability benefits." ${ }^{350}$ In addition, the Committee submitted that these reforms were intended to harness the positive effects of privatization and market forces and at the same time contain their negative effects on basic social security. Nevertheless, since these reforms were new they posed many new problems of organization and governance. In view of this, the Committee recalled that,

"[...] while there is no single right model of social security, all systems should conform to certain basic principles of good governance and social cohesion, the observance of which comes under the general responsibility of the State established in Articles 71(3) and 72(2) of the Convention. Moreover, it is during such periods of reforms and transition that the responsibility of the State takes on particular importance for the future development of social security, including at the international level. In view of the profound and continuing nature of the social security reforms in the Netherlands, the Committee would like the Government to provide in its next report $[\ldots]$ an in-depth explanation of its strategy and reform policies, highlighting the principles on which the new design of the sickness and disability schemes is based, the difficulties encountered in the reform process and the major decisions handed down in this respect by courts of law and other tribunals." 351

From this observation, it is clear that the CEACR still views the State as the ultimate body which is responsible for implementing social security obligations under Convention No. 102 even though some of its tasks have been delegated to privatized service providers. Additionally it would appear that the CEACR expects that a privatized system of social security should also be subject to decisions "handed down by courts of law and other tribunals."

\subsubsection{Privatization and the prohibition of discrimination at work}

The CEACR has also investigated allegations relating to discrimination practices during the privatization process of a number of public utilities in Brazil in the framework of Convention No. 111 on discrimination in employment or occupation. The allegations were made by a number of Brazilian trade unions during the discussion of a periodic report of Brazil in 1997. According to the trade unions,

to the private sector in the hope that competition and the responsibility of private employers would help restrain the influx of workers to costly social security schemes. Ibid. In the last ten years, the number of workers making use of sickness and disablement benefits has increased enormously placing the Dutch social security system under great financial strain. 
representatives of one of the financial groups involved in the privatization of the electricity sector requested the identification of workers who are black, HIV positive, homosexual or who suffer from physical handicaps and who were working at one of the companies that had been privatized. ${ }^{352}$ The trade unions considered this to be discriminatory and wanted support in stopping similar conduct during the privatization process. The government noted that such information had not been requested and that such information as was requested did not appear in the workers' forms. Additionally, the company that had allegedly requested the information denied ever having made such a request. This led the CEACR to conclude that the lack of evidence did not support the allegation that there had been discriminatory conduct contrary to the Convention. 353

\subsubsection{Privatization and employment injury benefits}

During the examination of a report presented by Venezuela in 1997 on Convention No. 121 dealing with employment injury benefits, ${ }^{354}$ the CEACR has expressed concern about the apparent absence of a legal guarantee in Venezuelan legislation for victims of industrial accidents. According to the Committee, such a guarantee is demanded by Convention No. 121 and may become particularly important in view of the restructuring of the Venezuelan social security system and the potential privatization of some medical care services. ${ }^{355}$ Although it is not clear in which ways the Committee envisages what the importance is of legal guarantees for awarding

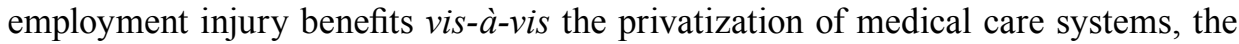
Committee did urge the government to take the necessary measures to expressly specify in the legislation the types of medical care provided by the Venezuelan social security system to insured persons. The types of medical care referred to should at least include those mentioned in Article 10, paragraph 1 of Convention No. 121. In this context, it can be presumed that the Committee is concerned that the privatization of certain medical care services could exclude workers who were injured as a result of an industrial accident from benefiting from these services.

\subsubsection{Privatization and employment}

Arguably, one of the biggest complaints against privatization has been its alleged effect on employment. Workers' unions and researchers have constantly emphasized

\footnotetext{
352 CEACR: Individual Observation concerning Convention No. 111, Discrimination (Employment and Occupation), 1958 Brazil (ratification: 1965) Published: 1997, para. 1.

353 Ibid.

354 Convention No. 121 specifies the types of medical care that should be available to workers in case of industrial accidents or occupational diseases and covers the situations under which such benefits should be awarded.

355 CEACR: Individual Observation concerning Convention No. 121, Employment Injury Benefits, 1964 Venezuela (ratification: 1982) Published: 1997, para. 4.
} 
the dangers that privatization might bring to employment. ${ }^{356}$ Privatization, they claim, entails massive lay-offs with the resulting unemployment. Although the jury is still out on whether privatization has indeed led to massive unemployment, ${ }^{357}$ the ILO has given special attention to this issue in view of Convention No. 122 on Employment Policy. The CEACR's preoccupation with the subject stems from its fears that structural adjustment measures such as privatization could have a detrimental effect on employment. This has moved the Committee to seek information from the State parties to Convention No. 122 regarding the nature and effects of the adjustment measures. In turn this information has led the Committee to observe that under Convention No. 122, the State has certain obligations to consult those sectors in which the effects of these policies will be felt before taking the measures, to assess the effects and take them into consideration before applying the policies and to take the necessary steps to ameliorate those effects.

One of the first occasions on which the CEACR was confronted with this issue arose during the examination of Zambia's report in 1993. Responding to Zambia's comment that envisaged privatization measures leading to the eventual creation of jobs, the Committee requested additional information from Zambia regarding whether the effects of structural adjustment policies on employment had been taken into account. ${ }^{358}$ The Committee further noted that according to Article 2 of Convention No. 122, “[...] the measures to be taken in order to attain employment objectives should be placed 'within the framework of a coordinated economic and social policy." ${ }^{359}$ In its follow-up to this report, the CEACR observed that Zambia

356 See for example NGO report by D. MacCuish, "Water, Land and Labour: The Impacts of Forced Privatization in Vulnerable Communities," Halifax Initiative Coalition and The Social Justice Committee available at $<$ www.halifaxinitiative.org $>$.

357 See S. Kikeri, "Privatization and Labor: What Happens to Workers When Governments Divest?," World Bank Technical Paper No. 396, WTP396, The World Bank, Washington D.C., (1998); N. Birdsall and J. Nellis, "Winners and Losers: Assessing the Distributional Impact of Privatization," World Development Vol. 31 (2003), p. 1622-1623.

358 CEACR: Individual Observation concerning Convention No. 122, Employment Policy, 1964 Zambia (ratification: 1979) Published: 1993, para. 2. A similar request was made to Algeria, where the Committee wanted to know the effects on growth and employment of structural adjustment programs applied with the support of the IMF and World Bank, following Algeria's contention that privatization will allow the country to maintain present employment. See CEACR: Individual Observation concerning Convention No. 122, Employment Policy, 1964 Algeria (ratification: 1969) Published: 1996, para. 2. In the observations to Algeria's report in 1998 the Committee once more asked the Algerian Government how it envisaged the impact on employment of implementing its privatization program. CEACR: Individual Observation concerning Convention No. 122, Employment Policy, 1964 Algeria (ratification: 1969) Published: 1998, para. 2.

359 Ibid. The Committee made a similar observation during the examination of Uganda's report in 1996 where the perceived acute problems of unemployment and poverty in the context of privatization, the liberalization of the economy and other structural adjustment policies were noted. See CEACR: Individual Observation concerning Convention No. 122, Employment Policy, 1964 Uganda (ratification: 1967) Published: 1996, para. 3. 
had provided some information regarding privatization legislation but had not answered its previous request for information on how this legislation would affect production and employment. ${ }^{360}$ Furthermore, the Committee was alarmed at the Government's assessment that the economic stabilization policies would have negative consequences on the population, although the Government did not specify which measures it had take to ameliorate these effects. Additionally, the Committee of Experts noted that according to a World Bank report the structural adjustment measures envisaged by Zambia would initially increase unemployment and decrease the standard of living of the poorest sectors of the population. This contrasted with Zambia's initial optimistic observation regarding the possible positive effects of privatization on the creation of jobs. In this regard the Committee asked the Government to "[...] indicate in its next report the measures taken to evaluate the effect on employment of adjustment policies and to mitigate their social repercussions so as to ensure that the social costs and benefits are fairly distributed." 361

In its examination of other country reports, the Committee has also adopted the view that consultation with the potentially affected sectors is essential when governments plan to adopt economic reform measures such as privatization. During the examination of a German report on the implementation of Convention No. 122, the CEACR requested information on the contribution of privatization, among other economical policies, to the realization of the employment objectives set out in Article 1 of the Convention. Additionally, it asked whether the effects of these policies on employment was taken into account when applying them and the manner in which the Government consulted with representatives of the persons affected by the economic policies and how they cooperated in their implementation. ${ }^{362}$ While examining the Turkish report in 1994, the Committee noted that Turkey's privatization plans would result in the abolition of 230,000 jobs over a period of five years and asked the State to provide information with regards to the measures taken to ensure that the workers made redundant by these

360 CEACR: Individual Observation concerning Convention No. 122, Employment Policy, 1964 Zambia (ratification: 1979) Published: 1995, February, para. 1.

361 Ibid., para. 2. In a latter report, the Committee of Experts noted that studies had been commissioned to assess the impact of privatization on employment in Zambia and requested the Government provide their conclusions as soon as possible. It also trusted that Zambia would keep close contact with the ILO to consier the measures needed in the light of Convention No. 122. See CEACR: Individual Observation concerning Convention No. 122, Employment Policy, 1964 Zambia (ratification: 1979) Published: 1997, para. 2.

362 CEACR: Individual Observation concerning Convention No. 122, Employment Policy, 1964 Germany (ratification: 1969) Published: 1993, para. 4. During the examination of other reports in which privatization policies were being discussed, the Committee has reiterated "[...] its hope that that the representatives of the persons affected by the employment reduction measures will be consulted, within the meaning of the Convention, and will be involved in the consultation referred to by the Government in its report." See CEACR: Individual Observation concerning Convention No. 122, Employment Policy, 1964 Ecuador (ratification: 1972) Published: 1996, para. 3. 
plans were redeployed in productive jobs. ${ }^{363}$ In its follow-up report, Turkey mentioned that the Turkish Privatization Act provided for indemnities for workers who had been laid off as a result of privatization and that the government was implementing policies, such as vocational trainings, and seeking resources to create new jobs for them. In this regard, the CEACR recalled that, "[...] it is essential for redundancies in the public sector to be accompanied by effective measures to promote the employment in the private sector of the workers made redundant as a result of privatization." ${ }^{364}$

Other general requests for receiving information related to whether employment was taken into consideration while applying or devising privatization programs, the probable impact on employment of these programs and whether those affected by them were consulted prior to and during their implementation were submitted during the examination of reports by Germany, ${ }^{365}$ Morocco, ${ }^{366}$ Peru $^{367}$ and Slovenia. ${ }^{368}$

363 CEACR: Individual Observation concerning Convention No. 122, Employment Policy, 1964 Turkey (ratification: 1977) Published: 1994, para. 3.

364 CEACR: Individual Observation concerning Convention No. 122, Employment Policy, 1964 Turkey (ratification: 1977) Published: 1996, para. 3. Subsequent observations to Turkey's reports related to Convention No. 122 called for additional information about the success and effectiveness of the measures encouraging employment among the workers affected by privatization efforts. See CEACR: Individual Observation concerning Convention No. 122, Employment Policy, 1964 Turkey (ratification: 1977) Published: 1998, para. 3 and CEACR: Individual Observation concerning Convention No. 122, Employment Policy, 1964 Turkey (ratification: 1977) Published: 2000, para. 4.

365 CEACR: Individual Observation concerning Convention No. 122, Employment Policy, 1964 Germany (ratification: 1971) Published: 1999 paras. 1 and 2.

366 See CEACR: Individual Observation concerning Convention No. 122, Employment Policy, 1964 Morocco (ratification: 1979) Published: 1998, para 2 and CEACR: Individual Observation concerning Convention No. 122, Employment Policy, 1964 Morocco (ratification: 1979) Published: 2000.

367 See CEACR: Individual Observation concerning Convention No. 122, Employment Policy, 1964 Peru (ratification: 1967) Published: 1999, para. 8 and CEACR: Individual Observation concerning Convention No. 122, Employment Policy, 1964 Peru (ratification: 1967) Published: 2000 , para. 1. These observations followed allegations by trade unions on the dismissals in Peru's telecommunications sector following its privatization. In 2003, the Committee repeated its previous views with regards to Peru and added that, "[...] where privatization that might lead to dismissals is undertaken, account should be taken of the instruments on termination of employment adopted by the Conference in 1982 which aim to achieve a balance between protection of the worker in the event of redundancy and the necessary flexibility of the labour market." See CEACR: Individual Observation concerning Convention No. 122, Employment Policy, 1964 Peru (ratification: 1967) Published: 2003, para. 2.

368 CEACR: Individual Observation concerning Convention No. 122, Employment Policy, 1964 Slovenia (ratification: 1992) Published: 1998, para. 3. 
Chapter V

\subsection{ILO Bodies Dealing with complaints and allegations}

The ILO Constitution has established two types of procedures to investigate allegations of non-observance of ratified conventions in Articles 24 and 26 respectively. ${ }^{369}$ The representations and complaints procedures are not open to individuals claiming to be victims of violations, ${ }^{370}$ but are aimed at examining and securing solutions to general situations in which it is claimed that national law and practice do not comply with ratified ILO conventions. The ILO Governing Body is entrusted with dealing with representations and has coped with a number of representations in which privatization of public companies or services has been an issue. Because so far no complaints pertaining to privatization have been submitted under Article 26, this procedure will not be further discussed. ${ }^{371}$ Additionally, a specific complaints procedure has been established under the auspices of the ILO Governing Body and the UN Economic and Social Council to deal with specific allegations in the field of freedom of association. ${ }^{372}$ The body assigned to handle these complaints is the Committee on Freedom of Association. In the context of complaints arising out of situations in which the freedom of association was at stake, this Committee has made a number of observations related to privatization and its effect on this specific freedom.

\subsubsection{The ILO Governing Body}

Under Article 24 of the ILO Constitution, national and international employers' or workers' organizations may present a representation to the International Labor Office when it believes that '[...] any of the Members has failed to secure in any respect the effective observance within its jurisdiction of any Convention to which it is a party $[\ldots]^{373}$ The ILO's Governing Body may then decide to communicate the representation to the government against which it was filed and invite the government to submit a statement on the subject. In the event the Governing Body does not receive the government's statement or if the statement is not considered to be satisfactory, the Governing Body has the right to publish both the representation and the eventual statement made in reply to the representation. ${ }^{374}$ The ILO's

Samson and Schindler, "The Standard-Setting and Supervisory System of the International Labour Organisation," p. 203.

Ibid. Additionally according to Samson and Schindler, these procedures do not pronounce judgments on individual cases.

Article 26 of the ILO Constitution makes it possible for States party to a specific convention or for any delegate to the ILO Conference to submit a complaint when they are not satisfied of the effective observance of that convention by another State party that has also ratified the convention. See also Samson and Schindler, "The Standard-Setting and Supervisory System of the International Labour Organisation," p. 206.

Ibid., p. 209.

Article 24 ILO Constitution.

Article 25 ILO Constitution. 
Governing Body is entrusted with the appointment of tripartite committees, which in turn examine the substance of the representations.

In 1993, one of the tripartite committees set up by the Governing Body dealt with a complaint lodged against Poland for non-observance of Convention No. 122 on employment policy. The complaint alleged that the Polish government had remained idle and had not taken appropriate measures to curb unemployment that, according to the alleging trade unions, was affecting broad sectors of society. In its government's statement, the Polish government explained that a number of factors had caused a drop of demand for labor and had increased unemployment. These factors included market geared economic policies and privatization. In its concluding observations, the tripartite committee pointed to earlier conclusions by the CEACR regarding employment policy and concurred by noting that the consultation process envisaged by Convention No. 122 not only extended to employment policy questions in a narrow sense but also included other economic measures which have an effect on employment. ${ }^{375}$ Although not expressly stated, this comment would imply that privatization measures would also have to be subject for consultation with workers' organizations in the event these measures have an impact on employment.

Another representation made by a Latin American trade union in 1993 alleged that Peru was not fulfilling its obligations under Convention No. 102 on the minimum standards of social security, by restructuring and modifying the pension system, its funding and organization. ${ }^{376}$ This had particularly affected the fishing sector. Although the representation did not directly deal with privatization per se, the tripartite committee noted in its conclusions that the object of the complaint was part of the more general context of the privatization of the pension scheme, which Peru had established in 1992. ${ }^{377}$ The tripartite committee then drew attention to the conclusions of a previous CEACR report, which had already noted that the privatization of Peru's pension funds raised certain questions concerning the application of Convention No. 102. ${ }^{378}$

375 ILO Governing Body, Report of the Committee set up to examine the representation made by the All-Poland Trade Union Alliance (OPZZ) under article 24 of the ILO Constitution alleging non-observance by Poland of the Employment Policy Convention, 1964 (No. 122), (GB.265/12/5), 1993, para. 40.

376 ILO Governing Body, Report of the Committee responsible for examining the representation made by the Latin American Central of Workers (CLAT) under article 24 of the ILO Constitution alleging non-observance by Peru of the Social Security (Minimum Standards) Convention, 1952 (No. 102), (GB.264/16/6), 1994. Ibid., para. 31.

378 Ibid. In any event, the tripartite committee closed the representation's procedure after concluding that Convention No. 102 expressly excluded the fishing sector from its scope. 
Chapter V

\subsubsection{Committee on Freedom of Association}

The ILO's Governing Body established the Committee on Freedom of Association in 1951 to assist a Fact-Finding and Conciliation Commission which had been previously created to deal with cases on the freedom of association. ${ }^{379}$ However, the Committee quickly took over the tasks of this Commission regarding the examination of the substance of complains related to the freedom of association. Similar to other ILO organs, the Committee is a tripartite body that proceeds on the basis of documents submitted by parties to a case (the complaints can be submitted by governments or employers' or workers' organizations having an interest in the case). ${ }^{380}$ The Freedom of Association Committee's decisions concerning privatization can be divided into three general categories. These concern the direct and indirect effects of privatization on job dismissals and anti-union discrimination, on the suspension of collective agreements and the duty to consultation, and on the restrictions on the right to strike or bargain collectively. These categories are not strict and may at times be interrelated with each other.

\subsubsection{Privatization, job dismissals and anti-trade union discrimination}

As noted above, the ILO has shown grave concern about the effects of privatization on employment. The Committee on Freedom of Association has examined a number of allegations dealing with job dismissals and anti-trade union discrimination that have directly or indirectly been the result of privatization measures. In 1989, a complaint submitted by a trade union in the Philippines alleged that a governmental decision to privatize a number of government owned enterprises, including a hotel, violated trade union rights and the right to self-organization and collective bargaining. ${ }^{381}$ The complaint noted that the privatization decision allowed for the automatic dismissal of employees at those enterprises without the assurance that they would be rehired. This mass dismissal violated a previously arranged collective agreement and in the words of the Committee, virtually busted the trade union. ${ }^{382}$ The government claimed however, that its decision was not contrary to Conventions No. 87 and 95 on the freedom of association. After dismissing the government's preliminary objections the Committee argued that the government was incorrect in assuming that the privatization decision did not violate the Conventions on freedom of association. The Committee noted that the government's intention was to

\footnotetext{
379 Samson and Schindler, "The Standard-Setting and Supervisory System of the International Labour Organisation,” p. 209-210.

380 Ibid., p. 210. Interestingly enough, the States which are subject to a complaint, are not required to have ratified a particular ILO convention related to the freedom of association.

381 Committee on the Freedom of Association, Complaint against the Government of the Philippines presented by the National Federation of Labor (NFL), report no. 268, case no. 1495, (Vol. LXXII, 1989, Series B, No.3), paras. 216-224. Ibid., para. 241.
} 
streamline its functional structures and that economic factors such as the financial costs incurred by a great number of government-owned or controlled corporations running at a loss were behind the privatization decision. The Committee nevertheless concluded, "[...] that this action removed the possibility of collective bargaining and led to the disappearance of the union." 383 The Committee observed that this was not a side effect of the privatization, but that the privatization decision had not spelled out the successor rights of workers and had given full and absolute discretion to the new owners of the privatized enterprises to fire and hire. This had the effect of ignoring the trade union and the collective agreement. The Committee regretted that the government had allowed this situation to arise and noted that under Convention No. 98 the obligations of the government to protect unions from anti-union discrimination not only extends to direct acts of discrimination but also to subtle acts resulting from omissions. It then went to request the Government to consider revising the privatization decision or to introduce, "[...] a successor rights and duties clause in the transfer documents made under it, with a view to ensuring that, in the future, proprietorial changes will not remove the right to collective bargaining from employees, or directly or indirectly threaten unionised workers and their organisations." 384 Accordingly, in its recommendations, the Committee on the Freedom of Association requested that appropriate measures be taken into consideration to mitigate the effects of privatization on the rights of workers and trade unions and to redress those workers who have been affected by the mass dismissals. ${ }^{385}$ The Committee confirmed this view in a complaint filed against Nicaragua. ${ }^{386}$

In another complaint filed in 1993 against Peru, a number of Peruvian, Latin American and international trade unions complained inter alia about the discriminatory dismissal of trade union leaders. This dismissal took place in the context of the privatization of a state owned enterprise carried out within the framework of a state enterprise privatization policy. ${ }^{387}$ The government pointed out that a legislative decree had been created for this purpose and that it encouraged the adoption of a program for voluntary reduction of staff. After the expiration of a certain period of time, the enterprise was then allowed to seek permission to dismiss surplus staff. According to the government, workers who felt that they had been wrongly dismissed could bring an action to counter the dismissal before national courts. After affirming that the dismissals stem from the implementation of

\footnotetext{
383 Ibid., para. 242.

384 Ibid., para. 244.

385 Ibid., paras. 246-247.

386 Committee on the Freedom of Association, Complaint against the Government of Nicaragua presented by the the "Nora Astorga" Trade Union, report no. 286, case no. 1673, (Vol. LXXVI, 1993, Series B, No. 1), para. 150.

387 Committee on the Freedom of Association, Complaints Against The Government Of Peru Presented By - General Confederation Of Workers Of Peru (Cgtp) et.al., report no:291, case(s) No(s). 1648,1650, (Vol.LXXVI, 1993, Series B, No.3), paras. 439 and 447.
} 
rationalization and staff reduction programs within the framework of a state enterprise privatization policy in Peru, the Committee regretted that, "the rationalization and staff reduction process did not involve any negotiations between the enterprise and the trade union organizations, and that the Government preferred to proceed unilaterally in this matter by decree." ${ }^{388}$ It then requested the government of Peru to allow negotiations to take place between the enterprises concerned and the trade unions when it deemed it necessary to apply staff reduction programs.

With regards to the grounds of dismissal during privatization processes, the Committee has taken the view that dismissals based on economic necessity do not authorize acts of anti-trade union discrimination. ${ }^{389}$ Additionally, measures to ensure the effective protection of workers' representatives should be adopted. This includes shifting the burden of proof that such a dismissal was indeed necessary to the privatizing entity. The Committee has also indicated that its mandate encompasses the examination of infringement of trade union rights and as such, "[...] it can express its opinions on restructuring programmes, which may or may not involve staff reductions, only to the extent that they may have given rise to acts of anti-trade union discrimination or interference." 390

Ibid., para. 271.

Committee on the Freedom of Association, Complaint against the Government of Hungary presented by the National Federation of Workers' Councils (MOSZ), report no. 294, case no. 1742, (Vol. LXXVII, 1994, Series B, No. 2), para. 517 and 518. In this complaint members of a workers' council in Hungary had been dismissed on the grounds of redundancy due to privatization and were additionally barred from initiating legal proceedings against the dismissals. A similar view was taken in a complaint against Argentina, which tried to justify the suspension of a number of collective agreements due to the necessity of privatizing certain sectors. The Committee on the Freedom of Association noted again that economic requirements do not justify the suspension and derogation of collective agreements in force as this would violate the principle of free and voluntary collective bargaining enshrined in Article 4 of Convention No. 98. See Committee on the Freedom of Association, Complaint against the Government of Argentina presented by the General Confederation of Labour of the Argentine Republic (CGT) and the International Confederation of Free Trade Unions (ICFTU), report no. 292, case no. 1684 (Vol.LXXVII, 1994, Series B, No.1). See also a recent case against Peru, in which employees working at a telecommunications company were dismissed during the privatization and restructuring process of the company and also following strikes against these policies. The Committee on the Freedom of Association reaffirmed that dismissals of workers because of a strike, which is a legitimate trade union activity, constitutes serious discrimination in employment and contrary to Convention NO. 98. See Committee on the Freedoms of Association, Complaints against the Government of Peru presented by the Peruvian General Confederation of Workers (CGTP), the Peruvian Unitary Confederation of Workers (CUT) and the International Confederation of Free Trade Unions (ICFTU), report no. 334, case No. 2211 (Vol. LXXXVII, 2004, Series B, No. 2), para. 678.

390 Committee on the Freedom of Association, Complaint against the Government of Colombia presented by the General Confederation of Labour (CGT), the Latin American Central of Workers (CLAT) and the World Confederation of Labour (WCL), report no. 292, case(s) no(s). 1620, 1702, (Vol.LXXVII, 1994, Series B, No.1), para. 280. 
The Committee has also spelled out that trade union leaders deserve special protection from dismissals, which also arise out of privatization. In another complaint against Peru, the Committee recalled its previous case law and stated that during a staff reduction process carried out in the context of privatization workers and particularly, trade union officials should also enjoy adequate protection against all acts of anti-union discrimination in respect of their employment. ${ }^{391}$ This includes protection against dismissal, demotion, transfer or other prejudicial measures. The special protection for trade union leaders or officials stems from the fact that they should "[...] be able to perform their trade union duties in full independence, [and] they should have a guarantee that they will not be prejudiced on account of the mandate which they hold from their trade unions." ${ }^{392}$ In this respect, the Committee requested Peru to ensure that, should new staff reduction programs become necessary, negotiations are held between the enterprise concerned and the trade union organizations involved and that these programs are not used to carry out acts of trade union discrimination.

The protection of trade union leaders against dismissals resulting from privatization is also reflected in a case against El Salvador. In this case, an international trade union representing a Salvadorian workers' organization contended that the dismissal of a number of trade union leaders was the result of the privatization of a telecommunications company. ${ }^{393}$ The Salvadorian government retorted that the dismissals were carried out by the new privatized telecommunications company in compliance with the obligations of the legislative act enabling the company's privatization. This included the payment of compensation for the dismissals of all the trade union leaders. The Freedom of Association Committee noted that 72 trade union leaders had been contracted by the new enterprise and subsequently dismissed on the grounds for termination of contract with liability for the employer as stipulated in the Salvadorian Labor Code. Furthermore, it observed that 70 of the 72 trade union leaders had accepted the compensation for their dismissal as required by the Labor Code and privatization Act. ${ }^{394}$ The Committee regretted these dismissals and, recalling its decision against the Philippines, ${ }^{395}$ observed that changes in the property status of an enterprise (from public to private through privatization) should not "[...] directly or indirectly threaten unionized workers and

391 Committee on the Freedom of Association, Complaints against the Government of Peru presented by the Trade Union of Workers of the Iron and Steel Plant of Peru (SIDERPERU), et. al., report no. 306, case no. 1796, (Vol. LXXX, 1997, Series B, No. 1), para. 506. For previous decisions on this issue see the ILO Digest of decisions and principles of the Freedom of Association Committee, $4^{\text {th }}$ edition, Geneva, 1996, para. 724.

392 Complaints against the Government of Peru, op cit., note 391.

393 Committee on the Freedom of Association, Complaint against the Government of El Salvador presented by Communications International (CI), report no. 313, case no. 1987, (Vol. LXXXII, 1999, Series B, No. 1).

394 Ibid., para. 114.

395 See Complaint against the Government of the Philippines, op.cit., note 381. 
their organizations." 396 Additionally, the Committee reminded El Salvador that according to previous decisions, measures should be taken to ensure the effective protection of trade union leaders with regard to their retention in employment in case of reduction of the workforce. Nevertheless, the Committee decided not to examine the dismissal of the 70 workers who had received the legal compensation and went on to shortly discuss the case of the two workers' representatives who had not accepted it. The Committee requested the government of El Salvador to take the steps to reinstate both trade union leaders and, "[...] to guarantee that in future proprietorial changes that occur in the framework of privatization do not directly or indirectly threaten unionized workers and their organizations." 397

Other examples of anti-trade union discrimination and dismissals as a result of privatization can be seen in a complaint against Japan. ${ }^{398}$ In this case, a number of railway trade unions alleged that following the decision to privatize the Japanese national railways, the succeeding companies declined to hire many of the trade union members on the basis of their trade union membership. Additionally, these workers were subsequently redeployed and dismissed. After confirming that the dismissals and discrimination arose within the context of privatization of the railway system, the Freedom of Association Committee recalled that, "[...] it can examine allegations concerning economic rationalization programmes and restructuring processes, whether or not they imply redundancies or the transfer of enterprises or services from the public to the private sector, only in so far as they might have given rise to acts of discrimination or interference against trade unions." ${ }^{399}$ The Committee noted Japan's efforts to solve the problem, but urged it to actively encourage the privatized enterprises and the workers' organizations to reach a rapid negotiated solution which would also ensure that the workers concerned were fairly compensated. ${ }^{400}$ It is worth observing that, compared to the decision in the case of Colombia, ${ }^{401}$ the Committee expressly stated that it will

\footnotetext{
396 See Complaint against the Government of El Salvador, op.cit., note 396, para. 115.

397 Ibid., para. 116.

398 Committee on the Freedom of Association, Complaint against the Government of Japan presented by the Japanese National Railway Workers' Union (KOKURO) and the All National Railway Locomotive Engineers' Union (ZENDORO), report no. 318, case no. 1991, (Vol. LXXXII, 1999, Series B, No. 3).

399 Ibid., para. 266. See also Committee on the Freedom of Association, Complaint against the Government of Peru presented by the General Confederation of Workers of Peru (CGTP), et al., report no. 323, case no. 2049, (Vol. LXXXIII, 2000, Series B, No. 3), where the Committee reaffirmed this decision in the context of the duty to consultation of a government with trade unions in the process of rationalization and staff-reduction programs arising out of privatization.

400 This request was once more made in a follow-up complaint. See Committee on the Freedom of Association, Complaint against the Government of Japan presented by the Japanese National Railway Workers' Union (KOKURO) and the All National Railway Locomotive Engineers' Union (ZENDORO), report no. 318, case no. 1991, (Vol. LXXXIII, 2000, Series B, No. 3).

401 See Complaint against the Government of Colombia, note 390, supra.
} 
revise anti-union discrimination practices with regard to dismissals in privatization situations, thus clarifying the Committee's role in this respect. In other similar cases, the Committee has confirmed this view although it has not always come to the conclusion that anti-trade union discrimination behavior was present. ${ }^{402}$

\subsubsection{Privatization measures, the suspension of collective agreements and the duty to consult}

Similarly, in an allegation involving the suspension of collective agreements by the Argentine government, the Committee rejected the government's arguments that the suspension had been justified on grounds of previous legislative acts that had subjected a number of sectors to privatization. ${ }^{403}$ According to the Committee, legislation that requires the renegotiation or derogation of collective agreements in force for reasons of economic crisis violates the principles of voluntary collective bargaining as protected by Article 4 of Convention No. 98.404 According to the Committee, a government attempting to bring economic policies such as privatization in line with collective agreements must seek to persuade the parties involved to voluntarily reconsider the agreements.

The Committee confirmed this last observation in a later case involving the refusal of the government of Congo to engage in dialogue with trade unions in order to discuss issues related to privatization. ${ }^{405}$ In this case, the Committee recalled the willingness of a number of Congolese trade unions to accept the privatization of a number of public sector enterprises and their efforts to set up a coordinating committee with the aim of discussing with the government the impact of the privatization measures. Since the government did not react to these efforts, the trade unions called for a strike, leading the government to take measures such as forced dismissals of workers involved in the strike, the arrest of certain trade union leaders and their subsequent sentencing to imprisonment and imposition of fines. In its conclusions and recommendations, the Committee pointed out to ILO Recommendation 113 concerning the consultation and co-operation between public

402 See f.e., Committee on the Freedom of Association, Complaint against the Government of Uganda presented by the International Textile, Garment and Leather Workers' Federation (ITGLWF), report no. 316, case no. 1996, (Vol. LXXXII, 1999, Series B, No. 2), para. 665.

403 Committee on the Freedom of Association, Complaint against the Government of Argentina presented by the General Confederation of Labour of the Argentine Republic (CGT) and the International Confederation of Free Trade Unions (ICFTU), report no. 292, case no.1684, (Vol. LXXVII, 1994, Series B, No.1).

404 Ibid., para. 126 and 127, quoting from a previous case involving Nicaragua.

405 Committee on the Freedom of Association, Complaint against the Government of Congo presented by the International Confederation of Free Trade Unions (ICFTU), report no. 305, case no. 1870, (Vol. LXXIX, 1996, Series B, No. 3). 
authorities and trade unions. ${ }^{406}$ In this context, the Committee remarked that measures aimed at restructuring the public sector and especially privatization, have undeniably a considerable impact on social and trade union matters. ${ }^{407}$ This makes it necessary for the public authorities to consult with the social partners on the social impact of these measures. The Committee then added that,

\begin{abstract}
"[...] in view of the impact that privatization measures in certain public sector enterprises and, in general, government structural adjustment and privatization policy can have on working conditions, the Committee would emphasize the importance that it attaches to the effective promotion of consultation and cooperation between public authorities and workers' organizations in this area, in accordance with the principles laid down in Recommendation No. 113, with the aim of joint consideration of matters of mutual concern with a view to arriving, to the fullest possible extent, at agreed solutions." ${ }^{308}$
\end{abstract}

The Committee then went on to reaffirm the right to strike as a way of supporting the position of workers in their search for solutions to problems and impact that economic measures have on workers' employment, social protection and the standard of living. ${ }^{409}$ The Committee finally requested the Government of Congo to keep it informed of the developments in this area.

In 2005, the Committee on the Freedom of Association stated that it can examine complaints related to economic policies such as privatization if they result in acts that discriminate and interfere against trade unions. In a case against Canada, a trade union alleged that legislation adopted to privatize a ferry service also allowed the cancellation of already existing collective agreements without consultation. ${ }^{410}$ The Committee firstly recalled that "[...] it can examine allegations concerning economic rationalization programmes and restructuring processes, whether or not they imply the transfer of enterprises or services from the public to the private sector, only in so far as they might have given rise to acts of discrimination and interference against trade unions." 411 After confirming that the provision in the

406 This recommendation urges both parties to discuss matters of mutual concern in order to reach to an agreement on possible solutions to problems. It also attempts to ensure that public authorities seek the views, advice and assistance of workers organizations when preparing legislation and its implementation, which could have an effect on the interests of workers. Complaint against the Government of Congo, op.cit. note 405, para. 142.

408 Ibid.

409 Ibid., para. 143.

410 Committee on the Freedom of Association, Complaint against the Government of Canada concerning the Province of British Columbia presented by the National Union of Public and General Employees (NUPGE), on behalf of the BC Government and Services Employees' Union (BCGEU) and the Health Sciences Association of British Columbia (HSABC), supported by the Canadian Labour Congress (CLC) and Public Services International (PSI), report no. 336, case no. 2324 (Vol. LXXXVIII, 2005, Series B, No. 1).

411 Ibid., para. 280. 
ferry privatization legislation that allowed the government to modify an existing collective agreement unilaterally was contrary to the principles of collective bargaining, the Committee stressed the importance of consultation in such cases. It then requested the government of Canada " [...] to refrain in future from cancelling through legislation existing provisions in negotiated collective agreements, and to undertake meaningful and adequate consultations when preparing and adopting legislation affecting the rights of workers." ${ }^{.12}$

\subsubsection{Privatization and restrictions on the right to strike or bargain collectively}

The Committee has also pronounced on the restriction of the right to strike in the public sector, which could have effects on the rights of workers in public services being privatized. In a complaint filed against Colombia, a trade union alleged that in instances where a policy of privatization and adjustment was carried out, trade union activity was being subject to a 'scorched earth' policy. ${ }^{413}$ This included a restriction of the right to strike. The Committee noted that as it had previously pointed out in various cases, "[...] the right to strike may only be restricted [...] or prohibited in essential services in the strict sense of the term, i.e. those services whose interruption would endanger the life, personal safety or health of the whole or part of the population." 414 The Committee went on to note that in Colombia, the prohibition to strike extended not only to essential services in the strict sense of the term, but to a wide range of the public services which are not necessarily essential, thus including some which have also been privatized. It then recommended the government to ensure that future legislation will respect the principles of freedom of association especially with regard to the right to strike and that its restriction should only take place on the grounds mentioned above. The European Committee on Social and Cultural Rights appears to have taken a similar view with regards to services that have also undergone privatization, but are not considered to be essential (postal and railway services). As observed above, according to the ECSC these privatized service providers should be allowed to strike. ${ }^{415}$

The prohibition to strike with regard to essential services that have been privatized was also an issue in a dispute between a trade union representing prison officers and the United Kingdom. ${ }^{416}$ In this case, the union complained that a statutory

\footnotetext{
412 Ibid.

413 Committee on the Freedom of Association, Complaint against the Government of Colombia presented by the the General Confederation of Labour (CGT) and the Latin American Central of Workers (CLAT), report no. 286, case no. 1620, (Vol. LXXVI, 1993, Series B, No. 1), para. 372.

414 Ibid., paras. 380 and 384.

415 See Section 3.3.2 above.

416 See Committee on the Freedom of Association, Complaint against the Government of United Kingdom presented by the Prison Officers' Association (POA), report no. 336, case no. 2383 (Vol. LXXXVIII, 2005, Series B, No. 1).
} 
provision in that country prohibited prison officers from striking on the basis that they exercise authority in the name of the State. The union argued that this prohibition constituted a breach of the right to strike since these officers did not exercise authority in the name of the State and did not provide essential services in the strict sense of the term. ${ }^{417}$ This applied to prison and custody officers working for publicly managed prisons as well as for privatized prisons. ${ }^{418}$ In addition, they argued that no adequate compensatory measures had been put in place whereby prison officers or their union (in particular with regard to privatized prisons) can ensure that their interests are protected in the absence of a right to strike. The Government replied that there could be no doubt that prison officers exercised authority in the name of the State due to the nature of the functions they perform and the special powers and protection which have been conferred on them so that they can carry out their work. The Government added that there was no material distinction in this regard between publicly employed prison officers and custody officers employed by private sector companies to whom certain of the functions of the prison service have been contracted out, since both are able to take decisions which affected the activities, the liberty and the other rights and privileges of prisoners, including decisions about discipline. ${ }^{419}$

Ibid., para. 725 .

According to the complainants custody officers employed by private companies do not exercise authority in the name of the State but rather owe their duty of loyalty to their employer, take their instructions from their employer and act in the name of their employer. "They are not public employees, and they are not subject to the Code of Discipline which applies to public sector prison officers, nor do they have the powers of a constable which are afforded to public sector prison officers." Ibid., para. 728. In addition according to the complainants prison officers in the public sector "[...] do not exercise authority in the name of the State: first, because they perform the same work as private sector prison officers and it would be anomalous to treat one group as exercising authority in the name of the State and the other as not doing so; second, they are not in a position to take decisions on behalf of the State but simply to be carrying out public functions. Prison officers are under a strict code of discipline, and are under the orders of the prison governor but do not actively exercise authority in the sense of making decisions on behalf of the State." Ibid., para. 729.

Ibid., para. 746. According to the Government custody officers working for privatized prisons had been endowed with special powers akin to those of public prison officers through a statute. These powers included "[...] powers to search the prisoner, to prevent his escape from lawful custody, to ensure good order and discipline on his part and to give effect to any directions as to the prisoner's treatment which are given by a court. They also have duties to prevent or detect crime by prisoners as well as to attend to their well-being. Prisoner custody officers have the right to use reasonable force where necessary and they are also given special protection by the criminal law against assault by prisoners and wilful obstruction. Thus, the Government concludes both prison officers employed by the Crown and prisoner custody officers employed by a private sector company exercise authority in the name of the State and have special powers and protections conferred on them by the law in order to do so. It is quite apparent that prison officers do take "decisions on behalf of the State" - a criterion used by the complainant in its submissions - as they are responsible for making decisions which affect the activities, the liberty and the other rights and privileges of prisoners, including decisions about discipline." Ibid., para. 748 . 
In its conclusions the Committee reiterated its previous findings stating the right to strike may be restricted or prohibited, "(1) in the public service only for public servants exercising authority in the name of the State; or (2) in essential services in the strict sense of the term (that is, services the interruption of which would endanger the life, personal safety or health of the whole or part of the population)." ${ }^{\prime \prime 20}$ According to the Committee, prison and custody officers working for public and privatized prisons fulfilled both alternate requirements. In the first place the Committee considered that officials working in the administration of justice are officials who exercise authority in the name of the State. Thus, to the extent that prison officers and prisoner custody officers working for privatized prisons exercise authority in the name of the State the limitations on the right to strike applied to them. ${ }^{421}$ In the second place, after recalling that essential services are those services whose interruption would lead to a clear and imminent threat to the life, personal safety or health of the whole or part of the population, the Committee concluded that the prison service is such a service. According to the Committee, "[...] the prison service is clearly one where the interruption of the service could give rise to an imminent threat to the life, personal safety or health of the whole or part of the population, in particular, the prisoners and the wider public." ${ }^{322}$ Thus, the right to strike could be limited or even prohibited on both grounds with regard to custody officers of privatized prisons. Having concluded this, however, the Committee recalled that where this right is restricted or prohibited in certain essential undertakings or services, adequate protection should be given to the workers to compensate for the limitation thereby placed on their freedom of action with regard to disputes affecting such undertakings and services. The Committee then requested the United Kingdom government to adopt the necessary measures "[...] so as to establish appropriate mechanisms in respect of prisoner custody officers in private sector companies to which certain of the functions of the prison have been contracted out so as to compensate them for the limitation of their right to strike, and to keep it informed in this respect." ${ }^{\prime 43}$

The conclusions of this case are interesting for a number of reasons. Firstly, there is the fact that under certain circumstances privatization of certain services does not preclude a legitimate limitation of certain rights of employees of those services. Thus, the right to strike of employees working for privatized enterprises may be restricted, albeit only in so far as the services provided by them are essential, or in the case they exercise authority in the name of the State. Secondly, it is interesting to note that the type of function and the nature of the service are relevant for determining whether a particular (private) entity can be equated to a purely public one for the purposes of applying a limitation on the right to strike (which arguably

\footnotetext{
$420 \quad$ Ibid., para. 759.

421 Ibid., para. 763.

422 Ibid., para. 766.

423 Ibid., para. 769.
} 
usually applies to public bodies). This lends more evidence to the assertion presented in Chapter IV that privatized bodies can be considered as a special type of public body and as such can be held directly accountable for human rights abuses in a similar fashion as 'traditional' public bodies.

In addition to dealing with cases related to the right to strike in the context of privatization, the Committee on the Freedom of Association has also addressed cases about how legislation that involves privatization may hamper the right to bargain collectively. For example, in a complaint against Peru, the Committee observed that legislation which prevented property, stocks, shares and rights of state enterprises undergoing privatization being the object of provisional measures ordered by judges or arbitration tribunals in labor cases could make it possible for these enterprises to avoid complying with previously established collective agreements. The Committee thus recommended Peru to take the necessary measures to ensure that such legislation could not be invoked to prevent judicial proceedings. ${ }^{424}$ This decision also reflects the Committee's position that proper judicial remedies should be available in the event of privatization measures.

Another way to restrict the right to bargain collectively has been through the dissolution of a trade union during or following the process of privatization. This was the case of a Thai trade union operating in a State company that was privatized. According to the trade union, the change of status of the company from public to private prevented the union from bargaining collectively since the company's management refused to deal with the union until it was clear whether the company had ceased to be a State enterprise and whether the union was allowed to submit collective demands. ${ }^{425}$ Moreover, following the privatization the Minister of Labor dissolved the trade union after the Thai Council of State argued that the trade union no longer fell under the legislation for trade unions operating in State owned companies. ${ }^{426}$ The Thai government confirmed that the conversion of the public company to a private enterprise automatically ended the union's status as a State enterprise trade union. This however did not prevent the old trade union from registering a new trade union under the normal labor relations legislation. The Committee observed that there had been some confusion as to the status of the

424 See Committee on the Freedom of Association, Complaint against the Government of Peru presented by the Trade Union of Workers of the Iron and Steel Plant of Peru (SIDERPERU), et. al., report no. 304, case no. 1796 (Vol. LXXIX, 1996, Series B, No. 2), para. 461.

425 Committee on the Freedom of Association, Complaint against the Government of Thailand presented by the Bangchak Petroleum Public Co. Ltd. Employees' Union (BCPEU), case no. 2181, report no. 329, (Vol. LXXXV, 2002, Series B, No. 3), para. 743-750.

According to the trade union this situation made it unclear whether previously reached collective agreements were still in force and whether the employer would take unilateral action to reduce wages and benefits without negotiating with the union. The trade union submitted that its right to exist should not be tied to the status of the employer as a public or private concern since its representational activities and duties had not changed in any way. Ibid. 
company (whether it was public or private) and that it was not for the Committee to determine the real status. Nevertheless, the fact remained that the trade union "[...] was dissolved, its registration was cancelled, it is prevented from bargaining collectively, the application of the previously negotiated agreement is unclear, and the representational gap may ultimately affect the working conditions of the workers." 427 After recalling that this amounted to grave infringements of the principles of freedom of association, ${ }^{428}$ the Committee requested the government to restore the legal personality and registration of the trade union even if it was necessary to transfer these rights under the legislation covering the privatized company. Additionally, the Committee remarked that "[i]n view of the serious consequences that the existing legislation may bring about for the existence of workers' organizations in such cases of conversion from state to private enterprise, the Committee requests the Government to take appropriate measures so that this situation will not arise again in future and trade union successors' rights are safeguarded." 429

The Committee has not only examined cases in which the curtailing of the right to bargain collectively occurs through State action, but also by privatized companies. In such a situation, the Committee has observed that the State remains responsible for protecting and ensuring the rights guaranteed in Conventions nos. 87 and 98 . The State also remains responsible for ensuring that these rights are respected by private parties. For example, the Committee has held that discrimination against trade union members after the privatization of an electricity company as well as the refusal of a privatized company to engage in collective bargaining with a trade union is contrary to Article 2 of Convention No. 87.430 In this respect, the Committee has noted that the State has to take the necessary measures to recognize the right of a trade union to represent its members and bargain collectively on conditions of work. ${ }^{431}$ Likewise the Committee has been of the opinion that under

427

\section{Ibid., para. 759.}

The Committee particularly noted that the dissolution of trade unions must only be resorted to in extremely serious cases and only following a judicial decision that fully guarantees the rights of defense and that a minister should not have the discretionary power to order the dissolution of a trade union without any right of appeal to the courts. Ibid., para. 760.

Ibid., para. 763.

Article 2 of Convention No. 87 guarantees the right of workers to join and establish the trade union of their own choosing.

Committee on the Freedom of Association, Complaint against the Government of Peru presented by the Unified Trade Union of Electricity Workers of Lima and Callao (SUTREL) and the General Confederation of Workers of Peru (CGTP), report no. 308, case no. 1926, (Vol. LXXX, 1997, Series B, No. 3), para. 628. In another recent case against Peru concerning a privatized electricity utility company that was involved in insolvency procedures, the Committee requested the government to ensure that the deduction of union dues is carried out by the company, as well as ensuring that wages, and other payments due to workers were paid. See Committee on the Freedom of Association, Complaint against the Government of Peru presented by the Federation of Peruvian Light and Power Workers (FTLFP), report no. 343, case no. 2452 (Vol. LXXXIX, 
the obligations of Articles 1 and 2 of Convention No. $98^{432}$ the State has to carry out an investigation into allegations of anti-union acts and interference against a trade union by a privatized company. ${ }^{433}$

\subsection{Preliminary conclusions}

In comparison with other human rights monitoring bodies, it is possible to state that privatization has received a surprisingly large amount of attention from the ILO, and arguably in a more systematic way. This could be partially attributed to the effects that privatization can have on the labor rights of those employees of enterprises or services that are being privatized. Thus, as illustrated by the various cases described in the previous paragraphs, privatization has been often used as an indirect excuse to curtail labor rights. Labor rights problems sometimes arise out of privatization directly. This is the case, for example, of forced dismissals as a result of privatization of companies, or the refusal by privatized companies to deal with trade unions. Anti-trade union discrimination, and measures or campaigns to promote the cancellation of trade union licensing can also result from privatization. Sometimes privatization has indirect consequences on the limitation of labor rights. This is the case when efforts to make privatization work 'effectively' lead to a restriction in labor rights without taking into consideration rights that were acquired prior to privatization and without consultation with trade unions or negotiation.

In general, the various monitoring mechanisms at the ILO's disposal have approached the problems that privatization can bring for the enjoyment of workers rights from a similar perspective as the United Nations human rights treaty monitoring bodies. Thus, the State remains responsible for implementing the rights enshrined in the numerous ILO conventions, and it cannot divest itself from the obligations ensuing from these conventions by contracting out certain tasks to private parties. However, the ILO has gone further than the UN in certain respects,

2006, Series B, No. 3), para. 1063. The Committee noted that this was necessary for enabling the workers to "[...] engage in collective bargaining and obtain union leave, which is extraordinarily important in the current insolvency proceedings affecting the enterprise." Ibid. It is worth noting that the trade union had claimed that the privatization process had been a failure, but the Committee did not go into that matter, just observing that the case occurred within the context of insolvency proceedings involving a privatized enterprise.

432 Articles 1 and 2 of Convention No. 98 entitle workers' organizations to an adequate protection against acts of anti-union discrimination in their enjoyment or against interference in their establishment, functioning or administration.

433 Committee on the Freedom of Association, Complaint against the Government of Peru presented by the Federation of Peruvian Light and Power Workers (FTLFP), report No. 308, case no. 1880, (Vol. LXXX, 1997, Series B, No. 3), para. 590. The anti-union and interference by the privatized company complained of consisted of making the granting of an open-ended contract conditional on worker's the resignation of his/her trade union membership, outright hostility towards the trade unions, obstruction of its activities and internal affairs. 
even though its monitoring bodies have not stated that privatization of services is contrary to any ILO obligation. The ILO's approach has been pragmatic, and although it has not provided extensive details about how a State has to manage privatization measures in order for them to be compatible with ILO's obligations, it has provided guidelines that correspond to the obligations arising out of the different conventions. Globally, the ILO has focused on the effects of privatization on the prohibition of forced labor (concerning privatized prisons), on the freedom of association and concomitant rights, on social security benefits for workers, and on the effects on employment.

With regard to the privatization of prisons, and following the provisions of Convention No. 29, the ILO has stated that the privatization of prisons does not allow the hiring of prisoners to work for or under the private prisons without their voluntary consent. Forced labor carried out for private parties breaches the obligations of Convention No. 29, even if a public authority supervises it. Additionally, even if prisoners of privatized prisons agree to work for the private prison or a third private party, they may do so only if certain requirements are met: working conditions, pay and social benefits should be similar to or approximate those offered in the private sector to normal workers.

With regard to the more classical labor rights such as the freedom of association, trade union liberties and the right to strike, the different ILO bodies have applied consistent standards. Privatization must not curtail labor rights ensuing from the freedom of association and the right to strike. The guarantees of, for example, Convention no. 87 on the freedom of association must be guaranteed. This entails that workers of privatized enterprises should not be deterred or debarred from continuing to be members of trade unions after privatization. Anti-trade union behavior and discrimination either from the part of the State or privatized companies lead to breaches of ILO obligations and entails that the State has the responsibility to take necessary measures to ensure that this behavior is stopped. This includes the restitution of trade union licenses, allowing workers of privatized services that do not exercise (public) authority or work for essential services to exercise the right to strike and to bargain collectively, the protection of trade union representatives, and encouraging negotiations between workers and privatized employers. Additionally, States have a duty to consult with the social partners in the event that measures to privatize industries or services are envisaged. Finally, it is noteworthy pointing out that in this context, at least one of the monitoring bodies has established that it is entitled to examine allegations concerning economic rationalization programs such as privatization if they lead to anti-trade union discrimination practices.

The effect of privatization on the enjoyment of social security benefits by workers has also been the subject of discussion within the ILO. Although the privatization 
of certain social security benefits does not constitute a violation of ILO principles and that their privatization may indeed have certain benefits, the ILO monitoring bodies have stated that the State maintains its general responsibility for the due provision of these benefits. In any case, the privatization of social security benefits and related reforms must take due notice of "certain basic principles of good governance and social cohesion" as established in various ILO Conventions.

The ILO's concerns with regard to privatization have also focused on its alleged effects on employment. This has led the monitoring bodies to conclude that the State has, again a duty to consult those who are presumably going to be affected by the privatization measures. Additionally, the State has duties related to ensuring that programs are in place to ameliorate the effects of privatization on employment. States also have duties to protect the already established rights of workers.

The ILO's approach is not without its problems, though. By placing the burden of responsibility on the State to ensure that its privatization practices and the behavior of privatizing or privatized enterprises are in concordance with ILO's obligations, the ILO misses an opportunity to look at the responsibility of the privatized entities (the employers) in the whole privatization scheme. This stems of course from the fact that the ILO's conventions are directed to the States that have ratified them. Nevertheless, the tri-partite structure of the ILO makes it the body par-excellence to study the behavior of privatized enterprises and note whether they can also be held accountable for labor rights violations.

\section{Concluding Remarks}

It cannot be denied that the treaty monitoring bodies of the various international and regional human rights instruments have shown concern regarding the issue of privatization and its consequences for the enjoyment of human rights. The different monitoring bodies have focused on the privatization of certain services, which could be problematic for the enjoyment of a number of civil, political, economic, social and cultural rights. They have identified and referred to these problems in their examination of state reports, their general comments, and in the individual or collective complaints mechanisms. The departing point for all these mechanisms appears to be that privatization does not absolve the State states implementing such a policy from its legal obligations under the various human rights instruments.

These observations might hint that the monitoring mechanisms would be skeptical of, or expressly opposed to privatization of State functions and Services. This is, however, not entirely the case. Although from the available summary records one could conclude that individual members of the different UN committees are generally downright negative towards privatization and are apprehensive of its 
effects on the rights identified above, the attitude of the monitoring mechanisms, at the universal and regional level, as a whole does not seem to reject privatization altogether. It would appear that if the privatization of certain functions and services are implemented in a particular way and with regard to certain principles, the monitoring bodies would not question privatization as such. Thus, the CPT even referred to the good practices of a privatized prison as an example to be followed by State run prisons. The general guiding notion of all monitoring bodies is that the delegation of tasks and services to private entities does not discharge States of their obligations to protect the rights protected in the various international human rights treaties. The relevant aspects that have to be taken into consideration in this respect are:

- The State is ultimately responsible for ensuring that rights are respected if they choose to privatize State functions and services. States cannot absolve themselves of their human rights obligations by privatizing public tasks.

- The State must establish independent monitoring mechanisms to supervise and ensure that human rights are respected by privatized service providers.

- Victims of rights abuses resulting from the activities of privatized service providers should have access to an effective remedy. Additionally, victims should be compensated for those abuses.

- The State must take measures to protect the most vulnerable sectors of society. These measures entail, among other things, providing extra protection to children of poor families (single parents children, orphans, children with mental or physical disabilities), preventing discrimination against minorities, women or persons with disabilities in privatized service provision, and guaranteeing the access to basic services to those who cannot afford it due to financial reasons.

- The privatization of essential services or services may entail the exercise of public authority.

- The State has a duty to consult with those directly and indirectly affected by privatization policies. 



\section{Chapter VI \\ Privatization of Security and \\ Military Services ${ }^{1}$}

\section{INTRODUCTION}

In 1995, the South African private security and military firm, Executive Outcomes (EO), was requested on behalf of the de facto military government of Sierra Leone to deploy personnel in its territory in order to train its army and help to stop the advances of the Revolutionary United Front (RUF). ${ }^{2}$ Within a couple of months after the arrival of EO personnel, the RUF troops had been routed several times and forced to retreat. RUF leader, Foday Sankoh, was forced to sign a cease-fire agreement and in early 1996, Sierra Leone was able to hold democratic elections. The RUF however continued its military campaign, and with some reluctance, the newly elected government of Sierra Leone approached EO once more requesting assistance against the RUF. After a number of armed clashes, the RUF was again forced to agree to a peace settlement on the condition that EO should leave the country. $^{3}$ In 1997, EO ceased its operation in Sierra Leone. Soon afterwards, hostilities between RUF and the Sierra Leone government started again with increased hostility.

During the Balkan conflict of the 1990s, the Croatian and Bosnian governments awarded a contract to Military Professional Resources Inc. (MPRI), a U.S. private security firm founded by former U.S. military personnel, to train, supply and advise the Croatian and Bosnian military in the rebuilding of their respective armed forces. ${ }^{4}$ Two other firms had participated in the bidding. The deployment of MPRI in the Balkans was meant as an alternative to direct U.S. intervention in those countries, an option that lacked political appeal for the U.S. and the countries involved. ${ }^{5}$ The newly trained Bosnian and Croatian armies were soon enough

1 This Chapter is partially based on two previous academic publications prepared by the present author in the wake of the abuse of prisoners in Abu Ghraib prison. See Hallo de Wolf, "Wordt oorlog geprivatiseerd? Het inzetten van particuliere militaire bedrijven in Irak in het licht van internationaal recht en de rechten van de mens (Is War Being Privatised? The deployment of private military companies in Iraq under international and human rights law)," p. 1687-1695; Hallo de Wolf, "Modern Condottieri in Iraq: Privatizing War from the Perspective of International and Human Rights Law," p. 315-356.

2 D. Shearer, Private Armies and Military Intervention, vol. 316, Adelphi Paper (London: Oxford University Press/The International Institute for Strategic Studies, 1998) p. 49.

3 Ibid., p. 51.

4 See J. C. Zarate, "The Emergence of a New Dog of War: Private International Security Companies, International Law, and the New World Disorder," Stan. J. Int'l. L. Vol. 34 (1998), p. 77; D. Kassebaum, "A Question of Facts - The Legal Use of Private Security Firms in Bosnia," Colum. J. Transnat'l L. Vol. 38 (2000), p. 582 and 586.

$5 \quad$ Kassebaum, “A Question of Facts - The Legal Use of Private Security Firms in Bosnia," p. 582. 
successfully involved in armed clashes in the Krajina region against the Bosnian Serb armies. ${ }^{6}$

On 12 February 2002, the British Foreign Office issued a Green Paper regarding the use of private military companies for certain functions in UN operations. ${ }^{7}$ According to the Secretary of State for Foreign and Commonwealth Affairs, Jack Straw, "States and international organisations are turning to the private sector as a cost effective way of procuring services which would once have been the exclusive preserve of the military." 8 In the Green Paper's foreword, Straw points out that "[a] strong and reputable private military sector might have a role in enabling the UN to respond more rapidly and more effectively in crises," as well as helping to reduce the costs of UN operations. ${ }^{9}$ The Green Paper immediately sparked a debate in the British political arena, ${ }^{10}$ but curiously enough did not generate any serious or immediate response inside the United Nations. ${ }^{11}$ The large-scale use of private military and security companies during and following the invasion of Iraq in 2003 has, however, focused the world's attention towards this controversial topic thus giving way to the question whether war is being privatized. The problematic use of private military contractors in the Iraqi conflict, including the incidents at Abu Ghraib prison, where personnel of PMSCs were allegedly involved in the abuses that took place in 2003-2004, and the recent shooting incident involving Blackwater personnel in September 2007, ${ }^{12}$ also raises human rights related questions.

6 Zarate, "The Emergence of a New Dog of War: Private International Security Companies, International Law, and the New World Disorder," p. 77; P.W. Singer, Corporate Warriors: The Rise of the Privatized Military Industry (Itacha and London: Cornell University Press, 2003) p. $126-127$.

7 See HC 577, "Private Military Companies: Options for Regulation," 2001-02, Foreign and Commonwealth Office, 12 February 2002 (hereafter referred to as the Green Paper). See also press release of the Foreign and Commonwealth Office dated 12 February 2002 on <www.fco. gov.uk/servlet/Front?pagename $=$ OpenMarket $/$ Xcelerate/ShowPage $\& \mathrm{c}=$ Page $\&$ cid $=100702939162$ $9 \& \mathrm{a}=$ KArticle $\&$ aid $=1013618417707 \% 20 \&$ year $=2002 \&$ month $=2002-02-01 \&$ date $=2002-02-12>$ last visited on 20 December 2007.

8 Green Paper, p. 4.

9 Ibid.

10 See "Peacekeeping 'role' for Mercenaries", BBC news report available on $<\mathrm{http} / /$ news.bbc. co.uk/hi/english/uk politics/newsid 1817000/1817495.stm> (last visited on 31 August 2011).

11 See UN news highlights on 13 February 2002 where M. Okabe, associate spokeswoman for the UN Secretary General noted that the UN had not officially received the Green Paper and that the Department of Peacekeeping Operations was not approached by the United Kingdom during the preparation of the paper. Document available on <www.un.org/News/ossg/hilites.htm $>$ (last visited on 14 February 2002).

12 On 16 September 2007, a group of private military contractors of U.S. based private military and security company (PMSC) Blackwater opened fire on cars and unarmed civilians in a square in Baghdad during a security operation to evacuate a number of U.S. officials. See news report "Blacwater Shooting Scene Was Chaotic," J. Glanz and S. Tavernise, New York Times, 28 September 2007. Reports suggest that at least 17 civilians were killed in the incident. See 
The above noted examples and especially the deployment of PMSCs in Iraq reflect a growing trend with regard to the use of force in (international) armed conflicts: the delegation of the coercive use of force from the State (or in the case of the United Nations, international organizations) to private parties. There is an increasing participation of private military and security companies in (international) conflict situations carrying out tasks formerly performed by the State. The participation of these private firms sometimes takes place in situations that are deemed to be politically, economically or militarily unattractive for the traditional deployment of regular armies, international peacekeeping or peace enforcement forces. Allowing private international security and military companies to take over the role of traditional armed forces is starting to become an appealing alternative when military involvement is desirable but the right political climate for a traditional intervention is not available. Active involvement in combat situations is, however, not the only type of involvement of international security and military firms. These companies are far more often contracted to provide training and military advice to armies of usually 'weak' states, gather intelligence information and resources and are commonly requested to provide security and protection arrangements for/to international organizations such as the UN and humanitarian NGOs working in the field. Additionally, PMSCs are being deployed to relieve the traditional military from certain tasks in order for it to concentrate on its core tasks.

The delegation or contracting out of what would appear to be 'typical' or essential State tasks and activities (the use of force in times of war, the provision of security, and the custody and interrogation of prisoners of war and common prisoners) to private companies is already contentious for a number of reasons. In the first place, PMSCs are often regarded as being the modern version of mercenaries. In fact, a number of PMSCs have been branded as mercenary forces that carry out activities, which (justifiably or not) earned them the mercenary label. ${ }^{13}$ Although not necessarily prohibited by international (customary) law, the international law of armed conflict and human rights law, the deployment of mercenaries in armed conflict is viewed with suspicion. According to Zarate, the aversion towards mercenaries is derived from the nature of their activities and the perception that there is a lack of accountability and control over their activities. ${ }^{14}$ In fact, it has been alleged that mercenary activities have contributed to the worsening of conflicts

news analysis report, "Blackwater Case Highlights Legal Uncertainties," A.J. Rubin and P. von Zielbauer, New York Times, October 11, 2007.

13 See report to the UN General Assembly by the Special Rapporteur of the UN Commission on Human Rights on the question of the use of mercenaries as a means of violating human rights and impeding the exercise of the right of peoples to self-determination (hereinafter Special Rapporteur on mercenaries) UN Doc. A/52/495, 16 October 1997, para. 69.

14 Zarate, "The Emergence of a New Dog of War: Private International Security Companies, International Law, and the New World Disorder," p. 77. 
and have been marked by human rights abuses. ${ }^{15}$ Indeed, this has led to the recognition of the need to regulate and restrict the categories of combatants during armed conflict. Currently, mercenaries are not considered to be lawful combatants and are therefore excluded from enjoying the rights provided to lawful combatants and prisoners of war. ${ }^{16}$ However, branding PMSCs as being mere mercenaries is somewhat deceitful and the position of these companies in international law and the new problems they generate should be accordingly studied with care.

Secondly, by delegating the coercive use of force to private enterprises, States are seen to give up their sovereignty and control over how the use of force might be employed with concomitant negative effects on the enjoyment of human rights. ${ }^{17}$ The delegation of these tasks to PMSC become even more questionable when it appears that these companies, or their employees, are actually directly responsible for, or have been involved in, the violation of rules of international humanitarian law and human rights. It has been argued in this regard that States cannot shirk their obligations to preserve internal order and security by privatizing security and military services. ${ }^{18}$

It is in this context that the use of PMSCs in (international) armed conflicts and the privatization of international security and military services set a number of challenges for the enjoyment of international human rights. To begin with, there is the question of whether the use of PMSCs in conflict situations contributes to the exacerbation of the conflict and leads to an increase in human rights violations. There is also a perceived lack of accountability for the activities performed by PMSCs. To what extent is the State responsible for the conduct of employees of these companies? Are these companies legally accountable for these actions under international law? What are the remedies available to the victims of abuses perpetrated by these companies or their employees? Finally, what are the remedies available for the victims of violations of human rights perpetrated by these companies or its employees? This last question is of special importance due to the

15 Mercenary activity in Africa during the de-colonization period of the 1960s and 1970s is regarded as corroborating to the exacerbation and prolongation of conflicts during the struggle for self-determination of former African colonies. See Green Paper HC 577, "Private Military Companies: Options for Regulation," 2001-02, p. 17.

16 Article 47 of the Protocol Additional to the Geneva Conventions of 12 August 1949, and relating to the Protection of Victims of International Armed Conflicts (Protocol I), 8 June 1977. See infra section 3.4 infra. See also K. Ipsen, "Methods and Means of Combat," in The Handbook of Humanitarian Law in Armed Conflicts, ed. D. Fleck, Oxford: Oxford University Press (1995), p. 69.

17 See report to the UN General Assembly, UN Doc. A/52/495, 16 October 1997, para. 60.

18 See Note by the United Nations High Commissioner for Human Rights, Report of the meeting of experts on the traditional and new forms of mercenary activities as a means of violating human rights and impeding the exercise of the right of peoples to self-determination, which took place in Geneva from 29 January to 2 February 2001, UN Doc. E/CN.4/2001/18 (14 February 2001), para. 114 . 
fact that in the case study described below dealing with the deployment of PMSCs by the United States in Iraq (see section 4 infra), the Iraqi judicial and court system is probably not yet in the position to function in a proper way that ensures objective and impartial dispute resolution that might arise out of alleged human rights violations perpetrated by these companies or their employees. Moreover, the U.S. has successfully negotiated and obtained immunity for its citizens, including private contractors, against criminal prosecution in Iraq for their activities in that country. ${ }^{19}$

This chapter attempts to clarify these questions and provide an overview of the relevant applicable rules of international law. Following a general overview of the privatization of military and security services and tasks, this chapter will analyze whether the use of PMSCs is contrary to international law. To this end the mercenary issue including a short description of the current definition of mercenary and its applicability to PMSCs as well as the emergence of these companies in the international arena will be examined. The concrete problems related to the deployment of PMSCs in conflict situations and human rights will then be analyzed by taking a look at the presence of these companies in Iraq. This case study will describe the alleged abuses of international humanitarian law and human rights perpetrated by contractors of these companies in Abu Ghraib prison. This will be followed by an attempt to examine the responsibility of the U.S. for abuses committed by PMSC contractors. Finally, an analysis of the available remedies for the victims of these abuses will be provided in light of the international legal obligations of the U.S.

\section{Is WAR BEING PRIVATIZED? THE DEFINITION OF PRIVATIZATION OF MILITARY AND SECURITY SERVICES}

Can contracting out military tasks to private companies be considered a type of privatization? It has already been observed in chapter II that there is no unambiguous and agreed-upon definition of privatization. Many scholars disagree on a concrete definition for the term privatization, although sometimes it is easier to point to situations that might indicate that privatization is taking place or has actually occurred. This is due to the fact that privatization can take many forms and facets and be achieved through a variety of techniques. Privatization can occur through the transfer of ownership, through the delegation of management, through contracting out, or through deliberate withdrawal from a public-delivered task with

19 See Section 4.4 infra. At the risk of getting ahead of the discussion, it is worth noting that following the 2007 incident with Blackwater, the United States government reconsidered this position and it appears that prosecution of PMSC personnel has been made possible due to a recent small amendment in the U.S. Military Code of Justice. 
the intention of letting private actors take over. ${ }^{20}$ With regard to the subject at hand, privatization would entail a transfer of military tasks, services, and functions normally carried out by a State's armed forces. It must be emphasized that the above-noted definition does not cover the public procurement or acquisition of projects and material in the private market. Public procurement and acquisition are not controversial, and governments all around the world make use of these tools.

As it will be made clear below, contracting out or delegating tasks that had previously been carried out exclusively by national armed forces is not a new phenomenon. It remains nevertheless a highly disputed and controversial issue that has gathered enormous momentum in the last thirty years. Among the reasons cited for the increasing reliance on private companies to provide military tasks and services are the reduction of military budgets in a number of Western countries and the desire to cut costs. This has spurred governments to search for alternatives by which certain military tasks can be carried out for a fraction of the cost and in a more efficient way. ${ }^{21}$ This initially involved contracting out certain logistical aspects of running an army, such as building military bases, the preparation and delivery of meals for military personnel and the maintenance and repair of military equipment and weaponry. More recently however, tasks that could be considered part of the core responsibilities of the armed forces are being contracted out to private companies. These may include training of soldiers, providing armed convoys in conflict situations, providing security for buildings, industrial installations and high-profile persons, ${ }^{22}$ and in some cases direct participation in combat activities. MPRI, for example, recruits experienced former army personnel that are then contracted out to provide training to military forces, develop military doctrine, provide assistance for peacekeeping and humanitarian operations, or to assist in combating terrorism. ${ }^{23}$ Greystone Ltd, a subsidiary of Xe Services LLC, the company formerly known as Blackwater, provides protective services which include

20 Chapter II, Section 3.

21 L.L. Turner and L.G. Norton, "Civilians at the Top of the Spear," Air Force Law Review Vol. 51 (2001), p. 8; Singer, Corporate Warriors: The Rise of the Privatized Military Industry, p. 53-54. Some commentators however have pointed out that the efficiency and cost reduction expectations were not at the top of the priority list of reasons to contract out certain military tasks to private companies in the United States, nor have all the expected efficiency and cost gains been realized. See A. Markusen, "The Case Against Privatizing National Security" (Meeting of the International Political Science Association, Section on the Structure of Governance, University of Oklahoma, 20 March 2001 of Conference), p. 5-10.

22 The security of the former head of the American established Iraqi Provisional Authority, Paul Bremer III, was entrusted to an American PMSC. See "Iraq: America's Private Armies," in The New York Review of Books, 12 August 2004, p. 48. Afghan leader Hamid Karzai, is continuously escorted by private security guards. See e.g. DynCorp's Assignment: Protect Afghan Leader, Washington Post, Dec. 2, 2002, at E1, available at <www.washingtonpost.com/ac2/wp-dyn/ A61827-2002Dec1?language $=$ printer $>$ (last visited on 31 August 2011).

23 The website of MPRI contains a list of the various activities which the company carries out. See MPRI: Services, <www.mpri.com/> under the what we do menu (last visited 31 August 2011). 
quick reaction support, armed and unarmed protective services, overt and covert protective details, and perimeter security. ${ }^{24}$ The United States Department of Defense already has many years of experience in actively contracting with various companies for the provision of these tasks and services. ${ }^{25}$ The demand for contracting out military tasks has also fueled the supply of private military companies. The demobilization of military personnel as a result of the end of the Cold War has encouraged many former soldiers to offer their expertise and experience to PMSCs or create companies of their own. Additionally, a number of developing countries are resorting more frequently to the use of PMSCs, in the absence of well-trained armed forces, to deal with internal conflict. ${ }^{26}$

Executive Outcomes' (EO) operation in Sierra Leone in $1995^{27}$ caused a serious debate about deploying PMSCs in armed conflicts. It raised questions about their use as a cheap alternative to traditional peace keeping and the necessity of regulating their activities. At the request of the House of Commons the British Minister of Foreign Affairs, Jack Straw, prepared a "Green Paper" describing the different options for regulation of PMSCs, as well as the possible scenarios in which these companies could be used, and noting the arguments for and against their use. ${ }^{28}$ Although the Green Paper was meant to stimulate debate on the use of PMSCs, the position taken by Straw and the response to the Green Paper from the House of Commons appeared to indicate that, at least from the perspective of the British Government, the deployment of PMSCs in conflict situations could be a positive development as long as their activities are carefully regulated. ${ }^{29}$

24 See website of Greystone Ltd. under heading Protective Services at <www.greystone-ltd.com/ protective.html> (last visited 31 August 2011).

25 The website of DynCorp International, another American PMSC has examples of the various and diverse activities that are currently being carried out and for which they are currently recruiting personnel, although the company claims in its website that in 2004 it decided to divest itself of some of its non-core businesses including security services. See DynCorp International: Careers, <http://dyn-intl.com/history.aspx > (last visited 31 August 2011).

26 See further section 3.3 for a more in-depth assessment for the reasons surrounding the emergence of these companies and their activities.

27 In general, EO's operation in Sierra Leone was considered successful. EO achieved what the regular army of Sierra Leone could not: It managed to pacify and restore order in the chaotic region where RUF rebels operated. EO's operation brought some stability and a (temporary) peace that paved the way for the first democratic elections in Sierra Leone. See H. M. Howe, "Private Security Forces and African Stability: The Case of Execuitve Outcomes," The Journal of Modern African Studies Vol. 36 (1998), p. 313-317. The country's relapse into chaos after EO's departure can be considered evidence of the importance of the presence of these companies in conflict regions, or, on the other hand, evidence of the failure on their part to bring actual stability in those conflicts.

29 See Select Committee on Foreign Affairs, Ninth Report, Private Military Companies, House of Commons, Session 2001-2, H.C., para. 67, available at $<$ www.publications.parliament.uk/pa/ $\mathrm{cm} 200102 / \mathrm{cmselect} / \mathrm{cmfaff} / 922 / 92202 . \mathrm{htm}>$ (last visited on 31 August 2011). 
These developments lead to the conclusion that the use of PMSCs in armed conflict is a particular type of privatization: the deliberate and policy-based transfer of public tasks to private actors. It must be noted, however, that most of the privatization initiatives in the military field are focused on the delegation of support and logistical tasks that were previously carried out by national armed forces. This type of privatization does not appear to be controversial and many armies around the world have taken steps to privatize these tasks. There is however an increasing tendency to contract out certain tasks that involve the lethal use of force and coerciveness. This was the case in Sierra Leone and Papua New Guinea, where due to a perceived lack of capacity, expertise, experience and professionalism of their own armed forces, the governments of these countries decided to hire the services of PMSCs for offensive operations. Additionally, countries such as the United States have chosen to contract out certain 'lighter' military tasks that can also involve the lethal use of force in order to allow their own armed forces to concentrate on the heavier and more earnest offensive tasks. These tasks include providing for the security of important buildings or installations in conflict areas, protecting political figures, escorting convoys, interrogating prisoners and providing intelligence and physical support to the military of a number of countries in counterinsurgency operations against guerrillas or terrorists. ${ }^{30}$ This type of privatization is even more controversial due to the fact that the State monopoly on the use of lethal force is, to a certain extent, being transferred to private entities, sometimes without any clear form of regulation.

For the purposes of this study, the privatization of international security and military services can be thus defined as the deliberate policy of (contractual) delegation of military services and related functions by States or international organizations to private military or security companies. Military services and functions include advisory military assistance and training, logistical and support services, intelligence services including the interrogation of prisoners (of war), security, escorting and policing services as well as the coercive use of military force and in general, tasks which are typically carried out by national or international armed and peace keeping forces. Private military and security firms which are entrusted with these delegated tasks are those that operate in a similar fashion as traditional military personnel and along the way make a profit out of it. An example of this type of privatization is the above mentioned Green Paper of the British Foreign Office evaluating the possible use of private military companies for certain UN operations. ${ }^{31}$

30 The U.S. has deployed employees of MPRI in Colombia to assist in the fight against extreme left-wing guerrillas and drug lords. Singer, Corporate Warriors: The Rise of the Privatized Military Industry, p. 207-208.

31 This definition does not include the 'subcontracting' of, for example, UN peace operations to regional security organizations such as NATO. M. Griffin, "Blue Helmet Blues: Assessing the 


\section{The MERCENARY ISSUE AND THE STATUS OF PRIVATE INTERNATIONAL SECURITY AND MILITARY COMPANIES}

The deployment of individuals who seek financial remuneration for their activities but do not belong to the armed forces of countries participating in war operations or armed conflict is not a new phenomenon. Mercenaries have participated in armed conflicts since ancient times. ${ }^{32}$ The status of mercenaries and other private entities participating in armed conflicts has, however, become subject of discussion at the international and national level. In the following paragraphs, the status of PMSCs under international and national law will be discussed before examining their use in the Iraqi conflict. In particular, attention will be paid to the question whether the deployment of PMSCs conflicts with international or national law.

\subsection{Mercenaries under international law}

International humanitarian law, including the 1907 Hague regulations on warfare and the Geneva Conventions of 1949, does not prohibit the deployment of private armies or mercenaries in armed conflicts ${ }^{33}$ and does not impose major restrictions on the use of private actors that support or accompany the conventional armed forces. ${ }^{34}$ These participants have, however, an obligation to abide by the rules of international humanitarian law and civilians, even if they are allowed to accompany

Trend Towards ‘Subcontracting' UN Peace Operations," Security Dialogue Vol. 30, no. 1 (1999), p. $43-60$.

32 The Greeks and Romans used mercenary battalions in their military campaigns. The Swiss free companies also frequently offered their services during conflicts in Europe. The condottieri who were particularly active during the Renaissance in Italy are also worth mentioning here. For a more complete description of mercenary activities throughout the ages see section 3.2 supra. With regard to mercenaries, Art. 17 of Hague Convention (V) Respecting the Rights and Duties of Neutral Powers and Persons in Cases of War on Land indicates that mercenaries do not violate international law by taking part in foreign conflicts. Once a mercenary from a neutral State joins a party to the conflict, he cannot use neutrality as a defense. See B.O. Goldstein, "Mercenarism," in International Criminal Law, Volume I, Crimes, ed. M. Cherif Bassiouni, Ardsley, New York: Transnational Publishers, Inc. (1999), p. 445.

34 Geneva Convention Relative to the Treatment of Prisoners of War art. 4 §A(4), Aug. 12, 1949, stipulates that the "[p]ersons who accompany the armed forces without actually being members thereof, such as civilian members of military aircraft crews, war correspondents, supply contractors, members of labour units or of services responsible for the welfare of the armed forces, provided that they have received authorization, from the armed forces which they accompany" are also entitled to the prisoner of war status when captured. See also Convention Respecting the Laws and Customs of War on Land (IV) art. 13, Oct. 18, 1907. These provisions entail, however, that this category of persons (which would include personnel of PMSCs) are not authorized, in principle, to actively participate in the hostilities. Doing otherwise would make this category of persons legitimate targets for the opposing parties of the conflict. See also S.J. Zamparelli, "Contractors on the Battlefield: What Have We Signed Up For?," Air Force Journal of Logistics Vol. XXIII (1999), p. 11, 16-17. 
the armed forces, are not allowed to participate in the fighting: A civilian who "aids, abets, or participates in the fighting is liable to punishment as a war criminal under the law of wars." 35

Due in part to the cruel behavior of mercenaries in several decolonization conflicts in Africa during the 1960s and 1970s, many countries agreed that it was necessary to effectively prohibit mercenaries' activities. This led to the inclusion of Article 47 of the First Additional Protocol to the Geneva Conventions (Protocol I) and the drafting of the 1989 International Convention against the Recruitment, Use, Financing and Training of Mercenaries (International Convention), which entered into force in 2001. Article 47 Protocol I does not actually prohibit the use of mercenaries, but it does deny them prisoner-of-war status. ${ }^{36}$ Under this provision, mercenaries have less protection than the regular personnel of armed forces and other lawful combatants. In contrast to Protocol I, the International Convention prohibits the deployment of mercenaries in armed conflicts and brands their activities as criminal. ${ }^{37}$ The question has been raised whether PMSCs can be equated as mercenaries and if so, whether their activities are illegal under international law. To answer this question, this section will first place mercenarism in a historical perspective. It will then briefly discuss the emergence of PMSCs. This will be followed by an analysis of the legal definition of mercenaries and its potential application to PMSCs.

\subsection{Mercenaries in historical perspective}

The presence of mercenaries in the battlefields of the world can be traced back to the ancient Greek time. ${ }^{38}$ Mercenaries have almost always been present throughout the history of warfare. Kings used mercenaries, or free companies, during the Middle Ages to constitute or bolster their armies due to the limitations the feudal

35 The Hostages Trial, United States Military Tribunal at Nuremberg (8 July 1947-19 Feb. 1948), Law Reports of Trials of War Criminals, United Nations Wartime Commission, Vol. XV, London (1947-49), p. 58.

36 Mercenaries are thus branded as unlawful combatants. See Ipsen, "Methods and Means of Combat," p. 69.

37 See Article 2 of the International Convention against the Recruitment, Use, Financing and Training of Mercenaries, 4 December 1989, which reads "any person who recruits, uses, finances or trains mercenaries, as defined in article 1 of the present Convention, commits an offence for the purposes of the Convention." Additionally, Article 5 of the International Convention obliges States to prohibit these activities and make them punishable with appropriate penalties.

38 See E. Kwakwa, "The Current Status of Mercenaries in the Law of Armed Conflict," Hastings Int'l \& Comp. L. Rev. Vol. 14 (1990), p. 75. See also A. Mockler, Mercenaries (London: Macdonald and Company, 1970) p. 21; Zarate, "The Emergence of a New Dog of War: Private International Security Companies, International Law, and the New World Disorder," p. 82. 
system imposed on the military system of the time. ${ }^{39}$ During the Renaissance Italian city-states relied on the condottieri for their protection and for waging war against rival kingdoms. The condottieri, mercenary leaders, offered their military services to monarchs and Popes by signing a condota, a written contract. The condota was carefully drafted by lawyers and specified the length and terms of service and the due payment. ${ }^{40}$ Niccolo Machiavelli, the famous Italian political philosopher viewed the condottieri with disdain and commented that,

"[m] ercenaries [...] are useless and dangerous; and anyone who relies upon mercenaries to defend his territories will never have a stable or secure rule. For they are disunited, ambitious, undisciplined and treacherous." ${ }^{\text {"41 }}$

Undaunted by Machiavelli's premise, rulers continued to hire soldiers and militias from outside their country. Swiss mercenaries, for example, were hired by French and Italian rulers and even by the Vatican, which enlisted these mercenaries to form the Swiss Guard. The ferocity of the Swiss mercenaries and their prowess in battle became famous. They spread terror throughout Europe and did not recoil from taking reprisals against their employers if betrayed. ${ }^{42}$

Up until the nineteenth century, the deployment of mercenaries in armed conflicts by States had not been controversial. ${ }^{43}$ Their use had been widespread and generally accepted. The emergence of the modern nation state led, however, to a gradual decline in the use of the classical mercenary. Since the end of the eighteenth century, the modern nation state enacted legislation limiting or prohibiting the enlisting of its own nationals in foreign armies. ${ }^{44}$ This was partially the result of the need to remain neutral and avoid becoming involved in foreign conflicts. At the same time, it was recognized that the modern nation state exerted a new authority claim over its citizens with the ultimate power to make decisions with regard to the

39 It would appear that kings could not easily rely on their vassal knights as the military duties of these knights were limited to a restricted number of days per year. To work around this problem, kings in England hired armies which were paid out of scutage: a tax paid by knights willing to escape their feudal obligations towards the king. Mockler, Mercenaries, p. 25-26.

40 Ibid., p. 43-44.

41 N. Machiavelli, The Prince, ed. Q. Skinner and R. Price, Cambridge Texts in the History of Political Thought (Cambridge: Cabridge University Press, 1988) p. 43.

42 Mockler, Mercenaries, p. 74-104.

43 The use of Hessian mercenaries by Great Britain during the American Revolutionary War did, however, stir deep emotions among the American revolutionary militias and led to their condemnation in the American Declaration of Independence of 1776. See H. C. Burmester, "The Recruitment and Use of Mercenaries in Armed Conflicts," AJIL Vol. 72 (1978), p. 40.

44 The United States was the first country to enact such legislation in order to prevent American ships to be hired by France to attack British vessels. As a result of these attacks, the United Kingdom requested the American government to take action against this practice. In 1794, the United States enacted the U.S. Neutrality Act.J. E. Thomson, "State Practices, International Norms, and the Decline of Mercenarism," International Studies Quarterly Vol. 34 (1990), p. 37. 
use of force..$^{45}$ This new relationship created "[...] a boundary between the public political and the private nonpolitical spheres [..." ${ }^{\prime 46}$ which was necessary to determine when a state can exert authority claims, when it can use coercion to enforce compliance with its norms and when it should respect the individual's liberty. According to this view, allowing individuals to take part in foreign conflicts would undermine the authority claim of a State over its citizens and become detrimental to the State's sovereignty. It was therefore necessary for the State to exert control over the citizen's violent activities beyond its boundaries. ${ }^{47}$ In other words, the nation state monopolized the use of force by its own citizens inside and outside its boundaries in order to establish its sovereignty. Together with this development, the emergence of the nation state also created the necessity of having a permanent standing army that relied on conscription to fill the ranks. ${ }^{48}$ The formation of national armies was regarded as a better alternative to ad-hoc (mercenary) troops that could prove unreliable and not trustworthy. The mercenary profession was, however, not legally banned. Even though national legislation restricting the individual's possibility to enlist abroad had been enacted in various countries leading to a general decrease in the deployment of mercenaries ${ }^{49}$ they continued to offer their services without serious opposition into the twentieth century.

The first attempts to regulate the use of mercenaries took place in 1907 during the Hague peace conferences. ${ }^{50}$ It was not until after World War II, however, that the mercenary profession started to be internationally vilified. The sudden, large-scale deployment of mercenary troops in armed conflicts during the African struggle for self-determination in the $1950 \mathrm{~s}, 60 \mathrm{~s}$ and $70 \mathrm{~s}$ led to the prompt condemnation of these mercenary activities by the international community. The Security Council issued a number of resolutions condemning the deployment of mercenaries during conflicts in former Zaire, Angola and Benin. ${ }^{51}$ The General Assembly for its part

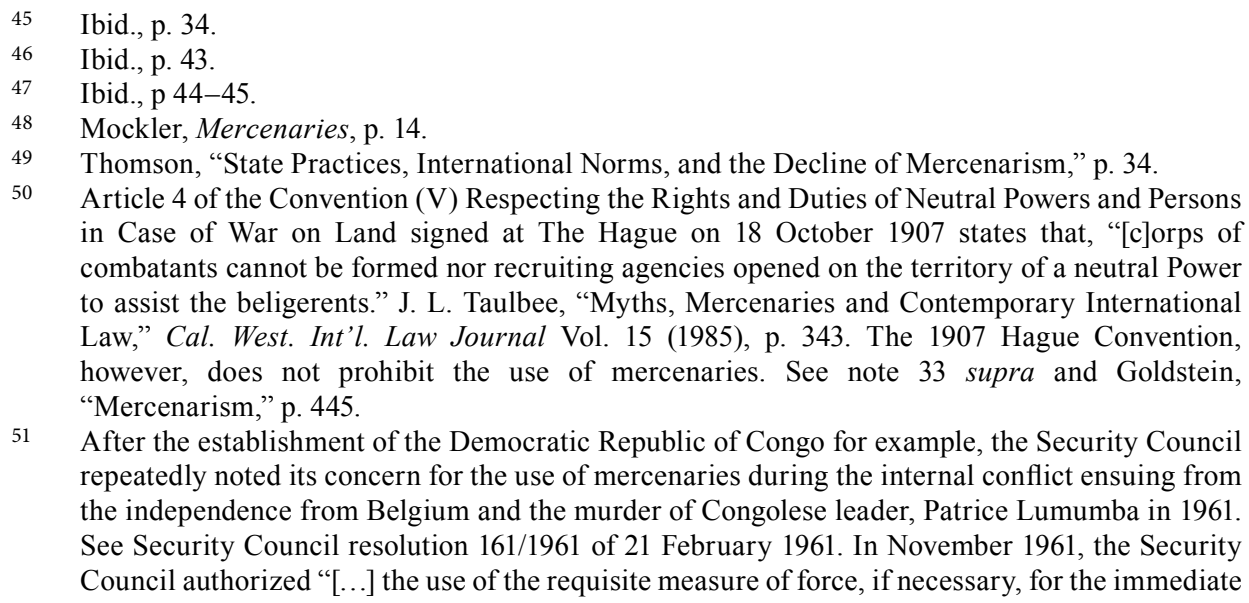
combatants cannot be formed nor recruiting agencies opened on the territory of a neutral Power to assist the beligerents." J. L. Taulbee, "Myths, Mercenaries and Contemporary International Law," Cal. West. Int'l. Law Journal Vol. 15 (1985), p. 343. The 1907 Hague Convention, however, does not prohibit the use of mercenaries. See note 33 supra and Goldstein, "Mercenarism," p. 445.

51 After the establishment of the Democratic Republic of Congo for example, the Security Council repeatedly noted its concern for the use of mercenaries during the internal conflict ensuing from the independence from Belgium and the murder of Congolese leader, Patrice Lumumba in 1961. See Security Council resolution 161/1961 of 21 February 1961. In November 1961, the Security Council authorized " [...] the use of the requisite measure of force, if necessary, for the immediate 
condemned the use of mercenaries against recognized national liberation movements as criminal ${ }^{52}$ and stated in the 1970 Declaration on the Principles of International Law Concerning Friendly Relations and Cooperation Among States that "[e]very state has the duty to refrain from organizing or encouraging the organization of irregular forces or armed bands, including mercenaries, for incursion into the territory of another state." ${ }^{53}$ Amidst reports of the frequent human rights abuses by mercenaries during these conflicts and the realization among African States that mercenaries were being used as tools of former colonial powers against national liberation movements and recently de-colonized countries, ${ }^{54}$ it was felt that the legal status of mercenaries had to be regulated.

At the regional and international level, countries have attempted to come up with instruments that would curb the use of mercenaries. At the regional level, African concerns towards the mercenary problem moved the Organization of African Unity (OAU) to draft an OAU Convention for the Elimination of Mercenaries in 1972. Although this Convention did not enter into force, it was the basis for the 1977 OAU Convention for the Elimination of Mercenarism. ${ }^{55}$ This Convention was also the result of African disappointment at the concurrent international efforts with regard

apprehension, detention pending legal action and /or deportation of all [...] mercenaries[...]". See Security Council resolution 169/1961 of 24 November 1961. Later on the Security Council condemned Portugal's leniency towards mercenaries who took action against the Democratic Republic of Congo from their bases in Portuguese controlled Angola. It also requested countries from refraining to assist mercenaries. See Security Council resolutions 226/1966 and 241/1967 of 14 October 1966 and 15 November 1967 respectively.

52 In 1968, the UN General Assembly declared in a resolution that the use of mercenaries against national liberation movements should be a criminal act. See General Assembly resolution 2465/ XXIII of 20 December 1968 on Implementation of the Declaration on the Granting of Independence to Colonial Countries and Peoples. This was later confirmed by General Assembly resolution 3103/XXVIII of 12 December 1973 on the Basic Principles of the Legal Status of the Combatants Struggling Against Colonial and Alien Domination and Racist Regimes. Article 5 of this resolution maintains that "[t]he use of mercenaries by colonial and racist regimes against the national liberation movements struggling for their freedom and independence from the yoke of colonialism and alien domination is considered to be a criminal act and the mercenaries should accordingly be punished as criminals."

53 General Assembly resolution 2625/XXV of 24 October 1970, Declaration on Principles of International Law Concerning Friendly Relations Among States in Accordance With the Charter of the United Nations, UN Doc. A/8028.

54 It should be also noted that the new African states condemned mercenaries. See Taulbee, "Myths, Mercenaries and Contemporary International Law," p. 340; Kwakwa, "The Current Status of Mercenaries in the Law of Armed Conflict," p. 82.

55 See Organization of African Unity Convention for the elimination of mercenarism in Africa of 3 July 1977, O.A.U. Doc. CM/433/Rev. L. Annex 1 (1972). See also C. Pilloud et al., eds., Commentary on the Additional Protocols of 8 June 1977 to the Geneva Conventions of 12 August 1949 (Geneva, Dordrecht: ICRC/Martinus Nijhoff Pubs., 1987) p. 572; D. Isenberg, "Soldier of Fortune Ltd.: A Profile of Today's Private Sector Corporate Mercenary Firms" [web document] Center for Defense Information, 1997; available from <www.cdi.org/issue/mercenaries/mercl. html>. 
to the mercenary issue as dealt with during the Diplomatic Conference that drafted the two additional protocols to the Geneva Conventions of 12 August 1949.56 During this Diplomatic Conference, the international community concerted its efforts to improve and develop the rules of international humanitarian law in armed conflict already established in the 1949 Geneva and 1907 The Hague conventions. ${ }^{57}$ In the light of serious mercenary activity in Africa, African countries lead the discussion on ways to deal with the mercenary issue. Although the views of many countries on the mercenary issue during the Conference were at odds with each other, a consensus on the issue was reached resulting in the adoption of Article 47 of the 1977 First Additional Protocol to the Geneva Conventions of 1949.58

Not satisfied with the results of the Diplomatic Conference in respect of mercenaries, other international efforts to regulate and study the issue of mercenaries were undertaken. On 4 December 1980, the UN General Assembly decided to establish an $\mathrm{Ad} \mathrm{Hoc} \mathrm{Committee} \mathrm{to} \mathrm{draft} \mathrm{an} \mathrm{international} \mathrm{convention} \mathrm{regarding} \mathrm{the} \mathrm{recruitment}$ and use of mercenaries. ${ }^{59}$ In 4 December 1989, the International Convention against the Recruitment, Use, Financing and Training of Mercenaries was adopted, ${ }^{60}$ but essentially did not improve upon Article 47 of Protocol I. ${ }^{61}$ In 1987, at the request of the UN Economic and Social Council, the UN Commission on Human Rights established a thematic mandate and appointed a Special Rapporteur to deal with the mercenary issue. ${ }^{62}$ The drift behind this new thematic mandate was the UN's

56 Due to the necessity of achieving consensus, the African desire for a stringent condemnation of the mercenary profession was not met during the Diplomatic Conference which drafted the First Additional Protocol. The summary records of the Conference show that African countries joined the consensus to adopt the provision on mercenaries. Throughout the drafting process, however, many African countries lamented that a stronger text had not been adopted. See f.e. comments of Mauritania, Mozambique, Senegal and Libya in Summary record of plenary meeting of 26 May 1977 (CDDH/SR.41, Annex; VI, 175) reproduced in H. S. Levie, Protection of War Victims: Protocol 1 to the 1949 Geneva Conventions, vol. Vol. 3 (Dobbs Ferry, N.Y.: Oceana Publications, Inc., 1980) p. 48-55. See also Pilloud et al., eds., Commentary on the Additional Protocols of 8 June 1977 to the Geneva Conventions of 12 August 1949 p. 572-573. See further Section 3 infra on the problems related to the mercenary definition.

57 C. Greenwood, "Historical Development and Legal Basis," in The Handbook of Humanitarian Law in Armed Conflicts, ed. D. Fleck, Oxford: Oxford University Press (1995), p. 25.

58 Protocol Additional to the Geneva Conventions of 12 August 1949, and relating to the Protection of Victims of International Armed Conflicts (Protocol I), 8 June 1977. For an analysis on the mercenary definition see infra section 3.4.1.

59 General Assembly resolution UN Doc. A/35/48 of 4 December 1980.

60 UN Doc. A/4/34. The Convention recently entered into force on 20 October 2001 after the 22 required instruments of ratification were deposited with the UN Secretary General.

61 It included a similar definition of the mercenary concept as Article 47 with some additional qualifications. See further infra section 3.4.1.

62 See Economic and Social Council resolution UN Doc. E/RES/1986/43 of 23 May 1986 and resolution of Commission on Human Rights UN Doc. E/CN.4/RES/1987/16 of 9 January 1987 on the question of the use of mercenaries as a means of violating human rights and impeding the exercise of the right of peoples to self-determination. In 1987, The Peruvian Mr. Enrique 
intention to contribute to the "effective exercise of the right to self-determination."63 Many governments, especially those from Africa, considered the mercenary issue a threat to the self-determination and independence of their countries.

The adoption of these texts and the yearly reporting of the Special Rapporteur, however, did not help to ban mercenary activities around the world. As recently as 2004, mercenaries were still active: the late Mobutu Sese Seko hired a number of mercenaries during his last months in power in former Zaïre to try to stop the military advances of his opponent, Laurent Kabila, without much success, and former Executive Outcomes co-founder, Simon Mann, was apprehended in 2004 in Zimbabwe for allegedly organizing a mercenary expedition to topple the government of Equatorial Guinea. ${ }^{64}$ This has been compounded with the lukewarm attitude of States towards Additional Protocol I and the International Convention. The major powers including the U.S. and the UK have not ratified both instruments and have expressed their reservations towards their attempt to define mercenarism. Additionally, with a few exceptions almost no legislative efforts have been undertaken at the national level to prevent people from enlisting as mercenaries other than making it illegal for nationals to enlist in foreign armies that are at war with the country of their own nationality or with allied countries. For example, in 1794 the U.S. adopted the Neutrality Act, which was followed by similar complementary laws now compiled together in the 1818 Neutrality Act. ${ }^{65}$ This Act forbids any other than the U.S. government from raising an army within U.S. territory to attack another State with which the U.S. is at peace. ${ }^{66}$ It also prohibits individuals from selling their services as soldiers to another State while they are in U.S. jurisdiction as well as organizing military expeditions against foreign political entities in their own private interests. ${ }^{67}$

Bernales Ballesteros was appointed as the first Special Rapporteur on the question of mercenaries and held the position until 2004 when he stepped down. Mrs. Shaista Shameem from Fiji took over the mandate, although the mandate was replaced in July 2005 with the establishment of a UN Working Group on the use of mercenaries as a means of violating human rights and impeding the exercise of the right of people to self-determination. See resolution 2005/2 of the Commission on Human Rights of 7 April 2005.

63 See report of the Special Rapporteur on mercenaries UN Doc. E/CN.4/2002/20 (10 January 2002), p.11.

64 See BBC news report "Q\&A: Equatorial Guinea 'coup plot'," available at $<$ http://news.bbc. co.uk/1/hi/world/africa/3597450.stm>, (last visited on 1 June 2005).

65 J. E. Thomson, Mercenaries, Pirates, and Sovereigns: State-Building and Extraterritorial Violence in Early Modern Europe (Princeton: Princeton University Press, 1994) p. 78.

66 Ibid., p. 79.

67 Ibid. 


\subsection{The emergence of PMSCs}

Together with the vilification of traditional mercenaries, a distinctly new variant of this phenomenon started to appear in the late 1960s. WatchGuard International, a firm created by former British special forces personnel was one of the first companies to offer military advice and training programs mainly to Middle East governments. ${ }^{68}$ Later on, other firms created by former professional soldiers such as Defense Systems Ltd (DSL) started to provide security advice and military training to a variety of legitimate customers. ${ }^{69}$ In the aftermath of the Cold War, PMSCs offered their services to established governments. EO, founded by former white South African soldiers who had fought in the Angolan Civil War against Angola's Marxist regime Popular Movement for the Liberation of Angola (MPLA), was contracted in 1993 by the same MPLA government to secure and protect oil installations from the rebel group National Union for the Total Independence of Angola (UNITA).$^{70}$ The 'success' of EO's operation in Angola, by which UNITA leader Jonas Savimbi was forced to the negotiating table helped to establish EO's reputation as a 'reliable' private military company working for governments and helped it to acquire its contract for the Sierra Leone operation. Similarly, companies like MPRI, Sandline Inc and DSL became increasingly popular under a number of governments in countries like Bosnia, Croatia, and Colombia. ${ }^{71}$

There are a number of reasons for the increasing interest in hiring the services of PMSCs by States. In the first place, demand for these services has been stimulated by the growing reluctance of third party States to intervene in conflict situations where the economical, military and political stakes are not so high. The American reluctance following the intervention in Somalia in 1993 to engage in peacekeeping and peace enforcement operations where American interests are not at stake is illustrative of this position. Confronted with such a situation, countries seeking for military assistance for their conflicts and faced with international unwillingness to intervene resort to PMSCs which are willing to provide their services.

Second, the demand is fueled by the prevailing lack of security and the deficient means to uphold the rule of law in poor and weak States. These countries usually do

68 Abdel-Fatau Musah and J. 'Kayode Fayemi, "Africa in Search of Security: Mercenaries and Conflicts - An Overview," in Mercenaries: An African Security Dilemma, ed. Abdel-Fatau Musah and J. 'Kayode Fayemi, London: Pluto Press (2000), p. 18; K. A. O'Brien, "Private Military Companies and African Security 1990-98," in Mercenaries: An African Security Dilemma, ed. Abdel-Fatau Musah and J. 'Kayode Fayemi, London: Pluto Press (2000), p. 46.

69 International organizations such as the World Bank and the UN as well as humanitarian NGOs have been among the clients of DSL. O'Brien, "Private Military Companies and African Security $1990-98, "$ p. $47-48$.

$70 \quad$ Ibid., p. 49. See also Shearer, Private Armies and Military Intervention, p. 46.

71 As already mentioned in the introduction to this section, MPRI was contracted by Bosnia and Croatia to train their respective armies. Colombia has. 
not have the expertise, know-how and experience to build up, train and equip their own armies in order to maintain order and security. ${ }^{72}$ The costs of training an army and providing it with the necessary material and know how is becoming increasingly prohibitive. As a result, countries that cannot afford the high costs of raising and training their military are turning to cheaper alternatives. Usually composed of former military personnel from developed countries, PMSCs fill in this demand by providing military advice, training, logistic support and supplies to the armies of the countries that contract them. A good example is Sierra Leone's reliance on the services of EO, which was contracted to do essentially what the national military could not: deal with rebel forces that were too powerful for Sierra Leone's armed forces to deal with. Another good example is the aborted deployment of Sandline International, a British PMSC (incorporated in the Bahamas), in Papua New Guinea. ${ }^{73}$ In 1997, the government of Papua New Guinea resorted to contracting the services of Sandline in order to deal with an insurrectional movement in the island of Bougainville. Sandline's military expedition was however terminated before it really began following protests from the Papuan Army, which together with the governments of Australia, New Zealand, United States and the $\mathrm{UK}$, at the last minute exerted pressure on the government to rescind the contract with Sandline. ${ }^{74}$

Another reason that has helped increase the use of PMSCs is the increased demand from international organizations, multinational companies and NGOs for protection of their activities, personnel and property during their operations in other countries. $^{75}$ International organizations, multinational companies and NGOs operating in danger zones in various countries are increasingly relying on the services of PMSCs for protection, especially in view of the fact that many of the host countries are not in the position to provide effective protection. Singer observes that contracting the services of PMSCs is a cost effective way of reducing the operating risks of humanitarian operations, and bodies such as UNHCR have relied on their services in countries such as Afghanistan. ${ }^{76}$ In other instances, the demand for PMSCs can also be ruled by political motivations. The deployment of MPRI in Bosnia and Croatia to train and advise their respective militaries apparently grew out of the United States' desire not to get drawn into the conflict directly. ${ }^{77}$ Finally, the demobilization of large armies at the end of the Cold War resulted in a surplus of jobless military personnel, many of who saw the financial advantages of providing

72 See Singer, Corporate Warriors: The Rise of the Privatized Military Industry, p. 56-57.

73 See T. McCormack, "The 'Sandline Affair': Papua New Guinea Resorts to Mercenarism to End the Bougainville Conflict," Yearbook of International Humanitarian Law Vol. 1 (1998), p. 292. See also Sturzaker and Cawood, "The Sandline Affair: Illegality and International Law."

74 See R. Savill, "British Mercenaries 'held by rebels'," The Dailiy Telegraph, 21 March 1997. See also further section 3.4.3 infra.

75 Singer, Corporate Warriors: The Rise of the Privatized Military Industry, p. 80-83.

76 Ibid., p. 82.

77 Kassebaum, “A Question of Facts - The Legal Use of Private Security Firms in Bosnia,” p. 582. 
their experience and expertise to those parties that requested them. Under the auspices of their own government or with its acquiescence, former military personnel established private companies to provide their services.

In short, the emergence of PMSCs would appear to be a result of supply and demand. The demand arises out of the lack of resources in certain States to develop and organize their military leading to problems in maintaining (internal) peace and order. There is also a demand from other international actors that need protection of their assets and personnel when operating in dangerous regions. The emergence of PMSCs also denotes a shift in the role of the State: from the main provider of peace and security - sentinel of the rule of law and monopolist in the coercive use of force - to a mere contractor.

\subsection{The legal status of PMSCs: mercenaries or legitimate businesses?}

It has already been stated that PMSCs are viewed as the modern counterparts of traditional mercenaries. This view needs, however, some qualification. Before examining the legal status of PMSC's, it is necessary to analyze whether PMSCs can be considered as mercenaries. For this purpose, the current legal definition of mercenary and its legal effects will be briefly reviewed. Then, it will be discussed whether it is appropriate to apply this definition to PMSCs. This will be followed by an examination of the legal status of PMSCs under international law.

\subsubsection{Defining the mercenary}

There is no agreement among scholars and governments on an adequate definition for the mercenary term. ${ }^{78}$ The problem revolves mainly around definitions based on motive (pecuniary, idealistic or adventurous) that would render any attempt to apply the mercenary term almost impossible since it is not always clear what motivations are behind those who engage mercenary activities. ${ }^{79}$ A number of

78 See Burmester, "The Recruitment and Use of Mercenaries in Armed Conflicts," p. 37; T. Boumedra, "International Regulation of the Use of Mercenaries in Armed Conflicts," Revue de Droit Pénal Militaire et de Droit de la Guerre Vol. XX (1981), p. 41-42; Kwakwa, "The Current Status of Mercenaries in the Law of Armed Conflict," p. 69-74; Thomson, Mercenaries, Pirates, and Sovereigns: State-Building and Extraterritorial Violence in Early Modern Europe, p. 23; Zarate, "The Emergence of a New Dog of War: Private International Security Companies, International Law, and the New World Disorder," p. 120.

79 During the drafting of Article 47 of Protocol I, for example, this problem was brought up by the Netherlands delegation. See summary record of plenary meeting of 26 May 1977, op. cit. note 56 supra, p. 52. See also Boumedra, "International Regulation of the Use of Mercenaries in Armed Conflicts," p. 42. 
authors seem to agree, however, that although it is not possible to define what a mercenary is, mercenaries can be recognized for what they do. ${ }^{80}$

There are also problems related to the legal consequences that should be attached to the definition of the term mercenary. Hinds states that the difficulties of achieving consensus during the Diplomatic Conference leading to the drafting of Art. 47 Protocol I related to the differing views on the issue between Third World and Western countries. ${ }^{81}$ Third World countries were eager to brand mercenaries as criminals and to ban their activities. These countries also argued that the recruitment and use of mercenaries should be penalized in the nations where mercenaries were being enlisted. Western countries, on the other hand, argued that mercenaries should enjoy the same privileges as prisoners of war and were adamant in maintaining that, at the very least, mercenaries should be able to enjoy a minimum of fundamental guarantees as specified in Article 75 of Protocol I. ${ }^{82}$

These differing views on the definition of mercenary and the legal consequences to be attached to this definition affected the final definition agreed upon in Art. 47 Protocol I to the Geneva Conventions of 12 August 1949. As it now stands, Art. 47 (1) states that, "[a] mercenary shall not have the right to be a combatant or a prisoner of war" and then defines a mercenary in its second paragraph as:

"[...] any person who:

(a) Is specially recruited locally or abroad in order to fight in an armed conflict;

(b) Does, in fact, take a direct part in the hostilities;

(c) Is motivated to take part in the hostilities essentially by the desire for private gain and, in fact, is promised, by or on behalf of a Party to the conflict, material compensation substantially in excess of that promised or paid to combatants of similar ranks and functions in the armed forces of that Party;

80 Mockler, for example, argues that it is useless to give a definition of the term mercenary since "[...] the meaning of the word has varied throughout history and has depended at any moment on the force of the spirit of nationalism at that particular epoch." Mockler, Mercenaries, p. 19.

81 L. S. Hinds, "The Legal Status of Mercenaries: A Concept in International Humanitarian Law," Philippine Law Journal Vol. 52 (1977), p. 400.

82 Australia, Canada, Ireland, Italy, Portugal, Switzerland, the United Kingdom, and the United States voiced these concerns during the drafting of Article 47. See summary record of the meeting of the Third Committee on 29 April 1977 (CDDH/III/SR.57; XV, 189) reproduced in Levie, Protection of War Victims: Protocol 1 to the 1949 Geneva Conventions, p. 33-42. Article 75 of Protocol I stipulates that "[i]n so far as they are affected by a situation referred to in Article 1 of this Protocol, persons who are in the power of a Party to the conflict and who do not benefit from more favourable treatment under the Conventions or under this Protocol shall be treated humanely in all circumstances and shall enjoy, as a minimum, the protection provided by this Article without any adverse distinction based upon race, colour, sex, language, religion or belief, political or other opinion, national or social origin, wealth, birth or other status, or on any other similar criteria. Each Party shall respect the person, honour, convictions and religious practices of all such persons." See also Hinds, p. 400-401, citing A. H. Thobhani, "The Mercenary Menace,” Africa Today (January 1977), p. 67. 
(d) Is neither a national of a Party to the conflict nor a resident of territory controlled by a Party to the conflict;

(e) Is not a member of the armed forces of a Party to the conflict; and

(f) Has not been sent by a State which is not a Party to the conflict on official duty as a member of its armed forces."

The requirements set in the second paragraph of Art. 47 are cumulative. This means that in order to be qualified as a mercenary, a combatant must fulfill all these requirements. Many commentators have already highlighted that under Art. 47 it is not difficult to think of circumstances/excuses to make one or more of these requirements inapplicable. The financial motivation requirement of paragraph 2(c), has for example, received a lot of attention due to the alleged difficulties of establishing the real motives for taking part in hostilities. ${ }^{83}$ Paragraph 2(e)'s requirement could also be easily circumvented by allowing mercenaries to 'officially' become members of the armed forces of one of the parties to the conflict. For example, in its aborted contract with Papua New Guinea, Sandline's employees were to be called Special Constables which would have prevented their classification as mercenaries under Paragraph 2(e). ${ }^{84}$

With regard to the legal consequences of Art. 47, paragraph 1 denies the status of lawful combatant and prisoner of war to mercenaries. This means that mercenaries do not enjoy the protected status and rights of prisoners of war if they are captured and can be tried as common criminals. Kwakwa considers this to be an unfortunate situation in light of the purpose of the Geneva Conventions and international humanitarian law in general and the First Additional Protocol in particular: the protection of individuals and victims of war. ${ }^{85} \mathrm{He}$ further argues that it would be in the best interests of all combatants to extend the prisoner of war protection to mercenaries as well. Denying this status to mercenaries could potentially discourage them from taking into account the laws of war and pose increased danger to the civilian population. ${ }^{86}$

As already stated above, the international community was not totally satisfied with Article 47 of Protocol I and efforts were made to draft an international convention which would regulate the status of mercenaries. The result of these efforts was the International Convention against the Recruitment, Use, Financing and Training of Mercenaries of 4 December 1989. Article 1 of this Convention uses exactly the same

83 Compare with Taulbee who argues that any objection towards the motivation requirement does not necessarily hold. He maintains that establishing motivation is a practice common under domestic law to make critical distinctions and collecting evidence for motivation is a difficulty that exists with all statutes that provide for extraterritorial jurisdiction over nationals. also HC 577, "Private Military Companies: Options for Regulation," 2001-02, para. 6.

85 Kwakwa, "The Current Status of Mercenaries in the Law of Armed Conflict," p. 88-89.

86 Ibid., p. 89. 
wording as Article 47 Protocol I to define a mercenary. It shares in this respect the same problems as Article 47 of Protocol I. However, the 1989 Convention adds a new number of elements to the mercenary definition. The second paragraph of Article 1 states that:

"2. A mercenary is also any person who, in any other situation:

(a) Is specially recruited locally or abroad for the purpose of participating in a concerted act of violence aimed at:

(i) Overthrowing a Government or otherwise undermining the constitutional order of a State; or

(ii) Undermining the territorial integrity of a State;

(b) Is motivated to take part therein essentially by the desire for significant private gain and is prompted by the promise or payment of material compensation;

(c) Is neither a national nor a resident of the State against which such an act is directed;

(d) Has not been sent by a State on official duty; and

(e) Is not a member of the armed forces of the State on whose territory the act is undertaken."

Besides explicitly expanding the definition of mercenaries to internal conflict situations, Article 1 of the International Convention seeks to emphasize the role of mercenaries vis-à-vis legitimate States. If a group of persons not officially attached to the military branch of a government were deployed to undermine the territorial integrity of another State, or overthrow its government, then this group of persons would be regarded as mercenaries. However the same group of persons claiming not to do so and claiming to work for legitimate governments might escape falling under this extended definition. This is reaffirmed by paragraph 2(d), which gives States the possibility of sending potential mercenaries on official duties thus making their activities legal and therefore preventing such persons being branded as mercenaries. Arguably, these elements make it more difficult to apply Article 1 paragraph two of the International Convention to proper mercenaries and to PMSCs. This difficulty is again reinforced by the fact that paragraph two's elements are cumulative making it relatively easy for mercenaries or PMSCs accused of being mercenaries to escape from this provision.

\subsubsection{Difficulties of applying the current definition of mercenary to PMSCs}

Aside from the fact that the current legal definition of mercenary, as defined by the above-mentioned instruments, contains a number of loopholes that would enable PMSCs to avoid falling under the definition, ${ }^{87}$ there are still a number of shortcomings if one would like to apply this definition to PMSCs. In the first place, the current definition (and in general the current attitude towards mercenaries) is 
geared towards mercenaries and private military groups who are fighting against legitimate regimes or against recognized national liberation movements. ${ }^{88}$ For instance, the former Special Rapporteur on mercenaries, Mr. Enrique Bernales Ballesteros, initially equated PMSCs to mercenaries and tried to brand their activities as contrary to the right to self-determination. For example, while discussing mercenary activity in Africa in his 1997 report to the UN General Assembly, the rapporteur observed that,

"[...] there is the rechannelling of mercenary activities through private security firms, which present a more modern façade and engage in activities which are apparently legal but are no less dangerous for the independence, economies, democracy and self-determination of the African peoples." ${ }^{\prime 89}$

However, and as already pointed out above, PMSCs are currently being contracted by 'legitimate' governments, international organizations, (multinational) companies operating in different countries, and also by NGOs working in the field for 'legitimate' reasons. The executives of these companies claim themselves that they only enter into contracts with legitimate governments. ${ }^{90}$ It appears that Article 1 §(d) of the International Convention even provides for this possibility. PMSCs are currently not being deployed in conflicts with the overt purpose of destabilizing other countries or otherwise affecting the right to self-determination of other States. Secondly, PMSCs have rarely taken part in actual combat situations. They are usually utilized to train troops and provide military advice and intelligence. It can therefore be easily maintained that these companies or their personnel are not actually taking part in offensive combat activities and that their contracts are usually limited to providing logistical support and protecting buildings and people. ${ }^{91}$ This makes it difficult for these companies to fall under the requirement of taking direct part in the hostilities as mentioned in Article 47 (2)(b), although it could be argued that training troops and providing extensive military advice could amount to doing so. It is thus submitted that the current scope of the mercenary definition which is focused on military groups or individuals taking part in combat situations without consent by the State and that threaten the right to self-

88 This is one of the main aspects of paragraph 2 of Article 1 of the International Convention against the Recruitment, Use, Financing and Training of Mercenaries of 4 December 1989.

89 See report of Special Rapporteur to the General Assembly UN Doc. A/52/495 (16 October 1997), para. 18.

90 Although, it would appear that some companies have provided aid to rebel factions and antigovernment dissidents. Singer, Corporate Warriors: The Rise of the Privatized Military Industry, p. 11.

91 As a number of incidents involving PMSC contractors in Iraq reveal, it is precisely in these types of situations that PMSC personnel can easily be exposed to combat situations. Thus their participation in actual hostilities cannot be ruled out. Moreover, this shows how problematic the definition of mercenary can be under Art. 47 Protocol 1 and the International Convention against the Recruitment, Use, Financing and Training of Mercenaries. 
determination, does not properly apply to PMSCs. This has also been recognized by the former Special Rapporteur on mercenaries, Enrique Ballesteros, who has acknowledged that the current mercenary definitions provided by Article 47 of Protocol I and Article 1 of the International Mercenary Convention could be inadequate for application in the case of PMSCs. ${ }^{92}$ The former Special Rapporteur has more recently implicitly acknowledged that it is necessary to distinguish these companies and their personnel from actual mercenaries. ${ }^{93}$ He nevertheless believed that these companies should not hire real mercenaries for their contracts and that the activities of PMSCs should be regulated at the national and international level. This was confirmed by the subsequent Special Rapporteur, Mrs. Shaista Shameem, in her report to the former UN Commission on Human Rights where she stated that in her new mandate she will explore, "[...] whether licensing and regulation of genuine private security companies, such as through strong national legislation or an international registration mechanism, could serve to identify clear lines of accountability for bona fide companies [...]"94 This position has been further maintained by the UN Working Group on the use of mercenaries as a means of violating human rights and impeding the exercise of the right of people to selfdetermination, which replaced the mandate of the Special Rapporteur in 2005. Although the mandate of the Working Group has been expanded to also monitor the impact of the activities of private military and security companies on the enjoyment of all human rights, it has not been able to establish that they are actually mercenaries. In fact, it has recently formally acknowledged the difficulty of applying the mercenary defintion of the International Mercenary Convention to many activities performed by PMSCs. ${ }^{95}$ Nevertheless, the UN Working group has emphasized the necessity to regulate PMSCs activities by States from which these companies originate and by the host States that use their services, ${ }^{96}$ and to this end has prepared a Draft International Convention to regulate their activities (see Section 3.4.3 infra).

92 See UN Doc. A/52/495 (16 October 1997), para. 69-72. See also Kassebaum, who applied the criteria of the Art. 47 Protocol 1 and the International Convention to the activities of MPRI in Bosnia and came to the conclusion that it would be difficult to apply the mercenary definition of both instruments to MPRI and its activities. Kassebaum, "A Question of Facts - The Legal Use of Private Security Firms in Bosnia," p. 594-597.

93 See Report of the Special Rapporteur, UN Doc. E/CN.4/2004/15 (24 December 2003), para. 67.

94 See Report of the Special Rapporteur, UN Doc. E/CN.4/2005/14 (8 December 2004), p. 2.

95 This realization came to light during the Working Group's discussion on the possibilities of drafting an international convention with the purpose of regulating the activities of these companies (on this topic see further Section 3.4.3 infra). See Report of the Working Group on the use of mercenaries as a means of violating human rights and impeding the exercise of the right of peoples to self-determination, Human Rights Council, UN Doc. A/HRC/10/14 (21 January 2009), para. 40.

96 See Report of the UN Working Group on the use of mercenaries as a means of violating human rights and impeding the exercise of the right of people to self-determination, UN Doc. A/HRC/7/7 (9 January 2008), p. 26. 
Aside from the fact that the provisions of Protocol I and the International Convention are difficult to apply in practice to the activities of PMSCs, there is an additional problem of whether international law can apply to these entities. The United States and the United Kingdom, the countries in which most of these companies have their statutory seats or operate, are either not parties to both instruments, or have not ratified them. It is doubtful whether Article 47 Protocol I and the International Convention reflect the status of international customary law with regard to the status of mercenaries. The relative low number of ratifications of the International Convention is an indication of this; only thirty two at the time of this writing, with no great military power among the ratifying countries. ${ }^{97}$

\subsubsection{The legal status of PMSCs and regulatory efforts}

What then is the status of PMSCs? Other than the provisions regarding mercenarism, there are currently no other rules of international law that prohibit or limit the activities of PMSCs. As already noted above, neither the 1907 Hague regulations on warfare nor the 1949 Geneva Conventions prohibit the deployment of civilians and contractors in support of armed forces. These civilians and contractors, however, are in principle not allowed to take active part in combat on penalty of losing their right to prisoner of war status if captured. There are "soft law" instruments that attempt to impose human rights obligations on the conduct of business enterprises providing security services. For example, the Norms on the responsibility of multinational corporations with regard to human rights of the now defunct UN SubCommission on the Promotion and Protection of Human Rights ${ }^{98}$ attempts to extend the reach of international human rights law obligations to the respective spheres of activity and influence of these corporations. The Norms also include a number of paragraphs that may provide some guidance with respect to the obligations of PMSCs. Paragraphs three and four specify that companies have to abstain from violations of international humanitarian law and human rights violations such as torture and extrajudicial executions, and that the security arrangements used by business enterprises abroad have to observe international human rights norms. ${ }^{99}$ Although the Norms are not legally binding for either

97 See the United Nations Treaties website for the ratification status of this 1989 International Convention at $<$ http://treaties.un.org/Pages/ViewDetails.aspx?src=TREATY\&mtdsg no=XVIII$6 \&$ chapter $=18 \&$ lang $=$ en $>$.

98 See Norms on the responsibilities of transnational corporations and other business enterprises with regard to human rights, UN Doc E/CN.4/Sub.2/2003/12/Rev.2 (26 August 2003). The Norms are discussed in more detail in Chapter III, section 3.2.2 supra.

99 Ibid. Paragraph 3 and 4 read as follows: "3. Transnational corporations and other business enterprises shall not engage in nor benefit from war crimes, crimes against humanity, genocide, torture, forced disappearance, forced or compulsory labour, hostage-taking, extrajudicial, summary or arbitrary executions, other violations of humanitarian law and other international crimes against the human person as defined by international law, in particular human rights and humanitarian law. 4. Security arrangements for transnational corporations and other business 
States or companies, and their usefulness and relevance have been questioned, ${ }^{100}$ it does show a development that acknowledges and attempts to identify the responsibilities of business enterprises under international law. Currently, however, business enterprises and, by extension, private military and security companies are very limited subjects of international law and do not have legally binding human rights obligations. ${ }^{101}$

It is worth noting that an arbitral tribunal, instituted to adjudicate in the dispute between Papua New Guinea and Sandline International, following the failed attempt to deploy the company's personnel in that country, ruled in favor of Sandline without questioning the company's status under international law or its activities. ${ }^{102}$ In early 1997 Sandline International signed an agreement ${ }^{103}$ with the Deputy Prime Minister of Papua New Guinea to provide military personnel for conducting offensive operations in the island of Bougainville against a separatist movement. On the eve of the operation's deployment, Sandline's personnel were arrested and their equipment confiscated by Papua New Guinea's national defense forces. ${ }^{104}$ The arrests were made following a military uprising in protest against the agreement between Papua New Guinea and Sandline. Following the arrests, the Prime Minister of Papua New Guinea suspended the agreement with Sandline and announced a judicial inquiry to establish the facts concerning the agreement. ${ }^{105}$ Although the judicial inquiry did not question Sandline's effective engagement under the agreement, Papua New Guinea definitely suspended the agreement, claiming the agreement had been frustrated since its performance had become impossible. ${ }^{106}$

In accordance with the agreement's arbitration clause, which allowed the parties to seek international arbitration under the UN Commission on International Trade Law (UNCITRAL) rules in case of dispute, Sandline brought the case before an

enterprises shall observe international human rights norms as well as the laws and professional standards of the country or countries in which they operate." Ibid, paras. 3 en 4.

100 See further Chapter III Section 3.2.2.1.

101 See further Chapter III, Section 3.2.1 and also Jägers, Corporate Human Rights Obligations: In Search of Accountability.

102 See In the Matter of an International Arbitration under the UNCITRAL Rules between Sandline International Inc and the Independent State of Papua New Guinea (Interim Award) [Arbitration Tribunal] Arbitral Award of 9 October 1998 and Independent State of Papua New Guinea v. Sandline International Inc, [Queensland Supreme Court of Appeal, Australia] Arbitral award of 30 March 1999, International Law Reports, Vol. 117 (2000), p. 552 and p. 565. See also BBC news report "PNG pays up to mercenaries" (1 May 1999) available at $<$ http://news.bbc.co.uk/1/ hi/world/asia-pacific/333234.stm> (last visited 25 May 2005).

103 The text of the agreement can be found at Sandline's website, <www.sandline.com $>$, last visited on 16 April 2004. As of that date, Sandline announced the closure of its activities. The website is no longer available, although most of its content is on file with the present author.

105 Ibid., para. 3.2.

106 Ibid. 
arbitral tribunal. The tribunal was seated in Cairns, Australia, on both parties' agreement. Sandline claimed that Papua New Guinea was obligated \$18 million for the deployment of Sandline's personnel and equipment in that country, in addition to $\$ 18$ million that had already been paid in advance to the PMSC. Papua New Guinea argued that the contract was illegal under its national Constitution, which prohibited the raising of unauthorized forces, and that those who singed the agreement on behalf of that country lacked the capacity to do so. Referring to other international arbitral awards the tribunal concluded that, since the agreement between Papua New Guinea and Sandline was an international contract, the former "cannot rely upon its own internal laws as the basis for a plea that a contract concluded by it is illegal." 107 With regard to Papua New Guinea's argument that officials who did not have the approval to do so had entered the agreement, the tribunal firstly answered that on the grounds of international state responsibility, the state is liable for the conduct of its organs, even if they acted without authorization. ${ }^{108}$ It then referred to the doctrine of preclusion and observed that "[...] a party may not deny the validity of a contract entered into on its behalf by another if, by its conduct, it later consents to the contract." 109 Because (a) the agreement was closed by the Deputy Prime Minister of Papua New Guinea and had the approval of the Prime Minister, the Minister of Defense, and other national organs, and (b) the question of illegality under national law was not raised at the time of the agreement with Sandline, the arbitral tribunal decided that a valid contract had been concluded between both parties. ${ }^{110}$ The arbitral tribunal did not question the legal status of Sandline under international law or the international legal validity of the contract and Sandline's activities. In fact, it concluded that even if the agreement was illegal under national law, this did not have any bearing on international law. The arbitral tribunal observed that,

"[t]he agreement was not illegal or unlawful under international law or under any established principle of public policy. A political decision having been made by PNG to enter into it, its execution by a person with apparent authority to bind the State gave rise to a valid contract in the eyes of international law."111

107 Ibid., para. 10.2. The arbitral tribunal further observed that "It is a clearly established principle of international law that acts of a State will be regarded as such even if they are ultra vires or unlawful under the internal law of the State." Ibid.

108 Ibid., para 10.2.

109 Ibid., para. 10.3.

110 Ibid., para. 11.1.

111 Ibid. Furthermore, the tribunal observed that Papua New Guinea had already participated in the performance of the agreement and had even made an advance payment of $\$ 18$ million dollars to the PMSC and facilitated the entry of Sandline and the equipment into the country with the purpose of carrying out the agreement. This precluded Papua New Guinea from claiming that the agreement was illegal. Ibid., para. 11.2. 
In the end, the arbitral tribunal rejected Papua New Guinea's arguments and concluded that it was liable to Sandline for its failure to perform the terms of the contract. ${ }^{112}$ Sandline was thus entitled to recover \$ 18 million from Papua New Guinea, plus interest. From this award it may be concluded that PMSCs can be regarded as international economic actors in the same vein as regular business enterprises. However, it is suggested that the services they rend place them in a somewhat different position than regular companies. Not only do the activities of PMSCs make it even more necessary to regulate their conduct in a stricter fashion than regular companies, but it also can be argued that the nature of the services they provide make it possible to classify them as public actors sui generis, for which international rules and obligations such as those emanating from human rights treaties could directly apply. ${ }^{113}$

Generally speaking, there exists no legislation at the national level that would prohibit the activities of PMSCs. A number of countries, however, have adopted legislation to regulate, restrict or control their business operations and conduct. South Africa, for example, adopted a law requiring the authorization of the South African government for each contract a PMSC signs involving a local or international operation. ${ }^{114}$ The United Kingdom also adopted legislation, the Private Security Industry Act 2001, in an attempt to regulate the activities of private security and guardianship companies. ${ }^{115}$ Although this legislation is aimed at regulating the activities of these companies at the national level, it can nevertheless provide some guidelines for regulating the activities of PMSCs which provide security and surveillance services abroad. For example, it establishes a Security Industry Authority which inter alia must "[...] monitor the activities and effectiveness of persons carrying on businesses providing [...]" security services, as well as setting or approving the standards of conduct, training and level of supervision of these companies. ${ }^{116}$ The Act moreover prohibits the activities of security companies without a requisite licence, and mandates the establishment of a register of companies approved to provide security services. ${ }^{117}$ Finally, the Act provides for the criminal liability of the directors of private security companies, when an offence is committed by the company with the consent or connivance of, or negligence on the part of the company's executives. ${ }^{118}$

\footnotetext{
112 Ibid., para. 12.

113 See Chapter IV, Section 3.

114 Regulation of Foreign Military Assistance Bill, 1997. The text of this bill can be found at $<$ www. gov.za/gazette/bills/1997/b54-97.pdf>.

115 See Private Security Industry Act $2001<$ www.legislation.gov.uk/ukpga/2001/12/contents>.

116 See Section 1 Private Security Industry Act 2001.

117 See Sections 3 and 14 Private Security Industry Act 2001.

118 See Section 23 Private Security Industry Act 2001.
} 
In the United States, PMSCs that wish to do business with other governments need to request authorization in advance from the State Department, the Department of Defense and the House of Representatives when the contracts deal with the supply of weapons. ${ }^{119}$ According to Singer, this procedure has not been applied in a consistent and uniform way and there appears to be no follow-up to monitor what happens with the contracts afterwards. ${ }^{120}$ In an effort to regulate the contracting out of military and security tasks to PMSCs, the Department of Defense and the United States Army have adopted a number of guidelines. These include regulations that dictate how Army officials must deal with contractors either for acquisition purposes or when the contractors accompany the force during "operations-otherthan-wartime and wartime operations". ${ }^{21}$ The Department of Defense and the United States Army consider contracting out to these companies to be a "force multiplier of combat service support"122, meaning that the contracting of PMSCs can be useful by offering support and taking certain tasks out of the hands of the armed forces, allowing them to concentrate on the more military hardcore tasks.

It is worth noting that, although the United States armed forces consider the privatization of a number of military tasks to be an acceptable policy, these guidelines nevertheless place some limits on privatization. Army regulation 715-9 states, for example, that the employees of PMSCs executing contracted out tasks have to follow general orders and 'force protection rules'. ${ }^{23}$ Additionally, these guidelines explicitly note that the support offered by these companies and their contractors is only meant to strengthen the 'military force structure', and not to replace it. Furthermore, PMSC contractors are not deployed to replace the military force structure but to augment it. ${ }^{124}$ This means that PMSC contractors may only be used to perform selected combat-support activities but may not be used to perform activities that could jeopardize their status as civilians accompanying the force. ${ }^{125}$ They also are not allowed to command, supervise, administer, or control Army

119 According to Singer contracts amounting to less than $\$ 50$ million U.S. dollars do not necessarily have to be notified to the U.S. House of Representatives. See P.W. Singer, "War, Profits and the Vacuum of Law: Privatized Military Frims and International Law," Colum. J. Transnat'l L. Vol. 42 (2004), p. 539. Ibid.

121 See Department of the Army, Contractors Accompanying the Force, Army Regulation 715-9, 29 October 1999, pag. 1. See also Department of the Army, Contractor Deployment Guide, Pamphlet 715-16, 27 February 1998. These guidelines have been taken over in the Army Field Manual No. 3-100.21, Contractors on the Battlefield, Department of the Army, Washington, DC, 3 January 2003. 13 January 1999, p. VIII-11. See also J.R. Perlak, "The Military Extraterritorial Jurisdiction Act of 2000: Implications for Contractor Personnel," Mil. L. Rev. Vol. 169 (2001), p. 108. 
personnel or wear military uniforms. ${ }^{126}$ Finally, these guidelines only allow the use of force by PMSCs and their contractors for self-defense purposes. ${ }^{127}$ In spite of these clear restrictions, and as we will see further below, it would appear that PMSC contractors have nevertheless been put in positions that allowed them to issue commands or supervise the activities of military personnel, especially during interrogations at Abu Ghraib prison.

Besides the limitations noted above, the glossary attached to Army regulation 715-9 appears to provide a further limitation on the tasks or functions that are to be contracted out to PMSCs. These are tasks that involve inherent government functions, which are defined to be those functions that are

"[...] necessary for the sustainment of combat operations, that are performed under combat conditions or in otherwise uncontrolled situations, and that require direct control by the military command structure and military training for their proper execution... This includes functions performed exclusively by military (active and reserve) who are trained for combat and the use of deadly force, where performance by a contractor or civilian would violate their non-combatant status under the Geneva Conventions or represent an inappropriate risk to military operations. "128

Other military functions that are considered to be inherently governmental and thus apparently not subject to privatization are:

"[f]unctions that require knowledge and skills acquired primarily through military training and current military experience for the successful performance of the prescribed duties... In all cases, such functions must require the kind of expertise that can only be derived from first-hand military experience - through the command of military forces or by participating in or conducting military operations, tactics, or systems operations. The required knowledge and skills must be more substantial than familiarity with military administrative procedures or similar capabilities reasonably attained by civilian employees or possessed by retired military personnel. This includes functions that (through example) reinforce the integrity of the military

126 Ibid., p. 15.

127 Ibid. See also Army Field Manual No. 3-100.21, paras. 6-3 and 6-6.

Army Regulation $715-9$, p. 21. The regulation further adds that a key criterion to identify an inherently governmental military function is "[...] whether the proper execution of the function under combat conditions has to be ensured, or safeguarded, through strict military command and extensive military training." Ibid. The notion of inherently governmental functions would appear to have been borrowed from the Federal Activities Inventory Reform Act of 1998 (31 U.S.C. §501) which defines an 'inherently governmental function' as '[...] a function that is so intimately related to the public interest as to require performance by Federal Government employees." The Federal Activities Inventory Reform Act was enacted in order to categorize all activities performed by government personnel as either commercial or inherently governmental to determine whether government personnel should perform commercial activities and thus determine whether the U.S. government can better rely on the private sector for the delivery of these commercial activities. 
command structure, acculturate military standards and conventions, or that otherwise serve to safeguard government responsibilities with regard to the appropriate use of deadly force and proper military conduct during war."129

Although these regulations also explicitly acknowledge the necessity of strictly monitoring contract performance and overseeing the quality of the services by PMSCs, they nevertheless are ambivalent with regard to how this supervision is to be achieved. Army regulation 715-9, for example, states that contractor employees are not under the direct supervision of military personnel in the chain of command. ${ }^{130}$ This means that PMSCs themselves have to perform the necessary supervisory and management functions over their employees. Nevertheless, the responsibility for monitoring the contractual performance of PMSC personnel rests on a so-called 'contracting officer' or its representative who then "[...] shall communicate the Army's requirements and prioritize the contractor's activities within the terms and conditions of the contract."'131 Whether this type of supervision will be sufficient to prevent eventual abuses by PMSC contractors is debatable. In addition, this type of supervision may not be adequate for monitoring compliance with contracts and adherence to international humanitarian law, as well as human rights norms when PMSCs are deployed in conflicts where the U.S. Army is not directly operating. This was evident in Bosnia in 2001 when two employees of the American PMSC DynCorp, providing police assistance to the international presence in that country on behalf of the U.S., were accused of committing statutory rape, abetting prostitution, and accepting bribes. DynCorp pulled these contractors out of the country before they could be arrested and prosecuted. ${ }^{132}$

It should be noted that as observed in Chapter II Section 4.3, voluntary initiatives have emerged in the field of security. Thus, a group of governments, NGOs and companies in the extractive industries have adopted the Voluntary Principles on Security and Human Rights. These principles, however, are geared towards companies that use security arrangements from both public or private security forces in conflict areas. Under these principles, companies that are in need of protection for their activities and assets need to proactively engage with these security forces. To this end, companies must carry out a risk assessment involving the screening of private security companies for their human rights records and the identification of the capability of such companies to respond to situations of violence in a manner that is consistent with applicable international standards. ${ }^{133}$ In addition, the Voluntary Principles require private security companies to

\footnotetext{
129 Ibid.

130 Ibid., p. 14

131 Ibid., p. 15

132 Singer, "War, Profits and the Vacuum of Law: Privatized Military Frims and International Law," p. 538 .

133 See < www.voluntaryprinciples.org/principles/risk_assessment $>$ (last visited 12 August 2010).
} 
"[...] observe the policies of the contracting Company regarding ethical conduct and human rights; the law and professional standards of the country in which they operate; emerging best practices developed by industry, civil society, and governments; and promote the observance of international humanitarian law."134

The Principles also require security companies to act in a lawful and restrained manner in accordance with applicable international guidelines regarding the use of force, including the UN Principles on the Use of Force and Firearms by Law Enforcement Officials and the UN Code of Conduct for Law Enforcement Officials. Moreover, security companies should engage in the monitoring of conduct and on the use of force, which should be used only when strictly necessary and to an extent proportional to a threat. Allegations of human rights abuses by private security employees should be investigated, and individuals who have been involved in human rights abuses should not be employed. The Principles also aim at limiting the activities of security companies to defensive and preventive actions, stating that they shoud not "[...] engage in activities exclusively the responsibility of state military or law enforcement authorities." 135 Finally, companies contracting private security details must included the principles in their contracts with security companies and ensure that the contractors are properly trained, as well as monitor that the activities of the security companies are consistent with the principles. In spite of the apparent thoroughness of the Voluntary Principles, their 'non-binding' nature render them less effective than national regulatory options. Moreover, the Principles are mainly applicable on situations in which companies in the extractive industries, such as oil and mining, make use of security arrangements, and not on situations such as those desribed in the case study below involving PMSCs in an active battlefield situation, operating at the behest of Governments. As noted in Chapter III, Section 4.3, an additional limitation of the Principles is the fact that, while these have attracted the participation of a limited number of companies in the extractive industries, NGOs, and Governments, PMSCs appear not to be engaged in the process.

Aside from the Voluntary Principles, which is an NGO, extractive industry, and governmental driven initiative, PMSCs themselves have also taken steps towards adopting some form of self-regulation that encourages these provate security companies to respect international humanitarian law and international human rights norms. ${ }^{136}$ Several PMSCs, for example, have organized themselves and formed the International Peace Operations Association (IPOA), and drafted a voluntary code of

\footnotetext{
134 See Interactions Between Companies and Private Security, <www.voluntaryprinciples.org/ principles/private_security $>$ (last visited 12 August 2010).

135 Ibid.

136 See also Bearpark and Schulz, "The Regulation of the Private Security Industry and the Future of the Market," p. 239-250, for a discussion of the issue of regulation and self-regulation of the private military and security sector.
} 
conduct. According to the code of conduct, the signatory companies are encouraged to

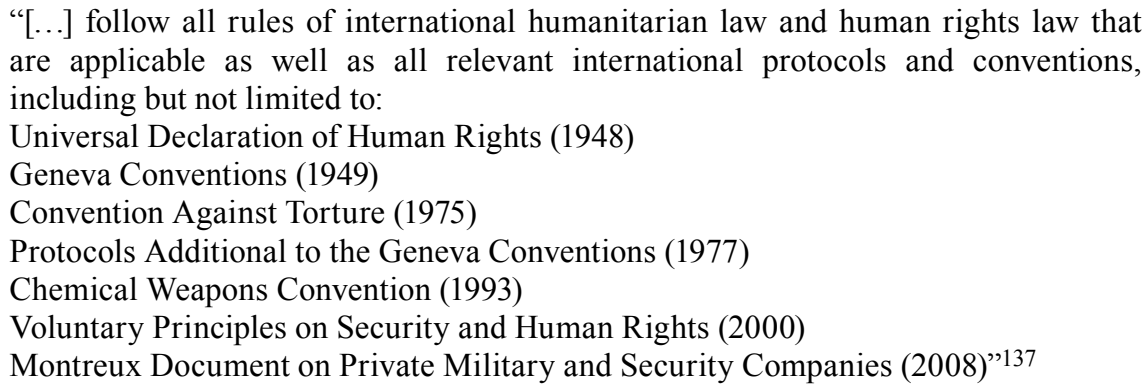

In addition Article 1.1 of the Code of Conduct establishes that "[i]n all their operations, Signatories will respect the dignity of all human beings and strictly adhere to all relevant international laws and protocols on human rights"138 Interestingly, the companies associated to the IPOA have adopted an enforcement mechanism to monitor "[...] Member compliance with the IPOA Code of Conduct ('the Code')." 139 On 29 September 2009, a Standards Compliance and Oversight Procedure (SCOPe) replaced the IPOA enforcement mechanism. ${ }^{140}$ Similar to the old enforcement mechanism, SCOPe provides a procedure for dealing with complaints lodged against companies that are members of the IPOA by 'individuals or entities' and is handled by the IPOA Standards Committee. However, SCOPe is not legally binding and according to its text, the IPOA "[...] is not a law enforcement or judicial organization, and will not attempt to prove the guilt or innocence of a member company in a criminal or civil legal case."141 In addition, the various panels of the Standards Committee involved in reviewing complaints can only "[...] review the operations and procedures of a Subject Company, to suggest and impose remedies, and to monitor the compliance of the Subject Company with the Code."142 The most extreme sanction which can be imposed on an IPOA member company is expulsion from the the association with no reimbursement of membership fees and the publication of "[...] the result of the Complaint in an appropriate public

\footnotetext{
137 See the preamble of the International Peace Operations Association Code of Conduct Version 12, available at $<$ http://ipoaworld.org/eng/codeofconduct.html $>$ (last visited 10 May 2010). See further below for a brief discussion of the Montreaux Document. Ibid.

139 The text of the enforcement mechanism can be found at <http://ipoaworld.org/eng/ enforcementv01eng.html $>$ (last visited on 20 October 2008, no longer available).

140 The text of SCOPe can be found at $<\mathrm{http}$ ://ipoaworld.org/eng/compliancev02eng.html $>$ (last visited 10 May 2010). The preamble to SCOPe mentions, like the text of the old enforcement mechanism, that it is not legally binding.

141 See preamble of SCOPe and of the enforcement mechanism text.

142 Section 5.2 SCOPe.
} 
forum." 143 Arguably, these two issues raise questions about the viability of these self-regulatory efforts to ensure proper accountability of PMSCs.

The general lack of trust towards self-regulation by the PMS industry and a perceived increase of the activities of PMSCs lies at the heart of recent efforts to improve upon regulatory and monitoring activities in the sector. Thus, at the initiative of the Government of Switzerland and the International Committee of the Red Cross, an international process was launched in 2006 to try to satisfy the demand for a clarification of pertinent legal obligations under international humanitarian law and human rights law with regard to the activities of PMSCs. ${ }^{144}$ The result of this initiative, the 'Montreux Document', highlights the obligations under international law and international humanitarian law of so-called home states (that is States in which PMSCs are registered or incorporated), contracting states (States which contract the services of PMSCs) and territorial states (the States on whose territories PMSCs operate). In particular, the 'Montreux Document' notes that PMSCs and their personnel are "[...] obliged to comply with international humanitarian law or human rights law imposed upon them by applicable national law, as well as other applicable national law such as criminal law, tax law, immigration law, labour law, and specific regulations on private military or security services." 145 This, of course, confirms the lack of horizontal effect of human rights obligations at the international level, without precluding the possibility that national law may impose human rights obligations on these companies. It also generally confirms the status of personnel of PMSCs as civilians under international humanitarian law, ${ }^{146}$ unless they directly take part in the hostilities or are incorporated into the regular armed forces of a State, in which case they may be object of attack or forfeit the right to protection as civilians under international humanitarian law respectively. In any event the document also confirms that PMSC personnel is entitled to prisoner of war status during an international armed conflict if they are considered to be persons accompanying the armed forces as understood in Article $4 \S \mathrm{A}(4)$ of the Geneva Convention Relative to the Treatment of Prisoners of War. ${ }^{147}$

The 'Montreux Document' also restates the question of attribution of the conduct of PMSCs to the State under international (customary) law. Thus it observes that

\footnotetext{
143 Sections 6.10 and 6.11 SCOPe.

144 See the "Montreux Document" on the pertinent international legal obligations and good practices for States related to operations of private military and security companies during armed conflict attached to a letter dated 2 October 2008 from the Permanent Representative of Switzerland to the United Nations addressed to the Secretary-General of the United Nations, UN Doc. A/63/467-S/2008/636 (6 October 2008), p. 3.

146 Ibid., paras 24-26.

147 See Section 3.1 supra.
} 
"Although entering into contractual relations does not in itself engage the responsibility of Contracting States, the latter are responsible for violations of international humanitarian law, human rights law, or other rules of international law committed by PMSCs or their personnel where such violations are attributable to the Contracting State, consistent with customary international law[...]"148

In this regard, the Document lists the possible means of attributing the conduct of PSMCs as established under the principles of state responsibility including acting as being an organ of the state, exercising elements of governmental authority, and acts directed or controlled by the State. ${ }^{149}$

In addition, the 'Montreux Document' contains a list of seventy good practices for all these types of States as well as for PMSCs. These good practices range from licensing programs, terms of contract, monitoring compliance and criminal accountability for crimes under international and national law as well as noncriminal accountability including contractual sanctions, to procedures regarding authorization of their deployment. It should be noted that the Document is not legally binding and was supported during its drafting through the participation of seventeen States, all of which have had varying degrees of experience with regard to the activities of PMSCs. ${ }^{150}$

The 'Montreux Document' has recently been complemented through the elaboration of an International Code of Condcuct for Private Security Service Providers. The Draft Code is the result of a joint initiative from the Swiss Government and industry associations together "with the support of main governmental clients, humanitarian organisations and civil society." 151 The International Code of Conduct builds on the foundations of the Montreux initiative and the framework established by John Ruggie in his capacity as Special Representative of the UN Secretary General on

148 'Montreaux Document', para 7.

149 See Chapter IV, Section 2. Paragraph 7 of the 'Montreux Document states that PMSC conduct is attributable to the State if they are: "a) incorporated by the State into their regular armed forces in accordance with its domestic legislation; b) members of organized armed forces, groups or units under a command responsible to the State; c) empowered to exercise elements of governmental authority if they are acting in that capacity (i.e. are formally authorized by law or regulation to carry out functions normally conducted by organs of the State); or d) in fact acting on the instructions of the State (i.e. the State has specifically instructed the private actor's conduct) or under its direction or control (i.e. actual exercise of effective control by the State over a private actor's conduct)."

150 The participating States were Afghanistan, Angola, Australia, Austria, Canada, China, France, Germany, Iraq, Poland, Sierra Leone, South Africa, Sweden, Switzerland, the United Kingdom of Great Britain and Northern Ireland, Ukraine, and the United States of America.

151 See Press Release of Swiss Government, "International Code of Conduct for Private Security Providers signed by close to 60 companies," 9 November 2010, available at $<$ www.news.admin. $\mathrm{ch} /$ dokumentation/00002/00015/index.html?lang=en\&msg-id=36144> (last visited 10 December 2010). 
Business and Human Rights (see Chapter III Section 3.2.2). ${ }^{152}$ With the International Code of Conduct, the signatory companies, which include major players of the industry such as DynCorp, Aegis, and Xe (formerly known as Blackwater), "[...] affirm that they have a responsibility to respect the human rights of, and fulfil humanitarian responsibilities towards, all those affected by their business activities, including Personnel, Clients, suppliers, shareholders, and the population of the area in which services are provided." 153 The companies signing the code agree to adhere to it, even if the code is not included in their contractual agreements with their clients, and should require their personnel to comply with international humanitarian law, and human rights law "[...] as imposed upon them by applicable national law, as well as all other applicable international and national law." ${ }^{54}$ Companies are also urged to exercise due diligence to ensure compliance with the law and to respect the human rights of the persons they come in contact with. The International Code also includes a number of principles regarding the conduct of the personnel of the signatory companies such as rules on the use of force, detention and apprehension of persons, and on the prohibition of torture or other forms of cruel, inhuman or degrading treatment or punishment. In addition, the Code comprises rules pertaining to the hiring of personnel, training (including weapons training), and the reporting of incidents. As a means to enforce the International Code, the document finally includes a procedure to address grievances from "[...] claims alleging failure by the Company to respect the principles contained in this Code brought by Personnel or by third parties." 155 The International Code of Conduct, being such a new initiative, is yet unproven, although the large number of companies that have signed it (over sixty) gives some hope that it will be taken seriously. On the other hand, since it is also a non-binding document, the means of enforcing any claims through the establishment of grievance procedures within each of the companies is probably its weakest point. To address this point, a steering committee will be established with a mandate to establish an independent governance and oversight mechanism, which will also be in charge of a certification process for companies that claim to fully comply with the code. ${ }^{156}$

Another initiative in the wake of the 'Montreux Document' is the Draft International Convention on the Regulation, Oversight and Monitoring Of Private Military and Security Companies (The Draft International Convention). ${ }^{157}$ The Draft

152 See preamble of the International Code of Conduct for Private Security Providers, availbale at $<$ www.news.admin.ch/NSBSubscriber/message/attachments/21143.pdf $>$ (last visited 10 December 2010).

153 Ibid., para. 4.

154 Ibid., paras. 19 and 21.

155 Ibid., para. 66.

156 Ibid., paras. 5, 9, 11 and 12.

157 Draft International Convention on the Regulation, Oversight and Monitoring Of Private Military and Security Companies, UN Working Group on the Use of Mercenaries as a Means of Violating Human Rights and Impeding the Exercise of the Right of Peoples to Self-Determination (13 July 
International Convention is the work of the UN's Working Group on the use of mercenaries as a means of violating human rights and impeding the exercise of the rights of peoples to self-determination, which had been authorized by the UN's Human Rights Council to

"[...] monitor and study the effects on the enjoyment of human rights, particularly the right of peoples to self-determination, of the activities of private companies offering military assistance, consultancy and security services on the international market and to prepare a draft of international basic principles that encourage respect for human rights by those companies in their activities." 158

While the Draft International Convention acknowledges the various efforts of the private military and security sector towards self-regulation, its preamble considers these efforts to be insufficient. The Draft International Convention aims at providing a comprehensive regime to regulate and monitor the activities of PMSCs by clarifying the state responsibility for the conduct of these companies, requiring the licensing of their activities, establishing the companies' obligations, and the proposing the adoption of an international monitoring system. ${ }^{159}$ Of particular relevance is the Draft International Convention's attempt to oblige PMSCs and their personnel to observe the norms of international humanitarian law and human rights when they provide their services. ${ }^{160}$ In addition it wants to oblige eventual States parties to prohibit PMSCs from carrying out activities that are "[...] intrinsically governmental, including waging war and /or combat operations, taking prisoners, espionage, intelligence and police powers, especially the powers of arrest or detention, including the interrogation of detainees."'161 Furthermore, the Draft

2009). The text of the Draft International Convention is available at a website specially created to highlight the activities of the UN Working Group. See <www.unwg.rapn.ru/en/legislation. htm> (last visited on 30 March 2009). The Draft International Convention was submitted for consideration and action to the UN Human Rights Council in September 2010. See <www.ohchr. org/EN/NewsEvents/Pages/DisplayNews.aspx?NewsID=9953\&LangID=E $>$ (last visited on 30 March 2010). As a result, a resolution was adopted to establish an intergovernmental working group that would study the Draft Convention. See footnote 164 infra. See for a deeper discussion of the Draft International Convention N.D. White, "The Privatisation of Military and Security Functions and Human Rights: Comments on the UN Working Group's Draft Convention," Human Rights Law Review Vol. 11 (2011), p. 133-151.

See Human Rights Council Resolution 7/21 adopted at its $41^{\text {st }}$ Meeting on the Mandate of the Working Group on the use of mercenaries as a means of violating human rights and impeding the exercise of the right of peoples to self-determination, UN Doc. A/HRC/RES/7/21 (28 March 2008), para. 2(e). and Monitoring Of Private Military and Security Companies.

160 Ibid., Article 7.

161 Ibid., Article 8. Article 2 (k) of the Draft International Convention defines 'fundamental State functions' as "[...] functions that a State cannot outsource or delegate to non-State actors. Among such functions, consistent with the principle of State monopoly on the use of force, are waging war and/or combat operations, taking prisoners, law-making, espionage, intelligence and 
International Convention aims at obliging States to adopt regulatory, oversight and licensing measures over PMSCs, including regulations on the use of force. ${ }^{162}$ In terms of legal oversight and monitoring, the proposed instrument adopts a two track approach. In the first place, it prescribes the criminalization of offenses by PMSCs and the establishment of (criminal) jurisdiction, the establishment of liability of legal persons, and the provision of remedies to victims of abuses by these companies at the national level (Articles 21-29). In the second place, the Draft International Convention aims to establish through Article 32 an international monitoring mechanism (an International Committee on the Regulation, Oversight and Monitoring of Private Military and Security Companies), with similar monitoring tools as other UN treaty bodies. Thus, a State reporting mechanism is prescribed, together with an inquiry procedure similar to that found in Article 20 of the Convention Against Torture, an inter-State complaint procedure, an ad-hoc conciliation commission to solve disputes between States parties, and optional individual and group petitions. ${ }^{163}$

As an initiative to regulate the use and the activities of PMSCs, the Draft International Convention, if ever adopted, ${ }^{164}$ would certainly be one of the first international human rights instruments to directly deal with the issue of privatization. There are, however, a number of issues that this initiative brings up to mind and which are worth of brief mention. In the first place, although it is too premature to discuss the potential impact of this Draft International Convention, the mere fact that it is being considered suggests that in spite of the controversies surrounding the privatization of military functions, international law appears to acquiesce the fact that States are going to use or need the services provided by these companies. Accepting the need to regulate the activities of PMSCs is also accepting the fact that States have the possibility of privatizing certain military and security functions, albeit within certain limits. Those who oppose privatization in this field

police powers, especially the powers of arrest or detention, including the interrogation of detainees." See also Article 31 which imposes certain obligations on PMSCs including refraining from carrying out those activities mentioned in Article $2(\mathrm{k})$.

162 Articles 14-20.

163 See Articles 33, 36, 37, 38 and 40. In addition, Article 35 allows the proposed Committee to issue interpretative Comments on the Draft Convention.

164 The UN Human Rights Council adopted on 1 October 2010 a resolution aimed "[...] to establish an open-ended intergovernmental working group with the mandate to consider the possibility of elaborating an international regulatory framework, including, inter alia, the option of elaborating a legally binding instrument on the regulation, monitoring and oversight of the activities of private military and security companies, including their accountability, taking into consideration the principles, main elements and draft text as proposed by the Working Group on the use of mercenaries as a means of violating human rights and impeding the exercise of the right of peoples to self-determination[...]" See Resolution 15/26 of the Human Rights Council, "Openended intergovernmental working group to consider the possibility of elaborating an international regulatory framework on the regulation, monitoring and oversight of the activities of private military and security companies," UN Doc. A/HRC/RES/15/26 (7 October 2010), para. 4. 
are likely not to be too pleased with the Draft Convention from this perspective. In the second place, this initiative is bound to face certain obstacles which put in doubt its eventual adoption or future effectiveness. It is, for example, highly conceivable that those countries that have the highest stake in the use and deployment of PMSCs will refuse to support the adoption of this instrument, let alone sign or ratify it. ${ }^{165}$ It is quite probable that these countries will be highly suspicious of an international monitoring body with 'far reaching' powers, including the proposed inquiry and individual complaint mechanisms and refuse to work towards the instruments adoption. ${ }^{166}$ When the UN Human Rights Council adopted a resolution in October 2010 to establish an open-ended intergovernmental working group with the aim of considering a regulatory framework for PMSCs including a legally binding document based on the Draft International Convention twelve of the forty seven Member States present voted against it. ${ }^{167}$ According to the press release announcing the adoption of the resolution, the United States requested a vote for the initiative denying a consensus vote, and mentioned its opposition to the resolution together with the United Kingdom and other countries of the European Union. ${ }^{168}$

165 Countries that come into mind are those who rely heavily on their use or in which these companies are usually based, like the United States and the United Kingdom. See news report on the efforts of the UN Working Group to hold consultations about the Draft Convention, and which mentions that "[o]pposition to a legally binding approach has come from a number of countries where the private military and security companies are headquartered[,]" available at $<$ www.ohchr.org/EN/NewsEvents/Pages/Gunsforhire.aspx > (last visited on 10 May 2010). The news report does mention that the Governments of many of these countries have responded to increased scrutiny from civil society, parliamentarians and media, and adopted regulations or other measures at the national level and are considering a model of self regulation for the industry.

166 To illustrate this point, during the initial years of the occupation of Iraq by the United States, the former Bush administration managed to arrange immunity from prosecution by local courts in Iraq for PMSCs and their personnel between 2003 and 2008. See further Section 4 infra. It is not unimaginable that the same considerations of military expediency and flexibility requirements in military operations that partially rely on the use and deployment of PMSC personnel and which probably led to arranging this immunity will motivate the governments of these countries to forego support of the proposed Draft Convention.

167 The resolution was adopted by thirty two votes in favor, twelve against and three abstentions. See note 164 supra.

168 See Press Release, Human Rights Council establishes Working Group on activities of Private Security Companies, renews mandates on Sudan and Somalia, 1 October 2010, available at $<$ www.ohchr.org/EN/NewsEvents/Pages/DisplayNews.aspx?NewsID=10407\&LangID=E $>$ (last visited 20 May 2011). It is worthy of note that the European Commission funded a research project on the regulation of PMSCs which resulted in a number of academic publications in the subject, and led to an initiative called the Priv-War Consortium. This Consortium, which is composed of a number of universities in Europe, including the European University Institute in Florence, Justus-Liebig Universität in Germany, Université Panthéon-Assas, Paris, University of Nottingham and Utrecht University in the Netherlands, adopted a number of recommendations for the EU on the regulation of the activities of PMSCs. See "Priv-War Recommendations for EU Regulatory Action in the Field of Private Military and Security Companies and their Services," March 2011 available at <http://priv-war.eu/wordpress/wp-content/uploads/2011/07/ Priv-War-Recommendations-_FINAL.pdf $>$ (last visited on 30 May 2011). Among the 
The reasons presented against the resolution by those opposing it included observations that the regulation of PMSCs would be better served through improved implementation of national legislation and the adoption of more robust codes of conduct. These countries further observed that the Human Rights Council was not the appropriate forum for discussing PMSCs, and even maintained that their use was not a human rights issue. ${ }^{169}$

Even if a legally binding instrument based on the Draft Convention is adopted, it is by no means certain that those countries that did not support the initiative would even be open to cooperate with any proposed monitoring body. For example, in its explanation of the vote before the vote to adopt the abovementioned resolution, the United Kingdom stated that if the resolution was adopted, the activities intergovernmental working group would have to be financed from the internal resources of the Office of the High Commissioner for Human Rights, probably meaning that the opposing States would not contribute in any way to the drafting of a legally binding document. Without the participation of these countries in any legally binding document resulting from the Draft Convention, the effect of the instrument would be quite limited. In addition, there is also the practical obstacle of establishing yet another UN human rights monitoring body alongside the ten already in existence given the current discussions within the UN to rationalize and streamline its human rights system through, for example, the adoption of a single standing human rights body. ${ }^{170}$ Establishing another monitoring treaty body that would impose and additional burden on the already limited budgetary and logistical capabilities of the UN human rights system is probably asking too much. Under these circumstances, it is quite unlikely that this well-meant initiative will have much chance of survival. It is suggested that a less ambitious approach is adopted, which does not exclude the possibility of an international treaty on the subject, but which places the emphasis on national regulation and the use of existing local and international human rights monitoring mechanisms, instead of trying to re-invent the wheel.

\subsection{Preliminary conclusions}

In sum, there is currently no rule of international law that prohibits the deployment of PMSCs or the privatization of military tasks and services as long as the personnel

recommendations is the adoption of a directive seeking to harmonize national measures regulating PMSCs, and a decision in the context of the Common Foreign and Security Policy of the EU.

Ibid.

170 For further discussions on the need to reform the UN Human Rights treaty body system see <www2.ohchr.org/english/bodies/treaty/reform.htm>. 
employed by these companies and States are not mercenaries. ${ }^{171}$ However, in light of the nature of the activities they carry out, offering services that may include the coercive use of lethal force, it is not unreasonable to conclude that their international status is somewhat uncertain and it would seem that some form of regulation is necessary. ${ }^{172}$ National efforts to attempt to regulate this business sector are initial steps toward improved monitoring of the activities of PMSCs. It is also worth noting that States themselves recognize that there can be certain limits to the privatization of military tasks. Various companies operating in the sector also acknowledge the need for self-regulation. However, given the fact that many of these companies operate abroad, directly or through subsidiary corporations, and often under contract with other governments, national regulation and self-regulation may not be sufficient. In view of the events in Iraq, which are discussed below, it would even appear that national regulations covering PMSC personnel accompanying their own national forces are insufficient to control their conduct. International regulation becomes even more indispensable due to the perceived necessity of delegating more military tasks to private actors in order to allow the real military to concentrate on their core business. In addition, it is not unthinkable that the deployment of PMSCs under certain circumstances could be a viable option to boost international peacekeeping operations, especially when states' unwillingness to participate in such operations creates a shortage of traditional peacekeeping troops. The absence of clear international rules regarding the privatization of military tasks is problematic. This problem is compounded when this type of privatization includes the delegation of tasks that could comprise the lethal use of force. A recent initiative to draft an international convention that regulates the activities of PMSCs is an interesting step towards closing this gap. However, in its current state, it is probably overly ambitious and may likely fail to attract the adherence of those States that make heavy use of PMSCs. A more cautious approach that prescribes regulation and the use of existing human rights monitoring arrangements would be more realistic and more palatable to these States.

171 See Art. 2 of the International Convention which states that "[a]ny person who recruits, uses, finances or trains mercenaries [...] commits an offence for the purposes of the Convention." See also D. Kritsiotis, "Mercenaries and the Privatization of Warfare," Fletcher F. World Aff. Vol. 22 (1998), p. 19.

172 The former Special Rapporteur on mercenaries has observed that "[t]he nature and degree of accountability of these organizations and their employees is uncertain, paving the way for impunity for a range of acts which would otherwise be criminal. Also, the legal status of private actors offering military services internationally is unclear, thus rendering the actor vulnerable to national legislation, often deficient where it exists, and thereby to improvised procedures in the case of perceived breaches. The uncertainty derives from the current inability of international law to accommodate actors whose attributes include international scope and private motive, and whose role may include either individual or corporate involvement in military operations." See UN Doc. E/CN.4/2005/14, para. 46. 


\section{Case Study: PMSCs, IHL and human Rights law in Abu GHRAIB PRISON, IRAQ}

The publication in April 2004 of the shocking photos depicting Iraqi prisoners that had allegedly been abused by U.S. military personnel at Abu Ghraib prison took world opinion by surprise. The question was raised how this could have happened and whether U.S. military personnel were properly trained in the basic rules of international humanitarian law and human rights. The surprise became even bigger after it became known that not only military personnel had been involved in the abuse, but also contractors of private military and security companies. As a way of compensating for the relative small numbers of regular army personnel involved with handling and processing detainees, the U.S. Army apparently contracted two private military and security companies to provide support for translation and interrogation duties. The presence of private military and security companies in Iraq had already been the focus of discussion following the shocking pictures of the burnt bodies of four PMSC contractors that had been ambushed by insurgent militia in the troubled city of Falluja while escorting a convoy at the beginning of April 2004. The apparent complicity of the personnel of PMSCs in the abuse scandal at Abu Ghraib fueled further controversy about the wisdom of utilizing their services. This controversy was again highlighted following the shoot-out incident on 16 September 2007 involving contractors of U.S. PMSC Blackwater, in which at least 17 Iraqi civilians were killed in an attempt by Blackwater to evacuate senior U.S. officials following a bomb explosion in the neighborhood where these officials were meeting.

\subsection{The presence of PMSCs in Iraq}

During the Persian Gulf War of 1991, the American armed forces already made use of PMSCs, to provide support for the military effort to repel the Iraqi army from Kuwait. The recent invasion and occupation of Iraq prompted the United States to make even further use of these companies. Until 2004 there were an estimated four thousand employees of PMSCs active in Iraq. ${ }^{173}$ By 2007, between 20,000 and 30,000 civilians were working for the United States in Iraq as private military contractors, 2500 of which were employed by the U.S. State Department mainly to guard American diplomats and sensitive facilities there. ${ }^{174}$ Most of these companies have been deployed for security and guarding purposes. The British company Erinys was contracted, for example, to protect oil installations and pipelines against

173 See CNN news report "7 U.S. security contractors killed in Iraq" (21 April 2005) available at $<$ www.cnn.com/2005/WORLD/meast/04/21/iraq.contractors/> (last visited 25 May 2005).

174 See news report, "Armed Guards in Iraq Occupy a Legal Limbo," J.M. Broder and J. Risen, New York Times, 20 September 2007. The State Department relies primarily on three companies: Dyncorp, Blackwater and Triple Canopy. 
armed assaults and sabotage by insurgents. ${ }^{175}$ Although it would appear that many of these companies have not been deployed for offensive military operations, a number of contractors of PMSCs have been regularly caught up in situations involving the lethal use of force. ${ }^{176}$ More recently, Blackwater has been investigated for being involved in various shooting incidents, which are twice as high as incidents involving other companies working in the country. ${ }^{177}$

Other companies have been contracted to provide translation and interrogation services in a number of Iraqi prisons. ${ }^{178}$ One of the best-known examples is the presence of contractors of two PMSCs, CACI International Inc. and The Titan Corporation, in the infamous Abu Ghraib prison. ${ }^{179} \mathrm{CACI}$, a company specializing in IT and network applications for "defense, intelligence and e-government" purposes, was contracted to provide interrogators for Abu Ghraib. Titan, a company that delivers information and communication services to the American armed forces, was assigned to provide translation services and interpreters to the same facility.

\subsection{Violations of international humanitarian and human rights law in Abu Ghraib by contractors of PMSCs}

Prior to the publication of the shocking photographs depicting the abuses at Abu Ghraib, the U.S. Army was already investigating the facts and circumstances that led to the controversial situation. Following confidential reports of the International Committee of the Red Cross regarding alleged physical abuses of prisoners at Abu Ghraib prison, Major General Antonio Taguba was appointed in January 2004 to lead an investigation of these allegations at the request of the highest ranking army officer in Iraq, Lt. General R. Sánchez. Taguba finished his investigation at the

175 See $<$ www.erinysinternational.com $>$.

176 See for example a news report of the New York Times describing how PMSC contractors in Iraq had to defend themselves against attacks by insurgents by throwing grenades at them. "2 Pipeline Blasts Halt Oil Exports at Top Iraq Port,” New York Times, 16 June 2004.

177 See news report, "State Dept. Tallies 56 Shootings Involving Blackwater on Diplomatic Guard Duty," J. Risen, New York Times, 28 September 2007.

178 In fact a report dealing with detainee operations in Iraq observes that interrogation contractors were deployed to conduct interrogations "[...] at locations throughout the battlespace [...]" See report Detainee Operations Inspection, Department of the Army, The Inspector General, 21 July 2004, p. 33.

179 See Article 15-6 Investigation of the $800^{\text {th }}$ Military Police Brigade (Taguba Report), which can be found at $<$ http://news.findlaw.com/hdocs/docs/iraq/tagubarpt.html $>$ (last visited on 15 June 2004). Secretary of Defense Rumsfeld and a number of high ranking generals at the Department of Defense confirmed the presence of contractors of both companies during a hearing at the U.S. Senate which was held on 7 May 2004 following the publication of the infamous photographs and reports of abuses of detainees in Abu Ghraib prison. See the transcript of the minutes of the hearing which can be found at the website of the Department of Defense: <www.dod.gov/ speeches/2004/sp20040507-secdef0443.html> (last visited on 14 June 2004). 
beginning of March 2004. His conclusions led to the dismissal of Brigadier General Janis Karpinski, who had command over the military personnel working at Abu Ghraib. ${ }^{180}$

Taguba's report identified the various problems plaguing Abu Ghraib. He found that, in general, there was a lack of sufficient and adequately trained personnel with adequate knowledge of international humanitarian law and human rights. ${ }^{181}$ Taguba divided his report into three sections describing the problems at Abu Ghraib. In each of these sections he briefly noted the degree of participation of $\mathrm{CACI}$ and Titan contractors in the abuses.

The first section of the investigation's findings described the grave prisoner abuse that has now been widely described in the media. This included punching, slapping, and kicking detainees; videotaping nude male and female detainees; forcibly arranging detainees in various sexually explicit positions for photographing; forcing nude male detainees to wear women's underwear; forcing groups of male detainees to masturbate while being photographed and videotaped; arranging nude male detainees in a pile and then jumping on them; and positioning a nude detainee on a box, with a sandbag on his head, and attaching wires to his fingers, toes, and penis to simulate electric torture. ${ }^{182}$ The abuses were determined on the basis of the photographs and videos made by the prison personnel and on the basis of conversations with detainees and witnesses, including one interpreter from Titan. This particular contractor is also considered to be one of the suspected participants responsible for the abuses. ${ }^{183}$ Nevertheless, Taguba did not mention anything about the actual participation of this contractor in his conclusions and recommendations regarding the abuses and did not provide any reccomendations for punishment for his participation. ${ }^{184}$

180 In March 2005, Brigadier General Karpinski was apparently given an administrative reprimand, being until now the only senior officer that has been officially berated for the abuses. See Washington Post news report, "Senators Question Absence of Blame in Abuse Report," 11 March 2005.

This finding was later verified by the report on Detainee Operations Inspection that concluded that $35 \%$ of the contract interrogators used to offset a shortage of interrogators lacked formal training in military interrogation policies and techniques. See report Detainee Operations Inspection, Department of the Army, The Inspector General, 21 July 2004, p. 87-89. It would appear that training in these policies, techniques and the Geneva Conventions started in May 2004, following the reported abuses in Abu Ghraib. Ibid., p. 88.

182 See Findings and Recommendations, Part One, Taguba Report, paras. 6 and 8.

183 See Findings and Recommendations, Part One Taguba Report, para. 7.

184 Several of the suspects, members of the Military Police who were depicted in the photographs and who were mentioned by name in the report, have already been subject to court martials. See BBC news report "Woman soldier admits Iraq abuse" (2 May 2005) available at http://news.bbc. co.uk/2/hi/americas/4504833.stm (last visited on 25 May 2005). 
The second section of the Taguba report describes the unclear situation and the lack of accountability within Abu Ghraib. Taguba notes that there was insufficient supervision over the activities of CACI's and Titan's personnel inside the prison. Additionally, he mentioned that these contractors had easy and unsupervised access to the section of the prison where the detainees were being held. Due to the fact that these contractors did not wear any uniforms, they were difficult to distinguish from normal detainees. Taguba, therefore, recommended limiting the access of PMSCs' contractors throughout the prison and providing them with uniforms in order to make them easily distinguishable from detainees. ${ }^{185}$

The third section of the report is dedicated to describing the general policy within the prison, as well as the inadequate training of personnel and the dubious standards that were applied in the prison, which probably led to the prisoner abuses. According to the report, one CACI interrogator allegedly allowed and encouraged physical abuse by the military police in the prison to facilitate interrogations. ${ }^{186}$ The report did not specify whether this particular contractor was also involved in committing the abuses himself. Taguba, however, suspects that this contractor, together with another CACI employee, was either directly or indirectly responsible for a number of abuses. This led Taguba to recommend the termination of these individuals' contracts and an investigation to determine the full extent of their culpability. ${ }^{187}$

Upon the heels of the Taguba report, other independent investigations of the Abu Ghraib incident were published in the summer of 2004. Reports by the Army Inspector General ${ }^{188}$ and by an independent panel set up by the then U.S. Secretary of Defense, Donald Rumsfeld, ${ }^{189}$ corroborate to a great extent the findings of the Taguba report regarding the abuses that took place at Abu Ghraib prison. Both reports go briefly into the role of PMSCs contractors in the interrogation procedures at the prison. Although the reports do not make any specific conclusions regarding the role of individual contractors in the abuses, they do point to the lack of proper training for these contractors with respect to the legal and legitimate ways of conducting interrogations according to U.S. Army and international humanitarian law standards. Additionally, the reports conclude that there was insufficient supervision over the activities of these contractors. ${ }^{190}$

185 See Findings and Recommendations, Part Two, Taguba Report, para. 30 and Recommendations Regarding Part Two of the Investigation, Taguba Report, para. 14.

186 See Findings and Recommendations, Part Three, Taguba Report, para. 11.

187 Ibid., para. 13.

188 See rapport van de Department of the Army, The Inspector General, "Detainee Operations Inspection" dated 21 July 2004.

189 See Final Report of the Independent Panel to Review DoD Detention Operations, dated 24 August 2004. The report can be found at $<$ http://news.findlaw.com/hdocs/docs/dod/ abughraibrpt.pdf $>$, (last visited on 25 August 2004).

190 The Independent Panel's report concludes nevertheless that the contracting out of PMSC should continue, with due regard to the recommendations of the Panel (these include having a stricter 
At the request of Lieutenant General Ricardo Sánchez and in view of the findings of the Taguba report, another investigation of the abuses at Abu Ghraib, the Fay report, appeared during the summer of 2004. ${ }^{191}$ This report went further than the abovementioned reports and described in detail forty-four individual cases of prisoner abuse and humiliation or degradation in the prison. According to the report, individual contractors of CACI and Titan were directly involved in four of these abuse cases. In one case the Fay report observed that a preponderance of evidence supported the fact that one of the CACI contractors, "[...] grabbed a detainee (who was handcuffed) off a vehicle and dropped him to the ground [and] then dragged him into an interrogation booth and as the detainee tried to get up, [the CACI contractor] would yank the detainee very hard and make him fall again."192 Another CACI contractor was suspected of encouraging physical abuse of an Iraqi detainee by military personnel, failing to prevent further abuse, intimidating other prisoners with dogs, and placing a detainee in an unauthorized stress position. ${ }^{193} \mathrm{~A}$ Titan contractor was suspected of failing to report detainee abuse that she apparently witnessed, ${ }^{194}$ while another Titan contractor who also failed to report or stop the abuse was suspected of actively participating in the abuse. This particular contractor was apparently present during the abuse of the detainees depicted in the various photographs and allegedly hit and cut the ear of a detainee requiring stitches. He is also suspected of having raped a young detainee. ${ }^{195}$

\subsubsection{Violations of international humanitarian law}

The findings of the Taguba report and the other more recent investigations ${ }^{196}$ raises the question as to whether these events amount to violations of international

selection of the personnel being hired, improving their training and furthering the supervision of their activities). Ibid, p. 69.

AR 15-6 Investigation of the Abu Ghraib Detention Facility and 205 Brigade, MG George R. Fay Investigating Officer, 25 August 2004. The report can be found at $<$ http://news.findlaw.com/hdocs/docs/dod/fay82504rpt.pdf >, last visited on 25 August 2004. The report describes the period between 20 September and 13 December 2003.

192 See Investigation of the Abu Ghraib Detention Facility, p. 131.

193 According to the report the detainee was placed "[...] in a dangerous position where he might fall back and injure himself." Ibid, p. 132. The contractor was also suspected of failing to prevent this detainee from being photographed. Ibid.

194 Ibid., p. 133.

195 Ibid.

196 In addition to the Inspector General's and Fay reports, the Naval Inspector General, Vice Admiral Albert T. Church III was directed by former Secretary of Defense Rumsfeld to conduct a comprehensive review of the interrogation operations of the Department of Defense (the Church report). An executive summary of the Church report was presented on March 2005 and devoted some paragraphs to the issue of contractor interrogation observing that there were "[...] very few instances of abuse involving contractors." The executive summary of this report is available at $<$ www.pentagon.gov/news/Mar2005/d20050310exe.pdf $>$, last visited on 22 May 2005. 
humanitarian law and of human rights. The present author submits that a number of the abuses committed against Iraqi prisoners of war amount to violations of international humanitarian law. Common Article 3 of the Geneva Conventions of 1949, which is applicable in non-international armed conflicts, forbids cruel treatment and torture, as well as other "outrages upon personal dignity" such as humiliating and degrading treatment in armed conflicts. The International Criminal Tribunal for the Former Yugoslavia (ICTY) has held in the Furundzija case that the prohibition of torture constitutes jus cogens, a peremptory norm of international customary law. ${ }^{197}$ In the Kunarac case, the ICTY defined torture as the intentional infliction, by act or omission, of severe pain or suffering, whether physical or mental, in order to obtain information or a confession, or to punish, intimidate or coerce the victim or a third person[...]"198 Additionally, according to Article 13 of Geneva Convention (III) and Articles 27 and 32 of Geneva Convention (IV) together with Article 76 of Geneva Convention (IV) prisoners of war as well as other detainees must at all times be humanely treated. ${ }^{199}$ Moreover, Article 13 in conjunction with Article 130 of Geneva Convention (III) stipulates that acts of commission or omission perpetrated by the "Detaining Power" (in this case the United States), which are harmful to the health and life of prisoners of war, amount to a grave breach of the Geneva Conventions. ${ }^{200}$ The United States is party to all these conventions, which, on the basis of Common Article 2 are also applicable to the present situation. ${ }^{201}$ Geneva Convention (III) is in any case applicable for Iraqi prisoners of war in Abu Ghraib on the basis of Article 5 which states that the convention applies to this category of prisoners from the time they fall into the power of the enemy and until their final release. Moreover, the protection granted by Geneva Convention (III) remains applicable for those prisoners whose status as prisoners of war is doubtful, until their status is determined by a competent

197 Prosecutor, v. Furundzija, ICTY, Trial Chamber, judgment of 10 December1998, Case IT-9517/1, para. 153. See also Y. Dinstein, The Conduct of Hostilities Under the Law of Armed Conflict (Cambridge: Cambridge University Press, 2004) p. 24.

198 Prosecutor, v. Kunarac, Kovac and Vukovic, ICTY, Trial Chamber, judgment of 22 February 2001, Case IT-96-23/1, para.497. See also J.- M. Henckaerts and L. Doswald-Beck, Customary International Humanitarian Law, Volume I: Rules (Cambridge: Cambridge University Press/ICRC, 2005) p. 318.

199 The prison population inside Abu Ghraib varies from common criminals to former soldiers and suspected terrorists.

200 See also Article 147 of Geneva Convention (IV) which defines grave breaches as acts committed against persons protected by the the Convention and which involve inter alia "[...] wilful killing, torture or inhuman treatment, including biological experiments, wilfully causing great suffering or serious injury to body or health[...]" Grave breaches may lead to international criminal responsibility of those suspected of committing the breaches and could lead them to be tried by a national (or international) court.

201 The situation in Iraq at that point in time (between the beginning of the invasion of Iraq on 20 March 2003 and the transfer of power from the Coalition Provisional Authority (CPA) to the Iraqi Interim Government on 28 June 2004) was arguably one of occupation as provided for in Common Article 2 to the Geneva Conventions. 
tribunal. ${ }^{202}$ With respect to the civilian prisoners found in Abu Ghraib, Geneva Convention (IV) is also applicable to the present situation. Article 6 Geneva Convention (IV) states that the convention applies from the outset of any conflict or occupation, and ceases to apply one year after the general close of military operations in cases of occupation (in this case one year after the proclamation by former president George W. Bush to the effect that hostilities had ceased on 1 May 2003). However, according to Article 6 of Geneva Convention (IV) the latter remains applicable for the duration of the occupation with respect to Articles 27, 32, and 76, when the occupying power exercises the functions of government in the occupied territory. Arguably this is also the case in the present situation.

In light of the nature of the abuses that took place in Abu Ghraib prison (heavy physical and sexual abuses, intimidations with or without the help of dogs and other denigrating treatment with the aim of obtaining information) there can be little doubt that these abuses amount to torture and other cruel treatment as defined in the Kunarac case and as understood by common Article 3 to the Geneva Conventions, Articles 13 of Geneva Convention (III), 27 and 32 of Geneva Convention (IV) and thus a 'grave breach' of these two Conventions.

\subsubsection{Violations of human rights}

The abuses committed in Abu Ghraib prison also amount to human rights violations, in particular with respect to normal detainees who are not prisoners of war. The most important rights at stake under these circumstances are the right not to be subjected to torture or to cruel, inhuman or degrading treatment or punishment found in Article 7 ICCPR $^{203}$ and Article 2 \$ CAT in connection with Article 1 $\mathrm{CAT}, 204$ and the right of a person to humane treatment while deprived of his liberty as protected by Article 10 ICCPR. ${ }^{205}$ Most importantly, according to Article 4 paragraphs 1 and 2 ICCPR, Article 7 ICCPR is nonderogable even in times of armed

202 See Article 5 Geneva Convention (III).

203 Article 7 ICCPR reads: "No one shall be subjected to torture or to cruel, inhuman or degrading treatment or punishment."

204 Torture is defined by Article 1 CAT as "[...] any act by which severe pain or suffering, whether physical or mental, is intentionally inflicted on a person for such purposes as obtaining from him or a third person information or a confession, punishing him for an act he or a third person has committed or is suspected of having committed, or intimidating or coercing him or a third person, or for any reason based on discrimination of any kind, when such pain or suffering is inflicted by or at the instigation of or with the consent or acquiescence of a public official or other person acting in an official capacity. It does not include pain or suffering arising only from, inherent in or incidental to lawful sanctions." Article 2 \$1 CAT states that "[e]ach State Party shall take effective legislative, administrative, judicial or other measures to prevent acts of torture in any territory under its jurisdiction."

205 Article 10 para. 1 ICCPR stipulates that "[a]11 persons deprived of their liberty shall be treated with humanity and with respect for the inherent dignity fo the human person." 
conflict. ${ }^{206}$ Similarly, Article 2 § CAT provides that “[n]o exceptional circumstances whatsoever, whether a state of war or a threat of war, internal political instability or any other public emergency, may be invoked as a justification of torture."207 The United States is party to both the ICCPR and the CAT, although it has ratified both instruments with a number of reservations and declarations that may limit their application in a number of ways. ${ }^{208}$ These rights and freedoms have also been laid down and further developed in other 'soft-law' instruments that are geared toward protecting the rights and dignity of persons who have been deprived of their liberty. 209

The Human Rights Committee has observed that Articles 7 and 10 ICCPR are each other's complement and that the obligations ensuing from Article 7 are of special importance for the application of Article 10. ${ }^{210}$ Violations of Article 7 ICCPR will often coincide with violations of Article 10. The Committee has not given a precise definition of torture and cruel and degrading treatment. It has, however, observed that the distinction between an acceptable punishment or treatment and punishment that can be regarded as torture will depend on "[...] the nature, purpose and severity

206 According to the Human Rights Committee "[t]he text of article 7 [ICCPR] allows of no limitation. The Committee also reaffirms that, even in situations of public emergency such as those referred to in article 4 of the Covenant, no derogation from the provision of article 7 is allowed and its provisions must remain in force. The Committee likewise observes that no justification or extenuating circumstances may be invoked to excuse a violation of article 7 for any reasons, including those based on an order from a superior officer or public authority." See General Comment No. 20 on the Prohibition of torture, or other cruel, inhuman or degrading treatment or punishment (1992), Human Rights Committee, UN Doc. HRI/GEN/1/Rev.6 (12 May 2003), p. 151. See also General comment No. 29 on Article 4: Derogations during a state of emergency (2001), Human Rights Committee, UN Doc. HRI/GEN/1/Rev.6 (12 May 2003), p. 184 and further.

207 Additionally, Article 2 para. 3 prohibits the justification of torture on the grounds of orders from superior officers or public authorities.

208 The text of these reservations and declarations can be found at the UN's treaty website $(<\mathrm{http}: / /$ treaties.un.org/Pages/Treaties.aspx?id=4\&subid=A\&lang=en>, last visited 31 August 2011) and relate, inter alia, to the definition of torture found in Article 7 ICCPR and Article 1 CAT and to the lack of self-executability of the rights in the Conventions.

209 The most relevant instruments are the Declaration of Basic Principles of Justice for Victims of Crime and Abuse of Power (UN Doc. A/40/34 of 29 November 1985), the Principles on the Effective Investigation and Documentation of Torture and Other Cruel, Inhuman or Degrading Treatment or Punishment (UN Doc. A/55/89 of 4 December 2000), the Body of Principles for the Protection of All Persons under Any Form of Detention or Imprisonment (UN Doc. UN Doc. A/43/173 of 9 December 1988), the Standard Minimum Rules for the Treatment of Prisoners adopted by the First United Nations Congress on the Prevention of Crime and the Treatment of Offenders, held at Geneva in 1955, and approved by the Economic and Social Council by its resolutions 663 C (XXIV) of 31 July 1957 and 2076 (LXII) of 13 May 1977 and the Basic Principles for the Treatment of Prisoners (UN Doc. A/45/111 of 14 December 1990).

210 See General Comments No. 20 and No. 21 on Humane treatment of persons deprived of their liberty (1992), Human Rights Committee, UN Doc. HRI/GEN/1/Rev.6 (12 May 2003), p. 151 and 153. 
of the treatment applied."211 Additionally, the Committee observed that the prohibition of torture as understood in Article 7 relates not only to acts that cause physical pain but also to "[...] acts that cause mental suffering to the victim." 212 In the Committee's eyes, the prohibition must also extend to "[...] corporal punishment, including excessive chastisement ordered as punishment for a crime or as an educative or disciplinary measure." 213 In the past, the Committee has concluded that serious physical abuse with the intent of extracting information from a detainee is a breach of the prohibition of torture under Article 7 ICCPR. ${ }^{214}$ The Committee concluded that the following treatments amount to torture: blindfolding which results in physical harm; hooding; forcing someone to sit up straight, night and day, for one week; and threatening that person with torture. ${ }^{215}$ Cruel treatment in detention is also considered to be a violation of both Articles 7 and 10 ICCPR. ${ }^{216}$

Similarly the Committee Against Torture has concluded that severe beating and punching, as well as insulting a suspect inflicted by public officials in the context of the investigation of a crime and resulting in severe pain or suffering intentionally amount to torture and thus a violation of Article $2 \S 1$ CAT in connection with Article $1 \mathrm{CAT}^{217}$ Beatings during an interrogation with loss of consciousness was also characterized by the Committee Against Torture as severe pain or suffering intentionally inflicted by public officials in the context of the investigation of a crime, and thus constituted torture. ${ }^{218}$ The fact that beatings are carried out by nonState actors is irrelevant if these are carried out with the acquiescence of official authorities or under their supervision or control. Articles 1 through 4 of the CAT, however, only speak of torture and do not automatically cover other acts of ill

211 Ibid., p. 151.

212 Ibid.

213 Ibid.

214 See inter alia Estrella v. Uruguay (74/1980) UN Doc. CCPR/C/18/D/74/1980 (23 March 1983), and Herrera Rubio v. Colombia (161/1983) UN Doc. CCPR/C/31/D/161/1983 (2 November 1987).

215 See Cariboni v. Uruguay Communication No. 159/1983 (27 October 1987) available at <www. bayefsky.com $/ \mathrm{html} / 149$ uruguay159vws.php $>$ (last visited 25 May 2005) and Chaparro et al v. Colombia (612/1995) UN Doc. CCPR/C/60/D/612/1995 (19 August 1997). See also N.S. Rodley, The Treatment of Prisoners Under International Law, $2^{\text {nd }}$ edition ed. (Oxford: Oxford University Press, 1999) p. 94.

216 See for example, Bazzano and Massera v. Uruguay (5/1977) UN Doc. CCPR/C/7/D/5/1977 (15 August 1979), and Muteba v. Zaire (124/1982) UN Doc. CCPR/C/22/D/124/1982 (24 July 1984).

217 See Dragan Dimitrijevic v. Serbia and Montenegro, Communication No. 207/2002, UN Doc. CAT/C/33/D/207/2002 (29 November 2004), paras. 2.1 and 5.3. See also M. Nowak, "What Practices Constitute Torture? US and UN Standards," Human Rights Quarterly Vol. 28 (2006), p. 821.

218 Jovica Dimitrov v. Serbia and Montenegro, Communication No. 171/2000, UN Doc. CAT/ C/34/D/171/2000 (23 May 2005), paras. 2.1 and 7.1. 
treatment. ${ }^{219}$ This means that not all acts of cruel, inhuman, or degrading treatment necessarily amount to torture. ${ }^{220}$ This however, does not mean that States have no further obligations with respect to these acts. According to Article 16 CAT, States have to prevent in any territory under its jurisdiction such acts if they are committed by or at the instigation of, or with the consent or acquiescence of, a public official or other person acting in an official capacity. Notwithstanding this strict division between torture as defined in Article 1 CAT and other ill treatment, the Committee Against Torture has concluded that the combination of certain techniques used during interrogation, including hooding, violent shaking and sleep deprivation, amount to torture. ${ }^{221}$

The abuses committed at Abu Ghraib were meant to extract information from the detainees by inflicting physical and psychological pain, and by sexually intimidating and denigrating them. ${ }^{22}$ This is documented by the Taguba and Fay reports, which note that the contractors boasted of creating the right environment to extract the information even if this entailed applying physical and mental abuse to the prisoners. $^{223}$ It is thus possible to conclude that these abuses amount to torture as understood by Article 7 ICCPR and Article 1 CAT, as well as a violation of Article 10 ICCPR.

\subsection{Is the U.S. responsible for the alleged violations committed by PMSCs or their staff?}

On the basis of the Taguba and Fay reports it can be argued that a number of CACI and Titan contractors, through commission or omission, directly contributed to violations of common Article 3 to Geneva Conventions (III) and (IV) and Article 76 of Geneva Convention (IV) as well as violations of Articles 7 and 10 ICCPR and Article 1 CAT. This leads to the following question: is the United States responsible for violations of international humanitarian law and human rights committed by private parties in Iraq?

219 Rodley, The Treatment of Prisoners Under International Law, p. 50. Further discussion on the difference between torture and other cruel, inhuman or degrading treatment or punishmen and the threshold separating both can be found in Nowak, "What Practices Constitute Torture? US and UN Standards," pp. 809-841.

220 Rodley, The Treatment of Prisoners Under International Law, p. 50.

221 See Concluding Observations to the special report of Israel, UN Doc. A/52/44 (9 May 1997), para. 257.

222 See $<$ http://news.findlaw.com/hdocs/docs/torture/30603wgrpt.html $>$ and $<$ http://news.findlaw. $\mathrm{com} / \mathrm{hdocs} / \mathrm{docs} / \mathrm{dod} / 62204$ index.html $>$, (last visited on 23 June 2004).

223 For example, one of the CACI interrogators allegedly told a detainee, "You see that dog there, if you do not tell me what I want to know, I'm going to get that dog on you.” Fay report, p. 132. 


\subsubsection{State responsibility under international law}

According to international customary law, the State is responsible for acts of commission or omission, that entail a breach of an international obligation of the State and which are attributable to it under international law. ${ }^{224}$ Are the abuses that were perpetrated by PMSC contractors attributable to the U.S.? The responsibility of the U.S. for the conduct of its own soldiers and officers is clear. States are always responsible for their own breaches of international obligations and for those breaches committed by an organ of the State or its agents. ${ }^{225}$

The responsibility of the U.S. for the acts of CACI and Titan contractors is not so evident, however, because here we are dealing with acts committed by private entities. The State, in principle, is not responsible for the acts of private actors. ${ }^{226}$ Notwithstanding this general rule, breaches of international obligations committed by private actors while exercising governmental authority or other public tasks which have been delegated to them by law, or carried out under the State's supervision or orders, are also attributable to the State as stated in Articles 5 and 8 of the ILC's Articles on Responsibility of the State respectively. ${ }^{227}$

In this context, the International Court of Justice has concluded that State responsibility arises when a State has 'effective control' over the activities of these actors. ${ }^{228}$ More recently, the Court has reaffirmed this in the Case Concerning the Application of the Convention on the Prevention and Punishment of the Crime of Genocide (Bosnia and Herzegovina v. Serbia and Montenegro), when it contended that it must "[...] be shown that this 'effective control' was exercised, or that the State's instructions were given, in respect of each operation in which the alleged violations occurred, not generally in respect of the overall actions taken by the persons or groups of persons having committed the violations." ${ }^{229}$ In addition, the

224 See also Articles 1 and 2, Articles on the Responsibility of States for international wrongful acts, UN Doc A/RES/56/83 (12 December 2001). Although the Articles on the Responsibility of States as drafted by the UN International Law Commission and as adopted for further consideration by the UN General Assembly are not legally binding, many of its provisions are considered to be rules of customary international law.

225 See also Article 4, Articles on Responsibility of the State.

226 See Chapter IV, Section 2 supra for a more in-depth treatment of the issue of State responsibility with regard to the conduct of private actors.

227 See further Chapter IV Section 2 for an in-depth discussion on the issue of State responsibility for the acts of private actors. See also Crawford, The International Law Commission's Articles on State Responsibility: Introduction, Text and Commentaries, p. 100 and p. 110-112. See further Brownlie, System of the Law of Nations: State Responsibility (Part I), p. 159-166, and Sperduti, "Responsibility of States for Activities of Private Law Persons," p. 373-375.

228 Military and Paramilitary Activities in and against Nicaragua (Nicaragua v. United States of America), Merits, Judgment, I.C.J. Reports 1986, para. 115.

229 Case Concerning the Application of the Convention on the Prevention and Punishment of the Crime of Genocide (Bosnia and Herzegovina v. Serbia and Montenegro), ICJ, judgment of 26 February 2007, para. 400. 
International Criminal Tribunal for the Former Yugoslavia has also ruled that, "[...] private individuals acting within the framework of, or in connection with, armed forces, or in collusion with State authorities may be regarded as de facto State organs. [note omitted] In these cases it follows that the acts of such individuals are attributed to the State, as far as State responsibility is concerned, and may also generate individual criminal responsibility."230

A State is also responsible if it has not taken the necessary measures to prevent breaches of its international obligations committed by private actors. This due diligence obligation requires that the State act diligently and promptly to prevent, investigate, and punish the harmful conduct of private actors. ${ }^{231}$

\subsubsection{U.S. responsibility for PMSCs in Iraq}

With regard to the responsibility for the conduct of CACI and Titan contractors it is submitted that delegating the interrogation of prisoners and prisoners of war to these contractors has been made possible through official U.S. military guidelines and policy. This privatization has also been endorsed and effected through the signing of official contracts with these companies. Additionally, the interrogation of prisoners and prisoners of war during an (international) armed conflict can be regarded as an intrinsic and inherent task of the State, due to the fact that these tasks or functions require military knowledge and skills that are essential for attaining their goals (seeking accurate and reliable information from individuals in military detention) and that these tasks also require extensive familiarity with international legal standards in the field of international humanitarian law and human rights. These functions can be regarded as core activities of the U.S. armed forces. As we have seen, Army Regulation 715-9 clearly regards these types of activities as inherently governmental activities that in principle should not be delegated. This leads to the conclusion that the abuses committed by contractors performing these officially delegated tasks can be considered breaches committed in the exercise of governmental authority, namely, those that belong to the core activities of the U.S. armed forces. The U.S. is thus responsible under international law for this conduct as expressed in Article 5 of the Articles on Responsibility of the State. ${ }^{232}$

Alternatively, the conduct of CACI and Titan can be attributed to the United States on the basis of Article 8 of the Articles on Responsibility of the State. It is thus

\footnotetext{
230 Prosecutor v. Dusko Tadic, Appeals Chamber, 15 July 1999, para. 144.

231 See United States Diplomatic and Consular Staff in Teheran (United States v. Iran), Judgment of 24 May 1980, I.C.J. Reports 1980, paras. 61-68. The Inter-American Court for Human Rights took a similar position in the leading Velásquez Rodríguez case. Velásquez Rodríguez $v$. Honduras, Merits, Judgment of 29 July 1988, IACtHR, Series C No. 4, para. 172. 
possible to argue that the contractors were under the direct control of the U.S. Army, which not only issued the instructions to the contractors about the interrogations, but also provided the setting for the interrogations themselves. These interrogations also took place in the presence of military personnel and with their acquiescence. From the Taguba and Fay reports, it appears that the U.S. military personnel acted in some instances collusively with the CACI and Titan contractors. Another factor indicated the existence of control is the fact that the U.S. Army was in charge of contractors' contracts and had the ability to terminate them if necessary. According to its own regulations, the U.S. Army even had a contract officer, who served as a liaison to the contractors and who was responsible for supervising their activities. ${ }^{233}$ Arguably, it can be concluded that the U.S. Army had what may amount to 'effective control' over the conduct of the contractors.

It can also be argued that the U.S. incurs responsibility for these abuses indirectly because it did not take the necessary measures to prevent them. From the Taguba and Fay reports one can infer that the U.S. military apparatus was aware that these contractors were being used for translation and interrogation purposes (in fact, it would appear to have been policy). ${ }^{234}$ The U.S., however, appears to have neglected to adopt sufficient precautions and supervisory mechanisms to monitor and restrain the activities of these private actors. Moreover, the Taguba report observed that several U.S. military personnel purposely strove to create a suitable environment for extracting information from the detainees and that the contractors of CACI and Titan actively contributed to this goal with the approval of the military responsible for the interrogations. This has been confirmed by the Fay report. Although these contractors did not belong to the military hierarchical structure, the United States exercised "effective control" over the conduct of CACI and Titan contractors through the contracts that regulated the relations between the Department of Defense and these companies. At the first sign of trouble, the U.S. should have ended the contracts with CACI or Titan, or at the very least have removed the contractors from the premises. By allowing PMSC personnel to carry out prisoner interrogations with the purpose of extracting military intelligence, the U.S. created a situation in which these personnel together, or in complicity with official U.S. Army personnel were in the position to commit abuses.

In addition, the abuses of humanitarian law in Abu Grahib by CACI and Titan contractors could lead to the individual criminal responsibility of the perpetrators, and possibly of the companies they are working for. This could open the possibility of criminal prosecution and claims for damages under the domestic law of the

233 See Army Regulation 715-9 "Contractors Accompanying the Force", p. 14.

234 See also the press release issued by CACI confirming that the company had indeed supplied contractors for interrogation purposes in Iraq: "CACI Interrogator Contract with the U.S. Army to Continue" CACI News release 25 May 2004, available at <www.caci.com/about/news/ news2004/05_25_04_2_NR.html > last visited on 31 August 2011. 
country of origin of both the contractors and the companies. Under current international human rights law, however, it would not be possible to hold these private actors directly accountable for violations of Articles 7 and 10 ICCPR and Article $2 \S 1$ CAT in connection with Article 1 CAT. This is due to the fact that human rights treaties contain obligations for States, not individuals. As we have seen in Chapter III, Section 4.4, the ensuing obligations are in principle only meant to work on a vertical basis, and the direct horizontal application of human rights has not yet been accepted. ${ }^{235}$ As a result, victims of human rights abuses by PMSCs can only bring claims against the State. As discussed under the theory of indirect Drittwirkung, the U.S. will be responsible for the conduct of PMSCs and as the UN Human Rights Committee stated, its positive obligations to ensure the ICCPR's rights, "[...] will only be fully discharged if individuals are protected by the State, not just against violations of Covenant rights by its agents, but also against acts committed by private persons or entities that would impair the enjoyment of Covenant rights in so far as they are amenable to application between private persons or entities." 236 Failure to engage these positive obligations against PMSCs could trigger the U.S.'s responsibility for not ensuring the rights under Article 7 ICCPR as required by Article 2 ICCPR. 237

Admittedly, the territorial reach of the ICCPR and CAT may limit this proposition. However, international and regional supervisory mechanisms for human rights such as the UN Human Rights Committee, The European Court of Human Rights (ECtHR) and the Inter-American Court and Commission for Human Rights have come to the conclusion that obligations ensuing from human rights treaties are also applicable on States that posses effective control over the territory of another State, such as in this case, the United States in Iraq. ${ }^{238}$ The United States has claimed that the ICCPR is not applicable extraterritorially. The Human Rights Committee, however, has recognized that the obligation to ensure the rights of the ICCPR and thus also the State's responsibility will extend,

235 Indirect horizontal application, is of course, possible: the State can be held accountable for human rights violations committed by private individuals if it has failed to take the necessary steps to prevent these violations, protect the victims and prosecute the perpetrators. See Chapter III, section 3.1.2.2 (iii) supra. See General Comment No. 31 on the Nature of the General Legal Obligation Imposed on States Parties to the Covenant, UN Doc CCPR/C/21/Rev.1/Add.13 (26 May 2004), para. 8.

237 Ibid. See also Chapter III.

238 For a more extensive discussion on this extraterritorial application of human rights obligations see F. Coomans and M. Kamminga, "Comparative Introductory Comments on the Extraterritorial Application of Human Rights Treaties," in Extraterritorial Application of Human Rights Treaties, F. Coomans en M. Kamminga eds., Intersentia, 2004, p. 3. One of the best known examples in this context is the Loizidou case. See Loizidou v. Turkey, judgment of 23 March 1995, ECtHR Series A-310. More recently and dealing with Iraq see Case of Al-Skeini and Others v. The United Kingdom, Grand Chamber judgment of 7 July 2011, ECtHR, application no. 55721/07 (not yet published). 
"[...] to all persons who may be within their territory and to all persons subject to their jurisdiction. This means that a State party must respect and ensure the rights laid down in the Covenant to anyone within the power or effective control of that State Party, even if not situated within the territory of the State Party."239

The Committee Against Torture has also recognized this, and has stated in its General Comment No. 2 on the Implementation of Article 2 of the Convention Against Torture by States parties hat the obligation to prevent torture covers the latter's sovereign territory and any other territory under their jurisdiction, including territory where they exercise, directly or indirectly, in whole or in part, de jure or de facto effective control. ${ }^{240}$ Places covered by this include any territory under control during military occupation such as embassies, military bases, detention facilities, or other areas over which a State exercises factual or effective control like in Iraq at the time of these events, or during peace keeping operations. ${ }^{241}$ Arguably, Abu Ghraib prison falls under this category, which leads to the conclusion that the obligations under the ICCPR and the CAT to prevent and punish torture apply to the United States in this context as well, and thus results in it being internationally responsible for breachs of human rights obligations that may have occurred there.

In any case, the Human Rights Committee has also concluded on a number of occasions that a State "[...] is not relieved of its obligations under the Covenant when some of its functions are delegated to other autonomous organs." 242 In the context of an individual complaint by two Mexican nationals who were placed in a privatized prison in Australian pending their extradition to Mexico, the Committee considered that "[...] the contracting out to the private commercial sector of core State activities which involve the use of force and the detention of persons does not absolve a State party of its obligations under the Covenant, notably under articles 7 and 10 which are invoked in the instant communication". ${ }^{243}$ Consequently, the Committee found that Australia was accountable under the ICCPR (and its Optional Protocol) for the treatment of inmates in the prison run by a private company. As already observed, the U.S. has delegated certain governmental functions to PMSCs. This means that the U.S. cannot shirk its obligations under the ICCPR for the conduct of the PMSCs. In a similar fashion, the Committee Against Torture

239 General Comment No. 31 on the Nature of the General Legal Obligation Imposed on States Parties to the Covenant, para. 10.

240 Committee Against Torture, General Comment No. 2, Implementation of article 2 by States parties, UN Doc. CAT/C/GC/2 (24 January 2008), para. 16.

241 Ibid.

242 B.d.B. v. The Netherlands (273/88), UN Doc. CCPR/C/35/D/273/1988 (2 May 1989), para. 6.5, Lindgren et al v. Sweden (298-299/88), UN Doc. CCPR/C/40/D/298/1988 (2 May 1989), and more recently Cabal and Pasini Bertran v. Australia (1020/2001), UN Doc. CCPR/C/78/D/1020/2001 (29 August 2003), para. 7.2. See also Costello Roberts v. UK, judgment of 25 March 1993, ECtHR Series A-247-C, para. 27.

Cabal and Pasini Bertran v. Australia, para. 7.2. 
observed in its General Comment No. 2 that detention centres are privately owned or run, the Committee considers that personnel are acting in an official capacity on account of their responsibility for carrying out the State function without derogation of the obligation of State officials to monitor and take all effective measures to prevent torture and ill-treatment.

In addition to the responsibility of the U.S. for the conduct of the PMSCs in Abu Ghraib, it can also argued that the latter can be regarded as special types of State actors because they are carrying out tasks or functions that arguably are of a public nature (e.g. extracting information from prisoners and prisoners of war for military purposes in a confined environment - a prison - thus serving a public need). ${ }^{244}$ U.S. military guidelines, as we have seen above, appear to consider the tasks carried out by these contractors to be inherently governmental since they require knowledge and skills acquired primarily through military training. Because these activities are also very closely linked to the public interest - the information to be extracted was supposed to help save U.S. soldiers and counter the Iraqi insurgency - and have been made possible through publicly sanctioned military guidelines, it stands to reason that the actors carrying them out can also be considered State actors for the purpose of applying human rights norms. ${ }^{245}$ In such a situation, international human rights norms could be directly (and vertically) applicable to PMSCs and their contractors.

In light of the above considerations - including the apparent accountability of the State for the conduct of privatized entities (presently, PMSCs and their personnel); the lack of direct horizontal application of human rights norms to the conduct of private actors; and the conclusions of the Human Rights Committee and the Committee Against Torture with respect to the State's obligations - the following question is of crucial importance: what are the available legal remedies for the victims of violations possibly committed by PMSCs in Iraq?

\subsection{Legal remedies available to victims}

As we have seen in Chapter III, section 4.3, States have under international human rights law an obligation to provide a remedy when rights are violated. In this section

\footnotetext{
244 See Chapter IV, section 3 supra.

245 This proposition is very similar to the State action doctrine, which has - not without some legal controversy - been recognized by the case law of the U.S. Supreme Court in cases such as Marsh v. Alabama, 326 U.S. 501 (1946), Jackson v. Metropolitan Edison Co., 419 U.S. 345 (1974), or Flagg Bros. Inc. v. Brooks, 436 U.S. 149 (1978). In the light of the nature of the functions exercised by these contractors and their close relationship with public actors (to the point of aiding and abetting U.S. military personnel in the abuse at Abu Ghraib), it may well be argued that the public function test and the nexus test as applied by the U.S. Supreme Court is also applicable to the present situation.
} 
we will focus mainly on procedural remedies. International and regional human rights instruments guarantee the right to a legal remedy and the effective access to a fair hearing by competent judicial authorities. ${ }^{246}$ These rights are guaranteed under Article 2 \$ ICCPR. ${ }^{247}$ For the purposes of the present discussion, it is useful to first distinguish which procedural remedies are in any case not available to the victims of the violations allegedly perpetrated by CACI and Titan contractors. The most evident forum for the victims to present complaints for the abuses would be an Iraqi court of law. The victims could then attempt to hold the contractors accountable for the abuses either through a criminal or civil procedure. This forum is, however, not available because the U.S.-led Coalition Provisional Authority (CPA) issued an order immediately following the occupation of Iraq awarding PMSCs and their personnel immunity from the "[...] Iraqi legal process with respect to acts performed by them pursuant to the terms and conditions of a Contract or any sub-contract thereto." 248 According to this order, the sending State of the contractor can waive the contractors' immunity and thus open the door for eventual legal proceedings against them. ${ }^{249}$ Until November 2007, a trial in Iraq has been nevertheless impossible without the explicit permission of the sending State (in this case, the U.S., which from the start of the occupation of Iraq in 2003 until now has not issued any waiver for the abuse cases). Following the Blackwater incident, however, and in the light of the intended gradual withdrawal of U.S. forces from Iraq, the U.S.

246 Shelton, Remedies in International Human Rights Law, p. 14-15.

247 Article 2 \$3 reads: "Each State Party to the present Covenant undertakes: a. To ensure that any person whose rights or freedoms as herein recognized are violated shall have an effective remedy, notwithstanding that the violation has been committed by persons acting in an official capacity; $b$. To ensure that any person claiming such a remedy shall have his right thereto determined by competent judicial, administrative or legislative authorities, or by any other competent authority provided for by the legal system of the State, and to develop the possibilities of judicial remedy[...]."

248 See $\$ 4$ (3), Coalition Provisional Authority Order Number 17, Status Of The Coalition, Foreign Liaison Missions, Their Personnel And Contractors, CPA/ORD/27 June 2004/17. §4 (3) further stipulates that, "[n]othing in this provision shall prohibit MNF Personnel from preventing acts of serious misconduct by Contractors, or otherwise temporarily detaining any Contractors who pose a risk of injury to themselves or others, pending expeditious turnover to the appropriate authorities of the Sending State. In all such circumstances, the appropriate senior representative of the Contractor's Sending State in Iraq shall be notified." The CPA originally issued the order on June 2003. In the meantime, the administration of Iraq has been officially transferred to an Iraqi interim government on 28 June 2004. Although Order Number 17 was slightly altered, the immunity remained, however, still in force. According to Article 26 of the "Law of Administration for the State of Iraq for the Transitional Period" (available on <www.cpa-iraq. org/government/TAL.html>, last visited on 10 May 2010, no longer accessible) all the orders issued by the CPA will remain in effect until these are amended or rescinded by the Iraqi transitional government. Order Number 17 pays particular attention to PMSCs: they are obliged to comply with all "CPA Orders, Regulations, Memoranda, and any implementing instructions or regulations governing the existence and activities of Private Security Companies in Iraq, including registration and licensing of weapons and firearms." See §4 (2) Coalition Provisional Authority Order Number 17.

See $\$ 5$ Coalition Provisional Authority Order Number 17. 
Government and Iraq have recently reached a new status of forces agreement (SOFA), which does away with the immunity for PMSC contractors and its employees. ${ }^{250}$ Even so, Iraqi jurisdiction will only be available for eventual cases that come after the signing of the agreement. Cases prior to the agreement, such as those dealt here, fall outside of its scope.

\subsubsection{International procedural remedies}

What about international procedural remedies? If the conduct of the contractors amounts to war crimes, the International Criminal Court (ICC) would be the most obvious judicial organ to hear any complaints in this regard. ${ }^{251}$ The victims could approach the prosecutor of the ICC to request an investigation and eventual prosecution of those implicated. However, it would appear unlikely hat the CACI and Titan contractors could be prosecuted due to the fact that neither the U.S. nor Iraq has ratified the ICC Statute, and, additionally, that the U.S. successfully managed, by means of Article 16 of the ICC's Statute, ${ }^{252}$ to force immunity from prosecution by the ICC through the UN Security Council up until 30 June 2004. If the conduct of the contractors qualifies as a violation of Articles 7 or 10 of the ICCPR and Article $2 \S 1$ and 1 of the CAT that either directly or indirectly can be attributed to the State, then, in theory, individual complaints could be submitted to the supervisory bodies of these conventions: the Human Rights Committee and the Committee Against Torture. This avenue is also barren, however. Though the United States and Iraq are both parties to the ICCPR and the CAT, they have not ratified the optional individual complaint mechanisms of these conventions. ${ }^{253} \mathrm{An}$

250 See Article 12 para. 2 of the Agreement Between the United States of America and the Republic of Iraq on the Withdrawal of United States Forces from Iraq and the Organization of Their Activities during Their Temporary Presence in Iraq (available at the White House's website: $<$ www.whitehouse.gov/infocus/iraq/SE_SOFA.pdf $>$, last visited on 20 December 2008, no longer available, which states that Iraq shall have the primary right to exercise jurisdiction over United States contractors and United States contractor employees (the Agreement can be found at: <www.globalsecurity.org/military/library/policy/dod/iraq-sofa.htm>). See also news report "American Contractors in Iraq Worry About Their Future," J. Risen, New York Times, 30 November 2008.

251 For a discussion on the individual criminal responsibility of PMSC personnel under international criminal law see C. Lehnardt, "Individual Liability of Private Military Personnel under International Criminal Law," EJIL Vol. 19 (2008), p. 1015-1034.

252 Article 16 of the ICC Statue states that "[n]o investigation or prosecution may be commenced or proceeded with under this Statute for a period of 12 months after the Security Council, in a resolution adopted under Chapter VII of the Charter of the United Nations, has requested the Court to that effect; that request may be renewed by the Council under the same conditions." See UN Security Council Resolutions UN Doc S/Res/1422 (12 July 2002) en UN Doc S/Res/1487 (12 June 2003). This resolution was not prolonged in June 2004, partly due to the Abu Ghraib scandal.

253 Another possibility would be to file a complaint through another State that is party to these conventions. The State complaint mechanism has, however, not been utilized out of diplomatic considerations. 
appeal to the International Court of Justice is also fruitless because only States can file a complaint before the Court, and then only if States have accepted the jurisdiction of the Court through the means stated in Article 36 of the Court's Statute. The U.S. has not done so.

\subsubsection{National procedural remedies ${ }^{254}$}

Given that the international and Iraqi legal remedies are not accessible to victims, only U.S. remedies remain available for them. There are a number of possibilities that are not mutually exclusive. First, the victims could press for criminal prosecution of the contractors on the grounds of Coalition Provisional Authority Order Number 17 and a number of U.S criminal statutes. An alternative option would be for the victims to sue the alleged perpetrators and their companies for committing an intentional tort, such as assault and battery.

The first option, filing criminal charges against the contractors, could in theory occur through the application of U.S. military justice. The relevant statute, the Uniform Code of Military Justice (UCMJ), makes it possible to prosecute military personnel that are "[...] guilty of cruelty toward, or oppression or maltreatment of, any person subject to his orders." 255 The UCMJ is in principle only applicable to American armed forces personnel, and served as the basis for the court-martials of the military personnel at Abu Ghraib. Nevertheless, the UCMJ opens the possibility of court-martialing civilians that are in the service of the armed forces or accompany them during military operations under $\S 802$, Article 2 sub a (10). ${ }^{256}$ This possibility, however, was until recently only available in the case of violations committed during a war that has been declared as such by the U.S House of Representatives, a circumstance that has not occurred since World War II. Under such circumstance, former armed forces personnel could only be prosecuted if they are still entitled to pay. ${ }^{257}$ A good number of PMSC contractors are former or retired U.S. armed forces personnel. ${ }^{258}$ However, on 17 October 2006, the U.S. Congress enacted an act authorizing appropriations for fiscal year 2007 for military activities of the Department of Defense, and which amended various related existing laws including the UCMJ. ${ }^{259}$ Under this amendment, which became law when it was signed by

254 For a deeper discussion about the challenges revolving around litigation against PMSCs that have allegedly committed abuses se. Cedric Ryngaert, "Litigating Abuses Committed by Private Military Companies," EJIL Vol. 19 (2008), p. 1035-1053.

255 See $\$ 893$, Article 93 UCMJ.

256 See $\S 802$, Article 2 sub a (10) UCMJ.

257 See $\$ 802$, Article 2 sub a (4) and (5) UCMJ.

258 A.D. Farallon and T.A. Keene, "Closing the Legal Loophole? Practical Implications of the Military Extraterritorial Jurisdiction Act of 2000,” Air Force Law Review Vol. 51 (2001), p. 273.

259 The text of the act called the "John Warner National Defense Authorization Act for Fiscal Year 2007 " is available at $<$ www.govtrack.us/congress/billtext.xpd?bill=h109-5122 $>$ (last visited on 19 December 2008). 
former President George Bush in October 2006, §802, Article 2 sub a (10) was broadened to include situations of declared war or a contingency operation. This allows the UCMJ to extend its jurisdiction over contractors to more situations of armed conflict instead of only ones of war declared by the U.S. Congress. It is however, questionable whether this recent and almost unknown amendment to the UCMJ will make it possible to prosecute under U.S. military justice any crimes committed by PMSCs contractors prior to the enactment of the amendment.

Another possibility for criminal prosecution of PMSC contractors could take place on the grounds of a number of criminal statutes in the U.S. The 1996 War Crimes Act (18 USC §2441) makes it possible to bring U.S. civilians to court and prosecute them for grave breaches as defined in Articles 130 Geneva Convention (III) and 147 Geneva Convention (IV). They can also be prosecuted for violations of common Article 3 of the Geneva Conventions, regardless of where these were committed. Assuming that the actions committed by the CACI and Titan contractors amount to grave breaches as defined in both Conventions, or a violation of common Article 3 of the Geneva Convention, a U.S. prosecutor would have enough grounds for instituting criminal proceedings. Given the nature of the abuses committed in Abu Ghraib, criminal prosecution can also be based on the legislation implementing the Convention Against Torture, 18 U.S.C. $\S \S 2340-2340$ A, which provide for the definition of torture and its criminalization.

In addition to the War Crimes Act and the Torture legislation, the Military Extraterritorial Jurisdiction Act (18 USC Chapter 212 \$3261-3267), also known as MEJA, provides another means for bringing charges against Titan and CACI contractors. The increasing use of privatization and the contracting of military tasks to PMSCs and civilians have caused the U.S. legislators to enact laws that permit the prosecution of private actors who commit crimes while accompanying the armed forces abroad. ${ }^{260}$ The crimes involved should be punishable by at least a oneyear prison sentence. Originally, the MEJA required that the contractors work for the Department of Defense. ${ }^{261}$ Contractors working for other governmental organizations fell outside the scope of this law. This would mean that CACI and Titan contractors could not be prosecuted if it turns out that the CIA hired them. This, however, should not pose much of a problem, because it is possible to prosecute contractors working for the CIA on the basis of other criminal statutes. ${ }^{262}$

260 Farallon and Keene, "Closing the Legal Loophole? Practical Implications of the Military Extraterritorial Jurisdiction Act of 2000," p. 271.

26118 USC $\$ 3267$ (1). See also ibid., p. 274.

262 See news report of the New York Times dated 18 June 2004, "Contractor Indicted in Afghan Detainee's Beating". See also the indictment against a PMSC contractor who was contracted by the CIA in http://news.findlaw.com/hdocs/docs/torture/uspassaro61704ind.html (last visited on 10 May 2010). The contractor in question has been indicted on grounds of Ttile 18 U.S.C. Section 113 (a)(3) and 113 (a)(6) (assault with a dangerous weapon resulting in serious bodily injury). 
Nevertheless, the MEJA was amended in 2005 to include military contractors of "any other Federal agency, or any provisional authority, to the extent such employment relates to supporting the mission of the Department of Defense overseas."263 Again, this amendment would only cover cases after 2005, thus leaving CACI and Titan out of the question. Finally, a new amendment to the MEJA was proposed in October 2007, sponsored by now President Elect Barack Obama, which seeks to strengthen the MEJA. The proposed changes extends the MEJA to persons who, while employed under a federal agency contract in or in close proximity to an area where the Armed Forces are conducting a contingency operation. It also requires the Inspector General of the Department of Justice to report to Congress on the status of the Department's investigations of violations alleged to have been committed by contract personnel and findings and recommendations about the Department's capacity and effectiveness in prosecuting misconduct by contract personnel. Finally, it requires the Director of the Federal Bureau of Investigation to ensure, through the creation of a special investigative unit, that there are adequate personnel to investigate allegations of criminal violations by contract personnel. ${ }^{264}$

In any event, the MEJA's major drawback, and for that matter of the other criminal statutes discussed so far, is that the victims are at the mercy of U.S. prosecutors' willingness to start a criminal trial against the contractors. ${ }^{265}$ It is worth noting that, to date, there have been no prosecutions against any of the contractors involved in the Abu Ghraib abuses under the MEJA. ${ }^{266}$ However, and for the first time, five Blackwater contractors involved in the shooting that took place on 16 September

26318 USC \$3267(1)(A)(ii)(II). See also I. Kierpaul, "The Mad Scramble of Congress, Lawyers, and Law Students After Abu Ghraib: The Rush to Bring Private Military Contractors to Justice," University of Toledo Law Review, Vol. 39 (2008), p. 417.

264 See Security Contractor Accountability Act of 2007, S.2147, Introduced on 4 October 2007. The draft bill has yet to be fully discussed and adopted by both houses of Congress. The text of the draft bill is available at the Library of Congress' website: http://thomas.loc.gov/cgi-bin/bdquery/ z?d110:SN02147:@@@\&summ2=m\& (last visited on 23 December 2008).

265 Perlak has identified another potential hurdle in the practical application of MEJA. Suspects need to be detained by military personnel, who may not necessarily be inclined to do so if the reliance on PMSC contractors to fulfill certain essential tasks is high and there is no prospect of immediate replacement. Perlak, "The Military Extraterritorial Jurisdiction Act of 2000: Implications for Contractor Personnel," p.137. In addition to this, Farallon and Keene have observed that the application of MEJA would require establishing a close nexus with the suspects with the United States if the U.S. wishes to extend its criminal law extraterritorially. U.S. nationality should be sufficient in most cases to establish such a nexus. Farallon and Keene, "Closing the Legal Loophole? Practical Implications of the Military Extraterritorial Jurisdiction Act of 2000," p. 282-283. This could have consequences for cases where suspects are PMSC contractors who are not U.S. nationals.

266 This has been confirmed in the civil law case against the contractors. See Saleh, et al. v. Titan Corporation (CACI International Inc. and CACI Premier, Intervenors), United States Court of Appeals for the District of Columbia Circuit, 11 September 2009, No. 08-7008, p. 3 (further discussed below). 
2007 were indicted on at the end of 2008 under the MEJA for a number of crimes including voluntary manslaughter. ${ }^{267}$ Although this is a positive step in holding individual PMSC contractors accountable for their conduct, which could have also served as a test ground to hold the PMSC itself accountable under this law, the latest developments in this saga do not bode well. A federal judge of the district court of the District of Columbia dropped the charges against the indicted contractors of Blackwater, now known as Xe Services, due to apparent misuse of statements made by the contractors when being debriefed and which were used for their prosecution. ${ }^{268}$ The judge observed that the use of these statements was a breach of the right against self-incrimination under the Fifth Amendment of the United States Constitution, and concluded, "[...] that the process aimed at bringing the accused to trial has compromised the constitutional rights of the accused." 269 In spite of Vice President Joseph Biden Jr.'s promise to appeal the federal judge's decision, the outlook for this case is not good. ${ }^{270}$

A second option would be for the victims to sue the CACI and Titan (and for that matter Blackwater) contractors or the companies themselves through a private law action under the Alien Torts Claims Act (ATCA). This statute, adopted in 1789, allows foreign individuals to sue others before a U.S. court for violations of the law of nations if these violations amount to a tort. ${ }^{271}$ Since the Filártiga v. Peña-Irala decision, ${ }^{272}$ victims of human rights violations committed outside the United States

267 A copy of the indictment can be found at http://news.findlaw.com/nytimes/docs/iraq/blackwaterindictment1208ind.html (last visited on 10 May 2010). See also news report "5 Guards Charged With Manslaughter in Iraq Deaths," G. Thompson, New York Times, 9 December 2008, and "Blackwater Guards Indicted for 2007 Baghdad Civilian Killings," AJIL, Vol. 103, (2009), p. 360-362.

See United States of America v. Paul A. Slough et al., Memorandum Opinion Granting the Defendants' Motion to Dismiss the Indictment; Denying as Moot the Government's Motion to Dismiss the Indictment Against Defendant Slatten Without Prejudice, United States District Court for the District of Columbia, Criminal Action No.: 08-0360 (RMU), 31 December 2009. See also news report, "Judge Drops Charges From Blackwater Deaths in Iraq," C. Savage, New York Times, 31 December 2009 available at <www.nytimes.com/2010/01/01/us/01blackwater. html $>$ (last visited on 20 January 2010). United States of America v. Paul A. Slough et al., p. 90.

270 See news report, "Biden Says U.S. Will Appeal Blackwater Case Dismissal," A. Shadid, New York Times, 23 January 2010, available at <www.nytimes.com/2010/01/24/world/ middleeast/24iraq.html $>$ (last visited on 25 January 2010).

271 An extensive discussion ATCA that appears to indirectly and extraterritorially apply international human rights norms for tort actions outside of the U.S. is beyond the scope of this contribution. For more information in this regard see Swan, "International Human Rights Tort Claims and Experience of the United States Courts: An Introduction to the US Case Law, Key Statutes and Doctrine," p. 65.

272 Filártiga v. Peña-Irala, 630 F.2d 876, $2^{\text {nd }}$ Circuit Court of Appeals, 1980. In this case, the family of a Paraguayan man who had been tortured to death in Paraguay by Peña-Irala (a member of the police forces of that country) was successfully sued for damages in the U.S. for this action under the ATCA. 
by a variety of actors ranging from former dictators and military personnel to U.S. and foreign business enterprises have frequently invoked this statute. Use of the ATCA, however, has had mixed results, and reliance upon it is often fruitless for a variety of reasons, which will be discussed further below. The victims of the contractors in Abu Ghraib could, nevertheless, argue under the ATCA that these contractors acted under the color of U.S. law, since the government consented to the contracting out of military interrogation services, and that they violated Articles 7 and 10 ICCPR as well as Article 1 CAT. Failure to argue that the action impugned took place under color of U.S. law may lead to a dismissal of the claim, as recently occurred with a lawsuit filed against CACI and Titan, detailed below.

The benefit of using the ATCA is the prospect of financial compensation for damages that a successful tort action can accomplish in the U.S. Litigating in the U.S., and even more so under the ATCA, can, however, be a long, time-consuming and financially prohibitive affair. On top of this, victims have to file the suit in the U.S., thus raising a difficult barrier for victims without any connections in the U.S. or for victims whose cases are not picked up by activist lawyers or organizations. Another complication could be reliance by PMSCs on the so-called government contractor defense. Under this defense, government contractors may claim protection from liability for deaths or injuries that result from design defects in products manufactured in strict accordance with government specifications. ${ }^{273}$ This defense has been used to fend off claims involving contractors performing publicworks projects, but has also been extended to contractors supplying services or material to the U.S. armed forces. ${ }^{274}$ One of the rationales for upholding the government contractor defense with regard to military contracts has been that holding military contractors or suppliers liable for defective designs that have been approved by the U.S. government would unduly subject military decision making to judicial review. ${ }^{275}$ In a recent decision regarding a claim by Vietnamese victims of the use of the chemical compound known as Agent Orange in the Vietnam War, a U.S. district court observed that "[h]olding the government contractor defense inapplicable to claims such as plaintiffs', which essentially challenge military judgments made by the President, would effectively invite all of the United States' past and future enemies to sue a wide variety of military contractors based on such Presidential decisions in United States courts."276 This observation notwithstanding,

273 M.S. Turner and A.N. Sutin, "The Government Contractor Defense: When Are Manufacturers of Military Equipment Shielded From Liability For Design Deffects?," Journal of Air Law and Commerce Vol. 52 (1986), p. 397.

274 Ibid., p. 399-420.

275 Ibid., p. 443-444.

276 See In re "Agent Orange Product Liability Litigation" The Vietnam Association for Victims of Agent Orange/Dioxin et al $v$ The Dow Chemical Company et al., U.S District Court Eastern District of New York, 10 March 2005, Memorandum, Judgment and Order MDL No. 381 (04CV-400) as amended on 28 March 2005, p. 137. The Vietnamese victims had claimed that the manufacturers of Agent Orange, which was used to defoliate the jungles of North Vietnam by 
the district court concluded that the government contractor defense does not apply to violations of human rights and norms of international law. ${ }^{277}$ In the end, however, the district court ruled against the Vietnamese plaintiffs on the grounds that the use of herbicides by the U.S. in the Vietnam War did not violate international law.

A final complication in using the ATCA would be that various U.S. judges confronted by ATCA claims have reasoned that the cases are better heard in the country where the alleged violation took place on the grounds of the principle of forum non conveniens. ${ }^{278}$ Although it is highly probable that a judge confronted with a case against a contractor for abuses in Abu Ghraib will not rely on forum non conveniens due to the fact that there is currently no alternative venue in Iraq (or anywhere, for that matter), the possibility cannot be completely ruled out. If a judge did determine that forum non conveniens is relevant, such a decision would in effect result in an exclusion of adequate legal remedies, given that current U.S. contractors enjoy immunity from the Iraqi legal system (except when this immunity is waived by the proper U.S. authorities), and thus breach the U.S.'s legal obligations under international law. ${ }^{279}$

At the time of this writing, two lawsuits have been filed under the ATCA against CACI and Titan, as well as against a number of their contractors. In July 2004, a lawsuit was filed on behalf of several victims against CACI and Titan for the abuses in Abu Ghraib before a district court in the District of Columbia (Ibrahim, Abbas, Aboud, Hadod, and Abbas v. Titan Corporation, CACI International Inc et.al). 280 Shortly thereater, a lawsuit targeting a number of individual contractors named in the Taguba and Fay reports was filed before a district court in Southern California,

the U.S. military during the Vietnam War and which resulted in various cases of sickness, cancer and other complaints more than ten years after its uses, were responsible under ATCA and under international law.

See In re "Agent Orange Product Liability Litigation" The Vietnam Association for Victims of Agent Orange/Dioxin et al v The Dow Chemical Company et al, p. 142.

278 See for example Aguinda v. Texaco Inc., U.S. $2^{\text {nd }}$ Circuit Court of Appeals, Docket No. 01-7756, 16 August 2002.

279 As previously noted, under Article 2 (3) ICCPR obliges States to ensure an effective remedy for violations of the rights guaranteed by that treaty and that victims have access to competent judicial authorities.

280 See Ibrahim, Abbas, Aboud, Hadod, and Abbas v. Titan Corporation, CACI International Inc et.al, U.S. District Court of the District of Columbia. The complaint for damages claims, inter alia that a number of (mostly unidentified) Titan and CACI contractors were involved in various instances of abuse resulting in significant physical injury, emotional stress and in one case wrongful death. Plaintiffs rely on a number of international legal instruments including the above-mentioned Geneva Conventions, and Articles 7 and 10 ICCPR. The complaint can be found at http://news.findlaw.com/cnn/docs/torture/ibrahimtitan $72704 \mathrm{cmp} . h t \mathrm{ml}$, last visited on 10 May 2010. See also CACI press release rejecting the claims as being slanderous and ludicrous. "CACI Rejects Lawsuit as Slanderous and Ludicrous: Frivolous Suit Based on False Statements Without Merit," CACI news release 27 July 2004, available at $<$ www.caci.com $>$, last visited on 22 May 2005. 
although a motion to transfer the action to another district court (in Eastern Virginia) was later granted (Saleh et al. v. Titan Corp. et al.). ${ }^{281}$ The Ibrahim lawsuit against CACI and Titan will briefly be discussed first in the following paragraph, although the case was merged with the Saleh one in 2006 (see further below).

With regard to the Ibrahim lawsuit, the plaintifs asserted claims under the ATCA for abuses including torture, government-contracting laws, and the common law of assault and battery, of wrongful death, false imprisonment, intentional infliction of emotional distress, conversion, and negligence. The defendant companies moved to dismiss the claims, arguing, among other things, lack of jurisdiction and the nonapplicability of the ATCA to the case because 'the law of nations' does not cover torture by non-State actors. In addition, the companies claimed that the plaintiffs' common law tort claims may be preempted by the government contractor defense. In August 2005 the district court of the District of Columbia granted a motion to dismiss all of the claims against CACI on the grounds of lack of jurisdiction since the company is incorporated in the Netherlands. ${ }^{282}$ With respect to the ATCA claim, the district court, cited previous ATCA case law, ${ }^{283}$ which held that, although acts of torture violate international law, the latter does not reach private, non-State conduct of this sort unless it is claimed that the private actors were acting 'under the color of state authority.' It would appear that during the proceedings, one of the plaintiffs made such a claim, but it was later withdrawn. The district court then held that

“[p]laintiffs' allegations describe conduct that is abhorrent to civilized people, and surely actionable under a number of common law theories. After Tel-Oren or Sanchez-Espinoza, however, it is not actionable under the Alien Tort Statute's grant of jurisdiction, as a violation of the law of nations." 284

With regard to the government contractor defense put forward by CACI and Titan, it was argued that the common law claims should be dimissed since 28 U.S.C. $\$ 2680(\mathrm{j})$ of the Federal Tort Claims Act (FTCA) bars suits against the federal government for "any claim arising out of the combatant activities of the military or naval forces, or the Coast Guard, during time of war." 285 What defendants argued

281 See Saleh et al. v. Titan Corp. et al., United States District Court for the Southern District of California, 361 F. Supp. 2d 1152, 2005 U.S. Dist. LEXIS 4521 (S.D. Cal., Mar. 21, 2005).

282 Ilham Nassir Ibrahim, et al. v. Titan Corporation, et al., U.S. District Court for the District of Columbia,12 August 2005, 391 F. Supp. 2d 10, p. 20.

283 Tel Oren v. Libyan Arab Republic, 233 U.S. App. D.C. 384, 726 F.2d 774 (D.C. Cir. 1984), and Sanchez-Espinoza v. Reagan, 248 U.S. App. D.C. 146, 770 F.2d 202 both of which held that although acts of torture violate international law (or the 'law of nations' as used in both cases), international law as such does not cover non-State conduct.

285 Ibid., p. 17. 
was that the contractors were 'essentially... integrated into the military' and thus could be considered to be soldiers, and as such were immune to a common law claim. ${ }^{286}$ The potential reasoning for this was based on the case of Boyle v. United Techs. Corp, ${ }^{287}$ in which the U.S. Supreme Court noted that, "[i]t makes little sense to insulate the Government against financial liability for the judgment that a particular feature of military equipment is necessary when the Government produces the equipment itself, but not when it contracts for the production." 288 The district court was, nonetheless, not really convinced of this argument and decided not to accept it entirely until they were able to produce better evidence. Finally, the court decided to allow the remaining common law claims, allowing the plaintiffs to amend their complaint.

Before it had merged with Ibrahim, the case in Saleh (being handled by the same judge) had reached similar conclusions. The ATCA claim was equally rejected on the same grounds. ${ }^{289}$ In addition, it dismissed the claims against the individual contractors due to lack of personal jurisditction. ${ }^{290}$ The district court then suggested to merge Ibrahim and Saleh because both cases had become virtually undistinguishable.

Following the cases' consolidation, new evidence was presented on behalf of the PMSC defendants to substantiate their arguments under the government contractor defense. The District Court decided to grant Titan's motion for summary judgment and dismiss the case against it. Having studied the materials presented by Titan, the District Court concluded that Titan's interpreters actually were integrated into the military units to which they had been assigned. They were thus under the direct command and exclusive operational control of the military chain of command in Abu Ghraib, since the military gave all the orders that determined how the interpreters performed their duties. ${ }^{291}$ As a result of this analysis, the District Court concluded that Titan could rely on the government contractor defense and were thus immune to the common law actions against it.

286

Ibid., p. 19.

Boyle v. United Techs. Corp., 487 U.S. 500 (1988).

Ibid, p. 512. Note that this is observation mirrors the one made with regard to holding private actors carrying out public functions as being State actors: why is it not possible to regard these private actors as public ones if they perform in essence the same functions as proper State actors?

Saleh, et al. v. Titan Corporation, et al., U.S. District Court for the District of Columbia, 29 June 2006, Civil Action No. 05-1165 (JR), Lexis 44020, p. 6-8.

Ibid., p. 12-13.

Saleh, et al. v. Titan Corporation, et al. and Saleh, et al. v. Titan Corporation, et al., U.S. District Court for the District of Columbia, 6 November 2007, Civil Action No. 04-1248 (JR) and Civil Action No. 05-1165 (JR), p. 18-21. The summary judgment can be found at http:// ccrjustice.org/files/Saleh_summaryjudgmentdec_11_07.pdf (last visited, 30 December 2008). 
This did not apply to CACI's interrogators, however. The court noted that "[t]here can be no question that the nature and circumstances of the activities that CACI employees were engaged in - interrogation of detainees in a war zone - meet the threshold requirement for preemption [from the FTCA claims] pursuant to the combatant activities exception." 292 In spite of this, the district court found that CACI's interrogators were not that integrated with the military. For instance, unlike military interrogators, CACI interrogators had a requirement to report abuse not only up the military chain of command but also to CACI. Moreover, the PMSC interrogators were subject to dual supervision (from CACI and from the military). In the eyes of the court, the CACI interrogators "[...] were subject to a dual chain of command, with significant independent authority retained by CACI supervisors." 293 The court thus concluded that CACI could not rely on the government contractor defense, denied its motion for summary judgment, and ordered a jury trial against CACI. Both CACI and the plaintiffs filed an appeal to this ruling before the Court of Appeals for the District of Columbia.

On 11 September 2009, however, the case was dismissed when the Court of Appeals decided on these appeals. ${ }^{294}$ In this decision, the Court of Appeals disagreed in general with the Circuit Court that CACI was not sufficiently integrated with the military. According to the Court of Appeals, the fact,
"[t]hat CACl's employees were expected to report to their civilian supervisors, as well as the military chain of command, any abuses they observed and that the company retained the power to give advice and feedback to its employees, does not, in our view, detract meaningfully from the military's operational control, nor the degree of integration with which CACI's employees were melded into a military mission." 295

This observation led to the conclusion that, like in the case of Titan, the tort law claims of the plaintiffs could be preempted by the combatant activities exception. Since the defendant CACI was engaged in combatant activities, tort law could not be applied to them because "no duty of reasonable care is owed to those against whom force is directed as a result of authorized military action." 296 The rationale behind this, of course, is to prevent others from regulating the United States'

Saleh, et al. v. Titan Corporation, et al. and Saleh, et al. v. Titan Corporation, et al., p. 21. Ibid., p. 22.

See Saleh, et al. v. Titan Corporation (CACI International Inc. and CACI Premier, Intervenors), United States Court of Appeals for the District of Columbia Circuit, 11 September 2009, No. 08-7008.

Ibid., p. 7-8. This was reiterated later on in the decision when the majority of the Appeals Court noted that " $[\ldots]$ there is no dispute that they were in fact integrated and performing a common mission with the military under ultimate military command. They were subject to military direction, even if not subject to normal military discipline." Ibid., p. 11. Ibid., p. 12, quoting from previous case law (Koohi v. U.S., 976 F.2d 1328, 1337 (9 $9^{\text {th }}$ Cir. 1992)).
} 
wartime conduct, and to "[...] free military commanders from the doubts and uncertainty inherent in potential subjection to civil suit." 297 According to the Court of Appeals, this exception applies equally to soldiers or contractors alike engaging in combatant activities at the behest of the military and under the military's control. ${ }^{298}$ Allowing tort suits to contractors would, in the eyes of the Court, "[...] surely hamper military flexibility and cost-effectiveness, as contractors may prove reluctant to expose their employees to litigation-prone combat situations."299 In short, such a suit would be contrary to the federal interests. With these observations, the Court of Appeals dimissed the District Court's judgment against CACI and its contractors, effectively barring the possibility of further suing them for the common law claims.

The Court of Appeals then moved on to confirm the District Court's decision to disallow the plaintiff's ATCA torture claims against Titan. According to the Court of Appeals, "[a]lthough torture committed by a State is recognized as a violation of a settled international norm, that cannot be said of private actors." 300 While it was suggested that defendants could be seen to have acted under color of law for the purposes of applying ATCA as established in Tel-Oren, ${ }^{301}$ the Court of Appeals noted that plaintiffs would be unwilling to assert such a proposition since that would entail that the contractors would be ellegible to claim sovereign immunity against such a suit. ${ }^{302}$ Even if the ATCA torture claim could be allowed, it would still ran afoul the preemption exception since allowing such a claim would be contrary to federal interests of effective performance in the battlefield. In the words of the Court, "[...] an elaboration of international law in a tort suit applied to a battlefield is preempted by the same considerations that led us to reject the D.C. tort suit."303 This leads to a Catch-22 situation for plaintiffs. The case was thus dismissed in its entirety, although it would appear that plaintiffs have decided to file a petition for writ of certiorari in the U.S. Supreme Court on 26 April 2010. ${ }^{304}$ However, on 27 June 2011, the Supreme Court denied the plainitffs' petition bringing the case to an end. ${ }^{305}$

297

298

299

300

301

302

Ibid., p. 12-13.

Ibid., p. 13.

Ibid., p. 14 (footnote omitted).

Ibid., p. 28.

See note 283.

Saleh, et al. v. Titan Corporation (CACI International Inc. and CACI Premier, Intervenors), p. 28. This is a similar proposition to the one discussed in Chapter IV, Section 3.4.1. with regard to the case of Richardson v. McKnight.

Saleh, et al. v. Titan Corporation (CACI International Inc. and CACI Premier, Intervenors), p. 30 .

See the website of Center for Constitutional Rights, which has supported plaintiffs during the whole procedure at $<\mathrm{http} / / /$ crjustice.org/ourcases/current-cases/saleh-v.-titan $>$ (last visited on 20 July 2011).

See $<$ www.supremecourt.gov/Search.aspx?FileName=/docketfiles/09-1313.htm $>$ (last visted on 20 July 2011). 
In spite of ruling that the PMSCs could not be sued under either the ATCA or regular tort actions, the Court of Appeals observed that this does not mean that PMSCs could not be brought to account. The Court noted that,

"[t]o be sure, to say that tort duties of reasonable care do not apply on the battlefield is not to say that soldiers are not under any legal restraint. Warmaking is subject to numerous proscriptions under federal law and the laws of war."306

The Court thus suggested that the U.S. Government has "[...] numerous criminal and contractual enforcement options available to the government in responding to the alleged contractor misconduct[,]" even though the Government has chosen not to use them in this case ${ }^{307}$ Furthermore, the Court pointed out that plaintiffs have alternative remedies, including a right to submit legitimate claims of relief under the Foreign Claims Act, ${ }^{308}$ a piece of legislation that allows reparation for, among other things, personal injury or death as a result of noncombat activities of the armed forces in foreign countries. ${ }^{309}$ The Court noted that according to the U.S. Army Claims Service, one of the various plaintiffs (Saleh) had successfully pursued such a route, obtaining $\$ 5,000$ U.S. Dollars in compensation, despite the fact that the Army's investigation indicated that Saleh was never actually interrogated or abused. ${ }^{310}$

The (preliminary) conclusions in the Ibrahim and Saleh cases as they now stand reveal an extraordinary irony. The plaintiffs' ATCA application was denied because both PMSC defendants were not found to fall under the color of law requirement since they did not perform governmental activities or where otherwise under strict supervision or control of the State. They were thus held to be pure private actors to which the law of nations does not apply. Nonetheless, the PMSC defendants were, for the purposes of establishing whether they enjoyed immunity from the FTCA under the government contractor defense, considered to be essentially integrated in the military, and thus arguably not longer mere private actors, but State actors. This seemingly contradictory situation is confusing and less than satisfactory. In addition, this idiosynchratic U.S. approach leads to another perplexing situation. In similar situations dealing with privatized prisons in the United States, the case of Richardson v. McKnight ${ }^{311}$ entailed that it is better for victims of human rights abuses by privatized actors in terms of seeking redress and proper substantive as

306 Ibid., p. 12. It did reaffirm in this respect that "[...] it is clear that all of the traditional rationales for tort law-deterrence of risk-taking behavior, compensation of victims, and punishment of tortfeasors-are singularly out of place in combat situations, where risk-taking is the rule." Ibid.

$307 \quad$ Ibid, p. 14.

308 Foreign Claims Act, 10 U.S.C. \$2734. Saleh, et al. v. Titan Corporation (CACI International Inc. and CACI Premier, Intervenors), p. 4 and p. 14.

310 Ibid., p. 4.

311 See Chapter IV, Section 3.4.1. 
well as procedural remedies, for such actors to be considered private ones, since otherwise these actors would be entitled to governmental immunity. However, since under current U.S. legal doctrine allowing private law actions against contractors involved in combat activities under the effective control of the State would be contrary to the State's interests, victims of abuses by PMSCs are bereft of important remedies. This is not a satisfactory state of affairs. In spite of the fact that victims may seek compensation through the use of the Foreign Claims Act, which would go some way in addressing the issue of remedies, one cannot escape the feeling that the victims would have been better off if the PMSC contractors that took part in the abuses in Abu Ghraib were indicted through the available criminal law remedies. It also shows to a certain extent, the difficulties of trying to hold privatized corporate entities accountable for their conduct in breach of human rights, and the necessity to seek for a more effective ways of enforcing this.

\subsection{Preliminary conclusions}

In sum, although international legal remedies are not available for the victims of Abu Ghraib, they could attempt to employ U.S. legal remedies. However, this will probably not be easy for the victims because they will be dependent upon the expediency and willingness of U.S. prosecutors to bring the case before a criminal court. There are signs that this is, with some caveats, already taking place, although it will probably be of no solace to the victims of the abuses at Abu-Ghraib. Whereas civil legal remedies appear to be readily available for filing suits against PMSCs and their contractors, and victims have already done so, they face long and expensive judicial procedures, including several hurdles such as a possible reliance on the government contractor defense. There is also the additional, albeit remote, possibility that a judge may decide not to deal with the case on the grounds of forum non conveniens. Finally, as the abovementioned cases against CACI and Titan illustrate, judges may consider certain aspects of international law nonapplicable to private actors such as PMSCs, thus making it difficult to claim that these actors have violated international legal norms, such as human rights.

\section{Concluding Remarks}

We have seen that the status of PMSCs is not altogether unambiguous. It is difficult to argue that these actors are mercenaries, in light of the convoluted definition provided by the applicable international instruments. It is also clear that the privatization of military and security tasks and services is a controversial topic. However, this privatization is a trend that cannot be easily stopped, taking into account the developments in a number of countries, including the reduction of military budgets. States will actively seek ways to delegate tasks formerly performed by military personnel that can be cheaply carried out by private companies. This 
may be reasonable, and it is certainly arguable that the privatization of certain military tasks and services, such as logistical support, is less problematic. However, it becomes more complicated when states contract out tasks that potentially involve the lethal use of force. Without sufficient and strict regulation and monitoring at the national and international level, the activities of PMSCs can lead to situations such as those that we have witnessed in Iraq. This does not mean, however, that states that choose to privatize these tasks are not responsible for the conduct of these companies. As we have seen, under international law the state is fully responsible for the conduct of PMSCs that carry out State functions or tasks. Therefore, States have the obligation to ensure that PMSCs can be brought to justice and held accountable for their conduct if such conduct violates the States' international legal obligations. Additionally, States have an obligation to provide victims of human rights abuses committed by PMSCs or their contractors with access to effective judicial remedies that bring relief to the victims' plights. As the case study shows, however, the availability of various potential remedies in criminal and private law does not necessarily guarantee that PMSCs will be brought into account. This will mainly depend on the willingness and expediency of public prosecutors, but also on how judges allow and interpret the application of international law on private actors that exercise public or governmental functions. 



\section{Chapter VII Privatization of Essential Public Utilities}

\section{INTRODUCTION}

The availability of (clean) water, electricity and other utilities is fundamental for society. According to the Dublin Principles, which were established at the International Conference on Water and the Environment held in Dublin in 1991, water "[...] is a finite and vulnerable resource, essential to sustain life, development and the environment." An adult human being has a physical dependency on water and needs at the minimum 2 liters of water a day to avert dehydration. ${ }^{2}$ Access to clean drinking water and adequate wastewater management is also fundamental to ensure a good level of public health, and also influences the education, life expectancy, well being and social development of people. ${ }^{3}$ Waterborne diseases are one of the worst nightmares afflicting the developing world, mainly due to the lack of access to clean drinking water and the nonexistence of sewer and drainage systems. Water is also necessary for human personal hygiene and sanitation. Brushing one's teeth, taking a shower, flushing the toilet are seemingly trivial activities that require access to clean water. Additionally, water is essential for economic and industrial activities: food production and agriculture need efficient access to water resources and several industries are dependent on water usage. Electricity is equally important. A modern livelihood without electricity, especially in urban areas is almost unthinkable. Many aspects of what one could brand a 'normal life' require the use of electricity: refrigerators rely on it to preserve the food people place in them; street and home lighting, the use of television, the computer and radio would not be possible without it. Many important sectors of the economy are dependent on the availability of electricity. The problems caused by the major electrical blackout in North-Eastern United States in the summer of 2003 is a reminder of the dependency of modern society on the use of electricity. ${ }^{4}$ Likewise basic telephony and communications services are

1 See Principle No. 1, Dublin Statement on Water and Sustainable Development, International Conference on Water and the Environment: Development Issues for the $21^{\text {st }}$ Century, Dublin, Ireland (1992). See also Guidelines for drinking-water quality: Volume 1 Recommendations, $2^{\text {nd }}$ edition, WHO, Geneva (1993) Switzerland, para. 1.1.

2 See G. Howard and J. Bartram, "Domestic Water Quantity, Service, Level and Health," WHO/ SDE/WSH/03.02, WHO, (2003), p. 5.

3 See Guidelines for drinking-water quality: Volume 3 Surveillance and Control of Community Supplies, $2^{\text {nd }}$ edition, WHO, Geneva (1997) Switzerland, p. 3-4; and Water for Life: Making it Happen, WHO/UNICEF Joint Monitoring Programme for Water Supply and Sanitation, WHO and UNICEF (2005), p. 10.

4 A number of commentators pointed out that the deregulation, and also privatization of the electricity market was indirectly the cause of the major 2003 blackout that brought life to a 
indispensable for a society. The ability to send and receive information has become important for social and economic reasons.

The importance of these services and utilities for developing countries and poor communities is hard to overstate. In the foreword to a World Bank sponsored report on contracting for public services, the authors of the report note that,

"[a]ccess to good, reliable public services is critical for the poor in developing countries if they are to rise out of poverty. Safe water and sanitation, modern energy and communications, good quality basic education and health services - all contribute directly to individual well-being, and all improve economic opportunities for low-income households." 5

A number of the UN's human rights treaty monitoring bodies have also acknowledged the importance of these services and their relationship with human rights in the concluding observations to several periodic reports submitted by States. The Committee on Economic, Social and Cultural Rights (CESCR), for instance, has expressed its concern about the poor living conditions of the majority of the population of Georgia due to an inadequate supply of water and the irregular provision of electricity. According to the Committee, these circumstances predominantly affected the most disadvantaged and marginalized groups of society. ${ }^{6}$ The Committee on the Elimination of Racial Discrimination (CERD) has noted that among the factors affecting the implementation of the Convention on the Elimination of All Forms of Racial Discrimination, was the extreme poverty which was "[...] evident in the lack of access to some basic services, such as provision of clean water, medical care, education and electricity." 7 Similarly, the Committee on the Elimination of Discrimination Against Women (CEDAW) observed that women

standstill in major cities of the United States and Canada. See "In Big Blackout, Hindsight Is Not 20/20," New York Times report, 13 May 2004, available at <http:/query.nytimes.com/gst/ fullpage.html?res=9504E5D8113CF930A25756C0A9629C 8 B63\&sec $=\&$ spon=\&pagewanted=pr int> (last visited on 30 December 2007), and "Utility Could Have Halted '03 Blackout, Panel Says," New York Times report, 6 April 2004, available at <http:/query.nytimes.com/gst/ fullpage.html?res=940DE1DC1F39F935A35757C0A9629C8B63\&sec=\&spon=\&pagewanted=pr int> (last visited on 30 December 2007).

5 Brook and Smith, "Contracting for Public Services: Output-based aid and its applications," p. ix.

6 These included older persons, persons with disabilities, internally displaced persons, prisoners and persons living in poverty. See Concluding Observations, Georgia, ICESCR, UN Doc. E/C.12/1/Add.83 (19 December 2002), para. 23. The Committee urged Georgia to, "[...] continue its efforts to improve the living conditions of its population, in particular by ensuring that the infrastructure for water, energy provision and heating is improved, and by paying priority attention to the needs of the most disadvantaged and marginalized groups of society [...]" Ibid., para. 40.

7 Concluding Observations Bolivia, CERD, UN Doc. CERD/C/304/Add.10 (27 September 1996), para. 4. 
suffered more than anyone else due to the lack of basic necessities such as potable water, sanitation and electricity in some rural areas of China. ${ }^{8}$

Evidently, municipal services and public utilities providing these goods and services are important and their proper functioning is essential for society. Although these services and utilities have not always been in hands of a public authority, ${ }^{9}$ it has almost been taken for granted that the government should be in charge of providing these services and guaranteeing that they are accessible to all the sectors of society. Universal access to these services is considered to be crucial for the well being of the society. However, the high costs of investing in, establishing and maintaining these services, as well as the failure of publicly managed municipal services and utilities to provide these services in an effective way in many countries has led to the debate of whether these services and utilities can be better, cheaper, and more efficiently provided by private parties. ${ }^{10}$

The privatization of essential utilities has been, to say the least, controversial. The privatization of the local water utility in Cochabamba, Bolivia, led to major riots following accusations of corruption and price increases that made the water unaffordable for low-income families. ${ }^{11}$ The privatization of water utilities in Argentina, where subsidiaries of a number of European water multinationals took over the operation and management of water services in various cities, became very contentious and some water privatization projects have been reversed. ${ }^{12}$ On the other hand, the privatization of essential public utilities such as telecommunication and telephony has been less controversial and can even be regarded as a major

8 Concluding Observations China, CEDAW, UN Doc. A/47/38 (1992), para. 204.

9 See Chapter II supra for a brief overview of the cyclic changes in ownership and management of utilities. For a brief historical account of water utilities, see further Section 2.4 infra.

10 I.N. Kessides, "Reforming Infrastructure: Privatization, Regulation, and Competition," A World Bank Policy Research Report, The International Bank for Reconstruction and Development/The World Bank and Oxford University Press, Washington D.C., (2004), p. 2-3.

11 See H.H. Abendroth, "Der 'Wasserkrieg' von Cochabamba: Zur Auseinandersetzung um die Privatisierung einer Wasserversorgung in Bolivien," Bundeskammer für Arbeiter und Angestellte, Vienna, Informationen zur Umweltpolitik Nr. 161 (2004). See also Nickson and Vargas, "The Limitations of Water Regulation: The Failure of the Cochabamba Concesion in Bolivia," p. 128-149; McFarland Sanchez-Moreno and Higgins, "No Recourse: Transnational Corporations and the Protection of Economic, Social and Cultural Rights in Bolivia," p. 16631805. The conflict in Cochabamba eventually led to the withdrawal of the privatization, and to an arbitral dispute before the International Center for the Settlement of Investment Disputes (ICSID) between Bolivia and Aguas del Tunari, the local subsidiary of an American-Dutch water consortium led by multinational Bechtel. See further Section 2.5 infra for a brief description of the conflict.

12 See for example the following New York Times article: "As Multinationals Run the Taps, Anger Rises Over Water for Profit," New York Times 26 August 2002. Article can be read at <www. nytimes.com/2002/08/26/international/americas/26WATE.html $>$ (last visited on 26 August 2002). See further Section 4 infra for an analysis of the privatization of water utilities in the city of Buenos Aires. 
success. The liberalization of the telecommunications market in the European Union and the privatization wave that swept over Europe's state PTT companies has led to a vast array of service providers with concomitant advantages for consumers including lower prices. ${ }^{13}$ Similarly, consumers in the Americas, Africa and Asia have vastly benefited from increasing coverage and decreasing costs of local and mobile telephony. ${ }^{14}$ One could even argue that the privatization of telephony services has improved the rights of consumers to receive and send information.

Much of the opposition to the privatization of public utilities and municipal services, in particular those related to the provision of water and sanitation, has been politically motivated. ${ }^{15}$ However, the current growing opposition towards the privatization of what are deemed to be essential services stems from the perception that privatization is,

"[...] fundamentally unfair in both concept and implementation: it is seen as harming the poor, the disenfranchised, the workers, and even the middle class; throwing people out of good jobs and into poor ones or unemployment; raising prices for essential services; giving away national treasures - and all this to the benefit of the local elite, agile or corrupt politicians, and foreign corporations and investors. The complaint is that, even if privatization contributes to improved efficiency and financial performance (some question this as well), it has a negative effect on the distribution of wealth, income and political power."16

In particular, fears that privatization of essential municipal services and public utilities in the water sector would result in less access to these services for the poor and higher costs, whether well founded or not, has fomented popular opposition to privatization measures. ${ }^{17}$ One of the arguments raised by the opponents of privatization of water utilities is the detrimental effect it can have on the enjoyment of certain human rights. ${ }^{18}$

13 See "Privatising State-Owned Enterprises - An Overview of Policies and Practices in OECD Countries," p. 36. and generally P. Larouche, The Bases of EC Telecommunications Law After Liberalization (Maastricht: Diss. Universiteit Maastricht, 2000).

14 For an example of some of the benefits that privatization of telecommunications has brought to a developing country see V. Foster and M.C. Araujo, "Does Infrastructure Reform Work for the Poor? A Case Study from Guatemala," World Bank Policy Research Working Paper 3185 (WPS3185), World Bank, (2004), p. 8-9.

15 See Hall, Lobina, and Motte, "Public Resistance to Privatisation in Water and Energy," p. 294.

16 Birdsall and Nellis, "Winners and Losers: Assessing the Distributional Impact of Privatization," p. 1617 (note omitted).

17 See Hall, Lobina, and Motte, "Public Resistance to Privatisation in Water and Energy," p. 292.

18 See for example "Relationship between the enjoyment of economic, social and cultural rights and the promotion of the realization of the right to drinking water supply and sanitation. Preliminary report submitted by Mr. El Hadji Guissé in pursuance of decision 2002/105 of the Commission on Human Rights and resolution 2001/2 of the Sub-Commission on the Promotion and Protection of Human Rights," UN Doc. E/CN.4/Sub.2/2002/10 (25 June 2002), para. 30. 
In essence, the privatization of water utilities in relationship to human rights appears to involve three concurring (even competing), but equally legitimate interests. Firstly, there are the interests of the privatized utility provider or operator that wants to recover the investments made to provide the service, and if possible make a profit out of it. ${ }^{19}$ These interests involve economic appreciations of the provision of water, which are mainly concerned with its optimal distribution, and the recovery of the costs involved while doing so. The basis for this is rational economic thought, which is not concerned with "[...] whether the initial distribution of resources is fair or just, but whether, given an initial distribution of resources, their allocation through a market mechanism is optimal." ${ }^{20}$ Under this train of thought, water has become an economic good, i.e. a good that is subject to the rules of a market and which commands a price in that market. ${ }^{21}$

Secondly, there are the interests of consumers in particular those who are poor or belong to a vulnerable sector of society, and who undeniably have a right to live with dignity. ${ }^{22}$ To achieve this they need to have (full) access to the water and sewerage services provided by the utilities at an affordable price (and sometimes even for free) and with guaranteed quality. In spite of claiming that water must be regarded as an economic good, Principle No. 4 of the Dublin Principles nevertheless accepts that "[...], it is vital to recognize first the basic right of all human beings to have access to clean water and sanitation at an affordable price."

19 See also A. Estache, A. Gomez-Lobo, and D. Leipziger, "Utilities Privatization and the Poor: Lessons and Evidence from Latin America," World Development Vol. 29 (2001), p. 1179-1198. Graham, "Human Rights and the Privatisation of Public Utilities and Essential Services," p. $34 .$. See P.H. Gleick et al., "The New Economy of Water: The Risks and Benefits of Globalization and Privatization of Fresh Water," Pacific Institute for Studies in Development, Environment, and Security, Oakland, (2002), p. 1; J. Budds and G McGranahan, "Are the Debates on Water Privatization Missing the Point? Experiences from Asia, Africa and Latin America," Environment \& Urbanization Vol. 15 (2003), p. 95; G. Meijerink and A. Ruijs, "Water as an Economic Good - Points of Interest for Policy," Projectcode 62804, LEI-Wageningen University and Research Centre, The Hague, (2003), p. 9-11. This has been corroborated by the Dublin Principles. According to Principle No. 4, "[w]ater has an economic value in all its competing uses and should be recognized as an economic good." Principle No. 4 further states that "[w] ithin this principle, it is vital to recognize first the basic right of all human beings to have access to clean water and sanitation at an affordable price. Past failure to recognize the economic value of water has led to wasteful and environmentally damaging uses of the resource. Managing water as an economic good is an important way of achieving efficient and equitable use, and of encouraging conservation and protection of water resources." The United Nations Conference on Environment and Development, held in Rio de Janeiro in 1992 has also reaffirmed the economic nature of water. In the Rio Declaration on Environment and Development (Agenda 21) the international community stated that "[i]ntegrated water resources management is based on the perception of water as an integral part of the ecosystem, a natural resource, and a social and economic good[...]" See Agenda 21, Chapter 18.8.

See Preamble of the Universal Declaration of Human Rights. 
Finally, there are the interests of the State that oblige it to provide clean water that is accessible and affordable to all without discrimination as a matter of public health and sanitation, to decrease water spillage, and promote rational and sustainable water consumption. ${ }^{23}$ In addition the State has to take into account the economic interests coupled to the delivery of water related services. Investments in the infrastructure and water network, their operation and maintenance are very costly. In providing these essential services the State will have to take into consideration efficiency aspects and budgetary concerns: how to provide water services in such a way that it is also affordable for the State and does not become an immense economic burden to public finances? This last question can imply issues such as cost recovery for the service and pricing the use of water at an economically sensible level to cover operational costs. The usual way of dealing with these issues is through taxation or through charging for usage at the point of delivery.

It has been argued that the clash between these three interests can bring about human rights conflicts in the context of the privatization of essential utilities such as water. ${ }^{24}$ Neglecting the interests of the poor in this respect could lead to human rights violations of the right to water, food or health due to lack of access to the essential services provided by water utilities. This conflict, however, does not mean that privatization of essential utilities will necessarily lead to a negative outcome for the human rights affected by it. Under the right circumstances, the privatization of public utilities can also help to improve human rights when appropriately implemented. Thus, a priori, the privatization of essential utilities such as water does not automatically lead to human rights problems by itself, and a combination of additional factors should be taken into account when States decide to privatize these services. Having said this, there are indications that the privatization of a number of essential utilities, in particular water, has not always led to all the expected beneficial results. It is thus time to take stock of the privatization of essential utilities and examine them from the perspective of international human rights. In this respect, the various legal obligations emanating from the rights that may be affected can provide useful guidelines for States that embark on the privatization of public utilities and municipal services.

23 For a brief discussion of these 'public service obligations' see Section 2.2 infra.

24 See among others N. Rosemann, "Financing the Human Right to Water as a Millenium Development Goal” Law, Social Justice \& Global Development Journal (LGD), 2005; available from <www.go.warwick.ac.uk/elj/lgd/2005_1/rosemann>. For a social-economical analysis of this conflict see Frohlich and Oppenheimer who argue that trying to obtain Pareto efficiencies through the privatization of water runs the risk of creating grave social problems if privatization is not accompanied by measures to prevent that individuals do not fall below what is considered to be acceptable: N. Frohlich and J. Oppenheimer, "Alienable Privatization Policies: The Choice Between Inefficiency and Injustice," in Water Quantity/Quality Management and Conflict Resolution: Institutions, Processes, and Economic Analyses, ed. A. Dinar and E.T. Loehman, Westport, CT: Praeger Publishers (1995), p. 131-142. 
The objective of this chapter is to examine the (potential) human rights issues arising out of the privatization of municipal services and public utilities and to investigate how human rights obligations can provide guidelines for the privatization of these services. Because it would appear to raise the most controversy regarding its possible effects on a number of economic, social and cultural rights, this chapter will only examine the privatization of water utilities. This chapter will seek to uncover the extent to which the privatization of water utilities can create human rights concerns and how these can be ameliorated. To this end, Section 2 of this chapter will first provide a definition of the privatization of water utilities, discuss its nature, and then place the privatization of water utilities in a general (and historical) context. The reasons behind their privatization, the modes and techniques of privatization utilized and the relationship between privatization, public service obligations, universal services and regulation will also be evaluated. In Section 3, a number of economic, social and cultural rights, which may be particularly affected by the privatization of water utilities, and their legal obligations, will be examined. These include the right to health and the right to an adequate standard of living, including the right to adequate housing and the right to water. Due to its controversial nature, special attention will be given to the right to water. This will be followed by Section 4, which will examine a case study dealing with the privatization of water utilities in the city of Buenos Aires, Argentina. This case study has been chosen for a number of reasons. In particular because initially it had been hailed by the World Bank as one of the most successful privatization efforts in the water sector. In spite of this initial positive assessment, the privatization was troublesome and was terminated thirteen years after its inception. ${ }^{25}$ Among the concerns expressed from elements of civil society and external actors during its thirteen year run, were that the privatization was not fulfilling its promise of delivering better service at a lower cost, and was even having a negative effect on human rights of consumers, in particular those who are poor. In addition, the privatization process and outcomes of the Buenos Aires water concession has been widely documented by international and national actors (including governmental and non-governmental), and access to primary sources is readily available. The availability of abundant documentation, combined with the positive and negative outcomes of the privatization of the water utility in Buenos Aires, as well as the relative long period available for analysis compared to the other controversial water privatization efforts such as the Cochabamba case, which lasted only one year, makes this case study ideal to provide a human rights assessment of the privatization of water utilities for the purposes of this study. took over the water services in Buenos Aires was supposed to last thirty years. 
Chapter VII

\section{The PRIVATIZATION OF WATER UTILITIES: DEFINITION, (HISTORICAL) CONTEXT, AND TECHNIQUES}

According to the UNDP's Human Development Report for 2006, public providers carry out more than $90 \%$ of the provision of water in developing countries. ${ }^{26}$ However, in the last twenty-five years, various countries in all regions of the world and from all levels of development have subjected their public water utilities to privatization. The privatization of these services has been spearheaded by the United Kingdom, where privatization of municipal services and utilities has been the most widespread and was the result of deliberate governmental policy under the auspices of the Conservative government of former Prime Minister Margaret Thatcher in the early 1980's. ${ }^{27}$ Ever since, the privatization of municipal services and public utilities has been adopted by a large number of countries in all continents. Many, if not most of the utilities privatization programs in Africa, Asia and Latin America have been the result of recommendations made by the World Bank and the IMF in the last twenty years. The World Bank has encouraged, sponsored, and sometimes provided assistance in various projects and programs to privatize the utilities sector in developing countries, often as a condition for receiving funding for development projects. ${ }^{28}$

The privatization of water utilities has become an important alternative to publicly provided water services. Public water utilities of mainly developing countries have been under performing, failing to provide adequate services in particular to the poorest segments of the population, and covering the costs of their operations. Publicly managed water utilities have not been able to extend access to the water network, have delivered poor quality services, and have operated in an often inefficient and corrupt way. ${ }^{29}$ The privatization of water utilities is thus regarded as

26 "Human Development Report 2006: Beyond Scarcity: Power, poverty and the global water crisis," United Nations Development Programme, New York, (2006), p. 10.

27 Graham, Regulating Public Utilities: A Constitutional Approach, p. 14-15. For a brief chronological overview of the privatization of various utilities in the UK see C. Waddams Price and A. Young, "UK Utility Reforms: Distributional Implications and Government Response," Discussion Paper No. 2001/10, World Institute for Development Economics Research (WIDER) - United Nations University, Helsinki, (2001), p. 2-5, and Florio, "A State Without Ownerhip: The Welfare Impact of British Privatizations - 1979-1997," p. 2-5.

28 See in general, Donaldson and Wagle, "Privatization: Principles and Practice," p. 14; Sader, "Privatizing Public Enterprises and Foreign Investment in Developing Countries, 1988-1993."; E. Lobina and D. Hall, "Problems with Private Water Concessions: A Review of Experience" Public Services International Research Unit (PSIRU), University of Greenwich, 2003; available from <www.psiru.org/reports/2003-06-W-over.doc>. See in particular for Latin America G.C. Guarda, "Financing Urban Services in Latin America: Spatial Distribution Issues," Report INU 48, Discussion Paper WPS 364, The World Bank, Washington D.C., (1989).

29 Budds and McGranahan, "Are the Debates on Water Privatization Missing the Point? Experiences from Asia, Africa and Latin America," p. 87, and A. Estache, V. Foster, and Q. Wodon, "Accounting for Poverty in Infrastructure Reform: Learning From Latin America's 
a solution to public sector inefficiency. It is also considered as a viable means of helping to realize two of the Millennium Development Goals as stipulated in the UN's Millennium Declaration: ${ }^{30}$ namely to halve the proportion of people who are unable to reach or to afford safe drinking water by 2015, and to stop the unsustainable exploitation of water resources by developing water management strategies at the regional, national and local levels, which promote both equitable access and adequate supplies. The estimated investments necessary to realize this hover around the 10 to 30 billion dollars per year on top of what is already being spent. ${ }^{31}$ It has been argued that one of the means for financing this is through active involvement of the private sector. ${ }^{32}$ Finally, and taking into consideration the figures involved in the financing of water networks, the private provision of water by large companies has also become a large international business. For example, one of the largest water companies in the world, Suez Environment (a subsidiary of French multinational GDF Suez) reported in 2005 an increase in its revenues of $5.1 \%$ with respect to the previous year amounting to $€ 11.1$ billion euros, that is $27 \%$ of Suez's total revenues for 2005 ( $€ 41.5$ billion euros). ${ }^{33}$

\subsection{Defining the privatization of water utilities}

Technically speaking, discussing 'the privatization of water' is not entirely correct. Water as such is not being privatized in the sense that the ownership of water shifts from the State to a private actor. What is being privatized, however, is the actual delivery of the service of providing drinking water and sometimes the body that in practice operates the service (the water utility). Budds and McGranahan have observed that there is some confusion with regard to what is actually understood by the privatization of water utilities. ${ }^{34}$ This is mainly due to the various types of participation of the private sector in those services related to the distribution of water and sanitation. For example, private actors may be marginally involved in the water utilities sector by only providing maintenance to the water distribution

Experience," World Bank Institute Development Studies, 23950, The International Bank for Reconstruction and Development/The World Bank, Washington D.C., (2002), p. 2.

30 See Resolution adopted by the General Assembly, United Nations Millennium Declaration, UN Doc. A/RES/55/2 (18 September 2000).

31 United Nations Department of Economic and Social Affairs UNDESA, "Recognizing and Valuing the Many Faces of Water," in Water for People Water for Life: The United Nations World Water Development ReportUNESCO-World Water Assessment Program (2003), p. 334. See also J. Winpenny, "Financing Water for All - Report of the World Panel on Financing Water Infrastructure," Chaired by M. Camdessus, World Water Council//3 ${ }^{\text {rd }}$ World Water Forum/Global Water Partnership, (2003), p. 3.

32 UNDESA, "Recognizing and Valuing the Many Faces of Water," p. 335.

33 See Suez Annual Results for 2005, available at <www.suez.com $>$ (last visited on 7 August 2007).

34 Budds and McGranahan, "Are the Debates on Water Privatization Missing the Point? Experiences from Asia, Africa and Latin America," p. 88-89. 
network. Private actors may also be involved in the small-scale sale of water to lowincome settlements. ${ }^{35}$ On the other hand, they may take responsibility for managing and operating a water network, but not actually owning it. In extreme circumstances, private actors could also take over the whole ownership of a water utility and be entirely responsible for its operations and expansion.

Given the number of possibilities of what have been called 'public-private partnerships ${ }^{\prime 36}$ in the water utilities sector, it may be difficult to come up with a concrete definition of what the privatization of water stands for. Budds and McGranahan, for example, argue that the definition should not cover the small-scale or informal vendors of water (most of which sell water supplies to low-income settlements, sometimes on a non-profit basis) since these actors are different from large water companies. ${ }^{37}$ They also play a very different role and operate on different principles. Although it can be debated whether small-scale informal vendors who do sell water for profit, often at higher prices than water companies, should not be included in a definition of the privatization of utilities, it can be stated that privatization in this sector has often involved the transfer to formal business enterprises of a varying degree of competences, management and tasks related to the operation of an already existing water network and pipeline that has been operated by the public sector until that point. Budds and McGranahan's definition of privatization of water utilities is, thus, useful since it covers these aspects in a satisfactory way. ${ }^{38}$

Accordingly, the privatization of water utilities could be understood as the process through which the participation of formal companies in the provision of water and sanitation services is increased by taking over certain aspects of the production, distribution, and cleaning of drinking water to households and related sewerage from the public sector. This does not necessarily mean a complete take over the ownership of a public water company (divestiture), or that the private water company is responsible for all aspects of the water distribution system. This may become clear once the methods of privatization in this sector are described in Section 2.3 infra.

\footnotetext{
35 See Winpenny, "Financing Water for All - Report of the World Panel on Financing Water Infrastructure," p. 32. See also Budds and McGranahan, "Are the Debates on Water Privatization Missing the Point? Experiences from Asia, Africa and Latin America," p. 89.

36 Budds and McGranahan, "Are the Debates on Water Privatization Missing the Point? Experiences from Asia, Africa and Latin America," p. 89.

37 Ibid.

38 Ibid.
} 


\subsection{The nature of essential network and water utilities and universal service obligations}

Before going into more detail about the types and/or methods of privatization of water utilities, it is necessary to make some observations regarding the nature of essential network utilities in general and water utilities in particular. Essential network utilities provide crucial services to the population and also have a tremendous effect on manufacturing and commerce. ${ }^{39}$ Multiple providers can provide a number of these services at the same time. This allows for competition and usually permits the market of those services to behave in an efficient way with concomitant economic benefits (lower prices, wider choice, etc.) Arguably, this has been the case of telephony utilities, which in many countries used to be run by state-owned monopolies. However, due to the nature of certain services it is not always possible for more than one service provider to operate the service. This is usually the case in situations where it would be inefficient to create a parallel infrastructure to provide the service in competition with others. Such a situation entails a 'natural monopoly'. According to Posner a natural monopoly exists,

"[i]f the entire demand within a relevant market can be satisfied at lowest cost by one firm rather than by two or more, the market is a natural monopoly, whatever the actual number of firms in it. If such a market contains more than one firm, either the firms will quickly shake down to one through mergers or failures, or production will continue to consume more resources than necessary. In the first case competition is short-lived and in the second it produces inefficient results. Competition is thus not a viable regulatory mechanism under conditions of natural monopoly." ${ }^{40}$

Examples of natural monopolies in the network and utilities sector are the railways, roads, gas transmission and distribution, electricity transmission, and water distribution and sewerage. ${ }^{41}$

Sometimes, advances in technology and deregulation can help to transform a natural monopoly into a situation in which normal competition between two or more service providers is possible. ${ }^{42}$ Thus improvements in technology and the advent of mobile telephony allowed the telecommunications sector to escape its former natural monopoly status. Similarly, the electricity sector was no longer

39 Kessides, "Reforming Infrastructure: Privatization, Regulation, and Competition," p. 29.

40 R. Posner, "Theories of Economic Regulation," Bell Journal of Economics Volume 5 (1974), p. 548. See also C. Jacobson, "Same Game, Different Players: Problems in Urban Public Utility Regulation, 1850-1987," Urban Studies Vol. 26 (1989), p. 14.

41 See M. Klein, "Competition in Network Industries," Policy Research Working Paper, WPS 1591, The World Bank/Private Sector Development Department, Washington D.C., (1996), p. 3; M. Kerf et al., "Concessions for Infrastructure: A Guide to their Desing and Award," World Bank Technical Paper No. 399 - Finance, Private Sector, and Infrastructure Network, The Wolrd Bank/The Inter-American Development Bank, Washington, (1998), p. 13.

Klein, "Competition in Network Industries," p. 4. 
considered a natural monopoly when advances in technology and deregulation separated the production, transmission and distribution of electricity unbundling it from one individual company, thus making competition possible in the production and distribution arms of the sector. ${ }^{43}$ Water, however, remains the quintessential natural monopoly since it would be difficult if not impossible to lay down a second or third network of pipes and sewerage as well as household connections that can be used by other competitors.

Depending on the privatization technique used (see further Section 2.3 infra), the natural monopoly aspect of water utilities has a number of consequences for their privatization. In the first place, if the privatization takes place through a concession or full divestiture, the privatization of this sector will not entail competition in the market for water provision, since only one company, will be able to operate in the market of the provision of water. Rather, the only competition possible will be competition for the market: a State that decides to privatize its water utilities will usually have to hold a tender to award the right to operate in the service provision to the company that offers the best terms. ${ }^{44}$ In the second place, this means that since only one private company will be able to operate the water utility, there will be a need to regulate its conduct due to its monopoly position to prevent an abuse of its monopoly position, as well as to ensure that consumer interests are protected, that the privatized company makes the adequate infrastructural investments, and to deal with externalities such as water pollution. ${ }^{45}$

In addition to the natural monopoly aspect of water utilities, there is also the issue of the type and nature of service they provide. The provision of drinking water, sewerage and sanitation can be regarded as public services with important effects on the local population. Although there is no concrete legal definition of a public service, ${ }^{46}$ it is possible to state that such a service is one that is affected with carrying out an activity necessary for the furtherance of a 'public interest' or for pursuing public policy objectives. ${ }^{47}$ This functional approach looks at the nature

$43 \quad$ Ibid., p. 5-9; R. Künneke, "Electricity Networks: How 'Natural' is the Monopoly?," Utilities Policy Vol. 8 (1999), p. 99-108.

44 Klein, "Competition in Network Industries," p. 10.

45 Ibid., p. 4; F. Neto, "Water Privatization and Regulation in England and France: A Tale of Two Models," Natural Resources Forum Vol. 22 (1998), p. 108. See further Section 2.6.2 infra.

46 E. Malaret García, "Public Service, Public Services, Public Functions, and Guarantees of the Rights of Citizens: Unchanging Needs in a Changed Context," in Public Services and Citizenship in European Law, ed. M. Freedland and S. Sciarra, Oxford: Oxford University Press (1998), p. 57; Scott, "Services of General Interest in EC Law: Matching Values to Regulatory Technique in the Public and Privatised Sectors," p. 312. See also Krajewski, "Public Services and Trade Liberalization: Mapping the Legal Framework," p. 343.

47 Krajewski, "Public Services and Trade Liberalization: Mapping the Legal Framework," p. 344. See also R. Adlung, "Public Services and the GATS," Journal of International Economic Law Vol. 9 (2006), p. 455-485. 
of the service and implies that a public authority will have a role in the provision of the service, although this role may not be necessarily the one of actually performing or carrying out the service. The status or ownership of the service provider is under this approach irrelevant, therefore transcending the "[...] traditional juridical public - private divide." 48

It is also irrelevant whether such a service is commercial or not. The provision of this type of service may not necessarily entail a non-commercial or non-profit activity, ${ }^{49}$ which is why it may be better to think in terms of 'services of general interest' as the EU has done. ${ }^{50}$ According to the Commission of the European Communities, these services are understood to be broad in nature, and cover "[...] both market and non-market services which the public authorities class as being of general interest and subject to specific public service obligations." 51 The EU's approach is based on various common legal concepts that impose special obligations on the operators of certain essential services. ${ }^{52}$ These concepts include for example the French notion of 'service public', the common law doctrines of 'common callings', 'common carriage', 'businesses affected with a public interest', and the doctrine of 'prime necessity'.53 Broadly speaking, these concepts require the providers of essential services (suppliers of 'prime necessities') to supply these

48 Scott, "Services of General Interest in EC Law: Matching Values to Regulatory Technique in the Public and Privatised Sectors," p. 312.

49 Krajewski, "Public Services and Trade Liberalization: Mapping the Legal Framework," p. 344. For definition of what is a commercial task or service (in particular within the context of the GATS, but also applicable to the current discussion) see Adlung, "Public Services and the GATS," p. 462-463. For a discussion about the provision of public services in a competitive market see E. Szyszczak, "Public Service Provision in Competitive Markets," Yearbook of European Law Vol. 20 (2001), p. 35-77.

50 See Communication from the Commission: Services of General Interest in Europe, Commission of the European Communities, COM(96) 443 final (11 September 1996). The EU has embraced the notion of 'services of general interest', which is a derivative of the term services of 'general economic interest' the latter of which have received particular attention in Article 16 and Article $86 \$ 2$ of the EC Treaty (now Article 14 and Article 106 in the Treaty on the Functioning of the European Union). See Green Paper on Services of General Interest, Commission of the European Communities, COM(2003) 270 final (21 May 2003), p. 5-7, and Communication from the Commission to the European Parliament, the Council, the European Economic and Social Committee and the Committee of the Regions, White Paper on services of general interest, Commission of the European Communities, COM(2004) 374 final (12 May 2004). According to Scott the main purpose of the notion of 'services of general interest' is to "delineate activities deserving of special treatment within the European Community legal system from those which must submit to all the rules of the internal market." Scott, "Services of General Interest in EC Law: Matching Values to Regulatory Technique in the Public and Privatised Sectors," p. 312.

51 Green Paper on Services of General Interest, para. 16.

52 Scott, "Services of General Interest in EC Law: Matching Values to Regulatory Technique in the Public and Privatised Sectors," p. 312.

53 See P. Craig, "Constitutions, Property and Regulation," Public Law (1991), p. 540-541; Oliver, Common Values and the Public Private Divide, p. 201-205; Scott, "Services of General Interest in EC Law: Matching Values to Regulatory Technique in the Public and Privatised Sectors," 
services to all who need them for a fair and reasonable price, in sufficient quantity and quality and in a non-discriminatory way, in particular if the providers have a dominant or monopoly position. This is also known as universal service obligations (USOs), which were briefly discussed in Chapter III, Section 4.1.3. The term 'universal service obligations' was apparently coined in 1907 by the then president of AT\&T, Theodore Vail, and has been traditionally connected to the telecommunications sector. ${ }^{54}$ Initially it referred to the need to have interconnection between competing telephone services, and not to extending telephony services to everyone, everywhere at affordable prices. ${ }^{55}$ The content of USOs has, however, gradually been expanded to refer to "the provision of a defined minimum set of services to all end-users at an affordable price," ${ }^{56}$ and their scope has gone beyond telecommunications and include now also other essential network services like water. According to Chisari, Estache, and Waddams Price, USOs arises when a. the product or service is essential; $b$. when there are groups of consumers that cannot gain access to a service at current tariffs, unless the latter are adjusted to meet the consumers' capacity to pay, for example through cross-subsidies; and c. when the lack of supply or impossibility of gaining access excludes consumers from other markets or activities. ${ }^{57}$

Among the public service obligations that the EU has recognized under the 'services of general interest' approach are: ${ }^{58}$

- universal service obligations: that is ensuring that certain services are made available at a specified quality to all consumers and users throughout the territory of a Member State, independently of geographical location, and, in the light of specific national conditions, at an affordable price;

- obligations related to continuity of service: the provider of the service is obliged to ensure that the service is provided without interruption;

- obligations related to quality of service and standards: these include, for instance, safety regulations, the correctness and transparency of billing, territorial coverage, and protection against disconnection;

p. 312-313. See also in general M. Taggart, "The Province of Administrative Law Determined?," in The Province of Administrative Law, ed. M. Taggart, Oxford: Hart Publishing (1997), p. 6-8.

54 Young, "The Future of Universal Service. Does it Have One?," p. 189.

55 Ibid.

56 See Directive 2002/22/EC of the European Parliament and of the Council of 7 March 2002 on universal service and users' rights relating to electronic communications networks and services (Universal Service Directive), Official Journal L 108, 24 April 2002, p. 0051-0077. See also ibid., Young, p. 190.

57 O. Chisari, A. Estache, and C. Waddams Price, "Access by the Poor in Latin America's Utility Reform - Subsidies and Service Obligations," Discussion Paper No. 2001/75, United Nations University/WIDER, (2001), p. 9.

58 Green Paper on Services of General Interest, paras. 49-63. 
- obligations related to affordability: services of general economic interest have to be offered at an affordable price in order to be accessible for everybody

- obligations related to user and consumer protection.

The European Court of Justice has acknowledged the importance of these obligations. In a number of cases related to utilities in the electricity and gas sectors, it concluded that EU competition rules could be set aside when their full application runs the risk of impeding a particular undertaking from performing its mission of general interest. ${ }^{59}$

Although the concept of 'services of general interest' is mainly applicable in the context of the EU, it is submitted that the broad principles enshrined therein, including the concept of USOs, are also of equal application to the issue of essential water utilities elsewhere and whatever the type of ownership or operation (public or private) in the context of the present study. This is underlined by the fact that 'services of general economic interest' have been brought within the ambit of the EU's Charter of Fundamental Rights. Article 36 of the Charter provides: "The Union recognises and respects access to services of general economic interest as provided for in national law and practices, in accordance with the Treaty establishing the European Community, in order to promote the social and territorial cohesion of the Union." 60 In addition, the recognition at the EU level of what appears to be a national development (namely the acceptance that there are certain services that are of essential importance for society and necessary for the realization of certain public goals and human rights) is also receiving acceptance at the international level. For example, a number of ICSID arbitration panels have concluded that the nature of the services provided by these companies is such that the issues revolving around these disputes are ones of public interest including human rights. Thus, in an order in response to a petition for participation as amicus curiae in a dispute between a Aguas Argentinas, an affiliate company of an international consortium led by French multinational Suez, and Argentina the ICSID panel observed that,

[...] the present case potentially involves matters of public interest. [...] The factor that gives this case particular public interest is that the investment dispute centers around the water distribution and sewage systems of a large metropolitan area, the city of Buenos Aires and surrounding municipalities. Those systems provide basic public services to millions of people and as a result may raise a variety of complex

59 See for example, ECJ, Case C-393/92 Almelo (1994) ECR I-1477, paras. 48-49 and ECJ, Case C-157/94 Commission v. Netherlands (1997) ECR I-5699, paras. 43 and 58. See also Szyszczak, "Public Service Provision in Competitive Markets," p. 46, and T. Prosser, "Competition Law and Public Services: From Single Market to Citizenship Rights?," European Public Law Vol. 11 (2005), p. 553.

60 See Charter of Fundamental Rights of the European Union, Official Journal of the European Communities, (2000/C 364/01). See also Prosser, "Competition Law and Public Services: From Single Market to Citizenship Rights?," p. 554. 
public and international law questions, including human rights considerations. Any decision rendered in this case, whether in favor of the Claimants or the Respondent, has the potential to affect the operation of those systems and thereby the public they serve." ${ }^{61}$ (emphasis added $A H W$ )

An important aspect of this observation by the arbitration tribunal is that the nature of the issue at hand and the nature of the services rendered by water utilities has moved the arbitration tribunals to recognize the necessity of allowing interested and relevant parties to participate in the arbitration proceedings as amicus curiae. This significant development arguably not only improves the transparency of arbitration disputes regarding the privatization of water utilities, but more importantly, acknowledges the relevance of public interest and human rights issues with regard to privatization of essential services such as the provision of water. Thus the promotion, respect and protection of human rights can be considered as issues of public interest that may fall within the remits of questions raised by the privatization of water utilities. Moreover, the right of a State to regulate the activities of these companies to protect human rights has been acknowledged, albeit within certain boundaries. ${ }^{62}$

The importance of discussing the nature of water utilities as a natural monopoly and as a 'service of general interest' which entail universal service obligations lies in the fact that water utilities, whether they are privatized or not, are under certain obligations to maintain the provision of their services for the benefit of realizing these rights.

\subsection{Methods and modes of the privatization of water utilities}

Chapter II described the various methods and techniques used for privatization in general. The privatization of water utilities follows these methods in general,

61 See Aguas Argentinas, S.A., Suez, Sociedad General de Aguas de Barcelona, S.A. and Vivendi Universal, S.A. v. Argentine Republic, ICSID, Order in Response to a Petition for Transparency and Participation as Amicus Curiae, ICSID Case no. ARB/03/19, 19 May 2005, para. 19. The case has been renamed to Suez, Sociedad General de Aguas de Barcelona S.A. and Vivendi Universal S.A v. Argentine Republic after Aguas Argentinas S.A. withdrew from the case in 2006 and a decision on liability was reached in July 2010. This case was discussed in Chapter III, Section 3.1.3 in the context of the responsibility of the State for the termination of privatization in breach of the BITs between Argentina and Spain, France and the United Kingdom, and will be further analyzed in Section 4 infra. See also Aguas Provinciales de Santa Fe S.A., Suez, Sociedad General de Aguas de Barcelona S.A. and InterAguas Servicios Integrales del Agua S.A. (Claimants) and The Argentine Republic (Respondent), ICSID, Order in Response to a Petition for Participation as Amicus Curiae, ICSID Case No. ARB/03/17, 17 March 2006, para 18.

62 As will be discussed further in sections 2.6 .2 and 4 infra, the ICSID arbitral tribunal dealing with the dispute between Aguas Argentinas and the Argentine Republic recognized the latter's right to regulate for the benefit of human rights. 
although due to its natural monopoly nature one of the general aims pursued by privatization (increased competition in the sector being privatized by opening the market to a plurality of competitors), will usually not be realized. The specialized literature differentiates several methods through which public water utilities can be privatized or through which private entities can participate in the water sector. ${ }^{63}$ The level of privatization or private participation in the water utilities and the methods used may vary depending on the functions being privatized. ${ }^{64}$ The various options available for private participation in the water utilities sector can be distinguished by the amount of risks and responsibilities that are allocated between the private and public actors with regards to the various aspects of owning, operating, managing, and investing in the utilities. ${ }^{65}$ These options vary in complexity and range from simple and limited forms of participation such as service contracts, to the transfer of management duties, to the full transfer of ownership of the water utilities. In practice hybrids of the methods that will be described below are often used. ${ }^{66}$

\subsubsection{Service contracts}

Service contracts can be regarded as the simplest form of private participation in the water utilities sector. ${ }^{67}$ Under this type of limited privatization, private actors are contracted to perform specific tasks, mainly related to the maintenance and upkeep of the infrastructure and water and wastewater networks. ${ }^{68}$ These tasks could include the installation of water meters, the repair of the water pipes and mains or the collection of tariffs. The ownership of the water utilities and the main responsibility for providing the service remains in the hands of the State.

63 W. Stottmann, "The Role of the Private Sector in the Provision of Water and Wastewater Services in Urban Areas," in Water for Urban Areas: Challenges and Perspectives, ed. J.I. Uitto and A.K. Biswas, Tokyo: United Nations University Press (2000), p. 160; "Approaches to Private Participation in Water Services: A Toolkit," The International Bank for Reconstruction and Development/The World Bank, Washington D.C., (2006), p. 7. Stottmann, "The Role of the Private Sector in the Provision of Water and Wastewater Services in Urban Areas," p. 166; Gleick et al., "The New Economy of Water: The Risks and Benefits of Globalization and Privatization of Fresh Water," p. 26. in Urban Areas," p. 160.

66 Ibid., p. 166; Gleick et al., "The New Economy of Water: The Risks and Benefits of Globalization and Privatization of Fresh Water," p. 26.

67 It could even be argued that this type of private participation in the water sector is not a type of privatization as defined above.

68 Stottmann, "The Role of the Private Sector in the Provision of Water and Wastewater Services in Urban Areas," p. 160-161. 


\subsubsection{Management contracts}

With management contracts, the responsibility for managing the water utility is transferred to a private actor. The State maintains the ownership and also the responsibility for investment in the utility. The management contract is sealed for a short period of time (three to five years), and is often coupled to a number of performance targets set in the contract between the State and the private company, and which the private company has to attain. ${ }^{69}$ In general, the private operator does not run high investment risks, which are mainly borne by the government. The returns for the private operator are also comparatively low, and there is no incentive for either the State or the private company to improve the operation of the utility. ${ }^{70}$ With management contracts, the remuneration of the private company for its activities does not depend on the customer tariff, which is still being set by the government. Management contracts can be used as transitional arrangements by the government in preparation of a more complex or deeper type of private participation in the utilities sector. ${ }^{71}$ Examples of this type of contract can be found in Mexico City and Trinidad and Tobago.

\subsubsection{Lease contracts}

Lease contracts, and related arrangements such as affermage contracts, delegate to a private company the responsibility for operating and maintaining the utility and the services provided by it. ${ }^{72}$ The State still maintains the responsibility for the investment, while the company operating the utility pays a lease fee to the contracting authority. In return for this, the company is allowed to keep the revenue of the utility's operation. ${ }^{73}$ Since this revenue depends on the utility's sales and costs, the operator has an incentive to improve the utility's efficiency and increase in sales. ${ }^{74}$ Investments in the infrastructure are usually paid from the lease fees, and sometimes the operator will be responsible for drafting the infrastructure plans. The privatization of the water services in Cartagena, Colombia is an example of a World Bank financed lease arrangement. The affermage variant has been implemented in various African countries such as Côte d'Ivoire and Senegal.

\footnotetext{
69 Ibid., p. 162; "Approaches to Private Participation in Water Services: A Toolkit," p. 7.

70 "Approaches to Private Participation in Water Services: A Toolkit," p. 7.

71 Stottmann, "The Role of the Private Sector in the Provision of Water and Wastewater Services in Urban Areas," p. 162; "Approaches to Private Participation in Water Services: A Toolkit," p. 7.

72 "Approaches to Private Participation in Water Services: A Toolkit," p. 7.

73 The difference between a lease contract and an affermage contract is that under a lease, the operator is allowed to keep the revenues of its operation, but pays a predetermined lease fee to the contracting authority, while under affermage, the operator and the contracting authority share in the revenue, but the operator pays an affermage fee to the authority. The affermage fee will vary depending on demand for the service and customer tariffs. Ibid., p. 10. Ibid.
} 


\subsubsection{Concession contracts}

Under concession contracts for water utilities, the State grants a company the sole rights of providing water services under conditions of significant market power. ${ }^{75}$ The concession does not necessarily require a private company, ${ }^{76}$ although in the water sector this has usually been the case. Concession contracts are designed to last for 20-30 years and offer a way to create competition for a market, when competition in a market is not possible, as is the case in water and sanitation utilities. ${ }^{77}$ For this reason, concessions are awarded to the company that offers to operate the water utility and meet investment targets set out in the contract for the lowest tariff. ${ }^{78}$ The winning concessionaire finances, constructs and operates the water utilities, but the ownership of the utility remains in hands of the State and the responsibility for the operation reverts to the State when the contract ends. ${ }^{79}$ Since investments in water infrastructure are very expensive and involve a lot of sunk costs, the long term contracts are necessary to allow the winning company to recuperate the invested capital. The private company involved in a concession, therefore runs a lot of financial risks. Examples of water concession contracts are the already mentioned and failed Cochabamba concession, the much disputed Manila concession, ${ }^{80}$ the still ongoing water concession in Guayaquil, Ecuador, ${ }^{81}$ and the recently terminated Buenos Aires water concession, which will be discussed in Section 4 infra.

See Kerf et al., "Concessions for Infrastructure: A Guide to their Desing and Award," p. 10.

Ibid.

Ibid; Stottmann, "The Role of the Private Sector in the Provision of Water and Wastewater Services in Urban Areas," p. 163.

Stottmann, "The Role of the Private Sector in the Provision of Water and Wastewater Services in Urban Areas," p. 163-164.

G. Roth, The Private Provision of Public Services in Developing Countries, EDI Series in Economic Development (Washington D.C.: The World Bank/Oxford University Press, 1987) p. 253; Stottmann, "The Role of the Private Sector in the Provision of Water and Wastewater Services in Urban Areas," p. 163.

The 1997 Manila water concession divided the city into two sectors (West and East) delegating the operation of the water services to two concessionaires (Maynilad Water Service Inc. a joint venture with Suez-Lyonnaise des Eaux, which operates the Western sector, Manila Water a joint venture with Bechtel and RWE, which operates the Eastern sector). For an overview of the problems and disputes that have arisen out of the operation of in particular the concession granted to Maynilad see Rosemann, "Das Menschenrecht auf Wasser unter den Bedingungen der Handelsliberalisierung und Privatisierung: eine Untersuchung der Privatisierung der Wasserversorgung und Abwasserentsorgung in Manila."

Díaz, "La participación del sector privado en los servicios de agua y saneamiento en Guayaquil, Ecuador." 


\subsubsection{Build-Operate-Transfer contracts}

Another way of privatizing water utilities, and somewhat related to the concession approach, is through the use of build-operate-transfer contracts (BOTs), whereby a tender is held for building, and operating a water utility. The company that wins the tender builds the water facility from scratch and operates it for a set period of time. ${ }^{82}$ Performance objectives are agreed in order to allow the company to pay off its investment and make a profit. Following this period, the facility is transferred fully to the State. Other variants of this type of privatization are the build-ownoperate (BOO), build-own-operate-train (BOOT), build-own-train-transfer (BOTT), and rehabilitate-operate-transfer (ROT) ${ }^{83}$

\subsection{6. (Full) divestiture}

Divestiture is the most extreme of the privatization options, and as such has been used in only few countries in the water utilities sector. Divestiture is similar to a concession in the sense that the private operator taking over the utility has full responsibility for the operation, maintenance, and investments. ${ }^{84}$ However, unlike the concession contract, a divestiture entails a full transfer of assets and ownership of the water utility from the State to a private actor. The most far-reaching water privatization endeavor took place in the UK in the late 1980s. Privatization of water utilities in the UK started under the government of Margaret Thatcher, but was fully consolidated under the New Labor government of Tony Blair.

\subsection{Historical overview and reasons behind the privatization of water utilities}

Having clarified what can be understood under the privatization of water utilities, and having discussed its nature and that of the utilities as well as the methods available for their privatization, it is now time to place it in a historical context. The distribution of water by private actors has a long history. Water vending, that is the sale of water by carriers, has been a commercial activity carried out by private individuals since ancient times. ${ }^{85}$ Selling non-piped water through small private water vendors is still a common type of business in developing countries. The provision of piped water through water utilities is more recent. However, public

82 "Competition and Regulation in the Water Sector," DAFFE/COMP(2004)20, OECD, (2004), p. 37. See also Budds and McGranahan, "Are the Debates on Water Privatization Missing the Point? Experiences from Asia, Africa and Latin America," p. 90.

83 Budds and McGranahan, "Are the Debates on Water Privatization Missing the Point? Experiences from Asia, Africa and Latin America," p. 90, and Kerf et al., "Concessions for Infrastructure: A Guide to their Desing and Award," p. 17.

84 "Approaches to Private Participation in Water Services: A Toolkit," p.10.

85 Roth, The Private Provision of Public Services in Developing Countries, p. 244. 
utilities and municipal services have not always been provided by or have been in the hands of a public authority or the State. ${ }^{86} \mathrm{Up}$ until the end of the $19^{\text {th }}$ Century, private operators or companies usually provided these services. Partly due to the convictions by States that these services were of vital and strategic importance for the development of a country, a wave of nationalizations started at the end of the $19^{\text {th }}$ Century, and ensured the creation of State monopolies entrusted with the provision of these services. Nationalizations were intensified following increasing regulation, the economic depression of the $1930 \mathrm{~s}$, and World War II. ${ }^{87}$ In the latter part of the $20^{\text {th }}$ century, the pendulum swung again in favor of private involvement in the water sector, as evidenced by the push towards privatization of water utilities in developed and developing countries, often at the behest of international financial institutions. Recent trends, however, show that in various countries, the privatization of water utilities is being reversed as a result of popular opposition and disappointment at the lack of perceived improvements in the provision of water by the private sector.

\subsubsection{Privatization of water utilities in 'developed' countries}

The private provision of piped water can be traced back to the $18^{\text {th }}$ century. New inventions and new developments in the network industries and utilities fostered the establishment of private companies to exploit them. ${ }^{88}$ In France, the brothers Perrier were granted a 15 -year concession in 1782 to deliver water in Paris on a commercial basis through one of the first modern water systems. ${ }^{89}$ Other French municipalities transferred the responsibility of water provision to private operators in the $19^{\text {th }}$ Century. ${ }^{90}$ Under the concession system, French water companies started to flourish. In fact, two of the largest private water (multinational) companies currently operating, Veolia Water (formerly known as Compagnie Générale des Eaux and Vivendi) and Suez (formerly known as Lyonnaise des Eaux), are the descendants of French water companies founded in 1853 and 1880 respectively. ${ }^{91}$ French companies also spread their activities abroad and acquired water supply concessions all over the world, in particular in Spain and in North and West

86 M. Klein and N. Roger, "Back to the Future: The Potential in Infrastructure Privatisation," in Finance and the International Economy, Vol. 8, ed. R. O'Brien, New York: Oxford University Press (1994), p. 46.

87 Ibid.

88 Foster, Privatization, Public Ownership and the Regulation of Natural Monopoly, p. 17.

89 Guislain, The Privatization Challenge: A Strategic, Legal and Institutional Analysis of International Experience, p. 204; Kerf et al., "Concessions for Infrastructure: A Guide to their Desing and Award," p. 11. See also Roth, The Private Provision of Public Services in Developing Countries, p. 251-252.

90 Gleick et al., "The New Economy of Water: The Risks and Benefits of Globalization and Privatization of Fresh Water," p. 24.

91 Guislain, The Privatization Challenge: A Strategic, Legal and Institutional Analysis of International Experience, p. 204. 
Africa. ${ }^{92}$ In the 1820 s six private water companies were servicing London, ${ }^{93}$ while other European cities such as Berlin and Barcelona were also serviced through private concessions. ${ }^{94}$ In the $1800 \mathrm{~s}$, the population explosion in various cities on the West coast of the United States moved local authorities to turn to private enterprises to provide water services. The exhaustion of water supplies that came from wells or local springs in San Francisco, for example, led to a number of water related epidemics. Being short of capital, the city accepted private initiatives to build water works as the best way to deal with these problems. ${ }^{95}$

The ownership and management of network utilities such as water, electricity and telecommunications companies in most of Europe and North America gradually passed from private to public hands during the latter part of the $19^{\text {th }}$ century and the first half of the $20^{\text {th }}$ century. ${ }^{96}$ In the United States, for example, increases in population resulted in the early dominance of private water utilities in major cities gradually giving way to more government intervention. Jacobson and Tarr observe "[...] the proportion of government owned waterworks in the United States increased from about 6 percent in 1800 to about 53 percent in 1896." 97 Nationalization of utilities and other strategic industries was regarded as necessary to guarantee their functioning for the benefit of all. According to Jacobson, many municipalities were prompted to take over the water utilities in the latter 1800 s for various public interest reasons. ${ }^{98}$ These included the lack of investment by private companies running the water utilities to expand the system in the bigger cities, and cherry picking: the laying down of water pipes in sectors which promised larger returns while avoiding poorer or remote districts. Moreover, private companies neglected to increase the installation of fire hydrants (necessary in cities in which most of the houses were built with wood), while the low quality of the service in a number of cities in the United States also pushed municipalities to take over the water services. In many cases government takeover of privately owned utilities was required in the aftermath of financial difficulties faced by the private companies controlling the utilities sector. ${ }^{99}$ Inefficiency, increasing costs and corruption were also cited as reasons

92 Roth, The Private Provision of Public Services in Developing Countries, p. 252.

93 See Kerf et al., "Concessions for Infrastructure: A Guide to their Desing and Award," p. 11.

94 Guislain, The Privatization Challenge: A Strategic, Legal and Institutional Analysis of International Experience, p. 204.

95 Jacobson, "Same Game, Different Players: Problems in Urban Public Utility Regulation, 18501987," p. 16.

96 Jacobson, Ties that Bind: Economic and Political Dilemmas of Urban Utility Networks, 18001900, p. 69-73.

97 Jacobson and Tarr, “Ownership and Financing Infrastructure: Historical Perspectives," p. 11.

98 Jacobson, Ties that Bind: Economic and Political Dilemmas of Urban Utility Networks, 18001900 , p. 70.

99 Guislain, The Privatization Challenge: A Strategic, Legal and Institutional Analysis of International Experience, p. 204. 
for the transfer in ownership and provision from the private to the public sector. ${ }^{100}$ By the end of the 1940s, most of the utilities in the United Kingdom had been nationalized. In spite of this nationalization wave, the ownership and management of certain utilities such as water and the distribution of their services remained in private hands in countries such as the United States and France. ${ }^{101}$

In a number of countries where public utilities were nationalized, public control and/or ownership of utilities and the distribution of their services remained State tasks until the (late) 1980s when, under the tutelage of conservative governments, and under the auspices of international financial institutions, governments in developed nations started to consider their privatization. ${ }^{102}$ For example, the privatization program in the United Kingdom introduced by the government of Margaret Thatcher, encompassed all the major public utilities including telecommunications, gas, electricity, the railways, and water. The public water utilities were sold in their entirety in $1989^{103}$ in what is arguably the farthestreaching privatization program of all. However, recognizing the natural monopoly aspects of the water industry, the government introduced a regulatory agency at the time of the privatization. ${ }^{104}$

\subsubsection{Privatization of water utilities in developing countries}

A similar trend to the one described in the previous paragraphs can be discerned in developing countries. Following their independence, various developing countries chose to rely on the private sector to manage their utilities and essential services. In addition, other former colonies inherited network utilities that were already managed by private companies, some of which were of foreign origin. During the late $19^{\text {th }}$ and early $20^{\text {th }}$ centuries, the public utilities in a number of Latin America were in the hands of private companies. ${ }^{105}$ In Africa, water utilities in a number of

100 P.S. Juuti and T.S. Katko, "Historical Development of Water and Sanitation Services," in Water, Time, and European Cities - History Matters for the Futures, available at <www.watertime.net/ Docs/WP3/WTEC.pdf $>$ (last visited 30 December 2007), ed. P.S. Juuti and T.S. KatkoWaterTime Project (2005), p. 39.

Jacobson, "Same Game, Different Players: Problems in Urban Public Utility Regulation, 18501987," p. 13-31; Guislain, The Privatization Challenge: A Strategic, Legal and Institutional Analysis of International Experience, p. 205.

See Chapter II.

103 See the 1989 Water Act (c. 15), and the 1991 Water Industry Act (c. 56), which consolidated the 1989 Water Act. See also Neto, "Water Privatization and Regulation in England and France: A Tale of Two Models," p. 108.

104 Ibid. Under Article 5 of the 1989 Water Act (c. 15), the Director General of Water Services was appointed as the independent economic regulator for the water sector. It was supported by a staff, which was collectively known as the Office of Water Services (OFWAT). In 2006, the Director General was replaced by the Water Services Regulation Authority with the adoption of the Water Act 2003 (c.37), which further amended the 1991 Water Industry Act.

Baer and Birch, "Privatization and the Changing Role of the State in Latin America," p. 8. 
former (French) colonies were also in the hands of private companies. The water distribution system in Morocco, which started around 1914, was developed on a private basis. ${ }^{106}$ The concessions with private French operators were, however, not renewed after Morocco's independence in 1956, with the exception of a portion of Casablanca's water supply system, which kept a 50 -year old concession that started in 1949.107 Guinea also had a private water distribution system, which was nationalized in 1989. On the other hand, the water distribution sector in Côte d'Ivoire has always been in the hands of a private operator. ${ }^{108}$

However, the initial reliance on (foreign) private enterprise to provide certain products and services following the independence of various Latin American countries gave way to increasing State intervention and nationalization in the wake of World War II. ${ }^{109}$ The desire to boost their economic independence vis-à-vis developed countries moved developing countries to adopt policies geared towards import substitution and stimulating industrial development through nationalization and direct government intervention in the economy. ${ }^{110}$ In addition, private investment in the various utilities sectors decreased due to a number of reasons. Government regulation in the utilities sector favoring mostly the productive sectors and lower income segments of the population resulted in artificially low prices for the services, which in turn resulted in lower revenue for the companies in the utilities sector. ${ }^{111}$ Further, the rapid growth of urban population following World War II required vast infrastructure investments. The bleak outlook for the future of private companies in the sector due to the expected government take over of these industries in pursuance of the abovementioned industrial policies made private investments in the sector unattractive. ${ }^{112}$ This situation strengthened State intervention in the utilities sector: the lack of private investment prompted States to take matters into their own hands. In other words, by pursuing industrial development policies aimed at self-sufficiency, and by making investment in the utilities sector unattractive to private investors due to the low returns and the prospects of eventual appropriation by the State of private property, the nationalization of private companies in the sector was facilitated. The provision of essential services thus passed unto the hands of the State and remained in public

\footnotetext{
106 Guislain, The Privatization Challenge: A Strategic, Legal and Institutional Analysis of International Experience, p. 205.

109 Chua, "The Privatization - Nationalization Cycle: The Link Between Markets and Ethnicity in Developing Countries." See also Baker, "Privatization in the Developing World: Panacea for the Economic Ills of the Third World or Prescription Overused?," p. 245-248.

Baer and Birch, "Privatization and the Changing Role of the State in Latin America," p. 4-6. See also Baker, "Privatization in the Developing World: Panacea for the Economic Ills of the Third World or Prescription Overused?," p. 245-248.

111 Baer and Birch, "Privatization and the Changing Role of the State in Latin America," p. 8.

112 Ibid., p. 8-9.
} 
hands until the early 1990s, when step by step, various developing countries started to privatize their (water) utilities.

There were several reasons for the re-privatization of water utilities in developing countries. In the first place, the failure of public water systems in those countries to provide universal coverage of water as well as proper sewerage for waste water, and to reduce water losses, moved various governments to seek private sector involvement in the water utilities as a way of improving the service. ${ }^{113}$ Poor service delivery by public utilities particularly affected the poorest sectors of the population, which were usually forced to rely on water delivery by small-scale private providers often at high prices. ${ }^{114}$ Privatization was therefore seen as a way of improving service delivery and initially did not encounter resistance from consumers, even those from the lowest incomes who were already used to dealing with unofficial private water providers. ${ }^{115}$

The trend towards privatizing water utilities in developing countries was further influenced by lending policies of the IMF, World Bank, and their regional counterparts such as the Inter-American Development Bank (IABD) in the late 1980s and 1990s. Acknowledging the importance of the water sector as an essential element for development and the role of the private sector therein, these international financial institutions started to change their lending policies. In particular, they encouraged reforms of the sector as a requirement for financial aid in the context of poverty reduction strategy programs (PSRPs), ${ }^{116}$ and so called 'adjustment lending.' 117 Full cost recovery, ${ }^{118}$ private sector participation, ${ }^{119}$ and privatization ${ }^{120}$ were among the suggested reforms. ${ }^{121}$

113 Gleick et al., "The New Economy of Water: The Risks and Benefits of Globalization and Privatization of Fresh Water," p. 24; Kessides, "Reforming Infrastructure: Privatization, Regulation, and Competition," p. 220.

114 Estache, "PPI Partnerships versus PPI Divorces in LDCs (Or Are We Switching From PPPI to PPDI?)," p. 3.

115 Ibid. Estache observes that the main opposition to privatization came from public sector workers who feared losing their jobs. See "Privatization in Latin America in the Early 1990s", Department of Economic and Social Affairs, Division for Public Economics and Public Administration, UN Doc. ST/ESA/PAD/SER.E/17 (1999), observing that in $199575 \%$ of the population in Latin America supported privatization policies back then.

116 Hall and Motte, "Dogmatic Development: Privatisation and Conditionalities in Six Countries," p. 4.

117 "Private Sector Development Strategy - Directions for the World Bank Group," p. 24-25 and 27.

118 Full cost recovery entails charging the end users of the services provided fees reflecting the actual costs of the service to cover the costs of the investments in infrastructure.

119 See in general "Private Sector Development Strategy - Directions for the World Bank Group," p. 21 and 25.

120 "World Bank Assistance to Privatization in Developing Countries," The World Bank, Operations Evaluation Department, Washington D.C., Report 13273 (1994). See also "Private Sector Development Strategy - Directions for the World Bank Group," p. 25 and 26.

121 Hall and Motte, "Dogmatic Development: Privatisation and Conditionalities in Six Countries," p. 4. 
For example, a 1989 World Bank discussion paper on the financing of urban services in Latin American countries described the explosive growth of population in the urban areas of the region and the fiscal strains such growth entails for their governments. This led to a situation in which governments did not have sufficient financial resources to expand and improve basic services. ${ }^{122}$ It was observed that end users were also less willing to be taxed or to pay for inefficient and low quality services. The discussion paper suggested that one of the solutions to improve these services (including water provision) would be to introduce the notion of cost recovery. Governments must ensure that sufficient resources are raised to expand basic services such as water utilities by adjusting "[...] their pricing so as to approach real costs and adopt standards of a level proportionate to the end user's ability and willingness to pay." 123 The discussion paper further suggested that the privatization of certain urban services could be one of the potential answers to relieve the fiscal burden on those services and promote cost recovery. ${ }^{124}$ In addition, it was argued that credit destined to improve long-lived capital assets related to urban services such as water mains "[...] should be made accessible to all jurisdictions meeting set criteria of eligibility, giving preference to revenuegenerating investments and setting some conditions for direct and indirect costrecovery." 125 In other words, credit loans should be made conditional on the introduction of cost-recovery promoting measures such as the privatization of water utilities. $^{126}$

As discussed in Chapter II, the World Bank's view that willingness to embrace privatization should be one of the potential pre-conditions for becoming eligible to receive funding in various sectors was embodied in Operational Directive 8.60 on Adjustment Lending Policy (OD 8.60). ${ }^{127}$ Although OD 8.60 noted that adjustment lending was not an appropriate instrument for supporting reforms in the infrastructure sectors, it observed that privatization was the best remedy to reform public enterprises. Thus, under official World Bank policy, various States received adjustment credit from the Bank's affiliate institutions such as the International

122 Guarda, "Financing Urban Services in Latin America: Spatial Distribution Issues,” p. 15.

123 Ibid., p. 69.

124 Ibid., p. 78

125 Ibid., p. 85-87.

126 The discussion paper did not directly advocate privatization as such, but saw it as a potential tool for making cost recovery for urban services possible. The paper departs from the assumption that even poor people are willing to pay something for a service they value, such as the provision of water. Ibid., p. 86. However, it also points out that "[i]n practice it does not matter much whether or not particular services are charged directly to individual users or indirectly to the urban community as a whole, as long as sufficient consensus can be achieved, within the community itself, to bear the corresponding costs through some type of collective fiscal effort." ibid., p. 91.

127 World Bank, Operational Directive 8.60: Adjustment Lending Policy (21 December 1992) [Archived]. 
Finance Corporation ${ }^{128}$ and the Inter-American Development Bank, to help them finance water utilities reform projects, oftentimes with the condition to privatize them. Examples include the privatization of the former state run water utility in Buenos Aires, Argentina in 1993 (see further Section 4 infra); the privatization effort in the metropolitan area of Manila, the Philippines in 1994:129 and the privatization of the municipal water utility in Guayaquil, Ecuador in 2001. ${ }^{130}$

Further incentives to increase the role of the private sector in the water utilities of developing countries have come from international initiatives and inter-institutional bodies working in the water sector. Thus bodies such as the World Water Council, ${ }^{131}$ the global Water Partnership, and the conclusions of the various meetings of the Council's brainchild, the World Water Forum, have given ample attention to the role of the private sector in the water utilities. ${ }^{132} \mathrm{In}$ an attempt to find the appropriate financial resources for the achievement of the two Millennium Development Goals related to water access and sanitation, the Global Water Partnership, the World Water Council, and the Third World Water Forum held in Kyoto in 2003 sponsored the creation of the World Panel on Financing Water Infrastructure. The Panel comprises a number of financial experts that come from the International Monetary Fund, the World Bank, other regional financial and development institutions, a number of private water companies and water NGOs and some academics.

128 For a past overview of the International Finance Corporation's role in privatization projects see Donaldson and Wagle, "Privatization: Principles and Practice," p. 14-15.

129 M. Dumol, The Manila water concession: A Key Government Official's Diary of the World's Largest Water Privatization, Directions in Development (Washington D.C.: The International Bank for Reconstruction and Development/The World Bank, 2000) p. 27-30; Rosemann, "Das Menschenrecht auf Wasser unter den Bedingungen der Handelsliberalisierung und Privatisierung: eine Untersuchung der Privatisierung der Wasserversorgung und Abwasserentsorgung in Manila," p. 66-67.

130 Díaz, "La participación del sector privado en los servicios de agua y saneamiento en Guayaquil, Ecuador."

131 The World Water Council, an international think tank composed of various governmental and non-governmental actors actively involved in the water sector was established in 1996 following recommendations of the 1992 Dublin Declaration and the 1994 Ministerial and Officials Conference on Drinking Water and Environmental Sanitation held in Noordwijk, the Netherlands. See the preamble to the World Water Council Constitution, available at $<w w w$. worldwatercouncil.org/fileadmin/wwc/About_us/official_documents/Constitution_ approved4thGA.pdf $>$ (last visited on 30 November 2007).

132 As a means of discussing global water related problems and debating and trying to find solutions to these problems, the World Water Council established the World Water Forum, an international water related event held every three years. The first World Water Forum was held in 1997 in Marrakech, followed by a meeting in The Hague in 2000, Kyoto in 2003, and Mexico in 2006. 
In its first report the Panel, chaired by former IMF president Michael Camdessus, acknowledged that the right to access to water is a human right and a need. ${ }^{133}$ In doing so, it noted General Comment No. 15 on the right to water which was drafted by the UN Committee on Economic, Social and Cultural Rights (See further Section 3.1 infra), thus validating in the eyes of this author the latter's approach. The Camdessus report, as it is known, also observed that access to water is also essential for the achievement of various Millennium Development Goals such as the reduction of poverty as well as being beneficial for public health in that the lack of access to clean water and sanitation contributes to various infectious diseases. ${ }^{134}$ At the same time, the Camdessus report recognized the fact that water is an economic good as stated in the 1992 Dublin Declaration, and that although water has to be affordable to everybody, it should be priced to reflect its economic value to prevent wasteful use and misallocation. ${ }^{135}$ In this regard the report considers that there appears to be willingness to accept pricing and other market mechanisms to manage water.

Meeting the targets required by the Millennium Development Goals will not come cheap and large investments that cost billions of dollars will have to be made. Using estimates provided by the Global Water Partnership, the Camdessus report states that in order to provide full water and sewerage connections and primary waste water treatment to urban populations, the required annual cost to fulfill the Millenium Development Goals would be \$17 billion US Dollars for water and \$32 billion US Dollars for sanitation and sewerage. ${ }^{136}$ Taking these figures into account, the report then went to observe that public funding of the water sector is at best stationary and that even private investment in the water sector has declined since 1996. ${ }^{137}$ It then gave its own account of privatization efforts in the water utilities sector in the 15 years prior to the report, observing that most private operations had achieved real progress in efficiency and some even provided affordable services to poor suburbs. ${ }^{138}$ However, it noted that some operations had failed mainly due to insufficient preparation, and others had been affected by financial crises. ${ }^{139}$ In spite

133 Winpenny, "Financing Water for All - Report of the World Panel on Financing Water Infrastructure," p. vii.

134 Ibid., p. viii.

135 Ibid., p. 1.

136 Ibid., p. 3.

137 Ibid., p. 6 and 7.

138 Ibid., p. 7.

139 Since revenues from water services are often based on local currencies, and private utilities companies have to finance investments with foreign loans, financial problems in host countries leading to devaluations of the local currency makes the repayment of those loans more expensive resulting in liquidity problems with the companies and increasing the costs of operation. This in turn leads to renegotiation of tariffs and unpopular tariff increases in an attempt to cover the increasing costs. Ibid., p. 11 and 33. In the case of the Buenos Aires water concession, this led to a quarrel between the private company operating the concession and the government following the 2002 Argentine financial crisis and ultimately leading to a cancellation of the concession contract. See further Section 4 infra. 
of a perceived decrease of private participation in the water sector because of these problems, the Camdessus report nevertheless advices that "[...] private participation should be included as an option, to be decided on specific grounds of efficiency, cost and effectiveness." 140 To encourage private sector participation, ameliorate the costs associated with political instability and the actual tendering for concessions, and to reduce the problems caused by the risks of financial problems and currency devaluations in developing countries seeking water privatization, the report suggests that international financial institutions provide financial assistance and create such tools as a 'devaluation liquidity backstopping facility'. ${ }^{41}$

\subsection{Recent developments in the privatization of water utilities}

As a result of the growing dissatisfaction with the outcomes of various privatization efforts, and a decrease of interest in the private sector for infrastructure investments in particular in the water utilities sector as described in the Camdessus report, ${ }^{142}$ the World Bank has revised its privatization as conditionality for lending policy. ${ }^{143}$ As of 2004, Operation Policy 8.60 and Bank Policy 8.60 on Development Policy Lending replaced OD 8.60, and the Bank no longer prescribes privatization as a condition of credit lending. Moreover, the new operational policies require that adjustment policies such as privatization be open to consultation and participation with key stakeholders such as civil society organizations in the countries where they will be implemented. ${ }^{144}$ The World Bank now also requires that impact assessment of adjustment policies on the poor and vulnerable sectors of society be made and recommendations adopted to mitigate any negative effects on these groups before or during the implementation of those policies.

140 Ibid., p. 33. The Panel also proposed that private participation "[...] should be facilitated by the better allocation and mitigation of risk. In view of the potentially vital contribution of private involvement, the panel proposes measures to address four specific problems that currently discourage private participation in water." Ibid.

141 Ibid., p. 29.

142 See for example, World Bank "Infrastructure Action Plan", Informal Board Meeting, 8 July 2003, p.3, available at <http://siteresources.worldbank.org/INTTRM/Resources/Infrastructure ActionPlan.pdf $>$ (last visited 10 December 2007), and World Bank "Infrastructure development: The roles of the public and private sectors - World Bank Group's approach to supporting investments in infrastructure", November 2005, p. 3-4, available at <http://siteresources. worldbank.org/INTINFNETWORK/Resources/Rolesupdt.pdf $>$ (last visited 10 December 2007). See also Hall, Lobina, and Motte, "Public Resistance to Privatisation in Water and Energy," p. 287.

143 See also Chapter II.

144 See World Bank, Operational Policy OP 8.60: Adjustment Lending Policy (11 August 2004), para. 6. See also “Approaches to Private Participation in Water Services: A Toolkit,” p. 33-36, in which the World Bank advises for consultation with relevant stakeholders such as consumers (including the poor), NGOs, workers, opinion leaders, and politicians. 
In spite of the growth of privatization in the water utilities sector in the last 20 years and its promotion by international financial institutions, privatized water utilities still compose a relatively small percentage of the sector. ${ }^{145}$ Furthermore, according to recent studies there has been a slight decline in the number of World Bank sponsored projects tied to private participation in the water sector over the last six years. ${ }^{146}$ This does not mean that the World Bank and other international financial institutions have abandoned privatization as a tool for financing development projects in the utilities sector. On the contrary, privatization and the involvement of the private sector in water utilities is still being recommended, albeit no longer as the most effective or sole way of improving the water sector. ${ }^{147}$

This trend towards moving away from the privatization of water utilities is also part of a trend to move away from privatization policies altogether. ${ }^{148}$ In the water sector this has sometimes been the result of the heavy criticism from civil society organizations, ${ }^{149}$ and the stiff opposition towards the policy in various countries, some of which have adopted legal measures to prevent their privatization. In 2003, for example, the Netherlands parliament adopted an amendment to the existing law on the water networks ('Waterleidingwet') preventing private companies from operating the water utilities. Under the amended law, the provision of drinking water has been placed under the responsibility of the State (Article 1a Waterleidingwet). ${ }^{150}$ Articles $3 \mathrm{i}$ and $3 \mathrm{j}$ of the Waterleidingwet prohibit the production and distribution of drinking water by entities other than qualified legal

145 As observed above, the provision of water by public actors still accounts for $90 \%$ of the total. See "Human Development Report 2006: Beyond Scarcity: Power, poverty and the global water crisis," p. 10.

See recent World Bank database on Private Participation in Infrastructure $<$ http://ppi.worldbank. org/explore/ppi_exploreSector.aspx?sectorID=4> (last visited on 1 December 2007).

147 In the 2006 World Bank Toolkit on approaches to private participation in water services, the World Bank acknowledges that under the right circumstances reforms in the water utilities without private participation can work. See "Approaches to Private Participation in Water Services: A Toolkit," p. xix. At the same time, the 2006 Toolkit still argues that engaging private firms and giving them defined responsibilities for the provision of water services widens the reform options at the disposal of governments.

148 See in general Estache, "PPI Partnerships versus PPI Divorces in LDCs (Or Are We Switching From PPPI to PPDI?)."; Kikeri and Fatima Kolo, "Privatization: Recent Trends and Developments."

149 See for example "Water Justice for All: Global and local resistance to the control and commodification of water," Friends of the Earth International, Issue 102, January 2003; G. Aegisson, "The Great Water Robbery," One World Action, London, (2002); Hall, Lobina, and Motte, "Public Resistance to Privatisation in Water and Energy," p. 288.

150 See Eerste Kamer der Staten-Generaal (2003), 28 339: Wijziging van de Waterleidingwet (eigendom waterleidingbedrijven), 9 December 2003, which was adopted by the Dutch Parliament (Tweede Kamer,) and not substantially altered by the Dutch Senate (Eerste Kamer). The law can be found at: <www.eerstekamer.nl/9324000/1/j9vvgh5ihkk7kof/vgm1 kje0 bqtk/f=y. pdf $>$. See also Hall, Lobina, and Motte, "Making Water Privatization Illegal: New Laws in the Netherlands and Uruguay," p. 3-4; Hall and Lobina, "Water as a Public Service," p. 10. 
persons ('gekwalificerde rechtspersonen'), which are defined as public law legal persons or publicly owned companies. ${ }^{151}$ Similarly, following a national referendum on water in October 2004, Uruguay amended its constitution introducing an article that guarantees the access to piped water and sanitation as a fundamental right. ${ }^{152}$ The amendment also prohibits the provision of water supply for human consumption by other entities than state entities. ${ }^{153}$ Although other countries have not yet adopted similar legal instruments limiting the provision of water services to governmental/ public bodies, various national constitutions determine that the provision of utility services is a task for which the State is responsible, even if it is allowed to delegate it. 154 This may provide further incentive for limiting the privatization of water utilities in the future.

Another development in the last seven years is the 're-nationalization' of privatized water utilities as a result of popular opposition, disenchantment and disappointment at their perceived lackluster performance, and sometimes as a consequence of financial crises as indicated in the Camdessus report. The best known example is the cancellation of the concession contract with the company Aguas del Tunari, a subsidiary of a consortium led by International Water Unlimited, ${ }^{155}$ in the city of Cochabamba, Bolivia, following what is now known as the 'water war'. Aguas del Tunari was awarded a forty-year concession to provide water services for Cochabamba. In November 1999 Aguas del Tunari took over the water service from the local municipal company, SEMAPA, which had failed to perform in a

151 Article 1 of the Waterleidingwet provides that the State should own the shares of these companies, and that these companies should not allow other entities to control or share control their management with the exception of other public law bodies (Article 1 §2 (f)(2)).

See Article 47 of the Constitution of Uruguay. Hall, Lobina, and Motte, "Making Water Privatization Illegal: New Laws in the Netherlands and Uruguay," p. 2; Hall and Lobina, "Water as a Public Service," p. 10.

153 Amended Article $47 \S 3$ of the Constitution of Uruguay reads: "El servicio público de saneamiento y el servicio público de abastecimiento de agua para el consumo humano serán prestados exclusiva y directamente por personas jurídicas estatales.' (The public service of sanitation and the provision of water for human consumption will be exclusively and directly provided by public legal persons) See also Hall, Lobina, and Motte, "Making Water Privatization Illegal: New Laws in the Netherlands and Uruguay," p. 2; Hall and Lobina, "Water as a Public Service," p. 10. In 2008 a Constitutional Assembly adopted a new Constitution was adopted in Ecuador. It, similarly prohibitsprohibiting the privatization of water (Articles 282 and 318 of the Constitution of Ecuador) and clarifiesestablishing that the State is responsible for the provision of water services (Article 314). It also establishes that potable water and sewerage services are to be provided solely by public or communal legal persons (Article 318). The text of the Constitution of Ecuador is available at: <www.asambleanacional.gov.ec/documentos/constitucion_de bolsillo.pdf $>$.

154 See for example Article 175 of the Constitution of the Federal Republic of Brazil, which determines that the State has the responsibility to provide utility services either directly or by grant or permit.

155 International Water Unlimited is a holding which was incorporated in the Netherlands, but actually owned by American water multinational Bechtel. 
satisfactory way in its thirty years of operation. ${ }^{156}$ It was expected that Aguas del Tunari would improve the service. The award process was controversial (Aguas del Tunari was the only company bidding for the project and there were accusations of corruption and political meddling), and in spite of various political and legal objections, the contract was awarded anyway. ${ }^{157}$ At the same time, and without much consultation with relevant parties and the population that was to be affected by the privatization, the government adopted a law enabling the privatization of water in Bolivia. ${ }^{158}$ Following an initial tariff increase in the provision of water and sewerage, ${ }^{159}$ various civil society groups seriously affected by the price hike in the water service organized themselves under the name Coordinadora del Agua y la Vida, and held major protests against the privatization of the water service. Although attempts were made by the regulator (Superintendencia Sectorial de Saneamiento Básico) to roll-back the tariff increase, the government initially refused to budge contending that the increase was necessary to finance the Misicuni project. ${ }^{160}$ This in turn led to increased protests and strikes, which the government tried to quell through the use of troops and additional police, resulting in a number of deaths. The government then decided to reverse the tariff increase, although it was announced that the tariff would increase again after six months. During all this time, there was barely any consultation carried out with stakeholders and the Coordinadora.

Eventually, growing unrest and violence in Cochabamba and the rest of the country, together with mounting pressure from various social groups keen to end the water privatization forced the government to cave in. In April 2000 the contract with

156 Nickson and Vargas, "The Limitations of Water Regulation: The Failure of the Cochabamba Concesion in Bolivia," p. 133-134. SEMAPA had a poor performance record, only managed to cover 57 per cent of the population and experienced serious problems of water availability.

See ibid., p. 135-136; Lobina and Hall, "Problems with Private Water Concessions: A Review of Experience". Part of the controversy surrounding the privatization was due to the agreement that Aguas del Tunari would also manage a complex, high profile water infrastructure project called Misicuni Project.

158 McFarland Sanchez-Moreno and Higgins, "No Recourse: Transnational Corporations and the Protection of Economic, Social and Cultural Rights in Bolivia," p. 1760.

159 The tariff increase had been pre-arranged during the negotiation of the concession contract and amounted to $35 \%$ of the original tariff. The increase was required to cover the necessary investments needed to expand the network as well as paying back an accumulated debt of SEMAPA which Aguas del Tunari had to take over. Nickson and Vargas, "The Limitations of Water Regulation: The Failure of the Cochabamba Concesion in Bolivia," p. 140. Although the tariff increase averaged $35 \%$, many consumers were faced with tariff increases of up to $200 \%$ as a result of a re-categorization of consumers into different groups. In addition, water bills also appear to have increased due to higher consumption of water as a result of improved availability. Ibid. See also McFarland Sanchez-Moreno and Higgins, "No Recourse: Transnational Corporations and the Protection of Economic, Social and Cultural Rights in Bolivia," p. 17631764.

160 McFarland Sanchez-Moreno and Higgins, "No Recourse: Transnational Corporations and the Protection of Economic, Social and Cultural Rights in Bolivia," p. 1769. 
Aguas del Tunari was cancelled, and SEMAPA resumed the operation of the water and sewerage service. ${ }^{161}$ In 2002 Aguas del Tunari filed a request for arbitration with the ICSID on the grounds that the actions leading to the termination of the contract amounted to expropriation, which could be attributed to Bolivia and which were in breach of Bolivia's obligations under the Netherlands - Bolivia BIT. ${ }^{162}$ However, on 19 January 2006, the international shareholders of Aguas del Tunari and Bolivia settled the dispute over the concession outside the ICSID agreeing to declare that "[...] the concession was terminated only because of the civil unrest and the state of emergency in Cochabamba and not because of any act done or not done by the international shareholders of Aguas del Tunari." ${ }^{63}$ The claim was withdrawn from the ICSID and it was agreed that no compensation was going to be paid by the government of Bolivia. According to one NGO that actively campaigned against Bechtel and the dispute this had been "[...] the first time that a major corporation has ever dropped a major international trade case such as this one as a direct result of global public pressure, and it sets an important precedent for the politics of future trade cases like it." 164

In Argentina the thirty-year water concession serving the province of Tucumán, awarded in 1995 to a consortium led by French water multinational Vivendi (formerly known as Compagnie Generale des Eaux) was terminated by the local government in 1998. The alleged reasons for the termination of the contract were complaints of inefficiency, high water bills and bad quality of service by Aguas de Aconquija, the affiliate company of Vivendi in Tucumán. ${ }^{165}$ The local government encouraged consumers not to pay their water bills and fined Aguas de Aconquija for

161 Ibid., p. 1771.

162 See Aguas del Tunari S.A. v. Republic of Bolivia, Decision on Respondent's Objection to Jurisdiction, ICSID Case No. ARB/02/3, 21 October 2005, ICSID Review-Foreign Investment Law Journal, para. 8.

163 See Press Release by Bechtel "Cochabamba Water Dispute Settled", available at $<$ www.bechtel. com/2006-01-19.html > (last visited on 31 August 2011). According to one NGO the decision to withdraw the case was the result of international public pressure and bad publicity on Bechtel. See "Bolivia, Cochabamba: public pressures forces Bechtel to drop water case," IRC, available at $<$ www.irc.nl/page/27840 $>$ (last visited on 31 August 2011).

164 See "Bechtel v. Bolivia," The Democracy Center, available at $<$ www.democracyctr.org/bolivia/ investigations/water/bechtel-vs-bolivia.htm> (last visited on 31 August 2011). Following this dispute and probably as part of the new governmental program of left-wing president Evo Morales geared towards reversing 'neo-liberal' policies of previous governments, Bolivia denunciated the Convention on the Settlement of Investment Disputes between States and Nationals of Other States (the ICSID Convention) in May 2007. See $<$ http://icsid.worldbank. org $/ \mathrm{ICSID} /$ FrontServlet?requestType $=$ CasesRH\&actionVal=OpenPage \&PageType=Announce mentsFrame\&FromPage $=$ NewsReleases\&pageName $=$ Announcement $3>$ (last visited on 31 August 2011).

165 See Gleick et al., "The New Economy of Water: The Risks and Benefits of Globalization and Privatization of Fresh Water," p. 32. At the time that the concession started, the local government of the province of Tucumán was replaced with a new one. The new local government was apparently opposed to the privatization of the water utilities in the province. 
alleged poor water quality discovered in tests by the local regulator. ${ }^{166}$ This prompted Vivendi to bring a claim for breaching the French-Argentine Bilateral Investment Treaty before the ICSID alleging that the local government had done everything to undermine the concession with acts and omissions which were contrary to to Argentina's obligations under the Argentina - France BIT to provide fair and equitable treatment as well as adopting measures that amounted to expropriation of property without due compensation. ${ }^{167}$ Following various proceedings, some of which attempted to annul some of the decisions in this case, the matter was settled by an Award issued by the an ICSID Tribunal in 2007. ${ }^{168}$ In general, the Tribunal concluded that the actions and omissions of the local Tucumán government amounted to a breach of the fair and equitable treatment of the BIT by improperly and without justification mounting an "[...] illegitimate 'campaign' against the concession, the Concession Agreement, and the 'foreign' concessionaire from the moment it took office, aimed either at reversing the privatisation or forcing the concessionaire to renegotiate (and lower) CAA's tariffs."169

\section{Other recent terminations of water privatizations include:}

- the rescission of the 1997 water concession contract of French company Suez subsidiary, Aguas de Illimani, which operated in the Bolivian cities of La Paz

166 During the ensuing arbitral dispute, it was found that in 1996 the water system in some parts of the concession area was affected by the presence of manganese in the water supply.

167 See Compañia de Aguas del Aconquija S.A. and Vivendi Universal v. Argentine Republic, Award, ICSID Case No. ARB/97/3, 20 August 2007, para. 5.1.2.

168 This dispute has a complicated and protracted history: the claim was brought forward in 1996. The ICSID tribunal initially dismissed the claims by Vivendi with an award issued on 21 November 2000. Although the tribunal concluded that it had jurisdiction over the issue, the claim on the merits was dismissed on the basis that the concession contract obliged both parties to first bring the claim before Argentine administrative courts. However, Vivendi successfully interposed a request to annul the award of 21 November 2000. See Compañia de Aguas del Aconquija S.A. and Vivendi Universal v. Argentine Republic, Decision on Annulment, ICSID Case No. ARB/97/3, 3 July 2002. The ad-hoc committee deciding on the issue of annulment concluded that the original tribunal had manifestly exceeded its powers by upholding its jurisdiction to hear the claimants' claims brought under the BIT, but not deciding on a significant portion of those claims. The proceedings resumed in 2004 with an award rendered in August 2007 by a newly composed tribunal. A second annulment procedure was, however, started in December 2007 upon a request by Argentina. On 10 August 2010, the second ad-hoc committee dealing with the annulment issued a decision denying Argentina's request on the grounds that the second tribunal had not manifestly exceeded its powers or provided insufficient reasoning for the second award. Compañia de Aguas del Aconquija S.A. and Vivendi Universal v. Argentine Republic, Decision on the Argentine Republic's Request for Annulment of the Award rendered on 20 August 2007, ICSID Case No. ARB/97/3 (Annulment Proceeding), 10 August 2010, paras. 262-267. On the issue of annulment in general see C. Schreuer, "ICSID Annulment Revisited," Legal Issues of Economic Integration Vol. 30 (2003), p. 103-122.

169 Compañia de Aguas del Aconquija S.A. and Vivendi Universal v. Argentine Republic, Award, 20 August 2007, para. 7.4.19. 
and El Alto. Following protests against the privatized utility in 2004 and 2005, and on the basis of an in-depth audit of the company's operations, the previous government of Bolivia decided in 2005 to terminate the concession contract, which was actually rescinded in January $2007 .{ }^{170}$

- The termination of the concession contract between Azurix, a U.S.-based water services company, and the Argentine province of Buenos Aires in 2002 following disagreements in the way the concession was being operated. ${ }^{171}$ The contract had been awarded in 1999, but right from the beginning both parties had a falling-out on issues regarding changes to the water tariffs, valuation of the assets, and the actual operation of the concession. Subsequent financial problems that allegedly were partly caused by the province moved the company to file for bankruptcy. This was followed by the termination of the contract on initiative of the province, alleging that Azurix abandoned the service and did not fulfill its contractual obligations. Azurix then filed a claim before the ICSID claiming that the conduct and measures adopted by the province amounted to expropriation and discrimination in breach of the U.S. -Argentina BIT. ${ }^{172}$

- The termination in May of 2005 of a ten-year lease contract between City Water Services Ltd. ${ }^{173}$ and the republic of Tanzania to manage and operate the water and sewerage system of the city of Dar es Salaam. The lease contract was agreed upon by both parties in 2003, and was part of a World Bank financed project that required the transfer of the operation and management of the water utility to a private operator. ${ }^{174}$ Tanzania terminated the lease contract alleging that the promised investments of City Water in the water infrastructure had not been realized and that the company had not fulfilled its terms of the contract. ${ }^{175}$ The parent companies of City Water, Biwater and Gauff, initiated proceedings before

170 See "Latin America Fails to Deliver on Basic Needs," New York Times, 22 February 2005; "Bolivia's Morales celebrates foreign water company's exit, plans more nationalization," International Herald Tribune, 4 January 2007, available at $<$ www.iht.com/articles/ap/2007/01/04/ america/LA_GEN_Bolivia_Nationalization.php> (last visited on 16 December 2007); and "Noviembre del 2004 marcó el inicio de la caída de la empresa," La Razón, at <www.la-razon. com/versiones/20070104_005776/nota_249_374665.htm> (last visited 16 December 2007, no longer available). Interestingly enough, the current government of Evo Morales in Bolivia agreed to compensate Aguas del Illimani for the termination of the contract. See "Evo termina con AISA y anuncia nuevas rupturas," La Razón, at <www.la-razon.com/versiones/20070104_005776/ nota_249_374663.htm> (last visited on 20 December 2007, no longer available).

171 This dispute should not to be confused with the concession contract involving the city of Buenos Aires, which is the subject of the case study presented in Section 4 infra.

172 Azurix Corp. v. Argentine Republic, ICSID, Award, ICSID Case No. ARB/01/12, July 14, 2006, paras. 43-44 and 244-245.

173 A company incorporated by a consortium composed by Biwater Ltd., an English water company together with HP Gauff Ingenieure GmbH \& Co. KG-JBG, a German corporation.

174 See Biwater Gauff (Tanzania) Limited v. United Republic of Tanzania, ICSID, Award, ICSID Case No. ARB/05/22, 24 July 2008, para. 3.

175 A. Houdret and M. Shabafrouz, "Privatisation in Deep Water? Water Governance and Options for Development Cooperation," INEF Report, 84/2006, Institute for Development and Peace, University Duisburg-Essen, Duisburg, (2006), p. 25. 
the ICSID claiming, inter alia, that a number of actions accompanying the termination of the lease contract constituted expropriation in breach of Tanzania's international (in particular the Bilateral Investment Treaty (BIT) between the United Kigndom and Tanzania), and domestic obligations. ${ }^{176}$ On 24 July 2008, the ICSID Arbitration Tribunal issued an award in which it concluded that Tanzania's actions had indeed amounted to expropriation, although it decided not to award any damages since the violations of the BIT did not cause any loss and damage to the parent companies. ${ }^{177}$

- The rescission of the 1993 city of Buenos Aires concession contract in 2006 which also resulted in a claim against Argentina before the ICSID. This case will be dealt with in more detail in Section 4 infra.

- the 'remunicipalization' of the water services of Paris, which had been privatized in 1985, following a decision by Paris city council adopted in September 2008 to revert to a publicly managed and operated service from January 2010. ${ }^{178}$ The mayor of Paris had already announced in June 2008 that the city was not going to renew the concession contracts with Veolia Environment and Suez Environment, which expired on the $31^{\text {st }}$ of December $2009 .{ }^{179}$ A public company, Eaux de Paris, which was already responsible for the production of water, took over the distribution of the water services.

All these examples show that the privatization of essential utilities like water as such is not an irreversible phenomenon, although abandoning the policy can come at a high cost for the government and society as a whole in terms of opening themselves to complicated, long and costly arbitration procedures involving claims of expropriation of property for which appropriate reparation may be due. ${ }^{180}$ Reversing the privatization of water utilities does raise the question whether the State is capable of practically and realistically taking over the service provision and management of the utilities? ${ }^{181}$ For example, the State may find it difficult to immediately resume operations due to lack of expert personnel. However, in the examples mentioned in the previous paragraphs, the public authorities were able to

176 Biwater Gauff (Tanzania) Limited v. United Republic of Tanzania, para. 16.

177 Ibid., para. 519, and paras. 807-808. It should be noted that the three members of the arbitration panel were split on the decision not to award damages to the company, with the majority thinking that the companies had not demonstrated a quantifiable monetary loss. See Biwater Gauff (Tanzania) Limited v. United Republic of Tanzania, ICSID, Concurring and Dissenting Opinion, ICSID Case No. ARB/05/22, 18 July 2008.

178 See "Paris remunicipalise son service de l'eau," press information by Eau de Paris, the public company that will take over the provision of water services, available at: <www.eaudeparis.fr/ cgi/epic/epic_200811.shtml> (last visited on 20 December 2008).

179 See $<$ www.remunicipalisation.org/cases\#Paris $>$ (last visited on 20 December 2008).

180 For the effects that the re-nationalization or reversal of privatization may have in terms of the responsibility of the State under international law see Chapter III Section 3.1.3.

181 For a similar question with regard to the privatization of prisons see Aman, "Privatisation, Prisons, Democracy and Human Rights: The Need to Extend the Province of Administrative Law," p. 113. 
continue delivering the service. This seems to indicate that it is indeed possible for the State to assume once again the responsibility of directly providing water services, although it may be too early to tell whether this has any effects on the quality and availability of the services.

This recent trend towards reversing the privatization of water utilities notwithstanding, the involvement of private actors in the water sector is still considered an important and viable means of improving service delivery in the sector. It would appear, however, that large multinational water enterprises are withdrawing from grand scale privatization projects in developing countries due to the financial and political risks involved. ${ }^{182}$ Instead, the focus of International Financial Institutions has been shifted towards engaging local (private) actors that may be more acceptable to the communities they are involved with. ${ }^{183}$

\subsection{Issues of general interest regarding privatization of water utilities and related services}

In addition to the human rights issues that will be analyzed in the next section, the privatization of water utilities raises also other topics that are worthy of brief discussion, as a number of them have important links to certain aspects of international law and human rights. These topics are related to the efficiency of privatized utilities vs. publicly run ones (thus raising the issue of whether it is necessary to privatize water utilities at all), and the need to regulate the activities of privatized utilities. Closely related to this latter point, is the question of the trade in water related services and GATS (a much debated aspect that is often linked, rightly or wrongly, to the privatization of water and other essential public utilities, in particular with regard to the regulatory ability of States that are willing to commit to the trade in these services under GATS). Each of these topics will be briefly considered in the following paragraphs before we embark on a more thorough analysis of the relationship between privatization of water utilities and human rights.

182 See M. Palaniappan et al., "Assessing the long-term outlook for current business models in the construction and provision of water infrastructure and services - Global Forum on Sustainable Development - OECD International Futures Project on Global Infrastructure Needs," ENV/ EPOC/GF/SD(2006)3 OECD - Environment Directorate - Environment Policy Committee, (2006), p. 5; T. Triche, S. Requena, and M. Kariuki, "Engaging Local Private Operators in Water Supply and Sanitation Services - Initial Lessons From Emerging Experience in Cambodia, Colombia, Parguay, The Philippines, and Uganda," Note No. 12 - Water Supply and Sanitation Working Notes, The International Bank for Reconstruction and Development/The World Bank, (2006), p. 1.

183 Triche, Requena, and Kariuki, "Engaging Local Private Operators in Water Supply and Sanitation Services - Initial Lessons From Emerging Experience in Cambodia, Colombia, Parguay, The Philippines, and Uganda," p. 1. 


\subsubsection{Private vs. public water}

Some commentators have observed that in practice shifts in international opinions regarding the appropriate roles of the public and private sectors in water and sanitation provision are influenced more by broad political trends than by the actual evidence emerging from experiences and actual operation of public and privatized water utilities. ${ }^{184}$ As explained in Section 2.2 supra, as a 'service of general interest', it does not really matter whether water for human consumption and use is in fact provided by a public or private entity, as long as the service is provided subject to a number of obligations that guarantee its affordability, quality and universal and non-discriminatory accessibility.

However, much has been debated about the merits of privatizing water utilities and the potential advantages it may have over public water utilities. The privatization of water utilities in various developing countries was encouraged on the basis that many States failed to provide effective services themselves, and privatization would bring benefits to States and consumers. ${ }^{185}$ For example, it has been argued that privatization also brings improvements in a sector plagued by inefficient public bodies that provided sub-par services and are not able to improve or expand connections in particular to the poor. It has also been contended that privatization brings several financial benefits: in the first place, States have no longer to pay for the costs of operating water utilities, plus they can receive additional income from privatized utilities in the form of concession fees or from the proceeds resulting when they are entirely divested. In the second place, it has been argued that private participation in the water utilities sector makes it easier to obtain (international) financing to finance the expansion of access to water services, ${ }^{186}$ although this claim is also disputable as private actors sometimes also face challenges in gathering sufficient interest for investments in the water sector. ${ }^{187}$ Nonetheless, the general alleged water utility privatization benefits include more efficient provision of water services at lower costs.

In practice, however, it appears that private sector participation in the water utilities does not per se lead to improved efficiency gains or that privately operated water utilities operate significantly better than publicly operated ones. Hall and Lobina

184 See Budds and McGranahan, "Are the Debates on Water Privatization Missing the Point? Experiences from Asia, Africa and Latin America," p. 92.

185 See Gleick et al., "The New Economy of Water: The Risks and Benefits of Globalization and Privatization of Fresh Water," p. 22-23; Budds and McGranahan, "Are the Debates on Water Privatization Missing the Point? Experiences from Asia, Africa and Latin America," p. 97.

186 Gleick et al., "The New Economy of Water: The Risks and Benefits of Globalization and Privatization of Fresh Water," p. 23.

187 See Palaniappan et al., "Assessing the long-term outlook for current business models in the construction and provision of water infrastructure and services - Global Forum on Sustainable Development - OECD International Futures Project on Global Infrastructure Needs,” p. 25. 
have compiled a number of comparative empirical studies that have studied the operation of privatized utilities vs. public ones in various countries in Latin America, Africa, Asia, and Europe. ${ }^{188}$ An analysis of these studies have led them to conclude that the evidence, "[...] points strongly to the conclusion that there is no systematic intrinsic advantage to private sector operation in terms of efficiency[,]" and that "[e]qually, there is no evidence to assume that a public sector operator is intrinsically less efficient and effective."189

A recent World Bank sponsored research and policy paper studies has also concluded that,

"[a]ccess to both water and sewerage tended to improve in areas with PSP [Private Sector Participation, $A H W]$ following privatization, consistent with the case study literature discussed above. However, access in cities that retained public ownership also tended to improve over those same years. [...] The results concerning coverage also hold across socioeconomic lines: access by the poorest households tended to improve or remain relatively constant following the introduction of PSP. However, changes in coverage for poor households did not appear any different in areas with PSP than it did in those with public access." 190

It would thus appear that there are no intrinsic advantages to water services provided by either privatized utilities or public ones. On the other hand, findings related to the distributional effects of privatization in a number of sectors suggest that privatization may have a marginal positive effect, albeit a limited one. In a study that analyzes the impact of privatization policies (in particular those related to essential services and utilities) in a number of developing countries, McKenzie and Mookherjee have observed that in general, privatization either reduced poverty, or had no effect on it. ${ }^{191}$ However, Budds and McGranahan have pointed out that although commercial pressures involved with privatization can indeed play a positive role in driving efficiency improvements in the provision of water, privately run utilities also respond to political pressures, and may have little incentive to improve efficiency. ${ }^{192}$ This will usually depend on the nature of the contract involved and how it is regulated. In their eyes, water provision "[...] raises a number

188 D. Hall and E. Lobina, "The Relative Efficiency of Public and Private Water," available at www. psiru.org, Public Services International Research Unit (PSIRU), Business School, University of Greenwich, (2005).

189 Ibid., p. 5.

190 G. Clarke, K. Kosec, and S. Wallsten, "Has Private Participation in Water and Sewerage Improved Coverage? Empirical Evidence from Latin America," Working Paper 04-02, AEIBrookings Joint Center for Regulatory Studies, (2004), p. 13-14.

191 D. McKenzie and D. Mookherjee, "Paradox and Perception: Evidence from Four Latin American Countries," in In Reality Check: The Distributional Impact of Privatization in Developing Countries, ed. J. Nellis and N. BirdsallCenter for Global Development (2005), p. 63.

192 Budds and McGranahan, "Are the Debates on Water Privatization Missing the Point? Experiences from Asia, Africa and Latin America," p. 96. 
of economic and governance issues that cannot simply be resolved by bringing in private operators, any more than they were resolved in the past by bringing in public operators." ${ }^{193}$ In any case, these debates lead to the conclusion that the jury is still out on whether privatized water utilities provide better services in absolute terms than public water utilities.

\subsubsection{Regulation of privatized water utilities}

The issue of regulation in the context of privatization is very important and has already been discussed to some extent in Chapter III, Sections 4.1.2.3 and 4.3.2.2. Proper regulation is particularly necessary with regard to the privatization of water utilities. As discussed in Section 2.2 of the present Chapter, the provision of water is a natural monopoly and the privatization of such a service will entail granting a private company the sole rights to operate in the sector without competition and its concomitant incentives. Regulation is necessary to ensure that public and privatized water utilities do not abuse their monopoly position, and were possible promote competition. ${ }^{194}$ Since the provision of water can also be regarded as a service of general interest that imposes a number of obligations on the service provider, a regulator will also play a crucial role in monitoring that public or privatized water utilities live up to these obligations such as the provision of universal service, of acceptable quality, at a fair price, and without discrimination. ${ }^{195} \mathrm{~A}$ regulator thus becomes essential to protect the interests of the consumers of water services, control the quality of the service provided, prevent water pollution or over-exploitation, and make sure that the water utilities make the proper investments in the infrastructure. The protection of these goals can be achieved through economic regulation and social regulation as observed in the abovementioned Chapter. ${ }^{196}$ Economic regulation deals with the promotion of competition and the control of the natural monopoly in order to enhance economic efficiency. On the other hand, social regulation is more concerned with the promotion of social objectives. Social regulation is, as already observed, closely related to the issue of positive obligations, and will be the main focus of this brief section.

Social regulation in the water sector can take place through the creation of regulatory mechanisms that promote social objectives, like safety, environmental protection, guarantee universal services, and look after the interests of consumers of the services provided by the utilities. ${ }^{197}$ In England and Wales, for example,

\footnotetext{
193 Ibid.

194 See Kessides, "Reforming Infrastructure: Privatization, Regulation, and Competition," p. $79-80$.

195 See ibid., p. 49.

196 See also Foster, Privatization, Public Ownership and the Regulation of Natural Monopoly, p. 186.

197 Ibid., 186 and 292.
} 
amendments to the legislation pertaining to the privatization of water were introduced to consolidate the protection of water consumers. Water utilities in England and Wales were privatized in 1989 through the Water Act 1989 (c. 15), which was later consolidated by the Water Industry Act 1991 (c. 56). The 1991 Water Industry Act was subsequently amended by the 1999 Water Industry Act (c. 9) that introduced important protections for water consumers including the removal of the privatized companies' ability to disconnect household customers for nonpayment of charges. This was deemed necessary on public health grounds ${ }^{198}$ and after political upheaval following large increases in the disconnection of low-income households from water services in the immediate years following privatization. ${ }^{199}$ The disconnections were mainly due to these household consumers' incapacity to pay water bills, which in turn appears to have been the result of major increases in the prices of water services by the privatized water utilities. ${ }^{200}$ The 1999 Water Industry Act also outlawed the use of pre-payment water meter units that cut off customers' water supplies, when the latter had insufficient credit on their payment cards. Pre-payment meters had been used by several privatized utilities following the ban on disconnections, and had been deemed unlawful by a court judgment in 1998. ${ }^{201}$ In addition, other regulations were introduced in 1999 to protect vulnerable and low-income customers. Thus the Water Industry (Charges) (Vulnerable Groups) Regulations 1999 requires water and sewerage companies' charges schemes to include special provision for assistance for certain groups of people on low incomes and medical conditions. ${ }^{202}$

The privatization legislation in England and Wales also introduced a regulator for the water and sewerage industry. Under the aforementioned Acts, economic regulation would be taken care for by the Director General of Water Services and a supporting office, known as the Office of Water Services (Ofwat) and a Drinking Water Inspectorate, which is responsible for setting standards for the quality of drinking water. The Water Services Regulation Authority replaced the Director

198 See House of Commons, Research Paper 98/117, 10 December 1998, Water Industry Bill, Bill 1 [1998/99], p. 25-26.

199 E. Lobina and D. Hall, "UK Water Privatization - a briefing" Public Services International Research Unit (PSIRU), University of Greenwich, 2001; available from <www.psiru.org/ reports/2001-02-W-UK-over.doc>.

200 Ibid.

201 See Lancashire County Council \& Ors, $R$ (on the application of) v. Director General Of Water Services, [1998] EWHC Admin 213 (20 ${ }^{\text {th }}$ February, 1998). See also House of Commons, Research Paper 98/117, 10 December 1998, Water Industry Bill, Bill 1 [1998/99], p. 27-29, and M. Drakeford, "Water Regulation and Pre-Payment Meters," Journal of Law and Society Vol. 25 (1998), p. 597-598.

202 See Statutory Instrument 1999 No. 3441, Water Industry, England and Wales, The Water Industry (Charges) (Vulnerable Groups) Regulations 1999. This statutory instrument was amended in 2005 , which slightly expanded the scope of the protection to some vulnerable groups. See Statutory Instrument 2005 No. 59, The Water Industry (Charges) (Vulnerable Groups) (Amendment) Regulations 2005. 
General $^{203}$ in 2003 through the Water Act 2003 (c. 37), which also established the Consumer Council for Water. The latter represents customers of the water services and deals with complaints from consumers. In particular, Ofwat's main role under Section 2 of the Water Industry Act 1991 and Section 39 of the Water Act 2003 amending the former is to, inter alia, protect and seek value to consumers by setting limits to water tariffs the private water utilities may charge, protecting the standards of service companies provide, and encouraging the private water utilities to be more efficient. More notably, under Sections 39 and 43 of the Water Act 2003, both Ofwat and the Consumer Council for Water are expected to have regard to the particular interests of, among others, individuals who are disabled or chronically sick, individuals of pensionable age, individuals with low incomes, and individuals residing in rural areas.

Regulatory efforts, particularly under a situation of privatized water utilities, have to strike the balance between ensuring proper economic efficiency of the sector and the protection of social values. Based on the findings of a number of studies, the World Bank has identified a number of institutional criteria to gauge the effectiveness of regulation and regulators for privatized infrastructure including water. ${ }^{204}$ First, regulation must be coherent, entailing agreement between the different laws guiding regulation and the elimination of inconsistencies. Coherence with regard to regulators aims at ensuring that the latter have clearly defined responsibilities, and it should require them to publish their goals and reasons for adopting decisions. Second, effective regulation requires the independence of the regulator from political influence. This can be achieved, for example, through the establishment of a statutory basis for the regulator, free of control from any ministerial control. It would also require the appointment of regulators on the basis of professional criteria through open processes with the participation of and consultation with those parties holding a stake such as water consumers, and the privatized companies. Additionally, it is of importance that in order to maintain a regulator's independence, the executive is barred from easily overturning the regulator's decisions. In the third place, the regulator must be accountable and the necessary steps have to be adopted to prevent the regulator becoming corrupt or inefficient. The stakeholders should be able to question why the regulator adopted decisions, and the latter should be subject to review by courts and other independent non-political bodies. Obliging the regulator to publish an annual report documenting its activities can also contribute to its accountability. In the fourth place transparency is essential for the effective work of the regulator. The regulatory rules and decisions need to be public and accessible to all actors which have a vested interest: the privatized service providers and consumers. Kessides argues that transparency is necessary to avoid corruption and maintain the perception that the regulator's

203 The Water Services Regulation Authority is still known as Ofwat.

204 Kessides, "Reforming Infrastructure: Privatization, Regulation, and Competition," p. 82-88. 
decisions are free from corruption. ${ }^{205}$ In the fifth place, the regulator needs to be predictable. This means following the rule of law and the regulator's decisions need to be based on durable rules and procedures. Finally, the regulator needs to have sufficient capacity in terms of budget and staff to fulfill its role in an effective manner: the regulator should be endowed with sufficient financial resources and its personnel must have relevant expertise. ${ }^{206}$

In addition to these criteria, it can be argued that the users affected by the activities of both the regulator and the regulated entity should be allowed to participate in the activities of the regulator. This could take place through direct representation in the regulator or through advisory commissions of users that are allowed to give some input in the fomer's activities and decisions. Such participation, it is suggested, could enhance the other criteria mentioned above such as transparency, but also in terms of independence and predictability, while at the same time enhancing inclusiveness. Here it is worthwhile to observe that these criteria are somewhat comparable to the ones expected to be present in National Human Rights Institutions (NHRIs) under the Principles relating to the status of national institutions (the Paris Principles). ${ }^{207}$ These Principles enumerate a number of requirements for NHRIs pertaining to composition and guarantees of independence, methods of operation and capacity to deal with complaints. Drawing some inspiration from these Principles could be a way of enhancing the standing of regulatory agencies dealing with essential services.

As stated in Chapter III, Section 3, States as sovereign entities under international law have the prerogative to adopt the laws and economic system they deem fit without interference from others. By extension, States also have a right to regulate for public purposes the activities of economic actors operating in their territory. This right is, however, not unfettered. A State's right to regulate may be limited if it clashes with its other international legal obligations. This applies for example when regulation has an impact on foreign investments. In such situations States need to be careful that their regulatory efforts are carried out within a proper legal framework for the pursuit of or to achieve an essential public interest, and in a way that does not discriminate foreign investments. This view was adopted by a North America Free Trade Agreement (NAFTA) arbitral tribunal in the Methanex Corp vs. United States arbitration. ${ }^{208}$ In this dispute about environmental measures that allegedly affected the investments of a Canadian corporation operating in

\footnotetext{
205 Ibid., p. 87.

206 Ibid., p. 87-88.

207 See National institutions for the promotion and protection of human rights, General Assembly, UN Doc. A/RES/48/134 (20 December 1993).

208 Methanex Corp. v. United States, Jurisdiction and Merits, NAFTA Tribunal, Chapter 11 Arbitration, 3 August 2005.
} 
California, the arbitral tribunal constituted under Chapter 11 of the NAFTA Agreement observed that,

"[...] as a matter of general international law, a non-discriminatory regulation for a public purpose, which is enacted in accordance with due process and, which affects, inter alios, a foreign investor or investment is not deemed expropriatory and compensable unless specific commitments had been given by the regulating government to the then putative foreign investor contemplating investment that the government would refrain from such regulation."209

As discussed in Chapter III, Section 4.1.2.3, however, from the perspective of human rights this right to regulate becomes an obligation to safeguard the rights of consumers of water services provided by privatized utilities. Thus, according to the UN Committee on Economic, Social and Cultural Rights the State has an obligation to protect these consumers by adopting the necessary measures to regulate the activities of private actors operating those utilities. ${ }^{210}$ An example of a failure to regulate the privatized water sector, with potential negative effects on human rights, can be found in the addendum to the 2002 report of the UN special rapporteur on the right to food, Jean Ziegler. ${ }^{211}$ After visiting Niger, the special rapporteur signaled that the privatization of water provision that Niger had adopted might violate the right to food. ${ }^{212} \mathrm{Mr}$. Ziegler emphasized that the Government of Niger needs to ensure that quality water standards are maintained. He pointed out that the privatized water company (a subsidiary of the French multinational Vivendi) sells water to resellers who then distribute the water through water points in the cities without any hygiene controls. ${ }^{213}$ These findings prompted the special rapporteur to recommend Niger to take measures for harnessing water resources for drinking water and irrigation in order to ensure food security of people, especially those living in rural areas.

209 Ibid., Part IV, Chapter D, page 4, para. 7. See also the UNCITRAL Award Saluka Investments B.V. v. the Czech Republic, in which the arbitration panel noted that "[...] the principle that a State does not commit an expropriation and is thus not liable to pay compensation to a dispossessed alien investor when it adopts general regulations that are "commonly accepted as within the police power of States' forms part of customary law today." Saluka Investments B.V. v. the Czech Republic (UNCITRAL), Partial Award (17 March 2006), para. 262.7. See also Leader, "Human Rights, Risks, and New Strategies for Global Investment," p. 674.

210 See General Comment No. 15 (2002), the Right to Water (Arts. 11 and 12 of the International Covenant on Economic, Social and Cultural Rights), CESCR, UN Doc E/C.12/2002/11 (20 January 2003), para. 24, further discussed in Section 3.2 infra.

211 See report of the special rapporteur on the right to food, Addendum, mission to Niger, UN Doc. E/CN.4/2002/58/Add.1 (23 January 2002).

212 The rapporteur considers the examination of the nutritional aspects of water to be a part of his mandate taking into account its close interdependence with food. Ibid., para. 50.

213 Ibid., para. 51. Additionally the special rapporteur expressed his concerns regarding possible substantial increases in the price of water following the privatization of water services, although this had not immediately occurred after the privatization. The special rapporteur urged the government to ensure that the price level of water remained accessible to the poor. 
The right to regulate privatized water utilities has also been acknowledged by arbitral bodies. This is the case of the ICSID arbitration panel that dealt with the already mentioned dispute between the privatized water utility of the city of Buenos Aires, Aguas Argentinas, its parent companies, and the Argentine Republic. ${ }^{214}$ In deciding whether Argentina bore responsibility for the rescission of the concession granted to Aguas Argentinas, on the grounds that the rescission was in breach of the obligation to offer fair and equitable treatment under the BITs between Argentina, France, Spain and the United Kingdom, the ICSD panel confirmed that

"[i]n interpreting the concept of fair and equitable, the Tribunal must also bear in mind that the Concession by its terms was subject to the regulatory authority of the Argentine State, which had a reasonable right to regulate. Thus in interpreting the meaning of fair and equitable treatment to be accorded to investors, the Tribunal must balance the legitimate and reasonable expectations of the Claimants with Argentina's right to regulate the provision of a vital public service."215

This right to regulate in a non-discriminatory way must, therefore, be exercised with due consideration of all the legal obligations of a State, such as respecting the rights of foreign investors involved in privatized utilities. This is also the case even if States regulate privatized utilities for the benefit of human rights. In the Aguas Argentinas arbitration dispute, Argentina adopted a number of measures which breached the right of the parent companies of the privatized water utility in Buenos Aires to a fair and equitable treatment (see Chapter III, Section 3.1.3, and Section 4.2 infra). Argentina claimed that it had adopted these measures because they were necessary "[...] to safeguard the human right to water of the inhabitants of the country." 216 Although the ICSID Tribunal implicitly acknowledged this, ${ }^{217}$ it also observed that a State should also take into account its other international legal obligations. Thus, the Tribunal was not convinced that the disputed measures adopted by Argentina were the only necessary means to safeguard the essential interest embodied in the provision of water. In the eyes of the Tribunal,

214 See Chapter III, Section 313 and footnote 61 supra.

215 Suez, Sociedad General de Aguas de Barcelona S.A. and Vivendi Universal S.A v. Argentine Republic, Decision on Liability, ICSID Case No. ARB/03/19, 30 July 2010, para. 236.

216 Ibid., para. 252. As previously observed, Argentina was supported in its position by a number of Argentine human rights NGO's which had filed a number of submission as amicus curiae maintaining that human rights law " [...] required that Argentina adopt measures to ensure access to water by the population, including physical and economic access, and that its actions in confronting the crisis fully conformed to human rights law. Since human rights law provides a rationale for the crisis measures, [the amicus curiae] argue that this Tribunal should consider that rationale in interpreting and applying the provisions of the BITs in question.” Ibid., para. 256.

217 The Tribunal agreed that the provision of water is vital for the health and well-being of the inhabitants of Buenos Aires, and is therefore and essential interest of the State. Ibid., para. 260. 
"Argentina could have attempted to apply more flexible means to assure the continuation of the water and sewage services to the people of Buenos Aires and at the same time respected its obligations of fair and equitable treatment. The two were by no means mutually exclusive." 218

It would therefore appear that for the ICSID Tribunal in this dispute, the protection of human rights (in particular the right to water) through regulation of privatized industry and the protection of foreign investments in that industry is not a zero-sum game. On the contrary, the Tribunal, pointedly observed that the human rights obligations of Argentina and its obligations ensuing from the BITs do not clash with each other. ${ }^{219}$ As a result, Argentina needs to satisfy both obligations equally.

The issue of regulation in the water sector is arguably very important if a State is to guarantee universal access to safe and affordable water services in either public or privatized water settings. In particular, the need to have social regulation that takes into account the needs of the poor and ensure that they "are not disadvantaged by private sector involvement" 220 makes it more important for a State to have a properly functioning regulatory mechanism. It has been argued in this regard that developing countries with limited regulatory resources and capabilities should be cautious when adopting liberalization and privatization policies in the area of water utilities. ${ }^{221}$ Kirkpatrick and Parker thus observed that "[...] many developing countries lack the administrative and institutional capacity to adopt the regulatory model and measures that have been developed in the context of the advanced

218 Ibid. For example, the Tribunal observed that if "[...] if Argentina's concern was to avoid an increase in tariffs during a time of crisis, it might have relieved AASA, at least temporarily, of investment commitments that were placing a crippling burden on the Concession so long as tariffs did not increase. If Argentina's concern was to protect the poor from increased tariffs, it might have allowed tariff increases for other consumers while applying a social tariff or a subsidy to the poor, a solution clearly permitted by the regulatory framework." Ibid., para. 235 .

219 The Tribunal noted down the suggestions posed by Argentina and by the amicus curiae (for a brief discussion of the participation of the amicus curiae in this dispute see Section 4.2 infra) in their submissions " [...] that Argentina's human rights obligations to assure its population the right to water somehow trumps its obligations under the BITs and that the existence of the human right to water also implicitly gives Argentina the authority to take actions in disregard of its BIT obligations[,]" and responded that it "[...] does not find a basis for such a conclusion either in the BITs or international law. Argentina is subject to both international obligations, i.e. human rights and treaty obligation, and must respect both of them equally. Under the circumstances of these cases, Argentina's human rights obligations and its investment treaty obligations are not inconsistent, contradictory, or mutually exclusive. Thus, as discussed above, Argentina could have respected both types of obligations.” Ibid., para. 262.

220 C. Kirkpatrick and D. Parker, "Regulation and the Privatisation of Water Services in Developing Countries: Assessing the Impact of the General Agreement on Trade in Services (GATS)," Paper No. 67, Centre on Regulation and Competition, Institute for Development Policy and Management, University of Manchester, Manchester, (2004), p. 14. Ibid., p. 19. 
economies, such as the UK."222 Lack of regulatory capacity and expert staff may make it difficult to regulate privatized industries in these countries. As observed in Chapter III, a State's failure to regulate private conduct may give rise to the State's responsibility under human rights law. ${ }^{223}$ Preventing or putting an end to any conduct of privatized water utilities which is contrary to human rights through proper regulatory legislation and the establishment of a regulatory body would be a step in that direction. The above-mentioned factors should be taken into consideration for ensuring that the regulatory efforts and bodies conform to human rights obligations. At the same time, these regulatory and pro-human rights efforts do not exist in a vacuum. In the exercise of the right to regulate, even for the benefit of human rights, States have also to take into account their other international legal obligations, such as those emanating from BITs, which are of no lesser importance under international law.

\subsubsection{Privatization of water utilities and GATS}

One of the major accomplishments of the Uruguay Round of multilateral trade negotiations was the conclusion of the General Agreement on Trade in Services (GATS) in 1994 together with the other agreements resulting in the further development of rules of international trade law and the establishment of the World Trade Organization (WTO). ${ }^{224}$ The GATS has been drafted to facilitate the trade in services through the acceptance of four modes of service supply 225 and the gradual removal of domestic regulatory barriers that could negatively impact on the trade in services. Although the international trade in services currently represents only twenty per cent of total global trade, ${ }^{226}$ it is increasingly becoming one of the most

222 Ibid., p. 14-15.

223 See in particular Fadeyeva v. Russia, judgment of 9 June 2005, ECtHR, Reports of Judgments and Decisions 2005-IV, para. 89. See also Ledyayeva, Dobrokhotova, Zolotareva and Romashina v. Russia, judgment of 26 October 2006, ECtHR, Applications Nos. 53157/99, 53247/99, 53695/00 and 56850/00 (not yet published), paras. 108-110.

224 See M. Footer, "The General Agreement on Trade and Services: Taking Stock and Moving Forward," Legal Issues of Economic Integration Vol. 29 (2002), p. 7. As is well known, the WTO is the result of negotiations to establish a formal international organization that would provide a forum of discussion on international trade issues, as well as to lay down a legal framework to facilitate trade in, inter alia, goods and services. It was built on the foundations of the General Agreement on Trade and Tariffs (GATT) of 1947, which had become a de facto international organization for trade. P. Van den Bossche, The Law and Policy of the World Trade Organization, First ed. (Cambridge: Cambridge University Press, 2005) p. 81. The Marrakesh Agreement Establishing the World Trade Organization constitutes the legal framework of the WTO, which includes, inter alia, the GATT 1994, the GATS, the Agreement on Trade-Related Aspects of Intellectual Property Rights (TRIPS).

Art. I GATS. These four modes are cross-border supply, consumption abroad, commercial presence and presence of natural persons (respectively identified as modes one, two, three and four).

226 According to the WTO website on the trade in services. See <www.wto.org/english/tratop_e/ serv_e/gatsqa_e.htm>, last visited on 25 October 2004. 
important areas of growth in international trade due to the increasing mobility of the services that can be offered between countries.

In the discussions surrounding privatization, one of the most commonly heard complaints has been that international trade law, and more specifically, the liberalization of trade in services with its concomitant opening of markets and increased competition, could force states to privatize state enterprises that provide essential services. ${ }^{227}$ These complaints have usually revolved against the alleged privatization of health related services, educational services, ${ }^{228}$ and public utilities services (including water and electricity). ${ }^{229}$ Thus in a report to the former UN Subcommission on the Promotion and Protection of Human Rights, the UN High Commissioner for Human Rights noted that mode three (commercial presence) can lead to an increase in direct foreign investment which can supplement government expenditures in essential services by supplying services which the Government was unable to supply before. ${ }^{230}$ However, the report then noted that an increased presence of foreign or national private suppliers of essential services, which would appear to imply privatization, "[...] can pose challenges to Governments as the guarantors of human rights." 231 The report then indirectly suggested that the privatization of essential services, which "[...] is leading to an increasingly large and powerful private sector [that] can also threaten the Government's role as primary duty bearer for human rights." ${ }^{232}$ The privatization of these services is allegedly the result of the obligations ensuing from the GATS and the on-going negotiations to implement the Agreement. Additionally, concerns have been raised that the application of the GATS together with the 'inevitable' privatization would result in less social protection since the Agreement appears to be geared towards reducing the regulatory capacity of States in favour of trade liberalization. ${ }^{233}$

Adlung, "Public Services and the GATS," p. 456.

For a discussion on the privatization of education and a short review of the impact of the trade in educational services with regard to privatization in this sector see Coomans and Hallo de Wolf, "Privatisation of Education and the Right to Education," p. 250-253.

See for example, J. Hilary, "GATS and Water: The threat of services negotiations at the WTO," Save the Children UK (2003), London. See also L. Mehta and B. La Cour Madsen, "Is the WTO After Your Water? The General Agreement on Trade and Services (GATS) and the Basic Right to Water," Paper Prepared for the Research Project on 'Linking the WTO to the PovertyReduction Agenda', Institute of Development Studies, University of Sussex, (2003). For a general overview of the arguments presented against the GATS in general with respect to essential services and for a fair rebuttal to these complaints see R. Chanda, "Social Services and the GATS: Key Issues and Concerns,” World Development Vol. 31 (2003), p. 1997-2011.

See Liberalization of trade in services and human rights, Report of the High Commissioner, UN Doc. E/CN.4/Sub.2/2002/9 (25 June 2002), para. 43.

Ibid., para. 44.

Ibid.

Ibid., para. 58. See also Mehta and La Cour Madsen, "Is the WTO After Your Water? The General Agreement on Trade and Services (GATS) and the Basic Right to Water," p. 16-19 and 21. 
In the following paragraphs, it will be briefly outlined why this perception is partly misguided. Although the liberalization of the trade in services could lead to privatization of certain services, this is not necessarily the result of the GATS alone. As it shall be explained below, the Agreement does not impose the privatization of services on States, nor does it completely do away or inherently limit States' abilities to regulate the sectors that are open to trade in services liberalization. This does not mean that the GATS is trouble-free or that its application with regard to regulation is without problems, most of which relate to the Agreement's ambiguous terminology. ${ }^{234}$ It is, however, unlikely that GATS and the WTO will force the privatization of water related services down the throat of the WTO's Member States. Before discussing this, however, we will briefly examine the scope and application of GATS.

\subsubsection{GATS: scope and application}

The GATS covers in theory all services with two exceptions. The first exception deals with services "supplied in the exercise of governmental authority" (Article I $\$ 3$ GATS). The precise meaning of this exception will be dealt with further below. Additionally, services directly related to air traffic rights and certain financial services, as well as the measures affecting these services, are exempted from coverage of the Agreement. ${ }^{235}$ The countries participating in GATS (that is, all of the members of the WTO ${ }^{236}$ have agreed upon a list of services that are to be negotiated for liberalization.

In order to make possible the liberalization of the trade in services that are covered by the Agreement, states are required to negotiate whether they are going to commit themselves to (progressively) open up their markets to the services of their choosing. ${ }^{237}$ States that make such commitments must then draw up a schedule where these commitments are laid down ${ }^{238}$ and which specify the sectors subject to (progressive) liberalization as well as, inter alia, the terms, conditions and limitations on market access to these sectors; the conditions and qualifications on national treatment; and the timeframe for implementation and entry into force of these commitments. Once a commitment has been made official, it is not possible to withdraw it without owing other Member States some sort of compensation. ${ }^{239}$

\footnotetext{
234 In the same vein, see Chanda, "Social Services and the GATS: Key Issues and Concerns."

235 See the Annexes on Air Transport Services and Financial Services appended to GATS.

236 At the time of this writing, 153 countries are members of the WTO.

237 Article XIX GATS.

238 Article XX GATS.

239 See S. Thomas and D. Hall, "GATS and the Electricity and Water Sectors," Public Services International Research Unit (PSIRU), Business School, University of Greenwich, London, (2006), p. 7.
} 
By allowing States to handpick which services they are willing to open up for trade liberalization across all four modes of cross-border supply and under which conditions, GATS provides plenty of flexibility for Member States to open up their markets for services from abroad as much as they deem necessary. This, however, also means that there is no uniformity across the actual implementation of GATS as each Member State will have different arrangements in place. In addition, this leads to complex negotiations between Member States as they present requests to each other indicating what improvements they are seeking for their services and service suppliers, as well as offers specifying how and to what extent they are willing to take binding commitments in response to these requests during successive rounds of negotiation. ${ }^{240}$ The current Doha Development Round of negotiations, which started in 2001 and was supposed to end in 2005, includes negotiations on the trade in services. However, due to various disagreements between Member States, little progress has been achieved after a number of failed meetings. ${ }^{241}$

In order to guarantee the free trade in services among the countries participating under the Agreement, the latter imposes a number of important obligations on its member States. These obligations relate to the principle of non-discrimination, which is a key concept of WTO law and policy. ${ }^{242}$ These obligations are the most favoured nation treatment (MFN) obligation and the national treatment obligation, which also have similar counterparts in the GATT 1994 Agreement. The MFN obligation under GATS prohibits discrimination between services and service suppliers from different Member State countries thus ensuring that they have the same equal opportunities as other like services and service suppliers of any other Member State country. ${ }^{243}$ Procurement by the government of goods and services is currently exempted from the MFN obligation under GATS, until a separate agreement on the matter is agreed upon. ${ }^{244}$ The national treatment obligation is concerned with prohibiting discrimination against services and service suppliers

\footnotetext{
240 See Article XIX GATS.

241 See for example, World trade talks end in collapse, BBC News, 29 July 2008, available at $<$ http:// news.bbc.co.uk/1/hi/business/7531099.stm $>$ (last visited on 5 December 2008). See also G. Hufbauer and S. Stephenson, "Services Trade: Past Liberalization and Future Challenges," Journal of International Economic Law Vol. 10 (2007), p. 606, 612, and 621-622. Bossche, The Law and Policy of the World Trade Organization, p. 308.

243 Article II $\$ 1$ GATS. See also ibid., p. 318-319. Services and service providers that are not 'like' may be treated differently. 'Like' services and 'like' service providers refer to services that share similar characteristics, qualities or nature and that are the same as those supplied by the concerned service providers. See European Communities - Regime for the Importation, Sale and Distribution of Bananas (Bananas III), Report of the Panel, WT/DS27/R/ECU (22 May 1997), para. 7.322, and Canada - Certain Measures Affecting the Automotive Industry (Canada - Autos), Report of the Panel, WT/DS139/R and WT/DS142/R (11 February 2000), para. 10.248. See also E.H. Leroux, "Eleven Years of GATS Case Law: What Have We Learned?," Journal of International Economic Law Vol. 10 (2007), p. 779.

See Article XIII §1 GATS.
} 
from other Member State countries. ${ }^{245}$ Thus Member States must offer service providers from other Member States the same treatment they provide their own domestic service providers. Contrary to the MFN obligation, which has a general application and applies to all services, the national treatment obligation under GATS only applies to services in so far as Member States have explicitly committed themselves to grant 'national treatment' to the services they choose to adopt in their schedules of commitment. ${ }^{246}$ Examples of discriminatory measures that could fall under the national treatment obligation unless otherwise explicitly exempted in the schedule of commitments are nationality or residence requirements, applying special limits to the operations of foreign service suppliers, and, granting special subsidies or tax benefits only to domestic suppliers.

Linked to the notion of non-discrimination, in particular national treatment, is the concept of market access. ${ }^{247}$ The national treatment obligation relates to de jure and de facto discriminatory measures against services and service suppliers from other countries. The concept of market access relates to measures that are not per se discriminatory, but nevertheless restrict trade and competition and hence access to the market. ${ }^{248}$ These measures include quantitative restrictions, such as a limit in the number of foreign service suppliers, measures requiring specific types of legal entity, and measures limiting the participation of foreign capital in terms of maximum percentage limit on foreign share-holding. ${ }^{249}$ As in the case of national treatment market access only applies to those services that have been explicitly singled out in the schedule of commitments. 250

\subsubsection{GATS and privatization of water utilities?}

Does GATS lead to the privatization of essential public utilities in particular those related to the delivery of water? As already stated, with the exception of two services, GATS covers all services, which have been compiled in a classification list by the WTO Secretariat. ${ }^{251}$ Certain water related services appear to fall under 'environmental services', ${ }^{252}$ although it has been observed that it is not entirely

245 Article XVII GATS. See also Bossche, The Law and Policy of the World Trade Organization, p. 365 .

246 Ibid.

247 Article XVI GATS.

248 Leroux, "Eleven Years of GATS Case Law: What Have We Learned?," p. 767.

249 See Article XVI §2.

250 Bossche, The Law and Policy of the World Trade Organization, p. 483-484; Leroux, "Eleven Years of GATS Case Law: What Have We Learned?," p. 768.

251 R. Adlung, "Public Services and the GATS," ibid.Vol. 9 (2006), p. 460.

252 See Background Note by the Secretariat, Environmental Services, Council for the Trade in Services, WTO, S/C/W/46, 6 July 1998. 
clear whether the provision of potable water may fall therein. ${ }^{253}$ Admittedly, the implementation of GATS could make States consider the privatization of those services that they deem could perform better in a liberalized service market. Krajewski has observed that privatization of public services coincides with general deregulation and liberalization policies in many countries. ${ }^{254}$ However, it does not necessarily follow that the liberalization of the trade in services will result in their privatization. ${ }^{255}$ It has been claimed that developed countries and business enterprises are, nonetheless, lobbying and attempting to pressure developing nations into gradually liberalizing and privatizing the provision of public services such as water, which is compounded with the policies of IFIs to encourage privatization. ${ }^{256}$ On the other hand, it is doubtful that given the current state of negotiations on specific commitments on environmental services, the liberalization of trade with regard to the provision and distribution of water will be agreed upon in the immediate future. In addition, and as noted earlier, IFIs have softened their stance with regard to privatization and no longer actively prescribe it in their lending policies. The lack of commitments and the decreased external pressure to privatize may move countries to be more careful in considering privatization in the context of GATS. Additionally, the application of GATS does not mean that States have no further role or authority to regulate or impose conditions under which the liberalization of trade in services under GATS may take place.

253 The services currently covered are: sewage services, refuse disposal services, and sanitation and similar services. See Services Sectoral Classification List, Note by the Secretariat, WTO, MTN. GNS/W/120, 10 July 1991. In 1999 and late 2000, the EU attempted to clarify the classification by proposing the inclusion of water distribution services through mains (which comprises potable water treatment, purification and distribution including monitoring) in the list of environmental services. See Communication from the European Communities and their Member States, Classification Issues in the Environmental Sector, WTO, S/CSC/W/25, Document 99-4001, 28 September 1999, and Communication from the European Communities and their Member States, GATS 2000: Environmental Services, WTO, S/CSS/W/38, Document 00-5633, 22 December 2000. For a discussion on whether the provision of drink water falls under this classification and on attempts to include these services under the environmental services classification see Thomas and Hall, "GATS and the Electricity and Water Sectors," p. 8-9. Krajewski, "Public Services and Trade Liberalization: Mapping the Legal Framework," p. 346. In a promotional document on the GATS, the WTO Secretariat has noted that "[t]he GATS does not require the privatisation or deregulation of any service. In respect of water distribution and all other public services, the following policy options, all perfectly legitimate, are open to all WTO Members:

(i) To maintain the service as a monopoly, public or private;

(ii) To open the service to competing suppliers, but to restrict access to national companies;

(iii) To open the service to national and foreign suppliers, but to make no GATS commitments on it;

(iv) To make GATS commitments covering the right of foreign companies to supply the service, in addition to national suppliers." See GATS Facts, available at <www.wto.org/english/ tratop_e/serv_e/gatsfacts1004_e.pdf> (last visited on 10 May 2010).

Thomas and Hall, "GATS and the Electricity and Water Sectors," p. 6-7. 
There are a number of arguments that can be deployed to support these observations. In the first place, careful reading of GATS reveals that the Agreement is neutral with respect to privatization. The Agreement does not prescribe the privatization of any of the services that have been committed for liberalization. In fact, as noted above the Agreement excludes those services that are supplied in the exercise of governmental authority from its application. ${ }^{257}$ These are defined as those services which are supplied neither on a commercial basis nor in competition with one or more service suppliers. There appears to be a discussion as to the concrete meaning of this definition. ${ }^{258}$ The WTO secretariat has noted, for example, that basic education (that is, primary and secondary education) directly provided by the government may fall within the scope of this exception. ${ }^{259}$ The main issues at stake here is whether water related services fall under this exception. Admittedly, the provision of water can be done on a commercial basis. ${ }^{260}$ On the other hand, it is possible to argue that given the public interest in securing the proper provision of this service the commercial aspects of water provision could be limited. Moreover, as already observed, some countries have opted to declare the provision of drink water as an important task of the State and in certain extreme cases even constitutionally barred its provision by non-State actors on a commercial basis. In addition, since the provision of piped water entails a natural monopoly, it cannot be said that this is supplied in competition with one or more service suppliers. The only competition possible would be competition for the market as observed above. States would be free, nonetheless, to open up their services markets to allow parallel provision of the same public services by other actors. However, States must be mindful that competing with foreign service providers requires that national (and public) service providers are up to the challenge of competition and if they do choose to open up their services market under the restrictions they have negotiated, they will be bound by the rules of non-discrimination and market access.

In the second place, a look at the specific commitments made by states with regard to certain services does not demonstrate that states are committing themselves to privatize services. ${ }^{261}$ Opponents of GATS and privatization maintain that in their negotiations to incorporate the services that per country will be bound by the

257 Article I $\$ 3$ (b) and (c) GATS.

258 See Krajewski, "Public Services and Trade Liberalization: Mapping the Legal Framework," p. 348-359; Adlung, "Public Services and the GATS," p. 461-467; Leroux, "Eleven Years of GATS Case Law: What Have We Learned?," p. 793.

259 Education Services, Background Note by the Secretariat, WTO - Council for Trade in Services, Doc. No. S/C/W/49, 23 September 1998 (98-3691), §. 13. See also Coomans and Hallo de Wolf, "Privatisation of Education and the Right to Education," p. 251.

260 Adlung observes, for example, that BOT arrangements may have a commercial background and thus probably not fall under the governmental exception of Article I $\$ 3$ GATS. Adlung, "Public Services and the GATS," p. 466-467.

261 A list of commitments made until now by states engaging in GATS negotiations can be found at $<$ http://tsdb.wto.org/wto/WTOHomepublic.htm>. 
Agreement, certain States have pushed for the inclusion of a number of services and their privatization in particular with regard to environmental services, which include water treatment, distribution and sewerage services. ${ }^{262}$ However, an examination of the specific commitments made by States with regard to environmental services reveals that these are among the least committed sectors under the Agreement. ${ }^{263}$ As of August 2011, only 58 WTO Members (including the EU) have made any sort of commitments in environmental services, of which 49 relate to sewerage and 50 to sanitation services. ${ }^{264}$ In particular mode three of supply (commercial presence), if committed to, is frequently subjected to various limitations on market access and national treatment. ${ }^{265}$ Although proposals have been made by a number of countries to place the trade in water and sewerage services on the list of commitments to be made by countries, as far as is known, no State has until now made any actual commitments in this sector. ${ }^{266}$ This is currently the situation, in spite of apparent attempts by the EU to encourage States to open up their markets and accept commitments in services related to the provision of water. ${ }^{267}$ Further discussions during WTO ministerial meetings on GATS have also not advanced the matter. ${ }^{268}$

In the third place, careful consideration of the GATS rules on domestic regulation including the removal of national regulatory barriers, the provisions on general exceptions to the agreement, and the rules on market access, ${ }^{269}$ reveals that states which choose to open up their markets to the provision of the services covered by the Agreement still have the right to apply regulatory measures for protecting legitimate national policy objectives in the area of essential public services. Essentially, Article VI §4(b) GATS makes it possible for member States to adopt

262 See for example, "EU trade talks: a covert push for water privatisation?" Corporate Europe Observatory (CEO) March 2009 available at <www.corporateeurope.org/global-europe/ content/2009/03/covert-push-water-privatisation> (last visited on 10 May 2010).

263 With regard to educational services see Education Services, Background Note by the Secretariat, WTO - Council for Trade in Services, Doc. No. S/C/W/49, 23 September 1998 (98-3691), §37, where the WTO Secretariat observes that education has not been widely subject to many commitments. While this note by the WTO Secretariat is not recent, a survey of the commitments currently available confirms this view. See also Coomans and Hallo de Wolf, "Privatisation of Education and the Right to Education," p. 251. See WTO Trade in Services Database at $<$ http://tsdb.wto.org/default.aspx $>$. The European Communities' commitments in this sector, being one of the most complicated, reveals various limitations with regard to for example participation in investments and subsidies. See <http://tsdb.wto.org/simplesearch.aspx?id=186\&name=European\%20Community\&sc=hc $>$ (last visited 10 May 2010). It is worth noting that France's commitments within the EC's own commitments imposes some limitations on investments and subsidies in newly privatized companies).

See Adlung, "Public Services and the GATS," p. 460 at footnote 412. trade talks: a covert push for water privatisation?" op cit. note 262. 
regulatory measures although they must ensure that these are "[...] not more burdensome than necessary to ensure the quality of the service." This means, of course, that the measures have to apply to all service providers (both national and foreign), be necessary and proportionate to protect these legitimate interests, and should not be used by States as an excuse to escape the commitments that they have agreed upon. ${ }^{270}$ Moreover, reasonable alternative measures that are less traderestrictive should be weighed and considered against the measures regarded as necessary. ${ }^{271}$ With respect to eventual restrictions or regulations of water services to protect the right to water, for example, the test would involve among other things showing that these regulations are 'necessary' to achieve objectives relating to public morals or public order in the context of Article XIV (a) GATS. It would also be necessary to point out why alternative measures would not achieve the same objectives as those which are deemed 'necessary. ${ }^{272}$

This necessity test has been deemed to be too narrow by opponents of GATS. ${ }^{273}$ This is probably further compounded by the fact that aside from the US-Gambling case, there is still no developing GATS case law that would help to properly determine the scope of this test for GATS. This arguably makes it difficult for States to gauge which are the proper regulatory measures that could ameliorate the effects of the liberalization of the trade in services and eventual privatization, and which do not run afoul the GATS. However, it has been observed that the WTO's Appellate Body has apparently loosened its stance towards the necessity test with respect to its application in the GATT, ${ }^{274}$ which may influence its future application in the context of GATS. Furthermore, there is also the possibility next to that of Article VI $\S 4(b)$ GATS, for States to limit their national treatment obligations in mode 3 through their commitments. ${ }^{275}$ This would arguably give them some room for deciding or not whether essential services such as the provision of water are fully

270 On the question of how to assess when a measure is really necessary to protect legitimate interests and an overview of the relevant jurisprudence of the WTO's dispute settlement system in this regard see 'Necessity Tests' in the WTO, Note by the Secretariat, WTO - Working Party on Domestic Regulation, Doc. No. S/WPDR/W/27, 2 December 2003 (03-6404). The WTO's Appellate Body has further asserted in the only GATS case dealing with 'necessity' until now that the test is similar to the one found in Article XX of GATT. See United States - Measures Affecting the Cross Border Supply of Gambling and Betting Services, Appellate Body Report, 20 April 2005, WT/DS285/AB/R, para. 291. Pointing to the Korea - Beef case the Appellate Body noted that there should be a weighing and balancing involved of the values that are to be protected through the measures. This includes among other things considering how the measures contribute "[...] to the realization of the ends pursued by it[,]" and what is "[...] the restrictive impact of the measure on international commerce." Ibid., para. 306.

271 Ibid., para. 307-309.

272 Ibid., para. 310.

273 S. Lester et al., World Trade Law - Text, Materials and Commentary (Oxford: Hart Publishing, 2008) p. 630.

274 Ibid.

275 See ibid., p. 615-616. See further Adlung, "Public Services and the GATS," p. 479. 
exposed to the international trade system and any expected inconveniences it may bring to securing a fair and equitable provision of these services to consumers.

In spite of the abovementioned concerns, Article XIV GATS does seem to allow States to take measures necessary for the protection of public morals and human health. Regulatory measures protecting the rights to an adequate standard of living (including water and housing), education and health could fall within this provision together with rules guaranteeing the availability, accessibility, adaptability and acceptability ${ }^{276}$ of these basic human rights could fall under the legitimate interests that can be protected through regulation. In other words, States have the right under GATS to set up regulation in the area of environmental services related to the supply of water that is necessary to protect and guarantee these rights, as long as it is not actually meant as a covert trade protectionist measure. On top of this, it should be noted that with respect to the issue of regulation, public services, trade and investment, there appears to be a tendency to bypass GATS altogether. For example, these issues are increasingly being dealt with through bilateral investment treaties (BITs).

In sum, the liberalisation of trade in services does not, in itself, entail the privatization of public services. Moreover, those services that are of a core public nature and are not supplied on a commercial basis or are not competing with one or more service suppliers are exempted from the application of the Agreement. Even in the case where some publicly provided services compete with one or more service suppliers, the States participating in GATS remain free to maintain these services in public hands without privatising them and still allow the parallel provision of private services through opening up access to its market. In other words, States can allow public services to compete with private services without resorting to privatization.

Additionally, GATS would appear to provide enough room for states to come up with regulatory measures to protect a number of human rights, provided that these measures are not actually geared towards trade protectionism. These measures would also apply if states wish to privatise education in order to take further advantage of the liberalised education market. Nevertheless, it should be emphasized that a human rights approach to international trade in general and to the trade in services in particular as advocated by the UN High Commissioner of Human Rights $^{277}$ is indispensable to cope with any potential problems that the liberalisation of the trade in services might bring. In this respect it is also not unthinkable that the

\footnotetext{
276 See Section 3.3.2 infra.

277 Liberalization of the Trade in Services and Human Rights, UN Doc. E/CN.4/Sub.2/2002/9 (18 June 2002).
} 
WTO dispute settlement system in the future will have to take into consideration states' human rights obligations when dealing with trade disputes. ${ }^{278}$

\subsection{Preliminary conclusions}

The participation of private actors in the water utilities sector is not a recent development, but is part of a cycle that involves alternating public and private participation in the sector. The privatization of water utilities can take various forms, the most common of which are (affermage) leases and concessions, while full privatizations (divestitures) are rare. The nature of water utilities as a service of general interest and the natural monopoly aspects it entails, means that only one company will be able to operate a particular water utility, and that this company has a number of public service obligations that transcend the status or ownership of the utility. These universal service obligations should guarantee the affordability, quality and universal and non-discriminatory accessibility to essential water services. However, it is widely agreed even by privatization proponents that the attainment of these obligations makes it necessary to have a good regulatory scheme in place to ensure that the operating company lives up to its contractual and public service obligations. As we shall see in the following section, this fits quite well in the context of human rights obligations ensuing from a number of rights that are potentially affected by the privatization of water utilities. Finally, the issue of GATS and the privatization of water services was briefly considered. Although GATS may provide some incentives to privatize the environmental services related to the provision of water, it is not yet a foregone conclusion that this will happen. WTO Member States have had a lukewarm approach towards liberalizing the trade of environmental services related to water. In addition, although there are some legitimate concerns that GATS rules could hamper the regulatory power of States with respect to the provision of water in deference of an unhindered trade in services, these rules do recognize the importance of regulation. They provide several ways for States to adopt regulatory measures. However, these should not be too trade-restrictive and must be considered as indispensible for protecting certain interests, like human rights. This 'necessity' test is seen as controversial, but arguably provides some leeway for States to protect essential interests.

278 See in this regard E-U. Petersmann, "The 'Human Rights Approach' Advocated by the UN High Commissioner for Human Rights and by the International Labour Organization: Is It Relevant for WTO Law and Policy?," Journal of International Economic Law Vol. 7 (2004), p. 605. 
Chapter VII

\section{The Privatization of Water Utilities and Economic, Social and Cultural Rights}

As noted in the introduction to this chapter, the privatization of public utilities and municipal services raises serious concerns related to the human rights obligations engaged by States in various human rights treaties. In a report presented in 2003 for the UN Sub-commission for the Promotion and Protection of Human Rights dealing with investment, trade and human rights, the UN's High Commissioner for human rights summarized the general problems that privatization may pose for the enjoyment of human rights. ${ }^{279}$ The failed privatization of water provision services in the Bolivian city of Cochabamba and the contentious privatization of water delivery services in Manila, the Philippines, are often presented as examples of how privatization of water utilities have a negative impact on human rights. ${ }^{280} \mathrm{~A}$ former expert of the now defunct UN Sub-commission, Mr. El Hadji Guissé, observed in a report that a number of African States are no longer in the position to guarantee a right to drinking water as a result of the privatization of water supplies. ${ }^{281}$ After these States entered into an agreement with French transnational companies to privatize water supply systems, these multinationals apparently started to sell water required for basic needs at exorbitant prices even though these States seem to receive insignificant royalties from the companies. ${ }^{282}$ According to him, this led to extreme and now endemic poverty in these countries.

Given the controversial nature of the privatization of water utilities, it is necessary to explore how it relates to human rights. Which human rights are particularly affected by the privatization of water utilities and in which way? What are the legal obligations of States in this respect? To answer these questions this section will describe the relevant human rights that may be affected by the privatization of water utilities. These include the right to water, adequate housing and the right to health. Particular attention will be paid to the right to water since its existence is regarded as contentious and since it is possible to argue that a right to access water is of importance to realize the other rights mentioned. This will be followed by an analysis of the legal obligations of States emanating from the right to water as it relates to the privatization of water utilities.

\footnotetext{
279 Human rights, trade and investment, Report of the High Commissioner for Human Rights, UN doc. E/CN.4/Sub.2/2003/9 (2 July 2003), pag. 24.

280 McFarland Sanchez-Moreno and Higgins, "No Recourse: Transnational Corporations and the Protection of Economic, Social and Cultural Rights in Bolivia," p. 1663-1805. See also Rosemann, "Das Menschenrecht auf Wasser unter den Bedingungen der Handelsliberalisierung und Privatisierung: eine Untersuchung der Privatisierung der Wasserversorgung und Abwasserentsorgung in Manila."

281 UN Doc. E/CN.4/Sub.2/2002/10 (25 June 2002), para. 30

282 Ibid.
} 


\subsection{The relationship between the privatization of water utilities and human rights}

According to UNESCO’s 2006 Human Development Report,

"[c]lean water and sanitation are among the most powerful drivers for human development. They extend opportunity, enhance dignity and help create a virtuous cycle of improving health and rising wealth." 283

Access to water can be considered to be of utmost importance for the realization of the right to live with dignity as recognized in the Universal Declaration of Human Rights. The ICESCR has given further shape to this right in Articles 11 and 12 on the right to an adequate standard of living and health respectively. It has been argued that access to water is thus necessary to realize these rights and to prevent poverty. ${ }^{284}$ Access to water is also required in the production of agricultural products and for the preparation of meals. Moreover, running water, water piping and an adequate waste water disposal system or sewerage is necessary to guarantee a proper enjoyment of one's house. It can therefore be stated that activities that affect the access to water in a negative way can threaten the enjoyment of the right to an adequate standard of living including its components: the right to water, food and adequate housing. Since access to clean drinking water is also essential for proper hygiene and the prevention of infectious diseases, activities that affect the access to water can easily also have an effect on the right to health.

Public utilities in the water sector perform very important activities including the production and purification of water, the laying down and maintenance of the network and infrastructure necessary for its distribution and, the concomitant sanitary activities required to deliver safe and clean water to the end consumer and dispose of waste water. As stated in the previous section, these activities amount to services of general interest since they are aimed at attaining public policy objectives. A good or poor performance of these activities can also have direct effects on the rights discussed above, the protection and promotion of which can also be regarded as a public policy objective. The UN Committee on Economic Social and Cultural Rights (CESCR) has been keen to emphasize the importance of access to clean drinking water in relationship to the right to an adequate standard of living and the right to health. This has been made clear in the Committee's general observations on a number of State reports and its General Comment No. 15 on the right to water. ${ }^{285}$

283 "Human Development Report 2006: Beyond Scarcity: Power, poverty and the global water crisis," p. 5.

284 See M. Langford, "Ambition That Overleaps Itself? A Response to Stephen Tully's Critique of the General Comment on the Right to Water," Netherlands Quarterly of Human Rights Vol. 24 (2006), p. 433-459.

285 General Comment No. 15 (2002) The right to water (arts. 11 and 12 of the International Covenant on Economic, Social and Cultural Rights), UN Doc. E/C.12/2002/11 (20 January 2003). 
While reviewing the periodic reports submitted by States under the ICESCR, the Committee has on various occasions noted its concern about the lack of access to basic services such as sanitation and potable water. ${ }^{286}$ The Committee's concerns appear to be rooted in the link between health and the availability of both clean water and the functioning of a proper wastewater disposal system or sewerage. For example, while examining the Solomon Islands' initial report, the CESCR noted its concern that, "[...] many communities in the State party do not have access to safe water and proper sanitation facilities, which creates severe health risks to them."287

The relationship between the right to water and the impact of the availability and quality of water on the right to health has been widely documented. Studies by the WHO and other international organizations highlight the relationship between water and (public) health. ${ }^{288}$ There are a number of ways in which water and water management can be linked to health. Water can, for example, be the medium through which diseases can be spread (as a conveyance medium of disease causing organisms or materials/pollutants or as the habitat of organisms that can spread diseases such as malaria). ${ }^{289}$ Water can also play a role as a health promoting mechanism when used for purposes of hygiene. ${ }^{290} \mathrm{~A}$ WHO study, notes for example

See for example Concluding Observations, Mexico, CESCR UN Doc. E/1994/23, para. 234, where the Committee noted its concern "[...] about the fact that a large segment of the population of Mexico has to endure inadequate living and housing conditions, without access to basic services such as sanitation and potable water." The Committee repeated these concerns with regard to the lack of access to water after examining Mexico's third periodic report in 2000 (See Concluding Observations, Mexico, CESCR UN Doc. E/2000/22, para. 389). The Committee has repeatedly uttered similar concerns regarding the access to or availability of clean water in the Concluding Observations of the following countries: El Salvador, CESCR UN Doc. E/1997/22, para. 179; Dominican Republic, CESCR UN Doc. E/1997/22, para. 235; Azerbaijan, CESCR UN Doc. E/1998/22, para. 340; Cameroon, CESCR UN Doc. E/2000/22, para. 336; Bolivia, CESCR UN Doc. E/2002/22, para. 268; Brazil, CESCR UN Doc. E/C.12/1/Add.87 (2003), para. 33; China, CESCR UN Doc. E/2006/22 (2005), para. 188. With respect to China, the Committee recommended "[...] that the State party undertake effective measures to guarantee access to safe drinking water to all persons under its jurisdiction." Ibid., para. 191.33. See for example, WHO-UNICEF, "Basic Needs and the Right to Health," in Water for People Water for Life: The United Nations World Water Development Report, Barcelona: UNESCOWorld Water Assessment Program (2003), p. 102-108, in which the close relationship between water, sanitation and hygiene are seen as intertwined determinants of the water, ill-health and poverty spectrum. See also G. Howard and J. Bartram, "Domestic Water Quantity, Service, Level and Health," WHO, WHO/SDE/WSH/03.02, 2003, in which a comparison of numerous studies related to water and water transmitted diseases such as diarrhea, malaria, typhoid, hepatitis and trachoma, suggests that the availability and service level of water can have an impact on public health. Additional links between water availability, quality, water related diseases and health can be found in the WHO's Guidelines for Drinking Water quality (these can be found on the WHO's website at <www.who.int/water_sanitation_health/dwq/guidelines/ en/>,last visited on 30 December 2008). 
that the, "[...] need for domestic water supplies for basic health protection exceeds the minimum required for consumption (drinking and cooking), ${ }^{291}$ It also points to other studies that suggest that poor hygiene leading to diseases may partly be the result of a lack of sufficient quantity of domestic water supply and that an increase in water quantities may even help to prevent infectious diseases. ${ }^{292}$

Several UN treaty-monitoring bodies have also paid attention to this issue. The CESCR, the Committee on the Elimination of All Forms of Racial Discrimination (CERD) and the Committee on the Rights of the Child (CRC) have all acknowledged the link between the availability of water and its effects on (public) health while reviewing the States' periodic reports submitted under the reporting obligations of the respective covenants. In the concluding observations regarding Iraq's third periodic report, for example, the CESCR noted its concern that, "[...] with the destruction of parts of the infrastructure in the State party, the non-availability of safe drinking water has led to widespread contaminated water and related health problems, such as waterborne and diarrheal diseases and cholera." 293 Although the Committee has not expressly noted so in General Comment No. 14 on the right to health, it is suggested that in view of the relationship between clean water and the right to health these elements require the State to ensure that privatized water utilities provide water in such a way that it is available and accessible (and therefore affordable and within the reach of the most vulnerable sectors of society) if the enjoyment of the right to health is to be achieved in a meaningful way. Additionally the State has to guarantee that water provided by privatized utilities is of a quality fit for consumption and that it does not represent a significant risk to human health. ${ }^{294}$ These obligations imposed upon State parties are necessary in order to guarantee that an appropriate level of health under the ICESCR. ${ }^{295}$

On its part, the CERD placed some emphasis on the poor access to clean drinking water and adequate sanitation as obstacles to the enjoyment of the right to health of the Roma population during the examination of the report submitted by Slovakia. ${ }^{296}$ During the examination of the Central African Republic's initial report, the CRC

\footnotetext{
291 Howard and Bartram, "Domestic Water Quantity, Service, Level and Health,” p. 9.

292 Ibid. p. 10-15.

293 Concluding Observations, Iraq, ICESCR, UN Doc. E/C.12/1/Add.17 (12 December 1997), para. 22. See for another example the CESCR's concluding observations with regard to the report of the Solomon Islands noted above in paragraph 0.

294 In this respect it should be pointed out that some studies recognize that a 'zero-risk' scenario is not realistic or achievable and that therefore there is a need to define what are tolerable risks with regard to water quality. Howard and Bartram, p. 8.

295 In the opinion of this author, the elements of accessibility, affordability and quality should also apply to water provided by privatized utilities that is meant for irrigation and food preparation as these activities can also validly be seen as underlying preconditions of the right to health.

296 Concluding Observations, Slovakia, CERD, UN Doc. CERD/C/304/Add.110 (1 May 2001), para. 14.
} 
expressed its concern at, " $[\ldots]$ at the very high mortality rate among young children and the high maternal mortality rate, the high level of serious illnesses, problems related to malnutrition among children and mothers, low immunization rates and poor access to safe drinking water." 297

It follows from this relationship between water, water transmitted diseases, hygiene and health that the accessibility and quality of water provided by privatized water utilities and services can play an important role in implementing the rights to water and health or impairing them when the privatization of these utilities is not properly realized. Of course, the same holds true for publicly owned utilities.

A similar relationship exists between the right to food and the availability and quality of water and the privatization of water utilities. Water is necessary for the preparation of food and for the irrigation of agricultural products used for food consumption. Additionally, water is also an important if not essential element of nutritional value. Water is therefore necessary for producing food and preventing malnutrition. ${ }^{298}$ The CESCR and the Committee on the Rights of the Child have acknowledged this relationship. While considering the Russian Federation's third periodic report, the CESCR noted that, "[t]he question of an acceptable and adequate food supply is linked to a seriously polluted environment and the lack of investment in infrastructure for the maintenance and improvement of the water supply."299 Equally, the CRC has associated the prevalence of malnutrition in a number of countries together with the limited access to safe water and adequate sanitation. ${ }^{300}$ The Special Rapporteur on the Right to Food, Jean Ziegler, has also noted the relationship between water and food ${ }^{301}$ and in a number of his reports has expressed

297 Concluding Observations, Central African Republic, CRC, UN Doc. CRC/C/100 (14 November 2000), para. 451. Emphasis by $A H W$. The CRC has expressed similar concerns in the concluding observations of other State reports by noting a link between children's health problems and insufficient access to safe/clean water and sanitation. See Concluding Observations, Honduras, CRC, UN Doc. CRC/C/15/Add.24 (24 October 1994), para. 15; Nigeria, CRC, UN Doc. CRC/C/15/Add.61 (30 October 1996), para. 16; Togo, CRC, UN Doc. CRC/C/15/Add.83 (10 October 1997), paras. 23 and 46; Yemen, CRC, UN Doc. CRC/C/15/Add.102 (10 May 1999), para. 24; Benin, CRC, UN Doc. CRC/C/15/Add.106 (24 August 1999), para. 24; Chad, CRC, UN Doc. CRC/C/15/Add.107 (24 August 1999), para. 27; Vanuatu, CRC, UN Doc. CRC/C/15/Add.111 (10 November 1999), para. 18; South Africa, CRC, UN Doc. CRC/C/15/Add.122 (23 February 2000), para. 29; Dominican Republic, CRC, UN Doc. CRC/C/15/Add.150 (21 February 2001), paras. 35 and 36; and Sudan, CRC, UN Doc. CRC/C/15/Add.190 (9 October 2002), paras. 43 and 44.

This aspect of the availability has close relationship with the right to health, which will be discussed below in relationship with the privatization of water utilities.

299 Concluding Observations, Russian Federation, ICESCR, UN Doc. E/C.12/1/Add.13 (20 May 1997), para. 38.

300 See Concluding Observations of Micronesia, CRC, UN Doc. CRC/C/15/Add.86 (4 February 1998), para. 19 and Maldives, CRC, UN Doc. CRC/C/15/Add.91 (5 June 1998), para. 19.

301 See Report of the Special Rapporteur on the Right to Food, Jean Ziegler, UN Doc. E/ CN.4/2001/53 (7 February 2001), para. 32. 
his concerns with respect to the effects of the privatization of water on the right to food..$^{302}$ In so far as the privatization of water related utilities either hinders or facilitates the access to water for the production of food and/or the irrigation of agricultural goods, it can be affirmed that there exists a nexus between the privatization of water related utilities and the right to food.

With respect to the relationship between the right to adequate housing and the privatization of water utilities, the following can be pointed out. The CESCR has considered the link between the right to (adequate) housing and the availability of utilities and essential services such as water and electricity during the examination of various state reports. The Committee has, for example, expressed its concern about the fact that a large segment of the population in Mexico had to, "[...] endure inadequate living and housing conditions, without access to basic services such sewage and potable water." 303 The Committee's views regarding the availability of water, sewage and electricity and its relationship with the right to adequate housing have been further acknowledged in the concluding observations with respect to reports submitted by the Dominican Republic, ${ }^{304}$ Colombia, $^{305}$ Nigeria $^{306}$ and Kyrgyzstan. ${ }^{307}$ The Committee's concerns denote the importance of the availability

302 See Report of the Special Rapporteur on the Right to Food, Jean Ziegler, UN Doc. E/ CN.4/2002/58 (10 January 2002), para. 16 and its addendum on a mission to Niger, UN Doc. E/ CN.4/2002/58/Add.1 (23 January 2002), paras. 50 and 51. More recently, the Special Rapporteur has been concerned of the effects of privatization of water utilities on the poor. See Report of the Special Rapporteur on the Right to Food, Jean Ziegler, E/CN.4/2004/10 (9 February 2004), paras. 39 and 40.

303 Concluding Observations Mexico, ICESCR, UN Doc. E/C.12/1993/16 (5 January 1994), para. 9. This concern was repeated in the subsequent examination of Mexico's report in 1999 when the Committee noted its concern about the "[...] unsatisfactory condition of a high percentage of the housing stock, especially in rural areas where a significant number of dwellings lack electricity, adequate sewage disposal and piped water." Concluding Observations Mexico, ICESCR, UN Doc. E/C.12/1/Add.41 (8 December 1999), para. 27.

304 See Concluding Observations, Dominican Republic, ICESCR, UN Doc. E/C.12/1994/15 (19 December 1994), para. 24, were the Committee recommended that in order to achieve progressively the right to adequate housing, the State party should (was requested) provide, to the maximum of available resources, basic services such as water, electricity, drainage, sanitation, and refuse disposal to dwellings. These measures are to be undertaken with full respect for the law. A similar obligation applies regarding the provision of alternative housing to persons who have been evicted or relocated. Ibid., para. 11.

See Concluding Observations Colombia, ICESCR, UN Doc. E/1996/22 (1995) 41 at paras. 200, where the Committee noted that the Government should improve the supply of housing, especially low-cost housing for the benefit of the poorest sectors, in urban areas and also in rural areas, and allocate resources to provide the entire population with drinking-water and sewage services. Similar remarks were made in the Concluding Observations for EL Salvador's initial report, ICESCR, UN Doc. E/C.12/1/Add.4 (28 May 1996), para. 33. 2000), para. 21, were the Committee expressed its concern that the right to adequate housing is hampered by, inter alia, the insufficient provision of sanitation and potable water. 
of these utilities for the enjoyment of the right to (adequate) housing. This has been further emphasized in General Comment No. 4 on the right to adequate housing, in which the CESCR observed that,

"[...] the right to housing should not be interpreted in a narrow or restrictive sense which equates it with, for example, the shelter provided by merely having a roof over one's head or views shelter exclusively as a commodity. Rather it should be seen as the right to live somewhere in security, peace and dignity." 308

In particular, the aspect of the right to live somewhere in dignity is important in the context of the present discussion of the privatization of utilities such as water and electricity. Although the adequacy of housing, as the CESCR states in General Comment No. 4, is determined by social, economic, cultural, climatic and ecologic factors among others, ${ }^{309}$ the Committee is of the opinion that it is possible to identify certain aspects of the right to adequate housing that should be taken into account. Among these aspects, the Committee mentions the availability of certain services and facilities such as safe drinking water, energy for cooking, heating and lighting, sanitation and washing facilities, refuse disposal, and site drainage. . $^{310}$

It is therefore possible to state that any activity that has an impact on how water utilities perform, such as their privatization, can also have a serious impact on the enjoyment of these rights. A study commissioned by the Inter American Development Bank has acknowledged that the "[p]rivatization of infrastructure can have a direct impact on consumers by affecting their access to the network, the price they pay for the service, and the quality of the service received." 311 With respect to the rights to water, food and health, it can be pointed out that, the privatization of water related utilities could have an impact on their enjoyment in so far as privatization has an effect on the access, price and quality of water. This is due to the nature of the relationship between water, food preparation and health. With regard to the right to housing, the privatization of water utilities can have consequences on the quality and adequacy of housing.

308 See General Comment No. 4 (1991) The right to adequate housing (Art. 11 (1)), CESCR, contained in UN Doc. E/1992/23 (13 December 1991), para. 7. For a more in-depth discussion of the right to adequate housing see I. Westendorp, Women and Housing: Gender Makes a Difference (Antwerp: Intersentia, 2007).

309 See General Comment No. 4, para. 8. This would appear to hold true also to the concept of dignity in light of the right to adequate housing.

310 Ibid.

311 D. McKenzie and D. Mookherjee, "Distributive Impact of Privatization in Latin America: An Overview of Evidence From Four Countries," Inter American Development Bank - Universidad de las Américas - Puebla, (2002), p. 13. 


\subsection{The right to water: definition and normative content}

Having established the relationship between privatization of water utilities and certain economic, social and cultural rights, the present study will now turn to examine the right to water, as the effects on its enjoyment is usually brought up with regard to the discussion of privatization of water utilities. ${ }^{312}$ Before analyzing the legal obligations flowing from the right to water as it relates to the privatization of water utilities, this section will first provide a definition of this right. This definition is based on the current legal views of various international human rights monitoring bodies that have dealt with this right. Having provided a brief definition of the right to water, its normative content will be further examined.

\subsubsection{Definition of the right to water}

Officially, the right to water as an independent right, such as the right to health or the prohibition of torture, is not expressly codified in the extensive body of (international) human rights treaties. With the notable exception of Article $14 \S 2$ of the Convention on the Elimination of All Forms of Discriminations Against Women, and Article $24 \$ 2$ of the Convention on the Rights of the Child, international human rights treaties do not explicitly contain a provision that guarantees the right to water. ${ }^{313}$ Nevertheless, States have frequently acknowledged the vital importance of water in many international summits and declarations. ${ }^{314}$ In Europe, various States have ratified or signed the Protocol on Water and Health to the 1992 Convention on the Protection and Use of Transboundary Watercourses and International Lakes, which recognizes the importance of water as it relates to human health and provides inter alia that the Protocol's States Parties shall,

"[...] in particular, take all appropriate measures for the purpose of ensuring:

(a) Adequate supplies of wholesome drinking water which is free from any microorganisms, parasites and substances which, owing to their numbers or concentration,

312 See Report of the independent expert on the issue of human rights obligations related to access to safe drinking water and sanitation, Catarina de Albuquerque, Human Rights Council, UN Doc. A/HRC/15/31 (29 June 2010), paras. 14-16.

313 P.H. Gleick, “The Human Right to Water," Water Policy Vol. 1 (1999), p. 487-503.

314 See for example the preamble Mar del Plata Action Plan of the United Nations Water Conference; Agenda 21, Report of the United Nations Conference on Environment and Development, Rio de Janeiro, 3-14 June 1992, UN Doc. A/CONF.151/26/Rev.1, (Vol. I and Vol. I/Corr.1, Vol. II, Vol. III and Vol. III/Corr.1), vol. I: Resolutions adopted by the Conference, resolution 1, annex II, para. 18.47; Principle No. 3, The Dublin Statement on Water and Sustainable Development, International Conference on Water and the Environment (A/CONF.151/PC/112); Principle No. 2, Program of Action, Report of the United Nations International Conference on Population and Development, Cairo, 5-13 September 1994, chap. I, resolution 1, annex; Recommendation (2001) 14 of the Committee of Ministers to Member States on the European Charter on Water Resources, paras. 5 and 19. See also Langford, "Ambition That Overleaps Itself? A Response to Stephen Tully's Critique of the General Comment on the Right to Water," p. 445. 
constitute a potential danger to human health. This shall include the protection of water resources which are used as sources of drinking water, treatment of water and the establishment, improvement and maintenance of collective systems[...]"315

Additionally, international organizations, academics and NGO's have also highlighted the importance of water in society and its relationship with other rights and have pointed out that water is an essential good that should be available to all. ${ }^{316}$

With the adoption of its General Comment No. 15 on the right to water, the CESCR has formally consolidated the right to water as a component of the right to an adequate standard of living as guaranteed in Article 11 ICESCR. ${ }^{317}$ Building up

315 Article $4 \S 2$ of the Protocol on Water and Health to the 1992 Convention on the Protection and Use of Transboundary Watercourses and International Lakes, Economic and Social Council, Economic Commission for Europe-World Health Organization's Regional Office for Europe, UN Doc. MP.WAT/2000/1 EUR/ICP/EHCO 020205/8Fin (18 October 1999).

316 See for example WHO-UNICEF, "Basic Needs and the Right to Health.”, Decision 2/104 on Human Rights and Access to Water, Human Rights Council, 27 November 2006, and Report of the United Nations High Commissioner for Human Rights on the scope and content of the relevant human rights obligations related to equitable access to safe drinking water and sanitation under international human rights instruments, Human Rights Council, UN Doc. A/HRC/6/3 (16 August 2007). See also Gleick, "The Human Right to Water," p. 487-503; T. Kiefer and C Brölmann, "Beyond State Sovereignty: The Human Right to Water," Non-State Actors and International Law Vol. 5 (2005), p. 183-208; A. Kok and M. Langford, "The Right to Water," in Socio-Economic Rights in South Africa, ed. D. Brand and C. Heyns, Pretoria: Pretoria University Law Press (2005), p. 191-208. See further Manual on the Right to Water and Sanitation - A tool to assist policy makers and practitioners develop strategies for implementing the human right to water and sanitation, Centre on Housing Rights and Evictions (COHRE), Geneva, 2008.

317 General Comment No. 15 (2002), the Right to Water (Arts. 11 and 12 of the International Covenant on Economic, Social and Cultural Rights), CESCR, UN Doc E/C.12/2002/11 (20 January 2003). The General Comment asserts the legal basis for the right to water, defines its normative content, identifies the obligations that apply to States (and to a certain extent to nonState actors) with regard to this right and describes examples of possible violations to the right. In an article criticizing General Comment No. 15, Tully has, however, argued that the Committee on Economic, Social and Cultural Rights was wrong in distilling a new right from the text of Article 11 IESCR. In his opinion this should happen through an amendment to the Convention. In addition, he also argued that a right to water would not offer a tangible remedy to lack of access to water or to the conduct of multinational water companies. See S. Tully, "A Human Right to Access Water? A Critique of General Comment No. 15," Netherlands Quarterly of Human Rights Vol. 23 (2005). p. 35-63 Langford, on the other hand, has countered that an amendment is not really necessary as the right to water can be read in the context of the content of the Article itself and the related rights found therein, as well as the wide recognition of the right to water under international law. In addition, the travaux préparatoires of the IESCR appear not reveal any opposition to a potential inclusion of the right to water by the Committee. See Langford, "Ambition That Overleaps Itself? A Response to Stephen Tully's Critique of the General Comment on the Right to Water." 
on its analysis regarding the necessity to provide drinking water to people in various concluding observations to State reports ${ }^{318}$ the Committee declared that,

\begin{abstract}
"The human right to water entitles everyone to sufficient, safe, acceptable, physically accessible and affordable water for personal and domestic uses. An adequate amount of safe water is necessary to prevent death from dehydration, to reduce the risk of water-related disease and to provide for consumption, cooking, personal and domestic hygienic requirements." 319
\end{abstract}

According to General Comment No. 15, Article 11 ICESCR provides a legal basis for the right to water even though the right as such is not explicitly mentioned in that article. The General Comment notes that Article 11 ICESCR provides a number of rights that emanate from, and are indispensable for, the realization of the right to an adequate standard of living, "[...] including adequate food, clothing and housing, and to the continuous improvement of living conditions." 320 The Comment asserts that the use of the word 'including' indicates that this list of rights is not intended to be exhaustive, and since the right to water is clearly necessary to guarantee an adequate standard of living, it can be concluded that the right to water is implicitly embedded in Article 11 ICESCR. ${ }^{321}$

318 The concern for the availability of clean drinking water or the lack thereof has moved the CESCR to frequently recommend States to "[...] allocate resources to provide the entire population with drinking-water and sewerage services [...]," (Concluding Observations, Colombia, CESCR UN doc. E/1996/22, para. 200), and to ensure that safe drinking water is made available to the rural population and those living in deprived urban areas (Concluding Observations, Dominican Republic, CESCR UN Doc. E/C.12/1/Add.16 (12 December 1997), para. 40). The Committee has noted that this goal could also be achieved by urgently seeking international cooperation and assistance. See in this respect, Concluding Observations, Solomon Islands, CESCR, UN Doc. E/C.12/1/Add.84 (2002), para. 26. The Committee has also urged States to improve the access to water for certain indigenous populations. See Concluding Observations, Panama CESCR, UN Doc. E/2002/22, para. 466. With respect to China, the Committee recommended "[...] that the State party undertake effective measures to guarantee access to safe drinking water to all persons under its jurisdiction." China, CESCR UN Doc. E/2006/22 (2005), para. 191. Other UN treaty monitoring bodies have followed suit. See the concluding observations of the CERD on its concerns relating to the (lack of) availability of water and electricity for indigenous peoples in Costa Rica (UN Doc. CERD/C/60/CO/3 (2002), para. 11), the Concluding Observations of the CEDAW urging Cameroon to ensure the participation of decisions to guarantee access to drinking water for rural women in that country (CEDAW UN Doc. A/55/38 (2000), para. 62), and the CRC's concerns regarding the access to safe drinking water which it deemed responsible for 40 per cent of the deaths of children under five expressed in the Concluding Observations to Sudan's second periodic report as well as its recommendations to improve the access of safe drinking and adequate sanitation in that country (CRC UN Doc. CRC/C/121 (2002), paras. 262 and 263).

321 UN Doc. E/C.12/2002/11, para. 3. 
Additionally, and as already acknowledged in the previous section, General Comment No. 15 observes that the right to water is closely related to the rights to food and housing and the right to the highest attainable standard of health as guaranteed in Article 12, para. 1 ICESCR. The General Comment also notes that the right to water has close ties to other rights, especially the right to life and human dignity. ${ }^{322}$ General Comment No. 15 reinforces this view with references to a number of particular obligations of States to ensure the provision of water under the already mentioned Article 14 \$2 CEDAW (guaranteeing the right of women to enjoy adequate living conditions) and Article $24 \$ 2 \mathrm{CRC}$ (requesting State parties to combat children related diseases and malnutrition through the provision of, inter alia, clean drinking-water). ${ }^{323}$

The idea of access to drinking water as a human right was strengthened in the summer of 2010 through the adoption by the UN's General Assembly of a resolution on the human right to water and sanitation, which recognizes the "[...] right to safe and clean drinking water and sanitation as a human rights that is essential for the full enjoyment of life and all human rights[...]"324 Similarly, and deriving from the work of the CESCR in General Comment No. 15 as well as recalling the General Assembly's resolution on the right to water, the Human Rights Council adopted a resolution in October of 2010 affirming the human right to safe drinking water and sanitation, which "[...] is derived from the right to an adequate standard of living and inextricably related to the right to the highest attainable standard of physical and mental health, as well as the right to life and human dignity." 325 Although these resolutions are not legally binding, they provide some arguments that may allow us to take a leap of faith for recognizing the existence of the right to water implied within a number of codified rights such as the right to an adequate standard of living. Having established that there is some consensus with regard to the existence of a right to water, it is now possible to discuss its normative content.

\subsubsection{Normative content of the right to water}

In order to provide an overview of the normative content of the right to water, it is useful to follow the approach that the CESCR has been applying in its attempts to further delineate the substance of the rights guaranteed in the ICESCR. In

322 Ibid. With relationship to the right to food, the Committee additionally noted in General Comment No. 15 the importance of ensuring sustainable access to water for agriculture in order to realize the right to adequate food and pointed out to General Comment No. 12 on the right to adequate food. Ibid., para. 7. Ibid., para. 4.

64/292 The human right to water and sanitation, Resolution adopted by the General Assembly, UN Doc. A/RES/64/292 (3 August 2010), para 1.

$15 / 9$ Human rights and access to safe drinking water and sanitation, Resolution adopted by the Human Rights Council, UN Doc. A/HRC/RES/15/9 (6 October 2010), para. 3. 
determining the normative content of these rights, the Committee denotes that each right contains certain freedoms and entitlements defining the right's normative content. These freedoms and entitlements are composed of a number of interrelated elements, the application of which helps ensure the enjoyment of a specific right. These elements or factors are availability, quality and accessibility. ${ }^{326}$

General Comment No. 15 on the right to water notes that the freedoms defining the normative content of the right to water include the right to maintain access to existing water supplies necessary for the right to water, and the right to be free from interference (this includes being free from arbitrary disconnections or contamination of water supplies). ${ }^{327}$ The entitlements include a right to a system of water supply and management. This system should provide equal opportunity for people to enjoy the right to water. ${ }^{328}$ In any case, the elements of the right to water must be adequate for human dignity, life and health, in accordance with Articles 11, §1, and $\$ 12 .{ }^{329}$ In addition, the Committee notes in General Comment No. 15 that water should not be primarily treated as an economic good, but should also be treated as a social and cultural good. ${ }^{330}$

In order to guarantee the freedoms and entitlements of the right to water, General Comment No. 15 emphasizes that the availability, quality and accessibility of water should apply under all circumstances. ${ }^{331}$ According to General Comment No. 15, availability requires that, "[t]he water supply for each person must be sufficient and continuous for personal and domestic uses." 332 Quality entails that "[t]he water required for each personal or domestic use must be safe, therefore free from microorganisms, chemical substances and radiological hazards that constitute a threat to a person's health." 333 Accessibility in turn requires that water be physically and economically accessible on a non-discriminatory basis to everyone and that people have access to information related to water. Physical accessibility means that water and water related services or facilities should be within safe physical reach for all

326 See also Salman and McInerney-Lankford, The Human Right to Water: Legal and Policy Dimensions, p. 54-55.

327 See General Comment No. 15, para. 10.

328 Ibid.

329 Ibid., para. 11.

330 Ibid.

331 Ibid., para. 12.

332 According to the General Comment these uses ordinarily include drinking, personal sanitation, washing of clothes, food preparation, personal and household hygiene. Additionally, the quantity of water available for each person should correspond to World Health Organization (WHO) guidelines. Under some circumstances, some individuals and groups may also require additional water "due to health, climate, and work conditions [...]" Ibid.

333 The General Comment notes that the quality of water also requires water to be of an acceptable color, odor and taste for each personal or domestic use. Ibid. 
sections of the population. ${ }^{334}$ General Comment No. 15 notes in this respect that "[s]ufficient, safe and acceptable water must be accessible within, or in the immediate vicinity, of each household, educational institution and workplace."335 Economic accessibility requires that water and water related services are affordable to everybody. ${ }^{336}$ According to General Comment No. 15 this means that " $[\mathrm{t}] \mathrm{he}$ direct and indirect costs and charges associated with securing water must be affordable, and must not compromise or threaten the realization of other Covenant rights." ${ }^{337}$ This does not necessarily entail that people are entitled to free water, ${ }^{338}$ but that water has to be affordable. Thus, efforts are required to ensure that, for example, poor and vulnerable sectors of society are not shut off from accessing and using water because access and usage charges are too expensive for them. It also means that the affordability of water and related services has to be such that it does not reduce any person's capacity to acquire other essential goods and services such as food, housing, health or education. ${ }^{339}$ The non-discriminatory aspect of accessibility requires that water and water related services are accessible to all, including the most vulnerable or marginalized sectors of society without discrimination. ${ }^{340}$ Finally, accessibility demands that people have the right to seek, receive and impart information related to water issues. ${ }^{341}$ Arguably, the latter aspect demands that people should be involved and consulted on decisions affecting their access to water and water services. The characteristics of these factors, availability, quality and accessibility - in particular physical, economical and non-discriminatory accessibility - amount in fact to what is otherwise known as universal service obligations, which as discussed in section 2.6.4.

According to General Comment No. 15, the right to water applies to everyone, but special consideration should be given to groups that might be particularly affected by violations to the right to water. These groups include women, children, minority groups, indigenous people and people living in rural and deprived urban areas. ${ }^{342}$

334 Ibid. For a concrete example on this aspect see the Concluding Observation to Cameroon's initial report where the CESCR called upon the State party to "[...] make safe drinking water accessible to the entire population." CESCR, E/C.12/1/Add.40 (8 December 1999), para. 40. See also the Concluding Observations to the report by Serbia and Montenegro recalling the "[...] State party's obligation to ensure access to safe drinking water within, or in the immediate vicinity of each household." Serbia and Montenegro, ICESCR, UN Doc. E/2006/22 (2005) 41, para. 319. 
These groups should be consulted with and actively involved in the decision making process related to water issues. Having discussed the definition and normative content of the right to water, it is now time to examine the obligations under this right and their relationship with privatization of water utilities.

\subsection{Scope of obligations under the right to water}

Since 1990, the Committee has developed a set of typologies of obligations that illustrate the nature of the duties imposed on State parties to the ICESCR. Starting with General Comment No. 3 on the nature of States parties' obligations, ${ }^{343}$ the Committee has clarified the general obligations flowing from Part II of the ICESCR and applicable to all the rights in the Covenant. Later, the CESCR adopted a tripartite set of specific legal obligations originally developed by Shue and Eide. ${ }^{344}$ These obligations stem from the substantive rights in Part III of the Covenant and impose duties to respect, protect and fulfill. More recently, the Committee has supplemented the tripartite approach with another somewhat different method of looking at the Covenant's obligations: the so-called core obligations approach which specifies the duties to ensure the realization of the minimal essential levels of each right to the list of obligations. ${ }^{345}$ All these approaches tackle the obligations question from a somewhat different perspective but all appear to be closely linked to the elements composing the normative content of the rights (accessibility, availability and quality). In the following paragraphs these obligations will be examined from the context of privatization and the right to water.

\subsubsection{General obligations}

Part II of the ICESCR and more specifically, Article 2 imposes on State parties to the Covenant a number of obligations of a general nature, which may appear to be vague at first sight, but are nevertheless deemed necessary for progressively achieving the full realization of the rights recognized in the Covenant. ${ }^{346}$ The notion that the progressive realization of the rights guaranteed in the ICESCR is of a

seekers, internally displaced people, prisoners and people facing difficulties with physical access to water such as older persons, persons with disabilities, groups living in disaster areas, or arid or drought stricken areas. Ibid., para. 16.

343 General Comment No. 3 on the nature of States parties' obligations (art. 2, para. 1, of the Covenant) contained in UN Doc. E/1991/23.

344 See Chapter III, Section 4.1.3 on the development of the tripartite set of legal obligations.

345 For an analysis of the problems surrounding the applicability of the concept of minimum core content and core obligations see K.G. Young, "The Minimum Core of Economic and Social Rights: A Concept in Search of a Content " Yale Journal of International Law Vol. 33 (2008), p. $113-175$.

346 Article 2 \$1 ICESCR reads "Each State Party to the present Covenant undertakes to take steps, individually and through international assistance and co-operation, especially economic and technical, to the maximum of its available resources, with a view to achieving progressively the 
programmatic nature that does not impose any real legal obligations on States has gradually been abandoned. ${ }^{347}$ It has been replaced by a more strict conception which acknowledges that Article 2 imposes duties on the State considerably limiting their discretion with regard to the implementation of the Covenant and requiring its immediate implementation. ${ }^{348}$

As noted above, Article 2, $\$ 1$ and $§ 2$ ICESCR imposes a set of (general) obligations on the State that are to be carried out immediately. The general obligations that arise out of the right to water oblige the State to take steps without delay to implement this right to the maximum of its available resources. According to General Comment No. 3, these steps must be deliberate, concrete and targeted. ${ }^{349}$ Sepúlveda rightly notes in this respect that, while the term 'to the maximum of its available resources,' does not mean that the State should devote all its resources for the realization of these rights, it does limit the State's freedom to allocate these resources. The State has a duty to allocate these resources in an effective and efficient way. ${ }^{350}$ This could imply that a State that has engaged in the privatization of water utilities should be mindful of allocating its resources in such a way that the privatization does not harm the enjoyment of the rights guaranteed by the ICESCR. Additionally, Sepúlveda observes that these general obligations require the State to take an active role to prevent and protect individuals against abuses of these rights by private actors. ${ }^{351}$ This would naturally also include abuses of these rights by privatized utilities.

Additional general obligations include the duty to guarantee that these rights are enjoyed without discrimination of any kind. ${ }^{352}$ From the perspective of the

full realization of the rights recognized in the present Covenant by all appropriate means, including particularly the adoption of legislative measures."

347 Sepúlveda, The Nature of the Obligations under the International Covenant on Economic, Social and Cultural Rights, p. 311-313.

348 Ibid., p. 312. See in general, General Comment No. 3 for an outline of the nature of the general obligations that emanate from the ICESCR. The Limburg Principles on the Implementation of the International Covenant on Economic, Social and Cultural Rights, a set of principles drafted by a group of experts in the mid 1980's have provided further guidance on the nature of the 'progressive realization' requirement. According to the Limburg Principles, the 'progressive realization' obligation, "[...] requires States parties to move as expeditiously as possible towards the realization of the rights." States have the obligation to immediately begin to take steps to fulfill their obligations under the ICESCR and some obligations, such as the prohibition of discrimination of Article 2 (2) require immediate implementation. For a full discussion on the nature of the obligations related to Article 2 ICESCR see ibid., p. 313-365. General Comment No. 3, para. 2.

350 Sepúlveda, The Nature of the Obligations under the International Covenant on Economic, Social and Cultural Rights, p. 315.

351 Ibid., p. 314. See below for a more thorough analysis of these specific legal obligations including the obligations to respect, protect and fulfill.

352 Article 2 (2) ICESCR. 
privatization of water utilities, this could entail that the State has a duty to ensure that the outcome of this privatization does not result in discriminatory practices between social or ethnic groups. This could be the case, for example, if ethnic groups living in rural areas are denied the access to water services to which they are entitled. Additionally, the CESCR has noted that the State should not take retrogressive measures that endanger the achievements realized for the enjoyment of the economic, social and cultural rights such as the rights to water, food, housing and health. ${ }^{353}$ Therefore, if a State party to the ICESCR chooses to privatize its public utilities, it is under an obligation to ensure that this privatization does not result in diminishing the enjoyment of these rights that have been previously realized.

\subsubsection{Specific obligations of the right to water}

General Comment No. 15 states that like any other human right, the right to water imposes three types of obligations on State Parties to the ICESCR. ${ }^{354}$ These are the obligations to respect, protect, and fulfill, which have already been discussed in Chapter III. The obligation to respect as discussed in General Comment No. 15 is mainly geared towards requiring States to refrain from interfering directly or indirectly with the enjoyment of the right to water. ${ }^{355}$ This essentially negative obligation requires States not to engage in practices or activities that deny or limit equal access to adequate water. ${ }^{356}$

Put in terms of the topic of this Chapter, the obligation to respect would entail that States have to be careful not to implement water utilities privatization plans, contracts, or legislation if these are going to have adverse results on the enjoyment of the right to water. ${ }^{357}$ Thus, the legislative framework pertaining to water privatization has to avoid allowing arbitrary or unjustified disconnection from the

353 The CESCR has generally pointed towards these obligations in the individual general comments dealing with specific rights. See General Comment No. 12, para. 14; General Comment No. 14, paras 30-32; General Comment No. 15, paras. 17-19. Although General Comment No. 4 on the right to adequate housing does not mention these general obligations, it can be assumed that they also apply to this right as well.

354 General Comment No. 15, para. 20. See also Report of the independent expert on the issue of human rights obligations related to access to safe drinking water and sanitation, Catarina de Albuquerque, para. 19, note 312 .

355 Ibid., para 21.

356 Ibid., General Comment No. 15 furthers requires States to abstain from "[...] arbitrarily interfering with customary or traditional arrangements for water allocation; unlawfully diminishing or polluting water, for example through waste from State-owned facilities or through use and testing of weapons; and limiting access to, or destroying, water services and infrastructure as a punitive measure, for example, during armed conflicts in violation of international humanitarian law."

357 Arguably the State should also refrain from doing so if the privatization of water utilities would also result in hampering the related rights to food, adequate housing, and health. 
service or discriminatory increases in the price of water. As observed in Chapter III, Section 4.2, States will, however, enjoy a certain margin of discretion in deciding which social and economic policies (such as privatization) to deploy, and how to practically implement them if these are deemed necessary to pursue legitimate interests. These interests may be of a social or economic nature (f.e. the belief that privatization of water utilities will improve access to water for the everyone, at a lower cost). This is also recognized in General Comment No. 15 since Article $2 \S 1$ of the ICESCR, ${ }^{358}$ although it does observe that any national measures designed to realize the right to water should not interfere with the enjoyment of other human rights. General Comment No. 15, however does not provide any further guidance as to the limits to this margin. Nonetheless, it is reasonable to assume that these limits will be based on the proportionality of the privatization measures with respect to the aims to be pursued by them. Arguably, the threshold could be that the privatization of water should not make access to water illusory.

Since the privatization of water utilities will result in private entities operating the services, more emphasis will be laid on the State's positive obligations such as the obligation to protect and fulfill. According to General Comment No. 15, the obligation to protect "[...] requires State parties to prevent third parties from interfering in any way with the enjoyment of the right to water." 359 States should thus adopt the necessary measures, such as legislation, to restrain, third parties from, inter alia, denying equal access to adequate water. This position has been reaffirmed by the Human Rights Council in its resolution on human rights and access to safe drinking water and sanitation, in which it observed that "States have the primary responsibility to ensure the full realization of all human rights, and that the delegation of the delivery of safe drinking water and/or sanitation services to a third party does not exempt the State from its human rights obligations." 360

More specifically, and closer connected to privatization, the General Comment states that,

"[w]here water services (such as piped water networks, water tankers, access to rivers and wells) are operated or controlled by third parties, States parties must prevent them from compromising equal, affordable, and physical access to sufficient, safe and acceptable water. To prevent such abuses an effective regulatory system must be established, in conformity with the Covenant and this General Comment,

General Comment No. 15, para. 45.

Ibid, para. 23. Third parties include individuals, groups, corporations and other entities as well as agents acting under their authority.

See 15/9 Human rights and access to safe drinking water and sanitation, Resolution adopted by the Human Rights Council, note 325 supra, para. 6. 
which includes independent monitoring, genuine public participation and imposition of penalties for non-compliance." 361

From this description it is possible to distinguish two types of measures that could be adopted under the obligation to protect. These are substantive and procedural measures. Substantive measures would be those regulatory measures ${ }^{362}$ that are necessary to ensure that privatized water utilities do not compromise equal, affordable, and physical access to sufficient, safe and acceptable water. These measures are related to the availability, quality and accessibility both, economic and physical, of water. It is worth noting in this respect that the Human Rights Council has recalled that States should ensure that non-State service providers "[c]ontribute to the provision of a regular supply of safe, acceptable, accessible and affordable drinking water and sanitation services of good quality and sufficient quantity[...]"363

In terms of availability, the substantive aspect of the obligation to protect could be fulfilled if the State enacts regulatory measures that deal with rules on disconnection or denial of service. This is necessary to ensure that no one is arbitrarily cut off from the water provision service. In this respect, States should address the issue of disconnections respecting due process, and take into account a person's capacity to pay, so as to not deprive an individual who is unable to pay of a minimum essential level of water and basic sanitation. ${ }^{364}$ It is interesting in this regard to point out at the experience in the England and Wales where following legislative amendments in 1999 privatized water utilities were prohibited from disconnecting customers, even if the latter have not paid their water bills. ${ }^{365}$ One of the reasons for prohibiting disconnection was that "[...] the public health consequences involved with water mean that the implications of water disconnection can be much more severe" than

361 General Comment No. 15, para. 24. See also Human Rights Council resolution 15/9 on Human Rights and access to safe drinking water and santiation, which calls upon States to, inter alia, "[t]o adopt and implement effective regulatory frameworks for all service providers in line with the human rights obligations of States, and to allow public regulatory institutions of sufficient capacity to monitor and enforce those regulations[...]" See footnote 325 supra, para. 8(e).

362 A duty to implement regulatory measures can be also discerned in a concluding observation to Azerbaijan's initial report under the ICESCR, where the CESCR recommended that country to regulate its oil industry in respect of its potential adverse effects on the environment. See CESCR UN Doc. E/1998/22, para. 345. See also Section 2.6.2 supra.

363 See Human Rights Council resolution 15/9 on Human Rights and access to safe drinking water and santiation, footnote 325 supra, para. 9(b).

364 Report of the United Nations High Commissioner for Human Rights on the scope and content of the relevant human rights obligations related to equitable access to safe drinking water and sanitation under international human rights instruments, Human Rights Council, UN Doc. A/HRC/6/3 (16 August 2007), para. 59. See also Report of the independent expert on the issue of human rights obligations related to access to safe drinking water and sanitation, para. 46 (footnote 312 supra).

See Section 2.6.2 supra. 
with disconnection of other utilities such as gas or electricity. ${ }^{366}$ It was recognized that, probably due to the natural monopoly nature of the service, there is no alternative to the supply of water which is regarded as essential for good health and hygiene. Similarly, so-called Budget Payment Units (BPUs) or pre-paid water meters were banned following a court's judgment that failure to recharge them resulted in an automatic disconnection without companies having to apply to the courts in the usual way required by the old legislation and their conditions of appointment. 367

This stands in contrast with the position adopted by the Constitutional Court of South Africa, which concluded that the use of pre-paid meters in the township of Soweto and the suspension of the provision of water for non-payment were not in breach of the constitutional right of access to water, which is anchored in Section 27 of the Constitution. 368 The reason behind this was that the Water Services Act, which further regulates the right of access to water, and the by-laws implementing the use of pre-paid meters, protected consumers from a limitation, or discontinuation of water services. The Court observed that the Water Services Act and the Johannesburg by-laws guarantee a monthly right to free water for every household that is capped at six kiloliters of water. Water consumption on top of that has to be paid through the pre-paid meters, and failure to credit the pre-paid meter will suspend the consumption of water beyond what is allowed. The court noted that under this system, "[...] the suspension of water services [...] never results in indigent customers being denied access to basic water services which are supplied each month regardless of whether a customer topped up the water service during the previous month or not." 369 In the eyes of the Constitutional Court, this is a temporary suspension, which can be resumed next month when the allotted six kiloliters of free water is again provided or when the payments to the pre-paid meter is resumed, thus not entailing a final and permanent discontinuation of the service. ${ }^{370}$ Arguably, the availability of the service appears to be fulfilled through this system, although it can be contended that if a household consumes the free water allotted too quickly, it could be unreasonable to expect them to wait until the next month to receive water again if they are not in the economic position to further pay through the meter. On the other hand, the Constitutional Court observed that pre-paid meter water consumers understand that their free allotted water may be

366 See House of Commons, Research Paper 98/117, 10 December 1998, Water Industry Bill, Bill 1 [1998/99], p. 25.

367 See Lancashire County Council \& Ors, $R$ (on the application of) v. Director General Of Water Services, [1998] EWHC Admin 213 (20 th February, 1998), para. 47. House of Commons, Research Paper 98/117, 10 December 1998, Water Industry Bill, Bill 1 [1998/99], p. 27-29. for Water Affairs and Forestry, Case CCT 39/09, 2009 ZACC 28, Constitutional Court of South Africa, 8 October 2009.

$370 \quad$ Ibid., paras. 120 and 124. 
exhausted and then they could either purchase additional credit to continue the water supply or wait until next month for a fresh supply. ${ }^{371}$ In addition pre-paid meter consumers in Soweto paid less for water on top of their allotted free water through a system of cross-subsidies than those consumers not in the pre-paid meter system. ${ }^{372}$

With regard to quality, the State should adopt regulatory legislation that takes into account the health aspects of water from the perspective of water as an underlying determinant of health. This necessarily means that regulation should see to it that privatized water utilities provide water of sufficient quality to prevent the spread of infectious diseases, and that it is at least fit for normal consumption, hygiene and sanitation purposes. Thus, in South Africa, the Water Services Act obliges the relevant minister to prescribe compulsory national standards with respect of, among others, sanitation the quality of potable water, the control of objectionable substances, and the disposal of wastewater. ${ }^{373}$ Another aspect of the obligation to protect in the context of quality requires the State to protect the water from pollution caused by private entities including privatized water utilities, to provide for effective regulation that mandates them to take necessary steps to prevent pollution of water, and to provide effective legal remedies for persons that have been affected in their health due to water pollution. ${ }^{374}$

In terms of (economic) accessibility, the State could introduce a pricing regulation scheme or structure that would protect the poor and the most vulnerable from price increases either necessary or arbitrary, by the private/privatized utilities provider. During the examination of a number of State reports, the CESCR paid some attention to this matter. In the concluding observations to Nicaragua's initial report, the CESCR expressed its serious concern with regard to "[...] the extent that structural adjustment measures and the privatization of State property have had negative consequences for the enjoyment of the economic, social and cultural rights of the Nicaraguan people, and more specifically for the standard of living of the most vulnerable sectors." 375 To address this problem, the Committee recommended that Nicaragua should provide adequate safety nets for the vulnerable sectors of

371 Ibid., para. 123.

372 Ibid., paras. 140-141.

373 These standards have been set in the 'Regulations relating to compulsory national standards and measures to conserve water', GN R509 in GG 22355 of 8 June 2001.

374 With regard to the obligation to prevent pollution and contamination of water see the General Observations of the CRC with regard to Uzbekistan were, in light of Article 24 (c) of the Convention on the Rights of the Child, the CRC recommended the State party to take all the appropriate measures to prevent and combat the damaging effects on children of, inter alia, the pollution and contamination of water supplies. See General Observations Uzbekistan, CRC, CRC/C/111 (2001) 117, para. 577.

375 Concluding observations to Nicaragua's initial report, UN Doc. E/C.12/1993/14 (4 January 1994), para. 6. 
society in order to avoid a deterioration of the enjoyment of the rights protected in the Covenant. Although the Committee did not expressly note that its recommendation was intended as an example of an obligation to protect, it is illustrative of what such an obligation can encompass. A clearer example of the obligation to protect in relation to the rights to water and adequate housing and the accessibility element can be seen in the CESCR's comments and recommendations made during the examination of Benin's initial report. Picking up from a discussion that arose after Benin reported on its efforts to privatize electricity and water utilities in that country, the CESCR noted its worries about an increase in the costs of these services that could be caused by their privatization and the disparities in the standard of living between rural and urban areas which the privatization would generate. ${ }^{376}$ The Committee encouraged Benin to take effective measures to improve the access to these services and maintain accessible costs for them. ${ }^{377}$

Another way of meeting the substantive aspect of this obligation in terms of availability and physical as well as economic accessibility would entail providing a free or minimum fixed quantity of water for consumption that should meet the levels of water necessary for daily consumption. ${ }^{378}$ An example of this can be found in South Africa, where Regulation 3 of the 'Regulations relating to compulsory national standards and measures to conserve water' has included standards pertaining to basic water supply. ${ }^{379}$ According to this regulation the minimum quantity of potable water available to a household must be 25 liters per person per day or six kiloliters per household per month. ${ }^{380}$ The obligation to establish a pricing regulation structure could additionally require the provision of pricing subsidies to the poor or other disadvantaged sectors of society, or the application of price discrimination measures. This would be necessary in situations in which tariffs need to be levied or increased to recover the costs of providing the service. This means that in the event of tariff increases necessary to keep up with investment costs, to improve and expand the water delivery network and piping and to provide adequate maintenance and sanitation of water, the most vulnerable sectors of society

376 Concluding observations to Benin's initial report, UN Doc. E/C.12/1/Add.78 (17 May 2002), para. 22.

377 Ibid., para 41.

378 According to one study, the physiological basic water need for each individual human being amounts to approximately 5 liters of water per day. See WHO-UNICEF, "Basic Needs and the Right to Health." However, minimal water consumption for a family that would cover essential needs beyond physiological consumption (food preparation, sanitation and bodily hygiene) requires a higher amount of daily water. Gleick suggests that the recommended basic water requirement for food preparation, bathing and sanitation services amounts to 45 liters per person per day on top of the 5 liters mentioned above. Gleick, "The Human Right to Water," p. 496.

See footnote 373 supra. also M. Kidd, "Notes and Comments: Not a Drop to Drink: Disconnection of Water Services for Non-Payment and the Right of Access to Water," South African Journal of Human Rights Vol. 20 (2004), p. 122.

380 See also Mazibuko \& Ors. v. the City of Johannesburg, Johannesburg Water (PTY) Ltd and Minister for Water Affairs and Forestry, supra note. 368. 
would (temporarily) be spared having to pay higher prices. ${ }^{381}$ In other words, the State has a positive obligation to take measures to ameliorate the possible negative effects of privatization on the poor. Practical approaches to realize this would be through the introduction of targeted cross-subsidies to low-income and vulnerable groups either through fiscal methods, social security and welfare grants, or directly through price discrimination measures. ${ }^{382}$ Consumption above eventual fixed quantities could be subject to incremental pricing according to the additional units of consumed water above the free quantity. Again, a concrete example of this can be found in England and Wales where privatized water utilities must set up special charging schemes for low-income households and individuals with medical conditions. ${ }^{383}$

The second type of measures that can be distinguished under the obligation to protect the right to water, procedural measures, require the establishment of effective regulatory or monitoring mechanisms that monitor the activities of privatized water service providers and the quality of their services. ${ }^{384}$ Thus, regulators should be able to receive complaints from water consumers and should also revise decisions of privatized utilities that affect consumers. In this respect, the State must take measures to ensure that privatized water utility companies apply appropriate procedural safeguards before anybody is disconnected from the service and therefore unable to enjoy access to water. Such measures are in any event necessary in cases of non-payment for the service, where consumers have to be given sufficient opportunity and time to rectify non-payment of water bills prior to considering a disconnection. Consumers should also be entitled to appeal to the regulator in cases of disagreement with the decision to disconnect. In South Africa, for example, a disconnection from the water service amounts to a limitation of the right to water as enshrined in the South African Constitution. ${ }^{385}$ Section 4(3) of the South African Water Services Act 108 of 1997 states that a water supply might not be discontinued if it resulted in a person being denied access to basic water services

381 See in general for a discussion of the various options that may be available to privatized utilities, regulators, and policy makers to assist the poor and ameliorate the effects of privatization Estache, Gomez-Lobo, and Leipziger, "Utilities Privatization and the Poor: Lessons and Evidence from Latin America."

382 According to Gleick, Wolff, et al., cross-subsidies and price discrimination measures should be carefully designed and applied so that they are socially and economically sound. Gleick et al., "The New Economy of Water: The Risks and Benefits of Globalization and Privatization of Fresh Water," p. 41. For example, subsidies to low-income customers should not reduce the price of water because lower water prices encourage inefficient water use.

383 See Statutory Instrument 1999 No. 3441, Water Industry, England and Wales, The Water Industry (Charges) (Vulnerable Groups) Regulations 1999 and Statutory Instrument 2005 No. 59, The Water Industry (Charges) (Vulnerable Groups) (Amendment) Regulations 2005.

384 See Report of the independent expert on the issue of human rights obligations related to access to safe drinking water and sanitation, paras. 51-52.

385 Kidd, "Notes and Comments: Not a Drop to Drink: Disconnection of Water Services for NonPayment and the Right of Access to Water," p. 129. 
for non-payment, where that person proved, to the satisfaction of the relevant water services authority, that he or she was unable to pay for basic services. Disconnection is nonetheless possible under the Water Services Act if certain procedural requirements are met. In particular, the procedures leading to disconnection must be fair and equitable; they must provide for reasonable notice of termination and for an opportunity to make representations; and they must not result in a person being denied access to basic water services for non-payment where that person proved, to the satisfaction of the water services authority, that he or she was unable to pay for basic services. ${ }^{386}$ In the already mentioned Mazibuko case, the Constitutional Court of South Africa concluded that the temporal suspension of water for consumers with pre-paid water meters in Soweto when they stopped paying additional credit to continue to receive water did not amount to a disconnection, since the service could be resumed immediately after payment of credit and consumers could in any case wait for the free water they were entitled to at the beginning of the month. ${ }^{387}$

Regulators in the water sector should also have a mandate to effectively impose sanctions or penalties on the privatized water utilities on a transparent and objective basis in case of non-compliance with the universal service obligations. Arguably these universal service obligations should have a statutory basis and also be included in the contract with the private water utility in order to make them effective. In the United Kingdom, Section 22A of the Water Industry Act 1991 (as amended by the Water Industry Act 1999 and the Water Act 2003) allows the regulator, OFWAT to impose fines on the privatized service providers if they do not fulfill the conditions of their appointment or fails to achieve the standards of performance required by the Act. To effectively comply with the procedural aspect of the obligation to protect, States should also allow decisions taken by privatized water service providers to be subject to some form of review. ${ }^{388}$ This involves setting up administrative and judicial remedies and recourse procedures ${ }^{389}$ for consumers and

386 See Residents of Bon Vista Mansions v. Southern Metropolitan Local Council, Case No: 01/12312, High Court, Witwatersrand Local Division, 2002 (6) BCLR 625 (W), paras. 27-28. See also ibid., p. 126-129.

387 Mazibuko \& Ors. v. the City of Johannesburg, Johannesburg Water (PTY) Ltd and Minister for Water Affairs and Forestry, footnote 368 supra, paras. 120-121. The Court also concluded that such a temporal suspension also did not require a reasonable notice since it was impractical (consumers could stop paying the pre-paid meter at any moment and then pay again immediately to resume the service, meaning that a notice would had to be issued every time this happened in a month) and consumers could understand from the meters what was expected from them in terms of additional payments to secure resumption of the service. Ibid., para. 123.

On the question whether decisions by a privatized service provider are amenable for (administrative) judicial review, see Chapter IV, Section 3 on the accountability of privatized actors.

389 See General Comment No. 15, para. 50. See also Human Rights Council resolution 15/9 on Human Rights and access to safe drinking water and santiation, footnote 325 supra, para. 9(d). 
potential victims of violations of the right to water, either through the monitoring/ regulatory mechanisms themselves or through national adjudicatory bodies.

Finally, the right to water imposes an obligation to fulfill. ${ }^{390}$ The CESCR has further specified this obligation to include obligations to facilitate, promote and provide. ${ }^{391}$ According to the CESCR, the obligation to facilitate imposes on the State a duty to take positive measures to assist individuals and communities to enjoy the right to water. Such measures include the adoption of legislation that recognizes the right to water and provides for a national water strategy plan. ${ }^{392}$ In the context of privatization of water utilities the obligation to fulfill (facilitate) demands that the State ensures that water is affordable to everyone. ${ }^{393}$ To guarantee this General Comment No. 15 notes that States must implement appropriate pricing policies and income supplements. ${ }^{394}$ According to the Committee,

"[a]ny payment for water services has to be based on the principle of equity, ensuring that these services, whether privately or publicly provided, are affordable for all, including socially disadvantaged groups. Equity demands that poorer households should not be disproportionately burdened with water expenses as compared to richer households." 395

Another way of facilitating the right to water requires the State to guarantee that private/privatized water utilities companies provide improved and sustainable access to water with special attention to rural or deprived urban areas, therefore fulfilling the accessibility component of the right to water. ${ }^{396}$ It is interesting to note in this respect that, during the examination of the periodical report of Nepal, the Committee apparently conceded, although not explicitly, in its concluding observations that the obligation to fulfill (facilitate) can be realized through the privatization of water utilities which in turn realizes the right to an adequate standard of living. After noting with regret that 29 per cent of the population in Nepal had no access to safe water and 84 per cent had no access to sanitation, the Committee concluded that, "[p]rojects involving privatization of water supply should provide for continued, assured and affordable access to water by local communities, indigenous people, and the most disadvantaged and marginalized groups of society." 397 It would appear that in countries where public provision of

See also Report of the independent expert on the issue of human rights obligations related to access to safe drinking water and sanitation, para. 58 .

390 General Comment No. 15, para. 25.

391 Ibid, para. 25.

392 Ibid., para. 26.

393 Ibid., para. 26.

394 Ibid., para. 27.

395 Ibid.

396 Ibid., para. 26.

397 Concluding Observations Nepal, ICESCR, E/2002/22 (2001) 83, paras. 543 and 576. 
basic services such as water is not good or developed enough to achieve a higher standard of living, the CESC will accept its privatization if they contribute to the facilitate the right to water.

The obligation to fulfill (promote) requires the State to ensure that all sectors of society are made aware of water usage and the methods to reduce water wastage, of water hygiene and the protection of water sources. The State should promote this by proper education on these issues and by awareness raising campaigns. ${ }^{398}$ In the context of privatization of water utilities, this obligation necessarily requires that the State together with the companies providing the service provide information regarding the privatization process. This includes increasing the awareness of the public and consumers about private/privatized water utilities providers, the means of seeking redress, and spreading information about best practices regarding the use of water. Not explicitly mentioned in the General Comment, but arguably necessary in this context is the requirement of consultation, transparency, and participation of stakeholders in the decision-making process leading to privatization of water utilities.

In the eyes of the CESCR, the obligation to fulfill (provide) obliges States to provide the right to water when individuals or a group are not able to realize this right themselves by the means at their disposal for reasons beyond their control. ${ }^{399}$ Nevertheless, an obligation to provide from the perspective of the privatization of water related utilities also requires the State to intervene and directly assume the tasks of a privatized water utility in the event of breach of contact leading to severe limitations in the provision of safe and sufficient water, expiration of concession contract, the company's insolvency, or whenever a natural disaster hampers the proper functioning of privatized water utilities providing water services. In this way the accessibility to water can be guaranteed when the private/privatized utilities provider is not in the position to deliver the service. It can be argued thus that the State has an obligation to step in and guarantee the right to water whenever a third (privatized) party willingly or unwillingly endangers the an essential service such as water.

\subsubsection{Core obligations of the right to water}

The core obligations of these rights entail the necessary duties imposed upon states to ensure, in the words of the Committee, "[...] the satisfaction of, at the very least, minimum essential levels of each of the rights enunciated in the Covenant." ${ }^{\prime 40}$ The concept of minimum core obligations denotes the essential elements without which

400 See General Comment No. 3, para. 10. See also General Comment No. 15, para. 37. 
a right loses its substantive significance as a human right. ${ }^{401}$ The State has the duty to, at the very least, do its utter best to implement these minimum levels of the rights guaranteed in the ICESCR. In the event that the State does not even meet these minimum obligations, the burden of proof lies on the State to demonstrate its inability to comply with them. ${ }^{402}$

According to the CESCR, the core obligations of the right to water comprise obligations to ensure access to the essential minimum amount of water. This minimum amount of water should be sufficient and safe for personal and domestic uses to prevent disease. ${ }^{403}$ The General Comment does not specify a minimum amount or quantity of water that should be available. It has also been noted that it is up to individual States to determine the minimum reasonable amount of water needed to cover personal and domestic uses. ${ }^{404}$ However, guidance can be found in recommendations issued by the WHO. A WHO study estimates that the minimum quantity of water for domestic use that is necessary for daily consumption is 20 liters per capita per day. ${ }^{405}$ This amount is deemed necessary for most people to guarantee basic health protection and hygiene. Similarly, the minimum safety and quality of water can be judged on the basis of the WHO Guidelines for DrinkingWater Quality, which provide a framework for safe drinking-water and guidance relative to the chemical and microbial aspects necessary to guarantee water that is suitable for human consumption. ${ }^{406}$

The core obligations further relate to the conditions under which water must be accessed. This entails access to water and water related facilities on a nondiscriminatory basis, paying particular attention to disadvantaged and marginalized groups. This should be achieved through facilities and services that: provide adequate service and safe water; are available in sufficient number and are equitably distributed. ${ }^{407}$ Another core obligation includes the adoption and implementation of a national water strategy and plan of action that addresses the whole population (again, paying particular attention to disadvantaged and marginalized groups) and if necessary is periodically reviewed in a transparent way that ensures the

\footnotetext{
401 Chapman and Russel, "Introduction," p. 9.

402 Ibid., p. 10.

403 General Comment No. 15, para. 37 (a).

404 Report of the United Nations High Commissioner for Human Rights on the scope and content of the relevant human rights obligations related to equitable access to safe drinking water and sanitation under international human rights instruments, op cit. note 364, para. 15.

405 Howard and Bartram, "Domestic Water Quantity, Service, Level and Health," p. 9 and 23. Howard and Bartram are keen to point out that this is a minimal value and does not account for health and well-being-related demands outside normal domestic use such as water use in health care facilities, food production, economic activity or amenity use.

406 Guidelines for Drinking-water Quality, incorporating first addendum, Vol. 1 Recommendations, Third ed., 2006.

407 Ibid., para. $37(\mathrm{~b}-\mathrm{e})$.
} 
participation of those affected. ${ }^{408}$ Additional core obligations require measures to protect vulnerable and marginalized groups through relatively low-cost water programs, and measures necessary to prevent, treat and control water related diseases including ensuring access to adequate sanitation. Finally, the State has an immediate obligation to monitor the extent of the realization or non-realization of the right to water. 409

\subsubsection{Violations of the right to water}

Until now, the monitoring of (international) civil and political rights has received considerable attention. Due to a number of factors, the monitoring of economic, social and cultural rights, however, has lagged behind the monitoring of civil and political rights. ${ }^{410}$ It has been noted that the monitoring of economic, social and cultural rights has been particularly difficult, due to the fact that Article 2 (1) ICECSR calls for the 'progressive realization' of the rights recognized in the ICESCR. This standard has been deemed to be too vague and difficult to define and apply, certainly in comparison to the standard set forth in Article 2 ICCPR (the sister provision of Article 2 ICESCR), which imposes an immediate obligation to respect and ensure the rights recognized therein. ${ }^{411}$ In order to surmount this obstacle, and departing from the definition of a violation of the ICESCR provided by the Limburg Principles on the Implementation of the International Covenant on Economic, Social and Cultural Rights, ${ }^{412}$ Chapman proposed a 'violations approach' as a means to a more effective and simple way of monitoring the

408 Ibid, para. 37 (f).

409 Ibid, para. $37(\mathrm{~g}-\mathrm{i})$.

410 See A.R. Chapman, “A 'Violations Approach' for Monitoring the International Covenant on Economic, Social and Cultural Rights," Human Rights Quarterly Vol. 18 (1996), p. 29-36.

411 Ibid., p. 30-31.

412 The Limburg Principles on the Implementation of the International Covenant on Economic, Social and Cultural Rights are a set of precepts drafted in 1986 by a group of experts in international law (including members of the then newly created UN CESCR) and which provide an interpretation of the scope and nature of the States Parties' obligations under the ICESCR. The Limburg Principles define a violation of economic, social and cultural rights as: "A failure by a State party to comply with an obligation contained in the Covenant is, under international law, a violation of the Covenant (Principle 70)." The principles recognize that the Covenant leaves a certain margin of discretion to a State party in selecting the means of implementing the rights, but it considers that it will be in violation of the Covenant if, inter alia: "it fails to take a step which it is required to take by the Covenant; it fails to remove promptly obstacles which it is under a duty to remove to permit the immediate fulfilment of a right; it fails to implement without delay a right which it is required by the Covenant to provide immediately; it wilfully fails to meet a generally accepted international minimum standard of achievement, which is within its powers to meet; it applies a limitation to a right recognized in the Covenant other than in accordance with the Covenant; it deliberately retards or halts the progressive realization of a right, unless it is acting within a limitation permitted by the Covenant or it does so due to a lack of available resources or force majeure; or it fails to submit reports as required under the Covenant (Principle 72)." See UN Doc. E/CN.4/1987/17. 
implementation of economic, social and cultural rights. ${ }^{413}$ This approach has been further strengthened by the drafting of the Maastricht Guidelines on Violations of Economic, Social and Cultural Rights (hereinafter the Maastricht Guidelines), which have clarified the violations approach in an attempt to make it easier to apply in practice. ${ }^{414}$ It involves the identification of violations of the rights guaranteed in the ICESCR, which could arise from the failure of a State party to comply with the obligations emanating from the rights through acts of commission or omission.

It should be borne in mind that, although the violations approach is originally the result of academic debate and that the Maastricht Guidelines do not have any binding legal status, a number of human rights monitoring mechanisms including the UN Committee on Economic, Social and Cultural rights, have started to adopt the approach when assessing the implementation of human rights obligations. ${ }^{415}$ Thus section IV of General Comment No. 15 on the right to water is devoted to discuss the violations of that right. In this General Comment, the Committee observed that,

"[w] hen the normative content of the right to water [which describes the right in terms of availability, quality, and accessibility, $A H W$ ] is applied to the obligations of States parties [to respect, protect, and fulfill, as well as the core obligations pertaining to the right, $A H W$ ], a process is set in motion, which facilitates identification of violations of the right to water." ${ }^{416}$

General Comment No. 15 observes that in order to demonstrate compliance with their general and specific obligations, States parties must establish that they have taken the necessary and reasonable measures to realize the right to water. ${ }^{417} \mathrm{In}$ addition, the General Comment stresses that States parties cannot justify their non-

413 Chapman, "A 'Violations Approach' for Monitoring the International Covenant on Economic, Social and Cultural Rights," p. 36-38.

414 The Maastricht Guidelines were adopted on the occasion of the $10^{\text {th }}$ anniversary of the Limburg Principles by 30 experts to "[...] elaborate on the Limburg Principles as regards the nature and scope of violations of economic, social and cultural rights and appropriate responses and remedies." See "The Maastricht Guidelines on Violations of Economic, Social and Cultural Rights: Proceedings of the Workshop of Experts organised by the International Commission of Jurists (Geneva, Switzerland), the Urban Morgan Institute on Human Rights (Cincinnati, USA) and the Maastricht Centre for Human Rights of Maastricht University," 1997, SIM Special, No. 20, p. 1.

415 Chapman noted that the CESCR already has adopted a type of violations approach in its Concluding Observations, although she is quick to note that the Committee does not use the words violations as such. Chapman, "A 'Violations Approach' for Monitoring the International Covenant on Economic, Social and Cultural Rights," p. 45-46. The African Commission on Human and Peoples' Rights have been keen to use the violations approach as well. See F. Coomans, "The Ogoni Case Before the African Commission on Human and Peoples' Rights," ICLQ, Vol. 52, (2003), p. 758-759.

416 General Comment No. 15, para. 39.

417 Ibid., para 40. 
compliance with the core obligations on the right to water, which according to the Committee are non-derogable. ${ }^{418}$ This implies that a failure to fulfill the minimum core obligations related to the right to water could result in possible violations of the right.

According to the General Comment it is possible to identify two main types of violations of the right to water: a. violations through acts of commission entailing direct actions of States parties or other entities insufficiently regulated by States; ${ }^{419}$ and $b$. violations through acts of omission, which include the failure to adopt appropriate steps towards the full realization of the right to water, the failure to have a national policy on water, and the failure to enforce relevant laws. ${ }^{420}$ General Comment No. 15 provides examples of violations related to the different levels of obligations of the right to water including:

- Violations of obligation to respect: (i) arbitrary or unjustified disconnection or exclusion from water services or facilities; (ii) discriminatory or unaffordable increases in the price of water; and (iii) pollution and diminution of water resources affecting human health;

- Violations of obligation protect: (i) failure to enact or enforce laws to prevent the contamination and inequitable extraction of water; (ii) failure to effectively regulate and control water services providers; (iii) failure to protect water distribution systems (e.g., piped networks and wells) from interference, damage and destruction;

- Violations of obligation to fulfill: (i) failure to adopt or implement a national water policy designed to ensure the right to water for everyone; (ii) insufficient expenditure or misallocation of public resources which results in the nonenjoyment of the right to water by individuals or groups, particularly the vulnerable or marginalized; (iii) failure to monitor the realization of the right to water at the national level, for example by identifying right-to-water indicators and benchmarks; (iv) failure to take measures to reduce the inequitable distribution of water facilities and services; (v) failure to adopt mechanisms for emergency relief; (vi) failure to ensure that the minimum essential level of the right is enjoyed by everyone; (vii) failure of a State to take into account its international legal obligations regarding the right to water when entering into agreements with other States or with international organizations. ${ }^{421}$

It is worth pointing out that in a context of privatization, the examples of violations of the obligation to respect provided by the Committee seem out of place, as they apparently depart from the assumption that arbitrary disconnections or unaffordable

\footnotetext{
418 Ibid.

419 Ibid., para. 42.

420 Ibid., para. 43.

421 Ibid., 44.
} 
or discriminatory price increases would be the result of actions by the State itself or by a State owned water utility. In the case of privatization, of course, the acts leading to the violations referred to here would be executed by the privatized utility, and the State would be responsible under the obligation to protect for not adopting the necessary measures to prevent or stop these acts.

A further caveat before finishing this section is necessary. In the academic debate about violations of economic, social and cultural rights, and in the work of the UN CESCR there is barely any discussion on legitimate limitations to or derogation from these rights. ${ }^{422}$ With regard to the latter, it is possible to state that, contrary to its sister convention, the ICCPR, the ICESCR does not have a general derogation clause. ${ }^{423}$ Under the ICESCR, the individual rights recognized do not contain legitimate limitation clauses like in other human rights treaties, with the exception of the right to form trade unions in Article 8. ${ }^{424}$ Rather, a general limitation clause was adopted in Article 4 which recognizes that the State may subject, "[...] only to such limitations as are determined by law only in so far as this may be compatible with the nature of these rights and solely for the purpose of promoting the general welfare in a democratic society." ${ }^{25}$ The existence of a limitation clause is understandable given the fact that with only few exceptions, human rights are not absolute. There is in this regard a need to balance the interests of those who enjoy the rights, and the interests of society in general (or of other individuals in particular). In addition, the general limitations clause is sometimes coupled to the general obligations clause of Article 2 §1 ICESCR that requires States parties to progressively realize the rights of the Convention to the maximum of their available resources. Such a requirement entails implicitly that States could limit the realization of these rights if they do not have sufficient resources at their disposal. ${ }^{426}$

422 A. Müller, "Limitations to and Derogations from Economic, Social and Cultural Rights," Human Rights Law Review Vol. 9 (2009), p. 558.

423 Article 4 of the ICCPR provides for the derogation of most rights in times of public emergencies that may threaten the life of a nation. The existence of such public emergencies must be officially proclaimed, and certain rights are considered to be non-derogable (such as the right to life of Article 6 and the prohibition of torture of Article 7 ICCPR).

424 These limitation clauses usually mention that rights may be subject to limitations which should be prescribed by law and which are necessary in a democratic society in the interests of for example, public order, public health, public morals, national security, or the protection of the rights of others. See also Müller, "Limitations to and Derogations from Economic, Social and Cultural Rights," p. 559. For a discussion on the use of limitation clauses in the context of civil and political rights, for example see D.J. Harris et al., Law of the European Convention on Human Rights, $2^{\text {nd }}$ ed. (Oxford: Oxford University Press, 2009).

425 Article 4 ICESCR. Compare with Article $31 \S 1$ of the European Social Charter.

426 Müller, "Limitations to and Derogations from Economic, Social and Cultural Rights," p. 569. The UN CESCR has of course observed in this regard, that the States parties have only limited possibilities of adopting 'retrogressive measures' in such a situation. With regard to the right to water see General Comment No. 15, para. 19, in which the Committee observes that if States are to adopt such measures, they have to prove that " [...] they have been introduced after the most 
In any event, a limitation to the right to water as understood by the Committee will have, as prescribed by Article 4, to be determined by 'law'. Müller observes that there is no indication that the meaning of 'law' would be different than that used by other human rights monitoring mechanisms like the HRC and the ECtHR in their jurisprudence dealing with legitimate limitations. ${ }^{427}$ Laws may include parliamentary or executive statutory legislation, or judge made law. With regard to the right to water, the UN CESCR observed in its General Comment 15 that, " [ ...] any action that interferes with an individual's right to water [and which] is carried out by the State party, or by any other third party [... must be] performed in a manner warranted by law, compatible with the Covenant[...]"428 In addition, it is reasonable to expect that in a similar fashion to the ECtHR's case law on limitations, the law must be adequately accessible and formulated with sufficient precision (the latter of which implies that the law's restrictions should use precise criteria and should not provide unlimited discretion to authorities). ${ }^{429}$

In contrast with other limitations clauses, Article 4 provides only one single criterion for adopting a legitimate limitation: the promotion of general welfare in a democratic society. According to Müller, 'general welfare' must be understood as "[...] referring primarily to the economic and social well-being of the people and the community." ${ }^{30}$ Although the UN CESCR has not provided further insights as to what should be understood under 'general welfare', Müller observes that the Committee seems to think that "[...] that references to broad concepts like 'economic development' cannot easily justify limitations of ESC rights, since policies adopted towards this end often limit ESC rights of certain individuals or groups without "promoting general welfare'."431 The Limburg Principles on the Implementation of the International Covenant on Economic, Social and Cultural Rights has construed 'promoting general welfare' to mean "[...] furthering the wellbeing of the people as a whole." ${ }^{3} 2$

Finally, if a limitation on a right is to be imposed, such as on the right to water, the limitation has to be compatible with the nature of the rights, a condition which Müller maintains is unique in human rights treaties with respect to limitation

careful consideration of all alternatives and that they are duly justified by reference to the totality of the rights provided for in the Covenant in the context of the full use of the State party's maximum available resources."

427 Ibid., p. 578.

428 General Comment No. 15, para. 56. See also ibid., Muller, p. 578.

429 See f.e. Harris et al., Law of the European Convention on Human Rights, p. 133-136, discussing the ECtHR case law on the matter, and Human Rights Committee General Comment No. 27 on Freedom of Movement (Art. 12), UN Doc. CCPR/C/21/Rev.1/Add.9 (2 November 1999), para. 13.

430 Müller, "Limitations to and Derogations from Economic, Social and Cultural Rights," p. 573.

431 Ibid.

432 Limburg Principles, para. 52. 
clauses. ${ }^{433}$ The Committee has not yet established until now which rights types of limitations may not be compatible with the ESC rights' nature, although Müller suggests that the approach used by the Committee in its General Comment No. 3 with respect to the minimum essential levels present in the minimum core obligations of each right may represent the nature of these rights. ${ }^{434}$ Limitations affecting this minimum would accordingly make the exercise of the restricted rights illusory. Müller finds support for this proposition in the Human Rights Committee's General Comments No. 27 and 31, which state that restrictions must not impair the essence of the right being limited. ${ }^{435}$ If this approach is accepted, limitations on the right to water that deny the minimum amount of water that everyone should be entitled to consume (20 liters of water per day as per the WHO guidelines discussed in the previous section) and that arbitrarily restricts the minimum levels of quality, or discriminates in particular against vulnerable groups, would arguably be limitations contrary to the nature of the right to water and thus be illegitimate.

\subsection{Preliminary conclusions}

The right to water is closely related to other economic, social and cultural rights such as the right to food, housing and health. Arguably, the right to water also has links to the right to live with dignity and the right to life. As observed in this section the operation of water utilities, whether private or public have direct impact on this right. The right requires that water be available, of sufficient quality, and physically as well as economically accessible on a non-discriminatory basis to everyone. These characteristics amount, in fact, to what is otherwise known as universal service obligations, which were discussed in Section 2.2 supra. The normative content of the right to water includes the right to maintain access to existing water supplies necessary for the right to water, and the right to be free from interference (this includes being free from arbitrary disconnections or contamination of water supplies). In general it can be stated that to satisfy the obligation to protect under the right to water, the State should draft and implement, inter alia, legislative measures which guarantee the universal provision of these services to everyone, including the most vulnerable sectors of society and in areas which in principle are not profitable for the provider. This effectively imposes universal service obligations on privatized water utilities, which should be implemented in the privatization legislation and the contractual agreements between the company managing the utilities and the State. The obligation to protect requires special measures to prevent that privatized utilities abuse their natural monopoly position. In other words this obligation is necessary to protect individual consumers who do not have any other

\footnotetext{
433 Müller, "Limitations to and Derogations from Economic, Social and Cultural Rights," p. 579.

434 Ibid.

435 See Human Rights Committee General Comment No. 27, para. 13, and General Comment No. 31 on the Nature of the general legal obligation imposed on States Parties to the Covenant, UN Doc. CCPR/C/21/Rev.1/Add.13 (26 May 2004), para. 6; ibid., Müller, p. 581.
} 
alternatives to safeguard their rights: when privatizing water utilities, the consumer does not have a choice of service provider in comparison with the easier choice consumers have in the case of electricity utilities. The individual cannot just walk to another service provider. There are no other alternatives other than securing own access to water (by excavating a well or using public water sources such as communal water fountains/pipes or rivers). This lack of choice makes it imperative for the State to adopt measures to protect consumers, in particular those who are more vulnerable, from the conduct of privatized water utilities, and prevent any situations that may affect the right to water.

States' core obligations arising out of the rights to water, require the minimal implementation of measures that satisfy the common elements of accessibility, affordability and quality that compose these rights. The right to water requires that the privatization of water utilities results in at the very least minimal and affordable access of safe water to everyone, especially (ethnic or minority) groups living in marginal or rural areas.

Regardless of the implication of the core obligations that each State party must realize under this right, it should be noted that even the realization of minimum sanitation or the provision of adequate supply of potable water either through public or private initiatives or a mixture of both involves the allocation of economic resources or the attraction of capital investment that may be difficult to realize in the poorest countries. ${ }^{436}$ The maintenance of the network and infrastructure of utilities such as water and electricity is a very capital intensive activity even in the case of the most modest services and most developing countries have not been able to cope with these costs much less expand the network to cover their service. Already in the early 2000s the United Nations Department of Economic and Social Affairs together with the World Bank had estimated that the investment needed in the water and sanitation sector alone to meet the Millennium Development Goals could add up to $\$ 30$ billion US Dollars a year. ${ }^{437}$ This has led a number of authors to conclude that the involvement of private companies and capital in the utilities sector, especially in the water sector, is almost unavoidable. ${ }^{438}$ This is exacerbated by the fact that, developing countries facing difficulties in financing public spending in the utilities sector are usually encouraged to privatize these utilities by international financing institutions that couple privatization as a prerequisite to financial assistance.

\footnotetext{
436 Son this issue see Chapman, "Core Obligations Related to the Right to Health," p. 196.

437 UNDESA, "Recognizing and Valuing the Many Faces of Water," p. 334.

438 For an interesting view on the apparent inability of developing States to provide essential universal services see G. Clarke and S. Wallsten, "Universal(ly Bad) Service - Providing Infrastructure Services to Rural and Poor Urban Consumers," Policy Research Working Paper WPS 2868, The World Bank - Development Research Group Regulation and Competition Policy, Washington D.C., (2002).
} 
In this respect, the implementation of privatization measures as a means to theoretically help ease the financial burdens of poor States while at the same time help to (universally) provide essential services that were either not or poorly provided by the State, is appealing. From this perspective, the privatization of essential utilities can potentially help to achieve the minimal obligations. General Comment No. 15 appears to be fairly neutral on this, and does not reveal any explicit preference for either public or private provision of water. States are thus free to choose for privatization if they deem it necessary. This should not imply, however, that States do not have any more (human rights) responsibilities in this area once it has been decided to privatize the construction, implementation and management of essential utilities. The State's specific and core obligations under the right to water require it to maintain an active role to guarantee that privatized utilities provide minimal access to water services on an affordable and non discriminatory basis. It must also protect water consumers against privatized conduct such as indiscriminate disconnection or price increases without improvements in the service. Additionally the State must step in when the companies running privatized utilities are no longer in a position to operate them (either due to economical, political or other motives) and take over their operation to continue satisfying the minimum essential level of each right at stake. Establishing proper regulatory mechanisms is essential in achieving this.

\section{CaSe STUdy: THE PRIVATIZATION OF WATER UTILITIES IN THE CITY OF Buenos Aires}

On the $21^{\text {st }}$ of March, 2006, thirteen years after it was awarded a concession contract to provide potable water and sewerage services for the city of Buenos Aires in Argentina, the privatized water utility, Aguas Argentinas S.A. (the local subsidiary of a consortium of three water multinational companies, Suez, Sociedad General de Aguas de Barcelona S.A. and Vivendi Universal), ceased its operations. Citing the company's inability to properly implement the concession contract, and alleging various breaches of its contractual obligations throughout the thirteen years of operation, former Argentine President, Néstor Kirchner, decided to rescind the 30-year long concession contract between the company and the Argentine State. ${ }^{439}$ Thus came an end to what had been regarded one of the most successful water privatization projects of Latin America and a poster child of water privatization operations. ${ }^{440}$

439 See Presidential Decree No. 303/2006 of 21 March 2006, available at the website of the former regulator of the concession, the Ente Tripartito de Obras y Servicios Sanitarios (ETOSS): $<$ www.etoss.org.ar $>$ (last visited on 28 December 2008).

440 See D. Hall and E. Lobina, "Pipe Dreams: The Failure of the Private Sector to Invest in Water Services in Developing Countries," Public Services International Research Unit (PSIRU), Business School, University of Greenwich, London, (2006), p. 35. 
This section will attempt to provide an answer to the question whether the privatization of water utilities has actually resulted in abuses of human rights in a concrete situation by a privatized utility. On the basis of the so-called "violations approach' for monitoring the implementation of human rights, more specifically the right to water as guaranteed in Article 11 of the ICESCR, this section will make an evaluation of the privatization of water utilities in the city of Buenos Aires. This will be done through the examination of primary and secondary sources derived from the World Bank, the former water utilities regulator, the Ente Tripartito de Obras y Servicios Sanitarios (ETOSS), the Argentine Ombudsman, the academic world, and other (governmental and non-governmental) organizations. In the following paragraphs, a general background of the privatization of essential utilities in Argentina providing the broader context of the case study will be provided. This will be followed by a description of the privatization of water in the city of Buenos Aires and a brief analysis of its outcomes.

\subsection{The privatization of essential utilities in Argentina: background}

The privatization process in Argentina began following the election of former President Carlos Menem, who came into office in 1989 promising to reduce the hyperinflation affecting the country and to put the economy back on track through modernization. Menem's ambitious plans to revive the ailing economy included an extended economic liberalization program mainly aimed at reducing government spending by privatizing hundreds of publicly owned or managed firms and services. ${ }^{441}$ As a beneficial side effect of these plans the government expected an improvement in the efficiency of service delivery. These plans had the overall approval and backup of the IMF, World Bank and the Inter-American Development Bank. ${ }^{442}$ The privatization of essential utilities such as water and electricity began in 1989 through the adoption of legislation setting the stage for the privatization of most of Argentina's SOEs. ${ }^{443}$ Additionally, Law No. 23,696 of 23 August 1989 on State Reform was adopted declaring a state of economic emergency with regard to the provision of public services. ${ }^{44}$ This emergency legislation authorized the partial or total privatization of companies owned by the State ${ }^{445}$ and was adopted

441 A. Estache, “Argentina’s 1990s Utilities Privatization: A Cure or a Disease?” 2002, available from <http://papers.ssrn.com/sol3/papers.cfm?abstract_id=383500>.

442 See "Argentina's privatization program: Experience, Issues, and Lessons," The World Bank, Washington D.C., (Development in Practice series, p. 18-19.

443 H.M. Ennis and S.M. Pinto, "Privatization and Income Distribution in Argentina," in Seminar on the Effects of Privatization on Income Distribution in Latin America, Puebla, Mexico: InterAmerican Development Bank/Universidad de las Américas (2002), p. 2.

444 See Article 1 of Law No. 23,696 on State Reform available at $<$ http://infoleg.mecon.gov.ar $>$ (last visited on 10 May 2011). See also A. J. Loftus and D. McDonald, "Of Liquid Dreams: A Political Ecology of Water Privatization in Buenos Aires," Environment \& Urbanization Vol. 13, no. No. 2 (2001), p. 182.

445 Article 11 of Law No. 23,696. 
without any public consultation. ${ }^{446}$ The privatization process took place through the transfer of ownership (divestiture) and management (concessions) to the private sector. Utilities were mostly privatized through concession agreements. This required a major overhaul of the institutions involved in the sector and the introduction of a new regulatory framework since it was acknowledged that the privatization of former state monopolies in the utilities sector would not result immediately in the elimination of the monopolies themselves due to the nature of the industry ${ }^{447}$ In addition, Argentina adopted the Convertibility Law by which it tied the value of the Argentine Peso to the United States Dollar. ${ }^{448}$

The privatization of the electricity sector started in 1991 when most of the publicly owned electricity companies were transferred to the private sector. ${ }^{449}$ The first privatization in the water utilities sector took place in 1992/1993 in the metropolitan area of the city of Buenos Aires. ${ }^{450}$ Other major privatization endeavors in the water utilities sector took place in the cities of Tucumán (1995) and Córdoba (1997).

In spite of the initial embrace of privatization, especially in the utilities sector, dissatisfaction with the outcomes of many of the privatizations resulted in the termination of a number of concessions in the late 1990s and beginning of the year 2000. Two examples are the rescissions of the water concession contracts between Azurix Corp. and the province of Buenos Aires, and between Compania de Aguas del Aconquija S.A. (the local subsidiary of Vivendi Universal) and the province of Tucumán, briefly discussed in Chapter III. To recapitulate, in the Azurix rescission, the provincial government of Buenos Aires rescinded the concession contract with private water utility Azurix following popular protests due to perceived provision of inadequate services and unpopular price increases, and after the company filed for

446 Loftus and McDonald, "Of Liquid Dreams: A Political Ecology of Water Privatization in Buenos Aires," p. 182-183.

447 See Estache, “Argentina's 1990s Utilities Privatization: A Cure or a Disease?”. As noted in Section 2.2 supra, due to their nature, some utilities, such as those related to the provision of water and sewerage, are natural monopolies. As a result, competition for the market and within the market is more feasible in the electricity sector than in the water sector (where usually, competition for the market is the usual situation). Additionally, due to the way the way in which the concessions were awarded (international open bidding) and the lack of bidders competing for the concessions the privatization of essential utilities in Argentina usually ended in de facto monopolies even in the case of electricity utilities.

448 See Law No. 23,928 of 28 March 1991. See also Suez, Sociedad General de Aguas de Barcelona S.A. and Vivendi Universal S.A v. Argentine Republic, Decision on Liability, ICSID Case No. ARB/03/19, 30 July 2010, para. 29.

449 O. Chisari, A. Estache, and C. Romero, "Winners and Losers from Utility Privatization in Argentina: Lessons from a General Equilibrium Model," The World Bank Economic Review Vol. 13 (1999), p. 3.

450 L. Alcázar, M.A. Abdala, and M.M. Shirley, "The Buenos Aires Water Concession," Policy Research Working Paper No. 2311, World Bank/Development Research Group Regulation and Competition Policy, (2000), p. 1. 
bankruptcy, which it blamed on the conduct of the provincial government. ${ }^{451}$ In the case of Compania de Aguas del Aconquija the province of Tucuman's reason to unilaterally rescind the concession contract was the alleged deficient operation of the water concession by the company. However, the political context (popular opposition to privatization and the election of a local government which was ran on a platform against privatization) also had an effect on the termination of the concession contract. ${ }^{452}$

A major fall out with privatization took place in the wake of the financial crisis that struck Argentina in 2001 and 2002. Many of the concessionaires struggled to keep afloat amidst financial turmoil as a result of a number of measures adopted by the Argentine government to alleviate the crisis. ${ }^{453}$ These measures included prohibiting privatized utilities from raising the prices of their services to compensate for the

451 This case led Azurix Corp. to file a claim before the ICSID alleging, inter alia, expropriation of investments and the failure on the part of the government of the province of Buenos Aires to provide the company's investments with a fair and equitable treatment. See Azurix Corp. v. Argentine Republic, Award, ICSID Case No. ARB/01/12, 14 July 2006. In the wake of the award, Argentina submitted a request in December 2006 to annul the award, which was decided upon by an Ad hoc Committee on 1 September 2009 dismissing in its entirety the request for annulment, and thereby reaffirming the 2006 Award. See Azurix Corp. v. Argentine Republic, Decision on the Application for Annulment of the Argentine Republic, ICSID Case No. ARB/01/12 (Annulment Proceeding), 1 September 2009.

452 As in Azurix, Companía de Aguas del Aconquija and its parent company Vivendi Universal, filed a claim before the ICSID on similar grounds. Compania de Aguas del Aconquija S.A. and Vivendi Universal (Formerly Compagnie Generale Des Eaux) v. Argentine Republic, Award, ICSID Case No. ARB/97/3, 20 August 2007. The ICSID Tribunal concluded that the Province of Tucumán through its illegitimate attempts to discredit the concession, the concession contract, and the concessionaire with an aim to reverse the privatization of water in the Province or to force the concessionaire to renegotiate and lower its water tariffs under threats of rescinding the concession, acted in a way that amounted to a breach of the fair and adequate standard required under the Argentine - France BIT. Ibid., para. 7.4.19. This case has had a rocky procedural history and was only concluded in 2010 following a second request by Argentina to annul the 2007 award (previously, Argentina had successfully initiated an annulment procedure in 2002 against the initial award rendered in 2000, resulting in the resubmission of the proceedings by Compania de Aguas del Aconquija S.A. and Vivendi Universal). This request, however, was rejected by an Ad hoc Committee which held up the 2007 award (see Compania de Aguas del Aconquija S.A. and Vivendi Universal (Formerly Compagnie Generale Des Eaux) v. Argentine Republic, Decision on the Argentine Republic's Request for Annulment of the Award rendered on 20 August 2007, ICSID Case No. ARB/97/3 (Annulment Proceeding), 10 August 2010.

453 Many of the companies operating privatized utilities had made investments and incurred debt in local currency, which up to 2002 had maintained parity with the U.S. Dollar. Following the financial crisis in Argentina that included a bank holiday, the local currency's value was decoupled from the Dollar resulting in a devaluation of the investments and concomitant increase in the debt burdens of these companies. See W.W. Burke-White, "The Argentine Financial Crisis: State Liability Under BITS and the Legitimacy of the ICSID System," Asian Journal of WTO \& International Health Law and Policy Vol. 3 (2008), p. 202-204. 
devaluation of the national currency. ${ }^{454}$ In response various of these companies in the electricity, gas, and water sectors, took legal action against Argentina resulting in over forty cases before the ICSID for allegations of unlawful expropriations and taking of property, and violation of the obligation to provide fair and equitable treatment to their investments in breach of a number of several Bilateral Investment Treaties signed between Argentina and various countries. ${ }^{455}$

\subsection{The Buenos Aires water concession}

The state owned water utility serving the capital city of Buenos Aires, Obras Sanitarias de la Nación (OSN), was the first water utility to be privatized in Argentina. The main reasons for its privatization were "(1) the record of poor performance and mismanagement characterizing public utilities in general and (2) the insufficiency of public funds alone to meet the increasing investment needs of the water and sewerage sector." 456 OSN was regarded as an inefficient public utility with a low investment record, low quality of service resulting in low pressure, turbidity and bacterial contamination of water, poor customer response and high

454 Suez, Sociedad General de Aguas de Barcelona S.A. and Vivendi Universal S.A v. Argentine Republic, Decision on Liability, ICSID Case No. ARB/03/19, para. 44-47.

455 Cases include: Enron Corporation and Ponderosa Assets, L.P. v. Argentine Republic, ICSID Case No. ARB/01/3 (case still pending); CMS Gas Transmission Company v. Argentine Republic, Award, ICSID Case No. ARB/01/8, 12 May 2005 (the case has been finally settled following an unsuccessful attempt by Argentina to annul the award, see CMS Gas Transmission Company v. Argentine Republic, Decision of the ad hoc Committee on the Application for Annulment of the Argentine Republic, ICSID Case No. ARB/01/8, 25 September 2007); LG\&E Energy Corp., $L G \& E$ Capital Corp. and $L G \& E$ International Inc. v. Argentine Republic, ICSID Case No. $\mathrm{ARB} / 02 / 1$ (case still pending following a request submitted by Argentina to annul an award rendered in 2007); Sempra Energy International v. Argentine Republic, Award, ICSID Case No. $\mathrm{ARB} / 02 / 16,28$ September 2007 (case still pending following yet another a request submitted by Argentina to annul the award rendered in 2007); Aguas Cordobesas S.A., Suez, and Sociedad General de Aguas de Barcelona S.A. v. Argentine Republic, ICSID Case No. ARB/03/18 (proceedings in this case were discontinued following a settlement agreed by both parties on 24 January 2007); Camuzzi International S.A. v. Argentine Republic, ICSID Case No. ARB/03/2 (case still pending); and the aforementioned Aguas Argentinas, S.A., Suez, Sociedad General de Aguas de Barcelona, S.A. and Vivendi Universal, S.A. v. Argentine Republic, ICSID Case no. ARB/03/19 (renamed to Suez, Sociedad General de Aguas de Barcelona S.A. and Vivendi Universal S.A v. Argentine Republic after Aguas Argentinas S.A. withdrew from the case in 2006 and a decision on liability was reached in July 2010). For a discussion of the legality of the necessity to adopt the alleged measures and its impact see further Burke-White, "The Argentine Financial Crisis: State Liability Under BITS and the Legitimacy of the ICSID System," p. 202204.

456 E. Idelovitch and K. Ringskog, Private Sector Participation in Water Supply and Sanitation in Latin America, Directions in Development (Washington D.C.: The International Bank for Reconstruction and Development/The World Bank, 1995) p. 30. 
water loss. ${ }^{457}$ The poorer suburban areas of Buenos Aires were the most affected by OSN's inadequate performance. ${ }^{458}$

The privatization process of OSN was backed up by the two chambers of the Argentine Parliament, the government agencies involved, local government and the staff of OSN affected by the privatization, whom in accordance with the privatization legislation were offered a ten percent share in the privatized company. ${ }^{459}$ It has been observed that the government aimed at maintaining the credibility and transparency of the privatization process by establishing an elevenmember committee that was in charge of coordinating the privatization of OSN. This committee included representatives of the parliament, national government and local government, as well as the management and trade unions of OSN. ${ }^{460}$ Additionally, it has been claimed that the involvement of technical advisors, international agencies such as the IADB, the World Bank and UNDP, and the national monitoring agency for state owned enterprises enhanced the transparency of the process. ${ }^{461}$ However, there was no consultation with consumers and end users about privatization and its effects, and apparently the first public hearing of the privatization took place in 2000 , seven years after the privatization operation had started. ${ }^{462}$

457 R. Schusterman et al., Public Private Partnerships and the Poor: Experiences With Water Provision in Four Low-Income Barrios in Buenos Aires, ed. M. Sohail, Public Private Partnerships and the Poor (Leicestershire: Water, Engineering and Development Centre (WEDC) Loughborough University, 2002) p. 11. See also D. Artana, F.H. Navajas, and S. Urbiztondo, "La Regulación Económica en las Concesiones de Agua Potable y Desagües Cloacales en Buenos Aires y Corrientes, Argentina," Documento de Trabajo de la Red de Centros R-312, FIEL/Banco Interamericano de Desarrollo, Washington D.C., (1997), p. 8. Artana, Navajas and Urbiztondo have additionally noted that the infrastructure operated by OSN was in bad condition. Moreover, $83 \%$ of the network was over 40 years old and $55 \%$ was even over 60 years old. Ibid.

458 Zérah notes that of the 30 percent of the population without access to the municipal water network, most relied on well water for their water supply. This led to higher rates of water-borne diseases due to contamination of groundwater from industrial waste and cesspools of households that were not connected to the municipal sewerage system. M. Zérah and K. Graham-Harrison, "The Buenos Aires Concession - The Private Sector Serving the Poor," Report No. 23722, UNDP - Water and Sanitation Program, (2001), p. 2.

Alcázar, Abdala, and Shirley, "The Buenos Aires Water Concession," p. 17. See also Loftus and McDonald, "Of Liquid Dreams: A Political Ecology of Water Privatization in Buenos Aires," p. 183. Loftus and McDonald claim that the participation of the workers as stakeholders in the privatization process helped to decrease the resistance against the plans. Alcázar, Abdala, and Shirley, "The Buenos Aires Water Concession," p. 18-19.

461 Ibid. See also Loftus and McDonald, "Of Liquid Dreams: A Political Ecology of Water Privatization in Buenos Aires," p. 183.

462 Loftus and McDonald, "Of Liquid Dreams: A Political Ecology of Water Privatization in Buenos Aires," p. 183. See also Schusterman et al., Public Private Partnerships and the Poor: Experiences With Water Provision in Four Low-Income Barrios in Buenos Aires, p. 1. 
The privatization of OSN took place through an open tender which had the objective of awarding the concession to the company that offered the largest tariff reduction. ${ }^{463}$ Although this approach was partly geared to gather popular support for the privatization and could theoretically be beneficial for consumers, a World Bank project appraisal document claimed that the choice for this award criterion was poor because,

"[...] in actual practice, this method was shown a major flaw in that it has not been able to be sustained over time. Because the company's cash generation capacity did not turn out to be as expected, the concessionaire was forced to seek tariff increasesalbeit remaining below the original, pre-privatization level-to finance the investment program. This has severely eroded the public support and confidence for water privatizations as the promised benefits have not been realized." 464

Concerns have also been raised that the tender process was marked by a lack of reliable information available for the bidders. ${ }^{465}$ Zérah and Graham-Harrison have observed that low quality and unreliable information was a defining feature of the tender process. ${ }^{466}$ The government in fact explicitly waived any responsibility for the quality and accuracy of the pre-tender information in the concession contract. ${ }^{467}$ In this respect, it can be concluded that although in general the privatization process appears to have been transparent, during the crucial tendering period the aspect of transparency left something to be desired.

The award attracted five candidates of which only three actually made competitive bids. The concession was awarded to Aguas Argentinas S.A., a consortium made up of French, Spanish and British water companies and Argentine investors ${ }^{468}$ that had

463 Alcázar, Abdala, and Shirley, "The Buenos Aires Water Concession," p. 15. See also Loftus and McDonald, "Of Liquid Dreams: A Political Ecology of Water Privatization in Buenos Aires," p. 185.

464 "Project Appraisal Document on a Proposed Loan in the Amount of \$ 30.0 Million to the Argentine Republic for a Water Sector Reform Project in Support of the First Phase of the Water Sector Reform Program," Report No: 19258, World Bank/Finance, Private Sector and Infrastructure Country Management Unit 5, Latin America and the Caribbean Regional Office, (1999), p. 5.

465 Alcázar, Abdala, and Shirley, "The Buenos Aires Water Concession,” p. 21.

466 Zérah and Graham-Harrison, "The Buenos Aires Concession - The Private Sector Serving the Poor," p. 8.

467 Article 3.3 of the concession contract between the Argentine Republic and Aguas Argentinas as approved through Presidential Decree No. 787/93 of 22 April 1993. The text of the contract is available at $<$ www.etoss.org.ar $>$ (last visited on 30 December 2008). See also Alcázar, Abdala, and Shirley, "The Buenos Aires Water Concession," p. 21.

468 The French multinationals Suez and Vivendi Universal, together with Spanish Aguas de Barcelona S.A. and the U.K.s Anglian Water had 53 percent stake in the Aguas Argentinas, while 37 percent was in hands of Argentine investors including Sociedad Comercial del Plata, Meller, and Banco de Galicia. The last 10 percent was in hands of the workers of Aguas Argentinas. In 
offered the highest tariff reduction (26.9 percent). ${ }^{469}$ In May 1993 Aguas Argentinas started its operations after signing a 30 -year concession contract.

Together with the concession a regulatory mechanism, the ETOSS, was set in place and a regulatory framework established. ${ }^{470}$ ETOSS was constituted as an independent entity with regulatory, quality control, and policing powers. ${ }^{471}$ The regulatory framework determined ETOSS' main objectives which were to monitor and regulate the quality of service provided by Aguas Argentinas, to ensure the implementation of the tariffs regime and approve any changes thereof, to monitor the expansion of the services, to monitor the investment plans of Aguas Argentinas, to ensure that consumers are served in conformity with their rights, and to impose sanctions on Aguas Argentinas in case of breach of its (contractual) obligations. ${ }^{472}$ The regulatory framework also established the obligations imposed on Aguas Argentinas regarding the quality of service and of the water, and the expansion of the water and sewerage network. ${ }^{473}$ These provisions were also further specified in the concession contract. Thus, under the regulatory framework and the concession contract the concessionaire was required to provide water of sufficient quality to meet the standards established in the framework and the concession contract. These standards were based on WHO standards on safe water for human consumption. Aguas Argentinas was also required to provide six five-year plans determining the company's plans and investments to gradually expand the service and implement improvements to the network as well as make periodic tariff revisions. In addition, the regulatory framework laid down the tariff system, which some commentators considered to be inefficient and opaque, ${ }^{474}$ and other additional charges that

addition, the International Finance Corporation acquired a 5 percent stake in 1994. See ibid., Alcázar, Abdala, and Shirley, p. 20.

Ibid., p. 20. See also Loftus and McDonald, "Of Liquid Dreams: A Political Ecology of Water Privatization in Buenos Aires," p. 185.

The regulatory framework was established through presidential decree No. 999/92 of 18 June 1992, which was known otherwise as the 'Water Decree'. The text of the regulatory framework can be found at $<$ www.etoss.org.ar $>$ last visited on 30 December 2008.

See Articles 15 and 17 of the regulatory framework.

See among others, Article 3,17 and 34 of the regulatory framework. In particular Article 3 states that the objectives of the regulatory framework are to a. guarantee the maintenance and promote the expansion of water and sewerage networks; $b$. establish a normative system that guarantees the quality and continuity of the regulated public service; regulate activities and adequately protect the rights of the service users, the concessionaire and the regulatory entity; guarantee the operation of the services currently provided and those to be provided in the future according to the quality and efficiency levels provided in the regulatory framework; and to protect public health, water resources and the environment.

See Articles 42 and 56 of the regulatory framework.

Alcázar, Abdala, and Shirley, "The Buenos Aires Water Concession," p. 21; M. Solanes, "Efficiency, Equity and Liberalisation of Water Services in Buenos Aires, Argentina," in Liberalisation and Universal Access to Basic Services - Telecommunications, Water and Sanitation, Financial Services, and Electricity, Paris: OECD and The International Bank for Reconstruction and Development/The World Bank (2006), p. 154-155. 
consumers had to pay to have access to the water and sewerage network. ${ }^{475}$ Payment for use of the service was compulsory, and the regulatory framework as well as the concession contract granted the concessionaire the power to disconnect users if the latter had not paid three consecutive water bills. ${ }^{476}$ Finally the regulatory framework entitled service users to receive relevant information about the provision of the service, and enabled them to submit complaints before the ETOSS only after they had first directly filed a complaint before Aguas Argentinas or when the latter adopted a decision or failed to respond to a complaint. ${ }^{477}$

During the thirteen years of its existence, the concession contract was renegotiated three times. In 1994, eight months after the start of the operation of the concession, Aguas Argentinas requested a revision of the contract to allow an increase in the tariff rates for the provision of water and sewerage services as well as an increase in the connection charges to cover unexpected operational loses. ${ }^{478}$ These losses were incurred due to the deficient condition of the users' records and to the network's malfunctioning. Although it would appear that the conditions for the revision of the concession contract in the regulatory framework were not met, both the Argentine Government and the ETOSS approved the revision, which also included new expansion aims and investment projects. ${ }^{479}$ Following this first renegotiation, Aguas Argentinas started to attain unusually large profits for the sector. ${ }^{480}$

475 In a nutshell, there were two tariffs: metered and non-metered tariffs. Users without a water meter had to pay a flat rate, whereas metered users had to pay a high fixed rate and a variable rate based on meter readings. In addition to the tariff, all users who needed to be newly connected to the network (and those requesting improvements to the connection) had to pay an infrastructure charge, which was intended to finance network expansion. The infrastructure charge ranged from $\$ 200$ to $\$ 245$ US Dollars.

476 See Article 52 of regulatory framework and Article 39 of Annex VII to the concession contract.

477 See Articles 34, 41, and 72 of the regulatory framework. The framework also obliged the concessionaire to draft a regulation for users of the service which provided further details on the obligations of Aguas Argentinas with regard to the connection of new users, the procedures to follow for disconnections, the procedures to follow for lodging complaints, the billing for the service and the levels and quality of service. See Article 17 and Annex D of the regulatory framework.

478 D. Azpiazu and K. Forcinito, "Privatisation of the Water and Sanitation Systems in the Buenos Aires Metropolitan Area: Regulatory Discontinuity, Corporate Non-Performance, Extraordinary Profits and Distributional Inequality," in First Project Workshop on Private Sector Participation in Water and Sanitation: Institutional, Socio-political, and Cultural Dimensions, School of Geography and the Environment University of Oxford: PRINWASS (2002), p. 23.

479 Ibid., p. 23-24.

480 Loftus and McDonald point to a report prepared by a local university which concluded that Aguas Argentinas had profits over twenty percent (20\%) above annual revenues starting in 1995. In comparison, privatized utilities in England only earned nine percent (9\%) profits over the annual revenue. Loftus and McDonald, "Of Liquid Dreams: A Political Ecology of Water Privatization in Buenos Aires," p. 192. 
In spite of these profits, and following further delays in the promised investments as required under the 1994 renegotiation and subsequent fines imposed by ETOSS, Aguas Argentinas once again requested a renegotiation of the contract. ${ }^{481}$ Negotiations to revise the contract with ETOSS did not progress swiftly and in 1997 the Argentine Government reached an agreement with the concessionaire bypassing ETOSS. ${ }^{482}$ This renegotiation resulted in the elimination of the infrastructure charge and the introduction of new surcharges to cover for universal services and environmental measures (SUMA for its Spanish acronym). ${ }^{483}$ The new SUMA charges were to be paid by all service users. In addition, lower connection charges were implemented for new users, and planned expansions were cut back. In practical terms, the renegotiation resulted in lower average water bills for new customers, but higher ones for customers who were already connected to the network. ${ }^{484}$ It also resulted in a lower compliance of the original expansion targets, without a concomitant reduction of water tariffs, which were based on the promise of expansion. The renegotiation was nonetheless followed by further tariff increases that were approved by the executive branch and not by ETOSS, thus sidelining the regulator once again. ${ }^{485}$

In the wake of the financial crisis that hit Argentina between 1999 and 2002, the Argentine government adopted emergency legislation to attempt to curb down the effects of the crisis. These measures included changes in the monetary system to cut the link between the Argentine Peso and the U.S. dollar, resulting in a significant depreciation of the Peso. ${ }^{486}$ This in turn negatively affected the investments and debts of the water companies that formed Aguas Argentinas, all of which were made in Argentine Pesos. ${ }^{487}$ In addition, the government issued a decree to facilitate the start of renegotiations of the various concession contracts with privatized utilities including Aguas Argentinas in view of the financial crisis and with the aim of

481 Alcázar, Abdala, and Shirley, "The Buenos Aires Water Concession,” p. 36-37.

482 Ibid., p. 37. See also Loftus and McDonald, "Of Liquid Dreams: A Political Ecology of Water Privatization in Buenos Aires," p. 192.

483 Loftus and McDonald, "Of Liquid Dreams: A Political Ecology of Water Privatization in Buenos Aires," p. 192; Azpiazu and Forcinito, "Privatisation of the Water and Sanitation Systems in the Buenos Aires Metropolitan Area: Regulatory Discontinuity, Corporate Non-Performance, Extraordinary Profits and Distributional Inequality," p. 27; and Solanes, "Efficiency, Equity and Liberalisation of Water Services in Buenos Aires, Argentina," p. 159. Solanes, "Efficiency, Equity and Liberalisation of Water Services in Buenos Aires, Argentina," p. 159.

485 Ibid., p. 160.

486 See Ley 25.561 Emergencia Publica y Reforma del Regimen Cambiario [Law No. 25.561 on Public Emergency and Reforms to the Exchange Regime] of 6 January 2002.

487 See Solanes, "Efficiency, Equity and Liberalisation of Water Services in Buenos Aires, Argentina," p. 157. The result was that the debt incurred by Aguas Argentinas almost tripled due to the devaluation of the local currency. See A.A. Casarin, J.A. Delfino, and M.E. Delfino, "Failures in Water Reform: Lessons from the Buenos Aires's Concession," Utilities Policy Vol. 15 (2007), p. 245. 
freezing the tariffs of the services for consumers. ${ }^{488}$ The concessionaire submitted an emergency plan that placed on hold all non-emergency investments, and requested permission to readjust the tariffs to reflect the new situation. The request was denied, and after some fruitless negotiations, the consortium leading Aguas Argentinas submitted a claim before the ICSID on July 2003, arguing that the measures adopted by Argentina amounted to expropriation, and that Argentina failed to treat the investments of the consortium fairly and equitably in violation of the Argentina-France, the Argentina-Spain, and the Argentina-UK BITs. ${ }^{489}$

Aguas Argentinas and its parent companies were not the only stakeholders in the arbitration proceedings. In January 2005, a group of civil society organizations including human rights NGOs and consumer associations filed a 'Petition for Transparency and Participation as Amicus Curiae' before the ICSID. ${ }^{490}$ The petitioners asserted that "[...] the case involved matters of basic public interest and the fundamental rights of people living in the area affected by the dispute in the case," 491 and thus asked the ICSID Tribunal to grant three requests: a. to allow petitioners access to the hearings in the case; $b$. to allow petitioners opportunity to present legal arguments as amicus curiae; and c. to allow petitioners timely, sufficient, and unrestricted access to all of the documents in the case. Concluding that it had the power to admit amicus curiae submissions, ${ }^{492}$ the Tribunal set up

488 See Decree No. 293/2002 of 12 February 2002 on the renegotiation of contracts of public works and public services. Casarin et. al point out that the measures also required the concessionaires in Argentina to continue observing their contractual obligations, that is keep on investing without the support of higher tariffs to help finance those investments. Casarin, Delfino, and Delfino, "Failures in Water Reform: Lessons from the Buenos Aires's Concession," p. 245.

See Suez, Sociedad General de Aguas de Barcelona, S.A. and Vivendi Universal, S.A. v. Argentine Republic, Decision on Jurisdiction, ICSID Case no. ARB/03/19, 3 August 2006, para. 25. See Chapter III, Section 3.1.3 for a discussion of this case from the perspective of the international state responsibility of Argentina for the breach of the BITs between Spain, France and the United Kingdom.

490 Aguas Argentinas, S.A., Suez, Sociedad General de Aguas de Barcelona, S.A. and Vivendi Universal, S.A. v. Argentine Republic, Order in Response to a Petition for Transparency and Participation as Amicus Curiae, ICSID Case no. ARB/03/19, 19 May 2005. The organizations represented in the petition were Asociación Civil por la Igualdad y la Justicia (ACIJ), Centro de Estudios Legales y Sociales (CELS), Center for International Environmental Law (CIEL), Consumidores Libres Cooperativa Ltda. de Provisión de Servicios de Acción Comunitaria, and Unión de Usuarios y Consumidores.

491 Aguas Argentinas, S.A., Suez, Sociedad General de Aguas de Barcelona, S.A. and Vivendi Universal, S.A. v. Argentine Republic, Order in Response to a Petition for Transparency and Participation as Amicus Curiae, para. 1.

492 Ibid., paras- 14-16. The ICSID Tribunal reached this conclusion by relying on the observations in the Methanex v. United States of America case before the NAFTA arbitration tribunal. See Methanex v. United States of America, Decision of the Tribunal on Petitions From Third Parties to Intervene as Amici Curiae of 15 January 2001, available at <http://naftaclaims.com/Disputes/ USA/Methanex/MethanexDecisionReAuthorityAmicus.pdf> (last visited on 30 December 2008). The tribunal in the Methanex decision interpreted Article 15(1) of the UNCITRAL Rules, which is substantially similar to Article 44 of the ICSID Convention. Article 44 allows the 
the conditions for the admission of amicus curiae briefs. In the first place the case's subject matter has to be appropriate for receiving amicus submissions. In the second place the particular nonparty has to be suitable to act as amicus curiae in that case. Finally the ICSID Tribunal was to establish the procedure by which the amicus submission had to be made and considered. The Tribunal concluded that the petitioners fulfilled all criteria and allowed them to file an amicus curiae submission, although it denied them the possibility of attending the hearings of the case. ${ }^{493}$ In particular, and as already observed in Section 2.2 supra, the Tribunal noted with regard to the first condition (appropriateness of the subject matter), that the dispute revolved around matters of public interest that raises various complex issues of public and international law, including human rights issues with a potential to affect the operation of the service and the public it serves. ${ }^{494}$

By ascertaining that the nature of the issue at hand raises public interest concerns and human rights considerations, the Tribunal acknowledged the importance of the provision of basic public services such as water in terms of the role of the service provider (be it the State or the private water company) and in terms of the potential human rights effects such service can have. The importance and essential nature of the service was later once again reaffirmed by the Tribunal in its 2010 decision on Argentina's liability for the adopted measures. ${ }^{495}$

Notwithstanding the arbitration dispute before the ICSID, Aguas Argentinas continued its operations. On May 2004, the concessionaire and the Argentine government entered once again into negotiations to revise the concession contract, with the company agreeing to further invest money in the network. ${ }^{496}$ At the same

ICSID Tribunal to decide on any questions not covered in the Convention's section dealing with powers and functions of the Tribunal and in the Arbitration Rules. It is worth noting that following the decision in the Order in Response to a Petition for and Participation as Amicus Curiae in the Aguas Argentinas, S.A., Suez, Sociedad General de Aguas de Barcelona, S.A. and Vivendi Universal, S.A. v. Argentine Republic case, the ICSID modified its Rules of Arbitration to admit similar amicus curiae requests in future proceedings.

493 See Aguas Argentinas, S.A., Suez, Sociedad General de Aguas de Barcelona, S.A. and Vivendi Universal, S.A. v. Argentine Republic, Order in Response to a Petition for Transparency and Participation as Amicus Curiae, para. 33, reaffirmed in the same albeit later renamed case Suez, Sociedad General de Aguas de Barcelona, S.A. and Vivendi Universal, S.A. v. Argentine Republic, Order in Response to a Petition by Five Non-Governmental Organizations For Permission to Make an Amicus Curiae Submission, ICSID Case no. ARB/03/19, 12 February 2007.

494 Aguas Argentinas, S.A., Suez, Sociedad General de Aguas de Barcelona, S.A. and Vivendi Universal, S.A. v. Argentine Republic, Order in Response to a Petition for Transparency and Participation as Amicus Curiae, para. 19.

495 See Suez, Sociedad General de Aguas de Barcelona S.A. and Vivendi Universal S.A v. Argentine Republic, Decision on Liability, para. 260, and Section 2.2 supra.

496 See Water Firm Suez in Argentina Row, BBC News report available at $<$ http://news.bbc.co.uk/ go/pr/fr/-/2/hi/business/4201461.stm $>$ (last visited on 30 December 2008). 
time, the Argentine Ombudsman and ETOSS increasingly registered various complaints against Aguas Argentinas. Thus, the regulator fined the company for, inter alia, providing water to some sectors of the city at such a low pressure that it effectively denied water from the consumers living in those areas, in spite of the fact that they continued to pay for the service, ${ }^{497}$ and for providing water with high contents of arsenic and nitrates. ${ }^{498}$

Following attempts by Suez, Aguas de Barcelona, and Vivendi Universal to sell their shares in Aguas Argentinas, the latter decided to withdraw its claims before the ICSID Tribunal in February 2006 to facilitate the required approval of the sale by the Argentine Government. ${ }^{499}$ Shortly thereafter, however, the government decided to rescind the concession contract through a presidential decree in view of the company's continuing inability to properly implement the concession contract. The decree alleged in particular that in the latter stages of its operation, Aguas Argentinas was providing water that contained high amounts of nitrates to certain sectors of Buenos Aires. This made its consumption a health risk to a large portion of the population in violation of a number of constitutional rights. ${ }^{500}$ The government then decided to establish a new state-owned company called Agua y Saneamiento Argentinos (AySA) to take over the service formerly provided by Aguas Argentinas. ${ }^{501}$ In 2007, ETOSS was dissolved and two new regulatory

497 Resolución 01/05 del Defensor del Pueblo recomendando al Ente Tripartito de Obras y Servicios Sanitarios que ordene a Aguas Argentinas la provisión de agua potable (Resolution of the Argentine Ombudsman recommending ETOSS to order Aguas Argentinas to provide water) of 4 January 2005 (available at <www.defensor.gov.ar/informes/info31-sp.htm>.

See respectively ETOSS Resolutions $N^{\circ} 168 / 05$ of 21 December 2005 with respect to arsenic, and No 95/05 of 24 August 2005 with respect to nitrates (confirming previous resolutions in which it was declared that Aguas Argentinas, was not complying with its contractual obligations due to the presence of high levels of nitrates in the water which had been gradually increasing from the year 2000 up to 2005).

499 See Suez, Sociedad General de Aguas de Barcelona, S.A. and Vivendi Universal, S.A. v. Argentine Republic, Procedural Order No. 1 Concerning the Discontinuance of Proceedings with Respect to Aguas Argentinas S.A., ICSID Case no. ARB/03/19, 14 April 2006.

500 See Presidential Decree No. 303/2006 of 21 March 2006, available at the website of the former regulator of the concession, ETOSS at <www.etoss.org.ar $>$ (last visited on 28 December 2008). According to the Decree's preamble, the conduct of Aguas Argentinas was contrary to the right to a healthy environment, and the right of consumers to services that do not harm health and which are provided in an equitable and dignified way as guaranteed in Articles 41 and 42 of the Argentine Constitution.

501 See news report from Argentine newspaper El Clarín: "Crean una empresa estatal que se encargará del servicio de agua," Clarin.com, 22 Marzo, 2006, available at <www.servicios. clarin.com/notas/jsp/v7/notas/imprimir.jsp?pagid=1163125> (last visited on 30 December 2008). See also Presidential Decree No. 304/2006 of 21 March 2006, available at the website of ETOSS at <www.etoss.org.ar/desarrollo/sitioetoss05/decreto304.htm> (last visited on 30 December 2008). 
agencies set up: Ente Regulador de Agua y Saneamiento and the Agencia de Planificación. ${ }^{502}$

Possibly the final development in this privatization odyssey came in July 2010, when the ICSID Tribunal finally decided on the liability of the Argentine Government for the measures it had adopted in lieu of the financial crisis and which resulted in the termination of the concession contract with Aguas Argentinas. As explained in Chapter III, Setion 3.1.3, although the ICSID Tribunal came to the conclusion that the measures adopted by Argentina did not amount to expropriation and did not breach the obligation to provide protection and security to the investments, ${ }^{503}$ it did conclude that they were indeed in breach of the obligation to provide fair and equitable treatment to the investment. The conclusion was based on Argentina's refusal to revise the tariff according to the legal framework of the concession and through its attempt to force a renegotiation of the concession contract contrary to that legal framework. ${ }^{504}$ According to the Tribunal, the refusal and forced renegotiation thwarted the reasonable and legitimate expectations of Aguas Argentinas' investors. In the eyes of the Tribunal, the investors' expectations that Argentina would respect the concession contract throughout the thirty-year life of the concession were legitimate, reasonable, and justified "[i]n view of the central role that the concession contract and legal framework placed in establishing the Concession and the care and attention that Argentina devoted to the creation of that framework[...]"505 By not adopting a flexible position that would have protected both its own essential interests and those of the investors, Argentina showed it was not willing to reach an amicable solution to the problem. In addition, the Tribunal concluded that Argentina could not avail itself under international law of the defense of necessity to justify the measures. ${ }^{506}$ As already discussed in Chapter III, Section 3.1.3, Argentina claimed that the measures were necessary to safeguard the right to

502 See Law 26.221/2007 of 28 February 2007 (Creación del Ente Regulador de Agua y Saneamiento y de la Agencia de Planificación. Marco Regulatorio), available at the website of ETOSS at $<$ www.etoss.org.ar/desarrollo/sitioetoss05/ley26221.htm> (last visited on 30 December 2008).

503 See Suez, Sociedad General de Aguas de Barcelona S.A. and Vivendi Universal S.A v. Argentine Republic, Decision on Liability, ICSID Case No. ARB/03/19, paras. 157 and 179. With regard to the latter conclusion the Tribunal indicated that the obligation to provide protection and security only referred to a due diligence obligation to protect investors and investments from physical injury, something that was not an issue in the case.

504 Ibid., para. 247. The ICSID Tribunal, however, refused to go into the question whether the unilateral termination of the concession by Argentina was pursuant to the concession contract, something that needs to be dealt with by the dispute settlement procedures found in the contract itself. Ibid., para. 246.

505 Ibid., para. 231.

506 The Argentine Republic based the defense on Article 25 of the ILC's Articles on the Responsibility of States for Internationally Wrongful Acts which aims at precluding the wrongfulness of an act which breaches an international legal obligation. As explained in Chapter III, Section 3.1.3, the ICSID Tribunal interpreted the necessity defense and its requirements quite narrowly. 
water of the inhabitants of Buenos Aires. However, the Tribunal essentially argued that adopting measures to abide by the human rights obligations of Argentina did not exempt it from also respecting other legal obligations of equal worth such as those emanating from the BITs. ${ }^{507}$ Argentina could have safeguarded the human rights of consumers by adopting measures that were allowed by the regulatory framework it had established and which were compatible with the rights of the investors under the BITs. Thus according to the Tribunal, the most vulnerable consumers might have been shielded from the necessary price increases through the application of a social tariff or through cross subsidies. ${ }^{508}$

In the end, Argentina's measures to take on the crisis, and its awkward handling of its contractual relationship with Aguas Argentinas, were sufficient for the Tribunal to conclude that the Republic was responsible for breaching the BITs involved. The Tribunal's conclusions - in essence, the human rights obligations of Argentina do not trump those emanating from the BITs and both types of obligations are not mutually exclusive - are sound under general international law international law. Indeed, there are only very few human rights norms that could 'trump' other international legal obligations, namely those which have been recognized as embodying peremptory norms of international law (jus cogens), such as the prohibition of genocide, slavery, and, arguably, torture. The Tribunal's sobering observation may be wry for human rights activists who had probably hoped that bringing a human rights approach to the ICSID would have helped to dismiss the privatization of water utilities as being incompatible with human rights, in particular with the right to water. The ICSID is, however, not a human rights tribunal. It is arguably not the most adequate forum for venting human rights concerns in spite of the fact that a number of prominent international law experts with ample human rights experience have frequently been appointed as arbitrators in investment disputes under the ICSID system.

The ICSID Tribunal's decision on liability has, at least for the time being pending the final award on damages to be paid by Argentina, brought a formal end to the privatization of water services in the city of Buenos Aires, four years after the contract was rescinded and a public company took over the service provided by Aguas Argentinas. However, although it may be clear that Argentina did not live up to the obligations it had committed itself to under the BITs, it is still necessary to settle down the matter whether the same can be said with respect to its legal obligations with respect to the right to water.

507 Suez, Sociedad General de Aguas de Barcelona S.A. and Vivendi Universal S.A v. Argentine Republic, Decision on Liability, paras 260-262. 


\subsection{Outcomes of the Buenos Aires water privatization}

Given the background provided in the previous section, it is now time to analyze how the privatization of the water utility in Buenos Aires fared in terms of human rights compliance with the right to water as discussed in section 3.2. To this end, the approach used by the UN Committee on Economic, Social and Cultural Rights will be followed. The outcomes of the concession in terms of availability, quality, and accessibility of water will be reviewed in the following paragraphs. The assessment on the outcomes of this case study is made on the basis of documents from ETOSS, the Argentine Ombudsman, reports and analysis papers of the World Bank, reports from NGOs, and academic socio-economic research papers that have studied the privatization of water in Buenos Aires. This will be followed by an attempt to apply the violations approach developed to assess the implementation of economic, social, and cultural rights and adopted by the UN CESCR to the privatization of water utilities in Buenos Aires.

\subsubsection{Availability}

As noted above, General Comment No. 15 on the right to water underlines the importance of the availability requirement for water which requires that, "[t]he water supply for each person must be sufficient and continuous for personal and domestic uses."509 Domestic uses include drinking, washing of clothes, food preparation, and personal and household hygiene. Additionally, the quantity of water available for each person should correspond to WHO guidelines, which as discussed on section 3.3.3 amounts to an estimated minimum of 20 liters per capita per day to guarantee basic health protection and hygiene, of which 7.5 liters is required for consumption ${ }^{510}$ In order for this minimum amount to reach consumers through the water mains, there has to be sufficient water pressure throughout the network. ${ }^{511}$ Water pressure determines the flow of water from the tap. If pressure is not sufficient then the flow can reduce to a trickle, effectively denying availability of water. According to the WHO Guidelines for Drinking-water Quality, "[...] low water pressure will allow the ingress of contaminated water into the system through breaks, cracks, joints and pinholes [...]"512 thus also having an effect on the quality of water. General Comment No. 15 does not mention water pressure as an element to take into account with regard to availability. However, given that it can have a direct effect on the amount and continuity of water supply for personal and domestic

\footnotetext{
509 General Comment No. 15 para. 12.

510 Howard and Bartram, "Domestic Water Quantity, Service, Level and Health,” p. 9 and 23.

511 The website of the English Water Services Regulation Authority defines water pressure as "[...] the force that pushes water through pipes." See <www.ofwat.gov.uk/mediacentre/ informationnotes/prs_inf_pressure $>$ (last visited on 15 January 2009).

512 See Guidelines for Drinking-water Quality First Addendum to Third Edition, Vol. 1, Recommendations, $3^{\text {rd }}$ ed.,World Health Organization, 2006, p. 63.
} 
uses it provides a practical and measurable proxy to assess whether the operation Aguas Argentinas has had an impact on this aspect of the right to water.

Prior to the privatization of OSN, low water pressure had been one of the major problems of the services provided by the public company. A study noted that only 17 percent of the customers living in the Buenos Aires area received water with pressure greater than 8 w.c.m. before the concession. ${ }^{513}$ Privatization of OSN was supposed to improve the levels of water pressure. Thus, Article 42 (c) of the Regulatory Framework on the Levels of Appropriate Services and Article 4.5 of the Concession Contract determined that the water pressure should be a minimum of 10 w.c.m., ${ }^{514}$ although the concessionaire was allowed to provide less if he could demonstrate that due to technical reasons or the particular characteristics of the zone, the service could be provided satisfactorily at lower pressures.

Initially, it appeared that in respect of water pressure, the privatization of OSN had resulted in a positive improvement. Thus, the same study cited in the previous paragraph noted that two years after the Aguas Argentinas started its operations, 54 percent of the customers living in the Buenos Aires area were receiving water at pressures greater than 8 w.c.m. The company was, however, unable to maintain the pressure level required throughout all the thirteen years. ETOSS issued a number of resolutions against Aguas Argentinas observing that the company was charging for usage of the service to consumers with a fixed tariff, while the water pressure provided was under the 10 w.c.m. required. ${ }^{515}$ On the basis of a recommendation by the Argentine Ombudsman, ${ }^{516}$ ETOSS also required the concessionaire to reduce the tariffs of the affected zones for not fulfilling its contractual obligations, and to

513 Alcázar, Abdala, and Shirley, "The Buenos Aires Water Concession,” p. 47. Another study noted that at the start of the concession, only 15 percent of the connections in the city area had water pressure over 8 w.c.m. Artana, Navajas, and Urbiztondo, "La Regulación Económica en las Concesiones de Agua Potable y Desagües Cloacales en Buenos Aires y Corrientes, Argentina," p. 38.8 w.c.m. stands for 8 water column meters, which amounts to around 0.8 Bar or 80 kilopascal. By comparison the minimum amount of water pressure to be offered in England is 0.7 Bar (70 kilopascal) according to the Guaranteed Standards Scheme (GSS) used by Ofwat, the water regulator for England and Wales (the GSS can be found on Ofwat's website at: <www. ofwat.gov.uk/consumerissues/rightsresponsibilities/standards/gud_pro_gss08.pdf >, last visited on 15 January 2009). In the United States, the Uniform Plumbing Code requires a minimum water pressure of 276-345 kilopascal. See Drinking Water Distribution Systems: Assessing and Reducing Risks, National Research Council (U.S.), National Academies Press, 2006, p. 23.

514 See also ETOSS Resolution No. 86/1996 of 1 August 1996 reaffirming the water pressure amount and establishing that this amount is the minimum required. The resolution is available on the website of ETOSS at <www.etoss.org.ar/desarrollo/sitioetoss05/index.htm> (last visited on 15 January 2009.

515 See preamble to ETOSS Resolution No. 29/1999 of 23 March 1999 available on the website of ETOSS.

516 See Argentine Ombudsman Resolution DP No. 711/99 of 11 March 1999. 
report on how it was solving the water pressure problem. ${ }^{517}$ Aguas Argentinas, was later fined US $\$ 597,880$ for not complying with these requirements. ${ }^{518}$ In spite of these admonitions, the company continued to provide water at lower pressures in $70 \%$ of the network. ${ }^{519}$ In its annual report for the year 2003 the Argentine Ombudsman also addressed the problem of low water pressure and noted that Aguas Argentinas continued to charge users, in spite of the problems with the water pressure. ${ }^{520}$ The Ombudsman observed that it had received various complaints from a number of neighborhoods in the concession area affected by low-pressure water, which alleged that customers had been cut off the service and admonished to pay for the service in spite of the pressure problems. The Ombudsman concluded that the company had systematically not complied with its obligations related to the provision of water at the minimum required pressure as stipulated in the regulatory framework, the concession contract, and ETOSS Resolution No. 86/1996, and overcharged the customers in various neighborhoods affected by the problem. ${ }^{521} \mathrm{~A}$ human rights impact assessment report on the Buenos Aires concession prepared by the International Centre for Human Rights and Democratic Development, a Canadian NGO, noted that,

"[i]n 2005, 37,205 complaints were filed related to low water pressure, mostly in the southern area of the concession where many of the poor neighbourhoods are located. The pressure problem was particularly acute in the summer. Community leaders in some of these areas said that on many summer days almost no water came out of household faucets." 522

In addition the report ascertained that there was a lack of emergency water supplies, especially in the poorest zones served by the concession, which led to insufficient quantity of water being delivered. This affected in particular, women who had to carry water from water tanks filled by the company.

In sum, although it would appear that availability of water improved following the privatization of OSN, the concessionaire was not able to maintain the required water pressure in a large percentage of the concession area. This affected the availability

517 Ibid, Articles 1 and 4.

518 See ETOSS Resolution No. 63/2000 of 6 June 2000.

519 See "Human Rights Impact Assessments for Foreign Investment Projects: Learning from Community Experiences in the Philippines, Tibet, the Democratic Republic of Congo, Argentina, and Peru," Rights and Democracy, International Centre for Human Rights and Democratic Development, Montreal, 2007, p. 113.

520 See Annual Report for 2003 of the Argentine Ombudsman, Defensor del Pueblo de la Nación, Décimo Informe Annual, 1/1/2003-31/12/2003, República Argentina, 2003, p. 124-126.

521 Ibid., p. 126. See also Argentine Ombudsman Resolution No. 01/05 of 4 January 2005 recommending ETOSS to order Aguas Argentinas to provide water, op. cit footnote 497.

522 See "Human Rights Impact Assessments for Foreign Investment Projects: Learning from Community Experiences in the Philippines, Tibet, the Democratic Republic of Congo, Argentina, and Peru," p. 113. 
of water of, in particular, vulnerable sectors, which were effectively denied the minimum amount of water required for personal and domestic use as prescribed in General Comment No. 15, while at the same time being charged for the non-existent service.

\subsubsection{Quality}

The requirement of quality in terms of the right to water from the perspective of the privatization of water utilities demands that the water provided by the privatized utility should be free from micro-organisms, chemical substances and radiological hazards that constitute a threat to a person's health in order to fulfill the enjoyment of this right. ${ }^{53}$ Quality also requires water provided by the privatized water utility to be of an acceptable color, odor and taste for each personal or domestic use. Ideally, the quality of water should meet the requirements set by the WHO in its Guidelines for Drinking Water Quality. ${ }^{524}$ In addition the quality component also demands that the service and network be properly maintained. This includes reducing the rate of lost water to leakage, responding in a timely manner to claims by consumers and quickly repairing connection defects.

The quality of water in any given part of the metropolitan area of Buenos Aires prior to the privatization depended on whether that area was connected to the water and sewerage network. The majority of the population living in the center of the city and which already had a connection to the water and sewerage network usually had access to water of sufficient quality. Nevertheless, according to a World Bank policy research working paper the lack of investment and repairs in the water and sewerage network on the part of OSN had led to a deterioration of the system causing water shortages in parts of the city during the summer, frequent interruptions in the delivery of water, low pressure and poor water quality. ${ }_{525}$ Moreover, 30 percent of the population living outside the city core (in the suburban and marginal areas) that were not connected to the network and relied on groundwater drawn from wells for their water needs suffered from water borne diseases. ${ }^{526}$

During the privatization process account was taken of the necessity to maintain quality levels to ensure the provision of clean water. The regulatory framework and the concession contract contained provisions dealing with the quality of water and

\footnotetext{
523 See General Comment No. 15, para. 12 (b).

524 See footnote 288.

525 Alcázar, Abdala, and Shirley, "The Buenos Aires Water Concession,” p. 4.

526 Zérah and Graham-Harrison, "The Buenos Aires Concession - The Private Sector Serving the Poor," p. 2. Contamination of groundwater was not uncommon because of contact with untreated industrial waste and sewerage that leaked from cesspools and latrines of households not connected to the sewerage network.
} 
the service expected from the concessionaire. ${ }^{527}$ According to one of the first preliminary assessments one year into the Buenos Aires concession, there appears to have been a marked improvement in the quality of the water provided by Aguas Argentinas in comparison to that formerly provided by OSN. ${ }^{528}$ Additionally, there appears to have been an improvement in the relation between the utility provider and the consumers. An indication that the quality of and increased access to water appears to have improved as a result of privatization of water utilities in Argentina can be found in a study carried out by Galiani et al. This study suggests that between the start of the privatization program in 1993 and 1999, child mortality fell faster in Argentine municipalities that had privatized their water utilities in comparison to those that did not. ${ }^{529}$ According to Galiani et al, child mortality ascribed to water borne diseases fell approximately by 5 to 7 percent in these municipalities, including Buenos Aires. ${ }^{530}$ From this study it also would appear that the poorest sections of the population experienced the largest gains from water utility privatization in terms of reduction in child mortality. ${ }^{531}$ Arguably this

In spite of these early positive improvements on the quality of water provided by Aguas Argentinas, by 2002 the concession started to be plagued by problems related to water quality in a number of zones in the concession area. Thus, in three consecutive annual reports, the Argentine Ombudsman observed that Aguas Argentinas had been negligent to adopt measures to prevent or contain the overflow from underground water in various zones of the city, causing flooding, and carrying polluted water and contaminants to aquifers, wells and water reservoirs serving various sectors of the city. ${ }^{532}$ According to Loftus and McDonald, these problems

527 As already stated above, Article 42 of the regulatory framework prescribes the appropriate levels of service expected from the concessionaire. These norms include rules regarding the quality of water, the pressure of water required, continuity and interruption of the service, treatment of sewage effluents, sewer flooding and rules regarding user complaints. Annex A of the regulatory framework and Annex II of the concession contract provide in more detail the quality requirements for the physical and chemical characteristics (inorganic and organic) to which the water quality must conform. According to ETOSS and the concessionaire these requirements are very similar to those set by the WHO. A comparison between these requirements and WHO Guidelines confirm this. See also Idelovitch and Ringskog, Private Sector Participation in Water Supply and Sanitation in Latin America, p. 35. 
were partly the result of uncollected wastewater draining into the aquifers instead of being carried for treatment due to the neglect by the concessionaire in expanding the sewerage network. ${ }^{533}$

Other quality related problems were connected to the presence of high levels of chemical components in the water of certain zones of the concession area and which posed a threat to human health. Following a routine inspection, in 2003, levels of arsenic that surpassed those allowed under the concession contract were recorded in a particular zone of the concession area. ${ }^{534}$ After sending repeated warnings to Aguas Argentinas to adopt measures to address this problem, ETOSS finally fined the concessionaire for not resolving the situation. ${ }^{535}$

More problematic than the arsenic issue, however, was the presence of high levels of nitrates in various zones of the concession area. In the third year of the concession, higher levels of nitrates affected four to five percent of the people using water supplied by Aguas Argentinas. ${ }^{536}$ In 2001, inspection of the water quality by ETOSS confirmed the high concentration of nitrates in the water beyond de quality standards stipulated in Annex A of the regulatory framework and Annex II of the concession contract. ETOSS declared that the company was in continuous breach of Article 4.4 .3 of the concession contract, ${ }^{537}$ and imposed a cumulative fine on the company. ${ }^{538}$ Aguas Argentinas appealed the decision without success claiming that the financial crisis had negatively affected its capacity to fulfill its contractual and legal obligations. ${ }^{539}$ However, and in spite of subsequent requests by ETOSS and

533 Ibid., p. 195.

534 See Nota ETOSS No. 16.898 of 19 March 2003.

535 See ETOSS Resolution No. 168/05 of 21 December 2005.

536 "Human Rights Impact Assessments for Foreign Investment Projects: Learning from Community Experiences in the Philippines, Tibet, the Democratic Republic of Congo, Argentina, and Peru," Rights and Democracy, International Centre for Human Rights and Democratic Development, Montreal, 2007, p. 114.

537 Article 4.4.3 of the concession contract deals with irregularities in the quality of potable water and states that non-fulfillment of the quality requirements for drink water established in Annex II of the contract will be considered a potential health hazard for the population ("En todos los casos, el incumplimiento de los requerimientos técnicos de calidad para agua potable establecidos en el Anexo II será considerado un peligro potencial para la salud de la población.”). It further obliges the concessionaire to adopt all the necessary measures to rectify the situation and protect the services users.

538 See ETOSS Resolution No. 46/01 of 1 June 2001, which established the nature of the problem and imposed a fine on Aguas Argentinas, ETOSS Resolution No. 95/05 of 24 August 2005, and Annual Report for 2006 of the Argentine Ombudsman, Defensor del Pueblo de la Nación, Décimo Tercer Informe Annual, 1/1/2006-31/12/2006, República Argentina, 2006, p. 105. According to ETOSS Resolution No. 95/05, which was later annulled on a technical issue, the fine amounted to an accumulated total of US \$1,719,727.03. See also Presidential Decree No. 303/2006 of 21 March 2006.

539 See Draft Resolution prepared by the Argentine House of Representatives during a session of questions to the Minister of Federal Planning, Public Investment and Services on the Rescission 
the Argentine Ombudsman to improve the quality of the service with regard to nitrate levels in the water, the problem still persisted.

In early 2006, researchers of the Argentine Ombudsman collected water samples that were analyzed by an industrial technology research institute. ${ }^{540}$ The findings of this analysis confirmed the high level presence of nitrates in the water. On the basis of these findings, the Ombudsman recommended ETOSS to adopt the necessary measures to move Aguas Argentinas to improve on the provision of water to the affected service users, including the use of alternative ways to provide safe water, and to impose the corresponding sanctions due to the diminished levels of quality of the service. ${ }^{541}$ The Ombudsman also informed the Argentine Minister of Federal Planning, Public Investment and Services that the water provided by the company in one locality was not suitable for human consumption. ${ }^{542}$ The perceived lack of due diligence on the side of the concessionaire to resolve the problem, and the continuous presence of nitrates in the water in breach of Article 4.4.3 of the concession contract were deemed by the Argentine Government to be a serious threat to the health and well being of the population of Buenos Aires. ${ }^{543}$ This situation prompted the Government to rescind the concession contract with Aguas Argentinas at the end of March 2006 as established on Articles 14.3.1 and 14.3.2 of the concession contract ${ }^{544}$ on the grounds that the situation resulted in a violation of Articles 41 and 42 of the Argentine Constitution which guarantee a healthy environment and a right to adequate public services. ${ }^{545}$ The parent companies of Aguas Argentinas, however, argued during the arbitration dispute between them and Argentina that the claim of high nitrate levels was not true and was used as a pretext for ending the concession contract for other reasons. ${ }^{546}$ Even though the ICSID Tribunal contemplated the possibility that Argentina may have indeed used the high nitrate levels controversy as a mere pretext for "[...] an action that the

of the Concession Contract with Aguas Argentinas, Dossier No. 1252-D-2006, Parliamentary Proceeding: 21 (30/03/2006), available at <wwwl.hcdn.gov.ar/proyxml/expediente.asp? fundamentos=si\&numexp=1252-D-2006 $>$ (last visited on 10 March 2009).

540 See Argentine Ombudsman Resolution No. 17/06 of 2 March 2006 on the provision of water for human consumption and including recommendations to ETOSS and Aguas Argentinas, available at $<$ www.defensor.gov.ar/resoluciones/reso21-sp.htm $>$ (last visited on 10 March 2009). Ibid. See also Annual Report for 2006 of the Argentine Ombudsman, op cit., p. 107.

542 Ibid.

543 See Presidential Decree No. 303/2006 of 21 March 2006 rescinding the concession contract.

544 Article 14.3.1 of the concession contract establishes that the Government can rescind the contract in case the concessionaire seriously fails to fulfill its legal and contractual obligations including those imposed on it by ETOSS. Article 14.3.2 establishes that the contract can be also rescinded due to continuous and unjustified delays in the fulfillment of the established annual investments or goals on the side of the concessionaire.

545 See preamble and Article 1 of Presidential Decree No. 303/2006 of 21 March 2006.

546 Suez, Sociedad General de Aguas de Barcelona S.A. and Vivendi Universal S.A v. Argentine Republic, Decision on Liability, para. 150. 
Argentine authorities had already decided to take, ${ }^{, 547}$ in the end the Tribunal noted that "[...] there is evidence in the record that such high levels may have existed." 548

In sum, it can be established that some of the initial improvements on the quality of water provided to the city of Buenos Aires by the Aguas Argentinas were offset by subsequent failures to address problems that seriously affected the quality. These problems included, as already observed in the previous section, lack of pressure in several sectors of the city, particularly in poor neighborhoods, which amounted to a denial of service, as well as continuous presence of high levels of arsenic and nitrates that were deemed to be a hazard to the health of the users of the water service. In terms of the right of access to water of sufficient quality, it can be argued that in spite of initial improvements vis-à-vis the former public operator of the service, the privatized one partially failed to achieve the necessary level of quality in certain areas required under the right to water.

\subsubsection{Accessibility}

As noted in Section 3.2 supra, the accessibility element embedded in the right to water implies that the water and water related services or facilities provided by a privatized water utility must be physically and economically accessible on a nondiscriminatory basis to everyone. According to General Comment No. 15, in order to fulfill the physical accessibility element, the water service and facility must be within safe physical reach of all sections of the population, in or near the household. ${ }^{549}$ This means that the populations should be properly connected to the water network ideally through adequate piping connecting each house or dwelling to the mains, or, alternatively, though a central water pipe that serves a number of houses and which is within reasonable distance from a household. ${ }^{550}$ Economical accessibility requires water and water services that is affordable to everybody. This means ensuring that water tariffs and other water and sewerage related fees are not disproportionately high in respect of the income of every household. As noted above with respect to the obligation to protect, this can be implemented through (targeted) cross-subsidies or a special social tariff that guarantees that the poorest or more vulnerable sectors of society are in the position to pay their water bills. Finally, the non-discriminatory aspect of the accessibility element requires that water and water

547 Ibid., para. 244. In particular, the fact that the length of time between the investigation of the high nitrate claims and the abrupt termination of the contract was very short (the formal investigation started on 17 March 2006, whereas the consession was rescinded on 21 March 2006) raised possible inferences of its use as a pretext according to the Tribunal.

548 Ibid., para. 256.

549 General Comment No. 15, para. 12 (c)(i).

550 With regard to the latter aspect, Howard and Bartram have noted that in order to ensure basic access which guarantees the positive impact of water on hygiene, the distance between household and a public water tap has to be between 100 and 1000 meters. Howard and Bartram, "Domestic Water Quantity, Service, Level and Health," p. 22. 
related services are accessible to all, including the most vulnerable or marginalized sectors of society without discrimination. The outcomes of the Buenos Aires concession will be examined in the following paragraphs in the light of these three accessibility components pertaining to the right to water.

\subsubsection{Physical accessibility}

Buenos Aires is a major capital city that by the year 2001 had reached a population of over twelve million inhabitants. Prior to the privatization of OSN in $1993,70 \%$ of the population of Buenos Aires was connected to the water network, and $58 \%$ to the sewerage network. ${ }^{551}$ The lack of investment by OSN in the water and sewerage network hindered a proper maintenance of these services and more importantly it hindered the expansion of connections to areas where usually the poorest sectors of society dwelled (the 'villas miseria' or shantytowns). ${ }^{552}$ One of the objectives of the privatization of OSN was the expansion of water and sewerage services to achieve (near) universal coverage, especially to the poorer areas of the city.

The concession contract obliged Aguas Argentinas to improve and expand on the water and sewerage network so that at the end of the 30 year concession $100 \%$ of the population would be connected to the water mains and $85 \%$ to the sewerage network in all of the four geographical zones into which the concession was divided. ${ }^{553}$ Zérah observed that the projected growth of the water network by year 15 of the concession was 95\%. This implies that Aguas Argentinas was under an obligation to expand its water and sewerage services to areas of low coverage, which usually includes those areas where the poorest sections of the population live. The concession contract also required the implementation of six five-year service expansion plans imposing a set of performance targets designed to ensure that Aguas Argentinas would achieve its mandated coverage after 30 years. ${ }^{554}$ These

551 See Annex I to the concession contract between Argentine Republic and Aguas Argentinas. See also Idelovitch and Ringskog, Private Sector Participation in Water Supply and Sanitation in Latin America, p. 28; Alcázar, Abdala, and Shirley, "The Buenos Aires Water Concession,” p. 3; Loftus and McDonald, "Of Liquid Dreams: A Political Ecology of Water Privatization in Buenos Aires," p. 186; and Zérah and Graham-Harrison, "The Buenos Aires Concession - The Private Sector Serving the Poor," p. 4. See also, Solanes, "Efficiency, Equity and Liberalisation of Water Services in Buenos Aires, Argentina," p. 150, and "Human Rights Impact Assessments for Foreign Investment Projects: Learning from Community Experiences in the Philippines, Tibet, the Democratic Republic of Congo, Argentina, and Peru," Rights and Democracy, International Centre for Human Rights and Democratic Development, Montreal, 2007, p. 103.

552 Schusterman et al., Public Private Partnerships and the Poor: Experiences With Water Provision in Four Low-Income Barrios in Buenos Aires, p. 11.

553 See Annex I to the concession contract. See also Alcázar, Abdala, and Shirley, "The Buenos Aires Water Concession," p. 25. and Zérah and Graham-Harrison, "The Buenos Aires Concession - The Private Sector Serving the Poor," p. 4.

554 For example, performance targets set in the contract specify that after the first five years of operation, Aguas Argentinas should increase the coverage of the water network up to 81 percent 
service expansion plans included expansion targets on priority areas designed by Aguas Argentinas, ETOSS and the municipality. Additionally, Article 10 of the regulatory framework and Article 4.3.3 of the concession contract explicitly stipulated that connection to the water and sewerage network is obligatory for consumers.

According to several studies, the privatization of OSN led to an expansion of the water and sewerage network well within the required targets in its first ten years of operation. By 1997/1998, Aguas Argentinas met and even surpassed the 81 percent coverage target prescribed by the contract for water although it failed to increase sewerage coverage to the required 64 percent. ${ }^{555}$ As we will see below, however, others have disputed these facts. Nevertheless, by 31 December 2003 Aguas Argentinas claimed in its annual report that the population that had access to potable drink water amounted to 7,7 million inhabitants of Buenos Aires (up from the 5,5 million inhabitants at the start of the concession) and 5,8 million inhabitants were connected to the sewerage system (up from 4,6 million in 1993). ${ }^{556}$ The expansion of the network appears to have been mainly concentrated in the poorer suburban areas of Buenos Aires where, according to Galiani et al, over 80 percent of the new connections apparently belonged to lower-middle and low-income households. ${ }^{557}$

At first glance, it would appear that the privatization of water utilities in Buenos Aires helped to improve the physical accessibility to water and water related facilities and benefited especially the poorest segments of the population. By requiring in the concession contract and regulatory framework that the expansion of the coverage of water and sewerage by Aguas Argentinas should aim at physical universal coverage in the case of water and almost physical universal coverage in the case of sewerage even to areas which are in principle not profitable to the

(and 64 percent for sewerage). See Annex I to the concession contract, Alcázar, Abdala, and Shirley, "The Buenos Aires Water Concession," p. 25, and Loftus and McDonald, "Of Liquid Dreams: A Political Ecology of Water Privatization in Buenos Aires," p. 189.

555 Alcázar, Abdala, and Shirley, "The Buenos Aires Water Concession," p. 42-43; R.G. Noll, M.M. Shirley, and S. Cowan, "Reforming Urban Water Systems In Developing Countries," SIEPR Discussion Paper No. 99-32, Stanford Institute for Economic Policy Research, Stanford University, (2000), p. 36; Loftus and McDonald, "Of Liquid Dreams: A Political Ecology of Water Privatization in Buenos Aires," p. 188. Based on data obtained from the Universidad Argentina de la Empresa, Galiani et al. have estimated an increase in access to water and sewerage of 30 and 20 percent respectively over the period 1993-1999. Galiani, Gertler, and Schargrodsky, "Water for Life: The Impact of the Privatization of Water Services on Child Mortality," p. 11 and 34.

556 This information is distilled from data provided by Aguas Argentinas in its 2003 annual report and in its website. See "Informe Anual y de Niveles de Servicio: 10o Año de la Concesión," Aguas Argentinas, p. 7. This report can be found at the website of Aguas Argentinas: <www. aguasargentinas.com.ar/pdf/informe10.pdf > (last visited on 17 March 2004).

557 Galiani, Gertler, and Schargrodsky, "Water for Life: The Impact of the Privatization of Water Services on Child Mortality," p. 11-12. 
company, the Argentine Government attempted to comply with its obligation to protect under the right to water as well as the rights to food, housing and health with respect to the duty to facilitate universal services. Furthermore, the increase in access to the water and sewerage network through the privatized company had some positive effects on the realization of other economic, social and cultural rights that are related to the right to water. Thus, with regard to the right to health, some notable observations can be made. As noted above, adherence to this right from the perspective of the 'underlying preconditions for health' including drinking water and adequate sanitation would entail an increase in the access to water and sewerage. In the Buenos Aires case, according to Galiani et al., expansion of physical access to the network appears to have led to a decrease in child mortality related to water diseases. ${ }^{558}$ In this regard, the privatization of water utilities in Buenos Aires seems to have facilitated the enjoyment of the right to health.

The expansion in the coverage of the water network after privatization, however, stumbled into a number of problems. In the first place, although the concession contract appeared to favor universal connection to the water network through the obligation to gradually extend coverage up to 100 percent by the end of the contract, it did not require the concessionaire to provide services in areas where land ownership was not regularized. ${ }^{559}$ This effectively excluded many low-income areas from the service since land tenure is highly contentious in those areas. By neglecting to take into account this situation, the contract implicitly favored the expansion of the water network in the more affluent sections of the city. ${ }^{560}$ This problem was exacerbated by the initial requirement for all new connected users to pay the 'infrastructure charge', which was unaffordable to mostly low-income consumers. ${ }^{561}$ Some commentators have argued that contrary to privatization objectives, the several contract renegotiations leading to a downward scaling of expansion objectives, turned the initial access problem to one of affordability. ${ }^{562}$ To solve this problem, civil society organizations including the International Institute for Environment and Development - Latino América (IIED-LA) entered at their initiative into partnership with Aguas Argentinas to facilitate the expansion of the water and sewerage network to a number of the non-regularized areas. ${ }^{563}$

Ibid.

See Schusterman et al., Public Private Partnerships and the Poor: Experiences With Water Provision in Four Low-Income Barrios in Buenos Aires, p. 16.

Ibid.

Casarin, Delfino, and Delfino, "Failures in Water Reform: Lessons from the Buenos Aires's Concession," p. 239.

Ibid., p. 246. 2007 This situation will be discussed in the next section.

Schusterman et al., Public Private Partnerships and the Poor: Experiences With Water Provision in Four Low-Income Barrios in Buenos Aires, p. 1-2. The results of this partnership were mixed, and most of the expansion work was carried out by the local population together with IIED-LA cooperation, under the watchful eye of Aguas Argentinas. Although the company was not responsible for the construction efforts to connect the areas to the network, it did agree to take 
In the second place there were problems concerning delays in achieving investment and expansion goals required in the concession contract and the five-yearly expansion plans. Thus, the concessionaire was charged of continuously failing to fulfill the renegotiated contractual obligations pertaining to required investments. As observed above, some studies have suggested that by 2001, Aguas Argentinas had not been able to reach the prescribed investments related to expansion of the water and sewerage networks. Hall and Lobina argued, for example, that by 1998 , Aguas Argentinas had "[...] failed to realize 39 per cent of the projected investments in the expansion of the water supply network and 59.7 per cent of the projected investments in the expansion of the sewerage network." 564 Emilio Lentini, an employee of ETOSS, noted in 2004 that in 2001, the drinking water service covered 79 percent of the population of the concession area, whereas the original contract had stipulated 88 percent, amounting to 800 thousand inhabitants without a service. ${ }^{565}$ Joint efforts between ETOSS and the concessionaire attempted to make up for the delays in expansions. Thus an initiative was established through the Water + Work Plan (see further next subsection), which according to the website of Suez (one of the parent companies of Aguas Argentinas) had managed to extended the water network to 400,000 inhabitants of La Matanza district, one of the poorest neighborhoods in Buenos Aires by April 2005. ${ }^{566}$ Another attempt to extend the service was through a program for impoverished neighborhoods ('Programa Barrios Carenciados'). ${ }^{567}$ This program was established after ETOSS had ascertained that Aguas Argentinas was not properly fulfilling its expansion and investment obligations in a report detailing this situation. ${ }^{568}$ The program envisaged a participatory model by which the members of the impoverished neighborhoods would be involved in the construction of the works required to expand the network under the supervision of the concessionaire who also provides the materials. In spite of these efforts, by 2006 ETOSS had on various occasions fined the company for

over the responsibility to maintain and repair the water network. Satisfaction for the new service was relatively high under the new connections due to improved water quantity and quality, although there were still problems related to water pressure and billing. Ibid., p. 30-32.

564 Hall and Lobina, "Pipe Dreams: The Failure of the Private Sector to Invest in Water Services in Developing Countries," p. 36. See also Azpiazu and Forcinito, "Privatisation of the Water and Sanitation Systems in the Buenos Aires Metropolitan Area: Regulatory Discontinuity, Corporate Non-Performance, Extraordinary Profits and Distributional Inequality,” p. 40-44.

For sewerage Lentini noted that the attained coverage for sewerage in 2001 was 63 percent versus the 74 percent required by the original contract. E. Lentini, "La Regulación de los Servicios de Agua y Saneamiento: el Caso de la Consesión de Buenos Aires," Revista de Gestión del Agua de América Latina Vol. 1, no. No. 2 (2004), p. 15-16.

566 See website of Suez at <www.mexico.suez-environnement.com/en/enjeux-et-cas-locaux/waterand-sanitation-for-all/the-agua-mas-trabajo-program-in-argentina/> (last visited on 20 March 2009).

567 See Programa Barrios Carenciados on the website of ETOSS available at: <www.etoss.org.ar/ desarrollo/sitioetoss05/barrioscarenciados.htm $>$ (last visited on 20 March 2009). Ibid. 
reiterated delays in fulfilling the required expansion investments, ${ }^{569}$ and the presidential decree rescinding the contract alluded to the continuous delays in fulfilling the investment and expansion goals.

\subsubsection{Economic accessibility:}

One of the main selling points of water privatization has been the argument that privatization would bring efficiency improvements in the service resulting in lower costs to consumers. In theory, this would result in improving economical accessibility of an essential service to poorer households. The outcomes of the Buenos Aires water concession in terms of economic accessibility were, however, not very positive. Prior to the concession, the price of the water tariff in Buenos Aires was low, almost 99 percent of the water consumption was un-metered, billing was poor since it was based on factors that bore little relationship to consumption resulting in only 80 percent of the bills being collected, and consumers could not be cut off the service if they did not pay. ${ }^{570}$ This meant that consumers did not have any incentive to conserve water or pay for the service.

The privatization of OSN changed some of these aspects. Following privatization collection of the water bills, which were issued on a bi-monthly basis, was improved $^{571}$ although the regulatory framework and concession contract allowed for disconnection to the service if the water bill was not paid in three consecutive billing periods. As observed in Section 4.2 supra, Aguas Argentinas was awarded the privatization concession because it offered the highest tariff reduction (26.9 percent) to consumers. It must be noted, however, that prior to the tender the government had twice increased the water tariffs of OSN in 1991 by 25 and 29 percent respectively. ${ }^{572}$ Water bills were further inflated by a new tax for goods

569 See for example, ETOSS Resolution No. 81/02 of 2 October 2002 imposing four fines of $\$$ 268,914, \$1,344,567, \$ 134,457, \$1,344,567 Argentine pesos respectively on Aguas Argentinas for delays in the plans of improvement and expansion of the water network and sewerage services as required by Articles 1.1, 1.2 and 6 of Annex I of the concession contract. See also ETOSS Resolution No. 82/06 of 15 June 2006 (almost three months after the concession had been rescinded) imposing various fines for repeatedly failing to comply with annual expansion goals up to the eight year of the concession, and for which the company had already been fined by ETOSS in 2003.

570 Alcázar, Abdala, and Shirley, "The Buenos Aires Water Concession," p. 5. See also Solanes, "Efficiency, Equity and Liberalisation of Water Services in Buenos Aires, Argentina," p. 150.

571 Alcázar, Abdala, and Shirley, "The Buenos Aires Water Concession,” p. 43-44.

572 Azpiazu and Forcinito, "Privatisation of the Water and Sanitation Systems in the Buenos Aires Metropolitan Area: Regulatory Discontinuity, Corporate Non-Performance, Extraordinary Profits and Distributional Inequality," p. 7. A number of commentators have suggested that this increase in tariffs prior to the privatization may have been accomplished to attract potential bidders/investors. See f.e McKenzie and Mookherjee, "Distributive Impact of Privatization in Latin America: An Overview of Evidence From Four Countries," p. 55. Others have claimed that the increase in water tariffs was unavoidable regardless of whether privatization took place or 
and services of 18 percent, which was afterwards increased by eight percent a few months before the privatization. ${ }^{573}$ It can be reasonably concluded that the tariff increases preceding the privatization helped offset the economic impact of the winning bid.

It has been argued that one striking flaw of the Buenos Aires concession was to maintain the tariff regime used by OSN, which was regarded as inefficient and opaque. ${ }^{574}$ This tariff regime differentiated between metered and non-metered customers. Non-metered users paid a flat rate based inter alia on the location of the house, built surface, and age and quality of the construction. Metered users paid a high fixed charge based on similar characteristics, and on top of that a variable charge based on consumption of water above 20 cubic meters. ${ }^{575}$ According to commentators this regime discriminated against poor households in various ways. In the first place it was more profitable for Aguas Argentinas to serve areas that were able to pay more first. 576 In the second place, metering, which was originally mandatory for non-residential consumers, resulted in lower water bills for high income households, but higher bills for low-income ones. ${ }^{577}$ This is not surprising since newly metered consumers are going to necessarily pay more than the original flat rate if consumption of water is increased, in particular if physical availability of water is improved. However, poorer households also had to pay a high price for the connection of the meter (an estimated \$200 US Dollar), motivating Aguas Argentinas to force metering upon household that could not afford higher water bills. $^{578}$

In spite of the initial promise of a lower water tariff, it has been estimated that the average water bill for consumers living in the residential areas of Buenos Aires

not due to the fact that the tariffs were too low and eventual expansion of the network would require financing from higher tariffs. Additionally, due to the nature of the bidding (concession goes to the bidder with highest tariff reductions) a tariff reduction is sometimes used as a tool to give the impression that the privatization process generates a reduction of the tariffs and thus win public support for the process. See Dumol, The Manila water concession: A Key Government Official's Diary of the World's Largest Water Privatization, p. 42. See also Loftus and McDonald, "Of Liquid Dreams: A Political Ecology of Water Privatization in Buenos Aires," p. 190.

573 Loftus and McDonald, "Of Liquid Dreams: A Political Ecology of Water Privatization in Buenos Aires," p. 190.

574 Alcázar, Abdala, and Shirley, "The Buenos Aires Water Concession,” p. 21. See also Solanes, "Efficiency, Equity and Liberalisation of Water Services in Buenos Aires, Argentina," p. 154, and Casarin, Delfino, and Delfino, "Failures in Water Reform: Lessons from the Buenos Aires's Concession," p. 239.

575 Solanes, "Efficiency, Equity and Liberalisation of Water Services in Buenos Aires, Argentina," p. 154.

576 Ibid.

577 Alcázar, Abdala, and Shirley, “The Buenos Aires Water Concession,” p. 27-28.

578 Ibid. 
increased in 88 percent between 1993 and 2002. ${ }^{579}$ Although the concession contract stipulated that there would be no tariff increases in the first ten years of the concession, 580 Aguas Argentinas requested permission to revise the tariff and increase it by 13.5 percent only one year after it started its operations. ${ }^{581}$ Another tariff increase of 5.31 percent took place after the forced renegotiation of the concession contract in 1997-1999.582 This was followed by subsequent yearly tariff revisions to compensate for past inflation starting in $2001 .{ }^{583}$

In addition, privatization introduced new access costs to new customers, which predominantly impacted poorer households in a negative way. Thus, during the first four years of the concession new customers to the water and sewerage network were faced with high access charges (a \$785 US Dollars 'infrastructure charge' plus a $\$ 335$ US Dollars 'connection fee' both payable in monthly installments). ${ }^{584}$ These charges were way above the monthly average income of the poorest households, estimated at \$430 US Dollars in 1997,585 and thus unaffordable for them. Casarin et al. have calculated that together with the abovementioned tariff increases, the bi-monthly bill for a poor new customer in 1997 would have been \$125 US Dollars, or 23 percent of income. ${ }^{586}$ The affordability problem affected in particular

579 See ETOSS Report of June 2004 on the evolution of the tariffs under the Aguas Argentinas concession ("Evolución de las Tarifas de la Concesión de Aguas Argentinas") available at $<$ www.etoss.org.ar/desarrollo/sitioetoss05/regimentarifario/Evolucin\%20tarifas\%20

Concesin\%20a\%20Junio\%202004.pdf> (last visited on 20 March 2009). See also Lentini, "La Regulación de los Servicios de Agua y Saneamiento: el Caso de la Consesión de Buenos Aires," p. 16. This calculation takes into account the connection charges and the SUMA. Casarin et al. have calculated an increase of 93 percent for both water and sewerage over the same period.

580 See Article 11.12.1 of the concession contract. The only increase allowed was a tariff revision in the second five-year period of the concession if there was a price increase of more than 7 percent in the costs of managing the concession.

581 Idelovitch and Ringskog, Private Sector Participation in Water Supply and Sanitation in Latin America, p. 47; E. Saravia, "Privatization in Latin America: Private Sector Participation in Water, Gas and Electricity Utilities, Impact on Labour and Utility Company Performance," in Labour and Social Dimensions of Privatization and Restructuring: Public Utilities: Water, Gas, Electricity, ed. L. De Luca, Geneva: ILO (1998); Zérah and Graham-Harrison, "The Buenos Aires Concession - The Private Sector Serving the Poor," p. 5; Casarin, Delfino, and Delfino, "Failures in Water Reform: Lessons from the Buenos Aires's Concession," p. 240.

Lentini, "La Regulación de los Servicios de Agua y Saneamiento: el Caso de la Consesión de Buenos Aires," p. 16, and Casarin, Delfino, and Delfino, "Failures in Water Reform: Lessons from the Buenos Aires's Concession," p. 240.

583 Lentini, "La Regulación de los Servicios de Agua y Saneamiento: el Caso de la Consesión de Buenos Aires," p. 16, and Casarin, Delfino, and Delfino, "Failures in Water Reform: Lessons from the Buenos Aires's Concession," p. 240.

584 Casarin, Delfino, and Delfino, "Failures in Water Reform: Lessons from the Buenos Aires's Concession," p. 239.

585 Casarin et al. have calculated that the average yearly income for an average household in the period 1996-1997 was $\$ 19,650$ US Dollars, whereas the average yearly income of the poorest households was \$5,190 US Dollars. See ibid., p. 242. Ibid., p. 241. 
residents of poor settlements that had no clear land rights in two ways. Firstly, they were not in the position to pay the high access costs and secondly, Aguas Argentinas was reluctant to extend the network to these settlements. ${ }^{587}$ This problem was somewhat alleviated by the elimination of the infrastructure charge and introduction of the somewhat lower SUMA charges in 1997.588 Nevertheless, affordability problems persisted resulting in an increase of disconnections from the network for non-payment of water bills.

Several initiatives were undertaken in an attempt to circumvent the affordability problem with regard to low-income sectors. Thus, starting in 1995 civil society organizations such as CIEL-LA (see section 4.3.3.1 supra) entered into arrangements with the local government and Aguas Argentinas to collaborate on improving the provision of water and sanitation in a small number of low-income settlements whose residents did not have official land titles. ${ }^{589}$ Through these initiatives the residents built the connections to the network themselves in order to reduce connection costs. Aguas Argentinas then took over the provision of water and maintenance of the connection. This approach was given further impetus in 2004 with the adoption of the Water + Work Plan (Plan Agua + Trabajo). This plan involved a partnership between the communities in one of largest but least affluent neighborhoods in Buenos Aires, La Matanza, which carried out the work, the municipal authorities which oversaw the work, Aguas Argentinas which provided training and know-how in terms of social support, and the Argentine Government which coordinated and financed the project by paying the employees of the co-operatives. ${ }^{590}$ Additionally, in a further attempt to assist low-income users to afford payment of the service and to reduce the number of disconnections due to inability to pay, ETOSS introduced a 'Social Tariff Plan' in 2002.591 This plan provided a subsidy to the users of the service who lacked sufficient economic means to pay for the service. It also required Aguas Argentinas to refrain from cutting off the service to those users that fell under this program, which included vulnerable groups and individuals such as persons over 70 years of age, pregnant women, persons with disabilities, persons with chronic sickness, and single parent homes. 592

\footnotetext{
587 Schusterman et al., Public Private Partnerships and the Poor: Experiences With Water Provision in Four Low-Income Barrios in Buenos Aires, p. 1. See also next sub section.

588 See Section 4.2 supra.

589 Schusterman et al., Public Private Partnerships and the Poor: Experiences With Water Provision in Four Low-Income Barrios in Buenos Aires, p. 1.

590 See Framework Agreement on Plan Agua + Trabajo of 25 February 2004 available on the website of ETOSS at: <www.etoss.org.ar/desarrollo/sitioetoss05/planagua/planaguamarco.htm> (last visited 20 March 2009).

591 See ETOSS Resolution No. 2/02 of 9 January 2002.

592 See ETOSS Resolution No. 112/04 of 27 October 2004.
} 


\subsubsection{Non-discrimination accessibility}

In terms of non-discriminatory accessibility, the Buenos Aires concession also ran into some problems. The regulatory framework and the concession contract aimed at universal coverage within the concession area, entailing that every household and dwelling located in the area would have to be connected to the water mains by the end of the 30 year concession. Thus, Article 9 of the regulatory framework obliged the concessionaire to extend, maintain or renew the water mains, and connect it to every single inhabited real estate property within the concession area and the areas designated for service expansion. ${ }^{593}$ This was complemented with an obligation on the side of the owners, and other tenants or inhabitants of the real estate to facilitate the connection to the mains. ${ }^{594}$ Once the necessary arrangements within the property were made, the regulatory framework prescribed its connection to the mains and imposed an obligation on the users to pay for the service. These obligations are also reflected in Articles 4.3.2 and 4.3.3 of the concession contract. Furthermore, Article 32 of the regulatory framework established that all natural and legal persons that inhabit or are established within the concession area have a right to the provision of potable water and access to the sewerage system within the confines of the framework. ${ }^{595}$ To further cement this obligation, the concession contract even established the possibility of fining the concessionaire for any type of discriminatory or inappropriate conduct $v i s$ - $\grave{a}$-vis one or more groups of users. ${ }^{596}$ On paper, the provision of the service appeared to be non-discriminatory and geared towards universal connection.

In practice, however, the concessionaire initially subjected poor people and households, as well as those without clear or official land property titles to treatment that could be regarded as being discriminatory and exclusionary. For example, Solanes observed that the system put in place for the concession did not motivate Aguas Argentinas to extend the service to poorer areas since,

“i) rates paid in poorer areas were based on lower indexes than rates paid in other areas, since they were based not on consumption but on property valuation; ii) supply to such areas represents a higher investment in infrastructure, as well as relatively higher costs in transport, distribution and collection; iii) poorer areas represent higher commercial and collection risks" 597

593 See Article 9 of the regulatory framework.

594 See Article 10 of the regulatory framework.

595 See Article 32 of the regulatory framework, which establishes the general rights of the service users.

596 See Article 13.10 .2 of the concession contract. See also F. Almansi et al., "Everyday Water Struggles in Buenos Aires: The Problem of Land Tenure in the Expansion of Potable Water and Sanitation Service to Informal Settlements," Water Aid and Tearfund, (2003), p. 26.

597 Solanes, "Efficiency, Equity and Liberalisation of Water Services in Buenos Aires, Argentina," p. 156. 
As observed above, Aguas Argentinas was also initially reluctant to provide connections to people living in informal settlements or who did not have proper land titles. Requests by local groups to connect these households to the water and sewerage network were usually ignored due to the irregularity of the situation. ${ }^{598}$ This was not something new as OSN, prior to its privatization, also refused to provide informal settlements with connections since the Government was afraid that connecting these settlements to the network would formalize their status and would entail recognition of property rights for tennants over the they had settled on. ${ }^{599}$ It has been argued however, that there were no legal impediments for refusing to provide the service to those living in informal settlements and dwellings. ${ }^{600}$ The concession contract did not officially require the concessionaire to provide connections to areas in which the ownership of the land was not formalized, although as observed above it did oblige it to connect all the dwellings within the concession area. Aguas Argentinas was, however, not willing to connect the irregular or informal areas to the service. ${ }^{601}$ This has been explained on the basis that the concessionaire, being profit driven, did not have sufficient incentives to extend the water network to impoverished settlements due to the higher costs involved. ${ }^{602}$ Moreover, the concessionaire appeared to enjoy a high level of discretion as to how it was supposed to fulfill its universal coverage obligations. ${ }^{603}$ The fact that the administrative procedures, including connection contracts, geared towards facilitating connections only took account of real estate property for connections, also effectively limited the potential users to those with property titles. ${ }^{604}$ In addition, it would appear that billing systems were based on fixed registered addresses, proving inadequate for informal settlements. ${ }^{605}$ According to Schusterman et al., this situation excluded many low-income areas from the service since land tenure was highly contentious in those areas. ${ }^{606}$ By neglecting to take into account this situation, the regulatory framework and the concession contract, in spite of their goal of achieving universal connection, implicitly favored the expansion of the water network in the more affluent sections of the city. As already

\footnotetext{
598 Schusterman et al., Public Private Partnerships and the Poor: Experiences With Water Provision in Four Low-Income Barrios in Buenos Aires, p. 19.

599 Ibid.

600 Almansi et al., "Everyday Water Struggles in Buenos Aires: The Problem of Land Tenure in the Expansion of Potable Water and Sanitation Service to Informal Settlements," p. 26.

601 Schusterman et al., Public Private Partnerships and the Poor: Experiences With Water Provision in Four Low-Income Barrios in Buenos Aires, p. 16.

602 Almansi et al., "Everyday Water Struggles in Buenos Aires: The Problem of Land Tenure in the Expansion of Potable Water and Sanitation Service to Informal Settlements," p. 30. This is partly due to the fact that a number of these settlements were not located in the neighborhood of existing infrastructure leading to high investment costs.

603 Ibid.

604 Ibid., p. 30-31.

605 Ibid., p. 31.

606 Schusterman et al., Public Private Partnerships and the Poor: Experiences With Water Provision in Four Low-Income Barrios in Buenos Aires, p. 16.
} 
mentioned, this problem was exacerbated by the initial requirement for all new connected users to pay the 'infrastructure charge', which was unaffordable to mostly low-income consumers. ${ }^{607}$

Nonetheless, through the collaboration and negotiations between the local government, the representatives of local community organizations, NGO's, and Aguas Argentinas, the latter was eventually persuaded of providing access to the water mains through household water connections to three informal settlements (barrio San Jorge, barrio La Paz, and barrio San Martín) and one semi-formal neighborhood (barrio Jorge Hardoy). ${ }^{608}$ Pressure from civil society organizations, as well as a change in local government with greater willingness to extend the water services to these informal settlements helped to overcome Aguas Argentinas initial reticence toward offering access to the network. ${ }^{609}$ Thus, an initiative to provide piped household water and sanitation led by local community leaders in barrio San Jorge together with NGO IIED-AL at the beginning of the 1990s was later reinforced when an interim mayor assumed office in 1995 and gave official support to the initiative. ${ }^{610}$ This initiative entailed building a local network that would extract underground water for the settlement. Since Aguas Argentinas was extending the water mains in a near by formal urbanized area, the local community of barrio San Jorge and IIED-AL increased the pressure on the utility with the support of the interim mayor to extend the network to the settlement. Although the concessionaire did not respond to this request, the local community group and the NGO started to work on the construction of the network. ${ }^{611}$ Further pressure from the community groups and political pressure from the local government in the wake of local elections moved Aguas Argentinas to cave in, and in 1995 became an active participant in the project. ${ }^{612}$ In practical terms this collaboration meant that the local residents provided labor for expanding the network, while the NGO and the

607 Casarin, Delfino, and Delfino, "Failures in Water Reform: Lessons from the Buenos Aires's Concession," p. 239.

608 Schusterman et al., Public Private Partnerships and the Poor: Experiences With Water Provision in Four Low-Income Barrios in Buenos Aires, p. 24-45, discussing the ins- and outs of how Aguas Argentinas was involved in extending the network to these areas.

Ibid., p. 1-2 and 3. Schusterman et al. suggest that Aguas Argentinas unwillingness was overcome due to a mixture of practical factors and indirect benefits. Although these initiatives did not provide the company with regular profits, it did provide, "[...] important indirect benefits, however. Especially where the informal settlements are located near serviced settlement, the choice is often between providing some form of legal connections, or having to cope with illegal connections and the water losses and piped water contamination they typically bring. Moreover, simply ignoring the plight of the urban poor brings its own political and public relations problems, and would have gone against the image the company was trying to project. Finally, many of the difficulties encountered reflect a lack of experience rather than inherent costs associated with serving low- income areas." ibid., p. 3. 
utility provided financial assistance and expertise. Once the construction was finished, Aguas Argentinas "[...] became the operator and took over responsibility for the maintenance and repair of the water network." 613 Similar initiatives were extended to the three other settlements in a similar fashion, albeit that in the case of barrio Jorge Hardoy, both local government and Aguas Argentinas were involved from the outset. ${ }^{614}$

In sum, although initially it appeared that in spite of the claims to universal provision of the service found in the regulatory framework and the concession contract, the actual conduct of the privatized utility resulted in discrimination in fact and in practice of low-income individuals and groups settled in areas with no clear land tenure. This situation was at least partially reversed in a number of recorded instances, in which through the action of local communities and NGOs, and eventually through the co-sponsoring by local government, Aguas Argentinas changed its stance and started to actively participate in extending the services to these groups.

\subsubsection{Violations analysis}

Having described the outcomes of the privatization of water utilities in Buenos Aires in terms of availability, quality, and accessibility as components of the right to water, it is now time to assess whether these have resulted in a violation of the right to water. To this end the violations approach developed in the academic world by the Maastricht Guidelines on Violations of Economic, Social and Cultural Rights and adopted by the UN CESCR in its General Comment No. 15 on the right to water will be used. Thus, the outcomes will be examined in terms of whether the privatization of the Buenos Aires water utilities resulted in violations of the obligations to respect, protect, and fulfill either through acts of commission or omission; and whether there were violations resulting from failure to comply with minimum core obligations. Wherever possible an attempt will be made to link the outcomes to the example guidelines provided by the UN Committee on Economic, Social and Cultural Rights in General Comment No. $15 .{ }^{615}$ Before starting, however, it is necessary to indicate that Argentina ratified the ICESCR in 1986 without any reservations. In addition, Argentina's national Constitution recognizes that consumers and users of public services have a right, inter alia, to the protection of their health, security and economic interests with respect to the consumption of those services. ${ }^{616}$ The Government is under this constitutional provision also

613 Ibid.

$614 \quad$ Ibid., p. 33.

615 See General Comment No. 15, para. 44 and Section 3.3.4 supra.

616 Article 42 of the National Constitution of Argentina. The provision reads: "Los consumidores y usuarios de bienes y servicios tienen derecho, en la relación de consumo, a la protección de su salud, seguridad e intereses económicos; a una información adecuada y veraz; a la libertad de 
obliged to protect this right as well as providing adequate remedies for facilitating the prevention and solution of conflicts, and to provide the required regulatory measures of public services including the participation of all interested parties and users of these services in any control mechanism. Moreover, Article $75 \S 22$ of the Argentine Constitution grants the ICESCR, among other international and regional human rights treaties, constitutional status. ${ }^{617}$

\subsubsection{Violations of obligation to respect?}

As noted above, the obligation to respect requires the State to abstain from taking measures that are detrimental to the enjoyment of the right to water. The UN CESCR has observed in its General Comment No. 15 that violations of the obligation to respect may include, among other things, the arbitrary or unjustified disconnection or exclusion from water services or facilities and discriminatory or unaffordable increases in the price of water. However, in a situation of privatization, the State is not the one that has to refrain from such conduct since it is not providing the service directly. It will, nevertheless, need to adopt the necessary regulatory measures to prevent privatized entities from engaging in such conduct and to protect the right to water of users of those services. This will be discussed below. However, the question that can be posed at this stage is whether Argentina's policies regarding the privatization of the water utility in Buenos Aires may have violated its obligation to respect the right to water through acts of omission or commission?

In general it can be concluded that, with a number of exceptions, the decision to privatize OSN did not result in concrete practices that arbitrarily interfered, denied or limited equal access to water. As a matter of fact, the regulatory framework enacted by Argentina and the concession contract with Aguas Argentinas attempted in general to guarantee universal access to all the inhabitants of the concession area. In addition, the regulatory framework allowed the State sufficient flexibility to cater to the needs of the poor if necessary. ${ }^{618}$ Nevertheless, a potential violation of the obligation to respect could be discerned regarding the lack of attention in the regulatory framework and contract to the position of those sectors of the population

elección, y a condiciones de trato equitativo y digno. Las autoridades proveerán a la protección de esos derechos, a la educación para el consumo, a la defensa de la competencia contra toda forma de distorsión de los mercados, al control de los monopolios naturales y legales, al de la calidad y eficiencia de los servicios públicos, y a la constitución de asociaciones de consumidores y de usuarios. La legislación establecerá procedimientos eficaces para la prevención y solución de conflictos, y los marcos regulatorios de los servicios públicos de competencia nacional, previendo la necesaria participación de las asociaciones de consumidores y usuarios y de las provincias interesadas, en los organismos de control."

617 See Article 75 \$22. See also C. Courtis, "Argentina - Some Promising Signs," in Social Rights Jurisprudence - Emerging Trends in International and Comparative Law, ed. M. Langford, Cambridge: Cambridge University Press (2008), p. 166. 
living in informal settlements and those living in dwellings without proper land titles. The problem of access to water by the poor was further exacerbated to a certain degree due to the initial high costs imposed on connecting households to the water mains as established in the regulatory framework and concession contract.

In sum, the privatization of OSN established an environment meant to guarantee the right to water by allowing the privatized water utility to improve and expand the service in an attempt to guarantee universal access to water. However, although considerable gains were perceived in terms of expansion of the water and sewerage service and its quality, the privatized service provider was not in the position to fulfill in an efficient and effective way the milestones required by the concession contract in terms of expansion. The privatization also led to some situations of apparent discrimination of individuals living in settlements and who did not have a proper land title that would make them eligible to be connected to the service. This is also potentially in breach of Article 2 \$2 ICESCR, which establishes that States "[...] undertake to guarantee that the rights enunciated in the present Covenant will be exercised without discrimination of any kind as to [...] national or social origin, property, [...] or other status." Arguably, the initial exclusion of individuals without a proper land title or tenure to the water network would constitute an indirectly discriminatory measure in the sense of Article $2 \$ 2$ on the grounds of 'property' 619 The UN CESCR has reaffirmed this in General Comment No. $15^{620}$ and observed that

"Deprived urban areas, including informal human settlements, and homeless persons, should have access to properly maintained water facilities. No household should be denied the right to water on the grounds of their housing or land status[...]"621

On the other hand, and as explained in Section 4.3.3.3, the local government and non-governmental organizations attempted during the period of the concession to address these issues in a number of settlements and through the implementation of seemingly pro-poor programs to make access to the water network more affordable. This went into some lengths to remove some of the problems that could lead to establishing a potential violation of the right to water because of the shortcomings of the regulatory framework and the concession contract. Thus, if the Argentine authorities had not endeavored to try to address the issue, it would have been possible to establish a violation of the obligation to respect with regard to the adopted regulatory framework and concession contract.

619 See also General Comment No. 20, Non-discrimination in economic, social and cultural rights (art. 2, para. 2, of the International Covenant on Economic, Social and Cultural Rights), CESCR, UN Doc. E/C.12/GC/20 (2 July 2009), para. 10.

620 See General Comment No. 15, paras. $14-15$.

621 Ibid., para. 16. 


\subsubsection{Violations of obligation to protect?}

Turning now to an assessment of possible violations of the obligation to protect, the picture gets more complicated. The obligation to protect requires the State to adopt positive measures to ensure that third parties providing basic water services satisfy the requirements of availability, quality and accessibility (physical, economical and on a non discriminatory basis). ${ }^{622}$ It also requires the State to regulate the provision of basic water services and protect consumers from actions by the service provider such as unwarranted price hikes or arbitrary disconnections. Although it may not be entirely conclusive, it is quite possible to argue that through the adoption of the regulatory framework, Argentina has prima facie complied with this obligation. The regulatory framework provided the essential rules determining how the concession should be operated and monitored. It aimed at providing universal access to the service under certain quality guarantees as prescribed by Articles 6 and 42 of the regulatory framework. The regulatory framework also established in its Annex A the norms pertaining to the minimum quality of the water to be delivered to consumers and based on guidelines from the Ministry of Health. It also established the regulatory body, ETOSS, which was in charge of monitoring the provision of the service by the concessionaire, and which could impose fines on the concessionaire in cases of non- or inadequate performance of its obligations under the concession contract and regulatory framework. ${ }^{623}$

Chapter $\mathrm{V}$ of the regulatory framework set down the rights of consumers of the service. Under Chapter $\mathrm{V}$ consumers had a right to receive drink water services and access to the sewerage system. ${ }^{624}$ Other rights entitled consumers, inter alia, to demand from the concessionaire the provision of the service at the minimum quality levels provided by the framework; to submit a complaint before the regulatory body in case the service is not provided adequately; to receive information about the service and be informed of eventual alterations thereof; and to complain before the concessionaire regarding disagreements on the billing and changes of the tariff structure. To enforce the rights of consumers of the service, Article 72 of the regulatory framework established a complaints mechanism. Through this mechanism, consumers were first expected to submit their complaints to the concessionaire before engaging ETOSS. In case of non-resolution, consumers were allowed to present a complaint before the ETOSS within thirty days of the concessionaire's response or after thirty days following the submission of the complaint before the concessionaire in case the latter did not respond to the complaint. The decisions of the ETOSS in response to consumer's complaints were binding on the concessionaire. ${ }^{625}$ The rights of consumers were also protected in

\footnotetext{
622 Ibid., para. 23.

623 See Article 13 of the regulatory framework.

624 See Article 32 of the regulatory framework.

625 See last paragraph of Article 72 of the regulatory framework.
} 
other ways. For example, in an attempt to provide access to a minimum amount of water, the concession contract entitled certain users to a fixed amount of free water. Thus, under Article 22 of Annex VII of the concession contract, residential households that had metered connections had a right to receive thirty cubic meters of water for free on a bi-monthly basis. In addition, as will be discussed below, the regulatory framework and in particular the concession contract allowed the State to provide targeted subsidies and exemptions from payment to the poor.

In the case of the Buenos Aires water concession, it can be generally argued that the regulatory framework and concession contract went a good way in ensuring that Argentina complies with its obligation to protect vis-à-vis the physical accessibility requirement of the right to water. Economic accessibility was also on paper protected. A similar conclusion can be drawn with respect to the quality requirement: Argentina adopted on paper the necessary steps to guarantee that the concessionaire lived up to its obligations to provide safe drinking water that is up to international health standards through the relevant provisions of the regulatory framework and concession contract as well as through the action of the regulatory agency.

However, as observed in sections 4.3.1-4.3.3, the actual delivery of the service suffered a number of problems with respect to availability, quality, and accessibility. Although there was a noticeable the physical expansion of water and sewerage connections by Aguas Argentinas, the required targets imposed on the concessionaire were not fully met during the limited period of the privatization. Furthermore, there was the problem of water pressure in certain areas of the city, which the Argentine Ombudsman addressed in its annual report for the year 2003.626 This problem particularly affected the more disadvantaged and poor neighborhoods and the consumers of those areas were overcharged for a deficient and sometimes nonexistent service. Also, although the quality of the water provided was in general terms acceptable, there were some parts of the city which suffered from the concentration of high levels of nitrates posing a potential risk to the health of the consumers living in the affected areas. As observed, it was this problem, among others, that prompted the Argentine Government to rescind the concession contract. With respect to physical accessibility, the already mentioned problem with respect to the initial denial of service to consumers without land titles in the concession area by Aguas Argentinas, not only denotes a potential violation of the obligation to respect, but also of the obligation to protect since the denial to connect these consumers was also carried out by the concessionaire with acquiescence from the official authorities. As observed, this problem was somewhat mitigated later on with the adoption of a number of social plans aimed at connecting these types of consumers.

\footnotetext{
626 See Annual Report for 2003 of the Argentine Ombudsman, note 520 supra.
} 
In terms of economic accessibility, the following observations can be made. Solanes, noted that in general, the regulatory framework and concession contract did not take the poor into account. ${ }^{627}$ The obligatory requirement for new connections to adopt a metered connection at an initial high cost with the consent of the public authorities can in this light be regarded as a potential violation of the obligation to protect. The same may hold true for the tariff increases, which although arguably necessary, ${ }^{628}$ were not always carried out in the spirit of the concession contract or regulatory framework throughout the concession's period of operations. The regulatory framework provided sufficient tools at the disposal of the State to ensure the right of the most vulnerable sectors of society to access water and address the abovementioned problems. Thus, the regulatory framework allowed the State to adopt pro-poor policies, such as cross subsidies, ${ }^{629}$ and to direct the concessionaire to provide free or subsidized services to certain categories of consumers. ${ }^{630}$ However, pro-poor measures were only adopted almost ten years after the start of the concession to reduce the impact of the problems sketched above. In spite of their tardiness, the adoption of the Water + Work Plan to help consumers in certain areas connect to the water mains at reduced costs, plus the introduction of a Social Tariff Plan aimed at providing subsidies for vulnerable groups can be regarded as offsetting, albeit somewhat late, the negative outcomes sketched in this paragraph.

Another potential violation of the obligation to protect could entail a failure by the State to shield consumers from arbitrary disconnections to the water network. As reported above, disconnections were frequent among the least well-off consumers due to inability to pay. The regulatory framework and the concession contract did allow for disconnection following the failure to pay the bi-monthly bills for three consecutive terms. However, it can be argued that the procedure to disconnect users was endowed with sufficient guarantees to avoid any semblance of arbitrariness. In the first place, disconnections were possible following the three consecutive terms of non-payment, giving in theory reasonable time to consumers to still pay the debt before disconnection. In the second place disconnection took place only after the concessionaire had explicitly requested payment for the arrears in written in at least two occasions. ${ }^{631}$ In the third place, consumers in arrears could be offered the possibility of concluding alternative payment arrangements, and ETOSS could mediate between Aguas Argentinas and the debtors and eventually order the

627 Solanes, "Efficiency, Equity and Liberalisation of Water Services in Buenos Aires, Argentina," p. 158 and 163.

628 See further Casarin, Delfino, and Delfino, "Failures in Water Reform: Lessons from the Buenos Aires's Concession," p. 238-242.

629 See Article 44 of the regulatory framework.

630 See Article 54 of the regulatory framework. These possibilities allowed the ICSID Tribunal to observe that the Regulatory Framework provided sufficient flexibility to deal with the needs of the poor and protect them from tariff increases. Suez, Sociedad General de Aguas de Barcelona S.A. and Vivendi Universal S.A v. Argentine Republic, Decision on Liability, para. 235.

See Articles 11.10.2 and 11.10.3 of the concession contract. 
company not to disconnect. ${ }^{632}$ Finally, through the adoption of the 'Social Tariff Plan' and in particular the resolution on Social Cases, ${ }^{633}$ Aguas Argetinas' was ordered to abstain from cutting off the water service for non-payment. ${ }^{634}$

In assessing whether Argentina adopted the necessary efforts to regulate the conduct of Aguas Argentinas, it is also necessary to briefly consider the role of the regulator. According to the regulatory framework, ETOSS was established as an independent body with a mandate to control and regulate the activities of the concessionaire. ${ }^{635}$ As noted in Section 4.2 ETOSS was endowed through Article 17 of the regulatory framework with various control and policing functions to aid it in its regulatory role. ETOSS itself was constituted of a tripartite directorate together with an advisory commission performing a supporting role. The former was composed of six representatives from the federal government, the province and the city of Buenos Aires, while the latter was made up from representatives of sanitary and consumer organizations. ${ }^{636}$ In the previous section it was observed that ETOSS encountered some problems during its mandate. Apparently it was not taken seriously be either the Government nor the concessionaire, given the fact that it was by-passed on a number of occasions during tariff negotiations in which it had a role to play according to the regulatory framework. ${ }^{637}$ This raises doubts as to the regulator's independence. ${ }^{638}$ For example, the composition of the members of ETOSS' directorate did not bode well with respect to its independence given the fact that these were governmental representatives and appointees instead of truly independent experts. This has led to the impression that the directorate was politically influenced and there has been some criticism of the political nature of the appointments and the politicized performance of ETOSS' tasks. The fact that ETOSS was placed under control of the Secretary of the Environment through a presidential decision, further undermined the body's claim at independence. This was further exacerbated when the Government was able to by-pass ETOSS in the resolution of a number of conflicts with Aguas Argentinas, diminishing the body's

632 Article 11.10.7 of the concession contract. In addition, ETOSS could order the suspension of the disconnection in situations of unexpected and extraordinary circumstances. See also Section 2.2 of Annex D of the regulatory framework which describes the procedure to be followed in case of disconnection. ETOSS Resolution No. 112/04 of 27 October 2004 available at the website of ETOSS (<www.etoss.org.ar/desarrollo/sitioetoss05/index.htm >).

634 According to the preamble of ETOSS Resolution No. 112/04 and its Annex I, these social cases included: minors up to the age of 14 , senior citizens from the age of 70 , pregnant women, persons with disabilities, persons with serious chronic illnesses, victims of disasters, and single parent households.

635 Article 13 and 15 of the regulatory framework.

636 Article 19 and 21 of the regulatory framework.

637 Casarin, Delfino, and Delfino, "Failures in Water Reform: Lessons from the Buenos Aires's Concession," p. 245.

638 See for a brief discussion on the issue of the need for an independent regulatory body Section 2.6.2 supra. 
capacity to deal with issues and its independence. Moreover, the way ETOSS was financed further suggests a potential lack of independence. According to Article 25 of the regulatory framework, ETOSS financial resources were made up, from among other things the direct contributions from the government and a percentage of the water bill to be paid by service users. This means that ETOSS income was linked to tariff increases, and was thus proportional to the income obtained by the concessionaire from the water bills. It has been suggested that this was an issue of concern, and facilitated the regulatory capture of ETOSS, ${ }^{639}$ thus further affecting its independence. In addition, it is not clear whether ETOSS was able to dispose of its sources of revenue in any way it deems fit. Finally, citing other reports, Casarin et al have pointed out that the initial staff of ETOSS was mainly composed of former OSN personnel with little knowledge on tariff settings and a lack of experience of regulating a commercial undertaking. ${ }^{640}$ They argue that ETOSS appeared to be slightly biased towards the concessionaire since it

“(i) allowed the firm to set unusually high meter installation tariffs, (ii) granted unexplained tariff adjustments with little economic analysis, (iii) transferred business risk to consumers through adjustments in access charges and (iv) gave consent to delays in the installation of meters." 641

On the other hand, after being admonished by the Argentine Ombudsman, ETOSS did adopt a more proactive stance with respect to the presence of high levels of nitrates in the water of certain areas of the concession. It must also be acknowledged that throughout the duration of the concession, ETOSS did repeatedly fine Aguas Argentinas for non-compliance with its contractual obligations related to the expansion goals of the network, and later for the presence of nitrates in the water. Nonetheless, it is can be concluded that in the light of these facts, ETOSS did not perform an entirely effective role as a regulator. Although not entirely toothless, the fact that ETOSS was circumvented on a number of occasions by the other actors involved in the privatization of the Buenos Aires water utility, the State and the privatized entity, hints at its inability to deal effectively in sensitive situations in which the rights of consumers is at stake. In addition, there is the perception that ETOSS may not be entirely independent, making it a less than suitable regulator that can be entrusted with protecting the rights of consumers as stipulated in the regulatory framework. Another major potential issue in this respect was that the fact that the regulatory framework was based on a Presidential Decree as mandated through Law No. 23,696, which authorized the privatization of public services. This

\footnotetext{
639 Artana, Navajas, and Urbiztondo, "La Regulación Económica en las Concesiones de Agua Potable y Desagües Cloacales en Buenos Aires y Corrientes, Argentina," p. 11; Casarin, Delfino, and Delfino, "Failures in Water Reform: Lessons from the Buenos Aires's Concession," p. 244. Casarin, Delfino, and Delfino, "Failures in Water Reform: Lessons from the Buenos Aires's Concession," p. 244.

641 Ibid., p. 244-245.
} 
meant that the regulatory framework could have been easily changed at the whim of the Executive. ${ }^{642}$

Given the observations in the preceding paragraphs, is it possible to conclude that Argentina failed to effectively regulate and control the conduct of Aguas Argetinas in violation of its obligation to protect? It is suggested that the above mentioned facts (the mixed outcomes of the concession itself; the adoption by the Argentine Government of a regulatory framework and body that on paper seemed adequate, but in practice sometimes failed to deliver; and the Government's somewhat belated, but genuine efforts to address the needs of the most disadvantaged sectors of society which were confronted with a sometimes inflexible concessionaire) does not make it possible to conclude with absolute certainty that the whole situation can be qualified as a violation of the obligation to protect. Furthermore, although the actions leading to the rescission of the contract with Aguas Argentinas could be contested in terms of their compatibility with the BITs between Argentina and France, Spain, and the United Kingdom as noted by the ICSID Tribunal, the fact that the growing concerns about the levels of nitrates and their effect on public health resulted in the State finally pulling the plug off the concession suggests that Argentina can not decidedly be accused of violating the obligation to protect. In the end, it appears that the only way of deciding on this would be to discuss the problem based on the question whether Argentina's obligation to protect is an obligation of conduct or result. In the case of Concerning the Application of the Convention on the Prevention and Punishment of the Crime of Genocide (Bosnia and Herzegovina v. Serbia and Montenegro), the ICJ concluded that a positive obligation to prevent violations of international legal obligations is in essence an obligation of conduct, not of result. ${ }^{643}$ Arguably Argentina's case, this can also be applied, since prima facie it acted with some due diligence to adopt the measures that seemed to protect the right to water of the population of Buenos Aires. Although, their actual effectiveness can be doubted and there are hints that the obligation to protect may have been compromised at times, in the end Argentina took a step in an attempt to remedy the situation.

642 Solanes, "Efficiency, Equity and Liberalisation of Water Services in Buenos Aires, Argentina," p. 164.

643 Case Concerning the Application of the Convention on the Prevention and Punishment of the Crime of Genocide (Bosnia and Herzegovina v. Serbia and Montenegro), ICJ Judgment (26 February 2007), para. 429, available at <www.icj-cij.org/docket/files/91/13685.pdf $>$, para. 430. The ICJ noted, inter alia, that "[...] the obligation of States parties is rather to employ all means reasonably available to them, so as to prevent genocide so far as possible. A State does not incur responsibility simply because the desired result is not achieved; responsibility is however incurred if the State manifestly failed to take all measures to prevent genocide which were within its power, and which might have contributed to preventing the genocide. In this area the notion of 'due diligence', which calls for an assessment in concreto, is of critical importance." 


\subsubsection{Violations of obligation to fulfill?}

Arguably a major aspect of the obligation to fulfill is the adoption of positive measures to assist individuals and communities to enjoy the right to water. ${ }^{644}$ According to the UN CESCR Committee this may entail implementation of a national water policy that is designed to ensure the right to water for everyone. ${ }^{645}$ Lack of such a plan is regarded as a violation of the obligation to fulfill. Arguably, although there was probably no national water plan in Argentina at the time of the privatization of OSN in 1993, the adoption of the regulatory framework and the concession contract which aimed at guaranteeing guarantee universal service, provide for consumer protection, and protect human health and the environment could possibly be considered as reasonable alternatives, even more given the fact that the Argentine Constitution guaranteed the right to access to essential public services. Moreover, the Argentine Government adopted a national water program in 1999 aimed at

"[...] brindar asistencia técnica y financiera para la provisión de servicios de abastecimiento de agua potable y red de saneamiento, en comunidades rurales concentradas o dispersas, o en núcleos urbano-periféricos que se encuentren en situación de carencia, precariedad, o bajo contingencias extraordinarias de riesgo." $" 646$

In addition, specific social plans as detailed above served as complementary guidelines to further safeguard the right to water of the inhabitants of Buenos Aires. Arguably, all these programs and plans indicate that, even if they show a somewhat piecemeal approach towards adopting a consistent policy to secure the delivery of water for the population, the Argentine Government did not stand still.

Besides the existence of a national water plan, the obligation to fulfill may require, in the opinion of the present author, ensuring a transparent privatization process and consultation with the groups most affected by the privatization of water services. As noted in Section 4.2 supra the process of privatization of OSN itself appears to have been transparent in its initial stages, the bidding and tender process was not sufficiently so. The bidding process was poorly prepared and led to

644 See General Comment No. 15, para. 25.

645 Ibid., paras. 28 and 44.

646 "...] offering technical and financial assistance for providing drink water delivery services and sewerage networks to rural communities, which are dispersed or gathered together, or to urban and sub-urban centers, which are in conditions of poverty, precariousness or in extraordinary circumstances of risk [translation $A H W$ ]." Article 2 of Programa de Provision de Agua Potable, Ayuda Social y Saneamiento Basico [Program for the provision of drink water, social aid and basic sewerage], Resolution 458/99 Adopted by the Secretary of Natural Resources and Sustainable Development, Buenos Aires, 4 June 1999, available at <www.infoleg.gov.ar/ infolegInternet/anexos/55000-59999/58325/norma.htm> (last visited 10 May 2011). 
confusion with regard to the companies that participated during the bidding due to lack of reliable information. The award criterion was regarded as being flawed, and although it was initially regarded to be in the interests of consumers (due to the promised tariff reduction) in practice it did not prevent subsequent price hikes. Moreover, it has been recognized that the award criteria was merely a bait to make the privatization appear more consumer or poor friendly than it could have been. Additionally, the tariff structure and calculation of individual or collective water bills in the absence of metering has been considered to be too complex and nontransparent. Finally, although the government and the parliament supported the privatization agreement between the State and the consortium that made up Aguas Argentinas, and while the workers that would be affected by the privatization were involved in the process, civil society groups and the population that had the most at stake (the inhabitants of poor and marginal neighborhoods) were not consulted or represented during the process. In view of the present author's opinion that the obligation to fulfill requires in the first place the consultation with and involvement of groups in decisions that are going to affect them and secondly a positive obligation to provide full transparency of the privatization process and its results, it can be concluded that in respect of the privatization process there may also be a potential violation of the obligation to respect. The lack of public participation in the privatization process and its implementation, however, apparently became and issue of concern of both the company and ETOSS. ${ }^{647}$ The recognition of the need to larger involvement and participation of end users took official form in the Water + Work Plan and the 'Social Tariff Plan' detailed above, which were carried out after consultation and participation of direct stakeholders such as consumer associations, development NGOs, the municipality of Buenos Aires, ETOSS, and Aguas Argentinas.

Another aspect of the obligation to fulfill would require States to ensure that the minimum essential level of the right is enjoyed by everyone. Failure to do so would amount to a violation of the obligation to fulfill. As has been repeatedly observed throughout this section, it would appear that Argentina undertook a number of initiatives to guarantee that the service is expanded to everyone in the city of Buenos Aires. Thus the concession contract obliged the concessionaire to extend the water network on a progressive manner concluding in universal coverage of the system by the end of the concession. ${ }^{648}$

647 See Regulating Public and Private Partnerships for the Poor-Case Study: Argentina, Centre for Water Science, Cranfield University, Department for International Development DFID Knowledge and Research Contract R8320 (2005), p. 6-7 available at <www.dfid.gov.uk/r4d/ PDF/Outputs/Water/R8320-Sum6.pdf> (last visited 10 May 2011). 


\subsubsection{Violations of core obligations}

General Comment No. 15 establishes a number of 'benchmarks' that are regarded as the absolute minimum things that the State has to ensure with regard to the right to water. Failure to carry out these core aspects of the right to water would, according to the UN CESCR result in a violation of the right to water. Arguably some of these benchmarks can be applied to the privatized provision of the water service in Buenos Aires:

a. To ensure access to the minimum essential amount of water, that is sufficient and safe for personal and domestic uses to prevent disease

As stated in the previous sub-section, the Buenos Aires water concession allowed a basic amount of thirty cubic meters of free water on a bi-monthly basis to residential households with metered connections to the mains. Departing from the assumption that a household is composed of five members, this translates roughly to around 100 liters per person per day of free water. This is above the minimum quantity of water required for domestic used as estimated by the WHO. ${ }^{649}$ It would thus appear that in terms of quantity, the privatization of water services in Buenos Aires fulfilled the minimum core obligation to provide sufficient water. This assertion can be qualified by pointing out that that this only applied to residential households with a water meter. In addition, it would appear that one of the immediate effects of the expansion of the water network through privatization was a decline in child mortality rates due to access to safe drinking water as described in Section 4.3.3.1. However, the problem surrounding the high concentration of nitrates in some areas of the concession, in particular those in which less affluential people lived, gives rise to a potential violation of the minimum core obligation to provide safe water.

b. To ensure the right of access to water and water facilities and services on a nondiscriminatory basis, especially for disadvantaged or marginalized groups

The initial reluctance of Aguas Argentinas to extend the connection of the water services to neighborhoods and households that did not have regular land titles described in Sections 4.3.3.3 and 4.3.4.1 supra suggests that Argentina did not properly take this problem into consideration during the drafting of the regulatory framework and concession contract. However, with the introduction of a number of initiatives and cooperation with NGOs, Argentina did attempt to solve this problem. Thus, it can be argued that an initial violation of the core obligation to provide minimum service on a non-discriminatory manner was mended through these initiatives. Without further research, however, it is not possible to determine whether these initiatives helped to alleviate the problem in its entirety. In the end it would be difficult to do so given the fact that the concession was prematurely terminated. 
c. To ensure physical access to water facilities or services that provide sufficient, safe and regular water; that have a sufficient number of water outlets to avoid prohibitive waiting times; and that are at a reasonable distance from the household

Arguably, by obliging Aguas Argentinas to extend the service of the water network, a task at which OSN had not succeeded, Argentina did comply with this minimum core obligation to a large extent. Direct connections to individual households were preferred, although this initially carried a higher price in the form of the expensive connection charge. As observed, this was later ameliorated through the adoption of the Water + Work Plan aimed at helping reduce the costs of connection by allowing communities to work in laying down the necessary pipes to connect the homes to the mains.

d. To adopt and implement a national water strategy and plan of action addressing the whole population

As observed in the previous section, Argentina eventually adopted a number of plans aimed at securing access to water for vulnerable sectors of society. According to information provided at the website of ETOSS, these plans were apparently adopted on the basis of consultations with consumers and consumer associations. 650

e. To adopt relatively low-cost targeted water programs to protect vulnerable and marginalized groups;

In the previous section, it was made clear that Argentina adopted, albeit belatedly, a number of low-cost targeted water programs such as the 'Social Tariff Plan' that not only provided a subsidy for low income consumers, but also prevented the concessionaire from disconnecting the service of vulnerable groups such as pregnant women, elderly people, and persons with disabilities.

\subsubsection{Some observations}

With regard to this case study, it is difficult to conclude with absolute certainty that the privatization of the Buenos Aires water utility on its own resulted in a violation of the right to water of the population of that city. Arguably, the privatization of water services in Buenos Aires was not a retrogressive measure as meant in the UN CESCR's General Comment No. 3 that impaired the right to water. ${ }^{651}$ It can even be maintained that the decision to privatize OSN was in effect aimed at securing the right to water of the population of Buenos Aires by replacing an old ineffective public company, with a more effective, private one. This argument was of course also made by the parent companies of Aguas Argentinas in the ICSID Arbitration case against Argentina. They argued that "[...] Argentina's decision to privatize the Buenos Aires water service and to promote the creation of AASA was precisely to

650 See with respect to the Social Tariff Plan, <www.etoss.org.ar/desarrollo/sitioetoss05/tarifasocial. $\mathrm{htm}>$ (last visited on 20 May 2011).

651 See General Comment No. 3, para. 9. 
make that right more effective for larger numbers of Argentine inhabitants as the service was expanded through AASA's efforts." ${ }^{\prime \prime 2}$

In contrast to the more concrete case study discussed in the previous Chapter, the present analysis looks at a much larger picture to see the general human rights effects of the privatization of water. Thus, there are many factors at play here: first, it seems clear that Argentina did adopt a number of general measures intended to protect consumers and secure the provision of the service in a reasonable way. These measures and the introduction of a regulatory body were apparently not sufficient to entirely prevent situations that resulted in potential violations of the right to water. Additional measures had to be adopted to solve these problems. Although individual violations of the right to water can probably be identified (in particular with respect to the initial discriminatory exclusion of poor household from the service) this is outside the scope of the present study, and it is suggested that this could be the object of further research.

\subsection{Accountability for the effects of the privatization of water utilities in Buenos Aires?}

If the conduct of Aguas Argentinas can be qualified as a (potential) violation of the right to water, the question that then arises is whether the company itself or Argentina can be held responsible for this. It is possible to discuss this question from two different perspectives. From a traditional international law perspective, and from a mixed national law/international law one. From the former perspective, and as discussed in Chapter IV, Argentina is only internationally responsible for a violation of the UN ICESCR if the alleged conduct can be attributed to the State itself. This means that the conduct of private actors, in this case Aguas Argentinas, is as such not attributable to Argentina, unless it can be shown that the former exercised elements of governmental authority (Article 5 of the ILC Articles on responsibility of the State), or that it acted under orders or control of the former (Article 8 of the ILC Articles). Additionally, Argentina can indirectly be held responsible for the conduct of the concessionaire if it did not adopt the necessary measures to stop or prevent the latter's conduct in contravention with the UN ICESCR. With respect to attribution under Article 5 of the ILC Articles, can it be said that Aguas Argentinas exercised elements of governmental authority? If one adopts a strict and narrow approach towards defining the elements of governmental authority that have to be exercised by a private company in order to attribute its conduct to the State, then it would be difficult to attribute the concessionaire's conduct to Argentina. On the other hand, adopting a functional approach to Article 5 could, as suggested in Chapter IV, Section 2.2.1, result in attributing the conduct

652 See Suez, Sociedad General de Aguas de Barcelona S.A. and Vivendi Universal S.A v. Argentine Republic, Decision on Liability, para. 255. 
of Aguas Argentinas to the State. In the first place it must be demonstrated that the functions performed by the concessionaire contain elements of governmental authority. In the Case of Ximenes-Lopes v. Brazil $6^{63}$ the Inter-American Court of Human Rights noted that

"the acts performed by any entity, either public or private, which is empowered to act in a State capacity, may be deemed to be acts for which the State is directly liable, as it happens when services are rendered on behalf of the State." 654

The Inter-American Court looked in this particular case at whether the conduct of a private mental health institution, which had been engaged by the State to render mental health services under a public health scheme guaranteed by the Brazilian Constitution could be attributed to Brazil. The Court concluded that Brazil was "[...] liable for the conduct of the staff of the [private mental institution], which exercised the state authority in rendering public health services under Brazil's Single Health System." ${ }^{655}$ With respect to Aguas Argentinas, it is suggested that the provision of an essential service that is guaranteed in the Argentine Constitution. This service was previously entrusted by law to the State (and formerly performed by a public company) and arguably amounts to a function that contains elements of governmental authority. In spite of the presence of commercial elements in the provision of water services, the nature of the function is still essentially public, in particular given the fact that there are important public interests connected to the provision of water as recognized in the Aguas Argentinas, S.A., Suez, Sociedad General de Aguas de Barcelona, S.A. and Vivendi Universal, S.A. v. Argentine Republic case. ${ }^{656}$

In the second place, it has to be shown that the function must be delegated to Aguas Argentinas through a law, and that the entity acted in a public or governmental capacity. With respect to the former, this requirement is arguably fulfilled. The privatization of the water services in Buenos Aires took place through a public law and encompassed the provision of essential public services, delegated to a private actor, whose conduct was to be regulated through another public act (the Presidential decree establishing the regulatory framework and the regulator, ETOSS). With respect to the question as to whether Aguas Argentinas acted in a public capacity, it can be observed that the fact that the company provided water services in a commercial setting does not mean that it is not acting in a public capacity: the

\footnotetext{
653 Case of Ximenes-Lopes v. Brazil, Merits, Reparations and Costs, judgment of 4 July 2006, IACtHR, Series C no. 149. See also Chapter IV, Section 2.2.1.

654 Ibid., para. 87.

655 Ibid, para. 100.

656 See Aguas Argentinas, S.A., Suez, Sociedad General de Aguas de Barcelona, S.A. and Vivendi Universal, S.A. v. Argentine Republic, Order in Response to a Petition for Transparency and Participation as Amicus Curiae, para. 19 and Sections 2.2 and 4.2 supra.
} 
company had an obligation under the regulatory framework to provide the service, ensure the quality of the service, and make investments to increase the coverage of the service. In sum, it is suggested that the conduct of Aguas Argentinas can be attributed to Argentina given that it exercised functions containing elements of governmental authority.

With respect to the two other possible grounds for establishing the responsibility of Argentina, the following can be observed. It would be difficult to argue that the Aguas Argentinas was acting under instructions or orders, or was under control of the State as required by Article 8 of the ILC Articles: the service had after all been privatized. The only control that was exercised over the concessionaire's conduct was a regulatory and contractual one, albeit to facilitate the fulfillment of a public task. As noted in Chapter IV, Section 2.2.2, under Article 8 the control to be exercised over a private entity should be 'effective'. This imposes a high threshold to establish responsibility. In addition that control must be directed by the State, and not merely supported or encouraged. In contrast to the use of PMSC contractors in Abu Ghraib, whose conduct was arguably under the 'effective control' of the U.S. Army since they received the instructions from the latter, the activities of Aguas Argentinas were not directed by the State. The company did not receive direct instructions from the State, but had discretion to act within what the regulatory framework and concession contract permitted to fulfill its public obligations.

On the other hand, Argentina could be held indirectly accountable for the concessionaire's conduct for lack of due diligence. For example, although the regulatory framework and the concession contract provided for a wide array of measures intended to regulate the conduct of Aguas Argentinas, it apparently did not envision the possibility that the company could engage in a type of cherry picking by denying potential service users access to the network for lack of proper land or property title. As noted in Section 4.3.3, this led to the exclusion of a group of mainly vulnerable users from the service. They had to wait until NGOs took action in a (successful) attempt to move the public authorities and the company to assist in extending the service to them. In addition, it is possible to argue that the regulatory framework was flawed in the sense that it did not prevent ETOSS from falling ti regulatory capture, or properly secured its independence. These gaps in the State's obligation to protect entail a certain lack of effective measures for which Argentina could be held responsible. The same can be said for the issue of affordability. In spite of the fact that the regulatory framework allowed the State to adopt pro-poor measures that could aid vulnerable sectors of society to pay for the cost of connection and for the water bills, it took several years before it did so. Hence it can be concluded that, as in the case of Social and Economic Rights Action Centre and the Centre for Economic and Social Rights v. Nigeria, ${ }^{657}$ Argentina 
could be held indirectly responsible for lack adequate and effective measures to curb the conduct of Aguas Argentinas.

A brief issue remains. Until now we have discussed the issue of accountability of the host country of a private company that is owned by a consortium of companies based elsewhere. Can the home countries of this consortium, Spain, France, and the United Kingdom, be held accountable for abuses committed by Aguas Argentinas in breach of the right to water found in Article 11 ICESCR? The problem of extraterritorial application of human rights is a complex one. ${ }^{658}$ It is accepted that human rights obligations may have extraterritorial effect in situations of 'effective control', and in recent decision, the European Court of Human Rights has somewhat clarified this concept recognizing that this control not only has a spatial scope, but also a personal one. ${ }^{659}$ The UN Committee on Economic, Social and Cultural Rights observed in General Comment No. 15 that the extraterritorial effect of the Covenant is based in the Article 2 §1 ICESCR's obligation on States to take steps

"[...] through international assistance and co-operation, especially economic and technical, to the maximum of its available resources, with a view to achieving progressively the full realization of the rights recognized in the present Covenant by all appropriate means, including particularly the adoption of legislative measures. ${ }^{660}$

With respect to private entities, the Committee noted that "[s]teps should be taken by States parties to prevent their own citizens and companies from violating the right to water of individuals and communities in other countries." ${ }^{\prime 61}$ Given the tone of this observation (more a recommendation than a legal requirement or obligation as observed by Coomans), ${ }^{662}$ it is possible to argue that that there is an extraterritorial obligation to protect. However, it has been observed that such an obligation has yet to crystalize under international law. ${ }^{663}$ Although it is not the intention of this study to go deeper into this aspect, it may be possible to suggest that under the ICESCR there is at the most a hortatory obligation to ensure that the conduct of companies

658 See F. Coomans and M. Kamminga, "Comparative Introductory Comments on the Extraterritorial Application of Human Rights Treaties," and M. Gondek, The Reach of Human Rights in a Globalizing World: Extraterritorial Application of Human Rights Treaties (Antwerp: Intersentia, 2009).

659 See Case of Al-Skeini and Others v. The United Kingdom, Grand Chamber judgment of 7 July 2011, ECtHR (not yet published). See further, M. Milanovic, "European Court Decides Al-Skeini and Al-Jedda," available at EJIL: Talk! (<www.ejiltalk.org/european-court-decides-al-skeiniand-al-jedda/\#more-3543>, last visited on 8 July 2011).

660 Article 2 \$1 ICESCR, and General Comment No. 15, para. 31.

661 General Comment No. 15, para. 33.

662 F. Coomans, "The Extraterritorial Scope of the International Covenant on Economic, Social and Cultural Rights in the Work of the United Nations Committee on Economic, Social and Cultural Rights," Human Rights Law Review Vol. 11 (2011), p. 29. 
abroad is regulated in such a way as to prevent conduct that is in breach of the Covenant. Hence, it would be difficult to conclude that Spain, France, and the United Kingdom are legally responsible for the conduct of Aguas Argentinas.

Looking at the issue from a mixed national law/international law perspective, the possibility of holding Aguas Argentinas directly responsible in terms of human rights for its actions and potential human rights abuses should not be dismissed. Given the State centered nature of international law, the lack of horizontal effect of human rights treaties, as well as the lack of direct human rights obligations of business enterprises, ${ }^{664}$ only Argentina can be held accountable for Aguas Argentinas' conduct at the international level. However, at the national level and from the perspective of victims, it could be better if the responsibility is directly laid on the entity which actually perpetrated the abovementioned potential abuses. Arguably, the advantages of doing so for the victims are to be gained in terms of legal clarity and certainty. The legal fiction imposed by international law by which the State has to take indirect responsibility for the actions of private actors is for lay persons and victims incomprehensible. In addition, since as argued above, it is already possible on the basis of Article 5 of the ILC Articles to argue that Aguas Argentinas is exercising elements of governmental authority in the context of this legal fiction, it would seem reasonable to extend that at the national level and hence determine that the company is a public actor sui generis. This means that its actions in the performance of its public task as the water utility for Buenos Aires are amenable to direct human rights review. Moreover, it must be pointed out that through the amparo procedure found in Argentina's Constitution, Aguas Argentinas has been called in a number of occasions to answer for some of its actions. Thus, in a couple of cases users who were not in the possibility of paying their water bills and who were disconnected from the service by the concessionaire invoked human rights arguments to force the company to restore the connection. ${ }^{665}$ In respect to this point it should be noted that according to Courtis there seems to be some recognition in Argentine case law for the direct applicability of international human rights norms to the conduct of private entities. ${ }^{666}$ This suggests an even stronger argument for holding Aguas Argentinas directly accountable for potential abuses pertaining to the right to water.

\footnotetext{
664 With respect to non-State actors involved in the provision of water, the Independent Expert on the issue of human rights obligation related to access tosafe drinking water and sanitation, Catarina de Albuquerque, has noted that "[...]their activities are intrinsically linked to the realization of human rights, and therefore they need to observe particular requirements in exercising due diligence." Report of the independent expert on the issue of human rights obligations related to access to safe drinking water and sanitation, para. 28 (see note 312 supra). See Section 4.5 infra.

666 Courtis, "The Applicability of Human Rights Between Private Parties,” p. 165.
} 


\subsection{Legal remedies available to individuals}

In General Comment No. 15, the UN CESCR noted that,

"[...] any persons or groups who have been denied their right to water should have access to effective judicial or other appropriate remedies at both national and international levels. [...] All victims of violations of the right to water should be entitled to adequate reparation, including restitution, compensation, satisfaction or guarantees of non-repetition. National ombudsmen, human rights commissions, and similar institutions should be permitted to address violations of the right." 667

The issue of remedies is also coupled to the question of justiciability of economic, social and cultural rights. In the case of Argentina, there is "[...] an increasing acceptance of the possibility of invoking social and economic rights before courts both by the judiciary and scholars." ${ }^{\prime 668}$ Also, quite importantly in the context of this study, is the recognition of the existence of a right to water in Argentina, even if it is not expressly provided for in the Constitution. ${ }^{669}$ These developments have allowed a number of national courts in Argentina to issue judgments involving the right to water and the conduct of privatized water utilities. This has been further facilitated through the use of the constitutional amparo procedure providing an injunction to those who complain of a violation of constitutional rights. ${ }^{670}$ For example, in the case of Usuarios y Consumidores en Defensa de sus Derechos Asociación Civil c. Aguas del Gran Buenos Aires S.A, a civil trial court in the Province of Buenos Aires recognized that access to water is a right that should be ensured to every inhabitant of the country, regardless of their capacity to pay for the service. ${ }^{671}$ As a result, this lower court concluded that disconnecting individuals living in residential areas from the water service by either a privatized water utility or a public one on the grounds of non-payment of the service is unconstitutional and in violation of, inter alia, Article 42 of the National Constitution and Article 11

667 General Comment No. 15, para. 55.

668 Courtis, "Argentina - Some Promising Signs," p. 166-167.

669 N.C. Darcy, "El Derecho Humano al Agua y su Recepción como Derecho Fundamental en Argentina," Documento de Trabajo No. 06-2010, Agencia Española de Cooperación Internacional para el Desarrollo/Universidad de Alcalá (Programa Regional de Apoyo a las Defensorías del Pueblo en Iberoamérica, (2010), p. 21. Darcy argues that the direct applicability of international human rights instruments in the Argentine legal order by virtue of Article 75 of the Argentine Constitution, makes it possible to accept the existence of the right to water through Article 11 ICESCR as interpreted by the UN CESCR. The Argentine Supreme Court has recognized such an approach in one particular case dealing with the right to work and cited by Darcy: Supreme Court of the Republic of Argentina, Aquino, Isacio c/ Cargo Servicios Industriales S.A. s/ accidentes ley 9688, A. 2652. XXXVIII, p. 12-14.

670 Courtis, "Argentina - Some Promising Signs," p. 165.

671 Moreno, Province of Buenos Aires, Civil Trial Court, Usuarios y Consumidores en Defensa de sus Derechos, Asociación Civil c/ Aguas del Gran Buenos Aires S.A. s/ Amparo, 21 August 2002 in file with the author. 
of the ICESCR. ${ }^{672}$ Another interesting decision also involving disconnection for non-payment and reaffirming the justiciability of the right to water is the case of Quevedo Miguel Angel y Otros c/ Aguas Cordobesas S.A., Acción de Amparo. ${ }^{673}$ In this case a judge of first instance had to decide on an amparo request to prevent the disconnection of the water service provided by a privatized water company. ${ }^{674}$ Although the judge noted that the service could be disconnected, it concluded that the Argentine authorities had a duty to guarantee a minimum access to water for poor households. ${ }^{675}$ These examples suggest that individuals and groups in Argentina have prima facie access to meaningful and seemingly effective remedies to address problems related to the right to water.

In general, it is possible to differentiate between several remedies available to individuals or groups that have been affected by the decisions of Aguas Argentinas. These remedies entail a. remedies of an administrative nature; b. quasi adjudicatory remedies; and c. traditional judicial remedies.

672 Ibid. See also Courtis, "Argentina - Some Promising Signs," p. 179. and C. Fairstein and S. Niedzwiecki, "El Acceso al Agua en Argentina. Experiencias de reclamo ante situaciones de privación," in Derecho Al Agua, Spain: Ingeniería Sin Fronteras \& Prosalus (2008), p.110. This decision, which was reaffirmed in appeal, was later overturned by the Supreme Court of the Province of Buenos Aires, since it concluded that the complaint was inadmissible due to the fact that no actual disconnection of the service had taken place, meaning that the complaint had an abstract nature. Supreme Court of the Province of Buenos Aires, Usuarios y Consumidores en Defensa de sus Derechos, Asociación Civil c/ Aguas del Gran Buenos Aires S.A. s/ Amparo, Ac 86720 S, 22 September 2004 available at $<w w w . s c b a . g o v . a r>$. For a judgment that comes to a similar conclusion as the Civil Trial Court of Moreno and that also points to Article 42 of the Argentine Constitution as well as Article 11 of the ICESCR, see Appeals Chamber on Civil and Commercial Cases 8A, Province of Córdoba, Argañaraz, M. Francisco Godoy Juan Carlos y Otros c/ Aguas Cordobesas S.A. s/ Amparo, Judgment No. 77 of 24 March 2004, available at $<$ www.justiciacordoba.gov.ar>.

673 First Instance Judge 51 Nominación on Civil and Comercial Cases, City of Córdoba, Quevedo Miguel Angel y Otros c/ Aguas Cordobesas S.A., Acción de Amparo, Judgment of 8 April 2002 (available at $<$ www.cedha.org.ar/docs/doc220-spa.doc>, last visited on 10 May 2011).

674 Ibid. See also Winkler, I, "Judicial Enforcement of the Human Right to Water - Case Law from South Africa, Argentina and India", 2008 (1) Law, Social Justice \& Global Development Journal (LGD), Available at <www.go.warwick.ac.uk/elj/lgd/2008_1/winkler>.

675 Quevedo Miguel Angel y Otros c/ Aguas Cordobesas S.A., Acción de Amparo. In essence, the judge recognized the efforts made to facilitate the payment for water services to the most disadvantaged sectors and guarantee minimum access to water. This included the allowance for the provision of 50 liters per day per household free of charge to those households that had been disconnected. Arguing that the Argentine authorities have a duty to protect poor and disadvantaged groups, the judge concluded that the 50 liters of water per day per household is not sufficient and ordered the privatized company to provide these households 200 liters in order to effectively guarantee their right to water. It should be noted that the judge also observed that when privatized entities are responsible for the provision of such an essential service, they assume under the responsibility of the State one of the most important instruments in the pursuit of the common good. As such, the judge concluded that when the concessionaires are entrusted with the provision of a public service, they become public bodies amenable to the relevant laws and regulations in order to facilitate state action. Ibid. A similar case. 
a. The administrative remedies available to the consumers of the service provided by Aguas Argentinas included the bodies directly involved in the provision of the service and its monitoring. Thus, as observed in section 4.3.4 under the regulatory framework and the concession contract, service users were allowed to first submit any complaint related to the provision of the service, its quality and billing before the concessionaire. If the concessionaire's response did not satisfy the service user, it could bring the complaint to the attention of ETOSS. ${ }^{676}$ The main problem with ETOSS as a remedy relates to its suggested lack of independence and possibly even its impartiality. It was noted above that ETOSS's independence was compromised. In addition, it may be argued that as the regulator of the privatized concession, whose financial resources partially depended on a proportional percentage of the water bills, ETOSS had a stake not only in keeping bill collection high, but also in allowing tariff increases. ${ }^{677}$ Arguably this is a situation of regulatory capture, by which the regulator that is supposed to safeguard public interests ends up catering to the interests of the regulated company. This situation creates the impression that the regulator would not take complaints directed against high tariffs seriously. Although as far as the present author knows there has been no indication that indeed ETOSS' capacity to deal with service users' complaints was actually hampered by this perverse incentive, it is suggested that its credibility vis-à-vis consumers was tarnished and its effectiveness as a remedy reduced. On the other hand, it must be acknlowedged that Article 21 of the regulatory framework provided for (limited) participation of service users in in the activities of ETOSS through an advisory commission, which was formally established in ETOSS Resolution 23/93. ${ }^{678}$ Bloch, however, notes that the advisory commission was initially ineffective due to the fact that in only gathered together in a few occasions. ${ }^{679}$ ETOSS also established the possibility of calling for public consultations through Resolution 140/95 with which it could gather the opinions of service users and establishment of an independent consumer ombudsman during such consultations. ${ }^{680}$

Besides the administrative procedure prescribed by the regulatory framework, Argentina also implemented a specific complaints system for individual consumers through the Sub-secretary for the Protection of the Consumer (Sub-secretaría para la Defensa del Consumidor). This system, based on the Law for Consumer Protection, ${ }^{681}$ allows individuals to file complaints before the Sub-secretary against either public or private providers of public services. Although this system appears

676 See Article 72 of the regulatory framework. See also Section 4.3.4.2 supra.

677 Alcázar, Abdala, and Shirley, "The Buenos Aires Water Concession,” p. 30.

678 See Article 21 of the regulatory framework and D. Bloch, "Procedimientos de Participación de los Usuarios en la Regulación de los Servicios Públicos," Revista Argentina del Régimen de la Administración Pública No. 258 (2000), in file with the present author.

Ibid.

680 Ibid.

681 See Law No. 24.240 of 13 October 1993 on Consumer Protection, available at $<$ http://infoleg. mecon.gov.ar/infolegInternet/anexos/0-4999/638/texact.htm>. 
to provide a low threshold to consumers, the Sub-secretary itself is part of the public administration which suggests that it may not always be entirely independent or impartial.

b. In addition to remedies of an administrative nature, a quasi judicial remedy was also available for individuals affected by the activities of Aguas Argentinas. The Argentine Ombudsman arguably has played an important role in defending the rights of service users vis-à-vis the activities of the concessionaire. ${ }^{682}$ Under Article 14 of Law No. 24.284 establishing the institution of the Ombudsman, individuals may submit a petition before the Ombudsman to initiate an investigation into the facts, acts of omission or commission of the public administration and its agents with respect to, among other things, the illegitimate, irregular, abusive, arbitrary, and discriminatory exercise of their functions. ${ }^{683}$ According to Article 17 of the Argentine Ombudsman's jurisdiction to deal with these complaints also extends to the activities of private legal persons that are in charge of providing public services. ${ }^{684}$ In addition, Article 17 entitles the Ombudsman to entice public administrative bodies to exercise their functions vis-à-vis these companies. This was, for example, the case of the already mentioned complaint against ETOSS requesting it to take action against Aguas Argentinas with regard to the issue of the high levels of nitrates present in the water of certain areas of the concession. Arguably, his accessibility and power to bring legal actions against public bodies and privatized ones alike makes the Ombudsman a compelling remedy that has indeed helped to guarantee the rights of consumers.

c. The traditional judicial remedies available to users of the service provided by the concessionaire involve the regular adjudicatory bodies. Amparo procedures have been waged against decisions adopted by Aguas Argentinas to disconnect the provision of water services to individuals in the city of Buenos Aires. Lower civil courts in the province of Buenos Aires have in a number of amparo cases against Aguas Argentinas gone along the arguments deployed in Usuarios y Consumidores en Defensa de sus Derechos Asociación Civil c. Aguas del Gran Buenos Aires S.A. Thus in the case of Ronchi, Pablo Jorge c/ Aguas Argentinas S.A. S/Amparo (incidente apelación), the Federal Appeals Chamber of the Province of La Plata confirmed a preliminary injunction granted by a lower federal court in an amparo action filed by an individual who had been disconnected from the service by Aguas Argentinas due to lack of payment of three water bills that were contested by applicant. ${ }^{685}$ Through this preliminary injunction, applicant sought to have his

682 See for example, Section 4.3.2 supra.

683 See Article 14 of Law No. 24.284 establishing the institution of the Ombudsman of the Argentine Nation, available at the website of the Ombudsman (<www.dpn.gob.ar/main.php?cnt=22 >). Argentinas S.A. s/Amparo (incidente apelación), Expte. 2044/01, Rtro T.29 f 118/120 of 
access to the water service restored, while the main proceedings dealing with the contested water bills were still pending. The Federal Appeals Chamber motivated granting the injunction on the ground that it was necessary to

"[...] evitar la afectación de derechos constitucionales esenciales como son el derecho a la salud, a la vida, a la propiedad y a lo demás prescripto en el art. 42 de la Constitución Nacional, habida cuenta el daño inminente que traería aparejado la falta de pago de la facturación cuestionada, esto es, el corte del servicio de agua al usuario por parte de Aguas Argentinas." ${ }^{986}$

In a similar case, Bocanegra, Elida Leslie c/Aguas Argentinas S.A. s/Amparo, the Federal Appeals Chamber of the Province of La Plata, denied an appeal from the concessionaire aimed at reversing provisional measures granted by a lower federal court in an amparo action. ${ }^{687}$ The amparo action once again sought to prevent disconnection from the water service following threats from Aguas Argentinas to that effect during a dispute over unpaid water bills. The company claimed inter alia that the disputed water bills were accurate and had been unpaid for sometime even though the water service was still being provided. It also argued that the amparo applicant had not attempted to resolve the issue through the available administrative procedures ${ }^{688}$ According to the concessionaire the applicant had to first file a complaint before the concessionaire and then seek redress through ETOSS. The Federal Appeals Chamber, however, was not convinced. It observed that that the regulatory framework gave service users the choice to turn to ETOSS for review of the decisions or actions of Aguas Argentinas, or to submit the case to litigation before the courts. It argued that given the ongoing litigation with respect to the unpaid water bills, the amparo action was justified. In the Appeals Chamber's opinion this was due to the pending disconnection from the service and due to the fact that access to the public water service is rooted in a constitutional right of the users that is indispensable for the realization of their right to live in dignity and the protection of health as guaranteed in Article 42 of the Argentine Constitution. ${ }^{689}$

\footnotetext{
686 " [...] avoid essential constitutional rights from being affected such as the right to health, life and property and others as guaranteed in Article 42 of the National Constitution, taking into account the imminent damage that would take place due to lack of payment of the contested water bills, namely disconnection of the user from the water service by Aguas Argentinas." ibid., para. VI [translation $A H W]$. See also Darcy, "El Derecho Humano al Agua y su Recepción como Derecho Fundamental en Argentina," p. 55-56.

687 See Federal Appeals Chamber of La Plata Province, Sala III, Bocanegra, Elida Leslie c/Aguas Argentinas S.A. s/Amparo, Expte. 6236/04, $\mathrm{T}^{\circ} 132 \mathrm{~F}^{\circ} 194 / 195$ of 18 May 2006, available at $<$ www.pjn.gov.ar>.

688 Ibid.

689 Ibid., "[...] en virtud de que el acceso al consumo del servicio público de provisión de agua constituye un derecho de raigambre constitucional de los usuarios en tanto es imprescindible para el desenvolvimiento de una vida digna y la protección de la salud de aquellos (art. 42 de la Constitución Nacional)."
} 
Some of these amparo procedures have gone all the way from the local first instance tribunals in the Buenos Aires up to the Supreme Court of Argentina. It would appear, however, that even though the Argentine Supreme Court has dealt with various cases involving Aguas Argentinas, ${ }^{690}$ it has not issued a substantive judgment with respect to the right to water in relationship to the conduct of the company. The Supreme Court has until now mainly limited itself to discuss issues of jurisdiction related to the question whether amparo procedures against Aguas Argentinas should be dealt with by Federal courts, and whether civil courts were the proper legal venues to address the complaint instead of administrative courts. ${ }^{691}$ In general, the Supreme Court has concluded that civil courts had jurisdiction to deal with the amparo complaints, most of which were geared towards preventing Aguas Argentinas from disconnecting individual households from the water mains due to payment issues. ${ }^{692}$ These amparo cases are important from the perspective of the protection of the rights of consumers from the actions of a privatized entity that threatens to breach those rights, in particular, even if not mentioned directly, the right to water. On the other hand, given the nature of the procedure, the motivation of the decisions tends to be on the light side. There is no deep analysis of

690 A quick search in the website of the Argentine Supreme Court reveals 64 cases against Aguas Argentinas. See $<$ www.csjn.gov.ar $>$.

691 Supreme Court of the Republic of Argentina, Rodriguez, Hugo Manuel c/ Aguas Argentinas S.A. S/ Amparo Ley 16.986. S.C. Comp. N 379.XXXII, judgment of 6 February 1997. This case dealt with a request by complainant to prevent Aguas Argentinas from terminating the connection to the water mains as a result of his refusal to pay the water bills, which he argued were too high and not correctly calculated. The Supreme Court concluded that given the fact that the nature of the dispute was related to the contractual relationship between complainant and the company, a civil court had jurisdiction to deal with the request instead of an administrative one. An exception to these cases is a dispute concerning the payment of a water bill that had been globally calculated for apartment residences without individual water meters on the basis of a procedure established by ETOSS. The case originally started through an amparo procedure filed by the Argentine Ombudsman against Aguas Argentinas and ETOSS (see Defensor del Pueblo de la Nación, Séptimo Informe Anual, 2000 (1/1/2000-31/12/2000), p. 181, available at <www. dpn.gob.ar/informes/ianual2000.pdf $>$ ). The amparo procedure aimed at preventing the concessionaire from taking any action that would allow it to obtain payment for the bills until the matter was settled. Although the present author does not know whether the Ombudsman argued against the billing system based on human rights arguments, lower courts apparently decided that the billing methodology for those types of dwellings was not legal and nullified the procedure established by ETOSS. The Government, ETOSS and Aguas Argentinas appealed the lower courts' decisions before the Supreme Court. However, the latter concurred with the lower courts and the Ombudsman declaring the billing system inadequate. The decision was not motivated on human rights grounds. See Supreme Court of the Republic of Argentina, Defensor del Pueblo de la Nación c/ Estado Nacional-P.E.N. -M de Eco. Obras y Serv. Públ.- y otros s/ amparo ley 16.986, D. 1084. XXXII y D. 1032. XXXII. y D. 1040. XXXII. Recursos de Hecho, judgment of 14 September 2000.

692 See among others, Supreme Court of the Republic of Argentina, González, María Teresa y otro c/ Aguas Argentinas S.A. s/ amparo, Comp. № 894.XXXIII, judgment of 17 February 1998 and Supreme Court of the Republic of Argentina, Etchepare, Eduardo Victor c/ Aguas Argentinas S.A. s/medidas cautelares, Comp. N²53. XXXIX, judgment of 16 September 2003. 
the content right at stake and how the conduct of the privatized water provider may have a severe impact on those rights other than mere impairment, or whether there may be legitimate reasons to limit the right.

In sum it can be concluded that individuals had access to various levels of procedural remedies that could help them to deal with problems related to the right to water as affected by abusive behavior not only of the concessionaire, but potentially also by the regulator. Are these remedies effective? With the exception of ETOSS' somewhat tarnished independence and impartiality, it is very difficult to assess whether the other available remedies, both quasi-judicial and traditional judicial remedies could be regarded as being effective. The proactive attitude of the Argentine Ombudsman and its willingness to step up against ETOSS and Aguas Argentinas, as well as the fact that a number of its investigations ended up in concrete results such as moving ETOSS to impose sanctions on the concessionaire, suggest that it served as an effective remedy to redress any concrete situation of abuse.

For their part, traditional judicial remedies available for individuals to litigate against decisions adopted by both ETOSS and Aguas Argentinas in contravention of their right to water appear at first glance to provide an ideal avenue of redress. However, procedures before traditional courts may take years to conclude. This is for example clear in Torre, Hugo M. v. Aguas Argentinas SA y otro, another case involving the termination of the water service, this time to a lawyer's office. ${ }^{693}$ This particular case started as a request for provisional measures before a civil law tribunal in 2001 to put an end to the termination of the service. The complainant argued that such termination was contrary to his constitutional right to an essential public service. The injunction was granted to allow for the restitution of the water service in spite of the lack of payment, since it entails a "[...] servicio público que provee un elemento vital para la subsistencia. ['a public service that provides a vital element for the subsistence' $A H W]^{\prime \prime 694}$ However, the case ended up bouncing back and forth between civil law and administrative tribunals before ending at an administrative appeals court in 2010. It would appear that at the time of this writing the case is now pending resolution before the Argentine Supreme Court. ${ }^{65}$ This type of situations provides some perspective as to the possibilities to adjudicate economic, social and cultural rights before traditional courts. Requesting injunctions

\footnotetext{
693 See Appeals Chamber for Federal Administrative Cases, No.2, Torre, Hugo M. v. Aguas Argentinas SA y otro, Expte. 20000/2003, in file with author.

694 Federal Appeals Chamber for Civil Law cases, Sala de Feria, Torre, Hugo M. c. Aguas Argentinas S.A, judgment of 22 January 2001, in file with author. See also Darcy, "El Derecho Humano al Agua y su Recepción como Derecho Fundamental en Argentina," p. 55.

See Supreme Court of the Republic of Argentina, Torre, Hugo M. v. Aguas Argentinas SA y otro, Exp. No. 277/2010 website of the Argentine Supreme Court at <www.csjn.gov.ar/cfal/fallos/ cfal3/cons_fallos.jsp> (last visited 20 May 2011).
} 
such as amparo or other provisional measures, may initially lead to quick results in which the right to water, for example, is acknowledged as requiring protection from a particular court. However, the follow-up procedures may take a while to resolve, and it is not entirely clear whether they will be benefit users complaining for an abuse resulting in an alleged violation of the right to water. In the case of Torre, Hugo M. v. Aguas Argentinas SA y otro, an administrative appeals Court concluded that the termination of water by Aguas Argentinas was legitimate finding no constitutional breaches, in spite of the earlier decision on the injunction.

\subsection{Preliminary conclusions}

Arguably, the results of the Buenos Aires water privatization after thirteen years of operation have been mixed. On the one hand, Aguas Argentinas managed to expand the services to provide potable water and sewerage to a large portion of the population of the Argentine capital, albeit not in the amount it was obliged to by the concession contract. On the other hand, many of the expected benefits of privatization did not fully materialize. After an initial drop in tariffs, these gradually increased in spite of the fact that the original concession contract provided for tariff revisions only after the tenth year of operation. Access to the water network was also initially hampered by the high connection charges that new users were obliged to pay. This made it essentially difficult to the most impoverished sectors of society to benefit from the improved services. Although the quality of the services provided appears to have improved, there were still problems that crept up during the operational period of the concession. Some aspects of the regulatory system put in place were relatively weak and also contributed to some of the problems of the concession. The financial crisis that hit Argentina between 1999 and 2002 made matters more difficult for the concession.

The privatization of water utilities in Buenos Aires has been a mixed bag in human rights terms. Clearly, the privatization of Aguas Argentinas resulted in the expansion of the water and sewerage network and a general improvement in the quality of water and the general quality of the service delivery with all the concomitant positive effects on the rights to water, food, adequate housing and health. These positive effects are somehow counterbalanced with the negative aspects of privatization that may have resulted in potential violations of human rights obligations pertaining to the right to water. Although the physical accessibility of the water network has improved, the concession has also led to problems relating to the economical access to the network thus directly affecting the right to water and indirectly having an impact on the right to food, adequate housing and health. Additionally, there have been problems relating to the duty to consult those affected by the privatization. 
It is acknowledged that even without privatization, an increase in the water and sewerage tariffs was unavoidable. The water tariffs prior to privatization were too low and investment to improve the water and sewerage networks was necessary. The financing of this investment either through an increase in the tariffs or through higher taxes would have led in any case to higher costs among all consumers. It has also been noted that even poor consumers usually recognized the need to pay for the use of water and sewerage, as long as fees were fair and within their reach, and as long as charging for water led to improvements in access to the service. However, the privatization of the water utility in Buenos Aires was partially sold on the premise that water tariffs would be reduced and this would mainly benefit the poorest sectors of society. The tariff was indeed initially reduced as a result of the concession award criterion, although the circumstances surrounding this tariff reduction would appear to make the tariff reduction only a token/symbolic gesture. The requirement to charge a high fee for new connections has, however mainly affected the poor even though the 1997 contract renegotiation reduced the connection fees.

Between 1993 and 2006, the tariffs were gradually increased and although it has been claimed that the tariffs are still percentage wise lower than the official tariff prior to the privatization, the price increases together with high connection fees have had the greatest impact on the poorest sectors of society. ${ }^{696}$ This was compounded with an increase in unemployment since 1998 and the financial crisis that hit Argentina in 2001, which together with the gradual increase in tariffs and high connection costs have resulted in payment arrears and disconnections. Although the disconnections for non-payment of water bills may appear not to be arbitrary, it has resulted in a barrier to fulfill the availability and physical accessibility of water and water related services and thus in a violation of the obligation to protect on the side of the State for not taking the necessary measures to ensure that consumers are shielded against the prices increases. With respect to the gradual increase in tariffs, there also has been the problem of transparency and participation of those affected by it in relationship to the way the tariff increase was dealt with.

It is possible to argue that the case of the Buenos Aires water concession reveals a potential violation of the minimum core obligation to ensure non-discriminatory access to water. However, Principle 8 of the Maastricht Guidelines acknowledges that States enjoy a certain margin of appreciation in selecting the means for implementing their respective obligations. This has also been recognized in General Comment No. 3 on the nature of States parties' obligations. When a State chooses privatization as a means of progressively achieving the full realization of and

696 Additionally, some measures aimed at alleviating those with scarce incomes have not been properly implemented. 
implementing its obligations under the rights to water, food, adequate housing and health, it must do so in a way that does not harm more than necessary the immediate enjoyment of these rights. In trying to achieve a greater public interest goal such as increasing the physical accessibility of essential services which brings (immediate?) benefits to public health and goes some way to satisfying some aspects of the rights to water, food, housing and health, Argentina had a certain margin of discretion not only in choosing the means of their realization but also in the way of setting the priorities for their realization. However, in utilizing this margin of discretion in favor of for example physical accessibility, the State has to implement its policies with due consideration for those who are affected: this means that policy implementation should be proportional and necessary to achieve the aimed goal. Could the Government of Argentina have achieved the same result through the use of less intrusive means? Arguably, OSN could have been reformed to try to improve the provision of services. In the end, given that Argentina chose the path of privatization, and hereby attempted to live up to its obligations under the right to water, albeit not always successfully, it can be stated that, however unsatisfactory as it may seem, the privatization of the Buenos Aires water utility did not amount to a violation of the right to water. Further investigation of individual situations would be necessary to see if these yield different findings.

\section{Concluding Remarks}

It is suggested that the privatization of essential utilities is a priori not incompatible with human rights obligations. It can bring positive benefits to the enjoyment of certain rights such as the right to water, food, housing and health if properly designed and carried out. The privatization of utilities does require certain preconditions if it is going to live up to human rights standards. In the first place, it requires a transparent process in which all those who are affected or have a certain stake in the privatization are consulted and involved. This not only includes involving national and regional governments or consulting workers whose work could depend on the privatization, but also engaging the end users of the service including the poorest sectors of society.

Secondly, it requires pro-active measures from the State to ensure that the privatization of essential utilities does not end up harming the poor. Access to drink water is arguably a human right, but it also carries certain responsibilities/ obligations on the side of the right bearers: this includes the rational use of water in a way that is commensurate to everybody's needs, that is good for the environment, and in a way that does not hurt the rights of others. Water is indeed a social good, but at the same time it is a scarce good, that is capital intensive to treat and distribute in a proper way that ensures availability, quality, and accessibility. From this perspective the plea for free water even in poor countries may not be realistic. Charging for water that is provided either by a public utility or a privatized one is 
always going to hurt the poor. If the poor previously did not pay for water because they retrieved it out of (contaminated) wells and got rid of wastewater through cesspools, connecting them to the water and sewerage network will always bring financial costs for them. The same applies for those who previously had access to water through illegal connections. The State must therefore take measures to ameliorate any negative impact on the economical accessibility to essential utilities such as considering well targeted cross subsidies or price rebates for those who are not in the position to afford connection fees or pay water bills. In addition, disconnection from the water service should be only a measure of last resort. If such a measure is adopted, the affected user should have some consultation, and sufficient possibilities to remedy any problems, like outstanding bills, that led to the measure. A prohibition of disconnection to this essential service deserves preference, however, in particular if disconnection is related to inability to pay. In this regard both the State and the service provider (be it private or public) should have policies in place that are friendly towards those sectors of society that are not in the position to always pay their water bills. For example, the regulatory frameworks, and privatization contracts should make it possible to offer these vulnerable sectors subsidies or reasonable pro-poor tariffs and accessible, flexible, and simple procedures for payment of water bills.

Thirdly, a sound regulatory mechanism needs to be in place. This mechanism should be independent and be easily accessible for consumers. Participation of consumers, service users and civil society organizations in the activities of regulators should be considered. Inspiration for this could be drawn from the experiences of national human rights institutions, which are required under the Principles relating to the Status of National Institutions (The Paris Principles) to be inclusive. In addition, the decisions of privatized utilities should be amenable for review by the regulatory mechanism and if that is not sufficient, judicial review should be available. The decisions of the regulatory mechanism must themselves be subject to judicial review. As observed in the case study, such a regulatory mechanism can function as a form of administrative remedy to which service users can turn to in case of abuses by the privatized utility. The judicial remedies available to supplement those administrative remedies should allow individuals or groups to submit claims of violations of the right to water against private entities, when the regulator does not handle these claims in an adequate manner. Civil remedies may suffice although they can have a tendency to be slow and protracted. A procedure allowing provisional measures such as amparo, is arguably an effective way of guaranteeing that users of water services have their rights protected vis-à-vis privatized water utilities.

Has the privatization of public utilities and municipal services led to a deterioration of the capacity to guarantee the rights discussed in this chapter? The answer may lie in the way States are in the position of enacting an effective regulatory system. 
The fact that the privatization of water utilities is not irreversible, as the Argentine experience shows, may also mean that all is not lost in terms of ensuring that the rights of those affected by privatization are guaranteed. With respect to Argentina, however, is is not clear and is also probably too early to determine whether the rescission of Aguas Argentinas' contract resulted in an improvement on the service or not. Further research in this matter may be warranted. 


\section{Chapter VIII Summary and General Conclusions}

\section{Summary}

Privatization as an issue of concern under international law and human rights law remains a topic of current concern. The contentious and controversial discussions with respect to whether it is proper to transfer public tasks, functions or services to private entities who are going to exercise them for a profit does not appear to wane. This is true, in particular, when tasks or services that are considered to be sensitive or a matter of public importance are at stake, and in which concerns have been brought up with respect to their potential effects on the rights of individuals. This is for example the case of the use of private military and security companies in situations of armed conflict. For example, in the wake of the Wikileaks scandal British newspaper The Guardian, one of the first media outlets to get a hand on the leaked diplomatic cables, reported on an alleged scandal involving a PMSC operating in Afhganistan. ${ }^{1}$ One of the disclosed diplomatic cables from the American embassy in Kabul, Afghanistan, noted with concern the conduct of contractors working for PMSC DynCorp who apparently took part in a scandal that involved the use of drugs and the hiring of 'dancing boys' to entertain them. ${ }^{2}$ There is little doubt that the involvement of private actors in the exercise of privatized tasks or services will receive little sympathy from incidents like this. This warrants even further a deeper discussion of the issues that surround privatization from the perspective of international law and human rights law.

It was established in Chapter II that privatization is not a new phenomenon, and it is subject to a cyclical process with the involvement of various actors, such as the State, international financial institutions and multinational companies. The cyclical and dynamic nature of privatization together with the historical origin of certain functions, tasks or services that are sometimes considered to be the responsibility of the State alone, makes it difficult to conclude that there are inherently governmental functions, tasks or services that cannot be privatized. One commentator would even dare to speak of an 'inherently governmental fiction'. ${ }^{3}$

1 See "Foreign contractors hired Afghan 'dancing boys', WikiLeaks cable reveals," The Guardian news report, 2 December 2010 available at: <www.guardian.co.uk/world/2010/dec/02/foreigncontractors-hired-dancing-boys?intcmp $=239>$ (last visited 30 December 2010).

2 The particular cable can also be viewed on the website of The Guardian: <www.guardian.co.uk/ world/us-embassy-cables-documents/213720 > (last visited 30 December 2010).

3 See D. Guttman, "Public Purpose and Private Service: The Twentieth Century Culture of Contracting Out and the Evolving Law of Diffused Sovereignty," Administrative Law Review Vol. 52 (2000), p. 891. 
The cycles that end up determining a resurgence of or withdrawal from privatization usually depend on the reigning political, economic, and social views that determine what the role of the State is supposed to be. It would thus appear that currently the 're-nationalization' of a number of tasks and services that have been privatized in the last twenty years is taking place. This does not mean that the privatization or delegation of particular tasks has gone away entirely. Indeed, the increasing reliance of certain States on private military and security companies has been a growing source of concern, in particular with respect to its perceived detrimental effects on human rights. Privatization thus continues to be a controversial and divisive issue. Those who argue in favor of privatization will point out that it saves money, reduces public bureaucracy, and increases efficiency in the sectors it has been applied to. Opponents to privatization will point to examples in which privatization has run amok, created inequalities and has diminished the access of essential services to the poor, while at the same time exult the role of the State in the provision of these services.

In the end, it does not matter whether functions, tasks or services are 'inherently' or 'traditionally' governmental or not, or whether privatization has led to the paradoxical result of the growth of the State in other (regulatory) areas. What matters is what are the practical consequences of the delegation of these activities to private entities in the light of the current international legal obligations of States.

Under international law States may not interfere in the free choice of a State to arrange their political and economic organization in the way they see necessary. This means of course that States are free to adopt privatization policies. In Chapter III it was suggested that national law and national legal traditions may curb the State's discretion to privatize. These constraints can be of a constitutional nature, either explicit or implicit and may imply substantive or procedural limits. These constraints do not offer an absolute guarantee against privatization. Although some countries have prohibited certain types of privatization through constitutional amendments (f.e. the privatization of essential water utilities in Uruguay), it does not follow that other sectors will not be subjected to privatization, or that the constitution may be amended in the future to allow privatization. In contrast to national law, international law does not impose any explicit constraints on the State restraining its capacity to privatize public functions. This flows from the abovementioned freedom accorded to States under international law to adopt sovereign decisions involving economic policies without foreign interference. In spite of certain new developments under international human rights law, such as the adoption of the OPCAT, which have for first time, and to a limited degree addressed the issue of the use of private entities for 'public' tasks (in the case of OPCAT acknowledging the use of privatized prisons and ensuring their monitoring through pro-active visiting by independent bodies), it is probably fair to say that international law is privatization agnostic. Indirect implicit limitations constraining the States' 
freedom to adopt privatization policies do, nonetheless, exist. These include international legal obligations pertaining to international treaty law, the principle of non-intervention, and those arising under the law of state responsibility. The general obligations under international human rights law may additionally have an impact on how states proceed to privatize state tasks and services. Thus, States adopting privatization policies have to be mindful of their negative and positive obligations. However, there is nothing under human rights law that directly proscribes privatization. In fact, human rights monitoring bodies have acknowledged the fact that States can privatize public functions. Moreover, given the close relationship between privatization and economic policy, States enjoy a wide margin of appreciation in deciding whether privatization is the best policy to address certain issues such as the provision of certain public services like water, housing or health care, or even those related to the administration of justice like the operation of a prison. However, these bodies' response has consistently been that the delegation or transfer of these public tasks and services to private bodies does not exempt the State from its obligations under human rights treaties to respect, protect and fulfill the human rights of its population.

Due to the State centered nature of international law, however, these obligations do not apply to other actors playing important roles in the privatization process, namely International Financial Institutions and multinational companies. In spite of the fact that IFIs are not formally bound by direct human rights obligations as found in the various (international) human rights treaties, there appears to be a growing consciousness in their midst about taking into consideration the impact of their lending policies requiring privatization on human rights. Internal procedural guidelines prescribing the World Bank to be mindful of the human rights related aspects in the projects it finances, and internal auditing in the form of the Bank's Inspection Panel have contributed to increase such awareness. Nonetheless, as long as the constituent instruments of IFIs do not oblige these entities to respect human rights, these considerations will remain a relevant, but not essential element in their decision making process. Similarly, business enterprises do not have direct human rights obligations. This has to do with the fact that the legal obligations found in human rights treaties only apply to the States, which are the addressees of these treaties. The lack of so-called horizontal application of human rights obligations to private entities such as business enterprises that are carrying out privatized tasks or providing essential services formerly provided by the State underscores, once again, the State centered nature of international law and human rights. This has not prevented efforts to bring multinational companies to account for human rights abuses through soft law instruments adopted by several international organizations like the OECD, and the ILO, or through self-regulation. This however does not mean that business enterprises exercising privatized functions can be easily brought to account for human rights abuses. In this regard, the State is still considered under international and human rights law the primary entity that has a primary 
responsibility to ensure that the effects of privatization are not contrary to human rights.

The question is then who can be held accountable for the conduct of privatized entities? Chapter IV addressed this issue by analyzing two different approaches to accountability. The first approach looks at accountability from the perspective of general international law under which the State will always be held responsible for any wrongful acts of privatized entities. This flows from the general rules of attribution in international law, in particular those stating that the conduct of entities exercising elements of governmental authority may be attributed to the State. Since States still are the primary subjects of international law, it stands to reason that they should be held ultimately accountable for breaches of international legal obligations that have been committed with their acquiescence, under their supervision, or because of the delegation of governmental authority. The main aim is to prevent States from avoiding being held accountable for breaches of their international obligations committed by bodies, which are not legally or officially part of the State.

From the perspective of the end users or 'beneficiaries' of certain public functions, tasks or services it does not matter in general who provides or performs the function or service as long as its performed or delivered in a reasonable manner that takes their rights and interests into account. It is suggested, however, that when it comes down to ascertaining the accountability of a private entity for performing privatized functions in a manner that is contrary to human rights norms, the traditional approach towards accountability may not be entirely satisfactory. This may require a second approach. This is further justified with regard to abuses of human rights by privatized entities due to the lack of proper horizontal effect of these rights under international law thus preventing the actual 'perpetrators' of these abuses to be held directly accountable. In the second part of Chapter IV another approach to ascertain accountability was discussed. This second approach entails a refinement of the traditional one and considers privatized service providers/actors carrying out former State functions or tasks, or providing certain essential services formerly provided by the State as 'State actions' sui generis that are directly amenable to human rights review. It would appear that there is growing acceptance under human rights law, and other international or regional legal arrangements such as EU law of this approach. For example, in its General Comment No. 2 on the implementation of Article 2 of the Convention Against Torture by States parties, for example, the UN Committee Against Torture recently observed that

"[...] where detention centres are privately owned or run, the Committee considers that personnel are acting in an official capacity on account of their responsibility for 
carrying out the State function without derogation of the obligation of State officials to monitor and take all effective measures to prevent torture and ill-treatment." ${ }^{4}$

The realization that this approach may help to solve the issue of accountability is also gaining some recognition in a number of domestic legal orders with experience in privatization like the United Kingdom. An analysis of case law in these jurisdictions suggests that it is possible to argue that privatized service providers under certain circumstances can be regarded to have donned a public capacity that makes them susceptible to judicial review/human rights review for their actions. However, it may be too early to tell if this approach obtains unanimous recognition. Thus, although at first glance, the U.S. Supreme Court appears to have recognized this approach to a certain extent, major conceptual difficulties have led it to observe in various occasions that no quantitative or qualitative criteria have emerged to ascertain the dividing line between state action amenable to judicial review and private action that is not subject to it. ${ }^{5}$ Nevertheless, Chapter IV suggests that the lack of horizontal application of human rights norms to ascertain direct accountability of privatized actors that have carried out human rights abuses merits a new paradigm for the application of human rights obligations to these entities. Since privatization entails the conduct of private actors which are granted a mandate through laws and contracts allowing them to wield some sort of governmental power or influence (or at the very least having the possibility of influencing the rights of individuals in a similar way in which pure state entities would do if they were in a similar position), then it would follow that the conduct of these entities must be reviewed against the same obligations governing the conduct of the State. It is here argued that the performance by privatized entities of tasks and/or services that are considered essential for the public interest and that either historically, by law or tradition, or through nationalization were exercised by the State, and which individuals and groups still expect to be fulfilled, endows these entities with a certain public capacity for which neither themselves or the State should escape human rights responsibility.

Chapter $\mathrm{V}$ analyzed the practice of human rights monitoring bodies with respect to privatization. Treaty monitoring bodies of the various international and regional human rights instruments have shown concern on various levels regarding the issue of privatization and its consequences for the enjoyment of human rights. Their practice is however not always consistent. Human rights monitoring bodies may not always be in the best position to analyze privatization since it is a complex economical policy that requires expertise that is not always available in those bodies. Nonetheless, they have identified and referred to problems they consider may arise with respect to privatization in their examination of state reports, their

4 UN Committee Against Torture, General Comment No. 2, Implementation of Article 2 by States parties, (24 January 2008) UN Doc. CAT/C/GC/2.

5 Clapham, Human Rights in the Private Sphere, p. 163. 
general comments, and in a number of individual or collective complaints mechanisms. It should be noted, that even though privatization policies have been discussed as an issue of concern, there has been no adjudication through the various systems of individual complaints mechanisms in which privatization was the central cause for a human rights violation. It would appear, nonetheless, that the departing point for all these mechanisms appears to be that privatization does not absolve the State implementing such a policy from its legal obligations under the various human rights instruments. This was for example the case of the Human Rights Committee's views in Cabal \& Bertran v. Australia. ${ }^{6}$ In any case, it appears that human rights bodies at the international and regional level have not directly challenged a State's decision to privatize or pointed out that privatization policies may be incompatible with human rights. In fact, it would appear that they recognize the right of the State to adopt these policies, although as discussed in Chapter $\mathrm{V}$, a number of conditions should be met, which include the adoption of safeguards and regulatory measures, as well as independent regulatory bodies to monitor the exercise of privatized entities to ensure the respect of human rights. It can be concluded in this respect, that these bodies place a major emphasis on the positive obligation to protect individuals against the conduct of private actors exercising privatized tasks or performing essential public services. In addition, these bodies have usually noted the importance of participation and consultation with those groups potentially affected by privatization, and observed that States have a legal obligation in this respect.

Chapters VI and VII discuss two case studies involving privatization in two different sectors which may have an impact on civil and political rights, and economic, social and cultural rights respectively. Thus, Chapter VI discussed the controversial deployment of PMSCs in Iraq, with particular emphasis on the abuses of private contractors from two PMSCs that took place in the sadly famous prison of Abu Ghraib. This chapter observed that the status of PMSCs is not altogether unambiguous. They and their personnel cannot be considered as mercenaries, and their deployment has highlighted potential problems with respect to their participation in hostilities and the application of international humanitarian law. Although there are ongoing efforts to regulate the industry, it is still some way before any concrete solution is offered to the problems they cause. In any case, States that deploy them or consent to their deployment in their own territory have an obligation to ensure that PMSCs can be brought to justice and held accountable for any conduct contrary to the States' international legal obligations. Additionally, States have an obligation to provide victims of human rights abuses committed by PMSCs or their contractors with access to effective judicial remedies that bring relief to the victims' plights. It was possible to conclude that the abuses carried out

6 Cabal \& Bertran v. Australia (1020/2001), UN Doc. CCPR/C/78/D/1020/2001 (19 September 2003). This case is discussed in Chapter IV, Section 3.1.1 and Chapter V, Section 2.1.2. 
by PMSC personnel in Abu Ghraib amounted to a violation of a number of human rights, for which the United States, as being in effective control of Iraq at that point in time bears international legal responsibility. The case of the use of contractors from these companies in Abu Ghraib, and the Blackwater incident also in Iraq illustrates, however, the potential shortcomings of potentially available remedies in criminal and private law.

Chapter VII looked at the privatization of water utilities and reviewed in extenso the outcomes of such a privatization in the city of Buenos Aires, Argentina. The case study departed from a well-founded assumption that there is a right to water. This right imposes on Argentina a number of legal obligations (to protect, respect, and fulfill the right to water, and to guarantee an essential minimum content of the right). The question, however, whether the privatization of water utilities imperils the right to water of users of the services provided by those utilities, cannot be answered in a straightforward way.

\section{CONClUSIONS AND RECOMMENDATIONS}

One of the main conclusions of the present study is that general international law and human rights law does not prohibit the privatization of state functions, tasks or services. Privatization is also ab initio not incompatible with human rights (and under certain circumstances might even help to realize them). Privatization endeavors may sometimes lead to human rights improvements as the case study of the privatization of the water utility in Buenos Aires shows. ${ }^{7}$ This will naturally depend on the regulatory capacity of States. If privatization is short lived, the positive benefits of privatization (such as improving the availability of services) may not be realized and thus may not counterbalance any negative impacts (such as an increase in tariffs for water utilities). If there are any incompatibilities between privatization and international law and human rights then it is because of defects in the implementation of privatization policies. This is the case when States have not properly balanced the interests of the community as a whole, which may require privatization, against the interests of those individuals directly or indirectly affected by the policy. In addition privatization could be incompatible with human rights when States have not adopted sufficient cautionary measures a priori, or reparatory measures a posteriori to protect individuals from harmful conduct by privatized entities (i.e. by not providing adequate legal remedies or a functional regulatory mechanism).

Limits on privatization at the national level depend on national constitutional arrangements, and even then, prohibitions can relatively easily be circumvented.

At the same time the human rights outcomes of this privatization were mixed, and may have led to a number of potential violations of the right to water. 
Conversely, experience in several countries shows that privatization can also relatively easily be reversed. However, in the light of the various BITs signed between States that have privatized national industries to the benefit of foreign companies/investors, any change of policy that reverses privatization to the disadvantage of foreign investors may lead to State responsibility and that State might incur heavy financial losses.

At the international level the following may be concluded. In contrast to nationalization, privatization has not yet been subjected to specific rules of general international law (either in the form of treaty rules in the form of rules of customary law) that provide a framework as to how such an policy might be applied (under which circumstances and taking into account of which principles). Privatization is in any event an economic policy for which States have a relatively wide margin of appreciation. This is consistent with the accepted principles of national sovereignty, which allows States to adopt any economical arrangements they deem necessary. However, human rights law can and does impose certain limits on privatization. Even though States have a relatively wide margin of appreciation to adopt and implement privatization policies/measures, this margin has certain limits. Thus, privatization must not interfere too deeply with specific rights rendering them meaningless. Privatization measures that infringe non-derogable rights would arguably be contrary to human rights obligations.

In any case it is not possible to limit or prohibit privatization solely based on the argument that those functions, tasks or services are traditionally governmental. There is no universally agreed upon definition of what are inherently governmental functions, tasks and services. As observed throughout this study, private actors have in the past carried out many tasks or services that are currently exercised/ provided by the State. One must seek further pointers to conclude that certain tasks should not be privatized or only under certain circumstances/conditions. In theory all functions, tasks and services can be privatized. However, it may not always be wise to privatize them. There are, arguably a number of functions, tasks or services whose privatization could lead to problems, in particular if they are not properly surrounded with sufficient safeguards and adequate regulations:

1. Tasks involving legislative functions and tasks related to the imposition of criminal punishments;

2. Tasks involving the use of lethal force (other than self defense);

3. Tasks involving policing and the gathering of criminal intelligence through for example interrogation, and functions pertaining to the deprivation of liberty in criminal law settings, in particular when detainees are vulnerable because of an increased risk for physical or mental harm or coercion;

4. Tasks involving disciplinary measures against prisoners if it involves penalties for prisoners; 
5. Tasks in which the State reasonably and foreseeably will not be in the position to resume once the privatized entity retires or withdraws. This is particularly the case if it cannot immediately step back in to perform the function or in when there may be serious continuity problems;

6. Tasks related to monitoring of privatized entities (ideally the State should have the ultimate task of monitoring and regulating privatized entities). Of course, there are various proponents of self-regulation, and there have been instances in which a privatization of monitoring has been suggested. It is suggested, however, that with respect to sensitive sectors such as those pertaining to the provision of essential services whose operation have wide ranging public effects, or those that pertain to the administration of justice, law and order (in particular if they entail the use of - lethal - force), monitoring should be in the hands of a public body;

There is something to be said about the desirability of privatizing these functions or services since they can be regarded as 'core' state tasks. However, this is not what is suggested here. In essence, the question as to when is it not desirable to privatize can be answered as follows: when regulatory capacity of States is seriously put in doubt. Privatization requires stringent regulation. This is seen as an international legal obligation by human rights monitoring bodies. This means that in countries where such regulation is not readily available or the ability to apply such regulation is absent or deficient, it is wiser for the State not to engage in privatization exercises. There is a caveat to this proposition. What about countries in which the State is completely not in the position to provide certain basic services or exercise essential functions, and which would by extension not be able to provide a effective regulation? Not allowing privatization in such a situation would not only be unfair vis-à-vis the population of such a country, which would then be left without any alternative to receive essential services. Arguably, this would also be in breach of a State's obligation to fulfill certain human rights and in the context of economic, social and cultural rights such as the right to adequate housing, healthcare or water, most certainly be incompatible with the obligation to provide the barest minimum enjoyment of the essential elements of those rights. The obligation to provide minimum core content of certain rights may limit privatization if it is not regarded as the most adequate/appropriate measure to realize this minimum core content. However, it is not excluded that privatization can also help to realize the minimum core content of these rights if the State itself is not in the position to do it. In such a circumstance non-regulated privatization may be warranted, albeit with strict guarantees and monitoring from outside. In addition, in those circumstances the human rights accountability of the private actors engaging in those public tasks should be applied in the manner suggested by this study and further discussed below. ${ }^{8}$

8 This is a similar reasoning to the one used by the UN Committee Against Torture in the Elmi $v$. Australia case. See Chapter IV, Section 3.1.1. 
In this respect, it is recommended that States carefully consider their decision to adopt privatization policies, in particular in sectors that have a profound impact on the individuals or groups that are covered by them, such as those involving the provision of essential services, those pertaining to the administration of justice and to the maintenance of law and order including the use of force. In order to guarantee that the privatization of functions, tasks or services in these sensitive areas is not entirely incompatible with human rights States should:

1. Carefully consider the necessity of adopting a particular privatization measure, which should be judged/measured against the objectives to be achieved or the interests to be safeguarded, versus the interests of those affected by privatization.

2. Apply certain human rights principles such as necessity and proportionality, taking into consideration their positive obligations (or obligations to respect, protect and fulfill), and reasonableness, to determine prima facie whether in adopting privatization policies they have adequately balanced the competing interests.

3. If the same results can be reached through alternative measures (for example, through enabling or improving state provided services that had been carried out inefficiently until now with not much expense or at a cost which is only marginally worse than what the proceeds from privatization would provide), this alternative should be considered. One of the arguments in favor of privatization is that it leads to cost savings and more efficiency, but there are also many efficient publicly provided services and publicly managed bodies that do an excellent job at market level quality. ${ }^{9}$

4. Allow for consultation with those affected by the policy and implement measures to ameliorate any negative effects or curb any harmful conduct of privatized entities. The privatization process must be transparent and inclusive in as far as possible;

5. Ensure that privatization processes take place by law and include in the privatization enabling legislation, as well as in the contracts used to delegate functions, tasks or services to private actors, human rights 'language' that clearly spells out the human rights duties of both the privatizing State and the private actor engaged in the privatization process.

9 Arguably, the publicly operated water utilities in the Netherlands provide a service of high quality, which is the result of a strict regulatory framework and legislation pertaining to the use and distribution of water and the levels of quality and price expected from the service. In addition, private provision is not always effective or desirable, witness the decision of the Bush administration to replace private security guards at the airport security areas with public ones throughout airports in the United States in the wake of the terrorist attacks of 11 September 2001. See, for example, P.R. Verkuil, "The Publicization of Airport Security," Cardozo Law Review Vol. 27 (2006), p. 2243-2254. 
6. Offer effective legal remedies or avenues of redress for individuals or groups that have been negatively affected in their human rights by the conduct of privatized service providers;

7. Adopt effective regulatory measures, that take into consideration the rights of those individuals or groups that are affected by the privatization measures. These measures however, must not be discriminatory, arbitrary or unjustifiable, and thus compatible with the other international legal obligations of States, such as those emanating from BITs, or the WTO treaties;

8. Establish effective regulatory bodies with an appropriate mandate. Regulators should be independent and impartial, and should involve those affected in their decisions (participation). They should also allow individuals or groups to submit complaints dealing with the conduct of privatized entities and should have sufficient powers to enforce those decisions, or at least have recourse to judicial remedies that would enable them to impel the privatized bodies they monitor to comply with their decisions.

9. Spell out in the regulatory frameworks they adopt, that the provision of universal service obligations (USOs) should be mandatory with regard to the privatization of essential public services such as the provision of water, electricity, in a similar fashion as has been done in the telecommunications sector.

With respect to the last three points it is worth observing that there appears to be some convergence between the issues of regulation of public or essential services, universal service obligations and human rights. Under human rights law, in particular in the field of economic, social, and cultural rights, States have obligations to respect, protect, and fulfill. The obligation to protect, in particular, requires states to adopt regulatory measures and establish regulatory bodies to safeguard the rights of groups or individuals. Regulation is, however, traditionally couched in terms of economic efficiency and overcoming problems of information asymmetry. It is aimed at influencing the behavior of regulated entities in situations of market failure. The type of regulation that human rights obligations require arguably goes beyond improving the economic efficiency of regulated entities. To address concerns related to the protection of public interests such as public safety, public health, the environment or other social interests, the concept of social regulation has been developed. This means that the regulator not only has to monitor the economic effects of the conduct of regulated entities, but also the social effects. The introduction of the concept of universal service obligations is quite interesting in this respect, because it adds an additional dimension to this discussion. By requiring the provision of certain essential services in an efficient way on a universal basis without discrimination, at a particular quality, and at an affordable price, the concept of USOs mixes both the economic and social aspects of regulation. It is worth noting that certain human rights bodies like the UN CESCR have referred to USOs, albeit in an indirect way. For example, the requirement that States have to take into consideration the availability, quality, and both physical and economic 
accessibility with respect to their obligation to realize the right to water arguably entails the imposition of USOs upon States parties to the ICESCR. This necessarily requires the adoption of regulatory measures to satisfy USO goals, and of a regulatory authority to also satisfy the obligation to protect. The present author suggests that further research is required to further clarify the concepts of regulation, USOs, and human rights and their underlying relationships. This is even more important since these concepts can potentially become more relevant in the growing case law of international investment tribunals, in which the regulatory capacity of the State to safeguard human rights vis-à-vis its international obligations arising out of mainly bilateral investment treaties is being put into test.

With regard to the question of accountability under international law and human rights law for abuses that are the direct or indirect result of privatization or of the conduct of privatized entities, the following can be concluded. States always bear international responsibility for abuses caused by privatization (either directly because the conduct is carried out by private entities exercising elements of governmental authority or under the control or direction of the State, or indirectly through due diligence or through failure to take positive steps/obligations against the conduct of privatized actors). States are not allowed to shield themselves behind the curtain of privatization (i.e. they can not argue that since they have delegated tasks or services to private actors, they are no longer responsible for their proper delivery). This is international law as it now stands (lex lata) Although States could be directly or indirectly responsible for human rights problems caused by privatization or privatized entities, it may not always be the most satisfactory solution to the problem. Accountability of privatized entities should be sought. As observed in Chapters III and IV and in the previous section of the present chapter, the lack of general horizontal applicability of human rights obligations or Drittwirkung to private actors, and the limited accountability (or lack of legal obligations) of companies under international law is an obstacle to assigning accountability were it really belongs. It is submitted that a functional approach to secure direct accountability of privatized entities is a possible way out of this problem. The comparative analysis into various jurisdictions endeavored in Chapter IV suggests that there appears to be a cautious shift towards regarding private actors exercising formerly public functions as being a special type of public actors whose actions and decisions can be subjected to human rights reviews usually reserved to proper public/statal entities. By looking at the nature of the function, task or service that has been privatized, by analyzing national legislation to ascertain whether the State has some ultimate responsibility in ensuring that these are properly exercised or provided, and by looking at the legislation enabling the delegation of these tasks it may be possible to determine whether a privatized entity can be held accountable for eventual human rights abuses. This is particularly so if privatized bodies carry out certain tasks involving an essential public interest. In the end it does not matter who carries out these tasks as long as they are carried out in a dutiful and correct 
way. The State always remains responsible for the way they are carried out. However, under specific circumstances, privatized entities could be regarded as State actors sui generis and thus subject to human rights review. For victims of human rights abuses perpetrated by privatized entities this approach would have the advantage of allowing the former to directly start legal action against the latter in national courts. This would circumvent potential problems such as judges declaring cases to be inadmissible rationae persona due to the lack of horizontal effect of human rights obligation. In addition, it keeps the link between the direct perpetrator and the victim strong without having to resort to the abstraction of holding the State indirectly responsible for conduct of a private party. In terms of legal clarity for the victims, this is arguably a more palatable situation: the victim knows it can try to hold the actual perpetrator of abuses directly accountable.

A major obstacle in determining whether a particular private actor can be regarded as a State entity sui generis is the extent to which that actor should be regarded as a State entity. This obstacle relates to concerns with regards to extending the public sphere too far to the detriment of the private sphere. Clearly a privatized water utility cannot be held directly accountable for human rights impairing conduct when such conduct falls outside of the scope of its 'public' related activities. But where are the boundaries? Which activities of a privatized entity carrying out certain functions, tasks or services are amenable for human rights review? This question is not easily answerable. However, it is here suggested that in order to answer this question it has to be acknowledged that not all the activities of a privatized entity will be subject to human rights review. To do so would be to unduly extend the reach of human rights law to an area in which it currently has not gained acceptance by most of the States, notwithstanding the fact that human rights bodies have maintained that human rights obligations might have effects on the relations between private individuals. Only those privatized functions, tasks or services that are sufficiently linked to the realization of public goals and interests, and for which the State has assumed the legal obligation and thus the ultimate responsibility to fulfill should be amenable to such a review. Therefore, there must be a concrete link between the privatized activity in question, the realization of a public goal or purpose, and the enjoyment of a particular human right. It is suggested that the following (cumulative) criteria could play a role in making certain activities amenable for human rights review if they are carried out by a privatized entity:

1. When activities are directly related to the realization of nationally recognized public goals (such as the realization of public sanitation and health, protection of public safety, realization of fair dispute settlement remedies, provision of (primary) education) through national legislation;

2. When the State at the regional or international level has assumed legal obligations to guarantee these activities through the ratification of human rights instruments; 
3. When these activities have direct or indirect public effects or externalities (that is, by legally and in fact affecting a group or invididual in society in such a way that hinders or impedes its/her/his economic, social or political development, risks its/her/his safety or life, and harms its/her/his human dignity), even if they have mainly commercial elements necessary to realize them; ${ }^{10}$

4. When private actors perform these activities in the same way a formal public actor would perform them.

Privatization therefore produces an interesting paradox. Although one of the goals of privatization is to reduce the size of the State and reduce the amount of rules in the field which is being privatized, many privatization operations have witnessed just the opposite: States have perceived a necessity to actively regulate privatized entities, especially those involved in delicate sectors such as the provision of essential utilities to ensure that competition is available in sectors where multiple privatized entities compete for the provision of services, and to monitor activities of those entities in charge of natural monopolies. This has led to the creation of regulatory agencies and the drafting of complex rules to ensure proper operation of the privatization. Thus the size of the State has sometimes been reduced less than expected, and possibly increased in a certain unexpected way. ${ }^{11}$ This, in turn has led to an interesting development with regard to the human rights obligations of States. To a certain extent, privatization of a number of State-provided services has, under influence of the privatization paradox, resulted in a shift of the human rights obligations of the State. The obligations to respect (the State must refrain from certain action) and fulfill (the State must provide for a certain service) have been gradually 'replaced' by the obligation to protect: the necessity to regulate privatized industries and services.

\footnotetext{
10 For example activities such as signing contracts with new water customers or closing the water connection for non payment of services.

11 This is what Tony Prosser refers to as privatization's unexpected offspring. See Chapter II.
} 


\section{SAMENVATting}

Deze dissertatie gaat over mensenrechten en privatisering. Onder de invloed van globalisering voelen veel landen zich geneigd om de levering van een groot aantal staats- en overheidstaken en diensten te privatiseren. De redenen om dit te doen lopen uiteen. Echter, of het nu ligt aan interne politieke overtuigingen, de groeiende druk om de overheidsuitgaven terug te dringen, of het verlangen om de mededinging te verbeteren en te zorgen voor efficiënte diensten voor minder geld, de privatisering van deze taken en diensten kunnen voor verregaande implicaties zorgen voor de beleving van de mensenrechten, als ook voor de verplichtingen die staten zijn aangegaan onder mensenrechten verdragen.

Vanuit de mensenrechtenwereld is er met argwaan gereageerd op privatisering. Een aantal internationale en regionale mensenrechten toezichtmechanismen heeft vastgesteld dat het uitbesteden van contracten aan de commerciële sector van kernactiviteiten van de staat of de delegatie van haar verplichtingen aan particuliere organisaties de staten niet verlost van hun verplichtingen ten opzichte van de verschillende mensenrechtenverdragen. Wat de kernactiviteiten van de staat of haar verplichtingen onder de internationale en regionale mensenrechtenverdragen dan ook mogen zijn, het is duidelijk dat de toenemende afhankelijkheid van de staat ten opzichte van privé actoren voor het realiseren van publieke taken en de potentiële problemen die dat met zich mee brengt, een onderwerp is dat nader belicht moet worden. De hoofdvraag van dit onderzoek is dan ook: kan de privatisering van staats- en overheidsdiensten in overeenstemming gebracht worden met de rechten van de mens.

Hoofdstuk 2 beargumenteert dat privatisering geen nieuw fenomeen is. Het is onderworpen aan een cyclisch proces met de betrokkenheid van verschillende deelnemers zoals de staat, internationale financiële instellingen en multinationale ondernemingen. Het cyclische en dynamisch karakter van privatisering tezamen met de historische oorsprong van bepaalde functies, taken of diensten die pas later werden gerekend tot de 'traditionele' taken van de staat maakt het moeilijk om tot een eenduidige conclusie te komen dat dusdanige overheidsfuncties, taken of diensten niet kunnen worden geprivatiseerd. Een commentator durfde zelfs te spreken over een 'inherently governmental fiction'. De golfbewegingen die bijdragen aan een herleving of herroeping van privatisering hangen vaak af van de politieke, economische en sociale standpunten van de dag, die dan bepalen wat de rol van de staat zou moeten zijn. Het lijkt er dus op dat er op dit moment een 'hernationalisatie' gaande is van een aantal taken en diensten die in de afgelopen twintig jaar zijn geprivatiseerd. Dit betekent echter niet dat de privatisering of delegatie van bepaalde taken helemaal zijn weggevallen. Het is zelfs zo dat de 
privatisering van militaire en beveiligingsdiensten een groeiende bron van bezorgdheid is, in het bijzonder vanwege het vermeende nadelige effect dat deze heeft op de rechten van de mens. Aldus blijft privatisering een bron van controverse en verdeeldheid. Voorstanders ervan zullen zeggen dat privatisering geld besparend is, bureaucratische rompslomp minimaliseert en efficiency stimuleert in de sectoren waar het wordt toegepast. Tegenstanders van privatisering zullen voorbeelden aangeven waar privatisering mis is gegaan, ongelijkmatigheden heeft geschapen, en die de toegankelijkheid van essentiële diensten voor de minder bedeelden heeft verkleind. Zij benadrukken juist de belangrijke rol van de staat in het beschikbaar stellen van deze diensten.

Uiteindelijk maakt het niet uit of bepaalde functies, taken of diensten inherent zijn aan de staat of traditiegetrouw door deze werden uitgevoerd. Wat telt zijn de praktische consequenties van de delegatie van deze activiteiten naar particuliere entiteiten ten opzichte van de internationale wettelijke verplichtingen van staten.

Onder het internationaal recht mogen staten zich niet bemoeien met de keuzes van een staat om zijn politieke en economische ordening naar eigen inzicht in te richten. Dit betekent natuurlijk dat staten vrij zijn om privatiseringsmaatregelen toe te passen. Hoofdstuk III suggereert dat het nationaal recht en de grondwettelijke tradities van een staat de vrijheid tot het aannemen van privatiseringsmaatregelen beperken. Deze restricties geven echter niet een absolute garantie tegen privatisering. Hoewel sommige landen enkele vormen van privatisering hebben verboden door grondwetwijzigingen aan te brengen, betekent dit echter niet dat andere sectoren niet onderworpen kunnen worden aan privatisering, of dat de grondwet zo mogelijk aangepast kan worden in de toekomst zodat privatisering opnieuw toegestaan wordt. In tegenstelling tot het nationaal recht, heeft het internationaal recht geen expliciete restricties, die de staat ervan belet openbare diensten te privatiseren. Dit komt voort uit de al eerder genoemde vrijheid die een staat is toegekend onder het internationaal recht en die deze toestaat om zelf soevereine beslissingen te nemen met betrekking tot economisch beleid zonder tussenkomst van een ander land. Ondanks bepaalde recente ontwikkelingen in het internationale recht inzake mensenrechten, gebiedt het te zeggen dat het internationaal recht een neutrale houding handhaaft met betrekking tot privatisering. Er bestaan echter indirecte impliciete beperkingen die de vrijheid van de staat inperken bij het aannemen van privatiseringsmaatregelen. Deze vloeien onder andere voort uit de internationale verplichtingen aangaande het verdragen recht, het beginsel van non-interventie, en de verplichtingen uit internationale staatsaansprakelijkheid. De algemene verplichtingen die mensenrechtenverdragen met zich mee brengen kunnen ook invloed hebben op de wijze waarop staten taken en diensten privatiseren. Privatiserende staten dienen bijvoorbeeld aandacht te besteden aan hun negatieve en positieve verplichtingen onder mensenrechten. Er is echter geen mensenrechtenverplichting die privatisering rechtstreeks verbiedt. Feitelijk gezien mogen staten overheidsdiensten privatiseren. 
Het is zelfs zo dat gezien de verhoudingen tussen privatisering en economisch beleid, staten zelfs een ruime 'margin of appreciation' hebben om te beslissen of privatisering de beste optie is voor het voorzien van openbare diensten als de watervoorziening, gezondheidszorg en huisvesting, of zelfs voor het beheren van een justitiële inrichting. De mensenrechten toezichtmechanismen hameren echter wel constant op het feit dat de staten niet onder hun verplichtingen uit mogen komen om de mensenrechten van hun bevolking in acht te nemen bij het delegeren van overheidsdiensten en taken aan particuliere bedrijven.

Omdat het internationaal recht gericht is op staten gelden deze verplichtingen niet voor andere actoren die een belangrijke rol spelen bij privatisering, zoals internationale financiële instellingen (IFI's) en (multi-)nationale ondernemingen geen verplichtingen. Desondanks voelen IFI's zich in meerdere mate bewust van de mensenrechten gevolgen die hun beleid aangaande privatisering kunnen hebben. Interne procedurele richtlijnen schrijven de Wereld Bank voor om zich bewust te zijn van de mensenrechten gerelateerde aspecten in de projecten die zij financiert. Interne onderzoeken van de activiteiten en verrichtingen door de Inspection Panel van de Wereld Bank hebben bijgedragen aan dit bewustzijn. Desalniettemin, zolang als de oprichtingsverdragen van de IFI's deze organisaties niet verplichten de rechten van de mens te respecteren, zullen deze beschouwingen wel een relevant, maar geen essentieel element in hun besluitvorming blijven. Dit geldt ook voor zakelijke ondernemingen. Deze zijn niet onderworpen aan directe mensenrechten verplichtingen. Dit komt door het feit dat de juridische verplichtingen van mensenrechtenverdragen alleen staten betreffen. Het gebrek aan horizontale werking van de mensenrechten verplichtingen voor handelsondernemingen die geprivatiseerde taken uitvoeren of essentiële diensten verlenen, onderstreept het staats-georiënteerde karakter van het internationaal recht en mensenrechten. Staten kunnen wel indirect aansprakelijk worden gesteld voor het gedrag van ondernemingen als staten geen redelijke maatregelen hebben genomen om dat gedrag aan banden te leggen. Desalniettemin zijn er pogingen ondernomen om bedrijven bewuster te maken voor de gevolgen van hun gedrag op mensenrechten. Zo zijn er verscheidene initiatieven afkomstig uit internationale organisaties zoals de OESO en de Internationale Arbeidsorganisatie. Vrijwillige zelfregulering door ondernemingen wordt ook vaak gezien als een alternatieve manier om hun activiteiten te onderwerpen aan enig vorm van controle. Dit betekent echter niet dat ondernemingen die geprivatiseerde taken uitoefenen makkelijk verantwoordelijk kunnen worden gesteld voor mogelijke mensenrechten schendingen. In dit opzicht wordt de staat onder het internationale recht nog steeds geacht de primaire verantwoordelijkheid te dragen voor het respecteren van de rechten van de mens en dient ervoor te zorgen dat de effecten van privatisering niet tegenstrijdig zijn aan de mensenrechten. 
De vraag is dan ook wie verantwoordelijk gesteld kan worden voor het gedrag van geprivatiseerde ondernemingen. Hoofdstuk IV behandelt dit onderwerp door twee verschillende benaderingen voor het stellen van de aansprakelijkheid te analyseren. De eerste traditionele benadering kijkt naar de aansprakelijkheid van staten vanuit het perspectief van het algemene internationale recht, waarbij de staat altijd verantwoordelijk kan worden gehouden voor het gedrag van geprivatiseerde ondernemingen dat in strijd is met de internationale verplichtingen van staten. Dit komt voort uit de algemene regels inzake toerekening onder het internationaal recht. In het bijzonder de regels die stellen dat het gedrag van entiteiten die 'elements of governmental authority' uitoefenen, toegerekend kunnen worden aan de staat. Omdat staten nog steeds de primaire subjecten zijn van het international recht, is het redelijk dat zij ook de ultieme verantwoordelijkheid dragen voor schendingen van internationale verplichtingen die begaan zijn onder hun toezicht, goedvinden of vanwege de delegatie van autoriteit en staatstaken aan derden. Het belangrijkste doel is om te vermijden dat staten hun aansprakelijkheid ontlopen voor schendingen van internationale verplichtingen die begaan zijn door entiteiten die niet juridisch of officieel als onderdeel van de staat kunnen worden beschouwd.

Over het algemeen maakt het vanuit het perspectief van de gebruikers van geprivatiseerde diensten niet veel uit wie deze diensten of taken uitoefent mits dit op verantwoorde en redelijke wijze gebeurt, waarbij het inachtnemen van hun rechten en belangen ook verwacht wordt. Dit proefschrift stelt, echter, dat de traditionele benadering enigszins tekort schiet als het gaat om het vast stellen van de aansprakelijkheid van een particuliere entiteit voor het uitoefenen van een geprivatiseerde dienst of functie dat in strijd is met de mensenrechten. Een tweede benadering is zodoende wenselijk. Dit wordt verder gerechtvaardigd door het algemeen gebrek aan horizontale werking van mensenrechten onder het internationaal recht. Het is hierdoor niet mogelijk is om de echte 'daders' van mensenrechten schendingen rechtstreeks aansprakelijk te stellen. De tweede helft van Hoofdstuk IV probeert een alternatief voor dit probleem te bieden door de traditionele benadering te verfijnen. Het stelt dat particuliere entiteiten, die taken en diensten uitvoeren welke voorheen door de staat werden uitgevoerd, als bijzondere statelijke actoren kunnen worden beschouwd, als deze aan bepaalde voorwaarden voldoen. Deze studie suggereert dat zo'n benadering steeds meer acceptatie geniet onder sommige mensenrechten toezichtmechanismen en bepaalde regionale en nationale jurisdicties. De door deze studie onderzochte rechtspraak lijkt te suggereren dat geprivatiseerde dienstverleners en actoren onder bepaalde omstandigheden in een publieke hoedanigheid worden bekleed waardoor hun gedrag rechtstreek getoetst kan worden aan mensenrechten normen die doorgaans voor de staat gelden. Privatisering veronderstelt dat de entiteiten die de geprivatiseerde taken uit moeten voeren, een door wetgevingen gegeven mandaat genieten om een bepaalde macht of invloed uit te oefenen over individuen en groeperingen, alsmede hun belangen op een vergelijkbare wijze als een staat te 
dienen. Het is derhalve redelijk te stellen dat het gedrag van deze entiteiten ook door dezelfde normen die voor de staat gelden dient te worden beheerd, in ieder geval in zoverre dat hun activiteiten een publiek belang na streven. Deze particuliere entiteiten verkrijgen een bepaalde publieke hoedanigheid vanwege het uitvoeren van taken die een essentiële publiek belang behartigen, dat al dan niet historisch, door wetgeving of traditie, of door eerdere nationalisatie die ten laste van de staat kwam en die noodzakelijkerwijs nog uitgevoerd moeten worden. Hierdoor mogen zowel deze entiteiten als de staat niet onder hun verantwoordelijkheid ontsnappen.

Hoofdstuk V analyseert de praxis van een aantal mensenrechten toezichtmechanismen met betrekking tot privatisering. De toezichtmechanismen van de verschillende internationale en regionale mensenrechten verdragen hebben op verschillende wijzen hun bezorgdheid geuit betreffende de kwestie van privatisering en haar consequenties voor de beleving van de mensenrechten. Hun praxis is echter niet altijd consistent. Mensenrechten toezichtmechanismen zijn mogelijk niet altijd in de positie om privatisering te analyseren en te beoordelen omdat het een complex economisch beleid is die expertise nodig heeft die niet altijd beschikbaar is in deze mechanismen. Toch hebben zij wel problemen geïdentificeerd. Dit is onder andere aan de orde gekomen bij het bespreken van de periodieke rapporten die staten dienen voor te leggen aan een aantal van deze mechanismen, hun 'general comments', en in een aantal individuele en collectieve klachten procedures. Wel moet gesteld worden dat ook al wordt het privatiseringsbeleid gezien als een onderwerp dat bezorgdheid oproept, er geen concrete zaken zijn geweest binnen de verschillende individuele klachten procedures bij welke privatisering de hoofdoorzaak was van mensenrechten schendingen. Het lijkt er echter op dat het uitgangspunt van al deze mechanismen is dat staten die een privatiseringsbeleid uitvoeren niet geabsolveerd worden van hun verplichtingen onder mensenrechtenverdragen. Aan de andere kant hebben de international en regionale toezichtmechanismen niet direct een besluit van een staat om te privatiseren of een privatiseringsbeleid in strijd met mensenrechten verklaard. Het lijkt erop dat zij het recht van de staat om dit beleid te voeren erkennen. Dit recht is echter niet onbeperkt en deze mechanismen wijzen op een aantal voorwaarden waaraan een staat moet voldoen wil zij privatisering in overeenstemming brengen met mensenrechten. Deze mechanismen benadrukken de positieve verplichting van staten om individuen te beschermen tegen het gedrag van particuliere actoren die geprivatiseerde taken uitoefenen of belangrijke openbare diensten uitvoeren. Deze mechanismen hebben ook het belang vastgesteld van transparantie, deelname aan de besluitvorming en het raadplegen van individuen en groepen die mogelijk worden geraakt door privatisering. Deze mechanismen geven dan aan dat deze elemente behoren tot de positieve verplichtingen van staten.

Hoofdstukken VI en VII bespreken twee concrete situaties van privatisering in twee verschillende sectoren die mogelijkerwijs gevolgen kunnen hebben voor 
respectievelijk burger- en politieke rechten en economisch, sociaal en culturele rechten. Hoofdstuk VI bespreekt het controversieel gebruik van particuliere militaire en veiligheidsbedrijven in Irak, met nadruk op de mishandelingen door werknemers van twee van zulke bedrijven in de beruchte Abu Ghraib gevangenis. Het hoofdstuk stelt vast dat de status van deze bedrijven in het internationaal recht niet helemaal duidelijk is. Deze bedrijven en hun werknemers kunnen niet aangemerkt worden als huurlingen en hun gebruik in conflict gebieden kan onduidelijkheden veroorzaken met betrekking tot de toepasselijkheid van het internationale humanitair oorlogsrecht. Ondanks pogingen om de activiteiten van deze bedrijven te reguleren zijn er nog geen concrete oplossingen gevonden voor de problemen dat zij kunnen veroorzaken. Het kan in ieder geval vastgesteld worden dat staten die deze bedrijven gebruiken of hun gebruik in het eigen landgebied toelaten dienen te garanderen dat de bedrijven en hun werknemers vervolgd kunnen worden en aansprakelijk kunnen worden gesteld voor hun gedrag als het in strijd is met de internationale verplichtingen van deze staten. Staten hebben bovendien een verplichting om de slachtoffers van onrechtmatig gedrag van deze bedrijven en hun werknemers effectieve rechtsmiddelen te garanderen. Deze studie concludeert dat de mishandeling door werknemers van twee particuliere militaire en veiligheidsbedrijven in Abu Ghraib een schending van het verbod op foltering opleverde. Hiervoor zijn de Verenigde Staten hoofdzakelijk aansprakelijk gezien het feit dat zij deze bedrijven hebben ingeschakeld voor verhoor werkzaamheden in Abu Ghraib en bovendien effectief controle uitoefenden over het grondgebied van Irak ten tijde van de schendingen. De perikelen rond de pogingen om het personeel van de betrokken bedrijven in Abu Ghraib civiel of strafrechtelijk te vervolgen, tezamen met het incident waarbij het beruchte particuliere militaire en veiligheidsbedrijf Blackwater betrokken was, laten echter zien dat de beschikbare rechtsmiddelen voor de slachtoffers in Irak ernstige tekortkomingen vertonen.

Hoofdstuk VII analyseert de privatisering van waterdiensten in Buenos Aires, Argentinië. Het voorziet in een uitvoerige bespreking van de gevolgen van privatisering voor het recht op water van de inwoners van die stad. Het hoofdstuk bespreekt eerst de ontwikkelingen omtrent de betrokkenheid van multinationale ondernemingen in het leveren van waterdiensten en beschrijft de methodes om deze nutsdiensten te privatiseren. Het gebruik van privé-ondernemingen in de watersector is in de laatste twintig jaar toegenomen al is het nog niet bewezen dat geprivatiseerde waterdiensten beter, effectieve of goedkoper zijn dan hun publieke evenknieën. Wel is duidelijk dat afdoende regulering en het beginsel van universele dienstverlening ('universal service obligations') een belangrijk rol spelen bij het bepalen of geprivatiseerde of publieke water nutsdiensten mensenrechten vriendelijk zijn. Het hoofdstuk gaat ervan uit dat er een recht op water bestaat welk inbegrepen is in het recht op een behoorlijke levensstandaard in Artikel 11 van het Internationaal Verdrag inzake Economische, Sociale en Culturele Rechten. Dit recht legt een aantal verplichtingen aan staten, de zogenaamde 'obligations to respect, protect, 
and fulfill' (om het recht te respecteren, te beschermen, en te verwezenlijken). De vraag of de privatisering van water nutsdiensten nadelige gevolgen heeft gehad voor het recht op water van de inwoners van Buenos Aires is echter niet op eenduidige wijze te beantwoorden.

In 1993 werd de watervoorziening in Buenos Aires geprivatiseerd, die vervolgens na de financiële crisis die Argentinië rond 2002 trof, opnieuw in 2006 genationaliseerd werd. De privatisering van waterdiensten in Buenos Aires leidde in eerste instantie tot een flinke uitbreiding van het waternetwerk inclusief in de armere buurten. Deze uitbreiding moest echter deels gefinancierd worden door hogere aansluitingkosten te vragen voor nieuwkomers en later door een verhoging van de watertarieven in rekening te brengen. Hierdoor werden mensen met lagere inkomens getroffen. Een ander probleem bestond uit het feit dat sommige groeperingen en individuen aanvankelijk de toegang tot de dienst werden geweigerd omdat zij niet over geschikte eigendomstitels beschikten voor hun woningen. Dit werd later verholpen door tussenkomst van NGO's, de lokale regering en de regulerende instantie. Over het algemeen nam de kwaliteit van de dienstverlening en van de drinkwater na de privatisering wel toe. Een onderzoek concludeerde zelfs dat hierdoor de privatisering bijgedragen heeft aan de afname van kindersterfte in de stad. Aan de andere kant liet de kwaliteit van het drinkwater in sommige, vaak armere wijken te wensen over. Verder werd de integriteit en onafhankelijkheid van de regulerende instantie die in het leven werd geroepen om toezicht te houden op het gedrag van de geprivatiseerde wateronderneming soms in twijfel getrokken. In ieder geval bleek Argentinië wel over meerdere rechtsmiddelen te beschikken die het mogelijk makten voor consumenten om rechtstreeks de geprivatiseerde water onderneming aansprakelijk te stellen voor gebrekkige dienstverlening. De effectiviteit van deze rechtsmiddelen is echter niet altijd gegarandeerd, al blijkt het recht op water in Argentinië voor rechterlijke instanties wel afdwingbaar te zijn.

Een van de hoofdconclusies van dit onderzoek is dat het internationaal recht inclusief de mensenrechten het privatiseren van staatsfuncties, taken of diensten niet verbieden. Privatisering is dan ook in beginsel niet onverenigbaar met mensenrechten, en kan onder de juiste omstandigheden zelfs tot de realisatie ervan leiden. Zoals het praktijkgeval van Buenos Aires laat zien, kan privatisering bijdragen aan het verbeteren van mensenrechten, en tegelijkertijd er ook inbreuken op maken. Dit hangt grontendeels af van het regulerend vermogen van de privatiserende staat. Als de privatisering een kort leven is beschoren, is het mogelijk dat de positieve gevolgen van privatisering, zoals de uitbreiding van nutsdiensten ten gunste van de gebruikers ervan, niet zullen opwegen tegen de negatieve gevolgen zoals verhogingen van watertarieven om uitbreidingen in de dienstverlening te financieren. Een botsing tussen privatisering en het internationaal recht en mensenrechten zal vaak het gevolg zijn van een ondoordachte uitvoering van het privatiseringsbeleid, waarbij de staat niet voldoende de voordelen van 
privatisering voor de gehele maatschappij afweegt tegen de nadelige gevolgen voor de belangen van groepen of individuen die door privatisering worden getroffen. Hierbij is het van belang dat de staat vooraf of achteraf de nodige maatregelen treft om onwenselijke gedragingen van geprivatiseerde ondernemingen te voorkomen of te bestraffen. De staat dient derhalve afdoende rechtsmiddelen te scheppen voor slachtoffers van mogelijke schendingen gepleegd door deze ondernemingen, en een effectieve regulerende instantie in het leven roept die de handelingen ervan onder de loep kan nemen of slachtoffers kan beschermen.

De beperkingen op privatisering op nationaal niveau hangen af van de nationale constitutionele inrichting en zelfs dan kunnen verboden op privatisering relatief makkelijk worden omzeild. Daar tegenover staat de ervaring in verschillende landen, welke laat zien dat privatisering ook redelijk gemakkelijk teruggedraaid kan worden. Dit hoeft niet altijd gunstig te zijn. In het licht van verschillende bilaterale investeringsverdragen (BIT's) die door staten zijn geratificeerd, kan elk beleid dat privatisering terugdraait ten nadele van buitenlandse investeerders die een belang hebben bij geprivatiseerde diensten of ondernemingen, leiden tot de aansprakelijkheid van de staat. Hiermee kunnen forse financiële gevolgen gepaard gaan, zoals landen als Argentinië reeds hebben ervaren.

Op internationaal niveau kan het volgende worden geconcludeerd. In tegenstelling tot nationalisatie is privatisering nog niet onderworpen aan speciale regels van internationaal recht (zowel in de vorm van verdragsregels als in de vorm van internationaal gewoonterecht) die een kader bieden waarbinnen beleid kan worden toegepast. Privatisering is onderdeel van een economisch beleid waarvoor staten een redelijke mate van beleidsruimte genieten. Dit is consistent met de geaccepteerde beginselen inzake nationale soevereiniteit, die staten de vrijheid geeft om hun economische inrichting op eigen wijze te bepalen zoals zij het noodzakelijk achten. Echter, mensenrechten kunnen en zullen bepaalde beperkingen opleggen aan privatisering. De beleidsruimte om privatiseringbeleid en -maatregelen aan te nemen en toe te passen, is niet onbegrensd. Privatisering mag niet een zodanige inbreuk maken op bepaalde rechten waardoor deze rechten aan betekenis inboeten. Privatiseringsmaatregelen mogen in ieder geval niet in strijd zijn met bepaalde mensenrechten waarop geen afwijking mogelijk is zoals het verbod op foltering of discriminatie.

En nuance is hierbij echter op zijn plaats. Het is niet mogelijk om privatisering te beperken of te verbieden puur gebaseerd op het argument dat deze functies, taken of diensten traditioneel tot de Staat behoren. Er is namelijk geen universele definitie van wat eigenlijk de functies, taken en diensten van de staat zijn. Zoals geobserveerd in deze studie, hebben particuliere entiteiten in het verleden veel taken of diensten uitgevoerd die tegenwoordig aan de Staat toebehoren. Er zijn meer aanwijzingen nodig, eer geconcludeerd kan worden dat bepaalde taken niet geprivatiseerd mogen 
worden, of slechts onder bepaalde omstandigheden/voorwaarden. In theorie kunnen alle functies, taken of diensten geprivatiseerd worden. Men dient zich wel af te vragen of dit verstandig of juridisch praktisch is. Het kan zeker beargumenteerd worden dat de privatisering van een aantal functies, diensten of taken met betrekking tot mensenrechten tot problemen kan leiden, in het bijzonder als de privatisering niet voldoende gepaard gaat met adequate waarborgen.

Kortom de vraag of het zinvol is om te privatiseren kan als volgt worden beantwoord: het is beter om niet te privatiseren als het regulerend vermogen van de staat in twijfel kan worden getrokken. Privatisering vereist strikte regulering. De noodzaak om te reguleren wordt dan ook beschouwd als een juridische verplichting door toezichthoudende mensenrechtenorganen. Dit houdt dus in dat landen waarin regulering ontbreekt of gebrekkig is, of niet in staat zijn om afdoende regels vast te leggen, zich beter niet kunnen wagen aan privatisering willen zij de mensenrechten blijven respecteren. Hoe zit het echter met landen waar de staat niet eens in de positie verkeert om minimale diensten uit te voeren of basale staatstaken uit te oefenen, en die dus ook niet effectieve regulerende maatregelen kunnen nemen? Deze landen niet laten privatiseren onder zulke omstandigheden zou vanuit mensenrechtelijk oogpunt onwenselijk zijn. Deze staten zouden hun bevolking dan zonder voorziening van essentiële diensten laten welke tevens een inbreuk kan leveren op de verplichting van zulke landen om bepaalde mensenrechten te garanderen, al is het op minimum niveau. De verplichting om een minimum 'core content' van mensenrechten te garanderen (vooral op het gebied van economische, sociale en culturele rechten), kan dus de privatisering van bepaalde diensten beperken als privatisering niet bijdraagt aan het realiseren van dit minimum 'core content'. Aan de andere kant kan het niet uitgesloten worden dat privatisering zelf juist wel kan bijdragen aan het realiseren van zo'n minimum 'core content' als de staat zelf niet in de positie verkeer om het zelf te doen. Onder zulke omstandigheden zou niet gereguleerde privatisering mogelijk moeten zijn, al dient dit onder strikte voorwaarden te gebeuren en met toezicht van buitenaf.

Privatisering leidt dan ook tot een interessant vraagstuk. Hoewel een van de doelstellingen van privatisering het beperken van de omvang van de Staat is, alsmede de hoeveelheid regels in de sector tot een minimum te houden, laten veel privatiseringen zien dat juist het tegenovergestelde het geval is. Staten hebben het als noodzakelijk gezien om geprivatiseerde ondernemingen actief te reguleren in het bijzonder als deze opereren in zogenaamde 'delicate' sectoren die te maken hebben met de aanlevering van essentiële voorzieningen. De staat moet bijvoorbeeld zeker van zijn dat er geconcurreerd kan worden in die sectoren (zoals telefonie of elektriciteit) waar veel geprivatiseerde ondernemingen mededingen voor de voorziening van diensten. De staat moet tevens toezien op de activiteiten van ondernemingen die verantwoordelijk zijn voor een natuurlijke monopolie, zoals in de watervoorziening, of die actief zijn op het gebied van justitie, veiligheid of 
defensie (zoals gevangenissen, politie, of militaire diensten). Dit heeft geleid tot de oprichting van toezichthouders en het creëren van complexe regels om er zeker van te zijn dat de privatisering goed wordt uitgevoerd. Het blijkt dus dat de omvang van de Staat minder gereduceerd is dan verwacht en misschien zelfs wel onverwacht is toegenomen. Dit heeft geleid tot een opmerkelijke ontwikkeling met betrekking tot de mensenrechtenverplichtingen van de staat. Tot op zekere hoogte heeft privatisering van een aantal door de staat geleverde functies en diensten geresulteerd in een verschuiving van de mensenrechtenverplichtingen van de staat. De verplichtingen om te respecteren ('respect': de Staat moet zich onthouden van bepaalde inmenging) en te verwezenlijken ('fulfill': de Staat moet een bepaalde dienst zelf leveren) zijn geleidelijk vervangen door de verplichting om te beschermen ('protect': de noodzaak om geprivatiseerde ondernemingen en diensten te reguleren). 


\section{Selected Bibliography}

Adams, T. K. "The New Mercenaries and the Privatization of Conflict," Parameters, Summer (1999), p. 103-116.

Addo, M.K. "The Role of International Financial Institutions in Privatisation and the Need for Constitutional Reform.” In National and International Perspectives on Law and Privatisation, edited by J.F. McEldowney: The British Institute of International and Comparative Law, 1999. p. 145-167.

Adlung, R. "Public Services and the GATS," Journal of International Economic Law Vol. 9 (2006), p. 455-485.

Alcázar, L., M.A. Abdala, and M.M. Shirley, “The Buenos Aires Water Concession”, Policy Research Working Paper No. 2311, World Bank/Development Research Group Regulation and Competition Policy, (2000).

Alkema, E.A. "The Third-party Applicability or 'Drittwirkung' of the European Convention on Human Rights.” In Protecting Human Rights: The European Dimension, edited by F. Matscher, H. Petzold and G.J. Wiarda, Cologne: Carl Heymanns Verlag, 1990. p. $33-45$.

Almansi, F., A. Hardoy, G. Pandiella, R. Schusterman, G. Urquiza, and E. Gutierrez, "Everyday Water Struggles in Buenos Aires: The Problem of Land Tenure in the Expansion of Potable Water and Sanitation Service to Informal Settlements", Water Aid and Tearfund, (2003).

Alston, P. "The Myopia of the Handmaidens: International Lawyers and Globalization," EJIL Vol. 8 (1997), p. 435-448.

-, ed. Non-State Actors and Human Rights, Series: Collected Courses of the Academy of European Law. Oxford: Oxford University Press, 2005.

Aman, A.C. "Administrative Law for a New Century." In The Province of Administrative Law, edited by M. Taggart, Oxford: Hart Publishing, 1997. p. 90-117.

- The Democracy Deficit: Taming Globalization Through Law Reform. New York: New York University Press, 2004.

—. "Privatisation, Prisons, Democracy and Human Rights: The Need to Extend the Province of Administrative Law." In Privatisation and Human Rights in the Age of Globalisation, edited by K. De Feyter and F. Gómez Isa, Antwerp: Intersentia, 2005. p. $91-128$.

Anderson, G.W. "Social Democracy and the Limits of Rights Constitutionalism," The Canadian Journal of Law \& Jurisprudence Vol. 17 (2004), p. 31-59.

Annuati-Neto, F., "Costs and Benefits of Privatization: Evidence from Brazil - Research Network Working Paper \# R-455”, Inter-American Development Bank, Washington DC, (2003).

"Approaches to Private Participation in Water Services: A Toolkit", The International Bank for Reconstruction and Development/The World Bank, Washington D.C., (2006). 
Arai-Takahashi, Y. The Margin of Appreciation Doctrine and the Principle of Proportionality in the Jurisprudence of the ECHR. Antwerp: Intersentia, 2002.

Aronson, M. "A Public Lawyer's Responses to Privatisation and Outsourcing." In The Province of Administrative Law, edited by M. Taggart, Oxford: Hart Publishing, 1997. p. $40-70$.

Azpiazu, D., and K. Forcinito. "Privatisation of the Water and Sanitation Systems in the Buenos Aires Metropolitan Area: Regulatory Discontinuity, Corporate NonPerformance, Extraordinary Profits and Distributional Inequality." Paper presented at the First Project Workshop on Private Sector Participation in Water and Sanitation: Institutional, Socio-political, and Cultural Dimensions, School of Geography and the Environment University of Oxford, April 22-23 2002

Barak, A. "Constitutional Human Rights and Private Law." In Human Rights in Private Law, edited by D. Friedmann and D. Barak-Erez, Oxford: Hart Publishing, 2001. p. $13-42$.

Barak-Erez, D. "Civil Rights and Privatization in Israel," Israel Yearbook on Human Rights Vol. 28 (1998), p. 203-216.

-. "Civil Rights in the Privatized State: A Comparative View," Anglo-American Law Review 28 (1999), p. 503-524.

-. "A State Action Doctrine for an Age of Privatization," Syracuse Law Review Vol. 45 (1995), p. 1169-1192.

Baxi, U. "Market Fundamentalisms: Business Ethics at the Altar of Human Rights," Human Rights Law Review Vol. 5 (2005), p. 1-26.

Bayliss, K. "Privatization and Poverty: The Distributional Impact of Utility Privatization," Annals of Public and Cooperative Economics 73 (2002), p. 603-625.

Bearpark, A., and S. Schulz. "The Regulation of the Private Security Industry and the Future of the Market." In From Mercenaries to Market The Rise and Regulation of Private Military Companies, edited by S. Chesterman and C. Lehnardt, Oxford: Oxford University Press, 2007. p. 239-250.

Beerman, J.M. "Administrative-Law-Like Obligations on Private[ized] Entities," UCLA L. Rev. Vol. 49 (2002), p. 1717-1737.

-. "The Reach of Administrative Law in the United States." In The Province of Administrative Law, edited by M. Taggart, Oxford: Hart Publishing, 1997. p. 171195.

Bel, G. "The Coining of 'Privatization' and Germany's National Socialist Party," Journal of Economic Perspectives Vol. 20 (2006), p. 187-194.

Bentham, Jeremy. The Panopticon Writings. Edited by M. Bozovic. London: Verso, 1995.

Bianchi, A. "International Law and US Courts: the Myth of Lohengrin Revisited," EJIL Vol. 15 (2004), p. 751-781.

Birdsall, N., and J. Nellis. "Privatization Reality Check: Distributional Effects in Developing Countries.” In Reality Check: The Distributional Impact of Privatization in Developing Countries, edited by J. Nellis and N. Birdsall: Center for Global Development, 2005. p. $1-30$. 
- "Winners and Losers: Assessing the Distributional Impact of Privatization," World Development Vol. 31 (2003), p. 1617-1633.

Bossche, P. Van den. The Law and Policy of the World Trade Organization. First ed. Cambridge: Cambridge University Press, 2005.

Brown, L.N., and J.S. Bell. French Administrative Law. Oxford: Clarendon Press, 1998.

Budds, J., and G McGranahan. "Are the Debates on Water Privatization Missing the Point? Experiences from Asia, Africa and Latin America," Environment \& Urbanization Vol. 15 (2003), p. 87-113.

Burke-White, W.W. "The Argentine Financial Crisis: State Liability Under BITS and the Legitimacy of the ICSID System," Asian Journal of WTO \& International Health Law and Policy Vol. 3 (2008), p. 199-234.

Casarin, A.A., J.A. Delfino, and M.E. Delfino. "Failures in Water Reform: Lessons from the Buenos Aires's Concession,” Utilities Policy Vol. 15 (2007), p. 234-247.

Cass, R.A. "Privatization: Politics, Law and Theory,” Marq. L. Rev. Vol. 71 (1988), p. 449523.

Chanda, R. "Social Services and the GATS: Key Issues and Concerns," World Development Vol. 31 (2003), p. 1997-2011.

Chapman, A.R. "Core Obligations Related to the Right to Health.” In Core Obligations: Building a Framework for Economic, Social and Cultural Rights, edited by A.R. Chapman and S. Russel, Antwerp: Intersentia, 2002. p. 185-215.

-. "A 'Violations Approach' for Monitoring the International Covenant on Economic, Social and Cultural Rights,” Human Rights Quarterly Vol. 18 (1996), p. 23-66.

Chapman, A.R., and S. Russel. "Introduction.” In Core Obligations: Building a Framework for Economic, Social and Cultural Rights, edited by A.R. Chapman and S. Russel, Antwerp: Intersentia, 2002. p. 1-19.

Chinkin, C. “A Critique of the Public/Private Dimension,” EJIL Vol. 10 (1999), p. 387-395.

Chirwa, Danwood Mzikenge. "The Doctrine of State Responsibility as a Potential Means of Holding Private Actors Accountable for Human Rights," Melbourne Journal of International Law Vol. 5 (2004), p. 1-36.

Chisari, O., and A. Estache, "Universal Service Obligations in Utility Concession Contracts and the Needs of the Poor in Argentina's Privatizations", Working Paper No. 2250, World Bank, (1999).

Chisari, O., A. Estache, and C. Romero. "Winners and Losers from Utility Privatization in Argentina: Lessons from a General Equilibrium Model," The World Bank Economic Review Vol. 13 (1999), p. 357-378.

Chisari, O., A. Estache, and C. Waddams Price, "Access by the Poor in Latin America's Utility Reform - Subsidies and Service Obligations”, Discussion Paper No. 2001/75, United Nations University/WIDER, (2001).

Chua, A.L. "The Privatization - Nationalization Cycle: The Link Between Markets and Ethnicity in Developing Countries," Columbia Law Review Vol. 95 (1995), p. 223303. 
Clapham, A. "The 'Drittwirkung' of the Convention." In The European System for the Protection of Human Rights, edited by R.St.J. Macdonald, The Netherlands: Kluwer Academic Publishers, 1993. p. 163-206.

—. Human Rights in the Private Sphere: Oxford University Press, 1993.

—. Human Rights Obligations of Non-State Actors. Oxford: Oxford University Press, 2006. Clark, D.L. "The World Bank and Human Rights: The Need for Greater Accountability," Harvard Human Rights Journal Vol. 15 (2002), p. 205-226.

"Competition and Regulation in the Water Sector", DAFFE/COMP(2004)20, OECD, (2004)

Coomans, F. "The Role of the UN Committee on Ecnomic, Social and Cultural Rights in Strengthening Implementation and Supervision of the International Covenant on Economic, Social and Cultural Rights," Verfassung und Recht in Übersee Vol. 35 (2002), p. 182-200.

Coomans, F., and A. Hallo de Wolf. "Privatisation of Education and the Right to Education." In Privatisation and Human Rights in the Age of Globalisation, edited by K. De Feyter and F. Gómez Isa, Antwerp: Intersentia, 2005. p. 229-258.

Cossy, M. "Water Services at the WTO." In Fresh Water and International Economic Law, edited by E.B. Weiss, L. Boisson de Chazournes and N. Bernasconi-Osterwalder, Oxford: Oxford University Press, 2005. p. 117-142.

Costigan, R. "Determining 'Functions of a Public Nature' under the Human Rights Act 1998: A New Approach,” European Public Law Vol. 12 (2006), p. 577-601.

Courtis, C. “Argentina - Some Promising Signs.” In Social Rights Jurisprudence - Emerging Trends in International and Comparative Law, edited by M. Langford, Cambridge: Cambridge University Press, 2008. p. 163-181.

Craig, P. "Contracting Out, The Human Rights Act and the Scope of Judicial Review," Law Quarterly Review Vol. 118 (2002), p. 551-568.

—. "The Courts, the Human Rights Act and Judicial Review," Law Quarterly Review Vol. 117 (2001), p. 589-603.

—. "Directives: Direct Effect, Indirect Effect and the Construction of National Legislation," European Law Review Vol. 22 (1997), p. 519-538.

—. "Public Law and Control Over Private Power." In The Province of Administrative Law, edited by M. Taggart, Oxford: Hart Publishing, 1997. p. 196-216.

Craig, P., and G. De Búrca. EU Law: Text, Cases, and Materials. Oxford: Oxford University Press, 2003.

Crawford, J. The International Law Commission's Articles on State Responsibility: Introduction, Text and Commentaries. Cambridge: Cambridge University Press, 2002.

Daintith, T. "Legal Forms and Techniques of Privatisation." Paper presented at the Legal Aspects of Privatisation, XXIst Colloquy on European Law, Budapest, 15-17 October 1991 (1993), p. 50-87.

Daintith, T., and M. Sah. "Privatisation and the Economic Neutrality of the Constitution," Public Law (1993), p. 465-487.

Dankwa, E.V.O., C. Flinterman, and S. Leckie. "Commentary on the Maastricht Guidelines on Violations of Economic, Social and Cultural Rights." In The Maastricht Guidelines 
on Violations of Economic, Social and Cultural Rights, SIM Special No. 20, edited by T.C. Boven van, C. Flinterman and I. Westendorp, Utrecht: Netherlands Institute for Human Rights, 1998. p. 13-34.

Darcy, N.C. El Derecho Humano Al Agua Y Su Recepción Como Derecho Fundamental En Argentina. Documento de Trabajo No. 06-2010: Agencia Española de Cooperación Internacional para el Desarrollo/Universidad de Alcalá (Programa Regional de Apoyo a las Defensorías del Pueblo en Iberoamérica, 2010.

Delfino, J.A., and A.A. Casarin, "The Reform of the Utilities Sector in Argentina", Discussion Paper No. 2001/74, United Nations University/WIDER, (2001).

-. "Welfare Effects of Privatising Public Utilities in Argentina: A Household Level Analysis." Paper presented at the XXXVI Reunión Anual de la Asociacion Argentina de Economía Política, Buenos Aires, Argentina, November 2001.

Devroe, W. "Privatisering en Verzelfstandiging: Een Verkenning Vanuit Nationaal en Europees Economisch Recht." Faculty of Law, Katholieke Universiteit Leuven, Leuven, 2000.

—. "Privatizations and Community Law: Neutrality Versus Policy," CML Rev. Vol. 34 (1997), p. 267-306.

Dijk, van, P. “'Positive Obligations' Implied in the European Convention on Human Rights: Are the States Still the 'Masters' of the Convention?" In The Role of the Nation-State in the $21^{\text {st }}$ Century: Human Rights, International Organisations and Foreign Policy, Essays in Hounour of Peter Baehr, edited by M. Castermans-Holleman, van Hoof, G.J.H and J. Smith, The Hague: Kluwer Law International, 1998. p. 17-33.

Dinstein, Y. The Conduct of Hostilities Under the Law of Armed Conflict. Cambridge: Cambridge University Press, 2004.

Donnelly, C.M. "Leonard Cheshire Again and Beyond: Private Contractors, Contract and S.6(3)(B) of the Human Rights Act," Public Law (2005), p. 785-805.

Drakeford, M. "Water Regulation and Pre-Payment Meters," Journal of Law and Society Vol. 25 (1998), p. 588-602.

Dumol, M. The Manila water concession: A Key Government Official's Diary of the World's Largest Water Privatization, Directions in Development. Washington D.C.: The International Bank for Reconstruction and Development/The World Bank, 2000.

Dupuy, P-M. "Reviewing the Difficulties of Codification: On Ago's Classification of Obligations of Means and Obligations of Result in Relation to State Responsibility," EJIL Vol. 10 (1999), p. 371-385.

Díaz, J., "La participación del sector privado en los servicios de agua y saneamiento en Guayaquil, Ecuador”, Inter American Development Bank, Washington D.C., (2003).

Eide, A. "The Right to an Adequate Standard of Living Including the Right to Food." In Economic Social and Cultural Rights, edited by A. Eide, C. Krause and A. Rosas: Kluwer Law International, 2001. p. 133-148.

Estache, A. Argentina's 1990s Utilities Privatization: A Cure or a Disease? 2002, cited. Available from $<$ http://papers.ssrn.com/sol3/papers.cfm?abstract_id=383500 $>$. 
-, "PPI Partnerships versus PPI Divorces in LDCs (Or Are We Switching From PPPI to PPDI?)", World Bank Policy Research Working Paper 3470 (WPS3470), World Bank and ECARES (Université Libre de Bruxelles), (2005).

Estache, A., A. Goicoechea, and L. Trujillo, "Utilities Reforms and Corruption in Developing Countries", World Bank Policy Research Working Paper 4081 (WPS4081), The World Bank, (2006).

Estache, A., A. Gomez-Lobo, and D. Leipziger. "Utilities Privatization and the Poor: Lessons and Evidence from Latin America," World Development Vol. 29 (2001), p. 1179-1198.

Estache, A., J.-J. Laffont, and X. Zhang, "Universal Service Obligations in Developing Countries", Policy Research Working Paper WPS3421, World Bank, Washington D.C., (2004).

Evans, M.D. "State Responsibility and the European Convention on Human Rights: Role and Realm.” In Issues of State Responsibility Before International Judicial Institutions, edited by M. Fitzmaurice and D. Sarooshi, Oxford: Hart Publishing, 2004. p. 139160.

Fairstein, C., and S. Niedzwiecki. "El Acceso al Agua en Argentina. Experiencias de reclamo ante situaciones de privación.” in Derecho Al Agua, Spain: Ingeniería Sin Fronteras \& Prosalus, 2008. p. 101-119.

Farallon, A.D., and T.A. Keene. "Closing the Legal Loophole? Practical Implications of the Military Extraterritorial Jurisdiction Act of 2000," Air Force Law Review Vol. 51 (2001), p. 271-292.

Feigenbaum, H., J. Henig, and C. Hamnett. Shrinking the State: The Political Underpinnings of Privatization. Cambridge: Cambridge University Press, 1999.

Feyter, K. De, "The International Financial Institutions and Human Rights - Law and Practice”, IDPM - UA Discussion Paper 2002-7, Insitute of Development Policy Mangement - University of Antwerp, Antwerp, (2002).

Footer, M. "The General Agreement on Trade and Services: Taking Stock and Moving Forward," Legal Issues of Economic Integration Vol. 29 (2002), p. 7-25.

Foster, C.D. Privatization, Public Ownership and the Regulation of Natural Monopoly. Oxford: Blackwell Publishers, 1992.

Foster, V., and M.C. Araujo, "Does Infrastructure Reform Work for the Poor? A Case Study from Guatemala”, World Bank Policy Research Working Paper 3185 (WPS3185), World Bank, (2004).

Freedland, M. "Law, Public Services, and Citizenship - New Domains, New Regimes?" In Public Service and Citizenship in European Law, edited by M. Freedland and S. Sciarra, Oxford: Clarendon Press, 1998. p. 1-34.

Freeman, J. "Extending Public Law Norms Through Privatization," Harvard Law Review Vol. 116 (2003), p. 1285-1352.

—. "The Private Role in Public Governance," N.Y.U.L. Rev. Vol. 75 (2000), p. 543-675.

Friedman, M. Capitalism and Freedom. Chicago: The University of Chicago Press, 1982. 
Gaeta, A., and M. Vasilara, "Development and Human Rights: the Role of the World Bank", The International Bank for Reconstruction and Development/The World Bank, Washington D.C., (1998).

Galiani, S., P. Gertler, and E. Schargrodsky, "Water for Life: The Impact of the Privatization of Water Services on Child Mortality", Working Paper No. 154, Center For Research On Economic Development And Policy Reform, Stanford University, Stanford, (2002).

Gaudemet, Y. Traité de Droit Administratif - Tome 1: Droit Administratif Général. $16^{\text {th }}$ ed. Paris: L.G.D.J., 2001.

Genugten, W. van, P. Hunt, and S. Mathews, eds. World Bank, IMF and Human Rights Including the Tilburg Guiding Principles on World Bank, IMF and Human Rights. Nijmegen, The Netherlands: Wolf Legal Publishers (WLP), 2003.

Gleick, P.H. “The Human Right to Water,” Water Policy Vol. 1 (1999), p. 487-503.

Gleick, P.H., G. Wolff, E.L. Chalecki, and R. Reyes, "The New Economy of Water: The Risks and Benefits of Globalization and Privatization of Fresh Water", Pacific Institute for Studies in Development, Environment, and Security, Oakland, (2002).

Graham, C. "Human Rights and the Privatisation of Public Utilities and Essential Services." In Privatisation and Human Rights in the Age of Globalisation, edited by K. De Feyter and F. Gómez Isa, Antwerp: Intersentia, 2005. p. 33-56.

-. "Privatisation - the United Kingdom Experience." In National and International Perspectives on Law and Privatisation, edited by J.F. McEldowney: The British Institute of International and Comparative Law, 1999. p. 17-39.

—. "Public Law and the Regulation of Markets." In National and International Perspectives on Law and Privatisation, edited by J.F. McEldowney: The British Institute of International and Comparative Law, 1999. p. 49-59.

—. Regulating Public Utilities: A Constitutional Approach. Oxford: Hart Publishing, 2000.

Graham, C., and T. Prosser. Privatizing Public Enterprises: Consitutions, the State, and Regulation in Comparative Pespective. Oxford: Oxford University Press, 1991.

Grear, A. "Theorising the Rainbow? The Puzzle of the Public-Private Divide," Res Publica Vol. 9 (2003), p. 169-194.

Guislain, P., "Divestiture of State Enterprises: An Overview of the Legal Framework", World Bank Technical Paper WBTP 186, The International Bank for Reconstruction and Development/The World Bank, Washington D.C., (1992).

- The Privatization Challenge: A Strategic, Legal and Institutional Analysis of International Experience. Washington D.C.: The International Bank for Reconstruction and Development/The World Bank, 1997.

Hall, D., and E. Lobina, "Pipe Dreams: The Failure of the Private Sector to Invest in Water Services in Developing Countries", Public Services International Research Unit (PSIRU), Business School, University of Greenwich, London, (2006).

-, "The Relative Efficiency of Public and Private Water", available at <www.psiru.org>, Public Services International Research Unit (PSIRU), Business School, University of Greenwich, (2005).

—, "Water as a Public Service”, Public Services International (www.world.psi.org), (2006). 
Hall, D., E. Lobina, and R. de la Motte, "Making Water Privatization Illegal: New Laws in the Netherlands and Uruguay", Public Services International Research Unit (PSIRU), Business School, University of Greenwich, (2004).

—. "Public Resistance to Privatisation in Water and Energy," Development in Practice Vol. 15 (2005), p. 286-301.

Hall, D., and R. de la Motte, "Dogmatic Development: Privatisation and Conditionalities in Six Countries", Public Services International Research Unit, Business School, University of Greenwich, (2004).

Hallo de Wolf, A. "Modern Condottieri in Iraq: Privatizing War from the Perspective of International and Human Rights Law," Ind. J. Global Legal Stud. Vol. 13 (2006), p. $315-356$.

—. "Wordt oorlog geprivatiseerd? Het inzetten van particuliere militaire bedrijven in Irak in het licht van internationaal recht en de rechten van de mens (Is War Being Privatised? The deployment of private military companies in Iraq under international and human rights law)," Nederlands Juristen Blad Vol. 79 (2004), p. 1687-1695.

Harding, R.W. Private Prisons and Public Accountability: Open University Press, 1997.

Harris, D.J., M.O. O’Boyle, E.P. Bates, and C.M. Buckley. Law of the European Convention on Human Rights. $2^{\text {nd }}$ ed. Oxford: Oxford University Press, 2009.

Higgins, R. Problems and Process: International Law and How We Use It. Oxford: Oxford University Press, 1994.

Hoof, van, G.J.H. "The Legal Nature of Economic, Social and Cultural Rights: a Rebuttal of Some Traditional Views." In The Right to Food, edited by P. Alston and K. Tomasevski, Utrecht: Stichting Studie- en Informatiecentrum Mensenreechten (SIM)/ Martinus Nijhoff Publishers, 1984. p. 97-110.

Howard, G., and J. Bartram, "Domestic Water Quantity, Service, Level and Health", WHO/ $\mathrm{SDE} / \mathrm{WSH} / 03.02$, WHO, (2003).

Howard-Hassman, R.E. "The Second Great Transformation: Human Rights Leapfrogging in the Era of Globalization," Human Rights Quarterly Vol. 27 (2005), p. 1-40.

Hunt, M. "Constitutionalism and the Contractualisation of Government in the United Kingdom.” In The Province of Administrative Law, edited by M. Taggart, Oxford: Hart Publishing, 1997. p. 21-39.

- "Human Rights Review and the Public-Private Distinction." In Litigating Rights: Perspectives From Domestic and International Law, edited by G. Huscroft and P. Rishworth, Oxford: Hart Publishing, 2002. p. 73-88.

Jacobson, C.D. Ties that Bind: Economic and Political Dilemmas of Urban Utility Networks, 1800-1900. Pittsburg: University of Pittsburg Press, 2000.

Joseph, S. "An Overview of the Human Rights Accountability of Multinational Enterprises." In Liability of Multinational Corporations Under International Law, edited by M.T. Kamminga and S. Zia-Zarifi, The Hague: Kluwer Law International, 2000. p. 75-93.

Jägers, N. Corporate Human Rights Obligations: In Search of Accountability. Vol. 17, School of Human Rights Research. Antwerpen: Intersentia - Hart, 2002.

Kamminga, M.T. "Corporate Obligations Under International Law." In Report of the Seventy First Conference, Berlin: International Law Association, 2004. 
-. "Holding Multinational Corporations Accountable for Human Rights Abuses: A Challenge for the EC." In The EU and Human Rights, edited by P. Alston, Oxford: Oxford University Press, 1999. p. 553-626.

-. Inter-State Accountability for Violations of Human Rights. Philadelphia: University of Pennsylvania Press, 1992.

-. "Legal Consequences of an Internationally Wrongful Act of a State Against an Individual." In The Execution of Strasbourg and Geneva Human Rights Decisions in the National Legal Order, edited by T. Barkhuysen, M.L. Emmerik and P.H.P.H.M.C. van Kempen, The Hague: Martinus Nijhoff Publishers, 1999. p. 65-74.

Kamminga, M.T., and S. Zia-Zarifi. "Introduction." In Liability of Multinational Corporations Under International Law, edited by M.T. Kamminga and S. Zia-Zarifi, The Hague: Kluwer Law International, 2000. p. 1-15.

Kassebaum, D. "A Question of Facts - The Legal Use of Private Security Firms in Bosnia," Colum. J. Transnat'l L. Vol. 38 (2000), p. 581-602.

Kessides, I.N., "Reforming Infrastructure: Privatization, Regulation, and Competition", A World Bank Policy Research Report, The International Bank for Reconstruction and Development/The World Bank and Oxford University Press, Washington D.C., (2004).

Kikeri, S., and A. Fatima Kolo, "Privatization: Recent Trends and Developments", World Bank Policy Research Working Paper WPS3765, The World Bank, (2005).

Kikeri, S., and J. Nellis. "An Assessment of Privatization," The World Bank Research Observer Vol. 19 (2004), p. 87-118.

Kirkpatrick, C., and D. Parker, "Regulation and the Privatisation of Water Services in Developing Countries: Assessing the Impact of the General Agreement on Trade in Services (GATS)", Paper No. 67, Centre on Regulation and Competition, Institute for Development Policy and Management, University of Manchester, Manchester, (2004).

Klein, M., "Competition in Network Industries", Policy Research Working Paper, WPS 1591, The World Bank/Private Sector Development Department, Washington D.C., (1996).

Klein, M., and N. Roger. "Back to the Future: The Potential in Infrastructure Privatisation." In Finance and the International Economy, Vol. 8, edited by R. O’Brien, New York: Oxford University Press, 1994. p. 42-68.

Kok, A. "Privatisation and the Right to Access to Water." In Privatisation and Human Rights in the Age of Globalisation, edited by K. De Feyter and F. Gómez Isa, Antwerp: Intersentia, 2005. p. 259-287.

Kok, A., and M. Langford. "The Right to Water." In Socio-Economic Rights in South Africa, edited by D. Brand and C. Heyns, Pretoria: Pretoria University Law Press, 2005. p. 191-208.

Krajewski, M. "Public Services and Trade Liberalization: Mapping the Legal Framework," Journal of International Economic Law Vol. 6 (2003), p. 341-367.

Kwakwa, E. "The Current Status of Mercenaries in the Law of Armed Conflict," Hastings Int'l \& Comp. L. Rev. Vol. 14 (1990), p. 66-92. 
Langford, M. "Ambition That Overleaps Itself? A Response to Stephen Tully's Critique of the General Comment on the Right to Water," Netherlands Quarterly of Human Rights Vol. 24 (2006), p. 433-459.

Lawson, R. "Out of Control. State Responsibility and Human Rights: Will the ILC's Definition of the 'Act of State' Meet the Challenges of the $21^{\text {st }}$ Century?" In The Role of the Nation-State in the $21^{\text {st }}$ Century: Human Rights, International Organisations and Foreign Policy, Essays in Hounour of Peter Baehr, edited by M. CastermansHolleman, van Hoof, G.J.H and J. Smith, The Hague: Kluwer International Law, 1998. p. $91-116$.

—. "Positieve Verplichtingen Onder het EVRM: Opkomst en Ondergang van de 'FairBalance'-Test Deel I,” NJCM Bulletin Vol. 20 (1995), p. 558-573.

—. "Positieve Verplichtingen Onder het EVRM: Opkomst en Ondergang van de 'FairBalance'-Test Deel II," NJCM Bulletin Vol. 20 (1995), p. 727-750.

Lehnardt, C. "Individual Liability of Private Military Personnel under International Criminal Law," EJIL Vol. 19 (2008), p. 1015-1034.

Lentini, E. "La Regulación de los Servicios de Agua y Saneamiento: el Caso de la Consesión de Buenos Aires," Revista de Gestión del Agua de América Latina Vol. 1, no. No. 2 (2004), p. 11-24.

Leroux, E.H. "Eleven Years of GATS Case Law: What Have We Learned?" Journal of International Economic Law Vol. 10 (2007), p. 749-793.

Lester, S., B. Mercurio, A. Davies, and K. Leitner. World Trade Law - Text, Materials and Commentary. Oxford: Hart Publishing, 2008.

Liability of Multinational Corporations Under International Law. Edited by M.T. Kamminga and S. Zia-Zarifi. The Hague: Kluwer Law International, 2000.

Lobina, E., and D. Hall. Problems with Private Water Concessions: A Review of Experience Public Services International Research Unit (PSIRU), University of Greenwich, 2003, cited 28 July 2007. Available from <www.psiru.org/reports/2003-06-W-over.doc >.

-. UK Water Privatization - a briefing Public Services International Research Unit (PSIRU), University of Greenwich, 2001, cited 13 May 2002. Available from <www. psiru.org/reports/2001-02-W-UK-over.doc>.

-, "Water privatisation and restructuring in Latin America, 2007", Public Services International Research Unit (PSIRU), Business School, University of Greenwich, London, (2007).

Loftus, A. J., and D. McDonald. "Of Liquid Dreams: A Political Ecology of Water Privatization in Buenos Aires," Environment \& Urbanization Vol. 13, no. No. 2 (2001), p. 179-199.

Lowenfeld, A.F. International Economic Law. Edited by J.H. Jackson, International Economic Law Series. Oxford: Oxford University Press, 2002.

Macdonald, R.St.J. "The Margin of Appreciation." In The European System for teh Protection of Human Rights, edited by R.St.J. Macdonald and et al. (eds.): Kluwer Academic Publishers, 1993. p. 83-124.

Machiavelli, N. The Prince. Edited by Q. Skinner and R. Price, Cambridge Texts in the History of Political Thought. Cambridge: Cabridge University Press, 1988. 
Majone, G. "Paradoxes of Privatization and Deregulation," Journal of European Public Policy Vol. 4 (1994), p. 53-69.

Manunza, E. EG-aanbestedingsrechtelijke Problemen. Deventer: Kluwer, 2001.

Markus, K. "Leonard Cheshire Foundation: What is a Public Function?" European Human Rights Law Review (2003), p. 92-100.

McCormack, T. “The 'Sandline Affair': Papua New Guinea Resorts to Mercenarism to End the Bougainville Conflict," Yearbook of International Humanitarian Law Vol. 1 (1998), p. 292-300.

McFarland Sanchez-Moreno, M., and T. Higgins. "No Recourse: Transnational Corporations and the Protection of Economic, Social and Cultural Rights in Bolivia," Fordham Int'l L.J. Vol. 27 (2004), p. 1663-1805.

McGoldrick, D. "State Responsibility and the International Covenant on Civil and Political Rights." In Issues of State Resposibility Before International Judicial Institutions, edited by M. Fitzmaurice and D. Sarooshi, Oxford: Hart Publishing, 2004. p. 161200.

McKenzie, D., and D. Mookherjee, "Distributive Impact of Privatization in Latin America: An Overview of Evidence From Four Countries", Inter American Development Bank - Universidad de las Américas - Puebla, (2002)

Metzger, G.E. "Privatization as Delegation,” Colum. L. Rev. Vol. 103 (2003), p. 1367-1502.

Milanović, M. "Norm Conflict in International Law: Whither Human Rights?” Duke Journal of Comparative \& International Law Vol. 20 (2009), p. 69-131.

Mockler, A. Mercenaries. London: Macdonald and Company, 1970.

Muchlinski, P.T. "Human Rights and Multinationals: Is There a Problem?" International Affairs Vol. 71 (2001), p. 31-47.

- . "Human Rights, Social Responsibility and the regulation of international business: The development of international standards by intergovernmental organisations," NonState Actors and International Law Vol. 3 (2003), p. 123-152.

Müller, A. "Limitations to and Derogations from Economic, Social and Cultural Rights," Human Rights Law Review Vol. 9 (2009), p. 557-601.

Newberry, D.M. Privatization, Restructuring, and Regulation of Network Utilities. Cambridge, Massachusetts: The MIT Press, 2000.

Nickson, A., and C. Vargas. "The Limitations of Water Regulation: The Failure of the Cochabamba Concesion in Bolivia," Bulletin of Latin American Research Vol. 20 (2002), p. 128-149.

Nollkaemper, A. "Internationally Wrongful Acts in Domestic Courts," A.J.I.L. Vol. 101 (2007), p. 760-799.

Nowak, M. "What Practices Constitute Torture? US and UN Standards," Human Rights Quarterly Vol. 28 (2006), p. 809-841.

Oliver, D. "The Frontiers of the State: Public Authorities and Public Functions Under the Human Rights Act," Public Law (2000), p. 476-493.

- "Functions of A Public Nature Under the Human Rights Act," Public Law (2004), p. $329-351$. 
Paust, J.J. "Human Rights Responsibilities of Private Corporations," Vand. J. Transnat'l L. Vol. 35 (2002), p. 801-825.

Perlak, J.R. "The Military Extraterritorial Jurisdiction Act of 2000: Implications for Contractor Personnel," Mil. L. Rev. Vol. 169 (2001), p. 92-140.

Petersmann, E-U. "The 'Human Rights Approach' Advocated by the UN High Commissioner for Human Rights and by the International Labour Organization: Is It Relevant for WTO Law and Policy?" Journal of International Economic Law Vol. 7 (2004), p. 605-627.

Posner, E.A., and A.O. Sykes. An Economic Analysis of State and Individual Responsibility under International Law (John M. Olin Law \& Economics Working Paper No. 279 (2d Series)) The Law School, The University of Chicago, 2006, cited 10 July 2007.

Prosser, T. "Competition Law and Public Services: From Single Market to Citizenship Rights?” European Public Law Vol. 11 (2005), p. 543-563.

- "Constitutional Limitations on Privatisation." In UK Law for the Millennium: A Collection of Reports Delivered at the XVth International Congress of Comparative Law held in Bristol, United Kingdom, July 1998, Vol. 19, edited by J.W. Bridge, London: United Kingdom National Committee of Comparative Law, 1998. p. 445466.

- "Constitutions and Political Economy: The Privatisation of Public Enterprises in France and Britain," The Modern Law Review Vol. 53 (1990), p. 304-320.

- "Marketisation, Public Service and Universal Service." In Adapting legal Cultures, edited by D. Nelken and J. Feest, Oxford: Hart Publishing, 2001. p. 223-239.

—. "Public Service Law: Privatization's Unexpected Offspring," Law \& Contemp. Probs. No. 63 (2000), p. 63-82.

—. "Regulation and Social Solidarity," Journal of Law and Society Vol. 33 (2006), p. 364387.

—. "Social Limits to Privatization,” Brook. J. Int'l L. Vol. 21 (1995), p. 213-242.

Rivero, J., and J. Waline. Droit Administratif. 19 ${ }^{\text {th }}$ ed. Paris: Editions Dalloz, 2002.

Robbins, I.P. "Privatisation of Corrections: A Violation of U.S. Domestical Law, International Human Rights and Good Sense.” In Privatisation and Human Rights in the Age of Globalisation, edited by K. De Feyter and F. Gómez Isa, Antwerp: Intersentia, 2005. p. 57-90.

Rosemann, N., "Das Menschenrecht auf Wasser unter den Bedingungen der Handelsliberalisierung und Privatisierung: eine Untersuchung der Privatisierung der Wasserversorgung und Abwasserentsorgung in Manila”, Friedrich-Ebert-Stiftung, Division for International Cooperation, Global Trade Union Program, Bonn, (2003)

Ruggie, J.G. "Business and Human Rights: The Evolving International Agenda," AJIL Vol. 101 (2007), p. 819-840.

Ryngaert, Cedric. "Litigating Abuses Committed by Private Military Companies," EJIL Vol. 19 (2008), p. 1035-1053.

Salman, S.M.A., and S. McInerney-Lankford. The Human Right to Water: Legal and Policy Dimensions. Washington D.C.: The International Bank for Reconstruction and Development/The World Bank, 2004. 
Savas, E. Privatization: The Key to Better Government. Chatham, New Jersey: Chatham House, 1987.

Schneiderman, D. "Constitutional Approaches to Privatization: An Inquiry Into the Magnitude of Neo-Liberal Constutionalism,” Law \& Contemp. Probs. Vol. 63 (2000), p. $83-109$.

Schreuer, C. "ICSID Annulment Revisited," Legal Issues of Economic Integration Vol. 30 (2003), p. 103-122.

Schusterman, R., F. Almansi, A. Hardoy, G. McGranahan, I. Oliverio, R. Rozensztejn, and G. Urquiza. Public Private Partnerships and the Poor: Experiences With Water Provision in Four Low-Income Barrios in Buenos Aires. Edited by M. Sohail, Public Private Partnerships and the Poor. Leicestershire: Water, Engineering and Development Centre (WEDC) Loughborough University, 2002.

Scott, C. "Accountability in the Regulatory State," Journal of Law and Society Vol. 27 (2000), p. 38-60.

- . "Services of General Interest in EC Law: Matching Values to Regulatory Technique in the Public and Privatised Sectors," European Law Journal Vol. 6 (2000), p. 310-325.

Sepúlveda, M. The Nature of the Obligations under the International Covenant on Economic, Social and Cultural Rights. Vol. 18, School of Human Rights Research. Antwerpen: Intersentia - Hart, 2003.

Servicios Públicos: Privatización, Regulación y Protección al Usuario en Bolivia, Ecuador y Venezuela. Edited by Comisión Andina de Juristas. Lima: CAJ, 2001.

Shaw, M.N. International Law. $6^{\text {th }}$ ed. Cambridge: Cambridge University Press, 2009.

Shelton, D. Remedies in International Human Rights Law. Oxford: Oxford University Press, 1999.

Simpson, R. "Universal Access in the Water and Sanitation Sector." In Liberalisation and Universal Access to Basic Services - Telecommunications, Water and Sanitation, Financial Services, and Electricity: OECD and The International Bank for Reconstruction and Development/The World Bank, 2006. p. 97-134.

Singer, P.W. Corporate Warriors: The Rise of the Privatized Military Industry. Itacha and London: Cornell University Press, 2003.

—. "War, Profits and the Vacuum of Law: Privatized Military Frims and International Law," Colum. J. Transnat'1 L. Vol. 42 (2004), p. 521-549.

Sklansky, D.A. “The Private Police," UCLA L. Rev. Vol. 46 (1999), p. 1165-1287.

Skogly, S.I. "The Human Rights Obligations of the World Bank and the IMF." In World Bank, IMF and Human Rights - Including the Tilburg Guiding Principles on World Bank, IMF and Human Rights, edited by W. van Genugten, P. Hunt and S. Mathews, Nijmegen, The Netherlands: Wolf Legal Publishers (WLP), 2003. p. 45-78.

- . The Human Rights Obligations of the World Bank and the International Monetary Fund. London: Cavendish, 2001.

Smits, J.M. "Private Law and Fundamental Rights: a Sceptical View.” In Constitutionalisation of Private Law, edited by T. Barkhuysen and S. Lindenbergh, Leiden/Boston, 2006. p. 9-22.

Stiglitz, J. Globalization and Its Discontents. London: Allen Lane/The Penguin Press, 2002. 
Szyszczak, E. "Public Service Provision in Competitive Markets," Yearbook of European Law Vol. 20 (2001), p. 35-77.

Teubner, G. "After Privatization? The Many Autonomies of Private Law," Current Legal Problems Vol. 51 (1998), p. 393-424.

Toebes, B.C.A. The Right to Health as a Human Right in International Law. Vol. 1, School of Human Rights Research. Antwerpen: Intersentia - Hart, 1999.

Tully, S. "A Human Right to Access Water? A Critique of General Comment No. 15," Netherlands Quarterly of Human Rights Vol. 23 (2005), p. 35-63.

Vuylsteke, C., "Techniques of Privatization of State-Owned Enterprises, Vol. I Methods and Implementation”, World Bank Technical Paper WTP - 88, The International Bank for Reconstruction/World Bank, Washington D.C., (1988).

Waddams Price, C., and A. Young, "UK Utility Reforms: Distributional Implications and Government Response", Discussion Paper No. 2001/10, World Institute for Development Economics Research (WIDER) - United Nations University, Helsinki, (2001).

Walker, C., and D. Whyte. "Contracting Out War? Private Military Companies, Law and Regulation in the United Kingdom,” ICLQ Vol. 54 (2005), p. 651-690.

Walker, S. The Future of Human Rights Impact Assessments of Trade Agreements. Antwerp: Intersentia, 2009.

Weissbrodt, D., and M. Kruger. "Norms on the Responsibilities of Transnational Corporations and Other Business Enterprises with Regard to Human Rights," A.J.I.L. Vol. 97 (2003), p. 901-922.

Williamson, J. "Democracy and the 'Washington Consensus'," World Development Vol. 21 (1993), p. 1329-1336.

Young, K.G. "The Minimum Core of Economic and Social Rights: A Concept in Search of a Content," Yale Journal of International Law Vol. 33 (2008), p. 113-175.

Young, M. “The Future of Universal Service. Does it Have One?” International Journal of Law and Information Technology Vol. 13 (2006), p. 188-205.

Zamparelli, S.J. “Contractors on the Battlefield: What Have We Signed Up For?” Air Force Journal of Logistics Vol. XXIII (1999), p. 10-19.

Zarate, J. C. "The Emergence of a New Dog of War: Private International Security Companies, International Law, and the New World Disorder,' Stan. J. Int'l. L. Vol. 34 (1998), p. 75-162.

Zérah, M., and K. Graham-Harrison, "The Buenos Aires Concession - The Private Sector Serving the Poor”, Report No. 23722, UNDP - Water and Sanitation Program, (2001) 


\section{Table of Cases}

\section{INTERNATIONAL}

\section{International Court of Justice (case law and advisory opinions)}

- Anglo-Iranian Oil Company case, ICJ Reports (1951). 72

- Barcelona Traction, Light and Power Company Limited (Belgium v. Spain), ICJ Reports 1970. 90, 108, 128, 203, 229

- Case Concerning the Application of the Convention on the Prevention and Punishment of the Crime of Genocide (Bosnia and Herzegovina v. Serbia and Montenegro), ICJ, judgment of 26 February 2007. 203, 205, 227, 508

- Case Concerning the Arrest Warrant of 11 April 2000 (Democratic Republic of the Congo v. Belgium), ICJ Reports, 2002. 214

- Difference Relating to Immunity From Legal Process of a Special Rapporteur of the Commission on Human Rights, ICJ Reports 1999. 204

- Gabčikovo-Nagymaros Project (Hungary v. Slovakia)(Merits), ICJ Reports 1997. 202

- Interpretation of the Agreement of 25 March 1951 between the WHO and Egypt, Advisory Opinion, ICJ Reports (1980). 92

- Legal Consequences of the Construction of a Wall in the Occupied Palestinian Territory, Advisory Opinion, ICJ Reports 2004. 203

- Military and Paramilitary Activities in and against Nicaragua (Nicaragua v. United States of America), Merits, Judgment, ICJ Reports 1986. 205, 225, 507

- Reparation for Injuries Suffered in the Service of the United Nations, ICJ Reports (1949). 91, 92

- United States Diplomatic and Consular Staff in Tehran, ICJ Reports 1980. 206, 226, 231

\section{Permanent Court of International Justice}

- Factory at Chorzów (Juridsiction), 1927, PCIJ, Series A. No. 9. 72, 80, 203

- The Electricity Company of Sofia and Bulgaria (Preliminary Objection), PCIJ (4 April 1939), Judgments, Orders and Advisory Opinions, Series A/B, Fascicule No. 77. 218

\section{International Tribunal for the Former Yugoslavia}

- Prosecutor v. Dusko Tadic, ICTY, Appeals Chamber, judgment of 15 July 1999, Case IT-94-1. 216, 224, 226, 508

- Prosecutor, v. Furundzija, ICTY, Trial Chamber, judgment of 10 December1998, Case IT-95-17/1. 502 
Table of Cases

- Prosecutor, v. Kunarac, Kovac and Vukovic, ICTY, Trial Chamber, judgment of 22 February 2001, Case IT-96-23/1. 502

\section{Human Rights Committee}

- Bazzano and Massera v. Uruguay (5/1977) UN Doc. CCPR/C/7/D/5/1977 (15 August 1979). 505

- B.d.B. v. The Netherlands (273/88), UN Doc. CCPR/C/35/D/273/1988 (2 May 1989). 46, 237, 247, 511

- Cabal and Pasini Bertran v. Australia (1020/2001), UN Doc. CCPR/C/78/D/1020/2001 (29 August 2003). 7, 47, 216, 237, 243, 246, 511

- Cariboni v. Uruguay Communication No. 159/1983 (27 October 1987) available at $<$ www.bayefsky.com/html/149_uruguay159vws.php> (last visited 25 May 2005. 505

- Chaparro et al v. Colombia (612/1995) UN Doc. CCPR/C/60/D/612/1995 (19 August 1997). 505

- Estrella v. Uruguay (74/1980) UN Doc. CCPR/C/18/D/74/1980 (23 March 1983). 505

- Herrera Rubio v. Colombia (161/1983) UN Doc. CCPR/C/31/D/161/1983 (2 November 1987). 179, 505

- Lindgren et al v. Sweden (298-299/88), UN Doc. CCPR/C/40/D/298/1988 (2 May 1989). 237, 247, 511

- Malikv. Czech Republic (UN Doc. CCPR/C/64/D/669/1995 (3 November 1998). 361

- Muteba v. Zaire (124/1982) UN Doc. CCPR/C/22/D/124/1982 (24 July 1984). 505

- Scholsser v. Czech Republic (670/1995), UN Doc. CCPR/C/64/D/670/1995 (3 November 1998). 361

- Somers v. Hungary (566/1993), UN Doc. CCPR/C/57/D/566/1993 (29 July 1996). 361

\section{Committee Against Torture}

- Dragan Dimitrijevic v. Serbia and Montenegro, (207/2002), CAT, UN Doc. CAT/ C/33/D/207/2002 (29 November 2004). 505

- Elmi v. Australia (120/1998), CAT, UN Doc. A/54/44 (14 May 1999) 109. 248

- G. R. B. v. Sweden (83/1997), CAT, UN Doc. A/53/44 (15 May 1998) 92. 248

- Hajrizi Dzemajl et al. v. Serbia and Montenegro (161/2000), CAT, UN Doc. A/58/44 (21 November 2002) 248

- Jovica Dimitrov v. Serbia and Montenegro, (171/2000), UN Doc. CAT/C/34/D/171/2000 (23 May 2005). 505

- M.P.S. v. Australia (138/1999), CAT, UN Doc. A/57/44 (30 April 2002) 111. 248

- S.S. v. The Netherlands (191/2001), CAT, UN Doc. A/58/44 (5 May 2003) 115. 248

- V.X. N. and H. N. v. Sweden (130 and 131/1999), CAT, UN Doc. A/55/44 (15 May 2000) 248 


\section{European Court and Commission of Human Rights}

- Abdulaziz v. the UK, judgment of 28 May 1985, ECtHR, Series A-94. 169

- Appleby and Others v. The United Kingdom, judgment of 5 May 2003, ECtHR, Reports of Judgments and Decisions 2003-VI. 308

- “Artze für das Leben” v. Austria, judgment of 21 June 1988, ECtHR Series A-139. 190

- Ashingdane v. UK, judgment of 28 May 1985, ECtHR, Series A-93. 168

- Ayuntamiento de Mula v. Spain, judgment of 1 February 2001, ECtHR, Reports of Judgments and Decisions 2000-I. 253

- Bartold v. Germany, judgment of 25 March 1985, ECtHR, Series A-90. 222

- Broniowski v. Poland, judgment of 22 June 2004 ECtHR, Reports of Judgments and Decisions 2004 V. 162

- Buckley v. the United Kingdom, judgment of 26 August 1996, ECtHR, Reports 1996-IV. 154,165

- Budescu and Petrescu v. Rumania, judgment of 2 July 2002, ECtHR, Application No. 33912/96 (not yet published). 80, 403

- Buzescu v. Romania, judgment of 24 May 2005, ECtHR, Application No. 61302/00 (not yet published). 255, 257, 405

- Calvelli and Ciglio v. Italy, judgment of 17 January 2002, ECtHR, Reports 2002-I. 138

- Casado Coca v. Spain, judgment of 26 February 1994, ECtHR, Series A285-A. 250

- Case of Al-Skeini and Others v. The United Kingdom, Grand Chamber judgment of 7 July 2011, ECtHR (not yet published). 510, 669

- Case of Öneryildiz v. Turkey, judgment of 30 November 2004, ECtHR, Reports of Judgments and Decisions 2004-XII. 141, 152

- Case of Sporrong and Lönnroth v. Sweden, judgment of 23 September 1982, ECtHR,Series A-52. 127, 161

- Case of Vozár v. Slovakia, judgment of 14 November 2006, ECtHR, Application No. 54826/00, (not yet published). 399

- Costello-Roberts v. the United Kingdom, judgment of 25 March 1993, ECtHR Series A247-C. 7, 46, 127, 138, 144, 189, 243, 254, 402, 405

- Cubber v. Belgium, judgment of 26 October 1984, ECtHR, Series A-86. 402

- Dudgeon v. the UK, judgment of 22 October 1981, ECtHR, Series A-45. 166

- Fadeyeva v. Russia, judgment of 9 June 2005, ECtHR, Reports 2005-IV. 139, 143, 157, 164, 400, 400, 575

- Gerasimova v. Russia, application no. 24669/02, decision on admissibility of 16 September 2004, ECtHR. 253

- Golder v. UK, judgment of 21 February 1975, ECtHR, Series A-18, paras. 37-38. 168, 178

- Groppera Radio v. Switzerland, judgment of 28 March 1990, ECtHR, Series A-173. 154

- Guerra and Others v. Italy, judgment of 19 February 1998, ECtHR, Reports 1998-I. 138, 163

- Handyside v. The United Kingdom, judgment of 7 December 1976, ECtHR, Series A-24. $151,154,161$ 
- Hatton and Others v. the UK, Grand Chamber judgment of 8 July 2003, ECtHR Reports 2003-VIII. 141, 152, 156, 164, 165, 166, 170, 171, 400, 400

- Hilton v. UK, Application No. 12015/86, decision by the European Commission of Human Rights, 6 July 1988. 249

- Holy Monasteries v. Greece, judgment of 9 December 1994, ECtHR, Series A301-A. 252, 253, 302

- James and Others v. the UK, judgment of 21 February 1986, ECtHR Series A-98. 160

- Johnston and others v. Ireland, judgment of 18 December 1986, ECtHR, Series A-112. 156

- Klass and Others v. Germany, judgment of 6 September 1978, ECtHR, Series A no. 28. 177, 178

- Krcmár v. the Czech Republic, judgment of 3 March 2000, ECtHR, Application No. 35376/97 (not yet published). 403

- Kukalo v. Russia, judgment of 3 November 2005, ECtHR, Application No. 63995/00 (not yet published). 404

- Leander v. Sweden, judgment of 25 February 1987, ECtHR, Series A-116. 179

- Ledyayeva, Dobrokhotova, Zolotareva and Romashina v. Russia, judgment of 26 October 2006, ECtHR, Applications Nos. 53157/99, 53247/99, 53695/00 and 56850/00 (not yet published). 144, 400, 575

- Le Compte, Van Leuven and De Meyere v. Belgium, judgment of 23 June 1981, ECtHR, Series A-43. 218, 251

- Lithgow and Others v. the UK, judgment of 8 July 1986, ECtHR, Series A-102. 127, 160, 168

- Loizidou v. Turkey, judgment of 23 March 1995, ECtHR, Series A-310. 510

- López Ostra v. Spain, judgment of 21 February 1990, ECtHR, Series A-172. 137, 139, 143, 163, 165, 244, 296, 400

- Marckx v. Belgium, judgment of 13 June 1979, ECtHR, Series A-31. 132

- Moldovahidromaş v. Moldova, judgment of 27 February 2007, ECtHR, Application No. 30475/03 (not yet published). 404

- Moreno Gómez v. Spain, judgment of 16 November 2004, ECtHR Reports of Judgments and Decisions 2004-X. 139

- Popnikolov v. Bulgaria, judgment of 25 March 2010, ECtHR Application no. 30388/02 (not yet published). 404

- Powell and Rayner v. the UK, judgment of 21 February 1990, ECtHR Series A-172. 152, $155,162,164,399$

- Rees v. UK, judgment of 17 October 1986, ECtHR, Series A-106. 152, 155, 168, 169

- Rothenthurm Commune v. Switzerland, application no. 13252/87, Commission decision of 14 December 1988, Decisions and Reports, (DR) 59. 253

- Silver and Others v. UK, judgment of 25 March 1983, ECtHR Series A-61 177

- Storck v. Germany, judgment of 16 June 2005, ECtHR Reports of Judgments and Decisions 2005-V. 144, 256

- Sychev v. Ukraine, judgment of 11 October 2005, ECtHR, Application No. 4773/02 (not yet reported). 254, 256, 405 
- Sunday Times v. UK, judgment of 26 April 1979, ECtHR, Series A-30. 153, 222

- Taşkin and Others v. Turkey, judgment of 10 November 2004, ECtHR Reports of Judgments and Decisions 2004-X. 141, 141, 165, 166

- Van der Mussele v. Belgium, judgment of 23 November, 1983, ECtHR Series A-70. 250, 251, 255

- VGT Verein Gegen Tierfabriken v. Switzerland, judgment of 28 June 2001, ECtHR, Reports 2001-VI. 401, 403

- Vilvarajah and Others v. the UK, judgment of 30 October 1991, ECtHR Series A-94. 178

- Winterwerp v. The Netherlands, judgment of 24 October 1979, ECtHR, Series A-33. 168

- Woś v. Poland, judgment of 1 March 2005, ECtHR Reports of Judgments and Decisions 2005-IV. 127, 255, 297, 405, 405

- $X$ and $Y v$. The Netherlands, judgment of 26 March1985, ECtHR Series A-91. 138, 244

- Young, James and Webster v. the UK, judgment of 13 August 1981, ECtHR, Series A-44. $134,138,168,189,244,254$

\section{European Committee for Social Rights}

- Fédération européenne des Associations nationales travaillant avec les Sans-abri (FEANTSA) v. Slovenia, decision on the merits of 8 September 2009, European Committee of Social Rights, Complaint No. 53/2008. 421

\section{Inter-American Court and Commission of Human Rights}

- The Legal Status and Human Rights of the Child, Advisory Opinion OC-17/2002 of 28 August 2002, IACtHR, Series A, No. 17. 152

- Case of the "Gómez-Paquiyauri Brothers" v. Peru, judgment of 8 July 2004, IACtHR, Series C No. 110. 191

- Case of Tibi v. Ecuador, judgment of 7 September 2004, IACtHR, Series C No. 114. 191

- Case of Ximenes-Lopes v. Brazil, Judgment of 4 July 2006, IACtHR, Series C No. 149. 140, 144, 191, 213, 299, 356, 667

- Jesús Manuel Naranjo Cárdenas Et Al. Pensioners Of The Venezuelan Aviation Company - Viasa v. Venezuela, IACmHR, Report No 69/04, Petition 667/01, Admissibility, 15 October 2004. 356

- Juridical Condition and Rights of the Undocumented Migrants, Advisory Opinion OC-18 of 17 September 2003, IACtHR, Series A No. 18 (2003). 191

- Matter of the Peace Community of San José de Apartadó regarding Colombia, provisional measures, Order of 17 November 2004, IACtHR. 191, 193

- Velásquez Rodríguez v. Honduras, judgment of 29 July 1988, IACtHR, Series C No. 4. $133,133,140,174,191,232,232,508$ 
Table of Cases

\section{African Commission on Human and Peoples' Rights}

- Commission Nationale des Droits de l'Homme et des Libertes v. Chad, African Commission on Human and Peoples' Rights, Comm. No. 74/92 (1995). 191

- Social and Economic Rights Action Centre and the Centre for Economic and Social Rights v. Nigeria, Communication No. 155/96, African Commission on Human and Peoples' Rights (2001). 232, 669

\section{International Labor Organization}

- Committee on the Freedom of Association, Complaint against the Government of Canada concerning the Province of British Columbia presented by the National Union of Public and General Employees (NUPGE), on behalf of the BC Government and Services Employees' Union (BCGEU) and the Health Sciences Association of British Columbia (HSABC), supported by the Canadian Labour Congress (CLC) and Public Services International (PSI), report no. 336, case no. 2324 (Vol. LXXXVIII, 2005, Series B, No. 1). 446

- Committee on the Freedom of Association, Complaint against the Government of Colombia presented by the the General Confederation of Labour (CGT) and the Latin American Central of Workers (CLAT), report no. 286, case no. 1620, (Vol. LXXVI, 1993, Series B, No. 1). 442, 444, 447

- Committee on the Freedom of Association, Complaint against the Government of El Salvador presented by Communications International (CI), report no. 313, case no. 1987, (Vol. LXXXII, 1999, Series B, No. 1). 443

- Committee on the Freedom of Association, Complaint against the Government of Hungary presented by the National Federation of Workers' Councils (MOSZ), report no. 294, case no. 1742, (Vol. LXXVII, 1994, Series B, No. 2). 442

- Committee on the Freedom of Association, Complaint against the Government of Japan presented by the Japanese National Railway Workers' Union (KOKURO) and the All National Railway Locomotive Engineers' Union (ZENDORO), report no. 318, case no. 1991, (Vol. LXXXII, 1999, Series B, No. 3). 444

- Committee on the Freedom of Association, Complaint against the Government of Nicaragua presented by the the "Nora Astorga" Trade Union, report no. 286, case no. 1673, (Vol. LXXVI, 1993, Series B, No. 1). 441

- Committee on the Freedom of Association, Complaints Against The Government Of Peru Presented By - General Confederation Of Workers Of Peru (Cgtp) et.al., report no:291, case(s) No(s). 1648,1650, (Vol.LXXVI, 1993, Series B, No.3). 441

- Committee on the Freedom of Association, Complaint against the Government of Peru presented by the General Confederation of Workers of Peru (CGTP), et.al., report no. 323, case no. 2049, (Vol. LXXXIII, 2000, Series B, No. 3). 444

- Committee on the Freedom of Association, Complaints against the Government of Peru presented by the Trade Union of Workers of the Iron and Steel Plant of Peru (SIDERPERU), et.al., report no. 306, case no. 1796, (Vol. LXXX, 1997, Series B, No. 1). 443 
- Committee on the Freedom of Association, Complaint against the Government of the Philippines presented by the National Federation of Labor (NFL), report no. 268, case no. 1495, (Vol. LXXII, 1989, Series B, No.3). 440

- Committee on the Freedom of Association, Complaint against the Government of United Kingdom presented by the Prison Officers' Association (POA), report no. 336, case no. 2383 (Vol. LXXXVIII, 2005, Series B, No. 1). 447

\section{Dispute Settlement Body, World Trade Organization}

- Canada - Measures Affecting the Importation of Milk and the Exportation of Dairy Products, Report of the Appellate Body, WT/DS103/AB/R (13 October 1999). 211, 215, 216

- Japan - Measures Affecting Consumer Photographic Film and Paper, Report of the Panel, WT/DS44/R (31 March 1998). 216

- Korea - Measures Trade in Commercial Vessels, Report of the Panel, WT/DS273/R (7 March 2005). 220, 223

- United States - Definitive Anti-Dumping and Countervailing Duties on Certain Products from China, Report of the Appellate Body, WT/DS379/AB/R (11 March 2011). 216

\section{European Court of Justice}

- Case C-2/74 Reyners v. Belgium [1974] ECR 631. 261

- Case C-33/74 Van Binsbergen v. Bestuur van de Bedrijfsvereniging voor de Metaalnijverheid [1974] ECR 1299. 260

- Case 14/83 Von Colson and Kamman v. Land Nordrhein-Westfalen [1974] ECR 1891. 264

- Case C-152/84 Marshall v. Southhampton and South-West Hampshire Area Health Authority [1986] ECR 723. 264

- Case C-222/84 Johnston v Chief Constable of the Royal Ulster Constabulary, [1986] ECR 1651. 265

- Case C-118/85 Commission v Italy [1987] ECR 2599. 259

- Case C-147/86 Commission of the European Communities v Hellenic Republic (1988) ECR 1637. 261, 263

- Case 31/87 Gebr. Beentjes v. The Netherlands [1988] ECR 4635. 270

- Case C-106/89 Marleasing SA v. La Comercial Internacional de Alimentación SA [1990] ECR I-4135. 264

- Case C-188/89 Foster v. British Gas Plc, [1991] ECR I-3313. 265, 267, 295, 338

- Case C-306/89 Commission of the European Communities v Hellenic Republic (1991) ECR I-05863. 261

- Cases C-6 \& 9/90 Francovich and Bonifaci v. Italy [1991] ECR I-5357. 264

- Case C-42/92 Adrianus Thijssen v Controledienst voor de verzekeringen [1993] ECR I-04047. 262 
Table of Cases

- Case C-364/92 SAT Fluggesellschaft mbH v Eurocontrol [1994], ECR I-00043. 259, 259

- Case C-393/92 Almelo [1994] ECR I-1477. 543

- Case C-157/94 Commission v. Netherlands [1997] ECR I-5699. 543

- Case C-343/95 Diego Cali \& Figli Srl v Servizi ecologici porto di Genova SpA (SEPG) [1997] ECR I-01547. 259

- Case C-44/96 Mannesmann Anlagenbau Austria AG and Others $v$ Strohal Rotationsdruck GesmbH [1998] ECR I-73. 271

- Case C-360/96, Gemeente Arnhem and another v. BFI Holding BV [1999] All ER (EC), p. 709.273

- Case C-114/97 Commission of the European Communities v Kingdom of Spain [1998] ECR I-06717. 262

- Case C-275/98 Unitron Scandinavia A/S and 3-S A/S, Danske Svineproducenters Serviceselskab v. Ministeriet for Fødevarer, Landbrug og Fiskeri, [1999] ECR I-08291. 276

- Case C-355/98 Commission of the European Communities v Kingdom of Belgium [2000] ECR I-01221. 263

- Case C-367/98 Commission v. Portugal [2002] ECR I-4731. 229

- Case C-283/99 Commission of the European Communities v Italian Republic (2001) ECR I-04363. 263

- Case C-483/99 Commission v. France [2002] ECR I-4781. 229

- Case C-503/99 Commission v. Belgium [2002] ECR I-4809. 229

- Case C-373/00 Adolf Truley GmbH v. Bestattung Wien GmbH [2002] ECR 2003 I-01931. 273

- Case C-463/00 Commission v. Spain [2003] ECR I-04581. 229

- Case C-157/02 Rieser Internationale Transporte GmbH and Autobahnen- und Schnellstraßen-Finanzierungs-AG (Asfinag), [2004] ECR I-01477. 269

- Case C-180/04 Andrea Vassallo v. Azienda Ospedaliera Ospedale San Martino di Genova e Cliniche Universitarie Convenzionate, (2006) ECR I-7251. 267

- Case C-53/04 Cristiano Marrosu, Gianluca Sardino v. Azienda Ospedaliera Ospedale San Martino di Genova e Cliniche Universitarie Convenzionate, [2006] ECR I-7213. 267

\section{International Center for the Settlement of Investment Disputes}

- Aguas Argentinas, S.A., Suez, Sociedad General de Aguas de Barcelona, S.A. and Vivendi Universal, S.A. v. Argentine Republic, ICSID Case no. ARB/03/19.

Order in Response to Petition for Transparency and Participation as Amicus Curiae. $87,212,544,623,629,630$

Decision on Liability (30 July 2010), 75, 82, 54, 89, 136, 573, 621, 623, 630, 632, 633, 640, 658, 666, 667

- Aguas del Tunari S.A. v. Republic of Bolivia, ICSID, Decision on Respondent's Objection to Jurisdiction, ICSID Case No. ARB/02/3, 21 October 2005. 74, 561 
- Aguas Provinciales de Santa Fe S.A., Suez, Sociedad General de Aguas de Barcelona S.A. and InterAguas Servicios Integrales del Agua S.A. (Claimants) and The Argentine Republic (Respondent), ICSID Case No. ARB/03/17. 136, 544

- Azurix Corp. v. Argentine Republic, Award, ICSID Case No. ARB/01/12, 14 July 2006. $74,81,82,563,622$

- Biwater Gauff (Tanzania) Limited v. United Republic of Tanzania, ICSID, Procedural Order No. 1, ICSID Case No. ARB/05/22 31 March 2006. 74, 563, 564

- Camuzzi International S.A. v. Argentine Republic, Decision of the Arbitral Tribunal on Objections to Jurisdiction, ICSID Case No. ARB/03/7, 10 June 2005. 59, 623

- CMS Gas Transmission Company v. Argentine Republic, Award, ICSID Case No. ARB/01/8, 12 May 2005. 89

- Companía de Aguas del Aconquija S.A. and Vivendi Universal (Formerly Compagnie Generale Des Eaux) v. Argentine Republic, ICSID Case No. ARB/97/3. 73, 622

- Jan de Nul N.V. and Dredging International N.V. v. Arab Republic of Egypt, Decision on Jurisdiction, ICSID Case No. ARB/04/13 (Belgo-Luxembourg/Egypt BIT), 16 June 2006. 209

- Maffezini v. Kindgom of Spain, Decision on objections to jurisdiction, ICSID Case No. ARB/97/7, 25 January 2000. 215

- Noble Ventures, Inc. v. Romania, Award, ICSID Case No. ARB/01/11 (US/Romania BIT), 12 October 2005. 209, 215

- Sempra Energy International v. Argentine Republic, Decision on Objections to Jurisdiction, ICSID Case No. ARB/02/16. 74, 623

- Suez, Sociedad General de Aguas de Barcelona S.A. and Interagua Servicios Integrales de Agua S.A. v. Argentine Republic, Decision on Liability, ICSDI Case no. ARB/03/17, 30 July 2010. 59

\section{Iran-United States Claims Tribunal}

- Flexi-Van Leasing, Inc. v. Iran, Case no. 36, (1986) 12 Iran-U.S.C.T.R. 229

- Foremost Theran, Inc. v. Iran, Case no. 37, (1986) 10 Iran-U.S.C.T.R. 229

- Hyatt International Corporation v. Iran, Case No. 134, (1985) 9 Iran-U.S.C.T.R. 229

- INA Corp. v. Government of the Islamic Republic of Iran, AWD 184-161-1 (13 August 1985). 72

- Khosrowshahi v. Government of the Islamic Republic of Iran, AWD 558-178-2 (30 June 30 1994). 72

- Malek v. Government of the Islamic Republic of Iran, AWD 534-193-3 (11 August 1992). 72

- Yeager v. Islamic Republic of Iran, Case No. 10199 (1987)17 Iran-U.S.C.T.R., ILR Vol. 82 (1990). 208, 211 
Table of Cases

\section{Other}

- British Property in Spanish Morocco (Affaire des biens britanniques au Maroc espagnol) (Spain v. Great Britain), 1 May 1925, R.I.A.A., Vol. II. 231

- Charles S. Stephens and Bowman Stephens (U.S.A.) v. United Mexican States, Mexico/ U.S.A. (General Claims Commission, 15 July 1927, R.I.A.A., Vol. IV. 224

- D. Earnshaw and Others (Great Britain) v. United States (Zafiro case), Arbitral Tribunal Great Britain - United States, 30 November 1925, R.I.A.A., Vol, VI. 225

- Dispute Concerning Access to Information Under Article 9 of the OSPAR Convention (Ireland v. The United Kingdom), Permanent Court of Arbitration, (2 July 2003), para. 145. 209

- EnCana Corporation v. Republic of Ecuador, LCIA Case No. UN3481, UNCITRAL (Canada/Ecuador BIT), London Court of International Arbitration (3 February 2006). 209

- I.G. Farben Trial, Case No. 57, US Military Tribunal, Nuremberg (14 August 1947 29 July 1948). 121

- Independent State of Papua New Guinea v. Sandline International Inc, [Queensland Supreme Court of Appeal, Australia] Arbitral award of 30 March 1999, International Law Reports, Vol. 117 (2000), p. 565. 75, 481

- In the Matter of an International Arbitration under the UNCITRAL Rules between Sandline International Inc and the Independent State of Papua New Guinea (Interim Award) [Arbitration Tribunal] Arbitral Award of 9 October 1998, International Law Reports, Vol. 117 (2000), p. 552. 75, 481

- Methanex Corp. v. United States, Jurisdiction and Merits, NAFTA Tribunal, Chapter 11 Arbitration (3 August 2005). 81, 571

- Noyens case (United States v. Panama), 22 May 1933, R.I.A.A., Vol. VI. 231

- Texaco Overseas Petroleum Company v. Libyan Arab Republic, 53 ILR (1977) 389. 72

\section{NATional JurisprudenCe}

\section{Argentina}

- Appeals Chamber for Federal Administrative Cases, No.2, Torre, Hugo M. v. Aguas Argentinas SA y otro, Expte. 20000/2003 in file with author. 677

- Appeals Chamber on Civil and Commercial Cases 8A, Province of Córdoba, Argañaraz, M. Francisco Godoy Juan Carlos y Otros c/ Aguas Cordobesas S.A. s/ Amparo, Judgment No. 77 of 24 March 2004. 672

- Civil Trial Court, Moreno, Province of Buenos Aires, Usuarios y Consumidores en Defensa de sus Derechos, Asociación Civil c/ Aguas del Gran Buenos Aires S.A. s/ Amparo, 21 August 2002 in file with the author. 671

- Federal Appeals Chamber for Civil Law cases, Sala de Feria, Torre, Hugo M. c. Aguas Argentinas S.A, judgment of 22 January 2001, in file with author. 677 
- Federal Appeals of Appeals of La Plata Province, Sala III, Bocanegra, Elida Leslie c/ Aguas Argentinas S.A. s/Amparo, Expte. 6236/04, T $132 \mathrm{~F}^{\circ} 194 / 195$ of 18 May 2006. 675

- Federal Appeals Chamber of La Plata Province, Sala III, Ronchi, Pablo Jorge c/ Aguas Argentinas S.A. s/Amparo (incidente apelación), Expte. 2044/01, Rtro T.29 f 118/120 of 7 February 2002. 675

- First Instance Judge 51 Nominación on Civil and Comercial Cases, City of Córdoba, Quevedo Miguel Angel y Otros c/ Aguas Cordobesas S.A., Acción de Amparo, Judgment of 8 April 2002 (available at <www.cedha.org.ar/docs/doc220-spa.doc>, last visited on 10 May 2011). 672

- Supreme Court of the Province of Buenos Aires, Usuarios y Consumidores en Defensa de sus Derechos, Asociación Civil c/ Aguas del Gran Buenos Aires S.A. s/ Amparo, Ac 86720 S, 22 September 2004. 672

- Supreme Court of the Republic of Argentina, Defensor del Pueblo de la Nación c/ Estado Nacional - P.E.N. $-M^{\circ}$ de Eco. Obras y Serv. Públ.- y otros s/ amparo ley 16.986, D. 1084. XXXII y D. 1032. XXXII. y D. 1040. XXXII. Recursos de Hecho, judgment of 14 September 2000. 676

- Supreme Court of the Republic of Argentina, Etchepare, Eduardo Victor c/ Aguas Argentinas S.A. s/ medidas cautelares, Comp. $\mathrm{N}^{\circ}$ 253. XXXIX, judgment of 16 September 2003. 677

- Supreme Court of the Republic of Argentina, González, Maria Teresa y otro c/ Aguas Argentinas S.A. s/amparo, Comp. № 894.XXXIII, judgment of 17 February 1998. 677

- Supreme Court of the Republic of Argentina, Aquino, Isacio c/ Cargo Servicios Industriales S.A. s/ accidentes ley 9688, A. 2652. XXXVIII, p. 12-14. 671

- Supreme Court of the Republic of Argentina, Rodriguez, Hugo Manuel c/ Aguas Argentinas S.A. S/ Amparo Ley 16.986. S.C. Comp. $\mathrm{N}^{\circ}$ 379.XXXII, judgment of 6 February 1997. 676

- Supreme Court of the Republic of Argentina, Torre, Hugo M. v. Aguas Argentinas SA y otro, Exp. No. 277/2010 website of the Argentine Supreme Court at <www.csjn.gov.ar/ cfal/fallos/cfal3/cons_fallos.jsp> (last visited 20 May 2011). 678

\section{Canada}

- Douglas/Kwantlen Faculty Assn. v. Douglas College, Supreme Court of Canada (1990), 3 S.C.R. 326,328

- Eldridge v. British Columbia (Attorney General), Supreme Court of Canada (1997), 3 S.C.R. 624. 325, 326, 329, 330

- Lavigne v. Ontario Public Service Employees Union, Supreme Court of Canada (1991), 2 S.C.R. 326, 326, 328

- Lewis (Guardian ad Litem of) v. British Columbia, Supreme Court of Canada 3 S.C.R. 1145 (1997). 68

- McKinney v. University of Guelph, Supreme Court of Canada (1990) 3 S.C.R. 229. 325, $326,328,329,331,332$ 
Table of Cases

- R.W.D.S.U. v. Dolphin Delivery Ltd., Supreme Court of Canada (1986), 2 S.C.R. 573. 323

- Slaight Communications Inc. v. Davidson, Supreme Court of Canada (1989) 1 S.C.R. 1038. 327

- Stoffman v. Vancouver General Hospital, Supreme Court of Canada (1990) 3 S.C.R. 483. $325,327,331,332,333$

\section{Ecuador}

- Tribunal Constitucional, Resolución No. 335-2002-RA (25 October 2002). 345

- Tribunal Constitucional, Resolución No. 826-2004-RA (2 December 2004). 346

- Tribunal Constitucional, Resolución No. 0640-04-RA (2 March 2005). 345

- Tribunal Constitucional, Resolución No. 0604-2004-RA (11 March 2005). 345

- Tribunal Constitucional, Resolución No. 0801-2004-RA (10 March 2005). 346

- Tribunal Constitucional, Resolución No. 0748-2004-RA (18 March 2005). 345

\section{France}

- TC, 22 January 1921, Societé Commericale de l'Ouest Africain (Le Bac d'Eloka). 339

- CE, 13 May 1938, Caisse Primaire 'Aide et Protection'. 337

- CE, 3 March 1969, Societé Interlait. 341

- CE, 22 November 1974, Federation des Industries Françaises d'Articles de Sport. 337

- TC, 22 April 1980, Mme Girinon. 337

\section{South Africa}

- Grootboom and Others $v$ Government of the Republic of South Africa and Others Constitutional Court Order [2000] ZACC 14. 349

- Mazibuko \& Ors. v. the City of Johannesburg, Johannesburg Water (PTY) Ltd and Minister for Water Affairs and Forestry, Case CCT 39/09, 2009 ZACC 28, Constitutional Court of South Africa, 8 October 2009. 604, 606, 608

- Residents of Bon Vista Mansions v. Southern Metropolitan Local Council, Case No: 01/12312, High Court, Witwatersrand Local Division, 2002. 608

\section{United Kingdom}

- Aston Cantlow and Wilmcote with Billesley Parochial Church Council v. Wallbank and another, House of Lords, [2003] UKHL 37. 294, 295

- British Waterways Board v Severn Trent Water Ltd, Court of Appeal (Civil Division) [2001], 3 All ER 673. 278 
- Donoghue v. Poplar Housing and Regeneration Community Association Ltd, [2001] EWCA Civ 595. 282, 289

- Griffin \& others v South West Water Services Ltd, High Court, Chancery Division, [1995] IRLR 15. 267

- Hampshire County Council v. Graham Beer, judgment of 21 July 2003, Court of Appeal (Civil Division), [2003] LLR 681. 296

- Heather \& Ors, $R$ (on the application of) v Leonard Cheshire Foundation \& Anor [2001] EWHC Admin 429. 238

- Heather and others $v$ The Leonard Cheshire Foundation and another, Court of Appeal (Civil Division) [2002] EWCA Civ 366. 291

- Johnson and others v. London Borough of Havering [2007] EWCA Civ 26. 297

- Lancashire County Council \& Ors, $R$ (on the application of) v. Director General of Water Services, [1998] EWHC Admin 213 (20 ${ }^{\text {th }}$ February, 1998). 569, 604

- Marcic v. Thames Water Utilities Ltd [2003] UKHL 66 (04 December 2003). 297

- O'Reilly v. Mackman, [1982] 3 All ER 1124, [1983] 2 AC 237, [1982] 3 WLR 1096, HL. 280

- $R$ v. Chief Rabbi of the United Hebrew Congregations of Great Britain and the Commonwealth ex parte Wachman, Queen's Bench Division (Crown Office List) (1993) 2 All E.R. 249. 282, 283

- $\quad R$ v. Cobham Hall School Ex Parte S, High Court, Queen's Bench Division [1998] ELR 389. 283

- $R$ v. Disciplinary Committee of the Jockey Club, ex parte Aga Khan, Court of Appeal, Civil Division [1993], 2 All ER 853. 282, 283

- $R$ (on the application of A) v. Partnerships in Care Limited, Queen's Bench Division (Administrative Court) [2002] EWHC 529 (Admin). 295

- $\quad R$ v. Panel on Take-Overs and Mergers, ex p. Datafin plc [1987] Q.B. 815. 279, 280, 281, 283, 285

- $R v$. Servite Houses and another ex parte Goldsmith and another, High Court, Queen's Bench Division, Case No. CO/3652/99, [2001] LGR 55. 281, 282

- Wylie, Re An Application for Judicial Review, High Court of Justice in Northern Ireland Queen's Bench Division, NIQB 2 (19 January 2005). 284

- YL v. Birmingham City Council \& Ors [2007] UKHL 27. 294, 298, 299, 301

\section{United States of America}

- Adickes v. Kress \& Co., 398 U.S. 144 (1970). 304, 317

- Aguinda v. Texaco Inc., U.S. $2^{\text {nd }}$ Circuit Court of Appeals, Docket No. 01-7756, 16 August 2002 / Aguinda v. Texaco, Inc., 303 F.3d 470 (2d Cir. 2002). 123, 520

- Amalgamated Food Employees Union v. Logan Valley Plaza Inc, 391 U.S. 308 (1968). 308

- American Manufacturers Mutual Insurance Co. et al. v. Sullivan et al., 526 U.S. 40 (1999). 312

- Blum v. Yaretsky, 457 U.S. 991 (1982). 221, 307, 312, 315 
Table of Cases

- Brentwood Academy v. Tennessee Secondary School Athletic Association, 531 U.S. 288 (2001). 307, 315

- Burton v. Wilmington Parking Auth., 365 U.S. 715 (1961). 315, 321

- Civil Rights Cases, 109 U.S. 3 (1883). 304

- Doe I v. Unocal, 395 F.3d 932, 949 (9 $9^{\text {th }}$ Cir. 2002). 123

- Edmonson v. Leesville Concrete Co., 500 U.S. 614 (1991). 305, 312

- Evans v. Newton, 382 U.S. 296 (1966). 308, 308, 310, 321

- Filártiga v. Peña-Irala, 630 F.2d 876, $2^{\text {nd }}$ Circuit Court of Appeals, 1980. 80, 363

- Flagg Bros. Inc. v. Brooks, 436 U.S. 149 (1978). 305, 310, 311, 313, 512

- Flores v. S. Peru Copper, 343 F.3d 140, 156 (2d Cir. 2003). 123

- Griffin v. Maryland, 378 U.S. 130 (1964). 316

- Hudgens v. NLRB, 424 U.S. 507 (1976). 308

- In re "Agent Orange Product Liability Litigation" The Vietnam Association for Victims of Agent Orange/Dioxin et al $v$ The Dow Chemical Company et al., U.S District Court Eastern District of New York, 10 March 2005, Memorandum, Judgment and Order MDL No. 381 (04-CV-400) as amended on 28 March 2005. 519

- Iwanowa v. Ford Motor Co., 67 F. Supp. 2d 424 (D.N.J. 1999). 123

- Jackson v. Metropolitan Edison Co., 419 U.S. 345 (1974). 309, 314, 321, 512

- Lloyd Corp. v. Tanner, 407 U.S. 551 (1972). 308

- Lugar v. Edmondson Oil Co., 457 U.S. 922 (1982), p. 937. 304, 304, 306, 316

- Marsh v. Alabama, 326 U.S. 501 (1946). 307, 308, 310, 512

- NCAA v. Tarkanian, 488 U.S. 179 (1988). 315, 321

- North Georgia Finishing, Inc. v. Di-Chem, Inc., 419 U.S. 601 (1975). 315, 321

- Procunier v. Navarette, 434 U.S. 555 (1978). 318

- Rendell-Baker v. Kohn, 457 U.S. 830 (1982). 309, 311, 313, 315

- Richardson v. McKnight, 521 U.S. 399, 401, 412 (1997). 238, 318, 319, 320, 524, 525

- Saleh et al. v. Titan Corp. et al., United States District Court for the Southern District of California, 361 F. Supp. 2d 1152, 2005 U.S. Dist. LEXIS 4521 (S.D. Cal., Mar. 21, 2005). 521,522

- Saleh, et al. v. Titan Corporation (CACI International Inc. and CACI Premier, Intervenors), United States Court of Appeals for the District of Columbia Circuit, 11 September 2009, No. 08-7008. 517, 523, 524, 525

- San Francisco Arts \& Athletics v. United States Olympic Committee, 483 U.S. 522 (1987). 312

- Terry v. Adams, 345 U.S. 461 (1953). 307, 311, 312

- United States of America v. Paul A. Slough et al., Memorandum Opinion Granting the Defendants' Motion to Dismiss the Indictment; Denying as Moot the Government's Motion to Dismiss the Indictment Against Defendant Slatten Without Prejudice, United States District Court for the District of Columbia, Criminal Action No.: 08-0360 (RMU), 31 December 2009. 518

- United States v. Cruikshank, 92 U.S. 542, (1875). 304

- Virginia v. Rives, 100 U.S. 313, (1879). 304 
- Michael A. Lebron, v. National Railroad Passenger Corporation, 513 U.S. 374 (1995). 305

- West v. Atkins, 487 U.S. 42 (1988). 311, 315, 321

- Williams v. United States, 341 U.S. 97 (1951). 316

- Wiwa v. Royal Dutch Petroleum Co., 226 F.3d 88, 103 (2d Cir. 2000). 123

- Wiwa v. Royal Dutch Petroleum, United States District Court for the Southern District of New York, 22 February 2002, 2002 U.S. Dist. LEXIS 3293. 317

\section{Other}

- Academic Center of Law \& Business, Human Rights Division v. Minister of Finance, HCJ, 2605/05 (19 November 2009). 23, 66

- Mercury Energy Ltd v Electricity Corporation of New Zealand Ltd, (1994) 2 NZLR 385. 284 



\section{INDEX}

A

Abu Ghraib prison $14,15,388,457,458,461$, 485, 497, 498, 500, 503, 511

accountability 13-16, 37, 54-56, 96, 99, 100, $108,109,111-113,121-123,125,186,194$, 197, 199, 200, 221, 239, 240, 294, 322, 351, 367, 391, 395, 413, 459, 460, 479, 489, 490, 493, 496, 500, 512, 517, 570, $666,669,686,687,691,694$

accountability of business enterprises 108, 112

African Commission on Human and Peoples' Rights 191, 232, 355, 613

African Union 355

Aguas Argentinas 75, 82, 83, 86-89, 112, $136,212,543,544,573,619,623,625-$ $633,635,636,638-654,657-661,663-$ 671, 673-678, 682

Aguas de Aconquija 561

Aguas de Barcelona 59, 75, 82, 83, 86-89, 101, 112, 136, 212, 544, 573, 619, 621, $623,625,629-633,640,658,666,667$

Aguas del Tunari 74, 112, 136, 531, 559-561

Alien Torts Claims Act (ATCA) 111, 122124, 317, 518-522, 524, 525

American Convention on Human Rights (ACHR) 133, 172, 174, 175, 191, 193, 244,356

amparo 335, 344-348, 670-672, 674-678, 682

Appellate Body of the WTO 211

Argentine Ombudsman 620, 631, 634-636, 638-640, 657, 660, 674, 676, 677

attribution 200, 201, 204-208, 210, 214, 215, 217, 222, 224-226, 228, 234-236, 240, 489, 666, 686

Australasian Correction Management 32, 429

\section{B}

Bentham, Jeremy 27

Bilateral Investment Treaties (BITs) 59, 72, $75,83,85-88,90,110,136,544,573-575$, $584,622,623,629,633,661,690,693$, 694

Blackwater 2, 53, 458, 459, 461, 462, 491, 497, 498, 513, 517, 518, 689, 702

Bretton Woods Agreement 47

business enterprises 13, 44, 52-57, 91, 93, 108-113, 115-126, 136, 183, 197, 199, 235237, 480, 481, 483, 519, 538, 580, 670, 685

C

Camdessus report $556,557,559$

collective bargaining $417,418,429,440-442$, 445, 447, 451, 452

Commission of the European Communities 261-263, 541

Committee Against Torture (CAT) 44, 247, 248, 257, 351, 372, 385-390, 503-506, 510-512, 514, 519, 686, 687, 691

Committee of Experts on the Application of Conventions and Recommendations (CEACR) 423-437, 439

Committee on Economic, Social and Cultural Rights (UN CESCR) 71, 94, 99, 127, 133, 145, 158, 174, 182, 343, 356, 368, $375,383,530,556,572,594,612,613$, $615,616,634,653-655,662,664,665$, $669,671,693$

Committee on the Elimination of Discrimination Against Women (UN CEDAW) 382,530

Committee on the Elimination of Racial Discrimination (UN CERD) 152,530 
Index

Committee on the Rights of the Child (CRC) 372, 390-395, 589, 590, 595, 596, 605

concession contracts $275,341,342,547,564$, 621,628

concluding observations $23,145,152,358$, 365-368, 374-381, 383, 384, 387-389, 392394, 439, 506, 530, 531, 588-591, 595, $598,605,606,609,613$

Conseil d'Etat $\quad 63,336,337,339,341$

consumers, rights of $532,535,572,633,656$, $660,674,677$

contracting authorities $269,270,275$

contracting out $5,7,8,23,42-45,47,62,65$, $209,216,220,228,247,299,321,363-$ 366, 390, 426, 452, 459, 461-463, 484, $500,511,519$

contractors $14,15,68,219,220,228,229$, 292, 367, 368, 385, 386, 388, 427, 458, 461, 465, 478, 480, 484-487, 497-501, 506-510, 512-520, 522, 524, 526, 527, $668,683,688,689$

contrats administratifs $335,337,340-342$

Convention against Torture and Other Cruel, Inhuman or Degrading Treatment or Punishment $70,181,233,355,385,387$

Convention on the Elimination of All Forms of Discrimination against Women 355, 383

Convention on the Elimination of All Forms of Racial Discrimination $152,355,360$, $379,380,530$

Convention on the Rights of the Child 255, $355,390-392,593,605$

core State functions 26, 364, 366

Correctional Corporations of America (CCA) 1, 5, 29, 53

Council of Europe 15, 19-22, 246, 357, 395, 396, 405, 406, 413

D

definition of privatization $7,10,14,19,22$, $56,461,538$ divestiture $4,41,42,62,229,538,540,548$, 621

Doha Development Round 578

Draft International Convention on the Regulation, Oversight and Monitoring Of Private Military and Security Companies 70, 71, 75, 217, 491, 492

Drittwirkung 125, 128, 185-188, 190-194, 202, 236, 239, 243, 255, 352, 510, 694

Dublin Declaration 555, 556

due diligence $84,101,120,129,140,189$, 201, 230-236, 386, 491, 508, 632, 640, $661,668,670,694$

dynamic nature of privatization $38,40,41$, 44, 683

DynCorp International 463

$\mathbf{E}$

economic adjustment 378

Ente Tripartito de Obras y Servicios Sanitarios (ETOSS) 619, 620, 625-628, 631, 632, 634-636, 638-640, 643, 645, 646, 648, $649,656,658-660,663,665,667,668$, 673-677

Erinys International 53

essential utilities $8,37,39,44,49,150,180$, 212, 282, 342, 531, 534, 564, 619-621, $680,681,696$

ethnic groups 381,601

ethnic minorities 380,381

EU competition law $258,260,341$

EU procurement law 260, 269, 270, 274-278, 340

European Commission on Human Rights 248

European Committee on Economic and Social Rights and privatization 429

European Committee on the Prevention of Torture 396, 406

European Convention on Human Rights 80, $126,132,137,139,152,177-179,186-188$, 190, 192, 202, 234, 239, 243, 395, 406, 615,616 
European Court of Human Rights (ECtHR) 7, 13, 46, 80, 105, 126, 127, 132, 134, 137-139, 141, 143, 144, 147, 150-157, 159-166, 168-171, 177-179, 189193, 215, 216, 218, 222, 237, 243, 244, 246, 248-257, 286, 297, 298, 308, 357, 396, 399-405, 422, 510, 511, 575, 616, 669

European Court of Justice (ECJ) 230, 240, 258-271, 273, 274, 276, 277, 295, 338, 340,543

European Social Charter 132, 395, 413, 414, 416,615

European Union (EU) 34, 40, 46, 114, 147, $213,240,242,244,254,258-260,263-$ 265, 269-271, 274-278, 337, 338, 340, 341, 494, 495, 532, 541-543, 580, 582, 686

Executive Outcomes $\quad 457,463,471$

\section{F}

Fay report 501, 506, 509

First Additional Protocol to the Geneva Conventions 466, 470

'functional' public authorities 287, 288, 302

\section{G}

General Agreement on the Trade of Services (GATS) 540, 541, 565, 574-585

General Comment No. 2, Implementation of article 2 by States parties (CAT) 351, $385,511,687$

General Comment No. 12 on the right to food 146

General Comment No. 14 on the right to the highest attainable standard of health $133,149,174$

General Comment No. 15 on the right to water $94,95,99,127,133,149,158$, $172,174,371,556,587,594,597,613$, 634,653

General Comment No. 31 on the Nature of the General Legal Obligation Imposed on States Parties to the Covenant
(ICCPR) 129-131，140，173，177，188, $189,510,511,617$

Geneva Convention Relative to the Treatment of Prisoners of War 465, 489

Geneva Conventions of $1949 \quad 465,470,502$

governmental function $255,312,318,320$, 327, 331-334, 485

Group 4 Correction Services 246

Group 4 Securicor 53

Guiding Principles on Business and Human Rights 118

\section{H}

Hague Convention (V) Respecting the Rights and Duties of Neutral Powers and Persons in Cases of War on Land 465 heavily indebted poor countries 51

HM Inspectorate of Prisons 181

horizontal effect of human rights 185, 193, 197, 352, 489, 670, 695

House of Lords $\quad 248,266,280,285,287-289$, 294-298, 301

Hudson Bay Company 25

Human Rights Act (HRA) 185, 187, 241, $242,244,248,251,279,285-298,300-$ $303,331,335$

Human Rights Committee (HRC) 13, 23, 46, 47, 109, 110, 113, 115, 118, 119, 121, 129 , $130,132,139,145,152,173,177-179,183$, $188,191,193,203,216,237,244-247$, 257, 356, 359-368, 479, 492, 493, 504, $510-512,514,593,594,596,603,616$, 617,688

human rights responsibility 116,687

\section{I}

ICSID Arbitration Tribunal 82, 83, 212, 564 ILO Governing Body 438, 439

IMF Articles of Agreement 47

individual complaints 192, 193, 203, 244 $246,252,285,360,361,363,396,514$, 688

inherently governmental activity $\quad 24,219$ 
Index

Inter-American Court of Human Rights (IACtHR) 133, 139, 140, 144, 152, 156, 174, 191, 193, 212, 213, 231, 232, 299, $355,356,508,667$

Inter-American Development Bank (IADB) 4, 539, 553, 555, 620, 624

International Center for the Settlement of Investment Disputes (ICSID) 48, 59, 73-75, 81-83, 87-89, 110, 136, 209, 212, $215,531,543,544,561-564,573,574$, 621-623, 629-633, 640, 658, 661, 665

International Committee of the Red Cross (ICRC) 70, 469, 489, 498, 502

International Convention against the Recruitment, Use, Financing and Training of Mercenaries 466, 470, 476, 478

International Court of Justice (ICJ) 13, 72, 77-79, 90-92, 108, 202-206, 214, 225-229, $231,233-235,507,515,661$

International Covenant on Civil and Political Rights (ICCPR) 6，23，46，129-132, $140,152,172,173,175,177,179,188$, 189, 193, 203, 233, 234, 244-247, 285, $355,358-367,372,503-506,510,511,513$, $514,519,520,612,615$

International Covenant on Economic, Social and Cultural Rights (ICESCR) 6, 71, 94, 95, 129-133, 146, 148, 149, 158, 174, $188,245,338,349,370-375,378,379$, $530,572,587-591,594-596,598-603$, 609, 611-613, 615, 616, 620, 653-655, $666,669-672,694$

International Criminal Court (ICC) 121, $122,236,514$

International Development Association 48, 104

International Finance Corporation 4, 48, 49, 93, 106, 342, 343, 554, 555, 626

International Financial Institutions (IFIs) 11, 13, 19, 22, 34-36, 44, 47, 50, 52, 55-57, 59, 60, 79, 91-96, 98-100, 105, 106, 126, $197,199,343,368,369,549,551,553$, $557,558,565,580,683,685$
International Labor Organization (ILO) 15, $113,125,197,246,355,357,423,424$, $431,435,436,438-440,443,445,452-$ $454,648,685$

International Law Commission (ILC) 46, 79-81, 86, 87, 89, 200-211, 214-224, 228$231,233,235,236,239,248,507,632$, 666, 668, 670

International Law Commission's Articles on the Responsibility of States for international wrongful acts 200

International Monetary Fund (IMF) 4, 35, 47, 48, 50-52, 92-94, 96, 97, 342, 369, $376,435,536,553,555,556,620$

International Peace Operations Association (IPOA) 54, 114, 487, 488

international responsibility $90,110,140,145$, 194, 200, 202, 210, 216, 227, 231, 235, 236, 694

Israeli High Court of Justice 65

\section{$\mathbf{J}$}

'joint action' test 306,316

$\mathbf{L}$

legitimacy $45,66,120,183,197,366,622$, 623

liberalization $34,48,182,261,435,532,540$, 541, 574, 576-578, 580, 581, 583, 584, 620

Limburg Principles on the Implementation of the International Covenant on Economic, Social and Cultural Rights 130, 600, 612,616

$\mathbf{M}$

Machiavelli, Niccolo 467

margin of appreciation 128, 137, 138, 149171, 178, 179, 195-197, 199, 238, 239, 296, 397, 399, 400, 422, 680, 685, 690, 699

mercenaries $25,54,70,145,218,357,458$ $460,465-481,491-493,496,526,688$ 
Index

methods of privatization $19,41,42,56,163$, 170, 538, 539

Military Extraterritorial Jurisdiction Act (MEJA) 484, 515-518

Military Professional Resources Inc. (MPRI) 457, 462, 464, 472, 473, 479

Millennium Development Goals 537, 555, 556, 618

minimum core obligations $\quad 131,148-150,159$, $245,610,614,617,653$

Montreux Document 71, 488-491

multinational corporations 59, 79, 91, 109, 111-114, 116, 121-123, 125, 187, 317, 480

\section{$\mathbf{N}$}

nationalization $22,25,26,32,33,35,37,45$, 56, 71-73, 89, 126, 127, 160, 161, 339, 361, 396-398, 403, 421, 550-552, 559, 563, $564,684,687,690$

national preventive mechanisms 70,181 negative obligations $128,131-135,147,149$, $152,153,155,182$

network utilities $23,33,147,539,550,551$

'nexus' test $306,313,314$

Norms on the Responsibilities of Transnational Corporations and Other Business Enterprises with Regard to Human Rights 55, 109, 116, 480

North America Free Trade Agreement (NAFTA) $81,571,572,629$

\section{O}

OAU Convention for the Elimination of Mercenarism 469

obligations erga omnes 77, 90, 128, 203

Obligations of Non-State Actors 16, 53, 54, 60, 91, 94, 109, 123, 126, 185, 206, 306, 351

obligation to fulfill 146-148, 150, 195, 371, $382,609,610,614,662,663,691$

obligation to protect $119,126,143,144,146$, $147,149,179,192,233,371,372,382$, 572, 602, 603, 605-608, 615, 617, 632, 641, 644, 656-658, 661, 668, 669, 679, $688,693,694,696$ obligation to respect $146,147,149,191,192$, $371,382,601,612,614,654,655,657$, 663

Obras Sanitarias de la Nación (OSN) 623$625,635-638,642,643,646,647,651$, $654,655,660,662,665,680$

Optional Protocol to the Convention Against Torture and other Cruel, Inhuman or Degrading Treatment or Punishment (OPCAT) 70, 181, 196, 411, 684

Organization for Economic Cooperation and Development (OECD) 3, 20, 40, 110, $114,118,125,170,197,532,548,565$, $566,626,685$

Organization of African Unity 469

$\mathbf{P}$

pacta sunt servanda $76,77,128$

Permanent Court of International Justice 13, 203, 218

positive obligations $54,126,131-134,136-$ 144, 147, 149, 150, 152, 155-157, 162-165, 169, 172, 179, 180, 182, 186, 189, 190, 195, 197, 233, 234, 237, 238, 286, 290, 399, 402, 422, 510, 568, 602, 685, 692

Poverty Reduction Strategy Papers 51, 52 private actors as State organs 244, 245, 248 private actors exercising elements of governmental authority 200, 206, 236

private military and security companies (PMSCs) 14, 15, 25, 54, 70, 71, 75, 114, 145, 217, 228, 388, 458-461, 463-466, 472-474, 477-481, 483-498, 500, 506, 508, 510-513, 515, 516, 519, 525-527, 683, 684,688

private military contractors 228, 458, 497, 517

private prisons $5,6,27-30,181,304,306$, $308,318,364,365,376,409,411,415$, $425,428,453$

private security contractors 386

private security services 411

privatization of education 10,576 
Index

privatization of housing $150,377,421$

privatization of military and security services $8,15,75,168,220,357,461$

privatization of prisons $5,8,16,24,25,27$, $28,32,53,65,168,171,217,278,305$, $357,363,365,389,407,424,425,429$, 453,564

privatization of social security $10,373,375$, $431,432,454$

privatization of social welfare services 420

privatization of the public sector 375

privatization of water utilities $6,10,15,67$, $71,74,348,531-533,535-539,544,548$, 549 , 551, 553, 554, 557-559, 564-566, $568,575,579,585-587,590-593,599-$ $602,609,610,618-620,633,634,637$, $638,643,644,653,666,678,682,689$

privatization of water utilities in the city of Buenos Aires 531, 535, 619,620

privatization programs $4,30,61,68,156$, $378,381,437,536$

privatized prisons $23,27,29,54,70,176$, $181,182,186,188,195,217,318-320,360$, $365,367,376,386,387,389,411,415$, $422,424-429,448,449,453,525,684$

privatized utilities $54,55,59,176,186,297$, 565-567, 569, 572, 573, 589, 600, 605, $607,610,617,619,622,627,628,681$

procedural remedies $175-179,183,184,196$, 197, 513-515, 526, 677

prohibition of torture $14,167,168,278,298$, $359,386,491,502,504,505,593,615$

public authorities $21,132,138,162,164,190$, 191, 242, 248, 249, 251, 265, 274, 277, 278, 280, 285-288, 290-294, 298, 302, $336,339,340,345,359,365,432,445$, $446,504,541,564,658,668$

public function $31,241,282,283,285,289$, 291, 292, 298, 299, 302, 303, 306-314, $318,320,321,327,330,512$

'public function' test $306,307,309,310,312$ 314,321

public/private debate 242 public service $28,39,63,64,83,85,182$, 207, 219, 242, 249, 257, 266-269, 273, $276,278,295,309,313,318,328,331-$ $333,335,340-342,346,347,399,430$, $449,534,535,540-543,559,573,585$, $626,672,677$

\section{$\mathbf{R}$}

regulation $12,24,35,39,40,55,73,81,128$, 142-145, 150, 172, 176, 180-182, 184, 197, 213, 216, 222, 278, 282, 292, 299, 307, $314,315,349,350,369,395,426,463$, 464, 479, 489-496, 527, 535, 539-541, 549, 552, 568-572, 574, 577, 582-585, 605, 606, 691, 693, 694

remedies and privatization $120,173,175$

right to adequate healthcare 171

right to adequate housing 95, 98, 99, 105, $370,377,535,591,592,601,691$

right to an adequate standard of living 6, $346,349,357,370-372,374,375,377$, $535,587,594-596,609$

right to a private life 138

right to food $129,146,232,357,572,590$, 591, 596, 617, 679

right to life $167,171,596,615,617$

right to strike $342,416-418,429,430,440$, 446-450, 453

right to water $6,14,63,71,86-88,94-96,98$, $99,107,127,133,149,158,172,174,175$, $185,349,357,371,375,377,534,535$, $556,572-574,576,583,586-588,593-$ 602, 606, 607, 609-620, 632-635, 637, $641,642,644,653-655,657,661,662$, 664-666, 669, 671, 672, 676-681, 689, 694

Ruggie, John $\quad 109,112,115,118,490$

$\mathbf{S}$

Sandline $53,75,472,473,476,481-483$

service public $63,335-339,341,541$

services of general economic interest 258, 543 
services of general interest 213, 214, 242, $254,540-543,587$

social security $10,16,64,171,188,259,302$, $314,356,372,373,375,376,380,413$, 414, 419-422, 424-426, 429, 431-434, 439, 453, 454, 607

Standards Compliance and Oversight Procedure (SCOPe) 488, 489

state action $62,74,240,244,303-317,321$, $322,330,335,350,351,451,512,672$, 687

state owned enterprises 216,624

State reports 246, 358, 363, 372, 373, 375, 380, 383, 386, 391, 414, 419, 423, 454, $587,590,591,595,605,687$

State responsibility $13,15,30,46,79-82$, 86-89, 125, 165, 192, 195, 196, 199-211, 214-218, 221-224, 226-231, 233-236, 238, 245, 256, 372, 400, 405, 482, 490, 492, $507,508,629,685,690$

structural adjustment programs $51,368,394$, 435

Subcommittee on Prevention of Torture (SPT) 181

Suez 53, 59, 75, 82, 83, 86-89, 112, 136, 212, 537, 543, 544, 547, 549, 562, 564, 573, $619,621,623,625,629-633,640,645$, $658,666,667$

Supreme Court of Canada 65, 68, 323-328, $330,331,333$

\section{$\mathbf{T}$}

Taguba report 498-501, 509

Thatcher, Margaret $\quad 34,536,548,551$

Titan Corporation $\quad 498,517,520-525$

transparency $28,87,96,108,120,183,197$, $212,277,542,544,570,571,610,624$, $625,629,630,663,667,679$

Tribunal des Conflits 336, 339

$\mathbf{U}$

UK Prison Ombudsman 182
UN Commission on Human Rights 52, 55, 109, 116, 117, 459, 470, 479

UN Commission on International Trade Law (UNCITRAL) 75, 209, 481, 572, 629

UN Committee Against Torture (UN CAT) $44,351,686,687,691$

UNDP 95, 536, 624

UN General Assembly 45, 51, 69, 72, 79, 145, 201, 459, 460, 469, 470, 478, 507

UN Human Rights Council 118, 492-494

Uniform Code of Military Justice (UCMJ) 515, 516

Universal Declaration of Human Rights 2, $96,173,355,488,533,587$

universal service obligations (USOs) 147, $148,150,196,539,542-544,585,598$, $608,617,693,694,702$

UN Special Representative of the Secretary General on the issue of human rights and transnational corporations and other business enterprises 183

UN Sub-Commission on the Promotion and Protection of Human Rights $8,55,116$, 480

\section{V}

Veolia (formerly known as Compagnie Générale des Eaux and Vivendi) 53, 549,564

Verenigde Oostindische Compagnie (VOC, the United East India Company) 25, 53

Vienna Convention on the Law of Treaties $46,77,78,128$

vulnerable groups $50,116,135,156,180$, $373,375,384,394,569,607,617,649$, 658,665

W

Wackenhut Corrections Corporation (WCC) 29, 53, 408, 409

Washington Consensus 48-50, 92

water utilities privatization 601

World Bank 4, 6, 13, 33-36, 42, 43, 47-52, 73, 92-101, 104-106, 124, 141, 197, 342, 
Index

$369,435,436,472,530-532,535-537,539$, $545-547,553-555,557,558,563,565,567$, $570,618,620,621,623-626,634,637$, 685

World Health Organization (WHO) 92, 529, 588, 594, 597, 606, 611, 617, 626, 634, 637, 638, 664

World Panel on Financing Water Infrastructure $537,538,555,556$

World Trade Organization (WTO) 199, 211, 216, 223, 575-583, 585, 622, 693

World Water Forum 537, 555 


\section{Curriculum Vitae}

Antenor Hallo de Wolf (Quito, 1970) studied law at Maastricht University, in which he graduated as Master of Dutch law in 1996. From 1997-1998 he worked as a legal researcher at Africa Legal Aid, an African human rights NGO. In 2000 he became a junior lecturer on international and European Law at the Faculty of Law of Masatricht University and later tought courses on international relations and international organizations at University College Maastricht. From 2001 onwards he started his $\mathrm{PhD}$ research on privatization and human rights under the supervision of Prof. dr. Menno Kamminga and Prof. dr. Wouter Devroe. In 2006 he became a research assistant at the School of Law of Bristol University for a research project on the Optional Protocol to the Convention Against Torture and Other Cruel, Inhuman or Degrading Treatment or Punishment (OPCAT) together with Prof. dr. Rachel Murray, Prof. dr. Malcolm Evans, and dr. Elina Steinerte. Mr. Hallo de Wolf is currently a lecturer on human rights and international law at the Faculty of Law of Groningen University. $\mathrm{He}$ is also a visiting fellow of the Centre for the Implementation of Human Rights at the School of Law of Bristol University. His publications include papers on the status of NGOs under international law, the accountability of private military and security services, the use of diplomatic assurances and the OPCAT, and on the application of human rights in overseas territories. Together with Prof. Murray, Prof. Evans and dr. Steinerte, he co-authored a book on the Optional Protocol to the UN Convention Against Torture through Oxford University Press. His interests include the implementation an justiciability of economic, social and cultural rights, the public-private divide and human rights, international investment law and its impact on human rights, and the obligation to prevent torture under international law. 



\section{School of Human Rights Research Series}

The School of Human Rights Research is a joint effort by human rights researchers in the Netherlands. Its central research theme is the nature and meaning of international standards in the field of human rights, their application and promotion in the national legal order, their interplay with national standards, and the international supervision of such application. The School of Human Rights Research Series only includes English titles that contribute to a better understanding of the different aspects of human rights.

Editorial Board of the Series:

Prof. dr. J.E. Goldschmidt (Utrecht University), Prof. dr. D.A. Hellema (Utrecht University), Prof. dr. W.J.M. van Genugten (Tilburg University), Prof. dr. M.T. Kamminga (Maastricht University), Prof. dr. P.A.M. Mevis (Erasmus University Rotterdam), Dr. J.-P. Loof (Leiden University) and Dr. O.M. Ribbelink (Asser Institute).

Published titles within the Series:

1. Brigit C.A. Toebes, The Right to Health as a Human Right in International Law ISBN 90-5095-057-4

2. Ineke Boerefijn, The Reporting Procedure under the Covenant on Civil and Political Rights. Practice and Procedures of the Human Rights Committee ISBN 90-5095-074-4

3. Kitty Arambulo, Strengthening the Supervision of the International Covenant on Economic, Social and Cultural Rights. Theoretical and Procedural Aspects ISBN 90-5095-058-2

4. Marlies Glasius, Foreign Policy on Human Rights. Its Influence on Indonesia under Soeharto ISBN 90-5095-089-2

5. Cornelis D. de Jong, The Freedom of Thought, Conscience and Religion or Belief in the United Nations (1946-1992)

ISBN 90-5095-137-6

6. Heleen Bosma, Freedom of Expression in England and under the ECHR: in Search of a Common Ground. A Foundation for the Application of the Human Rights Act 1998 in English Law

ISBN 90-5095-136-8

7. Mielle Bulterman, Human Rights in the External Relations of the European Union ISBN 90-5095-164-3

8. Esther M. van den Berg, The Influence of Domestic NGOs on Dutch Human Rights Policy. Case Studies on South Africa,Namibia, Indonesia and East Timor ISBN 90-5095-159-7

9. Ian Seiderman, Hierarchy in International Law: the Human Rights Dimension ISBN 90-5095-165-1

10. Anna Meijknecht, Towards International Personality: the Position of Minorities and Indigenous Peoples in International Law

ISBN 90-5095-166-X 
School of Human Rights Research Series

11. Mohamed Eltayeb, A Human Rights Approach to Combating Religious Persecution. Cases from Pakistan, Saudi Arabia and Sudan ISBN 90-5095-170-8

12. Machteld Boot, Genocide, Crimes Against Humanity, War Crimes: Nullum Crimen Sine Lege and the Subject Matter Jurisdiction of the International Criminal Court ISBN 90-5095-216-X

13. Corinne Packer, Using Human Rights to Change Tradition. Traditional Practices Harmful to Women's Reproductive Health in sub-Saharan Africa ISBN 90-5095-226-7

14. Theo R.G. van Banning, The Human Right to Property ISBN 90-5095-203-8

15. Yvonne M. Donders, Towards a Right to Cultural Identity? ISBN 90-5095-238-0

16. Göran K. Sluiter, International Criminal Adjudication and the Collection of Evidence: Obligations of States ISBN 90-5095-227-5

17. Nicola Jägers, Corporate Human Rights Obligations: in Search of Accountability ISBN 90-5095-240-2

18. Magdalena Sepúlveda, The Nature of the Obligations under the International Covenant on Economic, Social and Cultural Rights ISBN 90-5095-260-7

19. Mitsue Inazumi, Universal Jurisdiction in Modern International Law: Expansion of National Jurisdiction for Prosecuting Serious Crimes under International Law ISBN 90-5095-366-2

20. Anne-Marie L.M. de Brouwer, Supranational Criminal Prosecution of Sexual Violence: The ICC and the Practice of the ICTY and the ICTR ISBN 90-5095-533-9

21. Jeroen Gutter, Thematic Procedures of the United Nations Commission on Human Rights and International Law: in Search of a Sense of Community ISBN 90-5095-557-6

22. Hilde Reiding, The Netherlands and the Development of International Human Rights Instruments ISBN 978-90-5095-654-3

23. Ingrid Westendorp, Women and Housing: Gender Makes a Difference ISBN 978-90-5095-669-7

24. Quirine A.M. Eijkman, We Are Here to Serve You! Public Security, Police Reform and Human Rights Implementation in Costa Rica ISBN 978-90-5095-704-5

25. Antoine Ch. Buyse, Post-conflict Housing Restitution. The European Human Rights Perspective with a case study on Bosnia and Herzegovina ISBN 978-90-5095-770-0

26. Gentian Zyberi, The Humanitarian Face of the International Court of Justice. Its Contribution to Interpreting and Developing International Human Rights and Humanitarian Law Rules and Principles

ISBN 978-90-5095-792-2

27. Dragoş Cucereanu, Aspects of Regulating Freedom of Expression on the Internet ISBN 978-90-5095-842-4 
28. Ton Liefaard, Deprivation of Liberty of Children in Light of International Human Rights Law and Standards

ISBN 978-90-5095-838-7

29. Laura van Waas, Nationality Matters. Statelessness under International Law ISBN 978-90-5095-854-7

30. Jeroen Denkers, The World Trade Organization and Import Bans in Response to Violations of Fundamental Labour Rights

ISBN 978-90-5095-855-4

31. Irene Hadiprayitno, Hazard or Right? The Dialectics of Development Practice and the Internationally Declared Right to Development, with Special Reference to Indonesia ISBN 978-90-5095-932-2

32. Michał Gondek, The Reach of Human Rights in a Globalising World: Extraterritorial Application of Human Rights Treaties

ISBN 978-90-5095-817-2

33. Jeff Handmaker, Advocating for Accountability: Civic-State Interactions to Protect Refugees in South Africa

ISBN 978-90-5095-910-0

34. Anna Oehmichen, Terrorism and Anti-Terror Legislation: The Terrorised Legislator? A Comparison of Counter-Terror Legislation and Its Implications on Human Rights in the Legal Systems of the United Kingdom, Spain, Germany and France ISBN 978-90-5095-956-8

35. Simon Walker, The Future of Human Rights Impact Assessments of Trade Agreements ISBN 978-90-5095-986-5

36. Fleur van Leeuwen, Women's Rights Are Human Rights: The Practice of the United Nations Human Rights Committee and the Committee on Economic, Social and Cultural Rights ISBN 978-90-5095-980-3

37. Eva Rieter, Preventing Irreparable Harm. Provisional Measures in International Human Rights Adjudication

ISBN 978-90-5095-931-5

38. Desislava Stoitchkova, Towards Corporate Liability in International Criminal Law ISBN 978-94-000-0024-7

39. Paulien Muller, Scattered Families. Transnational Family Life of Afghan Refugees in the Netherlands in the Light of the Human Rights-Based Protection of the Family ISBN 978-94-000-0021-6

40. Bibi van Ginkel, The Practice of the United Nations in Combating Terrorism from 1946 to 2008. Questions of Legality and Legitimacy

ISBN 978-94-000-0076-6

41. Christophe Paulussen, Male captus bene detentus? Surrendering suspects to the International Criminal Court

ISBN 978-94-000-0100-8

42. Brianne McGonigle Leyh, Procedural Justice? Victim Participation in International Criminal Proceedings

ISBN 978-1-78068-020-0 
43. Maria Ventegodt Liisberg, Disability and Employment. A Contemporary Disability Human Rights Approach Applied to Danish, Swedish and EU Law and Policy ISBN 978-1-78068-028-6

44. Tarlach McGonagle, Minority Rights, Freedom of Expression and of the Media: Dynamics and Dilemmas ISBN 978-94-000-0215-9

45. Marloes van Noorloos, Hate Speech Revisited. A comparative and historical perspective on hate speech law in the Netherlands and England \& Wales ISBN 978-1-78068-032-3

46. Hanneke Senden, Interpretation of Fundamental Rights in a Multilevel Legal System. An analysis of the European Court of Human Rights and the Court of Justice of the European Union ISBN 978-1-78068-027-9

47. Otto Spijkers, The United Nations, the Evolution of Global Values and International Law

ISBN 978-1-78068-036-1

48. Karin Veegens, A Disrupted Balance? Prevention of terrorism and compliance with fundamental legal rights and principles of law - the Dutch antiterrorism legislation ISBN 978-1-78068-042-2 